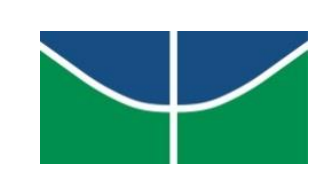

UNIVERSIDADE DE BRASÍLIA - UNB

INSTITUTO DE LETRAS - IL

DEPTO. DE LINGUÍSTICA, PORTUGUÊS E LÍNGUAS CLÁSSICAS - LIP PROGRAMA DE PÓS-GRADUAÇÃO EM LINGUÍSTICA - PPGL

UMA INTERFACE DA DOCUMENTAÇÃO LINGUÍSTICA E MODELOS LEXICOGRÁFICOS PARA LÍNGUAS INDÍGENAS BRASILEIRAS:

UMA PROPOSTA PARA O SURUÍ-AIKEWÁRA 


\section{JORGE DOMINGUES LOPES}

UMA INTERFACE DA DOCUMENTAÇÃO LINGUÍSTICA E MODELOS LEXICOGRÁFICOS PARA LÍNGUAS INDÍGENAS BRASILEIRAS:

UMA PROPOSTA PARA O SURUÍ-AIKEWÁRA

Tese apresentada ao Curso de Doutorado em Linguística do Programa de Pós-Graduação em Linguística do Instituto de Letras da Universidade de Brasília, como requisito parcial à obtenção do título de Doutor em Linguística.

Orientadora: Profa. Dra. Ana Suelly Arruda Câmara Cabral. 
Ficha catalográfica elaborada pela Biblioteca Central da Universidade de Brasília. Acervo 10199900.

Lopes, Jorge Domingues.

Uma interface da documentação I inguística e modelos lexicográficos para Iínguas indígenas brasileiras: uma proposta para o Suruí-Aikewára / Jorge Domingues Lopes. - - 2014.

599 f. : il. ; $30 \mathrm{~cm}$.

Tese (doutorado) - Universidade de Brasília, Instituto de Letras da Universidade de Brasília, Programa de Pós-Graduação em Linguística, 2014.

Inclui bibliografia.

Orientação: Ana Suelly Arruda Câmara Cabral .

1. Índios Suruí - Línguas - Tocantins. 2. Índios Suruí Línguas - Lexicografia. 3. Índios - Línguas. I. Cabral, Ana Suelly A. C. - (Ana Suelly Arruda Câmara). Il. Título. 
JORGE DOMINGUES LOPES

\title{
UMA INTERFACE DA DOCUMENTAÇÃO LINGUÍSTICA E MODELOS LEXICOGRÁFICOS PARA LÍNGUAS INDÍGENAS BRASILEIRAS: UMA PROPOSTA PARA O SURUÍ-AIKEWÁRA
}

\begin{abstract}
Esta tese foi julgada adequada à obtenção do título de Doutor em Linguística e aprovada em sua forma final pelo Curso de Doutorado em Linguística, do Programa de Pós-Graduação em Linguística do Instituto de Letras da Universidade de Brasília.
\end{abstract}

Brasília, 16 de dezembro de 2014.

Professora e orientadora Ana Suelly Arruda Câmara Cabral, Dra. (Presidente) Universidade de Brasília

Prof. Terrence Scott Kaufman, Dr. (Membro externo)

Prof. Emérito da University of Pittsburgh

Prof. Wolf Dietrich, Dr. (Membro externo)

Prof. Emérito da Universität Münster

Profa. Cristina Martins Fargetti, Dra. (Membro externo) Universidade Estadual Paulista Júlio de Mesquita Filho, Câmpus de Araraquara

Profa. Enilde Leite de Jesus Faulstich, Dra. (Membro interno) Universidade de Brasília

Prof. Sanderson Castro Soares de Oliveira, Dr. (Suplente)

Universidade do Estado do Amazonas, Centro de Estudos Superiores de Tabatinga 
Para Elizabete com amor. 


\section{AGRADECIMENTOS}

A Deus, a Quem só tenho a agradecer.

À minha querida esposa Elizabete e aos meus amados filhos Wendel, Catarina e Ícaro, por compartilhar e suportar com amor, alegria e fé, a longa caminhada não só destes anos de estudo, mas de toda uma vida; sei que não foi fácil, mas conseguimos chegar juntos até aqui.

Aos meus pais Eraldo e Natalice, que construíram uma bonita família que se multiplicou em tantas outras famílias; obrigado, do fundo do meu coração, por se dedicarem para que eu pudesse realizar meus estudos; esta conquista também é de vocês.

Aos meus sogros Orino e Eliana, por todo o apoio nestes anos e pelo carinho e preocupação em sempre querer bem.

Aos meus irmãos, pela história que construímos juntos e pela torcida em nossos diferentes projetos.

Aos amigos e parentes, os meus e os da Elizabete, que ficaram no Pará, sempre acreditando no sucesso de nossos planos em longes terras.

À profa. Ana Suelly Cabral, uma das profissionais mais competentes, alegres e éticas que tive o prazer de conhecer nestes anos no meio acadêmico, e que tenho o prazer maior ainda de tê-la como minha orientadora no doutorado; com ela dei meus primeiros passos no estudo da linguística indígena e tive, nela mesma, um exemplo de dignidade e respeito aos diferentes povos indígenas; com ela, enfim, descobri uma ciência linguística palpitante, instigante, desafiadora, que não pode prescindir, nunca, de ter como fim, a defesa e a valorização das línguas, das culturas, e, em última instância, da própria humanidade.

In memoriam ao prof. Aryon Dall'Igna Rodrigues, mestre paciente e perspicaz, fundador do Laboratório de Línguas e Literaturas Indígenas da UnB, que devotou sua vida ao estudo das línguas indígenas brasileiras, e de outras tantas, e de quem tive o privilégio de ser aluno; grande sábio que nos legou a luz de seu conhecimento e que nunca há de se apagar.

À profa. Ruth Maria Fonini Monserrat, primeira pesquisadora a estudar sob a ótica da linguística a língua Suruí do Tocantins e que, gentilmente, compartilhou comigo suas anotações desse estudo; foi ela também quem lançou as bases para o início da escrita dessa língua; obrigado pelas valiosas lições de fonética e fonologia; por instigar sempre o estudo das línguas indígenas e pela colaboração com minha pesquisa. 
Ao prof. Terrence Kaufman, pelas valiosas e oportunas observações feitas sobre meu trabalho, quando de sua vinda ao Brasil, que foram fundamentais para reorientar parte essencial da apresentação do material lexicográfico presente nesta tese.

À profa. Enilde Faulstich, coordenadora do Centro de Estudos Lexicais e Terminológicos - Centro Lexterm (LIP/IL/UnB), que contribuiu, sobremaneira, tanto com a minha formação no curso de doutorado, quanto com a minha pesquisa nas áreas da lexicologia, da lexicografia e da política linguística.

A todos os companheiros do Laboratório de Línguas e Literaturas Indígenas da UnB, Ana Maria, Ariel, Áustria, Beatriz, Chandra, Fábio, Gabriel, Joaquim, Kaman, Lidiane, Makaulaka, Mauro, Maxwell, Nanblá, Páltu, Rodrigo, Sanderson, Sissi, Suseile, Tiscianne, Wary e tantos outros que não estão nesta lista (mas são igualmente importantes), pelas horas de convívio, alegria, colaboração e troca de conhecimentos ao longo dos últimos quatro anos.

Ao amigo Lucivaldo Costa, que me incentivou a descobrir a linguística indígena e me apoiou do início ao fim de minha pesquisa de campo.

À profa. Eliete Solano, que me apoiou em vários momentos da minha pesquisa de campo e dos estudos da língua Suruí, valorizando e descobrindo, como eu, a riqueza dessa língua.

Ao Laboratório de Línguas e Literaturas Indígenas da UnB, primeiro coordenado pelo prof. Aryon Rodrigues e agora coordenado pela profa. Ana Suelly Cabral, pela acolhida, pelo apoio às pesquisas e pelas oportunidades de participar de tantos projetos e eventos científicos importantes em nossa área, por conhecer tantos pesquisadores importantes que contribuíram e contribuem para nossa formação científica e também por ser espaço de integração, de convivência, de colaboração mútua em prol do conhecimento científico na linguística-antropológica indígena brasileira.

Ao PPGL, sua coordenação e secretaria, principalmente a Ângela e Renata, incansáveis na lida para que tudo sempre saísse conforme o planejado, e ao Instituto de Letras da UnB, pela infraestrutura necessária nestes anos de estudo.

A todas as instituições que me apoiaram para que eu pudesse fazer o curso de doutorado, principalmente a Universidade Federal do Pará, por meio do Campus Universitário do Tocantins/Cametá, especialmente nas pessoas de Gilmar Pereira, Doriedson Rodrigues e Rubens Ferreira, e a Coordenação de Aperfeiçoamento de Pessoal de Nível Superior (CAPES), que me concedeu auxílio por meio do Programa de Formação Doutoral Docente (Prodoutoral). 
A todas as instituições (secretarias, bibliotecas), representados por seus respectivos coordenadores, secretários e diretores, que apoiaram a pesquisa bibliográfica sobre obras lexicográficas das línguas indígenas do Brasil, principalmente: Biblioteca Central da UnB, Biblioteca Berta e Darcy Ribeiro, Biblioteca Curt Nimuendajú da FUNAI, Biblioteca Brasiliana Guita e José Mindlin, Biblioteca Central da UFPA, Serviço de Biblioteca e Documentação do Museu de Arqueologia e Etnologia da USP, Centro de Estudos Ameríndios da USP, Núcleo de Inclusão Educacional da Secretaria da Educação do Estado de São Paulo, Biblioteca da Associação Brasileira de Imprensa, Centro de Documentação Regional da Fundação Universidade Federal da Grande Dourados, Comut da Biblioteca Universitária da UFSC; Biblioteca do IBGE; Biblioteca do Instituto Histórico e Geográfico Brasileiro; Biblioteca da Brotéria (Portugal); Fundação Biblioteca Nacional do Rio de Janeiro; Biblioteca Acadêmico Luiz Viana Filho do Senado Federal Brasileiro; Bibliothèque National de France; Biblioteca Nacional de Portugal; Deutsche Nationalbibliothek; Escola Sawarapy; e a todas as instituições que mantêm bibliotecas e acervos digitais na internet.

A todos os pesquisadores de línguas indígenas que, gentilmente, me enviaram e/ou me autorizaram a utilizar em minha pesquisa materiais lexicográficos de sua autoria, com certeza essas contribuições foram imprescindíveis para alcançar os resultados desta tese.

Por fim, mas não menos importante, a Ikatu, Tymykong, Muretama, Awasa'i (in memoriam), Waiwera, Miho, Maira e a todas as pessoas do povo Aikewára, gente forte que sobreviveu a grandes adversidades, e que me receberam com toda hospitalidade e confiando na minha proposta de trabalho, agradeço, então, por todo o aprendizado que eles me proporcionaram de sua língua, mas também pelo convívio harmonioso nestes anos e pelas valiosas experiências de vida que adquiri junto a eles: minha eterna gratidão. 
“As línguas indígenas constituem [...] um dos pontos para os quais os linguistas brasileiros deverão voltar a sua atenção. Tem-se aí, sem dúvida, a maior tarefa da linguística no Brasil."

Aryon Dall'Igna Rodrigues (1966, p. 5) 


\section{RESUMO}

A presente tese investiga aspectos fonológicos, morfossintáticos e lexicais da língua indígena Suruí do Tocantins (Mudjetíre, Suruí do Pará, Aikewára) do sub-ramo IV, da família linguística Tupí-Guaraní, tronco Tupí, falada pelo povo Aikewára, os quais vivem na T.I. Tuwa Apekuokawera, localizada próximo à região do Bico do Papagaio, no sudeste do estado do Pará. A tese considera também informações socio-históricos e culturais desse povo, os quais junto com os dados linguísticos são fundamentais para a construção de obras lexicográficas baseadas na língua-cultura de um povo. Foi realizada primeiramente uma pesquisa bibliográfica dos trabalhos linguísticos e antropológicos sobre a língua e o povo Suruí, e, em seguida, uma nova pesquisa bibliográfica permitiu a identificação de grande parte das obras lexicográficas de todas as línguas indígenas brasileiras dos últimos cinco séculos, o que contribuiu, sobremaneira, para a identificação dos diferentes padrões de macro e microestruturas já utilizadas no Âmbito dessas línguas. Uma vez coligidos e analisados esses dados, foi possível chegar a quatorze grupos de modelos lexicográficos, todos devidamente baseados e apresentados na língua Suruí. Paralelamente a essa etapa foi realizada a pesquisa de campo junto ao povo Suruí, sempre contando com a participação de professores Suruí como copesquisadores de sua própria língua. O resultado desta pesquisa foram os dados linguístico-culturais da língua Suruí, gravados e transcritos, e devidamente armazenados em um programa de computador, denominado Línguas - Banco de Dados para Documentação Linguística. Este programa foi desenvolvido especificamente para permitir não somente a documentação desse material linguístico obtido na pesquisa de campo, mas também, a sua utilização para a construção, da maneira mais prática possível, de materiais lexicográficos com diferentes configurações, dentre outros. Foram também tecidas considerações acerca da ortografia da língua Suruí, essencial para o estabelecimento de uma escrita para essa língua. Com isso, tornou-se também possível a proposição e efetivação de duas propostas de materiais lexicográficos da língua Suruí, nas direções Suruí-Português e Português-Suruí, descritas em suas macro e microestruturas, além de seu conteúdo semântico-lexical.

Palavras-chave: Língua Suruí do Tocantins. Modelos lexicográficos. Dicionários da língua Suruí do Tocantins. Programa de Documentação Linguística. 


\begin{abstract}
This work investigates phonological, morphosyntatic, and lexical aspects of Surui of Tocantins language (Mudjetíre, Surui of Pará, Aikewára), which belongs to branch IV of the Tupi-Guarani linguistic family (Tupi stock). The Suruí language is spoken by the Aikewára people, who lives at Sororo Indigenous Land, located near the Bico do Papagaio region, in the southeastern of the Pará state. The study also considers Suruí socio-historical and cultural aspects. A bibliographic review of the literature concerning linguistic and anthropological studies on the Suruí had been the fundamental basis of the present work. A bibliographic research aiming at the identification of most of the Brazilian indigenous languages lexicographical works produced during the past five centuries was also fundamental to empower this dissertation. The linguistic data collected in intermittent field works made it possible to reach fourteen types of lexicographical models, all based and presented in Surui language. Two Suruí teachers participated actively as linguistic researchers of their own language, and the data collected had been recorded, transcribed, and properly stored in a new software named Línguas - Banco de Dados para Documentação Linguística, which had been developed specifically to enable the present lexicographic work, culminating in two lexicographical materials in the Surui language: a Surui-Portuguese version and a PortugueseSurui whith a description of its macro-structures and lexicographical microstructures, including its lexical-semantic content.
\end{abstract}

Keywords: Tocantins Surui language. Lexicographical models. Tocantins Surui language dictionaries. Language Documentation Software. 


\section{RÉSUMÉ}

Ce travail examine les éléments linguistiques (phonologie, morphosyntaxe et lexique) de la langue indigène Suruí du Tocantins (Mudjetíre, Surui du Pará, Aikewára), branche IV, de la famille linguistique tupi-guarani, tronc Tupi, parlée par la population autochtone Aikewára, qui vit dans la Terre Indigène Sororó située près de la région du Bico do Papagaio au sud-est de l'état brésilien de Pará, en outre, on considère également les aspects socio-historiques et culturels de ce peuple, tout cela a contribué à la construction d'ouvrages lexicographiques basés sur cette langue-culture indigène. Pour effectuer cette étude, une recherche documentaire d'études linguistiques et anthropologiques ont été effectuées, il a rendu possible la revue de la littérature; puis une nouvelle recherche bibliographique a conduit à l'identification de la plupart des travaux lexicographiques de toutes les langues indigènes brésiliens des cinq derniers siècles, ce travail et sa systématisation ont largement contribué à l'identification des différents modèles de macrostructures et microstructures utilisées dans ce contexte. Une fois collecté et analysé ces données, il était possible de parvenir à quatorze groupes de modèles lexicographiques, tous basés et présenté dans la langue Surui. En même temps de cette étape, la recherche sur le terrain avec le peuple Surui a été effectuée, toujours avec la participation des enseignants qui sont aussi des chercheurs dans leur propre langue. Le résultat de cette recherche était de données linguistiques et culturelles de la langue de Surui, enregistrés et transcrits, et correctement stocké dans un logiciel appelé Línguas - Banco de Dados para Documentação Linguística, décrit en détail (la configuration et l'utilisation) dans ce travail; il a été développé spécifiquement pour permettre la documentation du matériel linguistique obtenue dans la recherche sur le terrain de la construction et de la pratique de matériaux lexicographiques avec des paramètres différents, par exemple. En outre, il a été nécessaire de revoir l'orthographe de la langue Surui, indispensable de proposer l'écriture de cette langue. Enfin, il était également possible de proposer et de construire deux propositions de matériaux lexicographiques pour la langue Surui, une dans le sens Surui-Portugais et l'autre dans le sens Portugais-Surui; a aussi une description de ses macrostructures et microstructures lexicographiques, au-delà de son contenu lexical-sémantique, tous présentés dans le dernier chapitre.

Mots-clés: Langue Surui du Tocantins. Modèles lexicographiques. Dictionnaires de langue Surui du Tocantins. Logiciel de documentation linguistique. 
FIGURA 01 - UNESCO INTERACTIVE ATLAS OF THE WORLD'S LANGUAGES IN DANGER

FIGURA 04 - FONEMAS VOCÁLICOS DA LÍNGUA SURUÍ.................................................74

FIGURA 02 - PÁGINA DA $1^{\text {a }}$ CARTILHA DE ALFABETIZAÇÃO DA LÍNGUA SURUÍ .............83

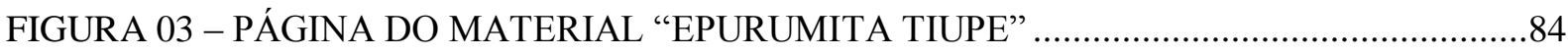

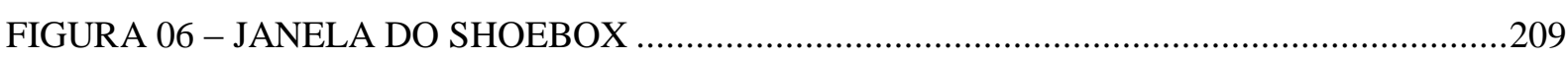

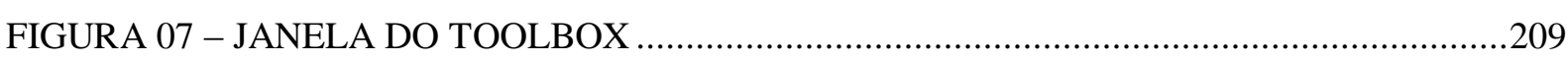

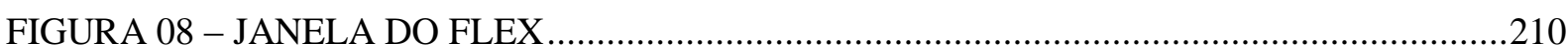

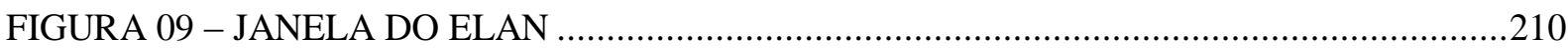

FIGURA 11 - INÍCIO DO ASSISTENTE DE INSTALAÇÃO DO PROGRAMA LÍNGUAS ........218

FIGURA 12 - JANELA 2 DO ASSISTENTE DE INSTALAÇÃO DO PROGRAMA LÍNGUAS ...218

FIGURA 13 - SELEÇÃO DO TIPO DE INSTALAÇÃO DO PROGRAMA LÍNGUAS ..................218

FIGURA 14 - JANELA DE INÍCIO DA INSTALAÇÃO DO PROGRAMA LÍNGUAS ................219

FIGURA 15 - JANELA DE CONCLUSÃO DA INSTALAÇÃO DO PROGRAMA LÍNGUAS .....219

FIGURA 16 - JANELA DE INÍCIO DA DESINSTALAÇÃO DO PROGRAMA LÍNGUAS ..........220

FIGURA 17 - JANELA DE OPÇÕES DA CONFIGURAÇÃO DO PROGRAMA LÍNGUAS........220

FIGURA 18 - JANELA DE DESINSTALAÇÃO DO PROGRAMA LÍNGUAS ............................221

FIGURA 19 - JANELA DE CONCLUSÃO DA DESINSTALAÇÃO DO PROGRAMA

LÍNGUAS

FIGURA 20 - JANELA DO WINDOWS PARA DESINSTALAÇÃO DO PROGRAMA

LÍNGUAS

FIGURA 21 - JANELA DE SOLICITAÇÃO DE SENHA INICAL DO PROGRAMA

LÍNGUAS

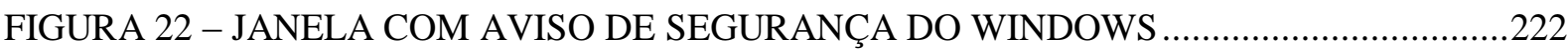

FIGURA 23 - JANELA DE ACESSO PRINCIPAL DO PROGRAMA LÍNGUAS .........................223

FIGURA 24 - MENSAGEM DE ACESSO PERMITIDO NO PROGRAMA LÍNGUAS .................223

FIGURA 25 - JANELA DO PROGRAMA LÍNGUAS COM INFORMAÇÕES E LINKS

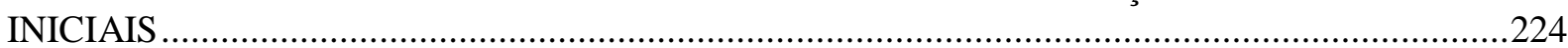

FIGURA 26 - JANELA DA ÁREA DE RECUPERAÇÃO DE SENHAS ......................................224

FIGURA 27 - JANELA PARA ATUALIZAÇÃO DE SENHA DE USUÁRIO...............................225

FIGURA 28 - JANELA PRINCIPAL DA ÁREA DE TRABALHO DO PROGRAMA LÍNGUAS.225

FIGURA 29 - JANELA DA ÁREA DE PROJETO DO PROGRAMA LÍNGUAS ..........................226

FIGURA 30 - JANELA DA ÁREA DE PROJETO DO PROGRAMA LÍNGUAS ..........................227

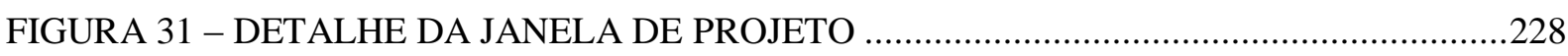

FIGURA 32 - JANELA DE CADASTRO DAS LÍNGUAS DO PDL …........................................229

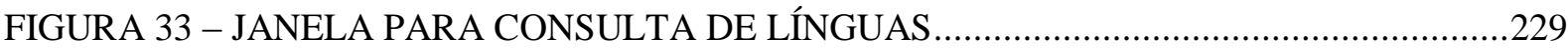


FIGURA 34 - JANELA PARA CADASTRO DE ABREVIATURAS …......................................230

FIGURA 35 - JANELA COM O TECLADO VIRTUAL DO PROGRAMA LÍNGUAS .................231

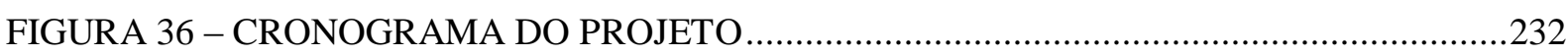

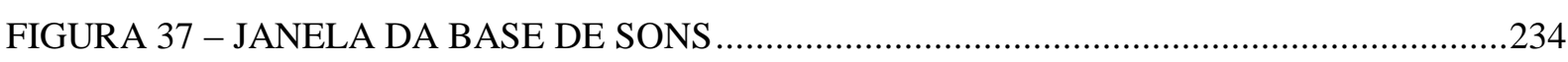

FIGURA 38 - JANELA DA BASE DE FONTES DO CONHECIMENTO ...................................236

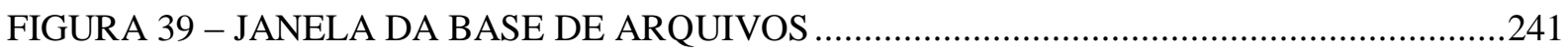

FIGURA 40 - EXPLICAÇÃO DO CÓDIGO-BASE PARA REGISTRO DE ARQUIVOS ..............243

FIGURA 41 - EXPLICAÇÃO DO CÓDIGO-BASE PARA REGISTRO DE ARQUIVOS

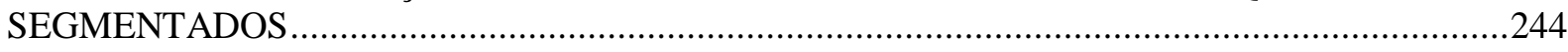

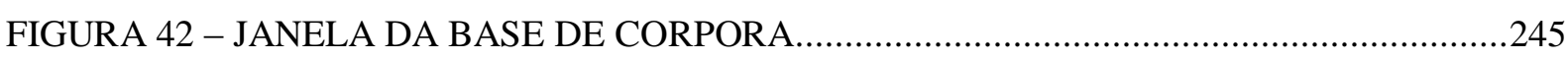

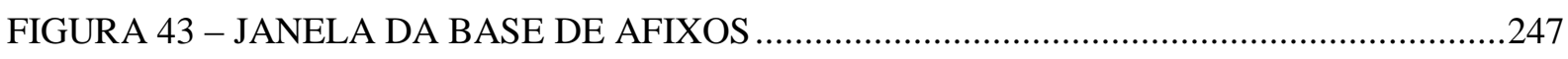

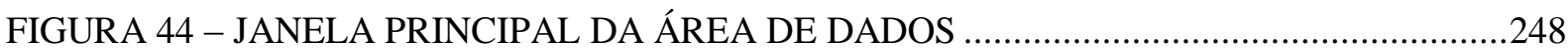

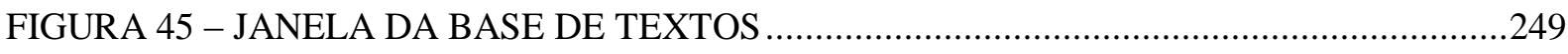

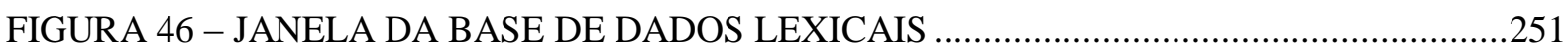

FIGURA 47 - ABA MARCADORES DA BASE DE DADOS LEXICAIS ...................................254

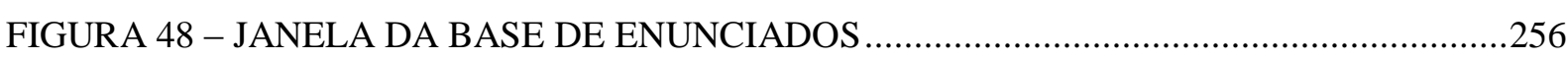

FIGURA 49 - JANELA DA BASE DE COMPARAÇÃO DE ITENS LEXICAIS ............................257

FIGURA 50 - JANELA DE COMPARAÇÃO DE ITENS LEXICAIS .............................................259

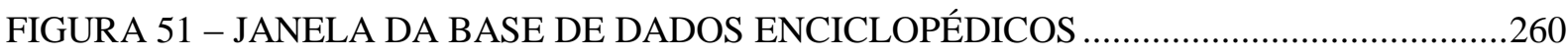

FIGURA 52 - JANELA DA ÁREA DE ANOTAÇÕES DO PROGRAMA LÍNGUAS ...................262

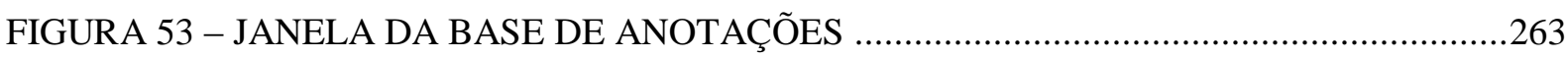

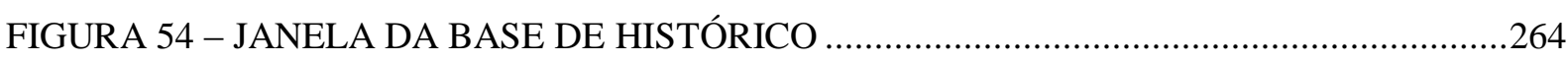

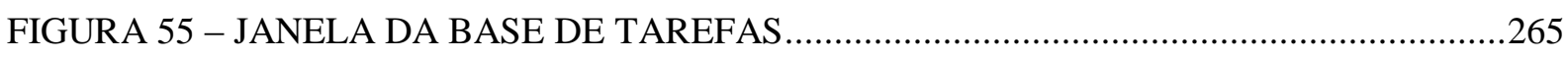

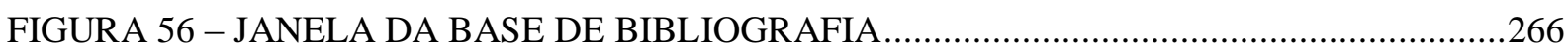

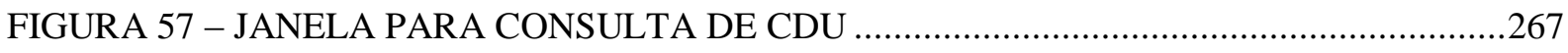

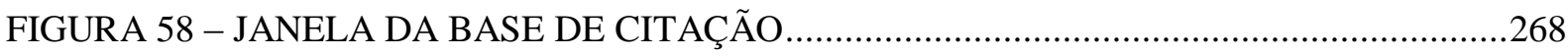

FIGURA 59 - JANELA DE CADASTRAMENTO DE PALAVRAS-CHAVE ................................268

FIGURA 60 - JANELA DA BASE DE NOTAS LINGUÍSTICAS .................................................269

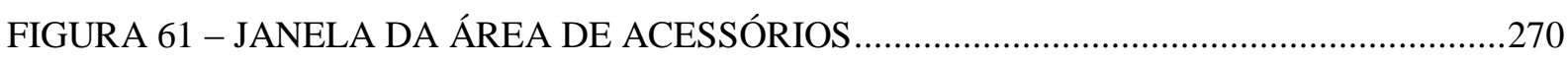

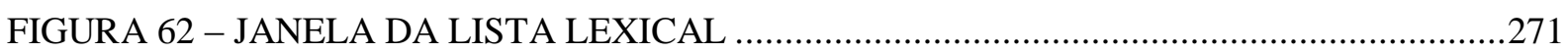

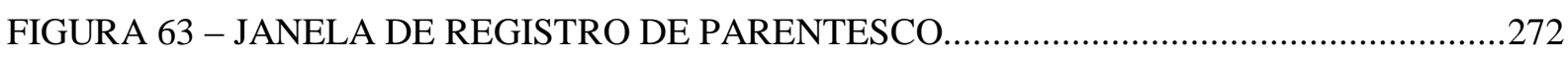

FIGURA 64 - PARTE INFERIOR DA JANELA DA ÁREA DE TRABALHO ..............................273

FIGURA 65 - JANELA PARA INSERÇÃO DA SENHA DE ACESSO ..........................................273

FIGURA 66 - JANELA DE AVISO DE PERMISS ÃO..............................................................274

FIGURA 67 - JANELA PRINCIPAL DA ÁREA DE EDIÇÃO ..................................................274

FIGURA 68 - EXEMPLO DE ÁREA DE EDIÇÃO DE DADOS INSERIDOS EM BASES...........275

FIGURA 69 - CAIXA DE DIÁLOGO PARA LOCALIZAÇÃO OU SUBSTITUIÇÃO DE

DADOS NO PROGRAMA LÍNGUAS 
FIGURA 70 - JANELA DA ÁREA DE MATERIAIS

FIGURA 71 - JANELA DO MICROSOFT WORD PARA PERMISSÃO DO USO DE

BANCO DE DADOS EXTERNO.

FIGURA 72 - JANELA DE ÁREA PARA PRODUÇÃO DE MATERIAIS: PROJETOS ................278

FIGURA 73 - JANELA DE ÁREA PARA PRODUÇÃO DE MATERAIS: BIBLIOGRAFIA.........280

FIGURA 74 - JANELA DE ÁREA PARA PRODUÇÃO DE MATERAIS: TEXTOS E

ENUNCIADOS

FIGURA 75 - JANELA DE ÁREA PARA PRODUÇÃO DE MATERAIS: ABA 1 ........................282

FIGURA 76 - JANELA DE ÁREA PARA PRODUÇÃO DE MATERAIS: ENCICLOPÉDIAS .....285

FIGURA 77 - JANELA DE ÁREA PARA PRODUÇÃO DE MATERAIS: COMPARAÇÃO

DE LÍNGUAS E NOTAS LINGUÍSTICAS ........................................................................... 286

FIGURA 78 - JANELA PRINCIPAL DA ÁREA DE SEGURANÇA ...........................................28

FIGURA 79 - ÁREA PARA VISUALIZAÇÃO DE RELATÓRIOS DO PROGRAMA

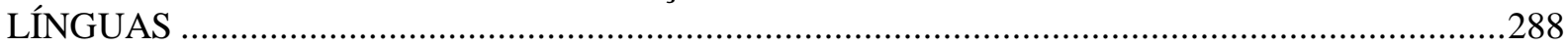

FIGURA 80 - OPÇÕES PARA EXPORTAÇÃO DOS RELATÓRIOS...........................................28

FIGURA 81 - OPÇÕES DE TIPOS DE DOCUMENTOS PARA EXPORTAÇÃO DOS

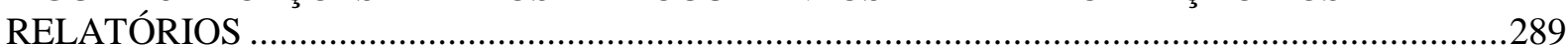

FIGURA 82 - EXPORTAÇÃO DE DADOS NO FORMATO DE TABELAS DO EXCEL .............290

FIGURA 83 - ÁREA PARA GERAÇÃO DA CÓPIA DE SEGURANÇA ……...............................291

FIGURA 84 - ÁREA PARA CONFIGURAÇÃO DO REGISTRO DE USUÁRIOS DO

PROGRAMA LÍNGUAS

FIGURA 85 - JANELA PARA INSERÇÃO DA PERGUNTA DE SEGURANÇA PARA

REDEFINIÇÃO DE SENHAS

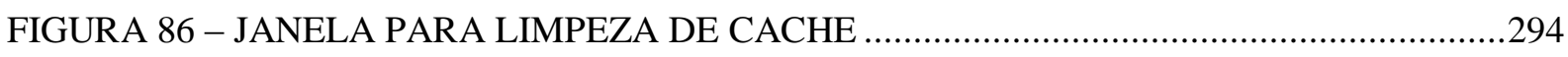

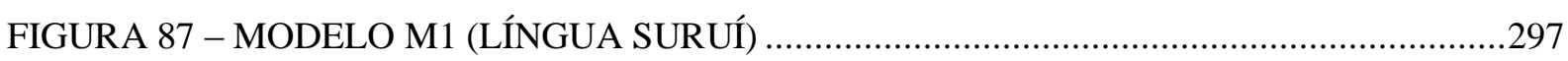

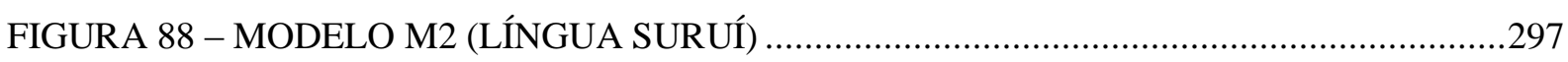

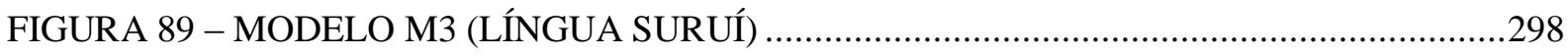

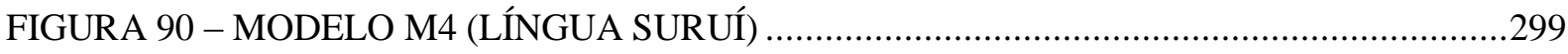

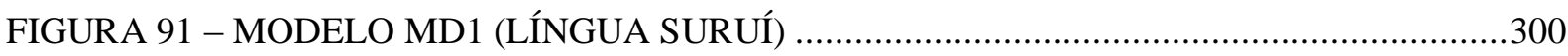

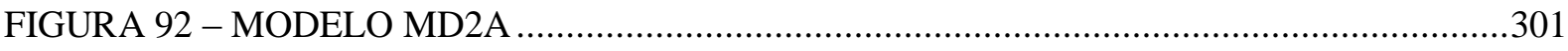

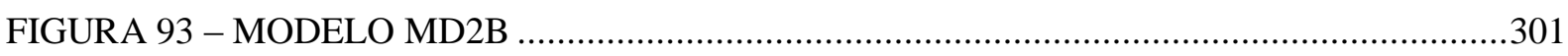

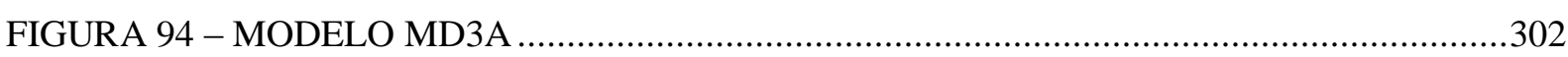

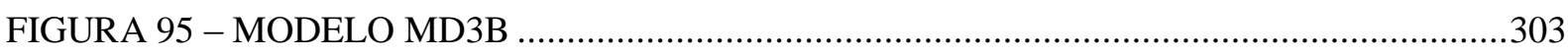

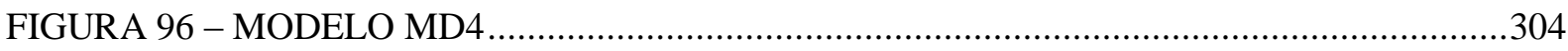

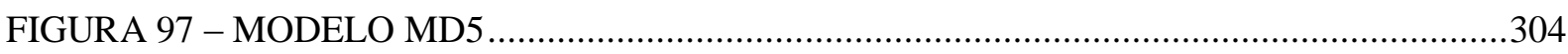

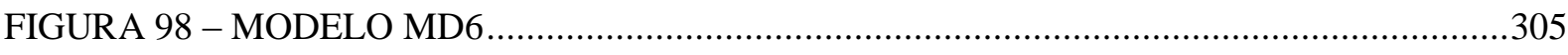

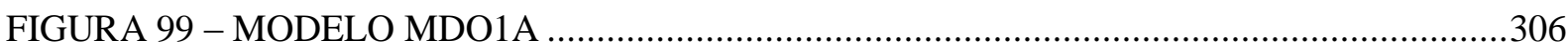

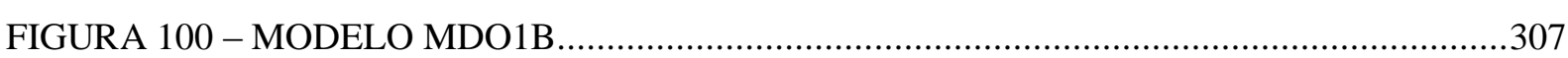

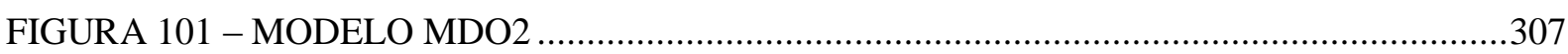

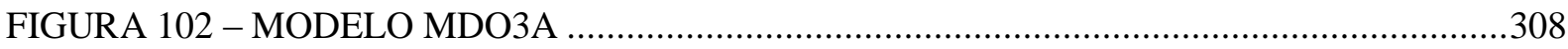




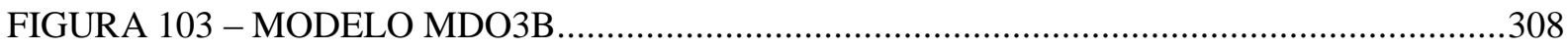

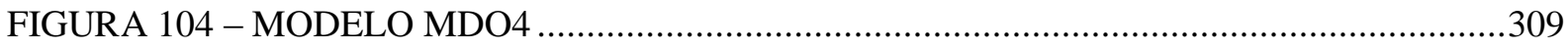

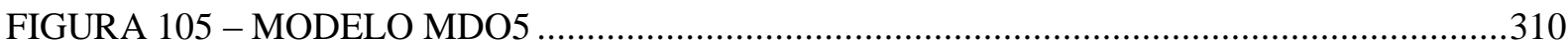

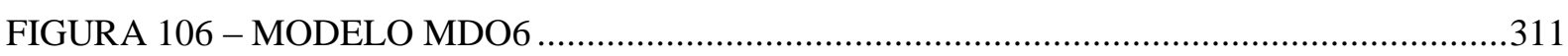

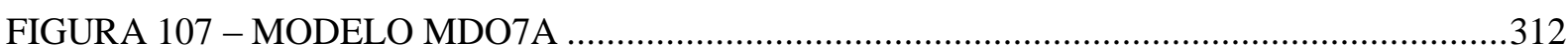

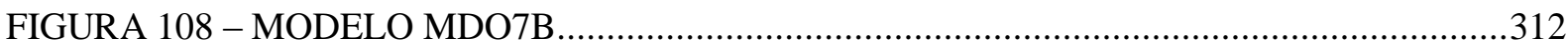

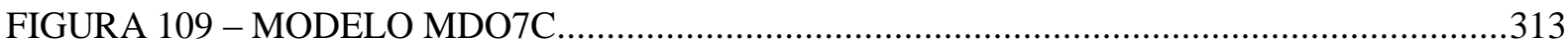

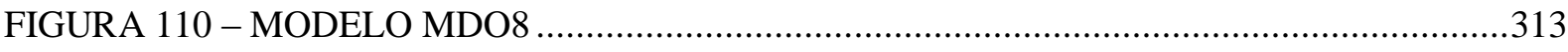

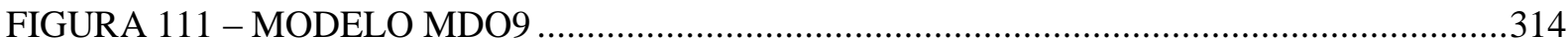

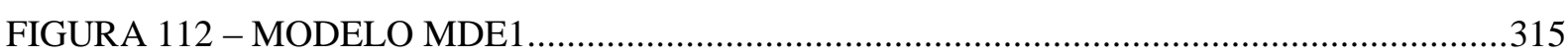

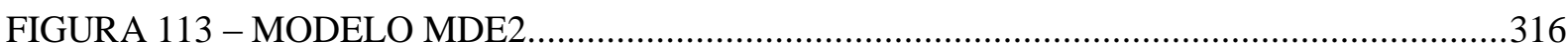

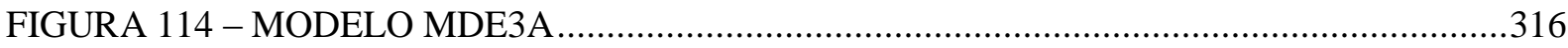

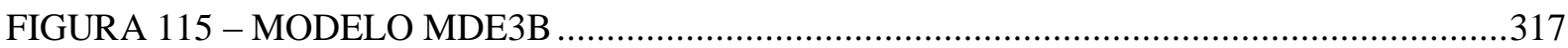

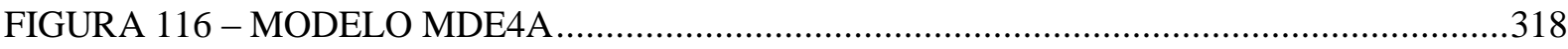

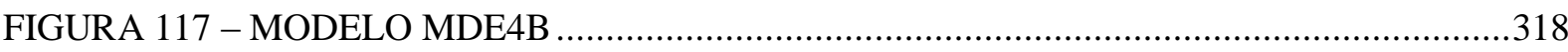

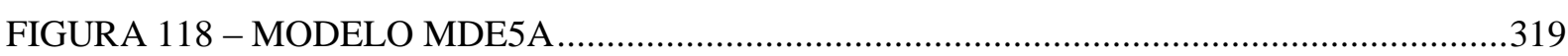

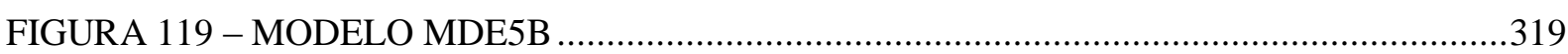

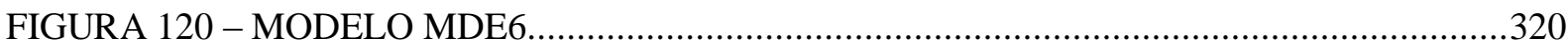

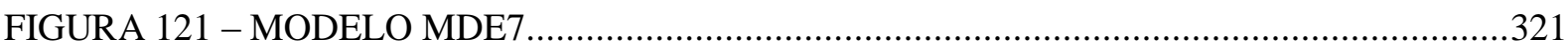

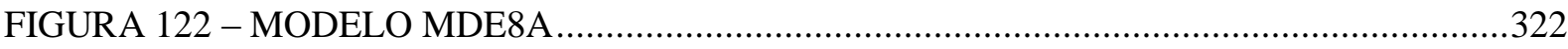

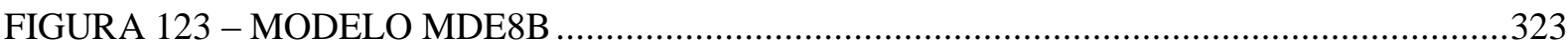

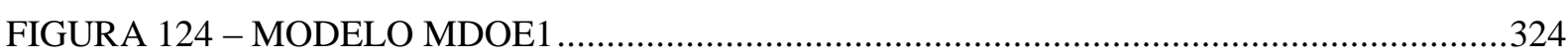

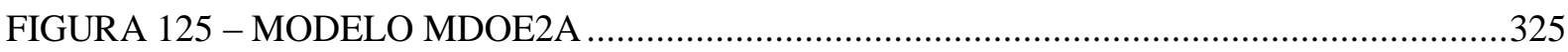

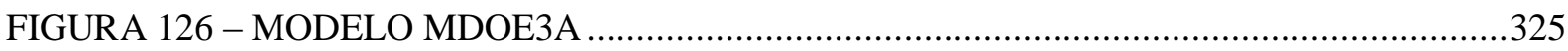

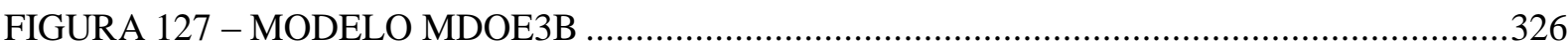

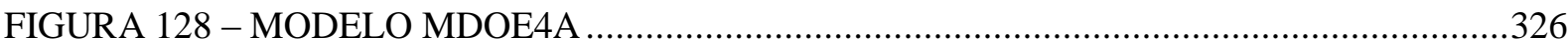

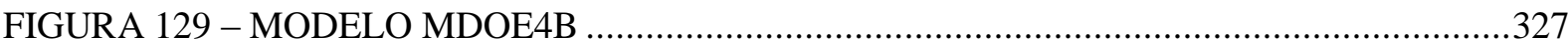

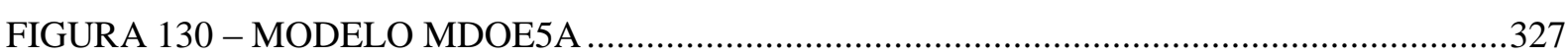

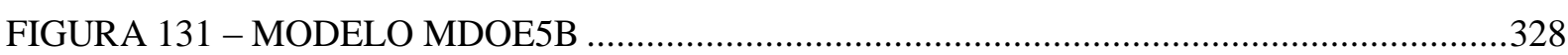

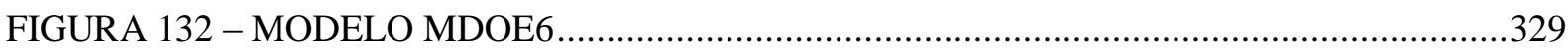

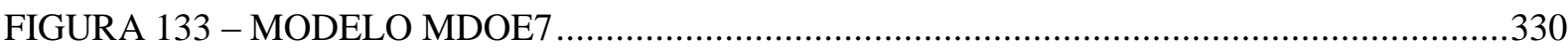

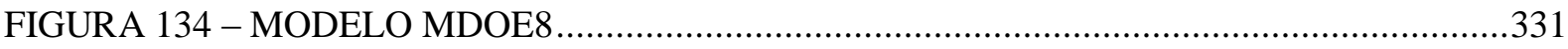

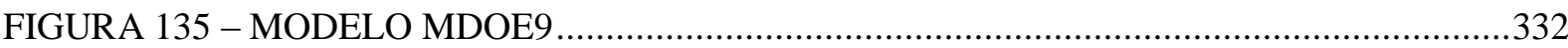

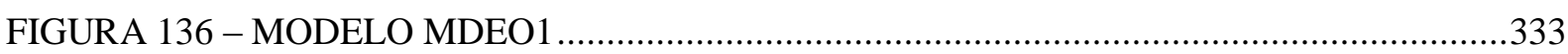

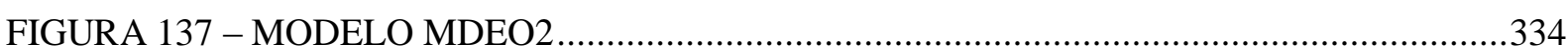

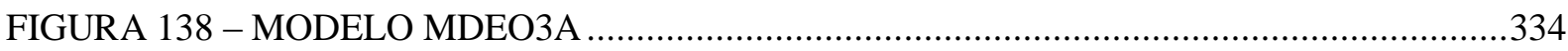

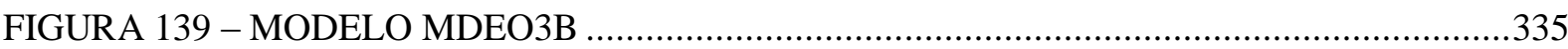




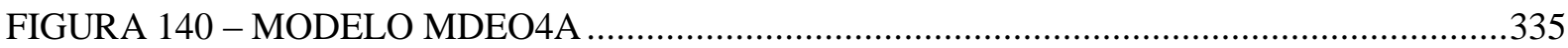

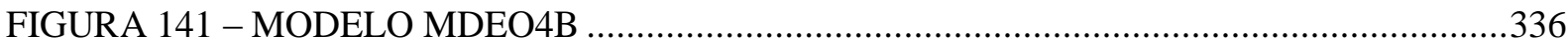

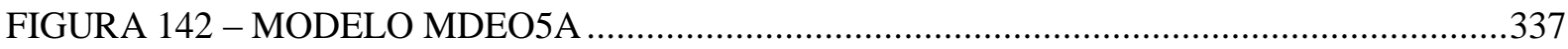

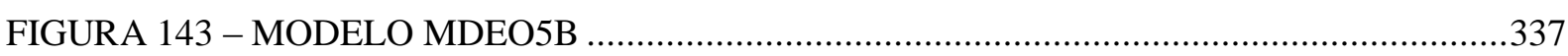

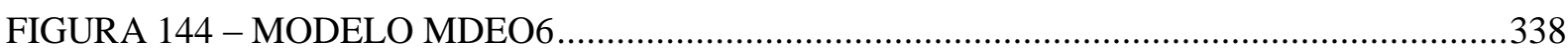

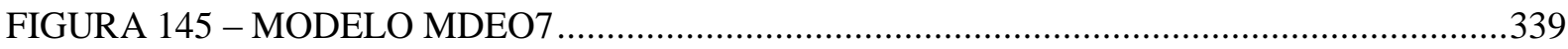

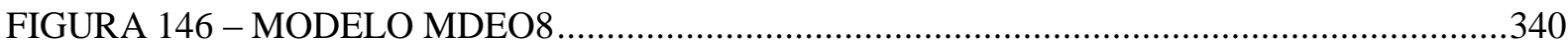

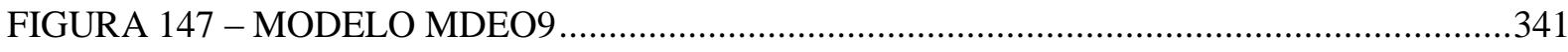

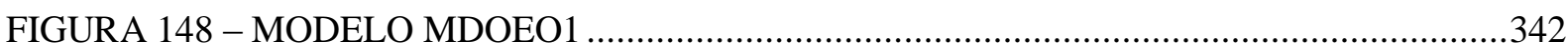

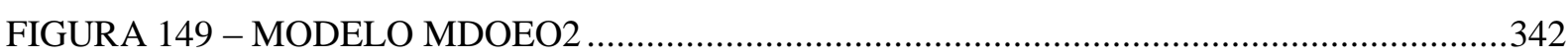

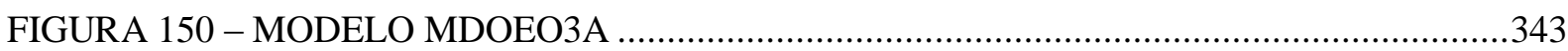

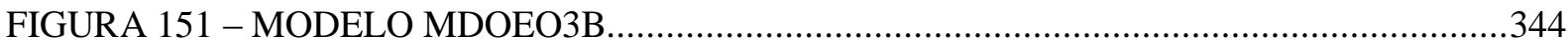

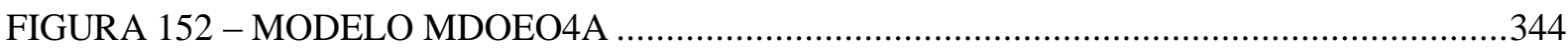

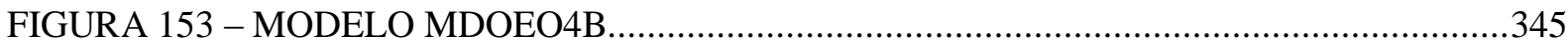

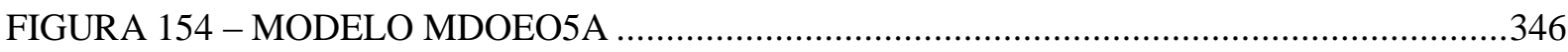

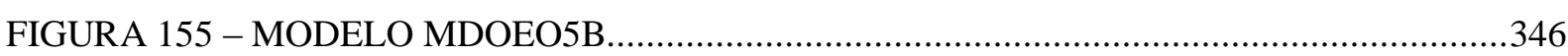

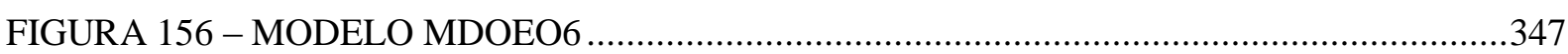

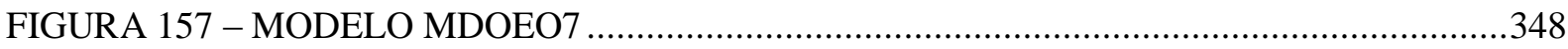

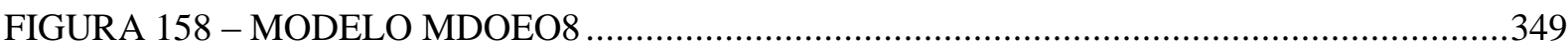

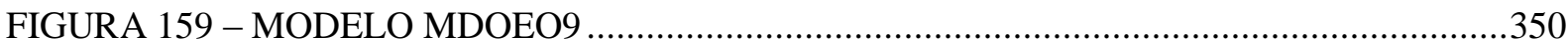

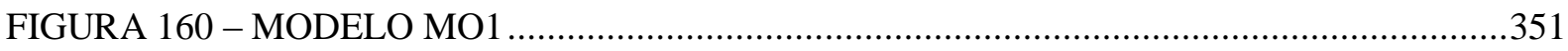

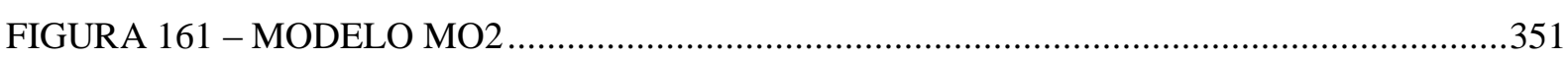

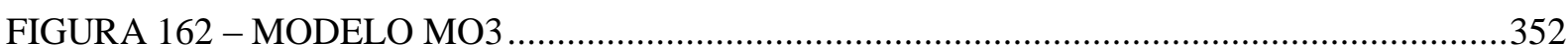

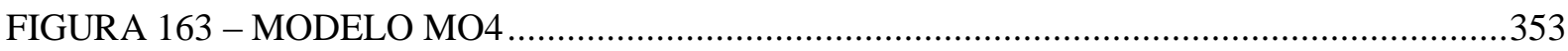

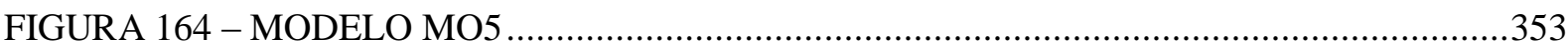

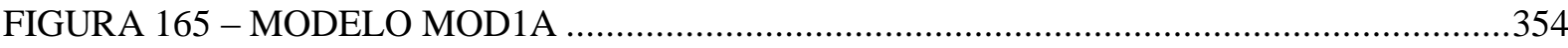

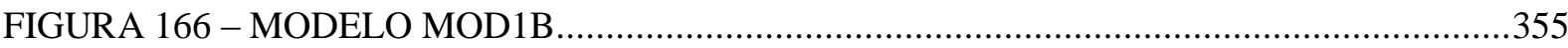

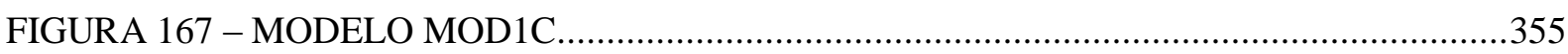

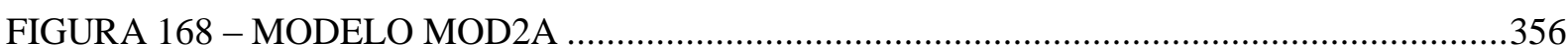

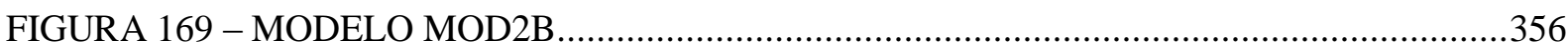

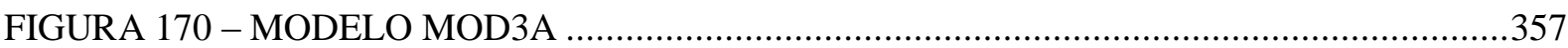

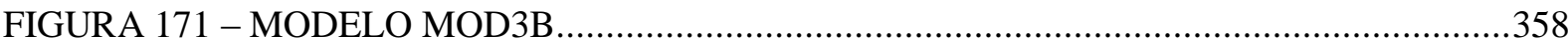

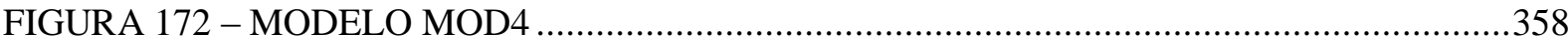

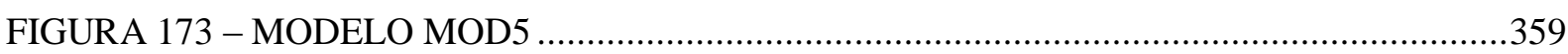

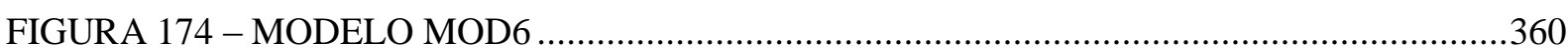

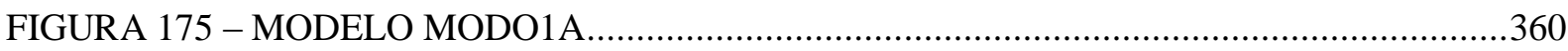

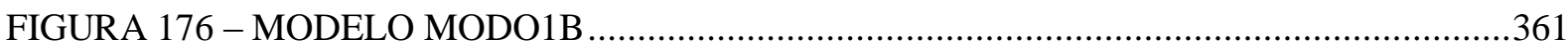




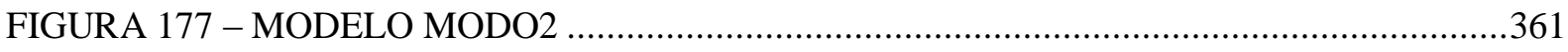

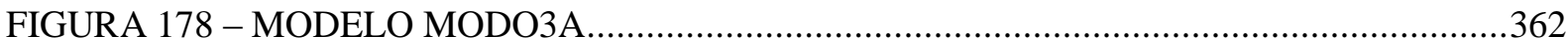

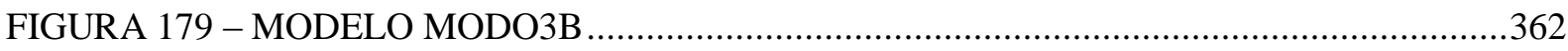

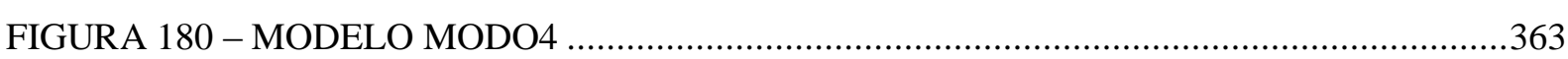

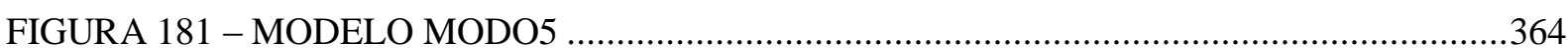

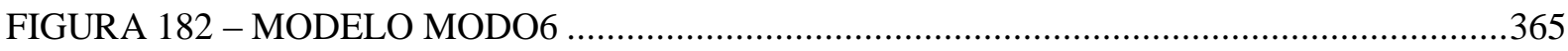

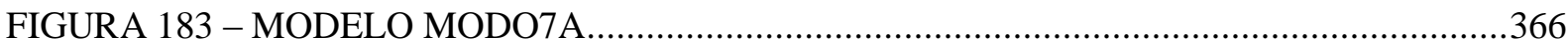

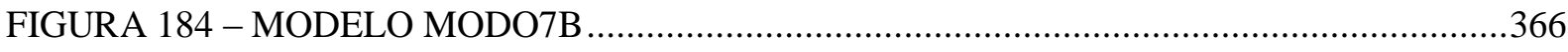

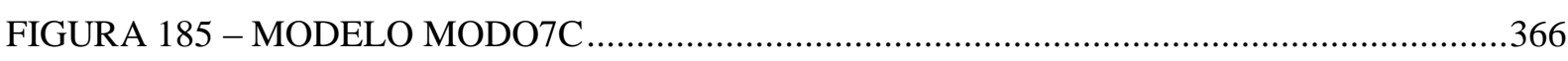

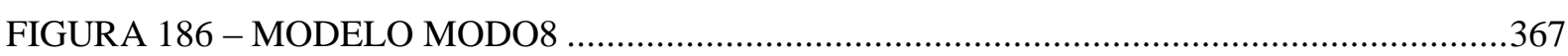

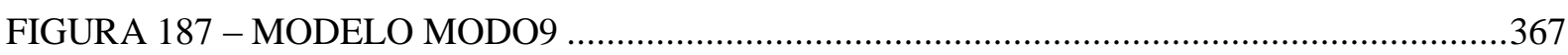

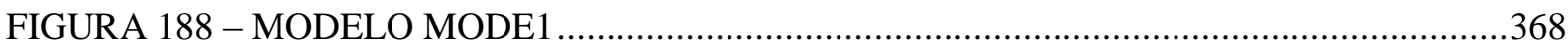

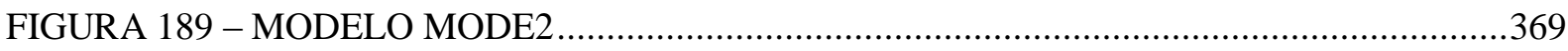

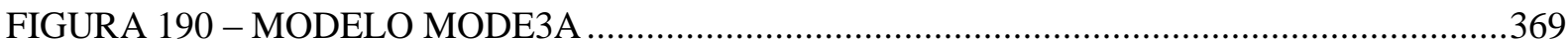

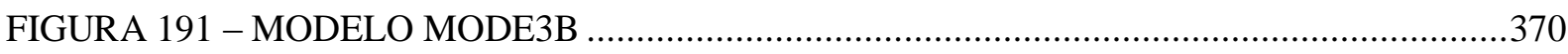

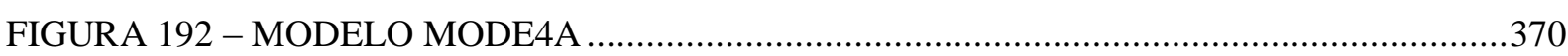

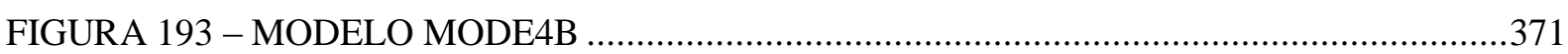

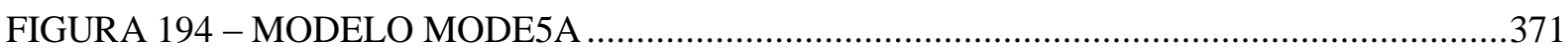

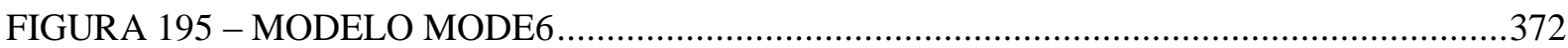

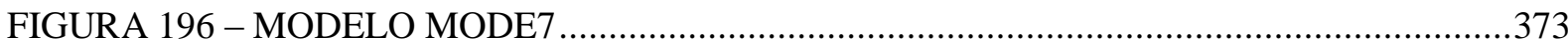

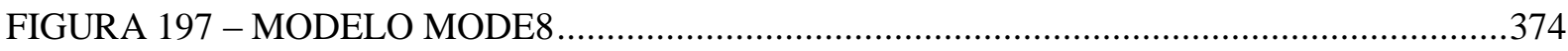

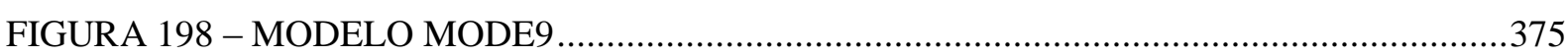

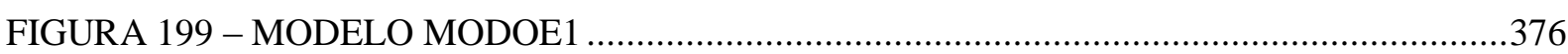

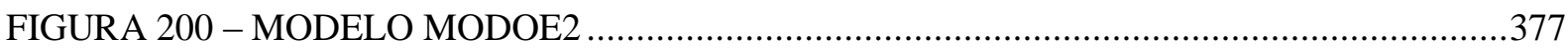

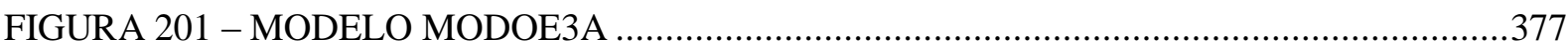

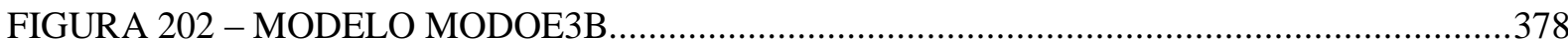

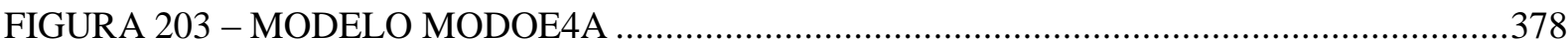

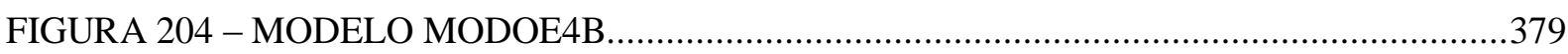

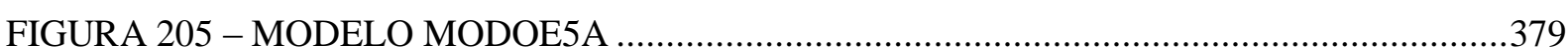

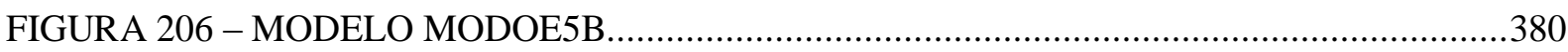

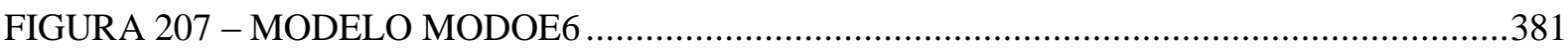

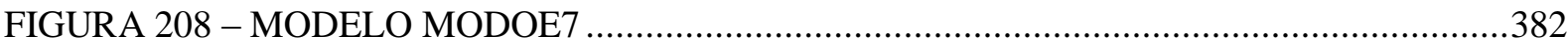

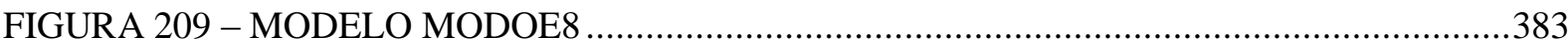

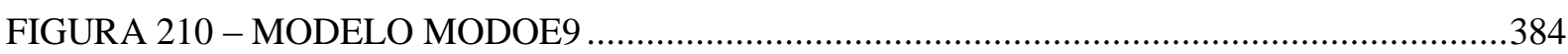

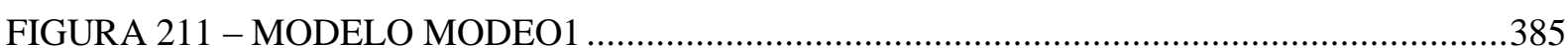

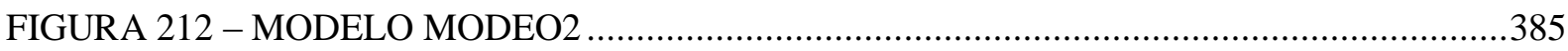

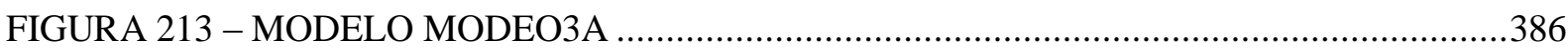




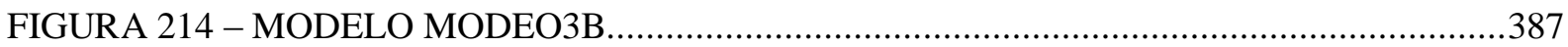

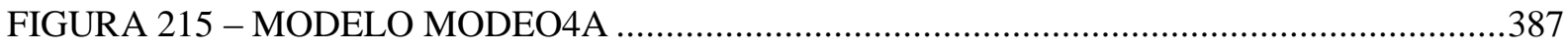

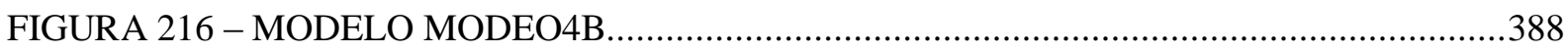

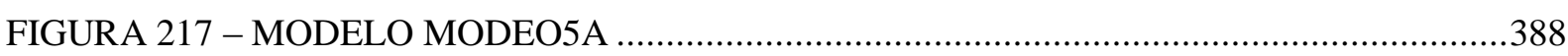

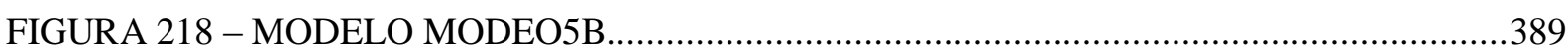

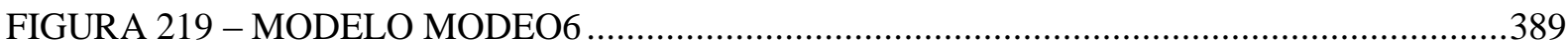

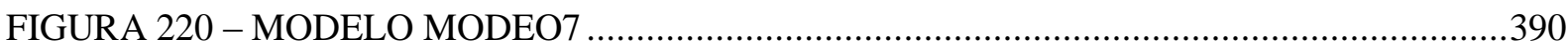

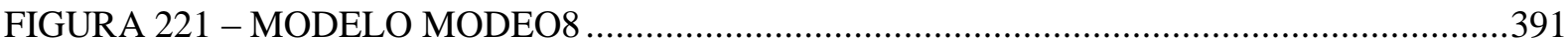

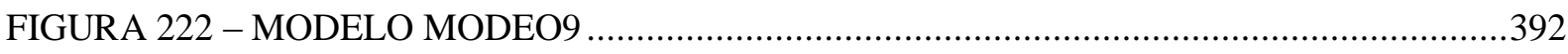

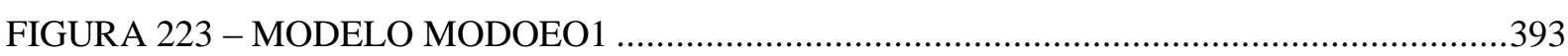

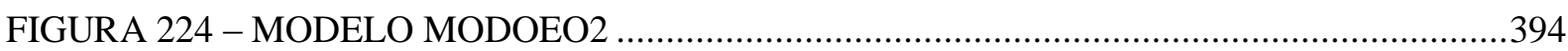

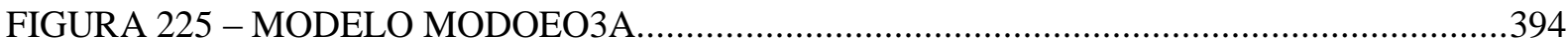

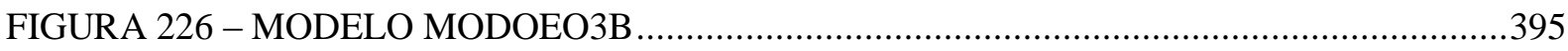

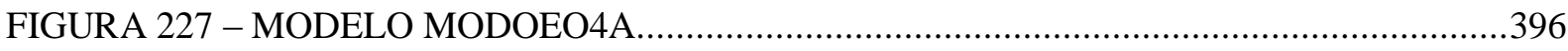

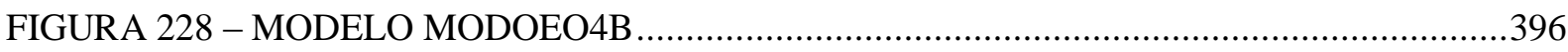

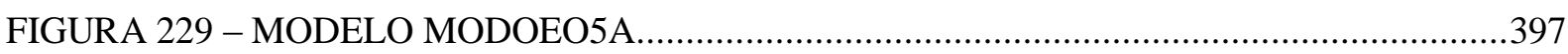

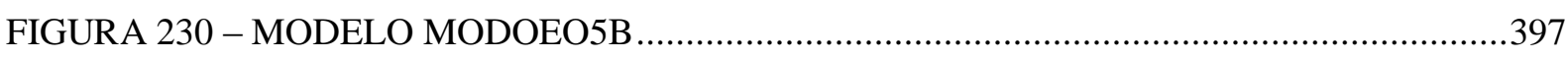

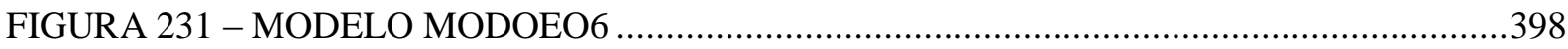

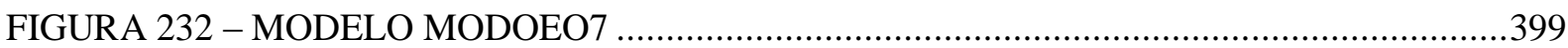

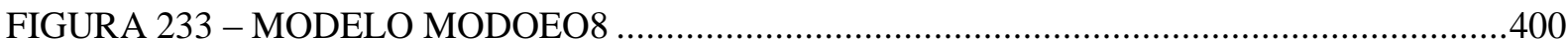

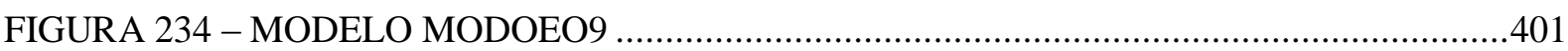




\section{LISTA DE GRÁFICOS}

GRÁFICO 01 - QUANTIDADE DE TIPOS DE MATERIAIS LEXICOGRÁFICOS DAS LIINGUAS INDÍGENAS BRASILEIRAS

GRÁFICO 02 - QUANTIDADE DE UBL'S DE LÍNGUAS INDÍGENAS BRASILEIRAS AGRUPADAS EM TRONCOS LINGUÍSTICOS 172

GRÁFICO 03 - FAMÍLIAS COM MAIOR QUANTIDADE DE UBL'S 174

GRÁFICO 04 - FAMÍLIAS COM QUANTIDADE INTERMEDIÁRIA DE UBL'S 174

GRÁFICO 05 - FAMÍLIAS COM MENOR QUANTIDADE DE UBL'S

GRÁFICO 06 - ESTATÍSTICA DO CONTEÚDO SEMÂNTICO-LEXICAL DA BASE DA LÍNGUA SURUÍ DO TOCANTINS 
QUADRO 01 - ESCALA DOS GRAUS DE RISCO REFERENTES À TRANSMISSÃO DE UMA LÍNGUA DE UMA GERAÇÃO À OUTRA

QUADRO 02 - SÍMBOLOS USADOS PELOS LINGUISTAS PARA REPRESENTAR OS FONEMAS DA LÍNGUA SURUÍ

QUADRO 03 - FONEMAS CONSONANTAIS DA LÍNGUA SURUÍ...............................................74

QUADRO 04 - PADRÃO SILÁBICO CVC DA LÍNGUA SURUÍ....................................................75

QUADRO 05 - PADRÃO SILÁBICO V DA LÍNGUA SURUÍ DO TOCANTINS............................76

QUADRO 06 - PADRÃO SILÁBICO CV DA LÍNGUA SURUÍ DO TOCANTINS .........................76

QUADRO 07 - PADRÃO SILÁBICO VC DA LÍNGUA SURUÍ DO TOCANTINS .........................77

QUADRO 08 - PROPOSTAS DE ESCRITA DA LÍNGUA SURUÍ DO TOCANTINS .....................85

QUADRO 09 - PROPOSTA DE ESCRITA DAS VOGAIS DA LÍNGUA SURUÍ ..........................87

QUADRO 10 - PROPOSTA DE ESCRITA DAS CONSOANTES DA LÍNGUA SURUÍ ................88

QUADRO 11 - PROPOSTA DE ORDEM ALFABÉTICA PARA A LÍNGUA SURUÍ, COM

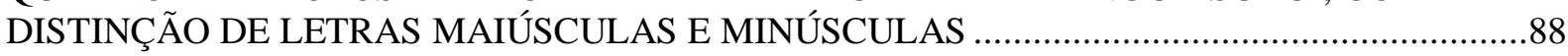

QUADRO 12 - MATRIZ COMPONENCIAL DOS PREFIXOS PESSOAIS EM SURUÍ,

BASEADO NA PROPOSTA DE RODRIGUES (2010, P. 13)

QUADRO 13 - DISTRIBUIÇÃO DOS PREFIXOS DAS CATEGORIAS R ${ }^{1}$ A R $^{4}$, SEGUNDO

AS CLASSES E SUBCLASSES DAS RAIIZES

QUADRO 14 - MATRIZ COMPONENCIAL DOS DEMONSTRATIVOS NA

LÍNGUA SURUÍ.

QUADRO 15 - MATRIZ COMPONENCIAL DOS PRONOMES (SÉRIE I)

QUADRO 16 - AS TRÊS SÉRIES DE PRONOMES E O DATIVO

QUADRO 17 - DA TIPOLOGIA DE MATERIAIS LEXICOGRÁFICOS 148

QUADRO 18 - PROPOSTA DE CÓDIGOS PARA CLASSIFICAÇÃO DAS QUANTIDADES

DE ENTRADAS DOS MATERIAIS LEXICOGRÁFICOS DE LÍNGUAS INDÍGENAS

BRASILEIRAS

QUADRO 19 - SIGLAS UTILIZADAS NA DESCRIÇÃO DE MICROESTRUTURAS .................160

FIGURA 05 - TRECHO DO DICIONÁRIO DA LÍNGUA ASURINÍ DO TOCANTINS

QUADRO 20 - DISTRIBUIÇÃO DAS 871 UBL'S DE ACORDO COM A PROPOSTA DE CLASSIFICAÇÃO QUANTITATIVA POR FAIXAS

QUADRO 21 - DISTRIBUIÇÃO DE 4 TIPOS DE UBL'S DE ACORDO COM A PROPOSTA

DE CLASSIFICAÇÃO QUANTITATIVA POR FAIXAS

QUADRO 22 - LÍNGUAS QUE OCUPAM A POSIÇÃO DO LEMA DOS VERBETES DAS UBL'S DAS LÍNGUAS INDÍGENAS BRASILEIRAS

QUADRO 23 - LÍNGUAS QUE OCUPAM A POSIÇÃO IMEDIATA APÓS O LEMA DOS

VERBETES DAS UBL'S DAS LÍNGUAS INDÍGENAS BRASILEIRAS

QUADRO 24 - CLASSIFICAÇÃO DAS MACROESTRUTURAS DAS UBL'S DAS LÍNGUAS

INDÍGENAS BRASILEIRAS SEGUNDO A ORDEM ADOTADA. 
QUADRO 25 - TIPOLOGIA PARA CLASSIFICAÇÃO DAS MICROESTRUTURAS DA UBL'S DAS LÍNGUAS INDÍGENAS BRASILEIRAS

QUADRO 26 - DA DISTRIBUIÇÃO DAS MICROESTRUTURAS DE UBL'S SEGUNDO A TIPOLOGIA PROPOSTA

QUADRO 27 - DISTRIBUIÇÃO DE UBL'S SEGUNDO A TIPOLOGIA PROPOSTA PARA CLASSIFICAÇÃO DE MICROESTRUTURAS 
TABELA 01 - RESUMO DA CRONOLOGIA HISTÓRICA E DEMOGRÁFICA DOS SURUÍ .......45

TABELA 02 - DENOMINAÇÕES DO POVO / DA LÍNGUA SURUÍ..............................................50

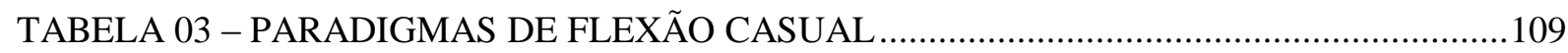

TABELA 04 - PARADIGMAS DE FLEXÃO DETERMINATIVA COM PREFIXOS

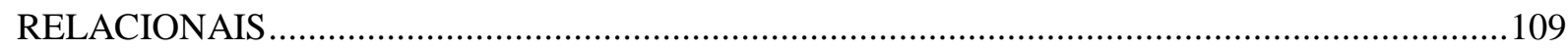

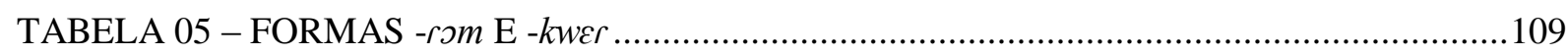

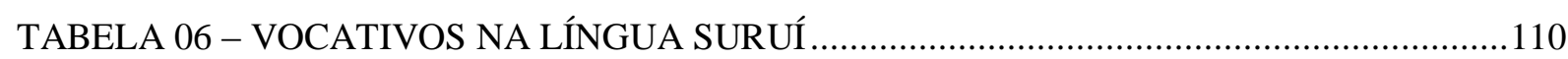

TABELA 07 - QUANTIDADE DE UBL'S REFERENTES AO SÉCULO XVI .............................176

TABELA 08 - QUANTIDADE DE UBL'S REFERENTES AO SÉCULO XVII .............................177

TABELA 09 - QUANTIDADE DE UBL'S REFERENTES AO SÉCULO XVIII ............................177

TABELA 10 - QUANTIDADE DE UBL'S REFERENTES AO SÉCULO XIX …...........................178

TABELA 11 - QUANTIDADE DE UBL'S REFERENTES AO SÉCULO XX...............................179

TABELA 12 - QUANTIDADE DE UBL'S REFERENTES AO SÉCULO XXI …..........................180

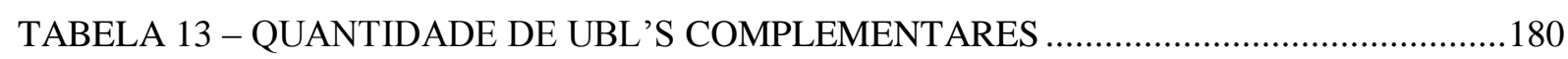

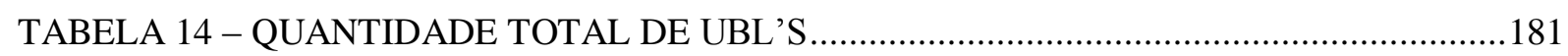

TABELA 15 - QUANTIDADE DE UBL'S REGISTRADAS POR LÍNGUA .................................183

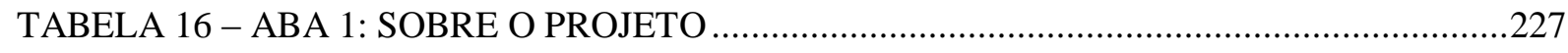

TABELA 17 - DADOS DA JANELA DE REGISTRO DE ABREVIATURAS ..............................220

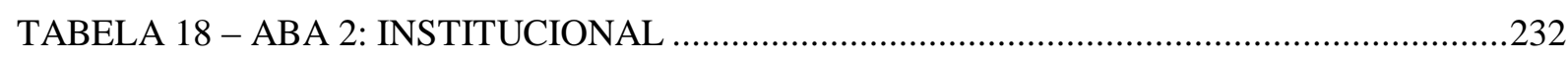

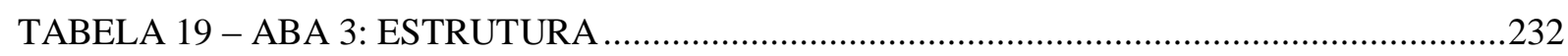

TABELA 20 - CAMPOS DA JANELA DE CRONOGRAMA DO PROJETO …...........................233

TABELA 21 - ABA 4: ORIENTAÇÕES PARA COLETA DE DADOS ...........................................233

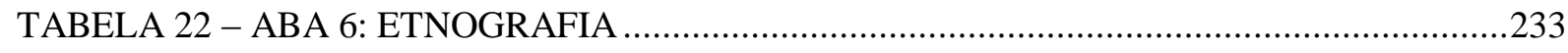

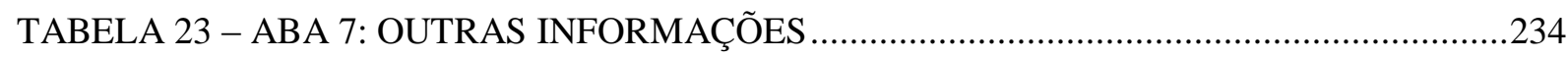

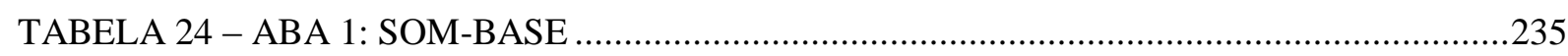

TABELA 25 - ABAS 2 E 3 - REALIZAÇÕES DO SOM-BASE (1) E (2)...................................235

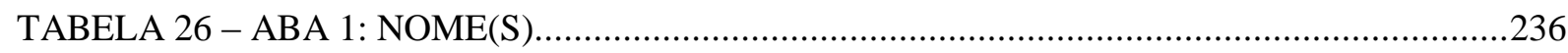

TABELA 27 - ABA 2: DADOS SOCIODEMOGRÁFICOS …......................................................23

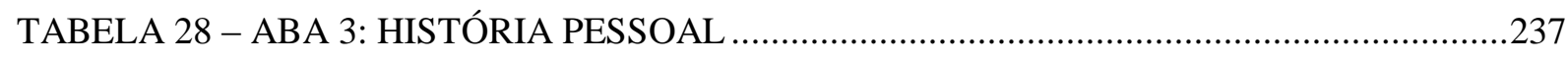

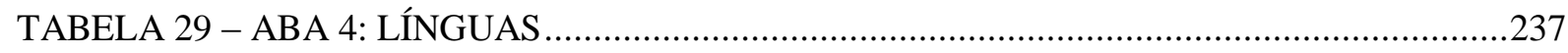

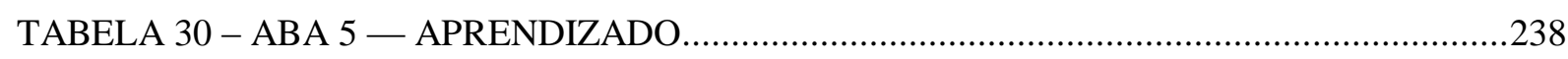

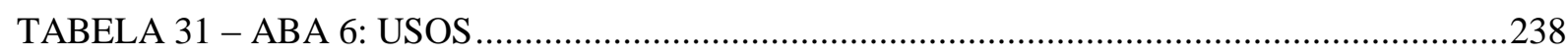

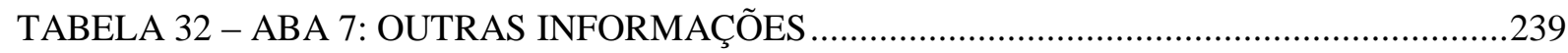

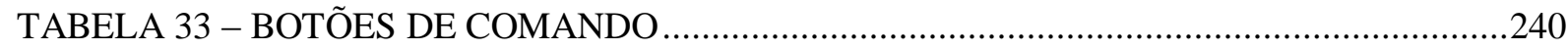


TABELA 34 - CAMPOS DA BASE DE ARQUIVOS.

TABELA 35 - EXPLICAÇÃO DOS COMPONENTES DO CÓDIGO-BASE .................................243

TABELA 36 - INFORMAÇÃO COMPLEMENTAR DO CÓDIGO-BASE ......................................24

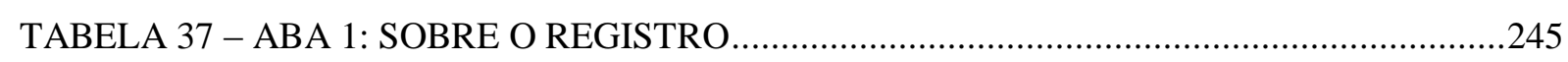

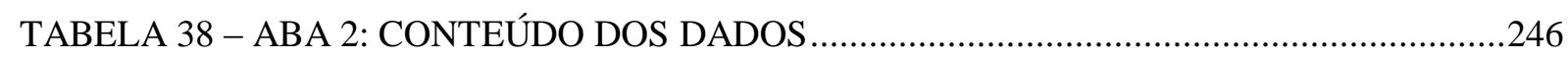

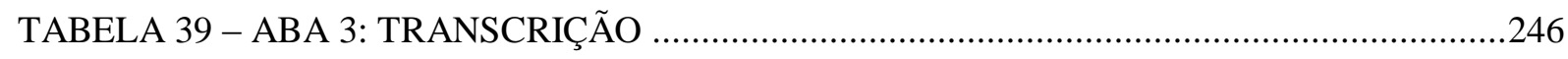

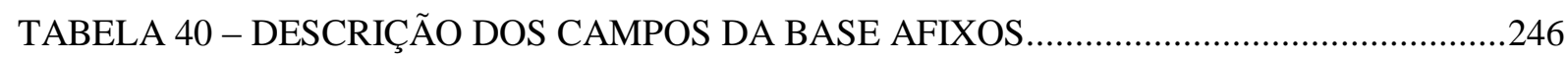

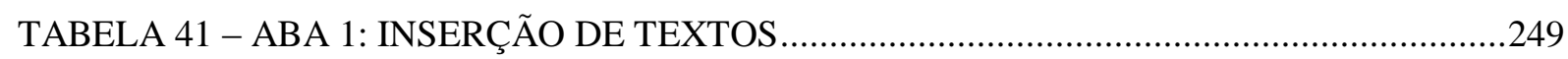

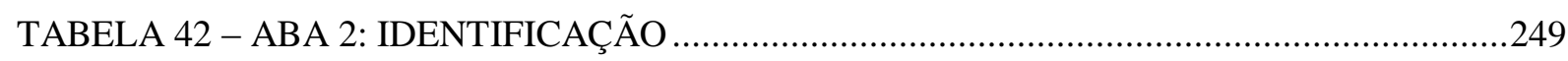

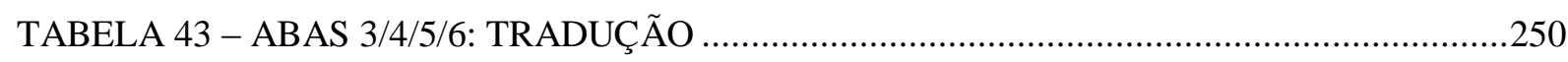

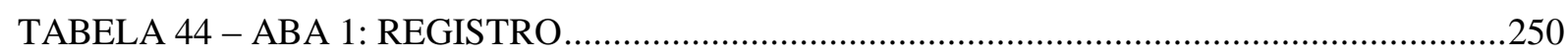

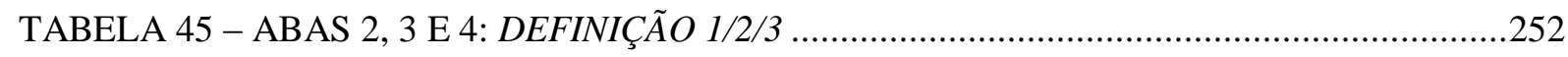

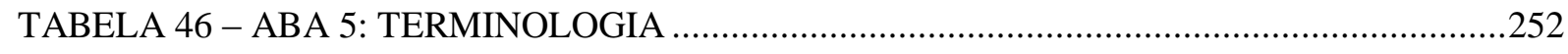

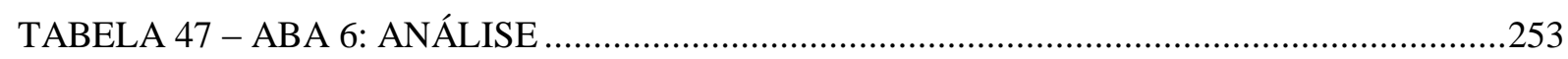

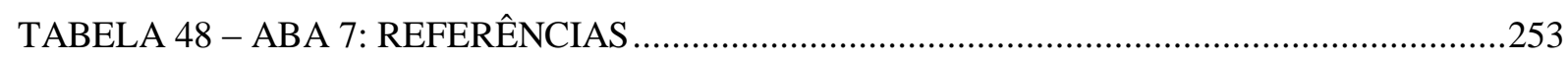

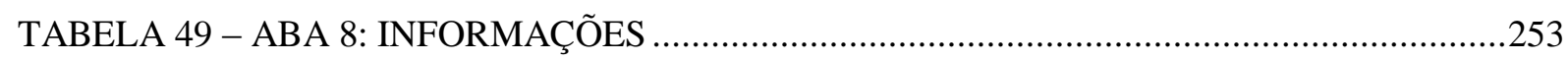

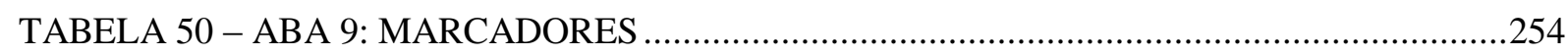

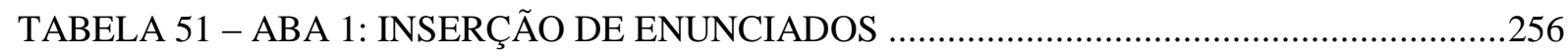

TABELA 52 - ABA 2: INFORMAÇÕES COMPLEMENTARES ….............................................25

TABELA 53 - ABA 1: INSERÇÃO DE DADOS LINGUÍSTICOS ...............................................258

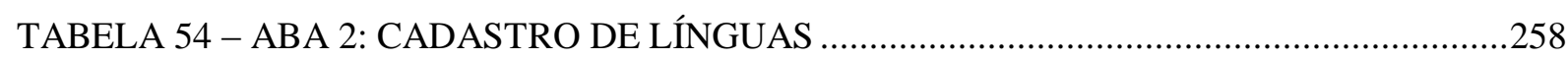

TABELA 55 - CAMPOS DA BASE DE COMPARAÇÃO DE ITENS LEXICAIS .........................259

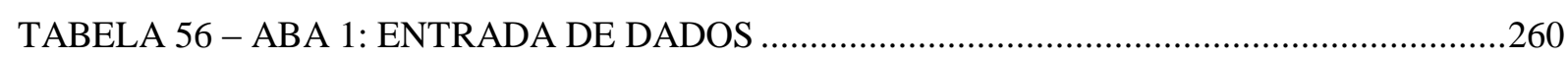

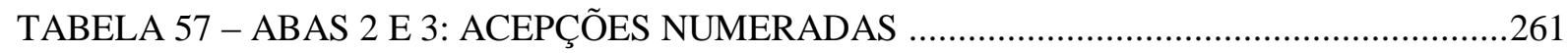

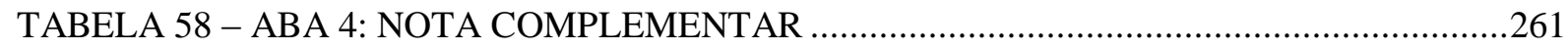

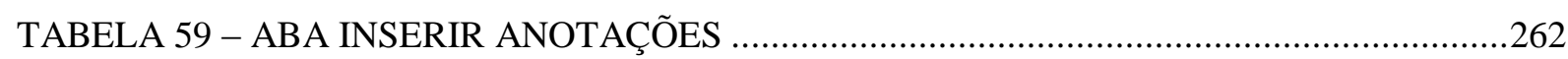

TABELA 60 - ABA INSERIR INFORMAÇÕES PARA O HISTÓRICO DO PROJETO ................263

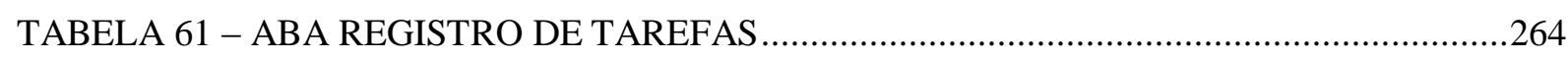

TABELA 62 - ABA 1: DADOS DA REFERÊNCIA BIBLIOGRÁFICA ….....................................266

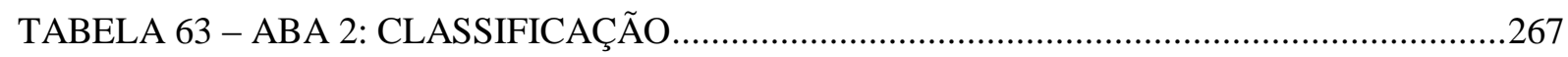

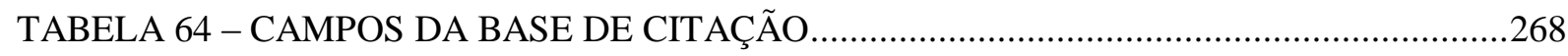

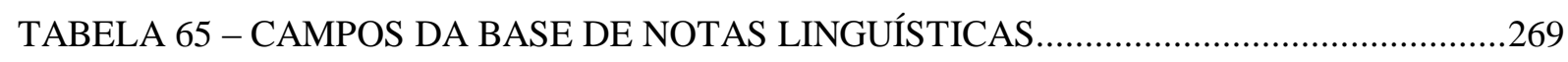

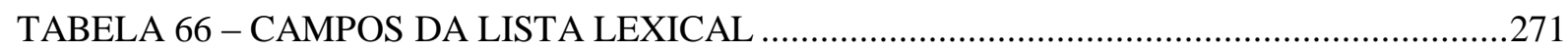

TABELA 67 - CAMPOS DO REGISTRO DE PARENTESCO ...................................................2

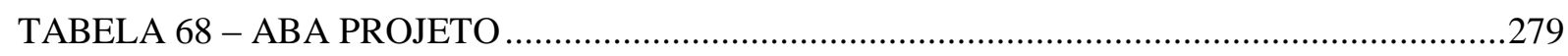

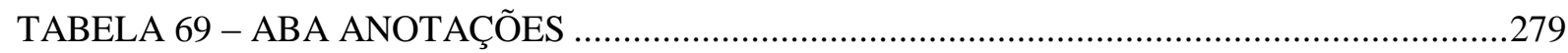

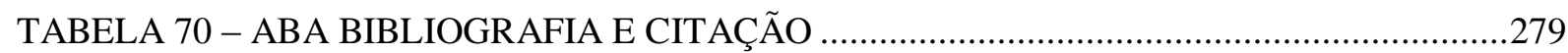




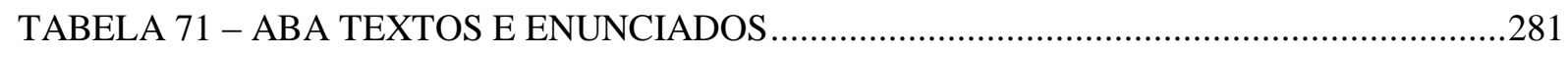

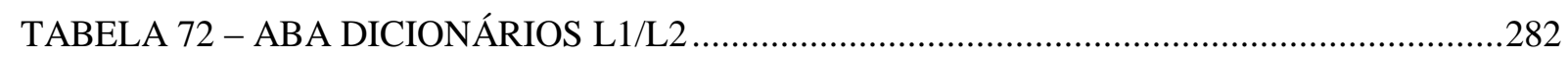

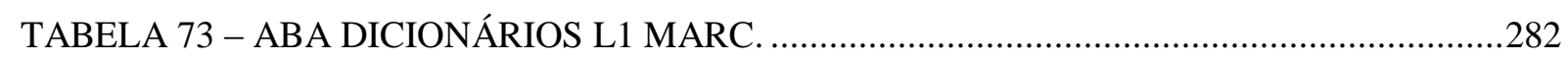

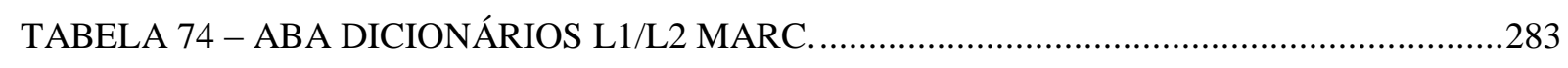

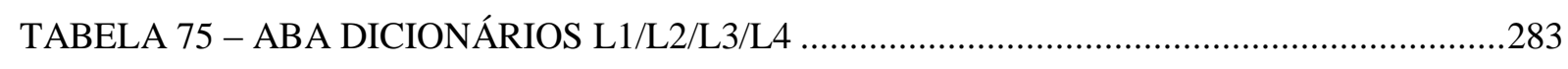

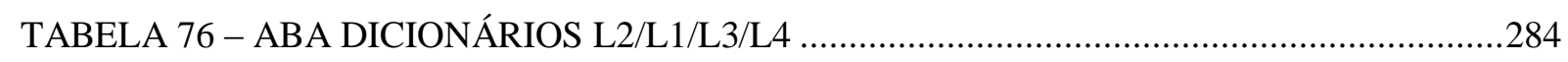

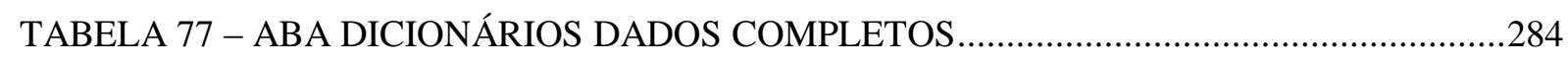

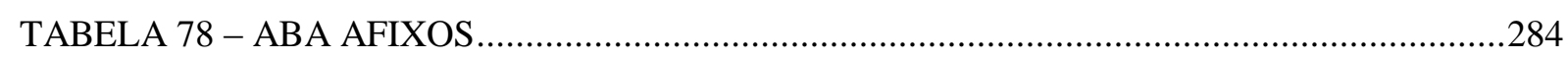

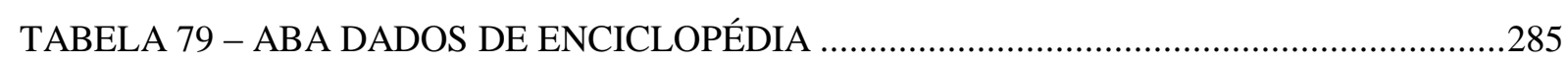

TABELA 80 - ABA COMPARAÇÃO DE LÍNGUAS E NOTAS LINGUÍSTICAS .......................286

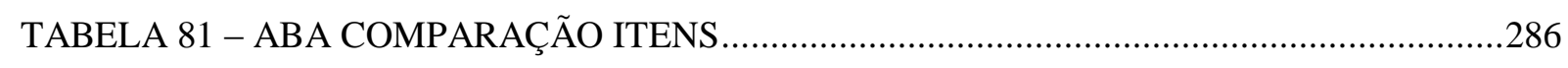

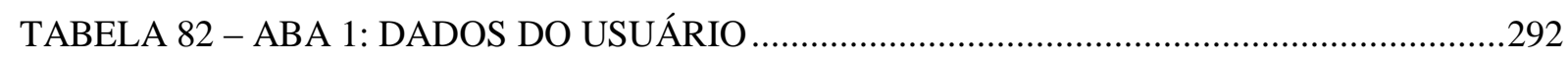

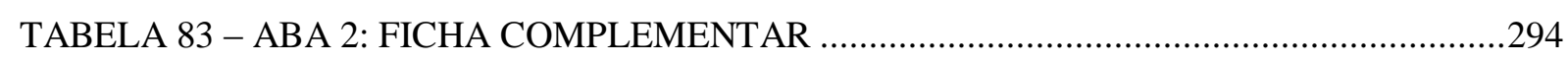

TABELA 84 - ABREVIATURAS USADAS NO DICIONÁRIO SURUÍ-PORTUGUÊS ................451

TABELA 85 - ABREVIATURAS USADAS NO DICIONÁRIO PORTUGUÊS-SURUÍ ................513 


\section{LISTA DE SIGLAS}

\begin{tabular}{|c|c|}
\hline Am & Análise morfológica [Operador] \\
\hline $\mathrm{Ar}$ & Área (Biologia, Geografia, História, Linguística, Matemática...) [Operador] \\
\hline CONDISI & Conselho Distrital de Saúde Indígena \\
\hline CNV & Comissão Nacional da Verdade \\
\hline Cs & Campo semântico \\
\hline $\mathrm{D}$ & Descritor \\
\hline DAl & Descritor (glosa, definição, paráfrase, tradução...) em Alemão \\
\hline DEs & Descritor (glosa, definição, paráfrase, tradução...) em Espanhol \\
\hline $\mathrm{DFr}$ & Descritor (glosa, definição, paráfrase, tradução...) em Francês \\
\hline DId & Descritor (glosa, definição, paráfrase, tradução...) em Língua Indígena \\
\hline DIn & Descritor (glosa, definição, paráfrase, tradução...) em Inglês \\
\hline DIt & Descritor (glosa, definição, paráfrase, tradução...) em Italiano \\
\hline DJp & Descritor (glosa, definição, paráfrase, tradução...) em Japonês \\
\hline DLt & Descritor (glosa, definição, paráfrase, tradução...) em Latim \\
\hline DPt & Descritor (glosa, definição, paráfrase, tradução...) em Português \\
\hline DRs & Descritor (glosa, definição, paráfrase, tradução...) em Russo \\
\hline DSEI & Distrito Sanitário Especial Indígena \\
\hline Dt & Datação do item lexical [Operador] \\
\hline $\mathrm{E}$ & Exemplo \\
\hline EAl & Exemplo em Alemão \\
\hline EEs & Exemplo em Espanhol \\
\hline EId & Exemplo em Língua Indígena \\
\hline EIn & Exemplo em Inglês \\
\hline EIt & Exemplo em Italiano \\
\hline EJp & Exemplo em Japonês \\
\hline ELt & Exemplo em Latim \\
\hline EML & Expressão da Microestrutura Lexicográfica \\
\hline $\mathrm{EPt}$ & Exemplo em Português \\
\hline ERs & Exemplo em Russo \\
\hline Et & Etimologia [Operador] \\
\hline Fn & Pronúncia/Fonética/Fonologia [Operador] \\
\hline $\mathrm{Fr}$ & Fraseologia [Operador] \\
\hline $\mathrm{Ft}$ & Fonte da informação [Operador] \\
\hline FUNAI & Fundação Nacional do Índio (Ministério da Justiça) \\
\hline FUNASA & Fundação Nacional de Saúde (Ministério da Saúde) \\
\hline Gf & Ortografia [Operador] \\
\hline Gr & Indicação da categoria gramatical [Operador] \\
\hline $\mathrm{Hm}$ & Indicação de ocorrência de homonímia [Operador] \\
\hline $\operatorname{Im}$ & Imagem (ilustração) [Operador] \\
\hline $\mathrm{L}$ & Lema \\
\hline
\end{tabular}




\begin{tabular}{|c|c|}
\hline LAl & Lema em Alemão \\
\hline LEs & Lema em Espanhol \\
\hline LFr & Lema em Francês \\
\hline LId & Lema na Língua Indígena (qualquer uma delas) \\
\hline LIn & Lema em Inglês \\
\hline LIt & Lema em Italiano \\
\hline LJp & Lema em Japonês \\
\hline LLt & Lema em Latim \\
\hline LPt & Lema em Português \\
\hline LRs & Lema em Russo \\
\hline $\mathrm{Lu}$ & Lema em contexto \\
\hline Mc & Marcas (de uso) [Operador] \\
\hline MEC & Ministério da Educação \\
\hline $\mathrm{Na}$ & Nota do autor [Operador] \\
\hline $\mathrm{Ne}$ & Nota do editor [Operador] \\
\hline NGB & Nomenclatura Gramatical Brasileiras \\
\hline $\mathrm{Nt}$ & Nota do tradutor [Operador] \\
\hline $\mathrm{O}$ & Operador \\
\hline $\mathrm{Rm}$ & Remissiva [Operador] \\
\hline $\mathrm{Rz}$ & Raiz (de item lexical, de palavra) [Operador] \\
\hline SASISUS & Subsistema de Atenção à Saúde Indígena \\
\hline SESAI & Secretaria Especial de Saúde Indígena \\
\hline SGDB & Sistema de Gerencialmento de Banco de Dados \\
\hline $\mathrm{Sm}$ & Segmentação Morfológica [Operador] \\
\hline SUS & Sistema Único de Saúde (Ministério da Saúde) \\
\hline T.I. & Terra Indígena \\
\hline Tc & Texto complementar [Operador] \\
\hline $\mathrm{Tl}$ & Tradução literal [Operador] \\
\hline $\mathrm{Tm}$ & Indicação de tom [Operador] \\
\hline UBL & Unidade de Base Lexicográfica \\
\hline VBA & Visual Basic for Applications \\
\hline $\mathrm{Vr}$ & Variante/Variedade [Operador] \\
\hline
\end{tabular}


1 Primeira pessoa do singular

2 Segunda pessoa do singular

3 Terceira pessoa do singular ou plural

12(3) Primeira pessoa do plural inclusiva

Primeira pessoa do plural exclusiva

23

Segunda pessoa do plural

1CORR $\quad 1^{\mathrm{a}}$ pessoa correferencial

2CORR $\quad 2^{\mathrm{a}}$ pessoa correferencial

3CORR $\quad 3^{\mathrm{a}}$ pessoa correferencial

2.ERG Pronome de $2^{\mathrm{a}}$ pessoa ergativo

ADV Advérbio

ADVERS Adversativo

AGT

Agentivo

ARG

Argumento

AT.I

Atestado pelo locutor / recente

AT.II

Atestado pelo locutor / imediato

AT.III

Atestado por um terceiro / recente

C.COM Causativo-comitativo

C.PREP Causativo-prepositivo

CAUS Causativo

COL

Coletivizador

COMPL Completivo

$\mathrm{D}$

Determinante

DAT

Dativo

DECL Declaração sem compromisso de verdade

DES Desiderativo

ESP Espécie

GEN Genuíno

GER

Gerúndio

$\mathrm{H}$

Humano

IND.II

Indicativo II

INESS Inessivo

INT

Intensivo (intensificador) 


\begin{tabular}{|c|c|}
\hline LD & Locativo difuso \\
\hline LP & Locativo pontual \\
\hline $\mathrm{N}$ & Nome \\
\hline N.CERT & Não certeza \\
\hline N.DESCR & Nome descritivo \\
\hline NEG & Negação \\
\hline NMLZ & Nominalizador \\
\hline NMLZ.AG & Nominalizador de agente \\
\hline NMLZ.PRED & Nominalizador de predicado \\
\hline PERG.I & Pergunta 1 \\
\hline PERG.II & Pergunta 2 \\
\hline PERG.III & Pergunta 3 \\
\hline POSP & Posposição \\
\hline POSS & Possibilidade \\
\hline PRIV & Privativo \\
\hline PROIB & Proibitivo \\
\hline PROJ & Projetivo \\
\hline PROSP & Prospectivo \\
\hline $\mathrm{R}^{1}$ & Relacional de contiguidade \\
\hline $\mathrm{R}^{2}$ & Relacional de não-contigüidade \\
\hline $\mathrm{R}^{3}$ & Relacional genérico e humano \\
\hline $\mathrm{R}^{4}$ & Relacional que marca um determinante genérico \\
\hline REC & Recíproco \\
\hline RED & Reduplicação \\
\hline REFL & Reflexivo \\
\hline REL & Relativo a \\
\hline RETR & Retrospectivo \\
\hline S & Sujeito \\
\hline SML & Similitivo \\
\hline SIT & Situacional \\
\hline TRANSL & Translativo \\
\hline V & Verbo \\
\hline V.INTR & Verbo intransitivo \\
\hline V.TR & Verbo transitivo \\
\hline
\end{tabular}


1 INTRODUÇÃ O..........................................................................................................................35

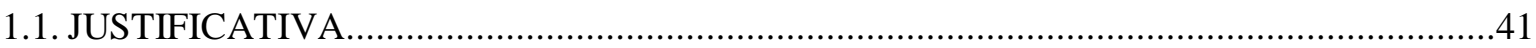

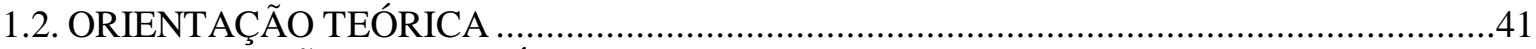

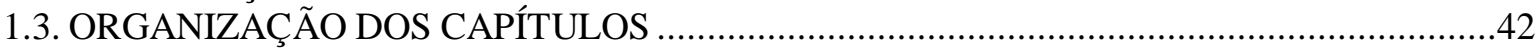

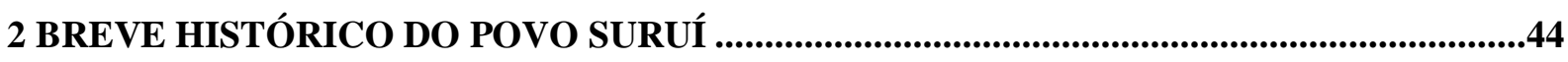

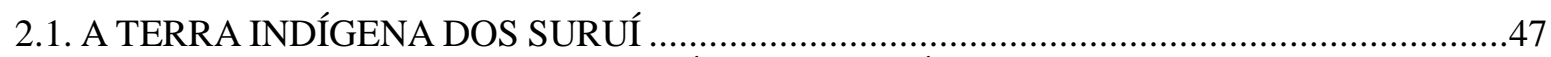

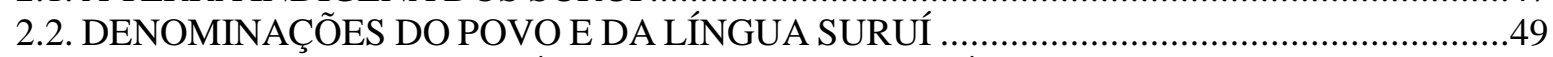

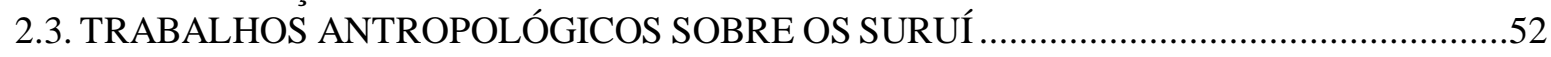

3 CLASSIFICAÇÃO E SITUAÇÃO LINGUÍSTICA DA LÍNGUA SURUÍ..............................54

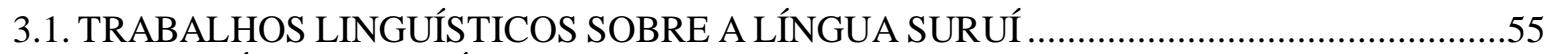

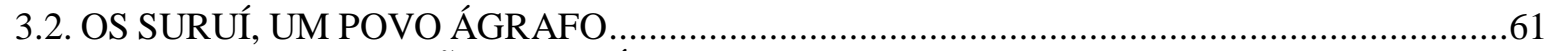

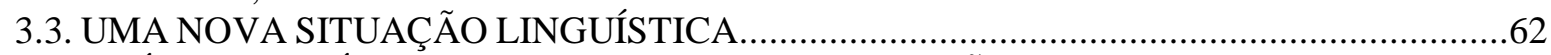

3.4. A LÍNGUA INDÍGENA NO CONTEXTO DA EDUCAÇÃO FORMAL ...............................65

4 FONOLOGIA DA LÍNGUA SURUÍ.................................................................................68

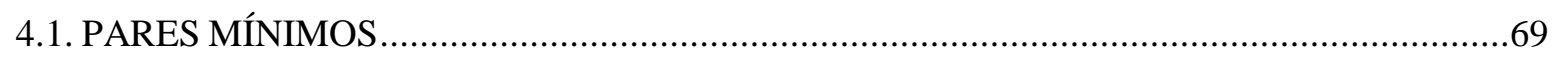

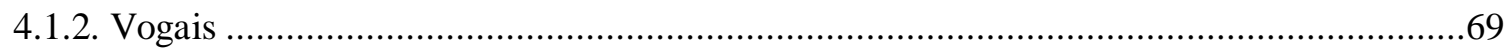

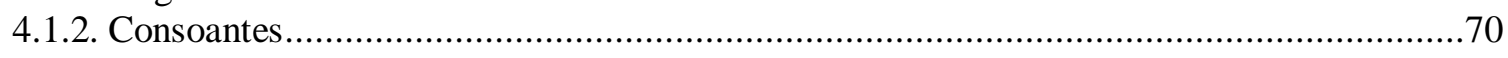

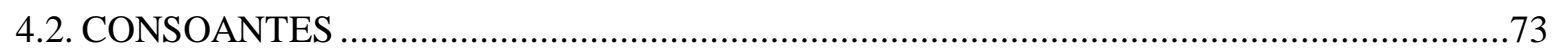

4.3. VOGAIS

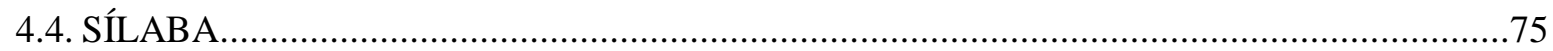

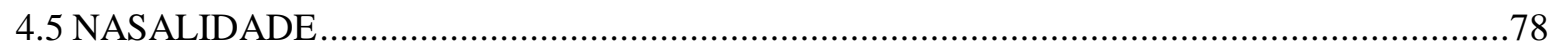

5 PARA UMA ESCRITA DA LÍNGUA SURUÍ ....................................................................80

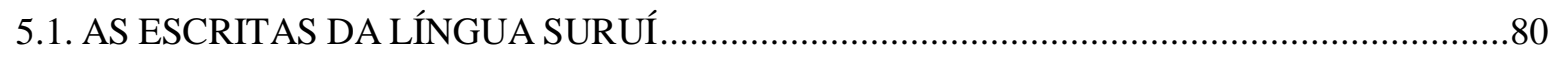

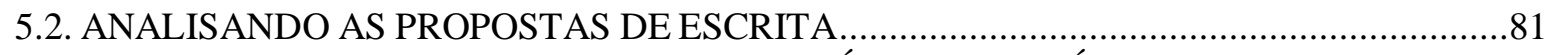

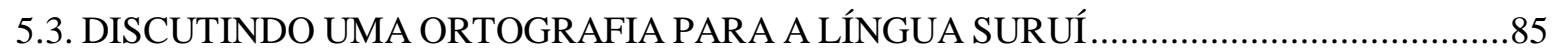

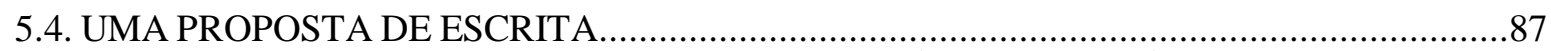

5.5. CONSIDERAÇÕES SOBRE A ORTOGRAFIA DA LÍNGUA SURUÍ .....................................89

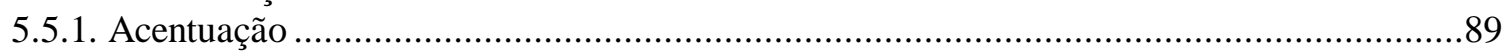

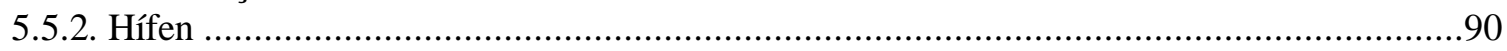

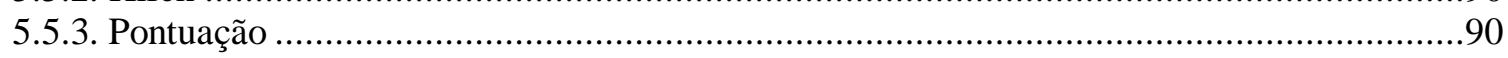

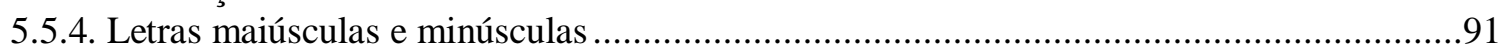

6 ELEMENTOS PARA UMA GRAMÁTICA DA LÍNGUA SURUÍ .......................................93

6.1. ASPECTOS DA MORFOLOGIA DA LÍNGUA SURUÍ ..................................................93

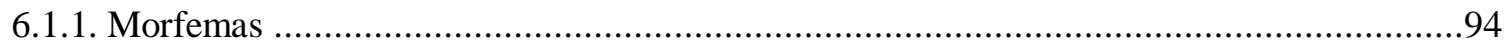

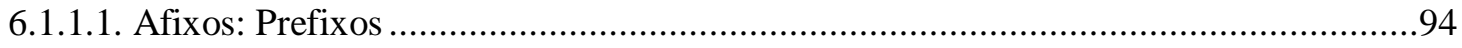

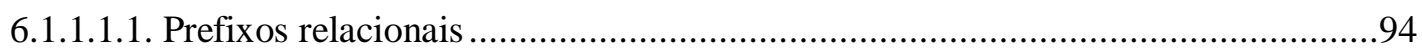

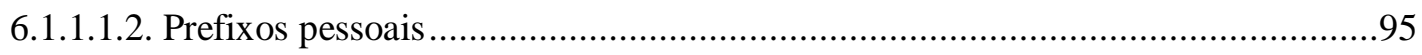

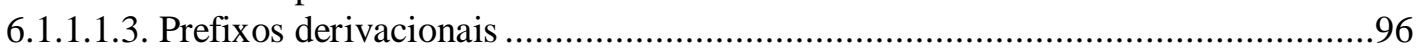

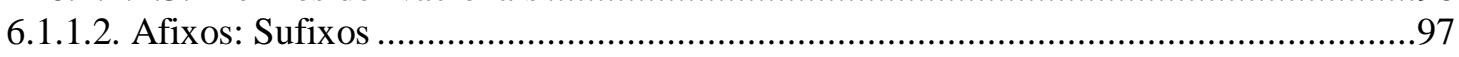

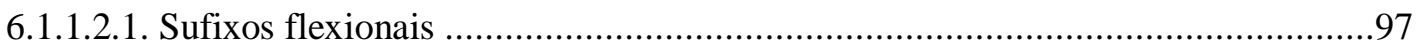

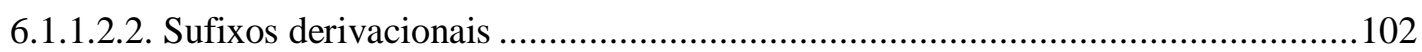

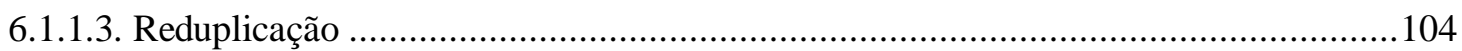

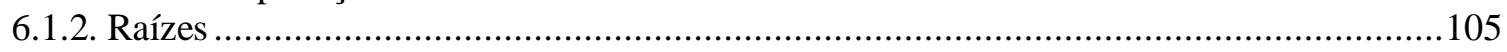

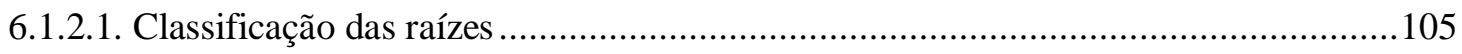

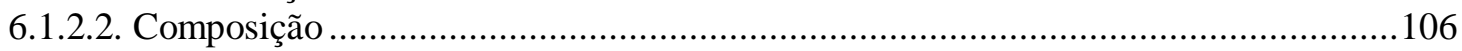




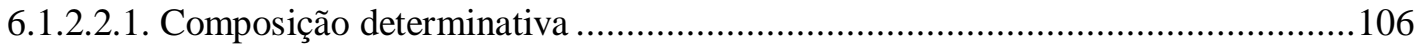

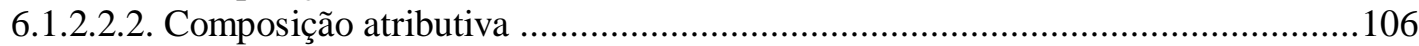

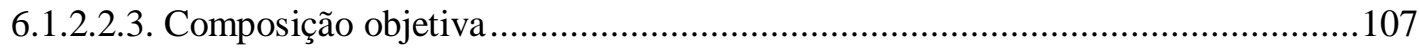

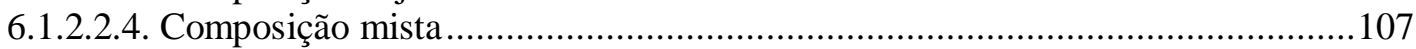

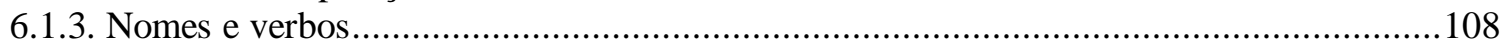

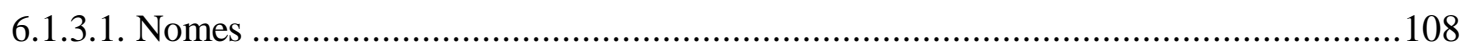

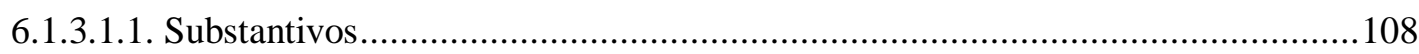

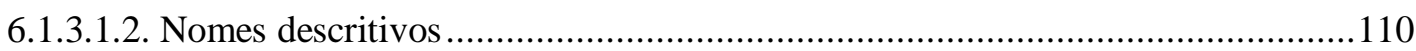

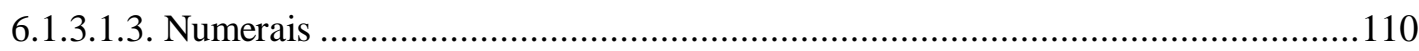

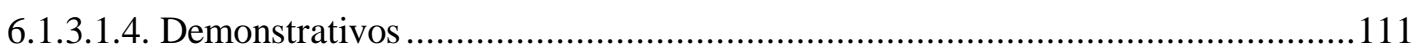

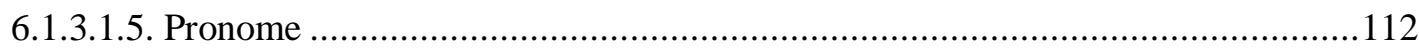

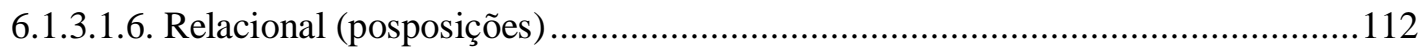

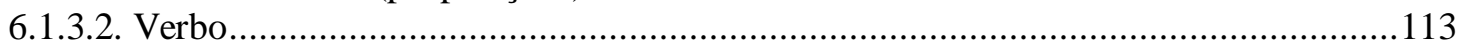

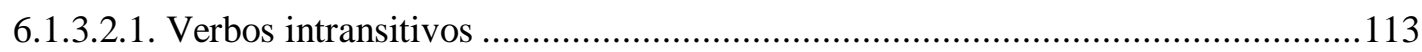

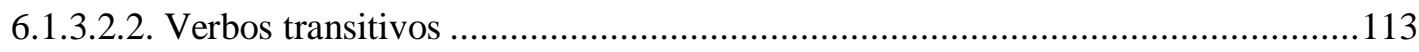

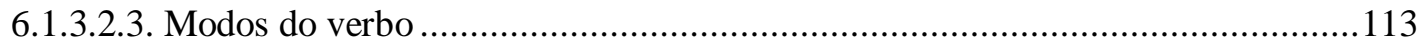

6.1.3.2.4. Negação dos predicados com núcleo verbal e com núcleo nominal descritivo ..117

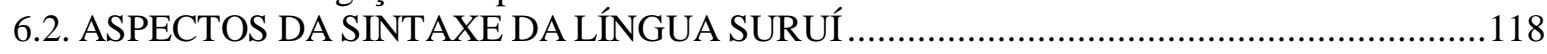

6.2.1. Principais constituintes das orações da língua Suruí ........................................................118

6.2.2. Ordenamentos de constituintes da oração na língua Suruí ..............................................120

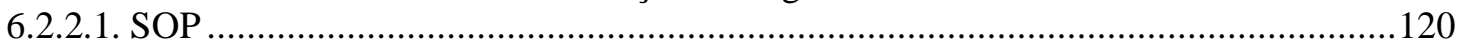

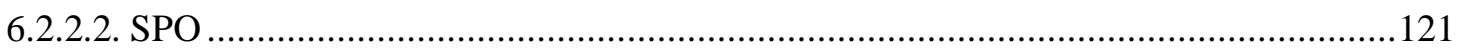

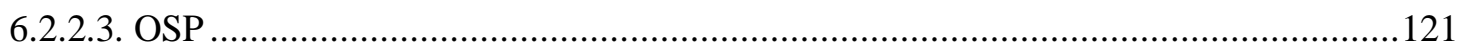

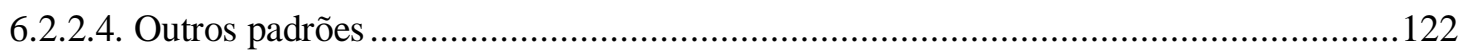

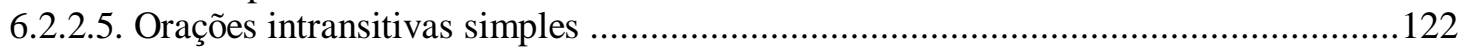

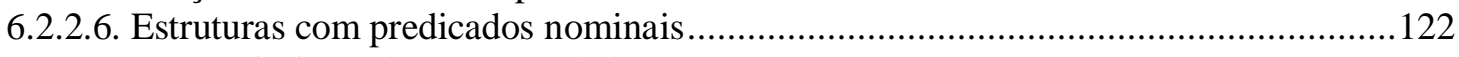

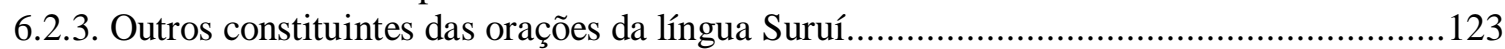

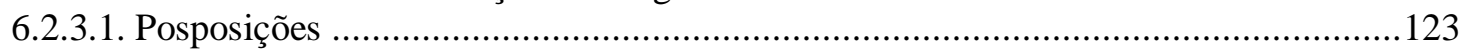

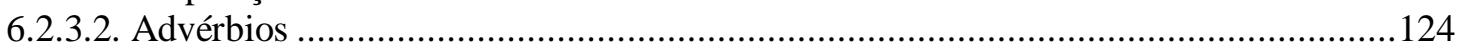

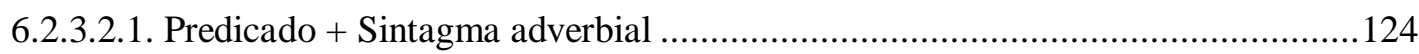

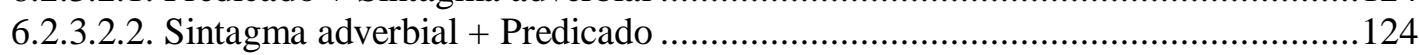

6.2.3.2.3. Predicado + Sintagma adverbial (oração no imperativo) ..................................125

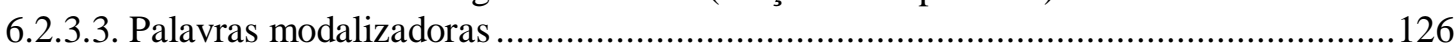

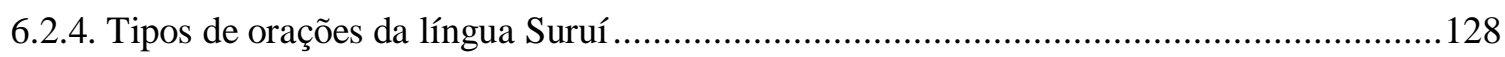

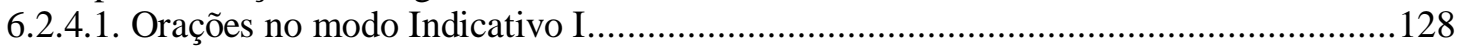

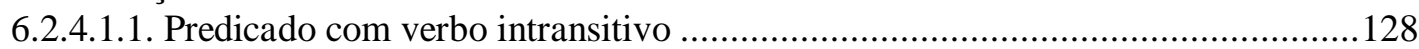

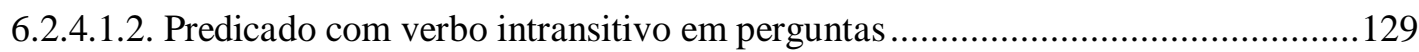

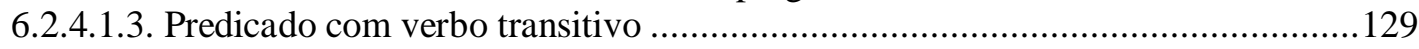

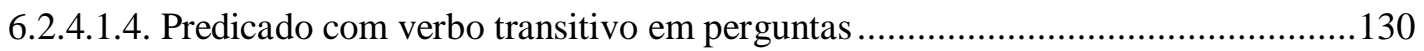

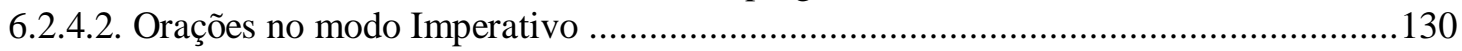

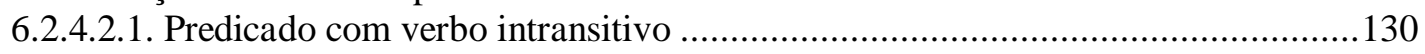

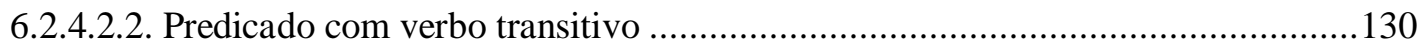

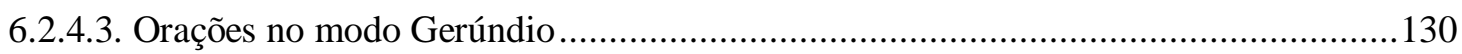

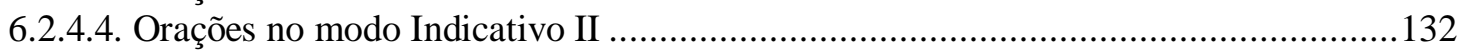

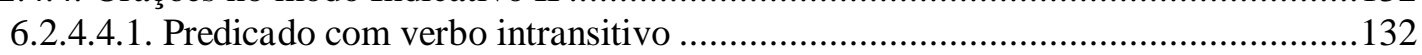

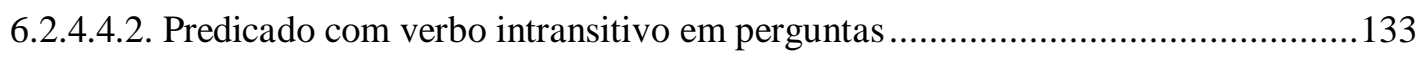

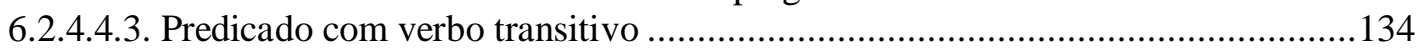

6.2.4.4.4. Predicado com verbo transitivo em perguntas .................................................... 134

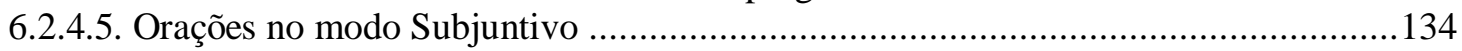

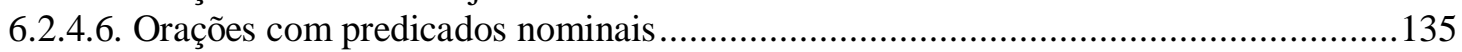

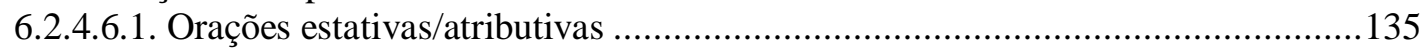

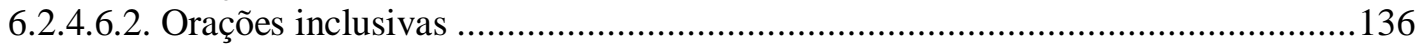

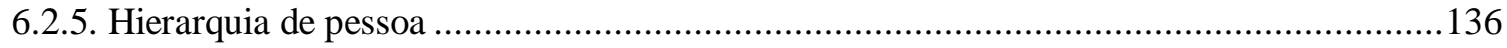

6.2.6. Negação de Predicados ......................................................................................... 138

6.2.6.1. Negação de predicados com verbo intransitivo ......................................................138 
6.2.6.2. Negação de predicados com verbo transitivo ..........................................................139

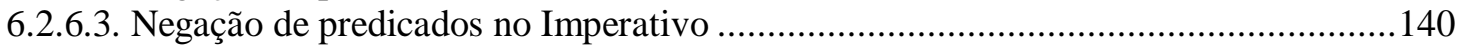

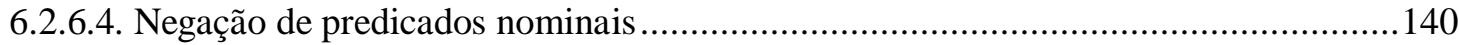

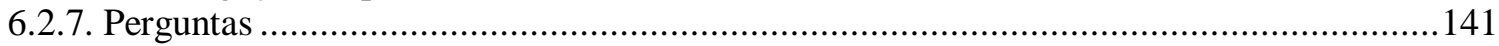

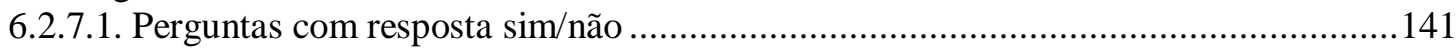

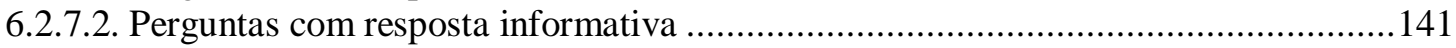

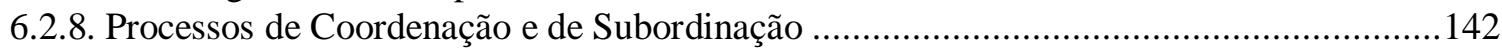

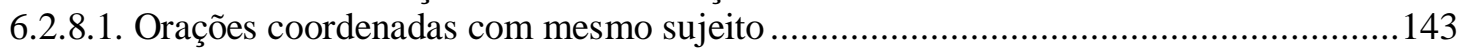

6.2.8.2. Orações coordenadas com sujeitos diferentes ......................................................... 143

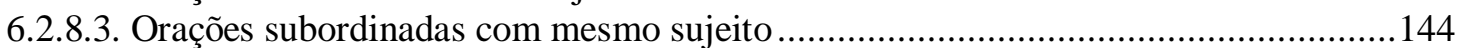

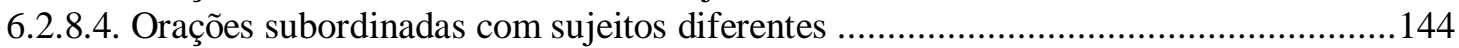

7 MATERIAIS LEXICOGRÁFICOS DAS LÍNGUAS INDÍGENAS BRASILEIRAS................145

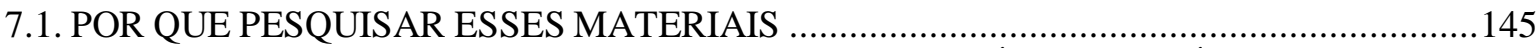

7.2. UMA METODOLOGIA PARA A PESQUISA DE DICIONÁRIOS DE LÍNGUAS

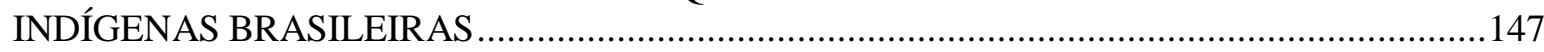

7.2.1. Definição do objeto da pesquisa com delineamentos de uma metodologia .....................147

7.2.1.1. Em busca de uma tipologia das obras lexicográficas ................................................148

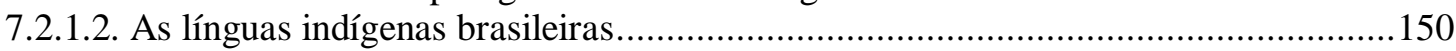

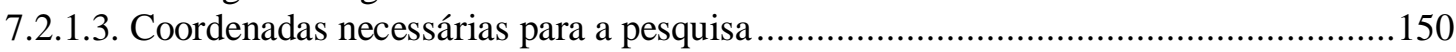

7.2.1.4. Identificando as informações dos materiais lexicográficos ....................................154

7.2.1.4.1. Proposta de classificação baseada na quantidade de entradas ............................158

7.2.1.4.2. Proposta de descrição da microestrutura dos materiais ......................................160

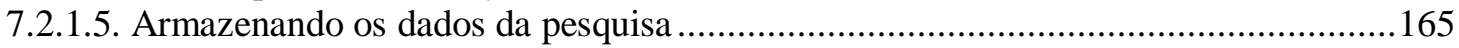

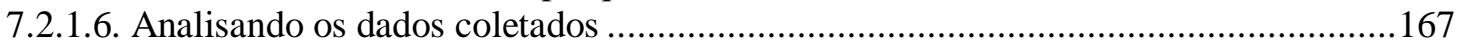

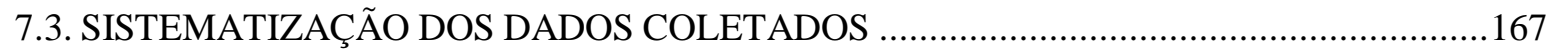

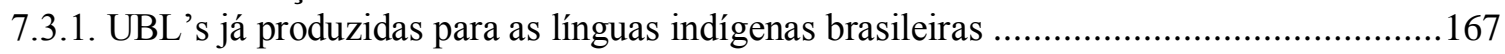

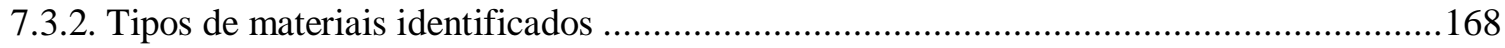

7.3.3. Quantificação detalhada das UBL's já produzidas para as línguas indígenas brasileiras .171

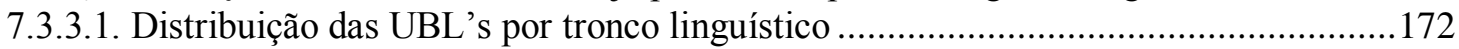

7.3.3.2. Distribuição das UBL's por família linguística ...................................................173

7.3.3.3. Distribuição cronológica das UBL's das línguas indígenas brasileiras.....................175

7.3.3.3.1. UBL's das línguas indígenas brasileiras referentes ao século XVI ...................176

7.3.3.3.2. UBL's das línguas indígenas brasileiras referentes ao século XVII ...................176

7.3.3.3.3. UBL's das línguas indígenas brasileiras referentes ao século XVIII ..................177

7.3.3.3.4. UBL's das línguas indígenas brasileiras referentes ao século XIX ...................177

7.3.3.3.5. UBL's das línguas indígenas brasileiras referentes ao século XX ......................178

7.3.3.3.6. UBL's das línguas indígenas brasileiras referentes ao século XXI ...................179

7.3.3.3.7. Contagem das UBL's das línguas indígenas brasileiras não consideradas na

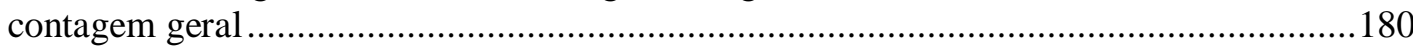

7.3.3.3.8. Resumo da contagem de UBL's das línguas indígenas brasileiras ....................181

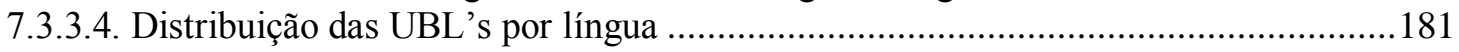

7.3.3.5. Distribuição das UBL's por quantidade de entradas ..............................................190

7.3.3.6. Distribuição das UBL's segundo a disposição das línguas envolvidas no verbete....193

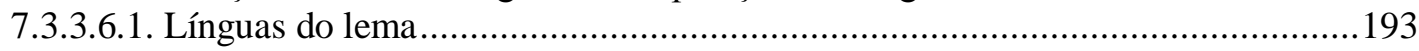

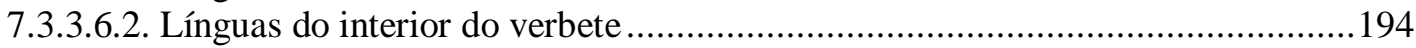

7.3.3.7. Distribuição das UBL's segundo o ordenamento de macroestruturas .......................194

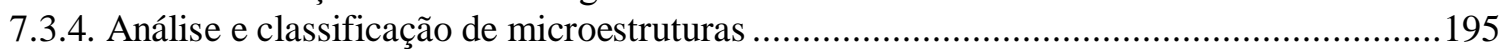

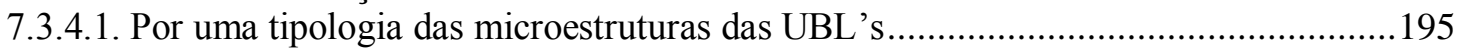

7.3.4.2. Quantificando microestruturas de UBL's a partir da tipologia proposta....................198

8 DESENVOLVENDO UM PROGRAMA DE DOCUMENTAÇÃO LINGUÍSTICA E DE CRIAÇÃO DE DICIONÁRIOS: PROJETO EXPERIMENTAL SURUÍ-AIKEWARA............202

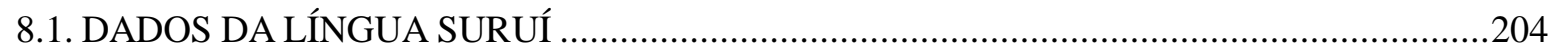

8.2. RECURSOS USADOS NO REGISTRO E TRATAMENTO DOS DADOS ..........................207 
8.3. EM BUSCA DE UM PROGRAMA DE BANCO DE DADOS ELETRÔNICO .......................208

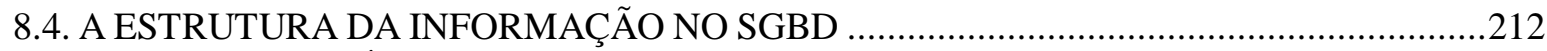

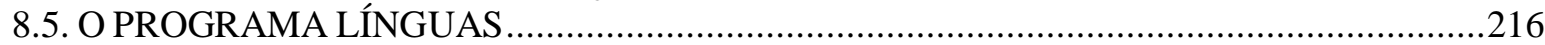

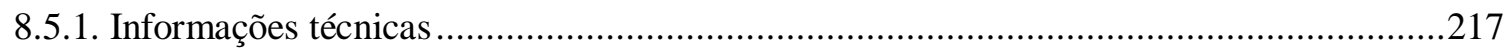

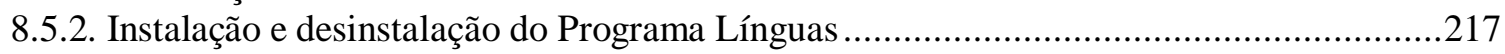

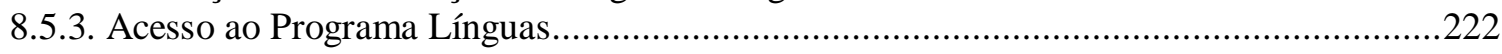

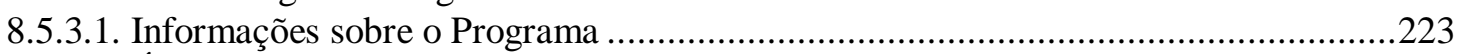

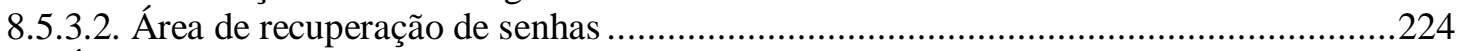

8.5.4. Área de Trabalho do Programa Línguas.........................................................................225

8.5.4.1. Iniciando um Projeto de Documentação Linguística ..............................................226

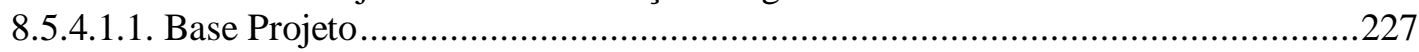

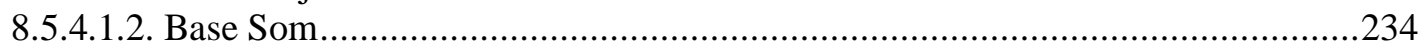

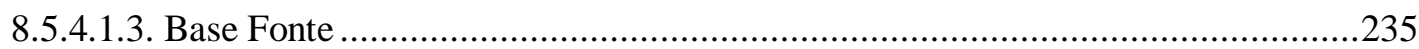

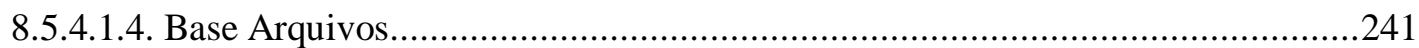

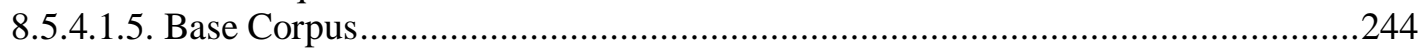

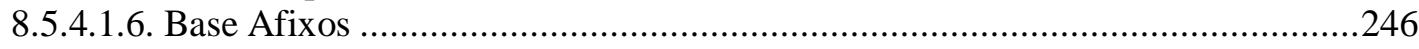

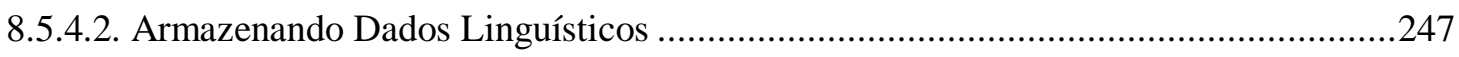

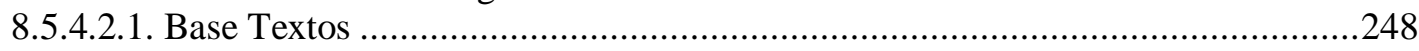

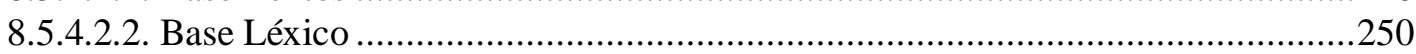

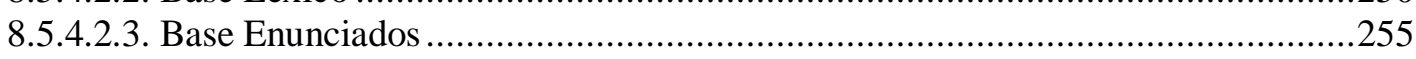

8.5.4.2.4. Base Comparação de Itens (línguas diferentes) ............................................257

8.5.4.2.5. Base Comparação de Itens (mesma língua).....................................................2.

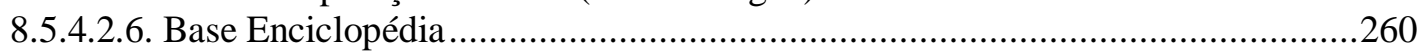

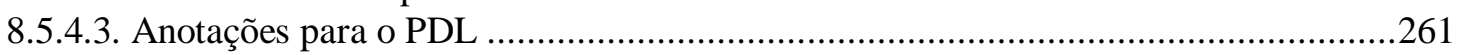

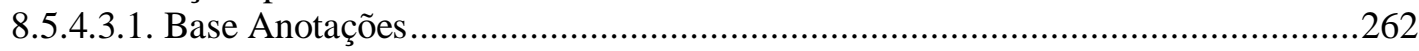

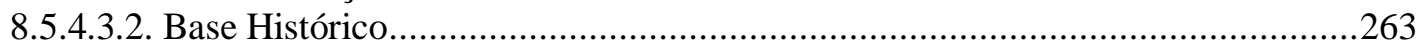

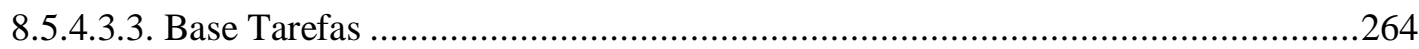

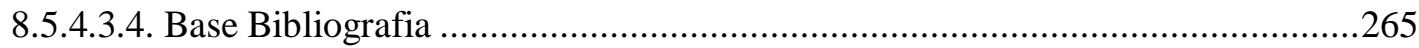

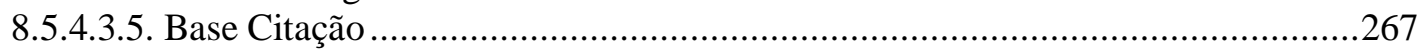

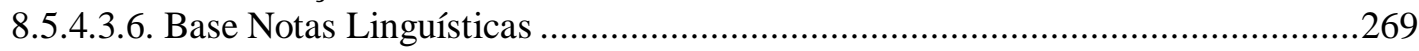

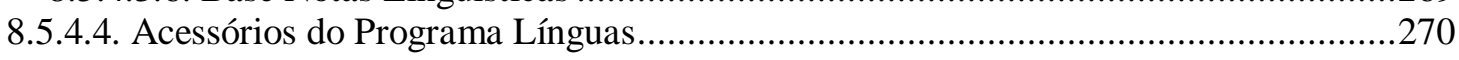

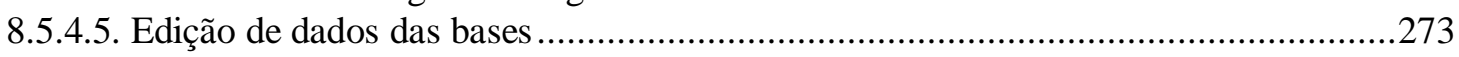

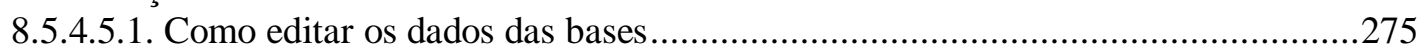

8.5.4.5.2. Como pesquisar dados em um formulário de edição .....................................2276

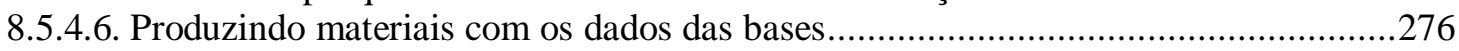

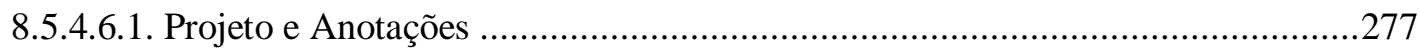

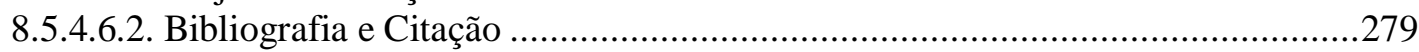

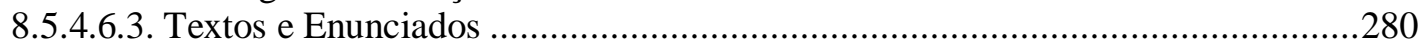

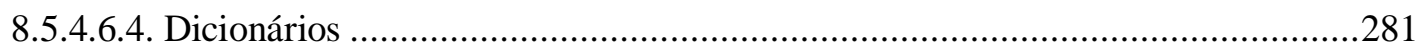

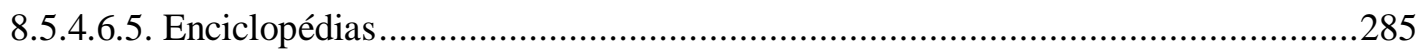

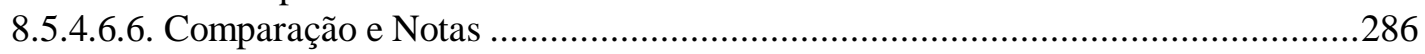

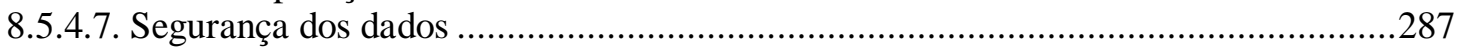

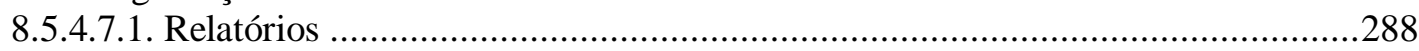

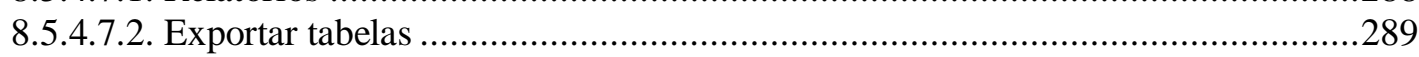

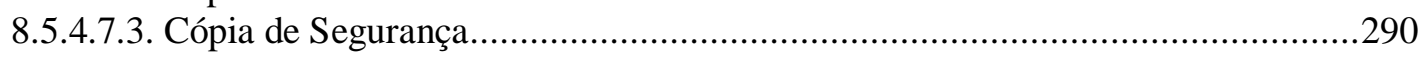

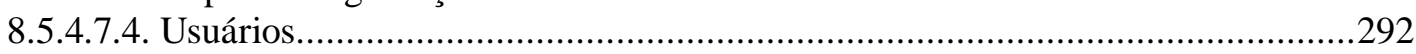

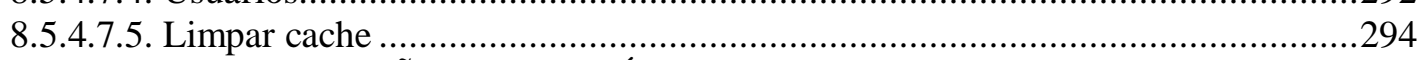

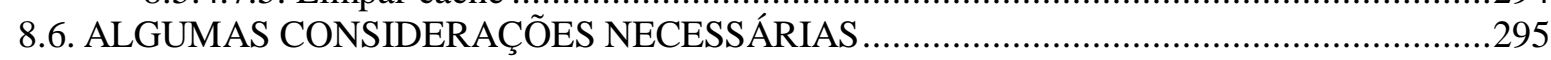

9 MODELOS LEXICOGRÁFICOS PARA A LÍNGUA SURUÍ ......................................................296

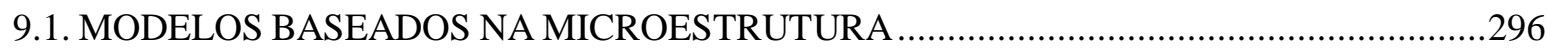

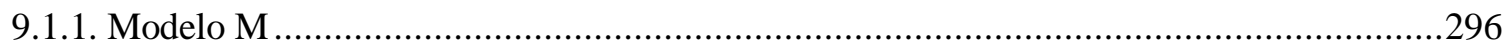

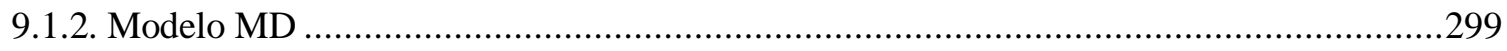

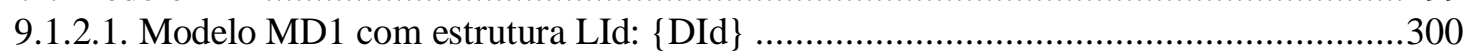

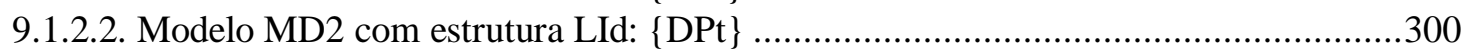




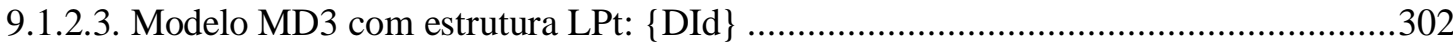

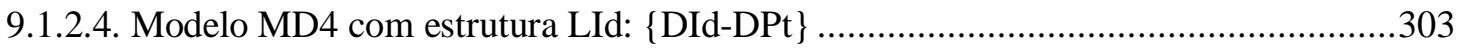

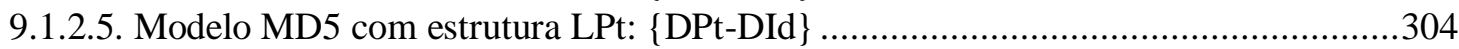

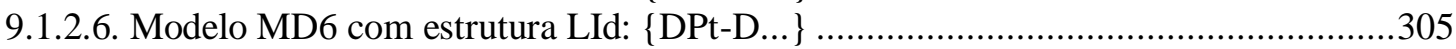

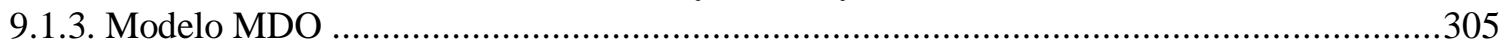

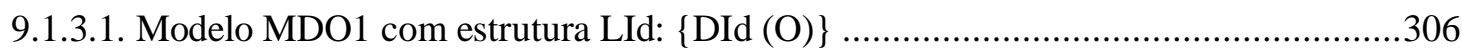

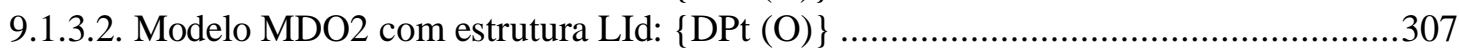

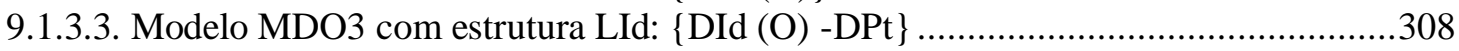

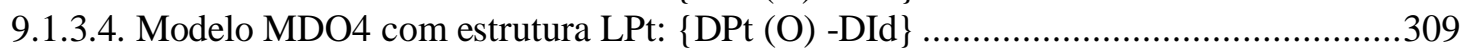

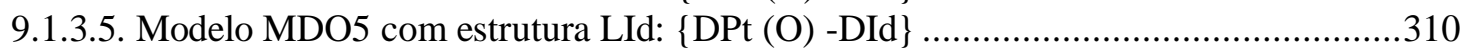

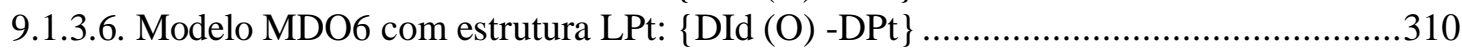

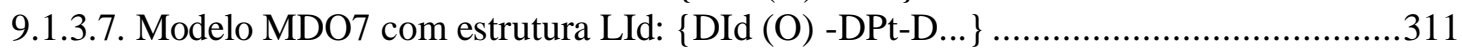

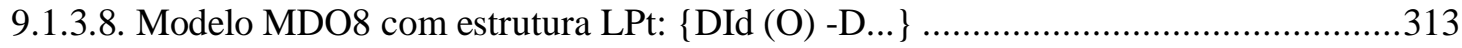

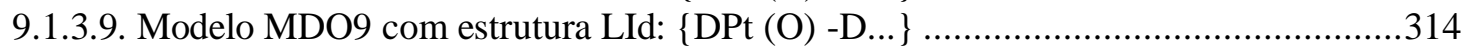

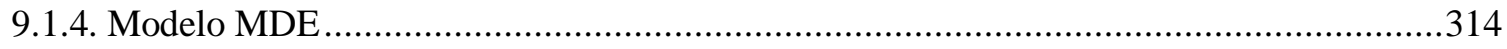

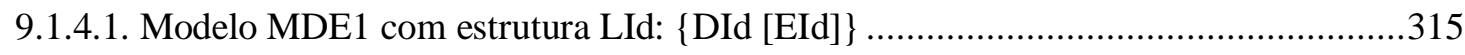

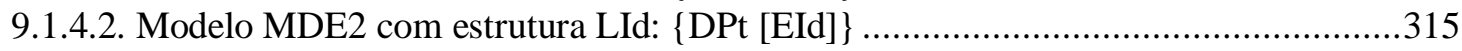

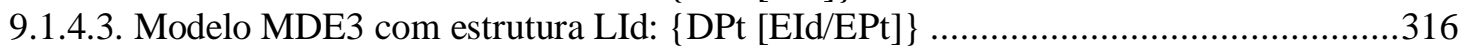

9.1.4.4. Modelo MDE4 com estrutura LPt: \{DId [EId]\} …..................................................

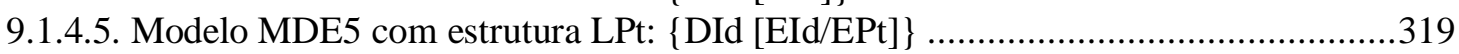

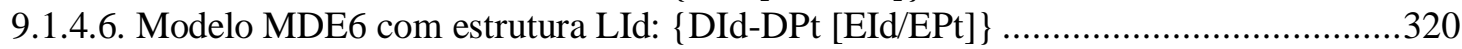

9.1.4.7. Modelo MDE7 com estrutura LPt: \{DPt-DId [EPt/EId] \} ......................................321

9.1.4.8. Modelo MDE8 com estrutura LId: \{DId-DPt-D... [EId/EPt/E...]\} ..........................321

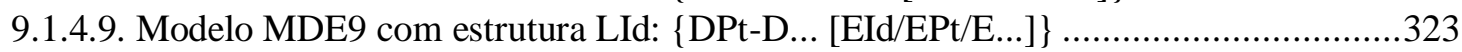

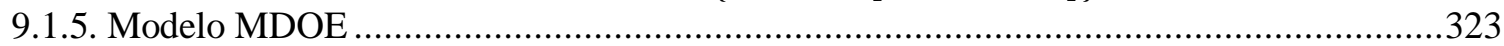

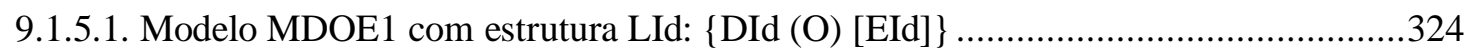

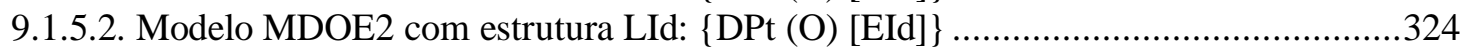

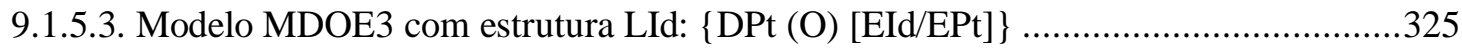

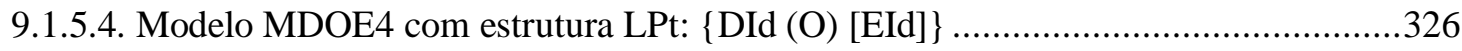

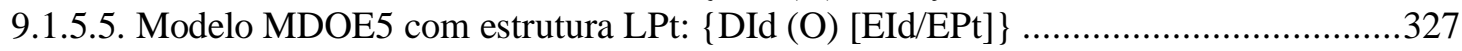

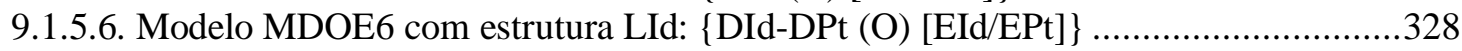

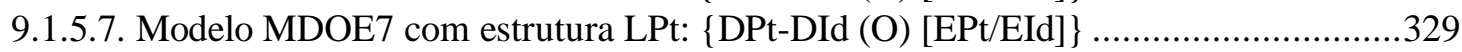

9.1.5.8. Modelo MDOE8 com estrutura LId: \{DId-DPt-D... (O) [EId/EPt/E...]\} .....................330

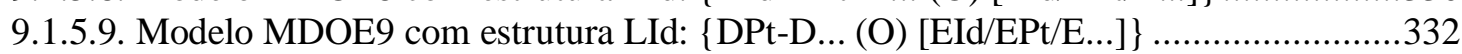

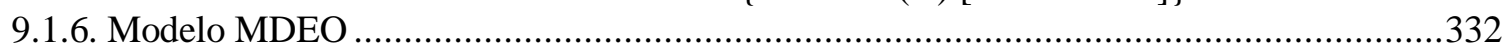

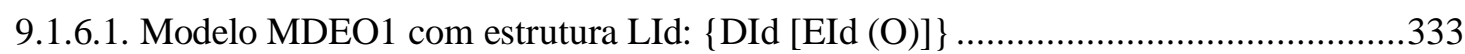

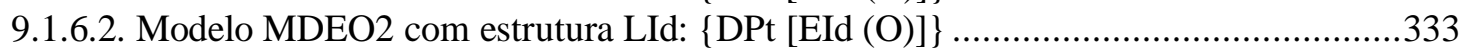

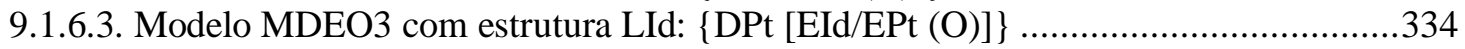

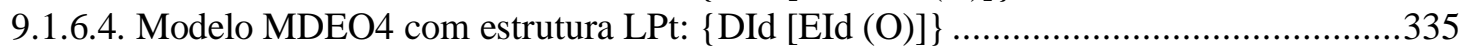

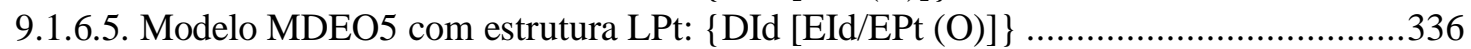

9.1.6.6. Modelo MDEO6 com estrutura LId: \{DId-DPt [EId/EPt (O)]\} .............................338

9.1.6.7. Modelo MDEO7 com estrutura LPt: \{DPt-DId [EPt/EId (O)]\} …..........................338

9.1.6.8. Modelo MDEO8 com estrutura LId: \{DId-DPt-D... [EId/EPt/E... (O)]\} ....................339

9.1.6.9. Modelo MDEO9 com estrutura LId: $\{\mathrm{DPt}-\mathrm{D} \ldots$... (O) [EId/EPt/E...] $\}$...........................340

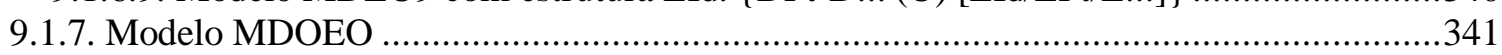

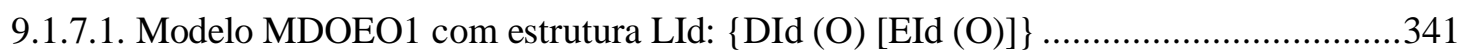

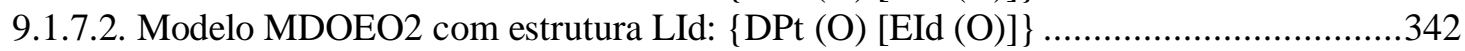

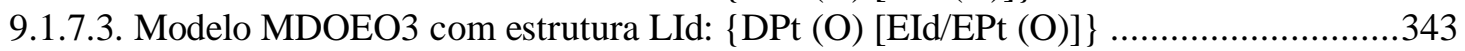

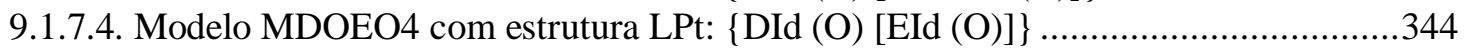

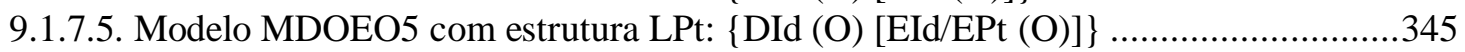

9.1.7.6. Modelo MDOEO6 com estrutura LId: \{DId-DPt (O) [EId/EPt (O)]\} …....................347

9.1.7.7. Modelo MDOEO7 com estrutura LPt: $\{$ DPt-DId (O) [EPt/EId (O)] $\ldots \ldots \ldots \ldots \ldots \ldots \ldots . . . . . . . . . .347$

9.1.7.8. Modelo MDOEO8 com estrutura LId: \{DId-DPt-D... (O) [EId/EPt/E... (O)]\} ........348

9.1.7.9. Modelo MDOEO9 com estrutura LId: $\{$ DPt-D... (O) [EId/EPt/E... (O)] $\ldots \ldots \ldots \ldots \ldots . . . . .350$

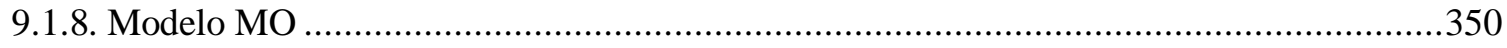




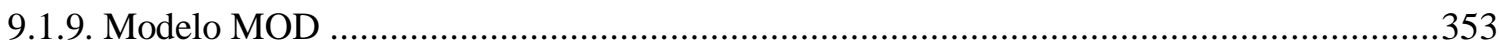

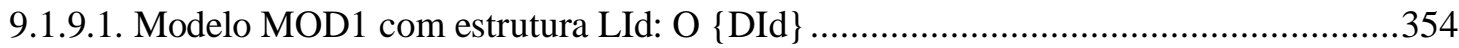

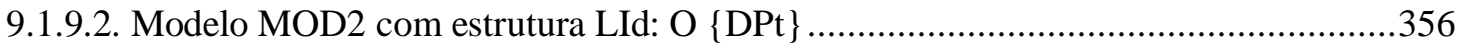

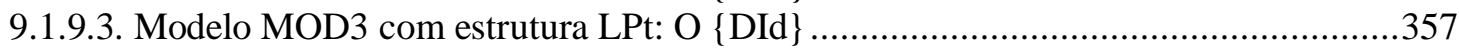

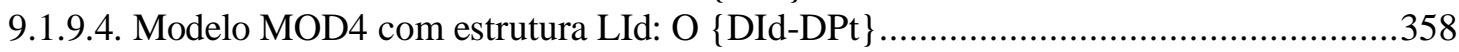

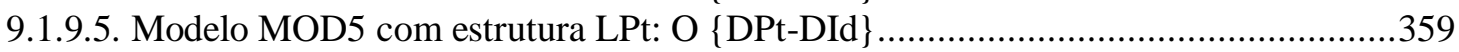

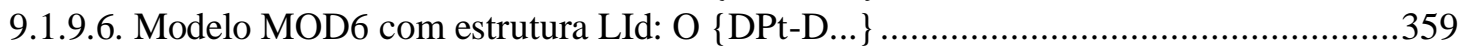

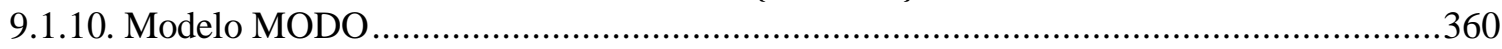

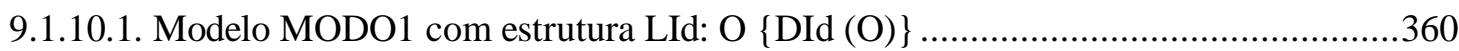

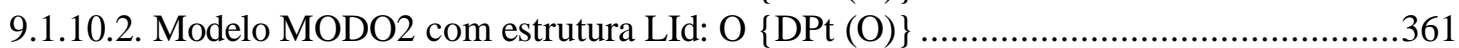

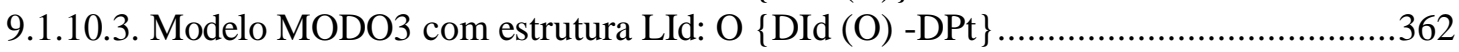

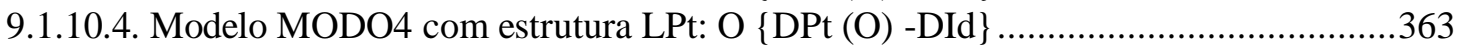

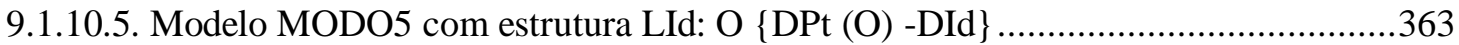

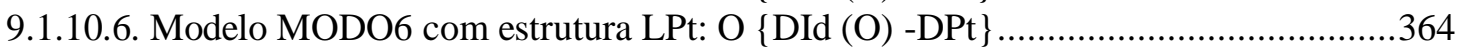

9.1.10.7. Modelo MODO7 com estrutura LId: O \{DId (O) -DPt-D... …..............................365

9.1.10.8. Modelo MODO8 com estrutura LPt: O \{DId (O) -D... ……................................367

9.1.10.9. Modelo MODO9 com estrutura LId: O \{DPt (O) -D...\} ......................................367

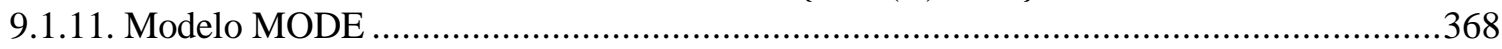

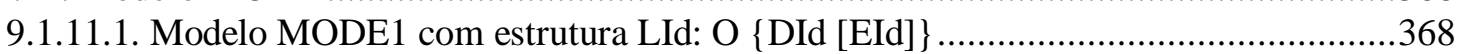

9.1.11.2. Modelo MODE2 com estrutura LId: O \{DPt [EId]\} ….............................................368

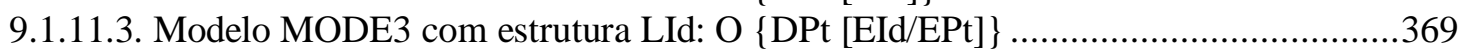

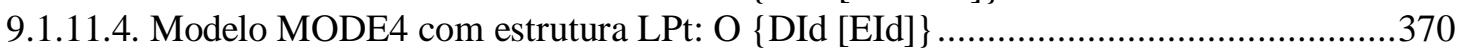

9.1.11.5. Modelo MODE5 com estrutura LPt: O \{DId [EId/EPt] \} .......................................371

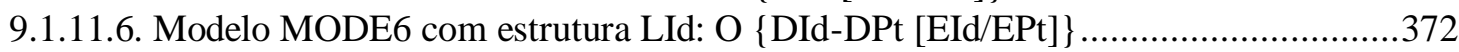

9.1.11.7. Modelo MODE7 com estrutura LPt: O \{DPt-DId [EPt/EId] $\ldots \ldots \ldots \ldots \ldots \ldots \ldots \ldots \ldots \ldots \ldots . . . . . . . . . . . . . . .373$

9.1.11.8. Modelo MODE8 com estrutura LId: O \{DId-DPt-D... [EId/EPt/E...]\} ....................374

9.1.11.9. Modelo MODE9 com estrutura LId: O \{DPt-D... [EId/EPt/E...]\} ...........................375

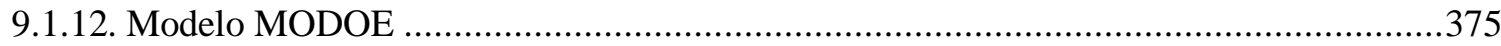

9.1.12.1. Modelo MODOE1 com estrutura LId: O \{DId (O) [EId]\} ....................................376

9.1.12.2. Modelo MODOE2 com estrutura LId: O \{DPt (O) [EId]\} …..................................376

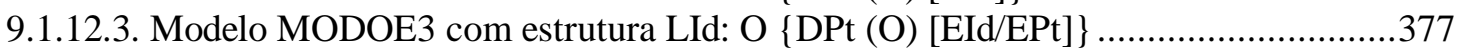

9.1.12.4. Modelo MODOE4 com estrutura LPt: O \{DId (O) [EId]\} …..................................378

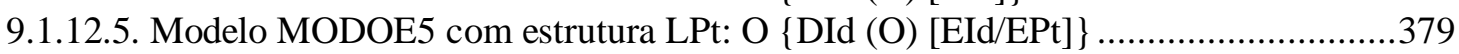

9.1.12.6. Modelo MODOE6 com estrutura LId: O \{DId-DPt (O) [EId/EPt]\} ........................380

9.1.12.7. Modelo MODOE7 com estrutura LPt: O \{DPt-DId (O) [EPt/EId] $\ldots \ldots \ldots \ldots \ldots \ldots \ldots \ldots . . . . . . . . . . .381$

9.1.12.8. Modelo MODOE8 com estrutura LId: O \{DId-DPt-D... (O) [EId/EPt/E...]\} ...........382

9.1.12.9. Modelo MODOE9 com estrutura LId: O \{DPt-D... (O) [EId/EPt/E...]\} ..................384

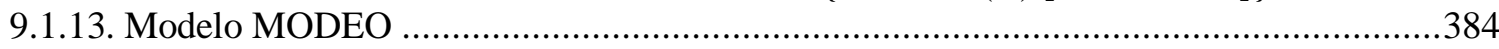

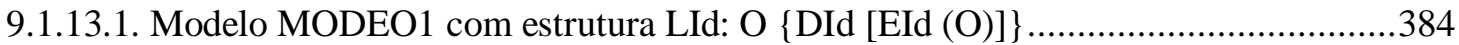

9.1.13.2. Modelo MODEO2 com estrutura LId: O \{DPt [EId (O)]\} .......................................385

9.1.13.3. Modelo MODEO3 com estrutura LId: O \{DPt [EId/EPt (O)]\} …..........................386

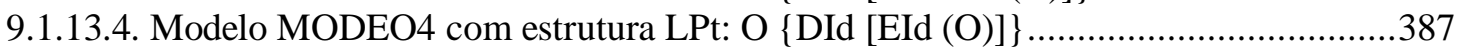

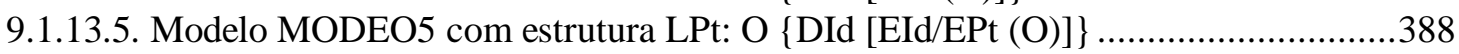

9.1.13.6. Modelo MODEO6 com estrutura LId: O \{DId-DPt [EId/EPt (O)]\} ..........................389

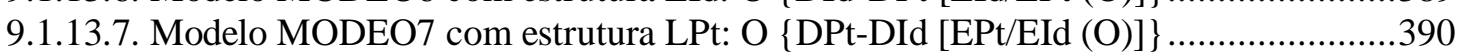

9.1.13.8. Modelo MODEO8 com estrutura LId: O \{DId-DPt-D... [EId/EPt/E... (O)]\}...........391

9.1.13.9. Modelo MODEO9 com estrutura LId: O \{DPt-D... [EId/EPt/E... (O)]\} .................392

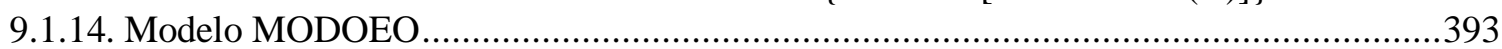

9.1.14.1. Modelo MODOEO1 com estrutura LId: O \{DId (O) [EId (O)]\} .............................393

9.1.14.2. Modelo MODOEO2 com estrutura LId: O \{DPt (O) [EId (O)]\} .............................394

9.1.14.3. Modelo MODOEO3 com estrutura LId: O \{DPt (O) [EId/EPt (O)]\} .......................394

9.1.14.4. Modelo MODOEO4 com estrutura LPt: O \{DId (O) [EId (O)]\} ..............................396

9.1.14.5. Modelo MODOEO5 com estrutura LPt: O \{DId (O) [EId/EPt (O)]\} .......................397

9.1.14.6. Modelo MODOEO6 com estrutura LId: O \{DId-DPt (O) [EId/EPt (O)]\} ................398

9.1.14.7. Modelo MODOEO7 com estrutura LPt: O \{DPt-DId (O) [EPt/EId (O)]\} ...............399 
9.1.14.8. Modelo MODOEO8 com estrutura LId: O \{DId-DPt-D... (O) [EId/EPt/E... (O)]\}.400

9.1.14.9. Modelo MODOEO9 com estrutura LId: O \{DPt-D ... (O) [EId/EPt/E... (O)] _.......401

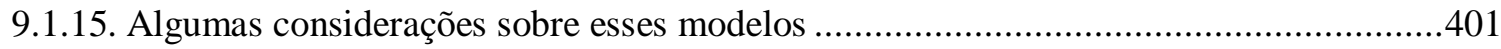

10 DICIONÁRIO DA LÍNGUA SURUÍ.....................................................................................403

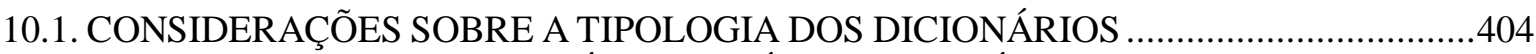

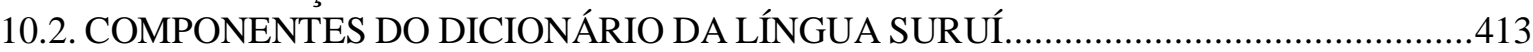

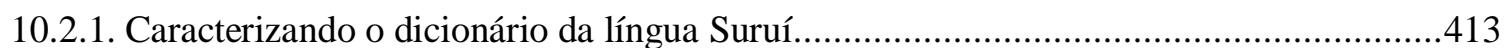

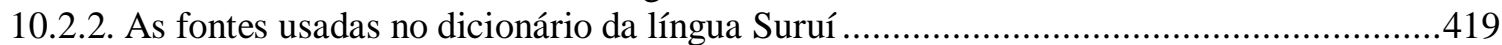

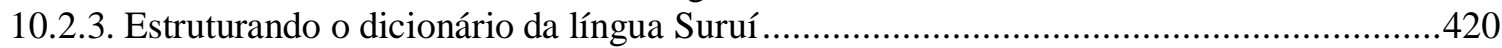

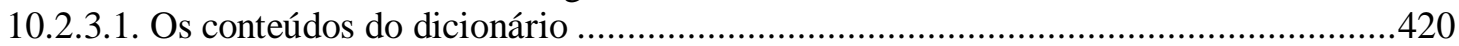

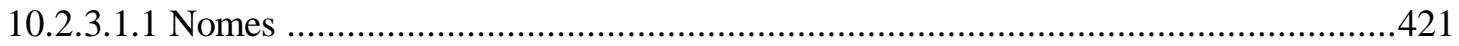

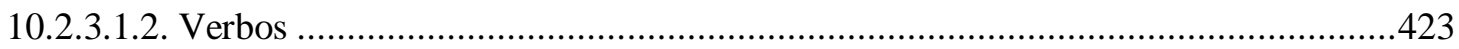

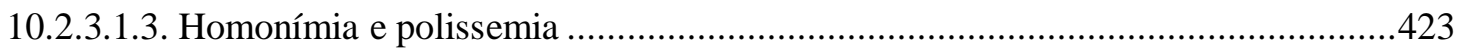

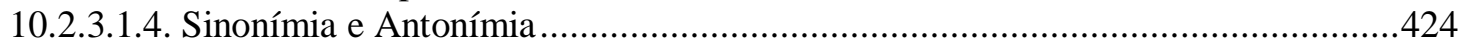

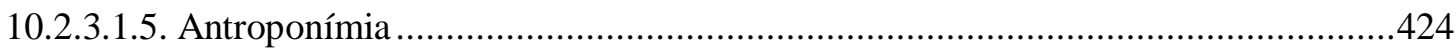

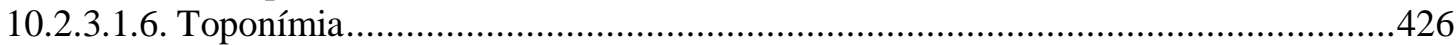

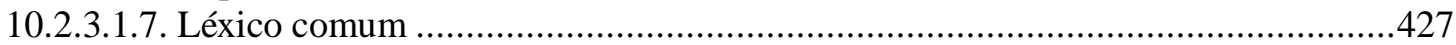

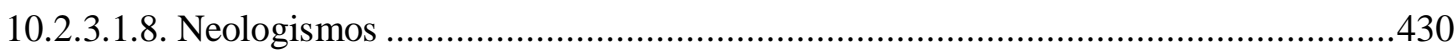

10.2.3.1.8.1. Classificação dos dados relacionados à neologia .......................................432

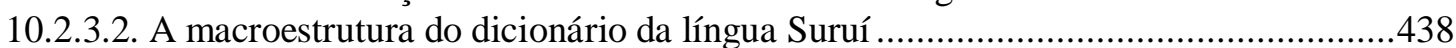

10.2.3.3. A microestrutura do dicionário da língua Suruí ......................................................441

10.2.3.3.1. A microestrutura do dicionário Suruí baseada no modelo MODOE.................444

10.2.3.3.2. A microestrutura do dicionário Suruí baseada no modelo MODE ...................447

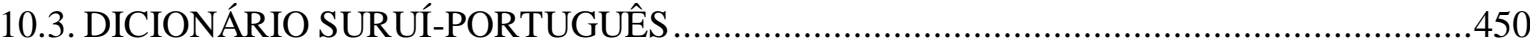

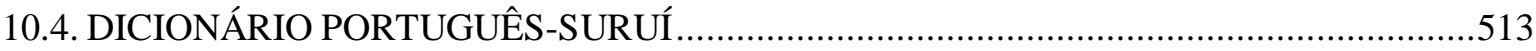

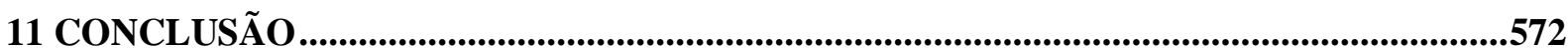

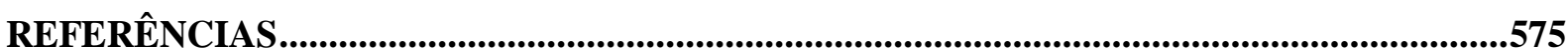

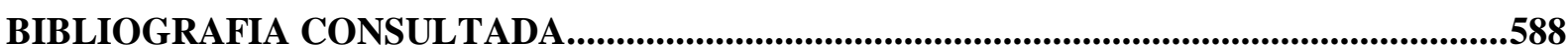

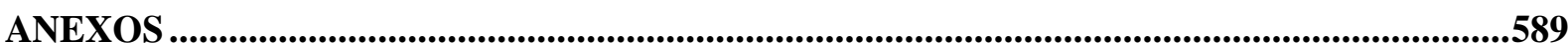

ANEXO A — MAPA DA ÁREA INDÍGENA SORORÓ (SURUÍ) EM 1983 ….............................589

ANEXO B — MAPA DA TERRA INDÍGENA TUWA APEKUOKAWERA ............................590

ANEXO C — MAPA DA TERRA INDÍGENA TUWA APEKUOKAWERA, ANEXADA À

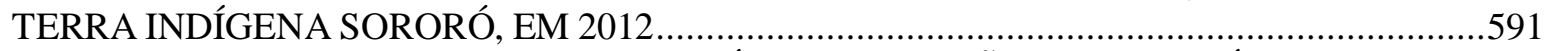

ANEXO D - TRECHO DE MAPA RODOVIÁRIO DA REGIÃO ONDE ESTÁ SITUADA A

TERRA INDÍGENA SORORÓ, COM DESTAQUE PARA OS CURSOS DE ÁGUA …................591

ANEXO E - TRECHO DO RESUMO DO RELATÓRIO CIRCUNSTANCIADO DE

IDENTIFICAÇÃO E DELIMITAÇÃO DA TERRA INDÍGENA TUWA APEKUOKAWERA...592

ANEXO F — PÁGINAS DO VOCABULÁRIO AIKEWAR (CIMI, 1986)...................................593

ANEXO G - MÚSICAS CANTADAS EM SURUÍ POR MIHO, GRAVADAS POR IKATU E

TRANSCRITAS E DIGITADAS NO COMPUTADOR POR TYMYKONG, EM ABRIL DE 2014

PARA SEREM USADOS NA FESTA SAPURAHAJ (INSERIDOS AQUI TAL COMO FORAM

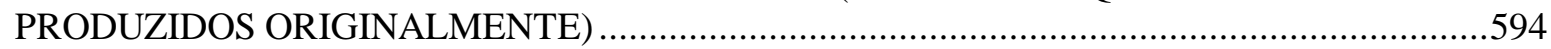




\section{INTRODUÇÃO}

O estudo das línguas indígenas brasileiras, segundo Rodrigues (1966, p. 5), é a primeira grande tarefa que os linguistas no Brasil devem tomar para si, pois, ao pesquisar essas línguas é possível adquirir novos conhecimentos linguísticos, além de permitir testar muitas das hipóteses levantadas nos diferentes sub-ramos da linguística.

Essa tarefa adquire um caráter de urgência ao se considerar que a maioria dessas línguas corre o risco de desaparecer em pouco tempo devido não só às pressões exercidas pelo idioma de maior difusão no país, o Português, mas, sobretudo, porque essas línguas já são sobreviventes de um longo processo de extinção em massa iniciado há 500 anos. Ou seja, ao longo dos últimos cinco séculos de história do Brasil, segundo Rodrigues (1999, p. 13), com o genocídio de populações indígenas inteiras, aconteceu a extinção de mais de 1000 línguas indígenas brasileiras, restando, hoje, apenas cerca de 200 delas, que correm ainda constante ameaça de desaparecimento.

Esse conjunto de línguas autóctones remanescentes em nosso país, apesar de bastante reduzido, ainda é representativo de uma grande diversidade linguística, que pode ser percebida ao se agrupar essas línguas em famílias e estas, quando for o caso, em troncos linguísticos. A título de ilustração, cito as línguas Cinta-Larga, Paitér, Zoró e Gavião que pertencem à família Mondé, as línguas Akuntsú, Makuráp, Sakyrabiát, Campé e Wayoró, que pertencem à família Tuparí, e as línguas Asuriní do Xingu, Kamayurá e Xetá, que pertencem à família Tupí-Guaraní, todas essas famílias pertencentes ao grande tronco Tupí.

No entanto, apesar de haver interesse pelo estudo de muitas destas e de outras línguas indígenas brasileiras ao longo dos séculos, seja, por exemplo, para fins de catequese dos povos indígenas, desde o século XVI, seja para fins de registro de dados etnográficos nas várias expedições que percorreram o Brasil, sobretudo a partir do século XIX, somente a partir do século XX é que começam os primeiros trabalhos de cunho propriamente científico de base linguística dessas línguas, a partir da iniciativa de pesquisadores em descrevê-las,

Além disso, apesar de haver pessoas interessadas pelo estudo das línguas e culturas dos povos indígenas no Brasil, esses pesquisadores, em sua maioria, eram estrangeiros que aportaram em terras brasileiras a fim realizar suas pesquisas linguísticas, dando os mais diferentes fins aos dados coletados e às informações obtidas, tais como, contribuir com a ampliação do conhecimento acadêmico-científico, em outros casos também para favorecer o proselitismo religioso ou, até mesmo, para fins puramente comerciais. 
Assim, é possível perceber que poucos eram os pesquisadores brasileiros que se interessavam pelo estudo de línguas indígenas e, dentre estes interessados, não havia espaço para que os próprios indígenas, falantes de suas respectivas línguas, se tornassem pesquisadores de seu(s) idioma(s), tal como ocorre com os falantes das línguas mais faladas no mundo, como o Inglês, o Espanhol, o Francês, o Inglês, o Chinês, o Português, que, muito naturalmente, estudam suas respectivas línguas.

Essa situação só começou a mudar muito recentemente, quando os primeiros indígenas começaram a frequentar os cursos universitários e obter seus diplomas nas mais diferentes áreas, dentre as quais estão as áreas das ciências humanas, interessando-se, inclusive, pelo estudo da(s) língua(s) falada(s) por seu povo. ${ }^{1}$

Portanto, esse estudo científico das línguas indígenas, em parceria com ou pelos próprios falantes, enquanto pesquisadores, pode, em alguma medida, contribuir para que houvesse um interesse cada vez maior pela valorização e conservação dessas línguas pelas comunidades indígenas - e também pelas autoridades do estado nacional —, porque, ao perceberem que não é exclusividade do Português possuir uma ortografia, uma gramática ou um dicionário, por exemplo, e que essas línguas também apresentam uma lógica de organização e de funcionamento tão completa e complexa quanto a de qualquer outra língua do mundo, há uma chance maior de se interessar não somente pelo seu uso mais constante e extensivo, mas, principalmente, por uma mudança radical de postura de todos, falantes ou não de determinada língua, no sentido de valorizá-la e incentivá-la, para que ela tenha seu uso fortalecido na comunidade e que, quando for caso, seja levada e ensinada nas escolas com o mesmo respeito e competência como ocorre com relação à(s) língua(s) oficial(is) do país.

Não se trata aqui de propor, entretanto, que o registro documental e o estudo das línguas indígenas, por si sós, serão capazes de determinar alguma mudança de pensamento ou de postura das pessoas, falantes ou não dessas línguas, mas sim que eles são necessários por possibilitarem uma apreensão mais nítida sobre a riqueza e a complexidade de cada uma dessas línguas, e, como isso, pode estimular a construção de uma série de materiais culturais,

\footnotetext{
${ }^{1}$ Um bom exemplo que podemos citar está nos alunos indígenas egressos de cursos universitários, inclusive os intitulados "interculturais", voltados quase que exclusivamente para esse público, que optam na pós-graduação pelos estudos linguísticos. Nesse sentido, há a inciativa dos professores doutores Aryon Dall’Igna Rodrigues e Ana Suelly Arruda Câmara Cabral, da Universidade de Brasília, que aceitaram indígenas oriundos de diferentes etnias (p.ex., Baníwa do Içana, Guaraní Tambeopé, Kaxinawá, Laklanõ, Tikúna, Kamayurá, Mehináku, Awetí, Manxinéru, Kalapálo) de várias partes do Brasil, como orientandos dos cursos de mestrado e doutorado em Linguística, onde cada um deles se ocupou com o estudo de suas respectivas línguas nas mais diferentes perspectivas.
} 
a serem usados em contextos reais do cotidiano de sua sociedade, e também nos mais diferentes ambientes de ensino formal ou não.

Ao compreender que a língua representa para o povo que a fala bem mais do que um dos mais eficazes instrumentos de comunicação entre as pessoas, que ela é um complexo sistema de formas e significados, transmitido de geração a geração, e que permite a cada ser humano estruturar pensamentos, expressar emoções, desejos e ideias, projetar mundos, conservar e compartilhar experiências, enfim, construir a própria cultura humana, conferindo aos seus detentores-usuários elementos que alimentam suas próprias identidades, nesse momento estaremos prontos para reconhecer todo o potencial que essa língua possui e passaremos a pensar de modo muito mais nítido políticas linguísticas, ações baseadas no respeito à diversidade linguística e, finalmente, descobrir todo o potencial de uma língua para transformar o mundo.

Por isso, conhecer linguisticamente a sua própria língua e, mais que isso, ampliar suas possibilidades e abrangência quando ela passa a ser escrita é mais do que gratificante, é necessário, é essencial, ainda mais quando os textos passam a se multiplicar e a circular nos mais diferentes espaços sociais, alimentando novas ideias, e, em última instância, fortalecendo a autoestima do povo.

Então, o que pensar diante da iminente morte de uma língua? Partindo da perspectiva de um linguista, esse processo indicaria a perda irreparável de um conhecimento único, irrepetível de uma experiência que foi construída ao longo de um tempo impossível de ser estabelecido. Essa língua que pôde se transformar a partir do contato, ou não, com outras línguas, acumulando marcas das várias experiências individuais, mas também dos temores e crenças individuais e coletivas, revelados nas várias interdições dos tabus, participando do dia a dia de tantas pessoas e servindo para estabelecer todo tipo de relações e rupturas, ela, mesmo que tenha sido registrada, não diminuiria as implicações desta perda para toda a comunidade de falantes e, sem dúvida, para toda a humanidade.

Já para um falante dessa língua, a sua perda seria ainda maior, pois, mesmo mantendo sua cultura por meio de outra língua, geralmente aquela que é falada por uma maioria (na região ou no país, por exemplo), esta nova língua não comportaria todas as nuanças estabelecidas na língua original, nem seria capaz de exprimir exatamente da mesma maneira todos os elementos construídos na base da outra língua. Logo, ao se perder uma língua, seja por extinção do povo, seja por substituição por outra língua, como ocorreu com a maioria dos povos indígenas do Nordeste do Brasil, desfigura-se boa parte do que foi aquele 
povo, quebra-se um elo invisível com todo um passado de experiências acumuladas e nega-se às futuras gerações o acesso a grande parte desse conhecimento original.

Reconhecendo esse valor das línguas para toda a humanidade e acreditando que a continuidade delas só será possível a partir do momento em que se assumir coletivamente esse compromisso, de pessoas comuns a grandes corporações e estados-nações, a UNESCO lançou o projeto Atlas of the World's Languages in Danger ("Atlas das Línguas em perigo no mundo"), por meio do qual apresenta um quadro relativamente completo de línguas de várias partes do mundo com a descrição do grau de vulnerabilidade que elas se encontram. No Brasil, esse Atlas reconhece 190 línguas que se encontram nas seguintes situações:

\section{QUADRO 01 - ESCALA DOS GRAUS DE RISCO REFERENTES À TRANSMISSÃO DE UMA LÍNGUA DE UMA GERAÇÃO À OUTRA}

\begin{tabular}{|c|c|c|}
\hline & Nível de vitalidade & Transmissão da língua de uma geração à outra \\
\hline & segura & $\begin{array}{l}\text { a língua é falada por todas as gerações; a transmissão } \\
\text { intergeracional é ininterrupta }\end{array}$ \\
\hline Q & vulnerável & $\begin{array}{l}\text { a maior parte das crianças fala a língua, mas ela pode estar } \\
\text { restrita a determinados domínios (por exemplo: a casa) }\end{array}$ \\
\hline 0 & em perigo & $\begin{array}{l}\text { as crianças não aprendem mais a língua como língua materna } \\
\text { em casa }\end{array}$ \\
\hline Q & seriamente em perigo & $\begin{array}{l}\text { a língua é falada pelos avós; enquanto a geração dos pais pode } \\
\text { compreendê-la, eles não a falam entre eles ou com seus filhos }\end{array}$ \\
\hline Q & em situação crítica & $\begin{array}{l}\text { os locutores mais jovens são os avós e seus ascendentes, e eles } \\
\text { não falam a língua senão parcialmente e com pouca frequência }\end{array}$ \\
\hline & extinta & $\begin{array}{l}\text { não há mais locutores > o Atlas contém as referências desde os } \\
\text { anos } 1950\end{array}$ \\
\hline
\end{tabular}

Fonte: UNESCO (2011, p. 6)

FIGURA 01 - UNESCO INTERACTIVE ATLAS OF THE WORLD'S LANGUAGES IN DANGER

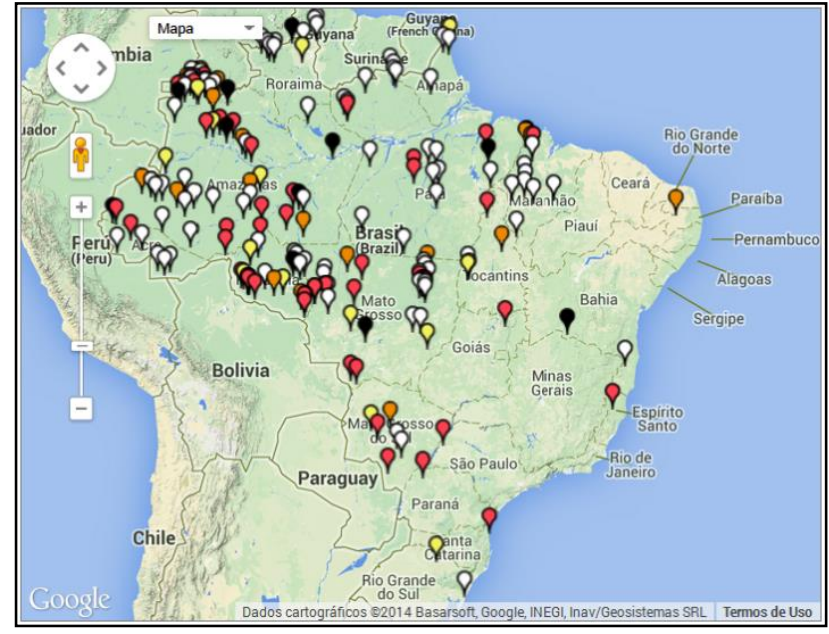

Fonte: Site da UNESCO (http://www.unesco.org/culture/languages-atlas) 
Dessas 190 línguas reconhecidas pelos Atlas, aproximadamente um quarto delas está em situação crítica, o que significa dizer que em poucas décadas, o Brasil perderá parte significativa de seu patrimônio linguístico.

Portanto, se há uma mobilização de organismos internacionais, como a ONU, voltada para a defesa dos direitos dos povos no que concerne à preservação e ao uso de suas línguas, e diante das várias reflexões não só de estudiosos (indígenas ou não) — sobretudo antropólogos e linguistas —, mas também das próprias comunidades indígenas sobre a necessidade de proteção de suas línguas e culturas autóctones, evidencia-se ainda mais a urgência de nossa tarefa não somente para documentar as línguas indígenas, mas, sobretudo, para contribuir com essa documentação e pesquisa para a valorização, o uso, o ensino e o constante estudo, pelos próprios falantes, de suas respectivas línguas.

No entanto, não é óbvia nem imediata essa relação entre documentação e pesquisa linguística e o uso do material coletado e produzido para fins educacionais e de uso pela comunidade indígena (cf. HAVILAND, 2007, p. 15-47). No Brasil, por exemplo, onde já existe uma certa tradição de pesquisa linguística, conforme apresentado acima, que documenta e pesquisa pelos mais diferentes meios e com mais diversos fins as línguas indígenas brasileiras, os dados coletados são, com frequência, armazenados, por exemplo, seja em fichas de papel seja em programas informatizados de bancos de dados, e sua utilização ficava restrita a especialistas. Mesmo com a maior difusão das novas tecnologias da informação, como os computadores pessoais, e também o advento da internet, cujo alcance é mundial (pelo menos é o que esse sistema pretende ser), não foram muitos os projetos que pensaram na utilização desses materiais para difusão dos dados coletados pelos linguistas por estudiosos de áreas outras além da linguística, e também pelos próprios indígenas que teriam fornecido esses dados.

Com isso, percebe-se que ainda existe grande carência no Brasil de ferramentas que possam contribuir não somente para essa documentação linguística, mas também para a própria construção de materiais baseados nesses dados.

No caso específico dos programas informatizados para armazenamento de dados, eles eram capazes, em alguma medida, de tornar acessíveis, sim, esses dados. Todavia, quando muito, eles conseguiam gerar não mais do que um ou dois tipos de material, por exemplo, um dicionário bilíngue com seu reverso. E, ademais, seu uso exigia conhecimentos aprofundados de informática (da programação à configuração da plataforma que iria receber os dados), tornando-o demasiadamente complexo para um usuário mediano. 
Nesse sentido, surge a pergunta: é possível a um programa de computador, além de comportar esse armazenamento, gerar de maneira automática mais do que um ou dois tipos de materiais (por exemplo, diferentes materiais lexicográficos)? Se isso for possível, como esse processo pode contribuir para que os indígenas, falantes de suas próprias línguas e detentores de conhecimentos de seu povo, se tornem, além de documentadores de seu próprio material linguístico, pesquisadores de suas línguas? Se os dados dessas línguas documentadas são continuamente produzidos e armazenados, esse programa de banco de dados teria como ser adaptado às diferentes línguas a fim de atender às especificidades de cada uma delas?

Ora, não resta dúvida quanto à relevância do desenvolvimento, no contexto da metodologia da documentação e pesquisa linguística, de ferramentas capazes de dar conta dos dados oriundos desse trabalho. Contudo, é imprescindível pensar, antes, sobre a própria natureza desses dados linguísticos. E, para isso, é necessário partir de uma situação real, ou seja, da própria documentação e descrição de uma língua, principalmente aquelas que estiverem em situação mais crítica, conforme a proposta de classificação das línguas apresentada no Quadro 01.

Nesse sentido, ressalto que uma das línguas mais ameaçadas no Brasil é, por exemplo, o Suruí do Tocantins (Suruí do Pará, Mudjetíre ou Aikewára). Apesar de ser classificada pela UNESCO como vulnerável, na verdade ela está seriamente em perigo, porque "a língua é falada pelos avós; enquanto a geração dos pais pode compreendê-la, eles não a falam entre eles ou com seus filhos" (UNESCO, 2011, p. 6).

Partindo da observação da comunidade de fala, que se reduziu a menos de $10 \%$ de toda a população Suruí, é possível constatar a gravidade dessa situação de vulnerabilidade da língua, e que a reversão desse quadro, se não é de todo impossível, torna-se uma tarefa bastante difícil.

Assim, diante dos poucos estudos linguísticos já realizados sobre esta língua e diante da inexistência de dicionários para uso social dentro e fora da escola, resolvi realizar esta pesquisa não somente com o intuito de ampliar o conhecimento linguístico sobre essa língua da família Tupí-Guaraní, tratando também de questões relacionadas à fonologia e à gramática da língua, mas, principalmente, para viabilizar a documentação linguística para que ela fosse, por meio de um novo programa informatizado para armazenamento de dados, gerar materiais que fossem úteis tanto à pesquisa linguística quanto aos próprios falantes da língua Suruí. 
Logo, o objetivo da pesquisa para construção desta tese de doutorado foi primeiramente descrever os principais aspectos da gramática e do léxico da língua Suruí do Tocantins, a fim de elaborar um material lexicográfico para atender, antes de tudo, às necessidades educacionais de alunos e professores Suruí no aprendizado de sua própria língua, mas também contribuir com as demais pessoas da comunidade indígenas e com a descrição linguística de línguas indígenas brasileiras. Logo, procedeu-se o aprofundamento da descrição gramatical da língua Suruí e também o inventário lexical da maior quantidade possível de unidades lexicais dessa língua.

Foi documentado e sistematizado, especialmente, o léxico relativo à fauna e à flora com embasamento no conhecimento tradicional indígena e no conhecimento científico sobre esses elementos, quando este estava disponível.

\subsection{JUSTIFICATIVA}

Diante da incipiente situação dos estudos sobre a língua Suruí do Tocantins e, sobretudo, diante da falta de recursos para o ensino dessa língua nessa comunidade de fala, é que se justifica o empreendimento deste projeto em estudar essa língua da família linguística Tupí-Guaraní.

À semelhança de tantas outras línguas indígenas no Brasil (e também no mundo), a língua Suruí do Tocantins está ameaçada de desaparecimento e, se não é uma pesquisa linguística e a produção de material lexicográfico que garantirão a sobrevivência dessa língua, pelos menos poderão contribuir para que outros Suruí, além dos professores Ikatu e Tymykong, grandes colaboradores desta pesquisa, possam ver em sua língua o potencial que ela guarda, e aspectos importantes da cultura que ela expressa e da história do povo que data tempos imemoriais. Munidos desses instrumentos, podem lutar mais adequadamente pela sobrevivência de sua própria língua.

\subsection{ORIENTAÇÃO TEÓRICA}

Língua do sub-ramo IV da família linguística Tupí-Guaraní, o Suruí do Tocantins é uma língua bastante próxima das línguas Asuriní do Tocantins e Parakanã. ${ }^{2}$ Essas línguas, apesar de possuírem traços gramaticais e lexicais comuns, diferem em vários aspectos e são consideradas línguas distintas por seus respectivos falantes. Disto decorre a necessidade de um maior aprofundamento na descrição e comparação dos subgrupos linguísticos da família

\footnotetext{
${ }^{2}$ Cf. Lopes e Cabral (2012, p. 1614-1624).
} 
Tupí-Guaraní, a fim de verificar a aproximação ou o distanciamento das línguas deste grupo em seus mais diversos aspectos linguísticos.

O estudo gramatical do Suruí do Tocantins tem sido realizado em uma perspectiva descritiva e de referência, lançando mão de descrições morfológicas e morfossintáticas como as de Rodrigues (2010), estudos tipológicos como o de Harrison (1986), do questionário gramatical do SALDIP de Kaufman, Berlin e Rodrigues (1985) e de importantes trabalhos de Cabral (1997, 2000, 2001, 2002, 2007, 2012, 2013) sobre línguas da família Tupí-Guaraní. Para o estudo do léxico, considerei Payne (1997, 2006) e Mithun (1984), e com respeito às classes de palavras e à análise sintática os trabalhos de Comrie (1976, 1985) e Van Valin Jr. (2004).

A dicionarização da língua foi desenvolvida a partir de pressupostos teóricos metodológicos de Atkins e Rundell (2008), Haensch, Wolf, Ettinger e Werner (1982), Dubois e Dubois (1971), Al-Kasimi (1983) e Yong e Peng (2007), e baseou-se nos estudos gramaticais da língua Suruí, resultando nas diferentes análises e propostas lexicográficas constantes na presente tese.

Assim, esse conjunto trabalhos teóricos não somente contribuiu com as reflexões dos vários temas abordados neste trabalho, mas também pôde ser usado, sob a forma de citação, para fundamentar vários pontos desta tese.

\subsection{ORGANIZAÇÃO DOS CAPÍTULOS}

Este trabalho foi construído como uma proposta de descrição linguística da língua Suruí do Tocantins, mas também de um modelo de documentação linguística e de um projeto lexicográfico, baseados nessa mesma língua, por isso, esse trabalho apresenta a seguinte configuração.

Inicialmente faço a contextualização do povo Aikewára que fala a língua Suruí do Tocantins, qual a sua história de contato com a sociedade não indígena, onde está localizada a sua terra, que denominações ele recebeu e que estudos antropológicos já foram desenvolvidos junto a esse povo.

Em seguida, após apresentar uma classificação linguística da língua Suruí do Tocantins, trato das questões relacionadas ao uso de sua língua e o contato com o Português, traçando um percurso acerca das experiências de escrita desse povo. 
Concluída essa etapa, apresento uma descrição da fonologia da língua Suruí, historiando os trabalhos já realizados nesse sentido, seguida de considerações acerca da escrita e da ortografia para essa língua da família Tupí-Guaraní.

O esboço gramatical (morfossintaxe) da língua Suruí, apresentado no capítulo seguinte, proporciona a fundamentação teórica indispensável para este trabalho que envolve aspectos léxicos e lexicográficos da língua Suruí.

Considerei, a partir de orientação recebida no decorrer da tese, a necessidade de realizar um levantamento do acervo de obras lexicográficas produzidas ao longo dos últimos cinco séculos da história no Brasil relacionadas a línguas indígenas brasileiras. Tal pesquisa, que demandou tempo e esforço consideráveis, se justifica no contexto da pesquisa desta tese, porque permitiu uma reflexão mais completa e abrangente sobre as possibilidades de compreensão tanto da documentação quanto da proposição de modelos lexicográficos para a língua que estou estudando.

No capítulo seguinte, apresento considerações acerca da documentação linguística da língua Suruí do Tocantins, no qual apresento elementos da pesquisa de campo para coleta de dados e também o programa de computador que utilizei para armazenar todos os dados coletados nesta pesquisa.

Dois outros capítulos importantes deste trabalho são os que tratam da apresentação dos modelos lexicográficos já baseados na língua Suruí e o capítulo em que descrevo, em detalhe, a macroestrutura e a microestrutura dos materiais lexicográficos propostos para essa língua. Ainda neste capítulo, trato de questões relacionadas ao léxico da língua Suruí, destacando inclusive os neologismos, o que muito contribuiu para o estabelecimento do conteúdo dos dicionários colocados ao final desse mesmo capítulo. 


\section{BREVE HISTÓRICO DO POVO SURUÍ}

Segundo o sábio Suruí Awasa'i, cujo centenário de nascimento foi comemorado em 2012, historicamente o seu povo ocupou a região nas encostas da Serra das Andorinhas, no município paraense de São Geraldo do Araguaia, próximo ao rio Araguaia.

Contudo, os Suruí foram forçados a sucessivos deslocamentos ou por conflitos com outros povos indígenas (sobretudo com os Kayapó, a quem eles denominavam Karasá) ou por pressão de garimpeiros (final do século XIX e início do século XX), de castanheiros e de fazendeiros que demandavam áreas cada vez maiores para atividades mineradoras, agrícolas e pecuárias. $\mathrm{O}$ grupo acabou, então, confinado em uma área que quase não dispunha de recursos hídricos e onde a caça e os castanhais eram escassos.

Apesar de os primeiros relatos escritos sobre os Suruí datarem de aproximadamente 100 anos, a presença deste grupo indígena na região próxima aos rios Tocantins e Araguaia é, certamente, de um período bem anterior.

Segundo hipótese levantada por Laraia e Matta (1967; 1978, p. 63): “[...] estes índios [os 'Sororós'] são os mesmos que, segundo Coudreau (1898, p. 78-81), apareceram no fim do século passado num lugar chamado Arara, um pouco acima da confluência do Itacaiúnas, nas margens do Tocantins". 3

Essa hipótese, proposta com base nos relatos acerca dos frequentes avistamentos na região próxima ao rio Itacaiúnas de indígenas desconhecidos, é bem plausível, pois, a maior parte dos povos indígenas que habita (ou habitava) aquela região fala (ou falava) línguas filiadas ao tronco Macro-Jê (Gavião e Xikrín do Cateté, por exemplo), e era relativamente bem mais conhecida pela população local do que os grupos falantes de línguas

\footnotetext{
${ }^{3}$ No final do século XIX, o francês Henri Coudreau registra em seu livro Voyage à Itaboca et à l'Itacayuna: “Toujours est-il que l'existence d'une tribu indienne dans la zone qui s'étend entre le confluent de l'Itacayuna et le confluent de Rio Fresco nous paraît un fait hors de doute. La fumée que j'ai vue s'élever des campos du Bas Rio Fresco, des vestiges de passages d'Indiens dans la région du Morro Vermelho, de subites apparitions d'Indiens inconnus à l'Igarapé do Bacury et à l'endroit appelé Prata, un peu du confluent de l'Itacayuna sur la rive gauche du Tocantins, tous ces faits réunis attestent l'existence d'une tribu dans la région indiquée. [...] Il y a cinq ou six ans, en aval de Prata, à l'endroit nommé Arara, une quarantaine d'Indiens inconnus, hommes, femmes et enfants, se montrèrent soudain. Ils firent comprendre, par signes, qu'ils avaient voyagé pendant quantité de « dormir » et qu'ils venaient d'une région de campos. " (COUDREAU, 1898, p. 78-79). Tradução: "De qualquer forma, a existência de uma tribo indígena na zona que fica entre o confluente do Itacaiúnas e o confluentes do rio Fresco nos parece um fato indubitável. A fumaça que vi se elevar acima dos campos do baixo rio Fresco, vestígios da passagem de índios na região do morro Vermelho, rápidas aparições de índios desconhecidos no igarapé do Bacuri e no lugar chamado Prata, próximo do confluente do Itacaiúnas na margem esquerda do Tocantins, todos esses fatos reunidos atestam a existência de uma tribo na região indicada. [...] Há cinco ou seis anos, acima do Prata, no lugar denominado Arara, uns quarenta índios desconhecidos, homens, mulheres e crianças, se mostraram rapidamente. Eles se fizeram compreender, por meio de sinais, que eles tinham viajado durante algum tempo e que eles vinham de uma região de campos." (tradução nossa).
} 
do troco Tupí, que não eram tão comuns naquela região, pelo menos na época em que se documentou a presença Jê.

No início do século XX, mais precisamente no dia 15 de novembro de 1904, foi publicada no Diario do Maranhão uma notícia sobre índios localizados exatamente na região hoje ocupada pelos Suruí:

\section{Noticias de Araguay EXTRACÇÃO DA BORRACHA}

Carta do capitão Felippe Moreira, presentemente no rio Vermelho, affluente do Itacaúnas, dirigida em data de 20 de setembro ao major, Luiz Leda, da B. do Corda, as seguintes noticias. A despeito das febres que tambem me accommetteram, tenho feito bom carregamento de borracha, que terei de embarcar em balsas no rio Sororó e leva-lo até Itacaúnas.

O Sororó é bastante obstruido de madeiras cahidas e do ponto em que estou ao rio Vermelho tambem affluente do Itacaúnas, são 12 leguas.

Mandei explorar a matta e fazer tres circulos com bastante madeira para a safra vindoura, visto não me convir abandonar um meio em que tenho as melhores vantagens. Conto que para o anno seguinte a extracção do cauxho me será muito mais favoravel, porque terei de subir pelo Itacaúnas e no ponto onde estou terei apenas precisão de farinha, visto como o peixe, a tartaruga a caça, o jaboti são aqi com abundancia. Como o mal anda ao lado do bem ha aqui tambem em grande abundancia a morissóca carrapato de fogo, a cuja mordedura se sente a impressão dolorosa de uma queimadura, pulgas, e indios em grande quantidade. Do rio Vermelho ao rio Branco, onde trabalha grande pessoal na extracção da borracha, a distancia è na direcção em que estou, de 12 leguas. Ha poucos dias foi alli atacado um barracão pelos indios, sendo repellidos energicamente e destroçados!

Os indios da região em que estou não obstante serem bravios, não offendem a ninguem. São de estatura pequena, não conhecem o u o (sic) de outra arma que não a flecha e apenas presentem a approximação de gente civilisada internam se nas mattas, abandonando os aldeiamentos.

Essa descrição sobre o modo de proceder (fuga) desses indígenas quando do contato com não indígenas é bem semelhante àquele registrado nas primeiras tentativas de contato de Gil Gomes, no início dos anos 1950.

Apresento, a seguir, uma tabela com os principais acontecimentos relacionados ao contato do Suruí com os não indígenas, bem como informações demográficas desse povo (dos anos 1950 até 2012):

TABELA 01 - RESUMO DA CRONOLOGIA HISTÓRICA E DEMOGRÁFICA DOS SURUÍ

\begin{tabular}{c|l|l}
\hline Data & Evento & Fonte \\
\hline 1898 & $\begin{array}{l}\text { Registro de avistamentos de indígenas nas proximidades dos } \\
\text { rios Itacaiúnas e Araguaia (seriam os Suruí?) }\end{array}$ & Coudreau (1898) \\
\hline 1904 & $\begin{array}{l}\text { Novo relato da presença de indígenas nas proximidades do } \\
\text { rio Vermelho, afluente do Itacaiúnas, e próximo ao Sororó }\end{array}$ & Jornal Diario do maranhão (1904) \\
\hline
\end{tabular}




\begin{tabular}{|c|c|c|}
\hline 1923 & $\begin{array}{l}\text { Registro de avistamentos de indígenas nas cabeceiras do rio } \\
\text { Sororó (então denominados Sororó, pelo Frei Antônio Sala) }\end{array}$ & Laraia e Matta (1978) \\
\hline 1947 & $\begin{array}{l}\text { Contato frustrado entre os Suruí e castanheiros da região } \\
\text { (reação violenta destes) }\end{array}$ & Laraia e Matta (1978) \\
\hline $\begin{array}{l}1951- \\
1952\end{array}$ & $\begin{array}{l}\text { Primeiras tentativas de contato de Frei Gil Gomes com os } \\
\text { Suruí }\end{array}$ & Laraia e Matta (1978) \\
\hline 1953 & $\begin{array}{l}\text { Após primeiro contato com os Suruí (cuja população era de } \\
\text { aproximadamente } 100 \text { pessoas), Frei Gil Gomes passou a } \\
\text { realizar visitas anuais regulares }\end{array}$ & Laraia e Matta (1978) \\
\hline 1957 & $\begin{array}{l}\text { Nova tentativa de aproximação com os castanheiros, } \\
\text { culminando com a morte de um Suruí }\end{array}$ & Laraia e Matta (1978) \\
\hline 1960 & $\begin{array}{l}\text { Epidemia de gripe mata } 2 / 3 \text { dos } 120 \text { Suruí. Morte de } \\
\text { Musenai, líder do grupo. População Suruí fica com } 40 \\
\text { pessoas }\end{array}$ & $\begin{array}{l}\text { Laraia e Matta (1978) } \\
\text { Laraia (2007) }\end{array}$ \\
\hline 1960 & $\begin{array}{l}\text { Uma pessoa da região, João Correia, aproveita o momento } \\
\text { de instabilidade dos Suruí com a morte de Musenai, e tenta } \\
\text { transformar o povo em caçadores de pele, mas é expulso por } \\
\text { Frei Gil, que tinha o apoio do SPI }\end{array}$ & Laraia e Matta (1978) \\
\hline 1960 & Kuarikuara herda, de seu pai, a liderança do grupo & Laraia e Matta (1978) \\
\hline 1962 & $\begin{array}{l}\text { Morte de Kuarikuara e de seus dois irmãos, Sarakoa e Koati } \\
\text { [ao todo foram sete mortes nesse ano] }\end{array}$ & Laraia e Matta (1978) \\
\hline 1966 & $\begin{array}{l}\text { Sawara assume a chefia do grupo, mas quem liderava de } \\
\text { fato era Uamassú (que melhor conhecia os brancos) }\end{array}$ & Laraia e Matta (1978) \\
\hline 1968 & Interdição da terra indígena ocupada pelos Suruí & Brasil (1968) \\
\hline 1968 & População Suruí: 38 pessoas & Queiroz (1976) \\
\hline 1972 & População Suruí: 44 pessoas & Dostal (1972) \\
\hline $\begin{array}{l}1972- \\
1973\end{array}$ & $\begin{array}{l}\text { O povo Suruí é envolvido nos acontecimentos da Guerrilha } \\
\text { do Araguaia. Muitos homens são usados como mateiros } \\
\text { pelos militares }\end{array}$ & Arnaud (1983); Lopes (2012) \\
\hline 1975 & População Suruí: 66 pessoas & Queiroz (1976) \\
\hline 1975 & $\begin{array}{l}\text { Expulsão do agente do Posto da FUNAI da área indígena } \\
\text { dos Suruí }\end{array}$ & Arnaud (1983) \\
\hline 1976 & População Suruí: 75 pessoas & Laraia e Matta (1978) \\
\hline 1976 & Retorno à aldeia antiga & Laraia e Matta (1978) \\
\hline 1976 & $\begin{array}{l}\text { Implantação do Projeto de Emergência do Plano Integrado } \\
\text { de Desenvolvimento Comunitário Gavião-Suruí (PIDC), } \\
\text { promovido pelo DGPC/FUNAI }\end{array}$ & Ferraz (1985) \\
\hline 1977 & População Suruí: 64 pessoas & Laraia e Matta (1978) \\
\hline 1982 & $\begin{array}{l}\text { Assinatura da portaria } \mathrm{n}^{\circ} 1.370 / \mathrm{E} \text { de } 24 / 08 / 1982 \text {, declarando } \\
\text { como de posse permanente do grupo indígena Suruí a área } \\
\text { da Área Indígena Sororó }\end{array}$ & Cedi (1983) \\
\hline
\end{tabular}




\begin{tabular}{|c|c|c|}
\hline 1983 & $\begin{array}{l}\text { O decreto } 88.648 \text { de } 30 / 08 / 1983 \text {, do Presidente da } \\
\text { República, homologa a demarcação da área indígena } \\
\text { Sororó, de posse imemorial do grupo indígena Suruí }\end{array}$ & Brasil (1983); Cedi (1984) \\
\hline 1985 & População Suruí: 101 pessoas & Cimi (1986) \\
\hline 1985 & População Suruí: 109 pessoas & Ferraz (1985) \\
\hline 1986 & Publicação do Vocabulário Aikewar & Monserrat (1986) \\
\hline 1988 & População Suruí: 122 pessoas & Vieira Filho (1988) \\
\hline 1990 & População Suruí: 130 pessoas & Vidal (1993) \\
\hline 1993 & População Suruí: 136 pessoas & Barbosa, J. A. (1993) \\
\hline 1995 & $\begin{array}{l}\text { Grande incêndio na Reserva Suruí (pelo menos 10,5 mil } \\
\text { hectares de mata consumidos pelo fogo) }\end{array}$ & Cedi (1996) \\
\hline 1996 & População Suruí: 153 pessoas & Idesp (1996) \\
\hline 1997 & População Suruí: 185 pessoas & Cedi (2000) \\
\hline 1999 & $\begin{array}{l}\text { Criação da Associação Indígena do Povo Aikewar do } \\
\text { Sororó (AIPAS) }\end{array}$ & Cedi (2000) \\
\hline 2004 & Participação no I Jogos tradicionais indígenas do Pará & Revista Pará+ (2004) \\
\hline 2006 & População Suruí: 264 pessoas & Funasa (2006 apud CEDI, 2006) \\
\hline 2010 & População Suruí: 332 & Funasa (2010 apud CEDI, 2010) \\
\hline 2010 & $\begin{array}{l}\text { Grande incêndio na Terra Indígena Sororó (pelo menos } \\
4 \text { mil hectares de mata consumidos pelo fogo) }\end{array}$ & Cedi (2011) \\
\hline 2012 & $\begin{array}{l}\text { Aprovação do relatório de identificação e delimitação da } \\
\text { Terra Indígena Tuwa Apekuokawera pela FUNAI }\end{array}$ & Pará (2012) \\
\hline 2012 & População Suruí: 370 pessoas & Funasa $(2012)^{4}$ \\
\hline
\end{tabular}

\subsection{A TERRA INDÍGENA DOS SURUÍ}

A Terra Indígena Sororó (doravante T.I. Sororó) ou, mais recentemente, T.I. Tuwa Apekuokawera (ver Anexo E), distante cerca de $100 \mathrm{~km}$ do principal centro urbano da região, a cidade de Marabá, e distante cerca de 70 quilômetros de São Geraldo do Araguaia, também

\footnotetext{
${ }^{4}$ Em 2012, foi divulgado o resultado do Censo Demográfico 2010 do Instituto Brasileiro de Geografia e Estatística (IBGE), que considerou informações sobre os povos indígenas brasileiros, "investigando o pertencimento étnico e as línguas indígenas faladas, além de identificar a população residente nas Terras Indígenas e fora delas" (IBGE, 2012). De acordo com esse recenseamento, a população Suruí (denominada nos documentos oficiais desse Instituto como "Suruí do Pará") seria constituída por 1258 pessoas. Acredito que tenha havido algum tipo de equívoco na computação dos dados relativos aos Suruí, pois esse total de pessoas está bem distante do quantitativo populacional Suruí, cujo crescimento demográfico pode ser acompanhado na Tabela 01.
} 
no sudeste do Pará, é cortada pela rodovia BR-153 (Belém-Brasília). ${ }^{5}$ Segundo o relatório produzido por Barnes (2012, p. 11) e publicado no Diário Oficial do Estado do Pará, os Suruí estão situados “[...] na região contornada pelo baixo rio Araguaia, próximo à sua foz, no rio Tocantins, e o rio Vermelho (afluente do rio Itacaiúnas, tributário do Tocantins), conformando a região conhecida como 'Bico do Papagaio'”.

Segundo Laraia e Matta (1978, p. 10), a viagem até a essa T.I. era feita nos anos 1960 em "três dias de cavalgada", partindo-se de Marabá, pela rodovia BR-230 (Transamazônica). Hoje, essa viagem é feita de carro em apenas 1 hora, aproximadamente, pela rodovia BR-153, antiga OP-2 (estrada operacional), criada na década de 1970, por ordem do governo militar e com a motivação da Guerrilha do Araguaia, e que cortou a terra dos Suruí, facilitando bastante o acesso à aldeia, mas também acentuando os conflitos causados pelo aumento das invasões à terra indígena.

Em 1968, o presidente Costa e Silva interditou, por meio do Decreto nº 63.367, a área habitada pelos Suruí para que a FUNAI pudesse promover "a regularização definitiva das terras indígenas existentes na área, através da medição, demarcação e registro da propriedade". Essa demarcação, dada por concluída pela FUNAI no final da década de 1970 após muitas discussões acerca dos reais limites da área, ${ }^{6}$ foi homologada no início da década de 1980, pelo Decreto n $^{\circ} 88.648$ assinado pelo então presidente João Figueiredo:

Art. $1^{\circ}$. - Fica homologada, para os efeitos legais, a demarcação administrativa promovida pela Fundação Nacional do Índio (FUNAI) da área indígena denominada SORORÓ, de posse imemorial do grupo indígena SURUÍ, localizada no Município de São João do Araguaia, Estado do Pará. (BRASIL, 1983)

Contudo essa demarcação (ver Anexo A), homologada às pressas segundo observou Ferraz (1984, p. 8), mesmo com uma área total de 26.257 hectares, não abrangeu áreas de antigas aldeias, com seus cemitérios e cursos d'água, além de extensas e produtivas áreas de castanhais, fazendo com que o povo Suruí, já bastante espoliado de seus direitos e de suas terras (há muito sendo invadidas e tomadas por posseiros e latifundiários), se limitasse a

\footnotetext{
${ }^{5}$ Legalmente, a T.I. Sororó fica na fronteira entre os municípios de São João do Araguaia e São Geraldo do Araguaia, sendo que era este último que, durante anos, serviu de referência para o povo Suruí, mas, devido a problemas políticos e desinteresse municipal, esse povo tomou a decisão de "migrar" para o município de Brejo Grande do Araguaia, que assumiu tanto o atendimento à saúde indígena quanto às demais questões sociais relacionadas aos Suruí-Aikewara.

${ }^{6}$ Segundo Ferraz (1985, p. 115), as primeiras propostas de demarcação da T.I. Sororó não estavam corretas, e só puderam ser corrigidas graças à participação dos próprios Suruí, que indicaram detalhadamente nos mapas "a localização das antigas aldeias, cemitérios, áreas de roças e, principalmente, concentrações de castanheiras, apontando com precisão as porções do território invadidas pelos latifundiários vizinhos".
} 
um espaço extremamente exíguo que não seria capaz de propiciar condições mínimas necessárias para sua sobrevivência.

Apresentei anteriormente (relatório de 1983), em detalhes, a necessidade de revisão da demarcação daquela área, o que parece ter sido motivo de objeções por parte da agência tutelar. [...] A importância da reparação das incorreções havidas na demarcação daquela área indígena prende-se exatamente à possibilidade de propiciar de fato condições dignas de existência para aquela sociedade tribal. (FERRAZ, 1984, p. 7-8)

Assim, ainda em meados de 1980, as discussões entre os Suruí e a FUNAI foram retomadas, contando, naquela ocasião, também com a participação da Companhia Vale do Rio Doce (CVRD), cujos projetos causariam impactos diretamente nos povos indígenas da região dos rios Araguaia e Tocantins.

A situação dos Suruí do Posto Indígena Sororó é paradigmática das pressões que vêm sofrendo, nessa região do sudeste paraense, as populações de pequenos produtores e de posseiros. É necessário considerar particularidades de ocupação dessa área que levaram à "pauperização" dos Suruí... (FERRAZ, 1984, p. 7) ${ }^{7}$

Somente em janeiro de 2012, o então presidente da FUNAI Márcio Meira, em seu despacho no 3 (BRASIL, 2012, p. 34), aprovou as conclusões do estudo feito pelo antropólogo Eduardo Vieira Barnes sobre a identificação e delimitação do território dos Suruí do Tocantins, identificando-o como Terra Indígena Tuwa Apekuokawera (alterando, assim, a denominação anterior que era Terra Indígena Sororó - Gleba Tuapekuakau). Com a adição desta terra, a reserva ganharia mais 11.764 hectares (ver Anexos B, C e E).

Esse processo de luta pela correta demarcação da T.I. continua, porém, o povo Suruí do Tocantins já obteve importantes conquistas para uma luta que dura mais de 30 anos.

\subsection{DENOMINAÇÕES DO POVO E DA LÍNGUA SURUÍ}

Os Suruí, ${ }^{8}$ que se autodenominam Aikewár ou Aikewára, receberam de povos indígenas e não indígenas diversas denominações. Desse modo, é possível identificar, atualmente, em registros escritos de diversos campos do conhecimento (da Linguística e da Antropologia, para citar os mais comuns), uma grande quantidade de denominações para esse

\footnotetext{
${ }^{7}$ Essa localização da T.I. Sororó, no entanto, de acordo com o Mapa Rodoviário Pará, produzido em 2002 pelo Departamento Nacional de Infraestrutura de Transportes (DNIT), situa essa área nos municípios de Marabá, São Domingos do Araguaia e São Geraldo do Araguaia, sendo que a maior parte da terra fica nos limites deste último município (ver Anexo D).

${ }^{8}$ É incerto o significado do termo Suruí, atribuído ao grupo quando de seus primeiros contatos com não indígenas. Já Mudjetire tem origem Jê e sentido depreciativo.
} 
mesmo povo, na maior parte delas relacionadas ao local onde vivem ou viveram (Sororó, Tocantins e Pará).

Antes, porém, de passar às denominações, é importante destacar que não distingui aqui a designação do povo e de sua respectiva língua, pois, segundo Rodrigues (1950, p. 100), “[...] tradicionalmente e naturalmente, tem-se aplicado à língua o mesmo nome da tribo ou povo que a fala". É isto o que acontece também com os Suruí do Tocantins, cujos termos que servem para denominar o povo são também usados para nomear a língua.

Apresentamos, abaixo, a Tabela 02 que contém uma série de denominações dadas a esse povo ao longo do século XX:

TABELA 02 - DENOMINAÇÕES DO POVO / DA LÍNGUA SURUÍ

\begin{tabular}{|c|c|c|c|}
\hline Data & Denominações registradas & Domínio & Fonte \\
\hline 1923 & Sororó & Religião & $\begin{array}{l}\text { Salas (1923 apud LARAIA; } \\
\text { MATTA, 1967) }\end{array}$ \\
\hline 1959 & Mudjetire & Religião & Carvalho (1959) \\
\hline 1963 & Suruí & Antropologia & Laraia $(1963,1978,1986,1993)$ \\
\hline 1967 & Mudjetire & Antropologia & Ribeiro $(1967)^{9}$ \\
\hline 1968 & Mudzyetíre & Linguística & Loukotka $(1968)^{10}$ \\
\hline 1970 & Suruí do Tocantins (Mudjetíre) & Linguística & Rodrigues (1970a) \\
\hline 1972 & Mudjetire (Suruí) & $\begin{array}{l}\text { Antropologia e } \\
\text { História }\end{array}$ & Dostal (1972) \\
\hline 1976 & Suruí, Tupi do Pará, & Antropologia & Queiroz $(1976,1980)$ \\
\hline 1983 & Suruí-Mudjetíre, Suruí, Mudjetíre & Antropologia & Arnaud (1983) \\
\hline 1984 & Suruí, Suruí do Tocantins (Majetíre) & Linguística & Rodrigues $(1985,2012)$ \\
\hline 1985 & Suruí, Suruí do Pará & $\begin{array}{l}\text { Antropologia, } \\
\text { política e } \\
\text { história }\end{array}$ & Ricardo (1985) \\
\hline 1986 & Suruí do Tocantins (Mudjetire) & Linguística & Rodrigues (1986) \\
\hline 1986 & Aikewar (Suruí do Pará), Suruí & Linguística & Monserrat (1986) \\
\hline 1988 & Suruí, Suruí do Sororó & Saúde & Vieira Filho (1988) \\
\hline 1993 & Suruí do Tocantins & Linguística & Barbosa, J. A. (1993) \\
\hline 1999 & Suruí do Tocantins & Linguística & Neves (1999) \\
\hline 1999 & $\begin{array}{l}\text { "suruí-pará 'mudjetíre', 'mudjetíre-suruí', in } \\
\text { [51=] Português: suruí do Tocantins, }\end{array}$ & Internet & The Linguasphere Register (1999) \\
\hline
\end{tabular}

9 Na década de 1960, os Suruí eram ainda pouco conhecidos do ponto de vista linguístico e antropológico. Ribeiro (1967) se refere a eles como "MUDJETÍRE (50 to 100) Tupi (?) Kayapó name (estojo peniano grande) for a group, possibly Tupi found along the Sororosinho, tributary of the Rio Sororó emptying into the Vermelho, tributary of the right bank of the lower Itacaiuna. State of Pará. (Isolated)".

${ }^{10}$ Menos informação ainda tem Loukotka (1968, p. 112), que escreve: "Mudzyetíre - a Cayapó name for an unknown Tupi tribe that lived on the Igarapé Sororosinho. [Nothing.]" 


\begin{tabular}{l|l|l|l}
\hline & $\begin{array}{l}\text { including akewere, aikewara -- São João do } \\
\text { Araguaia environs" }\end{array}$ & (linguística) & \\
\hline 2000 & Suruí do Tocantins, Suruí Mudjetíre, Suruí & Linguística & Mello (2000) \\
\hline 2000 & Suruí do Tocantins (Mudjetire) & Linguística & Monserrat (2000) \\
\hline 2004 & Suruí do Tocantins e Suruí & Linguística & Figueiredo (2004) \\
\hline 2005 & Suruí do Pará [mdz] & $\begin{array}{l}\text { Internet } \\
\text { (linguística) }\end{array}$ & Glottolog.org \\
\hline 2006 & Suruí do Tocantins (Mudjetíre, Aikewára) & $\begin{array}{l}\text { Linguística } \\
\text { (linguística) }\end{array}$ & Rodrigues (1993) \\
\hline 2009 & Suruí (Suruí-Mudjetire) & Antropologia & Silva (2009) \\
\hline 2010 & Suruí do Tocantins & Linguística & Corrêa-da-Silva (2010) \\
\hline 2010 & Aikewara (Suruí do Tocantins) & Educação & Brasil (2010) \\
\hline 2010 & Sikewara (Suruí, Sororós, Aikewara) & Saúde & FUNASA (2010) \\
\hline 2011 & Suruí of Tocantins, Suruí of Pará & $\begin{array}{l}\text { Internet } \\
\text { (linguística) }\end{array}$ & UNESCO (2010) \\
\hline 2011 & Suruí & Linguística & Aikhenvald (2011) \\
\hline 2012 & $\begin{array}{l}\text { Suruí do Pará, Suruí do Tocantins, } \\
\text { Mudjetire, ou Sororós }\end{array}$ & $\begin{array}{l}\text { Antropologia } \\
\text { Suruí (Suruí do Tocantins, Aikewara, }\end{array}$ & Mellati (2011) \\
\hline 2012 & Suruí (Suruí do Tocantins) & Pará (2012) \\
\hline 2014 & Aikewara & $\begin{array}{l}\text { Internet } \\
\text { (Notícia) }\end{array}$ & $\begin{array}{l}\text { JOGOŚística } \\
\text { INDÍGENAS DO PARÁ (2014) }\end{array}$ \\
\hline Campbell (2012) \\
\hline
\end{tabular}

Como se observa, a denominação Suruí do Tocantins, registrada pela primeira vez em Rodrigues (1970), foi a que se fixou na literatura da área da Linguística, sendo esta a que utilizo ao longo deste trabalho, alternando-se com a forma reduzida Suruí e a abreviatura, quando necessário, de sur.

Entretanto, atualmente, esse povo reivindica o uso somente do termo Aikewára (forma de autodenominação que alguns documentos oficiais, textos midiáticos e trabalhos acadêmicos já registram) e que sua língua também seja assim denominada. Por isso, reservo o uso da forma da autodenominação Aikewára para o material ainda a ser produzido com finalidade didática e/ou cultural, derivado deste trabalho. ${ }^{11}$

\footnotetext{
${ }^{11}$ Por exemplo, um material derivado diretamente desta tese será um dicionário, aqui denominado Dicionário da Língua Suruí, mas, em sua versão impressa para uso na aldeia, deverá ser chamado de Dicionário da Língua Aikewara, como é desejo manifesto desse povo.
} 


\subsection{TRABALHOS ANTROPOLÓGICOS SOBRE OS SURUÍ}

O primeiro estudo antropológico sobre os Suruí foi iniciado por Laraia no início da década de 1960. Esse pesquisador fez algumas viagens até a aldeia dos Suruí, onde documentou a situação desse povo, detendo-se, sobretudo, nas suas formas de parentesco.

Laraia e Matta produziram, a partir das observações colhidas nessas viagens, mas também das viagens para as aldeias dos Asuriní do Tocantins (Akuáwa Asurinî) e dos Gavião, o livro Índios e castanheiros: a empresa extrativista e os índios no médio Tocantins, com primeira edição de 1967 e segunda edição corrigida de 1978. Nesse livro, é apresentado o histórico da exploração do rio Tocantins desde o século XVII até o século XX, a formação da população às margens desse rio e de seus afluentes, principalmente da população indígena dos Asuriní, Suruí e Gavião, com breve análise de suas estruturas sociais e as consequências do contato com os não indígenas.

Ferraz, em 1985, escreve um dos mais completos trabalhos etnográficos sobre os Suruí do Tocantins. Passando pelas denominações que o grupo recebeu (Suruí do Pará e Mudjetíre) até a autodenominação (Aikewára), apresenta a localização da área indígena desse grupo ("município de São João do Araguaia, entre os rios Gameleira e Sororó, numa região

próxima à Serra das Andorinhas"), detalhando vias e formas de acesso. Ela ressalta que, no início da década de 1980, todos os Suruí utilizavam sua própria língua, e o Português ficava restrito ao contato com pessoas externas à aldeia e funcionários da FUNAI. O Português, nesse período, segundo o texto, já era falado por todos os adolescentes e crianças, mas entre os adultos, apenas $60 \%$ das mulheres e $80 \%$ dos homens falavam essa língua. Essa autora também apresenta o histórico do contato dos Suruí com os não indígenas, das primeiras informações sobre esse grupo na década de 1920 até início da década de 1980. Do contato preliminar à aproximação definitiva dos Suruí com a sociedade circundante, há o relato de algumas informações sobre a Guerrilha do Araguaia e de como ela afetou diretamente esse povo, mas também da luta pela manutenção e demarcação das suas terras, e resistência ao garimpo ilegal e à implantação de grandes projetos agrícolas e minerais na região. Finaliza esta parte com a descrição de como se estabeleceu o comércio da castanha e de outros produtos agrícolas e florestais entre os Suruí e as comunidades do entorno. 
Já o capítulo "Modos de vida", dividido em duas partes, apresenta o sistema social e a subsistência. Na primeira parte, descreve, antes de tudo, a própria aldeia, sua localização (mudada com certa frequência seja pela pressão externa, seja pela drástica redução da população), os sistemas de organização social (clã), de trabalho e de parentesco; já na segunda parte, é apresentada a base da alimentação dos Suruí, mas também suas principais atividades econômicas, a agricultura e a coleta da castanha-do-pará.

O penúltimo capítulo intitulado "Tutela e assistência" apresenta um resumo das principais pessoas e órgãos que prestaram assistência aos Suruí ao longo das décadas de 1960 a 1980, destacando o papel do frei Gil Gomes, da FUNAI e da antropóloga Iara Ferraz (membro do CTI). Além disso, trata brevemente dos serviços de saúde, destacando o serviço de vacinação, e da educação, informando que a primeira escola na aldeia foi construída entre os anos de 1981 e 1982 e que nesse mesmo período já havia indígenas alfabetizados em língua portuguesa.

"Situação atual das terras" é o título da última parte deste texto, que descreve a, então, Área Indígena Sororó [no ano de 1985] e apresenta um histórico detalhado da questão jurídica em torno da demarcação da terra dos Suruí. Foram inseridas neste trabalho cópias dos seguintes documentos: Decreto ${ }^{\circ}$ 88.648, de 30 de agosto de 1983; mapa da Área Indígena Sororó (Suruí) e mapa da “A.I. Sororo - Área de acréscimo e situação fundiária”.

Muitos outros trabalhos foram produzidos no âmbito da Antropologia envolvendo o povo Suruí, dentre os quais posso citar: uma entrevista feita com Tibakou, colhida, transcrita e publicada por Queiroz (1976), que também publicou em 1980 o artigo intitulado "Por falar em Suruí..."; uma série de relatórios produzida por Ferraz, entre as décadas de 1970 e 1980; duas dissertações de mestrado, uma defendida em 2002 ("O tempo antigo entre os Suruí/Aikewára: um estudo sobre mito e identidade étnica”, de Luiza de Nazaré Mastop Lima) e outra em 2007 ("Sapurahái de Karuára: mitos, instrumentos musicais e canto entre os Suruí Aikewára”, de Gilmar Matta da Silva); um laudo antropológico sobre a AI Sororó e a BR-153 produzido por Beltrão (1998); e os livros “Tupi, índios do Brasil atual” (LARAIA, 1986), “Los índios de Brasil” (LARAIA, 1993) e "Índios do Tocantins" (SAMPAIO SILVA, 2009). 


\section{CLASSIFICAÇÃO E SITUAÇÃO LINGUÍSTICA DA LÍNGUA SURUÍ}

Segundo Rodrigues (1984-1985, p. 39), Jensen (1999, p. 131) e Rodrigues e Cabral (2002, p. 335-341; 2012, p. 498), o Suruí do Tocantins pertence ao Ramo (sub-ramo, grupo ou subconjunto) IV, da família linguística Tupí-Guaraní, do tronco Tupí, aproximandose bastante das línguas Asuriní do Tocantins e Parakanã, como havia sido observado empiricamente pelo antropólogo Arnaud (1983, p. 8): “Os Akuáwa-Asuriní entendem-se de modo satisfatório com os Suruí-Mudjetíre e Parakanân, porém entre estes dois últimos a comunicação verbal ocorre com certa dificuldade". ${ }^{12}$

As línguas que fazem parte do Ramo IV, de acordo com Rodrigues e Cabral (2012, p. 498), são: Avá Canoeiro (TO), Tapirapé (MT), Parakanã (PA), Asuriní do Tocantins (PA), Suruí do Tocantins (PA), Tembé (MA, PA), Guajajára (MA) e †Turiwára (PA).

Partindo-se da comparação entre características do Suruí em relação ao ProtoTupí-Guaraní (PTG), conforme propõe Rodrigues (1984-1985, p. 39) e Rodrigues e Cabral (2002, p. 338-339), temos:

(a) conservação das consoantes finais, com ou sem modificações:

PTG *okér 'ele dorme' > Sur uker 'ele dorme'

(b) fusão de $* t \int \mathrm{e} * t s$, ambos mudados em $h$ :

PTG *jatfý 'lua' > Sur sahy 'lua'

PTG *potsy 'pesado' > Sur pihis 'pesado'

Com a pesquisa realizada para esta tese, obtivemos novos dados que mostram que alguns reflexos do PTG *ts mudaram para $h$ ou $\varnothing$.

$$
\text { PTG *ičipo 'cipó'> Sur ipo ‘cipó' }
$$

(c) mudança de *pw em $k w$ :

PTG *pwar 'amarrar' > Sur kwar 'amarrar'

(d) mudança de *pj em $t \int$ ou $t s$ :

PTG *epják 'ver'> Sur esak 'ver'

\footnotetext{
${ }^{12}$ Os trabalhos que tratam, em termos linguísticos, desta aproximação entre as línguas são os de Rodrigues (2002) e Lopes e Cabral (2012).
} 
(e) mudança de $* j$ em $t$, ts, $s$ ou $z$ :

PTG *jakaré 'jacaré'> Sur sakare 'jacaré'

\subsection{TRABALHOS LINGUÍSTICOS SOBRE A LÍNGUA SURUÍ}

Sob a coordenação do Conselho Indigenista Missionário Norte II (CIMI Norte II) e a assessoria linguística de Ruth Monserrat, foi produzido o material intitulado Vocabulário Aikewar, com o objetivo de auxiliar o povo Suruí a "participar ativamente no processo da escrita de sua própria língua" (CIMI, 1986, p. 3). Trata-se da primeira descrição sistemática sobre aspectos lexicais, fonológicos, morfológicos e morfossintático dessa língua, e apresentando uma proposta consistente de escrita para a língua. ${ }^{13} \mathrm{Um}$ dos materiais resultantes dessa descrição ${ }^{14}$ contém, grosso modo, três partes: as orientações para uso do vocabulário; um quadro ortográfico e o vocabulário propriamente dito.

$\mathrm{Na}$ primeira parte, a autora informa que as palavras do vocabulário podem apresentar um registro do tipo (i) ou (r), ou ainda não apresentar nada. Neste último caso, a palavra corresponde a um substantivo não possuível; já os registros com (i) correspondem a nomes possuíveis ou verbos no infinitivo; (i) ou (r) também são usados antes de substantivos, adjetivos e nomes relacionais; somente (r) depois da palavra "indica que a raiz começa com vogal e tem todos os pronomes dependentes".

Com relação à ortografia, a autora apresenta um quadro em que identifica 25 fones da língua Suruí e estabelece a correlação desses sons com 18 letras (incluindo, nesse caso, o par $n g$ e o apóstrofo).

O vocabulário está estruturado a partir do que a autora denominou Temas, são eles: nomes próprios; pessoa humana [denominações (49) e corpo (80)]; animal (126); a terra, as águas, o céu (24); plantas e frutas da terra (64); coisas que a gente fabrica (55); ações verbos (154); qualidade - descrição (60); quantidade (4); lugar e direção (19); tempo (5). Os termos desse Vocabulário estão dispostos em listas organizadas, na maior parte das vezes, em ordem alfabética (das palavras em Suruî), ${ }^{15}$ mas é possível identificar que nos temas Pessoa humana, Partes das plantas e Quantidade não se segue a ordem alfabética, mas sim um ordenamento segundo campos semânticos (observáveis, mas não explicitados no texto); por exemplo, em Pessoa humana, haveria os grupos relativos a: cabeça, pescoço, tórax, membros

\footnotetext{
${ }^{13}$ Ver no subcapítulo 3.1 as considerações sobre a proposta de Monserrat $(1985,1986)$.

${ }_{15}^{14} \mathrm{O}$ estudo morfológico e morfossintático ainda não foi publicado.

${ }^{15} \mathrm{Na}$ ordem alfabética desse Vocabulário, optou-se pela colocação das palavras iniciadas pela glotal no final das listas.
} 
superiores, abdome, pelve/região pubiana, membros inferiores; nos quais os elementos são apresentados correlacionados (do maior para o menor, do todo e de suas respectivas partes, formas específicas de cada gênero). Além disso, no interior dessas listas, alguns desses itens apresentam um recuo, indicando uma subcategorização (do tipo espécie ou forma variante).

Por ter uma finalidade didática, o material apresenta uma quantidade razoável de fotografias e desenhos, que servem para ilustrar alguns termos do vocabulário.

Algum tempo depois da produção deste trabalho do CIMI, esteve na Terra Indígena Sororó o casal Albert e Sue Graham, do Summer Institute of Linguistics, coletando dados linguísticos a fim de, segundo manifestaram em carta que eles dirigiram à FUNAI, fazer a Bíblia na língua dos Suruí, fazer a escrita da língua, fazer as primeiras cartilhas, escrever as lendas dos Suruí e pô-las em um livro para "ajudar a cultura a ficar mais firme"; além disso, pretendiam ajudar os Suruí a se tornarem professores usando sua própria língua, mas também fazer livros bilíngues, como um dicionário.

Segundo relatos coletados junto aos próprios Suruí, Albert Graham foi o primeiro a chegar à aldeia e a se estabelecer ali, sendo que Sue Graham chegaria lá somente algum tempo depois. No período em que esteve junto aos Suruí, ele buscou aprender a língua do povo, convivendo dia a dia com os Suruí e registrando por escrito palavras e frases na língua indígena. Parte desses dados foi impresso em uma brochura datilografada, que foi doada à biblioteca da Escola Trocará, na qual há o carimbo da Administração Regional de MarabáPA, da FUNAI.

Antes da apresentação dos registros, o material lista informação ortográfica, associando 21 sons (17 fonemas e 4 alofones) da língua Suruí com 17 letras (incluindo, nesse caso, um diacrítico).

Esse material, que contém mais de 2.800 registros (entre palavras e frases) na língua Suruí (cf. subcapítulo 5.2), muitos dos quais em duplicidade, não apresenta uma organização sistemática, apesar de, em algumas partes, agrupar informações baseadas em um mesmo vocábulo, ou em um mesmo campo semântico (p.ex., partes do corpo, elementos da natureza ou objetos fabricados). Observou-se, por fim, que há nesse material registros idênticos de palavras em Suruí, mas que correspondem a traduções diferentes em Português, e vice-versa. 
A dissertação Contribuição à análise fonológica do Suruí do Tocantins, de Barbosa, J. A. (1993), primeiro trabalho acadêmico, no âmbito da linguística, realizado sobre o Suruí, descreve os sons dessa língua com base na fonética e na fonologia orientada pela teoria estruturalista de Pike (1947).

Após apresentar informações histórico-culturais acerca do povo Suruí, o autor faz breve apreciação sobre a situação sociolinguística dessa língua da família Tupí-Guaraní, falada por "pouco mais de 136 falantes" (BARBOSA, J. A., 1993, p. 3) e que, segundo ele, estava ameaçada de desaparecer.

Essa dissertação utiliza como corpus linguístico os dados recolhidos por Monserrat (ver CIMI, 1986) e Graham e Graham (1988). Além disso, o autor cita onze nomes de pessoas que participaram como "informantes" em sua pesquisa.

Com o levantamento fonético em diferentes ambientes de ocorrência, identifica 23 sons consonantais e 23 sons vocálicos (13 orais e 10 nasais). Em seguida, partindo da identificação dos casos de variação livre entre consoantes $[\mathrm{s} \sim \breve{\mathrm{s}} \sim \breve{\mathrm{z}}$ (quando precedidos de [i]; $\mathrm{y} \sim \tilde{\mathrm{n}}$ (depois de [ĩ tônico); $\mathrm{w} \sim \mathrm{gw} \sim \mathrm{b} \sim \mathrm{v}$ (em diferentes ambientes); $\mathrm{d} \sim \mathrm{n}$ (antes de [e] no início de palavra); $\mathrm{g} \sim \mathrm{k}$ ' (em posição tônica final); $\mathrm{h} \sim$ 'ausência' (em sílaba tônica diante de pausa)] e vogais $\left[\mathrm{a} \sim \mathrm{e}^{6} \sim \varepsilon ; \mathrm{o} \sim \rho ; \mathrm{u} \sim v ; \dot{\mathrm{i}} \sim \mathrm{x}\right]$ da língua Suruí, mas também da análise das variantes posicionais $[\check{\mathrm{c}}($ diante de $[\mathrm{i} / \mathrm{i}]) \sim \mathrm{t}$; y $(\mathrm{em}$ final de sílaba) $\sim \mathrm{s}$ (somente em início de sílaba); a $\sim$ ว (antes de nasais) $\sim \Lambda$ (somente em átonas finas)] e da própria oposição, por meio do método da comutação, [/p/:/w/ e /p/:/m/ - /t/:/n/ e /t/:/r/ - /k/:/g/ e /k/:/y/ - /g/:/y $/$ - / $\mathrm{k}^{\mathrm{w}} /: / \mathrm{k} /$ - /?/:/k/ - /h/:/?/ - /m/:/n/ - /n/:/y $-/ \mathrm{y} /: / \mathrm{m} /-/ \mathrm{r} /: / \mathrm{n} /$ e $/ \mathrm{r} /: / ? /^{16}-/ \mathrm{w} /: / \mathrm{r} /$ - /y/:/w/ e $/ \mathrm{y} /: / \mathrm{r} /$ /i/:/a/, /i/:/e/ e /i/:/ì - /it:/e/, /it/:/a/ e /it/:/u/ - /u/;/o/ - /e/:/a/ - /o/:/a/], Barbosa, J. A. (1993) chega a um total de 13 fonemas consonantais (10 orais e 3 nasais $[/ \mathrm{p} /, / \mathrm{t} /,|\mathrm{m} /,| \mathrm{l} /,|\mathrm{l} /,| \mathrm{k} /, \mid \mathrm{g} /$,

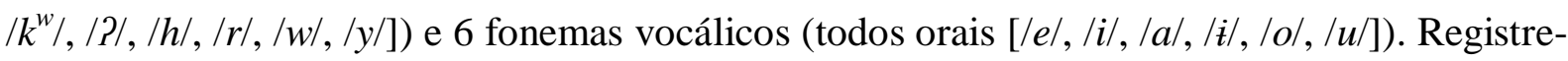
se que, tanto no capítulo da descrição fonética, quanto no da descrição fonológica, o autor insere de 1 a 12 ocorrências linguísticas abaixo de cada descrição de fone/fonema a fim de exemplificar o item que está sendo analisado.

Concluído esse inventário fonético-fonológico, Barbosa, J. A. (1993) apresenta brevemente os tipos de padrão silábico da língua Suruí, segundo o qual haveria as seguintes possibilidades: V (com ocorrência em todas as posições da palavra); VC (com ocorrência

\footnotetext{
${ }^{16}$ Originalmente, esse autor usou o ponto de interrogação para representar a consoante glotal / $\mathrm{P} /$.
} 
apenas no final da palavra, sendo que $\mathrm{C}$ restringe-se a /g/, /r/ e /y/); CV (com ocorrência em todas as posições da palavra) e $\mathrm{C}_{1} \mathrm{VC}_{2}$ (com ocorrência em todas as posições da palavra) (ver Capítulo 4.3 sobre a Sílaba em Suruí).

Na parte final da dissertação há considerações acerca do acento de intensidade em Suruí que, segundo o autor, teria "um valor fonológico" (BARBOSA, J. A., 1993, p. 54).

O segundo trabalho acadêmico produzido acerca dessa mesma língua foi o de Neves (1999), intitulado “A língua Suruí do Tocantins: uma introdução à morfossintaxe”.

$\mathrm{Na}$ introdução do trabalho, a autora, além de apresentar o objeto de sua pesquisa e de justificar sua escolha, apresenta as etapas da pesquisa de campo, dos primeiros contatos à coleta de dados (aproximadamente 15 horas de gravação em fitas K-7), baseada no "Formulário do Museu Nacional", adaptado por Ruth Monserrat em 1984, mas também trata da análise desses dados, sob uma perspectiva estruturalista.

No primeiro capítulo, a autora propõe-se a apresentar a etnografia do povo Suruí. Assim, trata dos seguintes assuntos: datação de quando o grupo foi contactado; situação linguística (caracterização como língua da família Tupí-Guaraní e breve informação sociolinguística); localização geográfica da Terra Indígena (T.I.) Sororó; dados demográficos; informações sobre subsistência; dados históricos sobre a demarcação da T.I.

No capítulo seguinte, reproduz resumidamente os dados fonético-fonológicos alcançados por Barbosa (1993), apenas acrescentando a existência da fricativa bilabial / $\beta /$, classificando-a como mais um alofone de /w/.

Com relação à morfofonologia, a autora trata pontualmente de dois fenômenos: a assimilação vocálica (do $u>o$ no prefixo de $3^{\text {a }}$ pessoa e no morfema causativo) e a nasalização (“da consoante surda inicial do morfema seguinte quando precedida de qualquer consoante nasal" [NEVES, 1999, p. 24]) (cf. Capítulo 4.5 sobre a nasalidade na língua Suruí).

A descrição morfossintática da língua Suruí, apresentada no quarto capítulo da dissertação, foi dividida em quatro partes, a saber: a) prefixos relacionais (segue a orientação de Rodrigues (1996) com relação aos prefixos relacionais, identificando em Suruí os morfemas que marcam três classes: $r_{-} \sim \emptyset_{-} ; i_{-}^{-} \sim h_{-} \sim t_{-} \sim \emptyset_{-} ; \emptyset_{-} \sim t_{-}$); b) marcadores de pessoa (distribui esses marcadores em cinco conjuntos: prefixos pessoais com o indicativo; prefixos pessoais com o imperativo; pronomes dependentes; pronomes independentes e 
portmanteau); c) classes de palavras (nome como sujeito e como complemento verbal; verbo que se combina com morfemas dos conjuntos 1, 2, 3 e 5; pronomes independentes do conjunto 5 e posposição) e d) ordem de palavras (o padrão em orações independente é $\mathrm{SV}(\mathrm{O})$, mas ocorrem também OSV e OV).

A conclusão do trabalho apresenta, essencialmente, um resumo de todos os assuntos desenvolvidos ao longo dos capítulos da dissertação, acrescentando, contudo, ao final uma proposta para a ampliação de estudos referentes aos prefixos relacionais e portmanteau.

Mello (2000), em sua tese de doutorado intitulada "Estudo Histórico da Família Linguística Tupi-Guarani: Aspectos Fonológicos e Lexicais", utiliza o programa de computador Wordsurv (Word Survey), produzido pelo SIL, que compila dados linguísticos, por meio do qual reúne dados de várias línguas da família Tupí-Guaraní, inclusive da língua Suruí. Com a ajuda desse programa, os dados dessas línguas foram comparados ao ProtoTupí-Guaraní.

Para cada língua analisada, foi destinado um breve capítulo em que se estabelecia a comparação. No caso do Suruí, o autor, que não construiu corpus próprio dessa língua, considerou os dados já compilados por Barbosa (1993), inclusive adotando o quadro de fonemas identificados, apresentado na mesma dissertação. Assim, Mello (2000) estabelece 34 comparações (22 para consoantes e 12 para vogais) entre o Suruí e o Proto-Tupí-Guaraní, as quais foram utilizadas, na tese, para fazer a estatística da comparação linguística e as reconstruções lexicais (estas apresentadas em um extenso capítulo à parte).

Ao final do trabalho, o autor apresenta a classificação interna da família TupíGuaraní, considerando os aspectos fonológicos e lexicais. Nesse contexto, chega aos seguintes resultados para a língua Suruí do Tocantins:

(1) Correspondências fonológicas entre o Proto-Tupí-Guaraní e o Suruí:

- "Oclusivas": *p > p; *t $>\mathrm{t}$; *k $>\mathrm{k}, \mathrm{g} /{ }_{-}$; $; *$ ? > ? (segundo o quadro comparativo de Mello (2000) não há correspondência entre as formas * ${ }^{\mathrm{w}}{ }^{\mathrm{w}} \mathrm{e}$ $* \mathrm{k}^{\mathrm{w}}$ do PTG na língua Suruí do Tocantins).

- 'Nasais, Africadas, Fricativa, Flap e Semivogal *j”: *m $>$ m; *n $>$ n; *y $>$

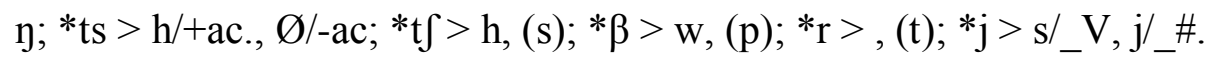


Ao apresentar as "generalizações das mudanças - consoantes", define, com relação ao Suruí:

- "espirantização do *t": "*t > t (em qualquer ambiente)", mas com a alofonia "[t $\left.\int\right]$ diante de /i/".

- "conservação de *k"

- "queda de *?" (afirma que houve a conservação da glotal na maioria das línguas da família Tupí-Guaraní): “*? > ?”.

- "queda ou mudança de *k em posição final": “*k > g / \#\#”.

- "queda de *m em posição final": “*m > m (em qualquer ambiente)".

- "queda de *n em posição final": “*n > n (em qualquer ambiente)".

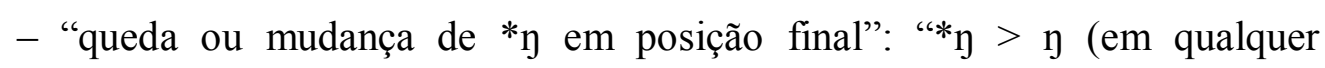
ambiente)".

- "queda e mudança de *r em posição final": “*r > r (em qualquer ambiente)".

- "mudança de "*ts": *ts > h / +ac.", “*ts> Ø / -ac.".

- "mudança de *t $\mathrm{f}$ ": *t $\int>\mathrm{h}$.

_ "mudança de "*j $>\mathrm{s} / \ldots \mathrm{V}$ ”, “*j $>\mathrm{j} / \ldots$ \#”

Já com relação às "generalizações das mudanças - vogais", pouco se refere à língua Suruí, mencionando esta língua, dentre os 12 processos, apenas em: "mudança de */o/ para /a/", "mudança de */o/ para /u/" e "desnasalização".

(2) Correspondências lexicais entre o Proto-Tupí-Guaraní e o Suruí. Dentre os 8 itens com evidências lexicais, apenas 2 apresentam referência ao Suruí, são eles:

- “As isoglossas demonstram coesão de grupos amazônicos": "12- amarelo: ASU, SRU, ASX e PAT”;17 “33- cabeça: coesão SRU-TAF-PAT”; “76guariba, bugio, 84- paca: demonstra coesão ASU, SRU, ASX, API, PAT, GUJ e URB"; "91- pequeno: liga SRU, API, AMD, UWW, PAT e TEH”; “100porco do mato, cateto [...] SRU, TAF e ASX", "111- veado: ligação ASU SRU - TAF - KAY - PAT".

- "As isoglossas opõem os subconjuntos I e III de um lado e subconjuntos amazônicos (IV, V, VI, VII e VIII) de outro”.

\footnotetext{
${ }^{17}$ Este trabalho adota a abreviatura SRU para representar a língua Suruí do Tocantins.
} 
Outro estudo que levou em consideração a língua Suruí do Tocantins foi realizado em 2004 por Figueiredo, cujo objetivo era testar a hipótese sobre o desmembramento do subconjunto (cf. RODRIGUES, 1984/1985), sub-ramo ou ramo IV (cf. CABRAL; RODRIGUES, 2002) da família linguística Tupí-Guaraní. Nessa dissertação de mestrado, Figueiredo não construiu um corpus próprio da língua Suruí do Tocantins, mas cita duas possíveis fontes, os trabalhos de Cabral e Mastop (2002) e Monserrat (1986b), que constituíram corpus dessa língua.

Com exceção do trabalho de Neves (1999), que reuniu um corpus com 15 horas de gravação em fita K-7, todos os anteriores produziram apenas corpus escritos da língua Suruí, e também os dados dispersos em diferentes trabalhos antropológicos, como os de Laraia (1978; 1996), que apresentam tentativas de escrita da língua Suruí. Contudo, é importante destacar que, ao longo dos anos, corpus sonoros dessa língua foram sendo construídos por diferentes pesquisadores. Dentre eles, cito: uma gravação datada de dezembro de 1985, da qual se tem, aproximadamente, 18min; outra gravação que data de 1997 feita por Cabral, baseada na lista de Kaufman, Berlin e Rodrigues (1985), aproximadamente 1 hora de gravação em fita K-7; Costa, em 2002, grava pouco mais 1h30min de dados; ainda em 2002, Cabral e Mastop recolhem aproximadamente 30min de gravação. Somente 10 anos após esta última gravação há notícia de uma nova coleta de dados da língua Suruí do Tocantins, desta vez feita por Lopes e Cabral (2012), Lopes (2012) e Cabral, Lopes e Solano (2013).

\subsection{OS SURUÍ, UM POVO ÁGRAFO}

O povo Suruí, à semelhança de muitos povos do mundo, vem de uma tradição linguística essencialmente oral, que lhe permitiu por muito tempo (não é possível determinar quanto) não só manter a necessária comunicação entre seus membros, mas, principalmente, conservar, por meio de sua língua, práticas e conhecimentos ancestrais (e os novos também) legados de uma geração a outra, até a época atual.

E foi um povo ágrafo, que durante muito tempo não manteve contato efetivo com não indígenas, lutando para resistir às pressões do mundo exterior (de garimpeiros, de 
fazendeiros e de donos de castanhais interessados nas terras ocupadas por eles) que Gil Gomes, frei missionário dominicano ligado à Prelazia de Marabá, contactou na década de 1950.

Contudo, essa aproximação com as sociedades não indígenas foi, já de início, fatídico para os Suruí, que não estavam preparados sequer para resistir a doenças como gripe, catapora e sarampo. Por isso, a população, que era de aproximadamente 120 pessoas, reduziuse, após o primeiro surto de gripe, a 40. Foi nesse estado desolador que o antropólogo Roque Laraia conheceu os Suruí, no início da década de $1960,{ }^{18}$ desestabilizados socialmente pela brusca redução populacional, quase sem condições de suprir suas necessidades mais básicas, como a própria subsistência alimentar, constantemente ameaçados de serem expulsos de suas terras, e enganados por pessoas que se aproveitaram do estado de fragilidade em sua história de, então, recente contato. Vale lembrar ainda o episódio histórico da Guerrilha do Araguaia, que aconteceu no Estado do Pará no período 1967 a 1974, do qual os Suruí fizeram parte ativamente, mesmo contra a própria vontade, o que provocou neles profunda instabilidade psíquica, cultural e social.

Todos estes episódios vividos por esse povo subsistem na memória das pessoas mais velhas da aldeia, que, mesmo com alguma reserva (ou dor?), transmitem os conhecimentos adquiridos por essas várias experiências às novas gerações, exatamente como há séculos vêm fazendo, ou seja, por meio da oralidade.

\subsection{UMA NOVA SITUAÇÃO LINGUÍSTICA}

Os Suruí, contrariando, todavia, qualquer prognóstico negativo sobre seu destino, resistiram e, hoje, após a primeira década do século XXI, contam com uma população dez vezes maior do que aquela remanescente da década de 1960, afastando um pouco mais a possibilidade de sua extinção; infelizmente, não se pode dizer o mesmo de sua língua.

Até antes do contato no início da década de 1950, todavia, a situação que prevalecia na comunidade, segundo informação dos sábios Aikewára, como Warini, era a de um monolinguismo total da língua Suruí. Apesar da resistência natural de um grupo minoritário diante de um grupo majoritário, os Suruí foram pouco a pouco sendo envolvidos pelo mundo dos não índios, e, na década de 1960, segundo Laraia e Matta (1978, p. 15), uma parte dos homens Suruí, já possuía razoável conhecimento da língua portuguesa.

\footnotetext{
${ }^{18}$ Entre 1961 e 1966, Laraia realizou pesquisas de cunho antropológico junto aos Suruí e publicou os resultados em artigos e livros, dentre os quais podemos citar: "Arranjos Poliândricos na Sociedade Suruí" (LARAIA, 1963) e "Índios e castanheiros: a empresa extrativa e os índios no médio Tocantins” (LARAIA; MATTA, 1967).
} 
Todavia, o contato com uma população falante de Português, língua majoritária no entorno da área indígena e no Brasil, aliado a um processo centenário de difusão e implantação da língua trazida pelos portugueses no século XVI, produziu um efeito de assimilação tão rápido que, 25 anos depois do contato, já havia uma nova geração bilíngue em Suruí e Português. Com o tempo, as trocas culturais e econômicas com a sociedade circundante de fala portuguesa e os casamentos com pessoas de fala não Suruí se intensificaram, além disso, houve a introdução de mídias como o rádio e a televisão, que transmitiam (e ainda transmitem) programas somente em Português, que passaram, com o tempo, a fazer parte do cotidiano desse povo. Tanto que os jovens nascidos a partir da última década do século XX são, em sua quase totalidade, monolíngues em Português, apenas sendo capazes de compreender algumas palavras ou pequenas frases na língua Suruí. ${ }^{19}$

Sem dúvida, o Suruí, à semelhança de muitas outras línguas indígenas brasileiras, passa por um processo de enfraquecimento ${ }^{20}$ que, às vezes é lento, mas não incontornável, com as novas gerações não mais falando a língua, o que pode, em certa medida, culminar na morte da língua falada de uma minoria linguística se nada for feito.

Por outro lado, a língua autóctone, ainda plenamente falada pela maioria dos adultos e idosos Suruí, dentre estes últimos há, inclusive, aqueles que são ainda monolíngues na língua indígena, representa, para muitos, uma das formas mais autênticas e eficazes de resistência cultural, ${ }^{21}$ frente à invasão linguístico-cultural que vem do exterior da aldeia através das músicas, dos filmes e novelas da TV e, mais recentemente, da escola, onde prevalece o ensino em língua portuguesa, com conteúdos que apenas tangenciam os saberes milenares do próprio povo Suruí. ${ }^{22}$

\footnotetext{
${ }^{19}$ Em minha ida à aldeia Suruí em novembro de 2012, pude constatar a seguinte situação: os mais velhos conversavam em Suruí (e, às vezes, em Português), enquanto os mais novos falavam somente em Português, apesar de compreenderem muito do que se falava em Suruí.

${ }^{20}$ Esse processo pode ser provocado por uma série de fatores, tais como a implantação da ideologia de colonizador, que busca desestabilizar o povo colonizado em sua capacidade de organização, de comunicação, e, principalmente, em sua própria identidade linguística e cultural, a fim de conseguir alguma coisa ("amansar", roubar terras, implantar ideologias militares, religiosas ou de qualquer ou tipo, ou ainda transformar as pessoas em mão-de-obra para atender aos interesses econômicos de alguém), pela interdição do uso da língua desse povo (ver, na História do Brasil, o exemplo do Diretório dos Índios, no século XVIII) ou, de modo mais extremo, pelo extermínio desse povo.

${ }^{21}$ Essa resistência é representada, por exemplo, nas ações dos professores indígenas de língua Suruí Tymykong e Ikatu, que atuam na escola da aldeia e, mesmo sem muitos recursos, ensinam aos mais jovens a sua língua.

${ }^{22} \mathrm{Na}$ "Relação dos estabelecimentos de educação escolar indígena, segundo a região geográfica e a unidade da federação - 2005" (BRASIL, 2007, p. 159), constam duas escolas na T.I. Sororó: a E. M. E. F. Aldeia Indígena Suruí (Código MEC: 15533476) e a E. M. E. F. Awayten (Código MEC: 15580350).
} 
Essa situação de vulnerabilidade linguística ${ }^{23}$ ocorre, muitas vezes, não exatamente pelo simples contato de um povo com outro, uma vez que, no mundo, intercâmbios linguísticos e situações de bilinguismo constituem realidades até bastante comuns. O problema está nos processos de dominação, explícita ou não, que levam um povo a querer subjugar o outro, principalmente por meio de sua tecnologia, de sua cultura e de sua língua. É comum, então, a disseminação de ideias que levem a comunidade, geralmente a mais vulnerável em termos quantitativos e tecnológicos, a acreditar que sua língua não é tão eficaz para comunicação quanto a do outro, nem contém, por exemplo, um léxico que dê conta de propiciar o acesso a novas tecnologias, não servindo, dessa maneira, para ser usada nos processos de educação formal na escola, nem deveria ser estimulada a sua escrita, pois haveria uma opção linguística mais eficiente. Isso tem levado, no Brasil, comunidades indígenas inteiras a estimularem o aprendizado da língua do outro, geralmente o Português, chegando ao extremo de, em poucas gerações, ter-se substituído a língua tradicionalmente usada por inúmeras gerações dessa comunidade pela língua dos recém-chegados. Portanto, o contato linguístico, em vez de ser fator de ganho cultural, de acréscimo de conhecimento e de melhoria das condições tecnológicas e socioculturais, pode tirar do grupo minoritário autóctone um de seus maiores bens, sua língua.

Essa prevalência da língua portuguesa, com relação ao Suruí, estaria apoiada tanto por ideologias disseminadas diretamente por pessoas ao longo das décadas de contato, quanto pelo próprio Estado brasileiro, através de políticas que supervalorizam a língua oficial em detrimento das línguas das minorias. ${ }^{24}$ Prova disso está, por exemplo, na própria escola da aldeia, onde o ensino da língua portuguesa, totalmente em Português, conta com professores com formação de nível superior específica para o ensino da língua, materiais didáticos, como livros e material multimídia, e uma vasta gama de textos escritos que servem de suporte para o ensino; do outro lado, vemos os professores de língua Suruí, ainda sem formação de nível superior (nem a específica para o ensino de língua, nem em qualquer outra área), sem materiais didáticos, a não ser a própria fala e alguns textos que eles mesmos escrevem, diante de um público jovem e bastante heterogêneo falante de Português. ${ }^{25}$

\footnotetext{
${ }^{23}$ No site UNESCO Atlas of the World's Languages in Danger (UNESCO, 2010), o Suruí do Tocantins foi classificado como língua em perigo, com vitalidade vulnerável.

${ }^{24}$ As línguas indígenas brasileiras nem sempre foram línguas de grupos minoritários no Brasil, pois, segundo Rodrigues (2000) e Oliveira e Freire (2006, p. 22-23), estima-se que, no século XVI, havia na área correspondente ao atual território brasileiro, uma população de milhões de indígenas distribuídos em centenas de povos, sendo, pois, os portugueses o grupo minoritário de então.

${ }^{25}$ Essa situação é bastante comum em comunidades indígenas, segundo consta no livro Estatísticas sobre educação escolar indígena no Brasil: "Como o uso de material didático diferenciado pode estar restrito a uma
} 
Ações como esta, por mais que ainda sejam incipientes e pontuais diante da onipresença do Português na vida da comunidade, são um sinal de que algo precisa ser feito. É necessário que o próprio povo lute para que sua língua não desapareça com a morte dos falantes, sobretudo dos mais velhos, pois, quando isso acontece, a língua leva consigo grande parte não só da história, dos conhecimentos e das culturas ancestrais, mas, principalmente, parte essencial da própria essência do povo que a fala.

\subsection{A LÍNGUA INDÍGENA NO CONTEXTO DA EDUCAÇÃO FORMAL}

O povo Suruí, em dado momento de sua história no século $\mathrm{XX}$, como foi visto acima, passou de uma possível situação de monolinguismo em sua língua original (anterior ao contato) ${ }^{26}$ a uma situação quase geral de bilinguismo (posterior ao contato) da língua Suruí e do Português e, mas recentemente, a um processo de retorno ao monolinguismo, mas desta vez em língua portuguesa (com exceção de alguns indivíduos que permanecem monolíngues até hoje); além disso, teve contato com a educação formal da escola implantada por não indígenas, cujo modelo era o mesmo usado em quase todo o Brasil: uma escola baseada em currículos construídos a fim de fortalecer uma planificação linguística e cultural (essencialmente monolíngue), com conhecimentos baseados nas diversas ciências (não indígenas) e voltada para inserção do indivíduo em uma sociedade fortemente marcada pela lógica do capitalismo. Com certeza, esse modelo está bem distante do apregoado pelos documentos legais, como a Lei de diretrizes e bases da educação nacional, no $\S 3^{\circ}$ do Art. 32 (Seção III), em que se determina "O ensino fundamental regular será ministrado em língua portuguesa, assegurada às comunidades indígenas a utilização de suas línguas maternas e processos próprios de aprendizagem.”, e no Art. 78, segundo o qual:

O Sistema de Ensino da União, com a colaboração das agências federais de fomento à cultura e de assistência aos índios, desenvolverá programas integrados de ensino e pesquisa, para oferta de educação escolar bilíngüe e intercultural aos povos indígenas, com os seguintes objetivos: I proporcionar aos índios, suas comunidades e povos, a recuperação de suas memórias históricas; a reafirmação de suas identidades étnicas, $a$ valorização de suas línguas e ciências. (BRASIL, 1996, grifo nosso).

ou da própria Constituição Federal, que em seu $\S 2^{\circ}$, do Art. 210 garante que: "O ensino fundamental regular será ministrado em língua portuguesa, assegurada às comunidades

única cartilha, livro de leitura ou mesmo dicionário, a situação é extremamente preocupante, demonstrando a insuficiência de materiais disponíveis para uma prática de educação pautada pela interculturalidade e pela valorização dos conhecimentos e saberes próprios às comunidades indígenas.” (BRASIL, 2007, p. 22).

${ }^{26}$ Não é possível afirmar com segurança se o povo Suruí era completamente monolíngue, haja vista o contato que deveria manter com outros povos de outras línguas. 
indígenas também a utilização de suas línguas maternas e processos próprios de aprendizagem. (BRASIL, 2013, p. 43, grifo nosso).

Outro documento importante nesse contexto é o Referencial curricular nacional para as escolas indígenas, onde se defende o uso das línguas indígenas como "língua de instrução oral e escrita":

[...] a língua indígena deverá tornar-se a língua de instrução escrita predominante naquelas situações que digam respeito aos conhecimentos étnicos e científicos tradicionais ou à síntese desses com os novos conhecimentos escolares de fora. Da mesma forma que acontece com a oralidade, os alunos aumentarão sua competência escrita em língua indígena Mais ainda, esse tipo de procedimento poderá contribuir para a criação e para o desenvolvimento de funções sociais da escrita nessas línguas. Como isso poderá ocorrer se houver uso intenso e extenso da língua escrita, em todos espaços e situações possíveis, a escola é, sem dúvida, o local ideal para se desencadear e reforçar tal processo. (BRASIL, 1988, p. 119-120).

O distanciamento entre o discurso oficial, que afirma a necessidade de uso da língua indígena no contexto escolar, destacando não somente a questão legal em si, mas também, sobretudo, questões relacionadas ao valor da leitura/escrita da língua no contexto social, de sua funcionalidade e de relevância para o estabelecimento da própria identidade do povo.

Entretanto, como a maioria das línguas indígenas no Brasil ainda permanece ágrafa, a língua que primeiro chega à escola (e, muitas vezes, a que fica) é o Português.

Certamente, essa é a história também do povo Suruí, no tocante à educação formal escolar, em que prevaleceu, desde a construção da primeira escola (denominada Moroneiko) na aldeia, o ensino somente de/em língua portuguesa nas séries iniciais, e, consequentemente, da escrita dessa língua, que foi ensinada para os mais jovens. Iniciou-se, dessa forma, um novo processo de aprendizado linguístico para os Suruí, que, pela primeira vez, passavam a ler e escrever.

Essa primeira experiência de escrita de uma língua é, sem dúvida, relevante para um povo, no entanto, ela não iniciou pela língua original desse povo, mas sim pela língua que havia sido transplantada para a comunidade; sem falar, também, que nem a língua nem as ciências dos Suruí foram valorizadas, não construindo qualquer forma de educação bilíngue. Então, para que houvesse um equilíbrio de forças, a língua original dos Suruí deveria também ter sido levada para a escola e, assim como o Português, ser lida e escrita pelo povo que a fala. Mas esse movimento de valorização de uma língua, para ter valor, deve partir de um anseio, de uma necessidade manifestada pelo próprio povo falante dessa língua, e é exatamente isso 
que está acontecendo, ainda que de modo lento, na comunidade Suruí: começa a se desenvolver um certo sentimento de valorização linguística, motivado sobretudo pelos únicos professores da língua Suruí Tymykong e Ikatu, que atuam na escola da aldeia e que iniciaram a produção dos primeiros textos escritos totalmente na língua indígena.

Adiante, apresento informações sobre algumas das tentativas de desenvolver uma forma escrita para a língua Suruí. 


\section{FONOLOGIA DA LÍNGUA SURUÍ}

O primeiro estudo sistemático da fonética e da fonologia da língua Suruí do Tocantins foi empreendido por Monserrat, nos anos de 1985 e 1986, quando, a convite do CIMI Norte II, esteve na terra indígena Sororó e registrou a língua dos Suruí; esse material seria a base para a produção do Vocabulário Aikewar.

Das notas de campo desta pesquisadora, depreende-se não só uma análise fonético-fonológica detalhada, mas também considerações morfossintáticas e históricocomparativas que apontam para a estrutura e história dessa língua.

Com relação à fonética, Monserrat $(1985 b)$ identifica 15 contóides $^{27}-\left[\mathrm{p}, \mathrm{t} \sim \mathrm{t}^{\mathrm{y}}\right.$, $\left.\mathrm{k}, \mathrm{g},{ }^{?}, \mathrm{~m}, \mathrm{y}, \mathrm{b} \sim \mathrm{w}, \mathrm{s} \sim \mathrm{s}^{\mathrm{y}}, \mathrm{y}, \mathrm{h}, \check{\mathrm{r}}\right]$, que correspondem a 11 fonemas consonantais $-/ \mathrm{p}, \mathrm{t}, \mathrm{k}, \mathrm{g}$, ? $, \mathrm{m}, \mathrm{y}, \mathrm{w}, \mathrm{s}, \mathrm{h}, \mathrm{r} /$, e 8 vocóides - [i, $\varepsilon, \dot{\mathrm{i}}, \mathrm{a}, \mathrm{u}, \mathrm{\jmath}, \mathrm{p}, \mathrm{a}]$, que correspondem a 6 fonemas vocálicos /i, $\varepsilon, \dot{\mathrm{i}}, \mathrm{a}, \mathrm{u}, \mathrm{o}$. Após descrever o contexto de cada som, a pesquisadora faz observações sobre diferenças de pronúncia entre a fala dos mais velhos e a dos mais jovens do grupo, o que lhe permite desenvolver considerações acerca do desenvolvimento histórico do sistema linguístico (fonologia e morfologia) do Suruí do Tocantins.

Outras duas descrições da fonologia da língua Suruí são feitas nas décadas de 1980 e 1990: a dos Graham (1988), que identifica também 17 fonemas nessa língua e propõe uma escrita com 17 letras, e a de Barbosa (1993), que propõe 19 fonemas para o Suruí.

Apresento, a seguir, um quadro com os símbolos usados pelos linguistas que estudaram a língua Suruí para representar os fonemas dessa língua de acordo com suas respectivas análises:

QUADRO 02 - SÍMBOLOS USADOS PELOS LINGUISTAS PARA REPRESENTAR OS
FONEMAS DA LÍNGUA SURUÍ

\begin{tabular}{|c|c|c|c|c|}
\hline & Fonema & Monserrat (1986a) & Graham (1988) & Barbosa, J. A. (1993) \\
\hline 1. & $\mathrm{a}$ & $\mathrm{a}$ & $\mathrm{a}$ & $\mathrm{a}$ \\
\hline 2. & $\mathrm{e}$ & $\varepsilon$ & $\mathrm{e}$ & $\mathrm{e}$ \\
\hline 3. & $\mathrm{~g}$ & $\mathrm{~g}$ & - & $\mathrm{g}$ \\
\hline 4. & $\mathrm{~h}$ & $\mathrm{~h}$ & $\mathrm{rr}$ & $\mathrm{h}$ \\
\hline 5. & $\mathrm{i}$ & $\mathrm{i}$ & $\mathrm{i}$ & $\mathrm{i}$ \\
\hline 6. & $\mathrm{k}$ & $\mathrm{k}$ & $\mathrm{c}$ & $\mathrm{k}$ \\
\hline 7. & $\mathrm{k}^{\mathrm{w}}$ & - & - & $\mathrm{k}^{\mathrm{w}}$ \\
\hline
\end{tabular}

${ }^{27}$ Cf. Pike (1947, p. 5) 


\begin{tabular}{|c|c|c|c|c|}
\hline 8. & $\mathrm{~m}$ & $\mathrm{~m}$ & $\mathrm{~m}$ & $\mathrm{~m}$ \\
\hline 9. & $\mathrm{n}$ & $\mathrm{n}$ & $\mathrm{n}$ & $\mathrm{n}$ \\
\hline 10. & $\eta$ & $\eta$ & ng & $\eta$ \\
\hline 11. & o & o & o & o \\
\hline 12. & $\mathrm{p}$ & $\mathrm{p}$ & $\mathrm{p}$ & $\mathrm{p}$ \\
\hline 13. & r & $\mathrm{r}$ & $\check{\mathrm{r}}$ & $r$ \\
\hline 14. & $\mathrm{~S}$ & $\mathrm{~S}$ & $\check{S}$ & $\mathrm{y}$ \\
\hline 15. & $\mathrm{t}$ & $\mathrm{t}$ & $\mathrm{t}$ & $\mathrm{t}$ \\
\hline 16. & $\mathrm{u}$ & $\mathrm{u}$ & $\mathrm{u}$ & $\mathrm{u}$ \\
\hline 17. & W & W & W & W \\
\hline 18. & $\dot{\mathbf{i}}$ & $\dot{\mathbf{t}}$ & $\dot{\mathbf{t}}$ & $\dot{\mathrm{t}}$ \\
\hline 19. & $?$ & ? & glotal & $?$ \\
\hline
\end{tabular}

\subsection{PARES MÍNIMOS}

\subsubsection{Vogais}

Conforme visto na seção anterior, a língua Suruí possui 6 fonemas vocálicos orais, sem contrapartes nasais. Apresento, a seguir, os pares mínimos que evidenciam contraste destas vogais em ambientes similares.

/i/ e /ì /

/i'po/ 'mão de algo ou de alguém'

/i'po/ 'cipó'

/'ti/ 'eu'

/'ti / 'seiva'

/i/ e / $/ \varepsilon /$

/u'pi/ 'pica/picou'

/u'pe/ 'para (dativo)'

/íl e /a/

/i'wì/ 'terra'

/a'wa/ 'quem' 
$/ \mathrm{u} / \mathrm{e} / \mathrm{o} /$

/i'ku/ 'língua de algo ou de alguém'

/i'ks/ 'roça de alguém'

$/ \varepsilon / \mathrm{e} / \mathrm{a} /$

/u'ke/ 'entra/entrou'

/u'ka/ 'junta/juntou'

$\mid \varepsilon / \mathrm{e} / \mathrm{\jmath} /$

/ع'mo/ 'pênis de alguém'

$/ \varepsilon^{\prime} m \varepsilon /$ 'lábio de alguém'

/a/ e /o/

/uma'nu/ 'engasga/engasgou'

/umo'no/ 'dá/deu'

/upu'Pan/ 'afia/afiou'

/upu'?om/ 'atola/atolou'

\subsubsection{Consoantes}

Conforme visto no Quadro 03, a língua Suruí possui 13 fonemas consonantais, sendo 10 orais e três nasais. ${ }^{28}$ Apresento, a seguir, exemplos de pares mínimos e/ou análogosque mostram contrastes entre esses fonemas.

$/ \mathrm{p} / \mathrm{e} / \mathrm{m} /$

/imi'ca/ 'mão-de-pilão'

/ipi'ra/ 'peixe'

/ipi'pir/ 'largo (ele é)'

/ime'mira/ 'filho (de mulher)'

$/ \mathrm{p} / \mathrm{e} / \mathrm{k} /$

/o'ko/ 'galho'

lo'po/ 'raiz'

${ }^{28}$ Conforme expliquei na nota 30 , há a possibilidade de existir um $14^{\circ}$ fonema, o yw que não foi registrado no corpus utilizado na pesquisa desta tese. 
$/ \mathrm{m} / \mathrm{e} / \mathrm{n} /$

$\mid \varepsilon^{\prime} m \varepsilon /$ 'lábio de alguém'

$/ \varepsilon$ 'n $\varepsilon /$ 'tu, teu'

/k/ e /g/

/uku'tuk/ 'fura/furou'

/uki'tig/ 'rola/rolou'

/i'gara/ 'canoa'

/i'kawa/ 'gordura de algo ou de alguém'

$/ \mathrm{k} / \mathrm{e} / \mathrm{h} /$

/iku'tuk/ 'fura/furou'

/iki'tin/ 'limpo'

$/ \mathrm{k} / \mathrm{e} / \mathrm{kw} /$

/u'kara/ 'terreiro'

/i'kwara/ 'vagina dela'

$/ \mathrm{g} / \mathrm{e} / \mathrm{y} /$

/a'sig/ 'veia de algo ou de alguém'

/a'soy/ 'tamanduá-mirim'

$/ \mathrm{g} / \mathrm{e} / \mathrm{kw} /$

/i'gara/ 'canoa'

/i'kwara/ 'vagina dela'

$/ \mathrm{g} / \mathrm{e} / \mathrm{w} /$

/'oga/ 'casa'

/'owa/ 'folha'

/nw/ e $/ \mathrm{kw} /$

/kati'Đwera/ 'veado-virá'

/tiri'kwera/ 'roupa'

/y/ e /nw/

/umune/ 'por'

/kati'ywera/ 'veado-virá' 
$/ \mathrm{y} / \mathrm{e} / \mathrm{m} /$

/i'koy/ 'calcinha dela'

/i'kom/ 'seio dela'

$/ \mathrm{n} / \mathrm{e} / \mathrm{s} /$

/u'pin/ 'raspa/raspou'

/u'pir/ 'ergue/ergueu'

/umo'mon/ 'enrola/enrolou'

/umo'mor/ 'joga/jogou'

/s/ e /k/

/o'ks/ 'galho'

/o'so/ 'sogra'

/s/ e/t/

/o'so/ 'sogra'

/o'to/ 'duro'

/s/ e /n/

/u'wos/ 'corrói/corroeu'

/u'won/ 'embrulha/embrulhei'

$/ \mathrm{p} / \mathrm{e} / \mathrm{p} /$

/ว'?ว/ 'carne'

/o'po/ 'raiz'

$/ \mathrm{R} / \mathrm{e} / \mathrm{t} /$

/o'to/ 'duro'

/o'?o/ 'carne'

/ $/$ e $/ \mathrm{k} /$

/O'Po/ 'carne'

/o'ko/ 'galho'

$/ \mathrm{P} / \mathrm{e} / \mathrm{h} /$

/O'To/ 'carne'

/o'ho/ 'vai/foi' 


\subsection{CONSOANTES}

Em todas as propostas de descrição acima citadas há registros de variação livre entre consoantes. São elas: o fonema /s/ pode se realizar como [s, $\int$ ou 3$]$; o fonema $/ \mathrm{y} /$, como [y ou $\mathrm{n}$ ]; o fonema /g/, como [子 ou g]. Já a consoante oclusiva alveolar surda /t/ realiza-se como consoante africada alveopalatal surda [t]] diante da vogal anterior alta /i/. A aproximante $/ \mathrm{w} /$ tem o alofone posicional $[\beta]$, que nunca ocorre diante de silêncio.

A aproximante [j], que ocorre em final de sílaba, ['moj] 'cobra', [ع'kuj] 'cuia', não consta no quadro de fonemas, pois, segundo os autores citados acima, se realiza apenas como alofone do fonema $/ \mathrm{s} / .^{29}$

Barbosa, J. A. (1993, p. 40) propõe, por uma questão de economia, a existência da consoante complexa $/ \mathrm{k}^{\mathrm{w}} /$ no quadro de fonemas do Suruí do Tocantins, ao passo que Graham (1988, p. 3) considera esse mesmo som um alofone de /k/ (que ele representa pela letra $c$ ao lado de que) e Monserrat (ver CIMI, 1986, p. 10) propõe, por sua vez, que a aproximante /w/ tem um alofone que se realiza como uma vogal enfraquecida / $/$ /, não havendo, assim, necessidade de computar mais um fonema nessa língua.

Esse som [kw], diferentemente do que ocorre em Tupinambá, no qual é interpretado por Rodrigues (2012 [1983], p. 227) como uma das "sequências bem estabelecidas de segmentos assilábicos (e não como fonemas unitários labializados)”, já que ocorrem várias outras sequências, como $m w, n w, \eta w$ e $r w$, é distintivo em Suruí e deve ser interpretado como uma unidade e não como sequência de dois sons, já que contrasta com $k$ e por não haver na língua nenhum outro som além de $\eta w$ que possa sugerir a possibilidade de sequências. Note-se que em Suruí, como ocorreu com as demais línguas do seu sub-ramo IV, os reflexos do PT * $p w$ se fundiram com $k w$, aumentando o número de palavras com esse som.

Logo, feitas estas considerações, apresento a seguir o quadro fonológico da língua Suruí do Tocantins que será considerado neste trabalho e que auxiliará na produção da proposta de escrita dessa língua:

\footnotetext{
${ }^{29}$ Apesar de concordarmos com Barbosa (1993, p. 35-36) com relação ao fato de "[y] e [s] serem variantes condicionadas de um mesmo fonema, não obstante a diferença fonética entre os dois fones", considero que a variante posicional, nesse caso, é o [j], pois o fonema /s/ ocorre em mais ambientes — início de palavra e de sílaba medial, e na posição medial intervocálica, como observou Monserrat (1985b). Devido a uma restrição fonotática da língua Suruí com relação ao uso de consoante fricativa surda diante de silêncio, o fonema /s/ ocorre como uma aproximante sonora [j] antes de outra consoante e antes de silêncio.
} 
QUADRO 03 - FONEMAS CONSONANTAIS DA LÍNGUA SURUÍ

\begin{tabular}{|c|c|c|c|c|c|c|c|c|c|c|}
\hline & 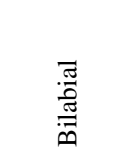 & 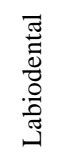 & $\begin{array}{l}\frac{\mathrm{g}}{\mathrm{g}} \\
\frac{8}{4}\end{array}$ & 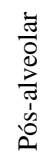 & 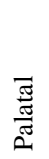 & \multicolumn{3}{|c|}{$\frac{\frac{\mathrm{c}}{0}}{\mathrm{j}}$} & 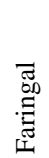 & $\begin{array}{l}\bar{\Xi} \\
\frac{\overline{0}}{0}\end{array}$ \\
\hline Oclusiva & $\mathrm{p}$ & & \multicolumn{2}{|l|}{$\mathrm{t}$} & & & $\mathrm{g}$ & & & ? \\
\hline Nasal & $\mathrm{m}$ & & \multicolumn{2}{|c|}{$\mathrm{n}$} & & & & $\left.\mathrm{n}^{\mathrm{w}}\right)^{30}$ & & \\
\hline \multicolumn{11}{|l|}{ Vibrante } \\
\hline Tape (ou flape) & & & \multicolumn{2}{|c|}{ r } & & & & & & \\
\hline Fricativa & & & $\mathrm{s}$ & & & & & & & $\mathrm{h}$ \\
\hline \multicolumn{11}{|l|}{ Fricativa lateral } \\
\hline Aproximante & $\mathrm{W}$ & & & & & & & & & \\
\hline
\end{tabular}

Quadro baseado na proposta do IPA (2012).

\subsection{VOGAIS}

A língua Suruí do Tocantins não distingue fonologicamente vogais médias abertas /ع/ e / / de vogais médias fechadas /e/ e /o/, realizando-se livremente em todos os contextos.

As vogais são, essencialmente, orais, ocorrendo vogais nasais apenas como resultado de nasalização pela proximidade com consoantes nasais, logo, sem valor distintivo em termos fonológicos. Dessa maneira, é comum encontrar variações de nasalidade na realização de uma mesma palavra. ${ }^{31}$

\section{FIGURA 04 - FONEMAS VOCÁLICOS DA LÍNGUA SURUÍ anterior central posterior}

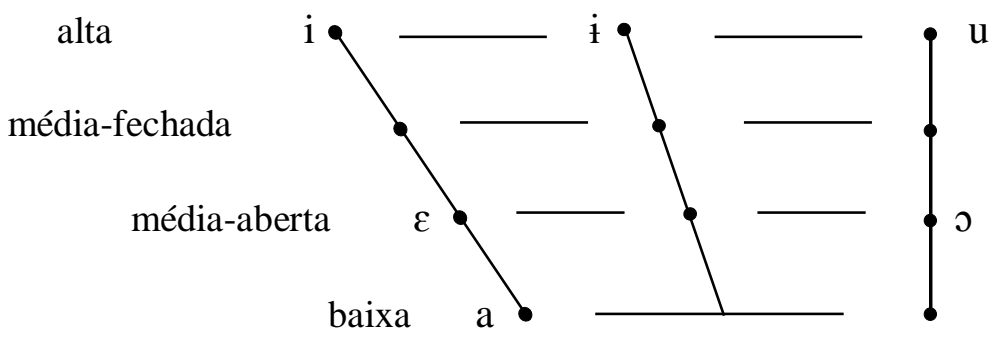

Esquema adaptado da proposta do IPA (2012).

\footnotetext{
${ }^{30}$ Espera-se encontrar em Suruí o fonema $/ \mathrm{y}^{\mathrm{w}} /$, reflexo das ocorrências dos antigos $\mathrm{k}^{\mathrm{w}}$, quando precedidos por temas nasais, como em Asuriní e em Tembé, p.ex. ti-ngwer 'nariz fora do corpo'.

${ }^{31}$ Vale lembrar que todas as pessoas que forneceram dados linguísticos para este trabalho são bilíngues em Suruí do Tocantins e Português, sendo que devemos, pois, considerar eventuais interferências de um sistema no outro.
} 


\subsection{SÍLABA}

A língua Suruí do Tocantins possui, de acordo com a descrição feita por Barbosa (1993, p. 51-53), os seguintes padrões silábicos: V, VC, CV e $\mathrm{C}_{1} \mathrm{VC}_{2}$.

Observa-se, assim, que o Suruí tem como estrutura máxima de sílaba a forma CVC (Consoante-Vogal-Consoante), cuja ocorrência é mais frequente no final de palavras: iwak (C.CVC) 'parte acima das nuvens'; iwitir (V.CV.CVC) 'morro'; tatatiron (CV.CV.CV.CVC) 'nuvem'; iwituhursn (V.CV.CV.CV.CVC) 'tempestade':

QUADRO 04 - PADRÃO SILÁBICO CVC DA LÍNGUA SURUÍ

\begin{tabular}{|c|c|c|c|c|}
\hline & cons. & No início da palavra & No meio da palavra & No final da palavra \\
\hline 1. & $\mathrm{~g}$ & - & - & /i'gar/ 'canoa' \\
\hline 2. & $\mathrm{~h}$ & - & - & /iwi'rapops'hom/ 'traíra pequena' \\
\hline 3. & $\mathrm{k}$ & - & - & $\begin{array}{l}\text { /ipira'kaw/ 'pacu' } \\
\text { /ia'kim/'molhado' } \\
\text { /namu'kus/ 'dois' }\end{array}$ \\
\hline 4. & $\mathrm{~m}$ & /mosson/ 'jararaca' & - & - \\
\hline 5. & $\mathrm{n}$ & - & - & /sawapi'nim/ 'onça pintada' \\
\hline 6. & $\eta$ & - & - & /ukisi'yog/ 'tira/tirou a sujeira' \\
\hline 7. & $\mathrm{p}$ & - & - & $\begin{array}{l}\text { /nupini'par/ pintador } \\
\text { /tawarerasa'pin/ 'peixe cabeça de } \\
\text { cachorro' } \\
\text { /ini?smu'pir/ 'cari, acari' } \\
\text { /akara'pew/ 'carazinho maior, mais } \\
\text { largo' }\end{array}$ \\
\hline 8. & c & - & /tarci'ri/ 'traíra' & $\begin{array}{l}\text { /werawe'raw/ 'relâmpago' } \\
\text { /Pikwere'rem/ 'cachoeira' } \\
\text { /akikipo'rəy/ 'macaco vermelho' } \\
\text { /misa'ron/ 'ovelha/bode' } \\
\text { /ipi'ros/ 'piranha' } \\
\text { /ara'run/ 'arara escura' }\end{array}$ \\
\hline 9. & $\mathrm{~S}$ & - & - & $\begin{array}{l}\text { /pia'ses/ 'meia-noite' } \\
\text { /amoka'sim/ 'eu perdi' (desapareci) } \\
\text { /sawapi'sun/ 'onça preta' } \\
\text { /a'sor/ 'eu venho' }\end{array}$ \\
\hline 10. & $\mathrm{t}$ & - & - & $\begin{array}{l}\text { ipi'ca ui'taw/ 'o peixe está nadando' } \\
\text { /iwi'tin/ 'areia' } \\
\text { /iwi'tir/ 'morro' } \\
\text { /aku'tuk/ 'eu furo' }\end{array}$ \\
\hline 11. & $\mathrm{~W}$ & - & - & $\begin{array}{l}\text { /i'wak/ 'parte acima das nuvens' } \\
\text { /a.ko'wos/ 'sapo verde' }\end{array}$ \\
\hline 12. & ? & - & - & $\begin{array}{l}\text { /mosokone''im/ 'cobra cega' } \\
\text { /a'?ar/ 'eu caio' }\end{array}$ \\
\hline
\end{tabular}


Além dessa estrutura silábica, também são possíveis no Suruí os padrões:

V - Sílabas constituídas somente por vogal podem ocorrer no início, no meio e no final de palavras em Suruí, conforme é possível observar no Quadro 05.

QUADRO 05 - PADRÃO SILÁBICO V DA LÍNGUA SURUÍ DO TOCANTINS

\begin{tabular}{|c|c|c|c|c|}
\hline & Vogal & No início & No meio & No final ${ }^{32}$ \\
\hline 1. & $\mathrm{a}$ & /a'hi/ 'dor' & /pia'scs/ 'meia-noite' & - \\
\hline 2. & $\mathrm{e}$ & /ع'ha/ 'olho' & /katuc'te/ 'bom' & - \\
\hline 3. & $\mathrm{i}$ & /i'pp/ ‘mão' & /ui'nu/ 'ouve/ouviu' & - \\
\hline 4. & $\mathrm{O}$ & /o'Po/ 'carne' & /ioronu'hu/ 'andiroba' & - \\
\hline 5. & $\mathrm{u}$ & /u'wì/ 'sangue' & /ipcu'hua/ 'pato' & - \\
\hline 6. & $\dot{\mathrm{i}}$ & /i'pi/ 'pé' & /ukii'se/ 'tem medo' & - \\
\hline
\end{tabular}

É importante destacar que não foi registrado no corpus desta pesquisa, até o momento, o padrão silábico $\mathrm{V}$ no final de palavra, com exceção da vogal a. Além disso, as

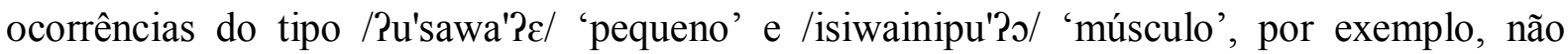
podem servir para exemplificar esse padrão porque a sílaba final é CV (/ใع/ e / $25 /)$.

CV - Esse padrão silábico é, sem dúvida, na língua Suruí o mais recorrente, podendo ocorrer no início, no meio e no final de palavras, com uma única restrição para /g/ e /y/ no início de palavras, conforme é possível perceber nos dados do Quadro 06.

QUADRO 06 - PADRÃO SILÁBICO CV DA LÍNGUA SURUÍ DO TOCANTINS

\begin{tabular}{|c|c|c|c|c|}
\hline & Cons. & No início da palavra & No meio da palavra & No final da palavra \\
\hline 1. & $\mathrm{~g}$ & - & $\begin{array}{l}\text { /usogu'pir/ 'levanta/levantou } \\
\text { casa' }\end{array}$ & /i'ge/ 'tripa' \\
\hline 2. & $\mathrm{~h}$ & /humy'ru/ 'procurar' & /kahena'Pi/ 'macaco (pequeno)' & /a'hi/ 'doído' \\
\hline 3. & $\mathrm{k}$ & /ku'?em/ 'madrugada' & /aku'tuk/ 'eu furo' & /apimu'ku/ 'cobra d'água' \\
\hline 4. & $\mathrm{~m}$ & /misar/ 'veado' & /amoa'ta/ 'tamuatá' & /na'mi/ 'orelha' \\
\hline 5. & $\mathrm{n}$ & /namu'kus/'dois' & /mani'?oga/ 'mandioca' & /poro'no/ 'rio' \\
\hline 6. & $\eta$ & - & 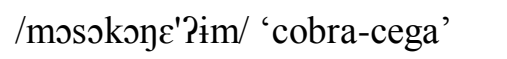 & /tatatina/ 'fumaça' \\
\hline
\end{tabular}

${ }^{32}$ É possível que na língua Suruí existam sílabas constituídas apenas por vogal que fiquem no final da palavra, mas, até o presente, não foi localizada nenhuma ocorrência desse padrão. 


\begin{tabular}{|c|c|c|c|c|}
\hline 7. & $\mathrm{p}$ & /pia'scs/ 'meia-noite' & /tapi'sa/'três' & /i'po/ 'mão' \\
\hline 8. & ᄃ & /ru'Pag/ 'virar' & /kwara'hi/ 'sol' & /ka'ru/ 'de tarde' \\
\hline 9. & S & /saka're/ 'jacaré' & /tasa'hu/ 'porcão' & /anu'sa/ 'rato' \\
\hline 10. & $\mathrm{t}$ & /tatiu'hu/ 'surucucu' & /ipi'tuna/ 'noite' & /i'ti/ 'nariz' \\
\hline 11. & $\mathrm{w}$ & $\begin{array}{l}\text { /we'rawe'raw/ } \\
\text { 'relâmpago' }\end{array}$ & /sa'wara/ 'onça' & /u'wa/ 'rabo' \\
\hline 12. & ? & /Pi'aw/ 'cabelo' & /ka'Pia/ 'macaco' & /o'?っ/ 'carne' \\
\hline
\end{tabular}

Como não há ocorrências dos fonemas /g/ e /ng/ no início de palavra, eles não constarão como formadores de grupos de palavras na macroestrutura do dicionário da língua Suruí, na direção Suruí-Português.

VC - Esse padrão silábico é bastante raro nessa língua e sua ocorrência está limitada ao final de palavras e a formas monossilábicas, conforme dados apresentados no Quadro 07:

QUADRO 07 - PADRÃO SILÁBICO VC DA LÍNGUA SURUÍ DO TOCANTINS

\begin{tabular}{|c|c|c|c|}
\hline & Consoante & Em monossílabos & No final da palavra \\
\hline 1. & $\mathrm{~g}$ & - & - \\
\hline 2. & $\mathrm{~h}$ & - & - \\
\hline 3. & $\mathrm{k}$ & - & - \\
\hline 4. & $\mathrm{~m}$ & - & - \\
\hline 5. & $\mathrm{n}$ & - & - \\
\hline 6. & $\eta$ & - & - \\
\hline 7. & $\mathrm{p}$ & - & - \\
\hline 8. & ؟ & /'ur/ 'vir' & - \\
\hline 9. & $\mathrm{~s}$ & - & - \\
\hline 10. & $\mathrm{t}$ & - & - \\
\hline 11. & $\mathrm{~W}$ & /'aw/ 'pessoa' & - \\
\hline 12. & $?$ & - & - \\
\hline
\end{tabular}


No padrão silábico VC da língua Suruí, mesmo com os novos dados que obtive com a pesquisa dessa língua, não foi possível sustentar a proposta de Barbosa (1993, p. 51), para quem a posição de consoante desse padrão poderia ser preenchida pelas formas /g/, /r/ e /y/, uma vez que, no caso de /og/ a forma correta da palavra conta com uma glotal inicial /Pog/, não servindo para essa proposta. Com relação à forma /akeriáy/ 'eu entro' apresentada por ele, não consegui obter nenhuma ocorrência desse verbo, apenas com a forma $/ \mathrm{a}$ 'ke/. A única exceção à proposta dele é com o verbo /aúr/ 'eu venho', este sim foi atestado no corpus e constitui, sem dúvida, um exemplo do padrão VC. Por outro lado, uma forma monossilábica que se encaixa nesse padrão pôde ser encontrada, trata-se do nome /'aw/, sem o caso argumentativo.

Por fim, esse estudo da fonologia da língua Suruí permite que se vislumbrem os padrões silábicos dessa língua, mas também colabora de maneira fundamental para a reflexão sobre as possibilidades de escrita iniciada no capítulo anterior. Completando essa descrição da língua Suruí, apresento, no capítulo 6, descrições relacionadas à morfossintaxe dessa língua da família Tupí-Guaraní.

\subsection{NASALIDADE}

A nasalidade na língua Suruí foi abordada, anteriormente, em duas dissertações de mestrado, a de Barbosa (1993, p. 49-50) e a de Neves (1999, p. 24). Barbosa já havia chegado à conclusão de que "a nasalização é sempre provocada por um segmento consonantal adjacente, cuja ressonância nasal se estende à vogal contígua” (BARBOSA, J. A., 1993, p. 49). Ou seja, não há vogais intrinsecamente nasais, mas vogais nasalizadas com a proximidade de uma consoante nasal.

Nesta tese, a forma fonológica dos dados não indica a existência de vogais nasais, por exemplo: a transcrição fonética de amona 'chuva' é [a'mænne], e a forma fonológica é /a'mona/. ${ }^{33}$

Barbosa (1993) observa também que essa nasalidade não ocorre sistematicamente, o que foi constatado in loco, junto a diferentes falantes. Eventualmente alguns indivíduos pronunciaram as mesmas palavras, sendo que uns realizaram nasalização de vogais, outros não. Exemplo disso ocorreu com a palavra manime 'farinha', que foi realizada foneticamente de duas formas $\left[\operatorname{mani}_{\sim} m \varepsilon\right]$ e $\left[\right.$ mani'me]. ${ }^{34}$ Dessa forma, esse autor conclui que "a melhor

\footnotetext{
${ }^{33}$ Mantenho na forma fonológica a marcação de tonicidade como ( ' ) presente na forma fonética.

${ }^{34}$ Barbosa (1993) registra, em seu trabalho, a forma [mani'me] apenas como não nasalizada.
} 
interpretação dos seguimentos vocálicos nasais em Suruí é considerá-los como alofones ou variantes condicionadas, mas facultativas, das respectivas vogais orais correspondentes" (BARBOSA, J. A., 1993, p. 50). ${ }^{35}$

Neves (1999, p. 24), por sua vez, aborda o fenômeno da nasalidade a partir do ponto de vista da morfofonêmica. Conforme já havia mencionado no Capítulo 3.1 desta tese, essa autora observa a nasalidade em construções de natureza nominal (exemplo 5 koך mukú ‘perna comprida' e verbal (exemplo $6 a+k u$ ?óm\#putá 'eu levantarei'). É possível constatar que há, sem dúvida, uma aparente alternância morfofonêmica, quando um tema termina em consoante nasal, por exemplo, na palavra /mona'tí/ (mongaty, na escrita ortográfica da língua Suruí adotada nesta tese). No entanto, trata-se de resquício de um processo que já fora produtivo na língua, quando os morfemas dessa língua eram marcados por nasalidade associada a acento de intensidade (cf. RODRIGUES; CABRAL, 2011). O que ocorre em Suruí, ocorre também nas línguas Tenetehára e no Asuriní. A perda da nasalidade nessas línguas, ocorreu com a fonemização de antigos /p/, /t/ e /k/ em contiguidade com morfemas intrinsecamente nasais em /m/, /n/ e / $/ \mathrm{y} /$ respectivamente (CABRAL, comunicação pessoal). Assim, não se trata de um processo de nasalização do $\mathrm{k}$ de kati 'na.direção.de' quando

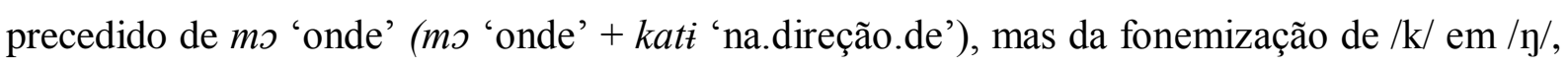
no momento da perda de nasalidade no Suruí. O que era resultado de nasalização, à força de ocorrer sempre nasal, se fixou como nasal. Assim, há que se considerar duas formas supletivas para todo tema verbal iniciado por umas das consoantes oclusivas mencionadas acima, pois essa é a forma que se combina com o morfema causativo. Mas é importante salientar que, ao combinarmos $m s$ - com, por exemplo, um empréstimo do Português iniciado por $/ \mathrm{p} /$, / $/ \mathrm{t}$ ou $/ \mathrm{k} /$, essas consoantes não se nasalizam, pois o morfema causativo não mais propaga nasalidade.

Um fenômeno distinto, mas que implica a supleção mencionada, ocorre quando um tema relativo da classe $1 \mathrm{~b}$ iniciado por $p$ está na forma genérica e humana. $\mathrm{O}$ tema usado nessa situação apresenta uma consoante nasal, $m$. A palavra ipo 'mão de algo ou de alguém' tem a forma supletiva $m$. O fato significativo é que nasalidade não mais é propagada internamente nos morfemas da língua nem em fronteiras morfológicas.

\footnotetext{
35 Observando os seguintes dados extraídos do corpus da pesquisa que realizei: [apimu'ku] 'cobra-d'água',

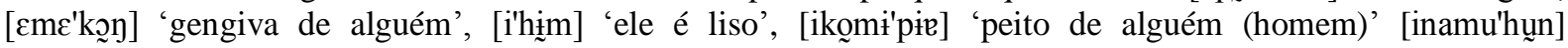
'inambu', constato a nasalidade em todas as vogais e em diferentes contextos de tonicidade, mas todos ocorrendo sempre junto a consoantes nasais.
} 


\section{PARA UMA ESCRITA DA LÍNGUA SURUÍ}

Neste capítulo, apresento, em primeiro lugar, as propostas de escrita orientadas à língua Suruí e, em seguida, analiso as configurações dessas propostas para, ao final, discutir questões relacionadas à ortografia.

\subsection{AS ESCRITAS DA LÍNGUA SURUÍ}

Dadas as experiências históricas vivenciadas pelos povos indígenas no Brasil, e, neste caso em particular, pelos Suruí ao longo do século XX, em que o contato com os não indígenas resultou em situações de exploração, de contaminação por doenças e/ou de perda de território, é mais do que esperado que esses povos mantenham uma postura de reserva, de desconfiança e, quando possível, de isolamento.

É por isso que, mesmo quando há, da parte do colonizador, a declarada intenção de ajudar um povo indígena, por exemplo, a alcançar algo como a escrita de sua língua, a reação é, no mínimo, de desconfiança, pois pode haver motivações subjacentes, como ensina a história.

No caso específico da escrita, desde o século XVI, vêm-se buscando no Brasil escrever as línguas indígenas, muito mais útil para os colonizadores do que para os falantes propriamente ditos da língua, e, em não poucas situações, com intenção de apoderar-se da língua para, em seguida, levar a cabo projetos de dominação, como bem observou Melià (1989, p. 9):

A redução de sons para letras, a compreensão de unidades como palavras, a formação de frases, tudo isso configurou uma espécie de conquista, às vezes paciente e difícil, da língua por parte do colonizador. [...] Essa conquista, porém, tinha uma intenção clara: a tradução. O desejo de entender a língua do outro trazia embutida a vontade de ser entendido, e o que devia ser entendido em primeiro lugar era uma nova mensagem: a "doutrina cristã".

Após quase 500 anos da chegada dos portugueses às terras brasileiras, os processos de catequização de indígenas para difusão da doutrina cristã continuam ativos, mas é necessário reconhecer que é somente por meio dele que, ainda hoje, muitas línguas passam a ter a sua primeira forma escrita.

Na história dos Suruí é possível identificar três situações envolvendo a sua língua e grupos religiosos: a primeira é a do próprio estabelecimento do contato na década de 1950 , não com o Estado, mas sim com a Igreja, representada por um frei dominicano católico que acompanhou o grupo por longo tempo; a segunda se deu em meados da década de 1980, 
quando o Conselho Indigenista Missionário Norte II (CIMI Norte II), com assessoria linguística da professora e pesquisadora Ruth Monserrat, produz um material linguístico, Vocabulário da língua Aikewar, cuja finalidade era "[...] a DEVOLUÇÃO ao povo Suruí, para que o mesmo participe ativamente no processo da escrita de sua própria língua." (CIMI, 1986, p. 3). Era a primeira vez que a língua Suruí do Tocantins era colocada sistematicamente na forma escrita. Contudo esse material serviu muito mais às pessoas falantes de Português (profissionais da saúde, religiosos, funcionários do Governo, etc.) que chegavam à aldeia e precisavam entrar em contato com os falantes de Suruí, do que efetivamente para o uso do povo indígena.

Já Albert e Sue Graham conviveram e fizeram pesquisa linguística junto aos Suruí no final da década de 1980. Ambos estavam associados ao Summer Institute of Linguistics (hoje denominada SIL International) e declararam, em documento por eles produzido, querer traduzir a bíblia para a língua Suruí, mas também se comprometiam a auxiliar o povo na formação de professores indígenas e na produção de material didático escrito para escritura e leitura na própria língua. ${ }^{36} \mathrm{O}$ material datilografado produzido por eles, à semelhança do Vocabulário Aikewar, não possui conotação religiosa explícita, registrando palavras e frases na língua e suas formas correspondentes em Português (ver Figura 03).

É necessário assinalar ainda a existência de outro tipo de registro escrito da língua Suruí que vem sendo praticado desde a década de 1960: é aquela proposta por diferentes antropólogos, que precisam grafar esparsamente palavras ou mesmo frases da língua e também nomes próprios. Como não havia nenhuma sistematização da língua, é possível encontrar, em trabalhos publicados, as mais diversas possibilidades de escrita para um mesmo termo, como, por exemplo, na grafia do nome Ma'ira, que também aparece escrito como Mahíra ou Mahira.

Na próxima subseção analiso propostas já feitas para a escrita da língua Suruí, a fim de verificar que elementos poderiam compor a escrita dessa língua.

\subsection{ANALISANDO AS PROPOSTAS DE ESCRITA}

Como foi apresentado na subseção anterior, pelo menos duas propostas de escrita da língua Suruí já foram elaboradas, ambas por linguistas que estiveram na T.I. Sororó na

\footnotetext{
${ }^{36}$ Os Graham manifestam suas intenções junto aos Suruí em carta dirigida a José Ferreira, representante da Funai na cidade de Marudá, anexada ao material produzido por eles.
} 
década de $1980 .^{37}$ Antes de passar à minha proposta de escrita da língua Suruí, faz-se necessária uma reflexão sobre as propostas já elaboradas para essa língua.

A primeira delas foi feita por Monserrat nos anos de 1985 e 1986 e publicada pelo CIMI Norte II no Vocabulário Aikewar, em 1986 (ver fragmentos desse trabalho no Anexo F). ${ }^{38}$ Nesse trabalho, a escrita da língua Suruí do Tocantins é feita com o alfabeto latino, ${ }^{39}$ do qual são selecionadas 16 letras $(a, e, g, h, i, k, m, n, o, p, r, s, t, u, w, y)$, mais o dígrafo $n g$, para representar a consoante nasal velar $/ \mathrm{y} /$, e o diacrítico ('), para representar a oclusiva glotal / $/$. Todas essas 18 formas estão associadas a "sons", e que, em alguns casos, apresentam variantes livres (indicadas no texto pelo $t i l$ ) e/ou variantes posicionais (escritas imediatamente abaixo da forma principal e relacionadas por uma chave).

Vale ressaltar ainda que, nesta proposta de escrita:

- A aproximante palatal [j], alofone posicional de /s/, não consta na lista de sons relacionados à escrita, pois foi representada pela mesma letra usada para representar a vogal anterior alta $/ \mathrm{i} /$.

- A consoante [t $\int$, por ser uma variante posicional de /t/, é grafada também pela letra $t$.

Como a finalidade do material produzido pelo CIMI talvez não fosse o de ensinar a escrever a língua Suruí, não há indicações específicas sobre ortografia, apenas "orientações para usar o vocabulário". Contudo, só pelo fato de começar a escrever a língua já foi uma ação relevante, pois serviu para demonstrar que aquela língua podia ser 'posta no papel', assim como é feito, por exemplo, há muito tempo com o Português.

A segunda proposta de escrita foi apresentada pelos Graham, em 1988, e consiste numa lista de enunciados escritos em Suruí com a respectiva tradução apresentada na lateral. Sua proposta, também baseada no alfabeto latino, propõe o uso de 16 letras $(a, e, h, i, k, m, n$, $g, o, p, r, s, t, u, w, y)$ e o diacrítico ', para representar a consoante glotal /?/.

\footnotetext{
${ }^{37}$ Essa situação é exatamente a que foi descrita por D’Angelis (2007, p. 17): “[...] o processo de definição ortográfica é feito 'externamente', por estudioso (lingüista ou missionário), e comunicado à comunidade para seu uso".

${ }^{38}$ Não foi possível determinar nem qual foi a tiragem do Vocabulário Aikewar, nem como e para quem ele foi distribuído.

${ }^{39}$ A decisão de usar determinado alfabeto para a escrita de uma língua é, antes de tudo, uma decisão política. Há vários casos no Brasil em que uma comunidade indígena aceitou adotar o mesmo alfabeto usado pela língua majoritária, criando ou estreitando vínculos linguísticos. Na maioria das escolas indígenas, a escrita e a leitura se dá inicialmente em Português, que é escrito com o alfabeto latino. Acredito que, no caso de haver uma forma de escrita de uma língua indígena, , que coincida com o alfabeto usado para a escrita do Português, esta deve só será válida se respeitar a fonologia da língua nativa.
} 
Destaquemos, antes de tudo, a coincidência perfeita entre as duas propostas no que se refere à representação das vogais da língua Suruí.

Entretanto, há diferenças significativas entre elas no que diz respeito às consoantes. O dígrafo $n g$ é representado pelos Graham apenas por uma letra, o $g$. Não consideram o som $[\mathrm{g}]$ no inventário fonológico da língua e representam o som $[\mathrm{kw}]$ como alofone de $/ \mathrm{k} /$.

Apesar das poucas informações sobre o destino que essa proposta de escrita da língua Suruí tomou, é possível afirmar que ela culminou na produção de um primeiro material didático para ensino da escrita dessa língua. Esse material chegou a ser usado na escola da aldeia, mas, segundo relatos dos próprios professores, teve um uso bastante restrito.

A título de exemplo, mostro, em seguida, um fragmento de cartilha de alfabetização, de autoria não confirmada: ${ }^{40}$

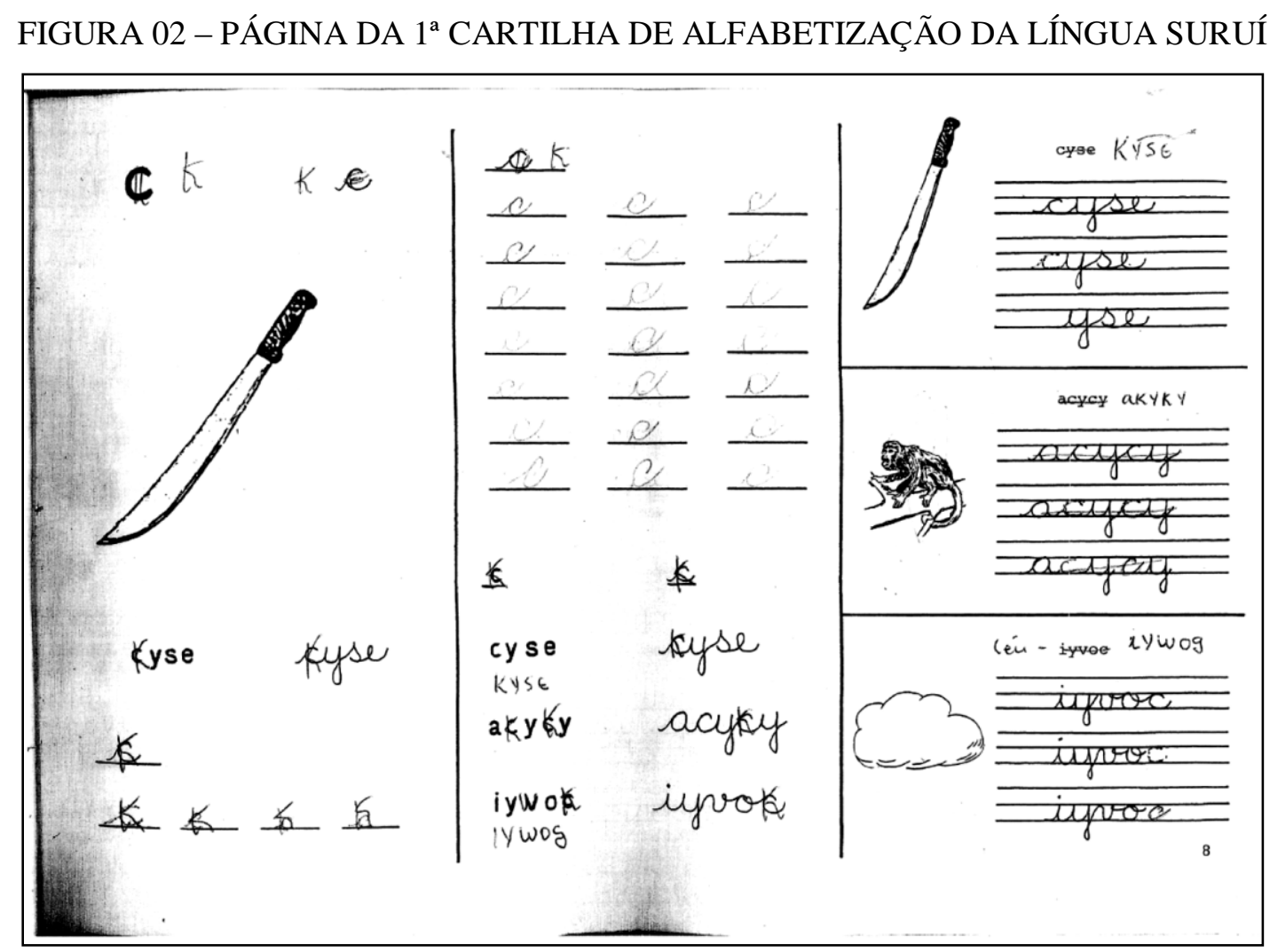

Além desse material, existe um outro, ainda mais difícil de ser encontrado, de autoria possivelmente de Graham e Graham (1991), que buscou sistematizar a língua Suruí na forma de um lista, ordenada alfabeticamente, com palavras e frases, acompanhadas de algumas ilustrações, como é possível ver na ilustração abaixo:

\footnotetext{
${ }^{40}$ Desse material, recuperei somente o seu conteúdo sem a capa onde deveria estar o crédito.
} 
FIGURA 03 - PÁGINA DO MATERIAL “EPURUMITA TIUPE”

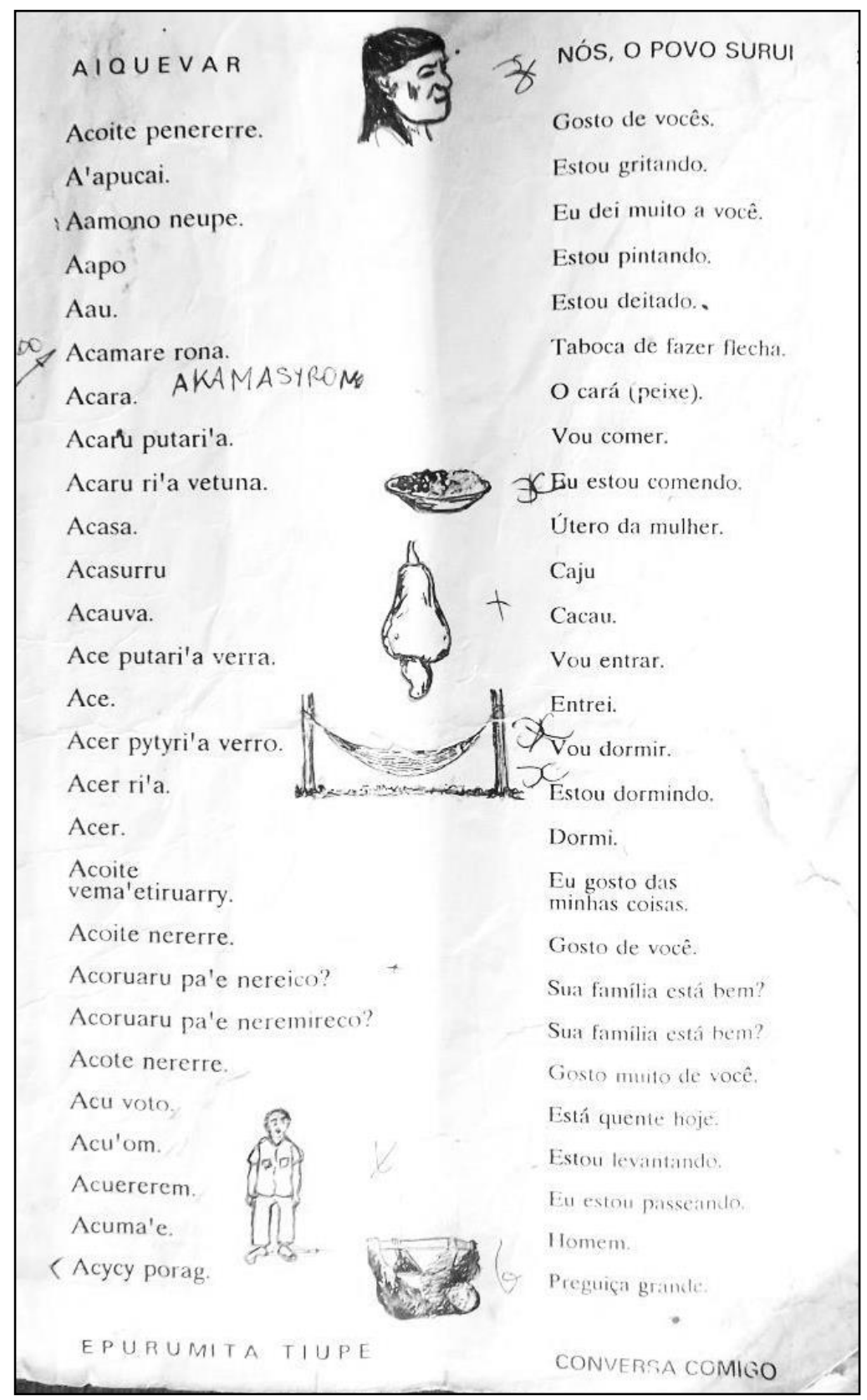

Esse material corresponde, certamente, a outro de mesma natureza, que foi produzido pelos próprios pesquisadores quando de sua estada na aldeia. $\mathrm{O}$ importante dessas duas propostas é que elas utilizam uma ortografia bem parecida com a do Português, com o uso da letra C para representar a oclusiva velar surda e RR para a fricativa glotal.

Em resumo, tanto a proposta de Monserrat quanto a dos Graham são resultado de reflexões linguísticas baseadas em dados coletados in loco. Além disso, tais propostas guardam muitas similaridades entre elas, como é possível observar no quadro abaixo em que estão dispostos lado a lado os elementos propostos por eles: 
QUADRO 08 - PROPOSTAS DE ESCRITA DA LÍNGUA SURUÍ DO TOCANTINS ${ }^{41}$

\begin{tabular}{|c|c|c|c|}
\hline & Monserrat (1986a) & Graham (1988) & Fones \\
\hline 1. & $a$ & $a$ & $\mathrm{a}$ \\
\hline 2. & $e$ & $e$ & $\mathrm{e} \sim \varepsilon$ \\
\hline 3. & $i$ & $i$ & $\mathrm{i} / \mathrm{j}$ \\
\hline 4. & $o$ & $o$ & $0 \sim 0$ \\
\hline 5. & $u$ & $u$ & $\mathrm{u}$ \\
\hline 6. & $y$ & $y$ & $\dot{\mathbf{t}}$ \\
\hline 7. & $g$ & - & $\mathrm{g} \sim \mathrm{g}$ \\
\hline 8. & $h$ & $h$ & $\mathrm{~h}$ \\
\hline 9. & $k$ & $k$ & $\mathrm{k}$ \\
\hline 10. & $m$ & $m$ & $\mathrm{~m}$ \\
\hline 11. & $n$ & $n$ & $\mathrm{n}$ \\
\hline 12. & $n g$ & $g$ & $\eta$ \\
\hline 13. & $p$ & $p$ & $\mathrm{p}$ \\
\hline 14. & $r$ & $r$ & f \\
\hline 15. & $s$ & $s$ & $\mathrm{~s}$ \\
\hline 16. & $t$ & $t$ & $\mathrm{t} / \mathrm{t} \int$ \\
\hline 17. & $w$ & $w$ & $\mathrm{w} \sim \beta$ \\
\hline 18. & , & , & $?$ \\
\hline
\end{tabular}

Certamente, a construção de uma proposta de ortografia que seja de fato usada pelos Suruí não está tão distante, pois, como se vê, apesar das divergências, as propostas apresentadas acima já dão conta da representação gráfica da língua.

\subsection{DISCUTINDO UMA ORTOGRAFIA PARA A LÍNGUA SURUÍ}

A discussão em torno da ortografia da língua Suruí iniciada na década de 1980 (cf. subseção 5.1) prossegue até o presente, sobretudo porque já há pessoas da própria comunidade Suruí que têm posições definidas de como ela deve ser.

\footnotetext{
${ }^{41}$ Barbosa (1993) empreendeu a descrição da fonética e da fonologia do Suruí do Tocantins, mas não propôs nenhuma forma de escrita para essa língua.
} 
O que é muito importante, pois, é dispor de uma forma escrita para sua língua, participando ativamente de sua construção, é ter a consciência de que essa proposta nasceu de um esforço empreendido coletivamente, mesmo que tenha sido iniciativa de poucas pessoas. Há ainda o fato de que uma proposta ortográfica pode sempre ser melhorada, aperfeiçoada.

Nesse sentido, o esforço empreendido, recentemente, por exemplo, pelos professores Tymykong e Ikatu para a construção ou definição de uma escrita para a língua Suruí não partiu de um interesse acadêmico, mas surgiu, sim, de uma demanda dos próprios Suruí, que querem sua língua ensinada na escola da aldeia.

É possível afirmar, grosso modo, que a proposta de escrita adotada até pouco tempo foi a de Monserrat (ver CIMI, 1986), registrada no Vocabulário Aikewar, mas que já passou por modificação.

É importante não esquecer que, para além de um sistema de escrita, a própria definição dessa escrita, das palavras e frases na língua, também fazem parte do sistema ortográfico de uma língua, o que, até este momento, ainda não havia sido feito.

Mesmo sem esta sistematização de sua língua, os professores partiram de suas próprias intuições de falantes da língua para estabelecer a escrita das palavras de sua língua, forma essa que está em uso na escola da aldeia. Abaixo, reproduzo uma amostra dessa forma de escrita da língua Suruí:

Esewag se'eng ete.

Pesewag.

urukeruki puta ka'ape uruhow.

turusepurakane ma'e amu isukaw.

ma'e sukaw puta uruw

imu'a hoj ta tire'ysape.

na uwi puta usepewei.

ma'e a sukaw arur puta

penupe.

Imuka'eu ke'erur tiupe tá une, aweiria imuka'e pyrera.

Akoj ete iw ika'e

ipise ike'epyra

Ahekwahaw imuka'e pyra

ma'e pa'e eresuka karuwaruhu

asukar.

aimim auwese ete wekow.

ma'e yrware pa'e eresuka,

kwatyg'yware asuka. 
ikaw we ete pa'e karuwaruhu

ipise pise i'ehyrypyra

imu'apyg'ipyra na'ipise aruwi

teramu i'eHyripyra ipise pise. ${ }^{42}$

A construção de uma escrita, e sua consequente funcionalidade, depende, em grande parte, segundo Cabral (2013, p. 9), da:

[...] consciência dos falantes a respeito do porquê de criar uma escrita para sua língua, quais as funções que essa escrita terá para a sua comunidade de fala e, fundamentalmente, sua participação na definição do alfabeto, dos diacríticos, se algum, e de outras convenções usadas para a escrita de sua língua.

Por isso, buscando contribuir com a discussão junto aos Suruí em favor do estabelecimento de uma ortografia para sua língua e, ao mesmo tempo, objetivando construir materiais lexicográficos que adotem essa língua, passo à apresentação de algumas considerações sobre os elementos necessários para a construção da proposta ortográfica, que já foi, em grande parte, definida pelos próprios Suruí.

\subsection{UMA PROPOSTA DE ESCRITA}

Qualquer proposta para a escrita da língua de um povo, há de passar, sem nenhuma dúvida, pela apreciação do povo que irá usá-la. Assim, a proposta que ora apresento serve bem mais como forma orientadora para este trabalho acadêmico, do que para determinar ao povo Suruí como ele deve escrever a sua língua.

Como foi visto nas seções anteriores, já foram apresentadas algumas propostas para a escrita da língua Suruí e agora apresento uma nova proposta:

QUADRO 09 - PROPOSTA DE ESCRITA DAS VOGAIS DA LÍNGUA SURUÍ

\begin{tabular}{|c|c|c|}
\hline & Fonema & Proposta de escrita \\
\hline 1. & $/ \mathrm{a} /$ & $\mathrm{a}$ \\
\hline 2. & $/ \varepsilon /$ & $\mathrm{e}$ \\
\hline 3. & $/ \mathrm{i} /$ & $\mathrm{i}$ \\
\hline 4. & $/ \mathrm{u} /$ & $\mathrm{u}$ \\
\hline 5. & $/ \mathrm{J} /$ & $\mathrm{o}$ \\
\hline 6. & $/ \mathrm{i} /$ & $\mathrm{y}$ \\
\hline
\end{tabular}

\footnotetext{
42 Tradução feita por Tymykong: "Escreva fala de Aikewara - Escreva. Eu vou pro mato pra mim matar uma caça. Se eu matar uma caça, eu vou distribuir para o meu parente. Eu não posso comer nada sozinho sem dar um pedaço para o meu parente. Eu gosto muito de comer assado. O que foi que você matou? Eu matei uma paca. Isso eu tava desejando de comer essa paca. Em que fruta que você matou? Foi em gameleira. Sim, a paca é tão gostosa. Eu gosto de comer paca. Ela é muito gostosa." Nota: O texto de Tymykong foi transcrito literalmente.
} 
QUADRO 10 - PROPOSTA DE ESCRITA DAS CONSOANTES DA LÍNGUA SURUÍ

\begin{tabular}{|c|c|c|}
\hline & Fonema & Proposta de escrita \\
\hline 1. & $/ \mathrm{g} /$ & $\mathrm{h}$ \\
\hline 2. & $/ \mathrm{h} /$ & $\mathrm{k}$ \\
\hline 3. & $/ \mathrm{k} /$ & $\mathrm{kw}$ \\
\hline 4. & $/ \mathrm{k} /$ & $\mathrm{m}$ \\
\hline 5. & $/ \mathrm{m} /$ & $\mathrm{n}$ \\
\hline 6. & $/ \mathrm{h} /$ & $\mathrm{ng}$ \\
\hline 7. & $/ \mathrm{h} /$ & $\mathrm{ngw}$ \\
\hline 8. & $/ \mathrm{h} /$ & $\mathrm{p}$ \\
\hline 9. & $/ \mathrm{p} /$ & $\mathrm{r}$ \\
\hline 10. & $/ \mathrm{s} /$ & $\mathrm{j}, \mathrm{s}$ \\
\hline 11. & $/ \mathrm{s} /$ & $\mathrm{t}$ \\
\hline 12. & $/ \mathrm{t} /$ & $\mathrm{w}$ \\
\hline 13. & $/ \mathrm{w} /$ &, \\
\hline 14. & $/ \mathrm{P} /$ & \\
\hline
\end{tabular}

Nesta proposta, há 6 fonemas vocálicos orais (não há fonemas vocálicos nasais nesta língua) representados por 6 letras; e 14 fonemas consonantais, representados por 11 letras simples, 3 dígrafos e um diacrítico.

Desse modo, a ordem alfabética escrita para a língua Suruí pode ser configurada da seguinte maneira:

QUADRO 11 - PROPOSTA DE ORDEM ALFABÉTICA PARA A LÍNGUA SURUÍ, COM DISTINÇÃO DE LETRAS MAIÚSCULAS E MINÚSCULAS ${ }^{43}$

\begin{tabular}{|ccc|}
\hline A a & E e & G g \\
\hline \hline $\mathrm{H} \mathrm{h}$ & $\mathrm{I} \mathrm{i}$ & $\mathrm{K} \mathrm{k}$ \\
\hline $\mathrm{KW} \mathrm{kW}$ &, & $\mathrm{M} \mathrm{m}$ \\
\hline
\end{tabular}

${ }^{43}$ A letra j não foi considerada nesta proposta de ordem alfabética em virtude de essa letra ser ocorrer apenas como alofone de /s/ em final de sílaba ou diante de silêncio, ou seja, ela nunca ocorre no início de sílaba. 


\begin{tabular}{|ccc|}
\hline N n & NG ng & NGW ngw \\
\hline $\mathrm{O} \mathrm{o}$ & $\mathrm{P} \mathrm{p}$ & $\mathrm{R} \mathrm{r}$ \\
\hline $\mathrm{S} \mathrm{s}$ & $\mathrm{T} \mathrm{t}$ & $\mathrm{W} \mathrm{w}$ \\
\hline $\mathrm{Y} \mathrm{y}$ & & \\
\hline
\end{tabular}

\subsection{CONSIDERAÇÕES SOBRE A ORTOGRAFIA DA LÍNGUA SURUÍ}

Partindo de uma observação bastante pertinente acerca da questão ortográfica no contexto dos povos indígenas, Melià (1979, p. 78-79) afirma que:

Dois perigos se devem evitar: uma ortografia, que pretendendo se aproximar o máximo possível das peculiaridades fonéticas, se torne complicada demais no uso de signos diacríticos e símbolos não usuais no português; o outro, de se assimilar tanto ao português que perca coerência interna.

Com relação à primeira observação, a ortografia que se esboça para a língua Suruí também deve buscar utilizar apenas diacríticos e símbolos comuns ao Português, língua amplamente utilizada no contexto da T.I. Sororó (cf. subseção 3.3), sem, contudo, reproduzir integralmente a estrutura ortográfica desta outra língua (e esta é a segunda observação).

\subsubsection{Acentuação}

A acentuação diz respeito ao uso de diacríticos para marcar determinados traços prosódicos da língua na escrita de suas palavras, dentre os quais intensidade, nasalidade, alongamento vocálico, dentre outros. ${ }^{44}$

Com relação à intensidade, a atual proposta ortográfica para a língua Suruí ainda não prevê o uso de diacríticos, como o uso do acento agudo no Português. Mas é evidente a vantagem de se marcar a tonicidade em línguas como estas da família Tupí-Guaraní, haja vista a possibilidade de muitas ocorrências de compostos e de sufixos tônicos, cuja intensidade não interfere na intensidade inerente aos temas que são base dos processos derivacionais, assim como para distinguir pares homônimos, mas não homófonos, como por

\footnotetext{
${ }^{44}$ Como não é fonológica a alternância /e/ e /ع/ nem /o/ e / /, não há necessidade de marcar essas ocorrências. Do mesmo modo, a língua Suruí, em sua prosódia, não faz uso de marcas de tom (ascendente, descendente, agudo, grave, alto, baixo, p.ex.) ou de duração (longas e breves, p.ex.).
} 
exemplo píra 'pele' e pirá 'peixe'. Essa marcação é importante na aprendizagem da língua pelas gerações mais novas que não são fluentes na língua nativa. ${ }^{45}$

O outro fenômeno que pode ser destacado por um diacrítico é a crase, que, no Português, é marcado com o acento grave. Apesar de esse fenômeno também ocorrer na língua Suruí (p.ex., em aiko namonowi ne upe 'esse eu não dou para você', o na 'neg' + amono 'dar' $\rightarrow$ namono), ele não gera nenhum tipo de ambiguidade na escrita Suruí (como, no Português, o $a$ resultante de crase é idêntico ao $a$ artigo definido), logo, acredito não haver necessidade de marcá-lo.

Por fim, a língua Suruí conta apenas com vogais nasalizadas, sendo que até mesmo sua ocorrência não é compartilhada por todos os falantes, por exemplo, o verbo amono 'dar' pode ser realizado tanto [amə̃ 'no] como [amo'no]. Assim, não possuindo vogal nasal com valor distintivo, não há razão para marcá-la.

\subsubsection{Hífen}

Na proposta ortográfica para a língua Suruí ainda não há a intenção de usar o hífen, nem para as palavras compostas (ver capítulo 6 sobre processos de composição) nem para marcar a translineação. Neste último caso, no entanto, apenas com a ampliação do uso da escrita é que se poderá dizer, de fato, se será usada ou não, pois existe a possibilidade de haver composições de palavras que resultem em formas extremamente longas e o que, no caso da escrita, o usuário decida que, para melhor comportar a forma no espaço da linha, seja mais adequado dividi-la; nesse caso, as regras de translineação deverão ser estabelecidas. ${ }^{46}$

\subsubsection{Pontuação}

A escrita na língua Suruí segue, grosso modo, o sistema de pontuação do Português, no entanto, partindo da observação de textos já produzidos pelos próprios Suruí, constatei as seguintes peculiaridades.

A primeira constatação é a de que os Suruí não fazem uso da vírgula para separar, por exemplo, vocativos, apostos e períodos oracionais, nem mesmo em caso de coordenação

\footnotetext{
${ }^{45}$ Como os materiais lexicográficos propostos nesta tese ainda não correspondem à versão final a ser impressa para uso do povo Suruí, atendendo, antes, a um público acadêmico (público formado por linguistas, antropólogos e pessoas de áreas afins), para o qual é suficiente a forma fonológica inserida na microestrutura do material, ainda haverá a discussão com os próprios Suruí para que avaliem e decidam sobre o uso ou não desse diacrítico). ${ }^{46}$ Em algumas situações na proposição dos modelos lexicográficos desta tese faço uso do recurso do hífen, a fim de evitar, por exemplo, grandes espaços entre as palavras do verbete. Esta decisão não possui, contudo, nenhuma intenção normativa, uma vez que caberá aos próprios Suruí essa decisão. Nessa situação, utilizo como critério de separação o ponto de articulação entre as formas (duas ou mais) envolvidas na composição.
} 
de nomes. Nesse sentido, há apenas o uso do ponto simples para marcar o final dos enunciados, formando, assim, sempre novos parágrafos. Por outro lado, como a ortografia dessa língua ainda está em construção, emprego, a título de experimentação, tanto a vírgula quanto o ponto simples nas transcrições que realizo da língua Suruí, mas isso não implica que esses símbolos serão usados sistematicamente pelo povo Aikewára.

Do mesmo modo, eles não empregam na escrita nem o sinal de exclamação nem o de interrogação. O primeiro sinal, mesmo em Português, tem uso extremamente restrito, e, no caso da língua Suruí, sua utilidade ainda não foi, aparentemente, sentida pelos usuários da escrita. Ressalte-se ainda que o uso de interrogação em Suruí seria redundante, uma vez que as perguntas são identificadas nos enunciados por meio de partículas de pergunta ( $p a$ 'e, pe, por exemplo).

Logo, tal como o hífen, esses dois sinais gráficos, apesar de constarem no interior das transcrições feitas por mim para esta tese, não têm, ainda, um uso efetivo na ortografia da língua Suruí.

Por fim, símbolos como ponto e vírgula ( ; ), dois pontos ( : ), aspas ( “"), parênteses ( ( ) ), colchetes ( [ ] ), chaves ( \{ \}), barra (/), travessão ( - ) e reticências ( ... ), não fazem parte ainda da escrita da língua Suruí, o que não exclui, de todo, a possibilidade de seu uso.

\subsubsection{Letras maiúsculas e minúsculas}

Da mesma forma, observando os escritos em língua Suruí, constatei que não havia, ainda, a preocupação em escrever nem as letras das palavras iniciais dos enunciados nem os nomes próprios com letras maiúsculas, ou seja, tudo era escrito com letras minúsculas. Mesmo nas situações em que escreviam frases em Português, empregando maiúsculas perfeitamente nos contextos acima mencionados, a respectiva tradução em Suruí não as empregava. Contrariamente, quando os professores Suruí utilizam o computador para escrever seus textos para a escola ou, por exemplo, no caso das músicas que seriam utilizadas na festa Sapurahaj, em geral não se preocuparam em escrever o texto distinguindo maiúsculas e minúsculas, e escrevem tudo com letras maiúsculas (cf. Anexo G).

Já no espaço desta tese, emprego, no caso das transcrições da língua Suruí, letras maiúsculas para destacar nomes próprios (Su'ara, Ikatu, Miho, p.ex.). Com relação aos enunciados em Suruí, preferi deixá-los com iniciais minúsculas no interior dos verbetes, 
empregando a maiúscula apenas nos marcadores Ajnon 'assim, isso mesmo' e Eisag 'veja' (ver Capítulo 9 sobre os modelos lexicográficos da língua Suruî).

Enfim, estas são algumas das questões relacionadas à escrita e à ortografia da língua Suruí, mas que devem ainda ser tratadas no contexto da sociedade Aikewára, a fim de se chegar a uma proposta que, ainda que incompleta (é possível chegar a um fim nesse processo?), seja resultado do conhecimento e das necessidades emanadas desse povo indígena. 


\section{ELEMENTOS PARA UMA GRAMÁTICA DA LÍNGUA SURUÍ}

Ao propor a construção de materiais lexicográficos para a língua Suruí, fez-se necessária a realização de uma breve descrição gramatical dessa língua, sobretudo para contemplar aspectos não contemplados em trabalhos anteriores, de forma que o trabalho de construção de materiais lexicográficos aqui proposto fosse devidamente fundamentado em um conhecimento das estruturas morfológicas e morfossintáticas dessa língua.

Apresento, aqui, uma descrição de aspectos morfológicos e morfossintáticos da língua Suruí. O estudo morfológico baseou-se no trabalho de Rodrigues (2010 [1981], p. 11 $42 ; 1996 ; 2000),{ }^{47}$ no qual ele descreve a estrutura morfológica da língua Tupinambá. ${ }^{48}$

O Tupinambá e o Suruí embora classificados em sub-ramos distintos da família linguística Tupí-Guaraní (RODRIGUES, 1985; 1986), são línguas gramaticalmente conservadoras, compartilhando uma alta percentagem de traços estruturais.

Há ainda o fato de que esse trabalho de Rodrigues tem sido referência de inúmeros outros trabalhos descritivos de línguas Tupí-Guaraní, ${ }^{49}$ os quais têm adotado sistematicamente a terminologia por ele proposta na descrição de modos verbais, de nominalizadores, de séries pronominais, de aspecto/modo de ação e de expressões de modalidade, além dos processos de composição e de reduplicação típicos dessas línguas.

\subsection{ASPECTOS DA MORFOLOGIA DA LÍNGUA SURUÍ}

No domínio da Morfologia, os morfemas, enquanto constituintes imediatos da palavra, podem ser classificados como afixos e raízes, e ambos podem ser subdivididos em:

$$
\begin{aligned}
& \text { - AFIXOS } \\
& \text { - PREFIXOS } \\
& \text { - flexionais } \\
& \text { " relacionais } \\
& \text { व pessoais } \\
& \text { - derivacionais } \\
& \\
& \text { a nominalizadores }
\end{aligned}
$$

\footnotetext{
${ }^{47}$ Nesse trabalho, Rodrigues (2010, p. 11-12) trata da "divisão dos morfemas em afixos e raízes e [...] da classificação das raízes em função de sua combinação com os diferentes afixos”, e também da reduplicação. Ele ainda classifica as raízes "segundo sua combinação ou não com os prefixos relacionais" e demonstra "as possibilidades do processo de composição em Tupinambá", tratando, por fim, "das duas grandes classes de palavras identificáveis nessa língua - nomes e verbos”.

${ }^{48}$ Segundo Rodrigues, esse trabalho de descrição da morfologia do Tupinambá foi iniciado na década de 1950 e concluído na década de 1980, com revisões na década de 1990.

${ }^{49}$ Ver, por exemplo, Jensen (1984, p. 75-117) e Cabral (2000, p. 233-262).
} 
- causativos

$\checkmark$ reflexivos

- SUFIXOS

- flexionais

- causais

- modais

- negação

- derivacionais

- endocêntricos

- exocêntricos

- REDUPLICAÇÃO

- monossilábica

- dissilábica

- RAÍZES

- CLASSIFICAÇÃO

- Classe I

- Classe II

- Classe III

- COMPOSIÇÃO

- Determinativa

- Atributiva

- Objetiva

\subsubsection{Morfemas}

Apresento, nesta primeira parte, a descrição morfológica da língua Suruí e, em seguida, trato da caracterização das palavras (nomes, verbos e partículas) nessa língua.

\subsubsection{Afixos: Prefixos}

\subsection{Prefixos relacionais}

Segundo Cabral, Rodrigues e Franceschini (2013, p. 402), os prefixos relacionais constituem "um conjunto de prefixos que expressam a dependência sintática de um tema relativo com respeito ao seu determinante". Essa classe de prefixos pode fazer referência ao contexto gramatical ou ao contexto pragmático. Em Suruí identificamos os seguintes prefixos relacionais: 
a) Prefixos relacionais que fazem referência ao contexto gramatical

\begin{tabular}{|l|l|}
\hline$\left(u-\sim u s^{-}\right) \infty w_{-}$ & "O determinante de um nome [...] é idêntico ao sujeito." \\
\hline$s \varepsilon^{-}$ & "O determinante de um verbo [...] é idêntico ao sujeito." \\
\hline$s \jmath^{-}$ & "O determinante alterna-se reciprocamente com o sujeito." \\
\hline$i-\infty \emptyset-\infty h-$ & "O determinante é diferente do sujeito e distinto do falante e do ouvinte." \\
\hline$(r-\sim n-) \infty \emptyset-$ & "O determinante é a locução nominal contígua (imediatamente precedente)." \\
\hline
\end{tabular}

b) Prefixos relacionais que fazem referência ao contexto pragmático

\begin{tabular}{|c|c|}
\hline uгu- & "O determinante é o ouvinte, sendo sujeito o falante ( \pm terceira pessoa)" \\
\hline$p \varepsilon-$ & $\begin{array}{l}\text { "O determinante é o ouvinte mais outrem, sendo sujeito o falante ( } \pm \text { terceira } \\
\text { pessoa)" }\end{array}$ \\
\hline $\begin{array}{l}t-\infty \emptyset-\infty P-\infty \\
p->m-\end{array}$ & $\begin{array}{l}\text { "O determinante é ser humano indefinido": } t \text { - } \varepsilon h a \text { 'olho de gente (ou de muitos)', } \\
t \text { - } a k u \text { 'quentura de gente', } t \text { - } u w i \dot{~ ' s a n g u e ~ d e ~ g e n t e ~(o u ~ d e ~ m u i t o s) ' ; ~} m \text { ' 'mão de } \\
\text { gente (ou de muitos)', Ø-pì?a 'fígado de gente (ou de muitos)' }\end{array}$ \\
\hline
\end{tabular}

\subsection{Prefixos pessoais}

\begin{tabular}{|c|c|c|}
\hline 1 & $a-\infty w \varepsilon-$ & a-wirəg 'eu roço', a-kupir 'eu capino'; ...we-ho-w 'indo eu' \\
\hline 2 & $\varepsilon r \varepsilon-\infty \varepsilon-$ & 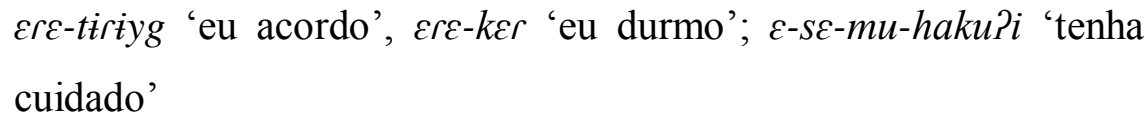 \\
\hline 13 & uгu- & $\begin{array}{l}\text { uru-asesmonəg 'nós (excl.) cortamos', uru-nups 'nós (incl.) } \\
\text { batemos' }\end{array}$ \\
\hline 23 & $p \varepsilon-$ & pe-suka 'eu mato', pe-wuhyj 'eu carrego', pe-raha 'eu levo' \\
\hline $12(3)$ & $s a-$ & $s a-k \varepsilon r$ 'nós (incl.) dormimos', $s a-h a$ 'nós (incl.) vamos' \\
\hline 3 & $u-\infty w-$ & u-pihig 'ele pega'; w-Eraha 'ele leva' \\
\hline
\end{tabular}


A partir dos dados apresentados acima, foi possível montar o seguinte quadro que leva em consideração a perspectiva de focalização do falante e do ouvinte.

QUADRO 12 - MATRIZ COMPONENCIAL DOS PREFIXOS PESSOAIS EM SURUÍ, BASEADO NA PROPOSTA DE RODRIGUES (2010, P. 13)

\begin{tabular}{|l|c|c|c|c|}
\hline & & \multicolumn{4}{|c|}{ Oposição entre Falante e Ouvinte } \\
\hline & & \multicolumn{2}{|c|}{+} & \multirow{2}{*}{-} \\
\hline \multirow{2}{*}{$3^{\text {a }}$ pessoa focal } & & Falante & Ouvinte & \\
\cline { 2 - 5 } & + & $a-$ & $\varepsilon r \varepsilon-$ & $s a-$ \\
\cline { 2 - 5 } & + & $u r u-$ & $p \varepsilon-$ & $u-$ \\
\hline
\end{tabular}

\subsection{Prefixos derivacionais}

a) Prefixos nominalizadores

A língua Suruí possui um único prefixo 'nominalizador de objeto' $\varepsilon m i-$.

001 ne remiriko ripo uapukaj ne upe
ne $\quad$ - $-\varepsilon m i-r-i k s-\varnothing$
ripo u-apukas ne $\varnothing$-up $\varepsilon$
2 R'-NMLZ-C.COM-estar.em.mov.-ARG DUB 3-gritar 2 R'-DAT
'a que faz você ficar com ela (sua esposa) está gritando para você'

002 ma'ea rupi pa'e eremukun ne remi'ua?

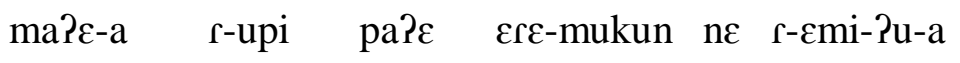
coisa-ARG R'-POSP PERG.I 2-engolir 2 R'-NMLZ-comer-ARG
'por onde você engole sua comida?'

b) Prefixo causativo

O prefixo causativo simples do Suruí é a forma $m u$-.

003 esemuhaku'i ke! ma'esawara rapo ne u'u
$\varepsilon$-se-mu-haku?i
ke ma?csawar-a rapo ne $\varnothing$-u?u
2-REFL-CAUS-cuidado DS cachorro-ARG POSS $2 \mathrm{R}^{1}$-morder
'tenha cuidado! o cachorro vai te morder'

O prefixo causativo comitativo do Suruí é a forma $r-\sim$ er- $\sim$ ero- $\sim$ ro-.

004 mowi pa'e ererur ma'ea ro'o?
mo +wi pa?e $\varepsilon r \varepsilon-\varsigma-u r$
ma?c-a $\quad \mathrm{\Upsilon}-\mathrm{\rho}$ ว
onde +ABL PERG.I 2-C.COM-trazer caça-ARG $\mathrm{R}^{1}$-carne

'de onde você trouxe esta carne de caça?' 


\subsubsection{Afixos: Sufixos}

\subsection{Sufixos flexionais}

a) Os sufixos flexionais causais da língua Suruí são os seguintes:

- $-a \sim-\emptyset$ (marca o caso argumentativo $)^{50}$

005 ne apina

ne $\varnothing$-apin-a

$2 \mathrm{R}^{1}$-cabeça-ARG

'tua cabeça'

006 pe nuwya

pe n-uwi-a

$23 \mathrm{R}^{1}$-sangue-ARG

'sangue de vocês'

007 hoga

h-og-a

$\mathrm{R}^{2}$-casa-ARG

'casa (de alguém)'

008 kunumia irumukusa'e

kunumi-a iru-mukus-a?E

menino-ARG irmão-dois-NMLZ.PRED

'o menino tem um irmão gêmeo'

009 sene po

sen $\varepsilon \quad \varnothing-\mathrm{po}-\varnothing$

12(3) $\mathrm{R}^{1}$-mão-ARG

'nossa mão'

\footnotetext{
${ }^{50}$ De acordo com Cabral, Silva e Andrade (2013, p. 3), o caso argumentativo "caracteriza-se por marcar tanto nomes e verbos em função de argumento, quanto por englobar as principais funções gramaticais: sujeito de verbos transitivos (A) e intransitivos $(\mathrm{S})$, objeto direto $(\mathrm{O})$ e objeto de posposições”. Há, na língua Suruí, a ocorrência regular desse caso. Indico ainda para uma discussão mais aprofundada do tema o artigo de Rodrigues (1996, 57-66), no qual ele registra sua nova análise desenvolvida em 1990 do morfema - $a$ que, em seus trabalhos anteriores, fora rotulado de caso nominal.
} 
010 sawara usaruetewa'e

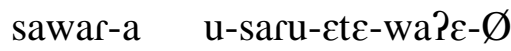

onça-ARG 3-ser.brabo-INT-NMLZ-ARG

'a onça é braba'

- -ати -raти -nати (marca o caso translativo)

011 aha puta ri'a isukaw tasahuamu

a-ha puta ri?a i-suka-w tasahu-amu

1-ir PROJ DECL $\mathrm{R}^{2}$-matar-GER porcão-TRANSL

'eu vou para matar porcão' (talvez eu mate um porcão)

012 ure purumu'etaramu

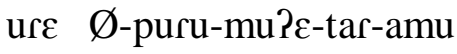

$13 \mathrm{R}^{1}$-gente-fazer.dizer-NMLZ.AG-TRANSL

'nós somos professores'

013 ma'eramu pa'e kuso nuse'engara uwi?

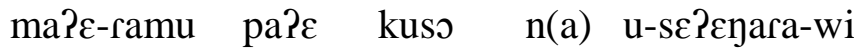

que-TRANSL PERG.I mulher NEG 3-cantar-NEG

'por que as mulheres não estão cantando?'

014 monamu puta pa'e ituri wahemamapa?

mo-namu puta pa?e i-tur-i w-ahe-ma-map-a

quando/onde-TRANSL PROJ PERG.I R R'-vir-IND.II 3CORR-chegar-COMPL-RED-GER quando todos vão chegar?

- -pe (marca o caso locativo pontual)

015 ita iwewu wewuj ti pope

ita- $\varnothing \quad$ i-wewu-wewus ti $\varnothing$-po-pe

pedra-ARG 3-ser.leve-RED 1 R $\mathrm{R}^{1}$-mão-LP

'a pedra está leve na minha mão' 
016 aiko ra'e wehe re pa'e erehow ka'a pe eataw

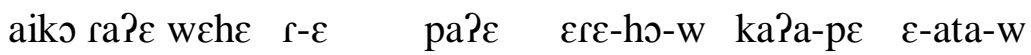
ontem $\quad{ }^{1}$-REL PERG.I 2-ir-GER mato-LP 2-andar-GER 'ontem você foi andar no mato'

- -imu (marca o caso locativo difuso)

017 'oga 'arimu

Pog-a Ø-?ar-imu

casa-ARG $\mathrm{R}^{1}$-superfície-LD

'em cima da casa'

018 'arimu

Par-imu

luz.do.dia-LD

'pelo dia'

b) Os sufixos flexionais modais da língua Suruí são os seguintes:

- $-a \sim-w \sim-t a$ (marca o modo gerúndio)

019 Muretama weraha kyse ipyhyka ti wi

murctam-a w- $\quad$ raha kyse- $\varnothing \quad$ i-pihik-a ti +wi

Muretam-ARG 3-levar faca-ARG $\mathrm{R}^{2}$-pegar-GER 1 +ABL

'Muretama levou a faca que pegou de mim'

020 tapi'ira puta oho ka'a wi uhema

tapi?ir-a puta o-ho ka?a +wi u-hem-a

anta-ARG PROJ 3-ir mato ABL 3CORR-sair-GER

'a anta vai sair do mato'

021 pehe puta pesuka ma'ea pesehow?

pehe puta pe-suka ma? $\varepsilon$-a pese-ho-w

23 PROJ 23-matar caça-ARG 23CORR-ir-GER

'vocês vão para matar aquelas caças?' 
022 aiko ra'e wehe rako aha ka'a pe weketa

aiks ra? $\varepsilon$ wehe rako a-ha kaPa-pe we-ke(r)-ta

ontem AT.I 1-ir mato-LP 3CORR-dormir-GER

'ontem eu fui dormir no mato'

- $-i \sim-s$ (marca o modo indicativo II) (cf. subseção 6.1.3.2.3)

023 mowi pa'e ripo iture sawara?

mo +wi pa?e ripo i-tur-i sawar-a

onde ABL PERG.I DUB $\mathrm{R}^{2}$-vir-IND.II onça-ARG

'de onde a onça vem?'

024 ka'awi puta ihoj tapi' ira

kaPa +wi puta i-ho-s tapi?ir-a

mato +ABL PROJ $\mathrm{R}^{2}$-ir-IND.II anta-ARG

do mato a anta vai sair

025 tipiw ihoj karuarahua usona

tipiw i-ho-s karuarahu-a u-son-a

perto $\mathrm{R}^{2}$-ir-IND.II paca-ARG 3-correr-GER

a paca correu perto de mim

- - ати -ramu -namu (marca o modo subjuntivo)

026 Suta'ar sene 'arimu ihoramu puhi ke pe esaukar puhi

sutaPar-a sene $\varnothing$-Par-imu i-ho-ramu

suta'ar-ARG $12(3) \quad \mathrm{R}^{1}$-superfície-LD $\mathrm{R}^{2}$-ir-SUBJ

puhi $\mathrm{k} \varepsilon \quad \mathrm{p} \varepsilon \quad \varepsilon$-sa-ukar-a puhi

PROIB DES 23 2CORR-ver-C.PREP-GER PROIB

'quando Suta'ar passar sobre nós, não amostrar (não apontar)' 
- Não há marcas sufixais para o modo indicativo I na língua Suruí. Entretanto, a morfossintaxe do verbo - marcas pessoais, hierarquia referencial - nesse modo o distingue dos demais modos.

027 pehe rako ti nupo pe

pehe raks ti Ø-nupo $p \varepsilon$

23 AT.I 1 R ${ }^{1}$-bater 2.ERG

'vocês bateram em mim'

028 ure uruapo 'oga

ure uru-apo ?-og-a

13 13-fazer $\mathrm{R}^{4}$-casa-ARG

nós fizemos estas casas

- Também não existem marcas sufixais para o modo imperativo na língua Suruí. Este modo também recebe prefixos pessoais próprios, embora se combine com prefixos pessoais próprios. Ressaltamos que a morfossintaxe do verbo no imperativo é também condicionada pela hierarquia referencial.

029 esuka

$\varepsilon$-suka

2-matar

mata

030 eho

$\varepsilon$-ho

2-ir

vá

031 pesahug peho

pe-sahug pe-ho

23-banhar 23-ir

vão tomar banho 
032 emono ma'esawara tukaru

pe-mon ma?zsawar-a t(a) u-karu

23-dar cachorro-ARG PERMISS 3-comer

deem comida pro cachorro

6.1.1.2.2. Sufixos derivacionais

a) endocêntricos

A língua Suruí também possui um conjunto de sufixos derivacionais que formam temas que mantêm a mesma classe da base, são eles:

- $-h u \sim-u h u$ (intensivo)

tatu $+-h u \rightarrow$ tatuhu 'tatu grande'

tarciri $+-u h u \rightarrow$ tarciriuhu 'traíra grande'

ame?a $+-u h u \rightarrow$ ame?auhu 'testículo grande'

- $-2 i$ (atenuativo)

wira +- -ii $\rightarrow$ wira?i 'pássaro pequeno'

akara $+-2 i \rightarrow$ akara?i 'acará pequeno'

- - $\varepsilon$ ?im (privativo)

tahi $+-\varepsilon$ Pim $\rightarrow$ tahí Pim 'sem dor de gente'

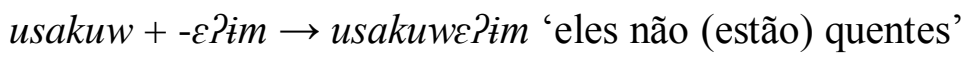

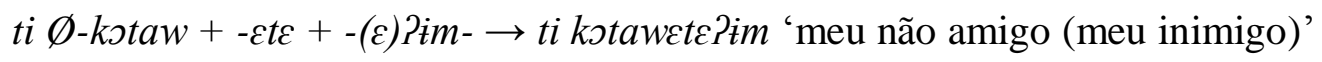

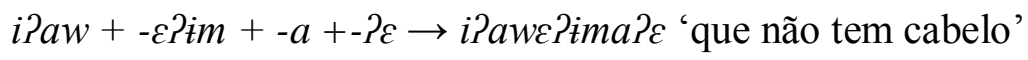

- -tus (coletivizador)

awaPiahu + -tus $\rightarrow$ awaPiahutus 'jovens'

awa?imon + -tus $\rightarrow$ awa?imontus 'velhos'

b) exocêntricos

Há vários sufixos derivacionais exocêntricos na língua Suruí que formam temas com classe diferente da classe da base, são eles:

- Nominalizadores de temas verbais 
- - ar 'nome de agente'

$$
\begin{aligned}
& i-+ \text { putat }+-a r+-a \rightarrow \text { iputatara 'aquele que quer, queredor' } \\
& i-+ \text { cnup }+-a r+-a \rightarrow \text { icnupara 'aquele que ouve' } \\
& i-+ \text { hest }+-a r+-a \rightarrow \text { ihestara 'lavador' }
\end{aligned}
$$

- $-a w \sim-h a w$ 'nome de circunstância'

$n \varepsilon \emptyset-k \varepsilon(r)+h a w+a \rightarrow n \varepsilon k \varepsilon h a w a$ 'lugar de deitar de você'

putik $+a w \rightarrow$ putikaw 'lugar para cagar'

tata $+p \varepsilon k w a+(a) w \rightarrow$ tatapckwaw 'instrumento para abanar o fogo'

so kitik $+a w+a \rightarrow$ so kitikawa 'ralador de castanha' ('paxiúba') ${ }^{51} \rightarrow$ 'liquidificador' (neologismo pós-contato)

$? \dot{t}+? u+a w+a \rightarrow ? \dot{i}$ ?uawa 'ingeridor de água' $\rightarrow$ 'copo' (neologismo pós-contato)

- - pir 'nome de paciente'

$$
\begin{aligned}
& \text { suka }+ \text { pir } \rightarrow \text { sukapir 'o morto' } \\
& \text { nups }+ \text { pir } \rightarrow \text { nupspir 'o que foi batido' }
\end{aligned}
$$

\section{- Nominalizadores de frases}

- $-w a$ ? $\varepsilon$ 'nominalizador de predicado'

033 u'yahawa'e urusuka misara
u-Piaha-wa?c
uru-suka misar-a
3-atravessar.o.rio-NMLZ.PRED 13-matar veado-ARG
'nós matamos o veado que atravessou o rio'

034 e rekatara'uwa'e
$\varepsilon-\varnothing \quad$ r-ckatar-a?u-wa? $\varepsilon$
esse-ARG $\mathrm{R}^{1}$-marido-DES-NMLZ.PRED
'que quer casar'

\footnotetext{
${ }^{51}$ A paxiúba era usada como ralador de castanha-do-pará pelos Suruí. Com a chegada do liquidificador, a função de ralar a castanha ficou a cargo deste novo aparelho, que recebeu, por sua vez, a mesma denominação, so kytykawa, do antigo instrumento de ralar.
} 
- -war 'nome de procedência'

Este nominalizador forma nomes de procedência construídos a partir de sintagmas posposicionais.

035 ti roga pupewara ripo mongaty oho
ti r-og-a
$\varnothing$-pupe-war-a
ripo mo Ø-kati o-ho

$1 \mathrm{R}^{1}$-casa-ARG $\mathrm{R}^{1}$-dentro-nmlz-ARG $\mathrm{DUB}$ onde $\mathrm{R}^{1}$-DIR 3-ir

'os que são de dentro de minha casa possivelmente foram na direção de algum lugar' (na minha casa não tem ninguém)

036 ka'apewara

kaPa-pe-war-a

mato-LP-NMLZ-ARG

'no mato ele foi'

- - wa?E 'nominalizador de circunstâncias'

037 Miho use'engar kwahawa'e

miho- $\varnothing \quad$ u-se?cya-kwaha(w)-wa? $\varepsilon$

miho-ARG 3-cantador-conhecer-NMLZ

'Miho é um bom cantador'

038 ti rirua iaturuewa'e

ti $\quad$-iru-a i-aturue-wa? $\varepsilon$

$1 \mathrm{R}^{1}$-camisa-ARG $\mathrm{R}^{2}$-curta-NMLZ

'minha camisa é a que está curta'

\subsubsection{Reduplicação}

a) Reduplicação monossilábica

kons ' torto' $\rightarrow$ kononss 'muito torto (manco)'

akus 'eu caio' $\rightarrow$ akukus 'eu caio várias vezes'

b) Reduplicação dissilábica

am๖m๖n 'eu enrolo' $\rightarrow$ am๖məməmən 'eu enrolo várias vezes' 
tapisar 'muitos (mais de quatro)' $\rightarrow$ tapisapisar 'muitos (em grande quantidade)'

apukas 'eu grito' $\rightarrow$ apukapukas 'eu grito ainda mais forte (ecoar)'

amupen 'eu quebro' $\rightarrow$ amupsmupen 'eu quebro em vários pedaços'

aru?ag 'eu viro' $\rightarrow$ aru?aru?ag 'eu viro várias vezes (girar)'

\subsubsection{Raízes}

Além dos afixos, a outra categoria analisada é a das raízes na língua Suruí.

\subsubsection{Classificação das raízes}

A classificação de raízes proposta por Rodrigues (2010, p. 16-17) leva em consideração a possibilidade ou não de combinação da raiz com afixos flexionais. Dessa forma, é possível identificar três classes de raízes:

- Classe I: combinável com o prefixo $i$ - do relacional $\mathrm{R}^{2}$.

- Subclasse Ia: raízes que não começam por /p/: combinam-se com o alomorfe $\emptyset$ - do $\mathrm{R}^{4}$.

- Subclasse $I b$ : raízes que começam por /p/: combinam-se com o alomorfe $m$ do $\mathrm{R}^{4}$.

- Classe II: combinável com os alomorfes $t$-, $h$ - e $\emptyset$ - do relacional $\mathrm{R}^{2}$ (admite somente raízes iniciadas por vogal).

- Subclasse IIa: raízes que se combinam com o $\emptyset$ - do relacional $\mathrm{R}^{2}$ e $t$ - do relacional $\mathrm{R}^{4}$.

- Subclasse IIb: raízes que se combinam com o $t$ - do relacional $\mathrm{R}^{2}$ e $t$ - do relacional $\mathrm{R}^{4}$.

- Subclasse IIc: raízes que se combinam com o $t$ - / $\varnothing$ - / $h$ - do relacional $\mathrm{R}^{2}$ e $\emptyset$ - / $t$ - / $h$ - do relacional $\mathrm{R}^{4}$.

- Subclasse IId: raízes que se combinam com o $\emptyset$ - do relacional $\mathrm{R}^{2}$ e $t$ - / $u$ - $\rightarrow$ $\emptyset$ - do relacional $\mathrm{R}^{4}$.

- Classe III: não combinável com prefixos relacionais (admite somente raízes nominais) 
QUADRO 13 - DISTRIBUIÇÃO DOS PREFIXOS DAS CATEGORIAS R ${ }^{1} \mathrm{~A} \mathrm{R}^{4}$, SEGUNDO AS CLASSES E SUBCLASSES DAS RAIIZES

\begin{tabular}{|c|c|c|c|c|c|c|}
\hline Classes & Subclasses & $\mathrm{R}^{1}$ & $\mathrm{R}^{2}$ & $\mathrm{R}^{3}$ & $\mathrm{R}^{4}$ & Exemplos \\
\hline \multirow[t]{2}{*}{$\mathrm{I}$} & $\mathrm{a}$ & $\varnothing-$ & $i-$ & $u-/ w-$ & $\varnothing-$ & $\begin{array}{l}\text { apin 'cabeça', 'aw 'cabelo', } k J \\
\text { 'roça', } k \varepsilon r \text { 'dormir', pit?a 'figado, } \\
\text { siw?a 'braço' }\end{array}$ \\
\hline & $\mathrm{b}$ & $\varnothing-$ & $i-$ & $u$ - & $p^{-}>m^{-}$ & $\begin{array}{l}\text { po 'mão', pir 'pele', purahas } \\
\text { 'dançar', pepuwìr 'sovaco' }\end{array}$ \\
\hline \multirow{6}{*}{ II } & a.i & $r-/ n-$ & $\varnothing-$ & $u-/ u s-$ & $t-$ & $\begin{array}{l}\text { aku 'quente', cha 'olho', } \varepsilon m \supset \\
\text { 'pênis', uwi 'sangue' }\end{array}$ \\
\hline & a.ii & $r-/ n-$ & $h-$ & $u-/ u s-$ & $t-$ & os 'dente' \\
\hline & a.ii & $r-/ n-$ & $h-$ & $u-/ u s-$ & $\varnothing-$ & ow 'folha' \\
\hline & $\mathrm{b}$ & $r-/ n-$ & $t-$ & $w$ - & $t-$ & $\begin{array}{l}u w \text { 'pai', a?tr 'filho (homem } \\
\text { falando)' }\end{array}$ \\
\hline & $\mathrm{c}$ & $r-/ n-$ & $h-$ & $w-$ & ?- & Pog 'casa' uPtw 'flecha' \\
\hline & d & $r-/ n-$ & $\varnothing$ & $w-$ & $t-\rightarrow \varnothing$ & $\begin{array}{l}\text { ckus 'cuia', puramsr 'peidar', } \\
\text { puti 'cagar' }\end{array}$ \\
\hline III & - & - & - & - & - & $\begin{array}{l}\text { amənisu 'algodão', arar 'arara', } \\
\text { sawar 'onça', kwarahy 'sol', } \\
\text { wasnom 'beija-flor' }\end{array}$ \\
\hline
\end{tabular}

Observação: No caso do relacional que marca um determinante genérico $\left(\mathrm{R}^{4}\right)$ do tema 1 b, existe, na língua Suruí, uma forma supletiva iniciada com $n$.

\subsubsection{Composição}

\subsection{Composição determinativa}

Nesse tipo de composição há duas raízes nominais em que a primeira determina a segunda:

aru nIII 'sapo (esp.)' + po nIb 'mão' $\rightarrow$ arups 'lit. mão do sapo $\rightarrow$ rastelo, garfo' inata nIII 'coco' + rí nIII 'água' $\rightarrow$ inatari 'água de coco' $k \supset m$ nIa 'seio' + iru nIII 'recipiente' $\rightarrow$ ksmiru nIa 'recipiente do seio $\rightarrow$ sutiã' sakare nIII 'jacaré' + siw nIa 'mandíbula' $\rightarrow$ sakarcasiw nIII 'mandíbula de jacaré $\rightarrow$ cangalha'

\subsection{Composição atributiva}

(a) há duas raízes nominais, sendo que a primeira é determinada pela segunda.

ipira nIII 'peixe' + os nIIb 'dente' $\rightarrow$ ipiros nIII 'peixe dentudo $\rightarrow$ piranha'

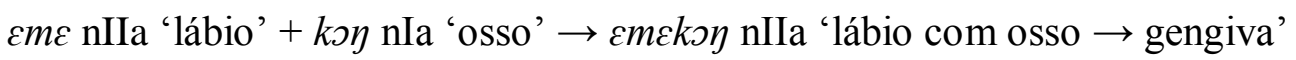


(b) há duas raízes, uma nominal e outra nominal descritiva; aqui a segunda determina a primeira.

misara nIII 'veado' + pirəy nIa 'vermelho' $\rightarrow$ misarapiron nIII 'veado-vermelho' sawara nIII 'onça' + pinima nIa 'pintado' $\rightarrow$ sawapinima nIII 'onça-pintada'

(c) há duas raízes, uma nominal e outra verbal intransitiva, em que a segunda determina a primeira.

ipira n.III 'peixe' + ku?om v.intr 'levantar' + -aw nmlz $\rightarrow$ ipiraku’omawa n.III 'peixe levantado'

ipira n.III 'peixe' + wewe v.intr 'voar' + - wa? $\mathrm{nmlz} \rightarrow$ ipirauwewewa? $\mathrm{n}$.III 'peixe voador'

(d) há duas raízes, uma verbal (transitiva ou intransitiva) e outra nominal descritiva, em que a segunda determina a primeira.

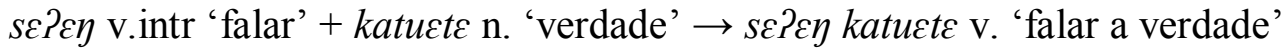

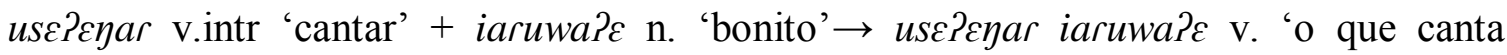
bonito'

\subsection{Composição objetiva}

(a) há duas raízes, uma nominal e outra verbal transitiva, em que a primeira determina a segunda.

puru nIII 'gente' + suka vt 'matar' $\rightarrow$ purusuka 'matar gente'

puru nIII 'gente' + mupise vt 'fazer bem' $\rightarrow$ purumupise 'fazer bem (pra) gente'

nami nIIa 'orelha' + kutuk vt 'furar' $\rightarrow$ namikutuk 'furar orelhar'

ti nIIa 'nariz' + nupen vt 'quebrar' $\rightarrow$ tinupen 'quebrar nariz'

\subsection{Composição mista}

Assim como no Tupinambá, na língua Suruí toda composição pode ser componente de uma nova composição.

misara nIII 'veado' + katiy nd 'fedorento' $\rightarrow$ misakatiy 'burro' + -rona sml 'parecido' $\rightarrow$ misakatiyrona nIII 'parecido com burro fedorento $\rightarrow$ vaca, boi' 


\subsubsection{Nomes e verbos}

Partindo da noção de classes de palavras da gramática tradicional, Payne (2006) afirma que, em muitas línguas, as duas principais classes são as dos nomes e dos verbos. Segundo esse autor,

For nouns and verbs, prototypes can be identified in terms of meaning. The class of NOUNS in any language includes words that refer to highly BOUNDED or INDIVIDUATED entities, e.g., 'tree,' 'mountain,' 'mausoleum,' etc. These are concepts that tend not to change very much over time, and which can be referred to repeatedly in discourse as the same thing. (PAYNE, 2006, p. $94)^{52}$

Ambas as categorias, a do nome e a do verbo, existem na língua Suruí e, conforme observado por Payne (2006), nesta língua elas correspondem às formas mais recorrentes. A seguir, trato de cada uma delas, separadamente.

\subsubsection{Nomes}

Os nomes em Suruí são flexionáveis e, com exceção dos nomes relacionais, se combinam com sufixos casuais. Além disso, eles não se combinam com os prefixos pessoais, nem com os sufixos modais.

Rodrigues (2010) identifica, em Tupinambá, subclasses dos nomes: substantivos, nomes descritivos, paradigmas do indicativo I de nomes descritivos como núcleos de predicados e demonstrativos. Essas mesmas subclasses também estão presentes na língua Suruí.

\subsection{Substantivos}

De acordo com Rodrigues (2010, p. 21), esta subclasse dos substantivos é aberta, não possui restrições quanto à sua distribuição, ou seja, ela pode ocorrer como "determinante ou determinado nas locuções, como sujeito ou objeto nas orações", como pode ser observado nos exemplos da língua Suruí, a seguir:

- Paradigmas de flexão casual: 1) -uw nIIb 'pai', 2) -iru nIa 'companheiro', 3) ka?a nIII 'mato', 4) kwar nIa 'buraco', 5) ipitun nIII 'noite', 6) Piwir nIa 'cintura'.

\footnotetext{
${ }^{52}$ Tradução: "Para nomes e verbos, protótipos podem ser identificados em termos de significado. A classe dos NOMES em qualquer língua inclui palavras que se referem a entidades DELIMITADAS ou INDIVIDUALIZADAS, por exemplo, 'árvore', 'montanha' 'mausoléu' etc. Estes são conceitos que não tendem a mudar muito ao longo do tempo, e que podem ser referidos repetidamente no discurso como a mesma coisa." (tradução nossa).
} 
TABELA 03 - PARADIGMAS DE FLEXÃO CASUAL

\begin{tabular}{|c|c|c|c|c|c|c|}
\hline Caso & & & & & & \\
\hline Argumentativo & $-u w-a$ & iru- $\varnothing$ & $k a ? a-\varnothing$ & $k w a r-a$ & ipitun-a & Piwir-a \\
\hline Translativo & $-u w-a m u$ & іги-пати & ka?a-ramu & $k w a r-a m u$ & & Piwirr-amu \\
\hline Loc. pontual & & & $k a ? a-p \varepsilon$ & & & \\
\hline Loc. difuso & & & & & ipitun-ати & Piwwir-imu \\
\hline
\end{tabular}

- Paradigmas de flexão determinativa com prefixos relacionais: 1) apin nIa 'cabeça', 2) ti nIa 'nariz', 3) po nIb 'mão', 4) cha nIIa 'olho', 5) uw nIIb 'pai', 6) upiw nIIc 'flecha', 7) pe nIId 'caminho', ekus nIId 'cuia'

\section{TABELA 04 - PARADIGMAS DE FLEXÃO DETERMINATIVA COM PREFIXOS RELACIONAIS}

\begin{tabular}{|c|c|c|c|c|c|c|c|c|}
\hline Prefixo & & & & & & & & \\
\hline $\mathrm{D}=\mathrm{S}$ & u-apina & $u-t i$ & o-po & $w-\varepsilon h a$ & $u s-u w a$ & u-upiwa & $w$-ape & $w$ - $\varepsilon k u s$ \\
\hline $\mathrm{D} \neq \mathrm{S}$ & $i$-apina & $i-t i$ & $i-p s$ & $h-\varepsilon h a$ & $t-u w a$ & $t$-upitwa & $h$-ape & $h$-ckus \\
\hline $\mathrm{D}=\mathrm{C}$ & $\emptyset$-apina & $\varnothing-t i$ & $\varnothing-p \supset$ & $r-\varepsilon h a$ & $r-u w a$ & $r-u p \dot{t} w a$ & $r-a p \varepsilon$ & r-ckus \\
\hline $\mathrm{D}=\mathrm{H}$ & $\varnothing$-apina & $\varnothing-t i$ & $m \nu$ & $t$-cha & $t-u w a$ & ?-upiwa & t-ape & $t$-ckus $\sim k u s$ \\
\hline
\end{tabular}

- Em Suruí, há três sufixos que expressam o estado de existência dos referentes de nomes, -Ø 'atual', -rom 'prospectivo' $e-k w \varepsilon r$ 'retrospectivo'.

TABELA 05 - FORMAS -rom E - $k w \varepsilon r$

\begin{tabular}{|c|c|c|}
\hline ATUAL & RETROSPECTIVO & PROSPECTIVO \\
\hline$\varnothing$-ko nIa 'roça' & kokwera 'ex-roça' & kərom 'que vai ser roça' \\
\hline$\emptyset$-Piwwi nIII 'árvore' & Piwipukwera 'tronco' & Piwipukurom 'que vai ser tronco' \\
\hline$\emptyset$-erckatara nIa 'marido' & crekatarera 'viúva' & Erekatararom 'futura viúva' \\
\hline 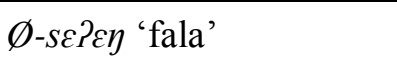 & se?zyawera 'recado' & 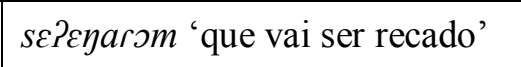 \\
\hline Ø-عmircks nIa 'esposa' & cmirckskwera 'ex-esposa' & عmirckorom 'futura esposa' \\
\hline
\end{tabular}

- Vocativos: Rodrigues (2010) identificou dois tipos de vocativo: vocativos substantivos e vocativos independentes. 
TABELA 06 - VOCATIVOS NA LÍNGUA SURUÍ

\begin{tabular}{|c|c|}
\hline \multirow{4}{*}{ vocativos substantivos } & timikoy nIa 'pelve': timiksy! 'Pelve!' \\
\hline & ikatu nIII 'macaxeira, o que é bom': ikatu! 'Macaxeira!' \\
\hline & iwikatu nIII 'terra boa': iwikatu! 'Terra boa!' \\
\hline & wasnom nIII 'beija-flor': wasnom! 'Beija-Flor!' \\
\hline \multirow{4}{*}{ vocativos independentes } & mitum voc 'pai!', 'papai!' (mulher falando) \\
\hline & na voc 'pai!', 'papai!' (homem falando) \\
\hline & mihì voc ‘mãe!', 'mamãe!' (mulher falando) \\
\hline & inc voc 'mãe!', ‘mamãe!' (homem falando) \\
\hline
\end{tabular}

\subsection{Nomes descritivos}

“Subclasse aberta, com restrições de distribuição; pode ocorrer como determinado nas locuções, como sujeito ou objeto nas orações verbais e como núcleo de predicados descritivos." (RODRIGUES, 2010, p. 24): uriw 'alegre, alegria', uriwa 'alegria', uriwramu 'na qualidade de estar alegre', indicativo II uriw 'está alegre'.

- Paradigmas do indicativo I de nomes descritivos como núcleos de predicados: esses paradigmas incluem formas com os prefixos relacionais $i$ $\infty \emptyset$ - $\infty$ - e $(r-\sim n-) \infty \varnothing$-: kuspia iapu?a 'a cuia é redonda', misara ipiroywa?ع 'o veado é vermelho'.

- Paradigmas do gerúndio de nomes descritivos como núcleos de predicados:

039 wakuwamu

w-akuw-amu

3-quente-GER

'ficando quente'

040 wurywamu

w-uriw-amu

3-alegre-GER

'ficando alegre'

\subsection{Numerais}

- usepese 'um'

- namukus 'dois' 


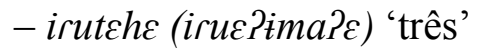

- irutchchik 'quatro'

- tapisar 'muitos'

- tapisapisar 'muitos (indefinido)'

\subsection{Demonstrativos}

"Subclasse fechada, com certas particularidades de distribuição morfológica e sintática." (RODRIGUES, 2010, p. 26).

QUADRO 14 - MATRIZ COMPONENCIAL DOS DEMONSTRATIVOS NA LÍNGUA SURUÍ

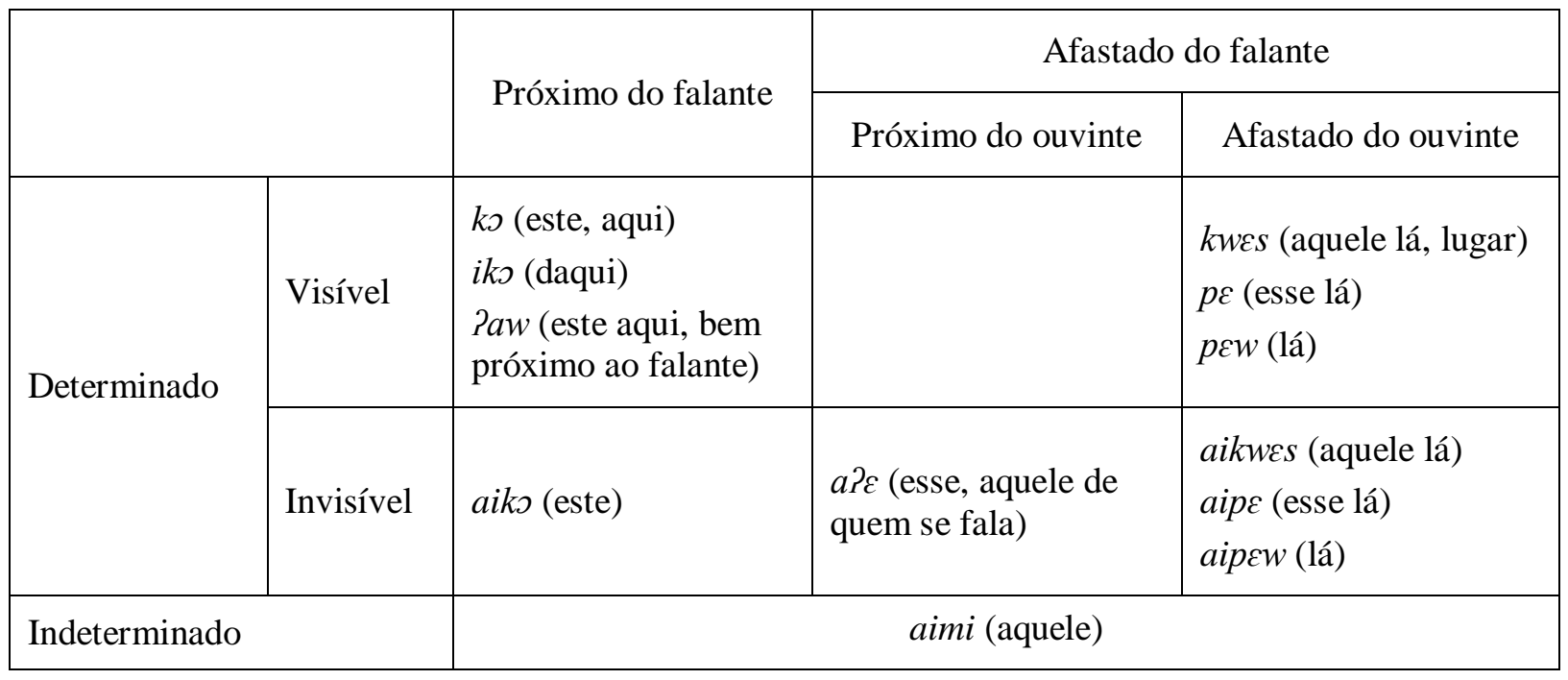

Rodrigues (2010) apresenta os demonstrativos da língua Tupinambá e evidencia se suas referências são visíveis ou invisíveis. Como ainda não aprofundei a descrição acerca dessa característica na língua Suruí, limito-me a apresentar os demonstrativos já repertoriados dessa língua, distribuídos por raízes:

$$
\begin{aligned}
& \text { - } k o \text { 'este, aqui' } \\
& \text { ko kati 'por aqui' } \\
& \text { aiks 'este' } \\
& \text { - Paw 'aqui' } \\
& \text { - kwes 'aquele' } \\
& \text { aikwes 'aquele' } \\
& \text { - pew 'lá' } \\
& \text { aipew 'lá' } \\
& \text { - aiks (esse) } \\
& \text { - } \quad a \text { ? } \varepsilon \text { 'esse, aquele' } \\
& \text { - } p \varepsilon \text { 'lá' } \\
& \text { aipe 'lá' } \\
& \text { - aimi 'aquele' }
\end{aligned}
$$




\subsection{Pronome}

"Subclasse fechada, com limitações de distribuição morfológica e sintática." (RODRIGUES, 2010, p. 29).

- Série I - "Só ocorre como enunciado independente, como sujeito de orações equativas e como sujeito enfático de outras orações."

- Série II - “Ocorre como determinante em sintagmas nominais.”

- Série III - "Só ocorre como sujeito de orações transitivas cujo objeto é ou inclui o falante."

QUADRO 15 - MATRIZ COMPONENCIAL DOS PRONOMES (SÉRIE I)

\begin{tabular}{|c|c|c|c|c|}
\hline & \multicolumn{3}{|c|}{ Oposição entre falante e ouvinte } \\
\hline & & \multicolumn{2}{|c|}{+} & \multirow{2}{*}{+} \\
\hline & & falante & ouvinte & \\
\hline \multirow{2}{*}{$3^{\mathrm{a}}$ pessoa focal } & - & $i s \varepsilon$ & $\varepsilon n \varepsilon$ & \multirow{2}{*}{ sene } \\
\hline & + & ure & pehe & \\
\hline
\end{tabular}

QUADRO 16 - AS TRÊS SÉRIES DE PRONOMES E O DATIVO

\begin{tabular}{|l|l|c|c|c|}
\hline \multicolumn{2}{|l|}{} & I & II & III \\
\hline falante $\pm 3^{\text {a }}$ pess. não focal & 'eu' & $i s \varepsilon(s \varepsilon)$ & $t i$ & - \\
\hline falante $\pm 3^{\text {a }}$ pess. focal & 'nós (excl.)' & $u r \varepsilon$ & $r \varepsilon$ & - \\
\hline ouvinte $\pm 3^{\text {a }}$ pess. não focal & 'você' & $\varepsilon n \varepsilon(n \varepsilon)$ & $n \varepsilon$ & $s \varepsilon p \varepsilon$ \\
\hline ouvinte $\pm 3^{\text {a }}$ pess. focal & 'vocês' & $p \varepsilon h \varepsilon$ & $p \varepsilon$ & $p \varepsilon n \varepsilon h \varepsilon$ \\
\hline falante \pm ouvinte $\pm 3^{\text {a }}$ pess. focal & 'nós (incl.)' & $s \varepsilon n \varepsilon$ & $s \varepsilon n \varepsilon$ & - \\
\hline
\end{tabular}

\subsection{Relacional (posposições)}

De acordo com Rodrigues (2010, p. 30), os relacionais (posposições) constituem uma "subclasse fechada, com limitações de distribuição morfológica e sintática", que "só se flexionam com os prefixos relacionais e só ocorrem formando complementos nas orações”. Essas formas ocorrem na língua Suruí, como pode ser observado nos exemplos a seguir:

$$
\begin{aligned}
& \text { - pe, upe rIa 'dativo' } \\
& \text { - pupe rIa 'dentro' }
\end{aligned}
$$


- upi rlb 'ao longo de, pelo'

- kati rla 'na direção de'

- cnunc rIIa 'na frente de'

\subsubsection{Verbo}

A classe dos verbos, de acordo com Rodrigues (2010, p. 31), forma uma "classe de palavras flexionadas que se combinam com os prefixos pessoais [...] e com os sufixos modais [...]". E, tal como no Tupinambá, a língua Suruí distingue, também, duas subclasses de verbos, a dos intransitivos e a dos transitivos, como pode ser verificado nos dados abaixo.

\subsection{Verbos intransitivos}

A subclasse dos verbos intransitivos na língua Suruí "se combina com os prefixos pessoais unidos diretamente ao tema” (RODRIGUES, 2010, p. 31): ho vi Ia 'ir', aha vi Ia 'eu vou'; son vila 'correr', assn 'eu corro/corri'.

Por outro lado, quando esses verbos são combinados com "o sufixo modal de gerúndio [...], os verbos intransitivos ocorrem com o alomorfe" $w \varepsilon$ - e $\varepsilon$ - dos prefixos $a$ - e $\varepsilon r \varepsilon$-: ho vi Ia 'ir', wchow 'indo eu', chðw 'indo você'.

\subsection{Verbos transitivos}

"Subclasse aberta, que se combina [...] com os prefixos pessoais e com os prefixos

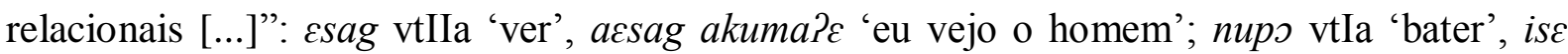
raks runups 'eu bati em vocês dois'; mukasim vtIIa 'perder', amukasim weiwirrapara 'eu perdi minha espingarda'.

\subsection{Modos do verbo}

- Indicativo I

- Paradigmas do Indicativo I de verbos intransitivos:

\begin{tabular}{|l|l|l|}
\hline 1 & aha & 'fui' \\
\hline 2 & $\varepsilon r \varepsilon h s$ & 'foste' \\
\hline 13 & uruhs & 'fomos' \\
\hline $12(3)$ & saha & 'fomos' \\
\hline 23 & peschs & 'fostes' \\
\hline 3 & shs & 'foi' \\
\hline
\end{tabular}




\begin{tabular}{|l|l|l|}
\hline 1 & apurahas & 'dancei' \\
\hline 2 & erepurahas & 'dançaste' \\
\hline 13 & urupurahas & 'dançamos' \\
\hline $12(3)$ & sapurahas & 'dançamos' \\
\hline 23 & pepurahas & 'dançastes' \\
\hline 3 & upurahas & 'dançou' \\
\hline
\end{tabular}

\begin{tabular}{|l|l|l|}
\hline 1 & akaru & 'comi' \\
\hline 2 & crekaru & 'comeste' \\
\hline 13 & urukaru & 'comemos' \\
\hline $12(3)$ & sakaru & 'comemos' \\
\hline 23 & pekaru & 'comestes' \\
\hline 3 & ukaru & 'comeu' \\
\hline
\end{tabular}

- O tema $k \varepsilon$ vi 'entrar':

\begin{tabular}{|l|l|l|}
\hline 1 & $a k \varepsilon$ & 'entrei' \\
\hline 2 & $\varepsilon r \varepsilon k \varepsilon$ & 'entraste' \\
\hline 13 & $u r u k \varepsilon$ & 'entramos' \\
\hline $12(3)$ & sacke & 'entramos' \\
\hline 23 & $p \varepsilon k \varepsilon$ & 'entrastes' \\
\hline 3 & $u k \varepsilon$ & 'entrou' \\
\hline
\end{tabular}

- O tema ur vi 'vir'

\begin{tabular}{|l|l|l|}
\hline 1 & asor & 'vim' \\
\hline 2 & cresor & 'vieste' \\
\hline 13 & ur & 'viemos' \\
\hline $12(3)$ & sasor & 'viemos' \\
\hline 23 & pesor & 'viestes' \\
\hline 3 & uasor & 'veio' \\
\hline
\end{tabular}

- Os temas pinu vi 'peidar' e puti vi 'cagar'.

\begin{tabular}{|l|l|l|}
\hline 1 & аріпи & 'peidei' \\
\hline 2 & вгеріпu & 'peidaste' \\
\hline 13 & игиріпu & 'peidamos' \\
\hline $12(3)$ & sаріпи & 'peidamos' \\
\hline 23 & реріпи & 'peidastes' \\
\hline 3 & иріпи & 'peidou' \\
\hline
\end{tabular}




\begin{tabular}{|l|l|l|}
\hline 1 & aputi & 'caguei' \\
\hline 2 & creputi & 'cagaste' \\
\hline 13 & uruputi & 'cagamos' \\
\hline $12(3)$ & saputi & 'cagamos' \\
\hline 23 & peputi & 'cagastes' \\
\hline 3 & uputi & 'cagou' \\
\hline
\end{tabular}

- Paradigmas do Indicativo I de verbos transitivos:

\begin{tabular}{|l|l|l|}
\hline 1 & asches & 'eu me lavei' \\
\hline 2 & eresches & 'tu te lavaste' \\
\hline 13 & urusches & 'nós nos lavamos' \\
\hline $12(3)$ & sacsches & 'nós nos lavamos' \\
\hline 23 & pesches & 'vós vos lavastes' \\
\hline 3 & usches & 'ele se lavou' \\
\hline
\end{tabular}

\begin{tabular}{|l|l|l|}
\hline 1 & akutuk... & 'eu furo...' \\
\hline 2 & crekutuk... & 'tu furas...' \\
\hline 13 & urukutuk... & 'nós furamos...' \\
\hline $12(3)$ & sakutuk... & 'nós furamos...' \\
\hline 23 & pekutuk... & 'vós furais...' \\
\hline 3 & ukutuk... & 'ele furou...' \\
\hline
\end{tabular}

\begin{tabular}{|c|c|c|}
\hline 1 & $a^{2} u \ldots$ & 'eu como...' \\
\hline 2 & 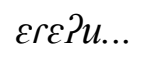 & 'tu comes...' \\
\hline 13 & игиРи... & 'nós comemos...' \\
\hline $12(3)$ & sa?u... & 'nós comemos...' \\
\hline 23 & $p \varepsilon ?$ p... & 'vós comeis...' \\
\hline 3 & $u P u \ldots$ & 'ele comeu...' \\
\hline
\end{tabular}

\begin{tabular}{|l|l|l|}
\hline 1 & $a ? \varepsilon_{\ldots} .$. & 'eu digo...' \\
\hline 2 & $\varepsilon r \varepsilon ? \varepsilon \ldots$ & 'tu dizes...' \\
\hline 13 & $u r u ? \varepsilon \ldots$ & 'nós dizemos...' \\
\hline $12(3)$ & $s a ? \varepsilon \ldots$ & 'nós dizemos...' \\
\hline 23 & $p \varepsilon ? \varepsilon_{\varepsilon} .$. & 'vós dizeis...' \\
\hline 3 & $u \uparrow \varepsilon \ldots$ & 'ele disse...' \\
\hline
\end{tabular}


- Imperativo

- Paradigmas de verbos intransitivos:

Na língua Suruí o imperativo é construído com o alomorfe $\varepsilon$ - do prefixo $\varepsilon r \varepsilon-: s \jmath n$ vi Ia 'correr', eson 'corra!', peson 'corram!'; karu vi Ia 'comer', ckaru 'coma!, pekaru 'comam!'; $k \varepsilon$ vi IIa 'entrar', $\varepsilon k \varepsilon$ 'entre!, $p \varepsilon k \varepsilon$ 'entrem!'.

- Paradigmas de verbos transitivos: $\varepsilon h \varepsilon s . .$. 'lava...', pehes... 'lavam...'; $\varepsilon ? u . .$.

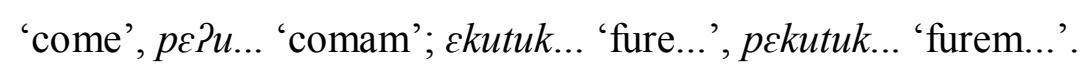

\section{- Gerúndio}

- Paradigmas do Gerúndio de verbos intransitivos:

\begin{tabular}{|l|l|l|}
\hline 1 & wepurahasta & 'eu dançando' \\
\hline 2 & epurahasta & 'tu dançando' \\
\hline 13 & urupurahasa & 'nós dançando' \\
\hline $12(3)$ & senepurahasa & 'nós dançando' \\
\hline 23 & pesepurahasa & 'vós dançando' \\
\hline 3 & usepurahasa & 'ele dançando' \\
\hline
\end{tabular}

\begin{tabular}{|l|l|l|}
\hline 1 & $w \varepsilon h \supset w$ & 'eu indo' \\
\hline 2 & $\varepsilon h \supset w$ & 'tu indo' \\
\hline 13 & uruhow & 'nós indo' \\
\hline $12(3)$ & scnchow & 'nós indo' \\
\hline 23 & peschow & 'vós indo' \\
\hline 3 & show & 'ele indo' \\
\hline
\end{tabular}

Na língua Suruí há verbos que, no Gerúndio, ocorrem com um alomorfe de we-, a forma wet-: wetuna, wetoga. (A mesma orientação é válida também para os exemplos intransitivos todos no gerúndio).

- Paradigmas do Gerúndio de verbos intransitivos:

\begin{tabular}{|l|l|l|}
\hline 1 & wetuna & 'eu sentando' / 'para eu sentar' \\
\hline 2 & ctuna & 'tu sentando' / 'para tu sentares' \\
\hline 13 & urutuna & 'nós sentando' / 'para nós sentarmos' \\
\hline $12(3)$ & senctuna & 'nós sentando' / 'para nós sentarmos' \\
\hline 23 & pesctuna & 'vós sentando' / 'para vós sentardes' \\
\hline 3 & stuna & 'ele sentando' / 'para eles sentarem' \\
\hline
\end{tabular}


- Indicativo II

Sobre o modo Indicativo II, Silva (2013, p. 423), citando trabalho de Rodrigues (1958), afirma que: "o modo Indicativo II era uma variedade de indicativo encontrada no Tupinambá, que ocorria quando uma circunstância antecedia um predicado com sujeito de primeira ou de terceira pessoa". Além disso, Cabral e Rodrigues (2003, p. 18) enfatizam que "Os verbos em frases independentes iniciadas por uma expressão adverbial, que as condiciona (inclusive os numerais, que nesta língua têm força adverbial) engatilha o modo Indicativo II", . Na língua Suruí eles podem ser demonstrados pelos seguintes paradigmas:

- Paradigmas de Indicativo II de verbos intransitivos: i-puraha-s 'dançar', $i$-ho-s 'ir', i-ata-s 'andar' (cf. subseção 6.1.1.2.1).

- Subjuntivo

- Paradigmas de Subjuntivo de verbos intransitivos: i-ho-ramu subj 'ir', $i$ purahas-amu subj 'dançar'.

- Paradigmas de Subjuntivo de verbos transitivos: i-suka-ramu subj 'matar...',

\subsection{Negação dos predicados com núcleo verbal e com núcleo nominal descritivo}

$\mathrm{Na}$ língua Suruí, a negação é marcada pelo sufixo -(u)wi, que ocorre simultaneamente com a partícula na 'não', e esta possui um alomorfe na forma $n$-, como pode ser observado nos exemplos abaixo:

ho viIa 'ir', aha vila 'eu vou', $n$ ahawi 'eu não vou'

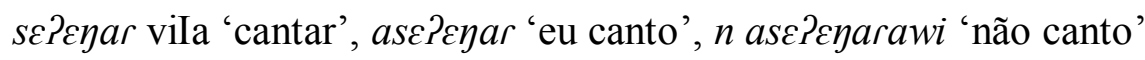

sahug vila 'banhar-se', asahug 'eu me banho', n asahuwi 'ele não banhou'

sckis 'morrer', usckis 'ele morreu', n usckisuwi 'ele não morreu'

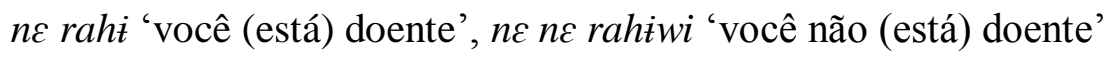

suka vtIa 'matar', asuka 'eu mato...', n asukawi 'eu não mato...'

$n$ erckatarawi 'não quer marido'

n uscpurakaruwi 'ninguém está caçando'

$n$ usctimiguwi 'ele não se sufocou'

Já a partícula puhi, posposta ao verbo, é responsável pelo imperativo negativo da língua Suruí.

suka vtIa 'matar', esuka 'mata ele!', esuka puhi 'não mata ele!' 
ho vila 'ir', chs 'vá', chs puhi 'não vá'

عmuku'om 'levante-o', cmuku'om puhi 'não o levante'

No gerúndio, no indicativo II e no subjuntivo a negação se exprime mediante o acréscimo do sufixo - $\varepsilon$ Pim 'proibitivo', formador de tema negativo, ao qual se acrescentam os sufixos modais respectivos:

tahi 'gente (está) doente', $t$-ahi-ع?im 'sem dor de gente (de muitos)'

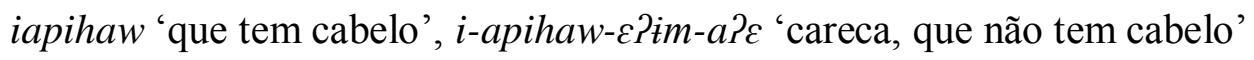

\subsection{ASPECTOS DA SINTAXE DA LÍNGUA SURUÍ}

Apresento, nesta seção, uma descrição de aspectos importantes da sintaxe (morfossintaxe) da língua Suruí, com foco especial nos processos por meio dos quais palavras se combinam para formarem agrupamentos maiores, chegando ao nível da frase e da oração. ${ }^{53}$

Este estudo se justifica no quadro desta tese, antes de tudo por permitir uma melhor compreensão da contextualização e funcionamento do léxico no discurso, o que é fundamental para a construção de uma obra lexicográfica, como o dicionário aqui proposto.

Além disso, o conhecimento gramatical da língua é do maior interesse dos professores Suruí, que almejam compreender melhor o funcionamento de sua própria língua.

Desta forma, apresento uma súmula de alguns dos principais aspectos da sintaxe da língua Suruí.

\subsubsection{Principais constituintes das orações da língua Suruí}

Para iniciar o estudo da sintaxe da língua Suruí, é necessário identificar, antes, quais são os principais constituintes oracionais nessa língua. Para isso, parto da observação dos seguintes enunciados:

\footnotetext{
${ }^{53}$ Segundo Matthews (1982, p. 1 apud VAN VALIN JR., 2004, p. 1), "The term 'syntax' is from the Ancient Greek sýntaxis, a verbal noun which literally means 'arrangement' or 'setting out together'. Traditionally, it refers to the branch of grammar dealing with the ways in which words, with or without appropriate inflections, are arranged to show connections of meaning within the sentence. Tradução: "O termo 'sintaxe' vem do grego antigo sýntaxis, uma forma verbo-nominal que significa literalmente 'arranjo' ou 'estabelecendo conjuntos'. Tradicionalmente, ele se refere ao ramo da gramática que trata das formas como as palavras, com ou sem flexões apropriadas, estão dispostas para mostrar conexões de sentido dentro da sentença." (tradução nossa).
} 
041 arara uwewe
arac-a u-wewe
arara-ARG 3-voar
'a arara voou'

042 arara uruwu ne iwewej
arar-a uruwu- $\varnothing \quad n \varepsilon \quad \mathrm{i}-\mathrm{w} \varepsilon \mathrm{w} \varepsilon-\mathrm{s}$
arara-ARG urubu-ARG ASSOC $\mathrm{R}^{2}$-voar-IND.II
'a arara e o urubu voaram'

043 ise apirog pahakurona
ise a-pirog pahakuron-a
1 1-descascar banana-ARG
'eu descasquei a banana'
044 aikwesa ti asuron
aikwes-a ti $\varnothing$-asuron
aquele-ARG 1 R'-abraçar
'ele me abraçou'

No primeiro exemplo, há um ser, identificado pelo nome arara 'arara', que pratica

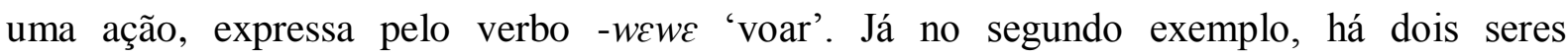
identificados pelos nomes arara 'arara' e uruwu 'urubu', conectados, que praticam a mesma

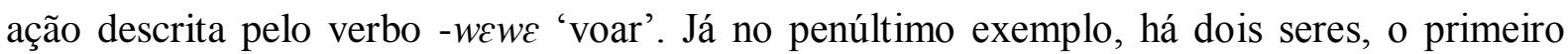
marcado pelo pronome ise 'eu', e o segundo identificado pelo nome pahakurona 'banana' e o primeiro agindo sobre o segundo, e o elemento responsável por essa ligação é o verbo -pirog 'descascar'.

Identifico três constituintes no último exemplo, um agente, aikwes- 'aquele', um objeto direto, o pronome $t i$ 'mim, me', e o verbo -asuron 'abraçar', flexionado pela primeira pessoa.

Os nomes arara 'arara', uruwu 'urubu' e os pronomes ise 'eu' e aikwes- 'aquele' desempenham o papel de Sujeito (S), enquanto o nome pahakurona 'banana' e o pronome $t i$ 'mim, me' têm a função de Objeto (O). Optamos neste estudo pelo uso de P(redicado) ao 
invés de verbo, de modo a incluir nessa categoria os nomes, que nessa língua, também predicam.

Dessa forma, uma vez definidos os componentes da oração, passo às possibilidades de ordenamento desses elementos.

\subsubsection{Ordenamentos de constituintes da oração na língua Suruí}

Uma vez identificados os principais componentes sintáticos na língua Suruí, é necessário estabelecer quais são as diferentes possibilidades de organização desses elementos. Vários autores já realizaram estudos linguísticos buscando determinar quais os padrões mais recorrentes seja em uma língua específica, seja em várias línguas a fim de verificar a existência ou não de padrões universais (cf., por exemplo, Comrie (1989, p. 81), Greenberg (1963, p. 58-85), Shopen (2007, p. 61-78) e Givón (2001, p. 233-284)).

Certamente, para estabelecer esse padrão, deve-se ter como base a definição de um tipo de oração que seja menos marcado e mais recorrente, que no caso do Suruí, como ocorre nas línguas da família Tupí-Guaraní, é a oração realizada no modo Indicativo I. ${ }^{54} \mathrm{Em}$ Suruí a ordem básica é SOP (SOV), como também ocorre nas línguas Mbyá (cf. DOOLEY, 2006, p. 14), Araweté (cf. SOLANO, 2009, p. 92), Kamayurá (cf. SEKI, 2000, p. 153-168) e Asuriní do Tocantins (cf. CABRAL et al., 2012, p.33). ${ }^{55}$

Apresento, a seguir, os padrões oracionais no Indicativo I da língua Suruí.

\subsubsection{SOP}

045 ene puta ti nupo pe

$$
\begin{aligned}
& \varepsilon \text { ne puta ti } \varnothing \text {-nupo p } \varepsilon \\
& 2 \quad \text { PROJ } 1 \text { R'-bater 2.ERG } \\
& \text { 'você vai bater em mim' }
\end{aligned}
$$

046 aikwesa ti asuron

$$
\begin{array}{lll}
\text { aikwes-a } & \text { ti } & \varnothing \text {-asuron } \\
\text { aquele-ARG } & 1 & R^{1} \text {-abraçar } \\
\text { 'ele me abraçou' }
\end{array}
$$

\footnotetext{
${ }^{54}$ Determinar se uma estrutura é mais recorrente que outra não é trabalho tão óbvio, pois, para isso, talvez seja necessário reunir um corpus considerável de enunciados, devidamente analisados para, só então, tentar fazer a estatística dessas ocorrências.

${ }^{55}$ Givón $(2012$, p. 352) faz uma observação acerca do padrão SOV: "Parece que a maioria das famílias de línguas por nós conhecidas exibe sintaxe SUJEITO-OBJETO-VERBO (SOV) e, tanto quanto pode ser dito, elas sempre foram SOV".
} 
Sem dúvida a estrutura SOP é bastante recorrente no corpus da língua Suruí analisado nesta pesquisa e é bem possível que constitua também a ordem básica dos constituintes da oração dessa língua. No entanto, outras ordens também são possíveis nesse mesmo tipo de oração, como apresento adiante.

\subsubsection{SPO}

Já o segundo tipo de organização dos componentes da oração na língua Suruí, SPO, também possui considerável número de ocorrências e essa estrutura se aproxima do padrão usado atualmente no Português.

047 ise awirog koa

$$
\begin{aligned}
& \text { ise a-wirog ko-a } \\
& 1 \text { 1-roçar roça-ARG } \\
& \text { 'eu rocei a roça' }
\end{aligned}
$$

048 ise ri'a asuka we'oma mosa

$$
\begin{array}{llll}
\text { is } \text { riPa a-suka } w \varepsilon-\text { Pom-a } & \text { mos-a } \\
1 \quad \text { DECL } & 1-\text { matar } & \text { 1CORR-em.pé-GER } & \text { cobra-ARG } \\
\text { 'eu estou matando a cobra' } &
\end{array}
$$

049 ure urusukaete ri'a ma'e ma'e

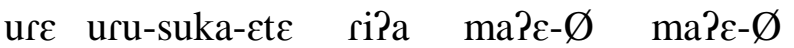

$$
\begin{aligned}
& 13 \text { 13-matar-GEN DECL caça-ARG caça-ARG } \\
& \text { 'nós matamos mesmo várias caças' }
\end{aligned}
$$

050 ise aihyra'u ri'a tiwa'a

$$
\begin{aligned}
& \text { ise a-ihir-a?u ri?a tiwa?a- } \varnothing \\
& 1 \quad 1 \text {-assar-DES DECL caititu-ARG } \\
& \text { 'eu quero assar o caititu' }
\end{aligned}
$$

\subsubsection{OSP}

Há uma terceira estrutura que também foi registrada no corpus da língua Suruí reunido nesta pesquisa, trata-se do padrão OSP, em que o Objeto aparece topicalizado. 
051 Ikatu ywykwara uhywykaj

Ikatu- $\varnothing \quad$ iwi- $\varnothing \quad$ Ø-kwar-a u-hiwikas

ikatu-ARG terra-ARG $\mathrm{R}^{1}$-buraco-ARG 3-cavar

'eu cavo buraco na terra'

052 ti se'eromamu puta ri'a ahywykaj

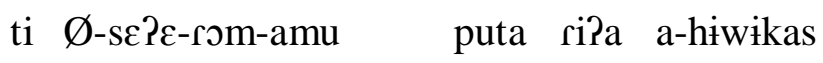

1 R'-poço-PROSP-TRANS PROJ DEC 1-cavar

'eu vou cavar meu poço'

\subsubsection{Outros padrões}

Com relação aos padrões PSO e POS, em que o verbo assume a posição inicial do enunciado, elas ainda não tiveram ocorrências no interior do corpus analisado nesta pesquisa. O que existem são orações com predicados nominais do tipo PS, como pode ser observado na subseção 6.2.2.6.

\subsubsection{Orações intransitivas simples}

A ordem básica em uma oração intransitiva no modo declarativo I na língua Suruí é SP, podendo vir acompanhada ou não de componentes complementos circunstanciais:

\section{3 uker ri'a}

waswer-a u-ker ri?a

wajwer-ARG 3-dormir DECL

'ele dormiu'

054 Tymykong uso'o remi
timikon- $\varnothing \quad$ u-so?っ $\quad$ remi
tymykong-ARG 3-chorar COL
'eles choraram'

\subsubsection{Estruturas com predicados nominais}

A língua Suruí possui estruturas frásticas sem verbo, mas que, segundo Cabral (2007), também predicam: “[...] os predicados, cujos núcleos se combinam com prefixos 
relacionais e/ou com pronomes dependentes ou nomes são de natureza nominal". Essa observação referente à língua Zo’é, é também válida para a língua Suruí, como pode ser observado nos exemplos abaixo.

055 'oga iaruaru

Pog-a i-araru

casa-ARG $\mathrm{R}^{2}$-bonita

'a casa é bonita'

056 ipyhysete ti 'ati'ywa

i-pihisete ti $\varnothing$-Pati?iw-a

$\mathrm{R}^{2}$-pesado 1 R'-ombro-ARG

'o meu ombro está pesado; existe peso no meu ombro'

As demais ordens dos constituintes oracionais/sentenciais são dependentes de vários fatores como hierarquia de pessoa (cf. MONSERRAT; SOARES, 1983; SOLANO, 2009, p. 349-351), topicalização/ focalização, modos verbais, entre outros, como veremos em seções subsequentes.

\subsubsection{Outros constituintes das orações da língua Suruí}

\subsubsection{Posposições}

Línguas da família Tupí-Guaraní, como o Asuriní, o Araweté e o Kamayurá, apresentam um conjunto de formas denominadas posposições, que integram uma classe fechada e que compartilham com os verbos e com os nomes a propriedade morfossintática de se combinarem com prefixos relacionais (cf. RODRIGUES, 2010; CABRAL, 1997; SOLANO, 2010). Da mesma maneira, a língua Suruí apresenta posposições, que ocorrem sempre precedidas por prefixo relacional, como pode ser observado nos exemplos a seguir.

057 ma'ea rupi pa'e eremukun ne remi'ua?

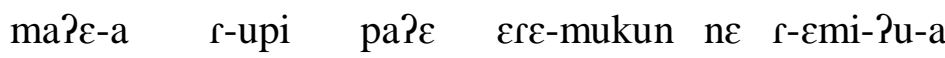
coisa-ARG $\mathrm{R}^{1}$-POSP PERG.I 2-engolir 2 R'-NMLZ-comer-ARG 'por onde você engole sua comida?' 
058 akojte ne rehe

$$
\begin{array}{lll}
\text { a-koste } & n \varepsilon & \mathrm{r}-\varepsilon \mathrm{h} \varepsilon \\
\text { 1-gostar } & 2 & \mathrm{R}^{1}-\mathrm{REL} \\
\text { eu gosto de você }
\end{array}
$$

\subsubsection{Advérbios}

Constituindo uma classe de palavras aberta, o rótulo advérbio é, segundo Shopen (2007, p. 19-20), aplicado a conjuntos muito diferentes de palavras na língua, tem como principal função modificar não apenas verbos e outros advérbios, mas também sentenças. Logo,

The notional range of adverbs varies with the type of constituent modified. Sentence modifiers, for example, commonly express the speaker's attitude toward the event being spoken of; modifiers of verbs or verb phrases commonly express time, place, direction, manner, etc.; and modifiers of adjectives and adverbs commonly express degree. (SHOPEN, 2007, p. 19$20) .{ }^{56}$

Apresento, em seguida, exemplos com sintagmas adverbiais em Suruí.

\subsection{Predicado + Sintagma adverbial}

\section{9 eho kokaty}

$$
\begin{array}{lll}
\varepsilon \text {-ho ko- } \varnothing & \emptyset \text {-kati } \\
3 \text {-ir } & \text { aqui-ARG } & \text { R-DIR } \\
\text { 'vá daqui' } &
\end{array}
$$

\subsection{Sintagma adverbial + Predicado}

060 aj'aw pa'e re-ko?
as?aw pa?e $\mathrm{s} \varepsilon$-ko
aqui PERG.I 2-estar.em.movimento
'você está morando aqui?'

\footnotetext{
56 Tradução: "A variedade de noções de advérbios varia conforme o tipo de constituinte modificado. Modificadores de frase, por exemplo, comumente expressam a atitude do falante em relação ao evento que está sendo falado; modificadores de verbos ou de frases verbais comumente expressam tempo, lugar, direção, forma, etc.; e modificadores de adjetivos e advérbios comumente expressam grau.” (tradução nossa).
} 
061 aiko re wehe ituri

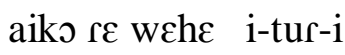

ontem $\quad \mathrm{R}^{\mathrm{1}}$-vir-IND.II

'ele chegou ontem'

062 aiko re wehe pa'e pesor?

aiko re wehe pa?e pe-sor

ontem PERG.I 23-chegar

'vocês chegaram ontem?'

063 aiko re wehe rako aesag akuma'e

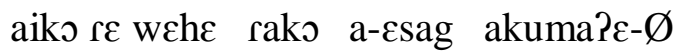

ontem AT.I 1-ver homem-ARG

'ontem eu vi este homem'

\subsection{Predicado + Sintagma adverbial (oração no imperativo)}

064 eho ko katy

$$
\begin{array}{lll}
\varepsilon \text {-ho } \quad \text { ko- } \varnothing & \emptyset \text {-kati } \\
\text { 3-ir } \quad \text { aqui-ARG } & \text { R}^{1} \text {-DIR } \\
\text { 'vá daqui' } &
\end{array}
$$

065 eraha arua katy

$\varepsilon$-raha arua $\varnothing$-kati

2-levar fora $\mathrm{R}^{1}$-DIR

'leve para fora'

066 eho ko katy

$$
\begin{array}{lll}
\varepsilon \text {-ho ko- } \varnothing & \emptyset \text {-kati } \\
3 \text {-ir } & \text { aqui-ARG } & \text { R}^{1} \text {-DIR } \\
\text { 'vá daqui' } &
\end{array}
$$




\subsubsection{Palavras modalizadoras}

A língua Suruí faz uso de palavras modalizadoras epistêmicas e aléticas. As

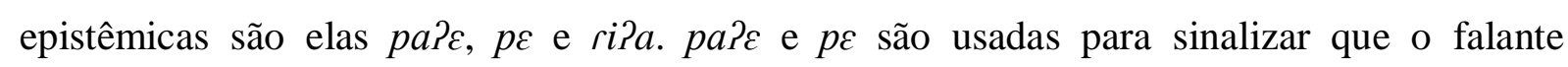
desconhece total ou parcialmente o valor de verdade do conteúdo informacional. Nesse sentido, correspondem a marcas de pergunta. Essas palavras têm um estatuto gramatical de partícula e seguem o constituinte perguntado. As partículas aléticas são raps e rips, que sinalizam na oração a possibilidade de veracidade do conteúdo informacional expresso pelo predicado.

As partículas $p a$ ? $\varepsilon$ e $p \varepsilon$ sinalizam que o falante desconhece totalmente o conteúdo informacional expresso pelo predicado.

067 mowi pa'e ipoiture sawara?

mo +wi pa?E ipo i-tur-i $\quad$ sawar-a
onde ABL PERG.I ? $\mathrm{R}^{2}$-vir-IND.II onça-ARG
'de onde a onça vem?'

068 mume pa'e he ereker ehow?
mu-me pa? $\quad \mathrm{h}-\varepsilon \quad \varepsilon r \varepsilon-\mathrm{k} \varepsilon \mathrm{s} \quad \varepsilon$-ho-w
onde-LOC PERG.I R Re-REL 2-dormir 2CORR-ir-GER
'onde você foi dormir?'

069 mongaty puta pa'e ihoj?

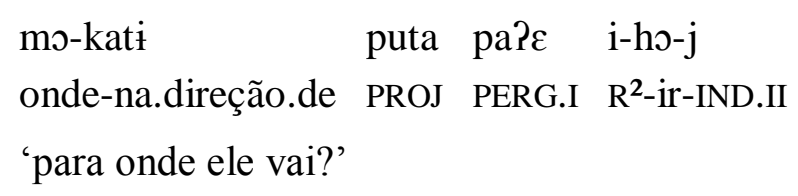

A palavra $r a$ ?ع sinaliza que o conteúdo da aserção não foi atestado pelo falante.

070 upurawyky pa'e ra'e?
u-purawiki pa?e ra?e
3-trabalhar PERG.I N.ATT
'eles trabalharam?' 
A palavra riPa sinaliza o conteúdo da aserção é conhecido apenas parcialmente ou inferido pelo falante.

071 pew ri'a awa iapukaj

pew ripa awa i-apukas

lá DECL alguém $\mathrm{R}^{2}$-gritar

'lá, alguém está gritando'

As palavras raps e rips, como explicado anteriormente, sinalizam a possibilidade de veracidade do conteúdo informacional expresso pelo predicado.

072 esemuhaku'i ke ma'esawara rapo ne u'u

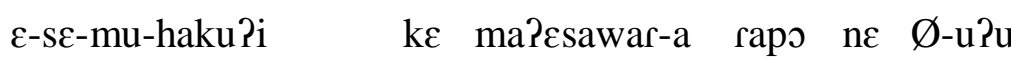

2-REFL-CAUS-cuidado DS cachorro-ARG POSS 2 R'-morder

'tenha cuidado! o cachorro pode te morder'

A palavra aspectual puta contribui com o significado de aspecto projetivo, mas pode contribuir com o significado de potencialidade, o que permite que seja descrita como uma partícula que combina noções de aspecto e de modalidade. Tem um estatuto gramatical de partícula e ocorre frequentemente precedendo o predicado.

1) Com valor aspectual

073 kuej wehe puta ihoj tasahua

kues wehe puta i-ho-j tasahu-a

amanhã PROJ R²-ir-IND.II porcão-ARG

'amanhã ele vai caçar porcão'

074 ko pupe puta aha

$\varnothing$-ko- $\varnothing \quad$ Ø-pupe puta a-ha

$\mathrm{R}^{4}$-roça-ARG $\mathrm{R}^{1}$-dentro PROJ 1 -ir

'pra roça eu vou'

2) Com valor modal

075 ise puta ri'a asoason

ise puta ripa a-so:a-son

1 PROJ DEC 1-correr:1-correr

'eu vou correr (bastante)' 


\subsubsection{Tipos de orações da língua Suruí}

A fim de classificar os diferentes tipos de orações da língua Suruí, as apresento a partir do modo verbal de cada uma delas, ${ }^{57}$ além de considerar, também, a sua natureza verbal ou nominal, como pode ser observado nas subseções a seguir.

\subsubsection{Orações no modo Indicativo I}

O primeiro grupo de orações é o que possui núcleo verbal no modo Indicativo I.

\subsection{Predicado com verbo intransitivo}

076 Ikatu uker ri'a upa
u-ker ri?a u-up-a
3-dormir DEC 3.deitar-GER
'ele está dormindo'

077 ise puta ri'a asoason
ise puta ri?a a-so:a-son
1 PROJ DEC 1-correr:1-correr
'eu vou correr (bastante)'

078 tekwawa utorog

$$
\begin{aligned}
& \mathrm{t} \text { - } \varepsilon \text { kwaw-a } \quad \text {-torog } \\
& \mathrm{R}^{4} \text {-rede-ARG } 3 \text {-rasgar } \\
& \text { 'a rede se rasgou' }
\end{aligned}
$$

079 ti 'aw kujpaw ri'a

$$
\begin{array}{llll}
\text { ti } & \varnothing \text {-Paw } \quad \text { u-kuj-paw } & \text { ri?a } \\
1 & \mathrm{R}^{1} \text {-cabelo } & \text { 3-cair-COMPL } & \text { DEC } \\
\text { 'meu cabelo caiu' }
\end{array}
$$

\footnotetext{
${ }^{57}$ Rodrigues (2010, p. 32) identifica, na língua Tupinambá, cinco diferentes modos verbais, são eles: Indicativo I, Imperativo, Gerúndio, Indicativo II e Subjuntivo. Com relação ao Indicativo II, ele afirma: "caracteriza-se morfologicamente pelo sufixo modal $-i \sim-w \sim-\emptyset$; em alguns dialetos, os nomes descritivos não se combinam com este sufixo, mas com o sufixo -amo -ramo. O Indicativo II combina-se, além disso, com os prefixos relacionais $-t \infty-\emptyset$ e $-r \infty-\emptyset$, os quais nos verbos intransitivos e nomes descritivos referem o sujeito, ao passo que nos verbos transitivos referem o objeto."
} 
080 ereker pa'e?

$\varepsilon г \varepsilon-\mathrm{k} \varepsilon \mathrm{\rho} \quad \mathrm{pa} \varepsilon$

2-dormir PERG.I

'você dormiu?'

081 upurawyky pa'e ra'e?

u-purawiki pa?e ra?e

3-trabalhar PERG.I N.ATT

'eles trabalharam?'

082 aiko re wehe pa'e pesor?

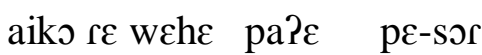

ontem PERG.I 23-chegar

'vocês chegaram ontem?'

\subsection{Predicado com verbo transitivo}

083 aiko na amonowi ne upe aiko n(a) a-mono-(u)wi ne $\varnothing$-up $\varepsilon$

esse NEG 1-dar-NEG $2 \quad \mathrm{R}^{1}$-DAT

'esse eu não dou para você'

084 Ikatua weraha 'ya sene upe

ikatu-a w- $\varepsilon$-aha $\quad$ ì-a sen $\varepsilon \quad \emptyset$-up $\varepsilon$ ikatu-ARG 3-C.COM-ir água-ARG 12(3) R-DAT

'Ikatu levou água para nós'

085 Muretama umur ti upe kysea

$\begin{array}{lllll}\text { murctam-a } & \mathrm{u} \text {-m-ur } & \text { ti } & \emptyset \text {-up } \varepsilon & \text { kise-a } \\ \text { muretam-ARG } & \text { 3-CAUS-vir } & 1 & \mathrm{R}^{1} \text {-DAT } & \text { faca-ARG }\end{array}$

'Muretama me deu a faca' 


\subsection{Predicado com verbo transitivo em perguntas}

086 ise pa aikysa'u mani'oga ne ko pupe?
ise pa a-ikis-a?u
mani?og-a
n $\varepsilon \quad \mathrm{k}$ - $\varnothing$
$\varnothing$-pupe
1 PERG.II 1-arrancar-poder mandioca-ARG 2 roça-ARG R ${ }^{1}$-dentro
'eu posso arrancar mandioca na tua roça?'

087 ene pa'e eremono ywyrapara ne ruwa pe?

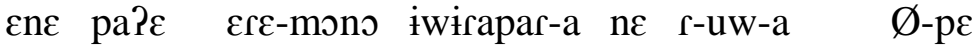
2 PERG.I 2-dar arco-ARG 2 R $\mathrm{R}^{1}$-pai-ARG $\mathrm{R}^{1}$-DAT
'você deu o arco para o teu pai?'

\subsubsection{Orações no modo Imperativo}

Os predicados das orações no modo Imperativo na língua Suruí, conforme descrito na subseção 6.1, não recebem marca modal específica, apenas marcas pessoais exclusivas desse modo.

\subsection{Predicado com verbo intransitivo}

088 eraha arua katy
$\varepsilon$-raha arua kati
2-levar fora na.direção
'leve para fora'

\subsection{Predicado com verbo transitivo}

089 emono ma'esawara tukaru
$\varepsilon$-mon
u-karu
3-dar cachorro-ARG PERMISS 3-comer
'dá comida pro cachorro'

\subsubsection{Orações no modo Gerúndio}

Dentre as orações dependentes, existe, segundo Cabral et al. (2012, p. 34), "aquelas no gerúndio, cujo sujeito é obrigatoriamente correferencial com o sujeito da frase 
principal”. Tal situação descrita para a língua Asuriní se aplica perfeitamente à língua Suruí, conforme pode ser observado a seguir.

090 wesowesona a'ar

we-so-weson-a a-Par

1CORR-correr-RED-GER 1-cair

'eu estava correndo e caí'

091 a'apyg wetuna

a-Papik wet-un-a

1-sentar 1CORR-sentar-GER

'eu estou sentado'

092 a'aw puta ri'a wehow

a-Paw puta ri?a we-ho-w

1-deitar PROJ já 1CORR-ir-GER

'estou indo me deitar'

093 aha isukaw

a-ha i-suka-w

1-ir $\quad \mathrm{R}^{2}$-matar-GER

'eu vou para matar'

094 tapi' ira puta oho ka'a wi uhema

tapi?ir-a puta o-ho ka?a +wi u-høm-a

anta-ARG PROJ 3-ir mato +ABL $\mathrm{R}^{3}$-sair-GER

'a anta vai saindo do mato'

095 awa ne pa'e ereho esepurakata

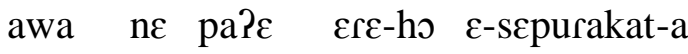

quem 2 PERG.I 2-ir 2-caça-GER

'com quem você foi caçar?' 
096 Muretama weraha kyse ipyhyka ti wi

murctam-a w- $\quad$ raha kise- $\varnothing \quad$ i-pihik-a ti +wi

muretam-ARG 3-levar faca-ARG $\mathrm{R}^{2}$-pegar-GER 1 +ABL

'Muretama levou a faca pegando-a de mim'

097 utasuse'ymamu nusahuwi

u-tasus- $\varepsilon$ Pim-amu n(a) u-sahu-iwi

3-sujo-PRIV-TRANSL NEG 3-banhar-NEG

‘ele não banhou porque não estava sujo'

098 upurahajta remi nupumaruwi ohow

u-purahas-ta remi n(a) u-pumar-uwi o-ho-w

3-dança-PROJ COL NEG 3-caçar-NEG 2CORR-ir-GER

'eles não estão indo caçar, vão dançar (porque é a festa do Sapurahaj)'

099 usahug ohow upisupisunawi

u-sahug o-ho-w u-pisu-pisun-a +wi

3-banhar 2CORR-ir-GER 3CORR-sujeira-RED-ARG +ABL

'ele banhou porque estava (muito) sujo'

100 aha puta ri'a isukaw tasahuamu

a-ha puta ripa i-suka-w tasahu-amu

1-ir PROJ DEC $\mathrm{R}^{2}$-matar-GER porcão-TRANSL

'eu vou para matar um porcão'

\subsubsection{Orações no modo Indicativo II}

No início da subseção 6.2.4, em nota de rodapé, apresentei as considerações feitas por Rodrigues (2010) acerca do modo Indicativo II. Agora, passo a exemplificá-lo com dados da língua Suruí.

\subsection{Predicado com verbo intransitivo}

101 erenune remi iataj

$\varepsilon-\varnothing \quad \Gamma-\varepsilon n u n \varepsilon \quad$ remi i-ata-s

esse-ARG $\mathrm{R}^{\mathrm{l}}$-frente $\mathrm{COL} \quad \mathrm{R}^{2}$-andar-IND.II

'na frente, eles andaram' 
102 'ywa rokowi i'ari

$$
\begin{aligned}
& \text { Piw-a r-oko- } \varnothing \quad+w i \quad \text { i-?ar-i } \\
& \text { árvore-ARG } \mathrm{R}^{1} \text {-galho-ARG +ABL } \mathrm{R}^{2} \text {-cair-IND.II } \\
& \text { 'ele caiu do galho da árvore' }
\end{aligned}
$$

103 ti rogawi ihoj usona
ti $\mathrm{r}-\mathrm{og}-\mathrm{a} \quad+$ wi $\mathrm{i}-\mathrm{ho}-\mathrm{j} \quad \mathrm{u}-\mathrm{s}$ - $-\mathrm{a}$
1 R'-casa-ARG +ABL $\mathrm{R}^{2}$-ir-IND.II 3CORR-correr-GER
'ele saiu correndo de casa'

104 aiko re wehe ituri

$$
\begin{array}{ll}
\text { aiko }\ulcorner\varepsilon \text { wehe } & \text { i-tur-i } \\
\text { ontem } & \mathrm{R}^{1} \text {-vir-IND.II }
\end{array}
$$

'ele chegou ontem'

105 arara uruwu ne'iwewej

$$
\begin{array}{llll}
\text { arar-a } & \text { uruwu- } \varnothing & n \varepsilon & \mathrm{i} \text {-wewe-j } \\
\text { arara-ARG } & \text { urubu-ARG } & \text { ASSOC } & \mathrm{R}^{2} \text {-voar-IND.II } \\
\text { 'a arara e o urubu voaram' }
\end{array}
$$

106 ka'ape ihoj

$$
\begin{aligned}
& \text { ka?a-pe } \quad \text { i-ho-j } \\
& \text { mato-LP } \quad \mathrm{R}^{2} \text {-ir-IND.II } \\
& \text { 'no mato ele foi' }
\end{aligned}
$$

\subsection{Predicado com verbo intransitivo em perguntas}

107 ma'e re pa'e ise'engi?

$$
\begin{aligned}
& \operatorname{ma} \varepsilon-\varnothing \quad \Gamma-\varepsilon \quad \text { pa? } \varepsilon \quad \mathrm{i}-\mathrm{s} \varepsilon ? \varepsilon \mathrm{r}-\mathrm{i} \\
& \text { sobre.o.que } \mathrm{R}^{1} \text {-REL PERG.I } \mathrm{R}^{2} \text {-falar-IND.II } \\
& \text { 'sobre o que eles falaram?' }
\end{aligned}
$$


108 mongaty puta pa'e ihoj?
mo-nati
puta pa?e i-ho-j
onde-na.direção.de PROJ PERG.I R²-ir-IND.II
'para onde ele vai?'

\subsection{Predicado com verbo transitivo}

109 kuej wehe puta ihoj tasahua
kues wehe puta i-ho-j tasahu-a
amanhã PROJ $R^{2}$-ir-IND.II porcão-ARG
'amanhã ele vai caçar porcão'

\subsection{Predicado com verbo transitivo em perguntas}

110 ma'eramu pa'e imonog 'ywa?
ma?e-ramu pa?e i-monog-i Piw-a
que-TRANSL PERG.I $\mathrm{R}^{2}$-cortar-IND.II árvore-ARG
'por que ele cortou a árvore?'

111 moron puta pe akuma'e ihoj osuna?

$$
\begin{aligned}
& \text { moron puta pe akuma?e- } \varnothing \text { i-ho-j o-sun-a } \\
& \text { quantos PROJ PERG.II homem-ARG } \mathrm{R}^{2} \text {-ir-IND.II 3-correr-GER } \\
& \text { 'quantos homens vão correr?' }
\end{aligned}
$$

\subsubsection{Orações no modo Subjuntivo}

No corpus linguístico da língua Suruí foi identificada, até o momento, somente uma ocorrência com verbo no modo Subjuntivo, que apresento, abaixo, a título de exemplo.

112 Suta'ar sene 'arimo ihoramu puhi ke pe isaukar puhi

$$
\begin{array}{lllll}
\text { sutaPar-a } & \text { sen } \varepsilon & \varnothing \text {-Par-imu } & \text { i-ho-ramu } \\
\text { suta'ar-ARG } & \text { 12(3) } & R^{1} \text {-superfície-LD } & R^{2} \text {-ir-SUBJ } \\
& & & & \\
\text { puhi } & \text { k } \varepsilon & \text { p } \varepsilon & \varepsilon \text {-sa-ukar-a } & \text { puhi } \\
\text { PROIB } & \text { DES } & 23 & \text { 2CORR-ver-C.PREP-GER } & \text { PROIB }
\end{array}
$$

'quando Suta'ar passar sobre nós, não amostrar (não apontar)' 
6.2.4.6. Orações com predicados nominais

Na língua Suruí há orações que não possuem núcleo verbal, mas sim nominal, conforme comentado na subseção 6.2.2.6, acima.

\subsection{Orações estativas/atributivas}

113 ti rirua iaturuewa'e

ti r-iru-a i-aturue-wa?

$1 \mathrm{R}^{1}$-camisa-ARG $\mathrm{R}^{2}$-curta-NMLZ

'minha camisa é curta'

114 kujpia iapu'a

kujpi-a i-apu?a

cuia-ARG $\mathrm{R}^{2}$-redondo

'a cuia é redonda'

115 tehahua iapu'a

tchahu-a i-apu?a

tucum-ARG $\mathrm{R}^{2}$-redondo

'o tucum é redondo'

116 ne memyra ahy pa'e?

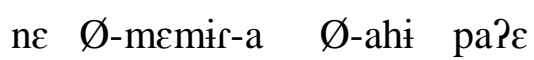

2 R ${ }^{1}$-filho-ARG $\mathrm{R}^{2}$-dor PERG.I

'teu filho dói (em ti, ao nascer)?'

117 ne atu'a pisun
ne $\varnothing$-atu?a- $\varnothing \quad \varnothing$-pisun- $\varnothing$
2 R'-nuca-ARG sujo-ARG
'tua nuca está suja'

118 ti rerekatara puta i'apihawe'ym

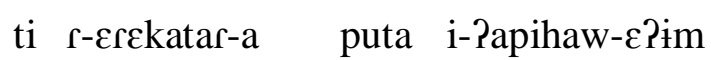

1 R'-marido-ARG PROJ 3-cabelo.da.cabeça-PRIV

'meu marido vai ficar sem cabelo' 


\subsection{Orações inclusivas}

119 ise purumu'etaramu

is $\varepsilon$ puru-mu? $\varepsilon$-tar-amu

1 gente-fazer.dizer-NMLZ-TRANSL

'eu sou professor'

120 ise purumupisetaramu

is $\varepsilon$ puru-mupise-tar-amu

1 gente-fazer.bem-NMLZ.AG-TRANSL

'eu sou pajé'

\subsubsection{Hierarquia de pessoa}

A hierarquia de pessoa em línguas Tupí foi descrita por Monserrat e Soares (1983) como hierarquia referencial (HR) "sintático-semântica que condiciona a escolha dos prefixos marcadores de pessoa nas orações transitivas" (MONSERRAT; SOARES, 1983, p. 165). Baseado nessa análise, busquei identificar na língua Suruí padrões correlatos.

- Objeto de $3^{\mathrm{a}}$ pessoa, o verbo recebe prefixo sujeito no Indicativo I:

121 Ikatua weraha 'ya sene upe

\begin{tabular}{|c|c|c|c|}
\hline ikatu-a & w-eraha & ?i-a & $\operatorname{sen} \varepsilon$ \\
\hline ikatu-ARG & 3-levar & água-ARG & $12(3)$ \\
\hline
\end{tabular}

122 uruasejmonog 'i'akorona uru-asesmonog Pi?akərən-a

13-cortar abóbora-ARG

'nós (excl.) partimos a abóbora'

123 pehe ta peraha pewuhyj myriti 'ywa

pehe ta pe-raha pe-wuhis miriti-?iw-a

23 PROJ 23-levar 23-carregar pau.de.buriti-ARG

'vocês carregaram a tora de buriti' 
124 ure uruapo 'oga

ure uru-apo P-og-a

13 13-fazer $\mathrm{R}^{4}$-casa-ARG

'nós fizemos estas casas'

125 awa pa'e utym mani'og?

awa pa?e u-tim mani?og- $\varnothing$

quem PERG.I 3-enterrar mandioca-ARG

'quem plantou a mandioca?'

- Com objeto de $1^{a}$ pessoa e o agente de segunda, o verbo não recebe prefixo de pessoa, mas sim prefixo relacional de contiguidade e o objeto é marcado por meio da série pessoal dependente. Além disso, o sujeito/agente é marcado por meio dos pronomes ergativos ipe- $\sim$ p $\varepsilon^{-}$' $2^{\mathrm{a}}$ pessoa ergativa':

126 ene puta ti nupo pe

$\varepsilon n \varepsilon$ puta ti $\varnothing$-nupo $\mathrm{p} \varepsilon$

2 PROJ 1 R'-bater 2.ERG

'você vai bater em mim'

- Quando o objeto é de $2^{\mathrm{a}}$ pessoa e o agente é de $1^{\mathrm{a}}$, o verbo recebe prefixo objeto uru-:

127 ise puta urunupo

ise puta uru-nups

1 PROJ 2-bater

'eu bato em você'

- Quando a $2^{\mathrm{a}}$ pessoa é plural, além de o verbo receber o prefixo de $2^{\mathrm{a}}$ pessoa objeto, é marcado pelo aspecto completivo -papaw:

128 ise puta urunupopapaw

ise puta uru-nupo-papaw

1 PROJ 2AC-bater-COMPL

'eu vou bater em vocês todos' 
- Há ainda a possibilidade de o pronome de $2^{\mathrm{a}}$ pessoa do plural ser expresso sintaticamente ( $p \varepsilon h \varepsilon)$, caso em que o verbo é marcado por prefixo de primeira pessoa singular $a-$, ou por prefixo de primeira exclusiva $u r u$ :

129 urunupo rako pehe

uru-nupo rako pehe

13-bater AT.I 23

'nós batemos em vocês'

- Quando o objeto é de $1^{\mathrm{a}}$ ou de $2^{\mathrm{a}}$ pessoa e o agente de $3^{\mathrm{a}}$ pessoa, o verbo recebe prefixos relacionais e o objeto é marcado por meio da série pronominal dependente:

130 aikwesa ti asuron

aikwes-a ti $\varnothing$-asuron

aquele-ARG 1 R'-abraçar

'ele me abraçou'

\subsubsection{Negação de Predicados}

A negação de predicados de orações na língua Suruí é feito por meio de um processo morfossintático, como pode ser observado nos exemplos a seguir.

\subsubsection{Negação de predicados com verbo intransitivo}

131 ma'eramu pa'e kuso nuse'engara uwi?

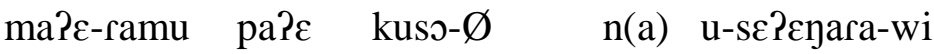

$$
\begin{aligned}
& \text { que-TRANSL PERG.I mulher-ARG NEG 3-cantar-NEG } \\
& \text { 'por que as mulheres não estão cantando?' }
\end{aligned}
$$

132 awa nusepurakaruwi ohow

$$
\begin{array}{llll}
\text { awa } & \mathrm{n}(\mathrm{a}) & \mathrm{u} \text {-scpurakar-uwi } & \text { o-ho-w } \\
\text { alguém } & \text { NEG } & \text { 3-caçar-NEG } & \text { 2CORR-ir-GER } \\
\text { 'ninguém está caçando' } &
\end{array}
$$


133 nukewi remi ’oga pupe
n(a) u-ke-wi
remi P-og-a
Ø-pupe
NEG 3-entrar-NEG COL $\mathrm{R}^{4}$-casa-ARG $\mathrm{R}^{1}$-dentro
'ninguém entrou na casa'

134 ise amupig mosa re, ise awisepe mosa nusekysuwi
ise a-mupig mos-a
$\mathrm{r}-\varepsilon \quad$ is $\varepsilon$ awisep $\varepsilon$ mos-a
n(a) u-sckis-uwi
1 1-atirar cobra-ARG $\mathrm{R}^{\mathrm{l}}$-REL 1 ADVERS cobra-ARG NEG 3-morrer-NEG 'eu atirei na cobra, mas ela ainda vive' (ela não morreu)

135 naesaguwi wehe weko asomera
na a-esag-uwi wehe
$\mathrm{W}-\varepsilon \mathrm{k} \mathrm{o}$
asomer-a
NEG 1-ver-NEG novamente
1CORR.estar.em.mov alma-ARG
'eu nunca vi alma' [asomera]

136 nusetimyguwi
n(a)-u-se-ti-mig-uwi
NEG-3-REFL-nariz-tapar-NEG
'ele não se sufocou'

6.2.6.2. Negação de predicados com verbo transitivo

137 aiko na amonowi ne upe

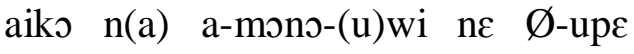
esse NEG 1-dar-NEG $2 \quad \mathrm{R}^{1}$-DAT
'esse eu não dou para você'

138 Muretama numuruwi kysea ti upe
muretam-a
n(a) u-m-ur-uwi
kise-a ti $\varnothing$-upe
muretam-ARG NEG 3-CAUS-entregar-NEG faca-ARG 1 R-DAT
'Muretama não me deu a faca' 
139 na esagwi wehe ipiraku'omawa
na esag-wi wehe ipira-kuPom-aw-a
NEG ver-NEG novamente peixe.levantado-NMLZ-ARG
'eu não vi mais peixe levantado'

6.2.6.3. Negação de predicados no Imperativo

140 esuka puhi

$\varepsilon$-suka puhi

2-matar NEG

'não mata ele'

141 emuku'om puhi

$\varepsilon$-muku?om puhi

2-levantar NEG

'não o levante'

6.2.6.4. Negação de predicados nominais

142 na se rahywi
na $\quad$ se $\mathrm{r}$-ahi-(u)wi
NEG 1 R $\mathrm{R}^{1}$-dor-NEG
'eu não tenho dor'

143 na se rakuwi
na se r-aku-(u)wi
NEG 1 R'-quente-NEG
'eu não tenho quentura'

144 na se mymyrwi

$$
\begin{aligned}
& \text { na se } \quad \varnothing \text {-mimir-(u)wi } \\
& \text { NEG } 1 \text { R'-filho-NEG } \\
& \text { 'eu não tenho filho' }
\end{aligned}
$$




\subsubsection{Perguntas}

Apesar de já ter inserido algumas orações com perguntas neste capítulo, busco agora sistematizá-las em função de sua natureza, ou seja, se são perguntas que esperam respostas do tipo sim/não ou se buscam obter alguma informação de conteúdo.

\subsubsection{Perguntas com resposta $\mathrm{sim} /$ não}

145 pehe puta pa'e re nupo pe?

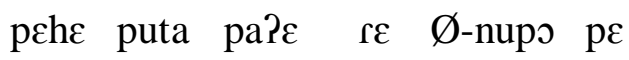

$$
\begin{aligned}
& 23 \text { PROJ PERG.I } 13 \text { R'-bater 2.ERG }
\end{aligned}
$$

'vocês vão bater em nós?'

146 ereker pa'e?

$\varepsilon r \varepsilon-\mathrm{k} \varepsilon \mathrm{pa} \boldsymbol{p} \varepsilon$

2-dormir PERG.I

'você dormiu?'

147 upurawyky pa'e ra'e?

u-purawiki pa?e ra?e

3-trabalhar PERG.I N.ATT

'eles trabalharam?'

148 Suara, eremunohonohog pa'e o'o?

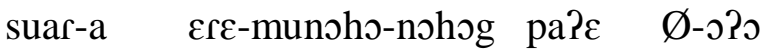
suar-ARG 2-cortar-RED PERG.I R2-carne
'Suara, você cortou (várias vezes) a carne?'

\subsubsection{Perguntas com resposta informativa}

149 awa pa'e uso'o?
awa pa?e u-so?s
quem PERG.I 3-chorar
'quem está chorando?' 
150 awa pa'e usekyj?

awa pa?e u-sckis

quem PERG.I 3-morrer (esticar-se)

'quem morreu?'

151 awa pa'e Wajwera uesag?

awa pare waswer-a u-esag

quem PERG.I wajwer-ARG 3-ver

'quem Wajwera viu?'

152 awa pa'e utym mani'og?

awa pa?c u-tim mani?og- $\varnothing$

quem PERG.I 3-enterrar mandioca-ARG

'quem plantou a mandioca?'

153 moron puta pe akuma'e ihoj osuna?

moron puta pe akuma?c- $\varnothing$ i-ho-j o-sun-a

quantos PROJ PERG.II homem-ARG $\mathrm{R}^{2}$-ir-IND.II 3-correr-GER

'quantos homens vão correr?'

154 moronime puta pe saha koa pupe?

moron-ime puta pe sa-ha ko-a pupe

quando-LP PROJ PERG.II 12(3)-ir roça-ARG dentro

'quando vamos para a roça?'

155 awa pe utyryg?

awa pe u-tirig

quem PERG.II 3-acordar

'quem acordou?'

\subsubsection{Processos de Coordenação e de Subordinação}

As orações da língua Suruí, dependendo de como se relacionam umas com as outras, evidenciam processos de parataxe (coordenação) e de hipotaxe (subordinação). Como não é escopo deste trabalho aprofundar a discussão sobre esse aspecto da sintaxe da língua 
Suruí, limito-me a exemplificá-los, separando-os em dois grandes grupos e identificando se a oração possui mesmo sujeito ou sujeitos diferentes.

\subsubsection{Orações coordenadas com mesmo sujeito}

156 aiko ra'e wehe rako awahem akaru akerako

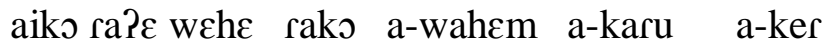

ontem AT.I 1-chegar 1-comer 1-dormir

'ontem eu cheguei, comi e dormi'

157 aiko ra'e wehe rako aata akaru ase'engar

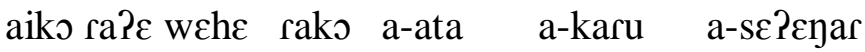

ontem AT.I 1-andar 1-comer 1-cantar

'ontem eu andei, comi e cantei'

158 ure kuso teseramu uruho ityma mani’og roko urutym

ure kusotese-ramu uru-ho i-tim-a maniog- $\varnothing$ r-oks uru-tim

13 mulher-TRANSL 13-ir $\mathrm{R}^{2}$-enterrar-GER mandioca-ARG $\mathrm{R}^{1}$-galho 13-enterrar 'nós fomos com as mulheres plantar mandioca'

159 ywyra re eseupir sawara wi ohow

iwis-a $\quad \mathrm{f}-\varepsilon \quad \mathrm{u}$-se-upir sawar-a +wi o-ho-w

pau-ARG $\mathrm{R}^{1}$-REL 3-REFL-subir onça-ARG ABL 3-ir-GER

'ele subiu na árvore afastando-se da onça indo'

\subsubsection{Orações coordenadas com sujeitos diferentes}

160 mosa u'u ma'e sawara usekyj puta

mos-a u-?u ma?csawar-a us- $\varepsilon$ kis puta

cobra-ARG 3-morder cachorro-ARG 3CORR-morrer PROJ

'a cobra mordeu o cachorro, ele vai morrer'

161 esemuhaku'i ke ma'esawara rapo ne u'u

$\varepsilon$-se-mu-haku?i $\quad \mathrm{k} \varepsilon$ ma?csawar-a rapo $\mathrm{n} \varepsilon$ Ø-u?u

2-REFL-CAUS-cuidado DS cachorro-ARG POSS 2 R'-morder

'tenha cuidado! o cachorro pode te morder' 
6.2.8.3. Orações subordinadas com mesmo sujeito

162 aiko ra'e wehe re pa'e erehow ka'ape eataw

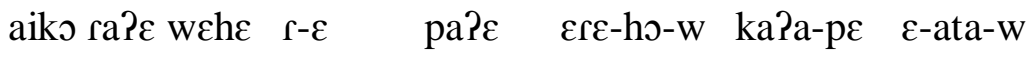
ontem $\quad{ }^{1}$-REL PERG.I 2-ir-GER mato-LP 2-andar-GER
'ontem você foi andar no mato'

\subsubsection{Orações subordinadas com sujeitos diferentes}

163 ma'esawara puta usekyj mosa u'uramu
ma?esawar-a puta us-ekis
mos-a $\quad \varnothing-u ' u-r a m u$
cachorro-ARG PROJ 3CORR-morrer cobra-ARG $\mathrm{R}^{1}$-morder-SUBJ
'o cachorro vai morrer, porque a cobra mordeu ele'

164 Suta'ar sene 'arimu ihoramu puhi ke pe esaukar puhi
suta?ar-a sene $\varnothing$-Par-imu i-ho-ramu
suta'ar-ARG $12(3) \quad \mathrm{R}^{1}$-superfície-LD $\mathrm{R}^{2}$-ir-SUBJ

$$
\begin{array}{lllll}
\text { puhi } & \mathrm{k} \varepsilon & \mathrm{p} \varepsilon & \varepsilon \text {-sa-ukar-a } & \text { puhi } \\
\text { PROIB } & \text { DES } & 23 & \text { 2CORR-ver-C.PREP-GER } & \text { PROIB }
\end{array}
$$

'quando Suta'ar passar sobre nós, não amostrar (não apontar)' 


\section{MATERIAIS LEXICOGRÁFICOS DAS LÍNGUAS INDÍGENAS BRASILEIRAS}

Neste capítulo, investigo o quadro geral dos materiais lexicográficos das línguas indígenas brasileiras, conjunto no qual se insere a língua Suruí do Tocantins, foco do trabalho desta tese. Essa investigação não apenas contribui para a apreensão dos diferentes projetos lexicográficos já desenvolvidos no Brasil e no exterior para essas línguas (conteúdos e estruturas), mas, permite, principalmente, obter parâmetros para avaliar a originalidade das propostas a serem apresentadas como modelos lexicográficos gerados com base no programa de documentação linguística em desenvolvimento.

\subsection{POR QUE PESQUISAR ESSES MATERIAIS}

Dicionários, vocabulários e glossários são materiais linguístico-culturais de circulação bastante comum nos mais diferentes contextos de uma sociedade letrada e seu uso perpassa pela necessidade específica de cada indivíduo seja em sua atividade profissional (como é o caso de professores de língua, jornalistas, revisores de texto, secretários, entre outros) seja em atividades pessoais de leitura (para fins de formação, por prazer, p.ex.), mas também esse uso pode decorrer de uma exigência social, como no caso de contextos escolares, em que se busca o desenvolvimento de competências linguísticas específicas de fala e escrita oriundas do uso sistemático desses materiais.

No caso do Brasil, os dicionários (e demais obras lexicográficas) há muito estão presentes no cotidiano das casas, das escolas e também, com frequência, nos locais de trabalho. Eles constituem peças obrigatórias nos acervos de bibliotecas e livrarias e garantem lucro certo a editoras, ${ }^{58}$ como demonstram as grandes somas de dinheiro usadas para compra de dicionários (para distribuição como material didático a professores e alunos das escolas públicas de todo o país) realizadas pelo governo brasileiro por meio do Ministério da Educação (MEC). ${ }^{59}$

Essa realidade de valorização dos dicionários pode ser atestada com o fato de que, já nas últimas décadas do século XX, o país dispunha de uma grande quantidade (e sempre crescente) não só de dicionários da língua oficial mais usada no país, o Português, tanto nas versões de dicionários da língua (monolíngues, bilíngues e multilíngues), dicionários enciclopédicos, dicionários técnicos (de especialidade, de tradução, p.ex.), impressos e

\footnotetext{
${ }^{58}$ Atualmente, os dicionários digitais, denominados eletrônicos, começam a ocupar um espaço considerável no mercado de aplicativos para aparelhos de comunicação (tablets, aparelhos de telefonia móvel, entre outros).

${ }^{59}$ A título de exemplo, o MEC (cf. BRASIL, 2011) adquiriu 10 milhões de exemplares de quatro tipos diferentes de dicionários para serem distribuídos nas mais de 130 mil escolas da rede pública de ensino de todo o Brasil.
} 
digitais, mas também dispunha de dicionários baseados nas línguas mais faladas no mundo, como o Inglês, o Espanhol, o Francês, o Chinês, entre outras.

Além disso, há de se considerar, nesse contexto, um terceiro grupo, o das línguas indígenas brasileiras.

Apesar da pouca visibilidade dos materiais lexicográficos já produzidos para essas línguas, não é possível negar o fato de que, mesmo com uma quantidade relativamente pequena de falantes (se considerada a totalidade da população no Brasil), elas compõem um importantíssimo elemento da diversidade linguística do país (cf. Capítulo 1). ${ }^{60}$

No entanto, apesar da existência de duas centenas de línguas indígenas no Brasil, difundiu-se com muita força a ideia de que todos os povos indígenas falam uma única língua, denominada, equivocadamente, "língua tupí-guaraní" ou "língua tupí”, e esse equívoco foi largamente reproduzido nas diversas publicações, sobretudo dicionários e vocabulários, que se multiplicaram, sobremaneira, a partir do século XX.

Assim, em várias bibliotecas (de escolas e universidades), por exemplo, é provável encontrar, ao lado dos dicionários das línguas mais difundidas e dos dicionários técnicos, algum material de língua indígena, ${ }^{61}$ e este, se existir, tem uma grande chance de estar relacionado à língua Tupinambá (sob as mais diversas denominações: "Tupí”, "Tupí Antigo", “Tupí-Guaraní”, “Língua Brasílica”) ou à língua Guaraní (geralmente o Guaraní Antigo). ${ }^{62}$

Nesse sentido, diante de um quadro em que a produção lexicográfica relacionada a línguas indígenas brasileiras parece se voltar, grosso modo, somente para uma língua morta, ${ }^{63}$ surgem as seguintes indagações: que tipos de materiais lexicográficos já foram produzidos

\footnotetext{
${ }^{60}$ Não busco, em nenhum momento, comparar ou avaliar o volume de produção de dicionários e vocabulários do Português com os materiais lexicográficos produzidos para as demais línguas faladas no Brasil (indígenas ou não), pois, se a demanda para os materiais em Português existe, e é crescente, é porque há um público também em expansão para consumir/usar esse tipo de material.

${ }^{61}$ A título de exemplo dessa afirmação, fiz uma consulta no motor de busca do sistema Pergamum disponível no site da Biblioteca Central da Universidade de Brasília (http://consulta.bce.unb.br/pergamum/biblioteca). No modo de pesquisa avançada, indiquei que queria apenas os resultados que contivessem referências com o termo "dicionário" no título. Ao final do processo, o sistema ofereceu 1915 resultados e, desse total, apenas 21 referências (ou seja, pouco mais de 1\% do total) estavam relacionadas a alguma língua indígena brasileira.

${ }^{62}$ Ao buscar referências de dicionários de línguas indígenas atualmente disponíveis para venda nas grandes livrarias brasileiras, não encontrei muitos títulos, e a maioria deles se refere a materiais das línguas Tupinambá e Guaraní, como vemos a seguir: Vocabulário tupi-guarani português, de Silveira Bueno; Dicionário TupiPortuguês; Vocabulário Tupi comparado e Dicionário Guarani-Português, de Luiz Caldas Tibiriçá; Dicionário Tupi Antigo, de Eduardo de Almeida Navarro; Dicionário Guarani-Português - Ne'e Ryru Avane'e, de Cecy Fernandes de Assis; e Vocabulário Português-Nheengatu, de E. Stradelli.

${ }^{63}$ O Tupinambá, língua plenamente falada no Brasil do século XVI, "foi deixando de ser falada, principalmente devido ao extermínio de sua população, num processo que se concluiu na primeira metade do século XVIII" (RODRIGUES, 1996, p. 57). O estudo dessa língua é, sem sombra de dúvida, extremamente necessário, assim como o de todas as demais línguas, vivas ou mortas.
} 
para as diversas línguas indígenas brasileiras? Quantas línguas (vivas ou mortas) possuem algum tipo de material lexicográfico? Quantos materiais já foram produzidos para essas línguas? Quando? Por quem? Quais as características estruturais dessas obras em termos de microestrutura e de macroestrutura?

Ademais, a pesquisa de informações sobre os tipos e as estruturas de materiais lexicográficos já existentes pode ser bastante útil para um projeto como o desenvolvido nesta tese, em que proponho, dentre outras coisas, a construção de um novo programa de computador para armazenamento de dados linguísticos com a possibilidade, em uma de suas perspectivas, de aproveitamento desses dados para a produção de diferentes dicionários e de outros tipos de materiais baseados em línguas indígenas brasileiras.

\subsection{UMA METODOLOGIA PARA A PESQUISA DE DICIONÁRIOS DE LÍNGUAS INDÍGENAS BRASILEIRAS}

A fim de responder às questões apresentadas acima, proponho um conjunto de ações para realizar a coleta e a análise das informações sobre os materiais lexicográficos das línguas indígenas brasileiras.

\subsubsection{Definição do objeto da pesquisa com delineamentos de uma metodologia}

Antes de partir em busca de dicionários e vocabulários das línguas indígenas, é fundamental que seja definido o que se quer de fato buscar, ou seja, o objeto da pesquisa, pois, caso contrário, pode-se não só empreender um esforço muito maior do que o necessário, mas também não aproveitar adequadamente os resultados do material pesquisado.

Apesar de, aparentemente, em um primeiro momento, não haver nenhuma dúvida sobre a natureza do objeto a ser buscado: dicionários, vocabulários e glossários de línguas indígenas brasileiras, um olhar mais atento sobre esse objeto revela que a apreensão correta dele não é tão fácil, nem tão óbvia, como se percebe ao questionar a sua própria natureza e os meios pelos quais se pode apreendê-la:

- Quais são, exatamente, os tipos de materiais a serem buscados?

- Quais são as línguas que compõem o conjunto "línguas indígenas brasileiras"?

- Qual a natureza desses materiais (física, virtual)?

- Onde buscar esses materiais? Durante quanto tempo?

- Que informações de cada material localizado serão registradas?

- Onde essas informações serão registradas? De que forma?

- Uma vez registradas as informações, como elas serão analisadas? 
A seguir, busco responder a cada uma destas questões na tentativa de construir de modo claro os delineamentos do objeto desta pesquisa bibliográfica.

\subsubsection{Em busca de uma tipologia das obras lexicográficas}

Produzidas no âmbito de diferentes sociedades, em épocas e lugares diversos, e com os mais variados recursos e finalidades, as obras lexicográficas assumiram uma pluralidade de formas e funções, e, por isso, classificá-las tornou-se, segundo Haensch (1982, p. 95), "una tarea muy ardua". ${ }^{64}$ Logo, a distinção, por exemplo, entre materiais do tipo “dicionário" dos do tipo "glossário" nem sempre é tão óbvia.

Essa perspectiva assume contornos de maior complexidade se for considerado que, no caso das línguas indígenas, significante parte delas não possui uma interface escrita, nem o povo que a fala domina a escrita, a própria produção de materiais escritos (tais como gramáticas e dicionários), muitas vezes, só faz sentido para as pessoas que não pertencem àquela comunidade indígena.

Por isso, partiremos de uma proposta básica apresentada por Correia (2009, p. 21 46) para classificar os tipos mais comuns de obras lexicográficas.

QUADRO 17 - DA TIPOLOGIA DE MATERIAIS LEXICOGRÁFICOS

\begin{tabular}{|c|c|c|}
\hline & Tipologia & Descrição \\
\hline 1. & Dicionário de língua & $\begin{array}{l}\text { "[...] livro que visa a descrição de unidades lexicais ou palavras. } \\
{[\ldots] \text { ele contém, necessariamente, }[\ldots] \text { informação gramatical..." }} \\
\text { (CORREIA, 2009, p. } 25 ; 130) \text {. }\end{array}$ \\
\hline 2. & Enciclopédia & $\begin{array}{l}\text { "[...] compêndio, geralmente de grandes dimensões, contendo } \\
\text { informações sobre os mais variados domínios do saber: visa } \\
\text { fornecer explicações sobre entidades da realidade extralinguística, } \\
\text { [...] por meio de textos informativos, acompanhados ou não de } \\
\text { ilustrações." (CORREIA, 2009, p. 27). }\end{array}$ \\
\hline 3. & Glossário & $\begin{array}{l}\text { "[...] lista restrita de vocábulos de um determinado domínio do } \\
\text { conhecimento, de um determinado registro linguístico [...], } \\
\text { específicos da obra de um autor. [...] Esta lista pode ser } \\
\text { apresentada, p.ex., como uma anexo a uma outra obra." } \\
\text { (CORREIA, 2009, p. 31). }\end{array}$ \\
\hline 4. & Tesauro & $\begin{array}{l}\text { "[...] dicionário em que se procura reproduzir um percurso } \\
\text { onomasiológico }[=\text { dicionário analógico]" (CORREIA, 2009, } \\
\text { p. 31). }\end{array}$ \\
\hline 5. & Vocabulário & $\begin{array}{l}\text { "[...] conjunto delimitado de vocábulos, isto é, de unidades } \\
\text { efectivamente atestadas num determinado registro de língua, num } \\
\text { conjunto de textos, na obra do autor, etc." (CORREIA, 2009, } \\
\text { p. 31). }\end{array}$ \\
\hline
\end{tabular}

${ }^{64}$ Tradução: "uma tarefa muito árdua” (tradução nossa). 
Contudo, ao lidar com materiais produzidos muitas vezes a partir de línguas tão diferentes entre si, que não dispunham ainda de nenhuma forma de escrita, com os mais diferentes status de uso, não esquecendo dos objetivos particulares e institucionais, do tempo e dos recursos disponíveis e também da competência técnico-científica de quem produziu ou colaborou com a produção da obra lexicográfica, todos esses fatores vão interferir diretamente na produção do material. Por isso, além dos materiais elencados acima, é possível que outros sejam acrescentados à lista ao decorrer da pesquisa.

Além disso, é possível que ocorram coincidências entre os termos descritos no Quadro 17 com os termos usados nas obras encontradas, sem que haja nenhuma relação entre o material (publicado ou manuscrito) e a proposta acima descrita.

Outra observação importante diz respeito às múltiplas possibilidades de especificação desses materiais, oriundas de particularidades relacionadas à quantidade de línguas envolvidas no trabalho (uma, duas ou várias), ao conteúdo selecionado (dados linguísticos, dados extralinguísticos ou ambos, mas também, nesses mesmos domínios, os diversos recortes possíveis), à forma de organização/ordenamento das informações (pela ordem alfabética, pelos sentidos, por imagens), à estruturação interna de cada informação (disposição, relacionamento e formatação dos elementos da microestrutura), à extensão da obra (dependendo da natureza da pesquisa e da destinação da obra, a quantidade de entradas pode variar bastante de obra para obra), ao público-alvo e finalidade a que elas atendem (para ensino de línguas, para tradução, para atendimento de diferentes áreas de especialidade, entre outros) e ao suporte em que foi construído (manuscrito, impresso, digital), pois essas características podem definir a nomenclatura, que, aliás, como em todo domínio científico, apresenta variação. Por isso, em um primeiro momento, devo fazer o registro da denominação original atribuída pelo(s) próprio(s) autor(es) de cada obra, sem nenhuma intervenção ou avaliação acerca da adequação entre título e conteúdo da obra. Somente com a descrição dos demais elementos (ver seções subsequentes) é que poderei propor alguma nomenclatura mais específica.

Em resumo, tomarei como ponto de partida na definição do objeto deste trabalho os cinco tipos de materiais identificados acima, com a perspectiva de acrescentar ou retirar tipos conforme for se desenvolvendo a pesquisa. 


\subsubsection{As línguas indígenas brasileiras}

Várias propostas de agrupamento ou de classificação das línguas indígenas brasileiras já foram realizadas ao longo dos últimos dois séculos, dentre as principais cito as de: Martius (1867), Steinen (1886), Ehrenreich (1892), Boas (1911), Rivet (1924), Schmidt (1926), Mason (1950) e ${ }^{65}$ Rodrigues (1970a; 1970b; 1986; 2013). Cada uma dessas propostas trouxe contribuições para o desenvolvimento de hipóteses sobre as relações genéticas das línguas indígenas do Brasil. Dentre as principais dificuldades de classificar essas línguas está a ausência de dados linguísticos suficientes e de estudos que descrevam com segurança cada uma das línguas. ${ }^{66}$ Embora vários agrupamentos genéticos sejam considerados consolidados, outros ainda não foram plenamente fundamentados.

Paralelamente a estas diversas propostas de classificação feitas por estudiosos, há o resultado do Censo Demográfico realizado pelo Instituto Brasileiro de Geografia e Estatística (IBGE) em 2010, que se baseou no registro das autoidentificações dos entrevistados, chegando, assim, a um total de 274 línguas. ${ }^{67}$

Vê-se, dessa forma, que estabelecer quais são as línguas indígenas brasileiras não é tarefa das mais fáceis.

Contudo, para delimitar um ponto de partida para este trabalho, optei pela classificação proposta por Rodrigues (2013), por ela representar a culminância de um trabalho científico de classificação, fundado no método histórico-comparativo e em mais de meio século de pesquisa. Trata-se de uma lista que apresenta 199 línguas classificadas, quando possível, em troncos (Macro-Jê e Tupi) e famílias linguísticas (41 ao total), além de registrar línguas isoladas e também uma língua mista.

Certamente, ao longo desta pesquisa, foram incorporados materiais relacionados a línguas mortas, cujos registros foram adicionados à lista original.

\subsubsection{Coordenadas necessárias para a pesquisa}

Uma vez definidos os tipos de materiais lexicográficos e a que línguas eles se referem, passo à questão da natureza desses materiais. Ao longo da história dos estudos

\footnotetext{
${ }^{65}$ Para informações mais detalhadas sobre algumas destas referências, consultar Rodrigues (2012, p. 279-283).

${ }^{66}$ Deve-se levar em consideração ainda o fato de vários povos indígenas, no passado e no presente, migrarem entre regiões de países diferentes, por eles não reconhecerem as fronteiras estabelecidas pelos não indígenas. Assim, um povo que antes vivia em terras brasileiras e que forneceu material linguístico para elaboração de dicionários e vocabulários, hoje, pode existir, por exemplo, somente no Peru, na Colômbia ou no Paraguai, e isso é uma questão que deve ser considerada na definição do conjunto "línguas indígenas brasileiras".

${ }^{67} \mathrm{O}$ próprio IBGE reconhece a necessidade de avaliar de modo mais aprofundado por linguistas e antropólogos esse total de línguas e de povos identificados no Censo 2010.
} 
linguísticos das línguas indígenas brasileiras, diversos pesquisadores, profissionais ou não, registraram dados dessas línguas, e a forma mais comum se deu com a utilização de registros escritos em papel. No entanto, com o advento de máquinas que armazenavam informações, como os computadores pessoais que se popularizaram na segunda metade do século $\mathrm{XX}$, os dados puderam passar a ser registrados de modo digital (ou virtual). Mais recentemente, esses dados digitais passaram a circular na "nuvem", ou seja, sob a forma de armazenamentos na internet, podendo ser compartilhados e acessados virtualmente de qualquer lugar do mundo.

Assim, ao se questionar sobre a natureza dos materiais a serem buscados, chega-se à questão seguinte: Onde buscar esses materiais? Pois, se a intenção for pesquisar materiais impressos ou conteúdos digitais, a forma e o local de pesquisa podem mudar drasticamente. Por exemplo, apesar de atualmente existirem muitas obras raras digitalizadas e disponíveis em site da internet, ainda há um grande acervo que só pode ser encontrado nas escuras e empoeiradas estantes de livros raros de uma biblioteca.

Logo, há de se estabelecer um percurso para desenvolvimento desta etapa da pesquisa, o que passo a fazer, a título de sugestão, a seguir. ${ }^{68}$

1) Acervo pessoal: buscar no conjunto de obras de sua biblioteca particular todos os materiais lexicográficos nele contidos. Por estarem mais próximos e à disposição, é recomendável identificá-los logo.

2) Computador pessoal: é possível que haja arquivos armazenados no disco rígido de seu computador, oriundos de pesquisas anteriores ou de materiais compartilhados, por exemplo, por terceiros.

3) Internet: sem dúvida, trata-se de um grande repositório de material lexicográfico digital. No entanto, ao mencionar pesquisa na internet, a primeira ideia que vem é a de utilizar um motor de busca; mas, há de se lembrar que existem muitos acervos não acessíveis mesmo aos mecanismos mais modernos de busca. Por isso, a pesquisa neste vasto mundo virtual também exige um esforço coordenado:

- Utilizar os motores de busca: a internet dispõe, hoje, de grande número de motores de busca, tais como Google (www.google.com), Yahoo (www.yahoo.com), Bing (www.bing.com), para citar apenas os maiores e mais conhecidos, cada um com sua base de dados, podendo oferecer resultados bem diferentes para um mesmo assunto pesquisado. No momento da busca, optar pela

\footnotetext{
${ }^{68}$ Para o desenvolvimento desta etapa da pesquisa, há de se ter à disposição a lista completa de línguas indígenas brasileiras mencionada no tópico anterior.
} 
combinação de palavras-chave como os tipos de materiais com as denominações de troncos e famílias linguísticas.

- Identificar as principais instituições de ensino e pesquisa, bibliotecas projetos relacionados a línguas indígenas no Brasil e no Exterior, pois eles, em geral, possuem sistemas de busca próprios, além de, com frequência, disponibilizarem materiais digitais para download. No Brasil, podemos citar além dos sites das bibliotecas da maioria das universidades públicas, instituições como a Fundação Nacional do Índio (FUNAI), que mantém a Biblioteca Curt Nimuendajú (http://biblioteca.funai.gov.br), a Biblioteca Nacional do Rio de Janeiro (www.bn.br), o projeto Europeana (www.europeana.eu), a Biblioteca Brasiliana Guita e José Mindlin (www.bbm.usp.br), o Portal Domínio Público (www.dominiopublico.gov.br), a Rede Pergamum de Bibliotecas Brasileiras (www.pergamum.pucpr.br/redepergamum/consultas/site_CRP/pesquisa.php), entre outros.

- Utilizar os fóruns de discussão especializados da área da linguística, da lexicografia e de áreas afins para obter informações com pessoas que compartilham de interesses comuns aos seus. Esses fóruns, mesmo que não ofereçam o material, podem ajudar a localizar o que se procura em alguma biblioteca.

- Bases especializadas de bibliografias, como as de Dietrich (2002), de Fabre (2005) e de Rodrigues e Cabral (2014).

- Por fim, há ainda a possibilidade de pesquisar nos catálogos eletrônicos de livrarias nacionais e estrangeiras. Uma vez localizada uma obra que se deseja, o próprio site pode oferecer um sistema de venda on-line.

4) Bibliotecas institucionais: essas bibliotecas de instituições públicas ou privadas, de escolas, universidades, órgãos governamentais, comunitárias ou particulares, mantêm acervos físicos que, com muita frequência, ainda não foram digitalizados. Por isso, a pesquisa in loco pode render uma quantidade razoável de material. Como nem todas as bibliotecas dispõem de serviços de reprografia, e nem todas as obras estão disponíveis para empréstimo (os dicionários são considerados obras de referência e, por isso, apenas de circulação interna), pode ser necessário fazer anotações no próprio local ou, se possível, utilizar uma câmera fotográfica para o registro do conteúdo pesquisado. Por fim, as próprias bibliotecas, em geral, mantêm 
uma rede de comutação de materiais bibliográficos que pode ser bastante útil se a obra desejada estiver no acervo de outro setor ou instituição. ${ }^{69}$

Apesar de não se constituir exatamente em um lugar, a pesquisa em catálogos especializados de referências bibliográficas (impressos ou digitais) pode ser bastante produtiva. Nesse sentido, já existe uma quantidade significativa dessas obras, dentre as quais podemos citar:

- Apontamentos para a Bibliografia da língua tupí-guaraní, de Plinio Ayrosa, obra publicada em São Paulo, pela Gráf. Cruzeiro do Sul, em 1943.

- Bibliografia crítica da etnologia brasileira, de Herbert Baldus, obra publicada em São Paulo, por Nicolau Indústria Gráfica, em 1954.

- Classification of South American Indian Languages, de Čestmir Loukotka, obra publicada em Los Angeles, EUA, pela Latin American Center, University of California, em 1968.

- Catálogo do material linguístico da Comissão Rondon, de Ruth Wallace de Garcia Paula, obra publicada no Rio de Janeiro, pelo Museu do Índio, em 1982.

- Catálogo de las lenguas de América del Sur, de Antonio Tovar e Consuelo Larrucea de Tovar, obra publicada em Madrid, Espanha, pela editora Gredos, em 1984.

- The present state of the study of Brazilian Indian languages, de Aryon D. Rodrigues, obra publicada em Austin, EUA, pela University of Texas Press, em 1985.

- Linguas brasileiras: para o conhecimento das línguas indígenas, de Aryon D. Rodrigues, obra publicada em São Paulo, pela Editora Loyola, em 1986.

- Bibliografia das línguas Macro-Jê, de Wilmar da R. D’Angelis, Carla Maria Cunha e Aryon D. Rodrigues, obra publicada em Campinas, SP, pela Universidade Estadual de Campinas, em 2002.

- Diccionario etnolingüístico y guía bibliográfica de los pueblos indígenas sudamericanos, de Alain Fabre, obra disponível na internet desde 2005 http://www.ling.fi/DICCIONARIO.htm

\footnotetext{
${ }^{69}$ No Brasil, o principal serviço de compartilhamento de documentos entre bibliotecas é o Programa de Comutação Bibliográfica (Comut), mantido pela Fundação Coordenação de Aperfeiçoamento de Pessoal de Nível Superior (Capes) e pela Secretaria de Educação Superior (Sesu), do Ministério da Educação e junto ao Instituto Brasileiro de Informação em Ciência e Tecnologia (Ibict) e à Financiadora de Estudos e Projetos (Finep), do Ministério da Ciência e Tecnologia (MCT). O Comut pode ser utilizado a partir do site http://comut.ibict.br/comut.
} 
- Lingüística Amerindia Sudamericana: Las lenguas indígenas de América, de Wolf Dietrich, publicado e atualizado na internet - http://www.uni-muenster.de/ Romanistik/Organisation/Lehrende/Dietrich/LingAmerSud/index.html

Uma vez estabelecida a variedade de locais para pesquisa de materiais lexicográficos, passo à questão acerca da duração desse trabalho. Como são buscados materiais produzidos nas mais diferentes línguas, ao longo de, pelo menos, 400 anos, e armazenados nos mais diferentes lugares do Brasil e do exterior, a pesquisa se prolongará para além do término da presente tese.

\subsubsection{Identificando as informações dos materiais lexicográficos}

Ao atingir esta etapa da pesquisa em que os materiais já haviam começado a ser localizados, era fundamental responder adequadamente à questão de que informações seriam consideradas ou extraídas de cada obra.

Esse registro deveria ser feito da maneira mais sistemática possível, pois tantas poderiam ser as referências, que ficaria inviável primeiro reunir tudo para só então iniciar o registro delas.

Logo, se o objeto inicial era determinar que obras lexicográficas já haviam sido produzidas para todas as línguas indígenas brasileiras, e quais seriam as principais características dessas obras, a proposta era a de que as informações a serem coletadas fossem:

a) Identificação da língua, com a respectiva família e tronco, se houvesse. Para cada língua, uma entrada específica, ou seja, se o material contivesse mais de uma língua, seriam feitas entradas específicas para cada uma delas.

b) Identificação da tipologia atribuída no próprio material. Se o material for identificado pelo título "Dicionário de Tupi-Moderno" (BOUDIN, 1966), o tipo de material será dicionário, a não ser que, no interior dessa obra houvesse um vocabulário, situação bastante comum, aliás; nesse caso, a classificação deve considerar a identificação atribuída a cada parte do material. ${ }^{70}$

c) Elaboração da referência bibliográfica completa, apresentada conforme uma norma pré-estabelecida (ABNT, Chicago, Vancouver, entre outras). A referência completa de um material bibliográfico é composta, grosso modo, dos dados de autoria, do título, da edição, dos tradutores, do local e data de publicação, da quantidade de

\footnotetext{
${ }^{70}$ Como mencionei anteriormente, não cabe neste momento avaliar se o autor da obra empregou adequadamente a classificação lexicográfica da obra, pois o que conta é a "autoidentificação" presente na mesma.
} 
páginas e da coleção ou série. Além disso, nessa referência é possível especificar cada parte que contenha algum material lexicográfico. Ou seja, se numa determinada obra lexicográfica, um dicionário bilíngue possuir duas partes, uma com dados no sentido da língua 1 (L1) para a língua 2 (L2) e seu reverso, isto é, da L2 para a L1, é importante que sejam feitas duas entradas, uma para cada parte do dicionário. A cada um desses conjuntos de dados contidos na obra, denominei Unidade de Base Lexicográfica (UBL). Logo, o dicionário bilíngue acima, usado como exemplo, possui duas UBL's, que devem ser registradas separadamente, pois, só assim, podem ser analisados em suas macro e microestruturas específicas. Desse modo, reafirmo a necessidade de informar, no interior da referência bibliográfica, os dados de cada parte destacada, inclusive citando o intervalo de páginas correspondentes a cada uma delas.

d) Identificação das línguas envolvidas no material referenciado. A informação das línguas utilizadas no material lexicográfico pode ser útil para descobrir qual a frequência de uso de determinada língua, por exemplo, na entrada do verbete. Essas línguas podem vir citadas no interior da própria referência bibliográfica, logo após a citação da parte específica destacada na obra, mas também podem vir destacadas em campo próprio. Neste último caso, para registrar essa informação também de modo destacado, utilizei um sistema de siglas para identificar as línguas e uma seta horizontal apontando para a direita a fim de indicar a direção. ${ }^{71}$ Por exemplo, um material que tivesse o lema com uma palavra de uma língua indígena (Id) e com a tradução para o Português $(\mathrm{Pt})$, seria assim representado: Id $\rightarrow$ Pt. $^{72}$ Se a relação fosse entre mais de duas línguas, indicava todas as línguas na segunda parte do esquema, separando-as por barras diagonais ( / ). Ex.: Id $\rightarrow \mathrm{Pt} / \mathrm{In} / \mathrm{Lt}^{73}$

e) Quantificação das entradas (ou verbetes). Esta questão é bastante delicada, pois não há uma única forma de apresentar as entradas de um dicionário. Por exemplo, há obras que apresentam regularmente a distribuição dos verbetes, com apenas um lema para cada entrada; outros, porém, apresentam entradas e subentradas; e outros

\footnotetext{
${ }^{71} \mathrm{O}$ uso da seta nessa relação não define estritamente uma operação lógica do tipo condicional, mas sim que o elemento que está à esquerda da seta é o que serve como base na entrada e que os demais, à direita, ficam, de certa maneira, subordinados a ele.

${ }^{72}$ Abreviaturas de línguas usadas neste trabalho: Al: Alemão; Es: Espanhol; Fr: Francês; Id: Línguas Indígenas; In: Inglês; It: Italiano; Jp: Japonês; Lt: Latim; Pt: Português; Rs: Russo. Comentário: Como essas línguas são as usadas para traduzir as línguas indígenas brasileiras e são reduzidas em número, resolvi especificar cada uma delas, ao passo que para as línguas indígenas utilizei uma forma única (Id).

${ }^{73}$ Se uma das línguas citadas à direita tivesse uso esporádico, como ocorre no caso do uso da língua latina para designar termos científicos, a indicação dessa língua deveria vir entre parênteses. Ex.: Id $\rightarrow$ Pt/In(/Lt).
} 
apresentam ainda uma palavra como entrada de várias outras entradas. Há de se destacar ainda a grande diferença que existe no estabelecimento de um lema para o verbete e também do conteúdo associado a ele. Ou seja, o que para um dicionário pode constituir um verbete independente, para outro pode ser apenas um tópico dentro de outro verbete. Acredito que a solução mais prática é contar todos os itens de entrada, independentemente das suas qualidades e conteúdos; e, com relação às subentradas, estas devem ser avaliadas se se tratam de novos itens lexicais (apenas com um recuo na margem) associados semanticamente ou não ao item da entrada principal (neste caso, elas devem ser contadas como itens de entrada) ou se contêm apenas dados que exemplificam o conteúdo da entrada (neste caso, não devem ser contados com itens novos). Isto só o aprofundamento da pesquisa pode revelar. Em todo caso, essa contagem deve ter um caráter apenas indicativo para uso no estabelecimento de uma classificação dos materiais. ${ }^{74}$

f) Classificação a partir da quantidade de entradas. A contagem indicada no tópico anterior, mais do que revelar a quantidade de entradas de um dicionário, deve servir para estabelecer uma classificação dos materiais com base na quantidade de entradas. Essa classificação, por sua vez, contribui não só para dar alguma ideia da dimensão de uma obra em relação a outra, mas também ajudar a definir se há alguma relação entre os tipos de materiais e a quantidade de entradas (por exemplo, dicionários possuem mais entradas que vocabulários?). ${ }^{75}$ Por isso, ao término desta lista, apresento uma proposta detalhada de classificação baseada na quantidade de entradas dos materiais.

g) Identificação do ordenamento da macroestrutura. Todo material lexicográfico apresenta, a princípio, algum tipo de ordenamento que condiciona sua macroestrutura. Segundo Haensch (1982, p. 165), “El diccionario semasiológico

\footnotetext{
74 Não resta dúvida acerca da dificuldade de se estabelecer uma classificação dos dicionários baseada na quantidade de entradas, uma vez que, com arranjos simples, é possível multiplicar exponencialmente a quantidade de verbetes de um dado material. Por exemplo, se, para cada caso de polissemia, que poderia ser tratado dentro de um mesmo verbete, forem geradas novas entradas, ou seja, a polissemia passa a homonímia, originando, assim, vários novos verbetes.

75 Já foram feitos vários estudos acerca da quantidade das obras lexicográficas, assim como também foram propostas classificações baseadas nessas quantidades. No Brasil, uma das classificações mais mencionadas em trabalhos que analisam dicionários com base na quantidade de verbetes é a de Rangel (2006), adotada, inclusive, pelo MEC. Nessa proposta, os dicionários são direcionados para diferentes públicos escolares (do ensino infantil, do fundamental e do médio), baseado em um critério, sobretudo, quantitativo. Segundo essa proposta, os dicionários podem ser classificados como: Tipo 1: de 1.000 a 3.000 palavras; Tipo 2: de 3.500 a 10.000 palavras; Tipo 3: de 19.000 a 35.000 palavras.
} 
ordena por significantes; el diccionario onomasiológico, por conceptos". ${ }^{76} \mathrm{Sem}$ dúvida, não há uma fronteira nítida entre essas duas perspectivas, podendo, na prática, existirem, por exemplo, dicionários onomasiológicos (primeiro critério) com partes semasiológicas (segundo critério). Por isso, opto, para efeito de registro, para que seja considerada a primeira ordenação do material. Nesse sentido, pela ordenação dos materiais em "base semasiológica" e "base onomasiológica", com possibilidade de ajustes à medida que as análises forem sendo processadas. ${ }^{77}$

h) Descrição da microestrutura. Uma informação crucial para o desenvolvimento desta pesquisa está relacionada à microestrutura de cada material lexicográfico. Essa microestrutura compõe o artigo que, segundo Haensch (1982, p. 462), “es la más pequeña unidad autónoma de um diccionario, y puede tener una fisionomía muy variada" ${ }^{78}$ Essa variedade de estruturação dos artigos é resultado das opções teóricas (mas também de fatores de ordem prática) de cada projeto lexicográfico desenvolvido para determinada língua. Diante da multiplicidade de estruturas, proponho uma forma de descrição que dê conta de parte da complexidade dessa informação, ou seja, uma maneira prática e segura de apresentar os principais componentes das microestruturas encontradas. Como esta descrição requer um detalhamento maior, buscando manter, em certo sentido, a noção original do sistema microestrutural de cada obra, apresento, ao final desta subseção, a proposta completa.

i) A última informação a ser apresentada nesta lista diz respeito àquelas que surgiram no decorrer da pesquisa e não puderam ser previstas com exatidão. Contudo, a título de exemplo, uma informação recorrente nesta pesquisa estava relacionada à possibilidade de uma obra reproduzir o conteúdo de outra obra, sob a forma de tradução, reedição/republicação e mudança de suporte (do escrito para o digital). Neste caso específico a informação acessória é assim apresentada: "Dados obtidos em Fulano (ano, p. NN-NN)".

\footnotetext{
76 Tradução: "O dicionário semasiológico ordena por significantes; o dicionário onomasiológico, por conceitos" (Tradução nossa).

${ }^{77}$ Para uma discussão acerca das noções de onomasiologia e semasiologia indico a leitura dos textos de Wolf (1982), Baldinger (1966), Babini (2006) e Faulstich e Oliveira (2007).

${ }^{78}$ Tradução: "é a menor unidade autônoma de um dicionário e pode assumir uma fisionomia bastante variada" (Tradução nossa).
} 


\subsection{Proposta de classificação baseada na quantidade de entradas}

Apesar da dificuldade de estabelecer uma classificação precisa dos materiais lexicográficos baseada na quantidade de verbetes, conforme tratei anteriormente, busco classificá-los, antes de tudo, com a intenção clara de dar a conhecer esta informação, esses dados quantitativos.

Contudo, antes de apresentar a proposta, é necessário destacar que muitas outras propostas de classificação de dicionários (de línguas indígenas ou não) baseadas na quantidade de verbetes certamente já foram feitas, dentre as quais cito as de Sousa (1995) e Welker (2003 apud WELKER, 2004). A título de exemplo, no Brasil, uma das propostas mais conhecidas para classificar os dicionários de língua é a de Biderman (1984, p. 27), segundo a qual os dicionários podem ser distribuídos em categorias, estritamente relacionadas a uma destinação do material e a um tipo de usuário. Eis os dados de sua proposta:

1) o dicionário infantil e/ou básico com 5.000 verbetes aproximadamente; 2) o dicionário escolar e/ou médio contendo 10.000 - 12.000 verbetes, podendo totalizar até 30.000 verbetes; 3) o dicionário padrão com uma média de 50.000 verbetes, um pouco mais, um pouco menos; 4) os "thesauri" que podem incluir 100.000, 200.000, 500.000 verbetes. Biderman (1984, p. 27).

Essa proposta de Biderman (1984), assim como muitas outras, parte da experiência com dicionários que possuem longa tradição lexicográfica, como o Português, o Francês, o Alemão e Espanhol, onde obras com mais de 50.000 são bastante comuns. No entanto, no caso das línguas indígenas brasileiras, é possível que não existam dicionários tão volumosos, o que justificaria também a necessidade de apresentação de uma nova proposta de classificação quantitativa.

Essa proposta consiste no estabelecimento de faixas de quantidade, definidas a partir do seguinte cálculo: adotei uma base fixa 3 e um multiplicador também 3 , que é duplicado para estabelecer cada nova faixa por meio de multiplicações sucessivas, resultando em uma progressão geométrica, como pode ser observado, por exemplo, nos cálculos a seguir:

$$
\begin{array}{lll}
3 \times(3 \times 1)=9 & 3 \times(3 \times 16)=144 \\
3 \times(3 \times 2)=18 & 3 \times(3 \times 32)=288 \\
3 \times(3 \times 4)=36 & 3 \times(3 \times 64)=576 \\
3 \times(3 \times 8)=72 & 3 \times(3 \times 128)=1.152^{79}
\end{array}
$$

\footnotetext{
${ }^{79}$ Ao dividir um dos resultados por seu antecessor imediato, obtém-se como novo resultado um valor constante, neste caso, $2(1152 \div 576=2 ; 576 \div 288=2)$. Outro recurso que poderia ter usado para encontrar as faixas seria o da potenciação, porém, se assim procedesse, o espaçamento entre as faixas ficaria demasiadamente longo.
} 
Os resultados desses cálculos levados até o limite de 3 x (3 x 65.536) estabelecem os limites de faixas de quantidade, que mantêm entre elas uma proporcionalidade razoável. Tais faixas podem ser agrupadas da seguinte maneira:

\section{Grupo A}

- Corresponde às quantidades de 1 a 576.

\section{Grupo B}

- Corresponde às quantidades de 577 a 18.432.

\section{Grupo C}

- Corresponde às quantidades de 18.433 a 589.824.

Cada grupo está subdividido em 5 faixas, conforme apresentado no Quadro 18:

QUADRO 18 - PROPOSTA DE CÓDIGOS PARA CLASSIFICAÇÃO DAS QUANTIDADES DE ENTRADAS DOS MATERIAIS LEXICOGRÁFICOS DE LIINGUAS INDÍGENAS BRASILEIRAS

\begin{tabular}{|c|ccc|}
\hline CÓDIGO & \multicolumn{3}{|c|}{ FAIXAS DE QUANTIDADE } \\
\hline A1 & 01 & a & 36 \\
\hline A2 & 37 & a & 72 \\
\hline A3 & 73 & a & 144 \\
\hline A4 & 145 & a & 288 \\
\hline A5 & 289 & a & 576 \\
\hline B1 & 577 & a & 1.152 \\
\hline B2 & 1.153 & a & 2.304 \\
\hline B3 & 2.305 & a & 4.608 \\
\hline B4 & 4.609 & a & 9.216 \\
\hline B5 & 9.217 & a & 18.432 \\
\hline C1 & 18.433 & a & 36.864 \\
\hline C2 & 36.865 & a & 73.728 \\
\hline C3 & 73.729 & a & 147.456 \\
\hline C4 & 147.457 & a & 294.912 \\
\hline C5 & 294.913 & a & 589.824 \\
\hline
\end{tabular}

Como os dois primeiros valores de faixa encontrados nos cálculos acima são muito baixos (9 e 18), eles não constituirão faixas independentes, mas serão, sim, considerados dentro do Grupo A1. 
Essa classificação não busca de modo algum relacionar a quantidade de verbetes a, por exemplo, faixa etária de um possível público-alvo do material lexicográfico ou a determinado nível de escolaridade, nem tampouco estabelecer uma nomenclatura do tipo pequeno ou grande (dicionário, vocabulário, etc.).

\subsection{Proposta de descrição da microestrutura dos materiais ${ }^{80}$}

Com o objetivo de apreender o máximo de informação acerca da microestrutura de cada material lexicográfico encontrado e acreditando que toda microestrutura representa um conjunto organizado de informações dispostas intencionalmente para dar conta de aspectos relacionados ao léxico das línguas, proponho uma maneira esquemática para realizar essa descrição.

Como não era possível determinar todos os elementos que surgiriam ao longo da pesquisa, selecionei, para início dos trabalhos, alguns dos elementos básicos de uma microestrutura básica apresentada por Faulstich (2011a, p. 181-182), são eles: lema, categoria gramatical, variante(s) da entrada, marca de homonímia, indicação de área ou subárea de especialidade, exemplo (ou abonação), indicação de pronúncia, origem e etimologia, remissivas, fontes e notas. Cada um desses elementos que compõem a microestrutura recebeu uma etiquetagem. O mesmo foi feito para todos os novos itens adicionados ao longo da pesquisa.

Ao término da primeira etapa da pesquisa, o quadro de referências havia se ampliado bastante, como é possível ver a seguir:

QUADRO 19 - SIGLAS UTILIZADAS NA DESCRIÇÃO DE MICROESTRUTURAS

\begin{tabular}{|l|l|}
\hline SIGLA & EXPLICAÇÃO DA SIGLA \\
\hline $\mathrm{Am}$ & Análise morfológica [Operador] \\
\hline $\mathrm{Ar}$ & Área (Biologia, Geografia, História, Linguística, Matemática...) [Operador] \\
\hline $\mathrm{Cs}$ & Campo semântico \\
\hline $\mathrm{D}$ & Descritor \\
\hline $\mathrm{DAl}$ & Descritor (glosa, definição, paráfrase, tradução...) em Alemão \\
\hline DEs & Descritor (glosa, definição, paráfrase, tradução...) em Espanhol \\
\hline DFr & Descritor (glosa, definição, paráfrase, tradução...) em Francês \\
\hline DIn & Descritor (glosa, definição, paráfrase, tradução...) em Inglês \\
\hline DIt & Descritor (glosa, definição, paráfrase, tradução...) em Italiano \\
\hline
\end{tabular}

${ }^{80}$ Apesar de nem todos os materiais que contêm dados lexicais sejam do tipo dicionário ou vocabulário, considero que para todos eles seja possível depreender uma estrutura mínima, logo, passível de descrição assim como os demais materiais. 


\begin{tabular}{|c|c|}
\hline DId & Descritor (glosa, definição, paráfrase, tradução...) em Língua Indígena \\
\hline DJp & Descritor (glosa, definição, paráfrase, tradução...) em Japonês \\
\hline DLt & Descritor (glosa, definição, paráfrase, tradução...) em Latim \\
\hline $\mathrm{DPt}$ & Descritor (glosa, definição, paráfrase, tradução...) em Português \\
\hline DRs & Descritor (glosa, definição, paráfrase, tradução...) em Russo \\
\hline Dt & Datação do item lexical [Operador] \\
\hline $\mathrm{E}$ & Exemplo $^{81}$ \\
\hline EAl & Exemplo em Alemão \\
\hline EEs & Exemplo em Espanhol \\
\hline EId & Exemplo em Língua Indígena \\
\hline EIn & Exemplo em Inglês \\
\hline EIt & Exemplo em Italiano \\
\hline EJp & Exemplo em Japonês \\
\hline ELt & Exemplo em Latim \\
\hline $\mathrm{EPt}$ & Exemplo em Português \\
\hline ERs & Exemplo em Russo \\
\hline Et & Etimologia [Operador] \\
\hline Fn & Pronúncia/Fonética/Fonologia [Operador] \\
\hline $\mathrm{Fr}$ & Fraseologia [Operador] \\
\hline $\mathrm{Ft}$ & Fonte da informação [Operador] \\
\hline Gf & Ortografia [Operador] \\
\hline Gr & Indicação da categoria gramatical [Operador] \\
\hline $\mathrm{Hm}$ & Indicação de ocorrência de homonímia [Operador] \\
\hline $\operatorname{Im}$ & Imagem (ilustração) [Operador] \\
\hline $\mathrm{L}$ & Lema \\
\hline LAl & Lema em Alemão \\
\hline LEs & Lema em Espanhol \\
\hline LFr & Lema em Francês \\
\hline LId & Lema na Língua Indígena \\
\hline LIn & Lema em Inglês \\
\hline LIt & Lema em Italiano \\
\hline LJp & Lema em Japonês \\
\hline LLt & Lema em Latim \\
\hline
\end{tabular}

\footnotetext{
${ }^{81} \mathrm{Na}$ Lexicografia, geralmente se faz a distinção entre exemplo e abonação, como estratégias para demonstrar, no interior da própria microestrutura, o lema em uso, ou seja, dentro de um contexto, construído para esse fim ou tomado de um contexto exterior. Nesta proposta de descrição, emprego o termo 'exemplo' para designar indistintamente exemplo e abonação.
} 


\begin{tabular}{|l|l|}
\hline LPt & Lema em Português \\
\hline $\mathrm{LRs}$ & Lema em Russo \\
\hline $\mathrm{Lu}$ & Lema em contexto \\
\hline $\mathrm{Mc}$ & Marcas (de uso) [Operador] \\
\hline $\mathrm{Na}$ & Nota do autor [Operador] \\
\hline $\mathrm{Ne}$ & Nota do editor [Operador] \\
\hline $\mathrm{Nt}$ & Nota do tradutor [Operador] \\
\hline $\mathrm{O}$ & Operador \\
\hline $\mathrm{Rm}$ & Remissiva [Operador] \\
\hline $\mathrm{Rz}$ & Raiz (de item lexical, de palavra) [Operador] \\
\hline $\mathrm{Sm}$ & Segmentação Morfológica [Operador] \\
\hline $\mathrm{Tc}$ & Texto complementar [Operador] \\
\hline $\mathrm{Tl}$ & Tradução literal [Operador] \\
\hline $\mathrm{Tm}$ & Indicação de tom [Operador] \\
\hline $\mathrm{Vr}$ & Variante/Variedade [Operador] \\
\hline
\end{tabular}

Algumas explicações necessárias sobre as informações do Quadro 19. Tanto a análise morfológica quanto a segmentação morfológica têm ocorrências registradas em verbetes de materiais de línguas indígenas. Optei pelo termo descritor, ao invés de definição, por aquele ser mais abrangente que este e, como há materiais de natureza bem diversa, considerei melhor não fechar em apenas uma modalidade de microestrutura. $O$ texto complementar se refere a material linguístico acessório acrescentado ao verbete a fim de detalhar ainda mais alguma informação. Mesmo que esteja relacionado à pronúncia, a indicação de tom foi destacada porque, em geral, recebe marca própria no verbete. Sob o rótulo de Variante/Variedade foram registrados todos os casos de informação de variante semântico-lexical, fonético-fonológica ou morfossintática.

Uma vez estabelecida a base das abreviaturas, faço algumas breves considerações sobre essa proposta e passo, em seguida, à explicação das etapas de descrição das microestruturas.

Por se tratar de um estudo cuja intenção é dar conta dos principais aspectos de todas as microestruturas do maior número possível de materiais lexicográficos já produzidos para as línguas indígenas brasileiras, importante é apreender os componentes dessas microestruturas de modo prático e abrangente, ou seja, sem detalhar demais a proposta, pois isso demandaria um tempo significativamente maior de análise, muito maior do que o 
disponível para conclusão desta tese. Isso não significa que a descrição proposta seja superficial, nem que ela não vá atender às necessidades deste trabalho. Por ter realizado testes com o modelo antes da aplicação definitiva neste projeto, constatei alguns problemas e fiz os ajustes necessários para aprimorar a proposta.

Essa proposta de descrição parte da ideia de que um artigo de material lexicográfico (de um dicionário, de um vocabulário ou glossário, por exemplo) possui uma determinada composição básica, totalmente inter-relacionada, constituída de quatro partes:

1) Lema, parte que geralmente inicia o verbete e está inter-relacionada com a maioria dos elementos do interior do corpo do verbete;

2) Descritor, parte que contém as informações metalinguísticas relacionadas diretamente com o Lema. Nos dicionários monolíngues, identifica-se com as definições ou paráfrases, e nos dicionários bilíngues, com as glosas, explicações e traduções literais.

3) Operador, parte que se associa ao Lema ou ao(s) Descritor(es), e que pode ser identificado pelas seguintes funções: indicar variação, auxiliar na pronúncia, definir propriedades morfossintáticas, remeter para itens de outros verbetes, comentar aspectos relevantes, apresentar tradução literal, evidenciar área de especialidade, descrever etimologia, registrar a fonte da informação.

4) Exemplo, que pode conter exemplos e abonações relacionados ao Lema e/ou ao Descritor da microestrutura.

Como materiais bilíngues são uma realidade bastante comum no conjunto de materiais lexicográficos das línguas indígenas brasileiras, tanto o Lema, quanto o Descritor e o Exemplo devem ser capazes, nesta proposta, de registrar a língua em que estão sendo usados. Por isso, é necessário utilizar as abreviaturas acima apresentadas para construir uma descrição adequada de um material lexicográfico.

A fim de representar os relacionamentos lógicos existentes entre os componentes de uma microestrutura, proponho o uso de uma estrutura similar à de uma expressão numérica matemática, ${ }^{82}$ por ela ser capaz de representar com eficiência os componentes e suas interrelações.

A esta organização das informações da microestrutura denomino Expressão da Microestrutura Lexicográfica (EML). Essa expressão consiste em definir termos (elementos

\footnotetext{
${ }^{82}$ Outros trabalhos já buscaram descrever a microestrutura por meio de operadores de expressões numéricas, mas, até onde notei, há diferenças significativas de nomenclatura e de arranjo dos componentes entre a proposta que apresento e a de outros pesquisadores. Cf. Rey-Debove (1971), Finatto (1996) e Barbosa, M. A. (1999).
} 
da microestrutura) e relacioná-los logicamente a fim de estabelecer seus valores e funções. Logo, uma EML completa pode ser assim descrita: o primeiro elemento da esquerda é o Lema (L), destacado do restante do corpo do verbete por dois pontos; em seguida, sem nenhuma delimitação de marcadores, são apresentados os Operadores $(\mathrm{O})$ que possuem relação direta com o Lema e, se houver mais de um, devem vir separados por vírgula; à direita desses Operadores, são apresentados os Descritores (D), delimitados por chaves \{\} , esses Descritores devem vir separados por hífen ou, quando não recorrentes, vir dentro de parênteses ( ), esses Descritores devem ser apresentados na mesma ordem em que aparecem com maior frequência na microestrutura; assim como o Lema, um Descritor pode ter Operadores associados a ele, para isso, basta colocá-los à direita do Descritor a que se referem, dentro de parênteses; ${ }^{83}$ ainda dentro da área do Descritor, deve ser apresentado o Exemplo (E), entre colchetes [ ], buscando manter a mesma sequência em que são apresentados no corpo do verbete, além disso, se houver mais de um Exemplo, estes devem vir separados por uma barra diagonal /.

Em síntese, uma EML padrão apresentará a seguinte estrutura:

$$
\mathrm{L}: \mathrm{O}\{\mathrm{D}[\mathrm{E}]\}
$$

Como se trata de uma proposta de modelo, à medida que a aplicação ocorrer, devem ser feitas adaptações para que o modelo se ajuste à realidade dos dados.

Uma observação importantíssima relacionada a esse modelo é a de que ele foi projetado para descrever os componentes de uma microestrutura, buscando, em certa medida, registrar a ordem em que eles aparecem nos dados. No entanto, como em apenas uma obra lexicográfica, por exemplo, é possível ter inúmeras variações ou possibilidades de arranjo dos operadores de uma microestrutura, optei pela disposição em ordem alfabética desses elementos, padronizando, assim, a sua apresentação. ${ }^{84}$

A título de exemplo, apresento, por meio de uma EML, os dados de uma microestrutura do Dicionário da Língua Asuriní do Tocantins, organizado por Cabral e Rodrigues (2003):

\footnotetext{
${ }^{83}$ Neste caso, pode ocorrer interposição de Operadores entre dois Descritores.

${ }^{84}$ Esse mesmo modelo pode vir a ser aplicado para descrever os elementos de uma microestrutura em todas as suas variações.
} 


\section{FIGURA 05 - TRECHO DO DICIONÁRIO DA LÍNGUA ASURINÍ DO TOCANTINS}

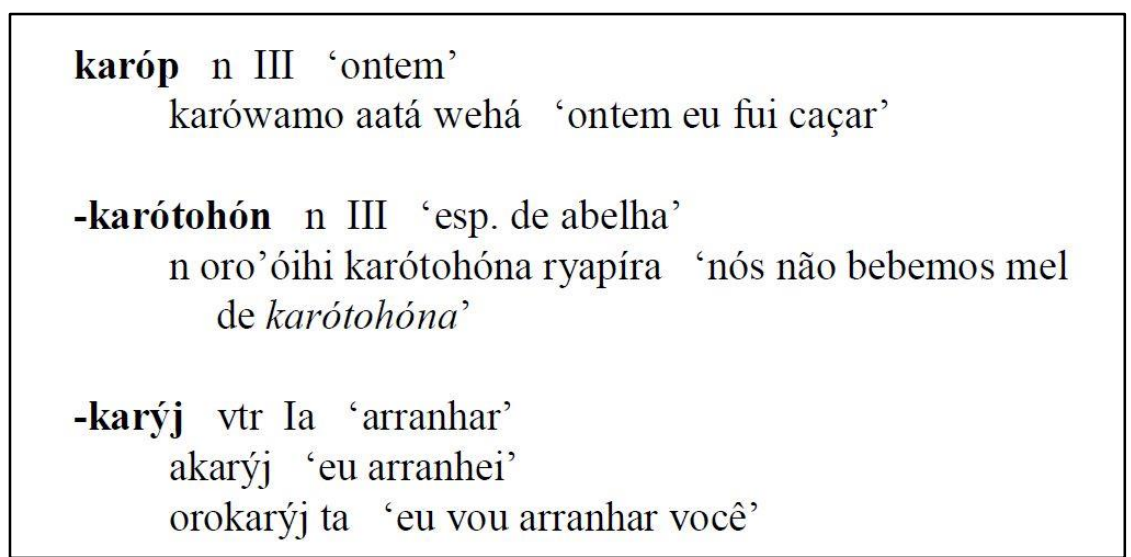

Fonte: Cabral e Rodrigues (2003, p. 98).

Analisando as três microestruturas, observa-se que elas contêm os seguintes elementos em sequência: Lema em Asuriní (língua indígena), Operador (Informação gramatical), Descritor em língua portuguesa, Exemplo em Asuriní e em Português. Logo, podemos usar uma mesma EML para descrever essas microestruturas:

\section{LId: Gr $\{\mathrm{DPt}[\mathrm{EId} / \mathrm{EPt}]\}$}

Essa EML descreve que o Operador Gr está relacionado diretamente ao Lema LId. Do mesmo modo, o conjunto Descritor DPt + Exemplo EId e EPt está subordinado a LId.

Na seção 7.3 apresento os resultados da análise de todas as microestruturas que tive acesso durante esta pesquisa.

\subsubsection{Armazenando os dados da pesquisa}

Ao estabelecer com clareza o objeto da pesquisa, os locais onde eles serão buscados e as informações a serem extraídas de cada material encontrado, surge a necessidade de definir como será feito o armazenamento dessas informações.

Esse armazenamento deve ser feito de modo que todas as informações não apenas possam ser recuperadas rapidamente, mas também que haja a possibilidade de usar esse mesmo recurso para selecionar, ordenar e categorizar cada uma delas.

Logo, por esses dados a serem coletados apresentarem características que podem ser agrupadas, a solução mais prática é a de construir uma base do tipo banco de dados.

Para isso, podem ser usados editores de texto comuns, como o Writer (do pacote LibreOffice, The Document Foundation), o WordPerfect (Corel) e o Word (do pacote Microsoft Office, Windows), editores de planilhas, como o Calc (do pacote LibreOffice, The 
Document Foundation) o Quattro Pro (Corel) e o Excel (do pacote Microsoft Office, Windows) ou qualquer um outro que permita a construção e edição de tabelas simples.

Além dessas opções, é possível usar programas específicos para geração de bancos de dados, como o MySQL (Oracle Corporation), o Base (do pacote LibreOffice, The Document Foundation) e o Access (do pacote Microsoft Office, Windows). No caso destes programas de gerenciamento de bancos de dados, é possível desenvolver programas e aplicativos para recebimento e processamento dos dados.

Como este trabalho está ligado ao desenvolvimento do Programa Línguas, espero, em futuro próximo, desenvolver uma base específica para receber todas as informações coletadas nesta pesquisa bibliográfica. Por ora, a fim de atender a uma demanda imediata, construí a base no programa Microsoft Office Word, editor de texto bastante popular, apesar de ser um software proprietário. ${ }^{85}$

O processo de criação de tabelas no Word, apesar de bastante simples, requer alguns ajustes para que os dados possam ser vistos adequadamente pelo usuário.

Os primeiros ajustes dizem respeito ao tamanho e à orientação da página. Uma página padrão, do tipo A4, com dimensões de 210 x 297mm, com orientação retrato, comporta uma tabela de até 4 colunas (cada uma com 40mm). Se a mesma página for girada para a orientação horizontal, comportará 6 colunas de igual dimensão. Como são necessárias, pelo menos, 12 colunas, com algumas delas com bastante espaço para receber as referências e as anotações, o ideal seria ter uma página com $420 \mathrm{~mm}$ ou mais.

Assim, ao concluir os ajustes da página, criei nela uma tabela com 12 colunas e inseri, em cada célula de coluna da primeira linha da tabela, um rótulo para identificar o tipo de dados a serem inseridos. Neste ponto do trabalho, foi possível dimensionar cada coluna para um tamanho adequado ao tipo de dados a serem inseridos. Optei pelos seguintes rótulos: tronco linguístico, família linguística, línguas, tipo de material, ano (de publicaçãoelaboração do material), UBL, quantidade (Quantidade de entradas), ordenação (da macroestrutura), Q. (Classificação da quantidade de entradas), EML (descrição sistematizada), direção (da língua X para a(s) língua(s) K/Y/W) e anotação.

\footnotetext{
${ }^{85}$ O programa de computador cujos direitos autorais e patentes são exclusivos de seu(s) produtor(es) e sua redistribuição e modificação dependem de autorização são denominados software proprietário. O Word é um exemplo de softaware proprietário que pertence à empresa Microsoft. Neste caso, ele não é o programa mais recomendado para este tipo de trabalho, haja vista sua limitação em lidar com documentos muito extensos, com grande quantidade de dados. Contudo, é o mais simples de todos para construir uma tabela e formatá-la conforme as necessidades do usuário comum. Além disso, ele possui boa integração com sistema de geração de mala-direta, recurso este bastante útil para exportação formatada dos dados da base.
} 
Uma vez iniciado o preenchimento desse documento, foi necessário fazer regularmente uma cópia de segurança desse banco de dados para fora do computador em que estava trabalhando, com o objetivo de manter seguras toda as informações já coletadas.

\subsubsection{Analisando os dados coletados}

Ao concluir a coleta de informações, o material foi analisado, em suas várias perspectivas, para, finalmente, se chegar a buscar respostas para as questões apresentadas no final da seção 7.1 .

De interesse crucial foi a informação de quantos materiais lexicográficos já haviam sido produzidos até hoje envolvendo as línguas indígenas brasileiras. Para isso, poderse-ia contar somente as obras lexicográficas em si, o que daria uma quantidade não tão precisa, pois, podem existir obras que armazenam vários conjuntos de dados de línguas. Por essa razão, optei pelo uso da UBL (cf. item C da subseção 7.2.1.4) como critério de contagem dos dados. Com base nessa informação, pude especificar quantos materiais existem no âmbito de cada tronco linguístico e em cada família linguística, mas também quantos materiais cada língua possui.

Outra preocupação foi a de determinar as características de ordenação dos dados na microestrutura e também em identificar o funcionamento do sistema das microestruturas.

Por fim, procedi à análise da própria produção de materiais lexicográficos ao longo dos séculos, investiguei quais línguas serviram de base para os materiais, e também identifiquei quais outras línguas foram usadas para traduzir as línguas indígenas brasileiras.

\subsection{SISTEMATIZAÇÃO DOS DADOS COLETADOS}

Uma vez realizada a pesquisa sobre materiais lexicográficos de línguas indígenas brasileiras, de acordo com as orientações descritas na seção 7.2, apresento, a seguir, os resultados dessa pesquisa obtidos até o presente.

\subsubsection{UBL's já produzidas para as línguas indígenas brasileiras}

Partindo da base de dados construída e alimentada durante este projeto, é possível apresentar com segurança a quantidade de UBL's.

Em uma contagem geral de registros na base de dados, identifiquei um total de 1556 linhas de dados, desse total, 23 continham informações de línguas que não dispõem 
ainda de nenhum material lexicográfico. Dessa forma, o total de linhas com registros válidos com UBL's ficou em 1533.

No entanto, se desconsiderarmos os 106 registros que se referem a reedições e traduções de materiais já publicados na língua original, a quantidade de UBL's fica em 1421.

Logo, para as demais contagens de dados, adotei como base este último total de UBL's, pois, assim, evitaria a repetição desnecessária de informações. ${ }^{86}$

\subsubsection{Tipos de materiais identificados}

Conforme apresentado na subseção 7.2.1.1 deste trabalho, parti de uma determinada quantidade de tipos de materiais para orientar a busca pelas referências de obras lexicográficas. Uma vez concluída a pesquisa, consegui registrar um total de 13 diferentes tipos de materiais (estabelecidos com base nas UBL's), a maioria deles, inclusive, com qualificativos:

1. Base de dados

a. - informatizada (computer) ${ }^{87}$

2. Complemento de Dicionário

3. Dicionário:
a. - analítico
b. - básico
c. - bilíngue
d. - bilíngue ilustrado (ou — ilustrado bilíngue)
e. - cultural
f. - da língua
g. — de alimentação
h. - de rimas
i. - dos termos
j. - eletrônico
k. - enciclopédico
1. - escolar
m. - experimental

\footnotetext{
${ }^{86}$ Da base de dados considerada nesta pesquisa, elaborada a partir da proposta de classificação das línguas indígenas brasileiras, não foram encontrados disponíveis materiais lexicográficos para 23 línguas. São elas: Aikanã (Aikaná, Tubarão), Apolíma-Arára, Arapáso, Aurê-Aurá, Banawá (Banawá-Yafí), Diahói (Diarroi, Jiahúi), Kaixána, Katuéna, Kontanáwa, Mandúka, Matipú, Mirití-tapúya, Mundúka, Nagarotú, Nambikwára del Pequizal, Nambikwára del Sur, Nambikwára del Valle del Guaporé, Sararé, Tenharim, Torá, Xambioá, Xawanáwa (Arara), Yanomám.

${ }^{87} \mathrm{O}$ travessão está sendo usado nesse contexto para evitar a repetição do termo de entrada, por exemplo, "— informatizada" corresponde a "Base de dados informatizada".
} 

n. - indígena
o. - infantil
p. - morfológico
q. - multilíngue
r. - para gestão ambiental
s. pequeno -
t. - por assuntos
u. - por tópicos
v. - preliminar
w. - semântico
x. - temático
y. — temático ilustrado

\section{Enciclopédia}

5. Glossário:
a. - básico
b. - da língua
c. - das palavras e frases
d. - de termos
e. - do corpo
f. - geral
g. - ilustrado
h. - semântico-gramatical

6. Índice/Index

7. Léxico
a. - bilíngue
b. - da fauna
c. - da língua
d. - do dicionário
e. - para estudos comparativos
f. pequeno -
g. - preliminar

8. Lista:
a. - breve
b. - comparativa
c. - de animais
d. - de espécies
e. - de itens lexicais 

f. - de palavras
g. - de peixes
h. - de plantas
i. - de substantivos
j. - de Swadesh
k. - de verbos
1. — de vocábulos
m. - geral
n. - lexical
o. — padrão
p. - resumida
q. - vocabular

9. Minidicionário

10. Miniglossário

a. — da língua

11. Nomenclatura
a. - botânica

12. Tesouro
a. - da língua

13. Vocabulário:
a. - básico
b. - bilíngue
c. - comparativo
d. - da língua (ou — na língua)
e. - da tribo
f. - das lições
g. - das palavras
h. - de dialetos
i. - dos índios
j. - elementar
k. - experimental
1. - ilustrado
m. - padrão
n. pequeno -
o. - poliglota
p. - prático
q. - sistemático
r. - temático 
Apresento, a seguir, um gráfico com o total de materiais classificados nos 13 grupos acima identificados.

\section{GRÁFICO 01 - QUANTIDADE DE TIPOS DE MATERIAIS LEXICOGRÁFICOS DAS LÍNGUAS INDÍGENAS BRASILEIRAS}

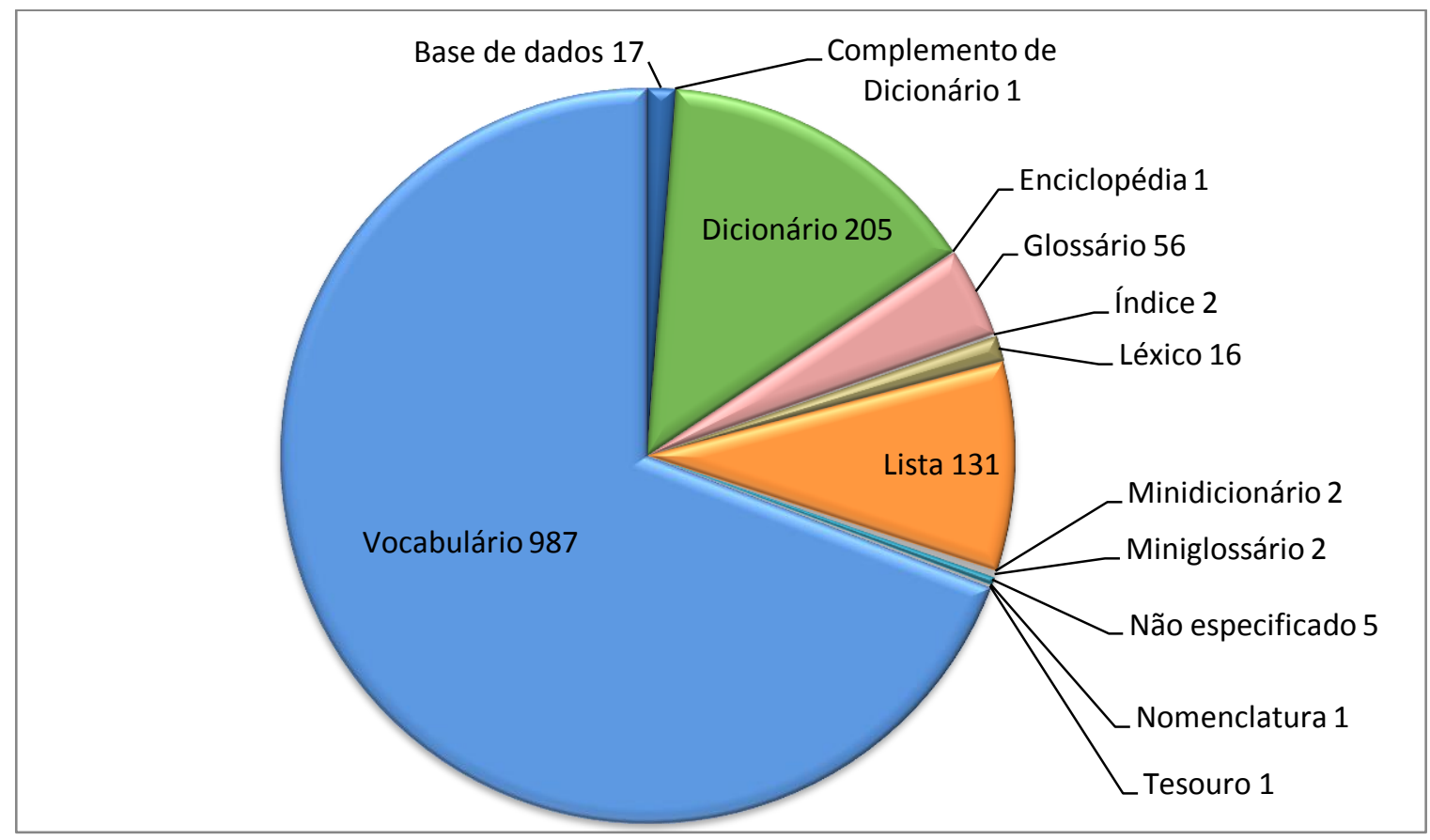

Observando os dados do Gráfico 01, pode-se identificar de imediato que os três tipos predominantes de UBL's são os vocabulários $(69,16 \%)$, os dicionários $(14,36 \%)$, as listas $(9,18 \%)$ e os glossários (3,93\%). Sem esquecer, no entanto, que esses dados são resultantes da caracterização dos próprios autores dos materiais e não de uma análise crítica que buscasse avaliar ou descobrir que tipos de materiais, de fato, cada um deles seria. Mesmo assim, os dados nessas condições demonstram que há, para as línguas indígenas brasileiras, dois tipos predominantes de materiais, os dicionários e os vocabulários, que, juntos, representam quase $84 \%$ do total de UBL's identificadas.

\subsubsection{Quantificação detalhada das UBL's já produzidas para as línguas indígenas} brasileiras

Cada um dos materiais identificados e registrados nesta pesquisa estão associados a alguma das línguas indígenas brasileiras. E muitas dessas línguas fazem parte de famílias linguísticas e algumas destas, por sua vez, integram um dos dois troncos linguísticos. Assim, partindo das informações das UBL's contidas no banco de dados, podemos definir exatamente quantos desses materiais foram produzidos por tronco, por família linguística e por língua. 


\subsubsection{Distribuição das UBL’s por tronco linguístico}

Embora iniciadas desde o século XIX, as classificações genéticas entre línguas, somente no século XX são apresentadas hipóteses classificatórias consistentes de línguas em famílias e em troncos linguísticos.

Em 1958, Rodrigues lança a hipótese, hoje já bem estabelecida, da existência de um Tronco Linguístico Tupí, que viria a englobar as famílias linguísticas Arikém, Jurúna, Mondé, Mundurukú, Ramaráma, Tuparí e três famílias de uma só língua sobrevivente, a Maué, a Awetí e a Puruborá. Também foi Rodrigues (1986) um dos que propuseram uma hipótese de outro tronco linguístico no Brasil, o Macro-Jê, admitindo, àquela época, que ele era "altamente hipotético ainda" (p. 49).

Desses dois grandes agrupamentos genéticos, apresento, a seguir, o total de UBL's já produzidas para cada um deles.

Das 1421 UBL's acima identificadas (ver subseção 7.3.1.), 660 não se relacionam com nenhum tronco linguístico. Já as 761 restantes, distribuem-se em três troncos linguísticos: o Indo-Europeu, ${ }^{88}$ o Tupí e o Macro-Jê, como pode ser observado no gráfico abaixo:

GRÁFICO 02 - QUANTIDADE DE UBL'S DE LÍNGUAS INDÍGENAS BRASILEIRAS AGRUPADAS EM TRONCOS LINGUÍSTICOS

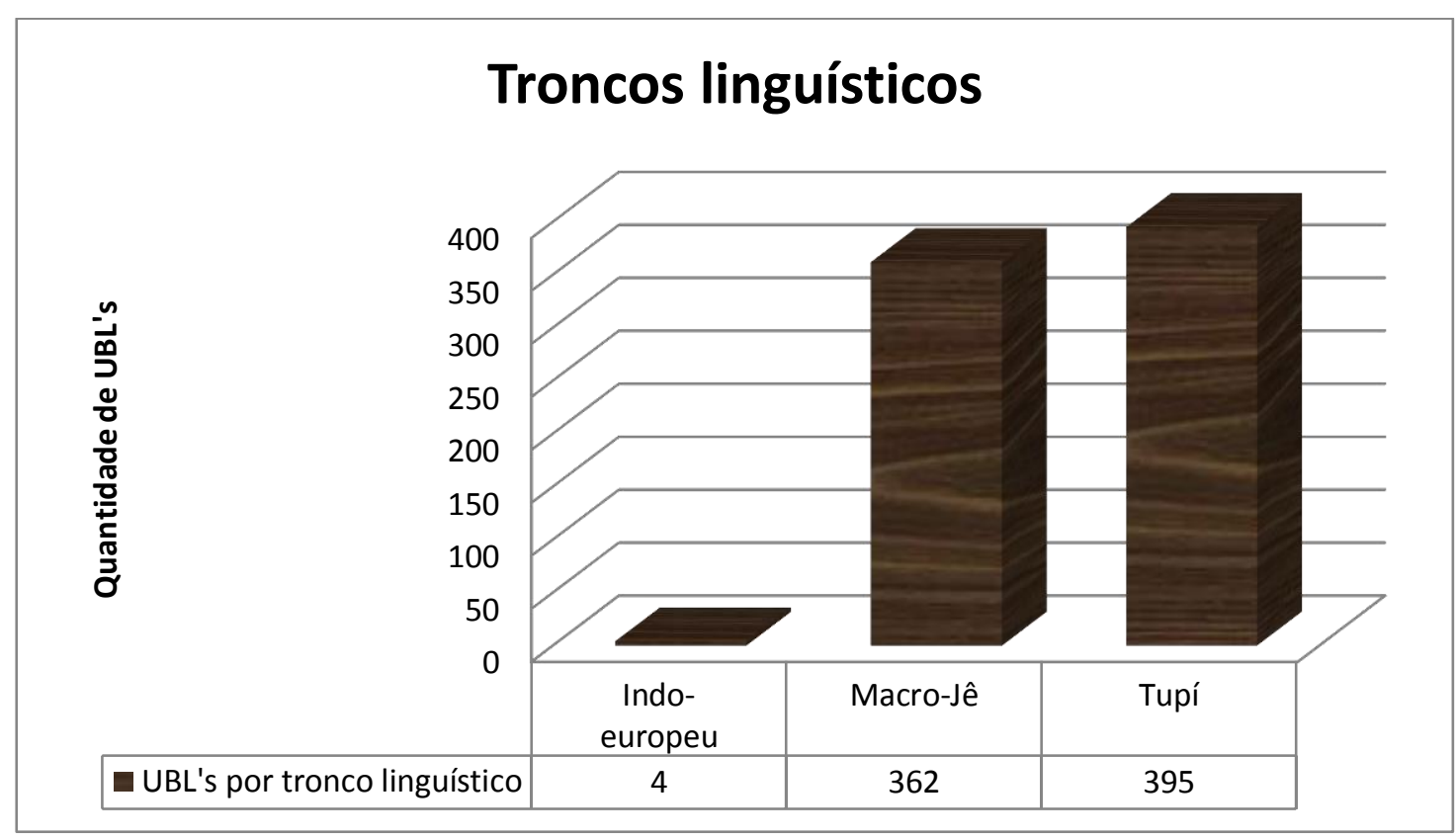

\footnotetext{
${ }^{88}$ Dentre as línguas identificadas, foi incluída o Karipúna do Amapá, de base indo-europeia.
} 
Os dados demonstram que, apesar de os dois maiores troncos possuírem quantidades não tão distantes, o tronco Tupí tem quase 5\% a mais de materiais do que o Macro-Jê. ${ }^{89}$

Apesar de não ter incluído nesta contagem de UBL's por tronco linguístico os dados selecionados que consistem em republicação ou tradução, e que reproduzem integralmente os dados originais, considero relevante apresentar rapidamente a estatística apenas desta parte excluída. Com 111 UBL's, das quais 32 não possuíam informação sobre tronco linguístico, sobraram 73 registros, que correspondem a 35 para o tronco Macro-Jê e 38 para o tronco Tupí. Com essa informação, pode-se deduzir que há, praticamente, uma mesma quantidade de materiais oriundos dos dois troncos linguísticos que foram reaproveitados em novas publicações.

\subsubsection{Distribuição das UBL’s por família linguística}

Do mesmo modo como foram contabilizadas as línguas indígenas brasileiras, por meio do registro de suas UBL's, e computadas a partir do critério de troncos linguísticos, apresento, a seguir os dados para o agrupamento em famílias linguísticas.

Também aqui não computei no total de UBL's aquelas que correspondiam a materiais reeditados ou traduzidos, mas, ao final deste subcapítulo, apresentarei o resumo dessas informações.

Logo, do total de 1421 UBL's identificadas para as línguas indígenas brasileiras, 81 não possuíam registro de família no banco de dados, ou porque se tratava de línguas isoladas, como, por exemplo, o Arikapú, o Awakê e o Máku, ou porque as línguas ainda não haviam sido classificadas. ${ }^{90}$ Assim, restaram 1340 UBL's que estavam relacionadas a alguma das 48 famílias linguísticas catalogadas na base. Desse total, construí três gráficos distribuindo essas informações, a saber:

- Famílias com maior quantidade de UBL's;

- Famílias com quantidade intermediária de UBL'S;

- Famílias com menor quantidade de UBL'S.

\footnotetext{
${ }^{89}$ Um dado para reflexão acerca desta diferença quantitativa está relacionado ao total de materiais de línguas associadas a cada tronco linguístico. Para a hipótese de um tronco Macro-Jê de Rodrigues, há 39 línguas e para a hipótese do tronco Tupí do mesmo autor, 64.

${ }^{90}$ Por exemplo, várias línguas reportadas por viajantes do século XIX, como Martius e Steinen, receberam denominações tão particulares que é extremamente difícil estabelecer, com precisão, se se tratava de uma língua até então não registrada, ou se era língua já conhecida e apenas denominada de forma diferente.
} 
GRÁFICO 03 - FAMÍLIAS COM MAIOR QUANTIDADE DE UBL'S

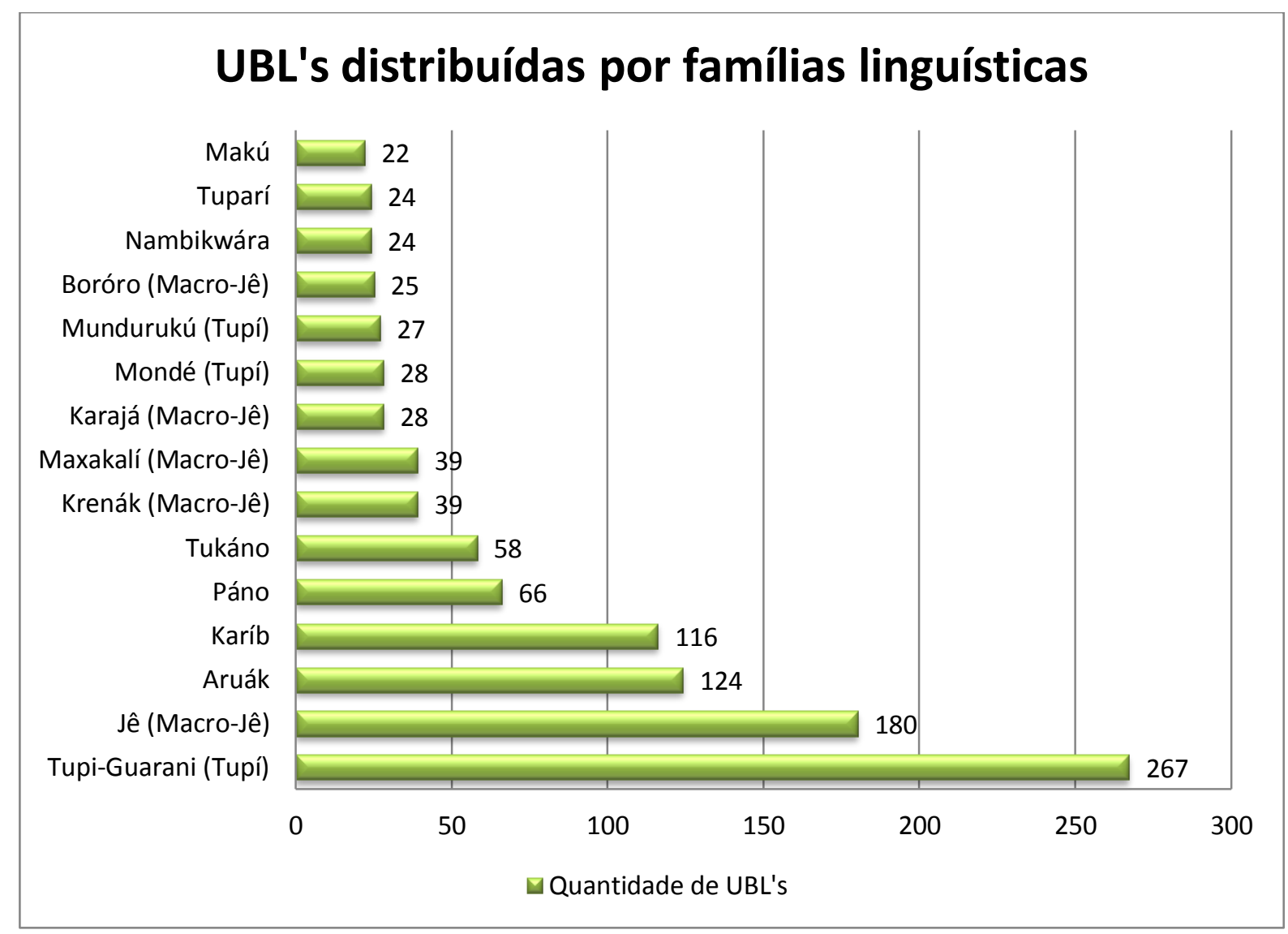

GRÁFICO 04 - FAMÍLIAS COM QUANTIDADE INTERMEDIÁRIA DE UBL'S

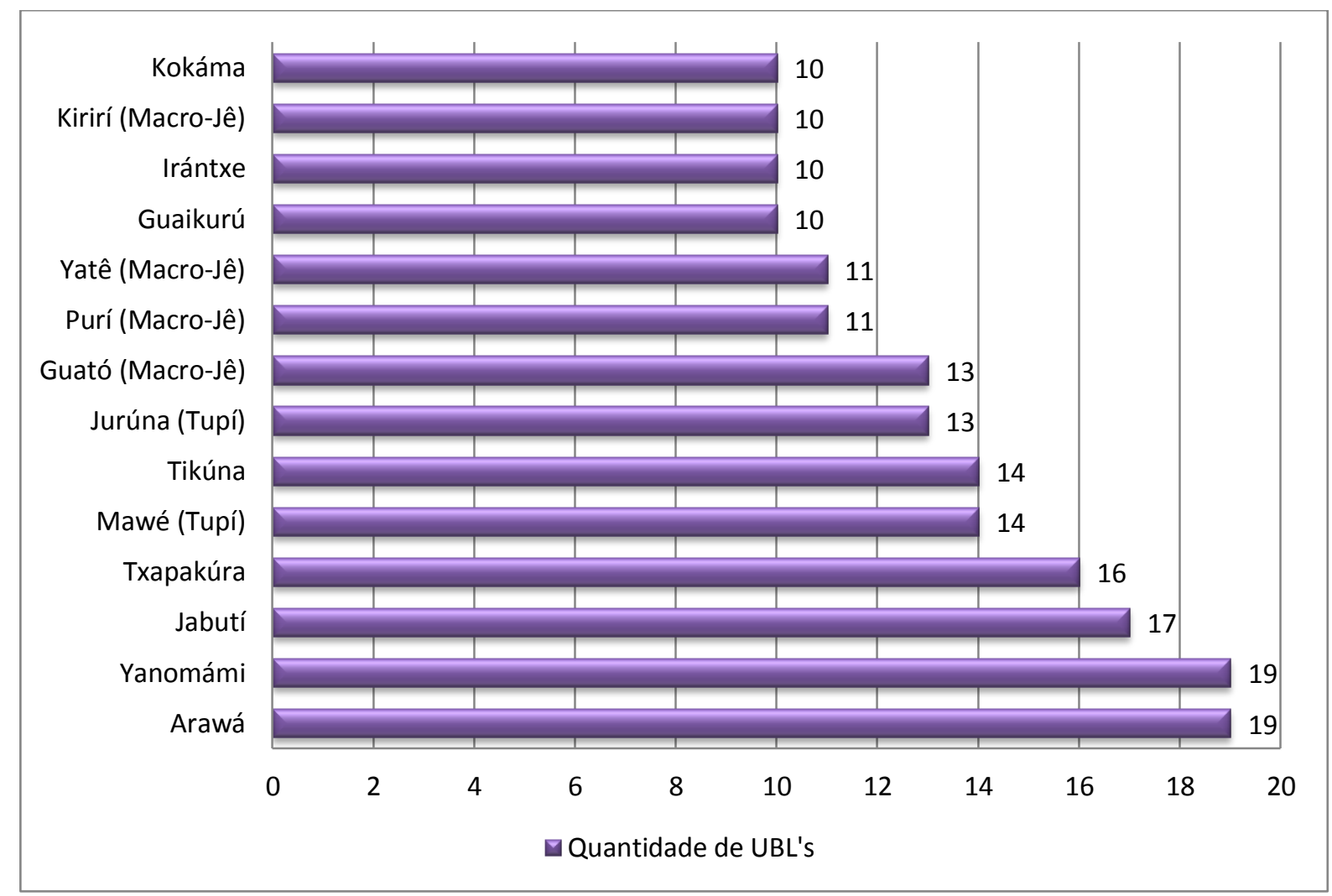


GRÁFICO 05 - FAMÍLIAS COM MENOR QUANTIDADE DE UBL'S

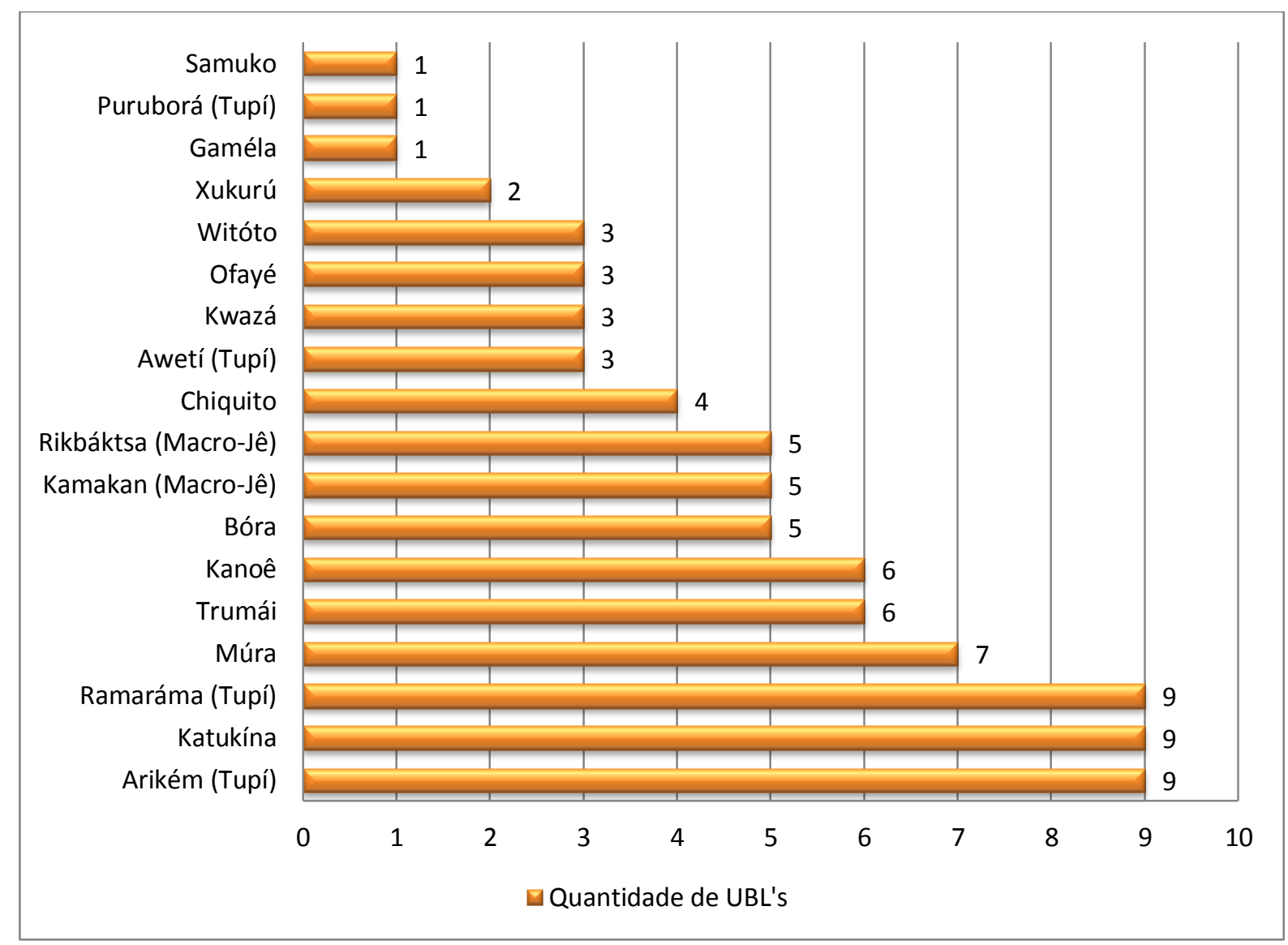

Analisando os gráficos acima, é possível concluir que, no Brasil, dentre as 48 famílias linguísticas incluídas neste trabalho, seis delas respondem por quase $60 \%$ de todas as UBL's registradas: Tupí-Guaraní (18,79\%), Jê (12,66\%), Aruák (8,72\%), Karíb (8,16\%), Páno $(4,64 \%)$ e Tukáno $(4,08 \%)$.

Já as línguas apresentadas no Gráfico 05, possuem uma quantidade intermediária de UBL's, ou seja, entre 10 e 20. As 14 línguas desse conjunto respondem por pouco mais $13 \%$ do total de UBL's.

Por fim, as 19 línguas apresentadas no Gráfico 05 são as que possuem menor quantidade de materiais, pouco mais de $6 \%$ de UBL's.

\subsubsection{Distribuição cronológica das UBL's das línguas indígenas brasileiras}

Desde os primeiros contatos dos viajantes e exploradores europeus em terras americanas, em particular no Brasil, houve o interesse pelas línguas dos diferentes povos autóctones do "novo mundo", tanto para identificar esses povos quanto para facilitar o acesso a esses e a outros grupos para servirem de mão-de-obra. Esse interesse pelas línguas, 
principalmente as dos índios do litoral, Tupinambás e Tupiniquins, por exemplo, levou muitos viajantes, religiosos e pessoas com interesses variados a aprenderem e, algumas vezes a registrarem línguas, ainda no século XVI, das mais diferentes maneiras. Um caso bastante conhecido em nosso país é o do padre Anchieta, da Companhia de Jesus, que, em 1595, conseguiu a publicação da $1^{\text {a }}$ gramática da "lingoa mais vsada na costa do Brasil" ou do alemão Hans Staden, que ficou por meses prisioneiro dos Tupinambá, e, ao relatar esta história em seu livro, anotou várias frases na língua Tupinambá (cf. STADEN, 1557).

Da mesma forma, os registros de palavras sob a forma de listas e vocabulários existem desde esse primeiro século de colonização portuguesa no Brasil, por isso, acredito ser mais prático apresentar os dados quantitativos de UBL's em ordem cronológica por século.

\subsection{UBL's das línguas indígenas brasileiras referentes ao século XVI}

Apesar de existirem vários registros linguísticos da língua Tupinambá falada no século XVI, consegui localizar nesta pesquisa apenas uma lista (?) com 88 entradas, elaborada por volta de 1540 por Jean Corbier (apud DALBY; HAIRE, 1966, p. 42-66). ${ }^{91}$ Contudo, ela tem o mérito de ter sido o primeiro registro com qualidade lexicográfica elaborado para uma língua indígena brasileira. Essa mesma lista só foi, no século XX, republicada e analisada por Dalby e Haire (1966), com uma reprodução da mesma por Santos (2000).

TABELA 07 - QUANTIDADE DE UBL'S REFERENTES AO SÉCULO XVI

\begin{tabular}{l|c|c}
\hline & TIPO DE UBL & QUANTIDADE \\
\hline 1$)$ & Não definido $^{92}$ & 1 \\
\hline & TOTAL & 1 \\
\hline
\end{tabular}

\subsection{UBL's das línguas indígenas brasileiras referentes ao século XVII}

No século XVII, encontra-se, de fato, uma produção lexicográfica mais significativa, com a edição de um dicionário, ainda que manuscrito, da língua Tupinambá, datado de 1621, e as primeiras edições do Tesoro de la lengva gvarani e do Bocabvlario de la lengva gvarani, de Ruiz de Montoya. ${ }^{93}$

\footnotetext{
${ }^{91}$ Há relatos da existência de dicionários e de outros materiais produzidos para as línguas indígenas brasileiras, mas que não chegaram até nós. Para saber um pouco mais sobre esse assunto, consulte Rodrigues (2005; 2006).

92 Os tipos de materiais lexicográficos "não definidos" se referem a documentos que não receberam de seus autores uma "autoidentificação" de cunho lexicográfico, tais como "dicionário da língua..." ou " vocabulário básico de...”.

${ }^{93} \mathrm{O}$ trabalho de Montoya, assim como os de outros autores, foi incluído neste levantamento em virtude de a língua por ele registrada ser falada por indígenas que estavam em uma região fronteiriça entre o Brasil e o Paraguai, próxima a Foz do Iguaçu, numa época de intensas disputas pela definição das fronteiras transnacionais.
} 
A seguir, apresento um resumo do total de UBL's das línguas indígenas brasileiras ordenadas pelo tipo de material.

TABELA 08 - QUANTIDADE DE UBL’S REFERENTES AO SÉCULO XVII

\begin{tabular}{l|l|c}
\hline & \multicolumn{1}{|c|}{ TIPO DE UBL } & QUANTIDADE \\
\hline 1$)$ & Tesouro & 1 \\
\hline 2$)$ & Vocabulário & 4 \\
\hline & TOTAL & 5 \\
\hline
\end{tabular}

\subsection{UBL's das linguas indigenas brasileiras referentes ao século XVIII}

No século XVIII, a quantidade de materiais permanece ainda muito pequena, mas já há uma melhora na produção de dois importantes tipos de obras lexicográficas, dicionários e vocabulários. Há de se observar que, ainda até esse século, apesar de se já ter ciência da grande diversidade linguística no Brasil, o interesse geral volta-se para poucas línguas, conforme observa Rodrigues (2005c, p. 35), “[...] durante os três séculos do período colonial fizeram-se gramáticas e dicionários de somente três línguas indígenas: do próprio tupinambá, de que foram feitas duas [...], da língua kirirí [...] e da língua dos maramonins ou guarulhos". A seguir, apresento o resumo da quantidade de UBL's registradas para esse século.

TABELA 09 - QUANTIDADE DE UBL'S REFERENTES AO SÉCULO XVIII

\begin{tabular}{|c|c|c|}
\hline & TIPO & QUANTIDADE \\
\hline 1) & Dicionário & 5 \\
\hline \multirow[t]{2}{*}{ 2) } & Vocabulário & 7 \\
\hline & TOTAL & 12 \\
\hline
\end{tabular}

7.3.3.3.4. UBL's das línguas indígenas brasileiras referentes ao século XIX

O século XIX marca uma mudança significativa em termos de produção de material lexicográfico. Além da republicação de obras lexicográficas de línguas indígenas brasileiras, passou-se a registrar uma quantidade cada vez maior de línguas no país. Para isso, foi fundamental o trabalho de estudiosos oriundos de outros países (os viajantes, dentre os quais naturalistas), como Carl Friedrich Philipp von Martius (1794-1868), Francis de Laporte de Castelnau (1810-1880), Henri Anatole Coudreau (1859-1899) e Karl von den Steinen (1855-1929). Todos eles tiveram contato com povos indígenas brasileiros e deixaram registros, geralmente listas e vocabulários, de várias línguas. A seguir, apresento o resumo do total de UBL's produzidas nesse período: 
TABELA 10 - QUANTIDADE DE UBL'S REFERENTES AO SÉCULO XIX

\begin{tabular}{|c|c|c|}
\hline & TIPO DE UBL & QUANTIDADE \\
\hline 1) & Dicionário & 3 \\
\hline 2) & Lista & 55 \\
\hline 3) & Vocabulário & 230 \\
\hline \multirow[t]{2}{*}{ 4) } & Não definido & 1 \\
\hline & TOTAL & 289 \\
\hline
\end{tabular}

Desse total de dados, surpreende a grande quantidade de vocabulários. No entanto, como esta pesquisa considera como critério de contagem a UBL (ver subseção 7.2.1.4) e não, por exemplo, a unidade da obra impressa, as quantidades tendem a ser bem maiores, pois, numa mesma obra, pode haver UBL's de diferentes línguas, como é o caso da obra de Martius (1858; 1867), que responde por um total de 87 UBL's, a de Castelnau (1851), que possui 13 UBL's, e a de Steinen (1886; 1894), com 15 UBL's.

\subsection{UBL's das línguas indígenas brasileiras referentes ao século $X X$}

O século XX é um marco no desenvolvimento de estudos e de trabalhos lexicográficos no Brasil. Diversificam-se os tipos de materiais produzidos e pesquisadores ligados a universidades e a centros de pesquisa, sobretudo na segunda metade do século XX, mas também a grupos religiosos, passam a elaborar um número cada vez maior de dicionários, vocabulários, listas e glossários, inclusive de línguas até então sem nenhum registro. Esse aumento da produção de material lexicográfico nesse século XX se deve, em parte, ao desenvolvimento de trabalhos acadêmicos (dissertações e teses) sobre línguas e culturas indígenas, nas universidades do Brasil e do exterior, principalmente nas áreas da Linguística e da Antropologia. ${ }^{94}$ Por outro lado, muitas línguas tiveram alguma forma de registro antes de desaparecer (e esse registro se deu, com muita frequência, sob a forma de listas de palavras ou de vocabulários da língua). ${ }^{95}$

Outro fator importante a ser considerado neste aumento da quantidade de obras lexicográficas foi a criação e aperfeiçoamento dos sistemas de computação eletrônica, que

\footnotetext{
${ }^{94}$ Apesar de todo esse esforço, o desaparecimento de línguas indígenas continuou, às vezes não restando nem vestígios da existência da língua indígena, ou porque todos os falantes morreram ou porque a língua original foi totalmente substituída por outra língua, sem haver lembradores ou registros escritos da língua desaparecida.

${ }^{95}$ Infelizmente, o século XX, em que houve o primeiro contato com muitos povos indígenas, foi também palco de extermínio de muitos desses povos (situação recorrente no país durante séculos), ou pela ação criminosa de, p.ex., fazendeiros, grileiros, garimpeiros, entre outros, com a intenção de se apossarem das terras ocupadas pelos indígenas, ou pela falta de cuidado dos órgãos oficiais que não tomaram as medidas necessárias para evitar surtos de inúmeras doenças, fatais para os indígenas, como a gripe, o sarampo e a varíola.
} 
tornaram acessíveis os computadores e a própria internet. Deste desenvolvimento tecnológico, não só os tipos de materiais lexicográficos mais tradicionais passam por mudanças significativas, mas também surgem novas tecnologias de bancos de dados, agora eletrônicos. A seguir, apresento a quantidade de UBL's produzidas no século XX:

TABELA $11-$ QUANTIDADE DE UBL'S REFERENTES AO SÉCULO XX
\begin{tabular}{c|l|c}
\hline \multicolumn{1}{|c}{ TIPO DE UBL } & QUANTIDADE \\
\hline 1$)$ & Base de dados & 17 \\
\hline 2$)$ & Complemento de Dicionário & 1 \\
\hline 3$)$ & Dicionário & 111 \\
\hline 4$)$ & Enciclopédia & 1 \\
\hline 5$)$ & Glossário & 27 \\
\hline 6$)$ & Índice & 3 \\
\hline 7$)$ & Léxico & 9 \\
\hline 8$)$ & Lista & 2 \\
\hline 9$)$ & Miniglossário & 1 \\
\hline 10$)$ & Nomenclatura & 663 \\
\hline 11$)$ & Vocabulário & 3 \\
\hline 12$)$ & Não definidos & 892 \\
\hline & & TOTAL \\
\hline
\end{tabular}

Os tipos de UBL que tiveram apenas 1 registro cada representam, com exceção da enciclopédia, formas não comuns no domínio da lexicografia. Com relação à enciclopédia, trata-se de um tipo de material recorrente em sociedades onde a escrita divide espaço com a fala, e que têm uma produção e um uso de materiais escritos de longa data, o que não é o caso da maioria dos povos indígenas.

Com relação às principais UBL's registradas nesse período, as do tipo Dicionário e do tipo Vocabulário são as que estão em maior quantidade e correspondem juntas a $86 \%$ do total. Além desse fator quantitativo, destaco também a melhora significativa em termos qualitativos, conforme pode ser observado na análise das microestruturas desses materiais.

\subsection{UBL's das línguas indígenas brasileiras referentes ao século XXI}

Para o século XXI, foi considerada toda a produção de material lexicográfico destes primeiros 14 anos, mas, apesar do reduzido período, já é possível antever um aumento significativo da quantidade de obras. 
TABELA 12 - QUANTIDADE DE UBL'S REFERENTES AO SÉCULO XXI

\begin{tabular}{c|l|c}
\hline \multicolumn{1}{|c|}{ TIPO DE UBL } & QUANTIDADE \\
\hline 1$)$ & Dicionário & 86 \\
\hline 2$)$ & Glossário & 29 \\
\hline 3$)$ & Índice & 2 \\
\hline 4$)$ & Léxico & 7 \\
\hline 5$)$ & Lista & 22 \\
\hline 6$)$ & Minidicionário & 2 \\
\hline 7$)$ & Vocabulário & 76 \\
\hline & & TOTAL \\
\hline
\end{tabular}

Nesse contexto, o número de dicionários supera o de vocabulário (situação inversa do que foi observado nos dados relativos ao século XX, cf. subseção 7.3.3.3.5.). Além disso, há mais glossários registrados nessas quase duas décadas do século XXI do que o total de glossários registrados em todo o século anterior.

\subsection{Contagem das UBL's das línguas indígenas brasileiras não consideradas na} contagem geral

A título de registro, apresento a seguir o resumo de todos os materiais registrados na base de dados, mas que não foram considerados na contagem geral, por serem, como já foi comentado, materiais republicados ou traduzidos.

TABELA 13 - QUANTIDADE DE UBL'S COMPLEMENTARES

\begin{tabular}{|c|c|c|c|c|c|}
\hline \multirow{2}{*}{ TIPO } & \multicolumn{4}{|c|}{ QUANTIDADE POR SÉCULO } & \multirow{2}{*}{ TOTAL } \\
\hline & XVII & XIX & $\mathrm{XX}$ & XXI & \\
\hline Dicionário & - & - & 2 & 5 & 7 \\
\hline Glossário & - & 4 & 1 & 1 & 6 \\
\hline Índice & - & - & - & 2 & 2 \\
\hline Léxico & - & & 1 & - & 1 \\
\hline Lista & - & 1 & 4 & 3 & 8 \\
\hline Tesouro & - & 1 & - & - & 1 \\
\hline Vocabulário & 2 & 15 & 49 & 19 & 85 \\
\hline Não definidos & - & 1 & - & - & 1 \\
\hline TOTAL & 2 & 22 & 51 & 30 & 111 \\
\hline
\end{tabular}




\subsection{Resumo da contagem de UBL's das línguas indígenas brasileiras}

Ao concluir o levantamento das quantidades de UBL's referentes aos séculos XVI a XXI, apresento, a seguir, o resumo desta contagem:

TABELA 14 - QUANTIDADE TOTAL DE UBL'S

\begin{tabular}{|c|c|c|c|c|c|c|c|}
\hline \multirow{2}{*}{ TIPO } & \multicolumn{6}{|c|}{ QUANTIDADE POR SÉCULO } & \multirow{2}{*}{ TOTAL } \\
\hline & XVI & XVII & XVIII & XIX & $\mathrm{XX}$ & XXI & \\
\hline Base de dados & - & - & - & - & 17 & - & 17 \\
\hline $\begin{array}{l}\text { Complemento de } \\
\text { Dicionário }\end{array}$ & - & - & - & - & 1 & - & 1 \\
\hline Dicionário & - & - & 5 & 3 & 111 & 86 & 205 \\
\hline Enciclopédia & - & - & - & - & 1 & - & 1 \\
\hline Glossário & - & - & - & - & 27 & 29 & 56 \\
\hline Índice & - & - & - & - & 3 & 2 & 5 \\
\hline Léxico & - & - & - & - & 9 & 7 & 16 \\
\hline Lista & - & - & - & 55 & 54 & 22 & 131 \\
\hline Miniglossário & - & - & - & - & 2 & - & 2 \\
\hline Minidicionário & - & - & - & - & - & 2 & 2 \\
\hline Nomenclatura & - & - & - & - & 1 & - & 1 \\
\hline Tesouro & - & 1 & - & - & - & - & 1 \\
\hline Vocabulário & - & 4 & 7 & 230 & 663 & 76 & 978 \\
\hline Não definidos & 1 & - & - & 1 & 3 & - & 5 \\
\hline TOTAL & 1 & 5 & 12 & 289 & 898 & 222 & 1421 \\
\hline
\end{tabular}

Observando a síntese dos dados, concluo que o tipo de UBL mais comum no conjunto lexicográfico das línguas indígenas brasileiras é o Vocabulário, com quase $69 \%$ do total registrado; seguido do Dicionário, com 14\%; e da Lista com pouco mais de 9\%. Vale lembrar que esses totais foram apresentados a partir da tipologia apresentada pelos próprios autores e que o mais relevante nesta etapa é perceber o crescimento exponencial da produção com a melhoria da qualidade das obras lexicográficas das línguas indígenas brasileiras.

\subsubsection{Distribuição das UBL's por língua}

Apresentei algumas considerações na subseção 7.2.1.2 acerca da definição do quadro das línguas indígenas brasileiras, demonstrando a grande dificuldade de se estabelecer com exatidão este conjunto. Assim, para viabilizar o desenvolvimento desta pesquisa, adotei como base para classificação das línguas indígenas brasileiras a proposta feita por Rodrigues 
(2013), por ela ser uma das mais atuais e confiáveis, pois ela é resultado de mais de meio século de reflexões de um dos nomes mais importantes da linguística contemporânea.

A essa proposta, que identifica quase duzentas línguas indígenas brasileiras, das quais aproximadamente 180 ainda faladas no país, foi necessário acrescentar informações sobre línguas já desaparecidas, mas que foram registradas, principalmente por meio de documentos lexicográficos. Além disso, foram mantidos no registro do banco de dados as várias denominações de línguas desconhecidas, como aquelas feitas pelos diversos viajantes no século XIX (cf. subseção 7.2.1.2). ${ }^{96}$

Desse modo, o total de registros de línguas indígenas brasileiras do banco de dados com, pelo menos, uma UBL, chegou a 309, isto sem contar com mais 23 línguas que estavam na lista original de Rodrigues (2013) e para as quais nenhum material lexicográfico foi localizado até a conclusão dessa primeira fase da presente pesquisa. São elas: Aikanã (Aikaná, Tubarão), Apolíma-Arára, Arapáso (Arapaço) (†), Aurê-Aurá, Banawá (BanawáYafî), Diahói (Diarroi, Jiahúi), Kaixána, Katuéna, Kontanáwa, Mandúka, Matipú, Miritítapúya, Mundúka, Nagarotú, Nambikwára del Pequizal, Nambikwára del Sur, Nambikwára del Valle del Guaporé, Sararé, Tenharim, Torá, Xambioá, Xawanáwa (Arara), Yanomám.

No entanto, é importante destacar que desse total de 309 registros, 103 não possuem mais do que um vocabulário. Assim, para não estender demasiadamente a tabela com o resumo de dados por língua, apresento as línguas que possuem apenas uma UBL do tipo vocabulário: Akroá (Coroá) (†), Akuntsú, Amanayé (Amanajé), Amõkapitöri, Araicu (Uaraicú), Arara do Beiradão (A. do Aripuanã)?, Arara do Xingu (Ukarangmã), Arauajú (Uara-guaçú), Aruac (Aruwaac, Aroaqui), Aticum (Araticum) (†), Canamirim (Canamare), Cariaŷ, Cauixana, Cayriri, Coëruna, Coretú, Coroado (Aldea da Pedra), Cotoxó, Curetú, Djiporóka (Xiporók), Gaméla (†), Geicó, Guachí, Guajá (Awá), Huhúdene, Íde-masã, Iquitos, Jaúna, Jaun-avo (Caripuna), Javaé, Jucúna, Júma, Jumana, Jupuá, Juri, Kaimbé (†), Kambiwá, Karapanã, Katawixí, KôhôrôšItari, Korúbo, Krekmún (Kraik-mús) (†), Krixaná (†), Kumãdene, Lakondê, Makiritaré (Dekuána, Deukwana), Makúna (Yebamasã), Manao (OreManao), Manitsauá, Marauha, Mariaté, Masacará, Maxuruna, Maxuruna doméstica, Maxuruna fera, Meniens, Mondé?, Mucury, Nadêb, Nenê, Palmela (†), Panos, Paravilhana, Passé, Patagon, Pauatê, Pebas, Pimenteira, Poianaua, Potiguára (Petigaré) (†), Pykopjê (Gavião), Rangú, Remo, Sabujá, Saynáwa, Siwsi, Sukuružú, Suruí do Tocantins (Aikewára),

${ }^{96}$ Essas informações foram mantidas, porque essas línguas desconhecidas podem servir como fonte de informação válida para novas pesquisas linguísticas, já que elas foram documentadas, da mesma maneira que as línguas hoje conhecidas. 
Suryana, Suyá (Kisédje), Tamaindé, Tatú, Tawité (Tawite), Tsẽna, Tutxiunaua, Tuxá (Tushá), Txunhuã-djapá (Tsohom-djapá), Uainuma, Uírina, Uru-eu-wau-wáu, Urumí (†), Xaranáwa, Yaguas, Yamamadí (Carabinani, Capaná) (†), Yawarete, Yebá, Yehúbde, Yuriti, Yurupari, Zapara, Žiboya, Zoé (Jo’é), Camé.

Uma vez extraídas todas as ocorrências de registros que continham apenas um vocabulário, apresento, a seguir, a tabela com os 206 registros de UBL's restantes:

TABELA 15 - QUANTIDADE DE UBL'S REGISTRADAS POR LÍNGUA

\begin{tabular}{|c|c|c|c|c|}
\hline Seq & Família & Línguas & Quant. por tipo de UBL's & Total \\
\hline 1. & Páno & Amawáka & Dicion.: 2; Vocab.: 1 & 3 \\
\hline 2. & Tupí-Guaraní & Amondáwa & Léx.: 1; Vocab.: 2 & 3 \\
\hline 3. & Tupí-Guaraní & Anambé & Vocab.: 2 & 2 \\
\hline 4. & Nambikwára & Anunzé (Soálesu) & Vocab.: 2 & 2 \\
\hline 5. & Jê & Apaniekrá (Canela, Timbira) & BD: 1; List.: 2; Vocab.: 7 & 10 \\
\hline 6. & Karíb & Aparaí (Apalaí) & List.: 2; Vocab.: 10 & 12 \\
\hline 7. & Tupí-Guaraní & Apiaká (Apiacá) & List.: 2; Vocab.: 9 & 11 \\
\hline 8. & Jê & Apinajé (Apinayé) & Dicion.: 2; List.: 2; Vocab.: 10 & 14 \\
\hline 9. & Aruák & Apurinã (Ipurinã) & Dicion.: 2; List.: 2; Vocab.: 4 & 8 \\
\hline 10. & Tupí-Guaraní & Araweté & Gloss.: 1; Vocab.: 1 & 1 \\
\hline 11. & Jabutí & Arikapú & Dicion.: 1; Gloss.: 1; Léx.: 1; Vocab.: 4 & 7 \\
\hline 12. & Arikém & Arikém & List.: 1; Vocab.: 2 & 3 \\
\hline 13. & Mondé & Aruá & Gloss.: 2; Vocab.: 5 & 7 \\
\hline 14. & Tupí-Guaraní & Asuriní do Tocantins (Akuáwa) & Dicion.: 2; List.: 2; Vocab.: 3 & 7 \\
\hline 15. & Tupí-Guaraní & Asuriní do Xingu (Awaeté) & Dicion.: 1; Gloss.: 1; Vocab.: 3 & 5 \\
\hline 16. & Tupí-Guaraní & Avá-Canoeiro & List.: 4; Vocab.: 4 & 8 \\
\hline 17. & Awetí & Awetí & Vocab.: 3 & 3 \\
\hline 18. & Karíb & Bakairí (Kúra) & List.: 1; Vocab.: 9 & 10 \\
\hline 19. & Aruák & Baníwa do Içana & Dicion.: 1; List.: 1; Vocab.: 8 & 10 \\
\hline 20. & Tukáno & Bará & Vocab.: 2 & 2 \\
\hline 21. & Tukáno & Barasána & Dicion.: 1; Léx.: 1; Vocab.: 2 & 4 \\
\hline 22. & Aruák & Baré $(\dot{t})$ & Vocab.: 5 & 5 \\
\hline 23. & Boróro & Boróro (Bóe) & $\begin{array}{l}\text { Dicion.: 3; Enciclopédia: 1; List.: 2; } \\
\text { Nomenclatura: 1; Vocab.:9 }\end{array}$ & 16 \\
\hline 24. & Samuko & Chamacoco & Dicion.: 1 & 1 \\
\hline 25. & Chiquito & Chiquito (Chiquitano) & Vocab.: 4 & 4 \\
\hline 26. & Mondé & Cinta-Larga & Vocab.: 6 & 6 \\
\hline 27. & Purí & Coroado (†) & List.: 1; Vocab.: 3 & 4 \\
\hline 28. & Purí & Coropó (t) & List.: 1; Vocab.: 3 & 4 \\
\hline
\end{tabular}




\begin{tabular}{|c|c|c|c|c|}
\hline 29. & Makú & $D \hat{a} w($ Kamã) & Vocab.: 2 & 2 \\
\hline 30. & Arawá & Dení & Dicion.: 2; Vocab.: 1 & 3 \\
\hline 31. & Tukáno & Desána (Desáno) & Dicion.: 3; Vocab.: 4 & 7 \\
\hline 32. & Tupí-Guaraní & Émérillon & Léx.: 1; Vocab.: 1 & 2 \\
\hline 33. & Karíb & Galibí do Oiapoque (Karíña) & Dicion.: 2; Vocab.: 7 & 9 \\
\hline 34. & Karíb & Galibí do Uaçá (G. Marworno) & Dicion.: 2; Vocab.: 2 & 4 \\
\hline 35. & Mondé & Gavião (Ikõro, Digüt) & Vocab.: 3 & 3 \\
\hline 36. & Tupí-Guaraní & Guajajára (Tenetehára) & Dicion.: 2; List.: 1; Vocab.: 8 & 11 \\
\hline 37. & Aruák & Guaná & List.: 2; Vocab.: 4 & 6 \\
\hline 38. & Tupí-Guaraní & Guarani Antigo (†) & Dicion.: 1; List.: 1; Tesouro: 1; Vocab.: 4 & 7 \\
\hline 39. & Guató & Guató & Dicion.: 2; List.: 3; Vocab.: 8 & 13 \\
\hline 40. & Tupí-Guaraní & Guayakí (Ache) & Dicion.: 2 & 2 \\
\hline 41. & Jê & Guayaná $(\grave{t})$ & Vocab.: 5 & 5 \\
\hline 42. & Karíb & Hixkaryána (Hixkariána) & Vocab.: 2 & 2 \\
\hline 43. & Makú & Húpda & Dicion.: 3; Vocab.: 9 & 12 \\
\hline 44. & Karíb & Ikpéng (Txikão) & List.: 1; Vocab.: 2 & 3 \\
\hline 45. & Jê & $\operatorname{Ingain}(\dagger)$ & Vocab.: 3 & 3 \\
\hline 46. & Karíb & Ingarikó & Vocab.: 3 & 3 \\
\hline 47. & Irántxe & Irántxe (Iránxe) & Vocab.: 4 & 4 \\
\hline 48. & Jabutí & Jabutí (Jeoromitxi) & Gloss.: 2; Vocab.: 8 & 10 \\
\hline 49. & Arawá & Jamamadi (Kanamantí) & Vocab.: 4 & 4 \\
\hline 50. & Arawá & Jarawára & Dicion.: 1; Gloss.: 1 & 2 \\
\hline 51. & Jurúna & Jurúna (Yudjá) & List.: 1; Vocab.: 6 & 7 \\
\hline 52. & Tupí-Guaraní & Ka'apór (Urubu) & Dicion.: 2; Gloss.: 1; List.: 1; Vocab.: 6 & 10 \\
\hline 53. & Guaikurú & Kadiwéu (Cadivéu) & Dicion.: 2; List.: 2; Vocab.: 7 & 11 \\
\hline 54. & Jê & Kaingáng (Caingangue) & $\begin{array}{l}\text { BD: 1; Dicion.: 8; Gloss.: 1; List.: 1; } \\
\text { Vocab.: } 31\end{array}$ & 42 \\
\hline 55. & Tupí-Guaraní & Kaiwá (Kayowá) & Gloss.: 1; List.: 2; Vocab.: 6 & 9 \\
\hline 56. & Karíb & Kalapálo & Gloss.: 1; Vocab.: 2 & 3 \\
\hline 57. & Kamakan & Kamakan $(\dagger)$ & List.: 1; Vocab.: 4 & 5 \\
\hline 58. & Tupí-Guaraní & Kamayurá & Gloss.: 2; List.: 2; Vocab.: 5 & 9 \\
\hline 59. & Aruák & Kámpa (Axaninka, Ashininka) & Dicion.: 4; List.: 1; Vocab.: 1 & 6 \\
\hline 60. & Katukína & Kanamarí & Vocab.: 3 & 3 \\
\hline 61. & Páno & Kanawari $(\dagger)$ & List.: 1 & 1 \\
\hline 62. & Kanoê & Kanô̂ & Dicion.: 2; Vocab.: 4 & 6 \\
\hline 63. & Karajá & Karajá (Carajá) & BD: 1; Gloss.: 1; List.: 2; Vocab.: 23 & 27 \\
\hline 64. & Tupí-Guaraní & Karipúna & Vocab.: 2 & 2 \\
\hline 65. & Páno & Karipúna & Vocab.: 3 & 3 \\
\hline 66. & Românica & Karipúna do Amapá & Dicion.: 2; List.: 1; Vocab.: 1 & 4 \\
\hline
\end{tabular}




\begin{tabular}{|c|c|c|c|c|}
\hline 67. & Arikém & Karitiána & Dicion.: 3; Gloss.: 1; Vocab.:2 & 6 \\
\hline 68. & Ramaráma & Káro (Arara) & Vocab.: 4 & 4 \\
\hline 69. & Páno & Katukína & BD: 1; MiniGloss.: 2; Vocab.: 3 & 6 \\
\hline 70. & Katukína & Katukína & Vocab.: 4 & 4 \\
\hline 71. & Páno & Kaxararí & List.: 1; Vocab.: 2 & 3 \\
\hline 72. & Páno & Kaxinawá, Caxinauá & Dicion.: 2; Vocab.: 9 & 11 \\
\hline 73. & Karíb & Kaxuyána (Katxuyána) & Vocab.: 2 & 2 \\
\hline 74. & Tupí-Guaraní & Kayabí (Caiabi, Kaiabí) & Dicion.: 3; Gloss.: 1; List.: 1; Vocab.: 6 & 11 \\
\hline 75. & Jê & Kayapó (Mebengokré) & Dicion.: 3; Gloss.: 1; List.: 5; Vocab.: 14 & 23 \\
\hline 76. & Mondé & Kepkeriwát & Vocab.: 2 & 2 \\
\hline 77. & Kirirí & Kiriri $(\dagger)$ & List.: 2; Vocab.: 8 & 10 \\
\hline 78. & mista & Kokáma (Omágua, Cambeba) & Dicion.: 1; Vocab.: 9 & 10 \\
\hline 79. & Nambikwára & Kokozú (Uaindze, Ualíxere) & Vocab.: 2 & 2 \\
\hline 80. & Jê & $\operatorname{Krahô}($ Craô) & Gloss.: 1; List.: 1; Vocab.: 8 & 10 \\
\hline 81. & Krenák & Krenák (Botocudo) & List.: 4; Vocab.: 31 & 35 \\
\hline 82. & Jê & Krenyé (Tañe) & Vocab.: 3 & 3 \\
\hline 83. & Jê & Krikatí (Timbira) & Vocab.: 2 & 2 \\
\hline 84. & Tukáno & Kubéwa (Kubéo) & Dicion.: 3; Vocab.: 9 & 12 \\
\hline 85. & Karíb & Kuikúru & Gloss.: 1; Vocab.: 2 & 3 \\
\hline 86. & Txapakúra & Kujubim (Kuyubí) & Léx.: 2 & 2 \\
\hline 87. & - & Kukura $(\dagger)$ & List.: 1 & 1 \\
\hline 88. & Arawá & Kulína (Kurína, Madihá) & Dicion.: 2; Vocab.: 2 & 4 \\
\hline 89. & Páno & Kulíno (Kulína) & Vocab.: 4 & 4 \\
\hline 90. & Maxakalí & Kumanasho (†) & Vocab.: 2 & 2 \\
\hline 91. & Aruák & Kuripáko & Vocab.: 2 & 2 \\
\hline 92. & Mundurukú & Kuruáya & List.: 2; Vocab.: 3 & 5 \\
\hline 93. & Aruák & Kustenáu & Vocab.: 2 & 2 \\
\hline 94. & Kwazá & Kwazá (Kwayá, Coaiá) & Índice: 1 ; Vocab.: 2 & 3 \\
\hline 95. & Nambikwára & Latundê & Dicion.: 1 & 1 \\
\hline 96. & Tupí-Guaraní & Língua Geral Amazônica & Dicion.: 10; Léx.: 1; List.: 3; Vocab.: 21 & 35 \\
\hline 97. & Tupí-Guaraní & Lingua Geral Paulista (†) & Vocab.: 4 & 4 \\
\hline 98. & - & Maconi & Vocab.: 2 & 2 \\
\hline 99. & Karíb & $\begin{array}{l}\text { Makiritaré (Dekuána, } \\
\text { Deukwana) }\end{array}$ & Vocab.: 2 & 2 \\
\hline 100. & Makú & Makú & List.: 1 & 1 \\
\hline 101. & isolada & Máku & Vocab.: 2 & 2 \\
\hline 102. & Tuparí & Makuráp & Dicion.: 1; Gloss.: 2; Vocab.: 6 & 9 \\
\hline 103. & Karíb & Makuxí & BD: 1; Dicion.: 2; Vocab.: 13 & 16 \\
\hline 104. & Maxakalí & Malali $(\dagger)$ & Vocab.: 4 & 4 \\
\hline
\end{tabular}




\begin{tabular}{|c|c|c|c|c|}
\hline 105. & Nambikwára & Mamaindê & Dicion.: 1; Vocab.: 3 & 4 \\
\hline 106. & Páno & Marúbo & List.: 2; Vocab.: 6 & 8 \\
\hline 107. & Páno & Matís & Dicion.: 1; Vocab.: 3 & 4 \\
\hline 108. & Páno & Matsés (Mayorúna) & Dicion.: 1; Vocab.: 7 & 8 \\
\hline 109. & Mawé & Mawé (Sateré-Mawé) & Dicion.: 3; List.: 2; Vocab.: 9 & 14 \\
\hline 110. & Maxakalí & Maxakali & Dicion.: 3; Gloss.: 4; List.: 2; Vocab.: 9 & 18 \\
\hline 111. & Aruák & Maxinéri (Manchineri) & Dicion.: 1; List.: 1 & 2 \\
\hline 112. & Tupí-Guaraní & Mbyá & Dicion.: 3; Gloss.: 1; List.: 1; Vocab.: 2 & 7 \\
\hline 113. & Tupí-Guaraní & Mbyá- Nandeva & índice: 1 ; Vocab.: 3 & 4 \\
\hline 114. & Aruák & Mehináku (Meinaco) & Dicion.: 1; Vocab.: 3 & 4 \\
\hline 115. & Tuparí & Mekém (Sakirabiat) & Vocab.: 2 & 2 \\
\hline 116. & Bóra & Miránha & Vocab.: 5 & 5 \\
\hline 117. & Txapakúra & Moré & Dicion.: 1; Léx.: 2 & 3 \\
\hline 118. & Mundurukú & Mundurukú & $\begin{array}{l}\text { BD: 1; Dicion.: 2; Gloss.: 1; List.: 5; } \\
\text { Vocab.: } 13\end{array}$ & 22 \\
\hline 119. & Múra & Múra & List.: 3; Vocab.: 2 & 5 \\
\hline 120. & Karíb & Mutuan (?) & Vocab.: 1; Dicion.:4; List.: 1; Vocab.: 1 & 7 \\
\hline 121. & Karíb & Nahukwá & Vocab.: 4 & 4 \\
\hline 122. & Krenák & Naknanúk (Nakyananiuk) & Vocab.: 2 & 2 \\
\hline 123. & Nambikwára & $\begin{array}{l}\text { Nambikwára Kithaulú } \\
\text { (Sawantesú e outros) }\end{array}$ & Dicion.: 2; Gloss.: 2; Vocab.: 2 & 6 \\
\hline 124. & Tupí-Guaraní & Ñandeva Tambeopé & Gloss.: 2 & 2 \\
\hline 125. & Tupí-Guaraní & $\tilde{N}$ andeva-Txiripá & Dicion.: 1 & 1 \\
\hline 126. & Yanomámi & Ninám & BD: 1; Léx.: 1 & 2 \\
\hline 127. & Ramaráma & Ntogapid (†) & Vocab.: 2 & 2 \\
\hline 128. & Páno & Nukuiní (Remo, Rheno) & Vocab.: 2 & 2 \\
\hline 129. & Ofayé & Ofayé (Opaié, Ofayé-Xavánte) & Vocab.: 3 & 3 \\
\hline 130. & $-?$ & Omágua & List.: 2; Vocab.: 1 & 3 \\
\hline 131. & Txapakúra & Orowin (Oro Win) & List.: 1 ; Vocab.: 1 & 2 \\
\hline 132. & - & Otí(†) & Vocab.: 2 & 2 \\
\hline 133. & Mondé & Paitér (Suruí de Rondonia) & Dicion.: 2; Gloss.: 1; List.: 1; Vocab.: 2 & 6 \\
\hline 134. & Aruák & Palikúr & Dicion.: 1; Vocab.: 9 & 10 \\
\hline 135. & Jê & $\begin{array}{l}\text { Panará (Kayapó del Sur, Kren- } \\
\text { akarôre) }\end{array}$ & List.: 1; Vocab.: 3 & 4 \\
\hline 136. & - & Pankarú (Pankararú) & Vocab.: 4 & 4 \\
\hline 137. & Tupí-Guaraní & Parakanã (Apiteréwa) & Dicion.: 1; Vocab.: 2 & 3 \\
\hline 138. & Aruák & Paresí (Pareci, Halití) & Dicion.: 3; List.: 2; Vocab.: 7 & 12 \\
\hline 139. & Tupí-Guaraní & Parintintín & Dicion.: 2; Gloss.: 1; List.: 1; Vocab.: 5 & 9 \\
\hline 140. & Karíb & Parirí (Arára) (†?) & List.: 1; Vocab.: 1 & 2 \\
\hline
\end{tabular}




\begin{tabular}{|c|c|c|c|c|}
\hline 141. & Jê & Parkatejê & Dicion.: 1; Gloss.: 1; Vocab.: 1 & 3 \\
\hline 142. & Karíb & Patamóna (Kapóng) & Vocab.: 2 & 2 \\
\hline 143. & Maxakalí & Pataxó & Dicion.: 1; List.: 5; Não def.: 1; Vocab.: 8 & 15 \\
\hline 144. & Arawá & Paumarí & Dicion.: 1; List.: 1; Vocab.: 1 & 3 \\
\hline 145. & Múra & Pirahã (Múra-Pirahã) & Vocab.: 2 & 2 \\
\hline 146. & Tukáno & Pirá-tapúya (Waíkana) & Vocab.: 4 & 4 \\
\hline 147. & Páno & Poyanáwa & Gloss.: 1; Vocab.: 1 & 2 \\
\hline 148. & Purí & Purí (†) & List.: 1; Vocab.: 2 & 3 \\
\hline 149. & Puruborá & Puruborá & List.: 1 & 1 \\
\hline 150. & Ramaráma & Ramaráma (Ytangá) & List.: 1; Vocab.: 1 & 2 \\
\hline 151. & Jê & $\begin{array}{l}\text { Ramkokamekrã (Canela, } \\
\text { Timbira) }\end{array}$ & Dicion.: 4; Gloss.: 1; Vocab.: 2 & 7 \\
\hline 152. & Rikbáktsa & Rikbáktsa (Rikbák, Canoeiro) & Dicion.: 2; Vocab.: 3 & 5 \\
\hline 153. & Nambikwára & Sabanê & Vocab.: 2 & 2 \\
\hline 154. & Aruák & Salumã (Enawenê-nawê) & List.: 1; Vocab.: 1 & 2 \\
\hline 155. & Yanomámi & Sanumá & Dicion.: 1; Gloss.: 1; Vocab.: 1 & 3 \\
\hline 156. & Tukáno & Siriána (Siriáno) & Vocab.: 2 & 2 \\
\hline 157. & Tupí-Guaraní & Sirionó (Horá, Jorá) & BD: 1; List.: 1 & 2 \\
\hline 158. & Nambikwára & Tagnaní & Vocab.: 2 & 2 \\
\hline 159. & Jê & Tapayúna & Dicion.: 1; Vocab.: 1 & 2 \\
\hline 160. & Tupí-Guaraní & Tapirapé & Gloss.: 1; Vocab.: 3 & 4 \\
\hline 161. & Aruák & Tariána (Tariáno) & Dicion.: 5; Vocab.: 6 & 11 \\
\hline 162. & Karíb & Taulipáng (Pemong) & Gloss.: 2; Vocab.: 2 & 4 \\
\hline 163. & Nambikwára & Tawandê & List.: 1 & 1 \\
\hline 164. & Tupí-Guaraní & Tembé & Dicion.: 2; List.: 2; Vocab.: 5 & 9 \\
\hline 165. & Aruák & Teréna & Dicion.: 6; Vocab.: 4 & 10 \\
\hline 166. & Tikúna & Tikúna (Tukúna) & List.: 1; Vocab.: 13 & 14 \\
\hline 167. & Jê & Timbira (Canela, Gavião) & List.: 1; Vocab.: 1 & 2 \\
\hline 168. & Karíb & Tiriyó (Tirió, Trio) & Dicion.: 1; Vocab.: 8 & 9 \\
\hline 169. & Trumái & Trumái & BD: 1; Gloss.: 1; Vocab.: 4 & 6 \\
\hline 170. & Tukáno & Tukáno (Tukána, Yepámasã) & Dicion.: 4; Gloss.: 1; Léx.: 1; Vocab.: 12 & 18 \\
\hline 171. & Tuparí & Tuparí & Dicion.: 4; Gloss.: 1; Vocab.: 2 & 7 \\
\hline 172. & Tupí-Guaraní & Tupinambá (Tupí Antigo) (†) & $\begin{array}{l}\text { Complemento de Dicion.: 1; Dicion.: 15; } \\
\text { Gloss.: 1; Léx.: 1; List.: 3; MiniDicion.: } \\
\text { 1; Não def.: 2; Vocab.: } 31\end{array}$ & 55 \\
\hline 173. & Tukáno & Tuyúka & Vocab.: 2 & 2 \\
\hline 174. & Boróro & Umutina & Gloss.: 2; Vocab.: 7 & 9 \\
\hline 175. & Txapakúra & Urupá & Vocab.: 2 & 2 \\
\hline 176. & Karíb & Waimirí (Waimirí-Atroarí) & Dicion.: 2; Vocab.: 3 & 5 \\
\hline
\end{tabular}




\begin{tabular}{|c|c|c|c|c|}
\hline 177. & Karíb & Waiwái & BD: 1; Dicion.: 3; Vocab.: 3 & 7 \\
\hline 178. & Tukáno & Wanáno (Wanána) & Dicion.: 1; Vocab.: 4 & 5 \\
\hline 179. & Aruák & Wapixána & BD: 1; Dicion.: 4; List.: 3; Vocab.: 6 & 14 \\
\hline 180. & Aruák & Warekéna (Werekéna) & Dicion.: 3; List.: 2; Vocab.: 4 & 9 \\
\hline 181. & Txapakúra & Warí (Pakaanóva) & BD: 1; Dicion.: 2; List.: 1; Vocab.: 2 & 6 \\
\hline 182. & Aruák & Waurá & BD: 1; Vocab.: 6 & 7 \\
\hline 183. & Tupí-Guaraní & Wayampí (Oyampi) & $\begin{array}{l}\text { BD: 1; Dicion.: 2; Gloss.: 1; Índice: 1; } \\
\text { Léx.: 1; List.: 1; Vocab.: } 9\end{array}$ & 16 \\
\hline 184. & Karíb & Wayána & Dicion.: 1; List.: 1; Não def.: 1; Vocab.: 5 & 8 \\
\hline 185. & Tuparí & Wayoró (Ajurú) & Gloss.: 2; Vocab.: 3 & 5 \\
\hline 186. & Tupí-Guaraní & Wiraféd & Vocab.: 2 & 2 \\
\hline 187. & Witóto & Witóto & Vocab.: 3 & 3 \\
\hline 188. & Jê & Xakriabá (Xikriabá) & Vocab.: 3 & 3 \\
\hline 189. & Páno & Xanenáwa & Léx.: 2 & 2 \\
\hline 190. & Jê & Xavánte (A'wén) & Dicion.: 5; List.: 3; Vocab.: 14 & 22 \\
\hline 191. & Jê & Xerénte (Akwén) & Dicion.: 2; List.: 1; Vocab.: 9 & 12 \\
\hline 192. & Tupí-Guaraní & Xetá & Vocab.: 7 & 7 \\
\hline 193. & Jê & Xikrín & Vocab.: 3 & 3 \\
\hline 194. & Jurúna & Xipáya & BD: 1; List.: 3; Vocab.: 2 & 6 \\
\hline 195. & Jê & Xokléng (Xokrén) & Dicion.: 1; MiniDicion.: 1; Vocab.: 4 & 6 \\
\hline 196. & Xukurú & Xukurú & Vocab.: 2 & 2 \\
\hline 197. & Páno & Yamináwa (Jaminaua) & BD: 1; Vocab.: 1 & 2 \\
\hline 198. & Yanomámi & Yanomámi & $\begin{array}{l}\text { BD: 1; Dicion.: 8; Gloss.: 2; List.: 2; } \\
\text { Vocab.: } 1\end{array}$ & 14 \\
\hline 199. & Yatê & Yatê (Carnijó, Fulniô) & Dicion.: 1; List.: 1; Não def.: 1; Vocab.: 8 & 11 \\
\hline 200. & Aruák & Yawalapití & Gloss.: 1; List.: 1; Vocab.: 2 & 4 \\
\hline 201. & Páno & Yawanáwa (Jaminaua) & Vocab.: 2 & 2 \\
\hline 202. & Páno & Yawanáwa (Yawanawá) & Vocab.: 2 & 2 \\
\hline 203. & Karíb & Yekuána (Mayongóng) & Gloss.: 1; Vocab.: 1 & 2 \\
\hline 204. & Makú & Yuhúp & Dicion.: 2; Gloss.: 2; Vocab.: 1 & 5 \\
\hline 205. & Mondé & Zoró & Vocab.: 2 & 2 \\
\hline 206. & Arawá & Zuruahá (Suruahá) & Dicion.: 1; Vocab.: 1 & 2 \\
\hline \multicolumn{4}{|r|}{ TOTAL } & 1318 \\
\hline
\end{tabular}

Algumas considerações acerca dos dados apresentados nesta seção:

1) As dez línguas indígenas brasileiras com maior quantidade de UBL's já produzidas até hoje (com um quinto do total de registros) são:

- Tupinambá (Tupí Antigo) (55 UBL's ou 3,87\% do total);

- Kaingáng (42 UBL's ou 2,95\%); 
- Krenák (Botocudo) (35 UBL’s ou 2,46\%);

- Lingua Geral Amazônica (Nheengatú) (35 UBL's ou 2,46\%);

- Karajá (Carajá) (27 UBL's ou 1,90\%)

- Kayapó (Mebengokré) (23 UBL’s ou 1,61\%);

- Mundurukú (22 UBL's ou 1,54\%);

- Xavánte (A'wén) (22 UBL's ou 1,54\%);

- Maxakalí (18 UBL's ou 1,26\%);

- Tukáno (Tukána, Yepámasã) (18 UBL’s ou 1,26\%).

2) As línguas com 4 ou mais UBL's do tipo Dicionário são: Tupinambá (15), Língua Geral Amazônica (10), Kaingáng (8), Yanomámi (8), Teréna (6), Tariána (5), Xavánte (5), Kámpa (Axaninka) (4), Ramkokamekrã (Canela, Timbira) (4), Tukáno (4), Tuparí (4), Wapixána (4).

3) Como as UBL's do tipo Vocabulário são bem mais numerosas no corpus do que as do tipo Dicionário, relaciono, a seguir, as línguas que possuem 10 ou mais desses registros: Kaingáng (31), Krenák (Botocudo) (31), Tupinambá (31), Karajá (23), Língua Geral Amazônica (21), Kayapó (Mebengokré) (14), Xavánte (A’wén) (14), Makuxí (13), Mundurukú (13), Tikúna (Tukúna) (13), Tukáno (12), Aparaí (10), Apinajé (10).

4) Como esta tese tem também um interesse no estudo de uma língua específica da Família Tupí-Guaraní, ou seja, o Suruí do Tocantins ou Aikewára, é necessário destacar que para ela foi registrado apenas uma UBL. ${ }^{97}$ Assim como ocorreu com muitas outras línguas ainda vivas, esse dado demonstra o quanto ainda pode ser feito em termos de trabalho lexicográfico. Tanto que, esta mesma tese, busca contribuir com o desenvolvimento dos processos de documentação de línguas indígenas brasileiras, mas também pretende apresentar novos materiais lexicográficos para essa língua.

5) Ao concluir a coleta de dados para esta etapa da pesquisa, não foram encontrados registros para as 23 línguas acima mencionadas (cf. subseção 7.3.3.4), contudo, isso não significa que, definitivamente, não existam materiais lexicográficos relacionados a elas. Eis, portanto, uma das razões para prosseguir esse estudo.

\footnotetext{
${ }^{97}$ Apesar de o contato com os não indígenas ter sido efetivado há mais de 60 anos (cf. Capítulo 2), os Suruí não contam ainda sequer com um dicionário ou gramática de sua língua. No entanto, merece destaque o trabalho pioneiro de Ruth Monserrat na década de 1980, quando ela, com o apoio do CIMI, fez os primeiros registros da língua Suruí e elaborou o primeiro vocabulário dessa língua, o Vocabulário Aikewar.
} 
Para concluir esta parte do levantamento de UBL's para as línguas indígenas brasileiras, apresento as quantidades relacionadas aos materiais não considerados na contagem geral, por serem reproduções de materiais já contidos no corpus principal. São 111 registros distribuídos para 60 línguas, relacionadas a seguir: Apiaká (Vocab.: 2), Apurinã (Dicion.: 1), Arara do Beiradão (Vocab.: 2), Arara do Xingu (Vocab.: 1), Awetí (Vocab.: 1), Bakairí (Kúra) (Vocab.: 2), Boróro (Bóe) (Vocab.: 2), Cinta-Larga (Vocab.: 1), Galibí do Oiapoque (Dicion.: 1; Vocab.: 1), Gavião (Ikõro, Digüt) (Vocab.: 1), Guaná (Vocab.: 2), Guaraní Antigo (†) (Tesauro; 1; Vocab.: 5), Guayaná (†) (Gloss.: 1), Ingain (†) (Vocab.: 2), Jarawára (Dicion.: 1; Gloss.: 1), Jurúna (Vocab.: 1), Ka’apór (Urubu) (Vocab.: 1), Kaingáng (Vocab.: 3), Kaiwá (Vocab.: 1), Kamayurá (Vocab.: 2), Karajá (Gloss.: 1), Kaxinawá (Vocab.: 1), Kayapó (Mebengokré) (Gloss.: 1; Vocab.: 1), Krenák (Lista:3; Vocab.: 4), Kujubim (Léxico: 1), Kustenáu (Vocab.: 2), Língua Geral Amazônica (Vocab.: 4), Língua Geral Paulista (†) (Vocab.: 1), Makuxí (Vocab.: 1), Matsés (Mayorúna) (Dicion.: 1; Índice: 2), Maxakalí (Vocab.: 1), Mehináku (Vocab.: 1), Mekém (Vocab.: 1), Nahukwá (Vocab.: 3), Ntogapíd (†) (Lista: 1), Ofayé (Vocab.: 2), Pakidái (Vocab.: 1), Palmela (†) (Vocab.: 2), Panará (Vocab.: 2), Paresí (Vocab.: 1), Pataxó (Vocab.: 1), Purí (†) (Vocab.: 1), Ramaráma (Lista: 1), Surára (Vocab.: 1), Suyá (Vocab.: 1), Tikúna (Vocab.: 1), Trumái (Vocab.: 1), Tukáno (Vocab.: 1), Tupinambá (†) (Dicion.: 1; Lista: 2; Vocab.: 6), Warekéna (Lista: 1; Vocab.: 1), Waurá (Vocab.: 1), Xakriabá (Vocab.: 2), Xavánte (A’wén) (Gloss.: 1; Vocab.: 5), Xerénte (Akwén) (Gloss.: 1), Xetá (Vocab.: 3), Yanomámi (Dicion.: 2), Yanumakapü (Vocab.: 1), Yarumá (Vocab.: 1), Yatê (Não defin.: 1), Yawalapití (Vocab.: 1).

Nesse conjunto de línguas acima, há somente 5 delas com 4 ou mais UBL's: Tupinambá (9), Krenák (7), Guaraní Antigo (6), Xavánte (A’wén) (6) e Língua Geral Amazônica (4).

\subsubsection{Distribuição das UBL's por quantidade de entradas}

Como não foi possível concluir o levantamento da quantidade de entradas de cada UBL das línguas estudadas, apresento os dados parciais, porque deles já é possível começar a depreender alguns fatos relevantes para esta pesquisa, como, por exemplo, verificar se há alguma relação entre o tipo de material e a sua respectiva quantidade de entradas.

Assim, das 1421 UBL's consideradas nesta contagem, 550 ainda não possuem o cômputo do total de entradas. Logo, os dados a seguir correspondem às 871 UBL's restantes, ou seja, a $61,29 \%$ do total de UBL's. 
Como a intenção deste trabalho é também determinar em que faixa de quantidade de entradas os materiais analisados se encaixam, não apresento as suas quantidades absolutas.

\section{QUADRO 20 - DISTRIBUIÇÃO DAS 871 UBL'S DE ACORDO COM A PROPOSTA DE CLASSIFICAÇÃO QUANTITATIVA POR FAIXAS}

\begin{tabular}{|c|c|}
\hline $\begin{array}{l}\text { FAIXA DE QUANT. } \\
\text { DE ENTRADA }\end{array}$ & $\begin{array}{l}\text { QUANTIDADE DE UBL'S } \\
\text { POR FAIXA COM PERCENTUAL }\end{array}$ \\
\hline A1 (01 a 36) & $164(18,82 \%)$ \\
\hline A2 (37 a 72$)$ & $110(12,62 \%)$ \\
\hline A3 (73-144) & $181(20,78 \%)$ \\
\hline A4 (145 a 288) & $162(18,59 \%)$ \\
\hline A5 (289 a 576) & $123(14,12 \%)$ \\
\hline B1 (577 a 1.152) & $79(9,07 \%)$ \\
\hline B2 (1.153 a 2.304) & $26(2,98 \%)$ \\
\hline B3 (2.305 a 4.608) & $17(1,95 \%)$ \\
\hline B4 (4.609 a 9.216) & $6(0,68 \%)$ \\
\hline B5 (9.217 a 18.432) & $3(0,34 \%)$ \\
\hline C1 (18.433 a 36.864$)$ & - \\
\hline C2 (36.865 a 73.728$)$ & - \\
\hline C3 (73.729 a 147.456) & - \\
\hline C4 (147.457 a 294.912) & - \\
\hline C5 (294.913 a 589.824) & - \\
\hline TOTAL & 871 \\
\hline
\end{tabular}

Com base nos dados do corpus sobre a quantidade de entradas dos materiais, foram considerados os percentuais de cada faixa, é possível concluir que a Faixa A, que reúne as UBL's com quantidade de entradas entre 1 e 576, contém 85\% do total de registros, ao passo que a Faixa B, com UBL's que contêm de 577 a 18.432 entradas, possui apenas 15\% do total. Já a Faixa C (de 18.433 a 589.824 entradas), até este momento, não registrou nenhuma ocorrência.

Certamente a quantidade de entradas ou de subentradas de uma obra lexicográfica não é fator determinante nem para avaliar a sua qualidade, nem a sua funcionalidade para determinado público. No entanto, pelo menos a título de curiosidade, se, por exemplo, os maiores dicionários e vocabulários de línguas indígenas brasileiras, que, conforme observado no quadro acima, chegam, no máximo, à Faixa B5 (mais especificamente, o maior registro feito até o momento é o de um material com quase 13.000 entradas), fossem classificados a partir da mesma nomenclatura usada para classificar as grandes línguas do tronco indoeuropeu, teriam de ser definidos, segundo Biderman (1984) e Sousa (1995), como dicionário 
escolar (entre 10.000 e 30.000 verbetes, para Biderman; e entre 5.000 e 25.000 para Sousa), ou como minidicionário, segundo a proposta de Welker (2003), que engloba os materiais que contêm entre 5.000 a 20.000 entradas.

Com isso, fica clara a inadequação da nomenclatura geralmente usada para descrever obras lexicográficas de línguas como o Português, o Inglês, o Francês, o Espanhol e o Alemão, para descrever os materiais lexicográficos das línguas indígenas brasileiras.

A fim de averiguar se há alguma relação entre o que os autores das diferentes obras lexicográficas denominaram dicionário, vocabulário glossário e lista, apresento, a seguir, a quantificação em paralelo dos dados referentes a essas UBL's:

QUADRO 21 - DISTRIBUIÇÃO DE 4 TIPOS DE UBL'S DE ACORDO COM A PROPOSTA DE
CLASSIFICAÇÃO QUANTITATIVA POR FAIXAS

\begin{tabular}{|c|c|c|c|c|}
\hline \multirow{2}{*}{$\begin{array}{c}\text { FAIXA DE QUANT. } \\
\text { DE ENTRADA }\end{array}$} & \multicolumn{5}{|c|}{ QUANTIDADE DE UBL'S POR FAIXA } \\
\cline { 2 - 5 } & DICIONÁRIO & VOCABULÁRIO & GLOSSÁRIO & LISTA \\
\hline A1 & 4 & 94 & 11 & 54 \\
\hline A2 & 1 & 84 & 6 & 17 \\
\hline A3 & 3 & 153 & 6 & 17 \\
\hline A4 & 3 & 129 & 16 & 11 \\
\hline A5 & 5 & 91 & 8 & 14 \\
\hline B1 & 12 & 45 & 2 & 3 \\
\hline B2 & 20 & 5 & - & - \\
\hline B3 & 12 & 5 & - & - \\
\hline B4 & 4 & 2 & - & - \\
\hline B5 & - & 2 & - & 1 \\
\hline C1 & - & - & - & - \\
\hline C2 & - & - & - & - \\
\hline C3 & - & - & - & - \\
\hline C4 & - & - & - & - \\
\hline C5 & - & - & - & - \\
\hline
\end{tabular}

Esses dados ainda não são conclusivos, apenas indicativos de que há uma tendência que está se construindo em torno do fator quantitativo. Assim, podemos levantar a hipótese de que é possível usar a quantidade de entradas como um dos critérios para distinguir dois tipos de UBL's, os Dicionários e os Vocabulários, pois estes ocuparam, sobretudo, a Faixa A, enquanto aqueles ocuparam a Faixa B. Isso, entretanto, não serviria para distinguir as UBL's do tipo Vocabulário das UBL's dos tipos Glossário e Lista, pois as três estão com suas quantidades concentradas na mesma Faixa. 
7.3.3.6. Distribuição das UBL’s segundo a disposição das línguas envolvidas no verbete

No banco de dados desta pesquisa foi feito o registro da direção das línguas no verbete, ou seja, foi indicada esquematicamente, para cada UBL, qual era a língua de entrada, no lema, e quais as demais línguas, no caso de materiais bilíngues ou plurilíngues, relacionadas à primeira língua, no interior do verbete (cf. subseção 7.2.1.4). Essas duas posições, no início e no interior do verbete, são apresentados com detalhes a seguir.

\subsection{Línguas do lema}

Dos 1421 registros de UBL's, 132 não possuíam ainda a indicação da direção das línguas, logo, para esta quantificação, utilizaremos um total de 1289 dados.

\section{QUADRO 22 - LÍNGUAS QUE OCUPAM A POSIÇÃO DO LEMA DOS VERBETES DAS UBL'S} DAS LÍNGUAS INDÍGENAS BRASILEIRAS

\begin{tabular}{|c|c|c|}
\hline & LÍNGUA DO LEMA & QUANT. \\
\hline 1. & Língua Alemã (Al) & 85 \\
\hline 2. & Língua Espanhola (Es) & 45 \\
\hline 3. & Língua Francesa (Fr) & 115 \\
\hline 4. & Língua Inglesa (In) & 84 \\
\hline 5. & Língua Italiana (It) & 5 \\
\hline 6. & Língua Latina (Lt) & 62 \\
\hline 7. & Língua Portuguesa $(\mathrm{Pt})$ & 496 \\
\hline \multirow[t]{2}{*}{8.} & Línguas Indígenas (Id) & 397 \\
\hline & TOTAL & 1289 \\
\hline
\end{tabular}

Observando o Quadro 22, é possível verificar que línguas ocupam a posição de entrada dos verbetes das UBL's do banco de dados. Ou seja, mesmo reunindo todas as línguas indígenas brasileiras, elas ocupam essa posição em somente $30 \%$ das UBL's, ao passo que as outras sete línguas, todas indo-europeias, predominam como línguas de lema em $70 \%$ das UBL's.

Esse dado não traduz somente as situações em que, no caso de um material feito em duas direções, da língua indígena para a língua indo-europeia, e vice-versa, seria esperada a ocorrência de ambas, nessa posição de lema; mas também, ela pode significar ou que existe uma preferência pelo uso da língua indo-europeia em trabalhos lexicográficos envolvendo línguas indígenas, ou que isso resulte da própria dinâmica da pesquisa do léxico de uma 
língua indígena, no momento em que se toma como base da pesquisa a língua indo-europeia na direção da qual o pesquisador vai tentar "encaixar" a língua indígena.

\subsection{Línguas do interior do verbete}

Apresento, a seguir, um resumo da quantidade de línguas encontradas na segunda posição após o lema das UBL's registradas.

\section{QUADRO 23 - LÍNGUAS QUE OCUPAM A POSIÇÃO IMEDIATA APÓS O LEMA DOS VERBETES DAS UBL'S DAS LÍNGUAS INDÍGENAS BRASILEIRAS}

\begin{tabular}{|c|c|c|}
\hline & LÍNGUA APÓS O LEMA & QUANT. \\
\hline 1. & Língua Alemã (Al) & 6 \\
\hline 2. & Língua Espanhola (Es) & 41 \\
\hline 3. & Língua Francesa (Fr) & 14 \\
\hline 4. & Língua Inglesa (In) & 84 \\
\hline 5. & Língua Italiana (It) & 1 \\
\hline 6. & Língua Latina (Lt) & 19 \\
\hline 7. & Língua Portuguesa (Pt) & 292 \\
\hline \multirow[t]{2}{*}{8.} & Línguas Indígenas (Id) & 829 \\
\hline & TOTAL & $1286^{98}$ \\
\hline
\end{tabular}

Como era de se esperar, nesse quadro que contém as línguas que ocupam a segunda posição nas microestruturas da UBL's do banco de dados, houve um número significativamente maior de ocorrências de línguas indígenas brasileiras (há na base ainda 60 casos de microestruturas em que a língua indígena não ocupa nem a segunda posição).

Uma última observação é sobre as línguas que não aparecem nos dois últimos quadros, neste caso o russo e o japonês, que foram também registrados no banco de dados. Isso para demonstrar que, nos trabalhos lexicográficos das línguas indígenas brasileiras, há línguas não indo-europeias.

\subsubsection{Distribuição das UBL's segundo o ordenamento de macroestruturas}

Conforme apresentei na subseção 7.2.1.4, foi feita a classificação das UBL's segundo o tipo de ordenamento das macroestruturas, considerando-se, inicialmente, que elas poderiam seguir uma base onomasiológica ou semasiológica. Uma vez de posse dos dados,

\footnotetext{
${ }^{98}$ A quantidade menor de resultados nesse segundo quadro ocorreu porque há três registros em que não há uma segunda língua, ou seja, são listas com apenas uma língua.
} 
constatei a existência de outras possibilidades de arranjo das macroestruturas das obras lexicográficas, conforme pode ser observado no Quadro 24.

Do total de 1421 UBL's selecionadas no banco de dados, foi possível identificar a ordem da macroestrutura em 1335 registros, ${ }^{99}$ que apresento a seguir:

\section{QUADRO 24 - CLASSIFICAÇÃO DAS MACROESTRUTURAS DAS UBL'S DAS LÍNGUAS INDÍGENAS BRASILEIRAS SEGUNDO A ORDEM ADOTADA}

\begin{tabular}{|c|c|c|}
\hline \multicolumn{2}{|r|}{ ORDEM DA MACROESTRUTURA } & QUANT \\
\hline 1. & Base onomasiológica & 561 \\
\hline 2. & Base semasiológica & 709 \\
\hline 3. & $\begin{array}{l}\text { Outros critérios (classificação taxionômica, uso de } \\
\text { motor de busca, elementos fonéticos, morfológicos, } \\
\text { categoria gramatical) }\end{array}$ & 15 \\
\hline \multirow[t]{2}{*}{4.} & Não especificado (geralmente aleatório) & 50 \\
\hline & TOTAL & 1335 \\
\hline
\end{tabular}

As informações desse quadro demonstram que o uso de bases semasiológicas é o que prevalece no caso das línguas indígenas brasileiras, contudo, a quantidade de UBL's que foram ordenadas onomasiologicamente não pode ser ignorada. Além disso, a existência de formas de arranjo das macroestruturas diferentes da tradicional ordem alfabética contribuem para a reflexão acerca das possibilidades de novos modelos lexicográficos para as línguas indígenas.

\subsubsection{Análise e classificação de microestruturas}

O tratamento a ser dispensado para as microestruturas inseridas no banco de dados exige que se vá além da simples quantificação de dados, haja vista sua complexidade estrutural e sua relevância para a discussão acerca das possibilidades de modelos na lexicografia brasileira.

\subsubsection{Por uma tipologia das microestruturas das UBL's}

A partir da descrição das microestruturas das UBL's das línguas indígenas brasileiras, segundo o modelo apresentado na subseção 7.2.1.4.2, e de seu armazenamento no

\footnotetext{
${ }^{99}$ Apesar de ter registrado mais de 1500 UBL's no banco de dados, não tive acesso a muitos dos materiais, apenas às suas respectivas referências. Questão que, com o tempo, espero resolver com o desenvolvimento de novas pesquisas ou com a permissão dos autores de obras ainda não disponibilizadas.

${ }^{100}$ Ao ordenar os dados a partir de elementos fonéticos ou morfológicos, utiliza-se uma base semasiológica, no entanto, optei em mantê-las separadas, reservando a base semasiológica para o uso mais comum da ordem alfabética.
} 
banco de dados desta pesquisa, comecei a perceber a grande variedade de formas, que iam das mais básicas, como LFr: \{DId $\}$ até as mais elaboradas, como LPt: Gr, Na, Rm \{DId (Vr) -DPt $[E P t / E I d]\}{ }^{101}$ Ao mesmo tempo em que essa variação se consolidava, havia, por outro lado, a identificação de certa recorrência, que poderia, por sua vez, levar a uma modelagem mais abstrata de EML's. Assim, a título de exemplo, apresento, esquematicamente, o processo de construção dessa proposta, que culminaria com a proposição de uma tipologia.

1) Observei todas as EML's armazenadas no banco de dados, como as apresentadas a seguir:

LLt: $\{\mathrm{DId}(\mathrm{Vr})\}$

LPt: $\{$ DIn-DId $\}$

LIn/LFr/LRs/LPt/LEs: Na, Vr \{DId $\}$

LPt: $\{$ DId (Et, Fn) $[$ EId/EPt $]\}$

LAl: $\{$ DId $\}$
LLt: $\{$ DIn-DPt-DId $\}$

LId: Vr $\{\mathrm{DPt}(\mathrm{Gr}, \mathrm{Na}, \mathrm{Vr})(-\mathrm{DLt})\}$

LFr: Na, Rm, Vr \{(DFr) DId [EFr/EId (Tl)] $\}$

LEs: Gr, Na \{DId (Na, Rm) [EEs/EId] $\}$

LId: Na, Rm, Rz, Tl, Vr \{DEs (Vr) [EId/EEs]\}

2) Utilizando a nomenclatura básica original da proposta (Lema, Operador, Descritor e Exemplo), reescrevi esses mesmos dados, com o acréscimo da informação de quantidade (quando o valor era superior a 1, inseri um número subscrito, à direita, de cada letra de categoria). Eis o resultado:
$\mathrm{L}:\{\mathrm{D}(\mathrm{O})\}$
$\mathrm{L}:\left\{\mathrm{D}_{3}\right\}$
$\mathrm{L}:\left\{\mathrm{D}_{2}\right\}$
L: $\mathrm{O}\left\{\mathrm{D}_{2}\left(\mathrm{O}_{3}\right)\right\}$
$\mathrm{L}_{5}: \mathrm{O}_{2}\{\mathrm{D}\}$
$\mathrm{L}: \mathrm{O}_{3}\left\{\mathrm{D}_{2}\left[\mathrm{E}_{2}(\mathrm{O})\right]\right\}$
L: $\left\{\mathrm{D}\left(\mathrm{O}_{2}\right)\left[\mathrm{E}_{2}\right]\right\}$
$\mathrm{L}: \mathrm{O}_{2}\left\{\mathrm{D}\left(\mathrm{O}_{2}\right)\left[\mathrm{E}_{2}\right]\right\}$
L: $\{D\}$
$\mathrm{L}: \mathrm{O}_{5}\left\{\mathrm{D}(\mathrm{O})\left[\mathrm{E}_{2}\right]\right\}$

3) Concluída esta reescrita de todos os dados, constatei que: a) o único componente que não pode ser omitido é o Lema; b) todos os componentes da expressão podiam ocorrer mais de uma vez; e c) existem estruturas de uso mais recorrentes e outras de uso mais restrito. Levando em consideração esses dados, foi possível estabelecer uma padronização, na qual não foi necessário especificar a quantidade de ocorrências de um

${ }^{101}$ Essas EML's mais desenvolvidas não implicam, necessariamente, que o material que a contém seja o mais bem elaborado, mais completo ou mais adequado para uso em dado contexto, mas sim que o projeto lexicográfico da obra considerou um determinado conjunto de componentes. 
componente, em virtude da observação do item b). ${ }^{102}$ Logo, a proposta de tipologia possui 14 itens, conforme descrição apresentada a seguir: ${ }^{103}$

QUADRO 25 - TIPOLOGIA PARA CLASSIFICAÇÃO DAS MICROESTRUTURAS DA UBL'S DAS LÍNGUAS INDÍGENAS BRASILEIRAS

\begin{tabular}{|l|c|l|}
\hline \multicolumn{2}{|c|}{ TIPOLOGIA DE EML } & \multicolumn{1}{c|}{ DESCRIÇÃO DA MICROESTRUTURA } \\
\hline 1. & M & L \\
\hline 2. & MD & L: $\{\mathrm{D}\}$ \\
\hline 3. & MDO & $\mathrm{L}:\{\mathrm{D}(\mathrm{O})\}$ \\
\hline 4. & MDE & $\mathrm{L}:\{\mathrm{D}[\mathrm{E}]\}$ \\
\hline 5. & MDEO & $\mathrm{L}:\{\mathrm{D}(\mathrm{O})[\mathrm{E}]\}$ \\
\hline 6. & MDOEO $:\{\mathrm{D}[\mathrm{E}](\mathrm{O})\}$ \\
\hline 7. & MO & $\mathrm{L}:\{\mathrm{D}(\mathrm{O})[\mathrm{E}](\mathrm{O})\}$ \\
\hline 8. & MODO & $\mathrm{L}: \mathrm{O}$ \\
\hline 9. & MODE & $\mathrm{L}: \mathrm{O}\{\mathrm{D}\}$ \\
\hline 10. & MODOE & $\mathrm{L}: \mathrm{O}\{\mathrm{D}(\mathrm{O})\}$ \\
\hline 11. & MODEO O $\{\mathrm{D}[\mathrm{E}]\}$ \\
\hline 12. & MODOEO & $\mathrm{L}: \mathrm{O}\{\mathrm{D}(\mathrm{O})[\mathrm{E}]\}$ \\
\hline 13. & & $\mathrm{~L}: \mathrm{O}\{\mathrm{D}[\mathrm{E}](\mathrm{O})\}$ \\
\hline 14. & & $\mathrm{~L}: \mathrm{O}\{\mathrm{D}(\mathrm{O})[\mathrm{E}](\mathrm{O})\}$ \\
\hline
\end{tabular}

Esses 14 itens da tipologia estão dispostos segundo o tipo de estrutura que descrevem. O primeiro item é o mais básico, o único que não pode ser excluído, pois implicaria na impossibilidade de se ter o mais básico dos tipos de materiais lexicográficos. Já os itens de 2 a 7, não apresentam operadores ligados diretamente ao lema, que é o contrário do que ocorre com os itens 8 a 14, que apresentam operadores nesse contexto. Logo, dentro desses dois grupos formados, o segundo critério de classificação é a presença ou não de exemplo. No primeiro grupo, somente os dois itens iniciais não apresentam exemplo; o mesmo ocorre com os três primeiros itens do segundo grupo. Por fim, a última subdivisão diz respeito à ocorrência de operadores junto a descritores e exemplos, ou seja, primeiro as ocorrências de operadores junto aos descritores, em seguida, junto aos exemplos, e, concluindo, simultaneamente junto aos dois.

\footnotetext{
${ }^{102}$ Como, para este trabalho, não tinha a intenção de chegar a uma descrição tão detalhada, optei pela não apresentação das quantidades de ocorrências de cada componente, o que não impede, em outro contexto, a utilização do modelo completo.

${ }^{103}$ Dos 14 itens, o único não atestado em nosso banco de dados é o $n^{\circ}$ 6, ou seja, o que equivale à estrutura L: $\{\mathrm{D}$ [E $(\mathrm{O})]\}$.
} 


\subsubsection{Quantificando microestruturas de UBL's a partir da tipologia proposta}

Do total de 1421 UBL's do banco de dados, foram consideradas para a contagem das microestruturas 1287, pois 134 delas ainda não havia tido suas microestruturas descritas. A seguir, apresento o quadro que resume o total de EML's do banco de dados, distribuídas segundo a tipologia descrita acima:

\section{QUADRO 26 - DA DISTRIBUIÇÃO DAS MICROESTRUTURAS DE UBL'S SEGUNDO A TIPOLOGIA PROPOSTA}

\begin{tabular}{|c|c|c|}
\hline \multicolumn{2}{|c|}{ TIPOLOGIA DE EML } & \multirow{2}{*}{$\frac{\text { QUANT. }}{3}$} \\
\hline 1. & $\mathrm{M}$ & \\
\hline 2. & MD & 399 \\
\hline 3. & MDO & 229 \\
\hline 4. & MDE & 12 \\
\hline 5. & MDOE & 74 \\
\hline 6. & MDEO & 0 \\
\hline 7. & MDOEO & 1 \\
\hline 8. & MO & 1 \\
\hline 9. & MOD & 145 \\
\hline 10. & MODO & 249 \\
\hline 11. & MODE & 44 \\
\hline 12. & MODOE & 123 \\
\hline 13. & MODEO & 6 \\
\hline 14. & MODOEO & 1 \\
\hline & TOTAL & 1287 \\
\hline
\end{tabular}

A primeira consideração a ser feita a partir dos dados apresentados acima, diz respeito à quase inexistência de materiais nas extremidades do quadro, os tipos $\mathrm{M}$ e MODOEO, que representam, consecutivamente, a estrutura mais simples ${ }^{104}$ e a estrutura mais complexa da proposta. Apesar de existirem ocorrências nos dados, seus usos parecem bem restritos. No sentido oposto, os tipos com maior ocorrência são aqueles que não apresentam a categoria exemplo, ou seja, os itens 2, 3, 9 e 10. Juntos esses itens possuem quase $80 \%$ do total. Todavia, não é possível ignorar que os itens 5 e 12, que apresentam o componente exemplo, alcançaram juntos um percentual de $15,3 \%$ do total.

\footnotetext{
${ }^{104}$ O mesmo vale para o item 8, que tem a mesma caraterística do primeiro item, apenas com acréscimo do componente operador.
} 
Destes últimos dados, é possível concluir, então, que a maior parte das microestruturas das línguas indígenas brasileiras não contém o componente exemplo.

Uma vez definida a distribuição dos tipos de microestrutura das UBL's das línguas indígenas brasileiras, ainda não se sabe a que tipo de material cada tipo de EML está associada e essa informação pode ser útil para determinar se existe alguma relação entre os tipos de microestrutura e os tipos de obras lexicográficas. Como há alguns tipos de UBL's com uma quantidade bastante pequena (cf. Gráfico 05), selecionei apenas aquelas com maior quantidade de registros, as quais serão relacionadas aos tipos de microestrutura.

\section{QUADRO 27 - DISTRIBUIÇÃO DE UBL'S SEGUNDO A TIPOLOGIA PROPOSTA PARA CLASSIFICAÇÃO DE MICROESTRUTURAS}

\begin{tabular}{|c|c|c|c|c|c|c|c|c|}
\hline & \multirow{2}{*}{$\begin{array}{c}\text { TIPOS DE } \\
\text { MICROESTRUTURA }\end{array}$} & \multicolumn{6}{|c|}{$\begin{array}{l}\text { TIPOS DE UBL'S DISTRIBUÍDAS SEGUNDO A PROPOSTA DE } \\
\text { CLASSIFICAÇÃO DAS MICROESTRUTURAS }\end{array}$} & \multirow[t]{2}{*}{ QUANT. } \\
\hline & & Dicionário & Glossário & Índice & Léxico & Lista & Vocabulário & \\
\hline 1. & $\mathrm{M}$ & 1 & - & - & - & 1 & 1 & 3 \\
\hline 2. & $\mathrm{MD}$ & 13 & 13 & - & 1 & 82 & 290 & 399 \\
\hline 3. & MDO & 6 & 6 & 1 & 2 & 31 & 186 & 232 \\
\hline 4. & MDE & 9 & 1 & - & - & - & 2 & 12 \\
\hline 5. & MDOE & 5 & 1 & 1 & - & - & 67 & 74 \\
\hline 6. & MDEO & - & - & - & - & - & - & - \\
\hline 7. & MDOEO & - & - & - & - & - & 1 & 1 \\
\hline 8. & $\mathrm{MO}$ & - & - & - & - & - & 1 & 1 \\
\hline 9. & MOD & 13 & 20 & - & 1 & - & 84 & 118 \\
\hline 10. & MODO & 38 & 12 & - & 9 & 13 & 175 & 247 \\
\hline 11. & MODE & 23 & 1 & - & - & 1 & 19 & 44 \\
\hline 12. & MODOE & 76 & 2 & - & 2 & - & 42 & 122 \\
\hline 13. & MODEO & 3 & 0 & 0 & 0 & 1 & 2 & 6 \\
\hline 14. & MODOEO & 1 & 0 & 0 & 0 & 0 & 0 & 1 \\
\hline & TOTAL & 188 & 56 & 2 & 15 & 129 & 870 & 1260 \\
\hline
\end{tabular}

Antes de passar às considerações mais generalizantes baseadas nos dados apresentados no quadro acima, comentarei cada coluna dos tipos de UBL's e, ao final, buscarei fazer a síntese das informações.

A primeira coluna do quadro está ocupada com os dados relacionados ao Dicionário, um dos mais importantes e recorrentes tipos de obras lexicográficas no contexto das línguas indígenas brasileiras. Partindo da consideração da ocorrência ou não do 
componente exemplo, $37,5 \%$ dos dicionários não possui em sua microestrutura o exemplo, ${ }^{105}$ ao passo que $62,5 \%$ apresentam esse componente. Além disso, a estrutura com maior quantidade de registros pode ser considerada uma das mais complexas, a do tipo MODOE, com $40 \%$ do total de registros.

Na segunda coluna, a do Glossário, com uma quantidade intermediária de dados, prevalecem os registros de microestruturas sem o componente exemplo (91\% do total), mas, mesmo assim, há alguns registros com esse componente.

$\mathrm{Na}$ terceira coluna, o Índice contou com apenas dois registros, um do tipo MDO e outro do tipo MDOE.

O Léxico, que aparece na quarta coluna, teve também uma quantidade baixa de registros, 15, dos quais 13 não apresentam o componente exemplo.

Na penúltima coluna, foram apresentados os dados relacionados à Lista. Quase 98\% dos 129 registros dessa coluna não apresentam o componente exemplo e o tipo de estrutura mais recorrente, com 63,5\% do total, é MD, ou seja, um dos mais básicos.

Por fim, na última coluna do Quadro 27, é apresentado o tipo com a maior quantidade de registros de UBL's do banco de dados, o Vocabulário. Desse conjunto, contei um total de 736 UBL's com microestruturas sem o componente exemplo, isto representa quase $85 \%$ de todos os registros. Além disso, o modelo de microestrutura com mais ocorrências é o do tipo MD (290), seguido dos tipos MDO (186) e MODO (175).

Uma vez concluídos os comentários acerca de cada um dos tipos de UBL's, apresentarei algumas considerações baseadas nessa síntese de dados.

Mesmo existindo três tipos de microestruturas (MDOEO, MO, MODOEO) cada um com apenas um registro de UBL, isso ainda não é suficiente para afirmar que eles são exclusivos de determinado tipo de obra lexicográfica. Assim como não é possível afirmar que não existam UBL com a microestrutura do tipo MDEO, isso só o avanço das pesquisas demonstrará.

Complementar à primeira observação do parágrafo anterior é a de que um mesmo tipo de microestrutura pode ser usado por todos os tipos de obras lexicográficas, como demonstra a estrutura MDO, com ocorrência em todas as colunas.

\footnotetext{
${ }^{105} \mathrm{O}$ único dicionário que apresenta a microestrutura do tipo $\mathrm{M}$ é um dicionário de rimas, elaborado por Mello (1967, p. 103-123). Nele são apresentadas apenas as palavras em “Tupi”, associadas umas com as outras a partir das últimas sílabas.
} 
Ao comparar dados das três colunas mais numerosas, surgem alguns fatos relevantes para esta pesquisa. O primeiro deles é o de que há seis tipos de microestrutura usados simultaneamente para o Dicionário, para a Lista e para o Vocabulário, são eles: M, MD, MDO, MODO, MODE, MODEO. O segundo fato é que a Lista e o Vocabulário possuem, cada um, a maior quantidade de suas UBL's concentradas no mesmo tipo de microestrutura, a MD. Por fim, o terceiro e, talvez, mais produtivo fato, é o de que, enquanto o Glossário, a Lista e o Vocabulário possuem a maior parte de microestruturas sem exemplo (totalizando 91\%, 98\% e 85\%, respectivamente), o Dicionário conta com pouco mais de 37\% de seu conjunto de dados sem o componente exemplo nas microestruturas, ou dito de outra forma, 2/3 dos dados relacionados ao Dicionário apresentam exemplo.

Esse último dado, apesar de, sozinho, não ser capaz de servir como critério classificatório, aponta para uma realidade que deve ser considerada se se quer chegar a uma tipologia segura das obras lexicográficas. 


\section{DESENVOLVENDO UM PROGRAMA DE DOCUMENTAÇÃO LINGUÍSTICA E DE CRIAÇÃO DE DICIONÁRIOS: PROJETO EXPERIMENTAL SURUÍ- AIKEWARA}

A documentação linguística de uma língua consiste, segundo Himmelmann (2007, p. 15), em "[...] compilar y preservar datos lingüísticos primarios y a crear interfaces entre estos datos primarios y varios tipos de análisis basados en ellos". ${ }^{106}$ Esses dados primários, coletados diretamente junto aos próprios falantes das línguas, se constituem, no caso das línguas indígenas brasileiras, em importante material, antes de tudo, oral, dada a realidade ágrafa de muitos dos povos falantes dessas línguas, mas também escrito, já que vários povos já fazem uso da escrita nos mais diversos contextos. ${ }^{107}$

Todavia, é possível afirmar que essa documentação, que começou no Brasil há quase 500 anos, nem sempre se destinou somente à pesquisa linguística propriamente dita, pois serviu também para auxiliar trabalhos catequéticos de diferentes grupos religiosos, para facilitar o comércio direto com populações indígenas e ainda para efetivar projetos de dominação sobre esses grupos (cf. subseções 3.3 e 3.4 sobre o contato linguístico). ${ }^{108}$ E ainda havia a situação, não tão rara, em que, mesmo nos casos em que o registro dos dados foi realizado com fins linguísticos por pessoas ou instituições, essa documentação se tornava, muitas vezes, inacessível para o próprio povo falante que produzia os dados.

Independentemente da motivação para registro desses dados linguísticos, um fato a ser observado hoje é o de que a maior parte das línguas indígenas brasileiras sobreviventes (e também algumas daquelas que não sobreviveram) já dispõe de alguma documentação (oral, escrita e audiovisual), usada para desenvolvimento de estudos linguísticos, mas também para a construção de materiais didáticos, úteis para a própria revitalização ou reinserção de línguas em comunidades indígenas, como é o caso da língua Kokáma (cf. CABRAL, 2013).

No caso específico da língua Suruí, objeto de estudo desta tese, a documentação linguística foi iniciada efetivamente com o trabalho da pesquisadora Ruth Monserrat, do Museu Nacional do Rio de Janeiro, em meados da década de 1980.

Além do registro sonoro da fala Suruí (palavras, frases e alguns textos), ela buscou sistematizar por escrito a fonética e a fonologia dessa língua, além de descrever vários

\footnotetext{
106 Tradução: “[...] reunir e preservar dados linguísticos primários e a criar interfaces entre estes dados primários e vários tipos de análises baseadas neles" (tradução nossa).

${ }^{107}$ Uma terceira categoria de dados linguísticos que pode ser registrada e estudada se refere à dos sinais gestuais de linguagens desenvolvidas por surdos indígenas.

${ }^{108}$ Mesmo no século XIX, quando a documentação linguística dessas línguas passa supostamente a atender a interesses estritamente científicos com as diferentes pesquisas empreendidas por naturalistas, o interesse científico está, na maior parte das vezes, subordinado a interesses econômicos ou políticos.
} 
elementos da morfologia e do léxico. ${ }^{109}$ Essa documentação continuou a ser construída e ampliada por outros pesquisadores, sobretudo linguistas e antropólogos, nas décadas seguintes. ${ }^{110}$

Com o desenvolvimento da pesquisa desta tese, busquei ampliar a documentação já iniciada da língua Suruí do Tocantins. Esse processo consistiu no registro dessa língua nos mais diferentes contextos, desde situações de fala cotidiana até a preparação e execução de cantos (como os da festa da dança "Sapurahaj") e cerimônias tradicionais (como a distribuição da bebida tradicional e os casamentos).

Essa documentação, feita em áudio, vídeo e por escrito de dados linguísticos da língua Suruí, além de servir para os fins da pesquisa desta tese, já estão sendo usados pelos próprios falantes da língua e, principalmente, pelos professores indígenas, alguns dos quais foram pesquisadores na coleta desses dados. ${ }^{111}$ Com isso, o povo passa a ser o primeiro beneficiário dessa documentação, pois dispõe de amostras duradouras de sua língua, e, no presente e no futuro, esse povo pode ouvir, ler e experienciar sua língua em uso, ou seja, em situações reais de interação; ademais, esses registros podem servir para estimular o desenvolvimento da reflexão linguística dos professores Suruí e respectivos alunos sobre sua própria língua, o que permitiria a eles participarem de modo mais efetivo na construção de políticas linguísticas e de planejamento educacional. Existe a possibilidade de estimular a produção de outros materiais derivados desses registros linguísticos, como, por exemplo, o desenvolvimento de uma escrita literária ou técnico-científica, contribuindo ainda mais para a necessária valorização de sua língua-cultura em face das demais línguas-culturas do mundo. $^{112}$

Vale lembrar, conforme apresentado no Capítulo 3.3, que a situação linguística da língua Suruí do Tocantins é de vulnerabilidade e que isso se deve a uma série de fatores

${ }^{109}$ Esse material linguístico serviu de base para produção de um vocabulário da língua Suruí-Aikewara, publicado pelo CIMI Norte II (cf. Capítulo 3.1)

${ }^{110}$ Um exemplo recente de "documentação linguística" é o que está sendo feito pelo CIMI Norte II e pela Comissão Nacional da Verdade (CNV), que fazem o registro oral, em Suruí (no caso dos falantes monolíngues) ou em Português (no caso dos falantes bilíngues) junto aos sábios Suruí, para coletar narrativas sobre as diversas experiências deles com relação à Guerrilha do Araguaia, que devem ser usadas pelo Governo para eventuais processos indenizatórios. Os principais meios de gravação das histórias são a filmadora e a câmera fotográfica.

${ }^{111}$ Um exemplo desse uso foi a reunião de todos os vídeos da festa do Sapurahaj, que aconteceu em abril de 2014, em um só arquivo de vídeo, do qual foram feitas várias cópias, e distribuídas para pessoas da comunidade. Além disso, esse "filme" foi apresentado pelos professores Ikatu e Tymykong em diferentes ocasiões na aldeia.

${ }^{112}$ Esse objetivo está de acordo com o que propõe o projeto "Banco de dados de línguas indígenas do Brasil e de áreas adjacentes", coordenado pelos professores Aryon D. Rodrigues (in memoriam) e Ana Suelly A. C. Cabral, cujo objetivo é o de construir um banco de dados que servirá "[...] ao mesmo tempo de repositório de dados dessas línguas, bens imateriais linguísticos e culturais dos povos que as falam e patrimônio cultural do Brasil e da humanidade. [mas também como servir de] fonte de referência linguística para fins científicos, educacionais e outros". 
socioculturais que envolvem, sem dúvida, o contato desse povo com os não indígenas e a força com que a língua nacional foi introduzida nesse grupo.

\subsection{DADOS DA LÍNGUA SURUÍ}

A fim de constituir a documentação linguística da língua Suruí de maneira mais completa possível, busquei, em um primeiro momento, compilar os corpora já produzidos por diferentes pesquisadores, o que contribuiu para identificar as diferentes perspectivas adotadas pelos responsáveis por essa documentação. Apesar de nem todas as bases estarem disponíveis, consegui reunir, ainda que parcialmente, dados coletados por Monserrat (1985a), Graham (1988), Cabral (1997), Costa (2002), Cabral e Mastop (2002). ${ }^{113}$ Muitos desses trabalhos consistem, grosso modo, no registro de palavras e frases, compiladas segundo diferentes orientações teóricas e técnicas.

O passo seguinte na constituição dessa documentação linguística foi a de reunir um corpus próprio para esta pesquisa da língua Suruí do Tocantins, o que foi iniciado em abril de 2012, sob a orientação da profa. Ana Suelly A. C. Cabral, no âmbito do Programa de PósGraduação em Linguística e do projeto Observatório da Educação Escolar Indígena, ${ }^{114}$ do Laboratório de Línguas Indígenas, do Instituto de Letras, da Universidade de Brasília. Esse registro da língua Suruí foi feito, no formato de áudio de alta qualidade, com os professores Ikatu e Tymykong, que viajaram a Brasília, onde permaneceram por uma semana.

Partindo do registro de um vocabulário básico da língua Suruí, relacionado principalmente a fauna, flora e partes do corpo, acrescido de enunciados que contextualizassem os termos desse vocabulário, iniciei os estudos acerca da fonologia, da morfologia, da sintaxe e do léxico dessa língua.

Esta abordagem para acesso aos dados da língua teve, para mim, sem dúvida, um caráter de iniciação, pois, permitiu-me estabelecer uma primeira aproximação ao léxico e a outras estruturas linguísticas que me permitiriam a compreensão de vários aspectos do funcionamento dessa língua. Contudo, devo enfatizar que não ignorei, em nenhum momento, o valor e a necessidade de coletar dados produzidos em ambiente de uso real dessa língua:

\footnotetext{
${ }^{113}$ Cf. capítulo 2 em que descrevo o conteúdo desses materiais.

${ }^{114} \mathrm{O}$ "Projeto em rede de estudos, pesquisas e formação de professores pesquisadores em linguística e educação escolar indígena - Observatório da Educação Escolar Indígena”, coordenado pela profa. Ana Suelly A. C. Cabral, foi desenvolvido no biênio 2011/2012, e teve como principal objetivo "[...] a formação qualificada de profissionais da educação básica intercultural indígena, principalmente profissionais indígenas, com experiência no estudo científico e aplicado de línguas indígenas brasileiras, em nível de graduação e de pós-graduação mestrado e doutorado" (LALI, 2013).
} 
momentos de conversa informal, de narrações de histórias e de cantos, enfim, situações em que os enunciados estivessem em seu contexto original.

Além de realizar essa atividade de registro da sua língua, os professores Suruí, em Brasília, manifestaram para os coordenadores do Laboratório de línguas indígenas algumas demandas com relação a materiais para língua Suruí, ou seja, Ikatu e Tymykong, enquanto únicos professores de sua língua, expuseram sua necessidade de possuírem materiais como livros, manuais didáticos e dicionários, para auxiliá-los no trabalho de ensino da língua Suruí na escola da aldeia. Dessa maneira, como resultado deste primeiro encontro de trabalho, auxiliei, junto com a professora Ana Suelly Cabral, a produção de um material didático monolíngue ilustrado intitulado Aikewara se'engete (IKATU; TYMYKONG, 2012), do qual foi feita uma pequena tiragem a título de material-piloto, usado por eles na Escola Sawarapy, da T.I. Sororó. ${ }^{115}$

Assim, após esse primeiro encontro de trabalho com os professores Aikewára, em Brasília, percebi que o projeto inicial para descrição da língua Suruí deveria estar associado, sem dúvida, à produção de materiais linguísticos relacionados a essa língua. Em outras palavras, a pesquisa linguística deveria permitir não só estudo linguístico do léxico, mas também culminar na produção de, por exemplo, um ou vários dicionários dessa língua estudada.

Por isso, com o foco na produção de material lexicográfico para a língua Suruí, dei prosseguimento à pesquisa com o início das idas a campo para registrar a língua in loco. Dessa forma, meu segundo contato com os falantes da língua Suruí, para fins de documentação, deu-se na T.I. Sororó, ${ }^{116}$ em novembro de 2012.

Munido de um gravador digital Zoom H4n e de uma câmera de vídeo portátil JVC, retomei o registro de dados linguísticos, mas, desta vez, com uma quantidade maior de pessoas, todas adultas. As principais foram dois homens Ikatu e Awasa'i (sendo este último monolíngue) e duas mulheres, Tymykong e Murue (ambas bilíngues). Awasa'i é marido de Murue, que são os pais de Tymykong, que é casada com Ikatu. Awasa'i é, provavelmente, a pessoa mais velha da aldeia e que participou da Guerrilha do Araguaia "a serviço" do Exército Brasileiro. Tymykong e Ikatu assumiram a função de professores da língua Suruí na aldeia e estão fazendo, desde 2012, um curso de graduação pela Universidade do Estado do Pará. ${ }^{117}$

\footnotetext{
115 Impresso no formato de brochura, esse material apresentava já uma nova proposta de escrita da língua Suruí. ${ }^{116}$ Cf. capítulo 2 em que apresento essa Terra Indígena.

117 Outras pessoas também participaram das gravações, mas sua participação foi bem mais breve do que a dos quatro citados acima e seus registros constam nas bases de dados organizadas para esta língua.
} 
Uma observação importante relacionada ao início da pesquisa de campo propriamente dita e, antes de iniciar o trabalho de gravação da língua Suruí, está relacionada à autorização de que necessitei para realizar essa atividade junto ao povo Aikewára. Fui orientado pelo próprio grupo que me recebeu na T.I. Sororó a solicitar pessoalmente à liderança indígena, exercida atualmente por Maira Suruí, uma autorização para a minha permanência e realização do trabalho junto aos Aikewára. Assim, em horário pré-estabelecido pela própria liderança, fui à sua casa, onde me apresentei e expliquei os objetivos, as etapas, o tempo de permanência na comunidade e os resultados esperados da pesquisa, destacando o interesse em contribuir com a comunidade com a elaboração de material linguístico a ser usado sobretudo na escola. Concluída a exposição, fui autorizado a permanecer no local durante o tempo estabelecido e a desenvolver a pesquisa.

Nessa etapa da pesquisa de campo, pude fazer registros sonoros em todos os dias de minha estada na comunidade, em diferentes horários e locais da T.I. Sororó, ${ }^{118}$ mas, principalmente, às margens do igarapé Sakareruna, local onde duas famílias haviam escolhido temporariamente para morar.

Antes de iniciar cada gravação com os falantes da língua, inseri no próprio arquivo de áudio os metadados relativos ao contexto de gravação, tais como: data, local, falantes presentes e conteúdo a ser tratado.

Iniciei essa etapa do trabalho com o registro de elementos do léxico da língua, a fim de ampliar o trabalho já iniciado, mas, à medida que as palavras surgiam e iam sendo explicadas, novos desdobramentos eram feitos e estes culminavam, frequentemente, em conversas entre eles, em Português e em Suruí, que também foram registradas. Nesta etapa foi fundamental a participação do sábio Awasa'i, um dos últimos Aikewára sobrevivente ao contato com os não indígenas. Registrei também várias narrativas míticas contadas por ele em Suruí, descrições de situações cotidianas e conversações. Um dos últimos registros que fiz com Awasa'i foi um longo relato sobre a sua participação, e também a de outros Suruí, no episódio histórico Guerrilha do Araguaia, na década de 1970.

Como as gravações aconteciam com frequência quando todos estavam reunidos, era comum que mais de uma pessoa participasse da gravação, ainda mais quando alguém não sabia como dizer alguma coisa na língua e tinha de recorrer aos mais velhos. Ficou claro que os mais jovens, certamente devido à situação de quase extermínio do povo e implantação da

\footnotetext{
${ }^{118}$ Para garantir a fonte de energia para o funcionamento do aparelho, fui munido tanto de pilhas recarregáveis quanto de pilhas comuns não recarregáveis, além de cartões de memória de grande capacidade.
} 
língua portuguesa na comunidade, não tiveram como desenvolver mais o conhecimento lexical da língua Suruí, ficando restrito aos poucos sábios do grupo.

Nos anos de 2013 e 2014 realizei outras pesquisas de campo à T.I. Sororó, onde pude não somente coletar novos dados para a pesquisa, como também levar dados já transcritos para revisão e versões prévias do dicionário Suruí para revisão e ampliação.

Paralelamente à pesquisa do léxico comum da língua Suruí, empreendi uma pesquisa sobre a onomástica desse grupo, a fim de determinar o significado dos diferentes nomes, mas também para verificar se havia alguma relação entre as denominações dadas às pessoas e o seu clã de origem (cf. capítulo 10).

\subsection{RECURSOS USADOS NO REGISTRO E TRATAMENTO DOS DADOS}

Antes de prosseguir com a apresentação dos dados da língua Suruí, descrevo os principais recursos usados nesta pesquisa para o registro e tratamento dos dados linguísticos.

O principal instrumento usado no registro da fala dos Aikewára nesta pesquisa foi o gravador digital Zoom H4n. Dentre as opções de gravação oferecida pelo aparelho, optei pelo formato de áudio WAV (som wave), $48 \mathrm{kHz}$ e taxa de bits de $1536 \mathrm{kbps}$, por ser esta configuração a que produz arquivos de tamanho médio com excelente qualidade. ${ }^{119}$

Uma vez concluído um registro sonoro da língua e de posse de todas as gravações originais, armazenadas originalmente em um cartão de memória encaixado no gravador, transferia os dados para um computador pessoal, sempre com cópia de segurança em um disco rígido (HD) externo.

Ao precisar utilizar qualquer um desses arquivos armazenados, fazia uma cópia dele, pois, caso fosse necessário fazer alterações nesse arquivo, como ajustes de ruídos ou amplificação de trechos, o arquivo original estaria preservado. Por exemplo, um dos formatos possíveis para conversão dos arquivos é o APF (Audacity Project File), a fim de ter um arquivo editável no programa Audacity 2.0.2. ${ }^{120}$

A etapa seguinte nesse trabalho de documentação se deu com a transcrição fonética dos registros sonoros, para isso, adotei a convenção do Alfabeto Fonético Internacional (AFI ou IPA, International Phonetic Alphabet, em Inglês), no padrão Unicode, versão 6.2, cuja base de dados está presente no Microsoft Office Word 2010 (cf. Apêndice).

\footnotetext{
119 As possibilidades de saída de som desse aparelho são: WAV: 44.1/48/96kHz e MP3 - 44.1/48kHz. As gravações podem ser retiradas do aparelho via cabo USB ou pelo próprio cartão de memória SD.

${ }_{120}$ Cópias dos arquivos originais coletados na pesquisa também são mantidas também no banco de dados do Laboratório de Línguas e Literaturas Indígenas da Universidade de Brasília.
} 
Com base nessas primeiras transcrições, realizava também a escrita ortográfica dos conteúdos, seguindo o padrão proposto no capítulo 5 deste trabalho.

À medida que processavam essas transcrições dos dados obtidos, armazenava-os, na mesma ordem em que haviam sido gravados, inicialmente, em linhas individuais de tabelas simples de arquivos de formatos .DOC e .RTF de um programa de edição de texto (Microsoft Office Word 2010). ${ }^{121}$ Esse processo de transcrição dos arquivos sonoros demandou bastante tempo, pois, além da própria dificuldade de transcrever uma língua a qual não domino como falante, há ainda as dificuldades advindas dos contextos da gravação: superposições de vozes, retomadas ou interrupções de explicações, reformulações de enunciados, acréscimos às explicações, apagamentos da fala, entre outros.

Ao concluir essas transcrições, procedi à revisão dos dados, com a orientação da professora Ana Suelly Cabral, mas também, quando possível, com os próprios falantes da língua Suruí. Para isso, as várias páginas de transcrições foram impressas ou, quando possível, as alterações eram feitas diretamente nas bases de dados, resguardadas, antes, todas as informações originais.

No entanto, com o aumento significativo da quantidade de dados reunidos, o uso de editores de texto simples não comportavam, com eficiência, nem a quantidade nem a diversidade de informações, logo, precisava de um meio mais eficaz para tratar toda essa documentação linguística.

\subsection{EM BUSCA DE UM PROGRAMA DE BANCO DE DADOS ELETRÔNICO}

Nesta fase do processamento da documentação linguística, os materiais coletados e transcritos da língua Suruí, além de seus metadados, se avolumavam e estavam dispersos em vários arquivos, o que tornava o trabalho de sistematização cada vez mais difícil.

Não restava dúvida da necessidade da construção de uma base de dados eletrônica, desenvolvida especificamente para o armazenamento dos dados reunidos com a pesquisa da língua Suruí. Contudo, além de armazenar conteúdos, essa base deveria permitir a manipulação e extração desses dados, além de colaborar com a produção de materiais, como listas e vocabulários, de maneira rápida e prática.

Logo, empreendi a busca para encontrar um programa de banco de dados eletrônico, capaz de atender às necessidades do projeto.

\footnotetext{
121 Com o tempo, passei a transcrever e armazenar dados transcritos diretamente no Programa Línguas, desenvolvido durante a pesquisa da língua Suruí.
} 
Existem, hoje, algumas ferramentas para construção de bancos de dados linguísticos distribuídos, inclusive, na internet, dentre as quais estão:

Shoebox, escrito originalmente em linguagem DOS, é software proprietário com distribuição livre desenvolvido pelo SIL para armazenamento e análise de dados lexicais. Ele foi substituído pelo programa Field Linguist's Toolbox.

FIGURA 06 - JANELA DO SHOEBOX

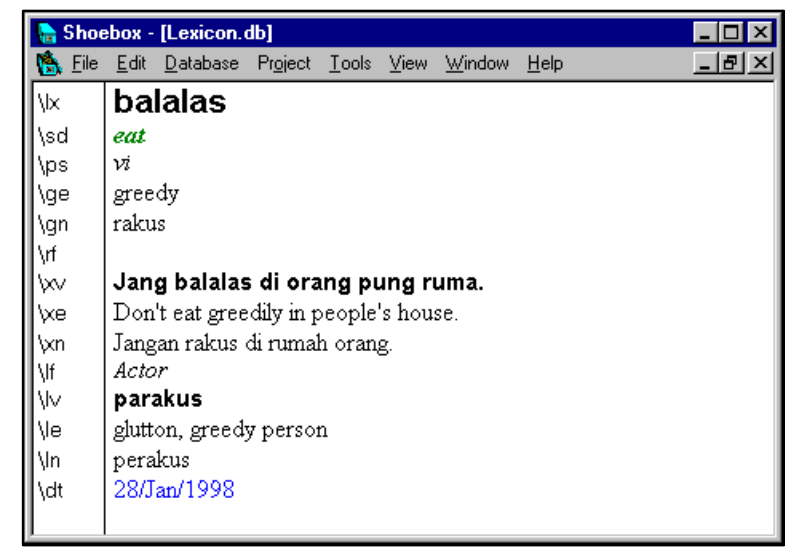

Fonte: http://www-01.sil.org/computing/shoebox/graphics/ DateStampRecord.gif

\section{FIGURA 07 - JANELA DO TOOLBOX}

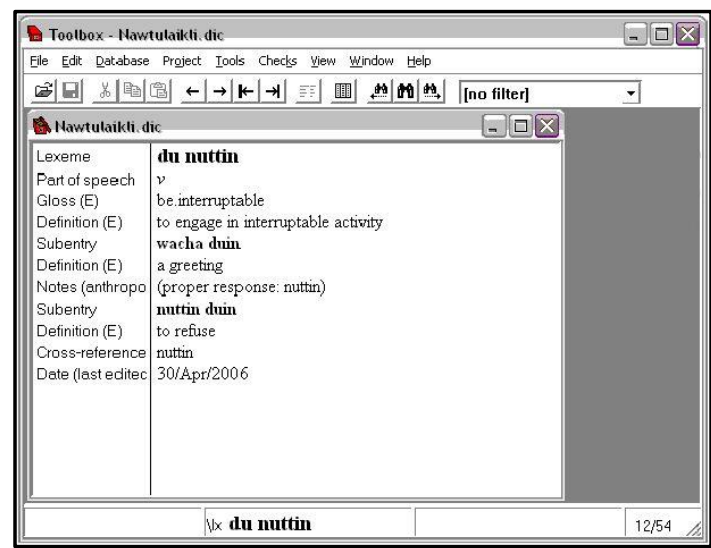

Fonte: http://www-01.sil.org/computing/toolbox/ Toolbox_Self-Training.pdf

Online Linguistic Database (OLD), software livre escrito em linguagem Python, conta com uma série de recursos como: base multi-usuário, sistema de busca, associação de arquivos texto-som, personalização de teclado, ligação de termos, exportação facilitada para interface de dicionário, exportação nos formatos LaTeX, Txt. Não há informação quanto à capacidade de armazenamento do sistema. Site: http://www.onlinelinguisticdatabase.org/ e https://code.google.com/p/onlinelinguisticdatabase/.

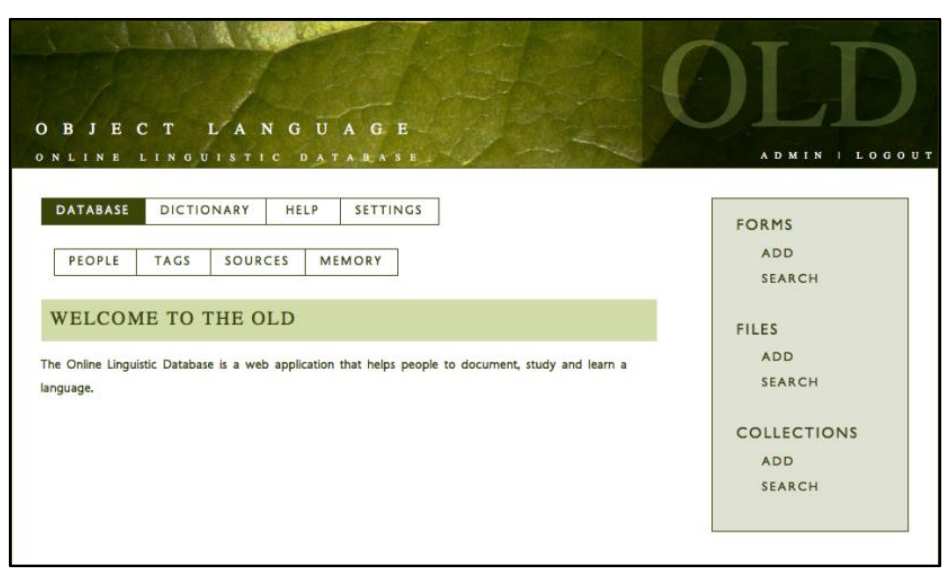

Fonte: http://www.onlinelinguisticdatabase.org/

Field Works Language Explorer (FLEx), software proprietário com distribuição livre desenvolvido pelo SIL International para construção de bases de dados linguísticos, que 
possui recursos de: organização do léxico, inserção de textos com segmentação em glosas, classificação dos elementos gramaticais, área para anotações, elaboração de listas de acordo com domínios linguísticos e de outras áreas, exportação dos dados da base em vários formatos. Site: http://fieldworks.sil.org/flex/.

FIGURA 08 - JANELA DO FLEx

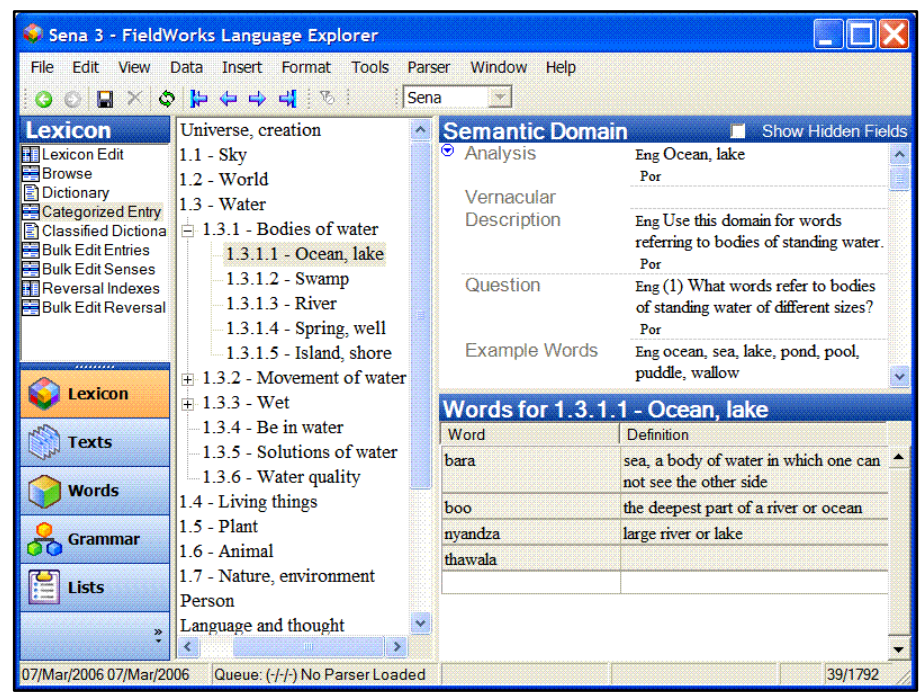

Fonte: http://fieldworks.sil.org/wp-content/uploads/2010/07/SemanticEntry.gif

ELAN (EUDICO Linguistic Annotator), software proprietário com distribuição livre desenvolvido por Max Planck Institute for Psycholinguistics. Trata-se de uma ferramenta de anotação linguística, que permite a visualização e edição de arquivos (linguísticos) de áudio e vídeo. Site: http://tla.mpi.nl/tools/tla-tools/elan/.

FIGURA 09 - JANELA DO ELAN

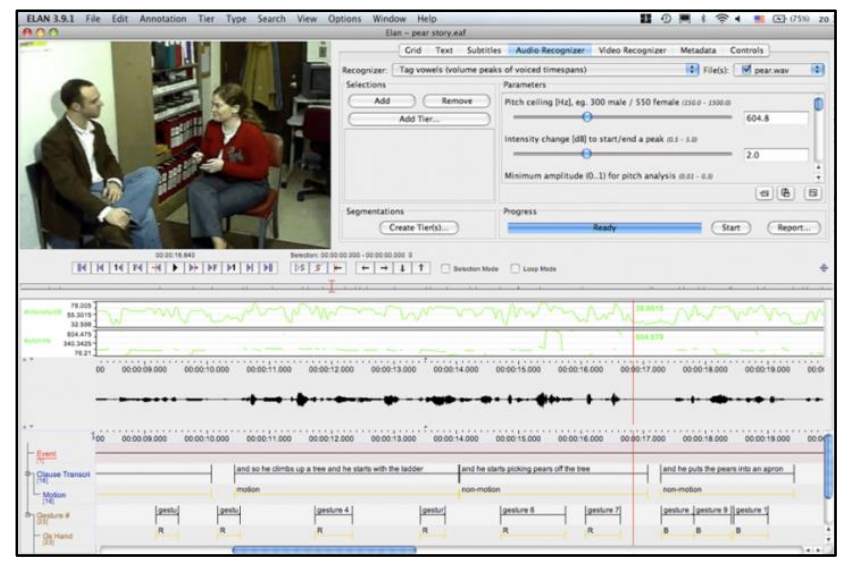

Fonte: Fonte: Site https://tla.mpi.nl/tools/tla-tools/elan/screenshot_elan_2/

Apesar de esses programas atenderem à maior parte das necessidades de projetos que utilizam bases de dados linguísticos, geralmente eles não podem ser adaptados para atender às especificidades de cada projeto, seja por lidarem com linguagens de programação 
pouco amigáveis (como a linguagem Python), seja por serem softwares proprietários que possuem direitos autorais e restrições quanto a alterações (como é o caso do FieldWorks Language Explorer, do Shoebox/Toolbox e do TLex Dictionary Compilation Software). Talvez por isso muitos projetos de universidades e empresas optem em desenvolver seus próprios programas de dados a partir de sistemas de gerenciamento de banco de dados (SGBD), como o Base, software livre da suíte LibreOffice, desenvolvido pela The Document Foundation, o $M y S Q L$, desenvolvido pela Oracle Corporation, e o Access, programa da suíte MS-Office Professional, software-proprietário desenvolvido pela Microsoft.

A principal vantagem de desenvolver um programa próprio a partir de um SGBD é que ele conterá exatamente os elementos e a estrutura necessários para receber os dados da documentação, como a linguística, por exemplo, que forem produzidos. Além disso, a maioria desses sistemas tem como características: portabilidade e compatibilidade com várias linguagens de programação, bom desempenho e estabilidade, não exigem muitos recursos do hardware, seu uso é bastante acessível, facilmente configurável e possui interface gráfica amigável.

Sem dúvida, de todas as opções disponíveis no mercado de softwares (livres e proprietários), o SGBD que apresenta maior facilidade de uso, bastante flexibilidade e considerável quantidade de recursos é ainda o MS Access ${ }^{122}$ que, em sua versão 2010, além da grande capacidade de armazenamento, permite até a exportação dos bancos de dados na forma de aplicativos executáveis. Esse sistema conta ainda com a linguagem de programação Visual Basic for Applications (VBA), nativamente integrada ao seu próprio ambiente de programação, permitindo não só a personalização de tarefas, mas, principalmente, adicionar mais recursos ao banco de dados. ${ }^{123}$

Diante do exposto, ao invés de utilizar um programa pronto, concluí que seria bem mais producente desenvolver um programa próprio, capaz de lidar com uma grande quantidade de informações não só para armazenar os dados linguísticos da língua Suruí, mas, principalmente, para administrá-los (editando-os ou excluindo-os, por exemplo), ao mesmo tempo em que permitisse acessar, com uma interface intuitiva, todos os dados, além de permitir a construção, por exemplo, de dicionários.

\footnotetext{
${ }^{122}$ A indicação para uso desse software para desenvolvimento de bancos de dados linguísticos foi feita pela profa. Enilde Faulstich, durante o curso Lexicografia e Terminografia, ministrado por ela no âmbito do Programa de Pós-Graduação em Linguística, Departamento de Linguística, Português e Línguas Clássicas, Instituto de Letras, da Universidade de Brasília.

${ }^{123}$ Antes de decidir pelo uso do Access, testei as demais ferramentas de banco de dados disponíveis e experimentei também a construção de bases em outros programas, mas nenhum deles atendia, de modo geral, aos requisitos e objetivos desta pesquisa linguística.
} 
Outra vantagem de desenvolver esse sistema, é que ele permitiria a exportação dos dados de forma estruturada (em tabelas) e personalizada em diversos formatos (XML, TXT, XLS, XPS, RTF, por exemplo), que seriam facilmente recuperáveis por outros sistemas de bancos de dados, evitando, assim, por causa da rápida obsolescência dos sistemas, impedimento de acesso aos dados.

Dessa maneira, uma vez definido que programa seria utilizado para desenvolvimento do SGBD, fiz a modelagem da base, conforme descrevo a seguir.

Antes de tudo, o sistema deveria ser projetado para comportar informações relativas ao conjunto de dados coletados na pesquisa de campo, por isso a necessidade de um espaço para inserir descrições dos corpora. Associados a cada corpus estão os dados propriamente ditos - textos, frases e palavras já transcritos -, que deveriam ser armazenados de forma estruturada, a fim de criar uma rede de informações entre eles. Por fim, todos esses dados deveriam estar associados a um projeto lexicográfico, cuja forma final dependeria estritamente do que desejava como produto; por exemplo, os dados poderiam ser compilados para construir, por exemplo, um dicionário monolíngue, um dicionário bilíngue, uma lista numerada de termos ou ainda fichas individuais com todas as informações de determinada palavra na forma de verbete de dicionário. Essa multifuncionalidade do sistema garantiria que a base não se tornaria um repositório estéril de registros linguísticos, pois, ao ser alimentada e administrada, poderia vir a ser utilizada para os mais diversos fins, por linguistas, antropólogos e até pelos próprios professores da comunidade Suruí.

Por fim, um sistema dessa natureza deveria levar em consideração os seguintes aspectos: (1) comportar, ao lado dos dados escritos inseridos, os respectivos registros sonoros; (2) permitir o backup dos dados para garantir a integridade do sistema; (3) garantir a segurança de acesso aos dados por meio de um sistema de senhas; (4) permitir a personalização das informações das várias bases de dados que integram o sistema; e (5) gerar materiais oriundos dos dados nela armazenados.

\subsection{A ESTRUTURA DA INFORMAÇÃO NO SGBD}

Como apresentei na seção anterior, um SGBD voltado para o armazenamento de dados linguísticos deve ser modelado conforme a natureza e as necessidades de cada projeto. Assim, neste projeto, desenvolvido no âmbito de um curso de doutorado e que envolve a pesquisa de uma língua indígena brasileira, busquei fazer uma primeira modelagem de um 
SGDB para compilar os dados linguísticos da língua Suruí. ${ }^{124}$ Intitulado Diccionario: Base de

Dados e Dicionário, esse programa apresentava a seguinte estrutura:

- Áreas de inserção de dados: corpus, falantes, enunciados, dicionário e verbetes.

- O registro de um corpus apresentará os seguintes atributos: tipo de registro (sonoro, escrito, audiovisual, etc.); identificação da língua registrada; local, data e responsável pelo registro; falantes que forneceram os dados; referências do registro.

- $\mathrm{O}$ registro dos falantes abrangerá informações como: nome completo; outros nomes (se houver), grupo/etnia a que pertence o falante, data e local de nascimento, atividade/profissão, escolaridade, endereço, línguas faladas por ele.

○ Os enunciados deverão ser inseridos em área própria, nos quais haverá os campos: transcrição do enunciado na língua 1, a sua estrutura morfológica, a respectiva análise morfológica e a glosa em uma segunda língua.

○ O dicionário refere-se ao projeto lexicográfico propriamente dito, que deve apresentar informações sobre: o tipo de dicionário, a(s) língua(s) envolvida(s), o título, a autoria e os direitos autorais, os colaboradores, a descrição da obra, a descrição da estrutura do(s) verbete(s) e a instituição (se houver).

- O verbete, por não se limitar a um tipo específico de dicionário, apresentará vários atributos, cujo uso deve ser definido conforme a proposta lexicográfica que se queira: associação direta com o dicionário; relacionamento com um corpus da base, indicação de eventuais casos de homonímia, registro do lema na língua 1, arquivo sonoro correspondente, definição na língua 1 com a respectiva indicação da propriedade gramatical, formas variantes, registro de transcrição fonética e regristro da forma fonológica, glosa (ou tradução) na língua 2, definição na língua 2, segmentação e análise morfológica do lema, datação e etimologia, frequência de uso, informação enciclopédica, informação sociolinguística, referência cruzada, termo científico (no caso de plantas e animais), exemplos L1/L2, categorização por assunto. ${ }^{125}$

- Área para registro do sistema de sons: registro da relação entre fonemas e fones, forma escrita (maiúscula e minúscula), armazenamento do respectivo som.

\footnotetext{
${ }^{124}$ Esse programa foi usado até julho 2013, quando passei a desenvolver uma segunda versão mais completa do programa.

${ }^{125}$ A categorização por assunto permitiu a classificação dos termos da base a partir de um critério semântico, por exemplo, separando plantas de animais, e subcategorizando, por exemplo, os termos ligados a animais segundo suas espécies mamíferos, aves.
} 
- Área para registro de tarefas relacionadas ao desenvolvimento do projeto lexicográfico: status da tarefa, prioridade, título e descrição da tarefa, prazos, registro de porcentagem e anexação de arquivos de apoio.

- Área de acesso: sistema de login e senha, que pode ser administrado por área própria no interior do sistema.

- O cadastro de usuários consistirá de: nome de usuário, senha, nível de acesso, nome completo, e-mail, titulação, instituição, telefones, endereço, responsável pelo cadastro e função no projeto.

- Área de acesso rápido a informações da base (relatórios): tarefas, anotações, verbetes, enunciados, falantes, sons (com possibilidade de impressão e exportação de todos esses dados).

- Área de administração de todos os dados constantes na base:

○ (1) dados nativos da base - lista de línguas, famílias e troncos; ${ }^{126}$ propriedades gramaticais; símbolos fonéticos, tipos de exemplificação; tipos de dicionários; assuntos;

○ (2) dados inseridos na base - dicionário, verbetes, corpus; enunciados; sons; falantes; tarefas; anotações; fontes de exemplificações;

○ (3) exportação dos dados no formato de tabelas (XLS).

- Área de exportação dos dados na forma de dicionários. ${ }^{127}$

- Exportação em formato de fichas individuais para dicionários monolíngues e bilíngues (ordem alfabética).

○ Exportação em formato de folhas formatadas em uma ou duas colunas para dicionários monolíngues e bilíngues completos (ordem alfabética).

- Exportação em formato de folhas formatadas em uma ou duas colunas para dicionários monolíngues e bilíngues reduzidos (ordem alfabética).

○ Exportação em formato de folhas formatadas em uma ou duas colunas para dicionários bilíngues L1 $\rightarrow$ L2 e L2 $\rightarrow$ L1 (ordem alfabética, por propriedades gramaticais ou por assunto).

○ Listas: de informação enciclopédica ou sociolinguística; numeradas de entradas em L1; de enunciados e de abreviaturas.

- Área para fazer cópias de segurança de toda a base de dados.

\footnotetext{
${ }^{126}$ As listas de línguas, famílias e troncos linguísticos foi baseada em Rodrigues (2013, p. 7-10).

${ }^{127}$ As estruturas de dicionários inseridas no sistema representam apenas as formas mais canônicas de dicionários, que podem atender sem dificuldade à maior parte das situações mais comuns. Contudo, o sistema deve permitir que os dados sejam manipulados conforme a necessidade de cada usuário.
} 
A etiquetagem dos elementos da base, que muitas vezes é feita de modo manual em sistemas de bancos de dados linguísticos, foi aqui substituída pela própria indicação constante nos formulários de entrada de dados, que estão diretamente relacionados, por sua vez, a etiquetas das próprias tabelas que recebem e estruturam as informações, conforme programação do software.

Uma vez desenvolvido esse SGBD, ele passou por uma fase de testes, que, apesar de curta, foi crucial tanto para a modelagem adequada dos conteúdos e da interface gráfica, quanto para a correção de problemas de programação, de inconsistências da base, de mal funcionamento de comandos e de uniformização de fontes e estilos. A seguir, apresento, um esquema com as relações de todos os componentes desse programa de banco de dados:

\section{FIGURA 10 - ESTRUTURA DO SGBD DICCIONARIO}

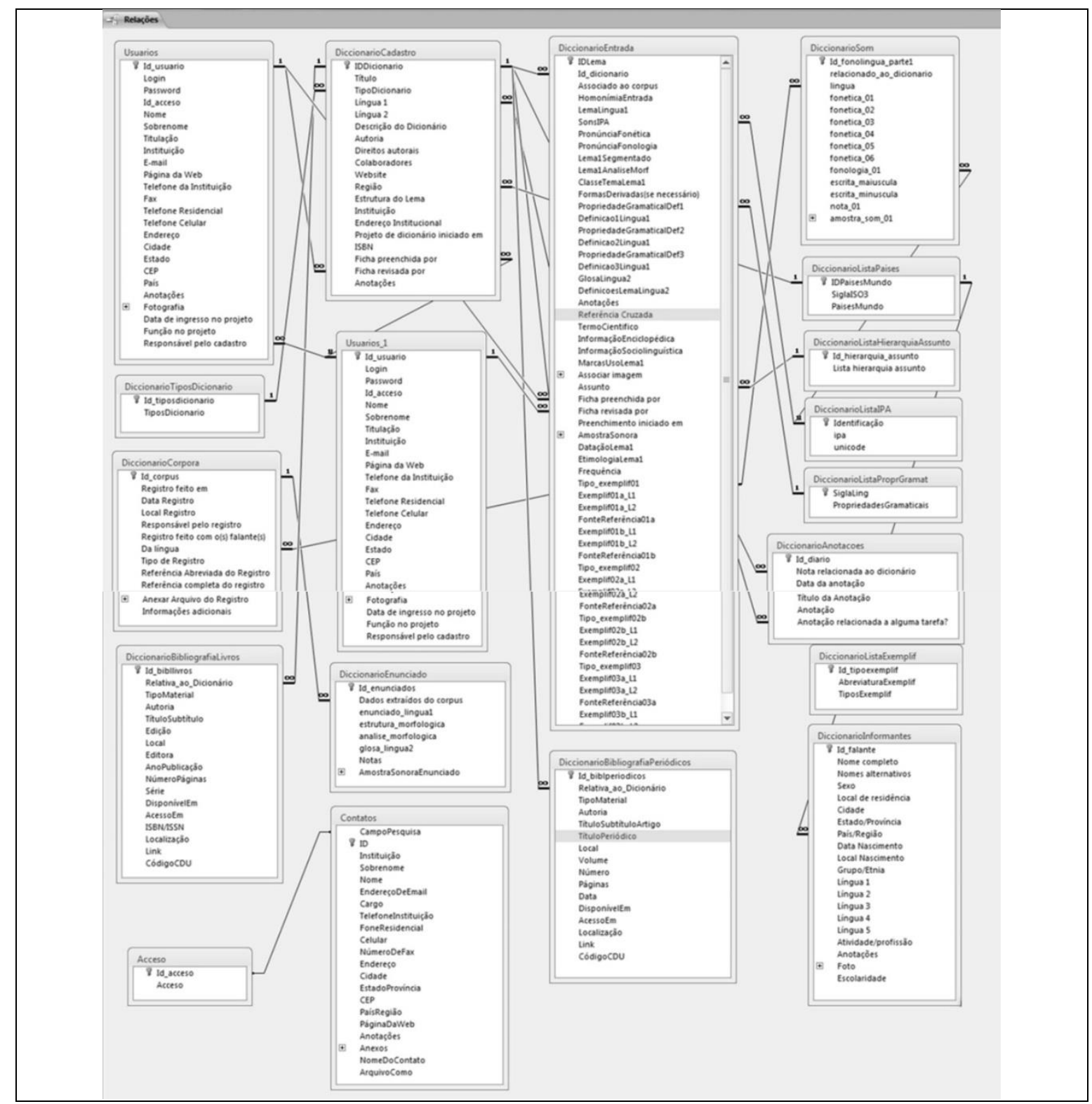


Ao finalizar o programa Diccionario, coloquei-o sob uma licença GNU-GPL$\mathrm{CC},{ }^{128}$ a fim de que outras pessoas pudessem usar e contribuir, se assim o desejassem, com o aperfeiçoamento do sistema. Nessa primeira fase do programa de banco de dados, alimentei a base com os dados da língua Suruí, correspondendo a quase 1.000 entradas.

Concluídos a construção, os testes e o uso efetivo da primeira versão do programa de banco de dados Diccionario, verifiquei que esse poderia ser aperfeiçoado e servir para além da construção específica de dicionários. Por isso, iniciei uma nova modelagem de SGDB, baseada em parte naquela proposta inicial, e construí um novo programa, com interface mais intuitiva, com novos inter-relacionamentos e capaz de armazenar e processar uma quantidade bem maior de dados. Assim nasceu o Programa Línguas, que apresento a seguir.

\subsection{O PROGRAMA LÍNGUAS}

Línguas - Banco de Dados para Documentação Linguística é um programa de gerenciamento de banco de dados baseado em Access e VBA, cuja principal finalidade é auxiliar o trabalho de pesquisadores na documentação e análise de línguas. ${ }^{129}$

Desenvolvido, inicialmente, como parte da metodologia desta tese sobre documentação e descrição da língua Suruí do Tocantins, sob a orientação da Profa. Dra. Ana Suelly Arruda Câmara Cabral (IL/UnB), o programa Línguas foi originalmente concebido como aplicativo para a construção de dicionários no âmbito da disciplina Lexicografia e Terminografia, ministrada pela Profa. Dra. Enilde Faulstich (PPGL/IL/UnB), mas foi ampliado a fim de permitir a documentação de outras línguas. ${ }^{130}$

A atual versão do programa Línguas herdou do programa Diccionario a função de gerar dicionários (e outros materiais) automaticamente a partir dos dados cadastrados nas

\footnotetext{
${ }^{128}$ GNU-GPL, sigla de Gnu General Public License (Licença Pública Geral), se refere a uma licença para uso de diferentes materiais, como programas de computador. A essa licença foi acrescida outra do tipo CC, sigla de Creative Commons. Juntas essas licenças estabelecem as condições de uso do material distribuído na condição de software livre. Mais informações podem ser obtidas nos sites http://creativecommons.org e http://softwarelivre.org/.

${ }^{129} \mathrm{O}$ desenvolvimento deste projeto só foi possível com o apoio técnico-científico do Laboratório de Línguas e Literaturas Indígenas (LALLI), da UnB, [site: http://www.laliunb.com.br], coordenado pelo Prof. Dr. Aryon Dall'Igna Rodrigues (in memoriam) e pela Profa. Dra. Ana Suelly Arruda Câmara Cabral, e do Centro de Estudos Lexicais e Terminológicos (Centro Lexterm), da UnB, coordenado pela Profa. Dra. Enilde Faulstich, nos quais foi possível apresentar e testar as várias versões do programa e receber valiosas contribuições dos colegas e professores acerca do trabalho de pesquisa para coleta de dados de línguas, mas também sobre o próprio conteúdo teórico da linguística, nos domínios da documentação e da descrição linguística e, particularmente, da lexicologia e lexicografia.

${ }^{130}$ Certamente esse programa ainda não alcançou todo o seu potencial de armazenamento e de processamento, pois, à medida que é utilizado por mim e por outros pesquisadores, ele passa por ajustes, que o tornam cada vez mais completo para o trabalho de documentação linguística e para os produtos gerados a partir dele, como tipos de obras lexicográficas, comparações, análise de textos, etc.
} 
diferentes bases de dados, contudo, ele permite, além disso, o trabalho com uma variedade ainda maior de informações, que vão desde o registro de dados etnográficos, passando pelo registro de dados lexicais e textuais, até chegar à comparação de dados de diferentes línguas. Daí, a importância deste capítulo em que é apresentada uma descrição completa sobre as formas de acesso e também como usar todos os recursos disponíveis no programa para a criação e gerenciamento de um Projeto de Documentação Linguística (PDL), mas também com orientações para uso das ferramentas para instalar e desinstalar o programa.

\subsubsection{Informações técnicas}

O projeto e a programação originais deste programa foram desenvolvidos por mim, a partir de maio de 2013. Para isso, utilizei a base do Microsoft Access 2010 com MS Visual Basic for Applications 7.0, com atualizações que chegaram até a versão 3.9 (concluída em junho de 2014).

Para executar o programa, os requisitos básicos são: Sistema Operacional: Windows 7 ou superior; Windows Server 2003 R2 (32-Bit x86); Windows Server 2003 R2x64 editions; Windows Server 2008 R2; Windows Server 2008 Service Pack 2; Windows Vista Service Pack 1; Windows XP Service Pack 3. Programas: MS Access 2010 ou MS Access Runtime, MS Word 2007 ou superior, Adobe Reader ${ }^{\circledR}$ (ou outro leitor de documento PDF). Além disso, são necessárias as fontes (tipos) Arial, Calibri, CM, Paulpan, Times New Roman. ${ }^{131}$

Ao ser concluído, o programa Línguas foi compilado em um arquivo executável, para ser instalado como qualquer outro programa de computador. Na próxima subseção, apresento as etapas dos processos de instalação e de desinstalação desse programa.

\subsubsection{Instalação e desinstalação do Programa Línguas}

O programa Línguas possui um Assistente de Instalação, para executá-lo, é necessário abrir o arquivo setup.exe, localizado na pasta Línguas. Clicando sobre ele, abre-se a janela de configuração, na qual é preciso clicar sobre o botão Avançar. ${ }^{132}$

\footnotetext{
${ }^{131}$ As seguintes marcas citadas ao longo deste trabalho pertencem aos seus respectivos proprietários: Windows 7 Home Premium $^{\circledR}$; Microsoft ${ }^{\circledR}{\text { Office Access } 2010^{\circledR} \text {; } \text { Microsoft }^{\circledR} \text { Access } 2010 \text { Runtime }^{\circledR} \text {; Adobe Reader }}^{(\text {(Adobe }}$ Systems $\left.{ }^{\circledR}\right)$.

${ }^{132}$ A instalação do programa pode requerer permissão de Administrador do sistema operacional.
} 
FIGURA 11 - INÍCIO DO ASSISTENTE DE INSTALAÇÃO DO PROGRAMA LÍNGUAS

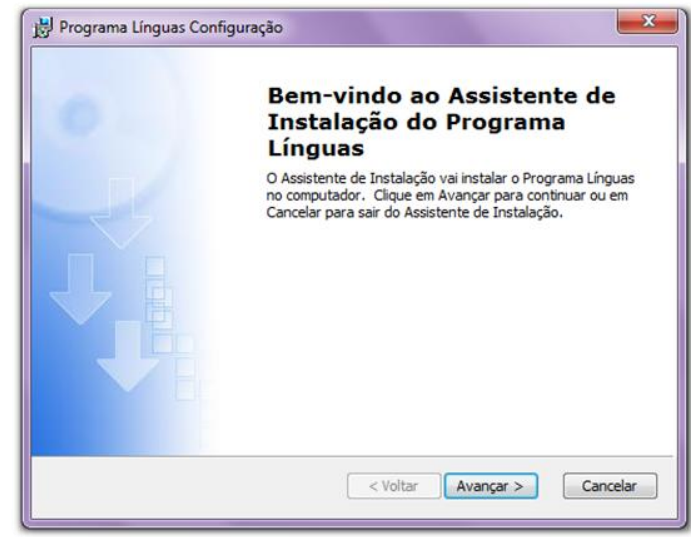

Na janela seguinte, há um espaço para inserção de um Nome de Usuário (para efeito de registro do Programa) e de uma informação sobre Organização (instituição a que está vinculado o usuário). Preenchidas as informações, clico em Avançar. ${ }^{133}$

\section{FIGURA 12 - JANELA 2 DO ASSISTENTE DE INSTALAÇÃO DO PROGRAMA LÍNGUAS}

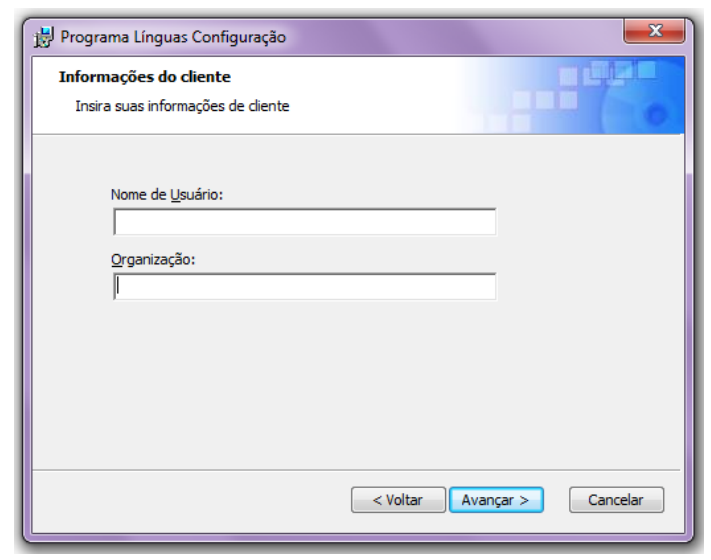

Na terceira janela, a opção a ser escolhida é a da Instalação Típica.

FIGURA 13 - SELEÇÃO DO TIPO DE INSTALAÇÃO DO PROGRAMA LÍNGUAS

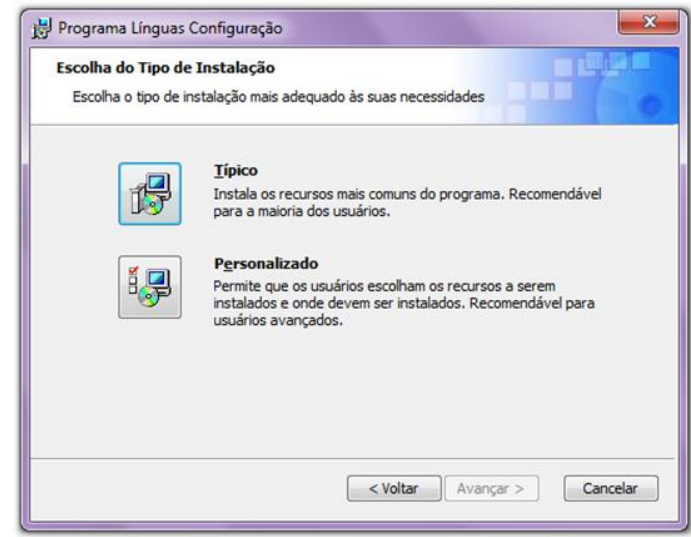

${ }^{133}$ As informações constantes nas janelas do processo de instalação do programa, tais como "Informações do cliente" e "Organização" fazem parte da programação original da base do SGDB, logo, não tive acesso a elas para eventuais ajustes. 
Nessa nova janela do programa de instalação, seleciono a opção Instalar e isso executa a instalação do programa na máquina. ${ }^{134}$

\section{FIGURA 14 - JANELA DE INÍCIO DA INSTALAÇÃO DO PROGRAMA LÍNGUAS}

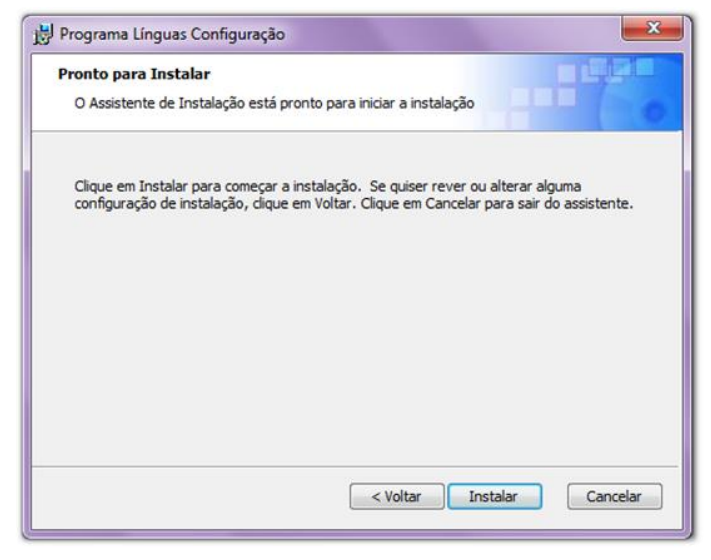

Clicando sobre o botão Concluir, o instalador do programa se fecha e o programa Línguas já está instalado e pronto para ser usado no computador.

FIGURA 15 - JANELA DE CONCLUSÃO da INSTALAÇÃO DO PROGRAMA LÍNGUAS

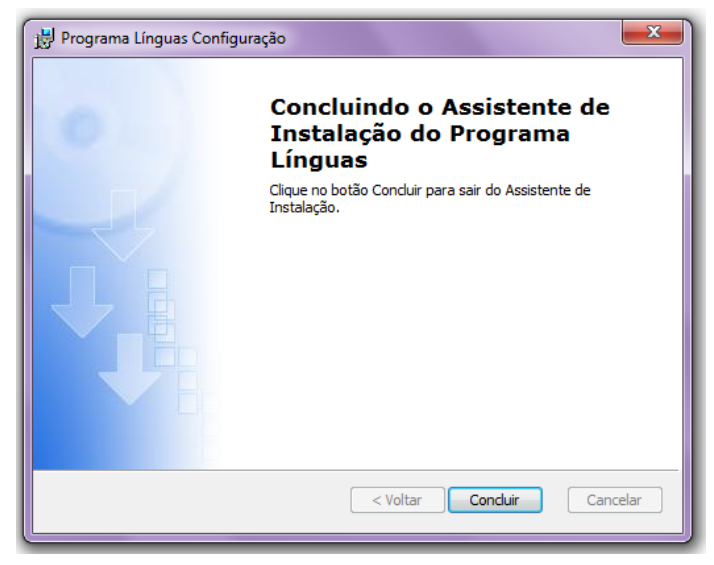

Para acessar o programa, um atalho do programa foi gerado na Área de Trabalho do computador.

Para executar o programa Línguas é necessário, contudo, que o programa Microsoft ${ }^{\circledR}$ Office Access $2010^{\circledR}$ esteja instalado no computador. Caso não haja este programa instalado, será necessário instalar o programa Microsoft ${ }^{\circledR}$ Access 2010 Runtime $^{\circledR} .135$

\footnotetext{
${ }^{134} \mathrm{O}$ tempo de conclusão dessa instalação pode variar de computador para computador, dependendo da configuração de hardware.

${ }^{135}$ Este software, distribuído gratuitamente pela própria Microsoft ${ }^{\circledR}$, serve para executar o programa de banco de dados, mesmo que a versão completa do Office não esteja instalada no computador. Dependendo da versão do instalador do Programa Línguas, ele será instalado automaticamente logo após a conclusão da instalação do programa principal. Nesse caso, devem ser seguidas as instruções de instalação do programa Microsoft ${ }^{\circledR}$ Access 2010 Runtime $^{\circledR}$ e aguardar a sua conclusão.
} 
Uma vez instalado o programa Línguas, ele pode ser desinstalado do computador utilizando o próprio arquivo de instalação setup.exe. Nesse caso, basta clicar sobre esse arquivo e uma janela de configuração será aberta. Nela, clico em Avançar.

FIGURA 16 - JANELA DE INÍCIO DA DESINSTALAÇÃO DO PROGRAMA LÍNGUAS

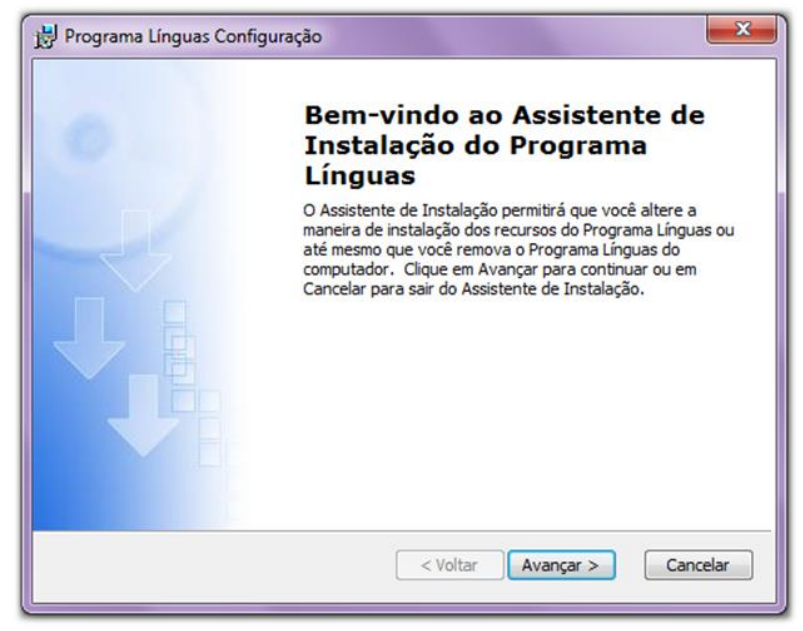

$\mathrm{Na}$ janela seguinte, duas opções são oferecidas: Reparar e Remover. A opção Reparar reinstala o programa Línguas, porém, apaga todos os dados já inseridos nele. ${ }^{136}$ Já a opção Remover executa a desinstalação completa do programa Línguas. Selecione a opção desejada.

\section{FIGURA 17 - JANELA DE OPÇÕES DA CONFIGURAÇÃO DO PROGRAMA LÍNGUAS}

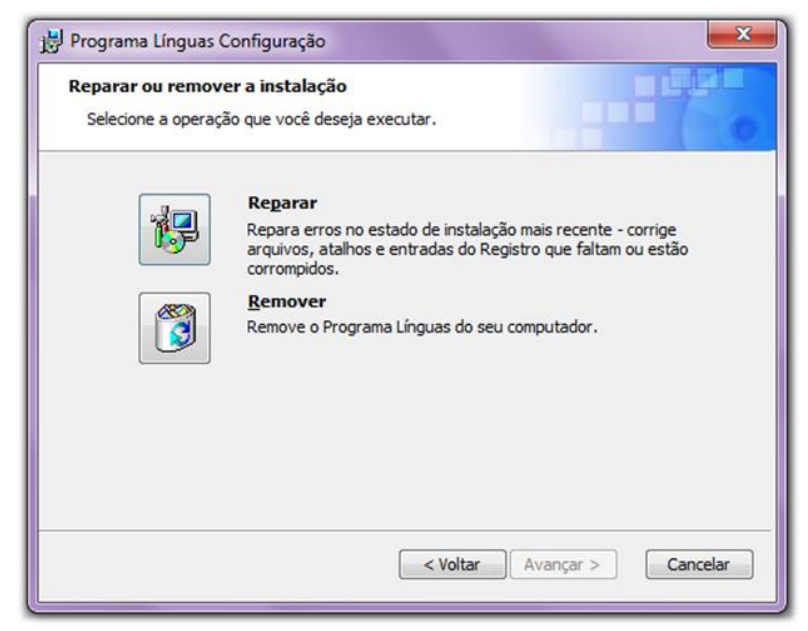

Ao escolher a opção Remover, uma mensagem sobre o processo é apresentada. Para prosseguir a desinstalação, clico em Remover.

\footnotetext{
${ }^{136}$ O programa Línguas conta com dois recursos para manutenção dos dados: um é por meio do backup do sistema (cf. subseção 8.5.4.7.3), outro é por meio da exportação de todos os dados armazenados em diferentes formatos, mas, sobretudo, em formato xls, arquivo padrão do programa Excel (cf. subseção 8.5.4.7.2).
} 
FIGURA 18 - JANELA DE DESINSTALAÇÃO DO PROGRAMA LÍNGUAS

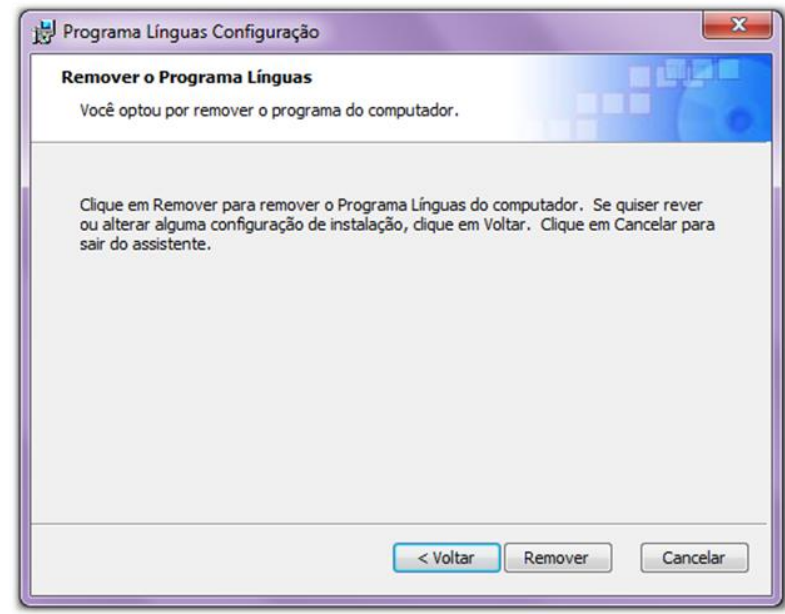

Aguarde a execução do processo de desinstalação e clique em Concluir.

FIGURA 19 - JANELA DE CONCLUSÃO DA DESINSTALAÇÃO DO PROGRAMA LÍNGUAS

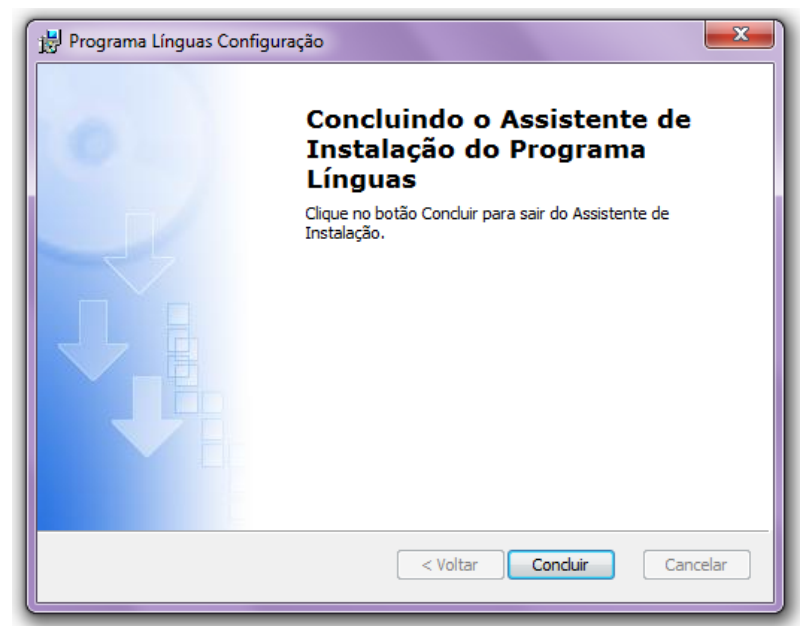

Outro modo para desinstalar o programa Línguas é utilizando o próprio desinstalador do Windows. ${ }^{137}$ Após localizar o programa Línguas na lista de programas instalados, basta clicar sobre ele. Em seguida, responder Sim à pergunta "Tem certeza de que deseja desinstalar Programa Línguas?”, e aguardar a finalização do processo. ${ }^{138}$

\footnotetext{
${ }^{137}$ O caminho para acessar a área de desinstalação do sistema operacional Window 7 é Painel de Controle do Windows > Programas > Desinstalar um programa.

${ }^{138}$ A desinstalação do programa Línguas implica no apagamento de todos os dados nele inseridos. Por isso, devo me certificar de que é exatamente isso que desejo fazer, pois, uma vez desinstalado, não há como reverter o processo.
} 
FIGURA 20 - JANELA DO WINDOWS PARA DESINSTALAÇÃO DO PROGRAMA LÍNGUAS

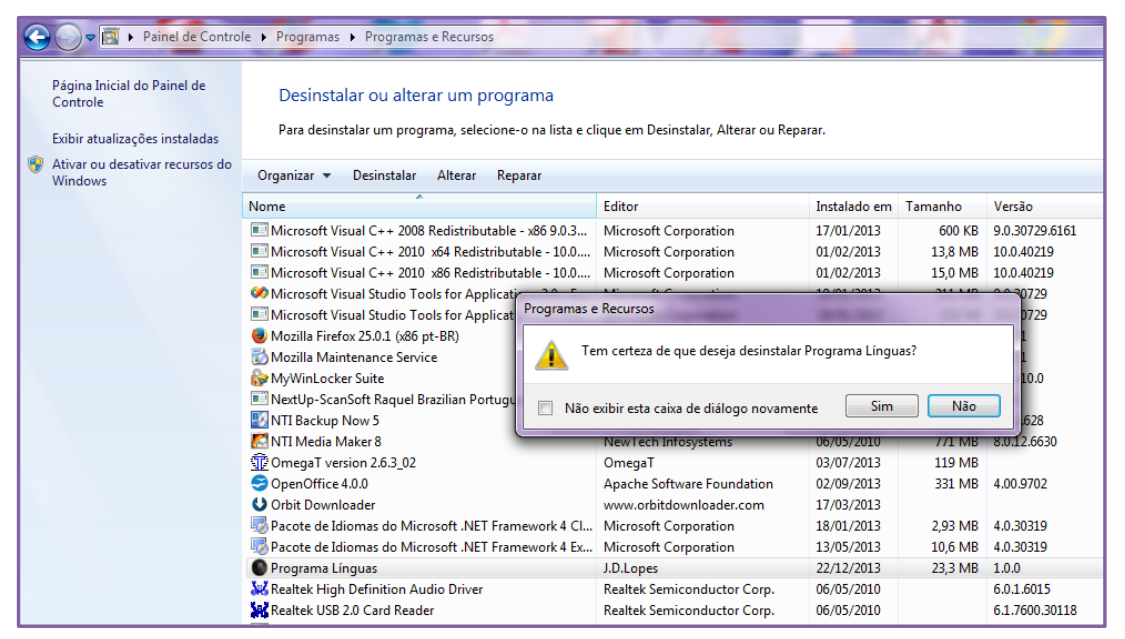

\subsubsection{Acesso ao Programa Línguas}

Para acessar o programa Línguas, clico sobre o ícone na Área de Trabalho do Windows. Ao abrir a janela Senha necessária, informo a senha do programa, fornecida pelo Administrador do sistema. Caso a senha inserida não esteja correta, uma mensagem de erro será mostrada.

\section{FIGURA 21 - JANELA DE SOLICITAÇÃO DE SENHA INICAL DO PROGRAMA LÍNGUAS}

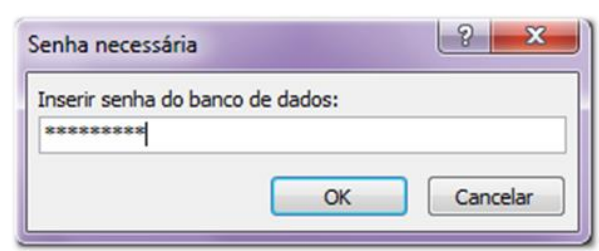

Então, clico sobre o botão $O k$ e insiro a senha fornecida pelo administrador do sistema. ${ }^{139}$ Se a senha estiver correta, abre-se, por padrão, um Aviso de Segurança do Microsoft Access. Para prosseguir o acesso ao programa, clico em Abrir.

FIGURA 22 - JANELA COM AVISO DE SEGURANÇA DO WINDOWS

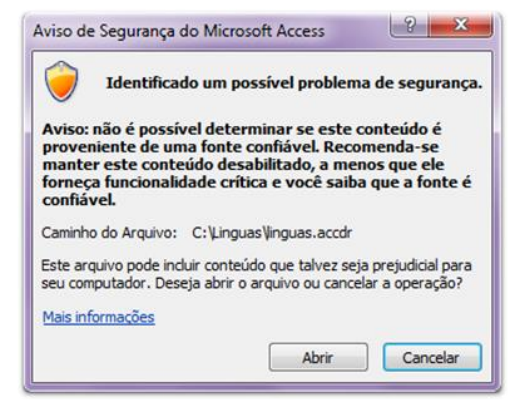

${ }^{139}$ Essa senha é fornecida com o arquivo de distribuição do programa. 
Na janela seguinte, uma segunda senha é requerida para acessar a área de trabalho do programa Línguas. Escolho um Nome de Usuário da lista (no primeiro acesso há somente o usuário Adm), insiro o Código de Segurança e clico em Entrar. ${ }^{140}$

\section{FIGURA 23 - JANELA DE ACESSO PRINCIPAL DO PROGRAMA LÍNGUAS}

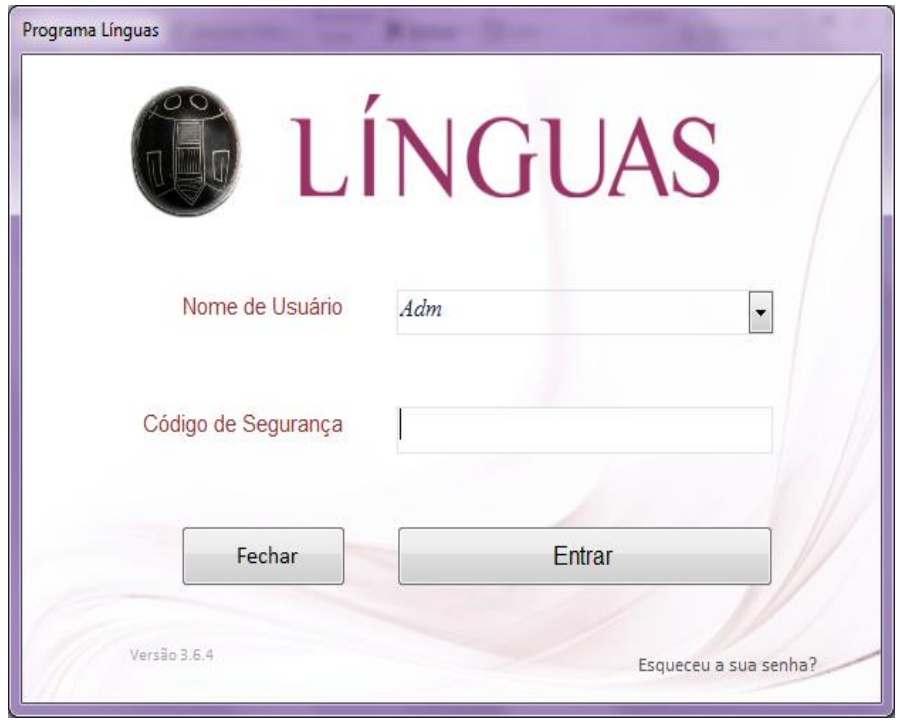

Se todos os dados estiverem corretos, uma janela de confirmação se abre, informando o status de usuário: Administrador ou Usuário.

FIGURA 24 - MENSAGEM DE ACESSO PERMITIDO NO PROGRAMA LÍNGUAS

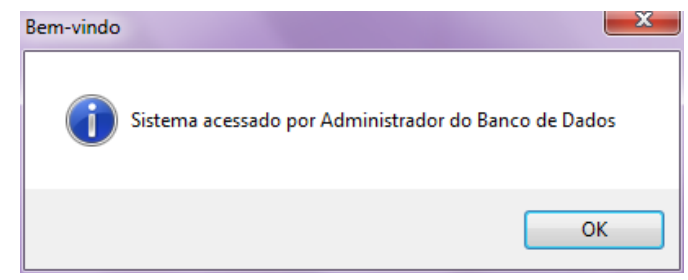

Clico em $O k$ para continuar a inicialização do programa.

\subsubsection{Informações sobre o Programa}

Antes da abertura da janela da Área de Trabalho do programa Línguas, uma nova janela apresenta informações úteis sobre navegação e segurança do software. São recomendações importantes, sobretudo para usuários que realizam seu primeiro acesso no programa. Para prosseguir a inicialização, clico sobre o logotipo LÍNGUAS, localizado no canto superior esquerdo da janela, que funciona com a função hiperlink. ${ }^{141}$

\footnotetext{
${ }^{140}$ Para fechar o Programa Línguas neste ponto do acesso, basta clicar sobre o botão Fechar.

${ }^{141}$ Também é possível acessar rapidamente áreas específicas do programa Línguas, clicando sobre o texto ou a imagem de qualquer um dos 5 primeiros tópicos da lista.
} 
FIGURA 25 - JANELA DO PROGRAMA LÍNGUAS COM INFORMAÇÕES E LINKS INICIAIS

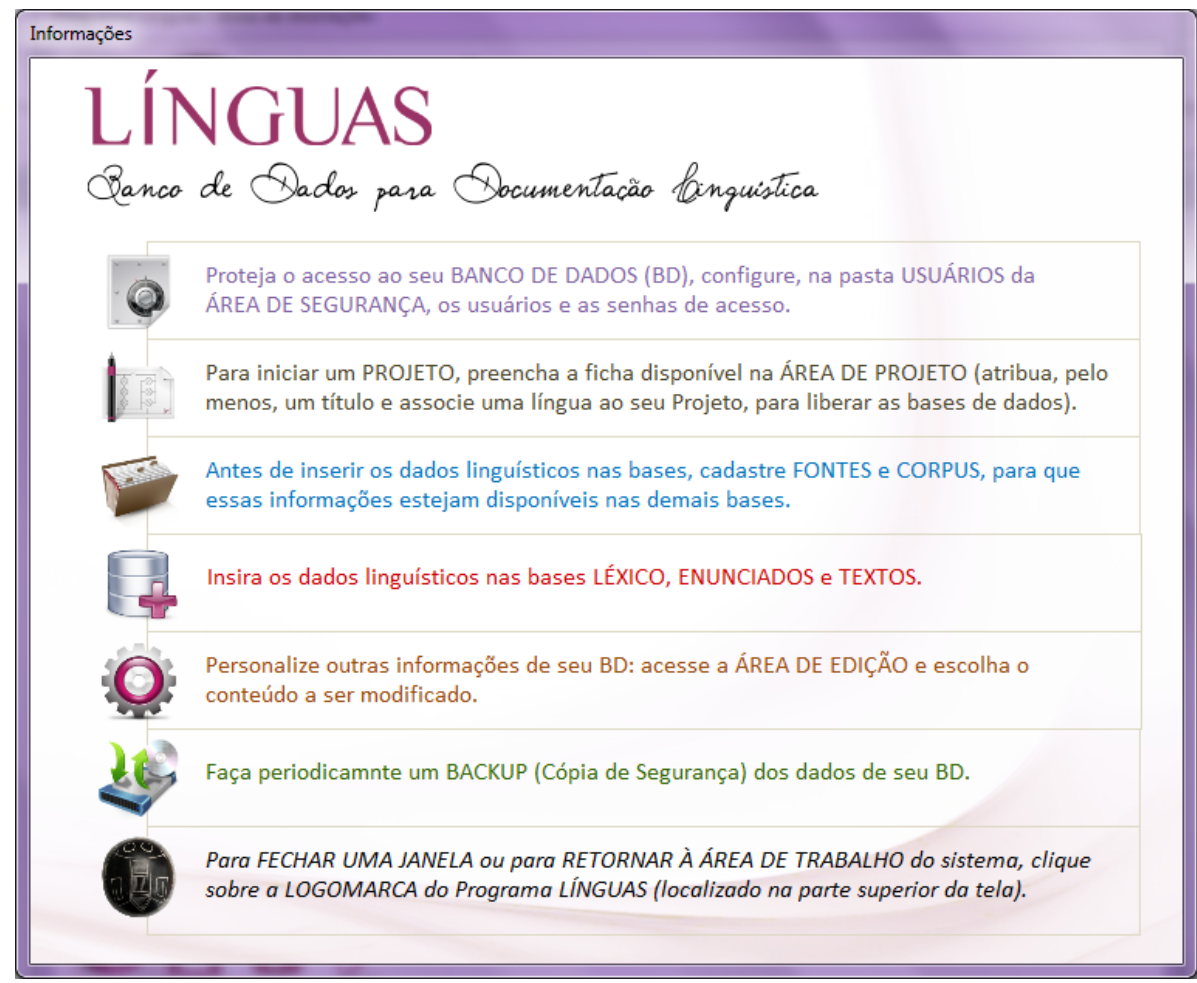

8.5.3.2. Área de recuperação de senhas

Ainda nesta janela é possível Recuperar a senha de usuário. Para isso, clico em Esqueceu a sua senha? e sigo os procedimentos descritos a seguir:

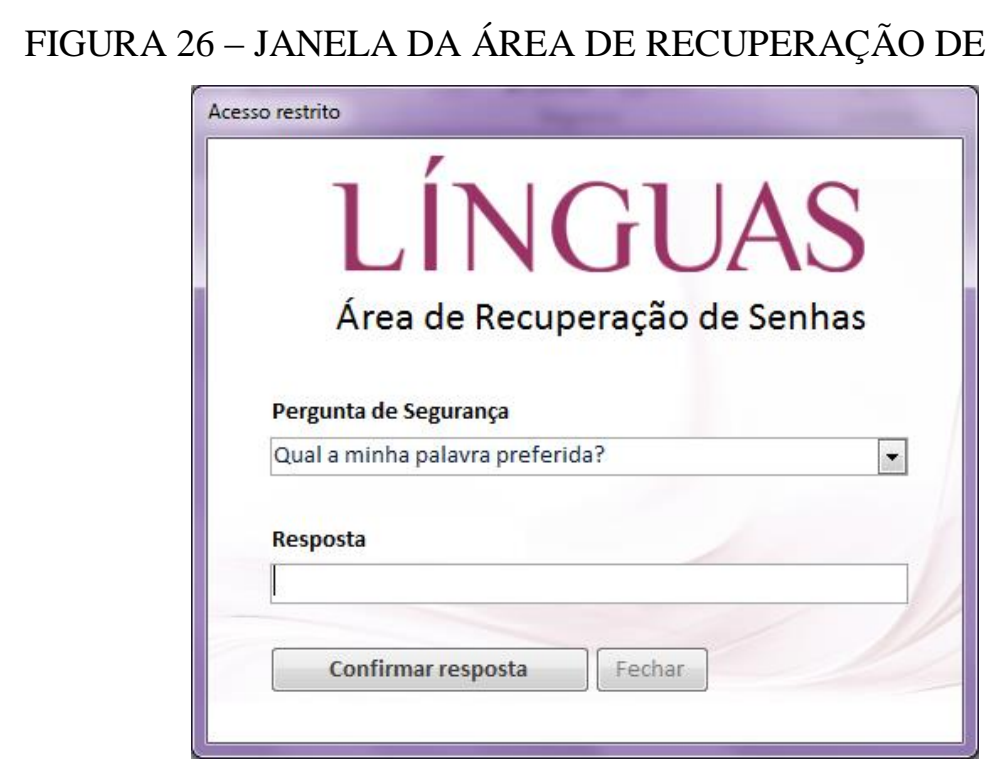

Seleciono uma Pergunta de Segurança na lista suspensa e, em seguida, preencho o campo Resposta. Se a resposta estiver correta, aparece uma janela de confirmação, onde clico em OK. 
Abre-se, então, a janela Atualizar senha de usuário, onde é possível redefinir a senha de acesso do usuário. ${ }^{142}$

\section{FIGURA 27 - JANELA PARA ATUALIZAÇÃO DE SENHA DE USUÁRIO}

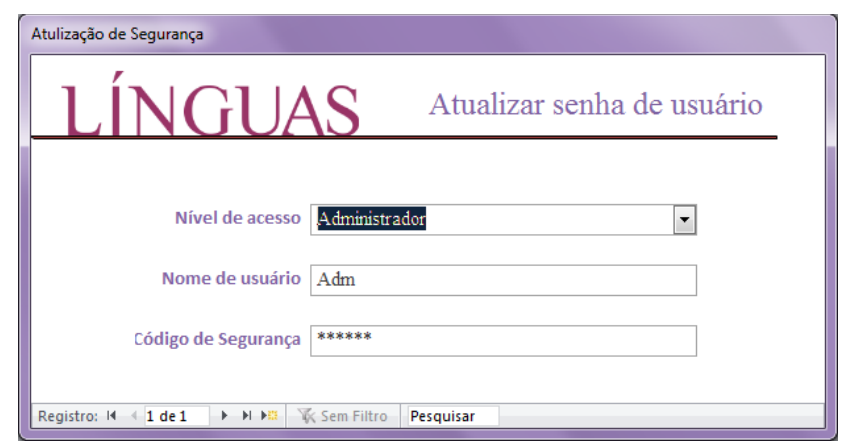

\subsection{4. Área de Trabalho do Programa Línguas}

A Área de Trabalho do programa Línguas é o ponto de partida para a inserção, edição e exportação de dados de um Projeto de Documentação Linguística (PDL).

\section{FIGURA 28 - JANELA PRINCIPAL DA ÁREA DE TRABALHO DO PROGRAMA LÍNGUAS}

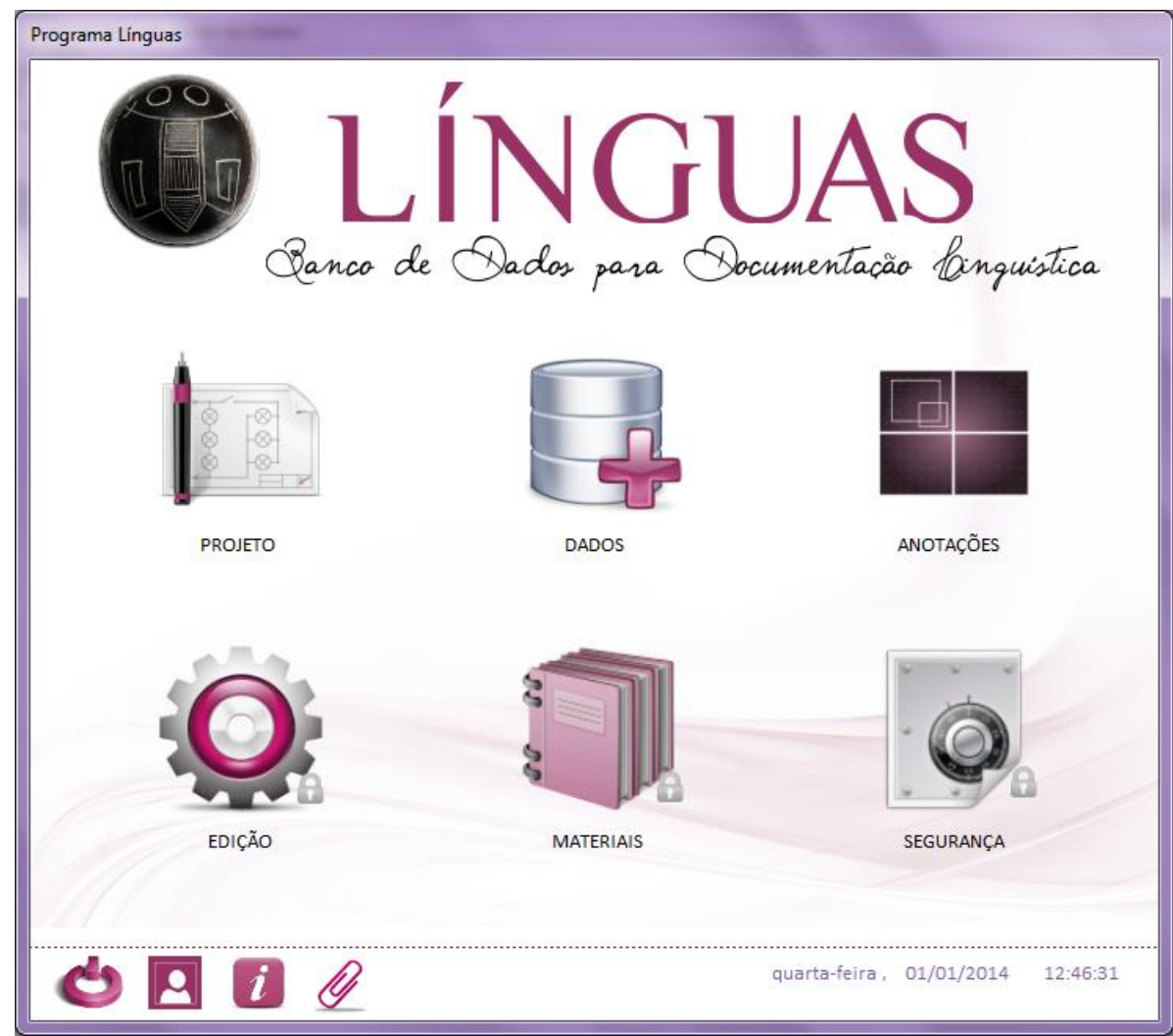

A Área de Trabalho do programa Línguas é o ponto de partida para construção da base de dados para documentação linguística. Ela é composta de 3 partes:

\footnotetext{
${ }^{142} \mathrm{O}$ cadastro das perguntas de segurança pode ser feito na entrada de Usuários, da Área de Segurança.
} 
- no alto da janela, há o logotipo, o título e o subtítulo do programa (sem função interativa, nesta janela);

- no centro há 6 ícones com hiperligações para acessar áreas específicas do programa: os três primeiros servem para a inserção de dados (Projeto, Dados e Anotações) e os três últimos para administração dos dados inseridos (Edição), exportação desses dados (Materiais) e configurações do sistema (Segurança);

- na parte inferior da janela, além das informações de data e hora, há 4 ícones que possuem as seguintes funções:

Desligar: fecha todo o programa Línguas.

9 Trocar usuário: encerra a sessão em uso e reinicia a abertura do programa.

i Orientações para uso do sistema: retoma a tela de orientações mostrada na inicialização do programa.

Sobre o programa: apresenta informações técnicas e notas sobre o programa Linguas.

\subsubsection{Iniciando um Projeto de Documentação Linguística}

Para que o programa Línguas armazene dados linguísticos, é necessário, antes, cadastrar informações referentes a um PDL. Para isso, clico sobre o ícone Projeto na Área de Trabalho e acesso a Área de Projeto.

\section{FIGURA 29 - JANELA DA ÁREA DE PROJETO DO PROGRAMA LÍNGUAS}

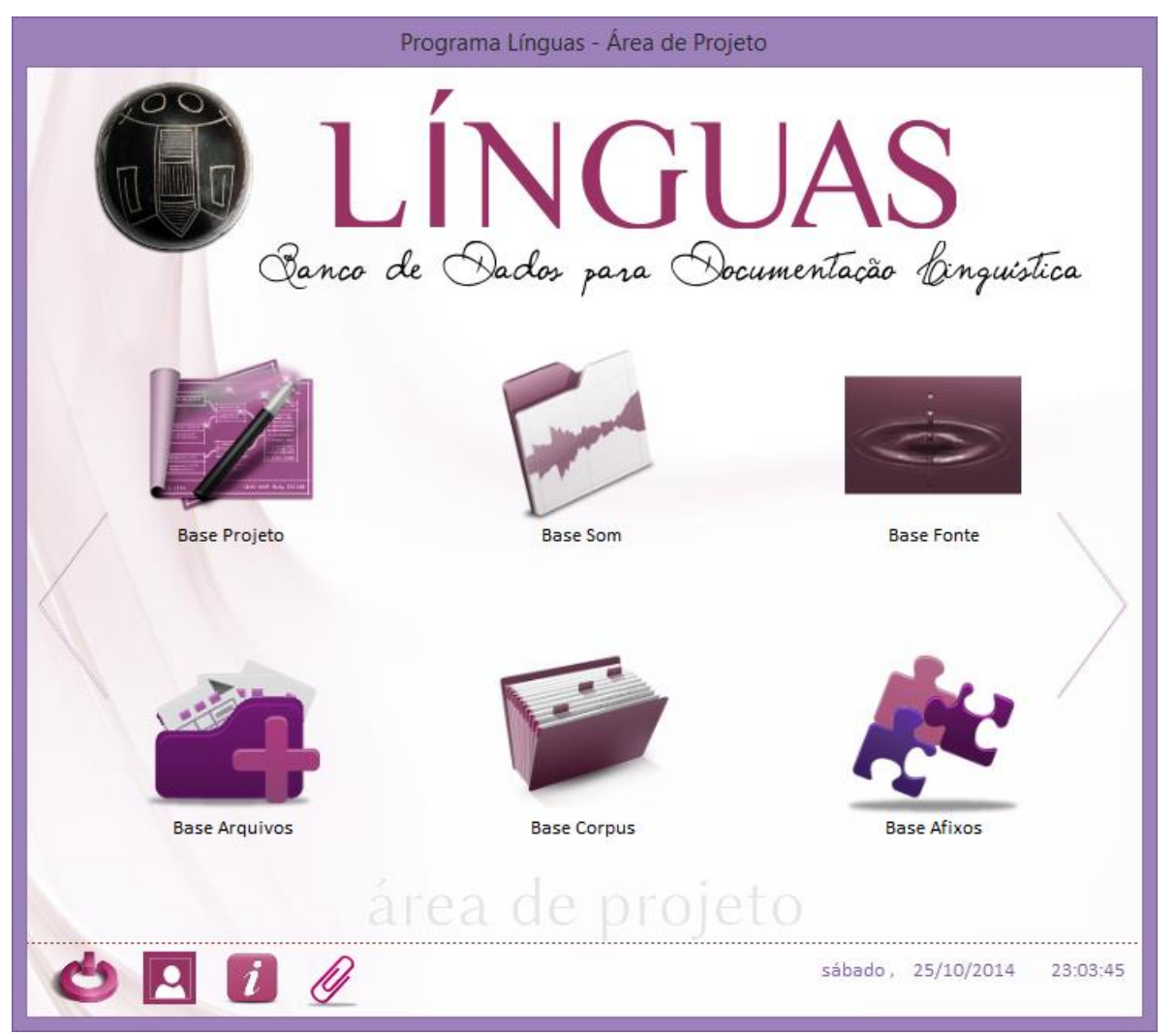


As setas laterais servem para navegação rápida entre as áreas do programa. A seta à esquerda leva para a janela precedente (neste caso, a Área de Trabalho) e a seta à direita leva para a janela seguinte (neste caso, a Área de Dados).

Nessa área, há seis novos ícones, correspondentes a bases para inserção das primeiras informações sobre o PDL. Apresento, a seguir, cada uma delas.

\subsection{Base Projeto}

É nesta base de dados que se deve cadastrar o PDL, ao qual todos os dados linguísticos inseridos no programa serão vinculados. Clico sobre o ícone referente à Base Projeto para acessar a área de cadastramento. ${ }^{143}$

A Base do Projeto apresenta um conjunto de 7 fichas identificadas por títulos nas respectivas abas, todas inter-relacionadas, que permitem o registro completo de um PDL.

\section{FIGURA 30 - JANELA DA ÁREA DE PROJETO DO PROGRAMA LÍNGUAS}

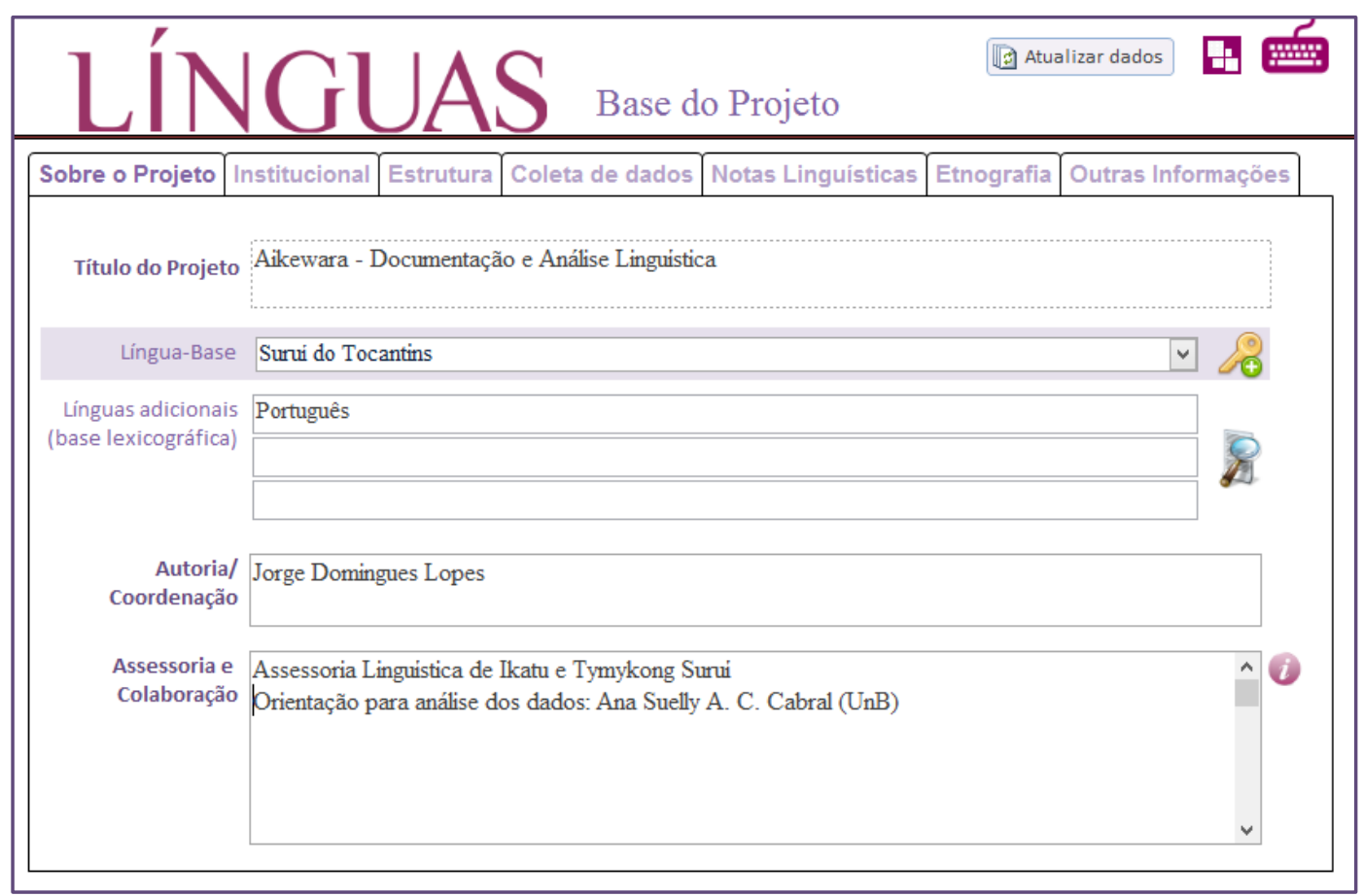

TABELA 16 - ABA 1: SOBRE O PROJETO

\begin{tabular}{ll}
\hline CAMPO & DESCRIÇÃO \\
\hline Título do Projeto & $\begin{array}{l}\text { Identifica o projeto de documentação linguística e é inserido } \\
\text { automaticamente em todas as fichas de dados. }\end{array}$ \\
\hline Língua-Base & Refere-se à língua que está sendo documentada. Recebe também, \\
\hline
\end{tabular}

${ }^{143}$ Os campos contidos na ficha de cadastramento do PDL deste programa não seguem nenhuma orientação institucional específica, buscando, na medida do possível, comportar a maior quantidade de informações necessárias para caracterização de um projeto de pesquisa na área da documentação linguística. 


\begin{tabular}{ll}
\hline & neste programa, a denominação L1. \\
\hline $\begin{array}{l}\text { Línguas adicionais } \\
\text { (base lexicográfica) }\end{array}$ & $\begin{array}{l}\text { Podem ser inseridas até 3 outras línguas para serem usadas na } \\
\text { construção de materiais lexicográficos. Essas línguas recebem, neste } \\
\text { programa, as denominações L2, L3 e L4, respectivamente. }\end{array}$ \\
\hline Autoria/Coordenação & $\begin{array}{l}\text { Identifica o(s) autor(es) e/ou coordenador(es) do projeto, que } \\
\text { pode(m) não coincidir com a autoria dos diferentes materiais } \\
\text { produzidos a partir dos dados armazenados no Banco de Dados. }\end{array}$ \\
\hline Assessoria e Colaboração & $\begin{array}{l}\text { Em muitos projetos, com ou sem apoio institucional, é possível } \\
\text { compor uma equipe de trabalho, cujos componentes e funções podem } \\
\text { aqui ser apresentados. }\end{array}$ \\
\hline Logomarca do Projeto & $\begin{array}{l}\text { É possível anexar uma imagem que represente a logomarca do } \\
\text { Projeto de Documentação. }\end{array}$ \\
\hline
\end{tabular}

Para passar de um campo a outro dentro de um mesmo formulário, é possível utilizar, além do mouse, a tecla $\stackrel{\text { tab }}{\rightarrow}$ (localizada mais comumente na extremidade esquerda de um teclado padrão).

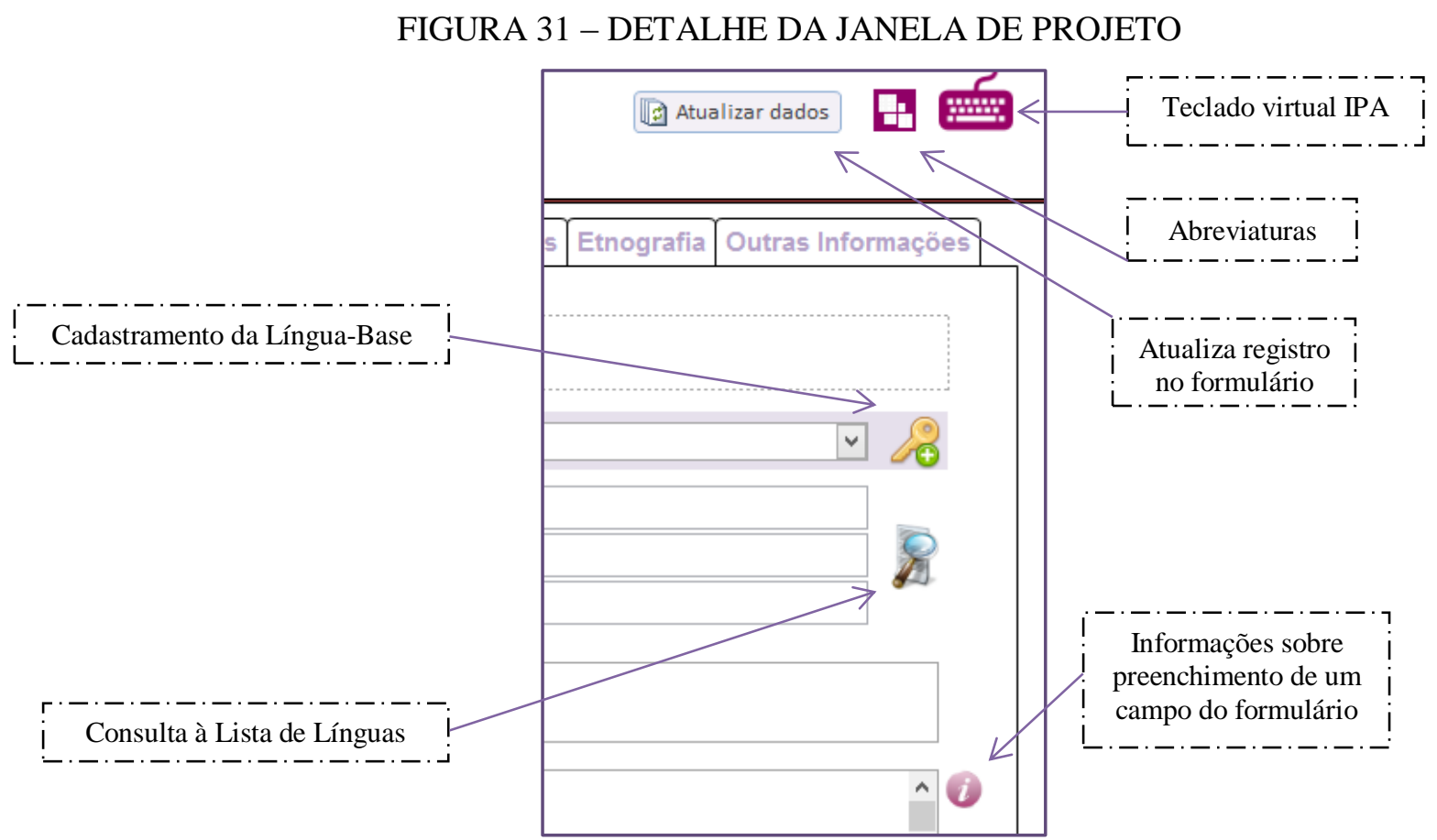

Detalhe da janela da Base de Projeto

\section{Língua-Base}

Para inserir a língua-base do Projeto, clico sobre o ícone $₫$. A janela Ficha de cadastro será aberta. Nessa janela há dois campos: Língua-Base, no qual se deve digitar o nome da língua, e Anotação Linguístico-Antropológica, no qual é possível fornecer 
informações detalhadas sobre a língua. Após preencher essas informações clico sobre o botão Salvar e fechar. ${ }^{144}$

FIGURA 32 - JANELA DE CADASTRO DAS LÍNGUAS DO PDL

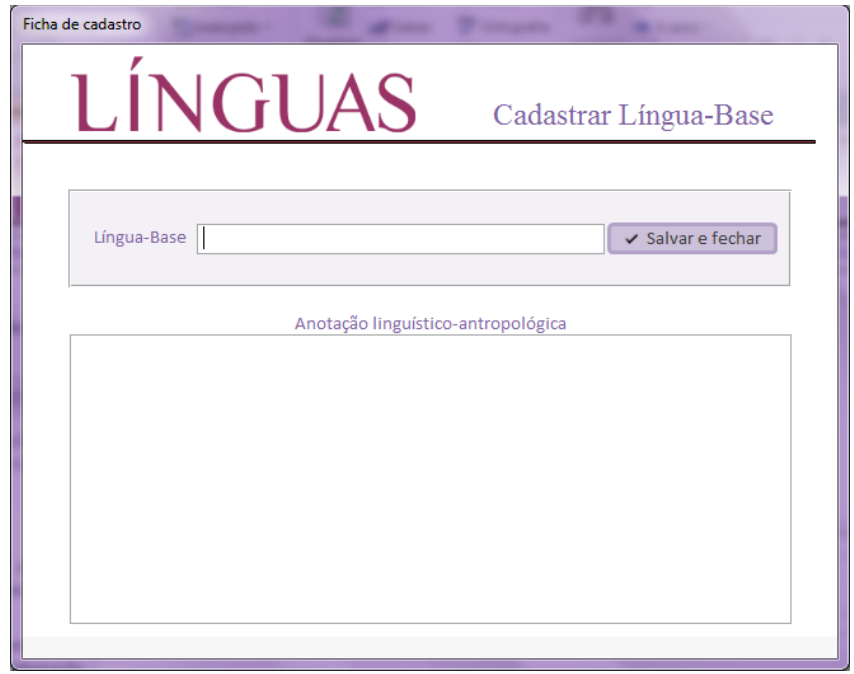

Lista de Línguas

Para visualizar a Lista de línguas, clico sobre o ícone 20. Essa lista, que possui, por padrão, um total de 238 registros (em sua maioria, línguas indígenas brasileiras), pode ser modificada conforme a necessidade do usuário (consulte a seção Área de Edição).

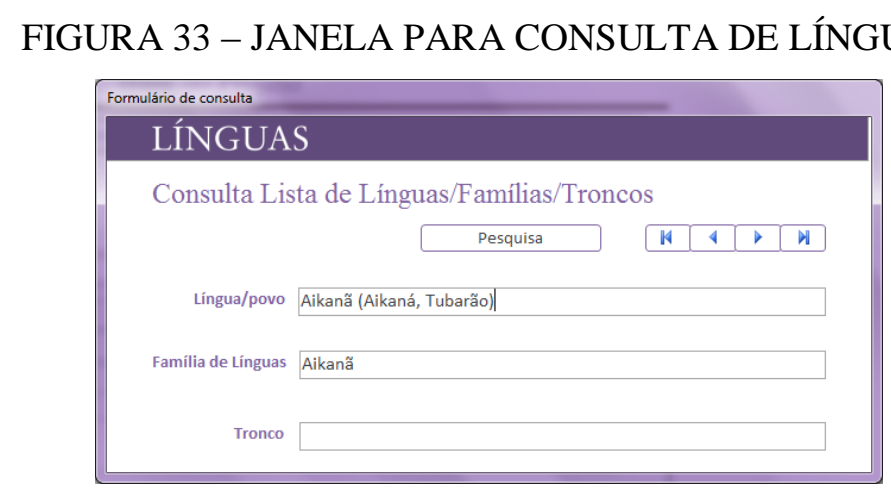

Abrir formulário para cadastrar abreviaturas

Abre um formulário para compor uma lista de abreviaturas usadas em todo o PDL.

Não confundir a finalidade desse campo de abreviaturas com o das abreviaturas da Lista de Propriedades Gramaticais. Enquanto esta última tem a finalidade de fornecer uma informação específica para uso na Base Léxico, o Registro de Abreviaturas serve como

\footnotetext{
${ }^{144}$ Para ver imediatamente no formulário a língua-base cadastrada, talvez seja necessário clicar sobre o botão Atualizar dados na parte superior direita da Base do Projeto.
} 
cadastro geral das chaves de leitura para os diversos textos compostos no interior do programa Línguas e também para os vários materiais derivados do Banco de Dados (artigos científicos, dicionários, catálogos, entre outros). Logo, pode haver coincidência de itens entre esses dois repositórios.

\section{FIGURA 34 - JANELA PARA CADASTRO DE ABREVIATURAS}

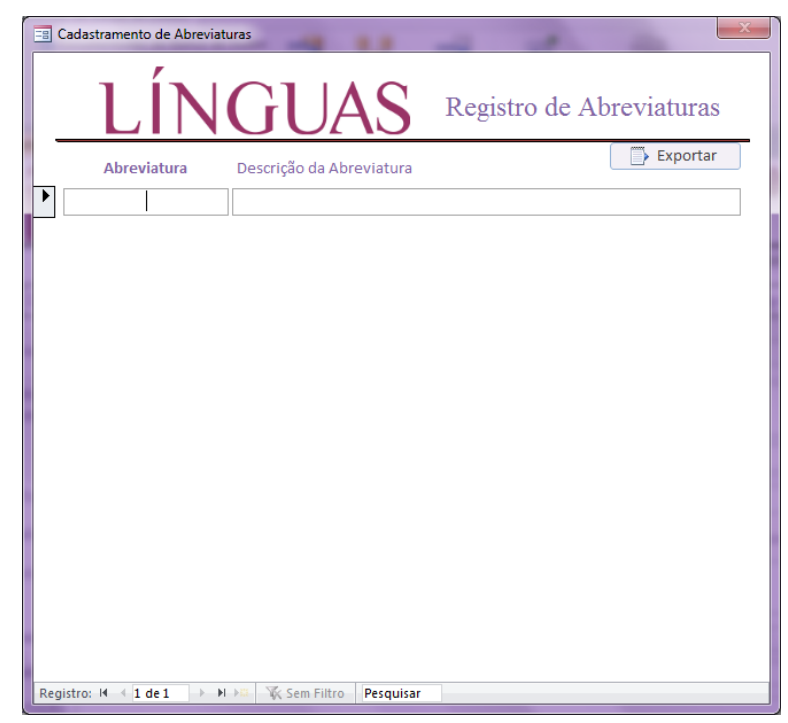

TABELA 17 - DADOS DA JANELA DE REGISTRO DE ABREVIATURAS

\begin{tabular}{ll}
\hline CAMPO & DESCRIÇÃo \\
\hline \multirow{2}{*}{ Abreviatura } & $\begin{array}{l}\text { Inserir neste campo a abreviatura a ser cadastrada. Estabelecer uma } \\
\text { padronização para todas as abreviaturas do Projeto. P.ex.: Utilizar } \\
\text { somente letras maiúsculas, não utilizar ponto entre os caracteres, } \\
\text { nunca usar parênteses. }\end{array}$ \\
\hline Descrição da Abreviatura & $\begin{array}{l}\text { Apresento, para cada abreviatura, uma descrição que explique o seu } \\
\text { significado. }\end{array}$ \\
\hline \multirow{2}{*}{ Exportar } & $\begin{array}{l}\text { Botão localizado na parte superior direita do formulário que permite a } \\
\text { exportação da lista completa de abreviaturas no formato RTF (Rich } \\
\text { Text Format). }\end{array}$ \\
\hline
\end{tabular}

Aplicativo Teclado Virtual

些些

Abre o Teclado Virtual de Símbolos IPA (Padrão Unicode).

O Teclado Virtual de Símbolos IPA (Padrão Unicode) é um aplicativo do programa Línguas que auxilia a escrita de caracteres do Alfabeto Fonético Internacional (International Phonetic Alphabet, IPA) para ser inserido em um texto. Ele contém os símbolos fonéticos agrupados em uma ordem que se aproxima bastante do alfabeto latino. Além disso, contêm diacríticos, símbolos adicionais (setas direcionais e símbolos para indicação de sexo) e uma barra de espaço. 
FIGURA 35 - JANELA COM O TECLADO VIRTUAL DO PROGRAMA LÍNGUAS

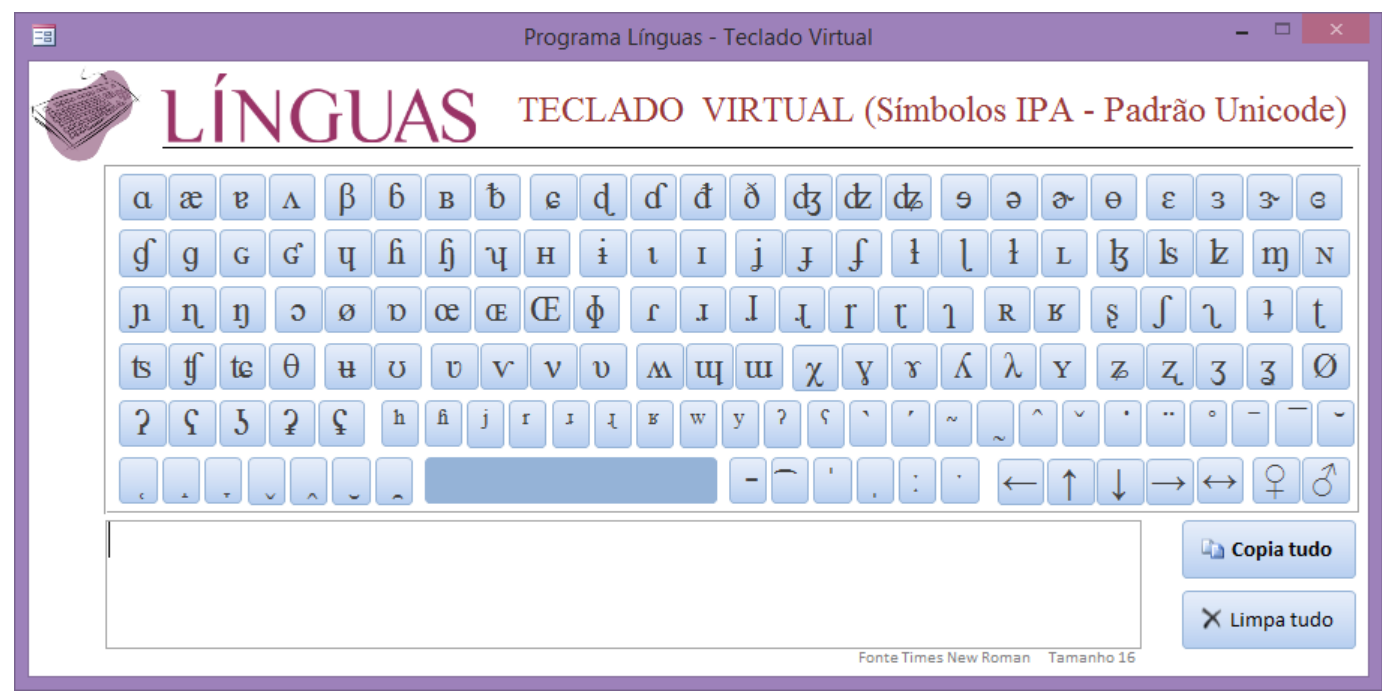

Para usar o Teclado Virtual IPA, clico sobre um caractere de cada vez para que ele seja inserido na área de texto localizada na base do aplicativo. Ao concluir a digitação, clico sobre o botão Copia tudo e o conteúdo digitado no campo será copiado para a Área de Transferência do computador. Para colar o conteúdo em outro local (dentro ou fora do programa Línguas), basta clicar CTRL+V ou pressionar o botão Colar (no caso de editores de texto) para inserir o texto copiado. ${ }^{145}$

Como não há, nesse teclado, os caracteres de um teclado padrão (tipo ABNT, p.ex.), a digitação pode ser combinada entre o teclado virtual e o teclado físico do computador.

Para apagar todo o conteúdo digitado no campo da área de texto do aplicativo, basta clicar sobre o botão Limpa tudo.

É possível ainda combinar um diacrítico com qualquer caractere do teclado. Para isso, clico sobre o caractere que deve receber o diacrítico e, em seguida, clico sobre o diacrítico desejado (o til, p.ex.). Assim, esse diacrítico é combinado imediatamente com o caractere.

Informações sobre preenchimento de um campo do formulário

Ao lado de vários campos do Programa há o ícone $i$, vinculado a uma janela que apresenta orientações específicas sobre o preenchimento de um campo.

\footnotetext{
${ }^{145}$ Por padrão, o texto produzido neste aplicativo é apresentado com a fonte Times New Roman, tamanho 16.
} 
TABELA 18 - ABA 2: INSTITUCIONAL

\begin{tabular}{ll}
\hline CAMPO & DESCRIÇÃo \\
\hline $\begin{array}{l}\text { Projeto vinculado à } \\
\text { Instituição }\end{array}$ & $\begin{array}{l}\text { Se o projeto tiver um vínculo institucional, inserir aqui o nome da } \\
\text { instituição. }\end{array}$ \\
\hline Endereço da Instituição & $\begin{array}{l}\text { Registrar o endereço da instituição com a qual o projeto mantém um } \\
\text { vínculo. }\end{array}$ \\
\hline CEP & Código de Endereçamento Postal (8 dígitos). \\
\hline Cidade & Registrar a cidade onde está sediada a instituição. \\
\hline Estado & Registrar o Estado ou Província correspondente. \\
\hline $\begin{array}{l}\text { Outras instituições que } \\
\text { colaboram com o Projeto }\end{array}$ & $\begin{array}{l}\text { Indicar aqui se o projeto conta com o apoio de outras instituições. É } \\
\text { possível descrever brevemente qual o papel de cada uma delas dentro } \\
\text { do PDL. }\end{array}$ \\
\hline
\end{tabular}

TABELA 19 - ABA 3: ESTRUTURA

\begin{tabular}{ll}
\hline CAMPO & DESCRIÇÃO \\
\hline Justificativa & $\begin{array}{l}\text { Apresentar, neste campo, os motivos que levaram à realização da } \\
\text { pesquisa, demonstrando a atualidade e a relevância da proposta de } \\
\text { documentação. }\end{array}$ \\
\hline Objetivo(s) & $\begin{array}{l}\text { Inserir informações sobre o que se quer alcançar com a execução } \\
\text { deste projeto. Essas informações apresentadas sob a forma de } \\
\text { objetivos gerais e objetivos específicos. }\end{array}$ \\
\hline Metodologia & $\begin{array}{l}\text { A descrição dos procedimentos a serem adotados no projeto contribui } \\
\text { para que haja um maior controle sobre cada uma das etapas da } \\
\text { pesquisa. }\end{array}$ \\
\hline Cronograma & $\begin{array}{l}\text { O Cronograma, que faz parte da metodologia da pesquisa, permite } \\
\text { uma sistematização e síntese das diferentes etapas do trabalho. Clico } \\
\text { sobre o ícone do campo Metodologia. }\end{array}$ \\
\hline
\end{tabular}

FIGURA 36 - CRONOGRAMA DO PROJETO

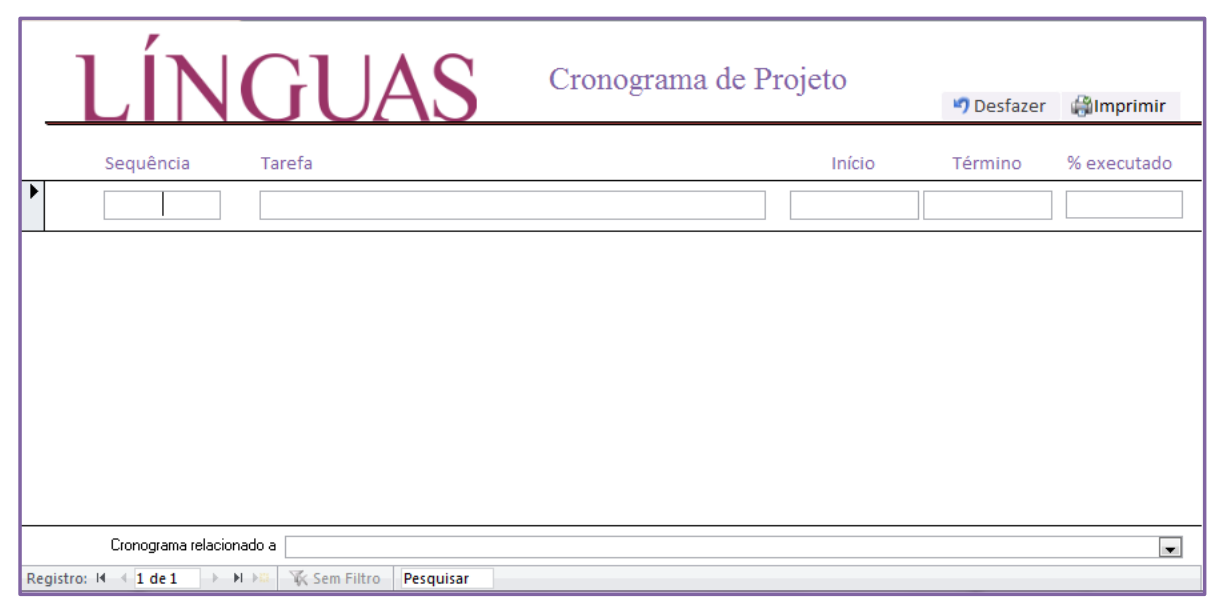

Esse Cronograma é apresentado em um formulário que contém os seguintes itens: 
TABELA 20 - CAMPOS DA JANELA DE CRONOGRAMA DO PROJETO

\begin{tabular}{ll}
\hline CAMPO & DESCRIÇÃo \\
\hline Sequência & Insiro manualmente uma sequência para o cronograma. \\
\hline Tarefa & $\begin{array}{l}\text { Utilize, de preferência, apenas uma frase para descrever o conteúdo } \\
\text { da tarefa a ser executada. }\end{array}$ \\
\hline Início e Término & $\begin{array}{l}\text { Apresentados em campos diferentes, servem para delimitar o período } \\
\text { de execução da tarefa. }\end{array}$ \\
\hline$\%$ executado & $\begin{array}{l}\text { Este campo pode ser atualizado à medida que as tarefas forem sendo } \\
\text { cumpridas. Na base da janela, informa-se a que PDL está ligado o } \\
\text { cronograma. }\end{array}$ \\
\hline
\end{tabular}

$\mathrm{Na}$ base de alguns formulários, há uma faixa de opções com botões minimizados que servem para a navegação entre os registros. Esses controles são padrões do sistema e permitem recuar ou avançar a visualização de registros gravados, pesquisar informações a partir de palavras-chave ou, até mesmo, filtrar a visualização de um conjunto de dados.

TABELA 21 - ABA 4: ORIENTAÇÕES PARA COLETA DE DADOS

\begin{tabular}{ll}
\hline CAMPO & DESCRIÇÃO \\
\hline $\begin{array}{l}\text { Orientação para coleta de } \\
\text { dados }\end{array}$ & $\begin{array}{l}\text { Apesar de fazer parte da Metodologia do PDL, a coleta de dados } \\
\text { recebe um espaço próprio devido à sua grande importância no } \\
\text { desenvolvimento de uma pesquisa desta natureza. }\end{array}$ \\
\hline
\end{tabular}

Notas Linguísticas da Aba 5

As orientações sobre o preenchimento das Notas Linguísticas são apresentadas na seção Área de Dados. Por ora, cabe a orientação acerca do conteúdo a ser inserido na ficha desta aba: privilegiar, por exemplo, as informações teóricas acerca da Ortografia adotada no Projeto (detalhamento sobre consoantes, vogais, diacríticos, entre outros) e das orientações sobre análise da Morfologia e da Sintaxe.

TABELA 22 - ABA 6: ETNOGRAFIA

\begin{tabular}{ll}
\hline CAMPO & DESCRIÇÃO \\
\hline Informação Etnográfica & $\begin{array}{l}\text { Por se tratar de um Projeto que envolve a língua de um determinado } \\
\text { povo, é possível registrar informações sobre a história e a cultura } \\
\text { desse povo. }\end{array}$ \\
\hline $\begin{array}{l}\text { Fontes de dados } \\
\text { relacionadas à informação } \\
\text { etnográfica }\end{array}$ & $\begin{array}{l}\text { Uma vez inseridas as informações etnográficas no campo anterior, é } \\
\text { necessário apresentar as fontes dessas informações, mas também } \\
\text { referências extras que contribuam para melhor conhecimento } \\
\text { antropológico do povo apresentado. }\end{array}$ \\
\hline
\end{tabular}


TABELA 23 - ABA 7: OUTRAS INFORMAÇÕES

\begin{tabular}{ll}
\hline CAMPO & DESCRIÇÃo \\
\hline $\begin{array}{l}\text { Arquivos relacionados à } \\
\text { Base do Projeto }\end{array}$ & $\begin{array}{l}\text { Permite a seleção de referências de arquivos previamente cadastrados } \\
\text { na base de dados do programa Línguas (ver a Base Arquivos). }\end{array}$ \\
\hline Website & $\begin{array}{l}\text { Se o projeto contar com um website na internet, é possível inserir } \\
\text { neste campo o endereço eletrônico dele. }\end{array}$ \\
\hline Anexar documentos oficiais & $\begin{array}{l}\text { Textos (portarias, projeto original, formulários, p.ex.) e imagens } \\
\text { (gráficos, fotografias, mapas, p.ex.) relacionados diretamente com o } \\
\text { PDL em desenvolvimento podem fazer parte da Base do Projeto, } \\
\text { como material anexado. }\end{array}$ \\
\hline Anotação & $\begin{array}{l}\text { Espaço reservado para anotações de qualquer ordem relacionadas à } \\
\text { proposta do Projeto. }\end{array}$ \\
\hline Projeto iniciado em & Indicação da data em que o Projeto foi iniciado. \\
\hline Ficha preenchida por & $\begin{array}{l}\text { Indicação da pessoa que preencheu os dados do Projeto nesta ficha do } \\
\text { programa Línguas. }\end{array}$ \\
\hline
\end{tabular}

\subsection{Base Som}

É nesta base de dados que se pode fazer o registro do conjunto de sons da línguabase do PDL. Clico sobre o ícone referente à Base Som para acessar a área para inserção dos dados.

FIGURA 37 - JANELA DA BASE DE SONS

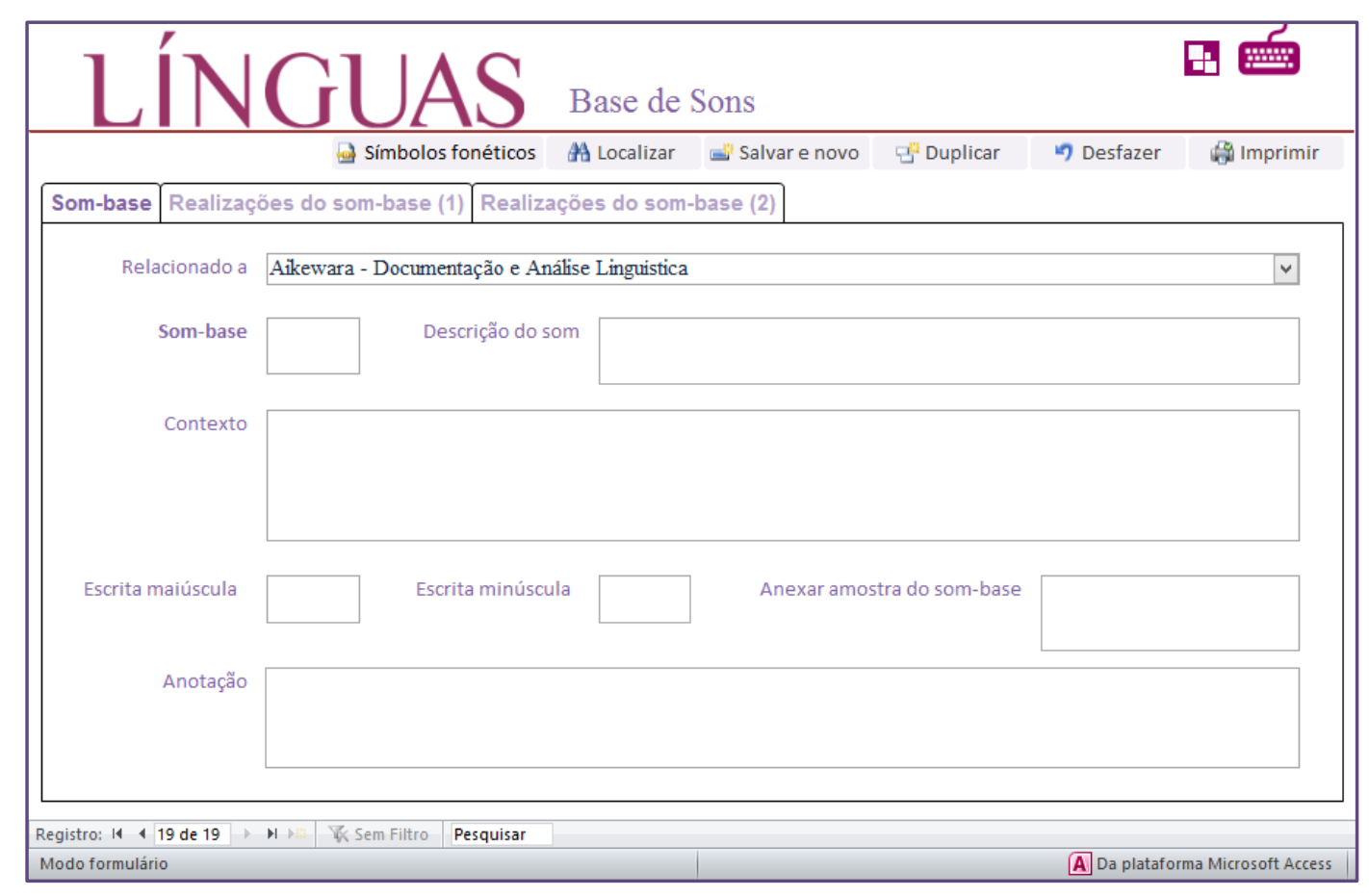

Esta base conta com apenas 3 abas para cadastramento dos sons da língua-base. 
TABELA 24 - ABA 1: SOM-BASE

\begin{tabular}{|c|c|}
\hline САMPO & DESCRIÇÃO \\
\hline Relacionado a & $\begin{array}{l}\text { Este campo possui como valor padrão o nome do primeiro Projeto de } \\
\text { Documentação Linguística cadastrado na Base Projeto. Assim, se não } \\
\text { houver outro projeto em execução, este valor não deve ser } \\
\text { modificado. }\end{array}$ \\
\hline Som-base & $\begin{array}{l}\text { Inserir neste campo um símbolo fonético de cada vez. Esse símbolo } \\
\text { deve corresponder a um som encontrado na língua que está sendo } \\
\text { documentada. }\end{array}$ \\
\hline & $\begin{array}{l}\text { Descrever as características do som inserido no campo anterior. } \\
\text { Sugestão: para obter uma lista com os principais sons e suas }\end{array}$ \\
\hline Descrição do som & $\begin{array}{l}\text { respectivas descrições, clico sobre o botão }{ }^{3} \text { Símbolos fonéticos e } \\
\text { consulte a Lista de símbolos no padrão Unicode do Alfabeto Fonético } \\
\text { Internacional (2005) para vogais e consoantes com as respectivas } \\
\text { definições. }\end{array}$ \\
\hline Contexto & $\begin{array}{l}\text { É possível descrever quais são os contextos de ocorrência/ uso do } \\
\text { som-base inserido neste formulário. }\end{array}$ \\
\hline Anotação & $\begin{array}{l}\text { Campo para anotações relacionadas ao som-base que esteja sendo } \\
\text { descrito. }\end{array}$ \\
\hline Anexar amostra do som & $\begin{array}{l}\text { Se houver um arquivo de áudio que sirva como amostra do som-base } \\
\text { descrito, ele pode ser incorporado diretamente no programa Línguas. }\end{array}$ \\
\hline
\end{tabular}

TABELA 25 - ABAS 2 E 3 - REALIZAÇÕES DO SOM-BASE (1) E (2)

\begin{tabular}{ll}
\hline CAMPO & DESCRIÇÃO \\
\hline Som-base & $\begin{array}{l}\text { O som-base cadastrado na primeira aba do formulário é transferido } \\
\text { automaticamente para o conteúdo desta aba. Nada deve ser feito, a } \\
\text { não ser que deseje modificar esse som. }\end{array}$ \\
\hline Realização & $\begin{array}{l}\text { Campo numerado (de 01 a 08) para registrar as diferentes formas de } \\
\text { realização de um mesmo som (essa variação do som-base equivale ao } \\
\text { fenômeno da alofonia). }\end{array}$ \\
\hline Contexto & $\begin{array}{l}\text { Descrever o contexto de ocorrência/uso de cada forma variante do } \\
\text { som-base. }\end{array}$ \\
\hline
\end{tabular}

\subsection{Base Fonte}

A Base de Fontes do Conhecimento foi projetada para armazenar informações etnográficas sobre os falantes de uma ou mais línguas que serão registradas no PDL. Clico sobre o ícone $\Leftrightarrow$ referente à Base Fonte para acessar a área de cadastramento.

A Base Fonte apresenta um conjunto de 7 fichas identificadas por títulos nas respectivas abas, todas inter-relacionadas, que permitem o registro completo da pessoa fonte do conhecimento. 
FIGURA 38 - JANELA DA BASE DE FONTES DO CONHECIMENTO

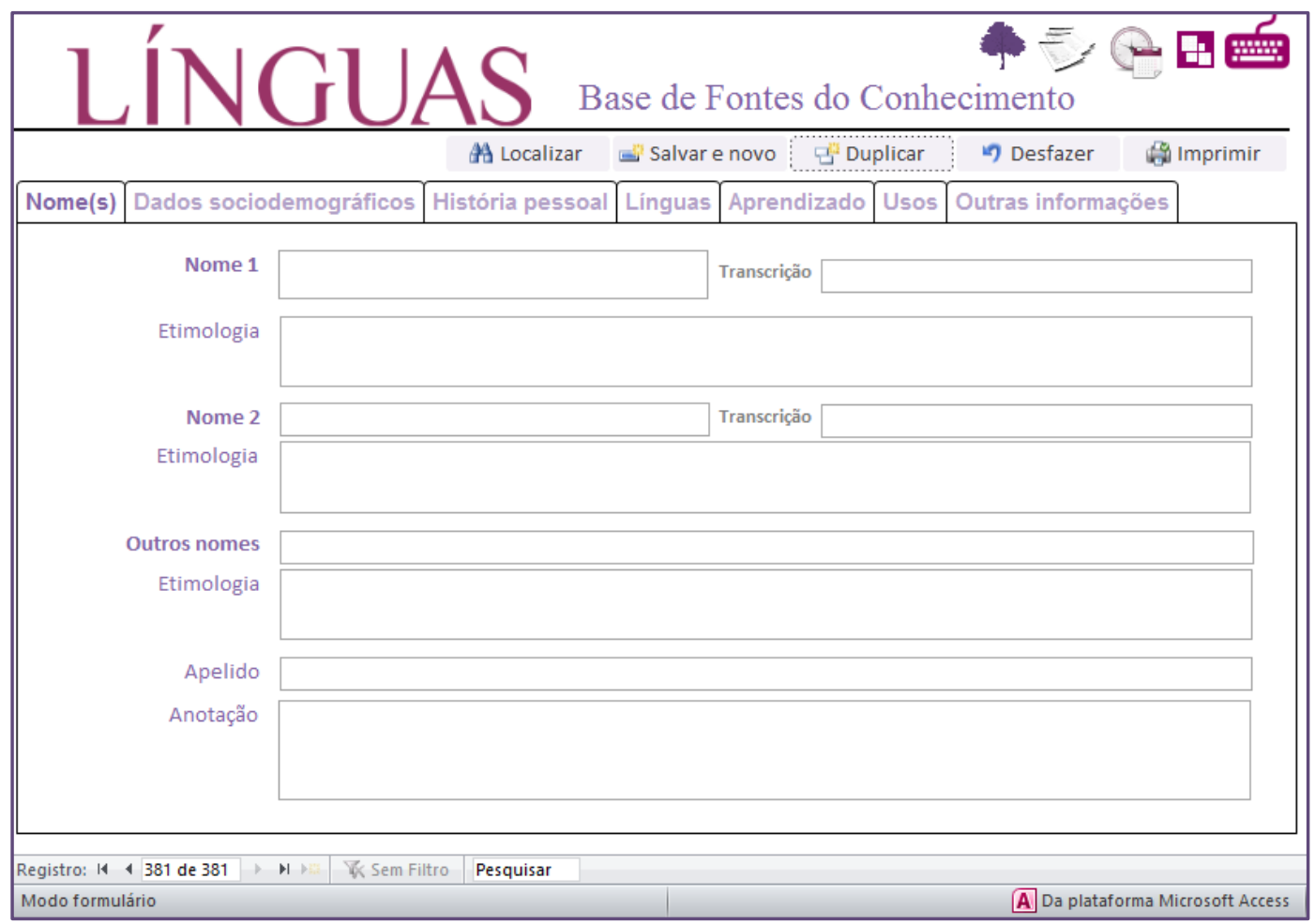

TABELA $26-$ ABA 1: NOME(S)

\begin{tabular}{ll}
\hline CAMPO & DESCRIÇÃo \\
\hline Nome 1 & Este é o nome principal da pessoa e deve ser grafado na íntegra. \\
\hline Transcrição & Espaço para transcrição fonética e da forma fonológica do nome 1. \\
\hline Etimologia & $\begin{array}{l}\text { Etimologia do Nome 1 (muitos nomes de pessoas possuem } \\
\text { significado dentro da cultura em que eles são escolhidos, caso não } \\
\text { seja este o caso da língua-cultura registrada, deixar este campo em } \\
\text { branco). }\end{array}$ \\
\hline Nome 2 & $\begin{array}{l}\text { Se a pessoa possuir um segundo nome (na mesma língua-base ou em } \\
\text { outras línguas), registro-o aqui. Não confundir com o Apelido } \\
\text { (alcunha). }\end{array}$ \\
\hline Transcrição & Espaço para transcrição fonética e da forma fonológica do nome 2. \\
\hline Etimologia & Etimologia do Nome 2. \\
\hline Outros nomes & No caso de a pessoa possuir outros nomes, registrar todos eles aqui. \\
\hline Etimologia & Etimologia dos outros nomes. \\
\hline Apelido & $\begin{array}{l}\text { Se a pessoa possuir, de fato, um apelido, registrar aqui (não confundir } \\
\text { com o segundo nome). }\end{array}$ \\
\hline Anotação & Espaço para anotações relacionadas ao(s) nome(s). \\
\hline
\end{tabular}


TABELA 27 - ABA 2: DADOS SOCIODEMOGRÁFICOS

\begin{tabular}{ll}
\hline CAMPO & DESCRIÇão \\
\hline Grupo étnico & $\begin{array}{l}\text { A denominação do grupo étnico pode ser baseada na literatura } \\
\text { antropológica, mas também seria bastante útil registrar a(s) palavra(s) } \\
\text { com que o grupo se autodenomina. Além disso, é possível que o } \\
\text { próprio PDL tenha uma forma própria de denominar o grupo. }\end{array}$ \\
\hline Clã/parentesco & $\begin{array}{l}\text { A informação deste campo segue a mesma orientação do campo } \\
\text { anterior. }\end{array}$ \\
\hline Data nascimento ou idade \\
aproximada & $\begin{array}{l}\text { De preferência deve-se colocar a data de nascimento, a partir da qual } \\
\text { se define a idade exata da pessoa. Contudo, caso não seja possível } \\
\text { definir esta data, informar, pelo menos, a idade aproximada } \\
\text { (estimada). }\end{array}$ \\
\hline Local de nascimento & $\begin{array}{l}\text { O local de nascimento deve ser o mais preciso possível. Contudo, } \\
\text { caso não seja possível definir este local, delimitar, pelo menos, a } \\
\text { região (mesmo que aproximada) do nascimento. }\end{array}$ \\
\hline Atividade/profissão & $\begin{array}{l}\text { Descrever a(s) atividade(s) [remunerada(s) ou não] desempenhada(s) } \\
\text { pela pessoa (p.ex., agricultor, caçador, coletor de castanha-do-pará). }\end{array}$ \\
$\begin{array}{l}\text { Contudo, se a pessoa tiver também uma profissão (formal, } \\
\text { remunerada ou não), incluir estas informações neste campo. }\end{array}$ \\
$\begin{array}{l}\text { O papel social da pessoa pode, em muitos casos, se confundir com a } \\
\text { profissão desempenhada por ela. Contudo, há funções sociais que } \\
\text { derivam de uma organização própria baseada, comumente, em uma } \\
\text { tradição (p.ex. liderança, pajé, músico). }\end{array}$ \\
\hline $\begin{array}{l}\text { Caso se aplique à realidade do grupo, informar em que nível de } \\
\text { escolaridade a pessoa se encontra (a descrição completa da } \\
\text { escolaridade pode ser apresentada no campo de informações } \\
\text { etnográficas do povo). }\end{array}$ \\
\hline
\end{tabular}

TABELA 28 - ABA 3: HISTÓRIA PESSOAL

\begin{tabular}{ll}
\hline CAMPO & DESCRIÇÃO \\
\hline & Espaço dedicado à descrição (o mais detalhadamente possível) da \\
& história de vida da pessoa fonte do conhecimento. Sugestão: ao \\
& realizar a entrevista com a pessoa (durante a coleta de dados \\
& linguísticos), reservar um tempo para que ela mesma possa contar sua \\
& história pessoal (de preferência na língua que está sendo registrada). \\
& Esse texto autobiográfico, uma vez transcrito (e eventualmente \\
& traduzido para a língua de trabalho do pesquisador), pode servir tanto \\
& como informação sobre a pessoa fonte do conhecimento quanto como \\
& material linguístico para a base de dados. \\
\hline
\end{tabular}

TABELA 29 - ABA 4: LÍNGUAS

\begin{tabular}{ll}
\hline CAMPO & DESCRIÇÃO \\
\hline Línguas que fala bem & $\begin{array}{l}\text { Registrar a(s) língua(s) da pessoa fonte do conhecimento conhece } \\
\text { bem e utiliza com maior fluência (língua materna e/ou segunda língua } \\
\text { e/ou outras línguas). }\end{array}$ \\
\hline Contexto de uso & Para cada língua inserida no campo anterior, apresentar o contexto de \\
\hline
\end{tabular}




\begin{tabular}{ll}
\hline & uso (p.ex., uso em família, uso ritual, uso na escola...). \\
\hline Línguas que fala pouco & $\begin{array}{l}\text { Registrar a(s) língua(s) da pessoa fonte do conhecimento conhece } \\
\text { pouco e utiliza com menor fluência. }\end{array}$ \\
\hline Contexto de uso & $\begin{array}{l}\text { Para cada língua inserida no campo anterior, apresentar o contexto de } \\
\text { uso. }\end{array}$ \\
\hline Línguas que entende & $\begin{array}{l}\text { Registrar a(s) língua(s) da pessoa fonte do conhecimento é capaz de } \\
\text { compreender, mesmo que não seja capaz de falar essa língua. }\end{array}$ \\
\hline Contexto de uso & $\begin{array}{l}\text { Para cada língua inserida no campo anterior, apresentar o contexto de } \\
\text { uso. }\end{array}$ \\
\hline
\end{tabular}

TABELA 30 - ABA 5 - APRENDIZADO

\begin{tabular}{ll}
\hline CAMPO & DESCRIÇão \\
\hline \multirow{2}{*}{ Foi criado(a) por } & $\begin{array}{l}\text { Informar com quem a pessoa fonte de conhecimento foi criada em } \\
\text { sua primeira infância, quando ela começou a usar sua(s) língua(s). }\end{array}$ \\
& $\begin{array}{l}\text { Nota: Apesar de ser, aparentemente, mais comum a participação dos } \\
\text { pais biológicos na criação dos filhos, muitos povos delegam o } \\
\text { cuidado das crianças aos avós (maternos ou paternos) ou mesmo a } \\
\text { uma coletividade. }\end{array}$ \\
\hline Línguas dos pais & $\begin{array}{l}\text { Informar a(s) língua(s) falada(s) pelo pai e pela mãe da pessoa fonte } \\
\text { de conhecimento. }\end{array}$ \\
\hline Línguas dos avós & $\begin{array}{l}\text { Informar a(s) língua(s) falada(s) pelo avô e pela avó da pessoa fonte } \\
\text { de conhecimento. }\end{array}$ \\
\hline \multirow{3}{*}{ Aprendizado linguístico } & $\begin{array}{l}\text { Informações sobre o processo de aprendizado linguístico da pessoa } \\
\text { fonte de conhecimento. Sugestão: Durante o processo de } \\
\text { documentação linguística, buscar obter informações da própria } \\
\text { pessoa sobre o processo do aprendizado linguístico (oral e, se } \\
\text { possível, escrito): idade aproximada do aprendizado de cada língua, } \\
\text { contextos desse aprendizado, possíveis interdições de uso de } \\
\text { determinada língua, motivações para o aprendizado, entre outras } \\
\text { informações. }\end{array}$ \\
\hline $\begin{array}{l}\text { Espaço para anotações acerca de questões relacionadas ainda ao } \\
\text { aprendizado linguístico da pessoa fonte de conhecimento. Sugestão: } \\
\text { além das informações dadas pela própria pessoa, também é possível } \\
\text { registrar depoimentos de outras pessoas que tenham informações } \\
\text { adicionais a esse respeito. }\end{array}$ \\
\hline Anotações
\end{tabular}

TABELA 31 - ABA 6: USOS

\begin{tabular}{ll}
\hline CAMPO & DESCRIÇÃo \\
\hline Ouve rádio & $\begin{array}{l}\text { Campo de opção do formulário. Marque a caixa de opção para } \\
\text { resposta sim ou deixe desmarcada para resposta não. }\end{array}$ \\
\hline & $\begin{array}{l}\text { Em caso de resposta positiva, informar que estações de rádio a } \\
\text { pessoa fonte de conhecimento prefere ouvir. Sugestão: Também é } \\
\text { possível inserir informações mais detalhadas como: em que época } \\
\text { começou a escutar rádio, duração diária, programas preferidos. }\end{array}$ \\
\hline
\end{tabular}




\begin{tabular}{|c|c|}
\hline Vê televisão & $\begin{array}{l}\text { Campo de opção do formulário. Marque a caixa de opção para } \\
\text { resposta sim ou deixe desmarcada para resposta não. }\end{array}$ \\
\hline Emissoras & $\begin{array}{l}\text { Em caso de resposta positiva, informar que emissoras de TV a } \\
\text { pessoa fonte de conhecimento prefere assistir. Sugestão: Também } \\
\text { é possível inserir informações mais detalhadas como: em que } \\
\text { época começou a assistir à } \mathrm{TV} \text {, tempo médio diário, programas } \\
\text { preferidos. }\end{array}$ \\
\hline Sabe ler & $\begin{array}{l}\text { Campo de opção do formulário. Marque a caixa de opção para } \\
\text { resposta sim ou deixe desmarcada para resposta não. }\end{array}$ \\
\hline Tipos de textos que lê & $\begin{array}{l}\text { Em caso de resposta positiva, informar que tipos de texto a pessoa } \\
\text { fonte de conhecimento prefere ler. Sugestão: Também é possível } \\
\text { inserir informações mais detalhadas como: em que época começou } \\
\text { a ler, tempo médio diário de leitura, livros/textos preferidos. }\end{array}$ \\
\hline Língua(s) & $\begin{array}{l}\text { Em caso positivo, informar em que língua(s) a pessoa sabe ler e } \\
\text { qual a sua língua preferida (ou mais usada) para leitura. }\end{array}$ \\
\hline Sabe escrever & $\begin{array}{l}\text { Campo de opção do formulário. Marque a caixa de opção para } \\
\text { resposta sim ou deixe desmarcada para resposta não. }\end{array}$ \\
\hline $\begin{array}{l}\text { Tipos de textos que } \\
\text { escreve }\end{array}$ & $\begin{array}{l}\text { Em caso de resposta positiva, informar que tipos de texto a pessoa } \\
\text { fonte de conhecimento prefere escrever. Sugestão: Também é } \\
\text { possível inserir informações mais detalhadas como: em que época } \\
\text { começou a escrever, tempo médio diário de escrita, textos que já } \\
\text { escreveu. }\end{array}$ \\
\hline Língua(s) & $\begin{array}{l}\text { Em caso de resposta positiva, informar em que língua(s) a pessoa } \\
\text { sabe escrever e qual a sua língua preferida (ou mais usada) para a } \\
\text { escrita. }\end{array}$ \\
\hline
\end{tabular}

TABELA 32 - ABA 7: OUTRAS INFORMAÇÕES

\begin{tabular}{ll}
\hline CAMPO & DESCRIÇão \\
\hline Endereço & $\begin{array}{l}\text { Registrar o endereço da pessoa fonte do conhecimento no momento } \\
\text { em que o registro linguístico foi feito. Como nem sempre é possível } \\
\text { registrar um endereço-padrão, com nomes de ruas, números da } \\
\text { residência, etc., registro o local onde a pessoa mora, fornecendo o } \\
\text { máximo possível de detalhes quanto à sua localização. }\end{array}$ \\
\hline $\begin{array}{l}\text { É comum que o endereço de uma pessoa seja fixado dentro dos } \\
\text { limites de apenas um município, contudo, pode haver situações } \\
\text { (como a de terras indígenas) em que o 'endereço' da pessoa se }\end{array}$ \\
$\begin{array}{l}\text { localiza numa extensão de, p.ex., dois ou três municípios. Por isso, } \\
\text { a possibilidade de se escolher na lista suspensa deste campo mais de } \\
\text { uma opção. }\end{array}$ \\
\hline Estado(s) & A mesma orientação do campo anterior. \\
\hline País/região & Indicar o país de residência da pessoa. \\
\hline $\begin{array}{l}\text { Realizou viagens? Indicar } \\
\text { motivo/local/duração }\end{array}$ & $\begin{array}{l}\text { Registrar as viagens que a pessoa tenha realizado ao longo da vida, } \\
\text { informando o local de destino, o motivo e a duração de cada uma }\end{array}$ \\
\hline
\end{tabular}




\begin{tabular}{ll}
\hline & $\begin{array}{l}\text { delas. Contudo, se alguma das viagens tiver como motivo fixar } \\
\text { moradia em outro lugar, indicar esta informação apenas no campo } \\
\text { seguinte (sobre moradia). }\end{array}$ \\
\hline $\begin{array}{l}\text { Morou em outros lugares? } \\
\text { Quais, durante quanto } \\
\text { tempo? }\end{array}$ & $\begin{array}{l}\text { Registrar se a pessoa já morou em lugares diferentes do local onde } \\
\text { ele reside no momento do registro. Em caso positivo, informar local } \\
\text { de residência e duração da estada. Também é possível informar o(s) } \\
\text { motivo(s) da mudança de residência. }\end{array}$ \\
\hline Se possui religião, informar & $\begin{array}{l}\text { Registrar neste campo se a pessoa fonte de conhecimento possui } \\
\text { qual }\end{array}$ \\
& $\begin{array}{l}\text { religião (uma ou mais). Nota: A lista suspensa neste campo pode ser } \\
\text { responsável pelo registro. }\end{array}$ \\
\hline Arquivos relacionados & $\begin{array}{l}\text { Campo para selecionar um ou mais arquivos relacionados } \\
\text { diretamente com a pessoa fonte de conhecimento. Podem ser } \\
\text { registros (sonoros, fotográficos, audiovisuais) feitos pela própria } \\
\text { pessoa ou sobre ela. Esses arquivos devem seguir, de preferência, a } \\
\text { padronização adotada no PDL. Esses arquivos devem ser } \\
\text { previamente registrados na Base Arquivos e referenciados sempre } \\
\text { que necessário. }\end{array}$ \\
\hline
\end{tabular}

TABELA 33 - BOTÕES DE COMANDO

\begin{tabular}{cl}
\hline \multicolumn{1}{c}{ ÍCONE } & DESCRIÇÃo \\
\hline \multirow{2}{*}{ Au Localizar } & $\begin{array}{l}\text { Permite a localização de qualquer registro dentro da Base de Dados onde o } \\
\text { botão estiver localizado. }\end{array}$ \\
\hline Salvar e novo & $\begin{array}{l}\text { Salva e fecha os dados que estiverem sendo registrados. Em seguida, abre } \\
\text { um novo formulário em branco para inserção de novos dados. }\end{array}$ \\
\hline Duplicar & $\begin{array}{l}\text { Salva e fecha os dados que estiverem sendo registrados. Em seguida, } \\
\text { duplica os dados do formulário anterior para um novo formulário. }\end{array}$ \\
\hline D Imprimir & $\begin{array}{l}\text { Desfaz a edição de dados que estiverem sendo inseridos e oferece o } \\
\text { formulário em branco. }\end{array}$ \\
\hline
\end{tabular}

Faixa de opções da Base Fonte

Em vários formulários há uma faixa de opções na parte superior direita, cuja função é permitir acesso rápido a outros formulários e aplicativos, tais como o Teclado Virtual.

\footnotetext{
$=\quad:$ Abrir formulário para impressão

Abre um documento, em formato PDF para impressão, que contém todos os campos do formulário eletrônico correspondente. Neste caso, o documento aberto contém todos os campos da Base Fonte, com espaços em branco para preenchimento manual.
}

\section{:: Calcular idade}

Abre o aplicativo Cálculo de idade, que serve para descobrir uma idade a partir de uma data de nascimento específica. 
Para usar esse aplicativo, digito no primeiro campo uma data de nascimento no formato $d d / m m / a a a a$ e, em seguida, pressiono a tecla Enter. Será mostrada, no segundo campo, a idade exata, e no último campo, a idade detalhada.

\subsection{Base Arquivos}

É nesta base de dados que se pode fazer o registro das referências a todos os arquivos armazenados no PDL. Clico sobre o ícone referente à Base Arquivos para acessar a área de cadastramento.

FIGURA 39 - JANELA DA BASE DE ARQUIVOS

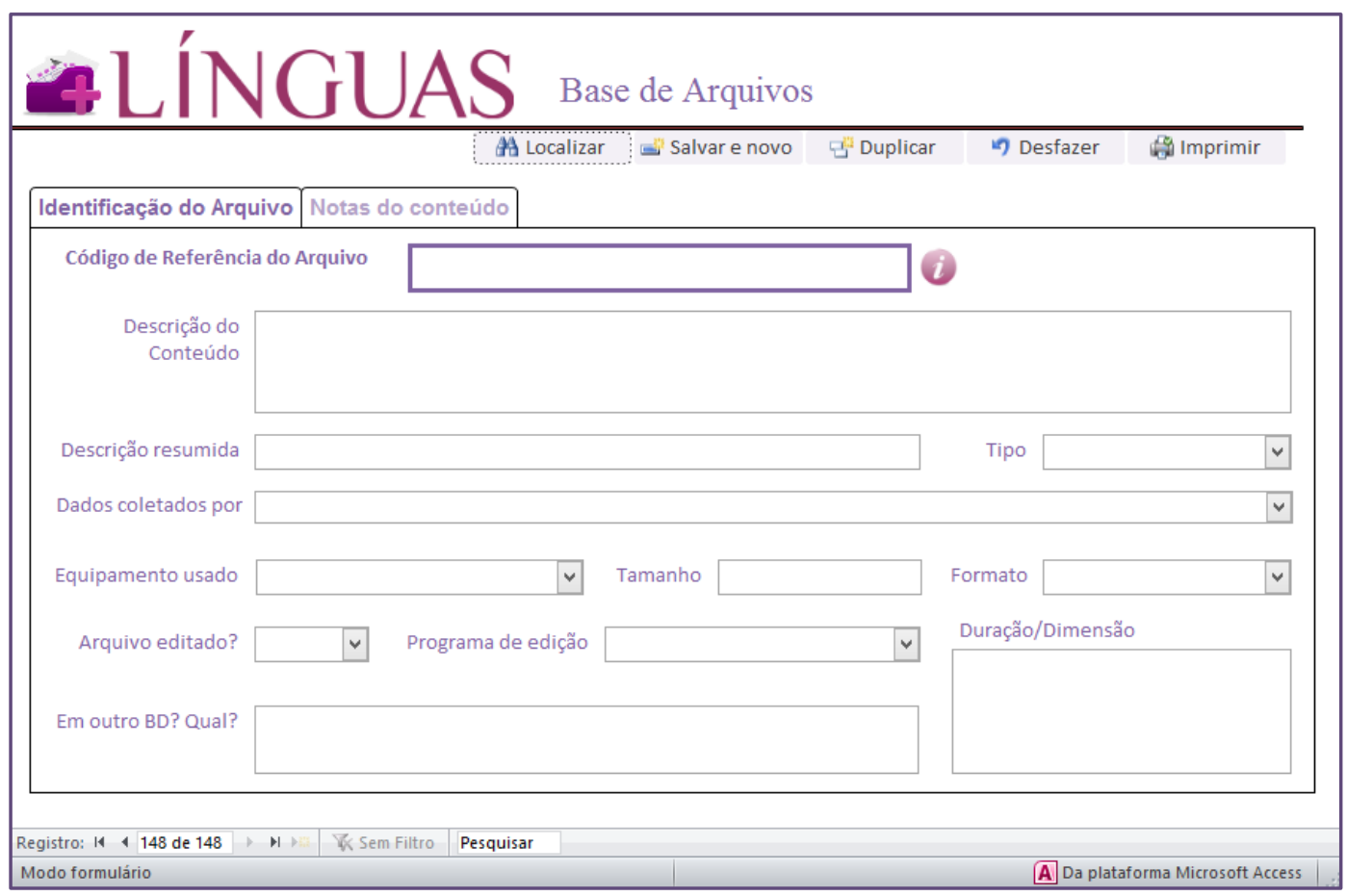

TABELA 34 - CAMPOS DA BASE DE ARQUIVOS

\begin{tabular}{ll}
\hline CAMPO & DESCRIÇÃo \\
\hline Código de Referência do Arquivo & $\begin{array}{l}\text { Atribuo um código para identificar o arquivo do acervo de } \\
\text { dados do PDL (para servir de referência em outras bases). }\end{array}$ \\
\hline Descrição & $\begin{array}{l}\text { Campo para descrever o conteúdo do arquivo referenciado no } \\
\text { campo anterior. }\end{array}$ \\
\hline Conteúdo resumido & $\begin{array}{l}\text { Insiro, neste campo, uma frase que sirva para dar uma ideia } \\
\text { precisa do conteúdo do arquivo registrado. Essa frase ajudará } \\
\text { na identificação dos arquivos nas demais bases do programa } \\
\text { Línguas. }\end{array}$ \\
\hline Tipo & $\begin{array}{l}\text { Escolho na lista suspensa o tipo de arquivo: áudio, imagem, } \\
\text { texto e vídeo. Essa lista pode ser editada conforme as } \\
\text { especificações do PDL. }\end{array}$ \\
\hline Dados coletados por & Lista suspensa (editável) que permite o cadastramento de todos \\
\hline
\end{tabular}


os responsáveis pela coleta dos dados que constam no arquivo referenciado.

No caso de arquivos de áudio, imagem e vídeo, pode-se informar qual foi o equipamento usado na captação dos dados

Equipamento usado linguísticos. Algumas sugestões são apresentadas na lista suspensa, mas é possível editar essa lista conforme a necessidade do Projeto.

Informar, neste campo, o tamanho do arquivo digital

Tamanho armazenado que contém os dados linguísticos. Usar uma só unidade de medida para todos os arquivos [Kb (kilobyte), $\mathrm{Mb}$ (megabyte) ou Gb (gigabyte)].

Esta lista suspensa contém um conjunto de extensões mais Formato comuns relacionados a cada tipo de registro apresentado no campo anterior. Essa lista também pode ser editada conforme necessidade do Projeto.

Campo de resposta do tipo Sim/Não, registra se o arquivo referenciado foi modificado. Nota: Nem sempre os arquivos depositados no acervo de um PDL mantêm sua forma original, ou seja, se esses arquivos são mantidos tais como foram captados originalmente junto às pessoas fontes de

Arquivo editado? conhecimento. Muitas vezes, esses arquivos passam por processos de edição que, não só buscam 'melhorar' a qualidade do áudio, removendo ruídos, p.ex., mas também seccionando o arquivo maior segundo algum critério: por sons isolados, por palavras, por enunciados, entre outros. Sugestão: Ao editar os arquivos, sempre manter cópia dos arquivos originais.

Se o arquivo tiver passado por qualquer tipo de edição, indicar o(s) programa(s) usado(s) ou edite a lista e acrescente um novo

Programa de edição programa. Nota: Para facilitar a localização dos programas, a lista está ordenada conforme o tipo de arquivo (áudio, imagem, texto e vídeo).

Trata-se do registro da duração (tempo) ou da dimensão (forma/quantidade) do arquivo referenciado. No caso de arquivos de áudio e vídeo, informar a duração (em segundos,

Duração/Dimensão minutos ou horas). Para textos escritos, informar a quantidade de caracteres, palavras ou páginas. Já no caso de arquivos de imagens, informar a dimensão (em pixel, milímetros, centímetros, metros ou outra medida adotada).

Campo para informar se o material que está sendo referenciado Arquivo em outro BD? que se encontra no banco de dados do PDL se encontra armazenado também em outro(s) Banco(s) de Dados. Caso positivo, informar neste campo em que BD ele se encontra.

O armazenamento de arquivos é uma das grandes preocupações quando se trata de arquivos de dados linguísticos (áudio, vídeo, imagem e texto). O programa Línguas, por padrão, não armazena diretamente esses arquivos, pois poderiam, em pouquíssimo tempo, comprometer o funcionamento do sistema, em virtude da sobrecarga de espaço ocupado. 
Logo, o que se armazena são as referências, por meio de códigos padronizados para a identificação, a esses dados, que ficam armazenados fisicamente no disco rígido do próprio computador ou em HD externo. É necessário, portanto, que, ao ser feito um backup do programa Línguas, também sejam feitas cópias de segurança de todos os arquivos referenciados no banco de dados.

\section{Código para Identificação de Arquivo}

Cada arquivo registrado nesta base de dados deve receber uma identificação própria, atribuída pelo Administrador do Projeto. Por isso, apresento, a seguir, uma proposta de código que permite catalogar de modo prático qualquer arquivo de dados (áudio, imagem, vídeo ou texto). ${ }^{146}$

FIGURA 40 - explicação do código-base para registro de arquivos

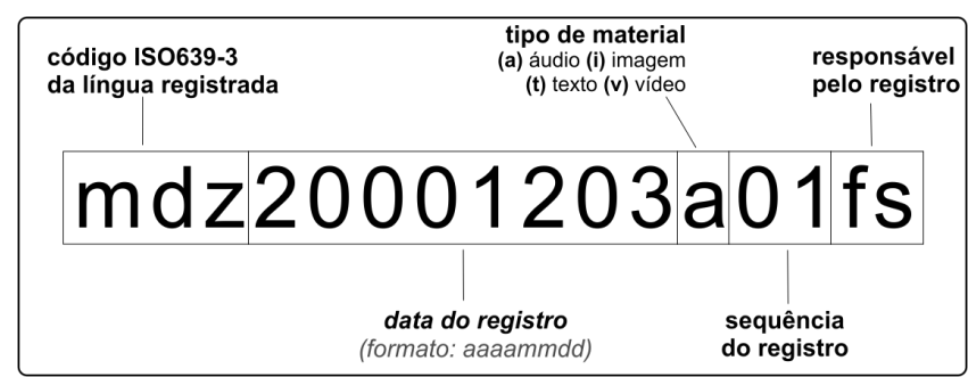

TABELA 35 - EXPLICAÇÃO DOS COMPONENTES DO CÓDIGO-BASE 1

\begin{tabular}{|l|l|}
\hline Campo & Descrição \\
\hline $\begin{array}{l}\text { Código ISO639-3 da } \\
\text { língua registrada }\end{array}$ & $\begin{array}{l}\text { As três primeiras letras (minúsculas) do código se referem a uma } \\
\text { abreviatura do nome da língua-base que está sendo documentada no } \\
\text { PDL. Optei pela utilização do padrão ISO639, contudo outros padrões } \\
\text { podem ser usados para identificação da língua-base. }\end{array}$ \\
\hline Data do registro & $\begin{array}{l}\text { A data em que foi o material foi coletado deve ser apresentada na forma } \\
\text { ano (aaaa), mês (mm) e dia (dd), pois, desta forma, consegue-se ordenar } \\
\text { em ordem crescente de data todos os arquivos que estiverem no mesmo } \\
\text { diretório. }\end{array}$ \\
\hline Tipo de material & $\begin{array}{l}\text { Situada após a data, a indicação do tipo de material serve como terceiro } \\
\text { critério de ordenação do arquivo. Uma letra minúscula informa se se } \\
\text { trata de um arquivo de áudio (a), imagem (i), texto (t) ou vídeo (v). }\end{array}$ \\
\hline Sequência do registro & $\begin{array}{l}\text { A quarta parte do código informa qual a sequência do arquivo de dados. } \\
\text { P.ex., em um turno de gravação de dados linguísticos, são produzidos, } \\
\text { em sequência, seis arquivos de áudio; logo, cada um dos arquivos } \\
\text { gravados receberá um código, neste caso de 01 a 06. }\end{array}$ \\
\hline
\end{tabular}

${ }^{146}$ Esse código pode ser usado tanto na identificação de arquivos digitais, quanto na etiquetagem de materiais físicos (CD-ROM, DVD, fitas cassete, entre outros).

${ }^{147}$ Os códigos ISO639-3 para a maioria das línguas do mundo podem ser encontrados no site The Linguistic List (http://linguistlist.org/forms/langs/find-a-language-or-family.cfm) 
Responsável pelo registro

Esse código pode também informar quem foi o responsável pela coleta dos dados. Mesmo que o material tenha sido coletado por um grupo de pessoas, informar, no interior do código, sempre a sigla ou abreviatura do nome de uma das pessoas do grupo (na Base Arquivos deverá constar a lista completa de nomes).

\section{FIGURA 41 - EXPLICAÇÃO DO CÓDIGO-BASE PARA REGISTRO DE ARQUIVOS SEGMENTADOS}

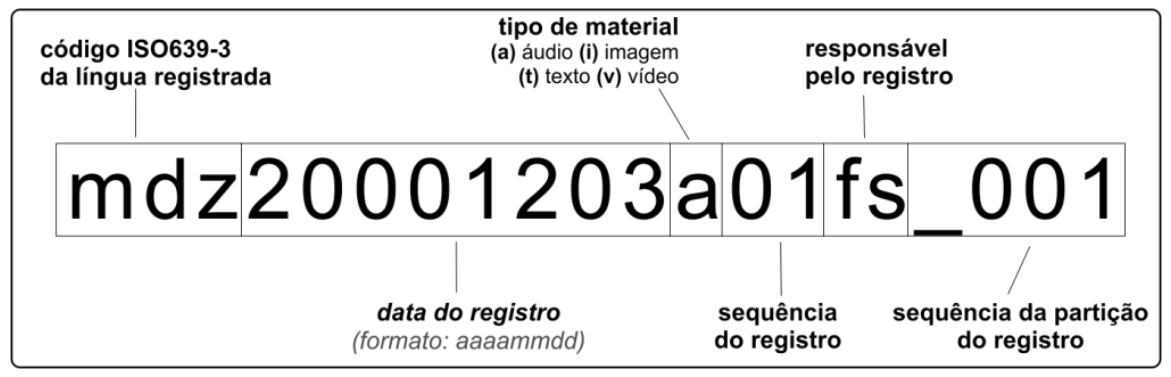

TABELA 36 - INFORMAÇÃO COMPLEMENTAR DO CÓDIGO-BASE

\begin{tabular}{|l|l|}
\hline CAMPO & DESCRIÇÃO \\
\hline $\begin{array}{l}\text { Sequência da partição do } \\
\text { registro }\end{array}$ & $\begin{array}{l}\text { Além da forma padrão do código para referenciar um arquivo completo, } \\
\text { é possível indicar se se trata de um arquivo que foi dividido em partes } \\
\text { menores. Para isso, utilize o mesmo código para referenciar um arquivo } \\
\text { original, seguido de uma sequência de três números, sempre iniciada em } \\
\text { 001 e separada por um traço baixo (underline) para separar esta } \\
\text { sequência do restante do código. }\end{array}$ \\
\hline
\end{tabular}

\subsection{Base Corpus}

É nesta base de dados que se pode fazer o registro de todos os corpora do PDL.

Clico sobre o ícone referente à Base Corpus para acessar a área de cadastramento.

O preenchimento desse formulário é muito importante, pois, para poder cadastrar os dados linguísticos, é solicitada a associação do material a um ou mais corpus cadastrados nesta base do Programa.

A definição do que será denominado corpus fica a critério de cada Projeto, podendo ser, por exemplo, tanto um único arquivo sonoro que contenha 2 horas de gravação, quanto um conjunto de arquivos sonoros gravados, em sequência, em determinado espaço de tempo. O importante é que, ao se definir os critérios de definição de um corpus, haja uniformidade na catalogação desses dados.

No caso deste projeto de documentação da língua Suruí, adotei como critério de definição de corpus, um conjunto de registros realizados em cada ida a campo. Ou seja, um corpus para esta pesquisa é, por exemplo, o total de gravações realizadas em uma semana. 
FIGURA 42 - JANELA DA BASE DE CORPORA

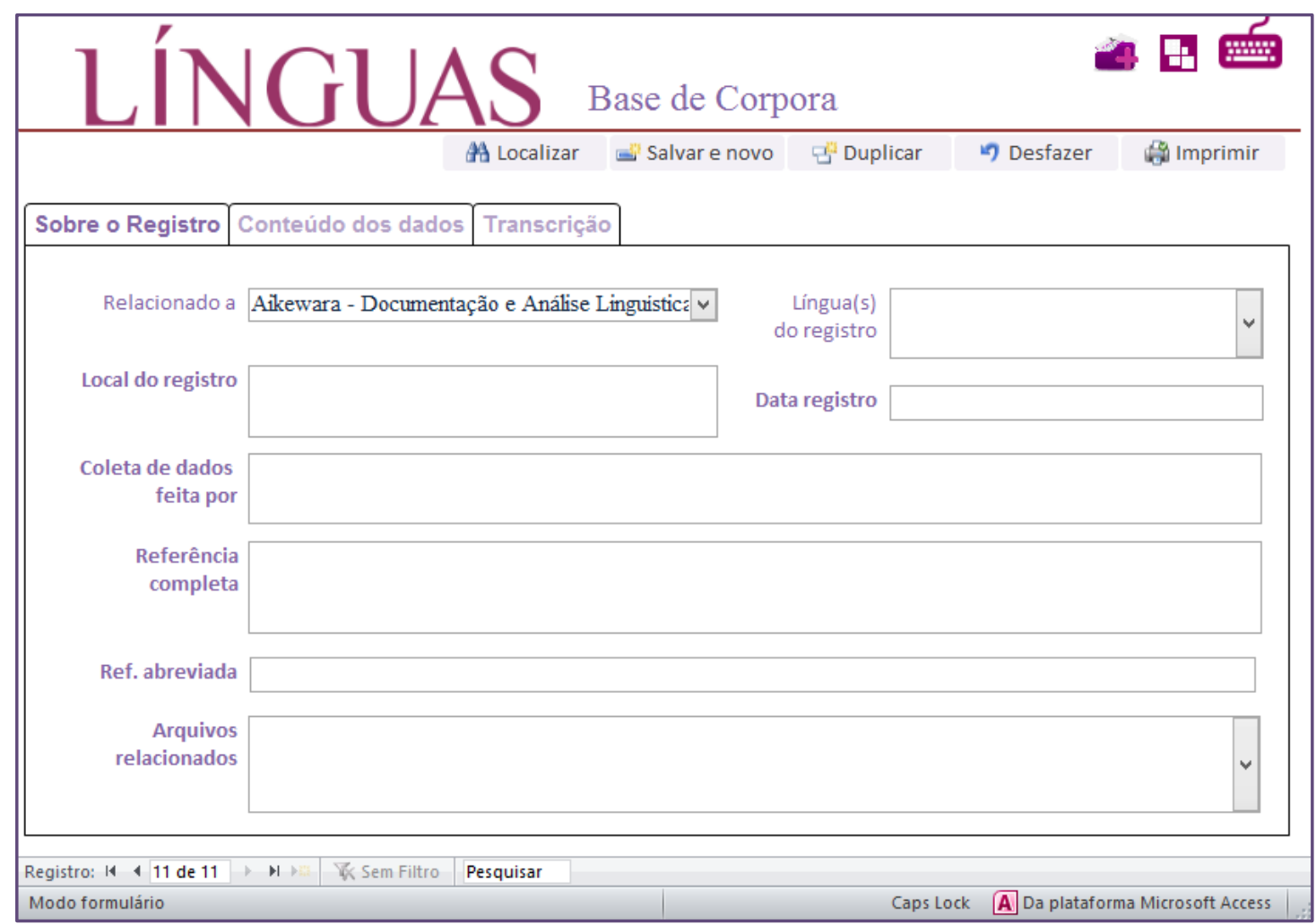

TABELA 37 - ABA 1: SOBRE O REGISTRO

\begin{tabular}{ll}
\hline CAMPO & DESCRIÇÃo \\
\hline Relacionado a & $\begin{array}{l}\text { Este campo possui como valor padrão o nome do primeiro Projeto de } \\
\text { Documentação Linguística cadastrado na Base Projeto. Assim, se não } \\
\text { houver outro projeto em execução, este valor não deve ser } \\
\text { modificado. }\end{array}$ \\
\hline Apesar de haver uma língua-base em cada projeto, é possível que o \\
material coletado para constituição do corpus do Projeto contenha \\
mais de uma língua, por isso o formulário oferece a possibilidade de \\
cadastrar mais de uma língua para um mesmo corpus.
\end{tabular}




\begin{tabular}{ll}
\hline & $\begin{array}{l}\text { abreviada é a que estará disponível quando do cadastramento dos } \\
\text { dados linguísticos. }\end{array}$ \\
\hline Arquivo(s) relacionado(s) & $\begin{array}{l}\text { Informar os arquivos relacionados a cada um dos corpora cadastrados } \\
\text { na base. }\end{array}$ \\
\hline
\end{tabular}

TABELA 38 - ABA 2: CONTEÚDO DOS DADOS

\begin{tabular}{ll}
\hline CAMPO & DESCRIÇÃO \\
\hline $\begin{array}{l}\text { Fonte(s) do conhecimento } \\
\text { do registro }\end{array}$ & $\begin{array}{l}\text { Lista suspensa que contém todos os nomes de pessoas fonte do } \\
\text { conhecimento já cadastradas na Base Fonte. Seleciono um ou mais } \\
\text { nomes que façam parte do arquivo que está sendo registrado. }\end{array}$ \\
\hline Contexto de registro & $\begin{array}{l}\text { Campo para descrição do contexto em que o registro foi efetuado } \\
\text { (hora, local, situação, pessoas presentes, duração, motivações). }\end{array}$ \\
\hline $\begin{array}{l}\text { Descrição do conteúdo } \\
\text { deste registro }\end{array}$ & $\begin{array}{l}\text { Campo para descrição do conteúdo do registro (sequência de assuntos } \\
\text { tratados, interrupç̃̃es e pausas, comentários). }\end{array}$ \\
\hline
\end{tabular}

TABELA 39 - ABA 3: TRANSCRIÇÃO

\begin{tabular}{ll}
\hline CAMPO & DESCRIÇÃo \\
\hline Material transcrito por & $\begin{array}{l}\text { É possível informar quem fez o trabalho de transcrição do material } \\
\text { sonoro que compõe o corpus do Projeto de Documentação } \\
\text { Linguística. }\end{array}$ \\
\hline $\begin{array}{l}\text { Orientação teórica/ modelo } \\
\text { adotado na transcrição }\end{array}$ & $\begin{array}{l}\text { Campo destinado à apresentação da orientação teórica e/ou do } \\
\text { modelo adotado na transcrição fonética e na escrita das formas } \\
\text { fonológica e ortográfica do material sonoro. }\end{array}$ \\
\hline Anotação & $\begin{array}{l}\text { Espaço para inserção de notas acerca do conteúdo do registro ou do } \\
\text { processo de transcrição do material. }\end{array}$ \\
\hline
\end{tabular}

\subsection{Base Afixos}

Esta base de dados recebe os afixos que podem se relacionar com itens lexicais da língua-base armazenados no PDL. Clico sobre o ícone referente à Base Afixos para acessar a área de cadastramento. ${ }^{148}$

TABELA 40 - DESCRIÇÃO DOS CAMPOS DA BASE AFIXOS

\begin{tabular}{ll}
\hline CAMPO & DESCRIÇÃo \\
\hline Afixo & $\begin{array}{l}\text { Campo para cadastrar afixos da língua-base e que estarão disponíveis } \\
\text { para uso na Base Léxico. }\end{array}$ \\
\hline Da língua & $\begin{array}{l}\text { Lista suspensa que contém as línguas cadastradas na Área de Projeto. } \\
\text { Seleciono a língua em que o texto foi produzido. }\end{array}$ \\
\hline Tipo & $\begin{array}{l}\text { Lista suspensa (editável) em que se pode definir o tipo de afixo } \\
\text { cadastrado no campo anterior. O programa Línguas contém, a título }\end{array}$ \\
\hline
\end{tabular}

${ }^{148}$ Os afixos cadastrados nesta base podem ser exportados como material lexicográfico. Para mais informações, consulte a Área de Materiais. 


\begin{tabular}{ll}
\hline & $\begin{array}{l}\text { de sugestão, uma lista predefinida com } 3 \text { opções, são elas: prefixo, } \\
\text { infixo, sufixo. }\end{array}$ \\
\hline Natureza & $\begin{array}{l}\text { Lista suspensa (editável) em que se pode definir a natureza do afixo } \\
\text { cadastrado no campo anterior. O programa Línguas contém, a título } \\
\text { de sugestão, uma lista predefinida com 2 opções, são elas: } \\
\text { derivacional e flexional. }\end{array}$ \\
\hline Significado/Definição & $\begin{array}{l}\text { Campo para registrar significados e/ou definições do afixo cadastrado } \\
\text { no campo anterior. }\end{array}$ \\
\hline Contexto de ocorrência & $\begin{array}{l}\text { É possível descrever o contexto de ocorrência de cada afixo } \\
\text { cadastrado nesta base. }\end{array}$ \\
\hline Glosa Língua 2 & Campo para inserir a glosa na língua 2 cadastrada na Base Projeto. \\
\hline Glosa Língua 3 & Campo para inserir a glosa na língua 3 cadastrada na Base Projeto. \\
\hline Glosa Língua 4 & Campo para inserir a glosa na língua 4 cadastrada na Base Projeto. \\
\hline Anotação & Campo para anotações relacionadas ao afixo cadastrado nesta base. \\
\hline
\end{tabular}

FIGURA 43 - JANELA DA BASE DE AFIXOS

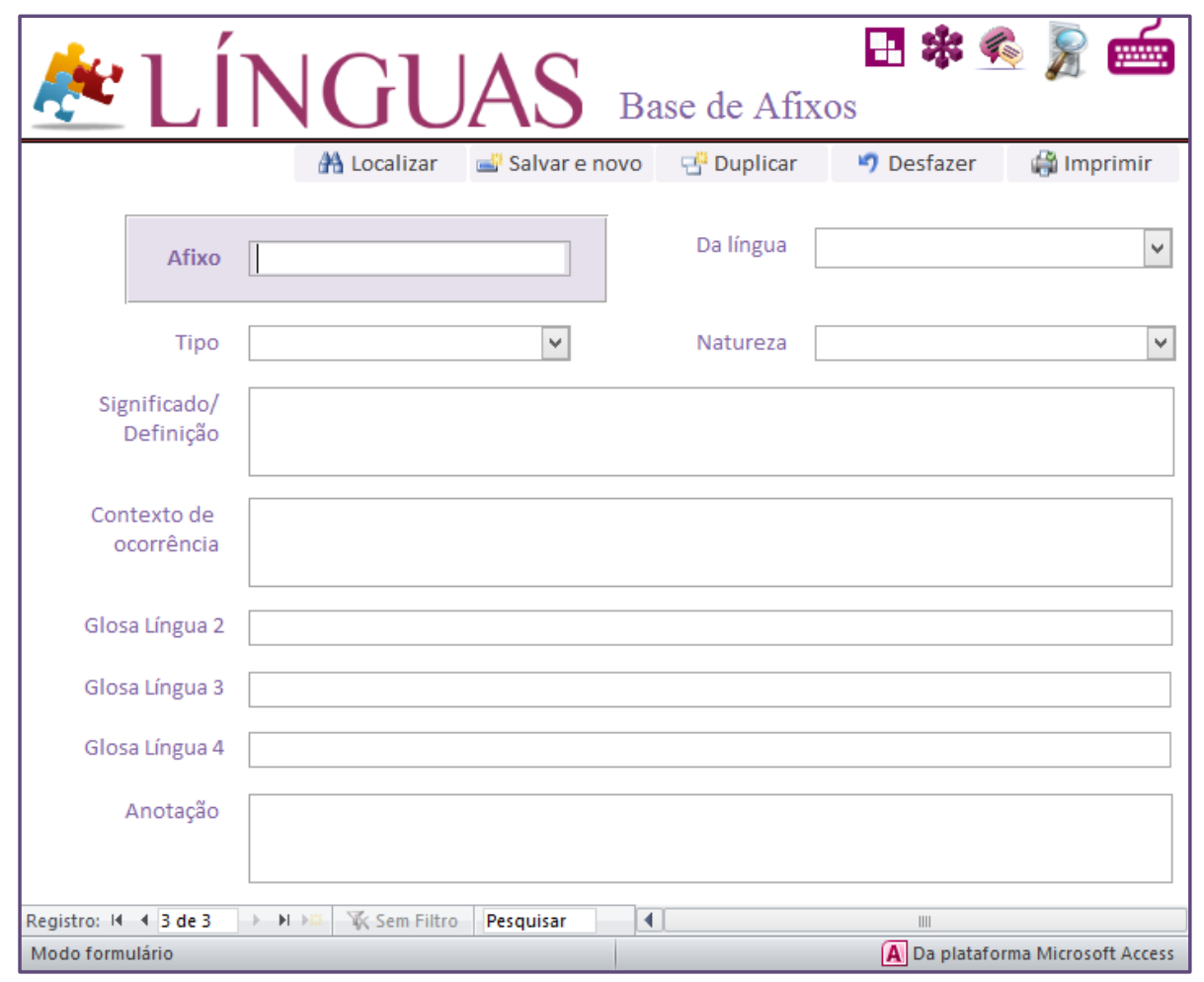

\subsubsection{Armazenando Dados Linguísticos}

Uma vez concluída a operação de cadastramento de um PDL na Área Projeto, o Programa Línguas já pode armazenar os dados linguísticos coletados. Para isso, clico sobre o ícone Dados na Área de Trabalho e acesso a Área de Dados. 
FIGURA 44 - JANELA PRINCIPAL DA ÁREA DE DADOS

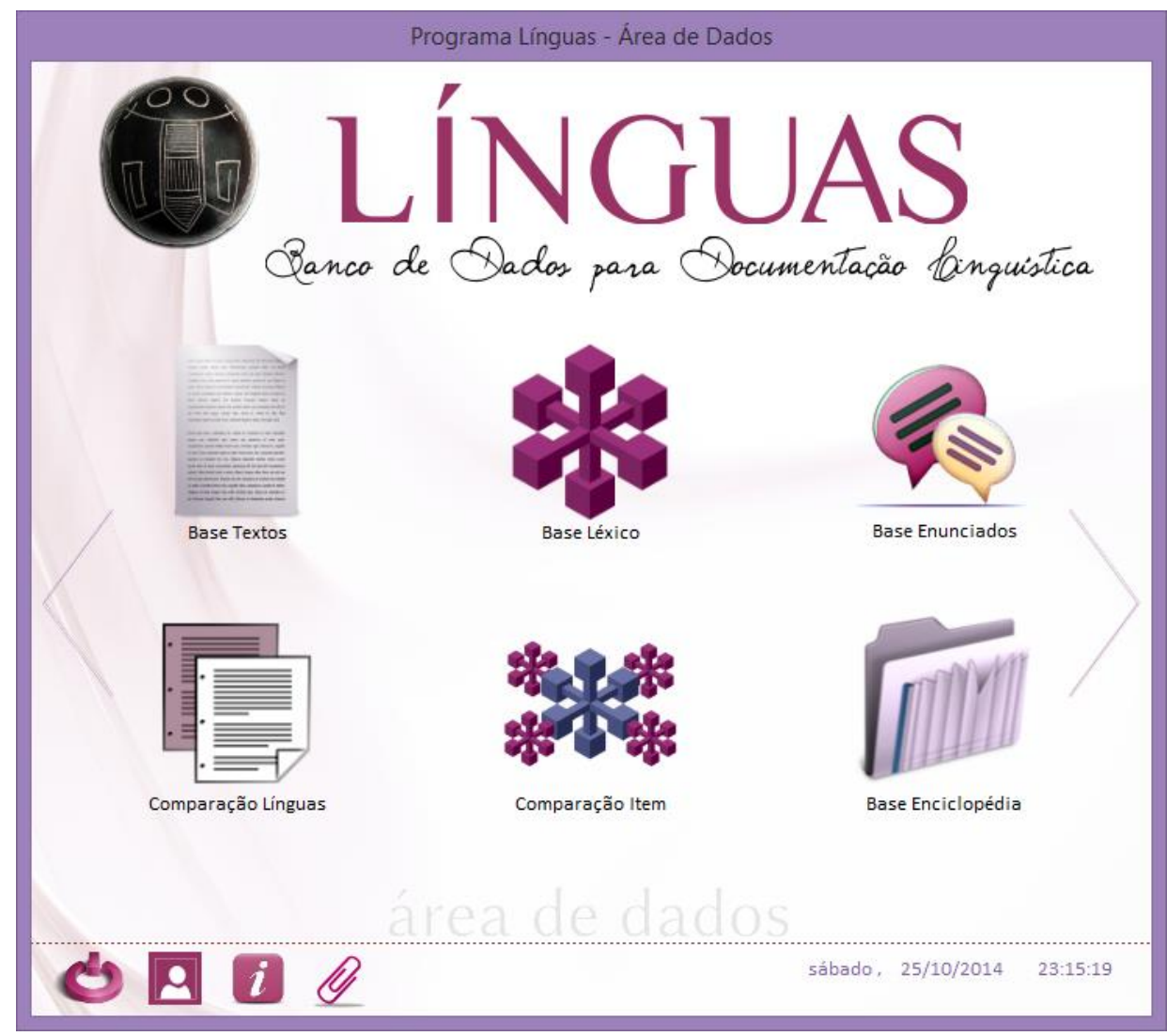

Nessa área, há seis ícones, correspondentes a bases para inserção dos dados linguísticos do Projeto de Documentação. Apresento, a seguir, cada uma dessas bases.

\subsection{Base Textos}

Esta base de dados recebe os textos completos que compõem o corpus do PDL.

Clico sobre o ícone referente à Base Texto para acessar a área de cadastramento. $^{149}$

Esta base contém seis abas inter-relacionadas para cadastramento de textos registrados e transcritos no âmbito do projeto de documentação.

\footnotetext{
${ }^{149}$ Não há, neste programa, nenhuma definição nem extensão para o que é denominado texto, pois, cabe a cada PDL definir as diferenças e os limites do que será denominado texto.
} 
FIGURA 45 - JANELA DA BASE DE TEXTOS

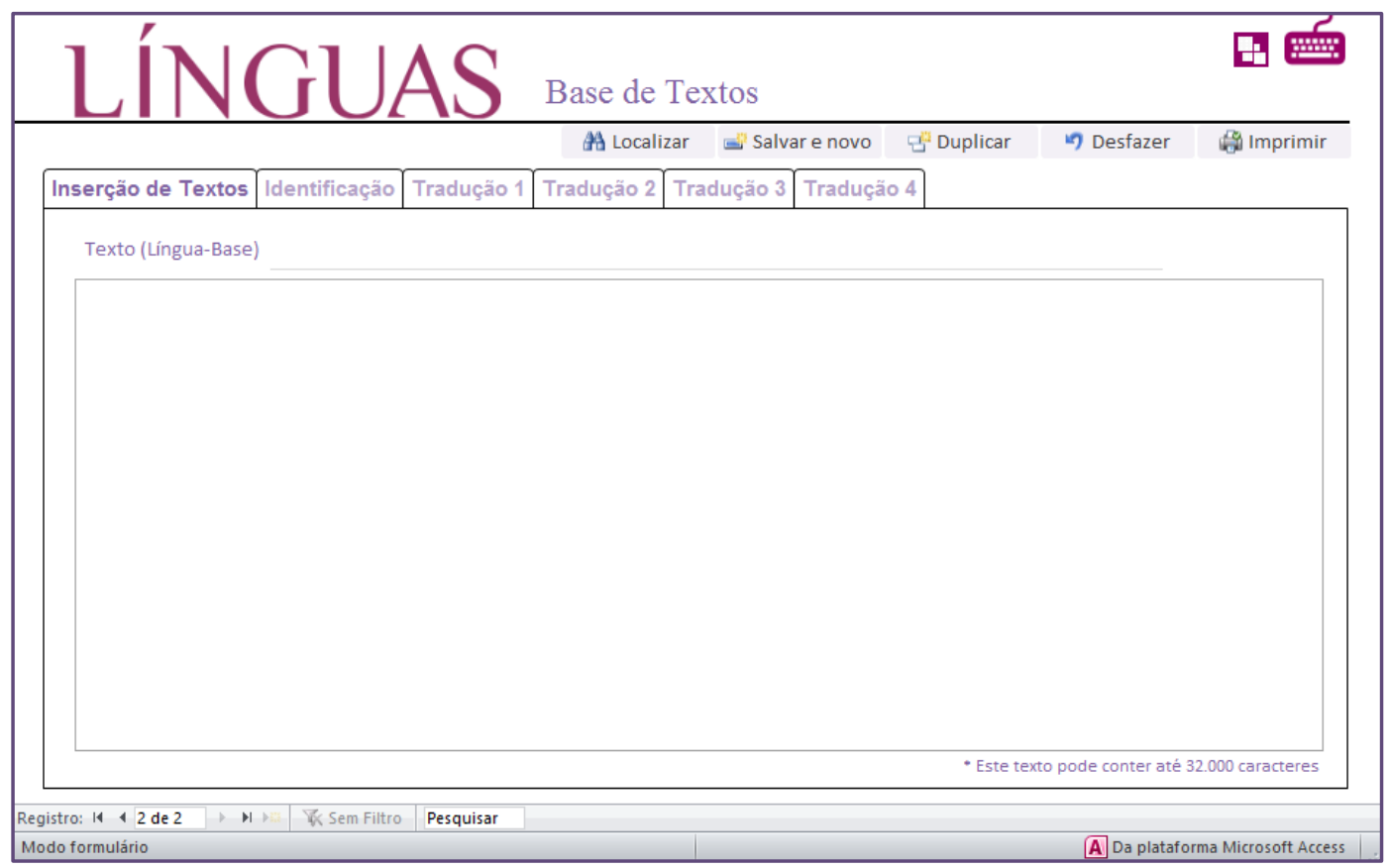

TABELA 41 - ABA 1: INSERÇÃO DE TEXTOS

\begin{tabular}{ll}
\hline CAMPO & DESCRIÇÃO \\
\hline & Há dois campos relacionados ao registro do texto na língua-base: \\
& acima, há um espaço (com uma linha) destinado ao título do texto; e \\
& abaixo, um campo (maior) destinado à inserção do texto (escrito ou \\
& transcrito) na língua-base. Nota: O título, que serve como forma de \\
& identificação do texto, deve ser atribuído mesmo que no registro (oral \\
& ou escrito) original ele não exista; cada registro de texto pode conter \\
Texto (Língua-Base) 32.000 caracteres.
\end{tabular}

TABELA 42 - ABA 2: IDENTIFICAÇÃO

\begin{tabular}{ll}
\hline CAMPO & DESCRIÇÃo \\
\hline Relacionado a & $\begin{array}{l}\text { Este campo possui como valor padrão o nome do primeiro PDL } \\
\text { cadastrado na Base Projeto. Assim, se não houver outro projeto em } \\
\text { execução, este valor não deve ser modificado. }\end{array}$ \\
\hline Do Corpus & $\begin{array}{l}\text { O item lexical pode ser relacionado a um arquivo já cadastrado na } \\
\text { Base Corpus do Projeto. Seleciono, na lista suspensa, a referência de } \\
\text { arquivo correspondente. }\end{array}$ \\
\hline Da Língua & $\begin{array}{l}\text { Lista suspensa que contém as línguas cadastradas na Área de Projeto. } \\
\text { Seleciono a língua em que o texto foi produzido. }\end{array}$ \\
\hline Gênero textual & $\begin{array}{l}\text { Lista suspensa (editável) com opções para definir a que gênero(s) } \\
\text { pertence o texto inserido na base. O programa Línguas contém, a } \\
\text { título de sugestão, uma lista predefinida com várias opções, tais } \\
\text { como: Interpessoal/Agradecimento e Lazer/Advinhas. }\end{array}$ \\
\hline Palavras-chave & $\begin{array}{l}\text { Seleciono uma ou mais palavras-chave relacionadas ao conteúdo do } \\
\text { fragmento de texto inserido. }\end{array}$ \\
\hline
\end{tabular}




\begin{tabular}{ll}
\hline \multirow{2}{*}{ Arquivos relacionados } & $\begin{array}{l}\text { Campo para selecionar um ou mais arquivos relacionados } \\
\text { diretamente com a pessoa fonte de conhecimento. Esses arquivos } \\
\text { devem ser previamente registrados na Base Arquivos e referenciados } \\
\text { sempre que necessário. }\end{array}$ \\
\hline Anotação & $\begin{array}{l}\text { Campo para anotações relativas ao texto da língua-base inserido no } \\
\text { formulário da Aba 1. }\end{array}$ \\
\hline
\end{tabular}

TABELA 43 - ABAS 3/4/5/6: TRADUÇÃO

\begin{tabular}{ll}
\hline CAMPO & DESCRIÇÃO \\
\hline Tradução & $\begin{array}{l}\text { Há também dois campos relacionados à tradução: acima, há um } \\
\text { espaço (com uma linha) destinado ao título do texto traduzido; e } \\
\text { abaixo, um campo (maior) destinado à inserção do texto traduzido. }\end{array}$ \\
\hline Língua-alvo & $\begin{array}{l}\text { Informar, em cada aba, para que língua (língua-alvo) o texto da } \\
\text { língua-base está sendo traduzido. }\end{array}$ \\
\hline Anotação & $\begin{array}{l}\text { Campo para anotações relativas ao conteúdo traduzido do texto da } \\
\text { língua-base inserido no formulário da Aba } 1 .\end{array}$ \\
\hline
\end{tabular}

À medida que o campo Texto é preenchido, inicia-se um contador de caracteres na parte superior direita do campo. Esse contador permite controlar a quantidade de caracteres já inseridos em cada campo de texto da base.

\subsection{Base Léxico}

Esta base de dados recebe os itens lexicais, relacionados ou não a enunciados e textos, que compõem o corpus do PDL. Clico sobre o ícone referente à Base Léxico para acessar a área de cadastramento. Esta base contém nove abas inter-relacionadas para cadastramento de itens lexicais.

TABELA 44 - ABA 1: REGISTRO

\begin{tabular}{ll}
\hline CAMPO & DESCRIÇÃo \\
\hline Relacionado a & $\begin{array}{l}\text { Este campo possui como valor padrão o nome do primeiro PDL } \\
\text { cadastrado na Base Projeto. Assim, se não houver outro projeto em } \\
\text { execução, este valor não deve ser modificado. }\end{array}$ \\
\hline Do Corpus & $\begin{array}{l}\text { O item lexical pode ser relacionado a um arquivo já cadastrado na } \\
\text { Base Corpus do Projeto. Seleciono na lista suspensa a referência de } \\
\text { arquivo correspondente. }\end{array}$ \\
\hline Do Texto & $\begin{array}{l}\text { O item lexical pode ser relacionado a um texto já cadastrado na Base } \\
\text { Texto do Projeto. Seleciono na lista suspensa a referência de arquivo } \\
\text { correspondente. }\end{array}$ \\
\hline Registro do Item Lexical & $\begin{array}{l}\text { Inserir neste campo o item lexical da língua 1. Como o campo } \\
\text { seguinte está reservado para o registro das raízes, o item lexical deste } \\
\text { campo poder, por exemplo, uma forma flexionada. }\end{array}$ \\
\hline Raiz & Campo para registrar a forma da raiz do item lexical inserido no \\
\hline
\end{tabular}


campo anterior. Esse campo é necessário, pois, em muitas línguas, não há coincidência entre o item lexical e sua raiz.

Lista suspensa que apresenta uma sequência numérica. Ao selecionar um número desta lista, ele será considerado para indicar que há casos

Homonímia de homonímia na língua. Nota: Na produção do material lexicográfico, esse número aparece sobrescrito junto ao item lexical da entrada.

\begin{tabular}{ll}
\hline Afixo(s) & $\begin{array}{l}\text { Selecionar, na lista suspensa, os afixos que o item lexical registrado } \\
\text { pode receber. Esses afixos devem ser previamente cadastrados em } \\
\text { formulário próprio disponível na Base Afixos. }\end{array}$ \\
\hline Variação & $\begin{array}{l}\text { As formas variantes do item lexical, se existirem, devem ser } \\
\text { apresentadas na forma de lista (preferencialmente), pois poderão ser } \\
\text { usadas na edição de materiais lexicográficos. Reservar os } \\
\text { comentários para o campo Anotação, abaixo. }\end{array}$ \\
\hline Natureza & $\begin{array}{l}\text { Lista suspensa (editável) com opções para definir a natureza da } \\
\text { variação do item lexical (ver campo anterior). O programa Línguas } \\
\text { contém, a título de sugestão, uma lista predefinida com as seguintes } \\
\text { opções: diafásica, diagenérica, diageracional, diastrática, diatópica. }\end{array}$ \\
\hline Anotação & Campo para anotações acerca da variação linguística do item lexical. \\
\hline Fonética & $\begin{array}{l}\text { Campo para inserção da transcrição fonética do item lexical. Nota: } \\
\text { Não é necessário inserir a transcrição entre colchetes, pois, no } \\
\text { momento da criação de material lexicográfico, eles serão } \\
\text { acrescentados automaticamente; o mesmo vale para a Fonologia. }\end{array}$ \\
\hline Fonologia & Campo para inserção da forma fonológica do item lexical. \\
\hline Anotação & Campo para anotaçães acerca da transcrição da língua documentada. \\
\hline
\end{tabular}

FIGURA 46 - JANELA DA BASE DE DADOS LEXICAIS

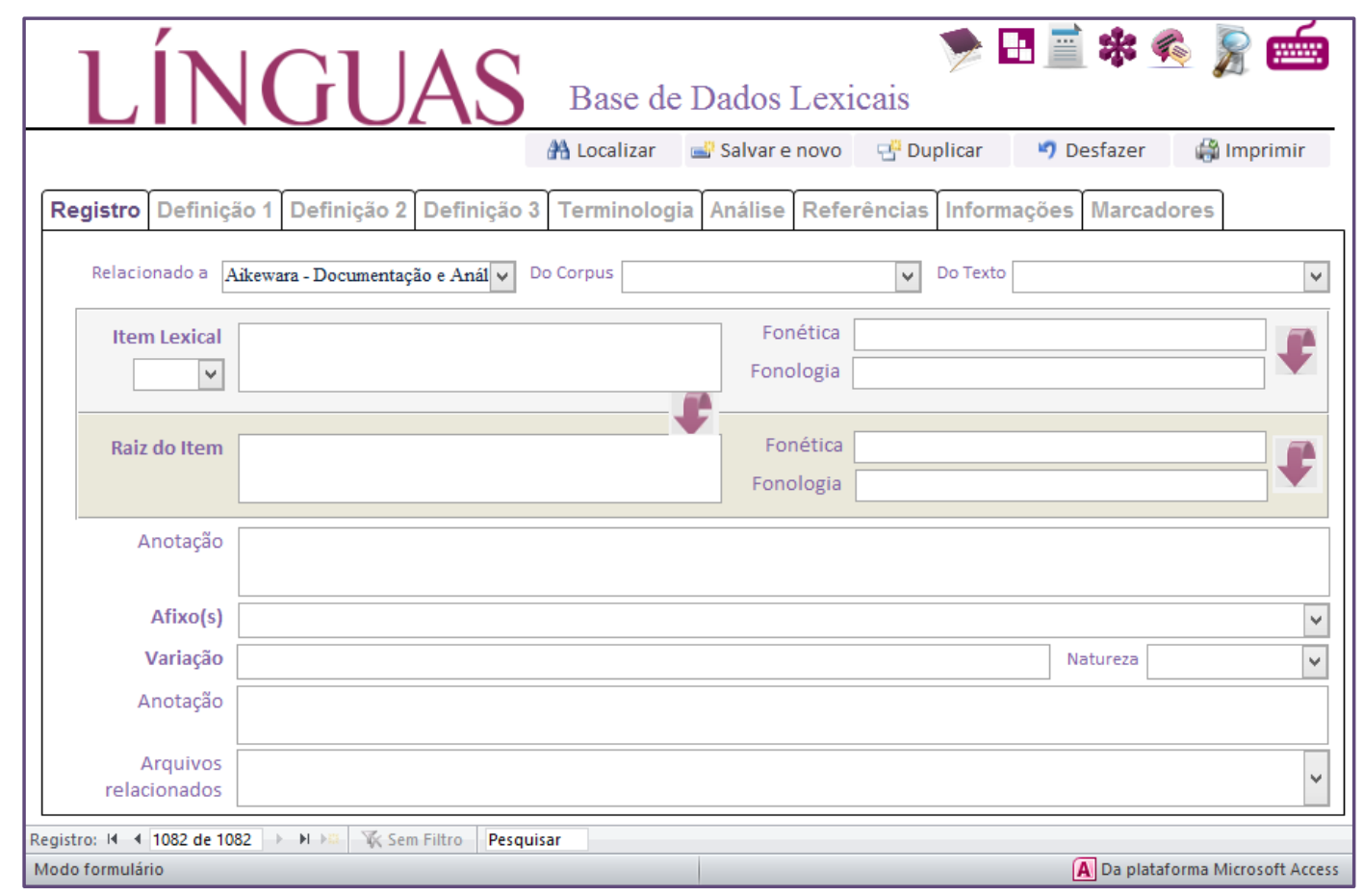


As setas 7 têm a função de copiar o conteúdo de um campo para outro. Por exemplo, é possível aproveitar a transcrição fonética como base para fazer o registro da forma fonológica. Deste modo, digito o conteúdo no campo Fonética e clico sobre a seta; assim, o conteúdo desse campo será duplicado para o campo imediatamente abaixo.

\section{TABELA 45 - ABAS 2, 3 E 4: DEFINIÇÃO 1/2/3}

\begin{tabular}{|c|c|}
\hline САМРО & DESCRIÇÃO \\
\hline Item Língua 1 & $\begin{array}{l}\text { O item lexical cadastrado na Aba } 1 \text { é, automaticamente, copiado para } \\
\text { este campo e serve como referência. Logo, não há o que preencher } \\
\text { neste campo. }\end{array}$ \\
\hline $\begin{array}{l}\text { Propriedade gramatical } \\
\text { Língual }\end{array}$ & $\begin{array}{l}\text { Lista suspensa (editável) com informações sobre propriedades } \\
\text { gramaticais que podem ser atribuídas ao item lexical apresentado no } \\
\text { campo anterior. Essa informação pode ser diferente em cada uma das } \\
\text { três abas. }\end{array}$ \\
\hline Definição 1/2/3 Língua1 & $\begin{array}{l}\text { O item lexical pode receber nesta base até } 3 \text { definições diferentes } \\
\text { (com propriedades gramaticais específicas - ver campo anterior). }\end{array}$ \\
\hline Item Língua2 & $\begin{array}{l}\text { Campo para inserir a tradução/correspondência do item lexical da } \\
\text { língua-base para a segunda língua definida no Projeto de } \\
\text { Documentação. }\end{array}$ \\
\hline $\begin{array}{l}\text { Propriedade gramatical } \\
\text { Língua2 }\end{array}$ & $\begin{array}{l}\text { Lista suspensa (editável) com informações sobre propriedades } \\
\text { gramaticais que podem ser atribuídas ao item lexical da Língua } 2 \\
\text { apresentado no campo anterior. Essa informação pode ser diferente } \\
\text { em cada uma das três abas. }\end{array}$ \\
\hline Definição 1/2/3 Língua2 & $\begin{array}{l}\text { O item lexical da Língua } 2 \text { pode receber nesta base até } 3 \text { definições } \\
\text { diferentes (com propriedades gramaticais específicas - ver campo } \\
\text { anterior). }\end{array}$ \\
\hline Exemplo 1/2/3 Língua1 & $\begin{array}{l}\text { Campo para inserir um enunciado que sirva de primeiro exemplo na } \\
\text { língua-base relacionado à definição dada em cada aba para o item } \\
\text { lexical registrado. }\end{array}$ \\
\hline Exemplo 1/2/3 Língua2 & $\begin{array}{l}\text { Campo para inserir uma tradução/correspondência para a Língua } 2 \text { do } \\
\text { exemplo apresentado no campo anterior. }\end{array}$ \\
\hline
\end{tabular}

TABELA 46 - ABA 5: TERMINOLOGIA

\begin{tabular}{ll}
\hline CAMPO & DESCRIÇÃO \\
\hline Item Língua 1 & $\begin{array}{l}\text { O item lexical cadastrado na Aba 1 é, automaticamente, copiado para } \\
\text { este campo e serve como referência. Logo, não há o que preencher } \\
\text { neste campo. }\end{array}$ \\
\hline Domínio 1/2/3/4 & $\begin{array}{l}\text { Campo com uma lista suspensa com dezenas de domínios (áreas } \\
\text { técnicas), tais como agr. (agricultura), cer. (cerâmica), pesc. (pesca) } \\
\text { disponível para seleção. Para editar essa lista, acessar a pasta } \\
\text { Configuração da Lista de Domínios, na Área de Edição. }\end{array}$ \\
\hline Definição & $\begin{array}{l}\text { Para cada domínio selecionado é possível inserir uma definição } \\
\text { própria, associada ao item do campo anterior. }\end{array}$ \\
\hline
\end{tabular}




\begin{tabular}{ll}
\hline Anotação & $\begin{array}{l}\text { Campo para anotações relativas a cada domínio e definição } \\
\text { apresentadas respectivamente nos campos anteriores. }\end{array}$ \\
\hline Termo científico & $\begin{array}{l}\text { No caso de itens lexicais com nomes de plantas e animais, pode ser } \\
\text { registrada a forma científica correspondente (geralmente apresentada } \\
\text { em latim). }\end{array}$ \\
\hline
\end{tabular}

\section{TABELA 47 - ABA 6: ANÁLISE}

\begin{tabular}{ll}
\hline CAMPO & DESCRIÇÃo \\
\hline Item Língua 1 & $\begin{array}{l}\text { O item lexical cadastrado na Aba 1 é, automaticamente, copiado para } \\
\text { este campo e serve como referência. Logo, não há o que preencher } \\
\text { neste campo. }\end{array}$ \\
\hline Divisão silábica & $\begin{array}{l}\text { O item lexical da língua-base pode ser dividido em sílabas e ser } \\
\text { usado para a entrada de verbetes de um dicionário. }\end{array}$ \\
\hline Segmentação & $\begin{array}{l}\text { O item lexical pode ser segmentado de acordo com suas propriedades } \\
\text { morfológicas. }\end{array}$ \\
\hline Morfologia & $\begin{array}{l}\text { Campo para registrar a análise morfológica correspondente a cada } \\
\text { parte da segmentação do item lexical do campo anterior. }\end{array}$ \\
\hline Etimologia & $\begin{array}{l}\text { Registro da etimologia do item lexical da língua-base. Essa } \\
\text { informação é utilizada na composição dos verbetes do material } \\
\text { lexicográfico. }\end{array}$ \\
\hline Anotação & $\begin{array}{l}\text { Espaço para outros comentários relacionados à etimologia } \\
\text { apresentada no campo anterior. }\end{array}$ \\
\hline Frequência & $\begin{array}{l}\text { Se houver um levantamento da ocorrência do item lexical dentro do } \\
\text { Corpus do PDL, é possível registrar, neste campo, esse dado } \\
\text { quantitativo. }\end{array}$ \\
\hline
\end{tabular}

TABELA 48 - ABA 7: REFERÊNCIAS

\begin{tabular}{ll}
\hline CAMPO & DESCRIÇÃo \\
\hline Item Língua 1 & $\begin{array}{l}\text { O item lexical cadastrado na Aba 1 é, automaticamente, copiado para } \\
\text { este campo e serve como referência. Logo, não há o que preencher } \\
\text { neste campo. }\end{array}$ \\
\hline \multirow{2}{*}{ Tipo } & $\begin{array}{l}\text { Lista suspensa com opções para definir o tipo de referência (a ser } \\
\text { usada na produção do material lexicográfico). O Programa apresenta } \\
\text { uma lista (editável) predefinida com as seguintes opções (e suas } \\
\text { respectivas formas abreviadas): Antônimo, Formas homógrafas, } \\
\text { Equivalência, Formas homófonas, Por extensão, Sinônimo, Ver. }\end{array}$ \\
\hline Itens da referência & $\begin{array}{l}\text { Campo para inserir os itens lexicais que se relacionam (conforme tipo } \\
\text { apresentado no campo anterior) ao item lexical Língua 1 [5 campos] }\end{array}$ \\
\hline
\end{tabular}

TABELA 49 - ABA 8: INFORMAÇÕES

\begin{tabular}{ll}
\hline CAMPO & DESCRIÇÃO \\
\hline Item Língua 1 & $\begin{array}{l}\text { O item lexical cadastrado na Aba 1 é, automaticamente, copiado para } \\
\text { este campo e serve como referência. }\end{array}$ \\
\hline
\end{tabular}


Informações culturais

Anotações sociolinguísticas
Campo para registro de informações culturais relacionadas diretamente ao item lexical da língua-base. Essas informações podem estar relacionadas a eventos, a mitos ou ainda, p.ex., a tabus.

Campo para registro de informações sociolinguísticas relacionadas diretamente ao item lexical da língua-base. Essas anotações podem apresentar detalhes relevantes sobre o uso do item lexical, tais como: idade, gênero, status social do falante, sua atividade, origem e/ou escolaridade.

FIGURA 47 - ABA MARCADORES DA BASE DE DADOS LEXICAIS

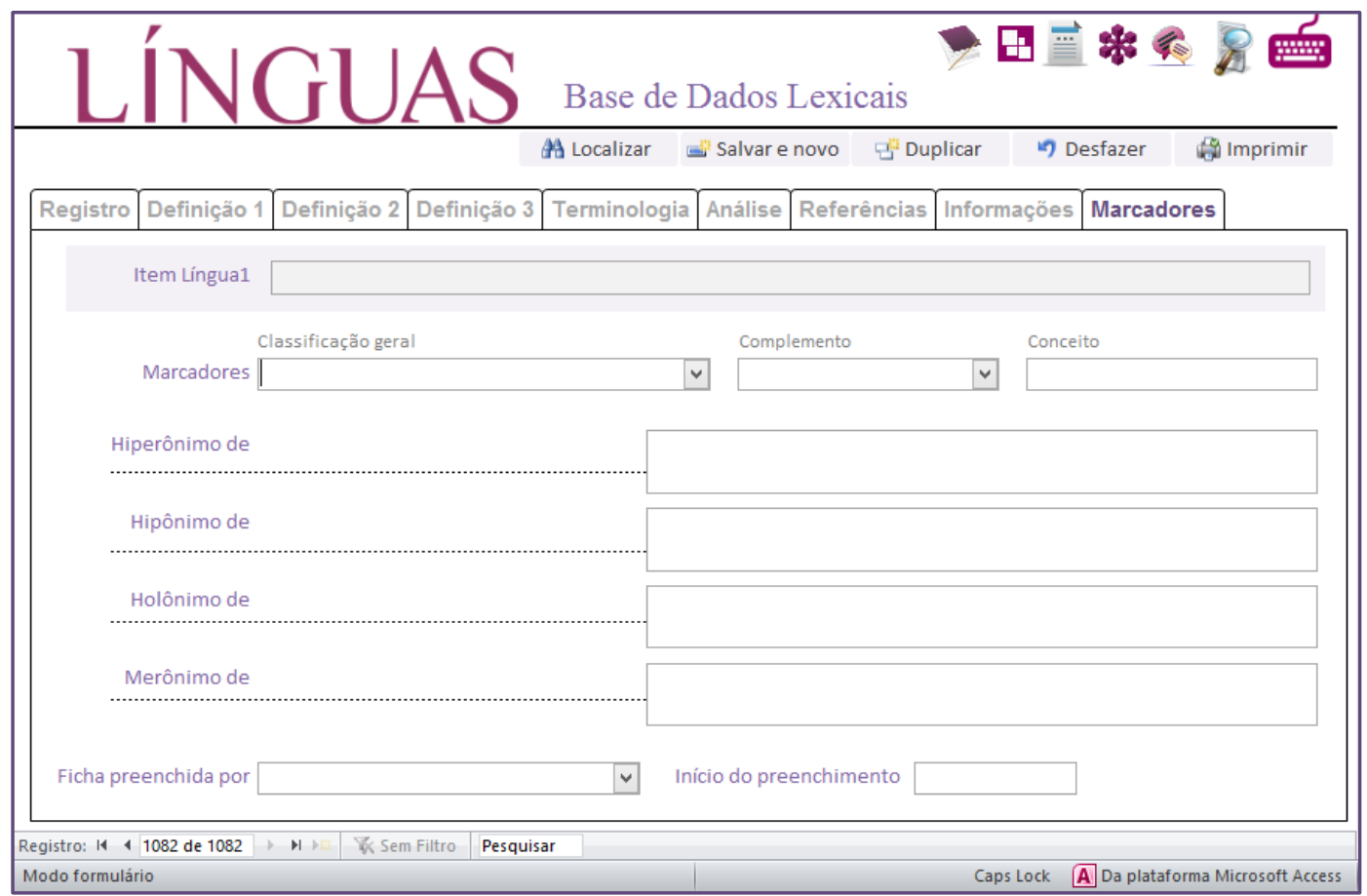

TABELA 50 - ABA 9: MARCADORES

\begin{tabular}{ll}
\hline CAMPO & DESCRIÇÃO \\
\hline Item Língua 1 & $\begin{array}{l}\text { O item lexical cadastrado na Aba 1 é, automaticamente, copiado para } \\
\text { este campo e serve como referência. }\end{array}$ \\
\hline
\end{tabular}

Lista suspensa (editável) com marcadores (label/tag) que servem para

Marcador 1

[Classificação geral]

Marcador 2

[Complemento] facilitar a localização (pelo sentido) de itens lexicais cadastrados na Base Léxico. Estes marcadores definem uma classificação geral para o item lexical. O programa Línguas contém, a título de sugestão, uma lista predefinida de marcadores, tais como: ação, alimentação, animal (anelídeo, anfíbio...).

Lista suspensa (editável) com marcadores (label/tag) que servem para facilitar a localização (pelo sentido) de itens lexicais cadastrados na Base Léxico. Estes marcadores definem uma qualidade para o item lexical. O programa Línguas contém, a título de sugestão, uma lista predefinida de marcadores, tais como: abaixo, aberto, achatado, acima... 


\begin{tabular}{|c|c|}
\hline $\begin{array}{l}\text { Marcador } 3 \\
\text { [Conceito] }\end{array}$ & $\begin{array}{l}\text { Lista suspensa (editável) com marcadores (label/tag) que servem para } \\
\text { facilitar a localização (pelo sentido) de itens lexicais cadastrados na } \\
\text { Base Léxico. Estes marcadores permitem uma especificação para o } \\
\text { item lexical, ou seja, é possível associar o item lexical, p.ex., a um } \\
\text { nome específico (referente dado pelo sentido literal): gato, cachorro } \\
\text { e porco são especificações de animais/ mamíferos (ver campo do } \\
\text { marcador Classificação geral). }\end{array}$ \\
\hline Hiperônimo de & $\begin{array}{l}\text { Campo para registro de hiperônimos do item lexical da língua-base. } \\
\text { Nota: De acordo com o Dicionário Eletrônico Houaiss da Língua } \\
\text { Portuguesa, hiperônimo é a "relação estabelecida entre um vocábulo } \\
\text { de sentido mais genérico e outro de sentido mais específico (p.ex., } \\
\text { animal está numa relação de hiperonímia com leão, gato etc.)". }\end{array}$ \\
\hline Hipônimo de & $\begin{array}{l}\text { Campo para registro de hipônimos do item lexical da língua-base. } \\
\text { Nota: De acordo com o Dicionário Eletrônico Houaiss da Língua } \\
\text { Portuguesa, hipônimo é a "relação existente entre uma palavra de } \\
\text { sentido mais específico e outra de sentido mais genérico, que tem } \\
\text { com a primeira traços semânticos comuns (p.ex., mamífero está numa } \\
\text { relação de hiponímia com animal)". }\end{array}$ \\
\hline Holônimo de & $\begin{array}{l}\text { Campo para registro de holônimos do item lexical da língua-base. } \\
\text { Nota: De acordo com o Dicionário Eletrônico Houaiss da Língua } \\
\text { Portuguesa, holônimo é uma "[...] unidade léxica que designa uma } \\
\text { totalidade da qual outras unidades (merônimos) fazem parte (p.ex., } \\
\text { corpo é h. de braço)". }\end{array}$ \\
\hline Merônimo de & $\begin{array}{l}\text { Campo para registro de merônimos do item lexical da língua-base. } \\
\text { Nota: De acordo com o Dicionário Eletrônico Houaiss da Língua } \\
\text { Portuguesa, merônimo "diz-se de ou unidade léxica que constitui } \\
\text { parte de um todo designado por outra unidade (holônimo) [p.ex., } \\
\text { braço é m. de corpo]". }\end{array}$ \\
\hline Ficha preenchida por & $\begin{array}{l}\text { Lista suspensa com nomes de usuários cadastrados no programa } \\
\text { Línguas e que podem ser informados como responsáveis pelo } \\
\text { preenchimento da ficha. }\end{array}$ \\
\hline Início do preenchimento & $\begin{array}{l}\text { Ao clicar sobre este campo, é mostrado o ícone }{ }^{-1} \text {, clico sobre ele } \\
\text { para abrir um calendário. Seleciono uma data para registrar o início } \\
\text { do preenchimento da ficha. Por padrão, a data destacada é sempre a } \\
\text { data atual. }\end{array}$ \\
\hline
\end{tabular}

\subsection{Base Enunciados}

Esta base de dados recebe os enunciados, relacionados ou não a textos, que compõem o corpus do Projeto de Documentação. Clico sobre o ícone referente à Base Enunciados para acessar a área de cadastramento. ${ }^{150}$

\footnotetext{
${ }^{150}$ A fim de facilitar a extração de dados para esta base, é importante começar a inserção dos dados pela base de textos.
} 
FIGURA 48 - JANELA DA BASE DE ENUNCIADOS

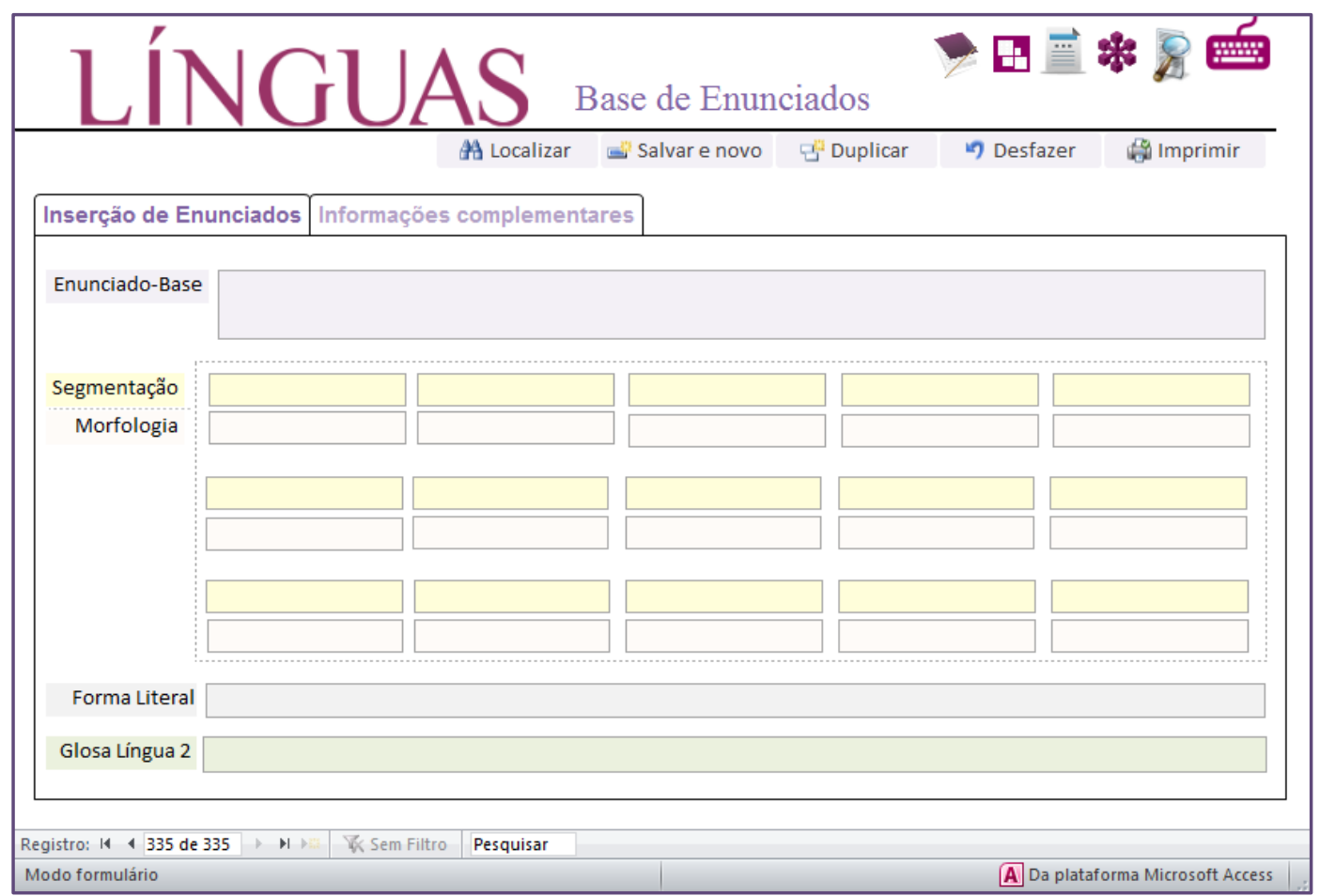

A Base de Enunciados contém duas abas inter-relacionadas para cadastramento de dados.

TABELA 51 - ABA 1: INSERÇÃO DE ENUNCIADOS

\begin{tabular}{ll}
\hline CAMPO & DESCRIÇão \\
\hline Enunciado-Base & $\begin{array}{l}\text { Neste campo podem ser inseridas frases (escritos ou transcritos) da } \\
\text { língua-base (oriundos ou não de textos). Sugestão: estabelecer um } \\
\text { padrão para a escrita ou transcrição desses enunciados, a fim de } \\
\text { manter certa uniformidade na apresentação dos dados; se a língua } \\
\text { possuir uma ortografia, dar preferência a ela; ou optar por uma forma } \\
\text { fonológica que atenda às necessidades do Projeto. }\end{array}$ \\
\hline Segmentação & $\begin{array}{l}\text { Trata-se de retomar o enunciado-base do campo anterior e dividi-lo } \\
\text { em partes menores, que possam ser analisadas segundo a orientação } \\
\text { teórica do Projeto. }\end{array}$ \\
\hline Morfologia & $\begin{array}{l}\text { Campo situado imediatamente abaixo de cada campo de segmentação } \\
\text { do enunciado-base, no qual pode ser inserida uma análise } \\
\text { morfológica, segundo a orientação teórica do Projeto. }\end{array}$ \\
\hline Forma Literal & $\begin{array}{l}\text { Campo para registrar a tradução literal do enunciado-base (língua 1) } \\
\text { para a língua 2 do Projeto. }\end{array}$ \\
\hline Glosa Língua 2 & $\begin{array}{l}\text { Campo em que se pode introduzir uma segunda tradução do } \\
\text { enunciado-base para a língua } 2 \text { do Projeto. Esta tradução, mais livre, } \\
\text { pode ser mais adequada à estrutura da língua 2. }\end{array}$ \\
\hline
\end{tabular}


TABELA 52 - ABA 2: INFORMAÇÕES COMPLEMENTARES

\begin{tabular}{ll}
\hline CAMPO & DESCRIÇÃo \\
\hline Relacionado a & $\begin{array}{l}\text { Este campo possui como valor padrão o nome do primeiro PDL } \\
\text { cadastrado na Base Projeto. Assim, se não houver outro projeto em } \\
\text { execução, este valor não deve ser modificado. }\end{array}$ \\
\hline Do Corpus & $\begin{array}{l}\text { O enunciado-base pode ser relacionado a um arquivo já cadastrado na } \\
\text { Base Corpus do Projeto. Seleciono na lista suspensa a referência de } \\
\text { arquivo correspondente. }\end{array}$ \\
\hline Do Texto & $\begin{array}{l}\text { O enunciado-base pode ser relacionado a um texto já cadastrado na } \\
\text { Base Texto do Projeto. Seleciono na lista suspensa a referência de } \\
\text { arquivo correspondente. }\end{array}$ \\
\hline Arquivos relacionados & $\begin{array}{l}\text { Permite a seleção de referências de Arquivos previamente } \\
\text { cadastrados na base de dados do Programa Línguas (Ver os botões } \\
\text { Pesquisadores e Arquivos). }\end{array}$ \\
\hline Anotação & $\begin{array}{l}\text { Espaço para anotações relacionadas ao enunciado-base cadastrado } \\
\text { nesta base. }\end{array}$ \\
\hline
\end{tabular}

\subsection{Base Comparação de Itens (línguas diferentes)}

Esta base de dados recebe itens lexicais de diferentes línguas para fins de comparação com itens lexicais da língua-base armazenados no PDL. Clico sobre o ícone referente à Comparação de Itens Lexicais (línguas diferentes) para acessar a área de cadastramento.

FIGURA 49 - JANELA DA BASE DE COMPARAÇÃO DE ITENS LEXICAIS

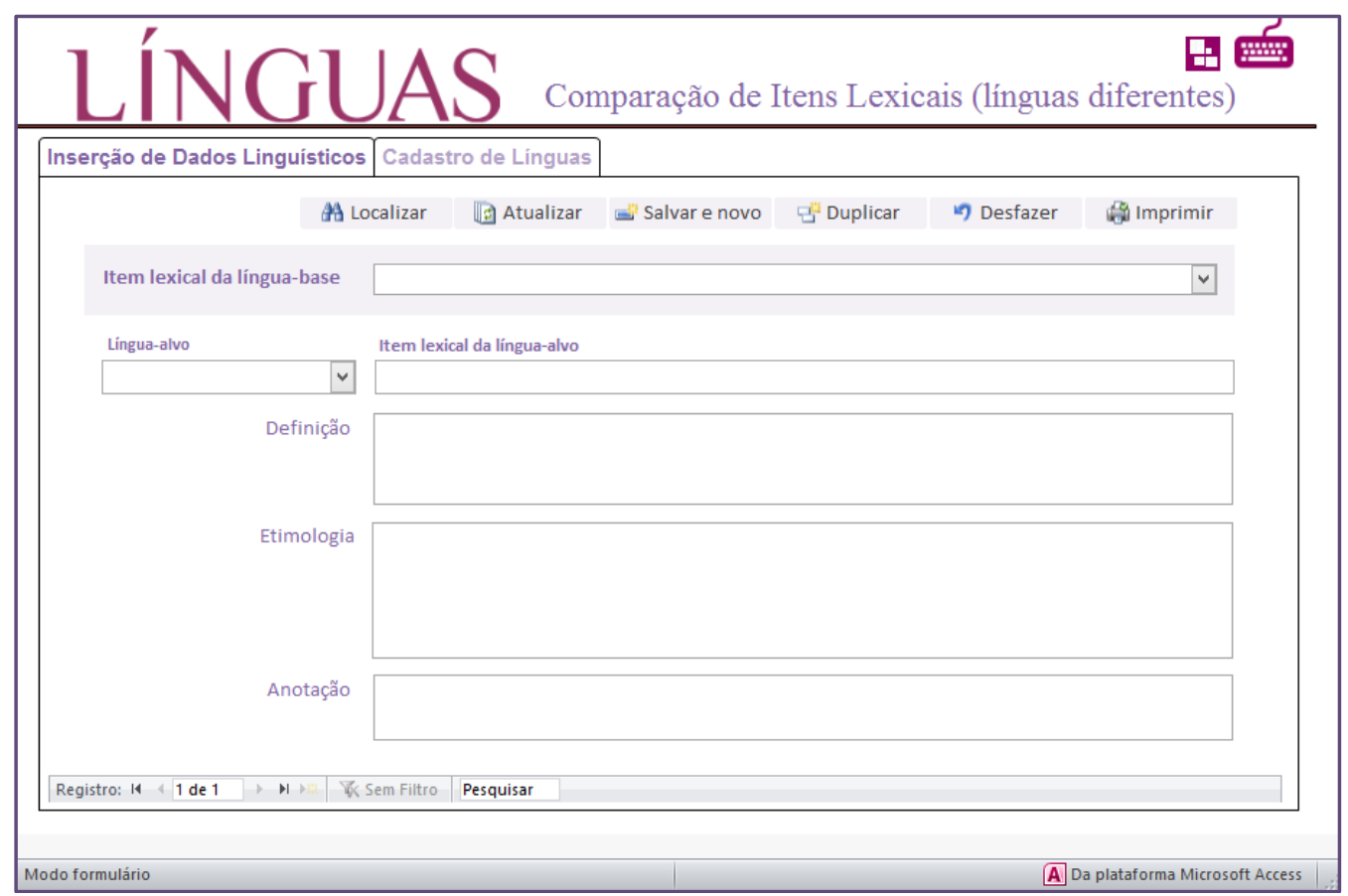

Esta base contém duas abas inter-relacionadas para cadastramento de textos. 
TABELA 53 - ABA 1: INSERÇÃO DE DADOS LINGUÍSTICOS

\begin{tabular}{ll}
\hline CAMPO & DESCRIÇÃo \\
\hline Item lexical da língua-base & $\begin{array}{l}\text { Lista suspensa que permite a seleção de um item lexical cadastrado } \\
\text { na Base Léxico e que servirá de base na comparação com os itens } \\
\text { lexicais de outras línguas. }\end{array}$ \\
\hline Língua-alvo & $\begin{array}{l}\text { Ao cadastrar as línguas para comparação, elas ficam disponíveis } \\
\text { neste campo. Seleciono a língua correspondente ao item lexical que } \\
\text { será cadastrado no próximo campo. }\end{array}$ \\
\hline Item lexical da língua-alvo & Campo para registro do item lexical da língua-alvo da comparação. \\
\hline Definição & $\begin{array}{l}\text { Registro a definição referente ao item lexical da língua-alvo da } \\
\text { comparação. Nota: Essa definição, por padrão, deve ser a mesma } \\
\text { encontrada no corpus da língua-alvo. }\end{array}$ \\
\hline Etimologia & $\begin{array}{l}\text { Registro a etimologia do item lexical da língua-alvo da comparação. } \\
\text { Nota: Essa etimologia, por padrão, deve ser a mesma encontrada no } \\
\text { corpus da língua-alvo. }\end{array}$ \\
\hline Anotação & $\begin{array}{l}\text { Campo para anotaçães relacionadas ao item lexical da língua-alvo da } \\
\text { comparação }\end{array}$ \\
\hline
\end{tabular}

TABELA 54 - ABA 2: CADASTRO DE LÍNGUAS

\begin{tabular}{ll}
\hline CAMPO & DESCRIÇÃO \\
\hline Língua para Comparação & $\begin{array}{l}\text { Formulário de vários itens para cadastro das línguas que serão } \\
\text { comparadas. Ao inserir neste campo o nome de uma língua a ser } \\
\text { cadastrada, imediatamente um novo campo de cadastro será criado. } \\
\text { Por padrão do sistema, a primeira língua desta lista é a língua-base } \\
\text { cadastrada na Base Projeto. }\end{array}$ \\
\hline $\begin{array}{l}\text { Anotação linguístico- } \\
\text { antropológica }\end{array}$ & $\begin{array}{l}\text { Para cada nova língua para comparação cadastrada, é possível } \\
\text { registrar informaçôes linguístico-antropológicas relacionadas a ela. }\end{array}$ \\
\hline
\end{tabular}

\subsection{Base Comparação de Itens (mesma língua)}

Muitas vezes, um item lexical da língua-base cadastrado na Base Léxico pode já ter sido registrado em outra(s) base(s) de dados. Assim, é possível pôr esse item lexical lado a lado com outros itens.

Esse recurso pode ser útil para fins de comparação linguística, pois, o mesmo item lexical, armazenado em diferentes bases de dados, de uma mesma época ou de épocas diferentes, pode apresentar variações de forma e/ou de sentido. A percepção dessas diferenças (e até mesmo das semelhanças) pode ser útil em alguma medida tanto para o estabelecimento de grafias, quanto, p.ex., para a observação de variações linguísticas ou de diferenças nas orientações teóricas para transcrição fonética de dados. 
FIGURA 50 - JANELA DE COMPARAÇÃO DE ITENS LEXICAIS

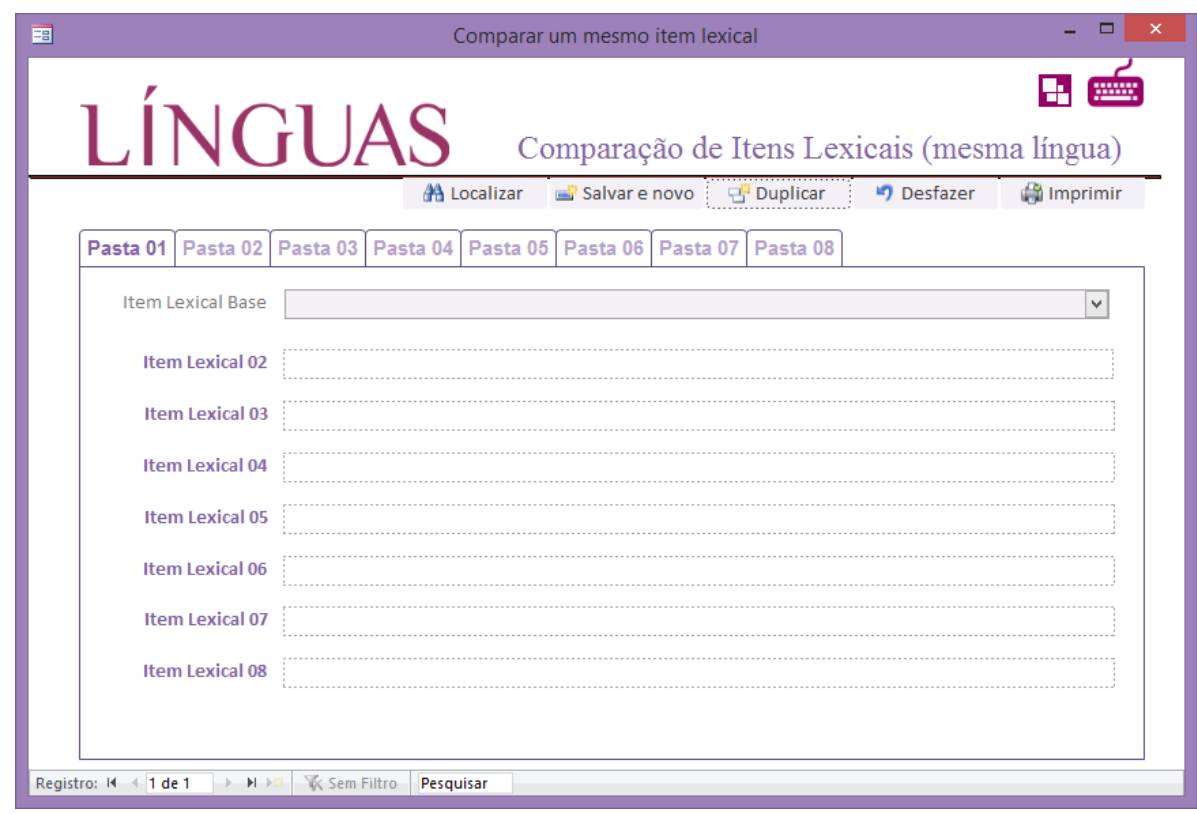

TABELA 55 - CAMPOS DA BASE DE COMPARAÇÃO DE ITENS LEXICAIS ${ }^{151}$

\begin{tabular}{|c|c|}
\hline Campo & Descrição \\
\hline $\begin{array}{l}\text { Pasta } 01 \\
\text { [Item Lexical Base] }\end{array}$ & $\begin{array}{l}\text { Lista suspensa que permite a seleção de um item lexical cadastrado } \\
\text { na Base Léxico e que servirá de base de comparação para os itens } \\
\text { lexicais cadastrados em outras bases. }\end{array}$ \\
\hline $\begin{array}{l}\text { Pastas } 02 \text { a } 08 \\
\text { [Itens Lexicais de } 2 \text { a } 8 \text { ] }\end{array}$ & $\begin{array}{l}\text { À medida que os itens lexicais de } 2 \text { a } 8 \text { forem sendo cadastrados nas } \\
\text { respectivas pastas, eles serão automaticamente transferidos para a aba } \\
\text { inicial. Nota: Também é possível preencher primeiro o item lexical } \\
\text { na primeira aba e ele será transferido para as respectivas pastas. }\end{array}$ \\
\hline $\begin{array}{l}\text { Pastas } 02 \text { a } 08 \\
\text { [Itens Lexicais de } 2 \text { a } 8 \text { ] }\end{array}$ & $\begin{array}{l}\text { Os itens lexicais identificados com os números de } 2 \text { a } 8 \text { representam } \\
\text { as formas equivalentes do item lexical da língua-base cadastrado na } \\
\text { Base Léxico. Nota: Ao cadastrar esse novos itens (de } 2 \text { a } 8 \text { ), buscar } \\
\text { manter a correspondência em relação ao corpus, p.ex., ao informar o } \\
\text { Item Lexical A como pertencente ao Corpus X, reservar os próximos } \\
\text { cadastros de itens A para dados do mesmo corpus X. }\end{array}$ \\
\hline $\begin{array}{l}\text { Pastas } 02 \text { a } 08 \\
\text { [Som] }\end{array}$ & $\begin{array}{l}\text { Campo para registro da forma fonética ou fonológica do item lexical } \\
(2 \text { a } 8 \text { ). Sugestão: Se possível, definir qual será a forma do registro } \\
\text { sonoro, se pela fonética, ou se pela fonologia. }\end{array}$ \\
\hline $\begin{array}{l}\text { Pastas } 02 \text { a } 08 \\
\text { [Corpus] }\end{array}$ & Associar o item lexical a um corpus. \\
\hline $\begin{array}{l}\text { Pastas } 02 \text { a } 08 \\
\text { [Definição] }\end{array}$ & $\begin{array}{l}\text { Campo para registrar as definições originais atribuídas ao item lexical } \\
\text { cadastrado no campo anterior. }\end{array}$ \\
\hline $\begin{array}{l}\text { Pastas } 02 \text { a } 08 \\
\text { [Anotação] }\end{array}$ & Espaço para anotações relacionadas a cada item lexical. \\
\hline
\end{tabular}

${ }^{151}$ Ao inserir os dados na Base Léxico, os itens lexicais ficam disponíveis automaticamente nestas bases. 


\subsection{Base Enciclopédia}

Esta base de dados recebe informações culturais do PDL principal para organizálas na forma de uma enciclopédia. Clico sobre o ícone [ill referente à Base Enciclopédia para acessar a área de cadastramento.

FIGURA 51 - JANELA DA BASE DE DADOS ENCICLOPÉDICOS

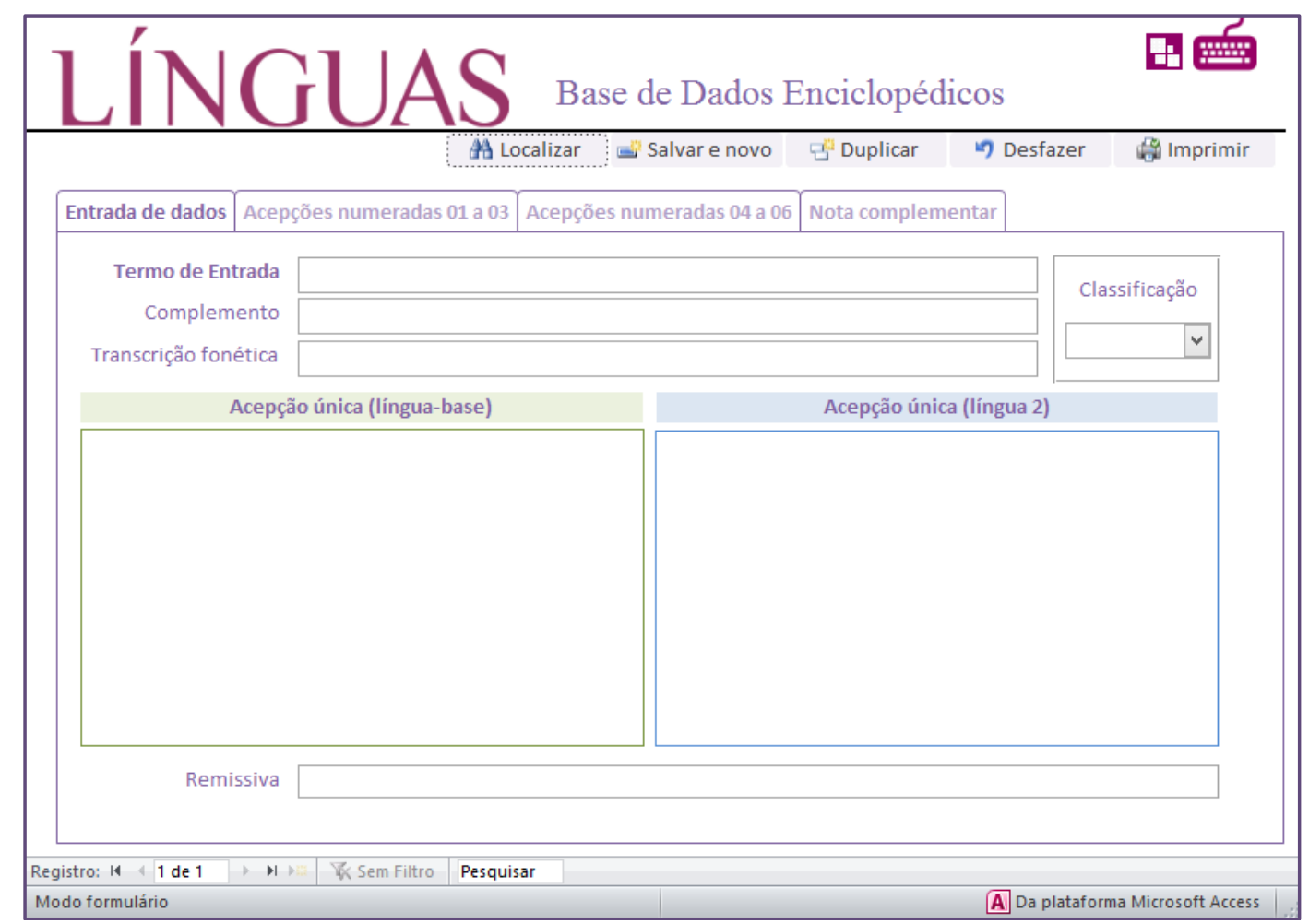

Esta base possui quatro abas, com duas possibilidades de inserção de dados, ou por acepção única ou por acepções numeradas, conforme apresentadas a seguir:

TABELA 56 - ABA 1: ENTRADA DE DADOS

\begin{tabular}{ll}
\hline CAMPO & DESCRIÇÃo \\
\hline Termo de entrada & $\begin{array}{l}\text { Área para inserção do lema na língua-base definida para a } \\
\text { composição da enciclopédia }\end{array}$ \\
\hline Complemento & $\begin{array}{l}\text { Informação complementar ao termo de entrada, se necessário. Essa } \\
\text { informação pode constar no resultado final da enciclopédia. }\end{array}$ \\
\hline Transcrição fonética & $\begin{array}{l}\text { O termo de entrada pode ter a sua forma fonética ou fonológica } \\
\text { inserida no corpo do verbete da enciclopédia. }\end{array}$ \\
\hline Classificação & $\begin{array}{l}\text { Especificação da categoria gramatical do termo de entrada, se } \\
\text { necessário. }\end{array}$ \\
\hline Acepção única (língua-base) & $\begin{array}{l}\text { A primeira possibilidade de apresentação do conteúdo dos verbetes } \\
\text { (ou artigos) da enciclopédia sob a forma de acepção única, que, } \\
\text { neste espaço, corresponde ao conteúdo da língua-base. }\end{array}$ \\
\hline Acepção única (língua 2) & Espaço para inserção do conteúdo em língua 2, ou seja, língua \\
\hline
\end{tabular}


correspondente ou equivalente (tradução, por exemplo) à da acepção da língua-base.

No verbete há a possibilidade de estabelecer uma rede de relações por meio de formas remissivas.

TABELA 57 - ABAS 2 E 3: ACEPÇÕES NUMERADAS

\begin{tabular}{ll}
\hline CAMPO & DESCRIÇÃo \\
\hline Termo de Entrada & $\begin{array}{l}\text { Reprodução automática do termo de entrada. Nada a ser preenchido } \\
\text { neste campo. }\end{array}$ \\
\hline Acepção 01-06 & $\begin{array}{l}\text { A segunda possibilidade de apresentação do conteúdo dos verbetes } \\
\text { (ou artigos) da enciclopédia sob a forma de acepção numeradas (que } \\
\text { podem corresponder a diferentes conteúdos por item), que, neste } \\
\text { espaço, corresponde ao conteúdo da língua-base. }\end{array}$ \\
\hline Marca de uso & $\begin{array}{l}\text { Nessa área pode-se especificar a área de conhecimento a que cada } \\
\text { conteúdo está relacionado. }\end{array}$ \\
\hline Acepção 01-06 Trad. & $\begin{array}{l}\text { Espaço para inserção do conteúdo em língua 2, ou seja, língua } \\
\text { correspondente ou equivalente (tradução, por exemplo) à da acepção } \\
\text { da língua-base. }\end{array}$ \\
\hline
\end{tabular}

TABELA 58 - ABA 4: NOTA COMPLEMENTAR

\begin{tabular}{ll}
\hline CAMPO & DESCRIÇão \\
\hline Termo de Entrada & $\begin{array}{l}\text { Reprodução automática do termo de entrada. Nada a ser preenchido } \\
\text { neste campo. }\end{array}$ \\
\hline Título & $\begin{array}{l}\text { Como o verbete pode ter um texto complementar ao conteúdo da } \\
\text { acepção, esse texto pode receber um título a ser inserido neste campo. }\end{array}$ \\
\hline Comentário complementar & Campo para inserção do texto complementar na língua-base. \\
\hline $\begin{array}{l}\text { Comentário complementar } \\
\text { Trad. }\end{array}$ & Campo para inserção do texto complementar traduzido na língua 2. \\
\hline $\begin{array}{l}\text { Referência de arquivo- } \\
\text { imagem }\end{array}$ & $\begin{array}{l}\text { Se o documento possuir imagem associada, apresentar neste campo a } \\
\text { referência a cada uma delas. }\end{array}$ \\
\hline Anotação & Campo para anotações relacionadas ao conteúdo do verbete. \\
\hline
\end{tabular}

\subsubsection{Anotações para o PDL}

Além do cadastramento do conjunto de dados linguísticos na Área de Dados, o programa Línguas possui uma área reservada para o registro de Anotações de conteúdos relevantes a um PDL.

Essa área apresenta seis bases: Anotações, Histórico, Tarefas, Bibliografia, Citação e Notas Linguísticas. 


\section{FIGURA 52 - JANELA DA ÁREA DE ANOTAÇÕES DO PROGRAMA LÍNGUAS}

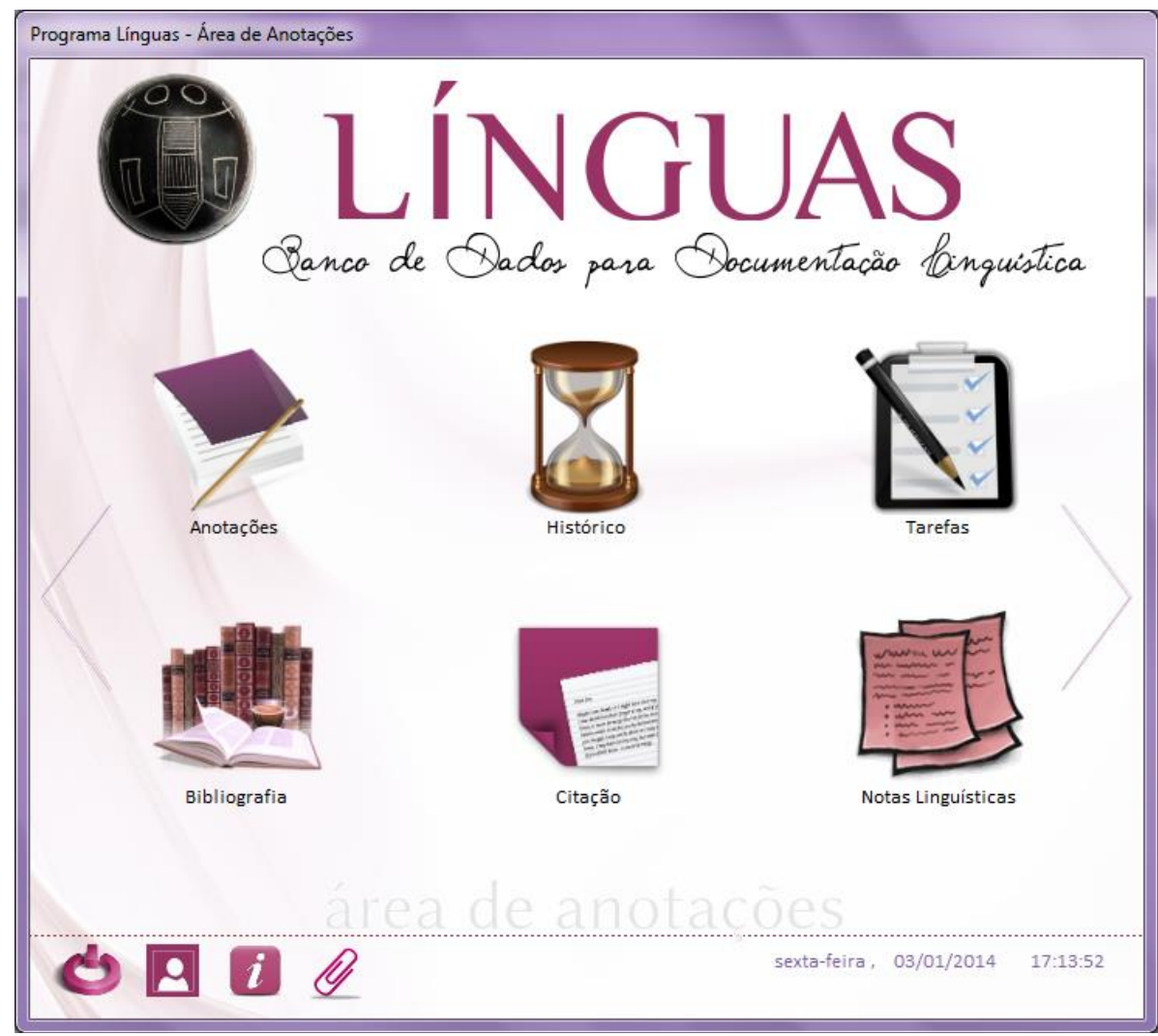

Nessa área, há seis ícones, correspondentes a bases para inserção dos dados linguísticos do PDL. A seguir, apresento cada uma dessas bases.

\subsection{Base Anotações}

Esta base de dados recebe anotações relacionadas, de modo geral, a um PDL.

Clico sobre o ícone referente a Anotações para acessar a área de cadastramento.

TABELA 59 - ABA INSERIR ANOTAÇÕES

\begin{tabular}{ll}
\hline CAMPO & DESCRIÇÃO \\
\hline Relacionado a & Este campo possui como valor padrão o nome do primeiro Projeto de \\
& $\begin{array}{l}\text { Documentação Linguística cadastrado na Base Projeto. Assim, se não } \\
\text { houver outro projeto em execução, este valor não deve ser } \\
\text { modificado. }\end{array}$ \\
\hline
\end{tabular}

Ao clicar sobre este campo, é mostrado o ícone ${ }^{\#}$, clico sobre ele

Data da anotação para abrir um calendário. Seleciono uma data para registrar o início do preenchimento da ficha. Por padrão, a data destacada é sempre a data atual.

\begin{tabular}{ll}
\hline Título & Atribuo um título à anotação. \\
\hline Anotação & Campo para inserir o texto da anotação. \\
\hline Arquivos relacionados & $\begin{array}{l}\text { Campo para selecionar um ou mais arquivos relacionados } \\
\text { diretamente à anotação. Esses arquivos devem ser previamente }\end{array}$ \\
\hline
\end{tabular}


registrados na Base Arquivos.

Lista suspensa com nomes de usuários cadastrados no programa

Anotação feita por Línguas e que podem ser informados como responsáveis pela anotação.

FIGURA 53 - JANELA DA BASE DE ANOTAÇÕES

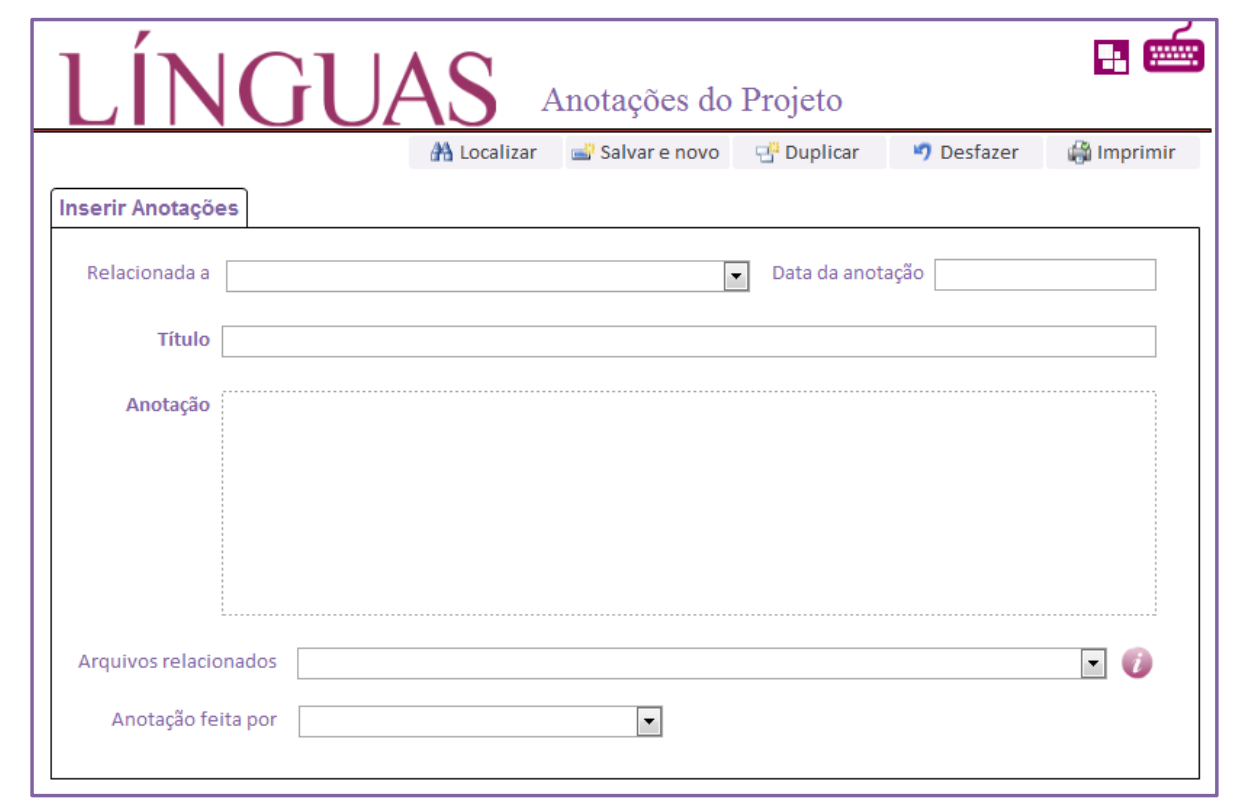

\subsection{Base Histórico}

Esta base de dados recebe anotações específicas relacionadas ao histórico do PDL.

Clico sobre o ícone referente ao Histórico para acessar a área de cadastramento.

TABELA 60 - ABA INSERIR INFORMAÇÕES PARA O HISTÓRICO DO PROJETO

\begin{tabular}{ll}
\hline CAMPO & DESCRIÇÃo \\
\hline Relacionado a & $\begin{array}{l}\text { Este campo possui como valor padrão o nome do primeiro Projeto de } \\
\text { Documentação Linguística cadastrado na Base Projeto. Assim, se não } \\
\text { houver outro projeto em execução, este valor não deve ser } \\
\text { modificado. }\end{array}$ \\
\hline Ao clicar sobre este campo, é mostrado o ícone & $\begin{array}{l}\text { para abrir um clico sobre ele } \\
\text { para abario. Seleciono uma data para registrar o início } \\
\text { do preenchimento da ficha. Por padrão, a data destacada é sempre a } \\
\text { data atual. }\end{array}$ \\
\hline Título & Atribuo um título à informação sobre o histórico do Projeto. \\
\hline Informação para o & $\begin{array}{l}\text { Campo para inserir o texto da informação para o histórico do Projeto. } \\
\text { Sugestão: Para obter um histórico com informaçães mais precisas } \\
\text { acerca do desenvolvimento do PDL, sugerimos que cada etapa do } \\
\text { trabalho seja registrada em detalhes. }\end{array}$ \\
\hline Arquivos relacionados & $\begin{array}{l}\text { Campo para selecionar um ou mais arquivos relacionados } \\
\text { diretamente à anotação. Esses arquivos devem ser previamente } \\
\text { registrados na Base Arquivos. }\end{array}$ \\
\hline
\end{tabular}


FIGURA 54 - JANELA DA BASE DE HISTÓRICO

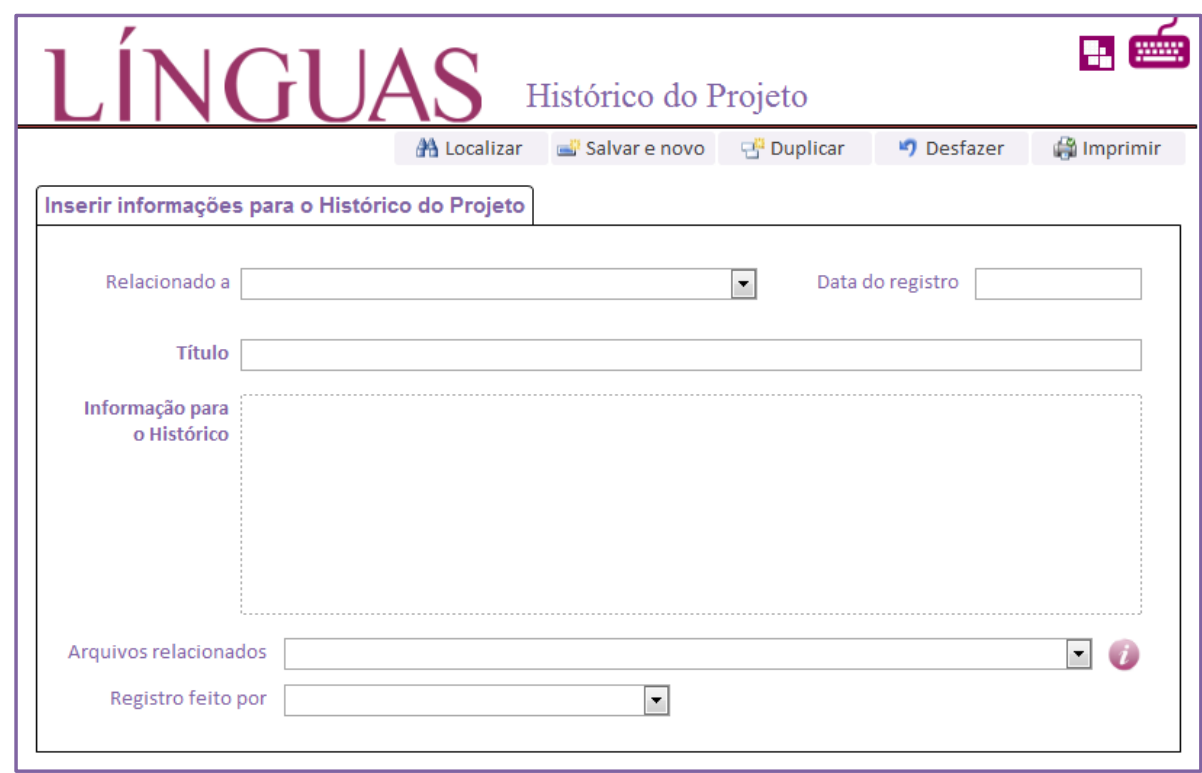

\subsection{Base Tarefas}

Esta base de dados recebe anotações específicas relacionadas a tarefas do PDL.

Clico sobre o ícone $\Delta$ referente a Tarefas para acessar a área de cadastramento.

TABELA 61 - ABA REGISTRO DE TAREFAS

\begin{tabular}{ll}
\hline CAMPO & DESCRIÇÃO \\
\hline Relacionado a & $\begin{array}{l}\text { Este campo possui como valor padrão o nome do primeiro Projeto de } \\
\text { Documentação Linguística cadastrado na Base Projeto. }\end{array}$ \\
\hline \multirow{3}{*}{ Status } & $\begin{array}{l}\text { Lista suspensa (editável) com opções para definir um status para a } \\
\text { tarefa cadastrada. O programa Línguas contém, a título de sugestão, } \\
\text { uma lista predefinida com } 5 \text { opções, são elas: Não iniciada, Em } \\
\text { andamento, Concluída, Adiada, Aguardando. }\end{array}$
\end{tabular}

Lista suspensa (editável) com opções para definir qual a prioridade da

Prioridade tarefa cadastrada. O programa Línguas contém, a título de sugestão, uma lista predefinida com 3 opções, são elas: (1) Alta, (2) Normal, (3) Baixa.

Título Atribuo um título à tarefa relacionada ao PDL.

Descrição da tarefa Campo para inserir a descrição completa da tarefa a ser executada.

Percentual executado À medida que a tarefa for sendo concluída, é possível registrar essa progressão sob a forma numérica de percentual. 


\begin{tabular}{|c|c|}
\hline Data de início/conclusão & $\begin{array}{l}\text { Ao clicar sobre algum destes campos, é mostrado o ícone }{ }^{-1} \text {, clico } \\
\text { sobre ele para abrir um calendário. Seleciono uma data para registrar } \\
\text { a data início/conclusão da tarefa. Por padrão, a data destacada é } \\
\text { sempre a data atual. }\end{array}$ \\
\hline Arquivos relacionados & $\begin{array}{l}\text { Campo para selecionar um ou mais arquivos relacionados } \\
\text { diretamente à anotação. Esses arquivos devem ser previamente } \\
\text { registrados na Base Arquivos. }\end{array}$ \\
\hline Responsável pela tarefa & $\begin{array}{l}\text { Campo para informar quem são as pessoas responsáveis pela } \\
\text { execução da tarefa cadastrada. }\end{array}$ \\
\hline Tarefa registrada por & $\begin{array}{l}\text { Lista suspensa com nomes de usuários cadastrados no programa } \\
\text { Línguas e que podem ser informados como responsáveis pelo } \\
\text { registro. }\end{array}$ \\
\hline
\end{tabular}

FIGURA 55 - JANELA DA BASE DE TAREFAS

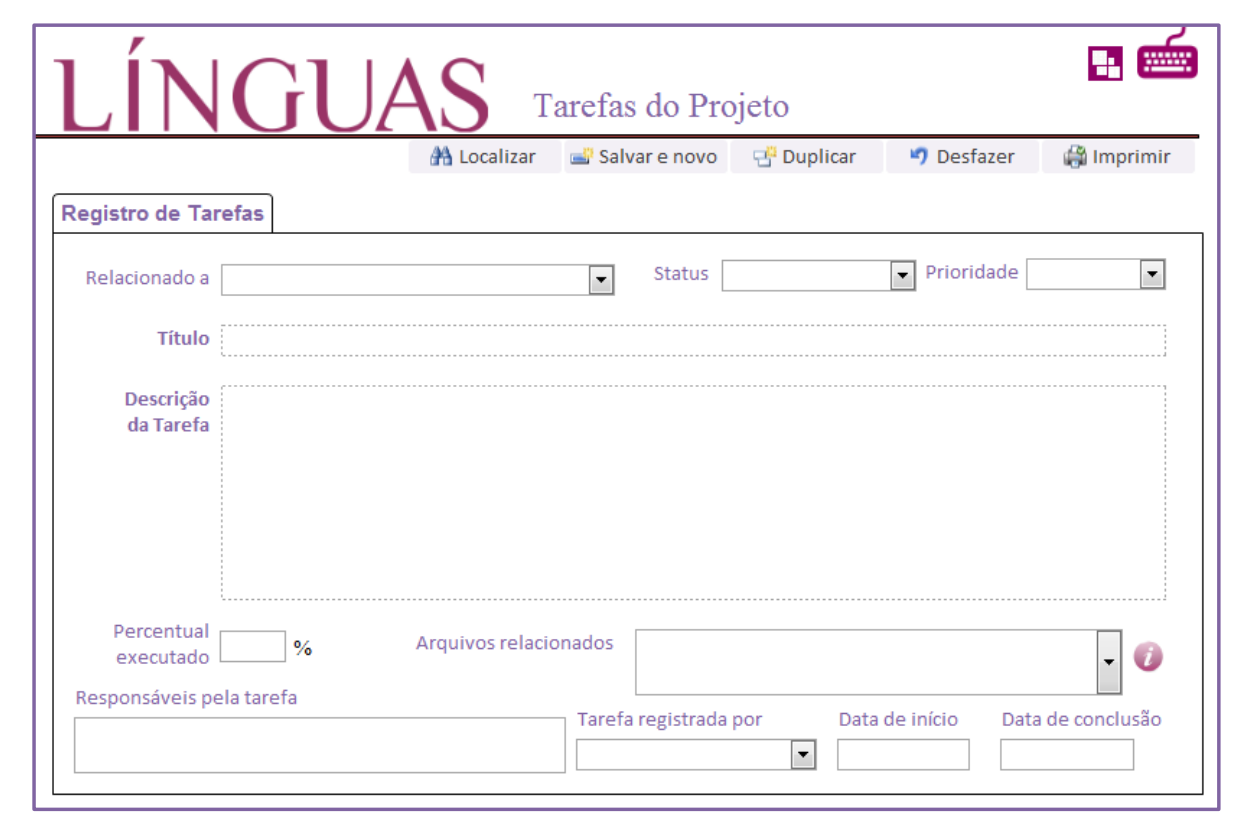

\subsection{Base Bibliografia}

É nesta base de dados que se pode fazer o registro de toda a bibliografia utilizada no PDL. Clico sobre o ícone referente à Base Bibliografia para acessar a área de cadastramento. O preenchimento dessa Base pode ser útil para reunir informações sobre toda a bibliografia existente acerca da(s) língua(s) documentada(s) no PDL.

O material bibliográfico reunido nesta base pode ser exportado de diversas maneiras: como lista organizada em ordem alfabética, como fichas completas com todos os dados ou como lista de tópicos classificados de acordo com a classificação CDU (cf. subseção Bibliografia e Citação na Área de Materiais). 
FIGURA 56 - JANELA DA BASE DE BIBLIOGRAFIA

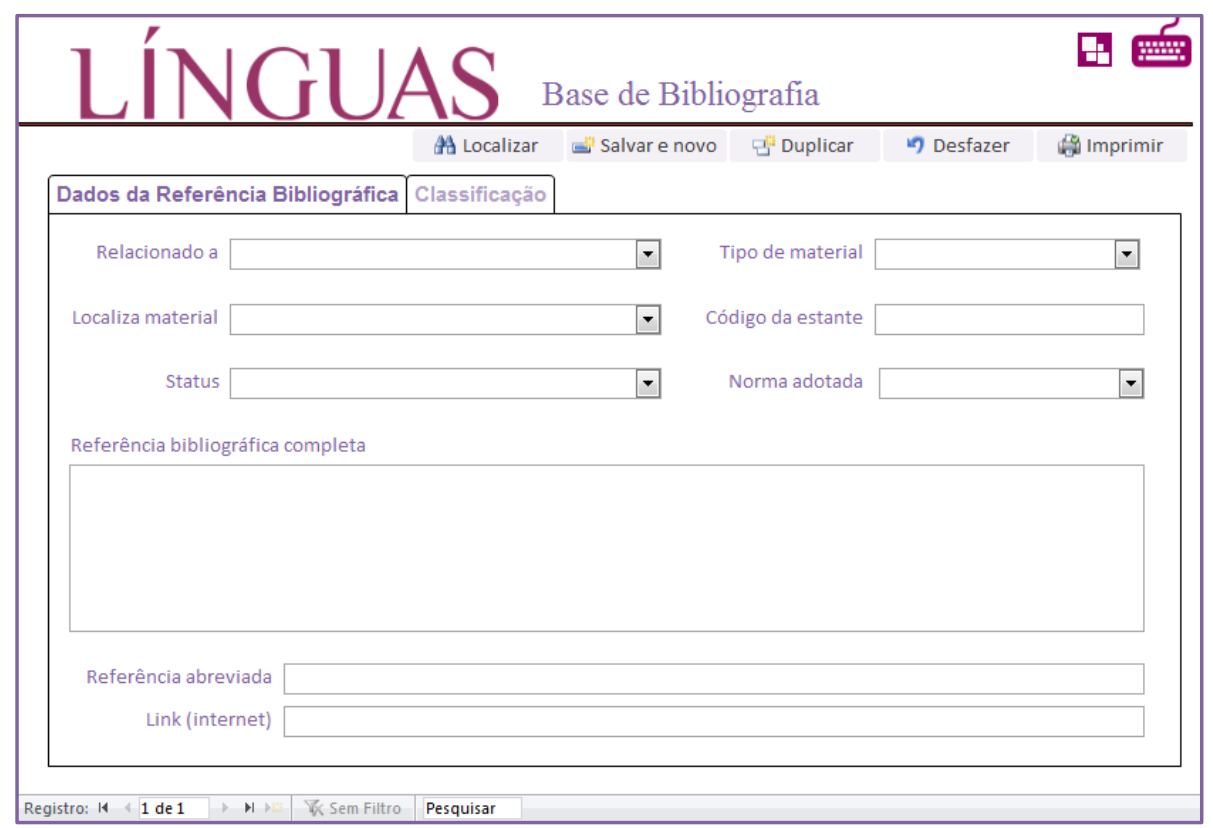

Esta base contém duas abas inter-relacionadas para cadastramento da bibliografia.

TABELA 62 - ABA 1: DADOS DA REFERÊNCIA BIBLIOGRÁFICA

\begin{tabular}{ll}
\hline CAMPO & DESCRIÇão \\
\hline Relacionado a & $\begin{array}{l}\text { Este campo possui como valor padrão o nome do primeiro PDL } \\
\text { cadastrado na Base Projeto. }\end{array}$ \\
\hline Tipo de material & $\begin{array}{l}\text { Lista suspensa com opções para definir o tipo de material da } \\
\text { bibliografia. O Programa apresenta uma lista (editável) predefinida } \\
\text { com os seguintes materiais: livro, revista, jornal, boletim, tese, } \\
\text { dissertação, monografia, folheto, site. }\end{array}$ \\
\hline Localiza material & $\begin{array}{l}\text { Lista suspensa (editável) com opções para definir em que acervo o } \\
\text { material referenciado está disponível. O programa Línguas contém, a } \\
\text { título de sugestão, uma lista predefinida com opções, são elas: Acervo } \\
\text { pessoal de..., Biblioteca Digital Domínio Público. }\end{array}$ \\
\hline Código da estante & $\begin{array}{l}\text { Se possível, indicar o código da estante (em se tratando de uma } \\
\text { biblioteca) onde o material se localiza. }\end{array}$ \\
\hline Status & $\begin{array}{l}\text { Lista suspensa (editável) com opções para definir, em relação ao } \\
\text { PDL, o status (ou relevância) do material bibliográfico. O programa } \\
\text { Línguas contém, a título de sugestão, uma lista predefinida com } \\
\text { opções, são elas: Referência obrigatória, referência optativa, apenas } \\
\text { consulta. }\end{array}$ \\
\hline $\begin{array}{l}\text { Para referenciar qualquer material bibliográfico, é possível adotar } \\
\text { uma das muitas normas existentes no mundo. O Programa apresenta } \\
\text { uma lista (editável) predefinida com as seguintes opções: ABNT } \\
\text { (Brasil), APA (EUA), Chicago (EUA), ISO (Internacional) e } \\
\text { Vancouver (Canadá). }\end{array}$ \\
\hline Norma adotada
\end{tabular}




\begin{tabular}{ll}
\hline Referência abreviada & $\begin{array}{l}\text { Refere-se à mesma referência bibliográfica do campo anterior, } \\
\text { porém, apresentada de modo abreviado. }\end{array}$ \\
\hline Link (internet) & $\begin{array}{l}\text { Se existir um link na internet para o material referenciado, inserir, } \\
\text { neste campo, o endereço eletrônico. }\end{array}$ \\
\hline
\end{tabular}

TABELA 63 - ABA 2: CLASSIFICAÇÃO

\begin{tabular}{|c|c|}
\hline САМРO & DESCRIÇÃO \\
\hline Código CDU & $\begin{array}{l}\text { O código de Classificação Decimal Universal (CDU) representa um } \\
\text { padrão internacional de classificação de documentos por assunto, } \\
\text { que, no caso deste Programa, permite a apresentação das referências } \\
\text { bibliográficas com um arranjo diferente do da ordem alfabética. }\end{array}$ \\
\hline Domínio CDU & $\begin{array}{l}\text { Relacionado ao Código CDU há uma descrição do domínio, que pode } \\
\text { ser inserida neste campo. }\end{array}$ \\
\hline ISBN & $\begin{array}{l}\text { Se o material referenciado possuir ISBN (International Standard } \\
\text { Book Number, ou, em Português, Número Padrão Internacional de } \\
\text { Livro), é possível informá-lo neste campo. }\end{array}$ \\
\hline ISSN & $\begin{array}{l}\text { Se o material referenciado possuir ISSN (International Standard } \\
\text { Serial Number, ou, em Português, Número Internacional } \\
\text { Normalizado para Publicações Seriadas), é possível informá-lo neste } \\
\text { campo. }\end{array}$ \\
\hline Anotação & $\begin{array}{l}\text { Insiro anotações referentes ao material bibliográfico que está sendo } \\
\text { referenciado nesta base. }\end{array}$ \\
\hline
\end{tabular}

Para consultar uma lista com todos os códigos CDU e seus respectivos domínios, clico no ícone 8 .

FIGURA 57 - JANELA PARA CONSULTA DE CDU

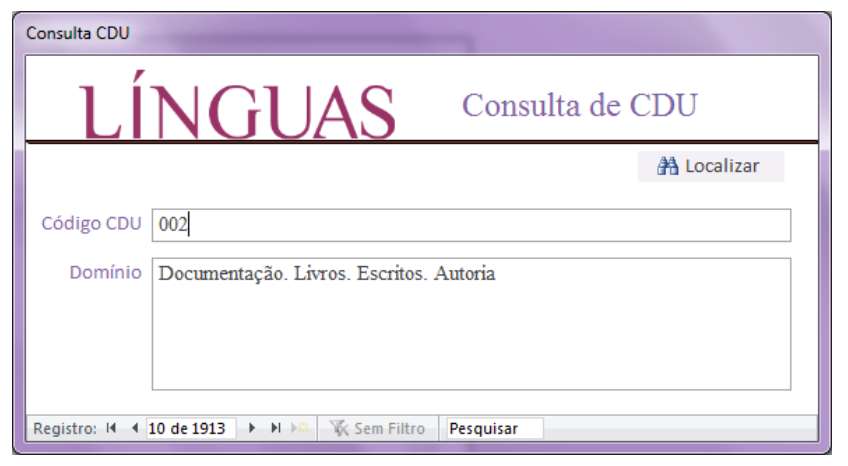

\subsection{Base Citação}

É nesta base de dados que trechos de material bibliográfico úteis para o PDL podem ser armazenados. Clico sobre o ícone $F$ referente à Base Citação para acessar a área de cadastramento. 
O preenchimento dessa base pode ser útil para a produção de artigos científicos ou de trabalhos acadêmicos relacionados à(s) língua(s) documentada(s) em um PDL.

FIGURA 58 - JANELA DA BASE DE CITAÇÃO

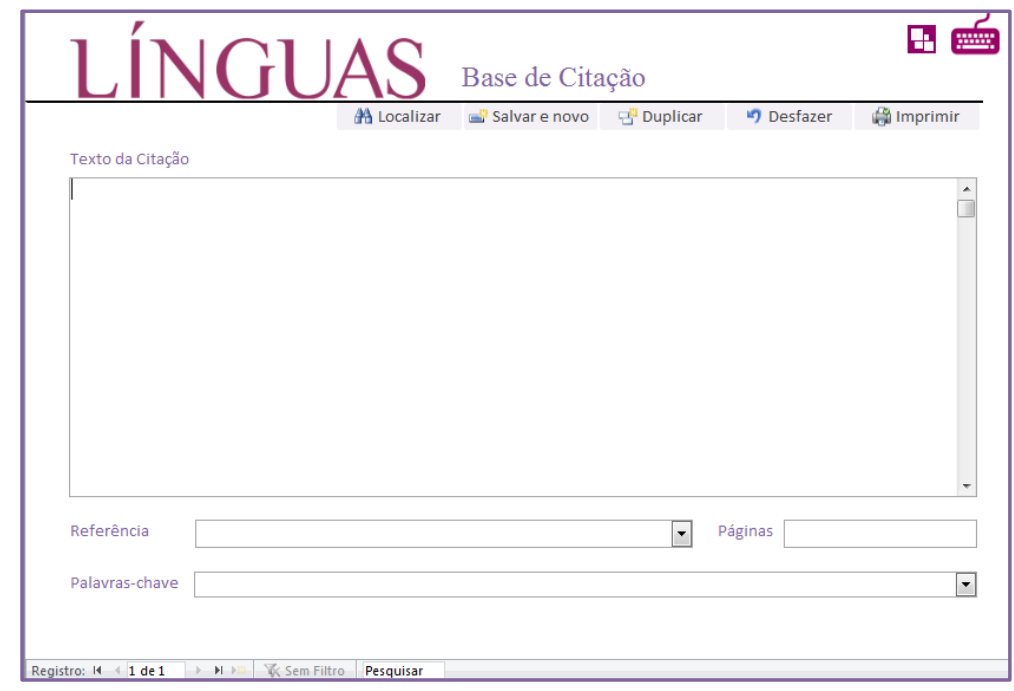

TABELA 64 - CAMPOS DA BASE DE CITAÇÃO

\begin{tabular}{ll}
\hline CAMPO & DESCRIÇÃO \\
\hline Texto da Citação & $\begin{array}{l}\text { Campo para inserir os fragmentos de texto que poderão servir de } \\
\text { material para citação. }\end{array}$ \\
\hline Referência & $\begin{array}{l}\text { Lista suspensa com todas as referências bibliográficas já } \\
\text { cadastradas na Base Bibliografia. Selecionar a referência que } \\
\text { contenha o fragmento de texto inserido. }\end{array}$ \\
\hline Páginas & $\begin{array}{l}\text { Informar o(s) número(s) da(s) páginas correspondentes ao } \\
\text { fragmento de texto inserido. }\end{array}$ \\
\hline Palavras-chave & $\begin{array}{l}\text { Seleciono uma ou mais palavras-chave relacionadas ao conteúdo } \\
\text { do fragmento de texto inserido. }\end{array}$ \\
\hline
\end{tabular}

As palavras-chave servem como marcadores que auxiliam no acesso rápido a uma informação da base de dados. Clico no ícone para abrir a janela Cadastramento de palavras-chave e cadastro quantas palavras-chave quiser.

FIGURA 59 - JANELA DE CADASTRAMENTO DE PALAVRAS-CHAVE

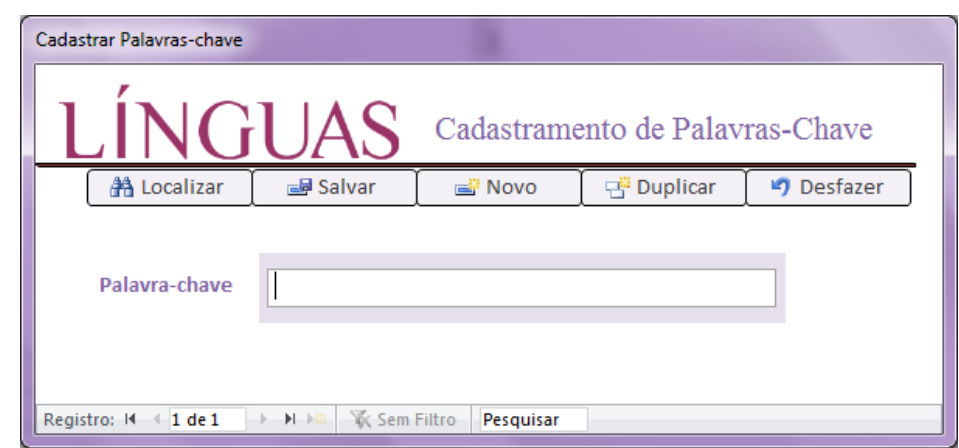




\subsection{Base Notas Linguísticas}

Esta base de dados recebe anotações linguísticas relacionadas aos dados do PDL.

Clico sobre o ícone referente à base Notas Linguísticas para acessar a área de cadastramento. $^{152}$

FIGURA 60 - JANELA DA BASE DE NOTAS LINGUÍSTICAS

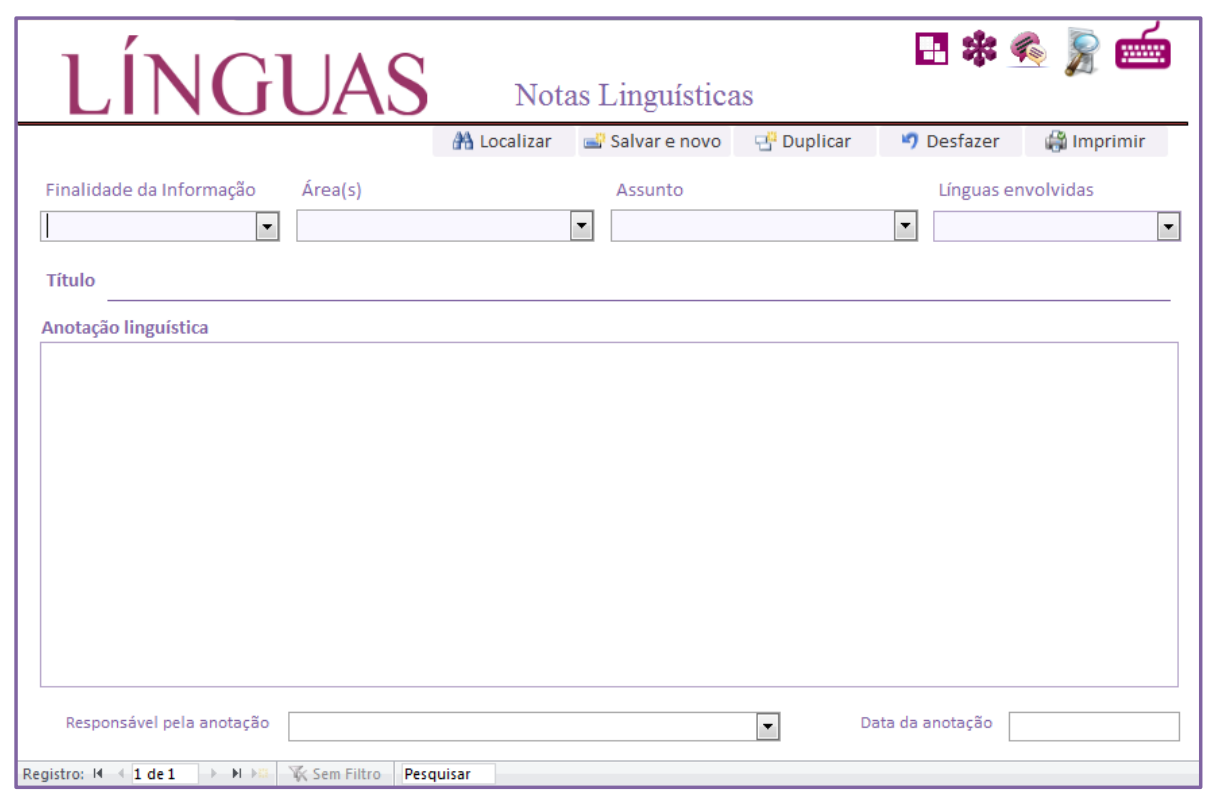

TABELA 65 - CAMPOS DA BASE DE NOTAS LINGUÍSTICAS

\begin{tabular}{|c|c|}
\hline САМРО & DESCRIÇÃO \\
\hline Finalidade da Informação & $\begin{array}{l}\text { Lista suspensa (editável) com opções para definir a finalidade da } \\
\text { informação a ser inserida. O programa contém, a título de sugestão, } \\
\text { uma lista predefinida com } 3 \text { opções, são elas: Descrição linguística, } \\
\text { Material didático, Orientação teórica. Observo que, quando há, ao } \\
\text { lado das opções da lista, botões de seleção, é possível selecionar mais } \\
\text { de uma opção num mesmo campo. }\end{array}$ \\
\hline Área(s) & $\begin{array}{l}\text { Lista suspensa (editável) com opções para definir a(s) área(s) da } \\
\text { informação a ser inserida. O programa Línguas contém, a título de } \\
\text { sugestão, uma lista predefinida com } 17 \text { opções, são elas: Análise do } \\
\text { Discurso, Documentação Linguística, Estilística, Filologia, Fonética, } \\
\text { Fonologia, Lexicologia, Linguística Histórica, Linguística Textual, } \\
\text { Morfologia, Morfossintaxe, Ortografia, Pragmática, Semântica, } \\
\text { Semiótica, Sintaxe, Sociolinguística e Dialetologia. }\end{array}$ \\
\hline Assunto & $\begin{array}{l}\text { Lista suspensa (editável) para inserção de termos que possam ser } \\
\text { usados como assunto(s) da informação a ser inserida. Não há } \\
\text { sugestões de assunto neste campo. }\end{array}$ \\
\hline Línguas envolvidas & $\begin{array}{l}\text { Lista suspensa que contém a língua-base do Projeto, além de todas as } \\
\text { línguas já cadastradas na base Comparação de Itens Lexicais (línguas } \\
\text { diferentes). }\end{array}$ \\
\hline
\end{tabular}

${ }^{152}$ Um formulário para Anotações Linguística está inserido na Base Projeto. Por se tratar da mesma fonte de dados, os dados inseridos em um dos formulários é visível no outro. 


\begin{tabular}{ll}
\hline Título & Espaço para inserir um título à sua nota linguística. \\
\hline & Campo para inserção de texto (longo) que sirva como anotação \\
& linguística. Nota: Não há uma ordem predefinida para inserção dessas \\
& notas, assim, a qualquer momento elas podem ser inseridas e \\
Anotação Linguística & alteradas de acordo com as necessidades dos usuários do sistema. \\
& Sugestão: Esse campo pode registrar toda orientação teórica \\
& relacionada à ortografia, à fonologia e à morfossintaxe do PDL. \\
\hline
\end{tabular}

\subsubsection{Acessórios do Programa Línguas}

Essa área, que contém atalhos para formulários e aplicativos usados em diferentes bases do programa Línguas, não possui link direto da Área de Trabalho. Por isso, o acesso só pode ser feito a partir da Área de Anotações (seta à direita) ou da Área de Edição (seta à esquerda).

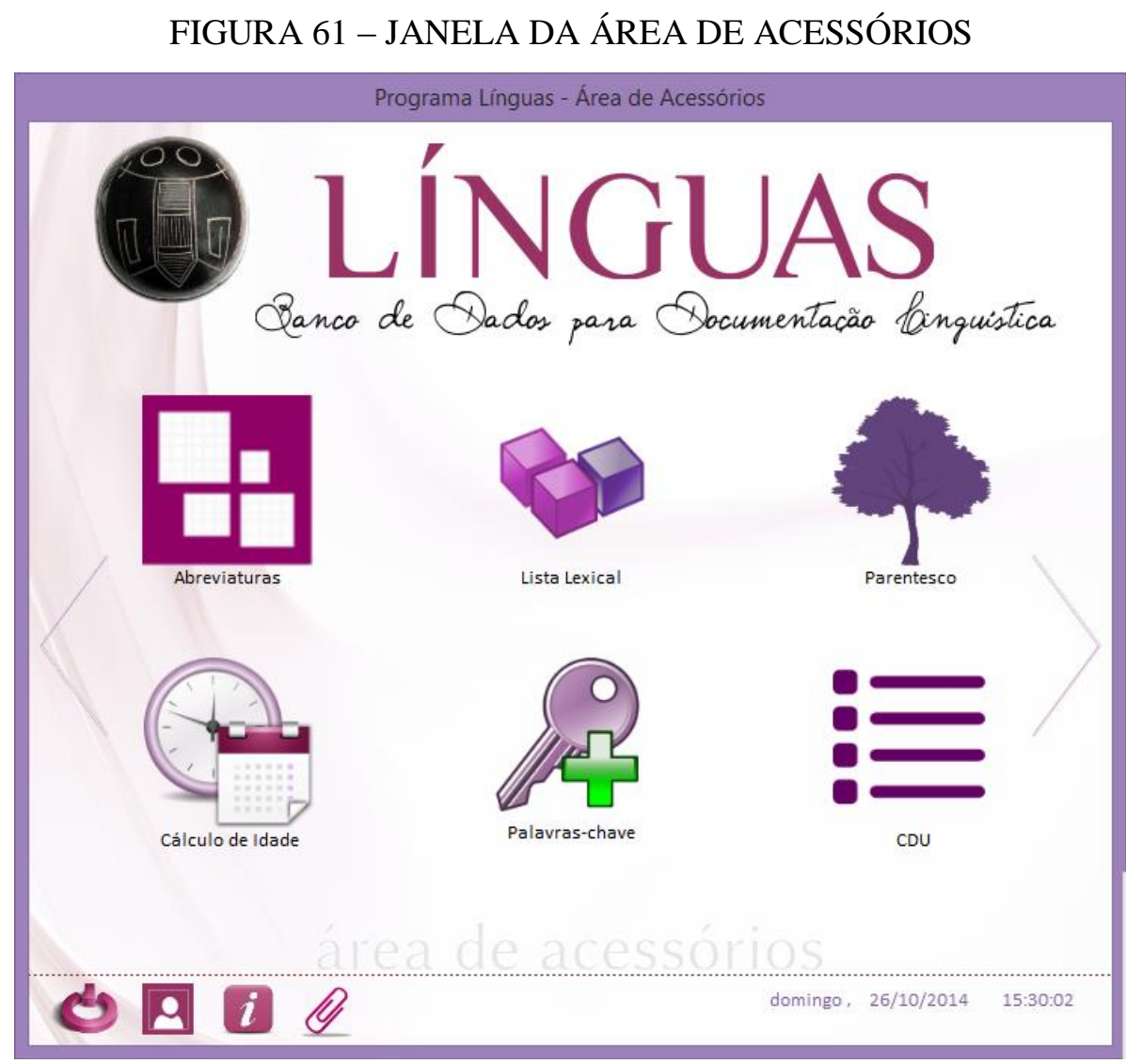

Os seis ícones servem para abrir os seguintes materiais:

- Abreviaturas, formulário disponível também na maior parte dos formulários do programa Línguas.

- Lista Lexical, formulário disponível também na Base Léxico.

- Parentesco, aplicativo disponível também na Base Fonte. 
- Cálculo de idade, aplicativo disponível também na Base Fonte.

- Palavras-chave, formulário de cadastramento disponível somente aqui.

- $\quad C D U$, formulário disponível também na Base Bibliografia.

Relacionar Item Lexical a uma lista predefinida

É possível relacionar o item lexical cadastrado a uma lista de itens lexicais predefinidos. Essa lista (editável), baseada na proposta de Kaufman, Berlin e Rodrigues (1985) ${ }^{153}$ pode ser usada como critério para apresentação dos itens lexicais da Base Léxico em, p.ex., materiais lexicográficos.

FIGURA 62 - JANELA DA LISTA LEXICAL

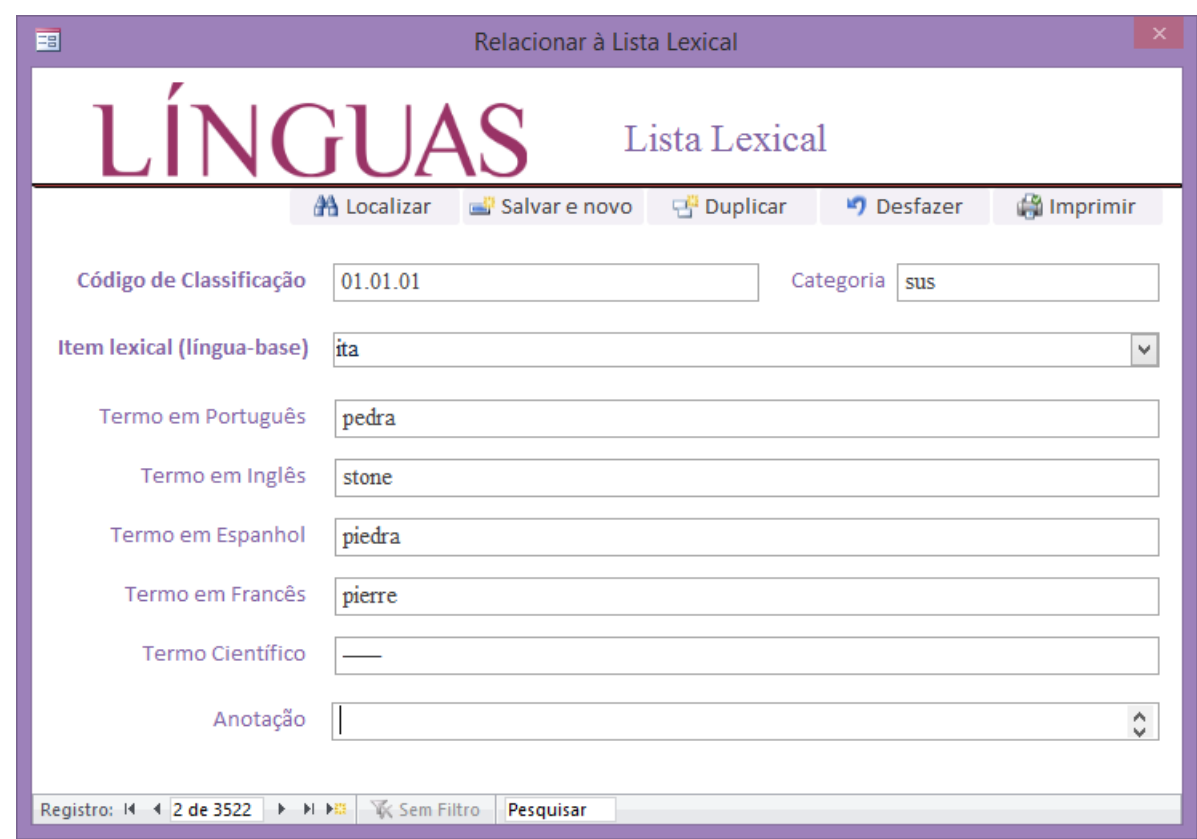

TABELA 66 - CAMPOS DA LISTA LEXICAL

\begin{tabular}{ll}
\hline CAMPO & DESCRIÇÃO \\
\hline & Código composto por até 4 grupos de dígitos atribuídos a cada item \\
da lista lexical. Os dois primeiros números à esquerda representam a \\
Código de Classificação \\
$\begin{array}{l}\text { categoria maior. O segundo par representa uma subcategorização. O } \\
\text { terceiro par, uma especificação dentro das duas categorias } \\
\text { precedentes. O último grupo representa formas variantes. }\end{array}$
\end{tabular}

Categoria Campo em que se apresenta a categoria gramatical do item lexical.

${ }^{153}$ BERLIN, Brent; KAUFMAN, Terrence. Questionnaire. In: Projeto de Documentação das Línguas Indígenas da América do Sul. [South American Indian Languages Documentation Project (SAILDP)]. Pittsburgh \& Berkeley: University of Pittsburgh \& University of California, 1985. Mimeo. Documento revisado a partir de: BERLIN, Brent; KAUFMAN, Terrence; CARSON, Neusa; RODRIGUES, Aryon. Diagnostic vocabulary. In: . Projeto de Documentação das Línguas Indígenas da América do Sul. [South American Indian Languages Documentation Project (SAILDP)]. Berkeley: University of California; Campinas, SP: Unicamp, 1986. Mimeo. 


\begin{tabular}{ll}
\hline Item lexical (língua-base) & $\begin{array}{l}\text { Lista suspensa preenchida à medida que os dados da Base Léxico } \\
\text { forem sendo inseridos. Seleciono o item lexical da língua-base } \\
\text { correspondente a um item já cadastrado da lista lexical. }\end{array}$ \\
\hline Termo em Português & $\begin{array}{l}\text { Item lexical, em Português, já cadastrado na lista lexical. Esse item } \\
\text { pode ser modificado conforme a proposta do PDL. }\end{array}$ \\
\hline Termo em Inglês & $\begin{array}{l}\text { Item lexical, em Inglês, já cadastrado na lista lexical. Esse item pode } \\
\text { ser modificado conforme a proposta do PDL. }\end{array}$ \\
\hline Termo em Espanhol & $\begin{array}{l}\text { Item lexical, em Espanhol, já cadastrado na lista lexical. Esse item } \\
\text { pode ser modificado conforme a proposta do PDL. }\end{array}$ \\
\hline Termo em Francês & $\begin{array}{l}\text { Item lexical, em Francês, já cadastrado na lista lexical. Esse item } \\
\text { pode ser modificado conforme a proposta do PDL. }\end{array}$ \\
\hline Termo Científico & $\begin{array}{l}\text { No caso de termos relacionados a animais e plantas, é possível } \\
\text { associar um termo científico (geralmente escrito em Latim). Além } \\
\text { disso, podem ser associados símbolos físicos, matemáticos ou } \\
\text { químicos, p.ex. }\end{array}$ \\
\hline Anotação & $\begin{array}{l}\text { Campo para anotações relacionadas ao item lexical registrado nesta } \\
\text { lista. }\end{array}$ \\
\hline
\end{tabular}

\section{Registros de Parentesco}

É nesta área que se podem ser feitos os registros de parentesco das pessoas fontes do conhecimento cadastradas no PDL. Clico sobre o ícone referente à Base Parentesco para acessar a área de cadastramento. ${ }^{154}$

FIGURA 63 - JANELA DE REGISTRO DE PARENTESCO

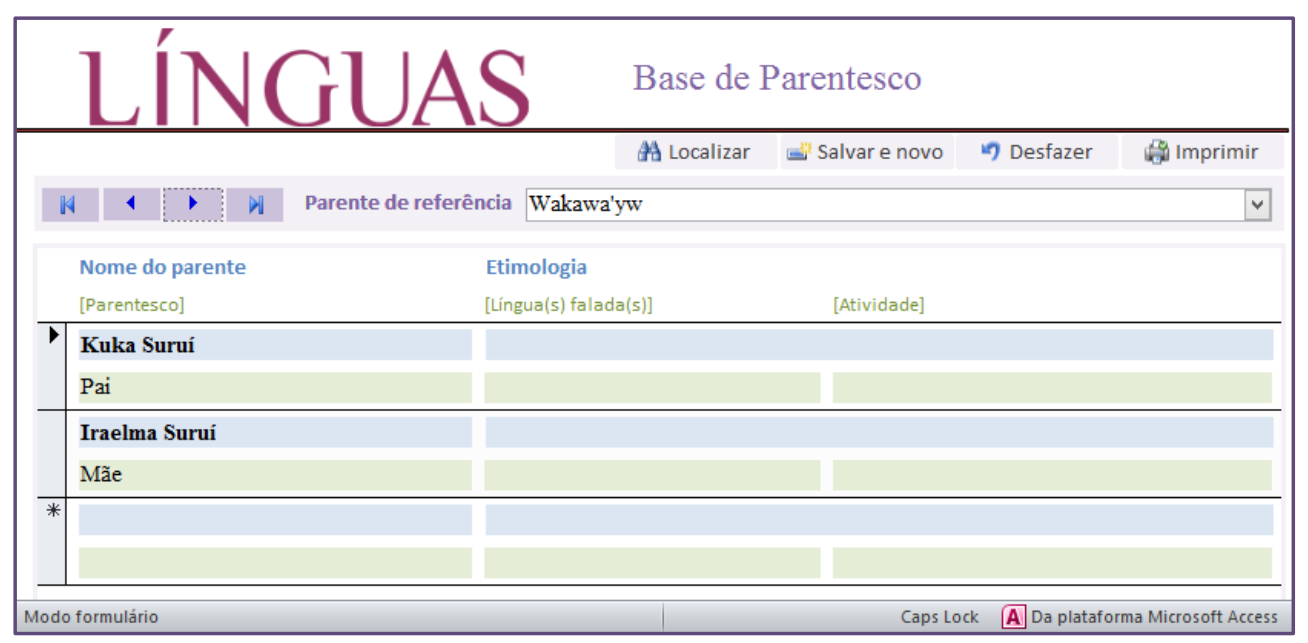

Construído em uma base de vários itens, o formulário Parentesco está associado à pessoa fonte de conhecimento e é composto pelos seguintes campos:

\footnotetext{
${ }^{154}$ Para preencher este formulário, é necessário, antes, ter cadastrado, pelo menos, uma pessoa, que servirá como referência do parentesco. Apesar de ser apresentado como uma base de dados, as informações de parentesco são tratadas, até esta versão do programa, como um item acessório, pois ainda há necessidade de aprofundar a pesquisa em termos de parentesco, a fim de verificar a maneira mais adequada de apresentar essas informações.
} 
TABELA 67 - CAMPOS DO REGISTRO DE PARENTESCO

\begin{tabular}{|c|c|}
\hline САMPO & DESCRIÇÃO \\
\hline Parente de referência & $\begin{array}{l}\text { Trata-se de uma lista suspensa contendo todos os nomes de pessoas fonte } \\
\text { do conhecimento já cadastradas na Base Fonte. O preenchimento deste } \\
\text { campo é obrigatório, pois é com ele que se relacionarão todos os itens } \\
\text { inseridos nos campos abaixo. }\end{array}$ \\
\hline • & $\begin{array}{l}\text { Botões para Recuar e Avançar a visualização dos registros. Ao selecionar } \\
\text { um nome da lista acima, ele será associado aos parentes cadastrados na } \\
\text { respectiva lista, por isso, utilize apenas as setas para navegar de um } \\
\text { registro a outro. }\end{array}$ \\
\hline Nome do parente & Inserir em cada linha de dados (cor azul) o nome de um parente. \\
\hline Etimologia & $\begin{array}{l}\text { Acrescentar, se possível, a etimologia do nome do parente cadastrado no } \\
\text { campo anterior. }\end{array}$ \\
\hline [Parentesco] & $\begin{array}{l}\text { Informar qual o grau de parentesco que o parente mantém com a pessoa } \\
\text { fonte de conhecimento de referência. }\end{array}$ \\
\hline [Língua(s) falada(s)] & Informar qual ou quais a(s) língua(s) falada(s) pelo parente cadastrado. \\
\hline [Atividade] & Informar qual ou quais a(s) atividade(s) desse parente. \\
\hline
\end{tabular}

\subsubsection{Edição de dados das bases}

Ao clicar em um dos três ícones da Área de Trabalho do programa Línguas, que contêm a figura de um cadeado, abre-se uma janela informando que o acesso à área solicitada é restrito. Assim, é necessário novamente selecionar o nome de um usuário e digitar a respectiva senha.
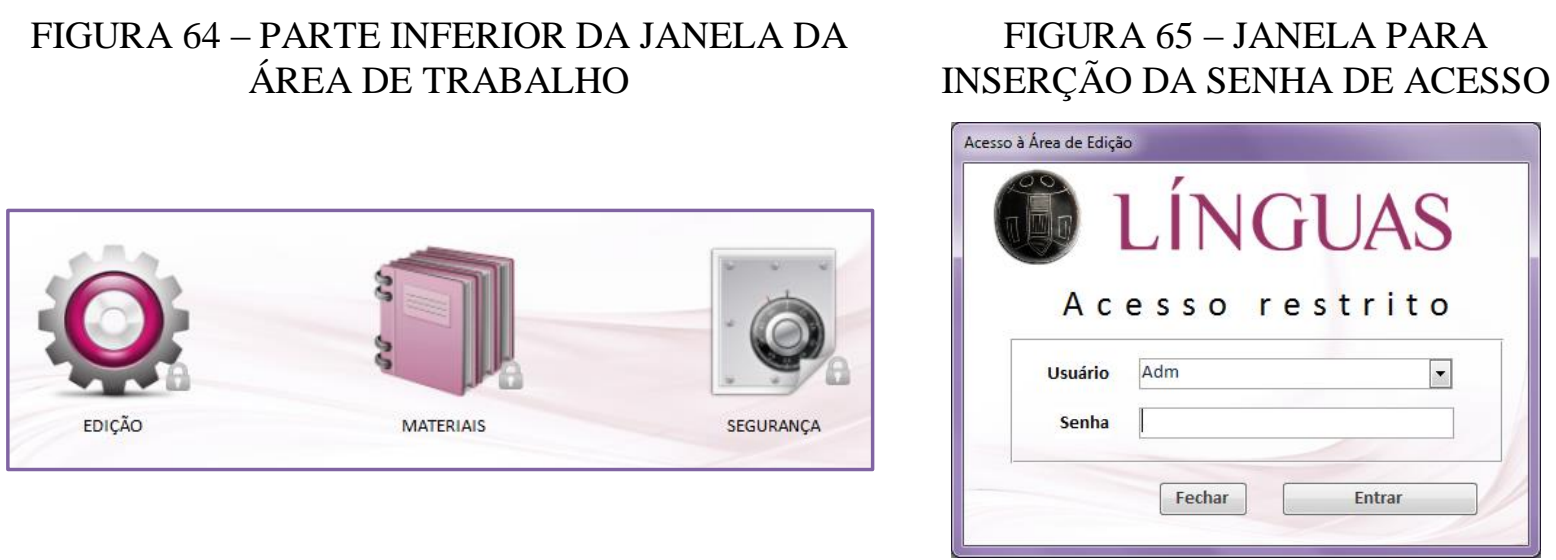

Somente usuários com o status de Administrador têm permissão para acessar as áreas restritas do programa Línguas. Se o usuário tiver permissão para acessar a área de acesso restrito, será mostrada a seguinte janela de informação. Clico em Ok para prosseguir. 


\section{FIGURA 66 - JANELA DE AVISO DE PERMISSÃO}

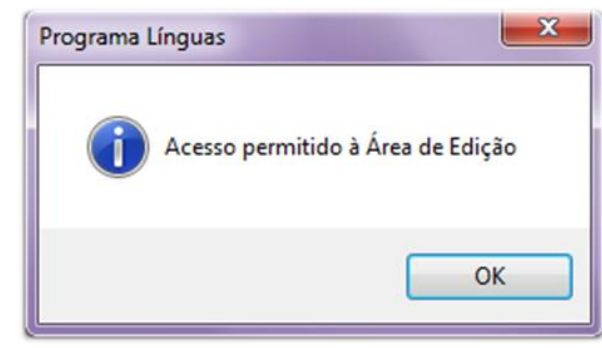

Então, abre-se a janela solicitada; neste caso, a Área de Edição.

FIGURA 67 - janela principal da área de edição

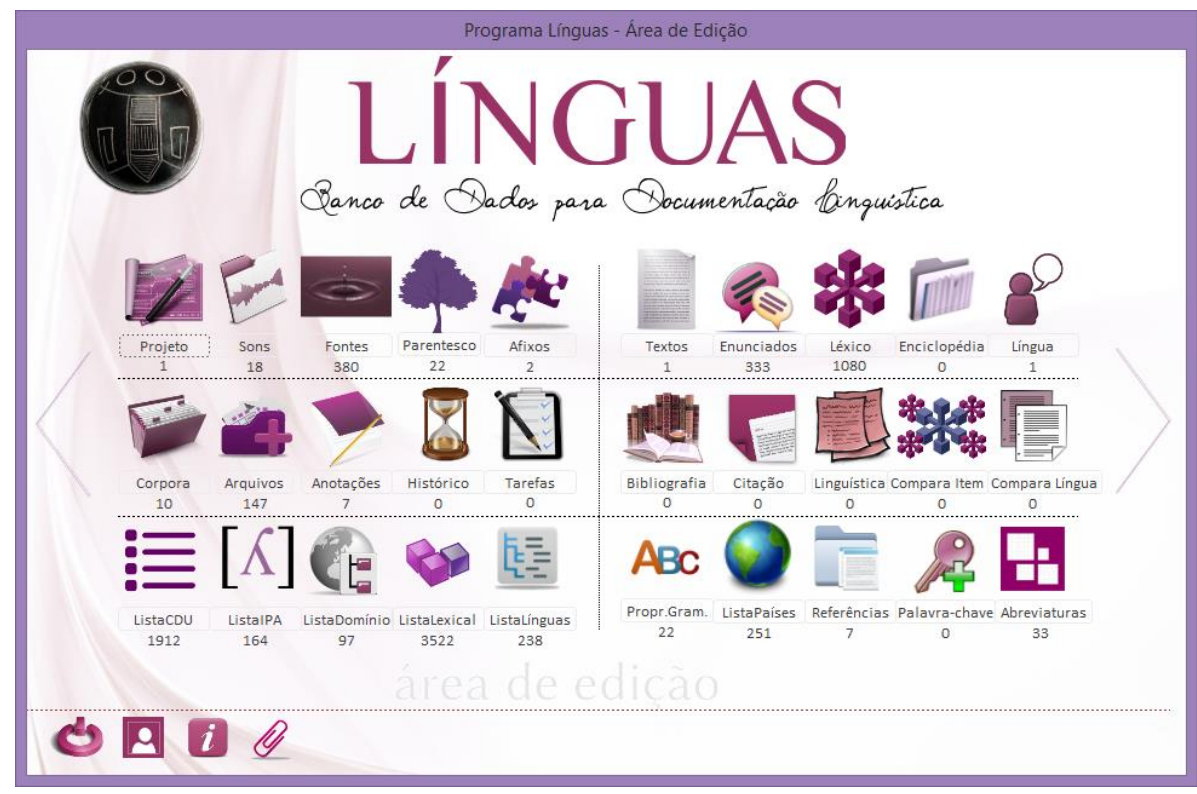

Nesta área, cada ícone, que representa uma subárea de edição diferente, é identificado com um título, algumas vezes abreviado, que identifica o conteúdo do formulário de edição. Abaixo desse título, há um número que corresponde ao total de registros que a respectiva base já contém, p.ex., ListaCDU possui 1912 registros, ao passo que Palavraschave está ainda zerado. Esses valores são atualizados automaticamente à medida que as bases vão recebendo/modificando dados.

Os 30 ícones na Área de Edição distribuem-se em seis agrupamentos, que correspondem, grosso modo, ou a bases que contém dados do próprio programa (p.ex. ListaIPA e ListaCDU) ou a bases que receberam dados de um PDL (p.ex., Textos, Enunciados, Léxico). Os grupos são:

- GRUPO 1: Projeto, Sons, Fontes, Parentesco e Afixos.

- Grupo 2: Textos, Enunciados, Léxico, Enciclopédia, Língua.

- GRUPO 3: Corpora, Arquivos, Anotações, Histórico, Tarefas. 
Na base do formulário há um campo de registro, em que são apresentados novamente botões de navegação, total de registro e campo de pesquisa rápida.

\subsection{Como pesquisar dados em um formulário de edição}

Para iniciar uma pesquisa de dados em um formulário de edição, clico sobre o botão Imprimir . Abre-se, em seguida, uma caixa de diálogo:

FIGURA 69 - CAIXA DE DIÁLOGO PARA LOCALIZAÇÃO OU SUBSTITUIÇÃO DE DADOS no programa línguas

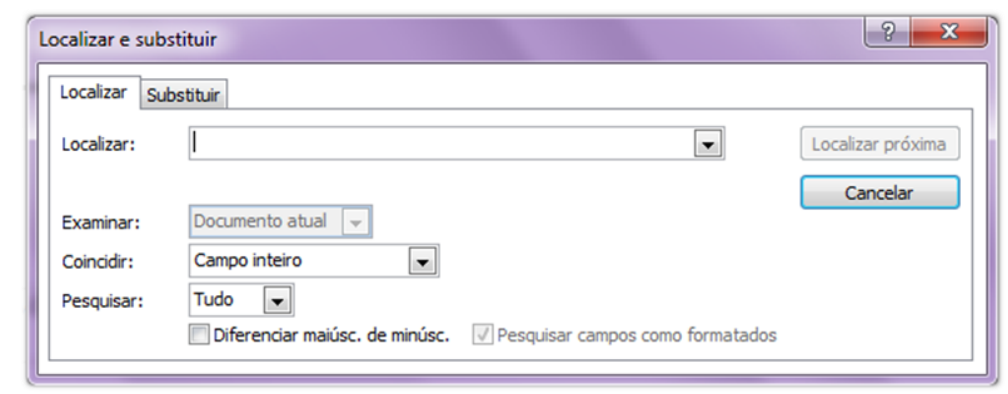

Clico no campo Localizar e digito a palavra a ser pesquisada. Em seguida, clico em Localizar próxima. Para ampliar as possibilidades da pesquisa, altere a informação do campo Coincidir de Campo inteiro para Qualquer parte do campo.

Não modifique os campos Pesquisar, que, por padrão, já pesquisa tanto registros acima quanto abaixo do local da lista. Se necessário, é possível ainda estabelecer como critério de busca a opção Diferenciar maiúsc. de minúsc.

\subsubsection{Produzindo materiais com os dados das bases}

Uma vez cadastrado um PDL e iniciada a inserção de dados linguísticos, o programa Línguas disponibiliza a função de criação de materiais.

Para acessar a Área de Materiais, à semelhança do acesso à Área de Edição, também será solicitado ao usuário que insira uma senha válida, a não ser que, utilizando as setas laterais, haja o deslocamento de uma área restrita para outra, neste caso, não é solicitada senha alguma.

Nessa área, há seis ícones, correspondentes a diferentes tipos de conteúdos dos dados linguísticos do PDL para criação de diferentes materiais: Projeto e anotações, Bibliografia e Citação, Textos e Enunciados, Enciclopédias, Comparação e Notas. A seguir, apresento cada uma dessas possibilidades. 
FIGURA 70 - JANELA DA ÁREA DE MATERIAIS

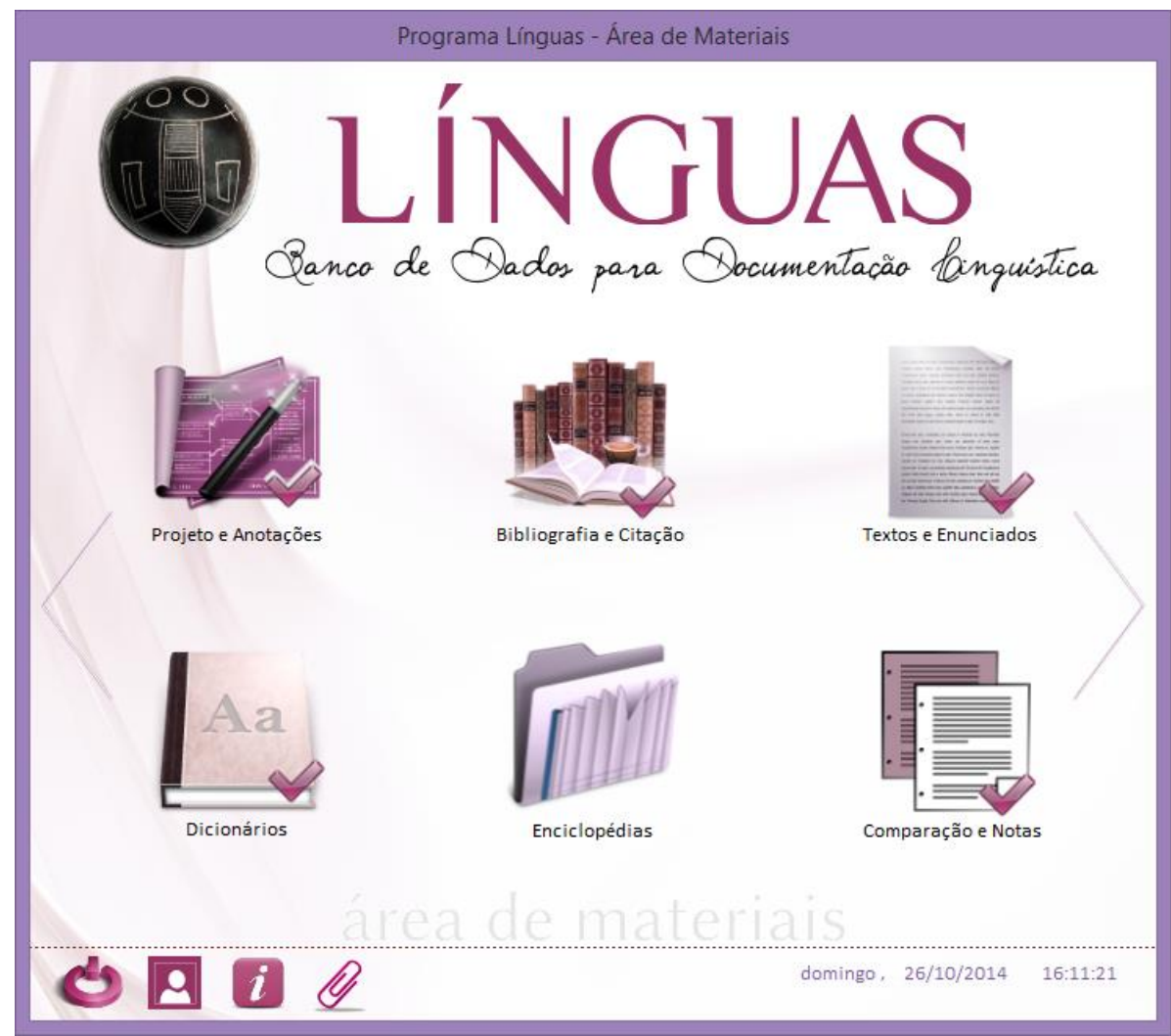

\subsection{Projeto e Anotações}

Nesta pasta podem ser gerados materiais com os dados armazenados nas bases Projeto, Som, Fonte, Arquivos, Corpus e Parentesco, Anotações, Histórico e Tarefas. Clico sobre o ícone referente à pasta Projetos e Anotações para acessar a área de criação.

Dependendo do conteúdo e da natureza dos dados, há mudanças na forma de apresentação do material produzido, p.ex., referências bibliográficas podem ser apresentadas numa lista simples, enquanto os dados lexicais podem ser organizados em um dicionário.

Cada pasta contém 8 caixas coloridas, cada uma com informações específicas para construir um material baseado nos dados das respectivas bases. As informações estão dispostas da seguinte maneira:

- No topo da caixa, há informação sobre o tipo de ordenamento dos dados na saída do material, p.ex. ordem alfabética, ordem de cadastramento.

- Ao lado da figura, o título em negrito indica a base de onde serão extraídos os dados para criação do material.

- No centro, há duas linhas de informações: a primeira indica o formato de saída do material criado, p.ex. DOC (documento do MS Word) e A4 (tamanho da página do 
documento); e a segunda, o conteúdo específico do material criado, p.ex., Dados completos (significa que todas as informações cadastradas na respectiva base estarão disponíveis no documento) ou há uma descrição de que parte do conteúdo da base estará disponível, p.ex. História das Pessoas.

- Na parte inferior, há um botão de comando que permite a construção do material descrito na caixa onde ele está situado.

Ao clicar sobre o botão construir, o programa Línguas abrirá automaticamente o programa MS Word 2010, no qual cruzará os dados da respectiva base e construirá o material solicitado.

O MS Word 2010 solicitará uma permissão de acesso, já que, para construir o material, será utilizado um banco de dados tipo SQL inserido em um documento do Word. Pressiono Sim e aguardo a conclusão do processo.

\section{FIGURA 71 - JANELA DO MICROSOFT WORD PARA PERMISSÃO DO USO DE BANCO DE} DADOS EXTERNO

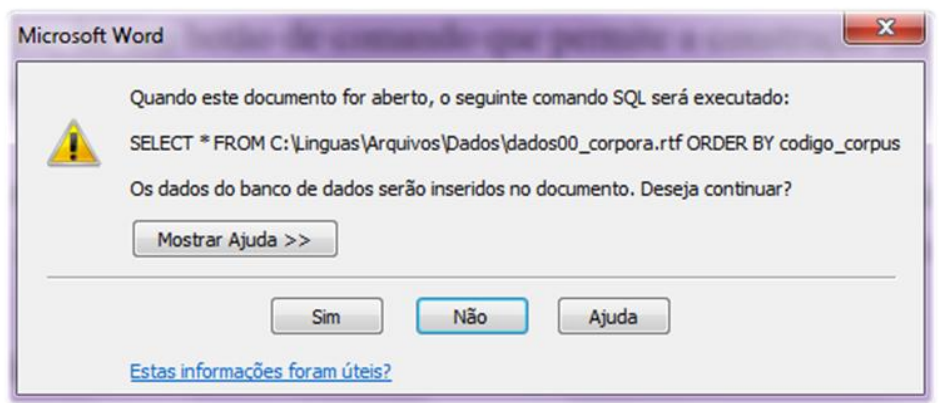

A seguir, descreveremos cada um dos materiais contidos nesta pasta:

FIGURA 72 - janela de área para produção de materiais: PROJETOS

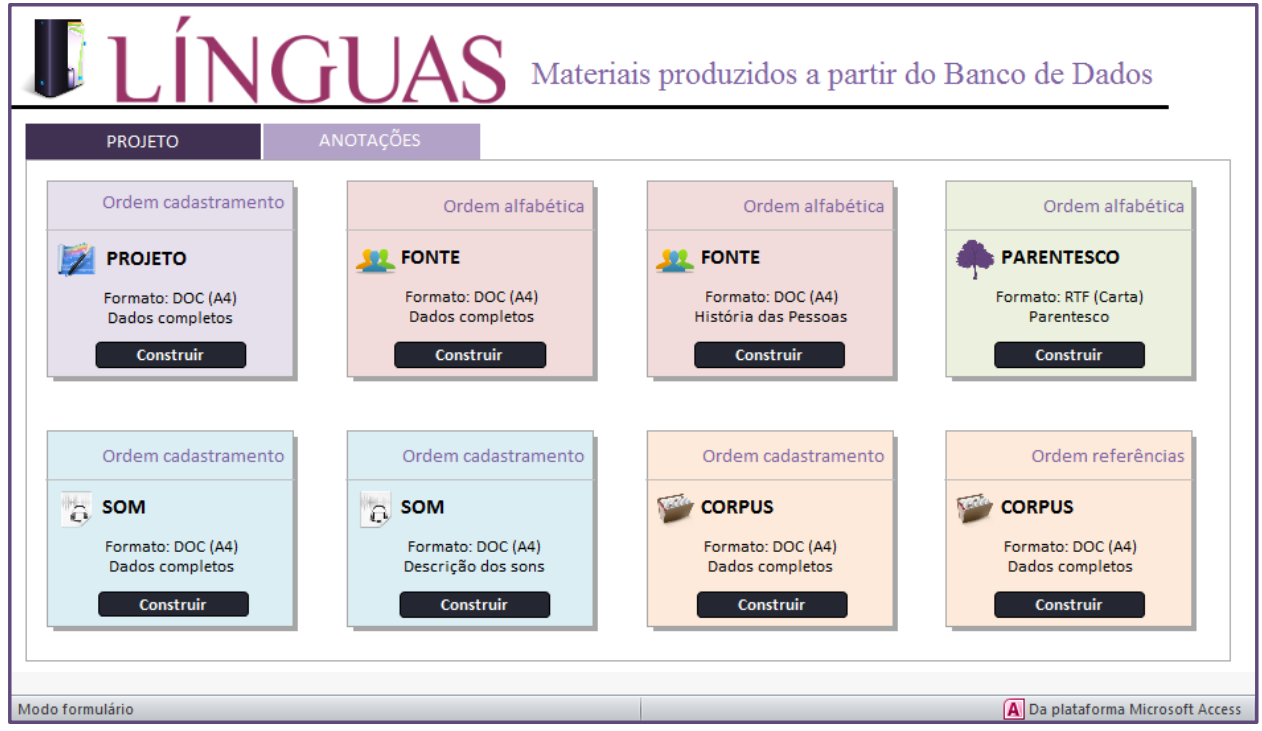


TABELA 68 - ABA PROJETO

\begin{tabular}{lll}
\hline BASE & ORDENAMENTO & DESCRIÇÃO DO CONTEÚDO \\
\hline Projeto & Ordem cadastramento & Dados completos do PDL. \\
\hline Fonte & Ordem alfabética & $\begin{array}{l}\text { Dados completos de todas as pessoas fontes de } \\
\text { referência. }\end{array}$ \\
\hline Fonte & Ordem alfabética & Dados sobre a história das pessoas fontes de referência. \\
\hline Parentesco & Ordem alfabética & Dados completos sobre o parentesco. \\
\hline Som & Ordem cadastramento & Dados completos de todos os sons. \\
\hline Som & Ordem cadastramento & Descrição dos sons cadastrados na base. \\
\hline Corpus & Ordem cadastramento & Dados completos sobre os corpora. \\
\hline Corpus & Ordem referências & Dados completos sobre os corpora. \\
\hline
\end{tabular}

TABELA 69 - ABA ANOTAÇÕES

\begin{tabular}{lll}
\hline BASE & ORDENAMENTO & DESCRIÇÃO DO CONTEÚDO \\
\hline Arquivos & Ordem código & Dados completos dos arquivos. \\
\hline Arquivos & Ordem cadastramento & Dados completos dos arquivos. \\
\hline Anotações & Ordem cadastramento & Dados sobre as anotações. \\
\hline Anotações & Ordem data inversa & Dados sobre as anotações. \\
\hline Histórico & Ordem cadastramento & Dados sobre o histórico do Projeto. \\
\hline Histórico & Ordem data inversa & Dados sobre o histórico do Projeto. \\
\hline Tarefas & Ordem cadastramento & Dados sobre as tarefas relacionadas ao Projeto. \\
\hline Tarefas & Ordem data inversa & Dados sobre as tarefas relacionadas ao Projeto. \\
\hline
\end{tabular}

\subsection{Bibliografia e Citação}

Nesta pasta podem ser gerados materiais com os dados armazenados nas bases Bibliografia e Citação do PDL. Clico sobre o ícone referente à pasta Bibliografia $e$ Citação para acessar a área de criação.

TABELA 70 - ABA BIBLIOGRAFIA E CITAÇÃO

\begin{tabular}{lll}
\hline BASE & ORDENAMENTO & DESCRIÇÃO DO CONTEÚDO \\
\hline Bibliografia & Ordem sobrenome autor & Dados completos de bibliografias. \\
\hline Bibliografia & Ordem de CDU & Apresentação das referências com $C D U$. \\
\hline Bibliografia & Ordem por tipo & Apresentação somente de referências. \\
\hline Bibliografia & Ordem sobrenome autor & Apresentação somente de referências. \\
\hline Citação & Ordem cadastro & Dados completos de citações. \\
\hline Citação & Ordem sobrenome autor & Dados completos de citações. \\
\hline
\end{tabular}




\begin{tabular}{lll}
\hline Citação & Ordem sobrenome autor & $\begin{array}{l}\text { Apresentação somente de citações com as respectivas } \\
\text { referências. }\end{array}$ \\
\hline Citação & Ordem palavras-chave & $\begin{array}{l}\text { Apresentação somente de citações com as respectivas } \\
\text { referências. }\end{array}$ \\
\hline
\end{tabular}

\section{FIGURA 73 - JANELA DE ÁREA PARA PRODUÇÃO DE MATERAIS: BIBLIOGRAFIA}

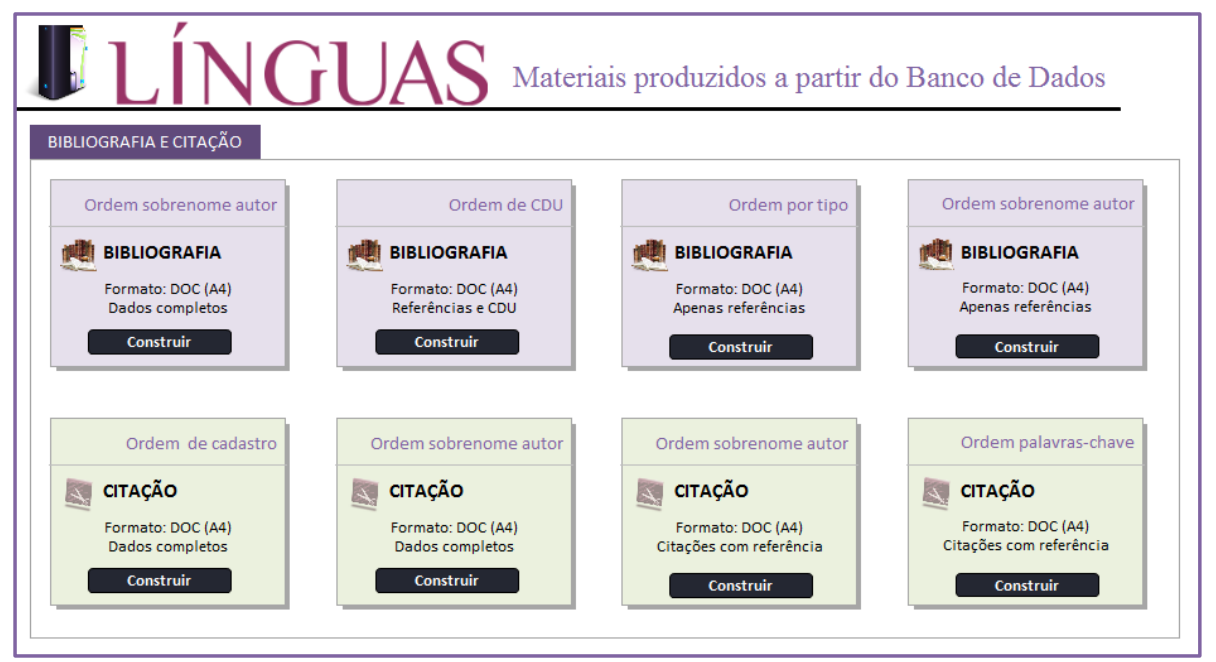

\subsection{Textos e Enunciados}

Nesta pasta podem ser gerados materiais com os dados armazenados nas bases Texto e Enunciados. Clico sobre o ícone $\checkmark$ referente à pasta Textos e Enunciados para acessar a área de criação.

O conteúdo desta janela está dividido em duas partes: a superior contém as opções de geração de materiais baseados em Textos, e a parte inferior, as de Enunciados.

\section{FIGURA 74 - JANELA DE ÁREA PARA PRODUÇÃO DE MATERAIS: TEXTOS E ENUNCIADOS}

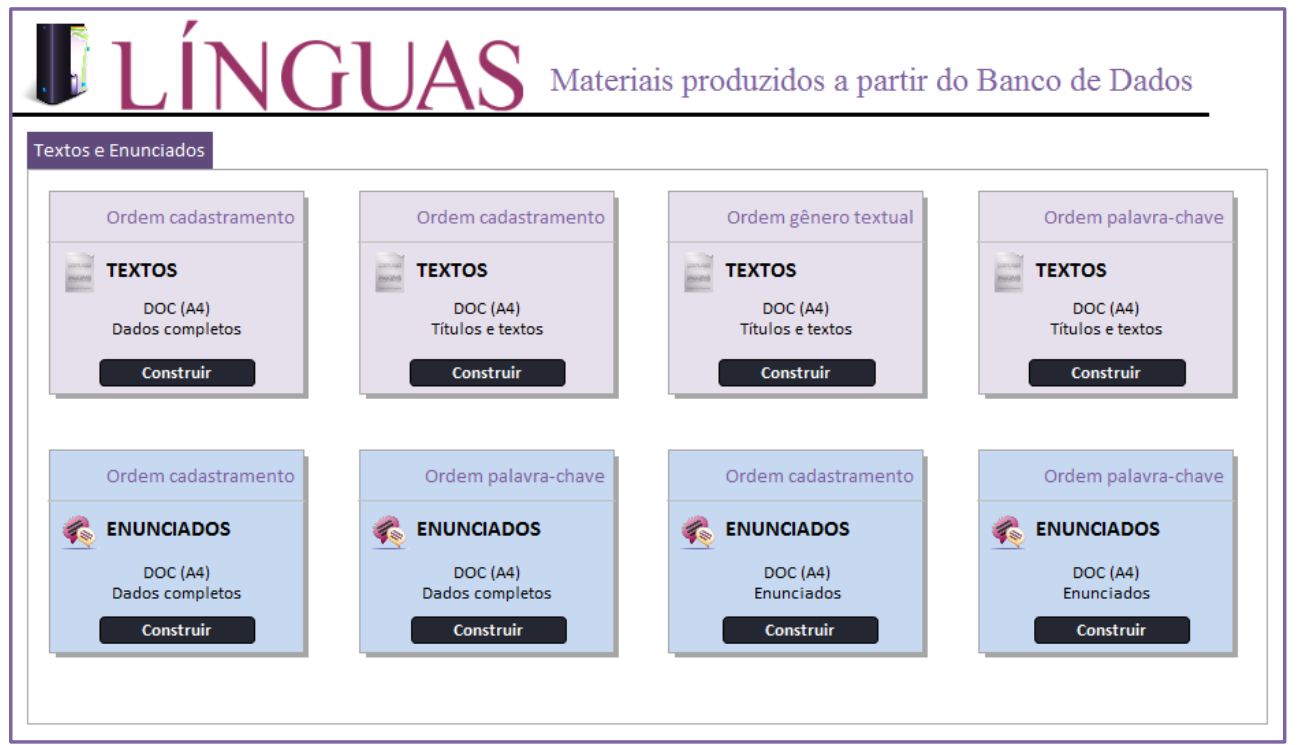


TABELA 71 - ABA TEXTOS E ENUNCIADOS

\begin{tabular}{lll}
\hline BASE & ORDENAMENTO & DESCRIÇãO DO CONTEÚDO \\
\hline Textos & Ordem cadastramento & Dados completos de textos. \\
\hline Textos & Ordem cadastramento & Apresentação somente de títulos e textos. \\
\hline Textos & Ordem gênero textual & Apresentação somente de títulos e textos. \\
\hline Textos & Ordem palavras-chave & Apresentação somente de títulos e textos. \\
\hline Enunciados & Ordem cadastramento & Dados completos de enunciados. \\
\hline Enunciados & Ordem palavras-chave & Dados completos de enunciados. \\
\hline Enunciados & Ordem cadastramento & Apresentação somente de enunciados. \\
\hline Enunciados & Ordem palavras-chave & Apresentação somente de enunciados. \\
\hline
\end{tabular}

\subsection{Dicionários}

O programa Línguas permite a construção automática de dicionários baseados nos dados cadastrados na Base Léxico. Clico sobre o ícone referente à pasta Dicionários para acessar a área de criação.

Por padrão pré-estabelecido para este projeto, todos os dicionários gerados no programa possuem macroestruturas baseadas na ordem alfabética seja dos itens lexicais seja de algum dos marcadores (ver Marcadores da Base Léxico). A forma de saída desses dicionários é também como Documento do Word (.doc), em página tamanho A4 (21 x $29,7 \mathrm{~cm}$ ) dividida em duas colunas.

Quanto à microestrutura, há variações conforme o tipo de dicionário construído. Por isso, se o dicionário for monolíngue, constarão apenas definições e exemplos da línguabase do PDL cadastrado. Já se ele for bilíngue, deverão constar dados da língua-base seguidos dos respectivos dados da segunda língua cadastrada na Base Projeto.

A seguir, apresento um exemplo da microestrutura de um dicionário monolíngue criada pelo programa Línguas:

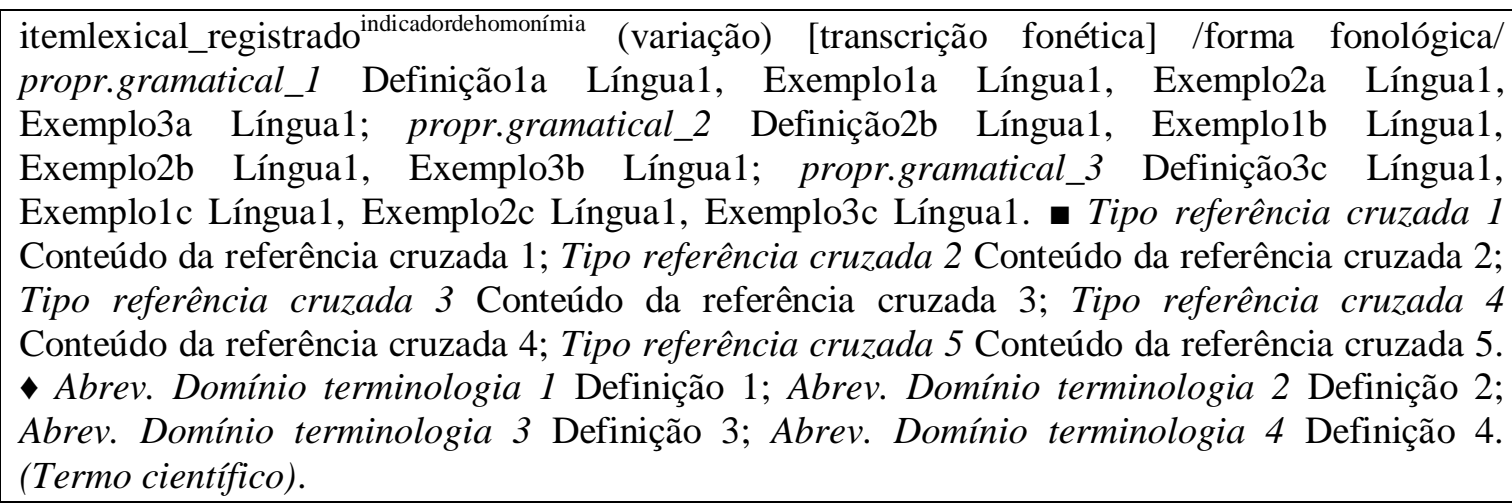


FIGURA 75 - JANELA DE ÁREA PARA PRODUÇÃO DE MATERAIS: ABA 1

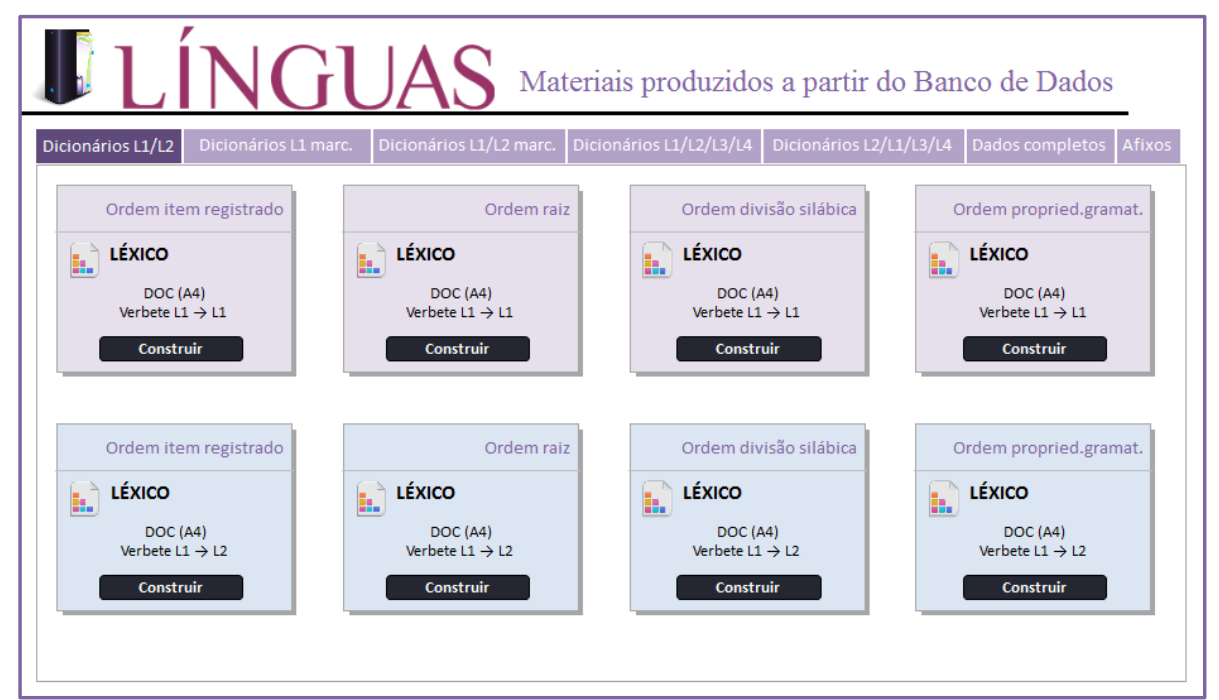

TABELA 72 - ABA DICIONÁRIOS L1/L2

\begin{tabular}{lll}
\hline BASE & ORDENAMENTO & DESCRIÇÃO DO CONTEÚDO \\
\hline Léxico & Ordem item registrado & Dicionário com dados somente em L1 \\
\hline Léxico & Ordem raiz & Dicionário com dados somente em L1 \\
\hline Léxico & Ordem divisão silábica & Dicionário com dados somente em L1 \\
\hline Léxico & Ordem propried.gramat. & Dicionário com dados somente em L1 \\
\hline Léxico & Ordem item registrado & Dicionário com dados em L1 $\rightarrow \mathrm{L} 2$ \\
\hline Léxico & Ordem raiz & Dicionário com dados em $\mathrm{L} 1 \rightarrow \mathrm{L} 2$ \\
\hline Léxico & Ordem divisão silábica & Dicionário com dados em $\mathrm{L} 1 \rightarrow \mathrm{L} 2$ \\
\hline Léxico & Ordem propried.gramat. & Dicionário com dados em $\mathrm{L} 1 \rightarrow \mathrm{L} 2$ \\
\hline
\end{tabular}

Todos os dicionários gerados nesta aba têm a língua-base na entrada do verbete, seja na forma de item lexical completo (ordem item registrado), de raiz do item lexical (ordem raiz), de item lexical dividido silabicamente (ordem divisão silábica) ou de propriedade gramatical do item lexical (ordem propried.gramat.).

TABELA 73 - ABA DICIONÁRIOS L1 MARC.

\begin{tabular}{lll}
\hline BASE & ORDENAMENTO & DESCRIÇÃO DO CONTEÚDO \\
\hline Léxico & Ordem marcadores 1-2 & $\begin{array}{l}\text { Dicionário com dados somente em L1 (entrada pelo } \\
\text { item lexical completo) }\end{array}$ \\
\hline Léxico & Ordem marcadores 1-2 & $\begin{array}{l}\text { Dicionário com dados somente em L1 (entrada pela } \\
\text { raiz do item lexical) }\end{array}$ \\
\hline Léxico & Ordem marcadores 2 & $\begin{array}{l}\text { Dicionário com dados somente em L1 (entrada pelo } \\
\text { item lexical completo) }\end{array}$ \\
\hline Léxico & Ordem marcadores 2 & Dicionário com dados somente em L1 (entrada pela \\
\hline
\end{tabular}




\begin{tabular}{lll}
\hline Léxico & Ordem marcadores 3 & $\begin{array}{l}\text { Dicionário com dados item lexical) } \\
\text { item lexical completo) }\end{array}$ \\
\hline Léxico & Ordem marcadores 3 & $\begin{array}{l}\text { Dicionário com dados somente em L1 (entrada pela } \\
\text { raiz do item lexical) }\end{array}$ \\
\hline Léxico & Ordem marcadores 4 & $\begin{array}{l}\text { Dicionário com dados somente em L1 (entrada pelo } \\
\text { item lexical completo) }\end{array}$ \\
\hline Léxico & Ordem marcadores 4 & $\begin{array}{l}\text { Dicionário com dados somente em L1 (entrada pela } \\
\text { raiz do item lexical) }\end{array}$ \\
\hline
\end{tabular}

Para gerar adequadamente dicionários com ordenamento de itens lexicais baseados em classificação de marcadores, é necessário que todos os itens lexicais cadastrados na Base Léxico tenham recebido os respectivos marcadores.

TABELA 74 - ABA DICIONÁRIOS L1/L2 MARC.

\begin{tabular}{lll}
\hline BASE & ORDENAMENTO & DESCRIÇÃO DO CONTEÚDO \\
\hline Léxico & Ordem marcadores 1-2 & $\begin{array}{l}\text { Dicionário com dados em L1 e L2 (entrada pelo item } \\
\text { lexical completo da língua-base) }\end{array}$ \\
\hline Léxico & Ordem marcadores 1-2 & $\begin{array}{l}\text { Dicionário com dados em L1 e L2 (entrada pela raiz } \\
\text { do item lexical da língua-base) }\end{array}$ \\
\hline Léxico & Ordem marcador 2 & $\begin{array}{l}\text { Dicionário com dados em L1 e L2 (entrada pelo item } \\
\text { lexical completo da língua-base) }\end{array}$ \\
\hline Léxico & Ordem marcador 2 & $\begin{array}{l}\text { Dicionário com dados em L1 e L2 (entrada pela raiz } \\
\text { do item lexical da língua-base) }\end{array}$ \\
\hline Léxico & Ordem marcador 3 & $\begin{array}{l}\text { Dicionário com dados em L1 e L2 (entrada pelo item } \\
\text { lexical completo da língua-base) }\end{array}$ \\
\hline Léxico & Ordem marcador 3 & $\begin{array}{l}\text { Dicionário com dados em L1 e L2 (entrada pela raiz } \\
\text { do item lexical da língua-base) }\end{array}$ \\
\hline Léxico & Ordem marcador 4 & $\begin{array}{l}\text { Dicionário com dados em L1 e L2 (entrada pelo item } \\
\text { lexical completo da língua-base) }\end{array}$ \\
\hline
\end{tabular}

TABELA 75 - ABA DICIONÁRIOS L1/L2/L3/L4

\begin{tabular}{lll}
\hline BASE & ORDENAMENTO & DESCRIÇÃO DO CONTEÚDO \\
\hline Léxico & Ordem item registrado & Dicionário com dados em L1 $\rightarrow \mathrm{L} 2 / \mathrm{L} 3$ \\
\hline Léxico & Ordem raiz & Dicionário com dados em L1 $\rightarrow \mathrm{L} 2 / \mathrm{L} 3$ \\
\hline Léxico & Ordem divisão silábica & Dicionário com dados em $\mathrm{L} 1 \rightarrow \mathrm{L} 2 / \mathrm{L} 3$ \\
\hline Léxico & Ordem marcadores 1-2 & Dicionário com dados em L1 $\rightarrow \mathrm{L} 2 / \mathrm{L} 3$ \\
\hline Léxico & Ordem item registrado & Dicionário com dados em L1 $\rightarrow \mathrm{L} 2 / \mathrm{L} 3 / \mathrm{L} 4$ \\
\hline
\end{tabular}




\begin{tabular}{lll}
\hline Léxico & Ordem raiz & Dicionário com dados em L1 $\rightarrow$ L2/L3/L4 \\
\hline Léxico & Ordem divisão silábica & Dicionário com dados em L1 $\rightarrow$ L2/L3/L4 \\
\hline Léxico & Ordem marcadores 1-2 & Dicionário com dados em L1 $\rightarrow$ L2/L3/L4 \\
\hline
\end{tabular}

Nos dicionários criados nesta aba do programa, apenas as duas primeiras línguas (L1 e L2) possuem item lexical acompanhados das respectivas definições e exemplos; quanto às demais línguas (L3 e L4), serão registrados somente os itens lexicais correspondentes.

TABELA 76 - ABA DICIONÁRIOS L2/L1/L3/L4

\begin{tabular}{lll}
\hline BASE & ORDENAMENTO & DESCRIÇÃO DO CONTEÚDO \\
\hline Léxico & Ordem alfabética & Dicionário com dados em L2 $\rightarrow \mathrm{L} 1$ \\
\hline Léxico & Ordem propried.gramat. & Dicionário com dados em L2 $\rightarrow \mathrm{L} 1$ \\
\hline Léxico & Ordem marcadores 1-2 & Dicionário com dados em L2 $\rightarrow \mathrm{L} 1$ \\
\hline Léxico & Ordem marcador 3 & Dicionário com dados em $\mathrm{L} 2 \rightarrow \mathrm{L} 1$ \\
\hline Léxico & Ordem alfabética & Dicionário com dados em L2 $\rightarrow \mathrm{L} 1 / \mathrm{L} 3$ \\
\hline Léxico & Ordem marcadores 1-2 & Dicionário com dados em L2 $\rightarrow \mathrm{L} 1 / \mathrm{L} 3$ \\
\hline Léxico & Ordem alfabética & Dicionário com dados em $\mathrm{L} 2 \rightarrow \mathrm{L} 1 / \mathrm{L} 3 / \mathrm{L} 4$ \\
\hline Léxico & Ordem marcadores 1-2 & Dicionário com dados em $\mathrm{L} 2 \rightarrow \mathrm{L} 1 / \mathrm{L} 3 / \mathrm{L} 4$ \\
\hline
\end{tabular}

TABELA 77 - ABA DICIONÁRIOS DADOS COMPLETOS

\begin{tabular}{lll}
\hline BASE & ORDENAMENTO & DESCRIÇÃO DO CONTEÚDO \\
\hline Léxico & Ordem propried.gramat. & Listagem com dados completos cadastrados na Base Léxico. \\
\hline Léxico & Ordem propried.gramat. & Listagem com dados completos cadastrados na Base Léxico. \\
\hline Léxico & Ordem marcador 3 & Listagem com dados completos cadastrados na Base Léxico. \\
\hline Léxico & Ordem marcador 3 & Listagem com dados completos cadastrados na Base Léxico. \\
\hline Léxico & Ordem alfabética (item) & Listagem com dados completos cadastrados na Base Léxico. \\
\hline Léxico & Ordem alfabética (raiz) & Listagem com dados completos cadastrados na Base Léxico. \\
\hline Léxico & Ordem alfabética (item) & Listagem com dados completos cadastrados na Base Léxico. \\
\hline Léxico & Ordem alfabética (raiz) & Listagem com dados completos cadastrados na Base Léxico. \\
\hline
\end{tabular}

TABELA 78 - ABA AFIXOS

\begin{tabular}{lll}
\hline BASE & ORDENAMENTO & DESCRIÇÃO DO CONTEÚDO \\
\hline Afixos & Ordem alfabética & Lista de dados completos somente em L1. \\
\hline Afixos & Ordem tipo/natureza & Lista de dados completos somente em L1. \\
\hline Afixos & Ordem alfabética & $\begin{array}{l}\text { Lista de dados completos somente em L1 (com } \\
\text { estrutura de verbetes). }\end{array}$ \\
\hline Afixos & Ordem tipo/natureza & Lista de dados completos somente em L1 (com \\
\hline
\end{tabular}




\begin{tabular}{lll}
\hline Afixos & Ordem alfabética & estrutura de verbetes). \\
\hline Afixos & Ordem tipo/natureza & Lista de dados completos em L1 $\rightarrow$ L2. \\
\hline Afixos & Ordem alfabética & $\begin{array}{l}\text { Lista de dados completos em L1 } \rightarrow \text { L2 (com } \\
\text { estrutura de verbetes). }\end{array}$ \\
\hline Afixos & Ordem tipo/natureza & $\begin{array}{l}\text { Lista de dados completos em L1 } \rightarrow \text { L2 (com } \\
\text { estrutura de verbetes). }\end{array}$ \\
\hline
\end{tabular}

\subsection{Enciclopédias}

Nesta pasta podem ser gerados materiais com os dados armazenados na base Enciclopédia. Clico sobre o ícone [ril referente à pasta Enciclopédias para acessar a área de criação.

FIGURA 76 - JANELA DE ÁREA PARA PRODUÇÃO DE MATERAIS: ENCICLOPÉDIAS

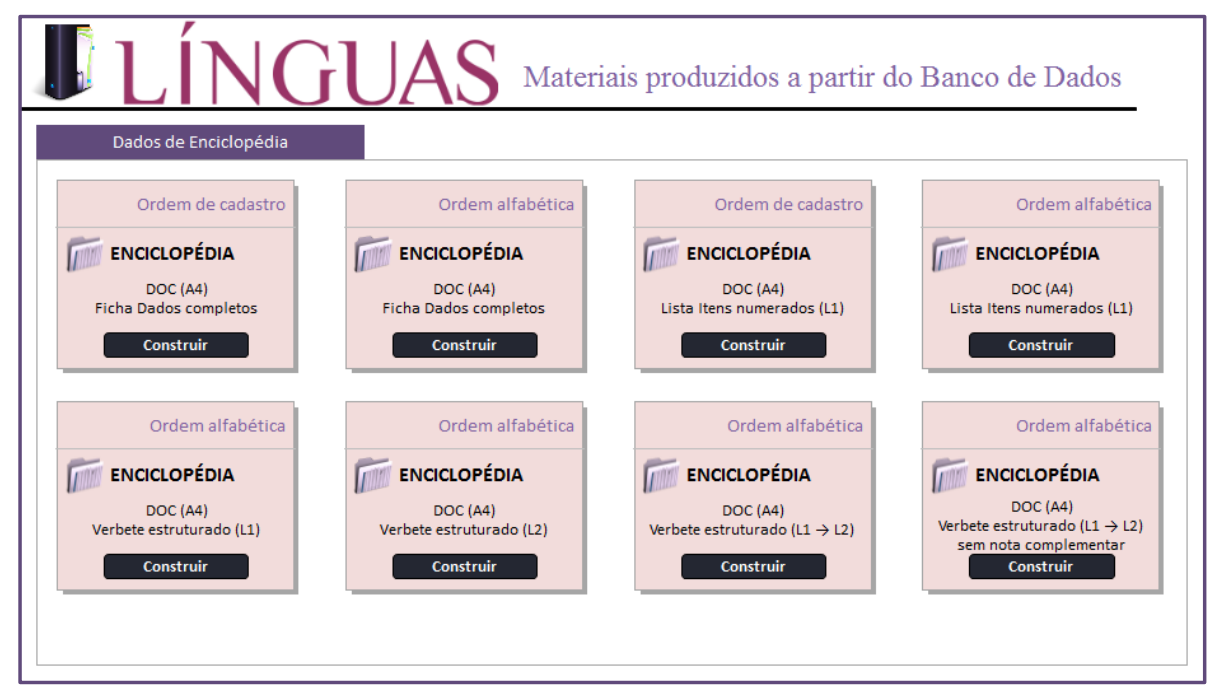

TABELA 79 - ABA dados de enciclopédia

\begin{tabular}{lll}
\hline BASE & ORDENAMENTO & DESCRIÇÃO DO CONTEÚDO \\
\hline Enciclopédia & Ordem item registrado & Ficha de dados completos somente em L1. \\
\hline Enciclopédia & Ordem alfabética & Ficha de dados completos somente em L1. \\
\hline Enciclopédia & Ordem item registrado & Lista de itens numerados somente em L1. \\
\hline Enciclopédia & Ordem alfabética & Lista de itens numerados somente em L1. \\
\hline Enciclopédia & Ordem alfabética & Enciclopédia com verbete estruturado em L1. \\
\hline Enciclopédia & Ordem alfabética & Enciclopédia com verbete estruturado em L2. \\
\hline Enciclopédia & Ordem alfabética & Enciclopédia com verbete estruturado de L1 $\rightarrow$ L2. \\
\hline Enciclopédia & Ordem alfabética & $\begin{array}{l}\text { Enciclopédia com verbete estruturado de L1 } \rightarrow \text { L2 } \\
\text { (sem nota complementar). }\end{array}$ \\
\hline
\end{tabular}




\subsection{Comparação e Notas}

Nesta pasta podem ser gerados materiais com os dados armazenados nas bases Comparação de itens lexicais (línguas diferentes) e Notas Linguísticas do PDL. Clico sobre o ícone 鳫 referente à pasta Comparação e Notas para acessar a área de criação.

\section{FIGURA 77 - JANELA DE ÁREA PARA PRODUÇÃO DE MATERAIS: COMPARAÇÃO DE LÍNGUAS E NOTAS LINGUÍSTICAS}

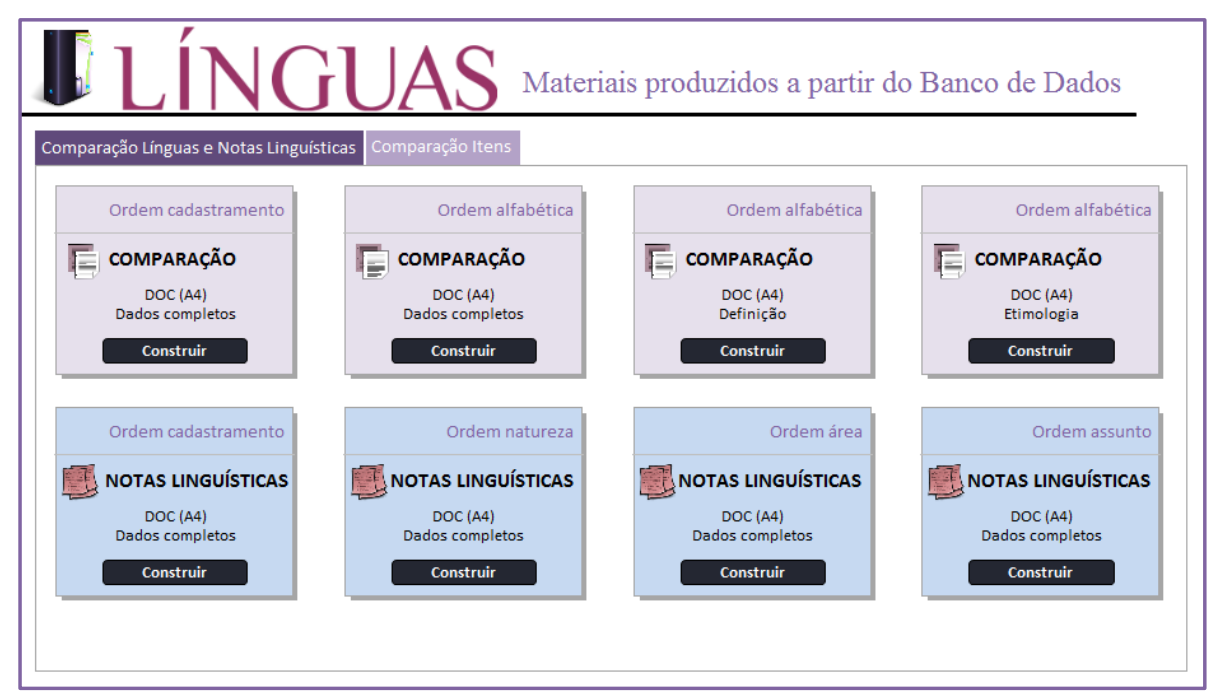

TABELA 80 - ABA COMPARAÇÃO DE LÍNGUAS E NOTAS LINGUÍSTICAS

\begin{tabular}{lll}
\hline BASE & ORDENAMENTO & DESCRIÇÃO DO CONTEÚDO \\
\hline $\begin{array}{l}\text { Comparação de itens } \\
\text { lexicais (línguas diferentes) }\end{array}$ & Ordem cadastramento & $\begin{array}{l}\text { Dados completos de comparações de itens } \\
\text { lexicais (línguas diferentes). }\end{array}$ \\
\hline $\begin{array}{l}\text { Comparação de itens } \\
\text { lexicais (línguas diferentes) }\end{array}$ & Ordem alfabética & $\begin{array}{l}\text { Dados completos de comparações de itens } \\
\text { lexicais (línguas diferentes). }\end{array}$ \\
\hline $\begin{array}{l}\text { Comparação de itens } \\
\text { lexicais (línguas diferentes) }\end{array}$ & Ordem alfabética & $\begin{array}{l}\text { Apresentação somente de itens lexicais com } \\
\text { respectivas definições. }\end{array}$ \\
\hline $\begin{array}{l}\text { Comparação de itens } \\
\text { lexicais (línguas diferentes) }\end{array}$ & Ordem alfabética & $\begin{array}{l}\text { Apresentação somente de itens lexicais com } \\
\text { respectivas etimologias. }\end{array}$ \\
\hline Notas Linguísticas & Ordem cadastramento & Dados completos de notas linguísticas. \\
\hline Notas Linguísticas & Ordem natureza & Dados completos de notas linguísticas. \\
\hline Notas Linguísticas & Ordem área & Dados completos de notas linguísticas. \\
\hline Notas Linguísticas & Ordem assunto & Dados completos de notas linguísticas. \\
\hline
\end{tabular}

TABELA 81 - ABA COMPARAÇÃO ITENS

\begin{tabular}{lll}
\hline BASE & ORDENAMENTO & DESCRIÇÃO DO CONTEÚDO \\
\hline $\begin{array}{l}\text { Comparação de itens } \\
\text { lexicais (mesma língua) }\end{array}$ & Ordem alfabética & $\begin{array}{l}\text { Comparação do item lexical base com outro } \\
\text { registro (mesma língua). }\end{array}$ \\
\hline Comparação de itens & Ordem alfabética & Comparação do item lexical base com \\
\hline
\end{tabular}




\begin{tabular}{lll}
\hline lexicais (mesma língua) & outros dois registros (mesma língua). \\
\hline $\begin{array}{l}\text { Comparação de itens } \\
\text { lexicais (mesma língua) }\end{array}$ & Ordem alfabética & $\begin{array}{l}\text { Comparação do item lexical base com } \\
\text { outros três registros (mesma língua). }\end{array}$ \\
\hline $\begin{array}{l}\text { Comparação de itens } \\
\text { lexicais (mesma língua) }\end{array}$ & Ordem alfabética & $\begin{array}{l}\text { Comparação do item lexical base com } \\
\text { outros quatro registros (mesma língua). }\end{array}$ \\
\hline $\begin{array}{l}\text { Comparação de itens } \\
\text { lexicais (mesma língua) }\end{array}$ & Ordem alfabética & $\begin{array}{l}\text { Comparação do item lexical base com } \\
\text { outros cinco registros (mesma língua). }\end{array}$ \\
\hline $\begin{array}{l}\text { Comparação de itens } \\
\text { lexicais (mesma língua) }\end{array}$ & Ordem alfabética & $\begin{array}{l}\text { Comparação do item lexical base com } \\
\text { outros seis registros (mesma língua). }\end{array}$ \\
\hline $\begin{array}{l}\text { Comparação de itens } \\
\text { lexicais (mesma língua) }\end{array}$ & Ordem alfabética & $\begin{array}{l}\text { Comparação do item lexical base com } \\
\text { outros sete registros (mesma língua). }\end{array}$ \\
\hline $\begin{array}{l}\text { Comparação de itens } \\
\text { lexicais (mesma língua) }\end{array}$ & Ordem alfabética & $\begin{array}{l}\text { Comparação do item lexical base com } \\
\text { outros sete registros (mesma língua). } \\
\text { (apenas itens). }\end{array}$ \\
\hline
\end{tabular}

\subsubsection{Segurança dos dados}

A última área do programa Línguas é a Área de Segurança, na qual é possível definir as configurações de acesso ao sistema do PDL, bem como gerar cópias de segurança de todos os dados já cadastrados.

FIGURA 78 - JANELA PRINCIPAL DA ÁREA DE SEGURANÇA

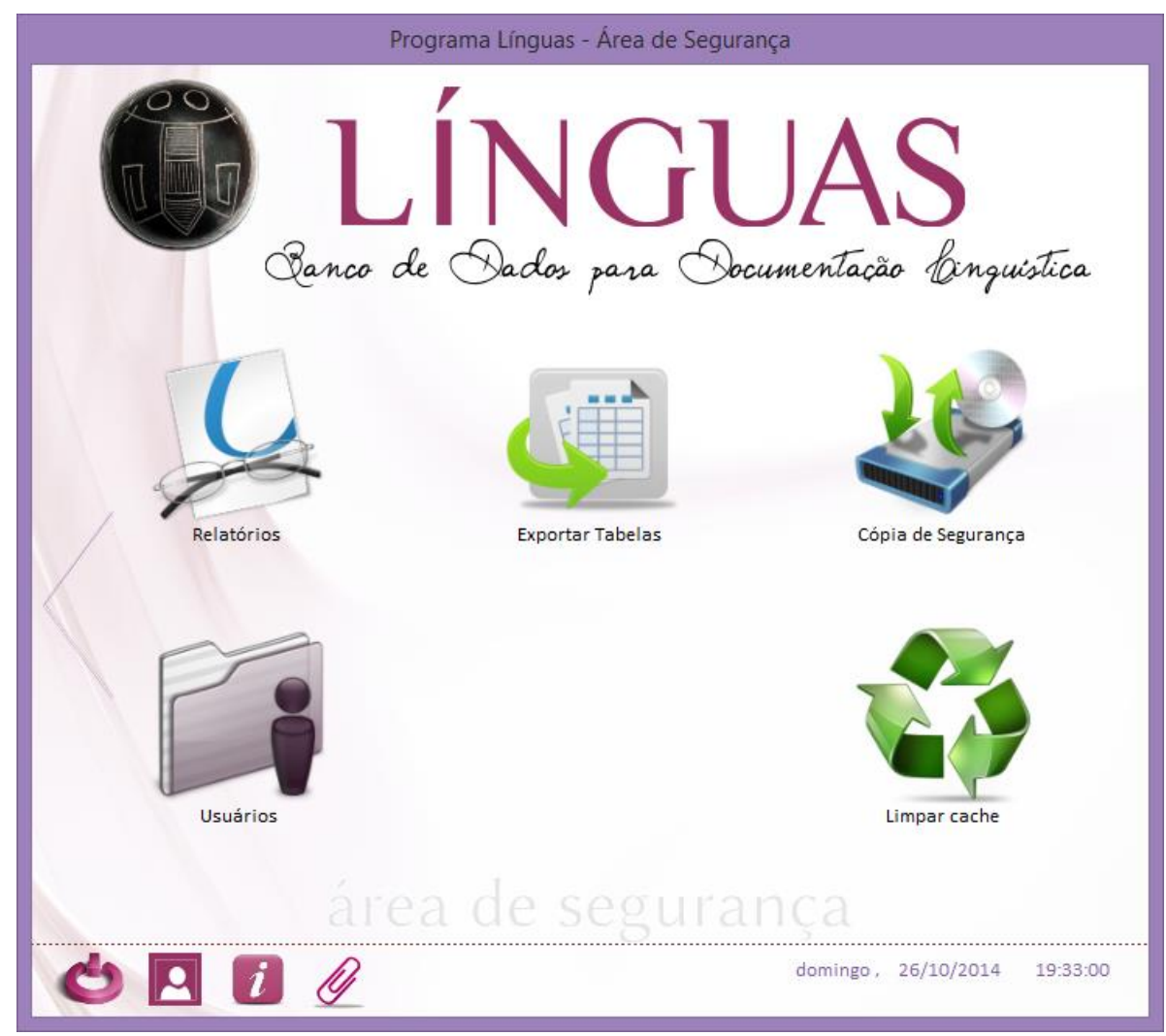


Nessa área, há cinco ícones, correspondentes a ferramentas para gerenciamento de usuários e a segurança de dados do PDL em desenvolvimento. A seguir, apresento cada uma dessas ferramentas.

\subsection{Relatórios}

O programa Línguas possui a opção de gerar Relatórios para exibição resumida de dados cadastrados nas bases do PDL. Clico sobre o ícone referente à pasta Relatórios para acessar a área de criação.

FIGURA 79 - ÁREA PARA VISUALIZAÇÃO DE RELATÓRIOS DO PROGRAMA LÍNGUAS

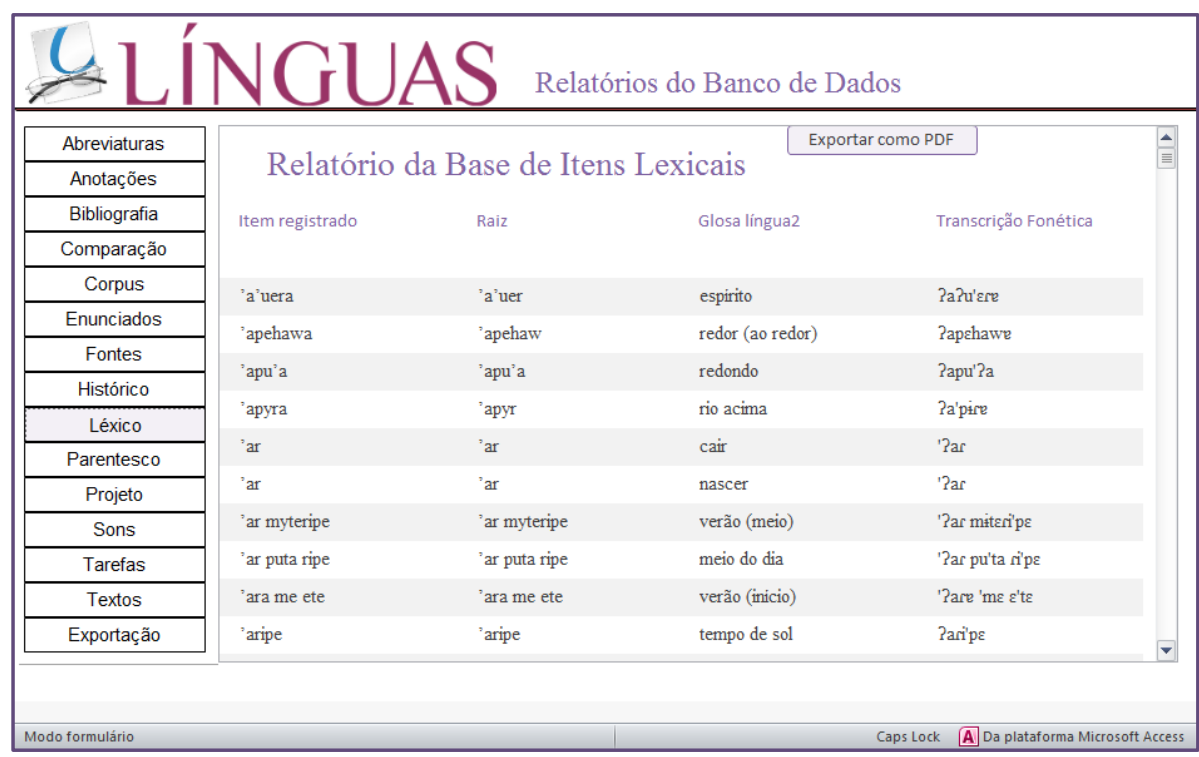

À esquerda da página há uma lista de botões rotulados com os nomes de diferentes bases, clico sobre qualquer um deles e os dados já cadastrados serão relacionados na área maior à direita da tela.

É possível exportar no formato PDF os dados apresentados em cada relatório. Para isso, clico sobre o botão Exportarcomo PDF, situado na parte superior direita de cada relatório selecionado.

À medida que os dados forem sendo inseridos nas bases, os relatórios serão automaticamente atualizados.

Exportação de relatórios

Todos os Relatórios podem ser exportados, além do formato PDF, em outros 8 diferentes formatos de arquivo, são eles: Arquivo de Texto (*.txt), Formato Instantâneo (*.snp), Formato Rich Text (*.rtf), Formato XPS (*.xps), HTML (*.htm; *.html), Pasta de 
Trabalho do Excel 97 - Excel 2003 (*.xls), Pasta de Trabalho do Microsft Excel 5.0/95 (*.xls) e $X M L(* . x m l)$.

FIGURA 80 - OPÇÕES PARA EXPORTAÇÃO DOS RELATÓRIOS

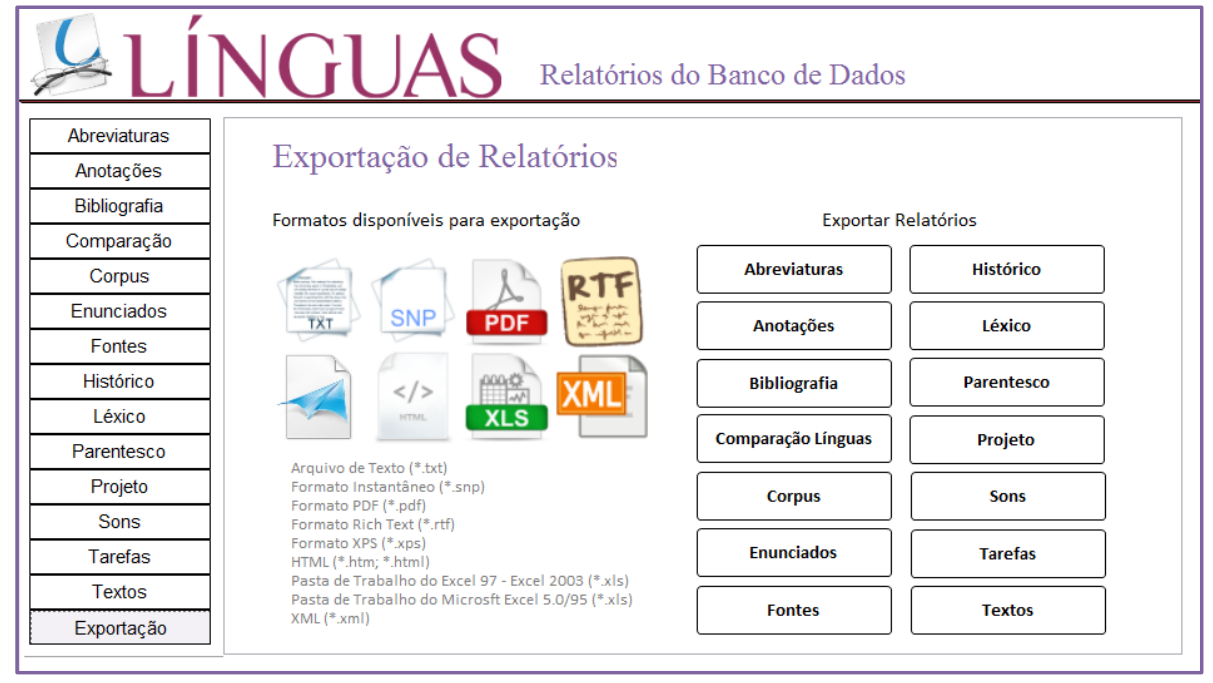

Clico sobre o botão rotulado com as denominações das diferentes bases do programa Línguas e em seguida será aberta a seguinte janela:

\section{FIGURA 81 - OPÇÕES DE TIPOS DE DOCUMENTOS PARA EXPORTAÇÃO DOS RELATÓRIOS}

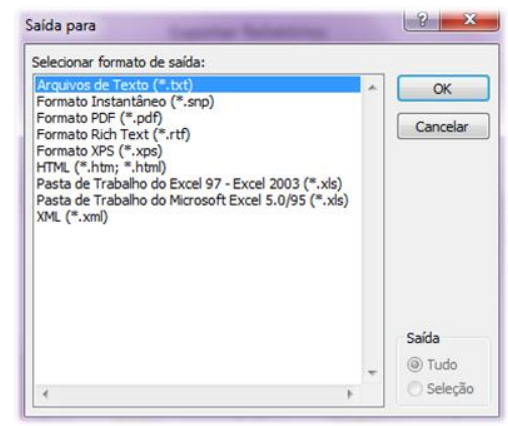

Seleciono o formato de saída do arquivo (exportação) e clico sobre o botão OK. Uma nova janela será aberta, agora para definir em que local do computador o arquivo gerado referente ao Relatório deve ser armazenado. Após selecionar a pasta, clico em OK para finalizar a operação.

\subsection{Exportar tabelas}

O programa Línguas dispõe de outro recurso para Cópia de Segurança dos dados do PDL: a exportação direta das tabelas de armazenamento do banco de dados. Clico sobre o ícone referente a Exportar tabelas para acessar a área de criação. 
FIGURA 82 - EXPORTAÇÃO DE DADOS NO FORMATO DE TABELAS DO EXCEL

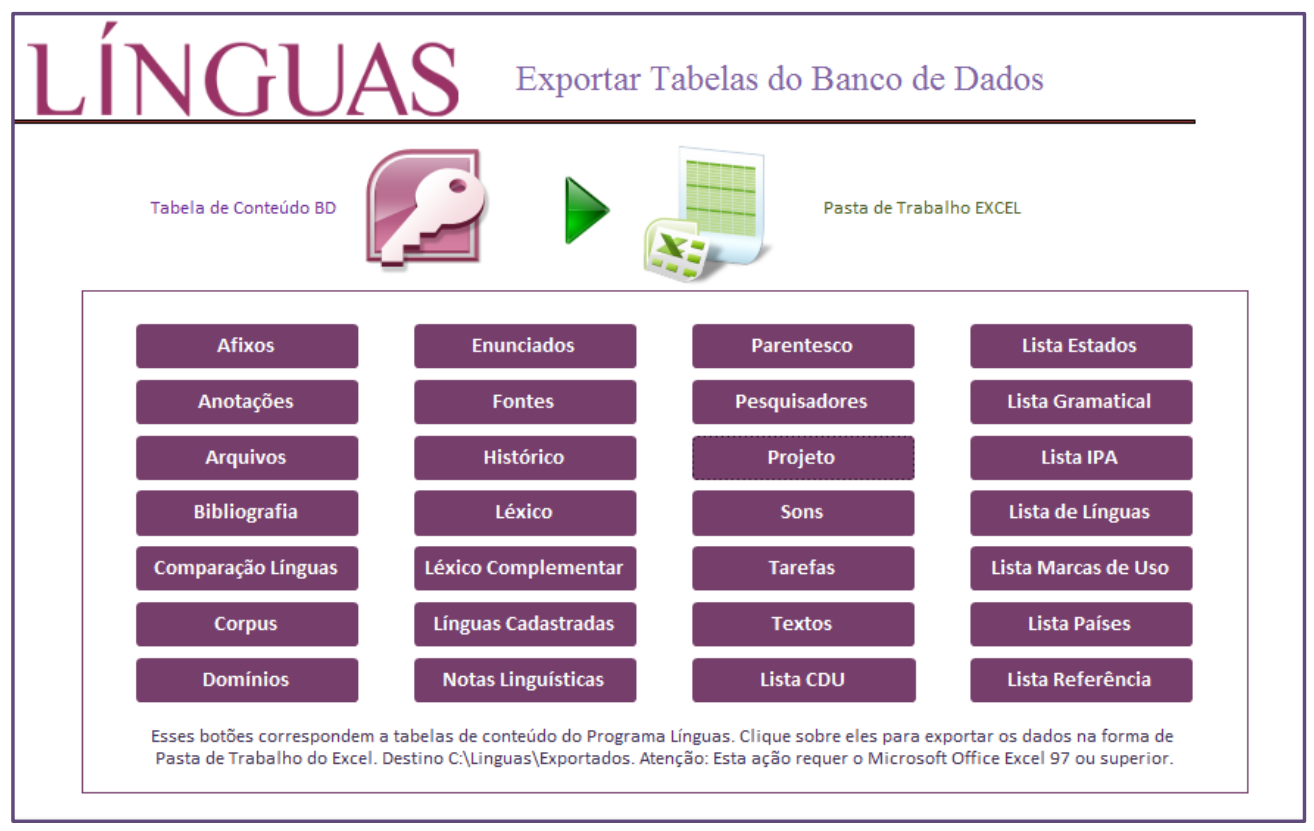

Essa exportação gera arquivos do tipo Pasta de Trabalho do Excel que contêm todos os dados já cadastrados nas diferentes bases. Para gerar um arquivo, clico sobre qualquer um dos 28 botões disponíveis nesta janela. O programa Microsoft Office Excel (97 ou superior) será aberto automaticamente e exibirá todos os dados dispostos em uma tabela. ${ }^{155}$

\subsection{Cópia de Segurança}

Os dados registrados em um PDL representam não apenas o esforço de um trabalho de reunião de informações dispersas em um único lugar, mas são, antes de tudo, produtos de um longo e difícil exercício de reflexão teórica de prática de análise e sistematização.

Dessa forma, é desejável manter todos esses dados já produzidos sempre em segurança, contra eventuais perdas ou, até mesmo, mal funcionamento de um sistema informatizado.

Por isso, inseri uma ferramenta no programa Línguas que permite assegurar a integridade dos dados do PDL por meio de um recurso de cópias de segurança de toda a matriz do banco de dados.

Para acessar essa ferramenta, clico, então, sobre o ícone referente à Cópia de segurança.

\footnotetext{
${ }^{155}$ Por padrão, todos os arquivos gerados nesta área serão armazenados na pasta C: LínguasไExportados.
} 
FIGURA 83 - ÁREA PARA GERAÇÃO DA CÓPIA DE SEGURANÇA

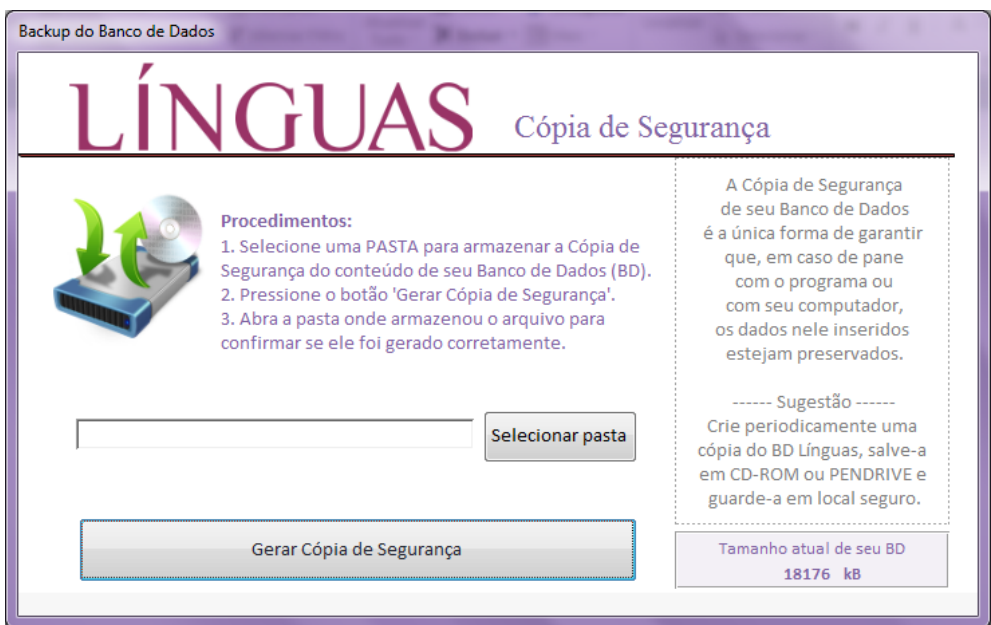

Em seguida, clicando sobre o botão Selecionar Pasta, é possível escolher uma pasta dentro do computador ou dentro de um dispositivo de armazenamento externo, como um pendrive ou HD Externo (recomendável). Uma vez selecionada a pasta de destino do arquivo, pressiono o botão Gerar Cópia de Segurança. Se a cópia do banco de dados for gerada corretamente, será mostrada a seguinte mensagem: “Cópia de segurança criada com sucesso. Verifique a pasta selecionada para confirmar".

Um arquivo gerado como Cópia de segurança no programa Línguas recebe, na pasta de destino, a denominação linguas_backup_20131104, sendo estes números relativos à data de criação do arquivo (neste caso, 04 de novembro de 2013). ${ }^{156}$ Além disso, esses arquivos de backup não contêm uma extensão definida, ficando como 'pastas em branco'. Em caso de necessidade de utilizá-los para substituir alguma versão do programa Línguas que esteja corrompida, eles devem receber a extensão .accdr logo após o último dígito de data do nome do arquivo. Feito este processo, esse arquivo pode ser utilizado normalmente para acessar o banco de dados.

Tamanho do Banco de Dados

Ainda nesta janela de Cópia de Segurança, há uma informação sobre o Tamanho atual do BD. Esse tamanho corresponde ao espaço já ocupado de armazenamento de dados no programa. $^{157}$

\footnotetext{
${ }^{156}$ Abro a pasta escolhida para armazenar o arquivo da cópia de segurança para se certificar que ele foi de fato criado.

${ }^{157}$ Como o programa não incorpora diretamente em sua estrutura os arquivos de dados como áudios e vídeos, toda a capacidade de armazenamento fica reservada a apenas informações alfanuméricas, que, mesmo sendo extensas, no caso de textos longos, ocupam pouco espaço no banco de dados.
} 


\subsection{Usuários}

É nesta área que são cadastrados todos os usuários do programa Línguas e também definidos os níveis de acesso de cada um deles. Clico sobre o ícone referente a Usuários para acessar a área de cadastramento. ${ }^{158}$

A área de Usuários é composta por duas abas, descritas a seguir:

\section{FIGURA 84 - ÁREA PARA CONFIGURAÇÃO DO REGISTRO DE USUÁRIOS DO PROGRAMA LÍNGUAS}

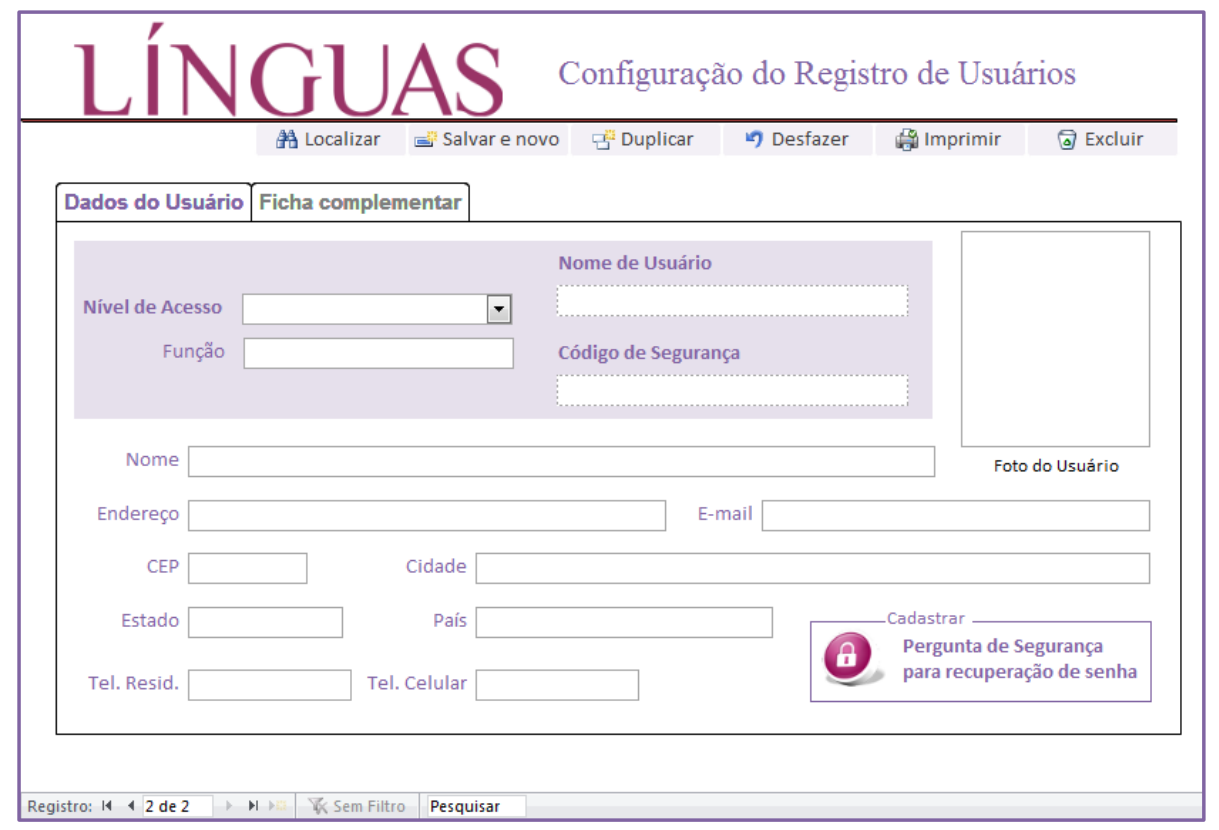

TABELA 82 - ABA 1: DADOS DO USUÁRIO

\begin{tabular}{ll}
\hline CAMPO & DESCRIÇão \\
\hline Nível de Acesso & $\begin{array}{l}\text { Lista suspensa (não editável) que contém os dois níveis de acesso } \\
\text { possíveis no programa Línguas: Administrador e Usuário. O primeiro } \\
\text { tem acesso livre a todas as áreas do programa, podendo, inclusive, } \\
\text { excluir e exportar dados e também gerenciar usuários; ao passo que o } \\
\text { segundo, pode apenas cadastrar dados, sem acesso às áreas restritas } \\
\text { do sistema. }\end{array}$ \\
\hline Função & $\begin{array}{l}\text { Campo para especificar a função que a pessoa exerce dentro do PDL. } \\
\text { Cabe a cada Projeto estabelecer as suas respectivas funções. }\end{array}$ \\
\hline Nome de Usuário & $\begin{array}{l}\text { Esse nome de usuário é o que aparecerá nas listas das áreas de acesso } \\
\text { do programa. Por isso, evite cadastrar um mesmo nome de usuário } \\
\text { para duas ou mais pessoas. }\end{array}$ \\
\hline Código de Segurança & $\begin{array}{l}\text { O acesso ao sistema só será permitido mediante a inserção de uma } \\
\text { senha (código de segurança). Sugestão: Escolho uma senha que tenha } \\
\text { algum grau de dificuldade, a fim de garantir a segurança dos dados. O }\end{array}$ \\
\hline 158 Antes de realizar qualquer alteração dos dados de usuários cadastrados nesta área, principalmente os dados do \\
$\begin{array}{l}\text { Administrador do programa, faço uma Cópia de Segurança de todo o banco de dados, pois, caso haja algum } \\
\text { problema nessas modificaçôes, como esquecimento da nova senha ou da palavra-código de acesso, tenho como } \\
\text { restaurar as informações do banco de dados. }\end{array}$
\end{tabular}




\begin{tabular}{ll}
\hline & $\begin{array}{l}\text { programa Línguas permite, no campo de código de segurança, a } \\
\text { utilização de letras e número variados, além de símbolos, tais como } \\
\# @ \$ * \%=.\end{array}$ \\
\hline Nome & $\begin{array}{l}\text { Campo para informar dados do usuário, neste caso, o nome completo } \\
\text { da pessoa. }\end{array}$ \\
\hline Endereço & Informar o endereço do usuário. \\
\hline CEP & Código de Endereçamento Postal (8 dígitos). \\
\hline Cidade & Registrar a cidade onde a pessoa reside. \\
\hline Estado & Registrar o Estado ou Província correspondente. \\
\hline País & Indicar o país de residência da pessoa. \\
\hline E-mail & Informar, pelo menos, uma conta de e-mail do usuário cadastrado. \\
\hline Tel. Resid. & Informar o telefone fixo da pessoa, com DDD. \\
\hline Tel. Celular & Informar o telefone móvel da pessoa, com DDD. \\
\hline Foto do Usuário & É possível inserir uma fotografia do usuário cadastrado. \\
\hline
\end{tabular}

Cadastrar Pergunta de Segurança para Recuperação de Senha

Em caso de esquecimento/perda da senha de acesso, o Administrador do sistema pode recuperar esse código utilizando uma Pergunta de Segurança. Por isso, ao se cadastrar como usuário, o Administrador deve criar uma pergunta de segurança na Base de Redefinição de Senhas, cujo atalho fica na parte inferior direita da pasta Usuários (Área de Segurança).

Para acessar essa base, clico sobre o botão Pergunta de Segurança para recuperação de senha e, em seguida, será aberta a seguinte janela:

\section{FIGURA 85 - JANELA PARA INSERÇÃO DA PERGUNTA DE SEGURANÇA PARA REDEFINIÇÃO DE SENHAS}

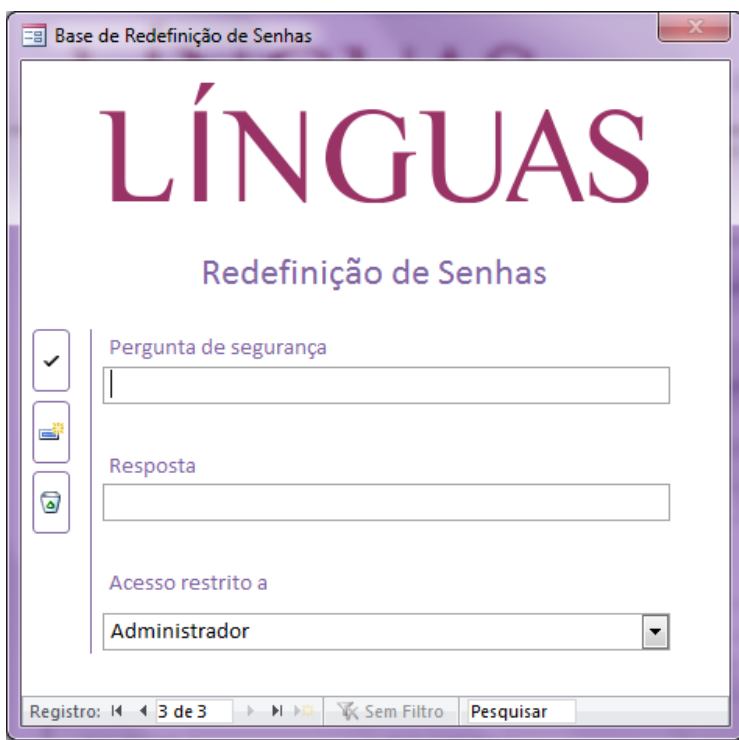


Escolho uma Pergunta de Segurança e a digito no primeiro campo de texto. No campo seguinte, insiro a Resposta correspondente à pergunta. Defini que o acesso seria restrito podendo ser efetuado apenas pelo administrador do sistema.

À esquerda destes campos de texto, os três botões permitem, respectivamente, salvar, adicionar ou excluir uma pergunta desta base.

TABELA 83 - ABA 2: FICHA COMPLEMENTAR

\begin{tabular}{ll}
\hline CAMPO & DESCRIÇÃO \\
\hline Titulação & $\begin{array}{l}\text { Informar neste campo a maior titulação acadêmica do usuário } \\
\text { cadastrado. }\end{array}$ \\
\hline Vinculado à Instituição & $\begin{array}{l}\text { Caso o usuário tenha algum tipo de vínculo institucional (com uma } \\
\text { universidade, p.ex.), informar neste campo o nome da instituição. }\end{array}$ \\
\hline Página Web Instituição & $\begin{array}{l}\text { Se for cadastrada uma instituição, informar qual é o endereço } \\
\text { eletrônico do usuário na internet. }\end{array}$ \\
\hline Tel. Instituição & Informar o telefone da instituição. \\
\hline Anotações & $\begin{array}{l}\text { Se necessário, acrescentar outras informações acerca da instituição } \\
\text { e/ou do vínculo institucional mantido pelo usuário. }\end{array}$ \\
\hline Data de ingresso no Projeto & $\begin{array}{l}\text { Informar a data em que o usuário passou a fazer parte da equipe do } \\
\text { PDL. }\end{array}$ \\
\hline $\begin{array}{l}\text { Responsável pelo cadastro } \\
\text { do Usuário }\end{array}$ & $\begin{array}{l}\text { Lista suspensa para seleção do nome do responsável pelo cadastro do } \\
\text { Usuário no programa Línguas. }\end{array}$ \\
\hline
\end{tabular}

\subsection{Limpar cache}

Ao construir documentos a partir das bases do programa Línguas, são armazenados arquivos numa pasta do computador (cache). Por isso, para manter a segurança dos dados, realizo a limpeza periódica dessa pasta de cache. Clico sobre o ícone referente a Limpar Cache para acessar esta ferramenta.

Ao abrir a seguinte janela, pressiono o botão Executar limpeza dos dados em cache. A janela se fecha e volta imediatamente para a Área de Segurança.

FIGURA 86 - JANELA PARA LIMPEZA DE CACHE

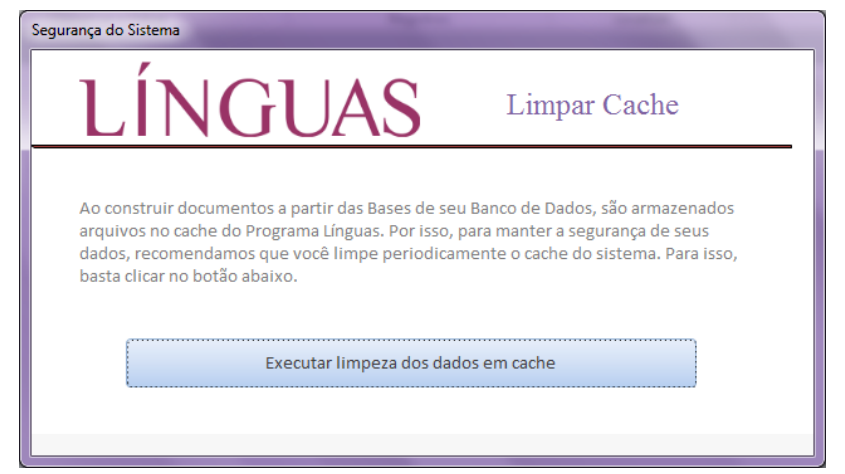




\subsection{ALGUMAS CONSIDERAÇÕES NECESSÁRIAS}

Ao concluir a apresentação desse programa de computador, desenvolvido com um fim específico de colaborar com o trabalho do pesquisador de línguas indígenas, é fundamental reafirmar que o uso desse programa requer, antes, que exista um projeto de documentação de língua(s) a ser documentada e, dentro dele, esteja previsto o uso desse recurso computacional.

Outra observação importante sobre esse programa é que, apesar de ter sido usado ao longo do trabalho desta tese, ainda requer mais testes por outros pesquisadores, a fim de que não apenas esteja livre de problemas técnicos, mas, principalmente, que consiga atender adequadamente às demandas de cada projeto em que ele for utilizado.

Como esse programa ainda é todo baseado em uma máquina para que funcione, acredito que a próxima etapa de seu desenvolvimento deve ser planejada no sentido de permitir o seu uso na Web, o que facilitaria bastante o acesso a ele. 


\section{MODELOS LEXICOGRÁFICOS PARA A LÍNGUA SURUÍ}

No capítulo 7 desta tese, apresentei as várias formas de organização das macroestruturas e microestruturas de obras lexicográficas já produzidas para as línguas indígenas brasileiras ao longo de quase cinco séculos. Baseando-me nessas formas, apresento a seguir um conjunto de modelos depreendidos, em parte, dessa pesquisa, mas, ao mesmo tempo, proponho formas diferenciadas de organização para esses materiais. É necessário destacar que todas essas propostas foram construídas utilizando dados armazenados no PDL para a língua Suruí, organizado e armazenado no Programa Línguas (cf. capítulo 8).

Uma última observação antes de passar à apresentação dos modelos: não pretendo contestar as diferentes tipologias para a classificação dos tipos de obras lexicográficas apresentadas por vários pesquisadores, ao longo das décadas, mas apenas apresentar de forma sistematizada propostas que colaborem com a reflexão acerca da caracterização de obras lexicográficas.

\subsection{MODELOS BASEADOS NA MICROESTRUTURA}

Na descrição das microestruturas das UBL's das línguas indígenas brasileiras (cf. subseção 7.2.1.4), identifiquei 14 tipos básicos, cada um deles podendo constituir modelos diferentes, conforme demonstro a seguir.

\subsubsection{Modelo M}

Esse modelo constitui a forma mais básica de apresentação de dados com uma única língua, ou seja, com a EML composta pela estrutura básica L. Contudo, mesmo aparentando ser uma forma muito simples, esse modelo resulta de uma série de decisões de quem o produziu, ou seja, ele pode conter desde os poucos dados linguísticos coletados junto a um lembrador de sua língua (neste caso, é comumente denominado lista ou lista de palavras) até mesmo as extensas compilações de dados (neste caso, pode receber o nome de vocabulário, p.ex.); ele pode ser apresentado em ordem alfabética ou separado por grupos de temas; pode ser numerado ou não, apresentar escrita ortográfica ou fonética/fonológica; enfim, estas e outras decisões devem ser tomadas para a adequada apresentação desse modelo. $^{159}$

\footnotetext{
${ }^{159}$ Para exemplificar o potencial desse modelo, basta ver o Vocabulário Ortográfico da Língua Portuguesa, publicado pela Academia Brasileira de Letras em 2009, que contém quase 400.000 verbetes.
} 
A seguir, apresento quatro propostas baseadas neste modelo e que utilizam dados apenas da língua Suruí.

FIGURA 87 - MODELO M1 (LÍNGUA SURUí)

\begin{tabular}{|l|}
\hline namikohom \\
namikwar \\
namukuj \\
nong \\
nonuwewaramu \\
nung \\
nupen \\
nupinipar \\
nupo \\
o'o \\
o'oj \\
'og \\
'ogete \\
oko \\
oko \\
opo \\
\end{tabular}

A Figura 87 apresenta o modelo com a estrutura LId, organizada em ordem alfabética estrita (e, para as formas iniciadas por glotal, considera o segundo elemento para determinar essa ordem). Disposto em apenas uma coluna, esse modelo utiliza a escrita ortográfica da língua Suruí (cf. Capítulo 4) e não há nenhum tipo de efeito tipográfico para destacar os itens (ou parte deles).

FIGURA 88 - MODELO M2 (LÍNGUA SURUÍ)

\begin{tabular}{|c|c|c|c|}
\hline 332. & /ma?esa'was/ & 352. & /sawa'ri/ \\
\hline 333. & /akapi'was/ & 353. & /karuaru'hu/ \\
\hline 334. & /misaka'tin/ & 354. & /tiwa'?a/ \\
\hline 335. & /tapi?i'se/ & 355. & /tasa'hu/ \\
\hline 336. & /sawami'maw/ & 356. & /tasahumi'maw/ \\
\hline 337. & /sawa'ron/ & 357. & /kwa'ti/ \\
\hline 338. & /sawata'rag/ & 358. & /iapua'?эj/ \\
\hline 339. & /aki'ki/ & 359. & /kareru'a/ \\
\hline 340. & /akikipo'roy/ & 360. & /supa'ti/ \\
\hline 341. & /Ehakwa'su/ & 361. & /anu'sa/ \\
\hline 342. & /i'?a/ & 362. & /a'son/ \\
\hline 343. & /ka'?i/ & 363. & /tamaw'?a/ \\
\hline 344. & /kahena'?i/ & 364. & /ta'tu/ \\
\hline 345. & /kuti'pi/ & 365. & /tatu'hu/ \\
\hline 346. & /sawiri're/ & 366. & /tatuc'te/ \\
\hline 347. & /sawapi'nim/ & 367. & /tatu'pew/ \\
\hline 348. & /sawapi'roy/ & 368. & /mi'sar/ \\
\hline 349. & /sawapi'sun/ & 369. & /kati'nwes/ \\
\hline 350. & /saw'ar/ & 370. & /misarapi'roy/ \\
\hline 351. & /sawa'run/ & 371. & /pakwo'how/ \\
\hline
\end{tabular}


A Figura 88 também apresenta o modelo com a estrutura LId, mas organizada por tema. Neste caso, trata-se da parte relacionada a animais/mamíferos, subdividida em grupos (p.ex., do item 347 ao 352 está o grupo das espécies de onça). Esse modelo apresenta dados distribuídos em duas colunas e utiliza a escrita do padrão IPA para a forma fonológica da língua Suruí. Além disso, todos os itens estão numerados e postos entre barras diagonais. ${ }^{160}$

FIGURA 89 - MODELO M3 (LÍNGUA SURUí)

\begin{tabular}{|c|c|c|c|}
\hline 597) & ywyterera [n.III] & 1) & 'aiko [v.int.] \\
\hline 598) & ywyting [n.III] & 2) & 'ar [v.int.] \\
\hline 599) & ywytuhu [n.III] & 3) & 'asupaw [v.int.] \\
\hline 600) & ywytuhuron [n.III] & 4) & 'aw [v.int.] \\
\hline 601) & ywyty [n.III] & 5) & 'e / 'i [v.int.] \\
\hline \multirow[t]{2}{*}{ 602) } & ywytyr [n.III] & 6) & apukaj [v.int.] \\
\hline & & 7) & apukapukaj [v.int.] \\
\hline 1) & namukuj [num.] & 8) & asun [v.int.] \\
\hline 2) & tapisara $[$ num.] & 9) & ata [v.int.] \\
\hline 3) & usepese [num.] & 10) & hem [v.int.] \\
\hline \multirow[t]{2}{*}{ 4) } & yrutehehy [num.] & 11) & ho [v.int.] \\
\hline & & 12) & hyryrym [v.int.] \\
\hline 1) & arumi [pron.] & 13) & ime [v.int.] \\
\hline 2) & ene [pron.] & 14) & kanawa [v.int.] \\
\hline 3) & ere [pron.dep.] & 15) & kasim [v.int.] \\
\hline 4) & ise [pron.] & 16) & $\mathrm{ke}^{[\mathrm{v} \text {.int. }]}$ \\
\hline 5) & pehe [pron.] & 17) & ker [v.int.] \\
\hline 6) & sene [pron.] & 18) & $\mathrm{kuj}$ [v.int.] \\
\hline \multirow[t]{2}{*}{ 7) } & ure [pron.] & 19) & kurug [v.int.] \\
\hline & & 20) & kwahaw [v.int.] \\
\hline
\end{tabular}

Já a Figura 89 apresenta um terceiro arranjo para o modelo com a estrutura LId. Organizada em ordem alfabética (com as formas iniciadas por glotal colocadas como primeiro item dessa ordem), distribuem-se em grupos definidos por suas propriedades gramaticais (nomes, numerais, pronomes, verbos, p.ex.) e com numeração que se reinicia em cada novo grupo. A lista é apresentada em duas colunas, utiliza a escrita ortográfica da língua Suruí e não há nenhum tipo de efeito tipográfico para destacar os itens (ou parte deles). Com relação à indicação gramatical, eu a apresentei para que facilitasse a identificação das respectivas categorias gramaticais, não sendo, portanto, obrigatória. ${ }^{161}$

\footnotetext{
${ }^{160}$ Essa categorização das palavras foi feita por mim com a finalidade exclusiva de ser apresentado nesta tese. Já a base que está sendo construída pelos próprios Suruí no projeto para um dicionário monolíngue, a categorização será realizada por eles mesmos, utilizando também o programa Línguas.

${ }^{161}$ Também estas categorias gramaticais foram definidas para a construção desta tese, pois ainda não foi desenvolvida nenhuma nomenclatura gramatical pelos próprios Suruí.
} 
FIGURA 90 - MODELO M4 (LÍNGUA SURUÍ)

\begin{tabular}{|rrr|}
\hline 'apehaw & akasuhu & tatuhu \\
'yahaw & anuhu & tatyuhu \\
ahekwahaw & ararakonuhu & tukanuhu \\
akojtimahaw & ararunuhu & turihiwnuhu \\
enywahaw & asururonuhu & uruwupeuhu \\
gahaw & asymuhu & uruwutinuhu \\
hahaw & eironuhu & ywytuhu \\
kwahaw & ikysuhu & \\
miahaw & ioronuhu & a'eteteron \\
pokwahaw & ipirarunuhu & akararon \\
puhapuhaw & karuaruhu & iakoron \\
sanupuhaw & kororonuhu & inasaron \\
sautiakarahaw & kujronuhu & ipirakaron \\
seputahaw & mytuwonguhu & kumanaron \\
typyhyhaw & paratuwakonguhu & ma'eahyron \\
upehaw & pisiuhu & misaron \\
upepikyohaw & sakuhu & mojron \\
wahaw & sapuhu & petiwaron \\
yahaw & sawtipeuhu & pina'iron \\
& tarejriuhu & sawaron \\
& & \\
\hline
\end{tabular}

Por fim, a Figura 90 apresenta um quarto arranjo para o modelo com a estrutura LId. Identificadas as terminações dos itens (p.ex., a partir do uso do mesmo sufixo), formamse grupos em que elas são o critério de separação (ordenação de base semasiológica) e, somente aí, dentro de cada grupo, é utilizada a ordem alfabética. O modelo é apresentado em três colunas, utiliza a escrita ortográfica da língua Suruí e há o uso de negrito (bold) para destacar apenas a terminação de cada item. Logo, o que interessa nesse arranjo não é o conteúdo semântico de cada item, mas a sua forma. Esse tipo de organização pode ser útil para a análise morfológica da língua ou seu uso para construção de textos poéticos que utilizem o recurso da rima.

\subsubsection{Modelo MD}

Esse modelo, em relação ao modelo anterior, constitui uma forma ampliada de apresentação de dados de uma ou mais línguas. Com estrutura básica do tipo L: $\{\mathrm{D}\}$, podem ser formadas, por exemplo, as seguintes EML's: (1) LId: \{DId $\}$; (2) LId: \{DPt $\}$; (3) LPt: \{DId\}; (4) LId: \{DId-DPt\}; (5) LPt: \{DPt-DId $\}$; (6) LId: \{DPt-D... $\}$. Dependendo do conteúdo linguístico do descritor, tem-se um dicionário monolíngue (ex. 1), bilíngue (ex. 2 e 3) ou multilíngue (ex. 4 e 5). A seguir, descrevo os modelos baseados nessas estruturas. 


\subsubsection{Modelo MD1 com estrutura LId: $\{$ DId $\}$}

Essa é a microestrutura mais rara, até o momento, no âmbito das línguas indígenas brasileiras (cf. subseção 7.3.4.2), pois ela se refere a materiais lexicográficos monolíngues que possuem Descritor na própria língua do Lema. A seguir, apresento esse modelo com dados da língua Suruí:

\section{FIGURA 91 - MODELO MD1 (LÍNGUA SURUÍ)}

ka'i ka'i iwete okowa'e; upyhyg iwyw ka'ia so uputia warimu irahaj awpita so akakaw yware; ka'ia awiton iapina pisuna.

manimea pykujtawa rog pykujpykujtawa upin mani'og, ukytyg, ukupepyg, umuhaw upykuj.

'og uruhywykaj ywya urumumug ywykwara rupi urumuku'om sura ykupyjta urumusarukong uruupir urukwar; ti roga ti kehaw, uruapo pinowa ku urusehe urukehawamu urukupepyg urusehe; un ti ma'epotawamu aapo rako iako tarukeke taruke ti ma'etiru umuakym rapo amona $\mathrm{n}$ usapy'u rapo tata.

'ogete uruapo ywya urumuseaupyta, uruupir pinowo ipyteripe ywa umuwyhog supatitawa; ipukuete muruwisaw erekehaw asehutese; upuga ruaw murerekotarete; upug ruaw hejkwehe $\mathrm{n}$ uhuwapyguwi namukuj hejkwehe upug.

tapyj ka'ape sepi uruapo tapyj urukehawamum amona wi uruapo tapyj amona neapy awi uruapo; urumonohog sepy ywyra iapoa nune sepi a'eramu uruwerur taapone usaw ka'ape sepi; pinowaku sepi uruupir sepi tapyjromamu.

Esse modelo está organizado em ordem alfabética, com verbetes apresentados em uma única coluna e com o lema destacado com efeito negrito. Nesse tipo de proposta, em que não constam Operadores nem Exemplos (cf. subseção 7.2.1.4.2), é inevitável a comparação dessa estrutura com a de uma enciclopédia, o que não é, em última instância, um problema, haja vista a utilidade que um material com informações culturais detalhadas pode vir a ter, por exemplo, para o povo Suruí.

\subsubsection{Modelo MD2 com estrutura LId: $\{\mathrm{DPt}\}$}

Esse outro modelo diferencia-se do anterior principalmente por envolver uma segunda língua, neste caso o Português. E, dependendo do conteúdo apresentado no campo Descritor, é possível ainda estabelecer uma subdivisão deste modelo em: a) tradução do conteúdo apresentado no modelo MD1 ou b) apresentação de uma ou mais palavras a fim de estabelecer a tradução do Lema em si. 
FIGURA 92 - MODELO MD2a

ka'i. O macaco-prego vive nas copas das árvores; ele desce para pegar ouriço da castanha e sobe com ele na árvore e começa a bater no pau até o ouriço rachar; ele é marrom com a cabeça preta.

manimea pykujtawa rog. Na casa de fazer farinha, a gente rala, prensa e peneira a mandioca. Depois torra ela, mexendo no forno.

'og. Nós cavamos o chão para enfiar a forquilha da casa; nós levantamos o esteio e encaibramos; nós arribamos e amarramos a casa. Depois colocamos todas as coisas pra dentro pra não molhar. Todos ajudam na construção da casa.

'ogete. Para fazer a casa tradicional, cavamos a terra e enfiamos os paus de amarrar rede nos buracos. Depois cobrimos a casa tradicional com a palha do babaçu. Nessa casa, todos nós dormimos nela, mas é o chefe quem dorme perto da porta. Essa casa só tem uma porta para entrar. Antigamente, essa porta não ficava fechada.

Esse modelo está organizado também em ordem alfabética, com verbetes apresentados em uma única coluna e com o lema destacado com efeito negrito. Nele o Descritor é apresentado unicamente em Português, sem, contudo, propor nenhuma palavra como tradução direta do Lema, o que não impede que essa tradução apareça no interior do próprio texto do Descritor.

FIGURA 93 - MODELO MD2b

\begin{tabular}{|c|c|}
\hline pyrongehe piscar & saltu esquerda \\
\hline pyrykyti'i rim & salung lavar-se \\
\hline pyryryryry enrugado & salty lua \\
\hline pysu'o tornozelo & salyaatwy eclipse \\
\hline pyta ficar parado & salytata estrela \\
\hline pyta calcanhar & salytataw'a estrela cadente \\
\hline pyter chupar & saimew panela de barro \\
\hline pytowoiluu bem-te-vi & sakami jacamim \\
\hline$p y w$ seco & sakare jacaré \\
\hline rajty borra & sakare akoj bule \\
\hline remun coceira & sakare asyw cangalha \\
\hline row amargo & sakarehu jacaré-açu \\
\hline ru'ag virar & sakareting jacaretinga \\
\hline nu'aru'ag girar & saku jacu \\
\hline rutyryryg puxar & sakulhu jacutinga \\
\hline sa'i'um barro & sakuna jacundá \\
\hline
\end{tabular}


O modelo apresentado acima possui os itens dispostos em ordem alfabética e divididos em duas colunas. Aos itens da esquerda (na língua Suruí) correspondem itens da direita (em Português), sendo que só o primeiro é destacado com efeito tipográfico (negrito com itálico). Esse modelo, sem nenhum tipo de Operador ou Exemplo, é bastante comum no conjunto das UBL's das línguas indígenas brasileiras e, geralmente, denominado vocabulário.

\subsubsection{Modelo MD3 com estrutura LPt: $\{\mathrm{DId}\}$}

O terceiro modelo corresponde ao inverso do modelo anterior, pois coloca o Português como língua do Lema e a língua indígena fica na posição de Descritor. Aqui também é possível subdividir essa proposta.

FIGURA 94 - MODELO MD3a

casa uruhywykaj ywya urumumug ywykwara rupi urumuku'om sura ykupyjta urumusarukong uruupir urukwar; ti roga ti kehaw, uruapo pinowa ku urusehe urukehawamu urukupepyg urusehe; un ti ma'epotawamu aapo rako iako tarukeke taruke ti ma'etiru umuakym rapo amona $\mathrm{n}$ usapy'u rapo tata.

casa de farinha pykujpykujtawa upin mani'og, ukytyg, ukupepyg, umuhaw upykuj.

casa tradicional uruapo ywya urumuseaupyta, uruupir pinowo ipyteripe ywa umuwyhog supatitawa; ipukuete muruwisaw erekehaw asehutese; upuga ruaw murerekotarete; upug ruaw hejkwehe n uhuwapyguwi namukuj hejkwehe upug.

tapiri ka'ape sepi uruapo tapyj urukehawamum amona wi uruapo tapyj amona neapy awi uruapo; urumonohog sepy ywyra iapoa nune sepi a'eramu uruwerur taapone usaw ka'ape sepi; pinowaku sepi uruupir sepi tapyjromamu.

Esse modelo apresentado na Figura 94 está organizado com lemas dispostos em ordem alfabética (mas também pode ser interpretado com ordenamento por tema, já que todos os itens apresentados pertencem ao mesmo campo semântico de habitação). Nele, apenas o Lema está destacado com efeito negrito e não há nenhum tipo de Operador ou Exemplo.

No levantamento que fiz sobre os tipos de UBL's (cf. subseção 7.3.4.1), não registrei nenhum material lexicográfico que possuísse exatamente a mesma configuração desse modelo.

A seguir, apresento a segunda possibilidade de apresentação deste modelo baseado na EML do tipo LPt $\{$ DId $\}$. 
FIGURA 95 - MODELO MD3b

\begin{tabular}{|c|c|}
\hline coriza yamyw & cunhada eke'i \\
\hline correr son & cunhado ekewen \\
\hline corroer woj & cupim kupi'i \\
\hline cortar em pedaços monohog & cupuaçu kujronuhu \\
\hline cortar monog & curica kykyra'yr \\
\hline cornija masakuw & curimatã karimata \\
\hline coruja-branca pypypypy & curto iaturu'e \\
\hline costela sarukong & cuspir unemun \\
\hline costurar suruhywo & cutia akuti \\
\hline cotovelo parati'iw & cuxiú kutipi \\
\hline coxa uwakasa & dançar purahaj \\
\hline cozinhar muapyg & daqui kokaty \\
\hline criança usawa'e & alar mono \\
\hline cueca ikong su'ar & dedo do pé pyhopi \\
\hline cuia ekuj & dedo indicador pyhope \\
\hline cuieira kujpia ’yw & dedo mindinho puhopi \\
\hline
\end{tabular}

Tal como apresentado no modelo MD2b (acima), mas desta vez com o Lema na língua portuguesa, essa proposta é uma das mais comuns também encontradas no conjunto de UBL's das línguas indígenas brasileiras e a que melhor revela o processo de pesquisa usado há séculos, ou seja, partindo-se de uma base da língua, em geral indo-europeia, para se chegar às formas do léxico da língua indígenas.

\subsubsection{Modelo MD4 com estrutura LId: \{DId-DPt $\}$}

Esse modelo, que também emprega duas línguas na microestrutura, diferencia-se do anterior por apresentar o Descritor nas duas línguas, ou seja, na língua indígena e na língua não indígena (ou vice-versa). Como não faria sentido, neste contexto, apenas repetir como Descritor (DId) o mesmo item do Lema (DId), não há porque apresentar propostas equivalentes às dos modelos MD2b e MD3b. ${ }^{162}$

O Lema aparece destacado com efeito negrito e os dois Descritores são apresentados em sequência, sendo que, na parte em Português, foi aplicado efeito do tipo itálico, a fim de facilitar a identificação desse texto. Além disso, encabeça o segundo Descritor a tradução do Lema, conforme pode ser visto na figura a seguir:

\footnotetext{
${ }^{162}$ A não ser que o Descritor DId se referisse a uma outra língua, mas, neste caso, o modelo corresponderia à de um modelo multilíngue (cf. .........).
} 
FIGURA 96 - MODELO MD4

manimea pykujtawa rog. Pykujpykujtawa upin mani'og, ukytyg, ukupepyg, umuhaw upykuj. Na casa de fazer farinha, a gente rala, prensa e peneira a mandioca. Depois torra ela, mexendo no forno.

'og. Uruhywykaj ywya urumumug ywykwara rupi urumuku'om sura ykupyjta urumusarukong uruupir urukwar; ti roga ti kehaw, uruapo pinowa ku urusehe urukehawamu urukupepyg urusehe. Nós cavamos o chão para enfiar a forquilha da casa; nós levantamos o esteio e encaibramos; nós arribamos e amarramos a casa. Depois colocamos todas as coisas pra dentro pra não molhar. Todos ajudam na construção da casa.

'ogete. Uruapo ywya urumuseaupyta, uruupir pinowo ipyteripe ywa umuwyhog supatitawa; ipukuete muruwisaw erekehaw asehutese; upuga ruaw murerekotarete; upug ruaw hejkwehe n uhuwapyguwi namukuj hejkwehe upug. Para fazer a casa tradicional, cavamos a terra e enfiamos os paus de amarrar rede nos buracos. Depois cobrimos a casa tradicional com a palha do babaçu. Nessa casa, todos nós dormimos nela, mas é o chefe quem dorme perto da porta. Essa casa só tem uma porta para entrar. Antigamente, essa porta não ficava fechada.

\subsubsection{Modelo MD5 com estrutura LPt: \{DPt-DId $\}$}

Este modelo espelha as línguas usadas no modelo MD4, apresentado acima, ou seja, o Lema está em Português com dois Descritores, em Português e na língua indígena, com a tradução do Lema encabeçando o segundo Descritor, tal como apresentado na figura a seguir:

\section{FIGURA 97 - MODELO MD5}

casa. Nós cavamos o chão para enfiar a forquilha da casa; nós levantamos o esteio e encaibramos; nós arribamos e amarramos a casa. Depois colocamos todas as coisas pra dentro pra não molhar. Todos ajudam na construção da casa. 'og. Uruhywykaj ywya urumumug ywykwara rupi urumuku'om sura ykupyjta urumusarukong uruupir urukwar; ti roga ti kehaw, uruapo pinowa ku urusehe urukehawamu urukupepyg urusehe.

casa tradicional. Para fazer a casa tradicional, cavamos a terra e enfiamos os paus de amarrar rede nos buracos. Depois cobrimos a casa tradicional com a palha do babaçu. Nessa casa, todos nós dormimos nela, mas é o chefe quem dorme perto da porta. Essa casa só tem uma porta para entrar. Antigamente, essa porta não ficava fechada. 'ogete. Uruapo ywya urumuseaupyta, uruupir pinowp ipyteripe ywa umuwyhog supatitawa; ipukuete muruwisaw erekehaw asehutese; upuga ruaw murerekotarete; upug ruaw hejkwehe n uhuwapyguwi namukuj hejkwehe upug.

casa de farinha. Na casa de fazer farinha, a gente rala, prensa e peneira a mandioca. Depois torra ela, mexendo no forno. Manimea pykujtawa rog. Pykujpykujtawa upin mani'og, ukytyg, ukupepyg, umuhaw upykuj. 


\subsubsection{Modelo MD6 com estrutura LId: $\{$ DPt-D... $\}$}

Esse sexto modelo proposto engloba, pelo menos, três línguas diferentes. Como o arranjo da estrutura pode variar bastante, pois, qualquer uma das línguas pode ser alçada à posição de Lema, apresento como modelo apenas a proposta com a língua Suruí nesta posição.

FIGURA 98 - MODELO MD6

$\begin{array}{ll}\text { pyrongehe piscar, to blink } & \text { sahug lavar-se, to wash } \\ \text { pyrykyti'i rim, kidney } & \text { sahy lua, moon } \\ \text { pyryryryry enrugado, wrinkled } & \text { sahyauwy eclipse, eclipse } \\ \text { pysu'o tornozelo, ankle } & \text { sahytata estrela, star } \\ \text { pyta ficar parado, stand still } & \text { sahytataw'a estrela cadente, falling star } \\ \text { pyta calcanhar, heel } & \text { saimew panela de barro, clay pot } \\ \text { pyter chupar, to suck } & \text { sakami jacamim, trumpeter } \\ \text { pytowoihu bem-te-vi, great kiskadee } & \text { sakare jacaré, alligator } \\ \text { pyw seco, dry } & \text { sakare akoj bule, teapot } \\ \text { rajty borra, dregs } & \text { sakare asyw cangalha, pack saddle } \\ \text { row amargo, bitter } & \text { sakarehu jacaré-açu, black caiman } \\ \text { ru'ag virar, to turn } & \text { sakareting jacaretinga, white caiman } \\ \text { ru'aru'ag girar, to spin } & \text { saku jacu, penelope } \\ \text { rutyryryg puxar, to pull } & \text { sakuhu jacutinga, black-fronted piping guan } \\ \text { sa'i'um barro, clay } & \text { sakuna jacundá, crenicichla } \\ \text { sahu esquerda, left } & \text { sanipaw jenipapo, genip }\end{array}$

Nesse modelo, com dados da língua Suruí, do Português e do Inglês distribuídos em duas colunas, dois efeitos tipográficos se destacam no texto: o negrito, no Lema, e o itálico, no segundo Descritor. Mesmo com a inserção de três línguas na proposta, não há nela nenhum Operador nem Exemplo. É importante destacar, por fim, que essa estrutura, apesar de pouco frequente, foi constatada no levantamento das UBL's das línguas indígenas brasileiras (cf. subseção 7.3.3.3).

\subsubsection{Modelo MDO}

Esse modelo se difere dos anteriores por conter um terceiro tipo de componente, o Operador, que pode ser, por exemplo, Am, Ar, Et, Fn, Fr, Ft, Gf, Gr, Hm, Mc, Na, Rm, Sm, $\mathrm{Tl}, \mathrm{Vr}$.

Teoricamente, qualquer um desses tipos de Operadores pode ocupar a posição junto a um Descritor, no entanto, o que a pesquisa de EML's dos materiais produzidos para línguas indígenas brasileiras demonstrou é que alguns desses operadores são usados de 
preferência junto ao Lema, tal é o caso dos Operadores Hm, Et e Rm; e os poucos registros de ocorrências desses Operadores junto a Descritores ainda se restringem ao contexto dos do tipo DId.

Assim, nesse modelo, a inserção de Operador(es) apenas para o(s) Descritor(es) leva à construção das seguintes estruturas envolvendo a língua Suruí: (1) LId: \{DId (O)\}; (2) LId: \{DPt (O) \}; (3) LId: \{DId (O) -DPt\}; (4) LPt: \{DPt (O) -DId $\}$; (5) LId: \{DPt (O) -DId \}; (6) LPt: \{DId (O) -DPt\}; (7) LId: \{DId (O) -DPt-D... \}; (8) LPt: \{DId (O) -D... $\}$ e (9) LId: $\{$ DPt (O) -D... $\}$.

\subsubsection{Modelo MDO1 com estrutura LId: $\{$ DId (O) $\}$}

Apresentando as mesmas características do modelo MD1, este modelo para um material monolíngue se distingue daquele por conter um Operador do tipo Ft, apresentado entre parênteses ao final do DId, como pode ser visto a seguir:

FIGURA 99 - MODELO MDO1a

ka'i ka'i iwete okowa'e; upyhyg iwyw ka'ia so uputi'a warimu irahaj awpita so akakaw yware; ka'ia awiton iapina pisuna (Tymykong umume'u).

manimea pykujtawa rog pykujpykujtawa upin mani'og, ukytyg, ukupepyg, umuhaw upykuj (Ikatu umume'u).

'og uruhywykaj ywya urumumug ywykwara rupi urumuku'om sura ykupyjta urumusarukong uruupir urukwar; ti roga ti kehaw, uruapo pinowa ku urusehe urukehawamu urukupepyg urusehe; un ti ma'epotawamu aapo rako iako tarukeke taruke ti ma'etiru umuakym rapo amona n usapy'u rapo tata (Wajwera umume'u).

'ogete uruapo ywya urumuseaupyta, uruupir pinow'o ipyteripe ywa umuwyhog supatitawa; ipukuete muruwisaw erekehaw asehutese; upuga ruaw murerekotarete; upug ruaw hejkwehe n uhuwapyguwi namukuj hejkwehe upug (Wajwera umume'u).

tapyj ka'ape sepi uruapo tapyj urukehawamum amona wi uruapo tapyj amona neapy awi uruapo; urumonohog sepy ywyra iapoa nune sepi a'eramu uruwerur taapone usaw ka'ape sepi; pinowaku sepi uruupir sepi tapyjromamu (Ikatu umume'u).

Outros operadores podem também se relacionar com o DId, tais como: Gr, Mc, Na, Rm e Vr. Além disso, no caso de um material em que o Descritor seja constituído de apenas uma palavra (por exemplo, indicando relações de hiponímia, hiperonímia, sinonímia, antonímia, entre outras), é possível empregar um Operador do tipo Vr para indicar que, para línguas como o Suruí, existe uma variação da palavra quando se emprega o sufixo do caso argumentativo. 
FIGURA 100 - MODELO MDO1b

\begin{tabular}{|ll|}
\hline A'aite & moj (mosa) \\
Akara'i & ipira \\
Inamu'i & wyra \\
Katinkwer & misar (misara) \\
Katykyehyr & tuw (tuwa) \\
Tapi'iting & tapi'ir (tapi'ira) \\
Tatuhu & tatu \\
\hline
\end{tabular}

Nessa proposta de material organizada em ordem alfabética, o Lema destaca-se com efeito negrito e o Descritor na mesma língua possui um Operador Vr, inserido entre parênteses, que apresenta a forma flexionada no caso argumentativo. ${ }^{163}$

\subsubsection{Modelo MDO2 com estrutura LId: $\{\mathrm{DPt}(\mathrm{O})\}$}

Nesse modelo, a inserção da segunda língua altera a relação entre os dois primeiros componentes, pois busca-se traduzir em um outra língua o conteúdo da língua apresentado como Lema. Todavia, esse modelo relaciona-se ao anterior por definir Operadores apenas para o Descritor, como demonstro na figura a seguir:

FIGURA $101-$ MODELO MDO2

\begin{tabular}{|ll|}
\hline AMUTINING maracá (tipo) & POPI anelar (dedo) \\
EMISARIRU neto (mulher falando) & PUHUKUPE sola (do pé) \\
ETYMASI'A canela (parte do corpo) & PYHEJ lavar (coisa) \\
HYRETOM cera (de abelha) & SUMI'A flauta (tipo) \\
KUPITAW sapo (esp.) & SYRUHEJ lavar (roupa) \\
KURETA'U tucano (esp.) & TYPAW seco (de líquido) \\
MISARAPIRONG veado-vermelho (veado-mateiro) & UKYSETEWA'E medroso (humano) \\
PETYMA PISARA tabaco (fumo) & URE nós (excl.) \\
PINA'IRONA'Yw graviola (árvore) & YMEMUR filhote (de bicho) \\
\hline
\end{tabular}

A informação do Operador Na se relaciona ao conteúdo do Descritor, a fim de desambiguar, especificar ou ampliar a informação contida neste componente.

\footnotetext{
${ }^{163}$ Um Operador pode ser obrigatório ou optativo dependendo da natureza do projeto lexicográfico, no entanto, há Operadores que são usados com maior frequência, como, por exemplo, os do tipo Et, Fn, Gr, Na, Rm e Vr.
} 


\subsubsection{Modelo MDO3 com estrutura LId: $\{$ DId (O) -DPt $\}$}

Com estrutura semelhante à do modelo MD4, o MDO3 diferencia-se por apresentar um Operador (neste caso, a título de exemplo, é um Operador do tipo Ft) para o DId. Esse novo componente relaciona-se diretamente com um dos Descritores, especificando qual a fonte da informação usada no DId, conforme a figura a seguir:

$$
\text { FIGURA } 102 \text { - MODELO MDO3a }
$$

ka'i ka'i iwete okowa'e; upyhyg iwyw ka'ia so uputi'a warimu irahaj awpita so akakaw yware; ka'ia awiton iapina pisuna (Tymykong umume'u). Macaco-prego. Ele vive nas copas das árvores; ele desce para pegar ouriço da castanha e sobe com ele na árvore e começa a bater no pau até o ouriço rachar; ele é marrom com a cabeça preta.

'og uruhywykaj ywya urumumug ywykwara rupi urumuku'om sura ykupyjta urumusarukong uruupir urukwar; ti roga ti kehaw, uruapo pinowa ku urusehe urukehawamu urukupepyg urusehe; un ti ma'epotawamu aapo rako iako tarukeke taruke ti ma'etiru umuakym rapo amona n usapy'u rapo tata (Wajwera umume'u). Casa. Nós cavamos o chão para enfiar a forquilha da casa; nós levantamos o esteio e encaibramos; nós arribamos e amarramos a casa. Depois colocamos todas as coisas pra dentro pra não molhar. Todos ajudam na construção da casa.

'ogete uruapo ywya urumuseaupyta, uruupir pinowo ipyteripe ywa umuwyhog supatitawa; ipukuete muruwisaw erekehaw asehutese; upuga ruaw murerekotarete; upug ruaw hejkwehe $\mathrm{n}$ uhuwapyguwi namukuj hejkwehe upug (Wajwera umume'u). Casa tradicional. Para fazer a casa tradicional, cavamos a terra e enfiamos os paus de amarrar rede nos buracos. Depois cobrimos a casa tradicional com a palha do babaçu. Nessa casa, todos nós dormimos nela, mas é o chefe quem dorme perto da porta. Essa casa só tem uma porta para entrar. Antigamente, essa porta não ficava fechada.

Por conter Descritores com textos longos o uso de apenas uma coluna na construção do modelo pode facilitar a leitura do material.

Outra possibilidade de apresentação dessa estrutura é a que se aproxima do modelo MDO1b, porém com o acréscimo da segunda língua:

FIGURA 103 - MODELO MDO3b

\begin{tabular}{|ll|}
\hline A'aite & moj (mosa), jiboia \\
Akara'i & ipira, carazinho \\
Inamu'i & wyra, inambumirim \\
Katinkwer & misar (misara), veado-virá \\
Katykyehyr & tuw (tuwa), abelha (esp.) \\
Tapi'iting & tapi'ir (tapi'ira), anta-branca (esp.) \\
Tatuhu & tatu, tatu-canastra \\
\end{tabular}


Nesse modelo, a língua do segundo Descritor, destaca com itálico, não corresponde a uma tradução do primeiro Descritor, mas sim do conteúdo do Lema. Contudo, no modelo MDO7a, apresentado em subseção subsequente, o segundo Descritor possui um Operador que contém também a tradução do primeiro Descritor.

\title{
9.1.3.4. Modelo MDO4 com estrutura LPt: $\{\mathrm{DPt}(\mathrm{O})-\mathrm{DId}\}$
}

Já o modelo MDO4 dá destaque para o uso do Português, pois tanto o Lema, quanto o primeiro Descritor com seu Operador estão nesta língua. Apesar de ser possível construir um material lexicográfico de uma língua indígena com estas características, essa forma de organização da microestrutura é encontrada com frequência em materiais lexicográficos monolíngues (do Português), em que a língua indígena serve apenas para indicar, por exemplo, a etimologia do Lema. ${ }^{164}$

\section{FIGURA 104 - MODELO MDO4}

\begin{abstract}
Casa. Nós cavamos o chão para enfiar a forquilha da casa; nós levantamos o esteio e encaibramos; nós arribamos e amarramos a casa. Depois colocamos todas as coisas pra dentro pra não molhar. Todos ajudam na construção da casa. (A construção de uma casa é uma ação coletiva na comunidade Suruí, na qual participam homens, mulheres e crianças, cada um desempenhando papéis específicos). 'og. uruhywykaj ywya urumumug ywykwara rupi urumuku'om sura ykupyjta urumusarukong uruupir urukwar; ti roga ti kehaw, uruapo pinowa ku urusehe urukehawamu urukupepyg urusehe; un ti ma'epotawamu aapo rako iako tarukeke taruke ti ma'etiru umuakym rapo amona n usapy'u rapo tata. Casa tradicional. Para fazer a casa tradicional, cavamos a terra e enfiamos os paus de amarrar rede nos buracos. Depois cobrimos a casa tradicional com a palha do babaçu. Nessa casa, todos nós dormimos nela, mas é o chefe quem dorme perto da porta. Essa casa só tem uma porta para entrar. Antigamente, essa porta não ficava fechada. (Atualmente, esse tipo de casa não é mais construída para fins de habitação, apenas como forma de manter a tradição). 'ogete. uruapo ywya urumuseaupyta, uruupir pinowo ipyteripe ywa umuwyhog supatitawa; ipukuete muruwisaw erekehaw asehutese; upuga ruaw murerekotarete; upug ruaw hejkwehe n uhuwapyguwi namukuj hejkwehe.

Macaco-prego. Ele vive nas copas das árvores; ele desce para pegar ouriço da castanha e sobe com ele na árvore e começa a bater no pau até o ouriço rachar; ele é marrom com a cabeça preta (na língua Suruí a palavra usada para designar 'macaco-prego' é também empregada para a forma genérica 'macaco'). Ka'i. ka'i iwete okowa'e; upyhyg iwyw ka'ia so uputi'a warimu irahaj awpita so akakaw yware; ka'ia awiton iapina pisuna.
\end{abstract}

Com apenas uma coluna, esse modelo apresenta notas histórico-culturais como Operadores que complementam a informação do Descritor e que vêm destacadas entre parênteses. Essas notas foram inseridas por mim, mas elas podem ser construídas também pelos próprios autores do texto do Descritor.

\footnotetext{
${ }^{164}$ Para exemplificar o uso desse tipo de estrutura em línguas da família Tupí-Guaraní, cf. as UBL's dos seguintes materiais: Silveira Bueno (1987, p. 23-382) e Clerot (2010, p. 17-514).
} 
Outra observação relevante é que, mesmo que três componentes da EML estejam em Português, isso não diminui o valor educacional-informativo-cultural da obra, uma vez que o texto pode ser construído com a própria variante de Português usada na comunidade indígena, revelando toda a sua cosmovisão de seus criadores.

\title{
9.1.3.5. Modelo MDO5 com estrutura LId: $\{$ DPt $(\mathrm{O})-\mathrm{DId}\}$
}

Esse quinto modelo é um dos menos comuns, porque, ao iniciar a EML com um LId, reutiliza a mesma língua apenas como segundo Descritor. A seguir, apresento este modelo:

\section{FIGURA 105 - MODELO MDO5}

\begin{abstract}
'og. Casa. Nós cavamos o chão para enfiar a forquilha da casa; nós levantamos o esteio e encaibramos; nós arribamos e amarramos a casa. Depois colocamos todas as coisas pra dentro pra não molhar. Todos ajudam na construção da casa. (A construção de uma casa é uma ação coletiva na comunidade Suruí, na qual participam homens, mulheres e crianças, cada um desempenhando papéis específicos). Uruhywykaj ywya urumumug ywykwara rupi urumuku'om sura ykupyjta urumusarukong uruupir urukwar; ti roga ti kehaw, uruapo pinowa ku urusehe urukehawamu urukupepyg urusehe; un ti ma'epotawamu aapo rako iako tarukeke taruke ti ma'etiru umuakym rapo amona $n$ usapy'u rapo tata.

'ogete. Casa tradicional. Para fazer a casa tradicional, cavamos a terra e enfiamos os paus de amarrar rede nos buracos. Depois cobrimos a casa tradicional com a palha do babaçu. Nessa casa, todos nós dormimos nela, mas é o chefe quem dorme perto da porta. Essa casa só tem uma porta para entrar. Antigamente, essa porta não ficcava fechada. (Atualmente, esse tipo de casa não é mais construída para fins de habitação, apenas como forma de manter a tradição). Uruapo ywya urumuseaupyta, uruupir pinowo ipyteripe ywa umuwyhog supatitawa; ipukuete muruwisaw erekehaw asehutese; upuga ruaw murerekotarete; upug ruaw hejkwehe n uhuwapyguwi namukuj hejkwehe.

$K \boldsymbol{K} \boldsymbol{i} i$. Macaco-prego. Ele vive nas copas das árvores; ele desce para pegar ouriço da castanha e sobe com ele na árvore e começa a bater no pau até o ouriço rachar; ele é marrom com a cabeça preta (na língua Suruí a palavra usada para designar 'macaco-prego' é também empregada para a forma genérica 'macaco'). ka'i iwete okowa'e; upyhyg iwyw ka'ia so uputi'a warimu irahaj awpita so akakaw yware; ka'ia awiton iapina pisuna.
\end{abstract}

O modelo MDO5 também é apresentado em uma coluna, com Lema destacado com efeito negrito e o DId, com itálico.

\subsubsection{Modelo MDO6 com estrutura LPt: $\{\mathrm{DId}(\mathrm{O})-\mathrm{DPt}\}$}

Esse modelo apresenta uma estrutura similar à do modelo MDO4, porém com a mudança da posição do DPt pelo DId. Com isso, o Operador passa a se referir ao conteúdo da língua indígena. Assim como o anterior, esse modelo também não é muito recorrente no conjunto de UBL's das línguas indígenas brasileiras. Apresento, a seguir, um exemplo desta proposta: 
FIGURA 106 - MODELO MDO6

Casa. 'og. uruhywykaj ywya urumumug ywykwara rupi urumuku'om sura ykupyjta urumusarukong uruupir urukwar; ti roga ti kehaw, uruapo pinowa ku urusehe urukehawamu urukupepyg urusehe; un ti ma'epotawamu aapo rako iako tarukeke taruke ti ma'etiru umuakym rapo amona n usapy'u rapo tata (Wajwera umume'u). Nós cavamos o chão para enfiar a forquilha da casa; nós levantamos o esteio e encaibramos; nós arribamos e amarramos a casa. Depois colocamos todas as coisas pra dentro pra não molhar. Todos ajudam na construção da casa.

Casa de farinha. manimea pykujtawa rog. pykujpykujtawa upin mani'og, ukytyg, ukupepyg, umuhaw upykuj (Ikatu umume'u). Na casa de fazer farinha, a gente rala, prensa e peneira a mandioca. Depois torra ela, mexendo no forno.

Casa tradicional. 'ogete. uruapo ywya urumuseaupyta, uruupir pinowo ipyteripe ywa umuwyhog supatitawa; ipukuete muruwisaw erekehaw asehutese; upuga ruaw murerekotarete; upug ruaw hejkwehe n uhuwapyguwi namukuj hejkwehe (Wajwera umume'u). Para fazer a casa tradicional, cavamos a terra e enfiamos os paus de amarrar rede nos buracos. Depois cobrimos a casa tradicional com a palha do babaçu. Nessa casa, todos nós dormimos nela, mas é o chefe quem dorme perto da porta. Essa casa só tem uma porta para entrar. Antigamente, essa porta não fícava fechada.

Macaco-prego. Ka'i. ka'i iwete okowa'e; upyhyg iwyw ka'ia so uputi'a warimu irahaj awpita so akakaw yware; ka'ia awiton iapina pisuna (Tymykong umume'u). Ele vive nas copas das árvores; ele desce para pegar ouriço da castanha e sobe com ele na árvore e começa a bater no pau até o ouriço rachar; ele é marrom com a cabeça preta.

Com verbetes organizados em ordem alfabética, essa proposta destaca com negrito o Lema em Português e com itálico, o primeiro Descritor. Junto ao DId está um Operador do tipo Ft.

\subsubsection{Modelo MDO7 com estrutura LId: \{DId (O) -DPt-D... $\}$}

Igualmente raro no conjunto de línguas indígenas brasileiras, esse modelo com entrada LId envolve Descritores em três ou mais línguas, e cada um deles podendo ter seu próprio Operador. Esse modelo pode ser construído sob duas perspectivas:

- a primeira, que é mais frequente, envolve a língua indígena, neste caso, o Suruí, uma segunda língua, o Português, e a terceira língua não obrigatória e com ocorrências pontuais, como o Latim, no caso da nomenclatura técnica de plantas e animais;

- a segunda, que é menos frequente, envolve as duas primeiras línguas da perspectiva anterior e uma terceira língua, por exemplo, o Inglês, o Francês ou o Espanhol (as mais comuns nesse contexto), usadas em todos os verbetes do material lexicográfico.

Apresento, a seguir, exemplos dos modelos baseados nessas duas perspectivas de organização da microestrutura: 
FIGURA 107 - MODELO MDO7a

\begin{tabular}{|ll|}
\hline A'aite & moj (mosa), jiboia, boa constrictor \\
Akara'i & ipira, carazinho \\
Inamu'i & wyra, inambumirim, crypturellus tataupa \\
Katinkwer & misar (misara), veado-virá, mazama gouazoubira \\
Katykyehyr & tuw (tuwa), abelha (esp.) \\
Tapi'iting & tapi'ir (tapi'ira), anta-branca (esp.), tapirus terrestris \\
Tatuhu & tatu, tatu-canastra, priodontes maximus \\
\hline
\end{tabular}

Nesse modelo, destaquei o Lema com efeito negrito e o terceiro Descritor, com efeito itálico. É importante observar que somente três verbetes do conjunto possuem o terceiro Descritor, justamente aqueles relacionados a espécies animais. ${ }^{165}$

Já no modelo seguinte, todos os verbetes apresentam o terceiro Descritor, conforme pode ser observado na figura a seguir:

FIGURA 108 - MODELO MDO7b

\begin{tabular}{|ll|}
\hline A'aite & moj (mosa), jiboia, boa constrictor \\
Akara'i & ipira, carazinho \\
Inamu'i & wyra, inambumirim, tataupa tinamou \\
Katinkwer & misar (misara), veado-virá, gray brocket \\
Katykyehyr & tuw (tuwa), abelha (esp.), bee \\
Tapi'iting & tapi'ir (tapi'ira), anta-branca (esp.), Brazilian tapir \\
Tatuhu & tatu, tatu-canastra, giant armadillo \\
\hline
\end{tabular}

Esse modelo contém DId, DPt e DIn, sendo que somente o primeiro possui Operador, e somente o último está destacado com itálico. Neste caso, o DIn corresponde a uma tradução do conteúdo do DPt, que, por sua vez, busca traduzir o LId, do mesmo modo como no modelo MDO3b.

Ainda com relação ao modelo MDO7b, ele pode apresentar uma variação se nele for introduzido o Descritor em Latim, uma vez que este ocorre em um contexto bem definido.

${ }^{165}$ Os nomes científicos em Latim usados neste modelo foram extraídos de Houaiss (2009). 
FIGURA 109 - MODELO MDO7c

\begin{tabular}{|ll|}
\hline A'aite & moj (mosa), jiboia, boa constrictor [boa constrictor] \\
Akara'i & ipira, carazinho \\
Inamu'i & wyra, inambumirim, tataupa tinamou [crypturellus tataupa] \\
Katinkwer & misar (misara), veado-virá, gray brocket [mazama gouazoubira] \\
Katykyehyr & tuw (tuwa), abelha (esp.), bee \\
Tapi'iting & tapi'ir (tapi'ira), anta-branca (esp.), Brazilian tapir [tapirus terrestris] \\
Tatuhu & tatu, tatu-canastra, giant armadillo [priodontes maximus] \\
\hline
\end{tabular}

Além das marcas tipográficas descritas acima, destaquei, nesse modelo, o DLt, colocando-o entre colchetes, ao final do verbete; dessa forma, esse Descritor pode ser facilmente identificado no conjunto de verbetes.

\subsubsection{Modelo MDO8 com estrutura LPt: $\{$ DId (O) -D... $\}$}

O penúltimo modelo do tipo MDO coloca na posição de Lema uma língua não indígena, neste caso o Português, e o Operador relacionado ao DId. Já os demais Descritores possuem línguas diferentes das usadas no Lema e no primeiro Descritor; essas outras línguas podem ser tanto línguas, por exemplo, de origem indo-europeia, como o Inglês, o Espanhol, o Francês, ou mesmo outras línguas indígenas, da mesma família linguística da língua do DId (neste caso, por exemplo o Asuriní do Trocará, o Tembé, o Parakanã, ou de famílias diferentes. ${ }^{166}$ Apresento, a seguir, um exemplo desta proposta:

FIGURA 110 - MODELO MDO8

\begin{tabular}{|ll|}
\hline abelha (esp.) & katykyehyr (tuw), bee, abeja \\
anta-branca (esp.) & tapi'iting, Brazilian tapir, tapir amazónico [tapirus terrestris] \\
carazinho & akara'i (ipira), acara, castañeta \\
inambumirim & inamu'i (wyra), tataupa tinamou, tataupá común [crypturellus tataupa] \\
jiboia & a'aite (moj), boa constrictor, boa constrictora [boa constrictor] \\
tatu-canastra & tatuhu, giant armadillo, armadillo gigante [priodontes maximus] \\
veado-virá & katinkwer (misar), gray brocket, guazuncho [mazama gouazoubira]
\end{tabular}

\footnotetext{
${ }^{166}$ Sem dúvida, isso não impede ainda que um dos descritores tenha a mesma língua do Lema, neste caso, o Português.
} 
A estrutura desse modelo é bem semelhante à do modelo MDO7d, porém, com a diferença que a língua Suruí entra como primeiro Descritor e não como Lema.

Apesar de serem possíveis muitas outras variações desse mesmo modelo, esclareço que não apresentarei todas elas aqui, haja vista que a quantidade indefinida de Descritores levaria também a uma quantidade igual de arranjos, todos apenas com mudança do Descritor que receberia o Operador.

\subsubsection{Modelo MDO9 com estrutura LId: $\{$ DPt (O) -D... $\}$}

Esse modelo contém Descritores em línguas diferentes da língua do LId, como pode ser observado na figura a seguir:

FIGURA 111 - MODELO MDO9

\begin{tabular}{|ll|}
\hline a'aite & jiboia (suaçu), boa constrictor, boa constrictora (mantona) \\
akara'i & carazinho (caraí), acara, castañeta \\
inamu'i & inambumirim (inambuzinho), tataupa tinamou, tataupá común \\
katinkwer & veado-virá (veado-mateiro), gray brocket, guazuncho (viracho, guazú virá) \\
katykyehyr & abelha (esp.), bee, abeja \\
tapi'iting & anta-branca (esp.), Brazilian tapir, tapir amazónico (mboreví, pinchaque) \\
tatuhu & tatu-canastra, giant armadillo, armadillo gigante (tatú carreta, pejichi) \\
\end{tabular}

Nesse modelo, dos três Descritores, dois apresentam Operadores, ou seja, o DPt e o DEs possuem operadores do tipo Vr. Decidir se um ou mais Descritores receberão operadores, e que operadores serão esses, é decisão exclusiva do PDL.

\subsubsection{Modelo MDE}

O quarto modelo de material lexicográfico não contém Operadores, mas sim Exemplos. Tal como apresentado no Capítulo 7 desta tese, o componente Exemplo é, geralmente, dividido em dois tipos, exemplos e abonação. ${ }^{167}$ Assim como os demais, esse modelo varia conforme a quantidade de línguas envolvidas e a disposição dos seus componentes. Por isso, são possíveis as seguintes estruturas envolvendo a língua Suruí: (1) LId: $\{$ DId [EId] $\}$; (2) LId: $\{$ DPt [EId] $\}$; (3) LId: $\{$ DPt [EId/EPt] $\}$; (4) LPt: \{DId [EId] $\}$; (5) LPt: $\{$ DId [EId/EPt] $\}$; (6) LId: \{DId-DPt [EId/EPt] ; (7) LPt: \{DPt-DId [EPt/EId] $\}$; (8) LId: \{DId-DPt-D... [EId/EPt/E...]\}; (9) LId: \{DPt-D... [EId/EPt/E...]\}.

\footnotetext{
${ }^{167}$ Para uma discussão mais detalhada sobre esse tema, cf. Welker (2004, p. 149-159) e Atkins e Rundell (2008, p. 452-461).
} 


\subsubsection{Modelo MDE1 com estrutura LId: \{DId [EId]\}}

Esse modelo é o que corresponde ao material monolíngue, pois todos os componentes se referem somente à língua Suruí, conforme exemplo a seguir:

\section{FIGURA 112 - MODELO MDE1}

manimea pykujtawa rog pykujpykujtawa upin mani'og, ukytyg, ukupepyg, umuhaw upykuj. Ajnon: aha puta manime roga pupe wewahema.

'og uruhywykaj ywya urumumug ywykwara rupi urumuku'om sura ykupyjta urumusarukong uruupir urukwar; ti roga ti kehaw, uruapo pinowa ku urusehe urukehawamu urukupepyg urusehe; un ti ma'epotawamu aapo rako iako tarukeke taruke ti ma'etiru umuakym rapo amona n usapy'u rapo tata. Ajnon: asehu tese saupir sene rehe 'og; ti popytywo e apo 'og; ti rehe taketehewehe ne wy wekow.

'ogete uruapo ywya urumuseaupyta, uruupir pinowo ipyteripe ywa umuwyhog supatitawa; ipukuete muruwisaw erekehaw asehutese; upuga ruaw murerekotarete; upug ruaw hejkwehe $\mathrm{n}$ uhuwapyguwi namukuj hejkwehe upug. Ajnon: uruapo puta 'ogete semu'etawa ukaripe uruapo puta 'ogete $t$ uesag wehe warasu tywo, 'og $t$ unawa.

Apresentado em uma coluna, em ordem alfabética e com Lema em negrito, esse modelo contém em todos os verbetes enunciados precedidos por ajnon, usado, neste contexto, para marcar os exemplos, que estão destacados com efeito itálico.

É necessário observar que a discussão acerca da natureza do enunciado a ser usado como exemplo ou abonação em determinada obra lexicográfica torna-se um pouco mais complexa se se considerar que línguas como o Suruí, que apenas começam a ser escritas pela comunidade Aikewára, ainda não dispõe de um acervo de língua escrita, por conseguinte, ainda não estabeleceu o que pode ser denominado literatura escrita. Por isso, todos os exemplos devem ser buscados diretamente no conjunto de registros orais.

\subsubsection{Modelo MDE2 com estrutura LId: $\{\mathrm{DPt}[\mathrm{EId}]\}$}

Esse segundo modelo possui o Descritor em uma língua diferente da do Lema, situação já observada nos modelos MD2, MD6, MDO2 e MDO5. Todavia, no componente Exemplo, volta-se a utilizar a língua indígena, sem a correspondente tradução para o Português. Tal proposta não foi ainda registrada no conjunto dos materiais lexicográficos das línguas indígenas brasileiras. 
FIGURA 113 - MODELO MDE2

ka'i Ele vive nas copas das árvores; ele desce para pegar ouriço da castanha e sobe com ele na árvore e começa a bater no pau até o ouriço rachar; ele é marrom com a cabeça preta. Ajnon: ka'ia usemuaraj yware ywokomumepem.

manimea pykujtawa rog $\mathrm{Na}$ casa de fazer farinha, a gente rala, prensa e peneira a mandioca. Depois torra ela, mexendo no forno. Ajnon: aha puta manime roga pupe wewahema.

'og Nós cavamos o chão para enfiar a forquilha da casa; nós levantamos o esteio e encaibramos; nós arribamos e amarramos a casa. Depois colocamos todas as coisas pra dentro pra não molhar. Todos ajudam na construção da casa. Ajnon: asehu tese saupir sene rehe 'og; ti popytywo e apo 'og; ti rehe taketehewehe ne wy wekow.

'ogete Para fazer a casa tradicional, cavamos a terra e enfiamos os paus de amarrar rede nos buracos. Depois cobrimos a casa tradicional com a palha do babaçu. Nessa casa, todos nós dormimos nela, mas é o chefe quem dorme perto da porta. Essa casa só tem uma porta para entrar. Antigamente, essa porta não ficava fechada. Ajnon: uruapo puta 'ogete semu'etawa ukaripe uruapo puta 'ogete t uesag wehe warasu tywo, 'og t unawa.

Talvez a não ocorrência desse modelo se deva ao fato de ele apresentar um Descritor em Português e não realizar a tradução do conteúdo do Exemplo, o que é feito no modelo próximo modelo.

\subsubsection{Modelo MDE3 com estrutura LId: $\{\mathrm{DPt}[\mathrm{EId} / \mathrm{EPt}]\}$}

Esse modelo se difere do anterior por apresentar a tradução do EId para a mesma língua do Descritor. A figura seguinte exemplifica esse tipo de modelo:

\section{FIGURA 114 - MODELO MDE3a}

ka'i macaco-prego. Ele vive nas copas das árvores; ele desce para pegar ouriço da castanha e sobe com ele na árvore e começa a bater no pau até o ouriço rachar; ele é marrom com a cabeça preta. Ajnon: ka'ia usemuaraj yware ywokomumepem o macaco-prego brinca no galho da árvore e quebra os galhos.

manimea pykujtawa rog casa de farinha. Na casa de fazer farinha, a gente rala, prensa e peneira a mandioca. Depois torra ela, mexendo no forno. Ajnon: aha puta manime roga pupe wewahema eu vou chegando para dentro da casa de farinha.

'og casa. Nós cavamos o chão para enfiar a forquilha da casa; nós levantamos o esteio e encaibramos; nós arribamos e amarramos a casa. Depois colocamos todas as coisas pra dentro pra não molhar. Todos ajudam na construção da casa. Ajnon: asehu tese saupir sene rehe 'og nós todos juntos vamos construir a casa; ti popytywo e apo 'og eu ajudo a fazer a casa.

'ogete casa tradicional. Para fazer a casa tradicional, cavamos a terra e enfiamos os paus de amarrar rede nos buracos. Depois cobrimos a casa tradicional com a palha do babaçu. Nessa casa, todos nós dormimos nela, mas é o chefe quem dorme perto da porta. Essa casa só tem uma porta para entrar. Antigamente, essa porta não ficava fechada. Ajnon: uruapo puta 'ogete semu'etawa ukaripe vamos fazer a casa tradicional no terreno onde a gente estuda; uruapo puta 'ogete $t$ uesag wehe warasu tywo, 'og $t$ unawa vamos fazer a casa tradicional para os não índios poderem ver. 
Mesmo com o componente Exemplo nas duas línguas, o modelo MDE3a com o DPt mais desenvolvido não é comum no conjunto das línguas indígenas brasileiras. Por isso, apresento a variação desse modelo, esta sim mais comum, em que o Descritor é apresentado sob a forma de uma palavra que traduz o Lema.

FIGURA 115 - MODELO MDE3b

ka'i macaco-prego. Ajnon: ka'ia usemuaraj yware ywokomumepem; o macacoprego brinca no galho da árvore e quebra os galhos.

manimea pykujtawa rog casa de farinha. Ajnon: aha puta manime roga pupe wewahema; eu vou chegando para dentro da casa de farinha.

'og casa. Ajnon: asehu tese saupir sene rehe 'og; eu vou chegando para dentro da casa de farinha; ti popytywo e apo 'og; eu ajudo a fazer a casa.

'ogete casa tradicional. Ajnon: uruapo puta 'ogete semu'etawa ukaripe; vamos fazer a casa tradicional no terreno onde a gente estuda; uruapo puta 'ogete $t$ uesag wehe warasu tywo; vamos fazer a casa tradicional para os não índios poderem ver.

No corpus de UBL's das línguas indígenas brasileiras, utilizado nesta pesquisa, constatei que, em geral, o componente Exemplo vem destacado com efeitos tipográficos (itálico, negrito, sublinhado); mas, outras vezes, ele pode vir precedido por símbolos do tipo • ou || ou "'” ou : entre outros, ou ainda ser diretamente identificado com a palavra exemplo ou abreviatura desta. Esta decisão de qual efeito ou marcador utilizar é exclusiva do projeto gráfico definido no interior do PDL.

No modelo acima, mantive busquei estabelecer um padrão: sem efeito para o Português, com efeito para o Suruí (negrito para o Lema e itálico para o Exemplo). Além disso, indiquei o Exemplo com uma palavra da língua Suruí, conforme mencionado na subseção 9.1.4.1, seguindo, desta forma, a mesma língua do LId.

\subsubsection{Modelo MDE4 com estrutura LPt: $\{$ DId [EId] $\}$}

Nesse quarto modelo, a língua indígena está em dois componentes, no Descritor e no Exemplo, mas o ordenamento é feito a partir da língua não indígena. Essa proposta é extremamente rara no corpus de UBL's reunido nesta pesquisa, uma vez que não é muito comum que os materiais lexicográficos apresentem o Exemplo sem a respectiva tradução.

A figura 116, a seguir, contém uma amostra desse modelo: 
FIGURA 116 - MODELO MDE4a

casa uruhywykaj ywya urumumug ywykwara rupi urumuku'om sura ykupyjta urumusarukong uruupir urukwar; ti roga ti kehaw, uruapo pinowa ku urusehe urukehawamu urukupepyg urusehe; un ti ma'epotawamu aapo rako iako tarukeke taruke ti ma'etiru umuakym rapo amona n usapy'u rapo tata. Ajnon: asehu tese saupir sene rehe 'og; ti popytywo e apo 'og; ti rehe taketehewehe ne wy wekow.

casa de farinha pykujpykujtawa upin mani'og, ukytyg, ukupepyg, umuhaw upykuj. Ajnon: aha puta manime roga pupe wewahema.

casa tradicional uruapo ywya urumuseaupyta, uruupir pinowo ipyteripe ywa umuwyhog supatitawa; ipukuete muruwisaw erekehaw asehutese; upuga ruaw murerekotarete; upug ruaw hejkwehe $\mathrm{n}$ uhuwapyguwi namukuj hejkwehe upug. Ajnon: uruapo puta 'ogete semu'etawa ukaripe uruapo puta 'ogete $t$ uesag wehe warasu tywo, 'og t unawa.

macaco-prego ka'i iwete okowa'e; upyhyg iwyw ka'ia so uputi'a warimu irahaj awpita so akakaw yware; ka'ia awiton iapina pisuna. Ajnon: ka'ia usemuaraj yware ywokomumepem.

Nesse modelo, o LPt vem destacado com efeito negrito e o EId, com itálico. Já o DId está em caixa normal, sem efeito. Esse Descritor com texto na língua Suruí pode ser substituído apenas por uma palavra ou expressão que busque traduzir o conteúdo do LPt. Essa variação do modelo teria a seguinte forma:

FIGURA 117 - MODELO MDE4b

cachorro ma'esawar. Ajnon: unupo ma'esawara; ma'esawara puta usekyj mosa u'uramu; esemuhaku'i ke! ma'esawara rapo ne u'u cavar hywykaj. Ajnon: ywykwara ahywykaj; ti se'eromamu puta ri'a ahywykaj dar mono Ajnon: syryg puta amono ne irua pe; ko, amono ne upe; ajko na amonowi ne upe

farinha de mandioca manime. Ajnon: manimea ko amumaraw wyra'yra rupi'a homem akuma'e. Ajnon: akuma'e akuraete; ajko re wehe rako aesag akuma'e; moron puta pe akuma'e ihoj osuna?

matar suka. Ajnon: pehe puta pesuka ma'ea pesehow?; aha puta ri'a isukaw tasahuamu; esuka puhi

morrer sekyj. Ajnon: akuma'e usekyi; ma'esawara puta usekyj mosa u'uramu mulher kuso. Ajnon: kuso sysyng; ma'eramu pa'e kuso nu se'engara uwi?; ure kuso teseramu uruho ytyma mani'og roko urutym

redondo 'apu'a. Ajnon: kuipia i'apu'a; tehahua i'apu'a 


\subsubsection{Modelo MDE5 com estrutura LPt: $\{$ DId [EId/EPt] $\}$}

Este modelo assemelha-se ao anterior, porém apresenta o componente Exemplo na mesma língua do Lema. Com esse acréscimo, essa EML coincide com a usada em vários materiais lexicográficos de línguas indígenas brasileiras. A seguir, apresento o modelo principal com a sua respectiva variação.

\section{FIGURA 118 - MODELO MDE5a}

casa uruhywykaj ywya urumumug ywykwara rupi urumuku'om sura ykupyjta urumusarukong uruupir urukwar; ti roga ti kehaw, uruapo pinowa ku urusehe urukehawamu urukupepyg urusehe; un ti ma'epotawamu aapo rako iako tarukeke taruke ti ma'etiru umuakym rapo amona $n$ usapy'u rapo tata. Ajnon: asehu tese saupir sene rehe 'og eu vou chegando para dentro da casa de farinha; ti popytywo e apo 'og; ti rehe taketehewehe ne wy wekow; eu ajudo a fazer a casa.

casa de farinha pykujpykujtawa upin mani'og, ukytyg, ukupepyg, umuhaw upykuj. Ajnon: aha puta manime roga pupe wewahema.; eu vou chegando para dentro da casa de farinha

casa tradicional uruapo ywya urumuseaupyta, uruupir pinowo ipyteripe ywa umuwyhog supatitawa; ipukuete muruwisaw erekehaw asehutese; upuga ruaw murerekotarete; upug ruaw hejkwehe n uhuwapyguwi namukuj hejkwehe upug. Ajnon: uruapo puta 'ogete semu'etawa ukaripe vamos fazer a casa tradicional no terreno onde a gente estuda; uruapo puta 'ogete $t$ uesag wehe warasu tywo, 'og t unawa vamos fazer a casa tradicional para os não índios poderem ver.

macaco-prego ka'i iwete okowa'e; upyhyg iwyw ka'ia so uputi'a warimu irahaj awpita so akakaw yware; ka'ia awiton iapina pisuna. Ajnon: ka'ia usemuaraj yware ywokomumepem; o macaco-prego brinca no galho da árvore e quebra os galhos.

\section{FIGURA 119 - MODELO MDE5b}

redondo 'apu'a Ex. kuipia i'apu'a a cuia é redonda; tehahua i'apu'a o tucum é redondo

homem akuma'e Ex. akuma'e akuraete homem gordo; ajko re wehe rako aesag akuma'e ontem eu vi este homem; moron puta pe akuma'e ihoj osuna? quantos homens vão correr?

cavar hywykaj Ex. ywykwara ahywykaj eu cavo buraco na terra; ti se'eromamu puta ri'a ahywykaj eu vou cavar meu poço

mulher kuso Ex. kuso sysyng mulher magra; ma'eramu pa'e kuso nu se'engara $u w i$ ? por que as mulheres não estão cantando?; ure kuso teseramu uruho ytyma mani'og roko urutym nós fomos com as mulheres plantar mandioca

cachorro ma'esawar Ex. unupo ma'esawara ele bate no cachorro; ma'esawara puta usekyj mosa u'uramu o cachorro vai morrer, porque a cobra mordeu ele; esemuhaku'i ke! ma'esawara rapo ne u'u tenha cuidado! o cachorro vai te morder

farinha de mandioca manime Ex. manimea ko amumaraw wyra'yra rupi'a farinha de mandioca misturada com ovo de galinha

dar mono Ex. syryg puta amono ne irua pe eu vou dar o machado para o teu irmão; $k o$, amono ne upe vou te dar isso; ajko na amonowi ne upe esse eu não dou isso para você

morrer sekyj Ex. akuma'e usekyi o homem morreu; ma'esawara puta usekyj mosa u'uramu o cachorro vai morrer, porque a cobra mordeu ele

matar suka Ex. pehe puta pesuka ma'ea pesehow? vocês vão matar aquelas caças?; aha puta ri'a isukaw tasahuamu talvez eu mate um porcão; esuka puhi não mata ele 
Além da diferença de o primeiro ser apresentado em uma coluna e o segundo em duas, ambos os modelos apresentam a mesma estrutura. No entanto, a segunda forma é mais recorrente no conjunto de UBL's das línguas indígenas brasileiras por apresentar apenas na língua indígena apenas uma palavra como tradução do LPt.

\title{
9.1.4.6. Modelo MDE6 com estrutura LId: $\{$ DId-DPt [EId/EPt] $\}$
}

Esse modelo apresenta uma estrutura semelhante à dos modelos MDE3 e MDE5, mas distingue-se deles por conter dois Descritores, conforme exemplo a seguir:

\section{FIGURA 120 - MODELO MDE6}

\begin{abstract}
ka'i ka'i iwete okowa'e; upyhyg iwyw ka'ia so uputi'a warimu irahaj awpita so akakaw yware; ka'ia awiton iapina pisuna. Macaco-prego. Ele vive nas copas das árvores; ele desce para pegar ouriço da castanha e sobe com ele na árvore e começa a bater no pau até o ouriço rachar; ele é marrom com a cabeça preta. Ajnon: ka'ia usemuaraj yware ywokomumepem $o$ macaco-prego brinca no galho da árvore e quebra os galhos.
\end{abstract}

manimea pykujtawa rog pykujpykujtawa upin mani'og, ukytyg, ukupepyg, umuhaw upykuj. Casa de farinha. Na casa de fazer farinha, a gente rala, prensa e peneira a mandioca. Depois torra ela, mexendo no forno. Ajnon: aha puta manime roga pupe wewahema eu vou chegando para dentro da casa de farinha.

'og uruhywykaj ywya urumumug ywykwara rupi urumuku'om sura ykupyjta urumusarukong uruupir urukwar; ti roga ti kehaw, uruapo pinowa ku urusehe urukehawamu urukupepyg urusehe; un ti ma'epotawamu aapo rako iako tarukeke taruke ti ma'etiru umuakym rapo amona n usapy'u rapo tata. Casa. Nós cavamos o chão para enfiar a forquilha da casa; nós levantamos o esteio e encaibramos; nós arribamos e amarramos a casa. Depois colocamos todas as coisas pra dentro pra não molhar. Todos ajudam na construção da casa. Ajnon: asehu tese saupir sene rehe 'og nós todos juntos vamos construir a casa; ti popytywo e apo 'og eu ajudo a fazer a casa.

'ogete uruapo ywya urumuseaupyta, uruupir pinowo ipyteripe ywa umuwyhog supatitawa; ipukuete muruwisaw erekehaw asehutese; upuga ruaw murerekotarete; upug ruaw hejkwehe $\mathrm{n}$ uhuwapyguwi namukuj hejkwehe upug. Casa tradicional. Para fazer a casa tradicional, cavamos a terra e enfiamos os paus de amarrar rede nos buracos. Depois cobrimos a casa tradicional com a palha do babaçu. Nessa casa, todos nós dormimos nela, mas é o chefe quem dorme perto da porta. Essa casa só tem uma porta para entrar. Antigamente, essa porta não ficava fechada. Ajnon: uruapo puta 'ogete semu'etawa ukaripe vamos fazer a casa tradicional no terreno onde a gente estuda; uruapo puta 'ogete t uesag wehe warasu tywo, 'og t unawa; vamos fazer a casa tradicional para os não índios poderem ver.

Esse modelo com verbetes distribuídos em uma coluna traz apenas os componentes em Português destacados com efeito tipográfico em itálico (Descritor e Exemplo). Ele representa um modelo de material bilíngue bastante completo, uma vez que possui seus componentes nas duas línguas. 


\subsubsection{Modelo MDE7 com estrutura LPt: $\{$ DPt-DId [EPt/EId]}

Este modelo retoma a estrutura do modelo anterior, ou seja, os componentes com língua indígena foram substituídos pelos de Português, e vice-versa, como pode ser observado na figura a seguir:

\section{FIGURA 121 - MODELO MDE7}

Casa. Nós cavamos o chão para enfiar a forquilha da casa; nós levantamos o esteio e encaibramos; nós arribamos e amarramos a casa. Depois colocamos todas as coisas pra dentro pra não molhar. Todos ajudam na construção da casa. 'og. Uruhywykaj ywya urumumug ywykwara rupi urumuku'om sura ykupyjta urumusarukong uruupir urukwar; ti roga ti kehaw, uruapo pinowa ku urusehe urukehawamu urukupepyg urusehe; un ti ma'epotawamu aapo rako iako tarukeke taruke ti ma'etiru umuakym rapo amona n usapy'u rapo tata. Ex.: nós todos juntos vamos construir a casa asehu tese saupir sene rehe 'og; eu ajudo a fazer a casa $t i$ popytywo e apo 'og.

Casa de farinha. Na casa de fazer farinha, a gente rala, prensa e peneira a mandioca. Depois torra ela, mexendo no forno. Manimea pykujtawa rog. Pykujpykujtawa upin mani'og, ukytyg, ukupepyg, umuhaw upykuj. Ex.: eu vou chegando para dentro da casa de farinha aha puta manime roga pupe wewahema.

Casa tradicional. Para fazer a casa tradicional, cavamos a terra e enfiamos os paus de amarrar rede nos buracos. Depois cobrimos a casa tradicional com a palha do babaçu. Nessa casa, todos nós dormimos nela, mas é o chefe quem dorme perto da porta. Essa casa só tem uma porta para entrar. Antigamente, essa porta não ficava fechada. 'ogete. Uruapo ywya urumuseaupyta, uruupir pinowo ipyteripe ywa umuwyhog supatitawa; ipukuete muruwisaw erekehaw asehutese; upuga ruaw murerekotarete; upug ruaw hejkwehe $n$ uhuwapyguwi namukuj hejkwehe upug. Ex.: vamos fazer a casa tradicional no terreno onde a gente estuda uruapo puta 'ogete semu'etawa ukaripe; vamos fazer a casa tradicional para os não índios poderem ver uruapo puta 'ogete t uesag wehe warasu tywo, 'og t unawa.

Macaco-prego. Ele vive nas copas das árvores; ele desce para pegar ouriço da castanha e sobe com ele na árvore e começa a bater no pau até o ouriço rachar; ele é marrom com a cabeça preta. Ka'i. Ka'i iwete okowa'e; upyhyg iwyw ka'ia so uputi'a warimu irahaj awpita so akakaw yware; ka'ia awiton iapina pisuna. Ex.: o macaco-prego brinca no galho da árvore e quebra os galhos ka'ia usemuaraj yware ywokomumepem.

Nesse modelo, o que está destacado com itálico é o Suruí. Além disso, a palavra ajnon do modelo anterior foi substituída por Ex., a fim de manter a orientação dada pelo Lema. Também esse modelo é bastante comum no conjunto das UBL's das línguas indígenas brasileiras.

\subsubsection{Modelo MDE8 com estrutura LId: \{DId-DPt-D... [EId/EPt/E...]\}}

Esse modelo retoma a estrutura do modelo MDE6 e a amplia com mais Descritores e seus Exemplos, sem que haja necessariamente Exemplos para todos os 
Descritores. A seguir, apresento proposta com verbetes de até quatro descritores, mas com somente três componentes do tipo Exemplo.

\section{FIGURA 122 - MODELO MDE8a}

\begin{abstract}
ka'i ka'i iwete okowa'e; upyhyg iwyw ka'ia so uputi'a warimu irahaj awpita so akakaw yware; ka'ia awiton iapina pisuna. Macaco-prego. Ele vive nas copas das árvores; ele desce para pegar ouriço da castanha e sobe com ele na árvore e começa a bater no pau até o ouriço rachar; ele é marrom com a cabeça preta. Capuchin monkey. He lives on the top of the trees; he goes to pick up hedgehog chestnut-nut and climbs the tree with him; then, he starts beating the Hedgehog until it cracks; $\mathrm{He}$ is brown with a black head. Cebus apella. Ajnon: ka'ia usemuaraj yware ywokomumepem $o$ macaco-prego brinca no galho da árvore $e$ quebra os galhos the capuchin monkey romps in the branch of the tree and the branches breaks.
\end{abstract}

manimea pykujtawa rog pykujpykujtawa upin mani'og, ukytyg, ukupepyg, umuhaw upykuj. Casa de farinha. Na casa de fazer farinha, a gente rala, prensa e peneira a mandioca. Depois torra ela, mexendo no forno. Flour's house. In the flour's house, the people grate, press and sieve cassava. After roasting it, they stir it on the oven. Ajnon: aha puta manime roga pupe wewahema eu vou chegando para dentro da casa de farinha I came into the house of flour.

'og uruhywykaj ywya urumumug ywykwara rupi urumuku'om sura ykupyjta urumusarukong uruupir urukwar; ti roga ti kehaw, uruapo pinowa $\mathrm{ku}$ urusehe urukehawamu urukupepyg urusehe; un ti ma'epotawamu aapo rako iako tarukeke taruke ti ma'etiru umuakym rapo amona n usapy'u rapo tata. Casa. Nós cavamos o chão para enfiar a forquilha da casa; nós levantamos o esteio e encaibramos; nós arribamos e amarramos a casa. Depois colocamos todas as coisas pra dentro pra não molhar. Todos ajudam na construção da casa. House. We dug the sticks into the ground of the futures house, then we raise its mainstay and put the rafter. Then we put our goods inside the house for them to not get wet. Everyone helps the building of the house. Ajnon: asehu tese saupir sene rehe 'og nós todos juntos vamos construir a casa all together we will build the house; ti popytywo e apo 'og eu ajudo a fazer a casa I help the building of the house.

'ogete uruapo ywya urumuseaupyta, uruupir pinowo ipyteripe ywa umuwyhog supatitawa; ipukuete muruwisaw erekehaw asehutese; upuga ruaw murerekotarete; upug ruaw hejkwehe n uhuwapyguwi namukuj hejkwehe upug. Casa tradicional. Para fazer a casa tradicional, cavamos a terra e enfiamos os paus de amarrar rede nos buracos. Depois cobrimos a casa tradicional com a palha do babaçu. Nessa casa, todos nós dormimos nela, mas é o chefe quem dorme perto da porta. Essa casa só tem uma porta para entrar. Antigamente, essa porta não ficava fechada. Traditional house. To make a traditional house, we dug the earth and we stuck the sticks into the holes, tying them to support the rafter. After we have covered the traditional house with thatched babassu we are able to sleep in it, but it is the chief who sleeps near the door. This house has only one door. Formerly, it door was not closed. Ajnon: uruapo puta 'ogete semu'etawa ukaripe vamos fazer a casa tradicional no terreno onde a gente estuda let's make a traditional house in the land where you study; uruapo puta 'ogete $t$ uesag wehe warasu tywo, 'og t unawa; vamos fazer a casa tradicional para os não índios poderem ver let's do the traditional house for the non Indians to see it.

Nesse modelo organizado em duas colunas, apenas os componentes em Português e em Latim possuem destaque com efeito itálico. Como é o Português que fica entre duas línguas, ele funciona como separador, ou seja, ele separa o DId do DIn, e também o EId do 
EIn. Dentre os verbetes da proposta, somente o primeiro apresenta quatro Descritores, são eles: DId, DPt, DIn e DLt, mas são apresentados Exemplos somente nas três primeiras línguas.

\subsubsection{Modelo MDE9 com estrutura LId: $\{$ DPt-D... [EId/EPt/E...] $\}$}

O último modelo deste conjunto retoma a proposta anterior, mas não inclui um Descritor na língua indígena. Enquanto modelo de material multilíngue ele é bem mais frequente no corpus das UBL's das línguas indígenas do que o modelo MDE8, justamente por utilizar como Descritores apenas palavras ou expressões que traduzem o LId, como pode ser observado no exemplo a seguir:

FIGURA 123 - MODELO MDE8b

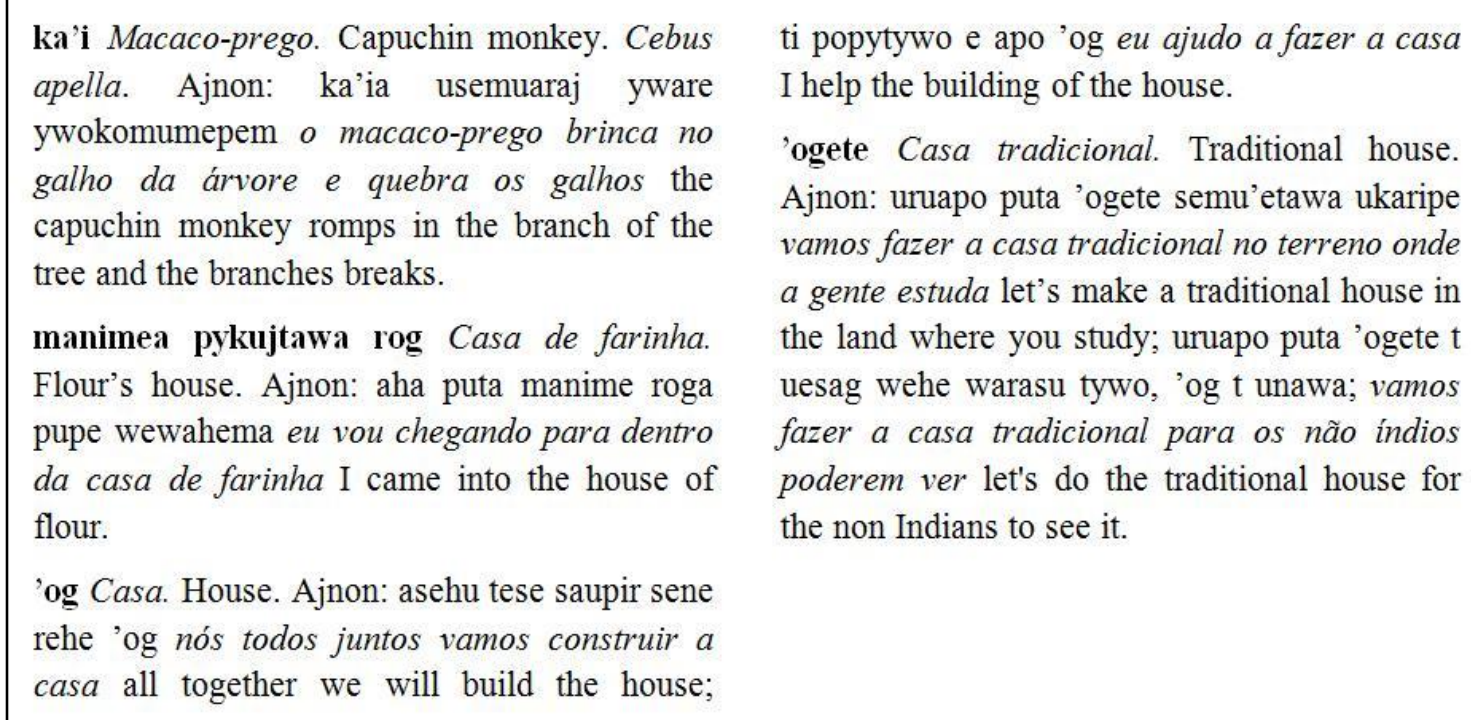

\subsubsection{Modelo MDOE}

Dentre as propostas de modelos para materiais lexicográficos deste trabalho, esse é o primeiro a conter, ao mesmo tempo, os quatro constituintes da microestrutura, ou seja, L, $\mathrm{D}, \mathrm{O}$ e $\mathrm{E}$, que, ao serem organizados em uma EML do tipo L: $\{\mathrm{D}(\mathrm{O})[\mathrm{E}]\}$, resultaram nos seguintes modelos: (1) LId: \{DId (O) [EId]\}; (2) LId: \{DPt (O) [EId]\}; (3) LId: \{DPt (O) [EId/EPt]\}; (4) LPt: \{DId (O) [EId] $\}$; (5) LPt: \{DId (O) [EId/EPt] $;$; (6) LId: \{DId-DPt (O) [EId/EPt]\}; (7) LPt: \{DPt-DId (O) [EPt/EId] $;$; (8) LId: \{DId-DPt-D... (O) [EId/EPt/E...]\} e (9) LId: $\{$ DPt-D... (O) [EId/EPt/E...] $\} .{ }^{168}$

\footnotetext{
${ }^{168}$ As similaridades entre os modelos são perceptíveis, pois, de um para outro, a variação, sobretudo nos exemplos, é, em geral, de apenas um componente. Mas acredito que, para a adequada apresentação das propostas é necessário observar rigorosamente essa sistematização dos modelos.
} 


\title{
9.1.5.1. Modelo MDOE1 com estrutura LId: $\{$ DId (O) [EId] $\}$
}

O primeiro modelo deste conjunto refere-se a uma proposta para um material lexicográfico apenas na língua Suruí. Ele se diferencia do modelo MDE1 por conter um Operador do tipo Fn junto ao DId, como representado na figura abaixo:

\section{FIGURA 124 - MODELO MDOE1}

\begin{abstract}
ka'i ka'i iwete okowa'e; upyhyg iwyw ka'ia so uputi'a warimu irahaj awpita so akakaw yware; ka'ia awiton iapina pisuna (Tymykong umume'u). Ajnon: ka'ia usemuaraj yware ywokomumepem.

manimea pykujtawa rog pykujpykujtawa upin mani'og, ukytyg, ukupepyg, umuhaw upykuj (Ikatu umume'u). Ajnon: aha puta manime roga pupe wewahema.

'og uruhywykaj ywya urumumug ywykwara rupi urumuku'om sura ykupyjta urumusarukong uruupir urukwar; ti roga ti kehaw, uruapo pinowa ku urusehe urukehawamu urukupepyg urusehe; un ti ma'epotawamu aapo rako iako tarukeke taruke ti ma'etiru umuakym rapo amona $\mathrm{n}$ usapy'u rapo tata (Wajwera umume'u). Ajnon: asehu tese saupir sene rehe 'og; ti popytywo e apo 'og; ti rehe taketehewehe ne wy wekow.

'ogete uruapo ywya urumuseaupyta, uruupir pinowo ipyteripe ywa umuwyhog supatitawa; ipukuete muruwisaw erekehaw asehutese; upuga ruaw murerekotarete; upug ruaw hejkwehe $\mathrm{n}$ uhuwapyguwi namukuj hejkwehe upug (Wajwera umume'u). Ajnon: uruapo puta 'ogete semu'etawa ukaripe uruapo puta 'ogete t uesag wehe warasu tywo, 'og t unawa.
\end{abstract}

Nesta proposta, organizada em uma coluna com LId em ordem alfabética, o destaque é dado para o Operador Fn, colocado entre parênteses. Apesar de ocorrer em todos os verbetes, esse Operador, dependendo do PDL, pode ocorrer esporadicamente (cf. subseção 9.1.3.2).

\subsubsection{Modelo MDOE2 com estrutura LId: $\{\mathrm{DPt}(\mathrm{O})[\mathrm{EId}]\}$}

Esse modelo apresenta a mesma estrutura do anterior, mas diferencia-se daquele por ter o Descritor em uma língua diferente da língua usada no Lema.

Tal como no modelo MDE2, nesta proposta o componente Exemplo é apresentado somente na língua do Lema, sem a tradução na língua do Descritor, tornando esse modelo menos comum no conjunto dos materiais lexicográficos das línguas indígenas brasileiras.

A seguir, apresento o modelo MDOE2, organizado em duas colunas paralelas, com Lema e Exemplo na língua Suruí ordenado alfabeticamente, mas com Descritor em Português: 


\section{FIGURA 125 - MODELO MDOE2a}

ka'i Ele vive nas copas das árvores; ele desce para pegar ouriço da castanha e sobe com ele na árvore e começa a bater no pau até o ouriço rachar; ele é marrom com a cabeça preta (na língua Suruí a palavra usada para designar 'macaco-prego' é também empregada para a forma genérica 'macaco'). Ajnon: ka'ia usemuaraj yware ywokomumepem.

manimea pykujtawa rog $\mathrm{Na}$ casa de fazer farinha, a gente rala, prensa e peneira a mandioca. Depois torra ela, mexendo no forno. Ajnon: aha puta manime roga pupe wewahema.

'og Nós cavamos o chão para enfiar a forquilha da casa; nós levantamos o esteio e encaibramos; nós arribamos e amarramos a casa. Depois colocamos todas as coisas pra dentro pra não molhar. Todos ajudam na construção da casa (a construção de uma casa é uma ação coletiva na comunidade Suruí, na qual participam homens, mulheres e crianças, cada um desempenhando papéis específicos). Ajnon: asehu tese saupir sene rehe 'og; $t i$ popytywo e apo 'og; ti rehe t aketehewehe ne wy wekow.

'ogete Para fazer a casa tradicional, cavamos a terra e enfiamos os paus de amarrar rede nos buracos. Depois cobrimos a casa tradicional com a palha do babaçu. Nessa casa, todos nós dormimos nela, mas é o chefe quem dorme perto da porta. Essa casa só tem uma porta para entrar. Antigamente, essa porta não ficava fechada (atualmente, esse tipo de casa não é mais construída para fins de habitação, apenas como forma de manter a tradição). Ajnon: uruapo puta 'ogete semu'etawa ukaripe uruapo puta 'ogete $t$ uesag wehe warasu tywo, 'og t unawa.

\subsubsection{Modelo MDOE3 com estrutura LId: $\{\mathrm{DPt}(\mathrm{O})[\mathrm{EId} / \mathrm{EPt}]\}$}

O terceiro modelo deste padrão diferencia-se do anterior por apresentar o componente EPt, como pode ser observado na figura seguinte:

\section{FIGURA 126 - MODELO MDOE3a}

ka'i macaco-prego. Ele vive nas copas das árvores; ele desce para pegar ouriço da castanha e sobe com ele na árvore e começa a bater no pau até o ouriço rachar; ele é marrom com a cabeça preta (na língua Suruí a palavra usada para designar 'macacoprego' é também empregada para a forma genérica 'macaco'). Ajnon: ka'ia usemuaraj yware ywokomumepem o macaco-prego brinca no galho da árvore e quebra os galhos.

manimea pykujtawa rog casa de farinha. $\mathrm{Na}$ casa de fazer farinha, a gente rala, prensa e peneira a mandioca. Depois torra ela, mexendo no forno. Ajnon: aha puta manime roga pupe wewahema eu vou chegando para dentro da casa de farinha.

'og casa. Nós cavamos o chão para enfiar a forquilha da casa; nós levantamos o esteio e encaibramos; nós arribamos e amarramos a casa. Depois colocamos todas as coisas pra dentro pra não molhar. Todos ajudam na construção da casa (a construção de uma casa é uma ação coletiva na comunidade
Suruí, na qual participam homens, mulheres e crianças, cada um desempenhando papéis específicos). Ajnon: asehu tese saupir sene rehe 'og nós todos juntos vamos construir a casa; ti popytywo e apo 'og eu ajudo a fazer a casa.

'ogete casa traldicional. Para fazer a casa tradicional, cavamos a terra e enfiamos os paus de amarrar rede nos buracos. Depois cobrimos a casa tradicional com a palha do babaçu. Nessa casa, todos nós dormimos nela, mas é o chefe quem dorme perto da porta. Essa casa só tem uma porta para entrar. Antigamente, essa porta não ficava fechada (atualmente, esse tipo de casa não é mais construída para fins de habitação, apenas como forma de manter a tradição). Ajnon: uruapo puta 'ogete semu'etawa ukaripe vamos fazer a casa tradicional no terreno onde a gente estuda; uruapo puta 'ogete $t$ uesag wehe warasu tywo, 'og $t$ unawa vamos fazer a casa tradicional para os não índios poderem ver. 
O próximo modelo é uma variante do anterior, com o texto do DPt substituído por uma palavra ou expressão que traduz o LId.

\section{FIGURA 127 - MODELO MDOE3b}

ka'i macaco-prego (na língua Suruí a palavra usada para designar 'macacoprego' é também empregada para a forma genérica 'macaco'). Ajnon: ka'ia usemuaraj yware ywokomumepem; o macaco-prego brinca no galho da árvore $\mathrm{e}$ quebra os galhos.

manimea pykujtawa rog casa de farinha. Ajnon: aha puta manime roga pupe wewahema; eu vou chegando para dentro da casa de farinha.

'og casa (a construção de uma casa é uma ação coletiva na comunidade Suruí, na qual participam homens, mulheres e crianças, cada um desempenhando papéis específicos). Ajnon: asehu tese saupir sene rehe 'og; eu vou chegando para dentro da casa de farinha; ti popytywo e apo 'og; eu ajudo a fazer a casa.

'ogete casa tradicional (atualmente, esse tipo de casa não é mais construída para fins de habitação, apenas como forma de manter a tradição). Ajnon: uruapo puta 'ogete semu'etawa ukaripe; vamos fazer a casa tradicional no terreno onde a gente estuda; uruapo puta 'ogete t uesag wehe warasu tywo; vamos fazer a casa tradicional para os não índios poderem ver.

\subsubsection{Modelo MDOE4 com estrutura LPt: $\{$ DId (O) [EId] $\}$}

Nesse quarto modelo, apenas o Lema é apresentado em Português, enquanto todos os demais componentes da microestrutura estão em Suruí. A figura seguinte contém uma amostra desse modelo.

\section{FIGURA 128 - MODELO MDOE4a}

casa 'og. Uruhywykaj ywya urumumug ywykwara rupi urumuku'om sura ykupyjta urumusarukong uruupir urukwar; ti roga ti kehaw, uruapo pinowa ku urusehe urukehawamu urukupepyg urusehe; un ti ma'epotawamu aapo rako iako tarukeke taruke ti ma'etiru umuakym rapo amona n usapy'u rapo tata (Wajwera umume'u). Ajnon: asehu tese saupir sene rehe 'og; ti popytywo e apo 'og; ti rehe taketehewehe ne wy wekow.

casa de farinha manimea pykujtawa rog. Pykujpykujtawa upin mani'og, ukytyg, ukupepyg, umuhaw upykuj (Ikatu umume'u). Ajnon: aha puta manime roga pupe wewahema.

casa tradicional 'ogete. Uruapo ywya urumuseaupyta, uruupir pinowo ipyteripe ywa umuwyhog supatitawa; ipukuete muruwisaw erekehaw asehutese; upuga ruaw murerekotarete; upug ruaw hejkwehe $n$ uhuwapyguwi namukuj hejkwehe upug (Wajwera umume'u). Ajnon: uruapo puta 'ogete semu'etawa ukaripe uruapo puta 'ogete t uesag wehe warasu tywo, 'og t unawa.

macaco-prego ka'i. Ka'i iwete okowa'e; upyhyg iwyw ka'ia so uputi'a warimu irahaj awpita so akakaw yware; ka'ia awiton iapina pisuna (Tymykong umume'u). Ajnon: ka'ia usemuaraj yware ywokomumepem. 
Baseado na mesma estrutura do modelo acima, o modelo MDOE4b possui DId com apenas uma palavra ou expressão traduzindo o LPt. Já o Operador usado não é o Ft, como na proposta anterior, mas sim do tipo Fn, que geralmente aparece relacionado ao Lema, mas aqui é empregado junto ao Descritor. Essa substituição do tipo de Operador de versão para outra só foi possível porque, na segunda proposta, o Descritor é composto, na maior parte dos casos, de apenas uma palavra.

\title{
FIGURA 129 - MODELO MDOE4b
}

cachorro ma'esawar /ma?esa'war/. Ajnon: unupo ma'esawara; ma'esawara puta usekyj mosa u'uramu; esemuhaku'i ke! ma'esawara rapo ne $u$ ' $u$

cavar hywykaj /kiwi'kaj/. Ajnon: ywykwara ahywykaj; ti se'eromamu puta ri'a ahywykaj

dar mono /mo'no/. Ajnon: syryg puta amono ne irua pe; ko, amono ne upe; ajko na amonowi ne upe

farinha de mandioca manime /mani'm $\varepsilon /$. Ajnon: manimea ko amumaraw wyra'yra rupi'a

homem akuma'e /akuma'?ع/. Ajnon: akuma'e akuraete; ajko re wehe rako aesag akuma'e; moron puta pe akuma'e ihoj osuna? matar suka /su'ka/. Ajnon: pehe puta pesuka ma'ea pesehow?; aha puta ri'a isukaw tasahuamu; esuka puhi

morrer sekyj /sc'kij/. Ajnon: akuma'e usekyi; ma'esawara puta usekyj mosa u'uramu

mulher kuso /ku'so/. Ajnon: kuso sysyng; ma'eramu pa'e kuso nu se'engara uwi?; ure kuso teseramu uruho ytyma mani'og roko urutym

redondo 'apu'a /Rapu'?a/. Ajnon: kuipia i'apu'a; tehahua i'apu'a

\subsubsection{Modelo MDOE5 com estrutura LPt: $\{\mathrm{DId}(\mathrm{O})[\mathrm{EId} / \mathrm{EPt}]\}$}

Já o quinto modelo deste conjunto acrescenta à estrutura anterior o EPt:

\section{FIGURA 130 - MODELO MDOE5a}

\begin{abstract}
casa 'og. Uruhywykaj ywya urumumug ywykwara rupi urumuku'om sura ykupyjta urumusarukong uruupir urukwar; ti roga ti kehaw, uruapo pinowa ku urusehe urukehawamu urukupepyg urusehe; un ti ma'epotawamu aapo rako iako tarukeke taruke ti ma'etiru umuakym rapo amona n usapy'u rapo tata (Wajwera umume'u). Ajnon: asehu tese saupir sene rehe 'og eu vou chegando para dentro da casa de farinha; ti popytywo e apo 'og; ti rehe $t$ aketehewehe ne wy wekow; eu ajudo a fazer a casa.
\end{abstract}

casa de farinha manimea pykujtawa rog. Pykujpykujtawa upin mani'og, ukytyg, ukupepyg, umuhaw upykuj (Ikatu umume'u). Ajnon: aha puta manime roga pupe wewahema.; eu vou chegando para dentro da casa de farinha

casa tradicional 'ogete. Uruapo ywya urumuseaupyta, uruupir pinowo ipyteripe ywa umuwyhog supatitawa; ipukuete muruwisaw erekehaw asehutese; upuga ruaw murerekotarete; upug ruaw hejkwehe $n$ uhuwapyguwi namukuj hejkwehe upug (Wajwera umume'u). Ajnon: uruapo puta 'ogete semu'etawa ukaripe vamos fazer a casa tradicional no terreno onde a gente estuda; uruapo puta 'ogete $t$ uesag wehe warasu tywo, 'og $t$ unawa vamos fazer a casa tradicional para os não índios poderem ver.

macaco-prego ka'i. Ka'i iwete okowa'e; upyhyg iwyw ka'ia so uputi'a warimu irahaj awpita so akakaw yware; ka'ia awiton iapina pisuna (Tymykong umume'u). Ajnon: ka'ia usemuaraj yware ywokomumepem; o macaco-prego brinca no galho da árvore e quebra os galhos. 
Nessa primeira proposta do modelo, a apresentação do Descritor na forma de texto mais desenvolvido torna esse modelo menos comum se comparado às estruturas de materiais já existentes, porque é bem mais fácil encontrar materiais que possuem estrutura semelhante à do modelo a seguir:

\section{FIGURA 131 - MODELO MDOE5b}

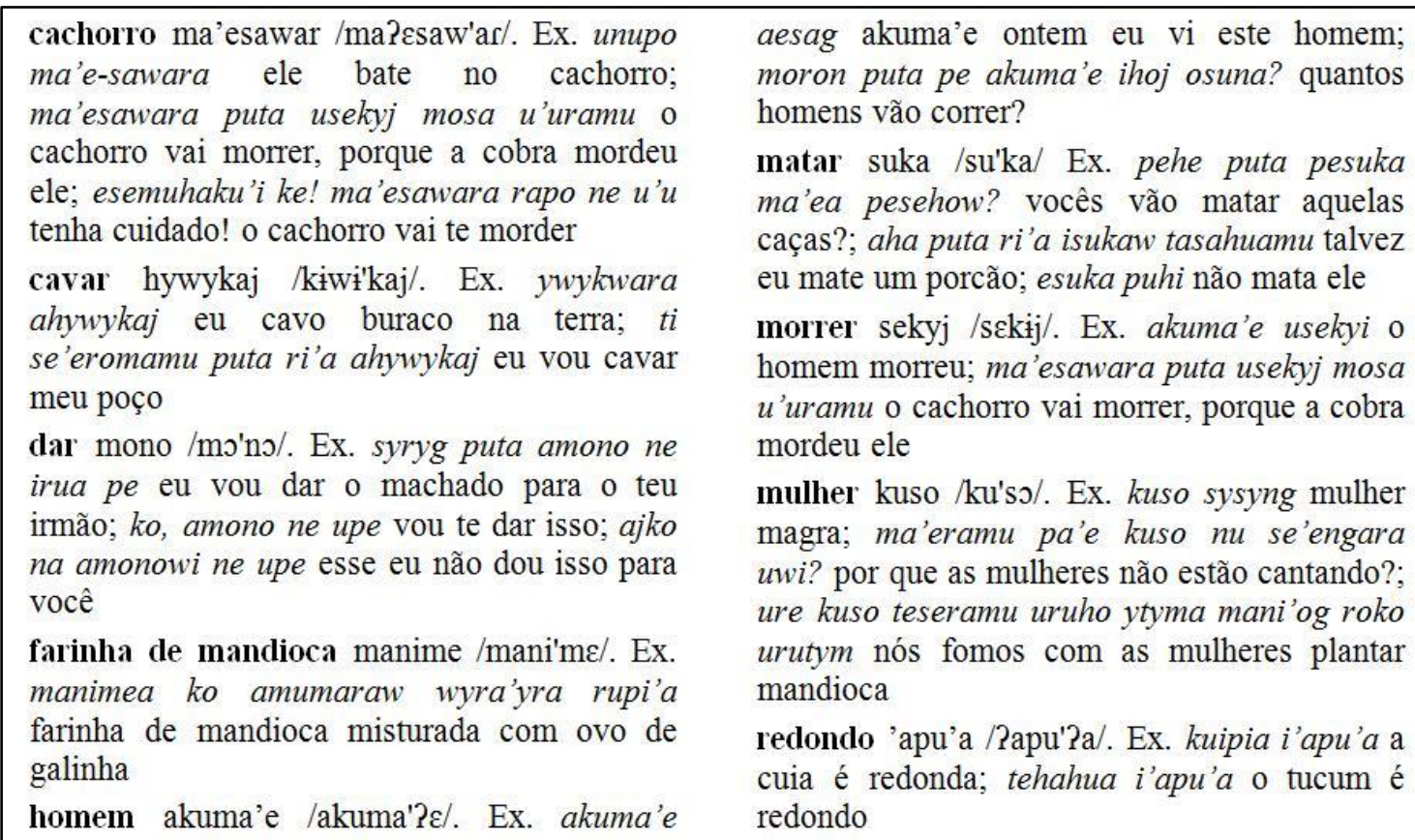
akuraete homem gordo; ajko re wehe rako

Uma observação é necessária com relação a esse modelo: o uso de uma forma de transcrição fonética, muitas vezes, não contribui, por exemplo, para que o usuário em uma situação escolar tenha acesso à pronúncia adequada da palavra, porque essa forma de escrever os sons é mais acessível ao linguista. Logo, o uso ou não deste Operador dependerá, como já comentei, do público a que se destina a obra lexicográfica em construção.

\subsubsection{Modelo MDOE6 com estrutura LId: $\{$ DId-DPt (O) [EId/EPt $]\}$}

Este modelo amplia bastante o tamanho da microestrutura, uma vez que prevê a utilização de dois Descritores com Operadores e Exemplos também em duas línguas.

Com Lemas em Suruí, essa proposta está em ordem alfabética, com destaque de efeito itálico para os componentes em Português. Já os dois operadores aparecem entre parênteses, seguindo os respectivos Descritores a que se referem, como demonstra a figura a seguir: 
ka'i ka'i iwete okowa'e; upyhyg iwyw ka'ia so uputi'a warimu irahaj awpita so akakaw yware; ka'ia awiton iapina pisuna (Tymykong umume'u). Macaco-prego. Ele vive nas copas das árvores; ele desce para pegar ouriço da castanha e sobe com ele na árvore e começa a bater no pau até o ouriço rachar; ele é marrom com a cabeça preta (na língua Suruí a palavra usada para designar 'macaco-prego' é também empregada para a forma genérica 'macaco'). Ajnon: ka'ia usemuaraj yware ywokomumepem o macacoprego brinca no galho da árvore e quebra os galhos.

manimea pykujtawa rog pykujpykujtawa upin mani'og, ukytyg, ukupepyg, umuhaw upykuj (Ikatu umume'u). Casa de farinha. Na casa de fazer farinha, a gente rala, prensa e peneira a mandioca. Depois torra ela, mexendo no forno. Ajnon: aha puta manime roga pupe wewahema eu vou chegando para dentro da casa de farinha.

'og uruhywykaj ywya urumumug ywykwara rupi urumuku'om sura ykupyjta urumusarukong uruupir urukwar; ti roga ti kehaw, uruapo pinowa ku urusehe urukehawamu urukupepyg urusehe; un ti ma'epotawamu aapo rako iako tarukeke taruke ti ma'etiru umuakym rapo amona n usapy'u rapo tata (Wajwera umume'u). Casa. Nós cavamos o chão para enfiar a forquilha da casa; nós levantamos o esteio e encaibramos; nós arribamos e amarramos a casa. Depois colocamos todas as coisas pra dentro pra não molhar. Todos ajudam na construção da casa (a construção de uma casa é uma ação coletiva na comunidade Suruí, na qual participam homens, mulheres e crianças, cada um desempenhando papéis específicos). Ajnon: asehu tese saupir sene rehe 'og nós todos juntos vamos construir a casa; ti popytywo e apo 'og eu ajudo a fazer a casa.

'ogete uruapo ywya urumuseaupyta, uruupir pinowo ipyteripe ywa umuwyhog supatitawa; ipukuete muruwisaw erekehaw asehutese; upuga ruaw murerekotarete; upug ruaw hejkwehe $n$ uhuwapyguwi namukuj hejkwehe upug (Wajwera umume'u). Casa tradicional. Para fazer a casa tradicional, cavamos a terra e enfiamos os paus de amarrar rede nos buracos. Depois cobrimos a casa tradicional com a palha do babaçu. Nessa casa, todos nós dormimos nela, mas é o chefe quem dorme perto da porta. Essa casa só tem uma porta para entrar. Antigamente, essa porta não ficava fechada (atualmente, esse tipo de casa não é mais construída para fins de habitação, apenas como forma de manter a tradição). Ajnon: uruapo puta 'ogete semu'etawa ukaripe vamos fazer a casa tradicional no terreno onde a gente estuda; uruapo puta 'ogete $\mathrm{t}$ uesag wehe warasu tywo, 'og t unawa; vamos fazer a casa tradicional para os não indios poderem ver.

\subsubsection{Modelo MDOE7 com estrutura LPt: $\{\text { DPt-DId (O) [EPt/EId] }\}^{169}$}

Esse modelo coloca na posição de Lema e de primeiro Descritor e Exemplo o Português, e nas posições secundárias a língua Suruí, logo, corresponde a um modelo inverso do MDOE6. Além disso, ele está distribuído não em uma, mas sim em duas colunas, e o efeito itálico é aplicado, agora, sobre os componentes na língua Suruí, como pode ser visto a seguir:

\footnotetext{
${ }^{169} \mathrm{O}$ componente Operador, nessa proposta, pode se relacionar a qualquer um dos Descritores, e seu uso dependerá exclusivamente das decisões do PDL.
} 
FIGURA 133 - MODELO MDOE7

Casa. Nós cavamos o chão para enfiar a forquilha da casa; nós levantamos o esteio e encaibramos; nós arribamos e amarramos a casa. Depois colocamos todas as coisas pra dentro pra não molhar. Todos ajudam na construção da casa (na língua Suruí a palavra usada para designar 'macaco-prego' é também empregada para a forma genérica 'macaco'). 'og. Uruhywykaj ywya urumumug ywykwara rupi urumuku'om sura ykupyjta urumusarukong uruupir urukwar; ti roga ti kehaw, uruapo pinowa $k u$ urusehe urukehawamu urukupepyg urusehe; un ti ma'epotawamu aapo rako iako tarukeke taruke ti ma'etiru umuakym rapo amona $n$ usapy'u rapo tata (Wajwera umume'u). Ex.: nós todos juntos vamos construir a casa asehu tese saupir sene rehe 'og; eu ajudo a fazer a casa ti popytywo e apo 'og.

Casa de farinha. Na casa de fazer farinha, a gente rala, prensa e peneira a mandioca. Depois torra ela, mexendo no forno. Manimea pykujtawa rog. Pykujpykujtawa upin mani'og, ukytyg, ukupepyg, umuhaw upykuj (Ikatu umume'u). Ex.: eu vou chegando para dentro da casa de farinha aha puta manime roga pupe wewahema.

Casa tradicional. Para fazer a casa tradicional, cavamos a terra e enfiamos os paus de amarrar rede nos buracos. Depois cobrimos a casa tradicional com a palha do babaçu. Nessa casa, todos nós dormimos nela, mas é o chefe quem dorme perto da porta. Essa casa só tem uma porta para entrar. Antigamente, essa porta não ficava fechada (atualmente, esse tipo de casa não é mais construída para fins de habitação, apenas como forma de manter a tradição). 'ogete. Uruapo ywya urumuseaupyta, uruupir pinowo ipyteripe ywa umuwyhog supatitawa; ipukuete muruwisaw erekehaw asehutese; upuga ruaw murerekotarete; upug ruaw hejkwehe $n$ uhuwapyguwi namukuj hejkwehe upug. Ex.: vamos fazer a casa tradicional no terreno onde a gente estuda uruapo puta 'ogete semu'etawa ukaripe; vamos fazer a casa tradicional para os não índios poderem ver uruapo puta 'ogete $t$ uesag wehe warasu tywo, 'og $t$ unawa.

Macaco-prego. Ele vive nas copas das árvores; ele desce para pegar ouriço da castanha e sobe com ele na árvore e começa a bater no pau até o ouriço rachar; ele é marrom com a cabeça preta. $K a^{\prime} i$. Ka'i iwete okowa'e; upyhyg iwyw ka'ia so uputi'a warimu irahaj awpita so akakaw yware; ka'ia awiton iapina pisuna (Tymykong umume'u). Ex.: o macaco-prego brinca no galho da árvore e quebra os galhos ka'ia usemuaraj yware ywokomumepem.

\subsubsection{Modelo MDOE8 com estrutura LId: \{DId-DPt-D... (O) [EId/EPt/E...]\}}

Esse penúltimo modelo apresenta uma forma aberta, ou seja, ele não estabelece a quantidade de línguas que a estrutura pode vir a ter, a não ser uma quantidade mínima estabelecida apenas para distingui esse modelo dos demais.

Há de se considerar ainda que a estrutura desse modelo é bem parecida com a do modelo MDE8, distinguindo-se dele por conter um Operador junto ao descritores.

Na utilização deste modelo, deve-se levar em conta que o verbete resultante é significativamente volumoso, o que exige um tratamento lexicográfico cuidadoso com a utilização adequada dos efeitos tipográficos, a fim de permitir que cada informação continue legível ao ser publicada. A seguir, apresento modelo envolvendo três línguas, o Suruí, o Português e o Inglês. 
FIGURA 134 - MODELO MDOE8

ka'i ka'i iwete okowa'e; upyhyg iwyw ka'ia so uputi'a warimu irahaj awpita so akakaw yware; ka'ia awiton iapina pisuna (Tymykong umume'u). Macaco-prego. Ele vive nas copas das árvores; ele desce para pegar ouriço da castanha e sobe com ele na árvore e começa a bater no pau até o ouriço rachar; ele é marrom com a cabeça preta. Capuchin monkey. He lives on the top of the trees; he goes to pick up hedgehog chestnut-nut and climbs the tree with him; then, he starts beating the Hedgehog until it cracks; He is brown with a black head. Cebus apella. Ajnon: ka'ia usemuaraj yware ywokomumepem o macaco-prego brinca no galho da árvore e quebra os galhos the capuchin monkey romps in the branch of the tree and the branches breaks.

manimea pykujtawa rog pykujpykujtawa upin mani'og, ukytyg, ukupepyg, umuhaw upykuj (Ikatu umume'u). Casa de farinha. $\mathrm{Na}$ casa de fazer farinha, a gente rala, prensa e peneira a mandioca. Depois torra ela, mexendo no forno. Flour's house. In the flour's house, the people grate, press and sieve cassava. After roasting it, they stir it on the oven. Ajnon: aha puta manime roga pupe wewahema eu vou chegando para dentro da casa de farinha I came into the house of flour.

'og uruhywykaj ywya urumumug ywykwara rupi urumuku'om sura ykupyjta urumusarukong uruupir urukwar; ti roga ti kehaw, uruapo pinowa $\mathrm{ku}$ urusehe urukehawamu urukupepyg urusehe; un ti ma'epotawamu aapo rako iako tarukeke taruke ti ma'etiru umuakym rapo amona $\mathrm{n}$ usapy'u rapo tata (Wajwera umume'u). Casa. Nós cavamos o chão para enfiar a forquilha da casa; nós levantamos o esteio e encaibramos; nós arribamos $e$ amarramos a casa. Depois colocamos todas as coisas pra dentro pra não molhar. Todos ajudam na construção da casa. House. We dug the sticks into the ground of the futures house, then we raise its mainstay and put the rafter. Then we put our goods inside the house for them to not get wet. Everyone helps the building of the house. Ajnon: asehu tese saupir sene rehe 'og nós todos juntos vamos construir a casa all together we will build the house; ti popytywo e apo 'og eu ajudo a fazer a casa I help the building of the house.

'ogete uruapo ywya urumuseaupyta, uruupir pinowo ipyteripe ywa umuwyhog supatitawa; ipukuete muruwisaw erekehaw asehutese; upuga ruaw murerekotarete; upug ruaw hejkwehe $n$ uhuwapyguwi namukuj hejkwehe upug (Wajwera umume'u). Casa tradicional. Para fazer a casa tradicion 通, (ctr) - amos a terra $e$ enfiamos os paus de amarrar rede nos buracos. Depois cobrimos a casa tradicional com a palha do babaçu. Nessa casa, todos nós dormimos nela, mas é o chefe quem dorme perto da porta. Essa casa só tem uma porta para entrar. Antigamente, essa porta não ficava fechada. Traditional house. To make a traditional house, we dug the earth and we stuck the sticks into the holes, tying them to support the rafter. After we have covered the traditional house with thatched babassu we are able to sleep in it, but it is the chief who sleeps near the door. This house has only one door. Formerly, it door was not closed. Ajnon: uruapo puta 'ogete semu'etawa ukaripe vamos fazer a casa tradicional no terreno onde a gente estuda let's make a traditional house in the land where you study; uruapo puta 'ogete $t$ uesag wehe warasu tywo, 'og t unawa; vamos fazer a casa tradicional para os não índios poderem ver let's do the traditional house for the non Indians to see it.

Nesse modelo, o LId é o único componente a receber efeito negrito, o que o destaca no início do verbete. Já o DPt e DLt recebem ambos o efeito itálico, do mesmo modo que o EPt. Nesse modelo de apresentação do material lexicográfico o tamanho do tipo (ou fonte) usado é padrão de muitos editores de texto, ou seja, 12 pontos. 


\subsubsection{Modelo MDOE9 com estrutura LId: $\{$ DPt-D... (O) $[\mathrm{EId} / \mathrm{EPt} / \mathrm{E} \ldots]\}$}

Este modelo diferencia-se do anterior por dois aspectos: o primeiro, ele não apresenta DId; o segundo, ele traz todos os Descritores reduzidos a uma palavra ou expressão traduzindo o conteúdo do LId. Essa proposta, apesar de rara, existe no conjunto de obras lexicográficas já produzidas para as línguas indígenas brasileiras. Apresento, a seguir, um exemplo deste modelo que segue as mesmas especificações formais do modelo anterior.

\section{FIGURA 135 - MODELO MDOE9}

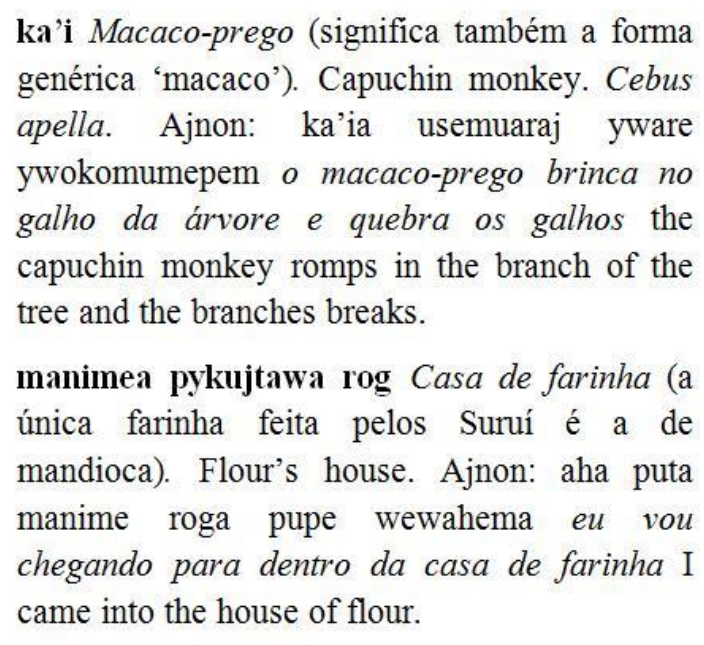

'og Casa. House. Ajnon: asehu tese saupir sene rehe 'og nós todos juntos vamos construir a casa all together we will build the house; ti popytywo e apo 'og eu ajudo a fazer a casa I help the building of the house.

'ogete Casa tradicional (lit. Casa verdadeira). Traditional house. Ajnon: uruapo puta 'ogete semu'etawa ukaripe vamos fazer a casa tradicional no terreno onde a gente estuda let's make a traditional house in the land where you study.

\subsubsection{Modelo MDEO}

De todos os modelos apresentados na subseção 9.3.4.1, este foi o único ainda não atestado. Logo, todas as propostas relacionadas a ele, aqui apresentadas, têm o papel de preencher a lacuna observada no corpus desta pesquisa.

A raridade desta proposta se deve, provavelmente, ao fato de essa estrutura prever o uso de Operadores relacionados ao componente Exemplo, que, em geral, não se associa a esse elemento na microestrutura. Além disso, há de se observar que alguns Operadores, mesmo não tendo o seu uso proibido, têm uma chance muito pequena de ocorrer nessa posição, são eles: Fn, Gr, Et, Hm e Vr.

Logo, as EML's possíveis nesse conjunto são: (1) LId: \{DId [EId (O)]\}; (2) LId: $\{$ DPt [EId (O)]\}; (3) LId: \{DPt [EId/EPt (O)]\}; (4) LPt: \{DId [EId (O)]\}; (5) LPt: \{DId [EId/EPt (O)]\}; (6) LId: \{DId-DPt [EId/EPt (O)]\}; (7) LPt: \{DPt-DId [EPt/EId (O)]\}; (8) LId: \{DId-DPt-D... [EId/EPt/E... (O)] \} e (9) LId: \{DPt-D... [EId/EPt/E...(O)]\}. 


\title{
9.1.6.1. Modelo MDEO1 com estrutura LId: $\{$ DId $[$ EId $(\mathrm{O})]\}$
}

Esse primeiro modelo contém apenas a língua Suruí com Operador associado ao componente Exemplo. Aqui também utilizo o Operador do tipo Ft, semelhante ao modelo MDE1, porém, com a possibilidade de indicar para cada Exemplo o nome de quem forneceu o dado. Há de se observar ainda que é possível usar outros Operadores nesse mesmo contexto, como, por exemplo, os do tipo $\mathrm{Na}$ ou $\mathrm{Tl}$.

A seguir, apresento um exemplo desse modelo:

FIGURA 136 - MODELO MDEO1

\begin{abstract}
ka'i ka'i iwete okowa'e; upyhyg iwyw ka'ia so uputi'a warimu irahaj awpita so akakaw yware; ka'ia awiton iapina pisuna. Ajnon: ka'ia usemuaraj yware ywokomumepem (Tymykong umume'u).

manimea pykujtawa rog pykujpykujtawa upin mani'og, ukytyg, ukupepyg, umuhaw upykuj. Ajnon: aha puta manime roga pupe wewahema (Ikatu umume'u).

'og uruhywykaj ywya urumumug ywykwara rupi urumuku'om sura ykupyjta urumusarukong uruupir urukwar; ti roga ti kehaw, uruapo pinowa ku urusehe urukehawamu urukupepyg urusehe; un ti ma'epotawamu aapo rako iako tarukeke taruke ti ma'etiru umuakym rapo amona n usapy'u rapo tata. Ajnon: asehu tese saupir sene rehe 'og (Ikatu umume'u); ti popytywo e apo 'og; ti rehe taketehewehe ne wy wekow (Wajwera umume'u).

'ogete uruapo ywya urumuseaupyta, uruupir pinowo ipyteripe ywa umuwyhog supatitawa; ipukuete muruwisaw erekehaw asehutese; upuga ruaw murerekotarete; upug ruaw hejkwehe n uhuwapyguwi namukuj hejkwehe upug. Ajnon: uruapo puta 'ogete semu'etawa ukaripe (Ikatu umume'u); uruapo puta 'ogete t uesag wehe warasu tywo, 'og t unawa (Wajwera umume'u).
\end{abstract}

Nesse modelo distribuído em uma cola, todos os Operadores de EId vêm destacados entre parênteses, sem efeito itálico, que é reservado apenas para o próprio EId.

\subsubsection{Modelo MDEO2 com estrutura LId: $\{$ DPt $[$ EId (O)] $\}$}

Esse segundo modelo não possui DId, mas DPt, introduzindo uma segunda língua no modelo. Os Exemplos continuam com Operador Fn, também destacados entre parênteses.

Distribuído em duas colunas, esse modelo, que pode ser visto na figura a seguir, também tem o Lema destacado com efeito negrito. 
FIGURA 137 - MODELO MDEO2

ka'i Ele vive nas copas das árvores; ele desce para pegar ouriço da castanha e sobe com ele na árvore e começa a bater no pau até o ouriço rachar; ele é marrom com a cabeça preta. Ajnon: ka'ia usemuaraj yware ywokomumepem (Tymykong umume'u).

manimea pykujtawa rog Na casa de fazer farinha, a gente rala, prensa e peneira a mandioca. Depois torra ela, mexendo no forno. Ajnon: aha puta manime roga pupe wewahema (Ikatu umume'u).

'og Nós cavamos o chão para enfiar a forquilha da casa; nós levantamos o esteio e encaibramos; nós arribamos e amarramos a casa. Depois colocamos todas as coisas pra dentro pra não molhar. Todos ajudam na construção da casa. Ajnon: asehu tese saupir sene rehe 'og (Ikatu umume'u); ti popytywo e apo 'og; ti rehe taketehewehe ne wy wekow (Wajwera umume'u).

'ogete Para fazer a casa tradicional, cavamos a terra e enfiamos os paus de amarrar rede nos buracos. Depois cobrimos a casa tradicional com a palha do babaçu. Nessa casa, todos nós dormimos nela, mas é o chefe quem dorme perto da porta. Essa casa só tem uma porta para entrar. Antigamente, essa porta não ficava fechada. Ajnon: uruapo puta 'ogete semu'etawa ukaripe (Ikatu umume'u); uruapo puta 'ogete $t$ uesag wehe warasu tywo, 'og t unawa (Wajwera umume'u).

\subsubsection{Modelo MDEO3 com estrutura LId: $\{\mathrm{DPt}[\mathrm{EId} / \mathrm{EPt}(\mathrm{O})]\}$}

Esse é o primeiro modelo deste conjunto a apresentar dois componentes do tipo Exemplo com línguas diferentes. E, assim como o modelo anterior, ele não apresenta DId, conforme pode ser observado a seguir:

\section{FIGURA 138 - MODELO MDEO3a}

ka'i macaco-prego. Ele vive nas copas das árvores; ele desce para pegar ouriço da castanha e sobe com ele na árvore e começa a bater no pau até o ouriço rachar; ele é marrom com a cabeça preta. Ajnon: ka'ia usemuaraj yware ywokomumepem (Tymykong umume'u) o macaco-prego brinca no galho da árvore e quebra os galhos.

manimea pykujtawa rog casa de farinha. $\mathrm{Na}$ casa de fazer farinha, a gente rala, prensa e peneira a mandioca. Depois torra ela, mexendo no forno. Ajnon: aha puta manime roga pupe wewahema (Ikatu umume'u) eu vou chegando para dentro da casa de farinha.

'og casa. Nós cavamos o chão para enfiar a forquilha da casa; nós levantamos o esteio e encaibramos; nós arribamos e amarramos a casa. Depois colocamos todas as coisas pra dentro pra não molhar. Todos ajudam na construção da casa. Ajnon: asehu tese saupir sene rehe 'og (Ikatu umume'u) nós todos juntos vamos construir a casa; ti popytywo $e$ apo 'og (Wajwera umume'u) eu ajudo a fazer a casa.

'ogete casa tradicional. Para fazer a casa tradicional, cavamos a terra e enfiamos os paus de amarrar rede nos buracos. Depois cobrimos a casa tradicional com a palha do babaçu. Nessa casa, todos nós dormimos nela, mas é o chefe quem dorme perto da porta. Essa casa só tem uma porta para entrar. Antigamente, essa porta não ficava fechada. Ajnon: uruapo puta 'ogete semu'etawa ukaripe (Ikatu umume'u) vamos fazer a casa tradicional no terreno onde a gente estuda; uruapo puta 'ogete $t$ uesag wehe warasu tywo, 'og $t$ unawa (Wajwera umume'u) vamos fazer a casa tradicional para os não índios poderem ver. 
Esse modelo pode também ser apresentado com um DId contendo apenas uma palavra ou expressão que traduz o LId. A próxima figura traz um exemplo dessa proposta:

\section{FIGURA 139 - MODELO MDEO3b}

ka'i macaco-prego. Ajnon: ka'ia usemuaraj yware ywokomumepem (Tymykong umume'u); o macaco-prego brinca no galho da árvore e quebra os galhos.

manimea pykujtawa rog casa de farinha. Ajnon: aha puta manime roga pupe wewahema (Ikatu umume'u); eu vou chegando para dentro da casa de farinha.

'og casa. Ajnon: asehu tese saupir sene rehe 'og (Ikatu umume'u); eu vou chegando para dentro da casa de farinha; ti popytywo e apo 'og (Wajwera umume'u); eu ajudo a fazer a casa.

'ogete casa tradicional. Ajnon: uruapo puta 'ogete semu'etawa ukaripe (Ikatu umume'u); vamos fazer a casa tradicional no terreno onde a gente estuda; uruapo puta 'ogete t uesag wehe warasu tywo (Wajwera umume'u); vamos fazer a casa tradicional para os não índios poderem ver.

\subsubsection{Modelo MDEO4 com estrutura LPt: $\{$ DId $[$ EId $(\mathrm{O})]\}$}

Esse modelo possui estrutura aproximada à das propostas MD3, MDO5 e MDOE5, mas diferencia-se delas por deslocar o Operador para junto do Exemplo.

\section{FIGURA 140 - MODELO MDEO4a}

\begin{abstract}
casa 'og. Uruhywykaj ywya urumumug ywykwara rupi urumuku'om sura ykupyjta urumusarukong uruupir urukwar; ti roga ti kehaw, uruapo pinowa ku urusehe urukehawamu urukupepyg urusehe; un ti ma'epotawamu aapo rako iako tarukeke taruke ti ma'etiru umuakym rapo amona $\mathrm{n}$ usapy'u rapo tata. Ajnon: asehu tese saupir sene rehe 'og; ti popytywo e apo 'og (Ikatu umume'u); $t i$ rehe $t$ aketehewehe ne wy wekow (Wajwera umume'u).
\end{abstract}

casa de farinha manimea pykujtawa rog. Pykujpykujtawa upin mani'og, ukytyg, ukupepyg, umuhaw upykuj. Ajnon: aha puta manime roga pupe wewahema (Ikatu umume'u). casa tradicional 'ogete. Uruapo ywya urumuseaupyta, uruupir pinowo ipyteripe ywa umuwyhog supatitawa; ipukuete muruwisaw erekehaw asehutese; upuga ruaw murerekotarete; upug ruaw hejkwehe n uhuwapyguwi namukuj hejkwehe upug. Ajnon: uruapo puta 'ogete semu'etawa ukaripe (Ikatu umume'u) uruapo puta 'ogete $t$ uesag wehe warasu tywo, 'og $t$ unawa (Wajwera umume'u).

macaco-prego ka'i. Ka'i iwete okowa'e; upyhyg iwyw ka'ia so uputi'a warimu irahaj awpita so akakaw yware; ka'ia awiton iapina pisuna. Ajnon: ka'ia usemuaraj yware ywokomumepem (Tymykong umume'u).

No modelo acima, a maioria dos EId é seguida por um Operador do tipo Ft, que fica entre parênteses sem efeito itálico. Esse modelo apresenta a seguinte variação: 
FIGURA 141 - MODELO MDEO4b
cachorro ma'esawar
Ajnon: unupo ma'esawara; ma'esawara puta usekyj mosa u'uramu (Ikatu umume'u); esemuhaku'i ke! ma'esawara rapo ne u'u
cavar hywykaj
Ajnon: ywykwara ahywykaj; ti se'eromamu puta ri'a ahywykaj
dar mono
Ajnon: syryg puta amono ne irua pe; ko, amono ne upe; ajko na amonowi ne upe (Muretama umume'u)
farinha de mandioca manime
Ajnon: manimea ko amumaraw wyra'yra rupi'a (Tymykong umume'u)
homem akuma'e
Ajnon: akuma'e akuraete; ajko re wehe rako

aesag akuma'e; moron puta pe akuma'e ihoj osuna?

matar suka

Ajnon: pehe puta pesuka ma'ea pesehow?; aha puta ri'a isukaw tasahuamu; esuka puhi (Masu umume'u)

morrer sekyj

Ajnon: akuma'e usekyi; ma'esawara puta usekyj mosa u'uramu

mulher kuso

Ajnon: kuso sysyng; ma'eramu pa'e kuso nu se'engara uwi? (Ikatu umume'u); ure kuso teseramu uruho ytyma mani'og roko urutym

redondo 'apu'a

Ajnon: kuipia i'apu'a; tehahua i'apu'a (Waywera umume'u)

Com verbetes distribuídos em duas colunas, esse modelo apresenta, em cada microestrutura, o LPt e o DId sempre na primeira linha, e nas linhas subsequentes os EId com os respectivos Operadores.

\subsubsection{Modelo MDEO5 com estrutura LPt: $\{$ DId $[\mathrm{EId} / \mathrm{EPt}(\mathrm{O})]\}$}

Seguindo a estrutura do modelo anterior, o MDOE5 diferencia-se dele por conter um segundo componente Exemplo com a mesma língua do Lema, ou seja, em Português. ${ }^{170}$

No entanto, nem todos os EId desse modelo possuem Operador Ft, haja vista a possibilidade de eles ocorrerem ou não na microestrutura da obra, conforme, como já mencionei, as especificações do PDL que vai originar a obra.

A título de exemplo, apresento, a seguir, a imagem desse modelo, com dados distribuídos em duas colunas, com LPt em negrito, EId em itálico e Ft entre parênteses.

\footnotetext{
${ }^{170}$ A quantidade de amostras usadas em cada componente Exemplo pode variar de uma microestrutura para outra, pois isso depende da quantidade de dados disponíveis em cada contexto, mas o que é imprescindível é que haja, pelo menos, um dado para garantir, por exemplo, neste modelo, a existência dos componentes EId e EPt.
} 
FIGURA 142 - MODELO MDEO5a

casa 'og. Uruhywykaj ywya urumumug ywykwara rupi urumuku'om sura ykupyjta urumusarukong uruupir urukwar; ti roga ti kehaw, uruapo pinowa ku urusehe urukehawamu urukupepyg urusehe; un ti ma'epotawamu aapo rako iako tarukeke taruke ti ma'etiru umuakym rapo amona $n$ usapy'u rapo tata. Ajnon: asehu tese saupir sene rehe 'og eu vou chegando para dentro da casa de farinha; ti popytywo e apo 'og; ti rehe $t$ aketehewehe ne wy wekow (Wajwera umume'u); eu ajudo a fazer a casa.

casa de farinha manimea pykujtawa rog. Pykujpykujtawa upin mani'og, ukytyg, ukupepyg, umuhaw upykuj. Ajnon: aha puta manime roga pupe wewahema (Ikatu umume'u); eu vou chegando para dentro da casa de farinha. casa tradicional 'ogete. Uruapo ywya urumuseaupyta, uruupir pinowo ipyteripe ywa umuwyhog supatitawa; ipukuete muruwisaw erekehaw asehutese; upuga ruaw murerekotarete; upug ruaw hejkwehe n uhuwapyguwi namukuj hejkwehe upug. Ajnon: uruapo puta 'ogete semu'etawa ukaripe (Wajwera umume'u) vamos fazer a casa tradicional no terreno onde a gente estuda; uruapo puta 'ogete t uesag wehe warasu tywo, 'og t unawa vamos fazer a casa tradicional para os não índios poderem ver.

macaco-prego ka'i. Ka'i iwete okowa'e; upyhyg iwyw ka'ia so uputi'a warimu irahaj awpita so akakaw yware; ka'ia awiton iapina pisuna. Ajnon: ka'ia usemuaraj yware ywokomumepem (Tymykong umume'u); o macaco-prego brinca no galho da árvore $e$ quebra os galhos.

Esse modelo apresenta a seguinte variação:

\section{FIGURA 143 - MODELO MDEO5b}

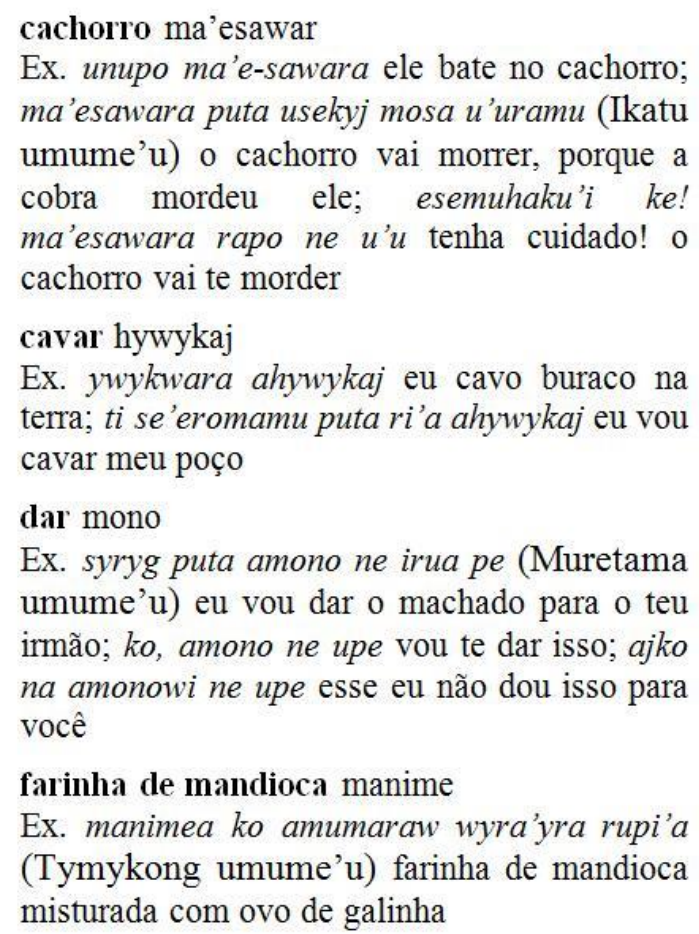

farinha de mandioca manime

Ex. manimea ko amumaraw wyra'yra rupi'a (Tymykong umume'u) farinha de mandioca misturada com ovo de galinha

\section{homem akuma'e}

Ex. akuma'e akuraete homem gordo; ajko re wehe rako aesag akuma'e ontem eu vi este homem; moron puta pe akuma'e ihoj osuna? quantos homens vão correr?

matar suka

Ex. pehe puta pesuka ma'ea pesehow? (Masu umume'u) vocês vão matar aquelas caças?; aha puta ri'a isukaw tasahuamu talvez eu mate um porcão; esuka puhi não mata ele

\section{morrer sekyj}

Ex. akuma'e usekyi o homem morreu; ma'esawara puta usekyj mosa u'uramu o cachorro vai morrer, porque a cobra mordeu ele

\section{mulher kuso}

Ex. kuso sysyng mulher magra; ma'eramu pa'e kuso nu se'engara uwi? (Ikatu umume'u) por que as mulheres não estão cantando?; ure kuso teseramu uruho ytyma mani'og roko urutym nós fomos com as mulheres plantar mandioca

No exemplo acima, o DId é apresentado com uma palavra ou expressão e o componente Exemplo é introduzido por Ex, com destaque em itálico para o EId. 


\subsubsection{Modelo MDEO6 com estrutura LId: $\{$ DId-DPt [EId/EPt (O)] $\}$}

Esse modelo se diferencia dos anteriores por conter Descritores e Exemplos em duas línguas, como pode ser observado no exemplo a seguir:

\section{FIGURA 144 - MODELO MDEO6}

ka'i ka'i iwete okowa'e; upyhyg iwyw ka'ia so uputi'a warimu irahaj awpita so akakaw yware; ka'ia awiton iapina pisuna. Macaco-prego. Ele vive nas copas das árvores; ele desce para pegar ouriço da castanha e sobe com ele na árvore e começa a bater no pau até o ouriço rachar; ele é marrom com a cabeça preta. Ajnon: ka'ia usemuaraj yware ywokomumepem (Tymykong umume'u) o macaco-prego brinca no galho da árvore e quebra os galhos.

manimea pykujtawa rog pykujpykujtawa upin mani'og, ukytyg, ukupepyg, umuhaw upykuj. Casa de farinha. Na casa de fazer farinha, a gente rala, prensa e peneira a mandioca. Depois torra ela, mexendo no forno. Ajnon: aha puta manime roga pupe wewahema (Ikatu umume'u) eu vou chegando para dentro da casa de farinha.

'og uruhywykaj ywya urumumug ywykwara rupi urumuku'om sura ykupyjta urumusarukong uruupir urukwar; ti roga ti kehaw, uruapo pinowa ku urusehe urukehawamu urukupepyg urusehe; un ti ma'epotawamu aapo rako iako tarukeke taruke ti ma'etiru umuakym rapo amona n usapy'u rapo tata. Casa. Nós cavamos o chão para enfiar a forquilha da casa; nós levantamos o esteio e encaibramos; nós arribamos e amarramos a casa. Depois colocamos todas as coisas pra dentro pra não molhar. Todos ajudam na construção da casa. Ajnon: asehu tese saupir sene rehe 'og (Wajwera umume'u) nós todos juntos vamos construir a casa; ti popytywo e apo 'og eu ajudo a fazer a casa.

'ogete uruapo ywya urumuseaupyta, uruupir pinowo ipyteripe ywa umuwyhog supatitawa; ipukuete muruwisaw erekehaw asehutese; upuga ruaw murerekotarete; upug ruaw hejkwehe $\mathrm{n}$ uhuwapyguwi namukuj hejkwehe upug. Casa tradicional. Para fazer a casa tradicional, cavamos a terra e enfiamos os paus de amarrar rede nos buracos. Depois cobrimos a casa tradicional com a palha do babaçu. Nessa casa, todos nós dormimos nela, mas é o chefe quem dorme perto da porta. Essa casa só tem uma porta para entrar. Antigamente, essa porta não ficava fechada. Ajnon: uruapo puta 'ogete semu'etawa ukaripe (Wajwera umume'u) vamos fazer a casa tradicional no terreno onde a gente estuda; uruapo puta 'ogete t uesag wehe warasu tywo, 'og t unawa; vamos fazer a casa tradicional para os não índios poderem ver.

Com Operadores relacionados apenas ao componente Exemplo, o modelo destaca com itálico apenas os componentes em Português.

\subsubsection{Modelo MDEO7 com estrutura LPt: $\{$ DPt-DId [EPt/EId (O)]\}}

Mantendo a estrutura do MDOE6, este modelo substitui a posição das línguas, por exemplo, o que era LId passa a LPt, o mesmo ocorrendo com todos os demais componentes desta proposta, como pode ser visto no exemplo a seguir organizado em duas colunas: 
FIGURA 145 - MODELO MDEO7

Casa. Nós cavamos o chão para enfiar a forquilha da casa; nós levantamos o esteio e encaibramos; nós arribamos e amarramos a casa. Depois colocamos todas as coisas pra dentro pra não molhar. Todos ajudam na construção da casa. 'og. Uruhywykaj ywya urumumug ywykwara rupi urumuku'om sura ykupyjta urumusarukong uruupir urukwar; $t i$ roga ti kehaw, uruapo pinowa ku urusehe urukehawamu urukupepys urusehe; un ti ma'epotawamu aapo rako iako tarukeke taruke ti ma'etiru umuakym rapo amona $n$ usapy'u rapo tata. Ex.: nós todos juntos vamos construir a casa asehu tese saupir sene rehe 'og (Wajwera umume'u); eu ajudo a fazer a casa ti popytywo e apo 'og.

Casa de farinha. Na casa de fazer farinha, a gente rala, prensa e peneira a mandioca. Depois torra ela, mexendo no forno. Manimea pykujtawa rog. Pykujpykujtawa upin mani'og, ukytyg, ukupepyg, umuhaw upykuj. Ex.: eu vou chegando para dentro da casa de farinha aha puta manime roga pupe wewahema (Ikatu umume'u).

Casa tradicional. Para fazer a casa tradicional, cavamos a terra e enfiamos os paus de amarrar rede nos buracos. Depois cobrimos a casa tradicional com a palha do babaçu. Nessa casa, todos nós dormimos nela, mas é o chefe quem dorme perto da porta. Essa casa só tem uma porta para entrar. Antigamente, essa porta não ficava fechada. 'ogete. Uruapo ywya urumuseaupyta, uruupir pinowo ipyteripe ywa umuwyhog supatitawa; ipukuete muruwisaw erekehaw asehutese; upuga ruaw murerekotarete; upug ruaw hejkwehe n uhuwapyguwi namukuj hejkwehe upug. Ex.: vamos fazer a casa tradicional no terreno onde a gente estuda uruapo puta 'ogete semu'etawa ukaripe (Wajwera umume'u); vamos fazer a casa tradicional para os não índios poderem ver uruapo puta 'ogete $t$ uesag wehe warasu tywo, 'og $t$ unawa.

Macaco-prego. Ele vive nas copas das árvores; ele desce para pegar ouriço da castanha e sobe com ele na árvore e começa a bater no pau até o ouriço rachar; ele é marrom com a cabeça preta. Ka'i. Ka'i iwete okowa'e; upyhyg iwyw ka'ia so uputi'a warimu irahaj awpita so akakaw yware; ka'ia awiton iapina pisuna. Ex.: o macacoprego brinca no galho da árvore e quebra os galhos ka'ia usemuaraj yware ywokomumepem (Tymykong umume'u).

Nesse modelo, o destaque em itálico passa a ser feito apenas nos componentes na língua Suruí, mantendo-se o recurso de parênteses para o Operador. Com relação à distribuição dos verbetes desse modelo em duas colunas, um problema que deve ser observado é a possibilidade de haver grandes espaços vazios entre uma palavra e outras, tal como ocorre nos verbetes 'casa tradicional' e 'macaco-prego'. Nesse caso, deve-se avaliar se a estrutura com apenas não acomodaria melhor os dados.

\subsubsection{Modelo MDEO8 com estrutura LId: \{DId-DPt-D... [EId/EPt/E... (O)]\}}

A mesma situação observada nos modelos MDE8 e MDOE8, em que a EML chegava à sua expansão máxima, ocorre nesse modelo, que se distingue desses dois citados por ter o Operador apenas junto ao s componentes Exemplos.

Nesse modelo, assim como nos demais, o Operador pode ocorrer em apenas um dos componentes do tipo Exemplo ou em todos eles, dependendo do PDL. A seguir, apresento a figura com um exemplo dessa proposta: 
FIGURA 146 - MODELO MDEO8

ka'i ka'i iwete okowa'e; upyhyg iwyw ka'ia so uputi'a warimu irahaj awpita so akakaw yware; ka'ia awiton iapina pisuna. Macaco-prego. Ele vive nas copas das árvores; ele desce para pegar ouriço da castanha e sobe com ele na árvore e começa a bater no pau até o ouriço rachar; ele é marrom com a cabeça preta. Capuchin monkey. He lives on the top of the trees; he goes to pick up hedgehog chestnut-nut and climbs the tree with him; then, he starts beating the Hedgehog until it cracks; $\mathrm{He}$ is brown with a black head. Cebus apella. Ajnon: ka'ia usemuaraj yware ywokomumepem (Tymykong umume'u) o macaco-prego brinca no galho da árvore e quebra os galhos the capuchin monkey romps in the branch of the tree and the branches breaks.

manimea pykujtawa rog pykujpykujtawa upin mani'og, ukytyg, ukupepyg, umuhaw upykuj. Casa de farinha. Na casa de fazer farinha, a gente rala, prensa e peneira a mandioca. Depois torra ela, mexendo no forno. Flour's house. In the flour's house, the people grate, press and sieve cassava. After roasting it, they stir it on the oven. Ajnon: aha puta manime roga pupe wewahema (Ikatu umume'u) eu vou chegando para dentro da casa de farinha I came into the house of flour.

'og uruhywykaj ywya urumumug ywykwara rupi urumuku'om sura ykupyjta urumusarukong uruupir urukwar; ti roga ti kehaw, uruapo pinowa ku urusehe urukehawamu urukupepyg urusehe; un ti ma'epotawamu aapo rako iako tarukeke taruke ti ma'etiru umuakym rapo amona n usapy'u rapo tata. Casa. Nós cavamos o chão para enfiar a forquilha da casa; nós levantamos o esteio e encaibramos; nós arribamos e amarramos a casa. Depois colocamos todas as coisas pra dentro pra não molhar. Todos ajudam na construção da casa.
House. We dug the sticks into the ground of the futures house, then we raise its mainstay and put the rafter. Then we put our goods inside the house for them to not get wet. Everyone helps the building of the house. Ajnon: asehu tese saupir sene rehe 'og (Wajwera umume'u) nós todos juntos vamos construir a casa all together we will build the house; ti popytywo e apo 'og eu ajudo a fazer a casa I help the building of the house.

'ogete uruapo ywya urumuseaupyta, uruupir pinowo ipyteripe ywa umuwyhog supatitawa; ipukuete muruwisaw erekehaw asehutese; upuga ruaw murerekotarete; upug ruaw hejkwehe $n$ uhuwapyguwi namukuj hejkwehe upug. Casa tradicional. Para fazer a casa tradicional, cavamos a terra e enfiamos os paus de amarrar rede nos buracos. Depois cobrimos a casa tradicional com a palha do babaçu. Nessa casa, todos nós dormimos nela, mas é o chefe quem dorme perto da porta. Essa casa só tem uma porta para entrar. Antigamente, essa porta não ficava fechada. Traditional house. To make a traditional house, we dug the earth and we stuck the sticks into the holes, tying them to support the rafter. After we have covered the traditional house with thatched babassu we are able to sleep in it, but it is the chief who sleeps near the door. This house has only one door. Formerly, it door was not closed. Ajnon: uruapo puta 'ogete semu'etawa ukaripe (Wajwera umume'u) vamos fazer a casa tradicional no terreno onde a gente estuda let's make a traditional house in the land where you study; uruapo puta 'ogete $t$ uesag wehe warasu tywo, 'og t unawa; vamos fazer a casa tradicional para os não índios poderem ver let's do the traditional house for the non Indians to see it.

\subsubsection{Modelo MDEO9 com estrutura LId: $\{$ DPt-D... (O) [EId/EPt/E...]\}}

O último modelo desse conjunto possui quase todos os componentes do modelo anterior, menos o DId, como pode ser visto no exemplo a seguir: 
FIGURA 147 - MODELO MDEO9

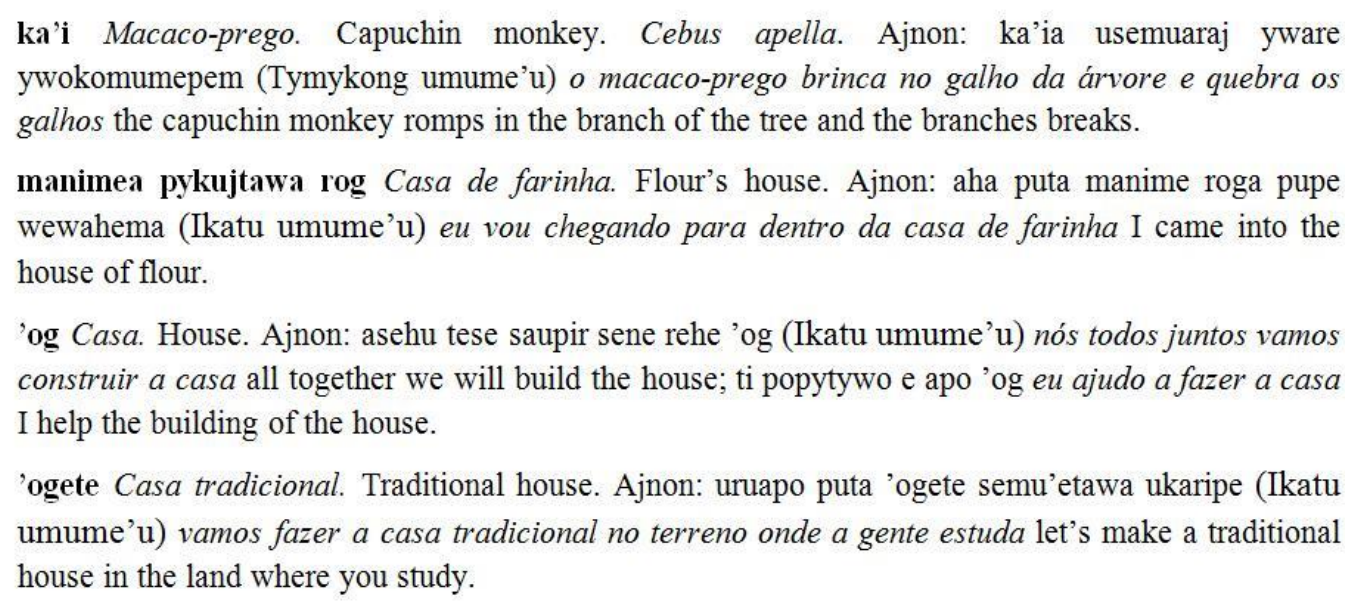

'ogete Casa tradicional. Traditional house. Ajnon: uruapo puta 'ogete semu'etawa ukaripe (Ikatu umume'u) vamos fazer a casa tradicional no terreno onde a gente estuda let's make a traditional house in the land where you study.

Com verbetes distribuídos em uma coluna, esse modelo destaca com efeito itálico somente o material em Português, que fica intercalado entre os dados das duas outras línguas.

\subsubsection{Modelo MDOEO}

$\mathrm{Na}$ sequência de modelos com Operadores não relacionados ao Lema, essa é a última proposta e, com certeza a mais completa. Logo, como havia observado anteriormente, são raros no corpus reunido nesta pesquisa ocorrência de modelos como esse, tanto que só há um registro, até o momento, de material com a estrutura MDOEO.

Contudo, tal como procedi no modelo anterior, apresento as propostas relacionadas a esse modelo para a língua Suruí: (1) LId: \{DId (O) [EId (O)]\}; (2) LId: \{DPt (O) [EId (O)]\}; (3) LId: \{DPt (O) [EId/EPt (O)]\}; (4) LPt: \{DId (O) [EId (O)]\}; (5) LPt: \{DId (O) $[$ EId/EPt (O)]\}; (6) LId: \{DId-DPt (O) [EId/EPt (O)]\}; (7) LPt: \{DPt-DId (O) [EPt/EId (O)]\}; (8) LId: $\{$ DId-DPt-D... (O)[EId/EPt/E... (O)]\} e (9) LId: \{DPt-D... (O)[EId/EPt/E... $(\mathrm{O})]\}$.

\subsubsection{Modelo MDOEO1 com estrutura LId: $\{$ DId (O) [EId (O)]\}}

Em um material lexicográfico para determinada língua, inserir a informação de quem é a pessoa responsável pela explicação sobre determinado item, ou seja, a fonte, colabora para sua credibilidade. Como a fonte da informação para a explicação apresentada no Descritor pode ser diferente da fonte do conteúdo do Exemplo, a inserção desses dois Operadores torna o material ainda mais preciso. Assim, o modelo exemplificado a seguir, apresenta dois Ft, um para o DId e outro para o EId: 
FIGURA 148 - MODELO MDOEO1

ka'i ka'i iwete okowa'e; upyhyg iwyw ka'ia so uputi'a warimu irahaj awpita so akakaw yware; ka'ia awiton iapina pisuna (Wajwera umume'u). Ajnon: ka'ia usemuaraj yware ywokomumepem (Tymykong umume'u).

manimea pykujtawa rog pykujpykujtawa upin mani'og, ukytyg, ukupepyg, umuhaw upykuj. Ajnon: aha puta manime roga pupe wewahema (Ikatu umume'u).

'og uruhywykaj ywya urumumug ywykwara rupi urumuku'om sura ykupyjta urumusarukong uruupir urukwar; ti roga ti kehaw, uruapo pinowa ku urusehe urukehawamu urukupepyg urusehe; un ti ma'epotawamu aapo rako iako tarukeke taruke ti ma'etiru umuakym rapo amona n usapy'u rapo tata (Ikatu umume'u). Ajnon: asehu tese saupir sene rehe 'og (Ikatu umume'u); ti popytywo e apo 'og; ti rehe $t$ aketehewehe ne wy wekow (Wajwera umume'u).

'ogete uruapo ywya urumuseaupyta, uruupir pinowo ipyteripe ywa umuwyhog supatitawa; ipukuete muruwisaw erekehaw asehutese; upuga ruaw murerekotarete; upug ruaw hejkwehe n uhuwapyguwi namukuj hejkwehe upug (Muretama umume'u). Ajnon: uruapo puta 'ogete semu'etawa ukaripe (Ikatu umume'u); uruapo puta 'ogete t uesag wehe warasu tywo, 'og t unawa (Wajwera umume'u).

Outros Operadores poderiam ser usados, por exemplo, no contexto do componente Exemplo, como o Tl ou o Vr.

\subsubsection{Modelo MDOEO2 com estrutura LId: $\{\mathrm{DPt}(\mathrm{O})[\mathrm{EId}(\mathrm{O})]\}$}

Esse modelo possui Operadores relacionados a dois componentes de línguas diferentes, o DPt e o EId, como pode ser observado no exemplo a seguir:

\section{FIGURA 149 - MODELO MDOEO2}

ka'i Ele vive nas copas das árvores; ele desce para pegar ouriço da castanha e sobe com ele na árvore e começa a bater no pau até o ouriço rachar; ele é marrom com a cabeça preta (na língua Suruí a palavra usada para designar 'macaco-prego' é também empregada para a forma genérica 'macaco'). Ajnon: $k a$ 'ia usemuaraj yware ywokomumepem (Tymykong umume'u).

manimea pykujtawa rog $\mathrm{Na}$ casa de fazer farinha, a gente rala, prensa e peneira a mandioca. Depois torra ela, mexendo no forno. Ajnon: aha puta manime roga pupe wewahema (Ikatu umume'u).

'og Nós cavamos o chão para enfiar a forquilha da casa; nós levantamos o esteio e encaibramos; nós arribamos e amarramos a casa. Depois colocamos todas as coisas pra dentro pra não molhar. Todos ajudam na construção da casa (a construção de uma casa é uma ação coletiva na comunidade Suruí, na qual participam homens, mulheres e crianças, cada um desempenhando papéis específicos). Ajnon: asehu tese saupir sene rehe 'og (Ikatu umume'u); ti popytywo e apo 'og; ti rehe $t$ aketehewehe ne wy wekow (Wajwera umume'u).

'ogete Para fazer a casa tradicional, cavamos a terra e enfiamos os paus de amarrar rede nos buracos. Depois cobrimos a casa tradicional com a palha do babaçu. Nessa casa, todos nós dormimos nela, mas é o chefe quem dorme perto da porta. Essa casa só tem uma porta para entrar. Antigamente, essa porta não ficava fechada (atualmente, esse tipo de casa não é mais construída para fins de habitação, apenas como forma de manter a tradição). Ajnon: uruapo puta 'ogete semu'etawa ukaripe (Ikatu umume'u); uruapo puta 'ogete t uesag wehe warasu tywo, 'og $t$ unawa (Wajwera umume'u). 
O primeiro Operador é do tipo $\mathrm{Na}$ e o segundo do tipo Ft, ambos destacados entre parênteses.

\subsubsection{Modelo MDOEO3 com estrutura LId: $\{\mathrm{DPt}(\mathrm{O})[\mathrm{EId} / \mathrm{EPt}(\mathrm{O})]\}$}

Já esse modelo contém duas ocorrências de Exemplo, uma para a língua Suruí, outra para o Português, conforme demonstrado na figura a seguir:

FIGURA 150 - MODELO MDOEO3a

ka'i macaco-prego. Ele vive nas copas das árvores; ele desce para pegar ouriço da castanha e sobe com ele na árvore e começa a bater no pau até o ouriço rachar; ele é marrom com a cabeça preta (na língua Suruí a palavra usada para designar 'macacoprego' é também empregada para a forma genérica 'macaco'). Ajnon: ka'ia usemuaraj yware ywokomumepem (Tymykong umume'u) o macaco-prego brinca no galho da árvore e quebra os galhos.

manimea pykujtawa rog casa de farinha. Na casa de fazer farinha, a gente rala, prensa e peneira a mandioca. Depois torra ela, mexendo no forno. Ajnon: aha puta manime roga pupe wewahema (Ikatu umume'u) eu vou chegando para dentro da casa de farinha.

'og casa. Nós cavamos o chão para enfiar a forquilha da casa; nós levantamos o esteio e encaibramos; nós arribamos e amarramos a casa. Depois colocamos todas as coisas pra dentro pra não molhar. Todos ajudam na construção da casa (a construção de uma casa é uma ação coletiva na comunidade Suruí, na qual participam homens, mulheres e crianças, cada um desempenhando papéis específicos). Ajnon: asehu tese saupir sene rehe 'og (Ikatu umume'u) nós todos juntos vamos construir a casa; ti popytywo e apo 'og (Wajwera umume'u) eu ajudo a fazer a casa.

'ogete casa tradicional. Para fazer a casa tradicional, cavamos a terra e enfiamos os paus de amarrar rede nos buracos. Depois cobrimos a casa tradicional com a palha do babaçu. Nessa casa, todos nós dormimos nela, mas é o chefe quem dorme perto da porta. Essa casa só tem uma porta para entrar. Antigamente, essa porta não fícava fechada (atualmente, esse tipo de casa não é mais construída para fins de habitação, apenas como forma de manter a tradição). Ajnon: uruapo puta 'ogete semu'etawa ukaripe (Ikatu umume'u) vamos fazer a casa tradicional no terreno onde a gente estuda; uruapo puta 'ogete $t$ uesag wehe warasu tywo, 'og $t$ unawa (Wajwera umume'u) vamos fazer a casa tradicional para os não índios poderem ver.

Esse modelo organizado em duas colunas e com destaque para um DPt bastante desenvolvido e acrescido de Operadores se aproxima à estrutura encontrada nos materiais lexicográficos do tipo Enciclopédia (cf., por exemplo, a Enciclopédia Bororo, de Albisetti \& Venturelli (1962)).

Nessa proposta, além do Lema em negrito, o único componente destacado com efeito itálico e o EId. A substituição do DPt mais desenvolvido por esse composto por uma palavra ou expressão permite ver com mais clareza a presença dos Operadores nos dois pontos das microestruturas. A seguir, apresento uma variação desse modelo: 
FIGURA 151 - MODELO MDOEO3b

ka'i macaco-prego (na língua Suruí a palavra usada para designar 'macaco-prego' é também empregada para a forma genérica 'macaco'). Ajnon: ka'ia usemuaraj yware ywokomumepem (Tymykong umume'u); o macaco-prego brinca no galho da árvore e quebra os galhos.

manimea pykujtawa rog casa de farinha. Ajnon: aha puta manime roga pupe wewahema (Ikatu umume'u); eu vou chegando para dentro da casa de farinha.

'og casa (a construção de uma casa é uma ação coletiva na comunidade Suruí, na qual participam homens, mulheres e crianças, cada um desempenhando papéis específicos). Ajnon: asehu tese saupir sene rehe 'og (Ikatu umume'u); eu vou chegando para dentro da casa de farinha; ti popytywo $e$ apo 'og (Wajwera umume'u); eu ajudo a fazer a casa.

'ogete casa tradicional (atualmente, esse tipo de casa não é mais construída para fins de habitação, apenas como forma de manter a tradição). Ajnon: uruapo puta 'ogete semu'etawa ukaripe (Ikatu umume'u); vamos fazer a casa tradicional no terreno onde a gente estuda; uruapo puta 'ogete $t$ uesag wehe warasu tywo (Wajwera umume'u); vamos fazer a casa tradicional para os não índios poderem ver.

\subsubsection{Modelo MDOEO4 com estrutura LPt: $\{$ DId $(\mathrm{O})[\mathrm{EId}(\mathrm{O})]\}$}

Esse quarto modelo leva o Português para a posição de Lema, como pode ser observado no exemplo a seguir:

\section{FIGURA 152 - MODELO MDOEO4a}

casa 'og. Uruhywykaj ywya urumumug ywykwara rupi urumuku'om sura ykupyjta urumusarukong uruupir urukwar; ti roga ti kehaw, uruapo pinowa $\mathrm{ku}$ urusehe urukehawamu urukupepyg urusehe; un ti ma'epotawamu aapo rako iako tarukeke taruke ti ma'etiru umuakym rapo amona $n$ usapy'u rapo tata (Ikatu umume'u). Ajnon: asehu tese saupir sene rehe 'og; ti popytywo e apo 'og (Ikatu umume'u); $t i$ rehe t aketehewehe ne wy wekow (Wajwera umume'u).

casa de farinha manimea pykujtawa rog. Pykujpykujtawa upin mani'og, ukytyg, ukupepyg, umuhaw upykuj. Ajnon: aha puta manime roga pupe wewahema (Ikatu umume'u).
Lasa tradicional 'ogete. Uruapo ywya urumuseaupyta, uruupir pinowo ipyteripe ywa umuwyhog supatitawa; ipukuete muruwisaw erekehaw asehutese; upuga ruaw murerekotarete; upug ruaw hejkwehe $\mathrm{n}$ uhuwapyguwi namukuj hejkwehe upug (Muretama umume'u). Ajnon: uruapo puta 'ogete semu'etawa ukaripe (Ikatu umume'u) uruapo puta 'ogete $t$ uesag wehe warasu tywo, 'og t unawa (Wajwera umume'u).

macaco-prego ka'i. Ka'i iwete okowa'e; upyhyg iwyw ka'ia so uputi'a warimu irahaj awpita so akakaw yware; ka'ia awiton iapina pisuna (Wajwera umume'u). Ajnon: ka'ia usemuaraj yware ywokomumepem (Tymykong umume'u). 
Também com Operadores juntos ao Descritor e ao Exemplo, essa forma do modelo se aproxima bastante à de um material monolíngue, só não efetivado por causa do LPt. Assim como nos modelos anteriores, essa proposta também apresenta uma variação, que está organizada em ordem alfabética do LPt e distribuído em duas colunas:

FIGURA 153 - MODELO MDOEO4b

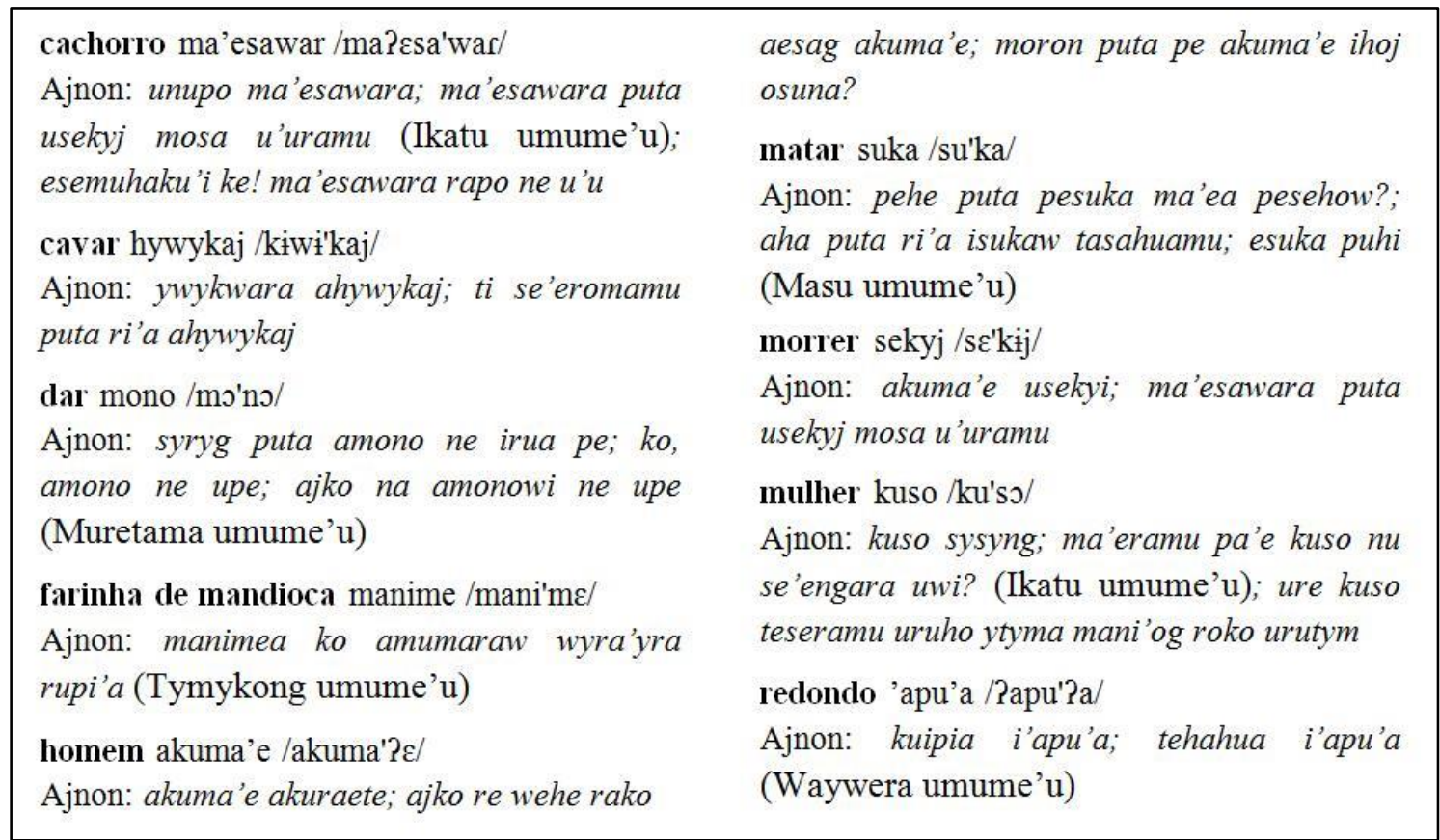

Nesse exemplo, o DId recebe um Operador do tipo Fn e o EId, um do tipo Ft. O primeiro colocado entre barras oblíquas, e o segundo, entre parênteses. Também nessa proposta o LPt e o DId ocupam a primeira linha do verbete, enquanto as demais informações são apresentadas a partir da linha seguinte.

\subsubsection{Modelo MDOEO5 com estrutura LPt: $\{$ DId (O) [EId/EPt (O)]\}}

O quinto modelo assemelha-se ao anterior, porém, nele foi acrescido o componente EPt com a utilização do Operador Ft nos dois contextos.

Com verbetes distribuídos em duas colunas, destaca com efeito negrito o LPt, e com efeito itálico o EPt, valorizando o DId que não tem correspondente na outra língua.

A seguir, apresento na figura 154 um exemplo do modelo MDOEO5 com a sua respectiva variação: 
FIGURA 154 - MODELO MDOEO5a

\begin{tabular}{|c|c|}
\hline $\begin{array}{l}\text { casa 'og. Uruhywykaj ywya urumumug } \\
\text { ywykwara rupi urumuku'om sura ykupyjta } \\
\text { urumusarukong uruupir urukwar; ti roga ti } \\
\text { kehaw, uruapo pinowa ku urusehe } \\
\text { urukehawamu urukupepyg urusehe; un ti } \\
\text { ma'epotawamu aapo rako iako tarukeke } \\
\text { taruke ti ma'etiru umuakym rapo amona n } \\
\text { usapy'u rapo tata (Ikatu umume'u). Ajnon: } \\
\text { asehu tese saupir sene rehe 'og eu vou } \\
\text { chegando para dentro da casa de farinha; ti } \\
\text { popytywo e apo 'og; ti rehe t aketehewehe ne }\end{array}$ & $\begin{array}{l}\text { ywa umuwyhog supatitawa; ipukuete } \\
\text { muruwisaw erekehaw asehutese; upuga ruaw } \\
\text { murerekotarete; upug ruaw hejkwehe n } \\
\text { uhuwapyguwi namukuj hejkwehe upug } \\
\text { (Muretama umume'u). Ajnon: uruapo puta } \\
\text { 'ogete semu'etawa ukaripe (Wajwera } \\
\text { umume'u) vamos fazer a casa tradicional no } \\
\text { terreno onde a gente estuda; uruapo puta } \\
\text { 'ogete t uesag wehe warasu tywo, og t } \\
\text { unawa vamos fazer a casa tradicional para } \\
\text { os não indios poderem ver. }\end{array}$ \\
\hline $\begin{array}{l}\text { wy wekow (Wajwera umume'u); eu ajudo a } \\
\text { fazer a casa. }\end{array}$ & $\begin{array}{l}\text { macaco-prego ka'i. Ka'i iwete okowa'e; } \\
\text { upyhyg iwyw ka'ia so uputi'a warimu irahaj }\end{array}$ \\
\hline $\begin{array}{l}\text { casa de farinha manimea pykujtawa rog. } \\
\text { Pykujpykujtawa upin mani'og, ukytyg, } \\
\text { ukupepyg, umuhaw upykuj. Ajnon: aha puta } \\
\text { manime roga pupe wewahema (Ikatu } \\
\text { umume'u); eu vou chegando para dentro da } \\
\text { casa de farinha. }\end{array}$ & $\begin{array}{l}\text { awpita so akakaw yware; ka'ia awiton iapina } \\
\text { pisuna (Wajwera umume'u). Ajnon: ka'ia } \\
\text { usemuaraj yware ywokomumepem } \\
\text { (Tymykong umume'u); o macaco-prego } \\
\text { brinca no galho da árvore e quebra os } \\
\text { galhos. }\end{array}$ \\
\hline $\begin{array}{l}\text { casa tradicional 'ogete. Uruapo ywya } \\
\text { urumuseaupyta, uruupir pinowo ipyteripe }\end{array}$ & \\
\hline
\end{tabular}

O exemplo seguinte é semelhante ao MDOEO4b, mas acrescido do segundo

Operador. Nele destaco também o LPt e o DId na primeira linha. Destaco novamente que a ocorrência de Operadores em dois pontos da microestrutura pode ser esporádica, havendo, portanto, situações em que o Operador não é usado.

\section{FIGURA 155 - MODELO MDOEO5b}

cavar hywykaj/kiwi'kaj/

Ex. ywykwara ahywykaj eu cavo buraco na terra; ti se'eromamu puta ri'a ahywykaj eu vou cavar meu poço

dar mono /mo'no/

Ex. syryg puta amono ne irua pe (Muretama umume'u) eu vou dar o machado para o teu irmão; ko, amono ne upe vou te dar isso; ajko na amonowi ne upe esse eu não dou isso para você

farinha de mandioca manime /mani'me/

Ex. manimea ko amumaraw wyra'yra rupi'a (Tymykong umume'u) farinha de mandioca misturada com ovo de galinha

homem akuma'e /akuma'?ع/

Ex. akuma'e akuraete homem gordo; ajko re wehe rako aesag akuma'e ontem eu vi este homem; moron puta pe akuma'e ihoj osuna? quantos homens vão correr?

\section{matar suka /su'ka/}

Ex. pehe puta pesuka ma'ea pesehow? (Masu umume'u) vocês vão matar aquelas caças?; aha puta ri'a isukaw tasahuamu talvez eu mate um porcão; esuka puhi não mata ele

morrer sekyj/sc'kij/

Ex. akuma'e usekyi o homem morreu; ma'esawara puta usekyj mosa u'uramu o cachorro vai morrer, porque a cobra mordeu ele

mulher kuso / ku'so/

Ex. kuso sysyng mulher magra; ma'eramu pa'e kuso nu se'engara uwi? (Ikatu umume'u) por que as mulheres não estão cantando?; ure kuso teseramu uruho ytyma mani'og roko urutym nós fomos com as mulheres plantar mandioca

redondo 'apu'a /Rapu'?a/

Ex. kuipia i'apu'a a cuia é redonda; tehahua i'apu'a o tucum é redondo 


\subsubsection{Modelo MDOEO6 com estrutura LId: $\{$ DId-DPt $(\mathrm{O})[\mathrm{EId} / \mathrm{EPt}(\mathrm{O})]\}$}

Um modelo MDOEO bilíngue com Descritores em Suruí e Português e também o componente Exemplo nas duas línguas, todos eles podendo ser seguidos por Operadores, como mostra a figura a seguir:

\section{FIGURA 156 - MODELO MDOEO6}

ka'i ka'i iwete okowa'e; upyhyg iwyw ka'ia so uputi'a warimu irahaj awpita so akakaw yware; ka'ia awiton iapina pisuna. Macaco-prego. Ele vive nas copas das árvores; ele desce para pegar ouriço da castanha e sobe com ele na árvore e começa a bater no pau até o ouriço rachar; ele é marrom com a cabeça preta (na língua Suruí a palavra usada para designar 'macaco-prego' é também empregada para a forma genérica 'macaco'). Ajnon: ka'ia usemuaraj yware ywokomumepem (Tymykong umume'u) o macaco-prego brinca no galho da árvore e quebra os galhos.

manimea pykujtawa rog pykujpykujtawa upin mani'og, ukytyg, ukupepyg, umuhaw upykuj. Casa de farinha. Na casa de fazer farinha, a gente rala, prensa e peneira a mandioca. Depois torra ela, mexendo no forno. Ajnon: aha puta manime roga pupe wewahema (Ikatu umume'u) eu vou chegando para dentro da casa de farinha.

'og uruhywykaj ywya urumumug ywykwara rupi urumuku'om sura ykupyjta urumusarukong uruupir urukwar; ti roga ti kehaw, uruapo pinowa ku urusehe urukehawamu urukupepyg urusehe; un ti ma'epotawamu aapo rako iako tarukeke taruke ti ma'etiru umuakym rapo amona n usapy'u rapo tata. Casa. Nós cavamos o chão para enfiar a forquilha da casa; nós levantamos o esteio e encaibramos; nós arribamos e amarramos a casa. Depois colocamos todas as coisas pra dentro pra não molhar. Todos ajudam na construção da casa (a construção de uma casa é uma ação coletiva na comunidade Suruí, na qual participam homens, mulheres e crianças, cada um desempenhando papéis específicos). Ajnon: asehu tese saupir sene rehe 'og (Wajwera umume'u) nós todos juntos vamos construir a casa; ti popytywo e apo 'og eu ajudo a fazer a casa.

'ogete uruapo ywya urumuseaupyta, uruupir pinowo ipyteripe ywa umuwyhog supatitawa; ipukuete muruwisaw erekehaw asehutese; upuga ruaw murerekotarete; upug ruaw hejkwehe $\mathrm{n}$ uhuwapyguwi namukuj hejkwehe upug. Casa tradicional. Para fazer a casa tradicional, cavamos a terra e enfiamos os paus de amarrar rede nos buracos. Depois cobrimos a casa tradicional com a palha do babaçu. Nessa casa, todos nós dormimos nela, mas é o chefe quem dorme perto da porta. Essa casa só tem uma porta para entrar. Antigamente, essa porta não ficava fechada (atualmente, esse tipo de casa não é mais construída para fins de habitação, apenas como forma de manter a tradição). Ajnon: uruapo puta 'ogete semu'etawa ukaripe (Wajwera umume'u) vamos fazer a cascl递 tradicional no terreno onde a gente estuda; uruapo puta 'ogete t uesag wehe warasu tywo, 'og t unawa; vamos fazer a casa tradicional para os não índios poderem ver.

\subsubsection{Modelo MDOEO7 com estrutura LPt: $\{$ DPt-DId (O) [EPt/EId (O)] $\}$}

Esse modelo mantém os mesmos componentes da proposta anterior, mas muda a posição das línguas, onde havia Suruí coloca o Português e vice-versa: 
FIGURA 157 - MODELO MDOEO7

Casa. Nós cavamos o chão para enfiar a forquilha da casa; nós levantamos o esteio e encaibramos; nós arribamos e amarramos a casa. Depois colocamos todas as coisas pra dentro pra não molhar. Todos ajudam na construção da casa (a construção de uma casa é uma ação coletiva na comunidade Suruí, na qual participam homens, mulheres e crianças, cada um desempenhando papéis específicos). 'og. Uruhywykaj ywya urumumug ywykwara rupi urumuku'om sura ykupyjta urumusarukong uruupir urukwar; ti roga ti kehaw, uruapo pinowa $k u$ urusehe urukehawamu urukupepyg urusehe; un ti ma'epotawamu aapo rako iako tarukeke taruke ti ma'etiru umuakym rapo amona $n$ usapy'u rapo tata. Ex.: nós todos juntos vamos construir a casa asehu tese saupir sene rehe 'og (Wajwera umume'u); eu ajudo a fazer a casa ti popytywo e apo 'og.

Casa de farinha. Na casa de fazer farinha, a gente rala, prensa e peneira a mandioca. Depois torra ela, mexendo no forno. Manimea pykujtawa rog. Pykujpykujtawa upin mani'og, ukytyg, ukupepyg, umuhaw upykuj. Ex.: eu vou chegando para dentro da casa de farinha aha puta manime roga pupe wewahema (Ikatu umume'u).

Casa tradicional. Para fazer a casa tradicional, cavamos a terra e enfiamos os paus de amarrar rede nos buracos. Depois cobrimos a casa tradicional com a palha do babaçu. Nessa casa, todos nós dormimos nela, mas é o chefe quem dorme perto da porta. Essa casa só tem uma porta para entrar. Antigamente, essa porta não ficava fechada (atualmente, esse tipo de casa não é mais construída para fins de habitação, apenas como forma de manter a tradição). 'ogete. Uruapo ywya urumuseaupyta, uruupir pinowo ipyteripe ywa umuwyhog supatitawa; ipukuete muruwisaw erekehaw asehutese; upuga ruaw murerekotarete; upug ruaw hejkwehe n uhuwapyguwi namukuj hejkwehe upug. Ex.: vamos fazer a casa tradicional no terreno onde a gente estuda uruapo puta 'ogete semu'etawa ukaripe (Wajwera umume'u); vamos fazer a casa tradicional para os não índios poderem ver uruapo puta 'ogete $t$ uesag wehe warasu tywo, 'og $t$ unawa.

Macaco-prego. Ele vive nas copas das árvores; ele desce para pegar ouriço da castanha e sobe com ele na árvore e começa a bater no pau até o ouriço rachar; ele é marrom com a cabeça preta (na língua Suruí a palavra usada para designar 'macaco-prego' é também empregada para a forma genérica 'macaco'). Ka'i. Ka'i iwete okowa'e; upyhyg iwyw ka'ia so uputi'a warimu irahaj awpita so akakaw yware; ka'ia awiton iapina pisuna. Ex.: o macaco-prego brinca no galho da árvore e quebra os galhos ka'ia usemuaraj yware ywokomumepem (Tymykong umume'u).

Dentro deste conjunto de modelos MDOEO, a proposta acima é uma das mais completas para um material lexicográfico bilíngue, com LPt destacado em negrito e DId e EId em itálico.

\subsubsection{Modelo MDOEO8 com estrutura LId: \{DId-DPt-D... (O) [EId/EPt/E... (O)]}

Esse modelo apresenta a maior EML desse conjunto, com pelo menos três componentes do tipo Descritor e três componentes do tipo Exemplo, e envolvendo, portanto, três línguas, no mínimo, em sua constituição.

O primeiro Operador é do tipo $\mathrm{Na}$ e o segundo, do tipo $\mathrm{Ft}$, ambos destacados entre parênteses, como pode ser observado no exemplo a seguir: 
FIGURA 158 - MODELO MDOEO8

ka'i ka'i iwete okowa'e; upyhyg iwyw ka'ia so uputi'a warimu irahaj awpita so akakaw yware; ka'ia awiton iapina pisuna. Macaco-prego. Ele vive nas copas das árvores; ele desce para pegar ouriço da castanha e sobe com ele na árvore e começa a bater no pau até o ouriço rachar; ele é marrom com a cabeça preta (na língua Suruí a palavra usada para designar 'macaco-prego' é também empregada para a forma genérica 'macaco'). Capuchin monkey. He lives on the top of the trees; he goes to pick up hedgehog chestnut-nut and climbs the tree with him; then, he starts beating the Hedgehog until it cracks; He is brown with a black head. Cebus apella. Ajnon: ka'ia usemuaraj yware ywokomumepem (Tymykong umume'u) $o$ macaco-prego brinca no galho da árvore $e$ quebra os galhos the capuchin monkey romps in the branch of the tree and the branches breaks.

manimea pykujtawa rog pykujpykujtawa upin mani'og, ukytyg, ukupepyg, umuhaw upykuj. Casa de farinha. Na casa de fazer farinha, a gente rala, prensa e peneira a mandioca. Depois torra ela, mexendo no forno. Flour's house. In the flour's house, the people grate, press and sieve cassava. After roasting it, they stir it on the oven. Ajnon: aha puta manime roga pupe wewahema (Ikatu umume'u) eu vou chegando para dentro da casa de farinha I came into the house of flour.

'og uruhywykaj ywya urumumug ywykwara rupi urumuku'om sura ykupyjta urumusarukong uruupir urukwar; ti roga ti kehaw, uruapo pinowa ku urusehe urukehawamu urukupepyg urusehe; un ti ma'epotawamu aapo rako iako tarukeke taruke ti ma'etiru umuakym rapo amona n usapy'u rapo tata. Casa. Nós cavamos o chão para enfiar a forquilha da casa; nós levantamos o esteio e encaibramos; nós arribamos e amarramos a casa. Depois colocamos todas as coisas pra dentro pra não molhar. Todos ajudam na construção da casa (a construção de uma casa é uma ação coletiva na comunidade Suruí, na qual participam homens, mulheres e crianças, cada um desempenhando papéis específicos). House. We dug the sticks into the ground of the futures house, then we raise its mainstay and put the rafter. Then we put our goods inside the house for them to not get wet. Everyone helps the building of the house. Ajnon: asehu tese saupir sene rehe 'og (Wajwera umume'u) nós todos juntos vamos construir a casa all together we will build the house; ti popytywo e apo 'og eu ajudo a fazer a casa I help the building of the house.

'ogete uruapo ywya urumuseaupyta, uruupir pinowo ipyteripe ywa umuwyhog supatitawa; ipukuete muruwisaw erekehaw asehutese; upuga ruaw murerekotarete; upug ruaw hejkwehe $n$ uhuwapyguwi namukuj hejkwehe upug. Casa tradicional. Para fazer a casa tradicional, cavamos a terra e enfiamos os paus de amarrar rede nos buracos. Depois cobrimos a casa tradicional com a palha do babaçu. Nessa casa, todos nós dormimos nela, mas é o chefe quem dorme perto da porta. Essa casa só tem uma porta para entrar. Antigamente, essa porta não ficava fechada (atualmente, esse tipo de casa não é mais construída para fins de habitação, apenas como forma de manter a tradição). Traditional house. To make a traditional house [일 (Ctrl) - ug the earth and we stuck the sticks into the holes, tying them to support the rafter. After we have covered the traditional house with thatched babassu we are able to sleep in it, but it is the chief who sleeps near the door. This house has only one door. Formerly, it door was not closed. Ajnon: uruapo puta 'ogete semu'etawa ukaripe (Wajwera umume'u) vamos fazer a casa tradicional no terreno onde a gente estuda let's make a traditional house in the land where you study; uruapo puta 'ogete t uesag wehe warasu tywo, 'og t unawa; vamos fazer a casa tradicional para os não índios poderem ver let's do the traditional house for the non Indians to see it. 


\title{
9.1.7.9. Modelo MDOEO9 com estrutura LId: $\{\mathrm{DPt}-\mathrm{D} . . .(\mathrm{O})[\mathrm{EId} / \mathrm{EPt} / \mathrm{E} \ldots(\mathrm{O})]\}$
}

Enfim, o último modelo do grupo MDOEO é semelhante ao anterior, mas elimina o componente DId. Nesse caso, optei por apresentar o conteúdo dos demais Descritores apenas com uma palavra ou expressão traduzindo o Lema em Suruí. Essas características podem ser observadas a seguir:

\section{FIGURA 159 - MODELO MDOEO9}

\begin{abstract}
ka'i Macaco-prego (mico-de-topete). Capuchin monkey. Cebus apella. Ajnon: ka'ia usemuaraj yware ywokomumepem (Tymykong umume'u) o macaco-prego brinca no galho da árvore $e$ quebra os galhos the capuchin monkey romps in the branch of the tree and the branches breaks.

manimea pykujtawa rog Casa de farinha (farinha de mandioca). Flour's house. Ajnon: aha puta manime roga pupe wewahema (Ikatu umume'u) eu vou chegando para dentro da casa de farinha I came into the house of flour.

'og Casa. House. Ajnon: asehu tese saupir sene rehe 'og (Ikatu umume'u) nós todos juntos vamos construir a casa all together we will build the house; ti popytywo e apo 'og eu ajudo a fazer a casa I help the building of the house.

'ogete Casa tradicional (casa verdadeira). Traditional house. Ajnon: uruapo puta 'ogete semu'etawa ukaripe (Ikatu umume'u) vamos fazer a casa tradicional no terreno onde a gente estuda let's make a traditional house in the land where you study.
\end{abstract}

\subsubsection{Modelo MO}

Neste ponto da apresentação dos modelos lexicográficos para a língua indígena Suruí, é importante destacar que, doravante, todas as propostas seguirão estruturas paralelas às sete primeiras apresentadas acima, porém com a diferença de conterem todos esses modelos o componente Operador relacionado ao Lema do verbete. ${ }^{171}$

Baseando-me na estrutura básica L: O, é possível construir uma série de propostas, à maneira do que foi feito com a estrutura L (ver subseção 9.1.1 acima). No entanto, é importante destacar que, no levantamento feito das UBL's das línguas indígenas brasileiras, registrei apenas uma ocorrência com essa estrutura.

Dessa forma, as propostas aqui construídas são, grosso modo, inéditas no contexto brasileiro. A seguir, apresento as propostas baseadas neste modelo e que utilizam dados apenas da língua Suruí.

\footnotetext{
${ }^{171}$ A decisão de apresentar separadamente esses modelos se deve ao fato de eles permitirem o uso de uma quantidade maior de tipos de Operadores.
} 
FIGURA 160 - MODELO MO1

\begin{tabular}{|c|c|c|}
\hline 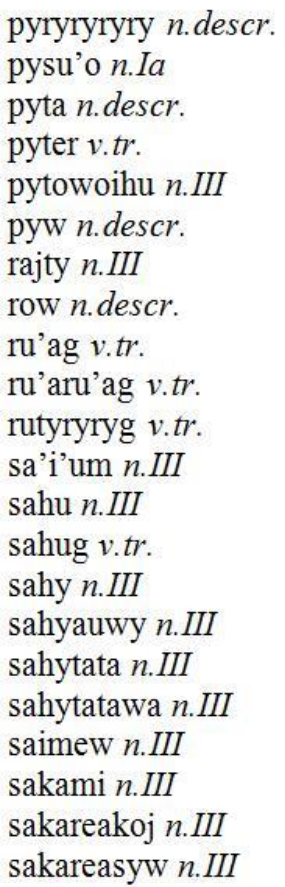 & $\begin{array}{l}\text { sakare } n . I I I \\
\text { sakarehu } n . I I I \\
\text { sakareting } n . I I I \\
\text { saku } n . I I I \\
\text { sakuhu } n . I I I \\
\text { sakuna } n . I I I \\
\text { samomor } n . \text { descr. } \\
\text { sanipaw } n . I I I \\
\text { sanu } n . I I I \\
\text { sanu'i } n . I I I \\
\text { sanua rekwaw } n . I I I \\
\text { sanupopuku } n . I I I \\
\text { sanupuhaw } n . I I I \\
\text { sanupyha } n . I I I \\
\text { sapakani } \\
\text { sapakaniron } n . I I I \\
\text { sapi'i } n . I I I \\
\text { sapuhu } n . I I I \\
\text { saratyta } n . I I I \\
\text { sarukaw } n . I I I \\
\text { sarukong } n . I a \\
\text { sasyu'u } n . d e s c r \text {. }\end{array}$ & 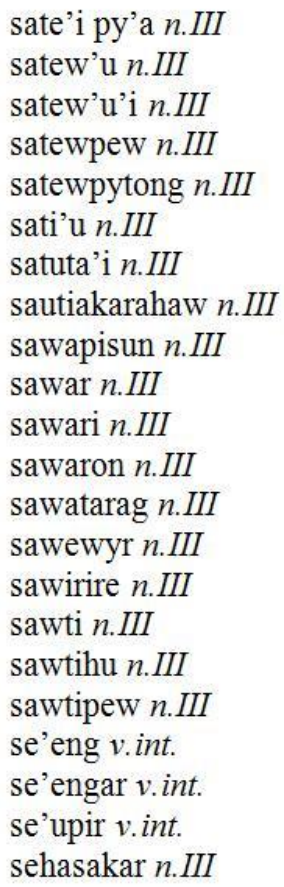 \\
\hline
\end{tabular}

Essa primeira proposta com verbetes distribuídos em três colunas e ordenados alfabeticamente, apresenta o LId na língua Suruí com um Operador do tipo Gr, destacado com efeito itálico. Um material desta natureza pode ser usado para construir, por exemplo, um vocabulário ortográfico da língua, adicionado da informação gramatical que pode ser aproveitada em um contexto escolar de ensino da língua. ${ }^{172}$

O próximo modelo retoma o anterior, inserindo nele um segundo Operador:

FIGURA 161 - MODELO MO2

\begin{tabular}{|c|c|c|c|}
\hline 585 . & nupinipar n.III /nupini'par/ & 601. & parati'iw $n \cdot I b$ /parati'?iw/ \\
\hline 586. & nupo v.tr. /nu'ps/ & 602. & pe $n . I a /$ pe/ \\
\hline 587. & o'o n.IIa /o'?ว/ & 603. & pehe pron. /pe'he/ \\
\hline 588. & o'oj n.III /o'?oj/ & 604. & pehitaw n.III /pshi'taw/ \\
\hline 589. & 'og n.III /'?og/ & 605. & peke’i n.III /pcke'?i/ \\
\hline 590. & 'ogete $n . I I I /$ Pog $\varepsilon$ 't $\varepsilon /$ & 606. & penur n.descr. /ps'nur/ \\
\hline 591. & oko n.III /o'ko/ & 607. & pepo n.III /pc'ps/ \\
\hline 592. & opo v.tr. /o'po/ & 608. & pepuwyr $n . I a /$ pspu'wir/ \\
\hline 593. & oso n.IIa /o'so/ & 609. & perew $n . I a / p \varepsilon^{\prime} r \varepsilon w /$ \\
\hline 594. & oto n.descr. /o'to/ & 610. & pesu v.tr. /pe'su/ \\
\hline 595. & ow n.IIa /'ow/ & 611. & petiwaron n.III /petiwa'ron/ \\
\hline 596. & pa'e part.int. /pa'?e/ & 612. & petiwaron'yw n.III /petiwa'ron'?iw/ \\
\hline 597. & pahaku /paha'ku/ & 613. & petym $n . I I I / p \varepsilon^{\prime}$ tim/ \\
\hline 598. & pakohow n.III /pako'həw/ & 614. & petymapysahy n.III /ps'timapisa'hi \\
\hline 599. & pakwohow n.III /pakwo'how/ & 615. & petymapisar n.III /'petimapi'sar/ \\
\hline 600 . & papar v.tr. /pa'par/ & 616. & petymu v.int. /peti'mu/ \\
\hline
\end{tabular}

172 Como mencionei anteriormente, um componente da microestrutura pode se associar a um ou mais Operadores, conforme o estabelecido no PDL que originou o material. 
No modelo MO2, numerado e organizado em ordem alfabética, além do Operador $\mathrm{Gr}^{173}$ do primeiro modelo, há também um operador do tipo Fn. Trata-se de uma proposta que associa a escrita ortográfica da língua à descrição da pronúncia e que, apesar de poder ser usada em um ambiente escolar, ela atende bem mais a um público especializado no estudo da língua, como professores de língua, linguísticas e antropólogos.

Já o próximo modelo estabelece uma rede de relações dentro do conjunto da macroestrutura, pois emprega o Operador Rm, como pode ser observado a seguir:

FIGURA 162 - MODELO MO3

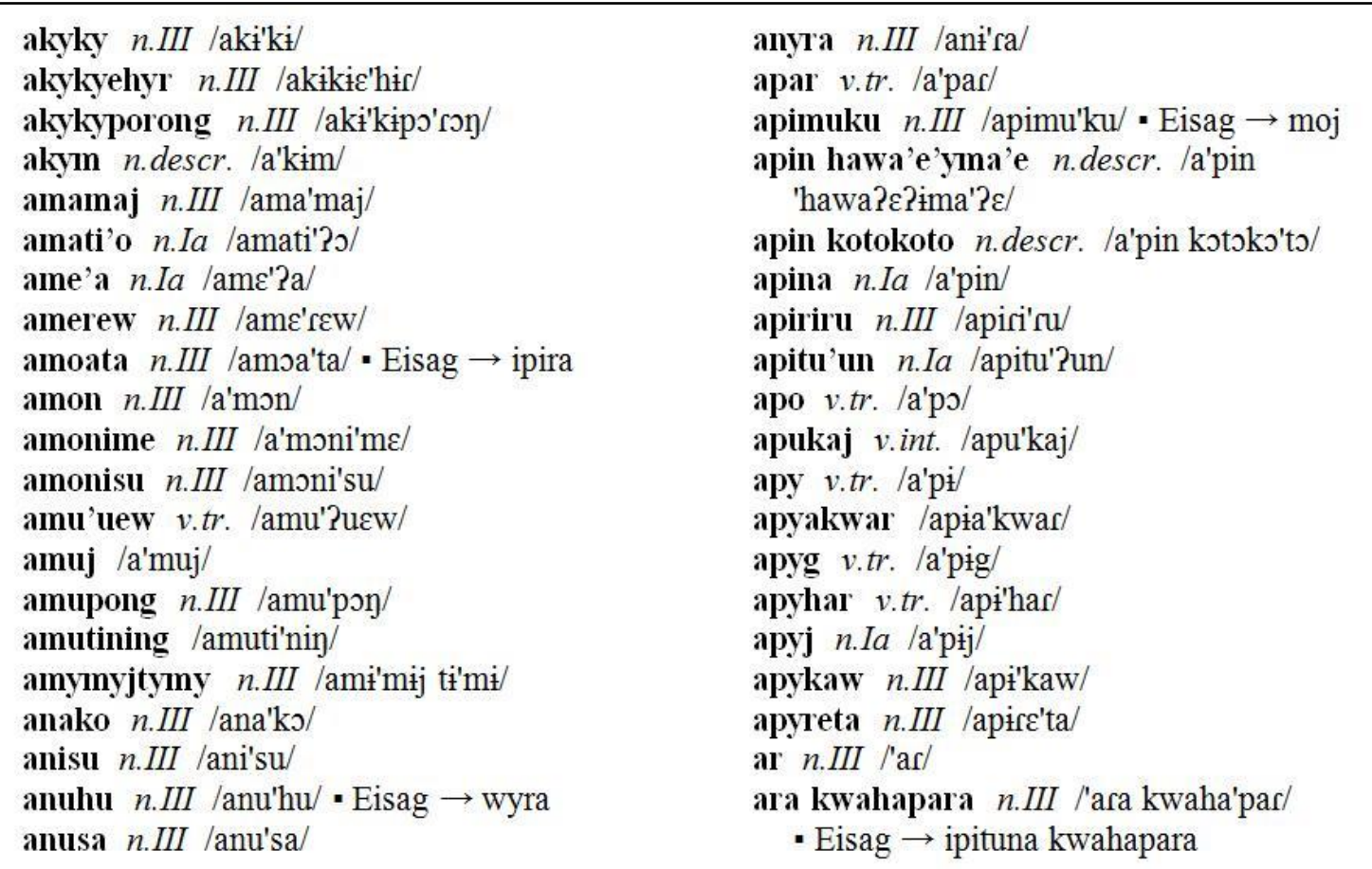

Nesse modelo há dois operadores tornados obrigatórios no PDL e um opcional, cuja função é remeter para outro(s) ponto(s) da macroestrutura de acordo com um critério préestabelecido (sinonímia, homonímia, heteronímia, antonímia entre outros). Esse Operador Rm é precedido pela palavra na língua Suruí eisag 'ver' com uma seta voltada para a direita. ${ }^{174}$

O próximo modelo retoma a estrutura MO2, mas reordena-a a partir do Operador Gr e substitui a forma fonológica pela transcrição fonética. Para melhor observação deste critério, separei os verbetes em grupos de acordo com a categoria gramatical.

\footnotetext{
${ }^{173}$ Como ainda não foi desenvolvida uma nomenclatura gramatical na língua Suruí, utilizo abreviaturas baseadas na nomenclatura gramatical brasileira.

${ }^{174} \mathrm{Na}$ ausência de uma forma ortográfica de escrita da língua, o LId pode ser escrito com a própria forma fonética ou fonológica, a fim de garantir o registro.
} 
Descritor. Com essa estrutura foi possível desenvolver as seguintes propostas de EML's: (1) LId: O \{DId\}; (2) LId: O \{DPt $\}$; (3) LPt: O \{DId\}; (4) LId: O \{DId-DPt $\}$; (5) LPt: O \{DPtDId \}; (6) LId: O \{DPt-D... $\}$.

Vale lembrar que essas estruturas assemelham-se à forma MD, acrescida de Operador(es).

\subsubsection{Modelo MOD1 com estrutura LId: O $\{$ DId $\}$}

Esse é o primeiro modelo MOD e que apresenta a estrutura mais básica, ou seja, apenas um Lema com Operador(es) e um Descritor. Podendo ser usado para materiais monolíngues, apresento-o, a seguir, em três versões: com um, dois e três Operadores.

FIGURA 165 - MODELO MOD1a

ka'i $n$.III. ka'i iwete okowa'e; upyhyg iwyw ka'ia so uputia warimu irahaj awpita so akakaw yware; ka'ia awiton iapina pisuna.

manimea pykujtawa rog pykujpykujtawa upin mani'og, ukytyg, ukupepyg, umuhaw upykuj.

'og n.III uruhywykaj ywya urumumug ywykwara rupi urumuku'om sura ykupyjta urumusarukong uruupir urukwar; ti roga ti kehaw, uruapo pinowa ku urusehe urukehawamu urukupepyg urusehe; un ti ma'epotawamu aapo rako iako tarukeke taruke ti ma'etiru umuakym rapo amona n usapy'u rapo tata.

'ogete $n . I I I$ uruapo ywya urumuseaupyta, uruupir pinowo ipyteripe ywa umuwyhog supatitawa; ipukuete muruwisaw erekehaw asehutese; upuga ruaw murerekotarete; upug ruaw hejkwehe $n$ uhuwapyguwi namukuj hejkwehe upug.

tapyj $n . I I I$ ka'ape sepi uruapo tapyj urukehawamum amona wi uruapo tapyj amona neapy awi uruapo; urumonohog sepy ywyra iapoa nune sepi a'eramu uruwerur taapone usaw ka'ape sepi; pinowaku sepi uruupir sepi tapyjromamu.

No modelo acima, o LId vem destacado com efeito negrito e o único Operador do tipo Gr com efeito itálico, seguidos do Descritor em texto sem efeito.

Já o modelo a seguir, apresenta as mesmas características do anterior, porém, com dois Operadores, um do tipo Gr e outro do tipo Fn. A figura abaixo contém um exemplo desse modelo: 
FIGURA 166 - MODELO MOD1b

ka'i n.III. /ka?i/ ka'i iwete okowa'e; upyhyg iwyw ka'ia so uputia warimu irahaj awpita so akakaw yware; ka'ia awiton iapina pisuna.

manimea pykujtawa rog /mani'mea pikuj'tawa 'rog/ pykujpykujtawa upin mani'og, ukytyg, ukupepyg, umuhaw upykuj.

'og n.III /Pog/ uruhywykaj ywya urumumug ywykwara rupi urumuku'om sura ykupyjta urumusarukong uruupir urukwar; ti roga ti kehaw, uruapo pinowa ku urusehe urukehawamu urukupepyg urusehe; un ti ma'epotawamu aapo rako iako tarukeke taruke ti ma'etiru umuakym rapo amona n usapy'u rapo tata.

'ogete n.III / Pogete/ uruapo ywya urumuseaupyta, uruupir pinowo ipyteripe ywa umuwyhog supatitawa; ipukuete muruwisaw erekehaw asehutese; upuga ruaw murerekotarete; upug ruaw hejkwehe n uhuwapyguwi namukuj hejkwehe upug.

tapyj $n . I I I /$ tapuj/ ka'ape sepi uruapo tapyj urukehawamum amona wi uruapo tapyj amona neapy awi uruapo; urumonohog sepy ywyra iapoa nune sepi a'eramu uruwerur taapone usaw ka'ape sepi; pinowaku sepi uruupir sepi tapyjromamu.

Da mesma maneira, a figura abaixo retoma a estrutura das duas anterior, porém conta com um terceiro Operador, o Rm, inserido no final do verbete. ${ }^{175}$

FIGURA 167 - MODELO MOD1c

ka'i n.III. /ka?i/ ka'i iwete okowa'e; upyhyg iwyw ka'ia so uputia warimu irahaj awpita so akakaw yware; ka'ia awiton iapina pisuna.

manimea pykujtawa rog /mani'mea pikuj'tawa 'rog/ pykujpykujtawa upin mani'og, ukytyg, ukupepyg, umuhaw upykuj.

'og n.III /Rog/ uruhywykaj ywya urumumug ywykwara rupi urumuku'om sura ykupyjta urumusarukong uruupir urukwar; ti roga ti kehaw, uruapo pinowa $\mathrm{ku}$ urusehe urukehawamu urukupepyg urusehe; un ti ma'epotawamu aapo rako iako tarukeke taruke ti ma'etiru umuakym rapo amona $n$ usapy'u rapo tata. - Eisag $\rightarrow$ 'ogete, tapyj.

'ogete n.III /Pogete/ uruapo ywya urumuseaupyta, uruupir pinowo ipyteripe ywa umuwyhog supatitawa; ipukuete muruwisaw erekehaw asehutese; upuga ruaw murerekotarete; upug ruaw hejkwehe $\mathrm{n}$ uhuwapyguwi namukuj hejkwehe upug. - Eisag $\rightarrow$ 'og.

tapyj $n . I I I /$ tapuj/ ka'ape sepi uruapo tapyj urukehawamum amona wi uruapo tapyj amona neapy awi uruapo; urumonohog sepy ywyra iapoa nune sepi a'eramu uruwerur taapone usaw ka'ape sepi; pinowaku sepi uruupir sepi tapyjromamu. - Eisag $\rightarrow$ 'og.

175 A posição que o Operador deverá ocupar é também decisão do PDL, contudo, é possível estabelecer certos padrões, como, por exemplo, a inserção de Rm no final do verbete ou de Gr logo após o Lema. 


\subsubsection{Modelo MOD2 com estrutura LId: O $\{\mathrm{DPt}\}$}

Esse segundo modelo do conjunto MOD inclui uma segunda língua, neste caso, o Português, como pode ser observado a seguir:

FIGURA 168 - MODELO MOD2a

ka'i. n.III. /ka'?i/ O macaco-prego vive nas copas das árvores; ele desce para pegar ouriço da castanha e sobe com ele na árvore e começa a bater no pau até o ouriço rachar; ele é marrom com a cabeça preta.

manimea pykujtawa rog. /mani'mea pikuj'tawa 'rog/ Na casa de fazer farinha, a gente rala, prensa e peneira a mandioca. Depois torra ela, mexendo no forno. 'og. n.III /'Pog/ Nós cavamos o chão para enfiar a forquilha da casa; nós levantamos o esteio e encaibramos; nós arribamos e amarramos a casa. Depois colocamos todas as coisas pra dentro pra não molhar. Todos ajudam na construção da casa.

'ogete. $n . I I I /$ Poge'te/ Para fazer a casa tradicional, cavamos a terra e enfiamos os paus de amarrar rede nos buracos. Depois cobrimos a casa tradicional com a palha do babaçu. Nessa casa, todos nós dormimos nela, mas é o chefe quem dorme perto da porta. Essa casa só tem uma porta para entrar. Antigamente, essa porta não ficava fechada.

No modelo acima, os dois Operadores Gr e Fn estão relacionados ao LId, enquanto o Descritor, sem Operador, está apenas em Português. Este Descritor com texto contrasta com o usado no modelo seguinte, que tem apenas uma palavra ou expressão, traduzindo o LId.

FIGURA 169 - MODELO MOD2b

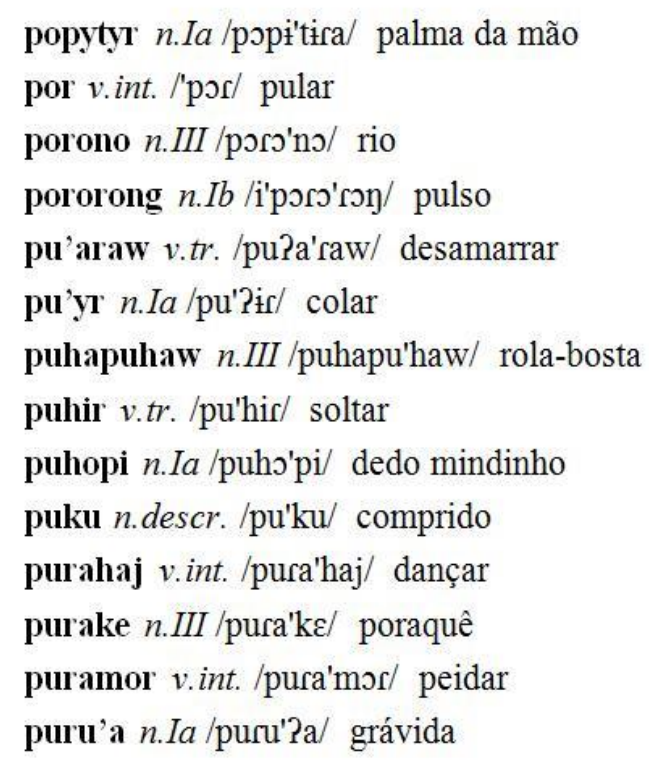

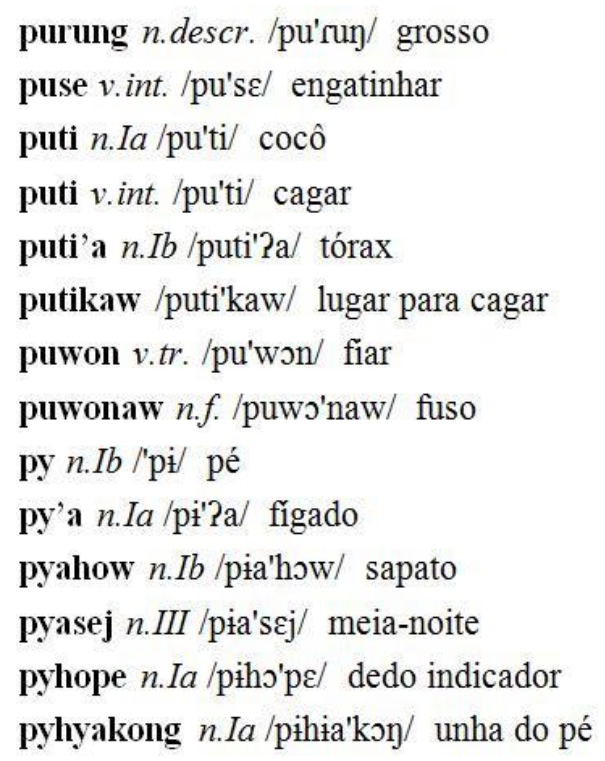


Esta segunda forma do modelo, ordenada alfabeticamente, é bastante recorrente no conjunto de UBL's (principalmente nas formas mais frequentes: dicionários, glossários e vocabulários.) das línguas indígenas brasileiras.

É importante destacar que, além dos Operadores usados nos exemplos acima, outros podem também configurar nos materiais produzidos a partir desse modelo, tais como Et, Rm, Tle Vr.

\subsubsection{Modelo MOD3 com estrutura LPt: O $\{$ DId $\}$}

Com a mesma estrutura do modelo anterior, esse outro modelo desloca a língua indígena para a posição de Descritor e a segunda língua, o Português, para a posição de Lema, conforme os exemplos abaixo:

FIGURA 170 - MODELO MOD3a

casa n.f. 'og. uruhywykaj ywya urumumug ywykwara rupi urumuku'om sura ykupyjta urumusarukong uruupir urukwar; ti roga ti kehaw, uruapo pinowa ku urusehe urukehawamu urukupepyg urusehe; un ti ma'epotawamu aapo rako iako tarukeke taruke ti ma'etiru umuakym rapo amona n usapy'u rapo tata. - Ver $\rightarrow$ casa de farinha, casa tradicional, tapiri.

casa de farinha n.f. manimea pykujtawa rog. pykujpykujtawa upin mani'og, ukytyg, ukupepyg, umuhaw upykuj. - Ver $\rightarrow$ casa.

casa tradicional $n . f$. 'ogete. uruapo ywya urumuseaupyta, uruupir pinowo ipyteripe ywa umuwyhog supatitawa; ipukuete muruwisaw erekehaw asehutese; upuga ruaw murerekotarete; upug ruaw hejkwehe $\mathrm{n}$ uhuwapyguwi namukuj hejkwehe upug. Ver $\rightarrow$ casa.

tapiri n.m. tapyj. ka'ape sepi uruapo tapyj urukehawamum amona wi uruapo tapyj amona neapy awi uruapo; urumonohog sepy ywyra iapoa nune sepi a'eramu uruwerur taapone usaw ka'ape sepi; pinowaku sepi uruupir sepi tapyjromamu. - Ver $\rightarrow$ casa.

No modelo acima, o LPt conta com Operadores do tipo Gr, destacado com itálico, e Rm, precedido da palavra 'Ver' seguida de uma seta voltada para a direita.

Como esse modelo possui o Descritor na forma de texto, não é tão comum quanto a sua variante, apresentada a seguir, que apresenta DId na forma de palavra ou expressão.

Assim, o próximo modelo aproveita elementos do anterior, mas insere na estrutura outro Operador, ou seja, um Na: 
FIGURA 171 - MODELO MOD3b

\begin{tabular}{|c|c|}
\hline $\begin{array}{l}\text { acari } n . m \text {. ini'omupir } \cdot \text { Ver } \rightarrow \text { peixe } \\
\text { acariciar v.tr. muw'iw } \\
\text { acertar (o alvo) v.tr. isakatuete } \\
\text { acocorar-se v.tr. mypukur } \\
\text { acordar v.int. tyryg } \\
\text { açúcar n.m. ywysukyr } \\
\text { afiar v.int. upu'an } \\
\text { afundar v.int. sepymy } \\
\text { agrisalhar v.int. 'asupaw } \\
\text { água n.f. 'y } \\
\text { águia n.f. sapakaniron - Ver } \rightarrow \text { pássaro } \\
\text { agulha n.f. tatina'yw } \\
\text { ajoelhar v.int. kanawa } \\
\text { ajudar v.tr. mupoiru } \\
\text { aldeia n.f. etom } \\
\text { aleijado n.descr. ikome'yma'e } \\
\text { algodão n.m. amonisu } \\
\text { algodoeiro n.m. amonisu 'yw } \\
\text { ali adv. pew } \\
\text { alma n.f. ywiterer } \\
\text { amanhã adv. use'iuhe ete } \\
\text { amarelo } n \text {. sukyry }\end{array}$ & 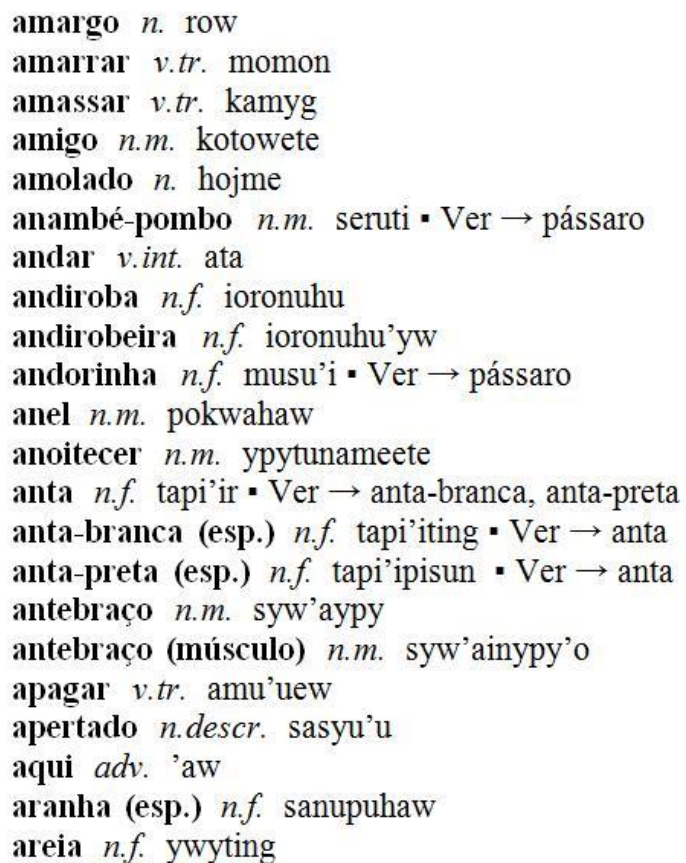 \\
\hline
\end{tabular}

O Operador Na acrescenta informação ao LPt, a fim de conferir maior precisão. Além disso, o Operador Rm remete para outros LPt do material.

\subsubsection{Modelo MOD4 com estrutura LId: O \{DId-DPt $\}$}

No conjunto de modelos MOD, esse é o primeiro a apresentar dois Descritores, um em Suruí, outro em Português, como pode ser observado a seguir:

\section{FIGURA 172 - MODELO MOD4}

manimea pykujtawa rog. /mani'mea pikuj'tawa 'rog/ Pykujpykujtawa upin mani'og, ukytyg, ukupepyg, umuhaw upykuj. Casa de farinha. Na casa de fazer farinha, a gente rala, prensa e peneira a mandioca. Depois torra ela, mexendo no forno.

'og. n.III / $20 \mathrm{~g} /$ Uruhywykaj ywya urumumug ywykwara rupi urumuku'om sura ykupyjta urumusarukong uruupir urukwar; ti roga ti kehaw, uruapo pinowa ku urusehe urukehawamu urukupepyg urusehe. Casa. Nós cavamos o chão para enfiar a forquilha da casa; nós levantamos o esteio e encaibramos; nós arribamos e amarramos a casa. Depois colocamos todas as coisas pra dentro pra não molhar. Todos ajudam na construção da casa.

'ogete. n.III / Pogete/ Uruapo ywya urumuseaupyta, uruupir pinowo ipyteripe ywa umuwyhog supatitawa; ipukuete muruwisaw erekehaw asehutese; upuga ruaw murerekotarete; upug ruaw hejkwehe n uhuwapyguwi namukuj hejkwehe upug. Casa tradicional. Para fazer a casa tradicional, cavamos a terra e enfiamos os paus de amarrar rede nos buracos. Depois cobrimos a casa tradicional com a palha do babaçu. Nessa casa, todos nós dormimos nela, mas é o chefe quem dorme perto da porta. Essa casa só tem uma porta para entrar. Antigamente, essa porta não ficava fechada. 
Dois Operadores estão associados ao LId, o Gr e o Fn. O primeiro deles em itálico, e o outro entre barras oblíquas. No mesmo verbete, o texto em Português vem destacado em itálico, para se diferenciar do texto do DId.

\subsubsection{Modelo MOD5 com estrutura LPt: O \{DPt-DId $\}$}

O penúltimo modelo MOD inverte a posição das línguas do modelo anterior, como pode ser visto no exemplo a seguir:

\section{FIGURA 173 - MODELO MOD5}

casa. $n . f$. Nós cavamos o chão para enfiar a forquilha da casa; nós levantamos o esteio e encaibramos; nós arribamos e amarramos a casa. Depois colocamos todas as coisas pra dentro pra não molhar. Todos ajudam na construção da casa. 'og. Uruhywykaj ywya urumuтug ywykwara rupi urumuku'om sura ykupyjta urumusarukong uruupir urukwar; ti roga ti kehaw, uruapo pinowa ku urusehe urukehawamu urukupepyg urusehe. - Ver $\rightarrow$ casa de farinha, casa tradicional.

casa de farinha. n.f. Na casa de fazer farinha, a gente rala, prensa e peneira a mandioca. Depois torra ela, mexendo no forno. Manimea pykujtawa rog. Pykujpykujtawa upin mani'og, ukytyg, ukupepyg, umuhaw upykuj. - Ver $\rightarrow$ casa.

casa tradicional. $n$.f. Para fazer a casa tradicional, cavamos a terra e enfiamos os paus de amarrar rede nos buracos. Depois cobrimos a casa tradicional com a palha do babaçu. Nessa casa, todos nós dormimos nela, mas é o chefe quem dorme perto da porta. Essa casa só tem uma porta para entrar. Antigamente, essa porta não ficava fechada. 'ogete. Uruapo ywya urumuseaupyta, uruupir pinowo ipyteripe ywa umuwyhog supatitawa; ipukuete muruwisaw erekehaw asehutese; upuga ruaw murerekotarete; upug ruaw hejkwehe n uhuwapyguwi namukuj hejkwehe upug. - Ver $\rightarrow$ casa.

Nesse modelo, o Operador Gr é inserido logo após o LPt, e o Operador Rm, no final do verbete, ambos se referindo ao Lema. O destaque fica também no LPt, com negrito, no Operador Gr e no DId, com itálico.

\subsubsection{Modelo MOD6 com estrutura LId: O \{DPt-D... $\}$}

No último modelo MOD, a estrutura prevê a inserção de dois ou mais Descritores, mas sem DId, ou seja, há, pelo menos, três línguas envolvidas nessa microestrutura, mas a língua Suruí fica apenas no Lema. Trata-se de um modelo pouco comum no conjunto de UBL's das línguas indígenas brasileiras.

Apresento, a seguir, um exemplo desse modelo, envolvendo, além do Suruí, o Português, o Inglês e o Espanhol. ${ }^{176}$

\footnotetext{
${ }^{176}$ Por se tratarem de nomes de animais, seria possível ainda inserir o nome científico em Latim.
} 
FIGURA 174 - MODELO MOD6

\begin{tabular}{|c|c|}
\hline $\begin{array}{l}\text { a'aite } n . I I I \text { /aPai'te/ jiboia, boa constrictor, } \\
\text { boa constrictora }\end{array}$ & $\begin{array}{l}\text { katykyehyr } n . I I I / \text { katikic'hir/ abelha (esp.), } \\
\text { bee, abeja }\end{array}$ \\
\hline $\begin{array}{l}\text { akara'i n.III /akara'?i/ carazinho, acara, } \\
\text { castañeta }\end{array}$ & $\begin{array}{l}\text { paratuwakonguhu n.III /paratuwakonu'hu/ } \\
n . I I I \text { pica-pau, woodpecker, pájaro carpintero }\end{array}$ \\
\hline $\begin{array}{l}\text { inamu'i n.III /inamu'Pi/ inambumirim, } \\
\text { tataupa tinamou, tataupá común }\end{array}$ & $\begin{array}{l}\text { tapi'iting } n . I I I / \text { tapi?i'tiy/ anta-branca (esp.), } \\
\text { Brazilian tapir, tapir amazónico }\end{array}$ \\
\hline $\begin{array}{l}\text { katinkwer } n . I I I \text { /kati'ywes/ veado-virá, gray } \\
\text { brocket, guazuncho }\end{array}$ & $\begin{array}{l}\text { tatuhu } n . I I I / \text { tatu'hu/ tatu-canastra, giant } \\
\text { armadillo, armadillo gigante }\end{array}$ \\
\hline
\end{tabular}

Nesse modelo, o único componente a receber efeito itálico é o DIn, que está inserido entre o DPt e o DEn. Além disso, só o LId tem Operadores (Gr e Fn) associados a ele.

\subsubsection{Modelo MODO}

Outro modelo comum no conjunto de UBL's das línguas indígenas do Brasil é o com EML do tipo L: $\mathrm{O}\{\mathrm{D}(\mathrm{O})\}$. Baseado nessa estrutura, apresento as seguintes propostas: (1) LId: O \{DId (O) \}; (2) LId: O \{DPt (O)\}; (3) LId: O \{DId (O) -DPt $\}$; (4) LPt: O \{DPt (O) -DId\}; (5) LId: O \{DPt (O) -DId\}; (6) LPt: O \{DId (O) -DPt\}; (7) LId: O \{DId (O) -DPtD... $\}$; (8) LPt: O \{DId (O) -D... $\}$ e (9) LId: O \{DPt (O) -D... $\}$

\subsubsection{Modelo MODO1 com estrutura LId: O $\{$ DId $(\mathrm{O})\}$}

Como as primeiras propostas dos modelos anteriores, esse modelo é também destinado a materiais monolíngues, como pode ser observado no exemplo a seguir:

FIGURA 175 - MODELO MODO1a

ka'i $n . I I I . /$ ka'?i/ ka'i iwete okowa'e; upyhyg iwyw ka'ia so uputi'a warimu irahaj awpita so akakaw yware; ka'ia awiton iapina pisuna (Tymykong umume'u).

manimea pykujtawa rog /mani'mea pikuj'tawa 'rog/ pykujpykujtawa upin mani'og, ukytyg, ukupepyg, umuhaw upykuj (Ikatu umume’u).

'og n.III /'?og/ uruhywykaj ywya urumumug ywykwara rupi urumuku'om sura ykupyjta urumusarukong uruupir urukwar; ti roga ti kehaw, uruapo pinowa ku urusehe urukehawamu urukupepyg urusehe; un ti ma'epotawamu aapo rako iako tarukeke taruke ti ma'etiru umuakym rapo amona $\mathrm{n}$ usapy'u rapo tata (Wajwera umume'u).

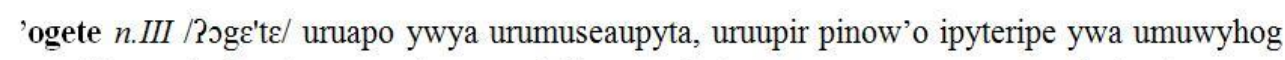
supatitawa; ipukuete muruwisaw erekehaw asehutese; upuga ruaw murerekotarete; upug ruaw hejkwehe $\mathrm{n}$ uhuwapyguwi namukuj hejkwehe upug (Wajwera umume'u).

tapyj $n$.III /ta'pij/ ka'ape sepi uruapo tapyj urukehawamum amona wi uruapo tapyj amona neapy awi uruapo; urumonohog sepy ywyra iapoa nune sepi a'eramu uruwerur taapone usaw ka'ape sepi; pinowaku sepi uruupir sepi tapyjromamu (Ikatu umume'u). 
Nessa proposta tanto o LId quanto o DId possuem Operadores. O primeiro, com Operadores dos tipos Gr e Fn, o segundo, com Operador do tipo Na.

Abaixo, apresento uma variação dessa proposta:

FIGURA 176 - MODELO MODO1b

A'aite /a?ai'te/ moj (mosa)

Akara'i /akara'?i/ ipira

Inamu'i /inamu'?i/ wyra

Katinkwer/kati'ywes/misar (misara)

Katykyehyr/katikic'hir/ tuw (tuwa)

Tapi'iting /tapi?i'tin/ tapi'ir (tapi'ira)

Tatuhu /tatu'hu/ tatu

Esse modelo se diferencia do anterior por apresentar como Descritor apenas uma palavra ou expressão, e não uma descrição completa. Nesse caso, o DId mantém uma relação de hiperonímia com o LId.

\subsubsection{Modelo MODO2 com estrutura LId: O $\{\mathrm{DPt}(\mathrm{O})\}$}

Já o segundo modelo, bastante comum no conjunto de UBL's das línguas indígenas brasileiras, corresponde à proposta envolvendo duas línguas, uma no Lema e outra no Descritor, como no exemplo seguinte:

FIGURA 177 - MODELO MODO2

\begin{tabular}{|c|c|}
\hline AMUTINING [amutfi'nịy] maracá (tipo) & POPI [po'pi] anelar (dedo) \\
\hline EMISARIRU [emisari'ru] neto (mulher falando) & PUHUKUPE [puhuku'pe] sola (do pé) \\
\hline ETYMASI'A [etimasi'Pa] canela (parte do corpo) & PYHEJ [pi'hej] lavar (coisa) \\
\hline HYRETOM [hire'təm] cera (de abelha) & suMr'A [sumi'?a] flauta (tipo) \\
\hline KUPITAW [kupi'taw] sapo (esp.) & SYRUHEJ [siru'hej] lavar (roupa) \\
\hline KURETA'U [kureta'?u] tucano (esp.) & TYPAW [ti'paw] seco (de líquido) \\
\hline $\begin{array}{l}\text { MISARAPIRONG [misarapi'œy] veado-vermelho } \\
\text { (veado-mateiro) }\end{array}$ & $\begin{array}{l}\text { UKYSETEWA'E [ukisctewa'? } \varepsilon \text { ] medroso } \\
\text { (humano) }\end{array}$ \\
\hline PETYMA PISARA [pe'time pi'sare] tabaco (fumo) & URE [u're] nós (excl.) \\
\hline PINA'IRONA'YW graviola (árvore) & YMEMUR [ime'mur] filhote (de bicho) \\
\hline
\end{tabular}

Tanto o LId quanto o DPt possuem Operadores. O primeiro, entre colchetes, é do tipo Fn, e o segundo, entre parênteses, é do tipo Na. 


\subsubsection{Modelo MODO3 com estrutura LId: O \{DId (O) -DPt $\}$}

Nesse modelo, a língua Suruí é usada no Lema e no Descritor da microestrutura, mas também há um Descritor em Português. Contudo, apenas os componentes em Suruí apresentam Operador(es), como é possível ver no exemplo abaixo:

FIGURA 178 - MODELO MODO3a

ka'i $n$.III [ka'?i] ka'i iwete okowa'e; upyhyg iwyw ka'ia so uputi'a warimu irahaj awpita so akakaw yware; ka'ia awiton iapina pisuna (Tymykong umume'u). Macaco-prego. Ele vive nas copas das árvores; ele desce para pegar ouriço da castanha e sobe com ele na árvore e começa a bater no pau até o ouriço rachar; ele é marrom com a cabeça preta.

'og n.III ['?og] uruhywykaj ywya urumumug ywykwara rupi urumuku'om sura ykupyjta urumusarukong uruupir urukwar; ti roga ti kehaw, uruapo pinowa ku urusehe urukehawamu urukupepyg urusehe; un ti ma'epotawamu aapo rako iako tarukeke taruke ti ma'etiru umuakym rapo amona n usapy'u rapo tata (Wajwera umume'u). Casa. Nós cavamos o chão para enfiar a forquilha da casa; nós levantamos o esteio e encaibramos; nós arribamos e amarramos a casa. Depois colocamos todas as coisas pra dentro pra não molhar. Todos ajudam na construção da casa.

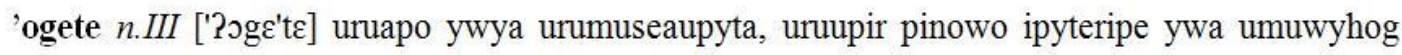
supatitawa; ipukuete muruwisaw erekehaw asehutese; upuga ruaw murerekotarete; upug ruaw hejkwehe $\mathrm{n}$ uhuwapyguwi namukuj hejkwehe upug (Wajwera umume'u). Casa tradicional. Para fazer a casa tradicional, cavamos a terra e enfiamos os paus de amarrar rede nos buracos. Depois cobrimos a casa tradicional com a palha do babaçu. Nessa casa, todos nós dormimos nela, mas é o chefe quem dorme perto da porta. Essa casa só tem uma porta para entrar. Antigamente, essa porta não ficava fechada.

Nesse modelo, os Operadores Gr e Fn se relacionam com o LId, e o Operador Na, com o DId; só o DPt, destacado com efeito itálico, não possui Operador.

Uma variação desse modelo é apresentada a seguir:

FIGURA 179 - MODELO MODO3b

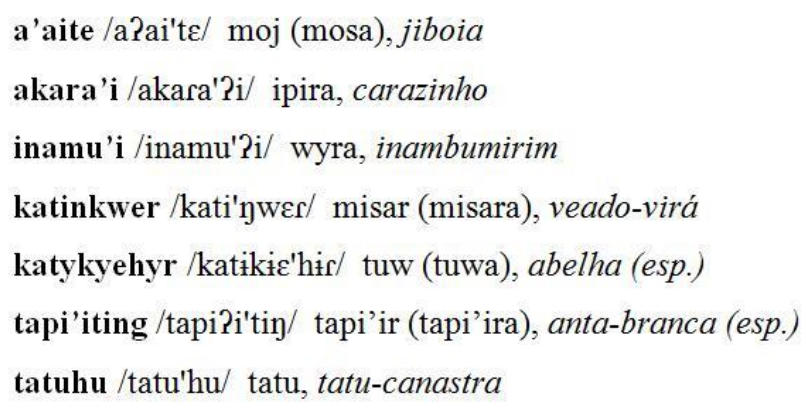

Essa proposta acima se diferencia da anterior por apresentar o DId e o DPt apenas com palavras e não com texto mais extenso. 


\title{
9.1.10.4. Modelo MODO4 com estrutura LPt: $\mathrm{O}\{\mathrm{DPt}(\mathrm{O})-\mathrm{DId}\}$
}

Essa proposta de modelo corresponde à anterior, mas com a posição das línguas trocadas, ou seja, o componente que antes estava em Suruí passou a Português e vice-versa, como é possível observar no exemplo abaixo:

\section{FIGURA 180 - MODELO MODO4}

\begin{abstract}
Casa. n.f. Nós cavamos o chão para enfiar a forquilha da casa; nós levantamos o esteio e encaibramos; nós arribamos e amarramos a casa. Depois colocamos todas as coisas pra dentro pra não molhar. Todos ajudam na construção da casa. (A construção de uma casa é uma ação coletiva na comunidade Suruí, na qual participam homens, mulheres e crianças, cada um desempenhando papéis específicos). 'og. uruhywykaj ywya urumumug ywykwara rupi urumuku'om sura ykupyjta urumusarukong uruupir urukwar; ti roga ti kehaw, uruapo pinowa ku urusehe urukehawamu urukupepyg urusehe; un ti ma'epotawamu aapo rako iako tarukeke taruke ti ma'etiru umuakym rapo amona n usapy'u rapo tata. - Ver $\rightarrow$ Casa tradicional.
\end{abstract}

Casa tradicional. n.f. (casa verdadeira) Para fazer a casa tradicional, cavamos a terra e enfiamos os paus de amarrar rede nos buracos. Depois cobrimos a casa tradicional com a palha do babaçu. Nessa casa, todos nós dormimos nela, mas é o chefe quem dorme perto da porta. Essa casa só tem uma porta para entrar. Antigamente, essa porta não fícava fechada. (Atualmente, esse tipo de casa não é mais construída para fins de habitação, apenas como forma de manter a tradição). 'ogete. uruapo ywya urumuseaupyta, uruupir pinowo ipyteripe ywa uтиwyhog supatitawa; ipukuete muruwisaw erekehaw asehutese; upuga ruaw murerekotarete; upug ruaw hejkwehe $n$ uhuwapyguwi namukuj hejkwehe. - Ver $\rightarrow$ Casa

Macaco-prego. n.m. (mico-de-topete) Ele vive nas copas das árvores; ele desce para pegar ouriço da castanha e sobe com ele na árvore e começa a bater no pau até o ouriço rachar; ele é marrom com a cabeça preta (na língua Suruí a palavra usada para designar 'macaco-prego' é também empregada para a forma genérica 'macaco'). Ka'i. ka'i iwete okowa'e; upyhyg iwyw ka'ia so uputi'a warimu irahaj awpita so akakaw yware; ka'ia awiton iapina pisuna.

Nessa proposta, apenas o que está na língua Suruí foi destacado com efeito itálico, já os Operadores, dois do tipo Na foram colocados entre parênteses, e um terceiro, posto logo depois do LPt, sem nenhum efeito.

\subsubsection{Modelo MODO5 com estrutura LId: O $\{\mathrm{DPt}(\mathrm{O})-\mathrm{DId}\}$}

Essa quinta proposta traz novamente a língua Suruí para a posição de Lema, mantendo o restante da microestrutura como no modelo anterior. A figura abaixo exemplifica esse modelo: 
FIGURA 181 - MODELO MODO5

'og. n.III /'Pog/ Casa. Nós cavamos o chão para enfiar a forquilha da casa; nós levantamos o esteio e encaibramos; nós arribamos e amarramos a casa. Depois colocamos todas as coisas pra dentro pra não molhar. Todos ajudam na construção da casa. (A construção de uma casa é uma ação coletiva na comunidade Suruí, na qual participam homens, mulheres e crianças, cada um desempenhando papéis específicos). Uruhywykaj ywya urumumug ywykwara rupi urumuku'om sura ykupyjta urumusarukong uruupir urukwar; ti roga ti kehaw, uruapo pinowa ku urusehe urukehawamu urukupepyg urusehe; un ti ma'epotawamu aapo rako iako tarukeke taruke ti ma'etiru umuakym rapo amona $n$ usapy'u rapo tata. - Eisag $\rightarrow$ 'ogete.

'ogete. n.III / Poge'te/ Casa tradicional. Para fazer a casa tradicional, cavamos a terra e enfiamos os paus de amarrar rede nos buracos. Depois cobrimos a casa tradicional com a palha do babaçu. Nessa casa, todos nós dormimos nela, mas é o chefe quem dorme perto da porta. Essa casa só tem uma porta para entrar. Antigamente, essa porta não ficava fechada. (Atualmente, esse tipo de casa não é mais construída para fins de habitação, apenas como forma de manter a tradição). Uruapo ywya urumuseaupyta, uruupir pinowo ipyteripe ywa umuwyhog supatitawa; ipukuete muruwisaw erekehaw asehutese; upuga ruaw murerekotarete; upug ruaw hejkwehe $n$ uhuwapyguwi namukuj hejkwehe. - Eisag $\rightarrow$ 'og.

Ka'i. n.III /ka'?i/ Macaco-prego. Ele vive nas copas das árvores; ele desce para pegar ouriço da castanha e sobe com ele na árvore e começa a bater no pau até o ouriço rachar; ele é marrom com a cabeça preta (na língua Suruí a palavra usada para designar 'macaco-prego' é também empregada para a forma genérica 'macaco'). ka'i iwete okowa'e; upyhyg iwyw ka'ia so uputi'a warimu irahaj awpita so akakaw yware; ka'ia awiton iapina pisuna.

Relacionados ao LId estão os Operadores Gr, Fn e Rm, e ao DPt, apenas o Operador Na.

\subsubsection{Modelo MODO6 com estrutura LPt: O $\{\mathrm{DId}(\mathrm{O})-\mathrm{DPt}\}$}

Nesse modelo, há um novo arranjo das línguas com a mesma estrutura dos dois modelos precedentes: o Português volta à posição de Lemas, mas o Suruí fica como primeiro Descritor com Operador(es), como pode ser observado no exemplo abaixo: 
Casa. n.f. 'og. uruhywykaj ywya urumumug ywykwara rupi urumuku'om sura ykupyjta urumusarukong uruupir urukwar; ti roga ti kehaw, uruapo pinowa ku urusehe urukehawamu urukupepyg urusehe; un ti ma'epotawamu aapo rako iako tarukeke taruke ti ma'etiru umuakym rapo amona $n$ usapy'u rapo tata (Wajwera umume'u). Nós cavamos o chão para enfiar a forquilha da casa; nós levantamos o esteio e encaibramos; nós arribamos e amarramos a casa. Depois colocamos todas as coisas pra dentro pra não molhar. Todos ajudam na construção da casa. - Ver $\rightarrow$ casa de farinha, casa tradicional.

Casa de farinha. n.f. manimea pykujtawa rog. pykujpykujtawa upin mani'og, ukytyg, ukupepyg, umuhaw upykuj (Ikatu umume'u). Na casa de fazer farinha, a gente rala, prensa e peneira a mandioca. Depois torra ela, mexendo no forno. $\cdot$ Ver $\rightarrow$ casa.

Casa tradicional. n.f. 'ogete. uruapo ywya urumuseaupyta, uruupir pinowo ipyteripe ywa umuwyhog supatitawa; ipukuete muruwisaw erekehaw asehutese; upuga ruaw murerekotarete; upug ruaw hejkwehe n uhuwapyguwi namukuj hejkwehe (Wajwera umume'u). Para fazer a casa tradicional, cavamos a terra e enfiamos os paus de amarrar rede nos buracos. Depois cobrimos a casa tradicional com a palha do babaçu. Nessa casa, todos nós dormimos nela, mas é o chefe quem dorme perto da porta. Essa casa só tem uma porta para entrar. Antigamente, essa porta não fícava fechada. - Ver $\rightarrow$ casa.

Macaco-prego. n.m. Ka'i. ka'i iwete okowa'e; upyhyg iwyw ka'ia so uputi'a warimu irahaj awpita so akakaw yware; ka'ia awiton iapina pisuna (Tymykong umume'u). Ele vive nas copas das árvores; ele desce para pegar ouriço da castanha e sobe com ele na árvore e começa a bater no pau até o ouriço rachar; ele é marrom com a cabeça preta.

Nesse modelo, foram usados os Operadores Gr e Rm para o DPt, e para o DId, o Operador Na.

\subsubsection{Modelo MODO7 com estrutura LId: O \{DId (O) -DPt-D... $\}$}

Dentre os modelos do tipo MODO, esse é o primeiro a apresentar três ou mais línguas, sendo que Lema e Descritores podem se relacionar a Operador(es).

A seguir, apresento um exemplo baseado nesta proposta: 
FIGURA 183 - MODELO MODO7a

A'aite /a?ai'tc/ n.III moj (mosa), jiboia, boa constrictor

Akara'i /akara'?i/ n.III ipira, carazinho, pterophyllum

Inamu'i /inamu'Pi/ n.III wyra, inambumirim, crypturellus tataupa

Katinkwer /kati'ywer/ n.III misar (misara), veado-virá, mazama gouazoubira

Katykyehyr /katikiz'hir/ n.III tuw (tuwa), abelha (esp.)

Tapi'iting /tapi?i'tin/ n.III tapi'ir (tapi'ira), anta-branca (esp.), tapirus terrestris

Tatuhu /tatu'hu/ n.III tatu, tatu-canastra, priodontes maximus

O LId, com destaque em negrito, se relaciona aos Operadores Fn e Gr, enquanto os Descritores se relacionam a Operadores do tipo Na. Nesse modelo, foram incluídas as línguas Suruí (LId e DId), Português (DPt) e Latim (DLt).

Já o próximo modelo não conta com o Operador Gr, nem com o DLt, mas inclui o Descritor em Inglês, na última posição do verbete.

FIGURA 184 - MODELO MODO7b

A'aite /a?ai'tc/ moj (mosa), jiboia, boa constrictor

Akara'i /akara'?i/ ipira, carazinho, angelfish

Inamu'i /inamu'?i/ wyra, inambumirim, tataupa tinamou

Katinkwer/kati'ywes/ misar (misara), veado-virá, gray brocket

Katykyehyr /katikiz'his/ tuw (tuwa), abelha (esp.), bee

Tapi'iting /tapiPi'tin/ tapi'ir (tapi'ira), anta-branca (esp.), Brazilian tapir

Tatuhu /tatu'hu/ tatu, tatu-canastra, giant armadillo

Outra possibilidade desse modelo é a inserção simultânea das línguas da proposta acima, acrescida do DLt, assim, o modelo contaria com quatro línguas.

FIGURA 185 - MODELO MODO7c

A'aite /aPai'te/ moj (mosa), jiboia, boa constrictor [boa constrictor]

Akara'i /akara'?i/ ipira, carazinho

Inamu'i /inamu'?i/ wyra, inambumirim, tataupa tinamou [crypturellus tataupa]

Katinkwer/kati'ywer/ misar (misara), veado-virá, gray brocket [mazama gouazoubira]

Katykyehyr/katikis'hir/ tuw (tuwa), abelha (esp.), bee

Tapi'iting /tapi2i'tiy/ tapi'ir (tapi'ira), anta-branca (esp.), Brazilian tapir [tapirus terrestris]

Tatuhu/tatu'hu/ tatu, tatu-canastra, giant armadillo [priodontes maximus] 1 


\subsubsection{Modelo MODO8 com estrutura LPt: O \{DId (O) -D... $\}$}

Nesse penúltimo modelo, o Lema fica em Português, enquanto o Suruí entra como primeiro Descritor, seguido dos Descritores nas demais línguas, conforme demonstra exemplo a seguir:

\section{FIGURA 186 - MODELO MODO8}

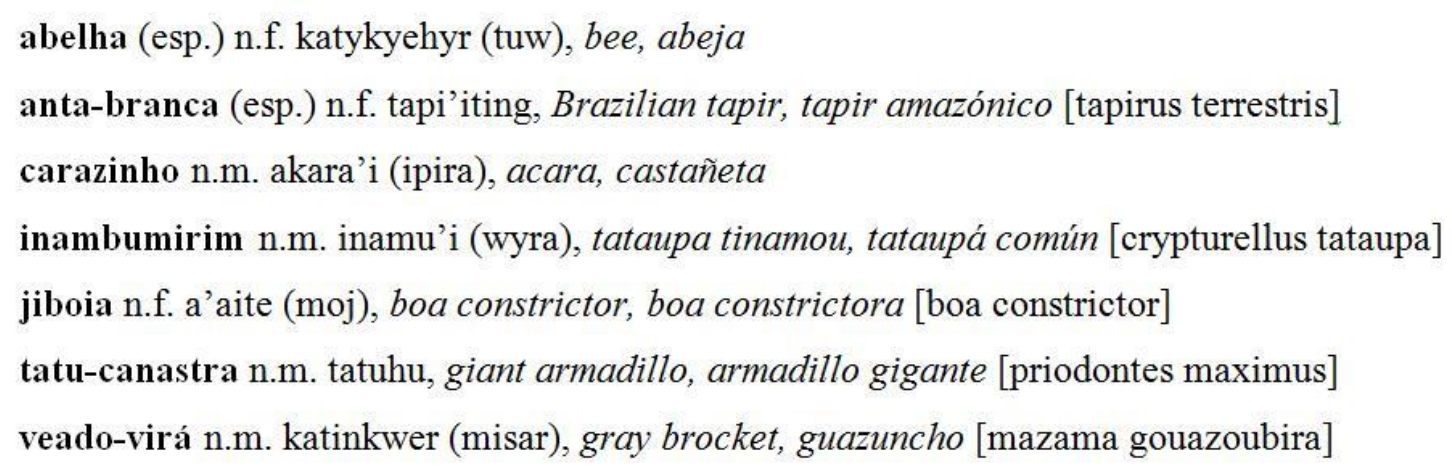

Nesse modelo, o Operador Gr está relacionado ao LPt, enquanto o Operador Na, com o DId.

\subsubsection{Modelo MODO9 com estrutura LId: O \{DPt (O) -D... $\}$}

Já na última proposta, a língua Suruí só é usada no Lema, como no exemplo abaixo:

FIGURA 187 - MODELO MODO9

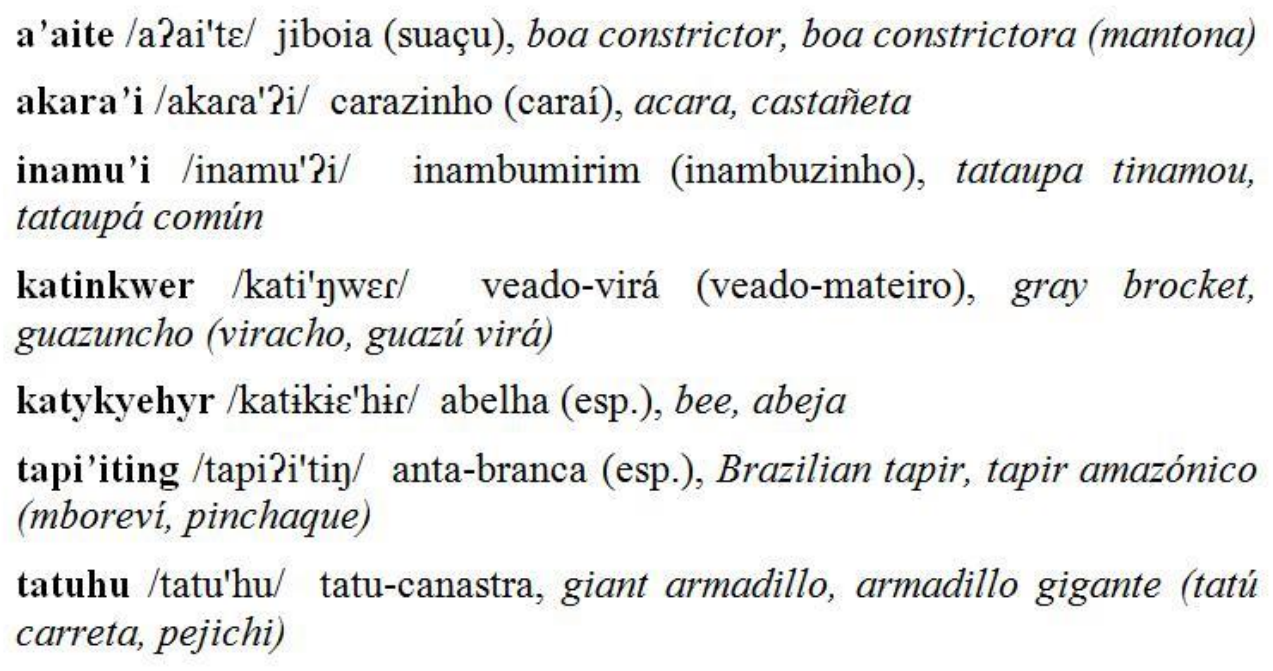

Os Descritores são apresentados em Português, Inglês e Espanhol, sendo que estas duas últimas estão destacadas no verbete com efeito itálico. 


\subsubsection{Modelo MODE}

Neste novo conjunto de modelos, apenas o Lema apresenta Operador(es), mas há a inclusão do componente Exemplo, não usado nas três propostas anteriores. Desse modo, com base na estrutura $\mathrm{L}: \quad \mathrm{O} \quad\{\mathrm{D} \quad[\mathrm{E}]\}$, cheguei às seguintes propostas: (1) LId: O \{DId [EId]\}; (2) LId: O \{DPt [EId] \}; (3) LId: O \{DPt [EId/EPt]\}; (4) LPt: O \{DId [EId]\}; (5) LPt: O \{DId [EId/EPt]\}; (6) LId: O \{DId-DPt [EId/EPt]\}; (7) LPt: O \{DPt-DId [EPt/EId]\}; (8) LId: O \{DId-DPt-D... [EId/EPt/E...]\}; (9) LId: O \{DPt-D... [EId/EPt/E...]\}.

\subsubsection{Modelo MODE1 com estrutura LId: O \{DId [EId] $\}$}

Nesse primeiro modelo do tipo MODE, utilizo apenas a língua Suruí em todos os componentes, conforme exemplo a seguir:

\section{FIGURA 188 - MODELO MODE1}

ka'i n.III /ka'Pi/ ka'i iwete okowa'e; upyhyg iwyw ka'ia so uputi'a warimu irahaj awpita so akakaw yware; ka'ia awiton iapina pisuna. Ajnon: ka'ia usemuaraj yware ywokomumepem.

manimea pykujtawa rog /mani'mea pikuj'tawa 'юg/ pykujpykujtawa upin mani'og, ukytyg, ukupepyg, umuhaw upykuj. Ajnon: aha puta manime roga pupe wewahema.

'og n.III /'Pog/ uruhywykaj ywya urumumug ywykwara rupi urumuku'om sura ykupyjta urumusarukong uruupir urukwar; ti roga ti kehaw, uruapo pinowa ku urusehe urukehawamu urukupepyg urusehe; un ti ma'epotawamu aapo rako iako tarukeke taruke ti ma'etiru umuakym rapo amona n usapy'u rapo tata. Ajnon: asehu tese saupir sene rehe 'og; ti popytywo e apo 'og; ti rehe t aketehewehe ne wy wekow.

'ogete n.III / Poge'te/ uruapo ywya urumuseaupyta, uruupir pinowo ipyteripe ywa umuwyhog supatitawa; ipukuete muruwisaw erekehaw asehutese; upuga ruaw murerekotarete; upug ruaw hejkwehe $\mathrm{n}$ uhuwapyguwi namukuj hejkwehe upug. Ajnon: uruapo puta 'ogete semu'etawa ukaripe uruapo puta 'ogete t uesag wehe warasu tywo, 'og t unawa.

Os dois Operadores usados nesse modelo são do tipo Gr, destacado com itálico, e Fn, entre barras oblíquas.

\subsubsection{Modelo MODE2 com estrutura LId: O \{DPt [EId] $\}$}

Utilizando no Descritor o Português e no Exemplo a língua Suruí, essa proposta não é muito comum no conjunto das línguas indígenas brasileiras. A seguir, apresento uma amostra desse modelo: 
FIGURA 189 - MODELO MODE2

ka'i $n . I I I / \mathrm{ka}$ '?i/ Ele vive nas copas das árvores; ele desce para pegar ouriço da castanha e sobe com ele na árvore e começa a bater no pau até o ouriço rachar; ele é marrom com a cabeça preta. Ajnon: ka'ia usemuaraj yware ywokomumepem.

manimea pykujtawa rog /mani'mea pikuj'tawa 'øg/ Na casa de fazer farinha, a gente rala, prensa e peneira a mandioca. Depois torra ela, mexendo no forno. Ajnon: aha puta manime roga pupe wewahema.

'og n.III /'?og/ Nós cavamos o chão para enfiar a forquilha da casa; nós levantamos o esteio e encaibramos; nós arribamos e amarramos a casa. Depois colocamos todas as coisas pra dentro pra não molhar. Todos ajudam na construção da casa. Ajnon: asehu tese saupir sene rehe 'og; ti popytywo e apo 'og; ti rehe taketehewehe ne wy wekow.

'ogete $n$.III / ogg'te/ Para fazer a casa tradicional, cavamos a terra e enfiamos os paus de amarrar rede nos buracos. Depois cobrimos a casa tradicional com a palha do babaçu. Nessa casa, todos nós dormimos nela, mas é o chefe quem dorme perto da porta. Essa casa só tem uma porta para entrar. Antigamente, essa porta não ficava fechada. Ajnon: uruapo puta 'ogete semu'etawa ukaripe uruapo puta 'ogete t uesag wehe warasu tywo, 'og t unawa.

Com Operadores do tipo Gr e Fn apenas para o LId, esse modelo apresenta Exemplo apenas na língua Suruí, destacado com efeito itálico.

\subsubsection{Modelo MODE3 com estrutura LId: O \{DPt [EId/EPt]}

Esse modelo retoma o anterior e apresenta o Exemplo nas duas línguas envolvidas no verbete, como pode ser observado na figura abaixo:

\section{FIGURA 190 - MODELO MODE3a}

manimea pykujtawa rog /mani'mea pikuj'tawa 'rog/ casa de farinha. Na casa de fazer farinha, a gente rala, prensa e peneira a mandioca. Depois torra ela, mexendo no forno. Ajnon: aha puta manime roga pupe wewahema eu vou chegando para dentro da casa de farinha.

- Eisag $\rightarrow$ 'og.

'og n.III /'?og/ casa. Nós cavamos o chão para enfiar a forquilha da casa; nós levantamos o esteio e encaibramos; nós arribamos e amarramos a casa. Depois colocamos todas as coisas pra dentro pra não molhar. Todos ajudam na construção da casa. Ajnon: asehu tese saupir sene rehe 'og nós todos juntos vamos construir a casa; ti popytywo e apo 'og eu ajudo a fazer a casa. - Eisag $\rightarrow$ 'ogete, manimea pykujtawa rog.

'ogete $n$.III / ogg't $\varepsilon /$ casa tradicional. Para fazer a casa tradicional, cavamos a terra e enfiamos os paus de amarrar rede nos buracos. Depois cobrimos a casa tradicional com a palha do babaçu. Nessa casa, todos nós dormimos nela, mas é o chefe quem dorme perto da porta. Essa casa só tem uma porta para entrar. Antigamente, essa porta não ficava fechada. Ajnon: uruapo puta 'ogete semu'etawa ukaripe vamos fazer a casa tradicional no terreno onde a gente estuda; uruapo puta 'ogete t uesag wehe warasu tywo, 'og t unawa vamos fazer a casa tradicional para os não índios poderem ver. - Eisag $\rightarrow$ 'og. 
Nesse modelo, são usados três Operadores relacionados ao LId, são eles: Fn, Gr e Rm. Além disso, essa proposta destaca o verbete com um recuo de margem a partir da segunda linha. Apresento, a seguir, uma variação desse modelo, com Descritor de apenas uma palavra ou expressão.

\title{
FIGURA 191 - MODELO MODE3b
}

\begin{abstract}
ka'i /ka'?i/ macaco-prego. Ajnon: ka'ia usemuaraj yware ywokomumepem; o macaco-prego brinca no galho da árvore e quebra os galhos.

manimea pykujtawa rog /mani'mea pikuj'tawa 'rog/ casa de farinha. Ajnon: aha puta manime roga pupe wewahema; eu vou chegando para dentro da casa de farinha.

'og /'?og/ casa. Ajnon: asehu tese saupir sene rehe 'og; eu vou chegando para dentro da casa de farinha; ti popytywo e apo 'og; eu ajudo a fazer a casa.

'ogete / Poge't $\varepsilon$ / casa tradicional. Ajnon: uruapo puta 'ogete semu'etawa ukaripe; vamos fazer a casa tradicional no terreno onde a gente estuda; uruapo puta 'ogete $t$ uesag wehe warasu tywo; vamos fazer a casa tradicional para os não índios poderem ver.
\end{abstract}

Nesse modelo, o único Operador é do tipo Fn e está relacionado ao LId, que também está destacado com negrito. Trata-se de um modelo bastante usado no conjunto de UBL's das línguas indígenas brasileiras.

\subsubsection{Modelo MODE4 com estrutura LPt: O \{DId [EId]\}}

Neste conjunto de modelos MODE, essa é a primeira proposta com Lema em uma língua diferente do Suruí. No entanto, essa língua indígena é usada no Descritor e no Exemplo.

\section{FIGURA 192 - MODELO MODE4a}

casa n.f. uruhywykaj ywya urumumug ywykwara rupi urumuku'om sura ykupyjta urumusarukong uruupir urukwar; ti roga ti kehaw, uruapo pinowa ku urusehe urukehawamu urukupepyg urusehe; un ti ma'epotawamu aapo rako iako tarukeke taruke ti ma'etiru umuakym rapo amona n usapy'u rapo tata. Ajnon: asehu tese saupir sene rehe 'og; ti popytywo e apo 'og; ti rehe taketehewehe ne wy wekow.

casa de farinha n.f. pykujpykujtawa upin mani'og, ukytyg, ukupepyg, umuhaw upykuj. Ajnon: aha puta manime roga pupe wewahema.

casa tradicional n.f. (casa verdadeira) uruapo ywya urumuseaupyta, uruupir pinowo ipyteripe ywa umuwyhog supatitawa; ipukuete muruwisaw erekehaw asehutese; upuga ruaw murerekotarete; upug ruaw hejkwehe $\mathrm{n}$ uhuwapyguwi namukuj hejkwehe upug. Ajnon: uruapo puta 'ogete semu'etawa ukaripe uruapo puta 'ogete t uesag wehe warasu tywo, 'og t unawa.

macaco-prego n.m. (mico-de-topete) ka'i iwete okowa'e; upyhyg iwyw ka'ia so uputi'a warimu irahaj awpita so akakaw yware; ka'ia awiton iapina pisuna. Ajnon: ka'ia usemuaraj yware ywokoтитерет. 
O modelo acima contém dois Operadores, o $\mathrm{Gr}$ e o $\mathrm{Vr}$, relacionados ao LPt. O primeiro deles ocorre regularmente em todos os verbetes, enquanto o segundo só ocorre se houver necessidade de explicitar alguma forma variante (de forma ou de sentido). Esse modelo também tem Descritor com apenas uma palavra ou expressão:

FIGURA 193 - MODELO MODE4b

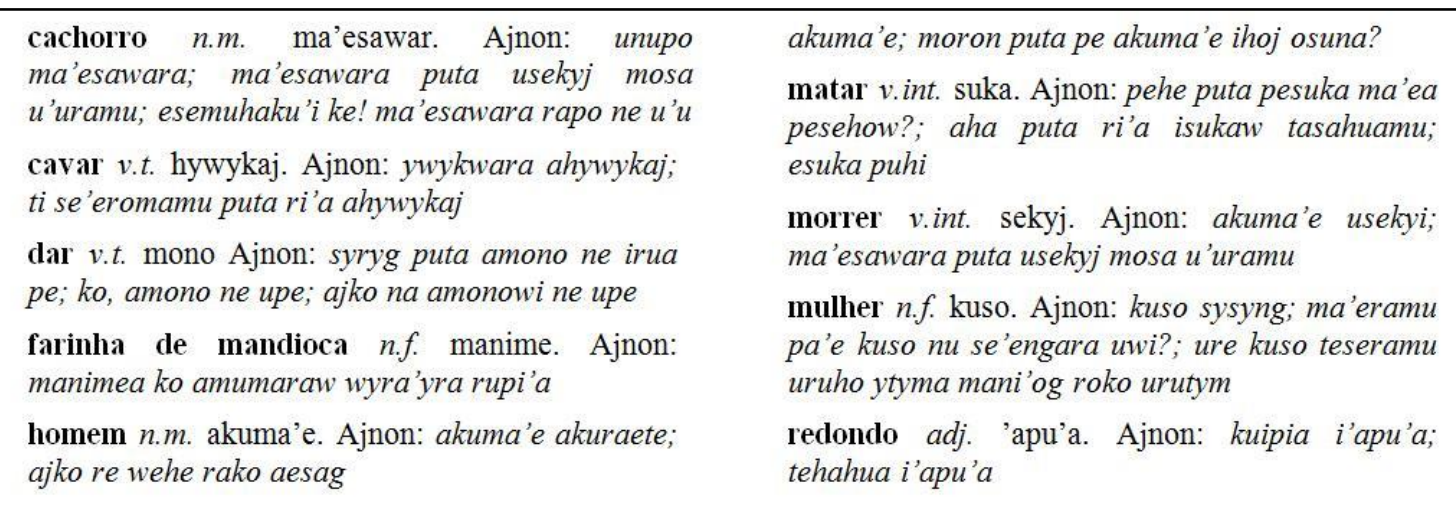

Com um Operador do tipo Gr relacionado ao LPt, esse modelo não é facilmente encontrado no conjunto de UBL's das línguas indígenas brasileiras, talvez por causa da ausência da tradução do exemplo.

\title{
9.1.11.5. Modelo MODE5 com estrutura LPt: O \{DId [EId/EPt]
}

Assim como o modelo MODE3, esta proposta apresenta o Exemplo nas duas línguas envolvidas na microestrutura, mas o Descritor não, diminuindo as chances de ocorrência dessa estrutura no corpus de UBL's desta pesquisa.

\section{FIGURA 194 - MODELO MODE5a}

\begin{abstract}
casa n.f. uruhywykaj ywya urumumug ywykwara rupi urumuku'om sura ykupyjta urumusarukong uruupir urukwar; ti roga ti kehaw, uruapo pinowa ku urusehe urukehawamu urukupepyg urusehe; un ti ma'epotawamu aapo rako iako tarukeke taruke ti ma'etiru umuakym rapo amona n usapy'u rapo tata. Ajnon: asehu tese saupir sene rehe 'og eu vou chegando para dentro da casa de farinha; ti popytywo e apo 'og; ti rehe t aketehewehe ne wy wekow; eu ajudo a fazer a casa. - Ver $\rightarrow$ casa de farinha, casa tradicional.

casa de farinha n.f. pykujpykujtawa upin mani'og, ukytyg, ukupepyg, umuhaw upykuj. Ajnon: aha puta manime roga pupe wewahema; eu vou chegando para dentro da casa de farinha. $\cdot$ Ver $\rightarrow$ casa.

casa tradicional n.f. uruapo ywya urumuseaupyta, uruupir pinowo ipyteripe ywa umuwyhog supatitawa; ipukuete muruwisaw erekehaw asehutese; upuga ruaw murerekotarete; upug ruaw hejkwehe $\mathrm{n}$ uhuwapyguwi namukuj hejkwehe upug. Ajnon: uruapo puta 'ogete semu'etawa ukaripe vamos fazer a casa tradicional no terreno onde a gente estuda; uruapo puta 'ogete $t$ uesag wehe warasu tywo, 'og t unawa vamos fazer a casa tradicional para os não indios poderem ver. $\cdot$ Ver $\rightarrow$ casa.
\end{abstract}

Esse modelo possui Operadores Gr e Rm, relacionados apenas ao LPt. 


\subsubsection{Modelo MODE6 com estrutura LId: O \{DId-DPt [EId/EPt]\}}

Esse modelo apresenta Descritores e Exemplos nas duas línguas envolvidas no verbete, conforme exemplo abaixo:

\section{FIGURA 195 - MODELO MODE6}

ka'i $n$.III /ka'?i/ ka'i iwete okowa'e; upyhyg iwyw ka'ia so uputi'a warimu irahaj awpita so akakaw yware; ka'ia awiton iapina pisuna. Macaco-prego. Ele vive nas copas das árvores; ele desce para pegar ouriço da castanha e sobe com ele na árvore e começa a bater no pau até o ouriço rachar; ele é marrom com a cabeça preta. Ajnon: ka'ia usemuaraj yware ywokomumepem o macaco-prego brinca no galho da árvore e quebra os galhos.

manimea pykujtawa rog /mani'mea pikuj'tawa 'rog/ pykujpykujtawa upin mani'og, ukytyg, ukupepyg, umuhaw upykuj. Casa de farinha. Na casa de fazer farinha, a gente rala, prensa e peneira a mandioca. Depois torra ela, mexendo no forno. Ajnon: aha puta manime roga pupe wewahema eu vou chegando para dentro da casa de farinha. $\cdot$ Eisag $\rightarrow$ 'og.

'og n.III /'Pog/ uruhywykaj ywya urumumug ywykwara rupi urumuku'om sura ykupyjta urumusarukong uruupir urukwar; ti roga ti kehaw, uruapo pinowa ku urusehe urukehawamu urukupepyg urusehe; un ti ma'epotawamu aapo rako iako tarukeke taruke ti ma'etiru umuakym rapo amona n usapy'u rapo tata. Casa. Nós cavamos o chão para enfiar a forquilha da casa; nós levantamos o esteio e encaibramos; nós arribamos e amarramos a casa. Depois colocamos todas as coisas pra dentro pra não molhar. Todos ajudam na construção da casa. Ajnon: asehu tese saupir sene rehe 'og nós todos juntos vamos construir a casa; ti popytywo e apo 'og eu ajudo a fazer a casa. • Eisag $\rightarrow$ 'ogete, manimea pykujtawa rog.

'ogete n.III /Poge'te/ uruapo ywya urumuseaupyta, uruupir pinowo ipyteripe ywa umuwyhog supatitawa; ipukuete muruwisaw erekehaw asehutese; upuga ruaw murerekotarete; upug ruaw hejkwehe n uhuwapyguwi namukuj hejkwehe upug. Casa tradicional. Para fazer a casa tradicional, cavamos a terra e enfiamos os paus de amarrar rede nos buracos. Depois cobrimos a casa tradicional com a palha do babaçu. Nessa casa, todos nós dormimos nela, mas é o chefe quem dorme perto da porta. Essa casa só tem uma porta para entrar. Antigamente, essa porta não ficava fechada. Ajnon: uruapo puta 'ogete semu'etawa ukaripe vamos fazer a casa tradicional no terreno onde a gente estuda; uruapo puta 'ogete t uesag wehe warasu tywo, 'og t unawa; vamos fazer a casa tradicional para os não índios poderem ver. Eisag $\rightarrow$ 'og.

Esse é um dos modelos mais completos já propostos até agora, porque apresenta o LId com três Operadores (Gr, Fn e Rm), dois Descritores ampliados em Suruí e Português, e Exemplos também nas duas línguas. Além do destaque em negrito para o LId, há o destaque em itálico para os componentes em Português. 


\subsubsection{Modelo MODE7 com estrutura LPt: O \{DPt-DId [EPt/EId]}

Esse modelo retoma a mesma estrutura do modelo anterior, apenas mudando a posição das línguas envolvidas, como é possível ver no exemplo a seguir:

\section{FIGURA 196 - MODELO MODE7}

Casa. n.f. Nós cavamos o chão para enfiar a forquilha da casa; nós levantamos o esteio e encaibramos; nós arribamos e amarramos a casa. Depois colocamos todas as coisas pra dentro pra não molhar. Todos ajudam na construção da casa. 'og. Uruhywykaj ywya uruтитиg ywykwara rupi urumuku'om sura ykupyjta urumusarukong uruupir urukwar; ti roga ti kehaw, uruapo pinowa ku urusehe urukehawamu urukupepyg urusehe; un ti ma'epotawamu aapo rako iako tarukeke taruke ti ma'etiru umuakym rapo amona n usapy'u rapo tata. Ex.: nós todos juntos vamos construir a casa asehu tese saupir sene rehe 'og; eu ajudo a fazer a casa ti popytywo e apo 'og. • Ver $\rightarrow$ Casa de farinha, casa tradicional.

Casa de farinha. n.f. Na casa de fazer farinha, a gente rala, prensa e peneira a mandioca. Depois torra ela, mexendo no forno. Manimea pykujtawa rog. Pykujpykujtawa upin mani'og, ukytyg, ukupepyg, umuhaw upykuj. Ex.: eu vou chegando para dentro da casa de farinha aha puta manime roga pupe wewahema. - Ver $\rightarrow$ Casa, casa tradicional

Casa tradicional. n.f. (casa verdadeira) Para fazer a casa tradicional, cavamos a terra e enfiamos os paus de amarrar rede nos buracos. Depois cobrimos a casa tradicional com a palha do babaçu. Nessa casa, todos nós dormimos nela, mas é o chefe quem dorme perto da porta. Essa casa só tem uma porta para entrar. Antigamente, essa porta não ficava fechada. 'ogete. Uruapo ywya urumuseaupyta, uruupir pinowo ipyteripe ywa umuwyhog supatitawa; ipukuete muruwisaw erekehaw asehutese; upuga ruaw murerekotarete; upug ruaw hejkwehe $n$ uhuwapyguwi namukuj hejkwehe upug. Ex.: vamos fazer a casa tradicional no terreno onde a gente estuda uruapo puta 'ogete semu'etawa ukaripe; vamos fazer a casa tradicional para os não índios poderem ver uruapo puta 'ogete $t$ uesag wehe warasu tywo, 'og $t$ unawa. - Ver $\rightarrow$ Casa, casa de farinha.

Macaco-prego. n.f. (mico-de-topete) Ele vive nas copas das árvores; ele desce para pegar ouriço da castanha e sobe com ele na árvore e começa a bater no pau até o ouriço rachar; ele é marrom com a cabeça preta. $K a^{\prime} i$. $K a^{\prime} i$ iwete okowa'e; upyhyg iwyw ka'ia so uputi'a warimu irahaj awpita so akakaw yware; ka'ia awiton iapina pisuna. Ex.: o macaco-prego brinca no galho da árvore e quebra os galhos ka'ia usemuaraj yware ywokomumepem. - Ver $\rightarrow$ Guariba, mão-de-ouro.

Como no modelo anterior o Operador Rm indicava palavras em Suruí (LId), o deste modelo indica palavras em Português (LPt). 


\subsubsection{Modelo MODE8 com estrutura LId: O \{DId-DPt-D... [EId/EPt/E...]\}}

Esse penúltimo modelo amplia os dois últimos ao propor uma estrutura com três ou mais Descritores e Exemplos. Neste caso, há a inclusão da língua Suruí como componente do conjunto de Descritores, conforme demonstra o exemplo a seguir:

\section{FIGURA 197 - MODELO MODE8}

ka'i n.III /ka'?i/ ka'i iwete okowa'e; upyhyg iwyw ka'ia so uputi'a warimu irahaj awpita so akakaw yware; ka'ia awiton iapina pisuna. Macaco-prego. Ele vive nas copas das árvores; ele desce para pegar ouriço da castanha e sobe com ele na árvore e começa a bater no pau atéo ouriço rachar; ele é marrom com a cabeça preta. Capuchin monkey. He lives on the top of the trees; he goes to pick up hedgehog chestnutnut and climbs the tree with him; then, he starts beating the Hedgehog until it cracks; $\mathrm{He}$ is brown with a black head. Cebus apella. Ajnon: ka'ia usemuaraj yware ywokomumepem $o$ macaco-prego brinca no galho da árvore $e$ quebra os galhos the capuchin monkey romps in the branch of the tree and the branches breaks. Eisag $\rightarrow$ akyky, ehakwasu, y'a.

manimea pykujtawa rog /mani'mea pikuj'tawa 'rog/ pykujpykujtawa upin mani'og, ukytyg, ukupepyg, umuhaw upykuj. Casa de farinha. Na casa de fazer farinha, a gente rala, prensa e peneira a mandioca. Depois torra ela, mexendo no forno. Flour's house. In the flour's house, the people grate, press and sieve cassava. After roasting it, they stir it on the oven. Ajnon: aha puta manime roga pupe wewahema $e u v o u$ chegando para dentro da casa de farinha I came into the house of flour. - Eisag $\rightarrow$ 'og, 'ogete.

'og $n . I I I / / 2 \circ g /$ uruhywykaj ywya urumumug ywykwara rupi urumuku'om sura ykupyjta urumusaru-kong uruupir urukwar; ti roga ti kehaw, uruapo pinowa ku urusehe urukehawamu urukupepyg urusehe; un ti ma'epotawamu aapo rako iako tarukeke taruke ti ma'etiru umuakym rapo amona $\mathrm{n}$ usapy'u rapo tata. Casa. Nós cavamos o chão para enfiar a forquilha da casa; nós levantamos o esteio e encaibramos; nós arribamos e amarramos a casa. Depois colocamos todas as coisas pra dentro pra não molhar. Todos ajudam na construção da casa. House. We dug the sticks into the ground of the futures house, then we raise its mainstay and put the rafter. Then we put our goods inside the house for them to not get wet. Everyone helps the building of the house. Ajnon: asehu tese saupir sene rehe 'og nós todos juntos vamos construir a casa all together we will build the house; ti popytywo e apo 'og eu ajudo a fazer a casa I help the building of the house.

'ogete n.III / oge'te/ uruapo ywya
urumuseaupyta, uruupir pinowo ipyteripe ywa
umuwyhog supatitawa; ipukuete muruwisaw
erekehaw asehutese; upuga ruaw murerekotarete;
upug ruaw hejkwehe n uhuwapyguwi namukuj
hejkwehe upug. Casa tradicional. Para fazer a
casa tradicional, cavamos a terra e enfiamos os
paus de amarrar rede nos buracos. Depois
cobrimos a casa tradicional com a palha do
babaçu. Nessa casa, todos nós dormimos nela,
mas é o chefe quem dorme perto da porta. Essa
casa só tem uma porta para entrar.
Antigamente, essa porta não ficava fechada.
Traditional house. To make a traditional house,
we dug the earth and we stuck the sticks into the
holes, tying them to support the rafter. After we
have covered the traditional house with thatched
babassu we are able to sleep in it, but it is the
chief who sleeps near the door. This house has
only one door. Formerly, it door was not closed.
Ajnon: uruapo puta 'ogete semu'etawa ukaripe
vamos fazer a casa tradicional no terreno onde a
gente estuda let's make a traditional house in the
land where you study; uruapo puta 'ogete t uesag
wehe warasu tywo, 'og t unawa; vamos fazer a
casa tradicional para os não indios poderem ver
let's do the traditional house for the non Indians
to see it. - Eisag $\rightarrow$ 'og.

Esse modelo apresenta o LId destacado com efeito negrito e tamanho maior da fonte, além disso esse Lema tem três operadores relacionados a ele ( $\mathrm{Gr}$, Fn e Rm). Além 
disso, há três línguas envolvidas em todos os verbetes, o Suruí, o Português e o Inglês, podendo ainda haver o Latim como Descritor se se tratar de nome de animal ou planta.

\subsubsection{Modelo MODE9 com estrutura LId: O \{DPt-D... [EId/EPt/E...]\}}

Retomando a estrutura do modelo anterior, essa proposta apenas não apresenta o DId, como pode ser observado no exemplo abaixo:

FIGURA 198 - MODELO MODE9

ka'i $n . I I I / k a ' ? i /$ Macaco-prego. Capuchin monkey. Cebus apella. Ajnon: ka'ia usemuaraj yware ywokomumepem o macaco-prego brinca no galho da árvore e quebra os galhos the capuchin monkey romps in the branch of the tree and the branches breaks. • Eisag $\rightarrow$ akyky, ehakwasu, y'a.

manimea pykujtawa rog /mani'mea pikuj'tawa 'rog/ Casa de farinha. Flour's house. Ajnon: aha puta manime roga pupe wewahema eu vou chegando para dentro da casa de farinha I came into the house of flour. • Eisag $\rightarrow$ 'og, 'ogete.

'og $n . I I I / ' P o g /$ Casa. House. Ajnon: asehu tese saupir sene rehe 'og nós todos juntos vamos construir a casa all together we will build the house; ti popytywo e apo 'og eu ajudo a fazer a casa I help the building of the house. - Eisag $\rightarrow$ manimea pykujtawa rog, 'ogete.

'ogete n.III / Poge'te/ Casa tradicional. Traditional house. Ajnon: uruapo puta 'ogete semu'etawa ukaripe vamos fazer a casa tradicional no terreno onde a gente estuda let's make a traditional house in the land where you study; uruapo puta 'ogete $t$ uesag wehe warasu tywo, 'og t unawa; vamos fazer a casa tradicional para os não índios poderem ver let's do the traditional house for the non Indians to see it. - Eisag $\rightarrow$ 'og.

Esse modelo apresenta os Descritores sob a forma de uma palavra ou expressão em línguas diferentes da usada no Lema, mas insere no componente Exemplo material em todas as línguas envolvidas no verbete. Trata-se de uma opção prática para desenvolvimento de materiais lexicográficos multilíngues para uma língua indígena brasileira.

\subsubsection{Modelo MODOE}

De todos os modelos propostos nesta tese, esse é o último com grande quantidade de registros observados no corpus de UBL's das línguas indígenas brasileiras (cf. subseção 7.3.4.2).

Com EML composta de L: $\mathrm{O}\{\mathrm{D}(\mathrm{O})[\mathrm{E}]\}$, desenvolvi as propostas a seguir: (1) LId: O \{DId (O) [EId]\}; (2) LId: O \{DPt (O) [EId]\}; (3) LId: O \{DPt (O) [EId/EPt]\}; (4) LPt: O $\{$ DId (O) [EId] $\}$; (5) LPt: O \{DId (O) [EId/EPt]\}; (6) LId: O \{DId-DPt (O) [EId/EPt] $;$; (7) 
LPt: O \{DPt-DId (O) [EPt/EId]\}; (8) LId: O \{DId-DPt-D... (O) [EId/EPt/E...]\}; (9) LId: O $\{\mathrm{DPt}-\mathrm{D} \ldots(\mathrm{O})[\mathrm{EId} / \mathrm{EPt} / \mathrm{E} \ldots]\}$.

\subsubsection{Modelo MODOE1 com estrutura LId: O \{DId (O) [EId] $\}$}

Esse modelo amplia a estrutura do modelo MODE1 ao acrescentar Operador(es) para o DId da microestrutura do verbete, como pode ser observado a seguir:

\section{FIGURA 199 - MODELO MODOE1}

ka'i $n$.III /ka'?i/ ka'i iwete okowa'e; upyhyg iwyw ka'ia so uputi'a warimu irahaj awpita so akakaw yware; ka'ia awiton iapina pisuna (Tymykong umume'u). Ajnon: ka'ia usemuaraj yware ywokomumepem.

manimea pykujtawa rog /mani'mea pikuj'tawa 'rog/ pykujpykujtawa upin mani'og, ukytyg, ukupepyg, umuhaw upykuj (Ikatu umume'u). Ajnon: aha puta manime roga pupe wewahema.

'og n.III /'?og/ uruhywykaj ywya urumumug ywykwara rupi urumuku'om sura ykupyjta urumusarukong uruupir urukwar; ti roga ti kehaw, uruapo pinowa ku urusehe urukehawamu urukupepyg urusehe; un ti ma'epotawamu aapo rako iako tarukeke taruke ti ma'etiru umuakym rapo amona n usapy'u rapo tata (Wajwera umume'u). Ajnon: asehu tese saupir sene rehe 'og; ti popytywo e apo 'og; ti rehe taketehewehe ne wy wekow.

'ogete n.III / oge'te/ uruapo ywya urumuseaupyta, uruupir pinowo ipyteripe ywa umuwyhog supatitawa; ipukuete muruwisaw erekehaw asehutese; upuga ruaw murerekotarete; upug ruaw hejkwehe $\mathrm{n}$ uhuwapyguwi namukuj hejkwehe upug (Wajwera umume'u). Ajnon: uruapo puta 'ogete semu'etawa ukaripe uruapo puta 'ogete t uesag wehe warasu tywo, 'og t unawa.

Esse modelo, que pode ser usado para materiais lexicográficos monolíngues, conta com Operadores do tipo Gr e Fn relacionados ao LId, e do tipo Ft, relacionado ao DId.

\subsubsection{Modelo MODOE2 com estrutura LId: O $\{\mathrm{DPt}(\mathrm{O})[\mathrm{EId}]\}$}

Esse segundo modelo acrescenta o Português no Descritor e possui Operadores relacionados a esse componente, mas também ao Lema. Todavia, não há Exemplo em Português, como pode ser visto no exemplo a seguir: 
FIGURA 200 - MODELO MODOE2

ka'i $n . I I I / \mathrm{ka}$ '?i/ Ele vive nas copas das árvores; ele desce para pegar ouriço da castanha e sobe com ele na árvore e começa a bater no pau até o ouriço rachar; ele é marrom com a cabeça preta (na língua Suruí a palavra usada para designar 'macacoprego' é também empregada para a forma genérica 'macaco'). Ajnon: ka'ia usemuaraj yware ywokomumepem.

manimea pykujtawa rog /mani'mea pikuj'tawa 'rog/ Na casa de fazer farinha, a gente rala, prensa e peneira a mandioca. Depois torra ela, mexendo no forno. Ajnon: aha puta manime roga pupe wewahema.

'og $n$.III /'?og/ Nós cavamos o chão para enfiar a forquilha da casa; nós levantamos o esteio e encaibramos; nós arribamos e amarramos a casa. Depois colocamos todas as coisas pra dentro pra não molhar. Todos ajudam na construção da casa (a construção de uma casa é uma ação coletiva na comunidade Suruí, na qual participam homens, mulheres e crianças, cada um desempenhando papéis específicos). Ajnon: asehu tese saupir sene rehe 'og; ti popytywo e apo 'og; ti rehe $t$ aketehewehe ne wy wekow.

'ogete n.III / ogg't $\varepsilon$ / Para fazer a casa tradicional, cavamos a terra e enfiamos os paus de amarrar rede nos buracos. Depois cobrimos a casa tradicional com a palha do babaçu. Nessa casa, todos nós dormimos nela, mas é o chefe quem dorme perto da porta. Essa casa só tem uma porta para entrar. Antigamente, essa porta não ficava fechada (atualmente, esse tipo de casa não é mais construída para fins de habitação, apenas como forma de manter a tradição). Ajnon: uruapo puta 'ogete semu'etawa ukaripe uruapo puta 'ogete t uesag wehe warasu tywo, 'og t unawa.

No modelo acima, o LId conta com Operadores do tipo Gr e Fn, ao mesmo tempo que o DPt recebe o Operador Na.

\subsubsection{Modelo MODOE3 com estrutura LId: O $\{\mathrm{DPt}(\mathrm{O})[\mathrm{EId} / \mathrm{EPt}]\}$}

Esse terceiro modelo inclui o EPt ausente na proposta anterior:

\section{FIGURA 201 - MODELO MODOE3a}

ka'i $n . I I I / \mathrm{ka}$ '?i/macaco-prego. Ele vive nas copas das árvores; ele desce para pegar ouriço da castanha e sobe com ele na árvore e começa a bater no pau até o ouriço rachar; ele é marrom com a cabeça preta (na língua Suruí a palavra usada para designar 'macacoprego' é também empregada para a forma genérica 'macaco'). Ajnon: ka'ia usemuaraj yware ywokomumepem o macaco-prego brinca no galho da árvore e quebra os galhos.

manimea pykujtawa rog /mani'mea pikuj'tawa 'rog/ casa de farinha. Na casa de fazer farinha, a gente rala, prensa e peneira a mandioca. Depois torra ela, mexendo no forno. Ajnon: aha puta manime roga pupe wewahema eu vou chegando para dentro da casa de farinha.

'og n.III /'?og/ casa. Nós cavamos o chão para enfiar a forquilha da casa; nós levantamos o esteio e encaibramos; nós arribamos e amarramos a casa. Depois colocamos todas as coisas pra dentro pra não molhar. Todos ajudam na construção da casa (a construção de uma casa é uma ação coletiva na comunidade Suruí, na qual participam homens, mulheres e crianças, cada um desempenhando papéis específicos). Ajnon: asehu tese saupir sene rehe 'og nós todos juntos vamos construir a casa; $t i$ popytywo e apo 'og eu ajudo a fazer a casa.

'ogete n.III / Poge'te/ casa tradicional. Para fazer a casa tradicional, cavamos a terra e enfiamos os paus de amarrar rede nos buracos. Depois cobrimos a casa tradicional com a palha do babaçu. Nessa casa, todos nós dormimos nela, mas é o chefe quem dorme perto da porta. Essa casa só tem uma porta para entrar. Antigamente, essa porta não ficava fechada (atualmente, esse tipo de casa não é mais construída para fins de habitação, apenas como forma de manter a tradição). Ajnon: uruapo puta 'ogete semu'etawa ukaripe vamos fazer a casa tradicional no terreno onde a gente estuda; uruapo puta 'ogete $t$ uesag wehe warasu tywo, 'og $t$ unawa vamos fazer a casa tradicional para os não índios poderem ver. 
Também nesse modelo o LId se relaciona aos Operadores Fn e Gr, ambos colocados no início do verbete. Da mesma forma ocorre na variação dessa proposta, em que o DPt é dado em uma palavra ou expressão, apresentada a seguir:

FIGURA 202 - MODELO MODOE3b

ka'i n.III /ka'?i/ macaco-prego (na língua Suruí a palavra usada para designar 'macaco-prego' é também empregada para a forma genérica 'macaco'). Ajnon: ka'ia usemuaraj yware ywokomumepem; o macaco-prego brinca no galho da árvore e quebra os galhos.

manimea pykujtawa rog /mani'mea pikuj'tawa 'rog/ casa de farinha. Ajnon: aha puta manime roga pupe wewahema; eu vou chegando para dentro da casa de farinha.

'og n.III /'?og/ casa (a construção de uma casa é uma ação coletiva na comunidade Suruí, na qual participam homens, mulheres e crianças, cada um desempenhando papéis específicos). Ajnon: asehu tese saupir sene rehe 'og; eu vou chegando para dentro da casa de farinha; ti popytywo e apo 'og; eu ajudo a fazer a casa.

'ogete n.III / Poge'te/ casa tradicional (atualmente, esse tipo de casa não é mais construída para fins de habitação, apenas como forma de manter a tradição). Ajnon: uruapo puta 'ogete semu'etawa ukaripe; vamos fazer a casa tradicional no terreno onde a gente estuda; uruapo puta 'ogete t uesag wehe warasu tywo; vamos fazer a casa tradicional para os não índios poderem ver.

\subsubsection{Modelo MODOE4 com estrutura LPt: O \{DId (O) [EId]\}}

O próximo modelo leva o Português para a posição de Lema:

FIGURA 203 - MODELO MODOE4a

casa n.f. 'og. Uruhywykaj ywya urumumug ywykwara rupi urumuku'om sura ykupyjta urumusarukong uruupir urukwar; ti roga ti kehaw, uruapo pinowa ku urusehe urukehawamu urukupepyg urusehe; un ti ma'epotawamu aapo rako iako tarukeke taruke ti ma'etiru umuakym rapo amona n usapy'u rapo tata (Wajwera umume'u). Ajnon: asehu tese saupir sene rehe 'og; ti popytywo e apo 'og; ti rehe taketehewehe ne wy wekow. - Ver $\rightarrow$ casa de farinha, casa tradicional.

casa de farinha n.f. manimea pykujtawa rog. Pykujpykujtawa upin mani'og, ukytyg, ukupepyg, umuhaw upykuj (Ikatu umume'u). Ajnon: aha puta manime roga pupe wewahema. $\cdot \operatorname{Ver} \rightarrow$ casa

casa tradicional n.f. 'ogete. Uruapo ywya urumuseaupyta, uruupir pinowo ipyteripe ywa umuwyhog supatitawa; ipukuete muruwisaw erekehaw asehutese; upuga ruaw murerekotarete; upug ruaw hejkwehe $\mathrm{n}$ uhuwapyguwi namukuj hejkwehe upug (Wajwera umume'u). Ajnon: uruapo puta 'ogete semu'etawa ukaripe uruapo puta 'ogete t uesag wehe warasu tywo, 'og t unawa. - Ver $\rightarrow$ casa.

macaco-prego n.m. ka'i. Ka'i iwete okowa'e; upyhyg iwyw ka'ia so uputi'a warimu irahaj awpita so akakaw yware; ka'ia awiton iapina pisuna (Tymykong umume'u). Ajnon: ka'ia usemuaraj yware ywokomumepem. 
Nesse modelo, o LPt se relaciona a dois Operadores, Gr e Rm, enquanto o DId recebe o Operador Ft. Apesar de ser uma proposta bem completa, não foi registrada no conjunto de UBL's das línguas indígenas brasileiras (talvez por apresentar o Descritor somente na língua indígena).

Do mesmo modo, a variante desse modelo, exemplificada a seguir, também não é comum no corpus de UBL's reunido nesta pesquisa.

FIGURA 204 - MODELO MODOE4b

\begin{tabular}{|c|c|}
\hline $\begin{array}{l}\text { achorro n.m. ma'esawar /ma?csa'war/. } \\
\text { Ajnon: unupo ma'esawara; ma'esawara puta } \\
\text { ısekyj mosa u'uramu; esemuhaku'i ke! } \\
\text { na'esawara rapo ne u'u }\end{array}$ & $\begin{array}{l}\text { homem n.m. akuma'e /akuma'?e/. Ajnon: } \\
\text { akuma'e akuraete; ajko re wehe rako aesag } \\
\text { akuma'e; moron puta pe akuma'e ihoj } \\
\text { osuna? }\end{array}$ \\
\hline $\begin{array}{l}\text { avar v.t. hywykaj /kiwi'kaj/. Ajnon: } \\
\text { wykwara ahywykaj; ti se'eromamu puta ri'a } \\
\text { hywykaj }\end{array}$ & $\begin{array}{l}\text { matar v.t. suka /su'ka/. Ajnon: pehe puta } \\
\text { pesuka ma'ea pesehow?; aha puta ri'a } \\
\text { isukaw tasahuamu; esuka puhi }\end{array}$ \\
\hline $\begin{array}{l}\text { dar v.t. mono /mo'no/. Ajnon: syryg puta } \\
\text { amono ne irua pe; ko, amono ne upe; ajko na } \\
\text { amonowi ne upe }\end{array}$ & $\begin{array}{l}\text { mulher n.f. kuso /ku'so/. Ajnon: kuso sysyng; } \\
\text { ma'eramu pa'e kuso nu se'engara uwi?; ure } \\
\text { kuso teseramu uruho ytyma mani'og roko } \\
\text { urutym }\end{array}$ \\
\hline $\begin{array}{l}\text { on: } \operatorname{mani} \\
\text { 'a }\end{array}$ & $\begin{array}{l}\text { dj. 'apu'a / } / 2 a p u ' ? a / . ~ A j \\
\text { hahua i'apu'a }\end{array}$ \\
\hline
\end{tabular}

Já nesse modelo, há apena um Operador relacionado ao LId: o do tipo Gr.

\subsubsection{Modelo MODOE5 com estrutura LPt: O \{DId (O) [EId/EPt]}

Completando a estrutura do modelo anterior, essa proposta inclui o Exemplo na segunda língua envolvida no verbete, mas continua ainda não correspondendo a um modelo comum no conjunto de UBL's das línguas indígenas brasileiras. Apresento, a seguir, um exemplo dessa proposta:

\section{FIGURA 205 - MODELO MODOE5a}

casa n.f. 'og. Uruhywykaj ywya urumumug ywykwara rupi urumuku'om sura ykupyjta urumusarukong uruupir urukwar; ti roga ti kehaw, uruapo pinowa ku urusehe urukehawamu urukupepyg urusehe; un ti ma'epotawamu aapo rako iako tarukeke taruke ti ma'etiru umuakym rapo amona $\mathrm{n}$ usapy'u rapo tata (Wajwera umume'u). Ajnon: asehu tese saupir sene rehe 'og eu vou chegando para dentro da casa de farinha; ti popytywo e apo 'og; ti rehe t aketehewehe ne wy wekow; eu ajudo a fazer a casa. - Ver $\rightarrow$ Casa de farinha, casa tradicional.

casa de farinha n.f. manimea pykujtawa rog. Pykujpykujtawa upin mani'og, ukytyg, ukupepyg, umuhaw upykuj (Ikatu umume'u). Ajnon: aha puta manime roga pupe wewahema.; eu vou chegando para dentro da casa de farinha. $\cdot$ Ver $\rightarrow$ Casa. 
casa tradicional n.f. 'ogete. Uruapo ywya urumuseaupyta, uruupir pinowo ipyteripe ywa umuwyhog supatitawa; ipukuete muruwisaw erekehaw asehutese; upuga ruaw murerekotarete; upug ruaw hejkwehe $\mathrm{n}$ uhuwapyguwi namukuj hejkwehe upug (Wajwera umume'u). Ajnon: uruapo puta 'ogete semu'etawa ukaripe vamos fazer a casa tradicional no terreno onde a gente estuda; uruapo puta 'ogete t uesag wehe warasu tywo, 'og $t$ unawa vamos fazer a casa tradicional para os não índios poderem ver. • Ver $\rightarrow$ Casa.

macaco-prego n.m. ka'i. Ka'i iwete okowa'e; upyhyg iwyw ka'ia so uputi'a warimu irahaj awpita so akakaw yware; ka'ia awiton iapina pisuna (Tymykong umume'u). Ajnon: ka'ia usemuaraj yware ywokomumepem; o macaco-prego brinca no galho da árvore e quebra os galhos.

Esse modelo inclui Operadores Gr e Rm que se relacionam ao LPt e outro do tipo Ft relacionado ao DId. Essa mesma estrutura pode ser reestrutura alterando o texto do DId para uma palavra ou expressão, como pode ser visto na figura seguinte:

\title{
FIGURA 206 - MODELO MODOE5b
}

\begin{abstract}
cachorro n.m. ma'esawar /ma?esaw'ar/. Ex. unupo ma'e-sawara ele bate no cachorro; ma'esawara puta usekyj mosa u'uramu o cachorro vai morrer, porque a cobra mordeu ele; esemuhaku'i ke! ma'esawara rapo ne u'u tenha cuidado! o cachorro vai te morder. - Ver $\rightarrow$ Onça.

cavar v.t. hywykaj/kiwi'kaj/. Ex. ywykwara ahywykaj eu cavo buraco na terra; $t i$ se'eromamu puta ri'a ahywykaj eu vou cavar meu poço

dar v.t. mono $/ \mathrm{mo} \mathrm{n} \mathrm{n} /$. Ex. syryg puta amono ne irua pe eu vou dar o machado para o teu irmão; ko, amono ne upe vou te dar isso; ajko na amonowi ne upe esse eu não dou isso para você

farinha de mandioca manime /mani'me/. Ex. manimea ko amumaraw wyra'yra rupi'a farinha de mandioca misturada com ovo de galinha. - Ver $\rightarrow$ Mandioca.
\end{abstract}

\begin{abstract}
homem n.m. akuma'e /akuma'?e/. Ex. akuma'e akuraete homem gordo; ajko re wehe rako aesag akuma'e ontem eu vi este homem; moron puta pe akuma'e ihoj osuna? quantos homens vão correr?

matar v.t. suka /su'ka/ Ex. pehe puta pesuka ma'ea pesehow? vocês vão matar aquelas caças?; aha puta ri'a isukaw tasahuamu talvez eu mate um porcão; esuka puhi não mata ele

mulher n.f. kuso /ku'so/. Ex. kuso sysyng mulher magra; ma'eramu pa'e kuso nu se'engara $u w i$ ? por que as mulheres não estão cantando?; ure kuso teseramu uruho ytyma mani'og roko urutym nós fomos com as mulheres plantar mandioca

redondo adj. 'apu'a /Rapu'?a/. Ex. kuipia i'apu'a a cuia é redonda; tehahua i'apu'a o tucum é redondo
\end{abstract}

Ordenado alfabeticamente, esse modelo apresente um Operador do tipo Fn junto a um Descritor, situação pouco típica no conjunto de UBL's já registradas nesta pesquisa.

\subsubsection{Modelo MODOE6 com estrutura LId: O \{DId-DPt (O) [EId/EPt]\}}

Esse modelo amplia a estrutura dos dois anteriores ao incluir Descritor e Exemplo nas duas línguas envolvidas na microestrutura. 
FIGURA 207 - MODELO MODOE6

ka'i n.III /ka'Pi/ ka'i iwete okowa'e; upyhyg iwyw ka'ia so uputi'a warimu irahaj awpita so akakaw yware; ka'ia awiton iapina pisuna (Tymykong umume'u). Macacoprego. Ele vive nas copas das árvores; ele desce para pegar ouriço da castanha e sobe com ele na árvore e começa a bater no pau até o ouriço rachar; ele é marrom com a cabeça preta (na língua Suruí a palavra usada para designar 'macaco-prego' é também empregada para a forma genérica 'macaco'). Ajnon: ka'ia usemuaraj yware ywokomumepem o macaco-prego brinca no galho da árvore e quebra os galhos.

manimea pykujtawa rog /mani'mea pikuj'tawa 'rog/ pykujpykujtawa upin mani'og, ukytyg, ukupepyg, umuhaw upykuj (Ikatu umume'u). Casa de farinha. Na casa de fazer farinha, a gente rala, prensa e peneira a mandioca. Depois torra ela, mexendo no forno. Ajnon: aha puta manime roga pupe wewahema eu vou chegando para dentro da casa de farinha. $\cdot$ Eisag $\rightarrow$ 'og.

'og $n$.III /'Pog/ uruhywykaj ywya urumumug ywykwara rupi urumuku'om sura ykupyjta urumusarukong uruupir urukwar; ti roga ti kehaw, uruapo pinowa ku urusehe urukehawamu urukupepyg urusehe; un ti ma'epotawamu aapo rako iako tarukeke taruke ti ma'etiru umuakym rapo amona n usapy'u rapo tata (Wajwera umume'u). Casa. Nós cavamos o chão para enfiar a forquilha da casa; nós levantamos o esteio e encaibramos; nós arribamos e amarramos a casa. Depois colocamos todas as coisas pra dentro pra não molhar. Todos ajudam na construção da casa (a construção de uma casa é uma ação coletiva na comunidade Suruí, na qual participam homens, mulheres e crianças, cada um desempenhando papéis específicos). Ajnon: asehu tese saupir sene rehe 'og nós todos juntos vamos construir a casa; ti popytywo e apo 'og eu ajudo a fazer a casa. - Eisag $\rightarrow$ manimea pykujtawa rog, 'ogete.

'ogete n.III /Poge't / uruapo ywya urumuseaupyta, uruupir pinowo ipyteripe ywa umuwyhog supatitawa; ipukuete muruwisaw erekehaw asehutese; upuga ruaw murerekotarete; upug ruaw hejkwehe $\mathrm{n}$ uhuwapyguwi namukuj hejkwehe upug (Wajwera umume'u). Casa tradicional. Para fazer a casa tradicional, cavamos a terra $e$ enfiamos os paus de amarrar rede nos buracos. Depois cobrimos a casa tradicional com a palha do babaçu. Nessa casa, todos nós dormimos nela, mas é o chefe quem dorme perto da porta. Essa casa só tem uma porta para entrar. Antigamente, essa porta não ficava fechada (atualmente, esse tipo de casa não é mais construída para fins de habitação, apenas como forma de manter a tradição). Ajnon: uruapo puta 'ogete semu'etawa ukaripe vamos fazer a casa tradicional no terreno onde a gente estuda; uruapo puta 'ogete $t$ uesag wehe warasu tywo, 'og t unawa; vamos fazer a casa tradicional para os não índios poderem ver. • Eisag $\rightarrow$ 'og.

Com três Operadores (Gr, Fn e Rm) relacionados ao LId e dois Operadores (Ft e Na) relacionados aos Descritores, esse modelo, que destaca os componentes em Português com efeito itálico, é uma excelente opção de organização de um dicionário bilíngue, por contar com componentes nas duas línguas envolvidas na microestrutura.

\subsubsection{Modelo MODOE7 com estrutura LPt: O \{DPt-DId (O) [EPt/EId] $\}$}

Esse modelo, com Lema em Português, reproduz a estrutura do anterior, como pode ser observado a seguir: 
FIGURA 208 - MODELO MODOE7

Casa. n.f. Nós cavamos o chão para enfiar a forquilha da casa; nós levantamos o esteio e encaibramos; nós arribamos e amarramos a casa. Depois colocamos todas as coisas pra dentro pra não molhar. Todos ajudam na construção da casa (na língua Suruí a palavra usada para designar 'macaco-prego' é também empregada para a forma genérica 'macaco'). 'og. Uruhywykaj ywya urumumug ywykwara rupi urumuku'om sura ykupyjta urumusarukong uruupir urukwar; ti roga ti kehaw, uruapo pinowa $k u$ urusehe urukehawamu urukupepyg urusehe; un ti ma'epotawamu aapo rako iako tarukeke taruke ti ma'etiru umuakym rapo amona $n$ usapy'u rapo tata (Wajwera umume'u). Ex.: nós todos juntos vamos construir a casa asehu tese saupir sene rehe 'og; eu ajudo a fazer a casa ti popytywo e apo 'og.

Casa de farinha. n.f. Na casa de fazer farinha, a gente rala, prensa e peneira a mandioca. Depois torra ela, mexendo no forno. Manimea pykujtawa rog. Pykujpykujtawa upin mani'og, ukytyg, ukupepyg, umuhaw upykuj (Ikatu umume'u). Ex.: eu vou chegando para dentro da casa de farinha aha puta manime roga pupe wewahema.

Casa tradicional. n.f. (casa verdadeira) Para fazer a casa tradicional, cavamos a terra e enfiamos os paus de amarrar rede nos buracos. Depois cobrimos a casa tradicional com a palha do babaçu. Nessa casa, todos nós dormimos nela, mas é o chefe quem dorme perto da porta. Essa casa só tem uma porta para entrar. Antigamente, essa porta não ficava fechada (atualmente, esse tipo de casa não é mais construída para fins de habitação, apenas como forma de manter a tradição). 'ogete. Uruapo ywya urumuseaupyta, uruupir pinowo ipyteripe ywa umuwyhog supatitawa; ipukuete muruwisaw erekehaw asehutese; upuga ruaw murerekotarete; upug ruaw hejkwehe n uhuwapyguwi namukuj hejkwehe upug. Ex.: vamos fazer a casa tradicional no terreno onde a gente estuda uruapo puta 'ogete semu'etawa ukaripe; vamos fazer a casa tradicional para os não índios poderem ver uruapo puta 'ogete $t$ uesag wehe warasu tywo, 'og t unawa.

Macaco-prego. n.m. (mico-de-topete) Ele vive nas copas das árvores; ele desce para pegar ouriço da castanha e sobe com ele na árvore e começa a bater no pau até o ouriço rachar; ele é marrom com a cabeça preta. Ka'i. Ka'i iwete okowa'e; upyhyg iwyw ka'ia so uputi'a warimu irahaj awpita so akakaw yware; ka'ia awiton iapina pisuna (Tymykong umume'u). Ex.: o macaco-prego brinca no galho da árvore e quebra os galhos ka'ia usemuaraj yware ywokomuтерет.

Relacionado ao LPt há somente um Operador do tipo Gr, enquanto os Descritores contam com dois Operadores, Na e Ft. Nessa proposta, são os textos em Suruí que recebem efeito itálico.

\subsubsection{Modelo MODOE8 com estrutura LId: O \{DId-DPt-D... (O) [EId/EPt/E...]\}}

O oitavo modelo deste conjunto amplia os dois anteriores ao estabelecer um mínimo de três Descritores e três componentes do tipo Exemplo envolvendo, assim, pelo menos três línguas nessa proposta.

Apresento, a seguir, um exemplo baseado nessa proposta: 
FIGURA 209 - MODELO MODOE8

ka'i $n$.III /ka'?i/ ka'i iwete okowa'e; upyhyg iwyw ka'ia so uputi'a warimu irahaj awpita so akakaw yware; ka'ia awiton iapina pisuna (Tymykong umume'u). Macaco-prego. Ele vive nas copas das árvores; ele desce para pegar ouriço da castanha e sobe com ele na árvore e começa a bater no pau até o ouriço rachar; ele é marrom com a cabeça preta. Capuchin monkey. He lives on the top of the trees; he goes to pick up hedgehog chestnut-nut and climbs the tree with him; then, he starts beating the Hedgehog until it cracks; He is brown with a black head. Cebus apella. Ajnon: ka'ia usemuaraj yware ywokomumepem o macacoprego brinca no galho da árvore e quebra os galhos the capuchin monkey romps in the branch of the tree and the branches breaks.

manimea pykujtawa rog /mani'mea pikuj'tawa 'юg/ pykujpykujtawa upin mani'og, ukytyg, ukupepyg, umuhaw upykuj (Ikatu umume'u). Casa de farinha. Na casa de fazer farinha, a gente rala, prensa e peneira a mandioca. Depois torra ela, mexendo no forno. Flour's house. In the flour's house, the people grate, press and sieve cassava. After roasting it, they stir it on the oven. Ajnon: aha puta manime roga pupe wewahema eu vou chegando para dentro da casa de farinha I came into the house of flour. • Eisag $\rightarrow$ 'og.

'og n.III /'Pog/ uruhywykaj ywya urumumug ywykwara rupi urumuku'om sura ykupyjta urumusaru-kong uruupir urukwar; ti roga ti kehaw, uruapo pinowa $\mathrm{ku}$ urusehe urukehawamu urukupepyg urusehe; un ti ma'epotawamu aapo rako iako tarukeke taruke ti ma'etiru umuakym rapo amona $n$ usapy'u rapo tata (Wajwera umume'u). Casa. Nós cavamos o chão para enfiar a forquilha da casa; nós levantamos o esteio e encaibramos; nós arribamos e amarramos a casa. Depois colocamos todas as coisas pra dentro pra não molhar. Todos ajudam na construção da casa. House. We dug the sticks into the ground of the futures house, then we raise its mainstay and put the rafter. Then we put our goods inside the house for them to not get wet. Everyone helps the building of the house. Ajnon: asehu tese saupir sene rehe 'og nós todos juntos vamos construir a casa all together we will build the house; ti popytywo e apo 'og eu ajudo a fazer a cas $a$ I help the building of the house. • Eisag $\rightarrow$ manimea pykujtawa rog, 'ogete.

'ogete n.III /Poge'te/ uruapo ywya urumuseaupyta, uruupir pinowo ipyteripe ywa umuwyhog supatitawa; ipukuete muruwisaw erekehaw asehutese; upuga ruaw murerekotarete; upug ruaw hejkwehe n uhuwapyguwi namukuj hejkwehe upug (Wajwera umume'u). Casa tradicional. Para fazer a casa tradicional, cavamos a terra $e$ enfiamos os paus de amarrar rede nos buracos. Depois cobrimos a casa tradicional com a palha do babaçu. Nessa casa, todos nós dormimos nela, mas é o chefe quem dorme perto da porta. Essa casa só tem uma porta para entrar. Antigamente, essa porta não ficava fechada. Traditional house. To make a traditional house, we dug the earth and we stuck the sticks into the holes, tying them to support the rafter. After we have covered the traditional house with thatched babassu we are able to sleep in it, but it is the chief who sleeps near the door. This house has only one door. Formerly, it door was not closed. Ajnon: uruapo puta 'ogete semu'etawa ukaripe vamos fazer a casa tradicional no terreno onde a gente estuda let's make a traditional house in the land where you study; uruapo puta 'ogete $t$ uesag wehe warasu tywo, 'og t unawa; vamos fazer a casa tradicional para os não índios poderem ver let's do the traditional house for the non Indians to see it. - Eisag $\rightarrow$ 'og.

O LPt desse modelo está relacionado a três Operadores, são eles: Fn, inserido logo após o Lema, Gr, entre barras oblíquas, fica depois do Operador Gr, e Rm, no final do verbete. Quanto ao outro Operador, colocado entre parênteses, ele se relaciona somente ao DId. 


\subsubsection{Modelo MODOE9 com estrutura LId: O \{DPt-D... (O) [EId/EPt/E...]\}}

Esse último modelo retoma a estrutura do anterior, mas não inclui o DId, como pode ser conferido no exemplo abaixo:

\section{FIGURA 210 - MODELO MODOE9}

ka'i n.III /ka'?i/ Macaco-prego (significa também a forma genérica 'macaco'). Capuchin monkey. Cebus apella. Ajnon: ka'ia usemuaraj yware ywokomumepem $o$ macaco-prego brinca no galho da árvore $e$ quebra os galhos the capuchin monkey romps in the branch of the tree and the branches breaks.

manimea pykujtawa rog /mani'mea pikuj'tawa 'юg/ Casa de farinha (a única farinha feita pelos Suruí é a de mandioca). Flour's house. Ajnon: aha puta manime roga pupe wewahema eu vou chegando para dentro da casa de farinha I came into the house of flour. - Eisag $\rightarrow$ 'og. 'og n.III /'Pog/ Casa. House. Ajnon: asehu tese saupir sene rehe 'og nós todos juntos vamos construir a casa all together we will build the house; ti popytywo e apo 'og eu ajudo a fazer a casa I help the building of the house. - Eisag $\rightarrow$ 'ogete.

'ogete n.III /Poge'te/ Casa tradicional (lit. Casa verdadeira). Traditional house. Ajnon: uruapo puta 'ogete semu'etawa ukaripe vamos fazer a casa tradicional no terreno onde a gente estuda let's make a traditional house in the land where you study. - Eisag $\rightarrow$ 'og.

\subsubsection{Modelo MODEO}

Diferente do modelo MDEO, que não foi atestado no conjunto de UBL's das línguas indígenas brasileiras, algumas formas desse modelo já foram encontradas, no entanto, é muito baixo o total de ocorrências dele.

Partindo dessa estrutura, foi possível chegar às seguintes EML's: (1) LId: O \{DId [EId (O)]\}; (2) LId: O \{DPt [EId (O)]\}; (3) LId: O \{DPt [EId/EPt (O)]\}; (4) LPt: O \{DId [EId (O)] \}; (5) LPt: O \{DId [EId/EPt (O)]\}; (6) LId: O \{DId-DPt [EId/EPt (O)]\}; (7) LPt: O \{DPtDId [EPt/EId (O)]\}; (8) LId: O \{DId-DPt-D... [EId/EPt/E... (O)]\} e (9) LId: O \{DPt-D... $[\mathrm{EId} / \mathrm{EPt} / \mathrm{E} \ldots(\mathrm{O})]\}$.

\subsubsection{Modelo MODEO1 com estrutura LId: O \{DId [EId (O)]\}}

Utilizando apenas a língua Suruí, esse modelo possui Operadores associados ao componente Lema e ao componente exemplo.

Esse primeiro modelo contém apenas a língua Suruí com Operador associado ao componente Exemplo, como pode ser observado na figura abaixo: 
FIGURA 211 - MODELO MODEO1

ka'i n.III /ka'2i/ ka'i iwete okowa'e; upyhyg iwyw ka'ia so uputi'a warimu irahaj awpita so akakaw yware; ka'ia awiton iapina pisuna. Ajnon: ka'ia usemuaraj yware ywokomumepem (Tymykong umume'u).

manimea pykujtawa rog /mani'mea pikuj'tawa 'юg/ pykujpykujtawa upin mani'og, ukytyg, ukupepyg, umuhaw upykuj. Ajnon: aha puta manime roga pupe wewahema (Ikatu umume'u).

'og n.III /'Pog/ uruhywykaj ywya urumumug ywykwara rupi urumuku'om sura ykupyjta urumusarukong uruupir urukwar; ti roga ti kehaw, uruapo pinowa ku urusehe urukehawamu urukupepyg urusehe; un ti ma'epotawamu aapo rako iako tarukeke taruke ti ma'etiru umuakym rapo amona n usapy'u rapo tata. Ajnon: asehu tese saupir sene rehe 'og (Ikatu umume'u); ti popytywo e apo 'og; ti rehe taketehewehe ne wy wekow (Wajwera umume'u).

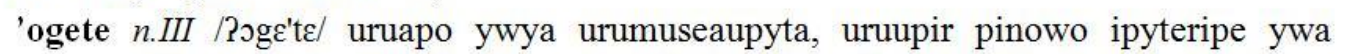
umuwyhog supatitawa; ipukuete muruwisaw erekehaw asehutese; upuga ruaw murerekotarete; upug ruaw hejkwehe $\mathrm{n}$ uhuwapyguwi namukuj hejkwehe upug. Ajnon: uruapo puta 'ogete semu'etawa ukaripe (Ikatu umume'u); uruapo puta 'ogete t uesag wehe warasu tywo, 'og t unawa (Wajwera umume'u).

Com Operadores relacionados aos componentes Lema e Exemplo, esse modelo conta com três tipos diferentes de Operadores, são eles: Fn, Ft e Gr.

\subsubsection{Modelo MODEO2 com estrutura LId: O \{DPt [EId (O)]\}}

O segundo modelo se difere do anterior por apresentar o Descritor em Português, conforme exemplo a seguir:

\section{FIGURA 212 - MODELO MODEO2}

ka'i $n . I I I / \mathrm{ka}$ '?i/ Ele vive nas copas das árvores; ele desce para pegar ouriço da castanha e sobe com ele na árvore e começa a bater no pau até o ouriço rachar; ele é marrom com a cabeça preta. Ajnon: ka'ia usemuaraj yware ywokomumepem (Tymykong umume'u).

manimea pykujtawa rog /mani'mea pikuj'tawa 'rog/ Na casa de fazer farinha, a gente rala, prensa e peneira a mandioca. Depois torra ela, mexendo no forno. Ajnon: aha puta manime roga pupe wewahema (Ikatu umume'u).

'og n.III /'?og/ Nós cavamos o chão para enfiar a forquilha da casa; nós levantamos o esteio e encaibramos; nós arribamos e amarramos a casa. Depois colocamos todas as coisas pra dentro pra não molhar. Todos ajudam na construção da casa. Ajnon: asehu tese saupir sene rehe 'og (Ikatu umume'u); ti popytywo e apo 'og; ti rehe taketehewehe ne wy wekow (Wajwera umume'u).

'ogete n.III /Poge'te/ Para fazer a casa tradicional, cavamos a terra e enfiamos os paus de amarrar rede nos buracos. Depois cobrimos a casa tradicional com a palha do babaçu. Nessa casa, todos nós dormimos nela, mas é o chefe quem dorme perto da porta. Essa casa só tem uma porta para entrar. Antigamente, essa porta não fícava fechada. Ajnon: uruapo puta 'ogete semu'etawa ukaripe (Ikatu umume'u); uruapo puta 'ogete $t$ uesag wehe warasu tywo, 'og $t$ unawa (Wajwera umume'u). 
Acredito que um modelo desse tipo possa ser bastante útil tanto para as comunidades indígenas onde o Português seja usado como segunda língua (ou mesmo como primeira), quanto para pesquisadores, principalmente antropólogos, uma vez que os Descritores são apresentados principalmente em Português, mas com Lemas na língua indígena. Talvez a única restrição para esse uso de especialistas seja o fato de o componente Exemplo ser dado somente em Suruí, situação esta que é solucionada no próximo modelo.

\subsubsection{Modelo MODEO3 com estrutura LId: O $\{$ DPt [EId/EPt (O)]}

Esse modelo retoma a estrutura do MODOE, mas desloca o segundo Operador do Descritor para o Exemplo. A seguir, apresento um exemplo baseado nesse modelo:

FIGURA 213 - MODELO MODEO3a

ka'i $n$.III /ka'?i/ macaco-prego. Ele vive nas copas das árvores; ele desce para pegar ouriço da castanha e sobe com ele na árvore e começa a bater no pau até o ouriço rachar; ele é marrom com a cabeça preta. Ajnon: ka'ia usemuaraj yware ywokomumepem (Tymykong umume'u) o macaco-prego brinca no galho da árvore e quebra os galhos.

manimea pykujtawa rog /mani'mea pikuj'tawa 'rog/ casa de farinha. Na casa de fazer farinha, a gente rala, prensa e peneira a mandioca. Depois torra ela, mexendo no forno. Ajnon: aha puta manime roga pupe wewahema (Ikatu umume'u) eu vou chegando para dentro da casa de farinha.

'og n.III /'Pog/ casa. Nós cavamos o chão para enfiar a forquilha da casa; nós levantamos o esteio e encaibramos; nós arribamos e amarramos a casa. Depois colocamos todas as coisas pra dentro pra não molhar. Todos ajudam na construção da casa. Ajnon: asehu tese saupir sene rehe 'og (Ikatu umume'u) nós todos juntos vamos construir a casa; ti popytywo e apo 'og (Wajwera umume'u) eu ajudo a fazer a casa.

'ogete $n$.III / ogg'te/ tradicional. Para fazer a casa tradicional, cavamos a terra e enfiamos os paus de amarrar rede nos buracos. Depois cobrimos a casa tradicional com a palha do babaçu. Nessa casa, todos nós dormimos nela, mas é o chefe quem dorme perto da porta. Essa casa só tem uma porta para entrar. Antigamente, essa porta não fícava fechada. Ajnon: uruapo puta 'ogete semu'etawa ukaripe (Ikatu umume'u) vamos fazer a casa tradicional no terreno onde a gente estuda; uruapo puta 'ogete $t$ uesag wehe warasu tywo, 'og $t$ unawa (Wajwera umume'u) vamos fazer a casa tradicional para os não índios poderem ver.

O Lema desse modelo se relaciona aos dois Operadores do tipo Fn e Gr, enquanto os Descritores, aos Descritores do tipo Ft. Apesar de esse modelo não ser muito comum, a sua variação, apresentada a seguir, é bem mais comum no conjunto de UBL's. 
FIGURA 214 - MODELO MODEO3b

ka'i $n . I I I / k a ' \mathrm{i}$ / macaco-prego. Ajnon: ka'ia usemuaraj yware ywokomumepem (Tymykong umume'u); o macaco-prego brinca no galho da árvore e quebra os galhos.

manimea pykujtawa rog /mani'mea pikuj'tawa 'rog/ casa de farinha. Ajnon: aha puta manime roga pupe wewahema (Ikatu umume'u); eu vou chegando para dentro da casa de farinha.

'og $n$.III /'?og/ casa. Ajnon: asehu tese saupir sene rehe 'og (Ikatu umume'u); eu vou chegando para dentro da casa de farinha; ti popytywo e apo 'og (Wajwera umume'u); eu ajudo a fazer a casa.

'ogete $n$.III /'?og/ casa tradicional. Ajnon: uruapo puta 'ogete semu'etawa ukaripe (Ikatu umume'u); vamos fazer a casa tradicional no terreno onde a gente estuda; uruapo puta 'ogete t uesag wehe warasu tywo (Wajwera umume'u); vamos fazer a casa tradicional para os não índios poderem ver.

\subsubsection{Modelo MODEO4 com estrutura LPt: O \{DId [EId (O)]\}}

Tendo o Lema agora em Português, esse modelo também não é comum no corpus de UBL's das línguas indígenas brasileiras. Apresento, a seguir, uma amostra desse modelo:

FIGURA 215 - MODELO MODEO4a

\begin{tabular}{|ll|}
\hline casa n.f. 'og. Uruhywykaj ywya & casa tradicional 'ogete. Uruapo ywya \\
urumumug ywykwara rupi urumuku'om & urumuseaupyta, uruupir pinowo ipyteripe \\
sura ykupyjta urumusarukong uruupir & ywa umuwyhog supatitawa; ipukuete \\
urukwar; ti roga ti kehaw, uruapo pinowa & muruwisaw erekehaw asehutese; upuga \\
ku urusehe urukehawamu urukupepyg & ruaw murerekotarete; upug ruaw hejkwehe \\
urusehe; un ti ma'epotawamu aapo rako & n uhuwapyguwi namukuj hejkwehe upug. \\
iako tarukeke taruke ti ma'etiru umuakym & Ajnon: uruapo puta 'ogete semu'etawa \\
rapo amona n usapy'u rapo tata. Ajnon: & ukaripe (Ikatu umume'u) uruapo puta \\
asehu tese saupir sene rehe 'og; ti & 'ogete t uesag wehe warasu tywo, 'og $t$ \\
popytywo e apo 'og (Ikatu umume'u); $t$ & unawa (Wajwera umume'u). - Ver $\rightarrow$ \\
rehe t aketehewehe ne wy wekow & casa, casa tradicional. \\
(Wajwera umume'u). - Ver $\rightarrow$ casa de & macaco-prego n.m. ka'i. Ka'i iwete \\
farinha, casa tradicional. & okowa'e; upyhyg iwyw ka'ia so uputi'a \\
casa de farinha n.f. manimea pykujtawa & warimu irahaj awpita so akakaw yware; \\
rog. Pykujpykujtawa upin mani'og, & ka'ia awiton iapina pisuna. Ajnon: ka'ia \\
ukytyg, ukupepyg, umuhaw upykuj. & usemuaraj yware ywokomumepem \\
Ajnon: aha puta manime roga pupe & (Tymykong umume'u). \\
wewahema (Ikatu umume'u). - Ver $\rightarrow$ & \\
casa. &
\end{tabular}

O LPt conta com dois Operadores, Gr e Rm, enquanto o DId, com um Operador do tipo Ft. Uma proposta como essa produziria material lexicográfico útil para uma comunidade indígena, sobretudo se a intenção fosse chegar à língua indígena tendo como 
orientação a palavra em Português. Esse modelo pode variar se, ao invés de texto, o DId contivesse apenas uma palavra ou expressão, como no exemplo a seguir:

\section{FIGURA 216 - MODELO MODEO4b}

\begin{tabular}{|ll|}
\hline cachorro n.m. ma'esawar & homem n.m. akuma'e \\
Ajnon: unupo ma'esawara; ma'esawara puta & Ajnon: akuma'e akuraete; ajko re wehe rako \\
usekyj mosa u'uramu (Ikatu umume'u); & aesag akuma'e; moron puta pe akuma'e ihoj \\
esemuhaku'i ke! ma'esawara rapo ne u'u & osuna? \\
cavar v.t. hywykaj & matar v.t. suka \\
Ajnon: ywykwara ahywykaj; ti se'eromamu & Ajnon: pehe puta pesuka ma'ea pesehow?; \\
puta ri'a ahywykaj & aha puta ri'a isukaw tasahuamu; esuka puhi \\
dar v.t. mono & (Masu umume'u) \\
Ajnon: syryg puta amono ne irua pe; ko, & mulher n.f. kuso \\
amono ne upe; ajko na amonowi ne upe & Ajnon: kuso sysyng; ma'eramu pa'e kuso nu \\
(Muretama umume'u) & se'engara uwi? (Ikatu umume'u); ure kuso \\
farinha de mandioca n.f. manime & teseramu uruho ytyma mani'og roko urutym \\
Ajnon: manimea ko amumaraw wyra'yra & redondo adj. 'apu'a \\
rupi'a (Tymykong umume'u) & Ajnon: kuipia i'apu'a; tehahua i'apu'a \\
& (Waywera umume'u)
\end{tabular}

\subsubsection{Modelo MODEO5 com estrutura LPt: O \{DId [EId/EPt (O)]\}}

Esse modelo retoma a estrutura anterior e a amplia com o componente EPt, como pode ser observado na figura abaixo:

\section{FIGURA 217 - MODELO MODEO5a}

casa n.f. 'og. Uruhywykaj ywya urumumug ywykwara rupi urumuku'om sura ykupyjta urumusarukong uruupir urukwar; ti roga ti kehaw, uruapo pinowa $\mathrm{ku}$ urusehe urukehawamu urukupepyg urusehe; un ti ma'epotawamu aapo rako iako tarukeke taruke ti ma'etiru umuakym rapo amona $n$ usapy'u rapo tata. Ajnon: asehu tese saupir sene rehe 'og eu vou chegando para dentro da casa de farinha; ti popytywo e apo 'og; ti rehe $t$ aketehewehe ne wy wekow (Wajwera umume'u); eu ajudo a fazer a casa. • Ver $\rightarrow$ casa de farinha, casa tradicional.

casa de farinha n.f. manimea pykujtawa rog. Pykujpykujtawa upin mani'og, ukytyg, ukupepyg, umuhaw upykuj. Ajnon: aha puta manime roga pupe wewahema (Ikatu umume'u); eu vou chegando para dentro da casa de farinha. - Ver $\rightarrow$ casa. casa tradicional 'ogete. Uruapo ywya urumuseaupyta, uruupir pinowo ipyteripe ywa umuwyhog supatitawa; ipukuete muruwisaw erekehaw asehutese; upuga ruaw murerekotarete; upug ruaw hejkwehe n uhuwapyguwi namukuj hejkwehe upug. Ajnon: uruapo puta 'ogete semu'etawa ukaripe (Wajwera umume'u) vamos fazer a casa tradicional no terreno onde a gente estuda; uruapo puta 'ogete t uesag wehe warasu tywo, 'og t unawa vamos fazer a casa tradicional para os não índios poderem ver. . Ver $\rightarrow$ casa.

macaco-prego ka'i. Ka'i iwete okowa'e; upyhyg iwyw ka'ia so uputi'a warimu irahaj awpita so akakaw yware; ka'ia awiton iapina pisuna. Ajnon: ka'ia usemuaraj yware ywokomumepem (Tymykong umume'u); $o$ macaco-prego brinca no galho da árvore e quebra os galhos. 
Mesmo com Operadores Gr e Rm relacionados ao LPt, essa proposta ainda não é comum no conjunto de UBL's das línguas indígenas brasileiras. Por outro lado, ao substituir o texto do DId por uma palavra ou expressão, esse modelo passa a ter mais chances de ocorrer.

FIGURA 218 - MODELO MODEO5b

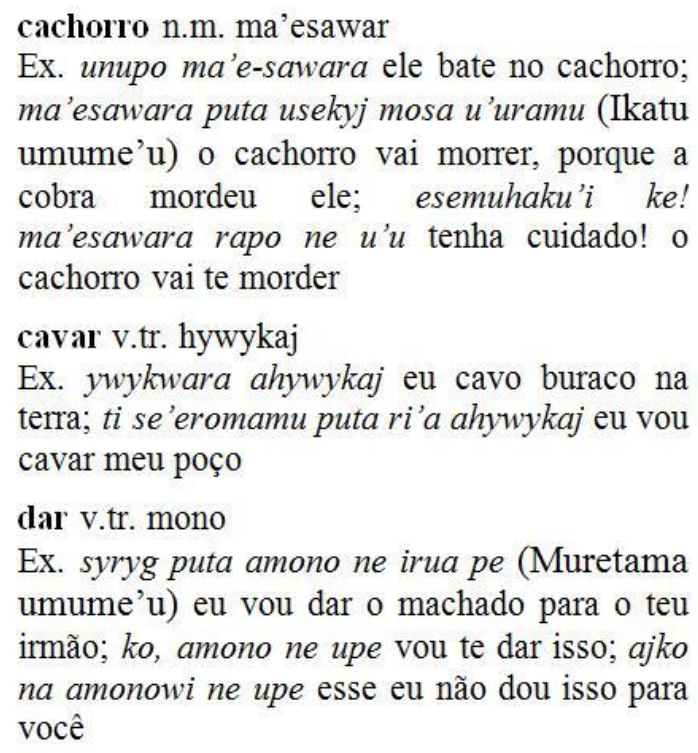

Ex. syryg puta amono ne irua pe (Muretama umume'u) eu vou dar o machado para o teu irmão; ko, amono ne upe vou te dar isso; ajko na amonowi ne upe esse eu não dou isso para você

\begin{abstract}
homem n.m. akuma'e
Ex. akuma'e akuraete homem gordo; ajko re wehe rako aesag akuma'e ontem eu vi este homem; moron puta pe akuma'e ihoj osuna? quantos homens vão correr?

matar v.intr. suka

Ex. pehe puta pesuka ma'ea pesehow? (Masu umume'u) vocês vão matar aquelas caças?; aha puta ri'a isukaw tasahuamu talvez eu mate um porcão; esuka puhi não mata ele

mulher n.f. kuso

Ex. kuso sysyng mulher magra; ma'eramu pa'e kuso nu se'engara uwi? (Ikatu umume'u) por que as mulheres não estão cantando?; ure kuso teseramu uruho ytyma mani'og roko urutym nós fomos com as mulheres plantar mandioca
\end{abstract}

O Operador do tipo Gr se relaciona ao LPt nesse modelo, enquanto o do tipo Ft, entre parênteses, se relaciona ao EId.

\title{
9.1.13.6. Modelo MODEO6 com estrutura LId: O \{DId-DPt [EId/EPt (O)]\}
}

Se comparado aos dois modelos anteriores, este pode ser considerado o mais completo, por apresentar componentes nas duas línguas envolvidas na estrutura do verbete, como pode ser observado a seguir:

\section{FIGURA 219 - MODELO MODEO6}

ka'i $n$.III /ka'?i/ ka'i iwete okowa'e; upyhyg iwyw ka'ia so uputi'a warimu irahaj awpita so akakaw yware; ka'ia awiton iapina pisuna. Macaco-prego. Ele vive nas copas das árvores; ele desce para pegar ouriço da castanha e sobe com ele na árvore e começa a bater no pau até o ouriço rachar; ele é marrom com a cabeça preta. Ajnon: ka'ia usemuaraj yware ywokomumepem (Tymykong umume'u) o macaco-prego brinca no galho da árvore e quebra os galhos.

manimea pykujtawa rog /mani'mea pikuj'tawa 'rog/ pykujpykujtawa upin mani'og, ukytyg, ukupepyg, umuhaw upykuj. Casa de farinha. Na casa de fazer farinha, a gente rala, prensa e peneira a mandioca. Depois torra ela, mexendo no forno. Ajnon: aha puta manime roga pupe wewahema (Ikatu umume'u) eu vou chegando para dentro da casa de farinha. 
'og n.III /'?og/ uruhywykaj ywya urumumug ywykwara rupi urumuku'om sura ykupyjta urumusarukong uruupir urukwar; ti roga ti kehaw, uruapo pinowa ku urusehe urukehawamu urukupepyg urusehe; un ti ma'epotawamu aapo rako iako tarukeke taruke ti ma'etiru umuakym rapo amona n usapy'u rapo tata. Casa. Nós cavamos o chão para enfiar a forquilha da casa; nós levantamos o esteio e encaibramos; nós arribamos $e$ amarramos a casa. Depois colocamos todas as coisas pra dentro pra não molhar. Todos ajudam na construção da casa. Ajnon: asehu tese saupir sene rehe 'og (Wajwera umume'u) nós todos juntos vamos construir a casa; ti popytywo e apo 'og eu ajudo a fazer a casa.

'ogete n.III /Poge'te/ uruapo ywya urumuseaupyta, uruupir pinowo ipyteripe ywa umuwyhog supatitawa; ipukuete muruwisaw erekehaw asehutese; upuga ruaw murerekotarete; upug ruaw hejkwehe n uhuwapyguwi namukuj hejkwehe upug. Casa tradicional. Para fazer a casa tradicional, cavamos a terra e enfiamos os paus de amarrar rede nos buracos. Depois cobrimos a casa tradicional com a palha do babaçu. Nessa casa, todos nós dormimos nela, mas é o chefe quem dorme perto da porta. Essa casa só tem uma porta para entrar. Antigamente, essa porta não ficava fechada. Ajnon: uruapo puta 'ogete semu'etawa ukaripe (Wajwera umume'u) vamos fazer a casa tradicional no terreno onde a gente estuda; uruapo puta 'ogete t uesag wehe warasu tywo, 'og t unawa; vamos fazer a casa tradicional para os não índios poderem ver.

Nesse modelo, o LId recebe Operadores Fn e Gr, e o EId, um do tipo Ft. Ao lado do modelo MODOE, constituem as propostas mais completas até o momento para construção de materiais lexicográficos bilíngues.

\subsubsection{Modelo MODEO7 com estrutura LPt: O \{DPt-DId [EPt/EId (O)]\}}

Essa proposta, que espelha as línguas usadas na anterior, desloca o segundo Operador para junto do componente Exemplo, conforme amostra a seguir:

\section{FIGURA 220 - MODELO MODEO7}

Casa. n.f. Nós cavamos o chão para enfiar a forquilha da casa; nós levantamos o esteio e encaibramos; nós arribamos e amarramos a casa. Depois colocamos todas as coisas pra dentro pra não molhar. Todos ajudam na construção da casa. 'og. Uruhywykaj ywya urumumug ywykwara rupi urumuku'om sura ykupyjta urumusarukong uruupir urukwar; ti roga ti kehaw, uruapo pinowa ku urusehe urukehawamu urukupepyg urusehe; un ti ma'epotawamu aapo rako iako tarukeke taruke ti ma'etiru umuakym rapo amona $n$ usapy'u rapo tata. Ex.: nós todos juntos vamos construir a casa asehu tese saupir sene rehe 'og (Wajwera umume'u); eu ajudo a fazer a casa $t i$ popytywo e apo 'og. - Ver $\rightarrow$ casa de farinha, casa tradicional. rede nos buracos. Depois cobrimos a casa tradicional com a palha do babaçu. Nessa casa, todos nós dormimos nela, mas é o chefe quem dorme perto da porta. Essa casa só tem uma porta para entrar. Antigamente, essa porta não ficava fechada. 'ogete. Uruapo ywya urumuseaupyta, uruupir pinowo ipyteripe ywa umuwyhog supatitawa; ipukuete muruwisaw erekehaw asehutese; upuga ruaw murerekotarete; upug ruaw hejkwehe n uhuwapyguwi namukuj hejkwehe upug. Ex.: vamos fazer a casa tradicional no terreno onde a gente estuda uruapo puta 'ogete semu'etawa ukaripe (Wajwera umume'u); vamos fazer a casa tradicional para os não índios poderem ver uruapo puta 'ogete t uesag wehe warasu tywo, 'og t unawa. - Ver $\rightarrow$ casa. 
Casa de farinha. $\mathrm{Na}$ casa de fazer farinha, a gente rala, prensa e peneira a mandioca. Depois torra ela, mexendo no forno. Manimea pykujtawa rog. Pykujpykujtawa upin mani'og, ukytyg, ukupepyg, umuhaw upykuj. Ex.: eu vou chegando para dentro da casa de farinha aha puta manime roga pupe wewahema (Ikatu umume'u). - Ver $\rightarrow$ casa.

Casa tradicional. Para fazer a casa tradicional, cavamos a terra e enfiamos os paus de amarrar

\begin{abstract}
Macaco-prego. n.m. Ele vive nas copas das árvores; ele desce para pegar ouriço da castanha e sobe com ele na árvore e começa a bater no pau até o ouriço rachar; ele é marrom com a cabeça preta. $K a$ 'i. Ka'i iwete okowa'e; upyhyg iwyw ka'ia so uputi'a warimu irahaj awpita so akakaw yware; ka'ia awiton iapina pisuna. Ex.: o macaco-prego brinca no galho da árvore e quebra os galhos ka'ia usemuaraj yware ywokomumepem (Tymykong umume'u). - Ver $\rightarrow$ guariba, mico mão-de-ouro.
\end{abstract}

Geralmente o Operador Fn não é usado com um componente do tipo LPt, pois se trata da língua de maior difusão no Brasil, mas se o interesse for ensinar, por exemplo, o Português como segunda língua a uma comunidade indígena, a inserção desse Operador se justificaria plenamente na proposta de material lexicográfico, pois ele poderia colaborar com o esclarecimento da pronúncia adequada do item lexical.

\subsubsection{Modelo MODEO8 com estrutura LId: O \{DId-DPt-D... [EId/EPt/E... (O)]\}}

Ampliando o número de Descritores e Exemplos na microestrutura, essa proposta atende à construção de materiais multilíngues, como demonstra a figura a seguir:

\section{FIGURA 221 - MODELO MODEO8}

ka'i $n$.III /ka'?i/ ka'i iwete okowa'e; upyhyg iwyw ka'ia so uputi'a warimu irahaj awpita so akakaw yware; ka'ia awiton iapina pisuna. Macaco-prego. Ele vive nas copas das árvores; ele desce para pegar ouriço da castanha e sobe com ele na árvore e começa a bater no pau até o ouriço rachar; ele é marrom com a cabeça preta. Capuchin monkey. He lives on the top of the trees; he goes to pick up hedgehog chestnut-nut and climbs the tree with him; then, he starts beating the Hedgehog until it cracks; He is brown with a black head. Cebus apella. Ajnon: ka'ia usemuaraj yware ywokomumepem (Tymykong umume'u) o macaco-prego brinca no galho da árvore $e$ quebra os galhos the capuchin monkey romps in the branch of the tree and the branches breaks.

manimea pykujtawa rog /mani'mea pikuj'tawa 'rog/ pykujpykujtawa upin mani'og, coisas pra dentro pra não molhar. Todos ajudam na construção da casa. House. We dug the sticks into the ground of the futures house, then we raise its mainstay and put the rafter. Then we put our goods inside the house for them to not get wet. Everyone helps the building of the house. Ajnon: asehu tese saupir sene rehe 'og (Wajwera umume'u) nós todos juntos vamos construir a casa all together we will build the house; ti popytywo e apo 'og eu ajudo a fazer a casa I help the building of the house.

'ogete n.III /Poge'te/ uruapo ywya urumuseaupyta, uruupir pinowo ipyteripe ywa umuwyhog supatitawa; ipukuete muruwisaw erekehaw asehutese; upuga ruaw murerekotarete; upug ruaw hejkwehe n uhuwapyguwi namukuj hejkwehe upug. Casa tradicional. Para fazer a casa tradicional, cavamos a terra e enfiamos os paus de 


\begin{abstract}
ukytyg, ukupepyg, umuhaw upykuj. Casa de farinha. Na casa de fazer farinha, a gente rala, prensa e peneira a mandioca. Depois torra ela, mexendo no forno. Flour's house. In the flour's house, the people grate, press and sieve cassava. After roasting it, they stir it on the oven. Ajnon: aha puta manime roga pupe wewahema (Ikatu umume'u) eu vou chegando para dentro da casa de farinha I came into the house of flour.
\end{abstract}

'og n.III /'Pog/ uruhywykaj ywya urumumug ywykwara rupi urumuku'om sura ykupyjta urumusaru-kong uruupir urukwar; ti roga ti kehaw, uruapo pinowa $\mathrm{ku}$ urusehe urukehawamu urukupepyg urusehe; un ti ma'epotawamu aapo rako iako tarukeke taruke ti ma'etiru umuakym rapo amona $\mathrm{n}$ usapy'u rapo tata. Casa. Nós cavamos o chão para enfiar a forquilha da casa; nós levantamos o esteio e encaibramos; nós arribamos $e$ amarramos a casa. Depois colocamos todas as amarrar rede nos buracos. Depois cobrimos a casa tradicional com a palha do babaçu. Nessa casa, todos nós dormimos nela, mas é o chefe quem dorme perto da porta. Essa casa só tem uma porta para entrar. Antigamente, essa porta não ficava fechada. Traditional house. To make a traditional house, we dug the earth and we stuck the sticks into the holes, tying them to support the rafter. After we have covered the traditional house with thatched babassu we are able to sleep in it, but it is the chief who sleeps near the door. This house has only one door. Formerly, it door was not closed. Ajnon: uruapo puta 'ogete semu'etawa ukaripe (Wajwera umume'u) vamos fazer a casa tradicional no terreno onde a gente estuda let's make a traditional house in the land where you study; uruapo puta 'ogete t uesag wehe warasu tywo, 'og t unawa; vamos fazer a casa tradicional para os não índios poderem ver let's do the traditional house for the non Indians to see it.

Além dos Operadores Fn e Gr relacionados ao LId, há também o Operador Ft do EId, nessa proposta que envolve o Suruí, o Português e o Inglês.

\subsubsection{Modelo MODEO9 com estrutura LId: O \{DPt-D... [EId/EPt/E... (O)]\}}

O último modelo deste conjunto não contém o DId, como na proposta anterior, mesmo assim, trata-se de um modelo que pode ser perfeitamente empregado na construção de um material multilíngue, sobretudo se os Descritores forem constituídos por palavras ou expressões que traduzam o LId.

\section{FIGURA 222 - MODELO MODEO9}

ka'i $n$.III /ka'?i/ Macaco-prego. Capuchin monkey. Cebus apella. Ajnon: ka'ia usemuaraj yware ywokomumepem (Tymykong umume'u) o macaco-prego brinca no galho da árvore e quebra os galhos the capuchin monkey romps in the branch of the tree and the branches breaks.

manimea pykujtawa rog /mani'mea pikuj'tawa 'rog/ Casa de farinha. Flour's house. Ajnon: aha puta manime roga pupe wewahema (Ikatu umume'u) eu vou chegando para dentro da casa de farinha I came into the house of flour. • Eisag $\rightarrow$ 'og.

'og n.III /'?og/ Casa. House. Ajnon: asehu tese saupir sene rehe 'og (Ikatu umume'u) nós todos juntos vamos construir a casa all together we will build the house; ti popytywo e apo 'og eu ajudo a fazer a casa I help the building of the house. • Eisag $\rightarrow$ manimea pykujtawa rog, 'ogete.

'ogete n.III / Poge'te/ Casa tradicional. Traditional house. Ajnon: uruapo puta 'ogete semu'etawa ukaripe (Ikatu umume'u) vamos fazer a casa tradicional no terreno onde a gente estuda let's make a traditional house in the land where you study. • Eisag $\rightarrow$ 'og. 


\title{
9.1.14. Modelo MODOEO
}

O último dos 14 modelos é o que emprega todos os componentes da microestrutura e cada um deles relacionados com os respectivos Operadores. Nesse modelo, a EML básica é L: $\mathrm{O}\{\mathrm{D}(\mathrm{O})[\mathrm{E}(\mathrm{O})]\}$, a partir da qual foram identificadas as seguintes estruturas: (1) LId: O \{DId (O) [EId (O)]\}; (2) LId: O \{DPt (O) [EId (O)]\}; (3) LId: O \{DPt (O) $[$ EId/EPt (O)] $\}$; (4) LPt: O \{DId (O) [EId (O)]\}; (5) LPt: O \{DId (O) [EId/EPt (O)]\}; (6) LId: O \{DId-DPt (O) [EId/EPt (O)]\}; (7) LPt: O \{DPt-DId (O) [EPt/EId (O)]\}; (8) LId: O \{DId-DPt-D... (O) [EId/EPt/E... (O)]\} e (9) LId: O \{DPt-D... (O) [EId/EPt/E... (O)]\}.

\subsubsection{Modelo MODOEO1 com estrutura LId: O \{DId (O) [EId (O)]\}}

Esse modelo a ser usado para uma UBL monolíngue insere Operadores em cada um dos componentes, como mostra o seguinte exemplo com a língua Suruí:

FIGURA 223 - MODELO MODOEO1

\begin{abstract}
ka'i $n$.III /ka'?i/ ka'i iwete okowa'e; upyhyg iwyw ka'ia so uputi'a warimu irahaj awpita so akakaw yware; ka'ia awiton iapina pisuna (Wajwera umume'u). Ajnon: ka'ia usemuaraj yware ywokomumepem (Tymykong umume'u).

manimea pykujtawa rog /mani'mea pikuj'tawa 'øg/ pykujpykujtawa upin mani'og, ukytyg, ukupepyg, umuhaw upykuj. Ajnon: aha puta manime roga pupe wewahema (Ikatu umume'u). - Eisag $\rightarrow$ 'og.

'og n.III /'?og/ uruhywykaj ywya urumumug ywykwara rupi urumuku'om sura ykupyjta urumusarukong uruupir urukwar; ti roga ti kehaw, uruapo pinowa ku urusehe urukehawamu urukupepyg urusehe; un ti ma'epotawamu aapo rako iako tarukeke taruke ti ma'etiru umuakym rapo amona n usapy'u rapo tata (Ikatu umume'u). Ajnon: asehu tese saupir sene rehe 'og (Ikatu umume'u); ti popytywo e apo 'og; ti rehe $t$ aketehewehe ne wy wekow (Wajwera umume'u). - Eisag $\rightarrow$ manimea pykujtawa rog, 'ogete.

'ogete n.III / oge'te/ uruapo ywya urumuseaupyta, uruupir pinowo ipyteripe ywa umuwyhog supatitawa; ipukuete muruwisaw erekehaw asehutese; upuga ruaw murerekotarete; upug ruaw hejkwehe n uhuwapyguwi namukuj hejkwehe upug (Muretama umume'u). Ajnon: uruapo puta 'ogete semu'etawa ukaripe (Ikatu umume'u); uruapo puta 'ogete $t$ uesag wehe warasu tywo, 'og t unawa (Wajwera umume'u). - Eisag $\rightarrow$ 'og.
\end{abstract}

Além dos Operadores usados nesse exemplo (Fn, Ft e Gr), é possível empregar outros, de acordo com as especificações do PDL em desenvolvimento. 


\subsubsection{Modelo MODOEO2 com estrutura LId: O $\{\mathrm{DPt}(\mathrm{O})[\mathrm{EId}(\mathrm{O})]\}$}

Também nessa proposta, todos os componentes possuem Operadores, mas ela se diferencia da anterior por conter uma segunda língua na microestrutura, como pode ser observado no exemplo abaixo:

\section{FIGURA 224 - MODELO MODOEO2}

ka'i $n$.III /ka'?i/ Ele vive nas copas das árvores; ele desce para pegar ouriço da castanha e sobe com ele na árvore e começa a bater no pau até o ouriço rachar; ele é marrom com a cabeça preta (na língua Suruí a palavra usada para designar 'macaco-prego' é também empregada para a forma genérica 'macaco'). Ajnon: $k a$ 'ia usemuaraj yware ywokomumepem (Tymykong umume'u).

manimea pykujtawa rog /mani'mea pikuj'tawa 'rog/ Na casa de fazer farinha, a gente rala, prensa e peneira a mandioca. Depois torra ela, mexendo no forno. Ajnon: aha puta manime roga pupe wewahema (Ikatu umume'u).

'og $n$.III /'?og/ Nós cavamos o chão para enfiar a forquilha da casa; nós levantamos o esteio e encaibramos; nós arribamos e amarramos a casa. Depois colocamos todas as coisas pra dentro pra não molhar. Todos ajudam na construção da casa (a construção de uma casa é uma ação coletiva na comunidade Suruí, na qual participam homens, mulheres e crianças, cada um desempenhando papéis específicos). Ajnon: asehu tese saupir sene rehe 'og (Ikatu umume'u); ti popytywo e apo 'og; ti rehe $t$ aketehewehe ne wy wekow (Wajwera umume'u).

'ogete n.III / Poge'te/ Para fazer a casa tradicional, cavamos a terra e enfiamos os paus de amarrar rede nos buracos. Depois cobrimos a casa tradicional com a palha do babaçu. Nessa casa, todos nós dormimos nela, mas é o chefe quem dorme perto da porta. Essa casa só tem uma porta para entrar. Antigamente, essa porta não ficava fechada (atualmente, esse tipo de casa não é mais construída para fins de habitação, apenas como forma de manter a tradição). Ajnon: uruapo puta 'ogete semu'etawa ukaripe (Ikatu umume'u); uruapo puta 'ogete $t$ uesag wehe warasu tywo, 'og t unawa (Wajwera umume'u).

Nesse modelo, o LId se relaciona com dois Operadores do tipo Fn e Gr; o DPt, com um Operador do tipo Na, e o EId, com um Operador Ft.

\subsubsection{Modelo MODOEO3 com estrutura LId: O $\{\mathrm{DPt}(\mathrm{O})[\mathrm{EId} / \mathrm{EPt}(\mathrm{O})]\}$}

Já nesse terceiro modelo, há cinco diferentes tipos de Operadores, exemplificados na figura abaixo:

\section{FIGURA 225 - MODELO MODOEO3a}

ka'i $n$.III /ka'?i/ macaco-prego. Ele vive nas copas das árvores; ele desce para pegar ouriço da castanha e sobe com ele na árvore e começa a bater no pau até o ouriço rachar; ele é marrom com a cabeça preta (na língua Suruí a palavra usada para designar 'macaco-prego' é também empregada para a forma genérica 'macaco'). Ajnon: ka'ia usemuaraj yware ywokomumepem (Tymykong umume'u) o macaco-prego brinca no galho da árvore e quebra os galhos.
Suruí, na qual participam homens, mulheres e crianças, cada um desempenhando papéis específicos). Ajnon: asehu tese saupir sene rehe 'og (Ikatu umume'u) nós todos juntos vamos construir a casa; ti popytywo e apo 'og (Wajwera umume'u) eu ajudo a fazer a casa. Eisag $\rightarrow$ manimea pykujtawa rog, 'ogete.

'ogete $n$.III / ogg't $\varepsilon /$ casa tradicional. Para fazer a casa tradicional, cavamos a terra e enfiamos os paus de amarrar rede nos buracos. Depois 
manimea pykujtawa rog /mani'mea pikuj'tawa 'rog/ casa de farinha. Na casa de fazer farinha, a gente rala, prensa e peneira a mandioca. Depois torra ela, mexendo no forno. Ajnon: aha puta manime roga pupe wewahema (Ikatu umume'u) eu vou chegando para dentro da casa de farinha. - Eisag $\rightarrow$ 'og.

'og n.III /'Pog/ casa. Nós cavamos o chão para enfiar a forquilha da casa; nós levantamos o esteio e encaibramos; nós arribamos e amarramos a casa. Depois colocamos todas as coisas pra dentro pra não molhar. Todos ajudam na construção da casa (a construção de uma casa é uma ação coletiva na comunidade cobrimos a casa tradicional com a palha do babaçu. Nessa casa, todos nós dormimos nela, mas é o chefe quem dorme perto da porta. Essa casa só tem uma porta para entrar. Antigamente, essa porta não ficava fechada (atualmente, esse tipo de casa não é mais construída para fins de habitação, apenas como forma de manter a tradição). Ajnon: uruapo puta 'ogete semu'etawa ukaripe (Ikatu umume'u) vamos fazer a casa tradicional no terreno onde a gente estuda; uruapo puta 'ogete $t$ uesag wehe warasu tywo, 'og $t$ unawa (Wajwera umume'u) vamos fazer a casa tradicional para os não índios poderem ver. • Eisag $\rightarrow$ 'og.

Relacionados ao LId estão os Operadores Fn, Gr e Rm; ao DPt, o Na; e ao EId, o Operador Ft. Como variação desse modelo, apresento a seguinte proposta:

\title{
FIGURA 226 - MODELO MODOEO3b
}

\begin{abstract}
ka'i $n$.III /ka'?i/ macaco-prego (na língua Suruí a palavra usada para designar 'macaco-prego' é também empregada para a forma genérica 'macaco'). Ajnon: ka'ia usemuaraj yware ywokomumepem (Tymykong umume'u); o macaco-prego brinca no galho da árvore e quebra os galhos.

manimea pykujtawa rog /mani'mea pikuj'tawa 'rog/ casa de farinha. Ajnon: aha puta manime roga pupe wewahema (Ikatu umume'u); eu vou chegando para dentro da casa de farinha. - Eisag $\rightarrow$ 'og.

'og n.III /'?og/ casa (a construção de uma casa é uma ação coletiva na comunidade Suruí, na qual participam homens, mulheres e crianças, cada um desempenhando papéis específicos). Ajnon: asehu tese saupir sene rehe 'og (Ikatu umume'u); eu vou chegando para dentro da casa de farinha; ti popytywo e apo 'og (Wajwera umume'u); eu ajudo a fazer a casa. - Eisag $\rightarrow$ manimea pykujtawa rog, 'ogete.

'ogete n.III / Poge'te/ casa tradicional (atualmente, esse tipo de casa não é mais construída para fins de habitação, apenas como forma de manter a tradição). Ajnon: uruapo puta 'ogete semu'etawa ukaripe (Ikatu umume'u); vamos fazer a casa tradicional no terreno onde a gente estuda; uruapo puta 'ogete t uesag wehe warasu tywo (Wajwera umume'u); vamos fazer a casa tradicional para os não índios poderem ver. - Eisag $\rightarrow$ 'og.
\end{abstract}

Nesse modelo de material bilíngue, o DPt é apresentado em uma palavra ou expressão que traduz o LId, o qual se associa a três Operadores, Fn, Gr e Rm, nessa proposta. 


\subsubsection{Modelo MODOEO4 com estrutura LPt: O $\{\mathrm{DId}(\mathrm{O})[\mathrm{EId}(\mathrm{O})]\}$}

Apesar de essa proposta ter o Português como língua do Lema, o que predomina no seu interior é o uso do Suruí, como Descritor e Exemplo. Apresento, abaixo, exemplo desse modelo:

\section{FIGURA 227 - MODELO MODOEO4a}

casa n.f. 'og. Uruhywykaj ywya urumumug
ywykwara rupi urumuku'om sura ykupyjta
urumusarukong uruupir urukwar; ti roga ti
kehaw, uruapo pinowa ku urusehe
urukehawamu urukupepyg urusehe; un ti
ma'epotawamu aapo rako iako tarukeke
taruke ti ma'etiru umuakym rapo amona n
usapy'u rapo tata (Ikatu umume'u).
Ajnon: asehu tese saupir sene rehe 'og; ti
popytywo e apo 'og (Ikatu umume'u); ti
rehe t aketehewehe ne wy wekow (Wajwera
umume'u). - Ver $\rightarrow$ casa de farinha, casa
tradicional.
casa de farinha n.f. manimea pykujtawa
rog. Pykujpykujtawa upin mani'og, ukytyg,
ukupepyg, umuhaw upykuj. Ajnon: aha
puta manime roga pupe wewahema (Ikatu
umume'u). - Ver $\rightarrow$ casa.

casa tradicional $n . f$. 'ogete. Uruapo ywya urumuseaupyta, uruupir pinowo ipyteripe ywa umuwyhog supatitawa; ipukuete muruwisaw erekehaw asehutese; upuga ruaw murerekotarete; upug ruaw hejkwehe $\mathrm{n}$ uhuwapyguwi namukuj hejkwehe upug (Muretama umume'u). Ajnon: uruapo puta 'ogete semu'etawa ukaripe (Ikatu umume'u) uruapo puta 'ogete $t$ uesag wehe warasu tywo, 'og $t$ unawa (Wajwera umume'u). - Ver $\rightarrow$ casa.

macaco-prego n.m. ka'i. Ka'i iwete okowa'e; upyhyg iwyw ka'ia so uputi'a warimu irahaj awpita so akakaw yware; ka'ia awiton iapina pisuna (Wajwera umume'u). Ajnon: ka'ia usemuaraj yware ywokomumepem (Tymykong umume'u).

Enquanto o LPt se associa a Operadores Gr e Rm, o DId e o EId se associam a um Operador do tipo Ft. Esse modelo é apresentado, a seguir, com DId reduzido a uma palavra ou expressão:

\section{FIGURA 228 - MODELO MODOEO4b}

cachorro n.m. ma'esawar/ma?csa'war/

Ajnon: unupo ma'esawara; ma'esawara puta usekyj mosa u'uramu (Ikatu umume'u); esemuhaku'i ke! ma'esawara rapo ne u'u cavar v.tr. hywykaj /kiwi'kaj/

Ajnon: ywykwara ahywykaj; ti se'eromamu puta ri'a ahywykaj

dar v.tr. mono /mo'no/

Ajnon: syryg puta amono ne irua pe; ko, amono ne upe; ajko na amonowi ne upe (Muretama umume'u)

farinha de mandioca manime /mani'ms/

Ajnon: manimea ko amumaraw wyra'yra rupi'a (Tymykong umume'u) homem n.m. akuma'e /akuma'? $\varepsilon$ /

Ajnon: akuma'e akuraete; ajko re wehe rako aesag akuma'e; moron puta pe akuma'e ihoj osuna?

morrer v.intr.sekyj /sc'kij/

Ajnon: akuma'e usekyi; ma'esawara puta usekyj mosa u'uramu

mulher n.f. kuso /ku'so/

Ajnon: kuso sysyng; ma'eramu pa'e kuso nu se'engara uwi? (Ikatu umume'u); ure kuso teseramu uruho ytyma mani'og roko urutym

redondo adj. 'apu'a /Papu'?a/

Ajnon: kuipia i'apu'a; tehahua i'apu'a (Waywera umume'u) 


\subsubsection{Modelo MODOEO5 com estrutura LPt: O $\{\mathrm{DId}(\mathrm{O})[\mathrm{EId} / \mathrm{EPt}(\mathrm{O})]\}$}

Essa quinta proposta é semelhante à anterior, com a diferença de acrescentar nela o componente EPt, conforme demonstra o próximo exemplo:

FIGURA 229 - MODELO MODOEO5a

\begin{abstract}
casa n.f. 'og. Uruhywykaj ywya urumumug ywykwara rupi urumuku'om sura ykupyjta urumusarukong uruupir urukwar; ti roga ti kehaw, uruapo pinowa $\mathrm{ku}$ urusehe urukehawamu urukupepyg urusehe; un ti ma'epotawamu aapo rako iako tarukeke taruke ti ma'etiru umuakym rapo amona $\mathrm{n}$ usapy'u rapo tata (Ikatu umume'u). Ajnon: asehu tese saupir sene rehe 'og eu vou chegando para dentro da casa de farinha; ti popytywo e apo 'og; ti rehe $\mathrm{t}$ aketehewehe ne wy wekow (Wajwera umume'u); eu ajudo a fazer a casa. - Ver $\rightarrow$ casa de farinha, casa tradicional.

casa de farinha $n . f$. manimea pykujtawa rog. Pykujpykujtawa upin mani'og, ukytyg, ukupepyg, umuhaw upykuj. Ajnon: aha puta manime roga pupe wewahema (Ikatu umume'u); eu vou chegando para dentro da casa de farinha. $\cdot$ Ver $\rightarrow$ casa.
\end{abstract}

casa tradicional n.f. 'ogete. Uruapo ywya urumuseaupyta, uruupir pinowo ipyteripe ywa umuwyhog supatitawa; ipukuete muruwisaw erekehaw asehutese; upuga ruaw murerekotarete; upug ruaw hejkwehe $n$ uhuwapyguwi namukuj hejkwehe upug (Muretama umume'u). Ajnon: uruapo puta 'ogete semu'etawa ukaripe (Wajwera umume'u) vamos fazer a casa tradicional no terreno onde a gente estuda; uruapo puta 'ogete $t$ uesag wehe warasu tywo, 'og $t$ unawa vamos fazer a casa tradicional para os não indios poderem ver. $\cdot \mathrm{Ver} \rightarrow$ casa.

macaco-prego n.m. ka'i. Ka'i iwete okowa'e; upyhyg iwyw ka'ia so uputi'a warimu irahaj awpita so akakaw yware; ka'ia awiton iapina pisuna (Wajwera umume'u). Ajnon: ka'ia usemuaraj yware ywokomumepem (Tymykong umume'u); o macaco-prego brinca no galho da árvore e quebra os galhos.

Nesse modelo, o LPt se associa a dois Operadores, enquanto o Descritor e o

Exemplo se associam a um mesmo tipo de Operador $(\mathrm{Ft})$. A variação desse modelo é apresentada abaixo:

\section{FIGURA 230 - MODELO MODOEO5b}

cavar v.tr. hywykaj /kiwi'kaj/

Ex. ywykwara ahywykaj eu cavo buraco na terra; ti se'eromamu puta ri'a ahywykaj eu vou cavar meu poço

dar v.tr. mono /mo'no/

Ex. syryg puta amono ne irua pe (Muretama umume'u) eu vou dar o machado para o teu irmão; ko, amono ne upe vou te dar isso; ajko na amonowi ne upe esse eu não dou isso para você

homem n.m. akuma'e /akuma'?e/

Ex. akuma'e akuraete homem gordo; ajko re wehe rako aesag akuma'e ontem eu vi este homem; moron puta pe akuma'e ihoj osuna? quantos homens vão correr? morrer v.intr. sekyj /s''kij/

Ex. akuma'e usekyi o homem morreu; ma'esawara puta usekyj mosa u'uramu o cachorro vai morrer, porque a cobra mordeu ele

mulher $n$.f. kuso /ku'so/

Ex. kuso sysyng mulher magra; ma'eramu pa'e kuso nu se'engara uwi? (Ikatu umume'u) por que as mulheres não estão cantando?; ure kuso teseramu uruho ytyma mani'og roko urutym nós fomos com as mulheres plantar mandioca

redondo adj. 'apu'a /Rapu'?a/

Ex. kuipia i'apu'a a cuia é redonda; tehahua i'apu'a o tucum é redondo

Nesse modelo, o LPt recebe o Operador Gr, o DId, o Operador Fn, e o EId, o Operador Ft. 


\subsubsection{Modelo MODOEO6 com estrutura LId: O $\{$ DId-DPt (O) $[$ EId/EPt (O)] $\}$}

Da mesma maneira que foi observado nos modelos MODOE e MODEO já apresentados, essa proposta é a mais completa possível para um material de natureza bilíngue, pois conta com Descritores e Exemplos nas duas línguas envolvidas, e também com Operadores para todos os componentes dessa microestrutura, como pode ser visto no exemplo a seguir:

\section{FIGURA 231 - MODELO MODOEO6}

ka'i $n$.III /ka'?i/ ka'i iwete okowa'e; upyhyg iwyw ka'ia so uputi'a warimu irahaj awpita so akakaw yware; ka'ia awiton iapina pisuna. Macaco-prego. Ele vive nas copas das árvores; ele desce para pegar ouriço da castanha e sobe com ele na árvore e começa a bater no pau até o ouriço rachar; ele é marrom com a cabeça preta (na língua Suruí a palavra usada para designar 'macaco-prego' é também empregada para a forma genérica 'macaco'). Ajnon: ka'ia usemuaraj yware ywokomumepem (Tymykong umume'u) o macaco-prego brinca no galho da árvore e quebra os galhos. - Eisag $\rightarrow$ akyky, y'a.

manimea pykujtawa rog /mani'mea pikuj'tawa 'юg/ pykujpykujtawa upin mani'og, ukytyg, ukupepyg, umuhaw upykuj. Casa de farinha. Na casa de fazer farinha, a gente rala, prensa e peneira a mandioca. Depois torra ela, mexendo no forno. Ajnon: aha puta manime roga pupe wewahema (Ikatu umume'u) eu vou chegando para dentro da casa de farinha. $\cdot$ Eisag $\rightarrow$ 'og.

'og $n$.III /'Pog/ uruhywykaj ywya urumumug ywykwara rupi urumuku'om sura ykupyjta urumusarukong uruupir urukwar; ti roga ti kehaw, uruapo pinowa ku urusehe urukehawamu urukupepyg urusehe; un ti ma'epotawamu aapo rako iako tarukeke taruke ti ma'etiru umuakym rapo amona n usapy'u rapo tata. Casa. Nós cavamos o chão para enfiar a forquilha da casa; nós levantamos o esteio e encaibramos; nós arribamos e amarramos a casa. Depois colocamos todas as coisas pra dentro pra não molhar. Todos ajudam na construção da casa (a construção de uma casa é uma ação coletiva na comunidade Suruí, na qual participam homens, mulheres e crianças, cada um desempenhando papéis específicos). Ajnon: asehu tese saupir sene rehe 'og (Wajwera umume'u) nós todos juntos vamos construir a casa; ti popytywo e apo 'og eu ajudo a fazer a casa. - Eisag $\rightarrow$ manimea pykujtawa rog, 'ogete.

'ogete n.III /Poge'te/ uruapo ywya urumuseaupyta, uruupir pinowo ipyteripe ywa umuwyhog supatitawa; ipukuete muruwisaw erekehaw asehutese; upuga ruaw murerekotarete; upug ruaw hejkwehe n uhuwapyguwi namukuj hejkwehe upug. Casa tradicional. Para fazer a casa tradicional, cavamos a terra e enfiamos os paus de amarrar rede nos buracos. Depois cobrimos a casa tradicional com a palha do babaçu. Nessa casa, todos nós dormimos nela, mas é o chefe quem dorme perto da porta. Essa casa só tem uma porta para entrar. Antigamente, essa porta não ficava fechada (atualmente, esse tipo de casa não é mais construída para fins de habitação, apenas como forma de manter a tradição). Ajnon: uruapo puta 'ogete semu'etawa ukaripe (Wajwera umume'u) vamos fazer a casa tradicional no terreno onde a gente estuda; uruapo puta 'ogete $t$ uesag wehe warasu tywo, 'og t unawa; vamos fazer a casa tradicional para os não índios poderem ver. - Eisag $\rightarrow$ 'og. 
Os Operadores Fn, Gr e Rm se associam ao LId, já o Operador Na, se associa ao

DPt, e o Operador Ft, ao EId. A fim de destacar as informações no interior da microestrutura, destaquei o DPt e EPt com efeito itálico.

\subsubsection{Modelo MODOEO7 com estrutura LPt: O \{DPt-DId (O) [EPt/EId (O)]\}}

Mudando a posição das línguas da EML anterior, chega-se à proposta atual, como pode ser observado na próxima figura:

\section{FIGURA 232 - MODELO MODOEO7}

Casa. $n . f$. Nós cavamos o chão para enfiar a forquilha da casa; nós levantamos o esteio e encaibramos; nós arribamos e amarramos a casa. Depois colocamos todas as coisas pra dentro pra não molhar. Todos ajudam na construção da casa (a construção de uma casa é uma ação coletiva na comunidade Suruí, na qual participam homens, mulheres e crianças, cada um desempenhando papéis específicos). 'og. Uruhywykaj ywya urumumug ywykwara rupi urumuku'om sura ykupyjta urumusarufong uruupir urukwar; ti roga ti kehaw, uruapo pinowa ku urusehe urukehawamu urukupepyg urusehe; un ti ma'epotawamu aapo rako iako tarukeke taruke ti ma'etiru umuakym rapo amona $n$ usapy'u rapo tata. Ex.: nós todos juntos vamos construir a casa asehu tese saupir sene rehe 'og (Wajwera umume'u); eu ajudo a fazer a casa $t i$ popytywo e apo 'og. - Ver $\rightarrow$ casa de farinha, casa tradicional.

Casa de farinha. n.f. Na casa de fazer farinha, a gente rala, prensa e peneira a mandioca. Depois torra ela, mexendo no forno. Manimea pykujtawa rog. Pykujpykujtawa upin mani'og, ukytyg, ukupepyg, umuhaw upykuj. Ex.: eu vou chegando para dentro da casa de farinha aha puta manime roga pupe wewahema (Ikatu umume'u). - Ver $\rightarrow$ casa.

Casa tradicional. n.f. Para fazer a casa tradicional, cavamos a terra e enfiamos os paus de amarrar rede nos buracos. Depois cobrimos a casa tradicional com a palha do babaçu. Nessa casa, todos nós dormimos nela, mas é o chefe quem dorme perto da porta. Essa casa só tem uma porta para entrar. Antigamente, essa porta não ficava fechada (atualmente, esse tipo de casa não é mais construída para fins de habitação, apenas como forma de manter a tradição). 'ogete. Uruapo ywya urumuseaupyta, uruupir pinowo ipyteripe ywa umuwyhog supatitawa; ipukuete muruwisaw erekehaw asehutese; upuga ruaw murerekotarete; upug ruaw hejkwehe n uhuwapyguwi namukuj hejkwehe upug. Ex.: vamos fazer a casa tradicional no terreno onde a gente estuda uruapo puta 'ogete semu'etawa ukaripe (Wajwera umume'u); vamos fazer a casa tradicional para os não índios poderem ver uruapo puta 'ogete $t$ uesag wehe warasu tywo, 'og $t$ unawa. $\cdot \mathrm{Ver} \rightarrow$ casa.

Macaco-prego. n.m. Ele vive nas copas das árvores; ele desce para pegar ouriço da castanha e sobe com ele na árvore e começa a bater no pau até o ouriço rachar; ele é marrom com a cabeça preta (na língua Suruí a palavra usada para designar 'macaco-prego' é também empregada para a forma genérica 'macaco'). Ka'i. Ka'i iwete okowa'e; upyhyg iwyw ka'ia so uputi'a warimu irahaj awpita so akakaw yware; ka'ia awiton iapina pisuna (Wajwera umume'u). Ex.: o macaco-prego brinca no galho da árvore e quebra os galhos ka'ia usemuaraj yware ywokomumepem (Tymykong umume'u).

Nesse modelo, com exceção do Operador Fn, todos os demais presentes na proposta anterior foram mantidos. Já o destaque com efeito itálico foi aplicado aos componentes na língua Suruí. 


\subsubsection{Modelo MODOEO8 com estrutura LId: O \{DId-DPt-D... (O) [EId/EPt/E... $(\mathrm{O})]\}$}

Dentre todos os modelos deste trabalho, essa oitava proposta é a maior delas, contando com, pelo menos, três Descritores (incluindo o DId) e três Exemplos, em línguas diferentes, todos relacionados a Operador(es), conforme exemplo abaixo:

\section{FIGURA 233 - MODELO MODOEO8}

ka'i $n . I I I / \mathrm{ka}$ '?i/ ka'i iwete okowa'e; upyhyg iwyw ka'ia so uputi'a warimu irahaj awpita so akakaw yware; ka'ia awiton iapina pisuna. Macaco-prego. Ele vive nas copas das árvores; ele desce para pegar ouriço da castanha e sobe com ele na árvore e começa a bater no pau até o ouriço rachar; ele é marrom com a cabeça preta (na língua Suruí a palavra usada para designar 'macaco-prego' é também empregada para a forma genérica 'macaco'). Capuchin monkey. He lives on the top of the trees; he goes to pick up hedgehog chestnutnut and climbs the tree with him; then, he starts beating the Hedgehog until it cracks; He is brown with a black head. Cebus apella. Ajnon: ka'ia usemuaraj yware ywokomumepem (Tymykong umume'u) o macaco-prego brinca no galho da árvore e quebra os galhos the capuchin monkey romps in the branch of the tree and the branches breaks.

manimea pykujtawa rog /mani'mea pikuj'tawa 'rog/ pykujpykujtawa upin mani'og, ukytyg, ukupepyg, umuhaw upykuj. Casa de farinha. $\mathrm{Na}$ casa de fazer farinha, a gente rala, prensa $e$ peneira a mandioca. Depois torra ela, mexendo no forno. Flour's house. In the flour's house, the people grate, press and sieve cassava. After roasting it, they stir it on the oven. Ajnon: aha puta manime roga pupe wewahema (Ikatu umume'u) eu vou chegando para dentro da casa de farinha I came into the house of flour. - Eisag $\rightarrow$ 'og.

'og n.III /'Pog/ uruhywykaj ywya urumumug ywykwara rupi urumuku'om sura ykupyjta urumusaru-kong uruupir urukwar; ti roga ti kehaw, uruapo pinowa $\mathrm{ku}$ urusehe urukehawamu urukupepyg urusehe; un ti ma'epotawamu aapo rako iako tarukeke taruke ti ma'etiru umuakym rapo amona $\mathrm{n}$ usapy'u rapo tata. Casa. Nós cavamos o chão para enfiar a forquilha da casa; nós levantamos o esteio e encaibramos; nós arribamos e amarramos a casa. Depois colocamos todas as coisas pra dentro pra não molhar. Todos ajudam na construção da casa (a construção de uma casa é uma ação coletiva na comunidade Suruí, na qual participam homens, mulheres e crianças, cada um desempenhando papéis específicos). House. We dug the sticks into the ground of the futures house, then we raise its mainstay and put the rafter. Then we put our goods inside the house for them to not get wet. Everyone helps the building of the house. Ajnon: asehu tese saupir sene rehe 'og (Wajwera umume'u) nós todos juntos vamos construir a casa all together we will build the house; ti popytywo e apo 'og eu ajudo a fazer a casa I help the building of the house. - Eisag $\rightarrow$ manimea pykujtawa rog, 'ogete.

'ogete n.III /Poge'te/ uruapo ywya urumuseaupyta, uruupir pinowo ipyteripe ywa umuwyhog supatitawa; ipukuete muruwisaw erekehaw asehutese; upuga ruaw murerekotarete; upug ruaw hejkwehe $n$ uhuwapyguwi namukuj hejkwehe upug. Casa tradicional. Para fazer a casa tradicional, cavamos a terra e enfiamos os paus de amarrar rede nos buracos. Depois cobrimos a casa tradicional com a palha do babaçu. Nessa casa, todos nós dormimos nela, mas é o chefe quem dorme perto da porta. Essa casa só tem uma porta para entrar. Antigamente, essa porta não ficava fechada (atualmente, esse tipo de casa não é mais construída para fins de habitação, apenas como forma de manter a tradição). Traditional house. To make a traditional house, we dug the earth and we stuck the sticks into the holes, tying them to support the rafter. After we have covered the traditional house with thatched babassu we are able to sleep in it, but it is the chief who sleeps near the door. This house has only one door. Formerly, it door was not closed. Ajnon: uruapo puta 'ogete semu'etawa ukaripe (Wajwera umume'u) vamos fazer a casa tradicional no terreno onde a gente estuda let's make a traditional house in the land where you study; uruapo puta 'ogete t uesag wehe warasu tywo, 'og t unawa; vamos fazer a casa tradicional para os não índios poderem ver let's do the traditional house for the non Indians to see it. - Eisag $\rightarrow$ 'og. 
Nesse modelo, os Operadores Fn, Gr e Rm se relacionam com o LId; o Operador $\mathrm{Na}$, com o DPt; e o Operador Ft, com o EId. Com a possibilidade de inserir outros tipos de Operadores, essa proposta é bastante completa para ser usada na construção de um material multilíngue.

\title{
9.1.14.9. Modelo MODOEO9 com estrutura LId: O \{DPt-D... (O) [EId/EPt/E... (O)]\}
}

Reproduzindo a proposta MODOEO8, esse modelo apenas exclui de sua estrutura o DId e apresenta os demais Descritores na forma de palavra ou expressão que traduz o LId. A figura a seguir exemplifica esse modelo:

\section{FIGURA 234 - MODELO MODOEO9}

\begin{abstract}
ka'i $n . I I I / k a ' P i /$ Macaco-prego (mico-de-topete). Capuchin monkey. Cebus apella. Ajnon: ka'ia usemuaraj yware ywokomumepem (Tymykong umume'u) o macaco-prego brinca no galho da árvore e quebra os galhos the capuchin monkey romps in the branch of the tree and the branches breaks.

manimea pykujtawa rog /mani'mea pikuj'tawa 'rog/ Casa de farinha (farinha de mandioca). Flour's house. Ajnon: aha puta manime roga pupe wewahema (Ikatu umume'u) eu vou chegando para dentro da casa de farinha I came into the house of flour. - Eisag $\rightarrow$ 'og.

'og n.III /'?og/ Casa. House. Ajnon: asehu tese saupir sene rehe 'og (Ikatu umume'u) nós todos juntos vamos construir a casa all together we will build the house; ti popytywo e apo 'og eu ajudo a fazer a casa I help the building of the house. - Eisag $\rightarrow$ manimea pykujtawa rog, 'ogete.

'ogete n.III / Poge'te/ Casa tradicional (casa verdadeira). Traditional house. Ajnon: uruapo puta 'ogete semu'etawa ukaripe (Ikatu umume'u) vamos fazer a casa tradicional no terreno onde a gente estuda let's make a traditional house in the land where you study. - Eisag $\rightarrow$ 'og.
\end{abstract}

\subsubsection{Algumas considerações sobre esses modelos}

Neste capítulo busquei apresentar sistematicamente as formas básicas de modelos que podem ser usados para a produção de materiais lexicográficos para a língua indígena Suruí e, com as devidas adaptações, para outras línguas indígenas brasileiras.

Certamente o arranjo dos componentes pode assumir configurações bem particulares, dependendo do PDL, dos dados coletados e disponíveis, das finalidades do material e, por fim, do próprio projeto gráfico desenvolvido.

Além da tipologia já adotada para as EML's nesta tese, não era minha intenção associar essa nomenclatura aos diversos tipos de obras lexicográficas já existentes (p.ex., dicionário, glossário, lista de palavras, vocabulário, índice), ainda mais porque diferentes obras podem apresentar estruturas mais ou menos semelhantes. 
Com relação aos diferentes exemplos apresentados ao longo deste capítulo, a função deles é muito mais ilustrativa das possibilidades de cada modelo do que normativa, pois não é objetivo deste trabalho propor padrões fechados e definitivos para nenhum material lexicográfico. Por isso, é fundamental esclarecer que, mesmo no caso da língua Suruí, os exemplos servem como formas de orientação para construção de propostas, que devem surgir e se desenvolver sempre em colaboração com os próprios usuários da língua, orientando, assim, a produção desses materiais.

Por fim, há de se esclarecer que essa sistematização de tipos de EML's é fundamental também para a construção de modelos a serem usados no programa Línguas, pois, ao prever a maior quantidade possível de arranjos, pode-se programar o banco de dados para gerar esses diferentes tipos de materiais, o que amplia sobremaneira as opções de escolha dos usuários do programa de computador. 


\section{DICIONÁRIO DA LÍNGUA SURUÍ}

Concluídas a modelagem e a construção do programa Línguas, e a proposição dos modelos lexicográficos baseados em uma língua indígena, passo a tratar neste capítulo da construção da proposta para um dicionário da língua Suruí.

A construção desse dicionário, mais do que uma finalidade acadêmica, busca atender a uma necessidade que o povo Suruí tem, na atualidade, de materiais escritos para o ensino de sua língua na escola Aikewára, por isso, além do valor acadêmico-científico desse trabalho, construído em colaboração com falantes da língua Suruí, principalmente os professores Ikatu e Tymykong, há, sem dúvida, uma motivação sociocultural e educacional.

Assim, baseada no material linguístico da língua Suruí coletado ao longo da pesquisa realizada para esta tese, e armazenada nas diferentes bases de dados do programa Línguas, essa proposta de dicionário parte de uma reflexão sobre diferentes aspectos linguísticos, que vão desde elementos fonético-fonológicos, até considerações acerca da morfossintaxe, da ortografia e do léxico dessa língua da família linguística Tupí-Guaraní.

É importante destacar que, à medida que os dados linguísticos iam sendo coletados, analisados e inseridos nas bases do programa Línguas, surgiam novas demandas que exigiam ajustes no programa, e alguns destes ajustes bem significativos, a fim de que houvesse o tratamento adequado para todo o conjunto dos dados, atualmente armazenados no programa Línguas e que constituem a base para a construção das diferentes propostas de obras lexicográficas para o Suruí, mas também para uma série de outros materiais sobre a língua.

Ademais, toda a modelagem do programa Línguas e dos modelos lexicográficos nele contidos buscou atender, em alguma medida, a demandas maiores do que somente as oriundas da língua Suruí, pois, acredito poder expandir os limites de uso do programa para chegar a um resultado que permita seu uso também por pesquisadores, indígenas e não indígenas, de outras línguas indígenas brasileiras.

Logo, o desafio foi o de apresentar e selecionar modelos de materiais lexicográficos que correspondessem, antes, aos tipos mais comuns das obras lexicográficas usadas no Brasil (cf. capítulo 9), ao mesmo tempo em que deveria permitir outras modelagens planejadas por um PDL.

No entanto, como o foco deste capítulo é a apresentação do que proponho como primeiro dicionário da língua Suruí, passo a algumas considerações acerca da construção dessa proposta específica, passando pela discussão acerca dos tipos de dicionário, retomando 
algumas observações já feitas no capítulo 7, em que fiz o levantamento dos materiais lexicográficos das línguas indígenas brasileiras, em seguida trato das questões mais relacionadas à configuração dessa proposta e, ao final, deste capítulo apresento o resultado desta construção.

\subsection{CONSIDERAÇÕES SOBRE A TIPOLOGIA DOS DICIONÁRIOS}

Já datam de, pelo menos, meio milênio, as discussões acerca da tipologia de obras lexicográficas (cf. BRANDON, 1904, p. 28-29), e nesse sentido uma das primeiras distinções que se buscou estabelecer foi a dos limites entre enciclopédias e dicionários (cf. AL-KASIMI, 1983, p. 29).

Apesar de existirem obras lexicográficas desde a Antiguidade Clássica, no Ocidente (cf. SNELL-HORNBY, 1986, p. 212), e também em vários países do Oriente, a exemplo da China e do Japão, é somente na baixa Idade Média, na Europa, que surgem as formas mais próximas do que hoje são denominados, por exemplo, vocabulário e dicionário. $^{177}$

No final desse período em que os resultados da invenção de Gutenberg começavam a se multiplicar, algumas obras lexicográficas tiveram um destaque especial. Dentre elas, cito o Catholicon ou Summa quae vocatur Catholicon, de Giovanni Balbi, publicado pela primeira vez no século XV (mas que existia como manuscrito já no século XIII), o Dictionum latinarum e greco... (1512), o Lexicon (1526) e o Dictionarium (1573), de Calepino, Ambrogio, e o Dictionarivm Latinogallicum... (1561), de Robert Estienne. ${ }^{178}$

Esses materiais que surgem no limiar da era Moderna já apresentam as características essenciais dos atuais dicionários, por exemplo, a obra de Estienne (1561) possui macroestrutura organizada alfabeticamente, com lemas, geralmente em latim, seguido das respectivas traduções para uma língua moderna, neste caso o francês, um sistema de remissivas, um sistema de abreviaturas, exemplos, fontes dos exemplos, efeitos tipográficos para distinguir partes do verbete e registro de variantes.

Esses primeiros materiais a serem denominados especificamente dicionários surgem, ainda, em um contexto onde a tradução entre línguas, principalmente do latim ou do

\footnotetext{
177 Apesar de vocabulários e dicionários, nesse contexto, serem materiais relativamente comuns a partir do século XIII, até meados do século XV eles existiam em geral apenas sob a forma manuscrita. Somente com o advento da imprensa de tipos móveis é que muitas dessas obras ganharam uma forma impressa e puderam, de fato, se estabelecer como materiais disponíveis para tradutores, professores e estudantes.

${ }^{178}$ Acerca das obras desse autor, cf. Brandon (1904).
} 
grego para as línguas indo-europeias modernas, passou a ter uma demanda cada vez maior. De certo modo, esse desenvolvimento dos dicionários bilíngues impulsionaria o surgimento de outro grupo de dicionários, os monolíngues, e, já no século XVII, aparecem as primeiras publicações de obras baseadas nas principais línguas nacionais europeias (cf. LARA, 1997, p. 34-39).

De certo modo, esse mesmo percurso pode ser atestado na história dos dicionários, ou melhor, das obras lexicográficas, das línguas indígenas no Brasil. Partindo-se de uma necessidade de compreensão dessas diferentes línguas, ${ }^{179}$ são produzidos, em um primeiro momento, materiais bilíngues ou multilíngues, para, só muito tempo depois, se chegar a obras lexicográficas monolíngues. ${ }^{180}$

Logo, a fim de iniciar e sistematizar uma breve apresentação acerca dos tipos e elementos dos dicionários, aproveito, neste trabalho, a tipologia proposta por Al-Kasimi (1983, p. 20-21) para caracterização de dicionários bilíngues, mas buscando, na medida do possível, expandi-la às obras lexicográficas que considerem as diferentes realidades das línguas indígenas brasileiras.

Segundo esse autor, três critérios devem ser considerados no estabelecimento dessa tipologia: a fonte, o escopo e a o propósito, manifestados nos seguintes pares:

(1) Dictionaries for the speakers of the source language vs. dictionaries for the speakers of the target language. (2) Dictionaries of the literary language vs. dictionaries of the spoken language. (3) Dictionaries for production vs. dictionaries for comprehension. (4) Dictionaries for human users vs. dictionaries for machine translation. (5) Historical dictionaries vs. descriptive dictionaries. (6) Lexical dictionaries vs. encyclopedic dictionaries. (7) General dictionaries vs. special dictionaries. (AL-KASIMI, 1983, p. 20). ${ }^{181}$

A primeira característica destacada nessa lista se refere ao público para o qual é destinada a obra lexicográfica, se para os falantes da língua-fonte ou para os da língua-alvo.

\footnotetext{
${ }^{179}$ Em nenhum momento afirmo que esse percurso seja exclusivo do contexto brasileiro, pois, ele também pode ser observado em diferentes partes do mundo e em diferentes épocas; mas sim que, neste caso, trato especificamente de realidade em nosso país.

${ }^{180}$ Até este ponto de minha pesquisa, não identifiquei ainda nenhum dicionário monolíngue publicado de uma língua indígena brasileira, apenas listas de palavras. No entanto, há um projeto de pesquisa que objetiva a publicação de uma obra lexicográfica monolíngue, trata-se do projeto Elaboração de um dicionário monolíngue Sateré-Mawé, coordenado pela professora e pesquisadora Dulce Franceschini, da Universidade Federal de Uberlândia (cf. SILVA; FRANCESCHINI; CARNEIRO, 2009, p. 3). Além deste projeto, iniciei com os professores Ikatu e Tymykong Suruí a construção de um dicionário monolíngue Aikewara, a ser desenvolvido nos próximos anos.

181 Tradução: “(1) Dicionários para falantes da língua-fonte vs. dicionários para falantes da língua-alvo. (2) Dicionários da linguagem literária vs. dicionários da língua falada. (3) Dicionários para produção versus dicionários para compreensão. (4) Dicionários para usuários humanos vs. dicionários para tradução mecânica (ou automática). (5) Dicionários históricos vs. dicionários descritivos. (6) Dicionários lexicais vs. dicionários enciclopédicos. (7) Dicionários gerais vs. dicionários especiais.” (Tradução nossa).
} 
Toda obra lexicográfica, antes mesmo de sua construção efetiva, já tem definido, implícita ou explicitamente, um público-alvo. ${ }^{182}$ No caso das línguas indígenas brasileiras, apesar de existirem obras que busquem atender às necessidades dos falantes das respectivas línguas, na maior parte das vezes essas obras são produzidas para especialistas, linguistas e antropólogos, por exemplo, ou para não falantes dessas línguas. ${ }^{183}$

Por isso, o próprio processo de produção de um determinado material lexicográfico de uma língua indígena brasileira já deve contar com a participação efetiva dos seus falantes, não como meros informantes, mas como principais colaboradores, ou seja, como tomadores de decisões sobre, por exemplo, que conteúdos, componentes e estruturas devem fazer parte da(s) obra(s) em construção.

Em termos práticos, essas decisões dizem respeito, por exemplo, à forma de apresentação dos lemas, o que pode facilitar ou não para o falante da língua indígena e usuário do material lexicográfico o seu acesso à informação. No caso dos dicionários de línguas da família Tupí-Guaraní, o lexicógrafo ${ }^{184}$ deve decidir se apresenta ou não a forma flexionada à esquerda de vários nomes, como os que se referem a partes do corpo, e, caso não as apresente, decidir se marca (com um hífen, p. ex.), aquelas palavras que recebem obrigatoriamente essa flexão.

Para comunidades que começam a perder a sua língua, como os Suruí do Tocantins e os Asuriní do Trocará, essa informação pode, em alguma medida, ser útil para o conhecimento dessa língua. ${ }^{185}$ Por outro lado, apresentar os lemas pela raiz pode criar um grande estranhamento para os usuários, pois essas formas não existem isoladas na língua.

Outra questão a ser considerada e que depende diretamente do público a que se destina a obra lexicográfica, diz respeito ao emprego de alguns operadores da microestrutura (cf. subseção 7.2.1.4.2), como a apresentação da transcrição fonética ou da forma fonológica, de informações etimológicas ou de notas com detalhamento de aspectos gramaticais. Em

\footnotetext{
${ }^{182}$ Há de se considerar ainda a situação de a obra ser construída para determinado público, mas, na realidade, não servir para esse público, mas sim para um público diferente.

183 Essa realidade começou a mudar significativamente no momento em que os próprios povos indígenas começaram a se manifestar, seja por ações individuais seja por meio das diversas associações e grupos criados para representá-los, lutando pela valorização de sua(s) língua(s) e pelo direito de ter materiais linguísticos próprios para seu uso nos mais diferentes contextos, como o escolar.

184 Apesar de usar a forma singular 'lexicógrafo', refiro-me, na verdade, ao conjunto de pessoas envolvidas na construção do projeto lexicográfico.

${ }^{185}$ A fim de exemplificar essa distinção, indico quatro dicionários de línguas da família Tupí-Guaraní, dois deles optaram pelo uso da raiz com hífen no lema para marcar a presença de relacional, por exemplo, nas palavras cabeça, olho e perna, são os trabalhos de Cabral e Rodrigues (2003) e Caldas (2009); mas há trabalhos que optaram pelo oposto, ou seja, não fizeram uso do hífen, como os trabalhos de Boudin (1966) e Harrison e Harrison (2013).
} 
ambos os casos, os futuros usuários da obra devem decidir se essas informações são relevantes ou não para o material a ser produzido. ${ }^{186}$

A título de exemplo, cito, a seguir, alguns trechos de apresentações de dicionários com essas diferentes situações:

\section{Material produzido somente para não indígenas.}

Apesar do exotismo aparencial do estudo em foco, êle se justifica por duas razões principais, entre outras: a) razões históricas, que, culturalmente, nos obrigam a deixar para as gerações futuras, um precioso material de estudo, cujo levantamento tornar-se-á impossível daqui a poucos anos, devido ao desaparecimento progressivo do elemento indígena no Brasil ou a sua aculturação. b) razões antropológicas, que nos levam a citar [...] Sapir, que justifica dêste modo tal tipo de estudo. "A língua está se tornando um guia cada vez mais valioso no estudo científico de uma cultura. [...]" (BOUDIN, 1966, p. 7).

Nesta apresentação, o autor do dicionário manifesta claramente a quem se destina a obra: um público não indígena e que tem interesse científico. Por isso, a obra apresenta, além dos elementos etimológicos e comparativos com outras línguas, a segmentação morfológica dos lemas, notas sobre gramática da língua e detalhamento das explicações na língua portuguesa. ${ }^{187}$

\section{Material produzido para indígenas e não indígenas}

Este dicionário quer ajudar a quem está aprendendo a conviver com a língua indígena Wapichana na sua comunidade. De geração em geração, com surgimento de novas tecnologias nas comunidades indígenas, muitos vêm parando de usar e esquecendo palavras da língua Wapichana. Este dicionário poderá contribuir para melhorar o ensino da língua Wapichana nas escolas indígenas e pelos falantes da língua. Os Wapichana não falantes e outros povos que queiram aprender a falar a língua Wapichana também serão beneficiados com esta obra. (OLIVEIRA, 2013, texto da orelha do livro).

Esse dicionário, segundo a apresentação nele contida, preparado para ambos os públicos, contém uma estrutura do tipo LId: $\{\mathrm{DPt}$ (EId-EPt) $\}$, sem nenhum operador, que, se comparada à do dicionário de Boudin (LId: Et, Ft, Na, Sm, Vr \{DPt (Vr) [EId/EPt]\}, parece ser bem mais simples. Isso não quer dizer, no entanto, que este último seja melhor ou pior do que aquele, mas sim que quem os elaborou tinha projetos com objetivos bem distintos e talvez focados em diferentes públicos.

\footnotetext{
${ }^{186}$ A fim de esclarecer sobre cada um dos componentes da estrutura de uma obra lexicográfica, ou mesmo da diferentes maneiras de organizar o material linguístico, acredito que seja fundamental a colaboração do linguistapesquisador como assessor das comunidades indígenas ao longo de todo o processo.

${ }_{187}$ Apesar de uma comunidade indígena poder optar pela inserção de componentes no material lexicográfico como os citados nesse parágrafo, em geral eles buscam, antes, atender às demandas de um público composto por linguistas, que, em sua quase totalidade, são não indígenas.
} 
Ao modelar um banco de dados eletrônico, como é o caso do programa Línguas, essa questão relacionada ao público-alvo teve de ser levada em consideração, a fim de selecionar o máximo de informações relevantes para cada público. Assim, há nas bases variados campos para inserção de um grande número de dados a serem selecionados conforme as necessidades do material a ser produzido. E mesmo que uma informação, por exemplo, sobre a terminologia científica de plantas e animais não seja utilizada em determinado projeto, ela poderá estar disponível no interior do banco de dados. Logo, a configuração de determinada obra lexicográfica fica a cargo das escolhas feitas pelo PDL em desenvolvimento, bastando, para isso, selecionar e alimentar as bases com as informações necessárias.

Com relação ao segundo item da tipologia acima citada, ela ainda não parece relevante para estabelecer uma distinção entre as obras lexicográficas das línguas indígenas brasileiras, uma vez que, a quase totalidade de suas respectivas comunidades, ainda não desenvolveu o que pode ser denominado tradição literária escrita ${ }^{188}$, pois o que predomina é o dicionário de língua falada, para o qual os dados são resultado de transcrição de registros sonoros feitos junto aos falantes nas mais diferentes situações de uso de sua(s) língua(s).

O terceiro item da tipologia, estritamente relacionado com o primeiro, requer uma distinção para ser bem compreendido no contexto brasileiro: se o público-alvo da obra lexicográfica for composto por pessoas alienígenas à comunidade de fala da língua indígena, o interesse sobre o estudo dessa língua levará à construção de dicionários para compreensão e, só muito raramente, há interesse, de fato, pela construção de um dicionário que leve o seu usuário a produzir (na fala ou na escrita) na respectiva língua. Por outro lado, se o públicoalvo for composto por pessoas indígenas à comunidade, o interesse pode envolver tanto uma quanto a outra perspectiva.

Acredito que esta divisão entre compreensão e produção linguística, por mais que possa colaborar para o estabelecimento de uma tipologia de materiais lexicográficos, tende a existir simultaneamente no que diz respeito nas dinâmicas de ensino e aprendizagem de línguas, pois a compreensão é manifestada na produção e só há produção se existe compreensão.

\footnotetext{
${ }^{188}$ No entanto, uma mudança começará a ser notada no momento em que os dicionários começarem a selecionar enunciados de obras escritas consideradas dentro de um determinado padrão. Nesse ponto, o processo de planificação linguística se mostra irreversível e, tal como ocorre com os grupos das línguas mais usadas no mundo, como o Chinês, o Inglês, o Alemão, o Espanhol e o Português, o que é produzido na escrita por um determinado grupo de pessoas passa a ter um valor normativo muito grande e um poder de definir o que é 'certo' ou não nos usos da língua.
} 
Ademais, é bastante frequente, no conjunto das UBL's das línguas indígenas brasileiras, que as obras lexicográficas não sejam construídas com base na distinção entre produção e compreensão, apresentando o material produzido como capaz não só de atender a essas duas finalidades, simultaneamente, mas também de atender aos mais diferentes públicos. $^{189}$

Dois fragmentos de textos, extraídos de dois dicionários publicados na primeira década do século XXI, ilustram essa perspectiva. O primeiro é o dicionário de Cabral e Rodrigues (2003):

Este dicionário tem por fim dar um conhecimento bastante amplo do léxico e da fraseologia da língua Asuriní do Tocantins tanto para os falantes do Português que não a conhecem, como para os índios cujos pais falam ou falavam a língua indígena. [...] o dicionário [...] Como peça dos projetos de educação, deve satisfazer [...] as seguintes necessidades: 1. para a língua indígena falada: (a) ampliar o conhecimento do vocabulário por aquelas crianças que, onde moram, ouvem mais o Português que a língua de seus pais e avós; [...] 3. para a língua indígena escrita: [...] (d) ajudar os indígenas que têm deficiência no uso da língua nativa a suprir os elementos lexicais que esqueceram ou que lhes faltam. (p. v-vi, grifo nosso).

E o segundo, é o dicionário de Kroeker (1996):

O propósito deste dicionário é o de ajudar a quem está estudando a língua Nambikuara ou a quem está num ambiente onde a língua Nambikuara seja falada. Também serve para ajudar a comunidade indígena a entender as palavras equivalentes na língua portuguesa. Não presume ser completo mas sim, abranger a maioria das palavras necessárias para ajudá-los a compreender e comunicarem-se melhor na língua portuguesa. (p. 2, grifos nossos).

Neste último dicionário, segundo o autor, a língua-alvo muda conforme a perspectiva do público, para os não indígenas, o interesse seria pela compreensão da língua portuguesa, ao passo que, para os falantes de Português, o interesse seria pela língua indígena. Em qualquer um dos casos, esse dicionário serviria tanto para a compreensão quanto para a comunicação das línguas envolvidas.

Apesar de já existirem muitos dicionários que privilegiam especificamente ou a compreensão ou a produção no contexto das línguas mais faladas no mundo, tais como o Inglês, o Francês, o Espanhol e o Português, no contexto das línguas indígenas brasileiras essa distinção ainda não produziu resultados notáveis.

\footnotetext{
${ }^{189}$ Essa constatação não é, de modo algum, uma crítica a esses materiais lexicográficos, nem a seus respectivos autores, mas sim uma questão teórico-prática que deve ser objeto de permanente reflexão por parte daqueles que se lançarem à árdua tarefa de construir, por exemplo, dicionário(s) de línguas indígenas brasileiras.
} 
Portanto, orientar uma obra lexicográfica para um ou outro fim é, neste momento, mais uma decisão do PDL do que propriamente do banco de dados eletrônico, como o programa Línguas, pois este é capaz de armazenar conteúdos para produzir materiais tanto na perspectiva de produção quanto na de compreensão.

Outra distinção na tipologia proposta por Al-Kasimi (1983), orientada para obras lexicográficas bilíngues, também se relaciona com a finalidade da obra produzida: se para usuários humanos ou se para uso em máquinas especificamente para tradução. ${ }^{190}$

Essa perspectiva está relacionada ao rápido desenvolvimento e popularização das novas tecnologias de comunicação e informação, como os computadores pessoais e a internet, permitiu, em um espaço de 30 anos, transformar um contexto que antes era exclusivo a técnicos altamente especializados do domínio da informática. Com isso, os registros informatizados, sobretudo os linguísticos, deixaram de existir apenas em grandes computadores de universidades e passaram a integrar o cotidiano de professores, pesquisadores e usuários comuns que podiam usar ferramentas como dicionários eletrônicos, off-line ou on-line, memórias de tradução, ferramentas de tradução de sites e motores de busca para finalidades do seu dia a dia.

Todavia, a organização dessas informações, se para uso humano ou se para uso mecânico (na programação de máquinas ou na tradução automática também feita por máquinas), permaneceu distinto. Assim, o resultado da organização de um dicionário eletrônico só faz sentido para o usuário final porque, entre os dados inseridos no banco de dados e a sua consulta, foram criados mecanismos e interfaces que permitiram aos humanos terem acesso a essas informações, caso contrário, de pouco adiantaria.

Há de se considerar ainda que, para uma pesquisa que envolva línguas faladas por minorias de um determinado território, como no caso da realidade brasileira, o resultado de qualquer esforço nesse sentido, mesmo que culmine com o uso desse material para processamento eletrônico, ele deve considerar sempre a perspectiva de uso das pessoas.

Para exemplificar essa situação, apresento uma amostra de um verbete de um conhecido dicionário em sua versão para internet:

\footnotetext{
${ }^{190}$ Se se considerar os materiais feitos para uso de máquinas têm, na verdade, a sua destinação final no usuário humano, essa distinção não parece tão evidente. Contudo, ela se estabelece muito mais na forma de aproveitamento dos dados e no suporte de saída das informações do que propriamente na pessoa do usuário.
} 
FIGURA 235 - CAPTURA DA TELA DO VERBETE DICIONÁRIO

dicionário
verbete Atualzado
(di.ci:o.ná.ri:o)
sm.
1. Obra que reúne, em ordeminal alfabética, as palavras de uma língua ou termos referentes a
uma matéria específica, e descreve seu significado, uso, etimologia etc., na mesma língua
ou em outra (dicionário de cinema / de inglês)
2. O conjunto das palavras ou termos reunidos nessa obra
3. Livro ou outro suporte que contém tais informações (dicionário eletrônico).

Fonte: Verbete Dicionário. Dicionário Aulete Digital. Disponível em: 〈http://www.aulete.com.br/dicionário〉.

\section{FIGURA 236 - CAPTURA DA TELA DO CÓDIGO-FONTE DO VERBETE DICIONÁRIO}

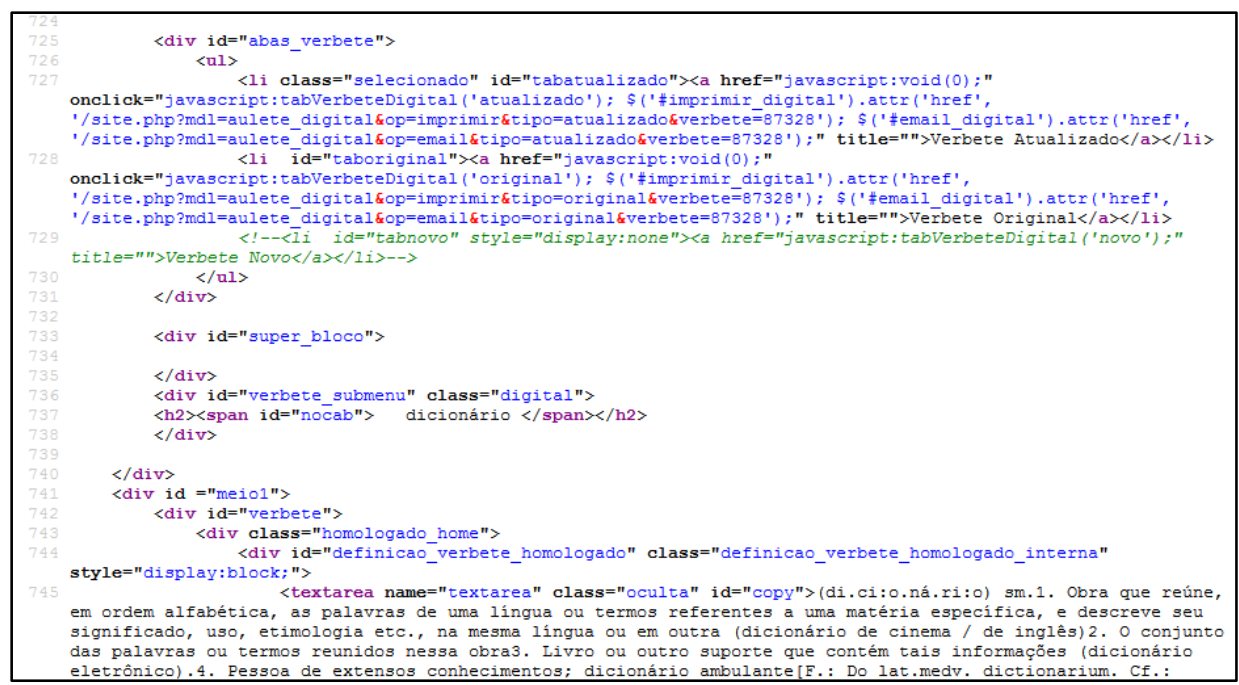

Fonte: Verbete Dicionário. Dicionário Aulete Digital. Disponível em: 〈http://www.aulete.com.br/dicionário〉.

É nítida a diferença entre as duas imagens, mesmo que a segunda contenha as mesmas informações da primeira, pois é a fonte (ou código-fonte) dela. Assim, pensar uma obra lexicográfica para ser lida e interpretada exige antes, nesse caso, uma codificação da informação dirigida para a máquina.

Nesse sentido, os programas de bancos de dados eletrônicos permitem ao usuário a geração de materiais, como os de natureza lexicográfica, uns com mais outros com menos esforço por parte desse usuário final. Por isso, a construção do programa Línguas vem no sentido de contribuir para que esse usuário tenha o mínimo ou mesmo nenhum contato com linguagens de programação (como html, php, vba, javascript, entre outras), ao mesmo tempo em que é possível fazer com que as informações contidas no programa "dialoguem" 
facilmente com outros programas para, se necessário, gerar uma base, por exemplo, para tradução automática.

A quinta distinção dessa tipologia também é pouco produtiva no caso das obras lexicográficas de línguas indígenas brasileiras, pois se baseia na opção em utilizar dados de natureza diacrônica ou sincrônica. Como não foram muitas as línguas no Brasil que tiveram dados registrados antes do século XX, a construção de dicionários históricos fica bastante difícil. Assim, a quase totalidade de dicionários desse conjunto de línguas é alimentada por dados coletados em sua própria época ou, no máximo, com dados de épocas relativamente próximas da época da pesquisa. ${ }^{191}$

Com relação à penúltima distinção tipológica, uma das mais relevantes na história da lexicografia, exatamente na transição da Idade Média para a Idade Moderna, em que se passou a distinguir com mais nitidez os materiais de natureza enciclopédica daqueles de cunho propriamente linguísticos, deve ser considerada no bojo das línguas indígenas brasileiras. Mesmo que haja nesse contexto o registro de uma única obra intitulada enciclopédia - a Enciclopédia Bororo, de Albisetti e Venturelli (1962) - e de duas outras intituladas dicionários enciclopédicos — o Diccionario enciclopédico de la lengua yãnomãmi (LIZOT, 2004) e o Dicionário Enciclopédico Kubeo-Multilingue (CHACON, 2012) - , muitas obras lexicográficas produzidas para línguas indígenas possuem caráter enciclopédico, uma vez que buscam registrar, além do léxico comum da língua, informações de natureza histórico-social, geográfica e cultural, como, por exemplo o Kwaza-English vocabulary, de Voort (2004), o Dicionário da língua Makuxi, de Raposo (2008) e a Proposta de Dicionário Terena-Português, de Silva (2013). Todos esses materiais citados são dicionários baseados no léxico, mas que contêm em vários verbetes extensas notas com informações adicionais, conferindo-lhes certo valor enciclopédico.

Conforme apresentado no Capítulo 8 desta tese, o programa Línguas pode armazenar separadamente dados para gerar tanto dicionários enciclopédicos, quanto as próprias enciclopédias. ${ }^{192}$

O último item da tipologia distingue os dicionários gerais da língua daqueles que são considerados especiais. De acordo com Al-Kasimi (1983, p. 31), “A general dictionary is

\footnotetext{
${ }^{191}$ Os poucos dicionários que se voltam para registros mais antigos de línguas indígenas, no geral, fazem essa comparação entre línguas diferentes, mas que pertencem a uma mesma família, este é o caso de Boudin (1966). Os demais registros históricos são tentativas de estabelecer etimologia para palavras usadas no Português que tenham origem indígena. Tal perspectiva ainda não foi devidamente contemplada no programa Línguas, mas, em atualizações futuras, a possibilidade de se construir dicionários históricos deve ser levada em consideração.

${ }^{192}$ Como a construção de uma enciclopédia exige um projeto específico e que não estava no projeto original da pesquisa desta tese, não apresento neste contexto nenhuma proposta desse tipo de material.
} 
one which attempts the coverage of the whole lexicon of the language whereas a special dictionary deals with one sector of the lexicon."193

Como exemplo de dicionários especiais no conjunto das línguas indígenas brasileiras, cito o Dicionário Cultural Mỹky (Fascículo 1: Ãkakje’y Alimentação), de Amarante e Monserrat (1998) e o Dicionário de verbos português-Yanomama, de Ferreira (2011). No primeiro, o recorte do léxico é estabelecido com base em um campo semântico, e, no segundo, com base em elemento gramatical da língua.

No caso da língua Suruí, é possível construir, sim, dicionários especiais, mas, como comentarei a seguir, não é esse o objeto da presente proposta.

\subsection{COMPONENTES DO DICIONÁRIO DA LÍNGUA SURUÍ}

No capítulo 9 desta tese, apresentei os diferentes modelos que poderiam ser usados para a construção de estruturas de obras lexicográficas baseados na língua Suruí. A partir dessas propostas e com a discussão sobre a tipologia de dicionários tratada na subseção anterior, passo a tecer considerações acerca da construção de um dicionário da língua Suruí que constará no interior desta tese. ${ }^{194}$

\subsubsection{Caracterizando o dicionário da língua Suruí}

Considerando que a proposta de construção de um dicionário monolíngue Suruí está em desenvolvimento pelos professores Ikatu e Tymykong, com minha colaboração, apresentarei nesta tese uma proposta de dicionário envolvendo o Suruí e o Português, sendo que a língua indígena representa a língua-fonte desse trabalho.

Como o Suruí é falado hoje por uma quantidade pequena de pessoas na T.I. Sororó e o Português é falado pela maioria dos jovens, que, em sua maioria, frequenta a escola regularmente, esse dicionário, a fim de atender aos dois públicos, deve ser configurado com Lema em Suruí, mas também em Português.

Baseado totalmente na língua falada, esse dicionário é fruto de transcrições de diferentes materiais, colhidos em diferentes situações de comunicação não só com os

\footnotetext{
${ }^{193}$ Tradução: "Um dicionário geral é aquele que busca dar conta de todo o conjunto do léxico, enquanto o dicionário especial se volta para uma parte específica do léxico" (Tradução nossa).

${ }^{194}$ Antes de passar à apresentação dos tipos e componentes desse dicionário, é fundamental esclarecer que a proposta a ser desenhada ainda está em construção, podendo ser ampliada e modificada até encontrar sua forma impressa.
} 
professores Suruí, mas também com sábios da comunidade Aikewára e outras pessoas falantes da língua Suruí. ${ }^{195}$

Assim, a construção de um dicionário bilíngue mostrou-se bem mais factível no contexto de desenvolvimento da pesquisa desta tese. Antes, porém, de prosseguir, é importante esclarecer o que aqui é denominado dicionário bilíngue, dada a variedade de significados atribuídos a esse tipo de material no domínio da lexicografia.

Três perspectivas podem colaborar com essa reflexão: a primeira é a de Porto Dapena (2002, p. 58-59), que define os dicionários bilíngues como aqueles que “[...] se ocupam del [léxico] de dos [...] lenguas [que] en efecto, se contentan normalmente com indicar al lado de cada entrada los términos de significado equivalente en la [lengua] de salida"; ${ }^{196}$ a segunda é a de Faulstich (2011b, p. 2), que define "dicionário multilíngue" como "Dicionário cujas unidades são apresentadas, e, por vezes, descritas, em duas ou mais línguas"; e a terceira é a de Haensch (1982, p. 134), para quem dicionário bilíngue é um tipo de dicionário plurilíngue, que "no dan, por lo general, una descripción metalingüística, sino equivalentes de las unidades léxicas en outras lenguas". 197

Envolvendo duas línguas em sua estrutura, um dicionário bilíngue apresenta, em geral, a entrada numa língua com forma(s) que se pretende(m) equivalente(s) em outra língua, havendo, no entanto, a possibilidade, bem mais rara, de se ter uma perífrase. ${ }^{198}$

Feitas essas considerações, a proposta de dicionário bilíngue que apresento envolve as línguas Suruí e Português, ambas já presentes no banco de dados do programa Línguas, conforme descrito no capítulo 8. Tal proposta não contém, ainda, perífrases na língua indígena, que só serão possíveis com o desenvolvimento da pesquisa, mas sim as formas equivalentes de uma língua à outra e, se necessário, perífrases em Português. Outro problema que se estabelece nesse ponto é a questão da equivalência entre as línguas envolvidas no material bilíngue. Sem dúvida é um desafio constante na pesquisa tentar encontrar formas que guardem correspondências semânticas de uma língua para outra, havendo, com frequência, situações de palavras que existem numa língua, mas que só podem

\footnotetext{
${ }^{195}$ Ao iniciar um processo de escolarização associado à escrita da língua Suruí, mas também com a escrita dos mitos e das músicas nessa língua, há grande possibilidade de, a médio prazo, ser desenvolvida uma literatura escrita em Suruí, o que poderá contribuir para uma futura construção de um dicionário de língua literária.

196 Tradução: "se ocupam do [léxico] de duas [...] línguas [que], com efeito, se contentam normalmente em indicar ao lado de cada entrada os termos de significado equivalente na [língua] de saída" (tradução nossa).

197 Tradução: "não dão, geralmente, uma descrição metalinguística, senão equivalentes das unidades léxicas em outras línguas" (tradução nossa).

${ }^{198}$ Muitos dos exemplos usados no capítulo 9 sobre modelos lexicográficos apresentam em sua microestrutura o uso da língua Suruí na posição de Lema com perífrases na mesma língua na posição de Descritor.
} 
ser apreendidos por outra através de perífrase, já que essa segunda língua não contaria com um termo com os mesmos traços semânticos do anterior. Por exemplo, em Suruí existe a palavra 'iakua', que só pode ser explicado em Português com uma perífrase do tipo 'bebida feita a base de mandioca cozida e peneirada, misturada com urucum e adoçada com mel de uma abelha nativa da região da T.I. Sororó'. Nesse caso, em que não existem formas que possam ser consideradas equivalentes, pode-se usar a estratégia de se apresentar a correspondência por uma palavra de conteúdo mais abrangente, ou seja, por um hiperônimo. Assim, 'iakua' na língua Suruí corresponderia a 'bebida' ou 'tipo de bebida tradicional Suruí', mas sabendo da limitação dessa equivalência já que existem outras bebidas tradicionais ou não nessa cultura.

Neste ponto, há de se considerar ainda, uma questão ligada ao dicionário bilíngue, que é a sua direção, ou seja, segundo Atkins e Rundell (2008, p. 39-40):

[...] it may be a 'unidirectional' dictionary, i.e. it consists of a single text from Language A (the source language, or SL) to Language B (the target language, TL).

It may be a 'bidirectional' dictionary, i.e. it contains two distinct texts in one volume:

- one from Language A to Language B, and

- one from Language B to Language A. ${ }^{199}$

Ao estabelecer a direção do dicionário bilíngue, deve-se também considerar que essa decisão terá repercussão na própria configuração da estrutura do dicionário, justamente como foi observado em diversos modelos de materiais lexicográficos para a língua Suruí apresentados no Capítulo 9: quando a estrutura era no sentido do Português para o Suruí, Operadores do tipo Et e Fn não eram tão necessários quanto em uma microestrutura que tivesse como entrada palavra na língua Suruí. ${ }^{200}$

Mas, por que construir um dicionário bidirecional das línguas Suruí e Português? Agora é o momento de retomar o segundo desdobramento relativo à natureza do dicionário. No Capítulo 3, verificou-se a situação linguística do povo Suruí, em que a nova geração dos Suruí, aqueles nascidos nos últimos 25 anos, são, essencialmente, monolíngues em Português, apesar de ainda serem capazes de compreender alguma coisa da língua Suruí. Essa mesma

\footnotetext{
199 Tradução: “pode ser um dicionário 'unidirecional', ou seja, consiste em um texto simples de Língua A (a língua de origem) para a Língua B (a língua-alvo). Mas pode ser também um dicionário 'bidirecional', ou seja, contém dois textos distintos em um volume: Um da Língua A para a Língua B, e um da Língua B para a Língua A." (tradução nossa).

${ }^{200}$ No conjunto de UBL's do corpus reunido nesta pesquisa, muitos materiais apresentavam a estrutura LId: $\{\mathrm{DPt}\}$ de forma muito mais detalhada ou ampliada, do que quando havia estrutura do tipo LPt: $\{\mathrm{DId}\}$, para a qual não havia mais do que a palavra em Português e sua equivalência na língua indígena.
} 
geral foi ou está sendo alfabetizada em Português, em uma escola onde predomina o uso dessa mesma língua.

Nesse sentido, o uso da língua portuguesa na produção dos dicionários bilíngues tem, num primeiro momento de aprendizagem de uma segunda língua como o Suruí no contexto da aldeia Sororó, o seu lugar, a fim de contribuir não só para o processo de aprendizado da língua Suruí, como também servir de material útil para a eventual tradução de textos. Todavia, essa nova geração pode vir a aprender a língua original de seu grupo e passar a utilizá-la cada vez mais. Caso isto ocorra, de fato, os dicionários (livros e outros materiais que servem para a leitura e escrita) serão mais do que necessários.

Outro aspecto a ser considerado nesta construção de obra lexicográfica se ela servirá para produção ou compreensão. Por ser a escola um espaço onde a compreensão da língua vem sempre associada à produção, é de se esperar que o dicionário atenda a ambos os requisitos, mas, sem dúvida, num primeiro momento a ênfase recairá sobre a compreensão. No entanto, ao tentar inserir a maior quantidade possível de exemplos para cada entrada, buscarei demonstrar os diferentes contextos de uso de cada item lexical selecionado no dicionário, a fim de auxiliar os jovens a também produzirem na escrita e na fala a língua Suruí.

Já com relação à forma dos dicionários, se para usuários humanos ou para tradução automática, as duas podem ser contempladas, simultaneamente, ao usar um programa como o Línguas. Mas no caso deste PDL em particular, o material buscará atender prioritariamente usuários humanos, e não máquinas, pois, no caso da realidade das comunidades indígenas brasileiras, ter o material impresso e organizado dentro de uma lógica que atenda aos seus interesses é, neste momento, fundamental e urgente.

Com relação à distinção entre dicionários históricos ou descritivos, vale lembrar que, devido aos primeiros registros da língua Suruí terem sido feitos somente há 30 anos, não existindo registros dessa língua anteriores à década de 1980, a pesquisa que realizei junto ao povo Suruí registrou a língua falada na atualidade, sendo mais plausível projetar um dicionário sincrônico contemporâneo, o que certamente não exclui o registro de variações sociolinguísticas e/ou formas diacrônicas sobreviventes ainda na língua. ${ }^{201}$

Outra decisão importante diz respeito ao conteúdo do dicionário. Como já havia mencionado, não foi objetivo deste trabalho construir uma enciclopédia da língua Suruí,

\footnotetext{
201 Se forem consideradas as reconstruções do Proto-Tupí-Guaraní de Rodrigues (1995; 2005a; 2005b), é possível fazer um estudo histórico-comparativo de natureza diacrônica envolvendo a língua Suruí.
} 
projeto até bastante necessário se considerado todo o conhecimento cultural e empírico desse povo e também de toda a sua história, antes e depois do contato com os não indígenas. Mas o escopo desta tese é apresentar um dicionário baseado no léxico da língua Suruí.

Nesse sentido, acredito ser necessário para bem compreender o que é esse 'dicionário baseado no léxico' tecer algumas considerações sobre o que frequentemente é denominado léxico de uma língua.

Ao definir como meta a elaboração de um dicionário da língua Suruí, aceitei, como é comum em qualquer projeto para construção de material lexicográfico, que seria possível estabelecer um conjunto de formas (com significado) dessa língua que poderiam configurar na entrada de cada verbete, servindo, dessa maneira, como lema da microestrutura, além de servir de base para um ordenamento a partir de sua própria forma (um ordenamento alfabético, por exemplo) ou de seu conteúdo (um ordenamento pelo sentido). Assim, ao constituir esse conjunto, ou melhor, cada componente desse conjunto usado como lema no dicionário, chega-se à percepção da existência de elementos, na língua, que comportam significados, capazes de constituir um ou vários conjuntos, ou ainda complexas redes de conjuntos.

Essas unidades, denominadas palavras por uma tradição já milenar ${ }^{202}$ ou lexemas $^{203}$ ou lexias, numa perspectiva da Linguística mais atual, passíveis de constituírem conjunto(s), seriam a prova da existência do que é comumente denominado léxico, cujo estudo levaria à compreensão das diferentes relações estabelecidas entre essas unidades acima mencionadas.

Essa apreensão do léxico por meio dos componentes de um dicionário representa uma maneira evasiva de perceber o léxico, mas isso tem sido prática tão comum ao longo dos

\footnotetext{
${ }^{202}$ Para uma discussão detalhada acerca das noções e usos do termo palavra nos campos da gramática tradicional e da linguística em diferentes épocas, ver Rey (1977, p. 183-188), Biderman (2001, p. 97-123) e Lara (2006, p. 17-35).

${ }^{203}$ Sobre o lexema, Bussmann (1996, p. 670) afirma que ele é "Basic abstract unit of the lexicon on the level of langue (langue vs parole) which may be realized in different grammatical forms such as the lexeme write in writes, wrote, written. A lexeme may also be a part of another lexeme, e.g. writer, ghostwriter, etc. In its broader sense, 'lexeme' is also used synonymously for 'word' to denote a lexical unit or element of the vocabulary." (Tradução: "Unidade básica abstrata do léxico no nível da língua (langue vs parole), que pode ser realizado em diferentes formas gramaticais, tais como as do lexema escrever em escreve, escreveu, escrito. Um lexema pode também ser uma parte de um outro lexema, por exemplo, escritor, escritor-fantasma, etc. Em seu sentido mais amplo, 'lexema' também é usado como sinônimo de 'palavra' para denotar uma unidade lexical ou elemento do vocabulário.").
} 
séculos, tanto que os termos dicionário e léxico passaram a representar, para vários autores, a mesma coisa. ${ }^{204}$

Tal percepção do léxico como conjunto, depósito ou repositório de unidades lexicais está presente em várias tentativas de definição dessa realidade, dentre as quais poderia citar os trabalhos de Neveu (2008, p. 189), que afirma ser o léxico um "conjunto aberto das unidades lexicais de uma língua" ou em Dubois (2002, p. 282), para quem o léxico é "l'ensemble des unités formant le vocabulaire, la langue d'une communauté, d'une activité humaine". 205

Partindo dessas definições, já antigas e muito difundidas ainda no domínio da linguística, que percebem o léxico numa perspectiva até certo ponto estática, colabora com a reflexão sobre a existência de elementos na língua que, apesar das diferenças de sentido e uso, e de função morfossintática, podem ser agrupados sob a forma de conjunto(s), cujas bordas não foram (ou não podem ser) estabelecidas, dada a sua natureza dinâmica (p.ex., os fenômenos da obsolescência de palavras ou da neologia nas línguas) e fragmentária manifestada em cada uso linguístico, escrito ou oral, nos mais diferentes contextos.

Considerando ainda que todas as línguas, em princípio, comportam léxico, que pode ser depreendido a partir de análises morfossintáticas e semântico-pragmáticas, a língua Suruí também contaria com léxico, a ser depreendido pouco a pouco dos discursos de falantes dessa língua. Como resultado desse trabalho, as formas do léxico começariam a aparecer, revelando o que o Suruí possui de particular nesse conjunto de unidades lexicais, que o diferenciaria não só de línguas como o Português, por exemplo, mas, sobretudo, de línguas próximas a ela, como o Asuriní do Tocantins, o Tembé e o Parakanã.

Logo, uma das tarefas da pesquisa foi tentar vislumbrar os contornos desse léxico e utilizar essas informações na construção do dicionário da língua Suruí. Importantes pistas foram dadas ao estudar a morfologia dessa língua (ver Capítulo 6 desta tese), onde foi possível compreender não só elementos constituintes da palavra da língua Suruí, mas, sobretudo, os processos de combinação e construção dessas palavras. Com a sintaxe, definindo os tipos de oração, foi possível identificar os principais contextos de uso de, por exemplo, nomes e verbos, vislumbrando as variações por que passavam esses elementos dentro de contextos linguísticos.

\footnotetext{
${ }^{204}$ No século XVIII léxico se referia a um material lexicográfico que reunia as palavras relacionadas em um texto de determinado autor, geralmente grego ou latino, consideradas mais "difíceis" de serem entendidas.

${ }^{205}$ Tradução: "o conjunto das unidades que formam o vocabulário, a língua de uma comunidade, de uma atividade humana" (tradução nossa).
} 
Nesse sentido, os principais elementos depreendidos como unidades lexicais, sem contar com elementos gramaticais, como, por exemplo, os pronomes pessoais e as posposições, sem contar também com as formas presas como os prefixos relacionais e os sufixos do caso argumentativo, foram nomes, relacionados a partes do corpo humano, estados físicos, tipos de animais e plantas, parentesco, entre outros (cf. subseção 10.2.3.1.6 para maiores detalhes); e verbos, indicando processos, estados, ações, entre outros.

Dessa maneira, uma vez constatada a existência do léxico e estabelecida a metodologia de coleta de dados desta pesquisa (ver capítulo 8), foi possível pensar na construção de um dicionário baseado no léxico, mas com a certeza de que se trata de um projeto que sempre estará em elaboração, dada a natureza dinâmica desse léxico.

Por último, faltava decidir se o dicionário seria um dicionário geral ou um dicionário especial. Como a língua Suruí ainda não contava com nenhum dicionário do tipo geral, ou seja, baseado no maior número de componentes da língua, sem focar em um tema ou assunto específico (como a alimentação, o corpo humano ou os animais, por exemplo), decidi direcionar o projeto para a construção daquele tipo de dicionário, por acreditar que, neste momento, ele serviria não somente como base de registro linguístico, mas, principalmente, por acreditar que, ao realizar a pesquisa para sua elaboração, estaria, de certo modo, construindo vários dicionários especiais, pois os dados coletados e reunidos no programa Línguas permitiria a seleção e construção dessa outra classe de dicionários.

Em resumo, o dicionário da língua Suruí a ser apresentado nesta tese é bilíngue, nos sentidos Suruí-Português e Português-Suruí, descritivo, baseado no léxico, para compreensão e produção de usuários, do tipo geral.

\subsubsection{As fontes usadas no dicionário da língua Suruí}

As fontes de informações que constituem o corpus lexicográfico deste trabalho, como já havia mencionado, são todas orais, dada a condição de escrita ainda incipiente na sociedade Suruí. Portanto, parte-se do conteúdo oral registrado junto aos falantes da língua Suruí, conforme apresentado na seção anterior, que foi transcrito nas formas fonética, fonológica e ortográfica, a fim de se obter o material necessário para armazenamento, análise e produção de documentos lexicográficos. ${ }^{206}$

\footnotetext{
${ }^{206}$ Apesar de a escrita na língua Suruí já ser uma realidade na T.I. Sororó, ela ainda está restrita a poucas pessoas e carece de alguma sistematização. É possível que, em futuro não muito distante, essa realidade ceda lugar a um produtivo processo de escrita nos mais diferentes contextos sociais.
} 
Além do corpus que reuni em pesquisa direta junto aos Suruí, resolvi considerar na base de dados outros materiais (todos orais) coletados em diferentes épocas, por diferentes pesquisadores, seguindo rigorosa metodologia de recolha e que tivessem boa qualidade de gravação, dentre os quais estão os de Monserrat (1985a), Cabral (1997) e Costa (2002). Desses corpora, apenas aproveitei os conteúdos que não estão não estavam registrados na base de dados lexicais.

Uma vez determinadas as fontes da língua Suruí, fiz a compilação dos dados no SGBD, de uso exclusivo para essa língua, a fim de constituir um arquivo lexicográfico útil para a construção de dicionários e de outros tipos de materiais.

Ora, um acervo construído com base em elementos lexicais, à medida que é alimentado, passa a representar uma significativa amostra do próprio léxico da língua. Por isso, ao analisar os itens da base de dados lexicais da língua Suruí, foi possível depreender quais os conteúdos semântico-lexicais estavam contidos nele.

Parte desse conteúdo lexical já havia sido estabelecido como uma das metas da própria pesquisa linguística realizada com a língua Suruí, ou seja, desde o planejamento deste trabalho, uma das intenções era focalizar a identificação das formas relacionadas às plantas e animais nessa língua indígena. No entanto, mesmo tendo esta perspectiva estabelecida, não restringi a pesquisa somente a ela, buscando registrar os mais diferentes conteúdos linguísticos a fim de ter uma amostra realmente significativa do léxico dessa língua.

\subsubsection{Estruturando o dicionário da língua Suruí}

A estruturação de uma obra lexicográfica exige que seja tomada uma série de decisões tanto sobre os conteúdos que farão parte dela quanto da forma que ela assumirá, ou seja, da configuração das microestruturas até o ordenamento geral dos verbetes.

Logo, no sentido de buscar apresentar da maneira mais sistemática possível essas informações, trato de cada um desses temas separadamente.

\subsubsection{Os conteúdos do dicionário}

Conforme defini na subseção 10.2.1, este dicionário da língua Suruí possui as seguintes características: bilíngue, baseado no léxico, descritivo e geral.

Assim, envolvendo duas línguas, o Suruí e o Português, esse dicionário contará com dados colhidos no léxico da língua indígena, dentre os quais estão nomes (substantivos e nomes descritivos), verbos, advérbios, posposições e pronomes. 
Com relação a essas unidades do léxico, na subseção 10.2.1 deste trabalho já havia tecido algumas considerações sobre elas, mas é necessário retomar essa discussão a fim de tratar de temas igualmente importantes.

Neste trabalho, considero a noção de unidade léxica, ou lexia, conforme apresentado por Pottier (2001, p. 18f):

La lexie est toute séquence (de 1 à n éléments) mémorisée par les locuteurs à un moment donné de l'histoire de la langue [...]. Son contenu sémantique est la sémie [...]. Cette notion s'applique:

- aux « mots simples »: vache, casser, devant, que

- aux « mots composés » ou « complexes »: tire-bouchons, œil-de-bœuf, s'en aller, au-delà

- aux séquences plus ou moins figées: raser les murs, un angle d'ataque, en plein milieu de, tomber de haut (être déçu). ${ }^{207}$

Partindo de uma noção semântica, Pottier estabelece essa classificação das unidades léxicas, que pode ser aplicada às palavras da língua Suruí. Assim, também podemos identificar: $^{208}$

a) lexias simples: misar (veado), kyty (esfregar), sene (nós inclusivo)

b) lexias compostas ou complexas: akutia nami pe pytukaw (laranja), sahytataw (estrela cadente maior).

Certamente, deve-se acrescentar a esse critério o uso da unidade lexical em um contexto morfossintático, pois isso ajuda a definir se determinada forma, por exemplo, no caso de um nome, se ele recebe o sufixo $\mathrm{X}$ ou $\mathrm{Y}$, ou no caso de verbos, se ele pode receber um prefixo pessoal Z (cf. análise morfológica da língua Suruí no Capítulo 6.1).

\subsection{Nomes}

Aproveitando essa discussão, é necessário considerar ainda que na língua Suruí, como em muitas outras línguas da família Tupí-Guaraní (e também em várias outras línguas do mundo), nem sempre há coincidência, no caso dos nomes, entre o morfema raiz e a palavra simples, por isso, no discurso, nunca se emprega isoladamente, por exemplo, a palavra apin (cabeça), pois é obrigatória a indicação de quem possui a cabeça, assim, tem-se a forma $t i$

\footnotetext{
${ }^{207}$ Tradução: "A lexia é qualquer sequência (de $1 \mathrm{a} \mathrm{n}$ elementos) memorizado pelos locutores em um dado momento da história da língua [...]. Seu conteúdo semântico é o sema [...]. Essa noção se aplica: - às 'palavras simples': vaca, quebrar, diante, que; - às 'palavras compostas' ou 'complexas': saca-rolhas, olho-de-boi, ir embora, para além; - às sequências mais ou menos congeladas: ficar colado na parede, um ângulo de ataque, em pleno meio de, esticar as canelas (estar morto)." (tradução nossa).

${ }^{208}$ Quanto às sequências mais ou menos fixas na língua Suruí ainda não tenho exemplos para inserir, pois serão tratadas na segunda parte desta pesquisa.
} 
apina (minha cabeça) ou iapina (cabeça de algo ou de alguém). Nesse sentido, na macroestrutura do dicionário bilíngue Suruí-Português, que deve ser organizada em ordem alfabética das palavras em Suruí, utilizo como base nas unidades léxicas as formas com prefixo relacional da classe $\mathrm{R}^{2}$ (cf. Capítulo 6.1 sobre a morfologia da língua Suruî), ${ }^{209}$ que, segundo Cabral, Rodrigues e Franceschini (2013, p. 404), "sinaliza que o determinante de um tema não forma com este uma unidade sintática e que é diferente do falante e do ouvinte". Procedendo desta forma mantenho como entrada do dicionário apenas formas existentes e efetivamente usadas na língua. Desta forma, por exemplo, a palavra Suruí py'a 'fígado' deve ser procurada na forma ipy'a 'fígado de algo ou de alguém'; e é essa forma que faz todo o sentido para um falante da língua Suruí, facilitando para ele o acesso à informação no material lexicográfico.

Logo, nesse caso, a glosa em Português, por exemplo, 'fígado de algo ou de alguém', no dicionário Suruí-Português, é usada como Lema no material com a direção Português-Suruí. O resultado desta opção é fazer com que a maior parte dos nomes descritivos esteja concentrada no grupo de palavras iniciadas pela letra $I$.

Essa mesma lógica de construção do termo de entrada para o dicionário é empregada na própria base de dados da língua Suruí, mantendo-se, dessa maneira, a coerência interna com a proposta.

Com relação à grafia das sequências compostas, escrevê-las juntas ou separadas pode ser uma questão ortográfica apenas, entretanto, segundo Pottier (2001, p. 107), ela pode ser reveladora de certo grau de integração. Por isso, na escrita das lexias compostas sahytataw (dois morfemas sahy+tataw) e ma'esawar (dois morfemas ma'e+sawar) ambas unidas, podese interpretar como indicativo de que nos dois casos as expressões já se encontram totalmente lexicalizadas, apesar de a segunda delas ainda ser passível de discussão haja vista a grande produtividade do morfema $m a$ 'e, como mediador de construções genitivas na língua Suruí. ${ }^{210}$

Enfim, o dicionário deve comportar diferentes tipos de entradas, tanto com nomes como palavras simples quanto nomes como palavras complexas. Nesta última situação, em se tratando do dicionário na direção Português-Suruí, destaco da expressão a palavra com maior força semântica a fim de usá-la como Lema e reservo ao Exemplo a apresentação da forma completa. Essa estratégia é necessária se se quiser construir automaticamente um dicionário

\footnotetext{
${ }^{209}$ Como demonstrei no Capítulo 6, os prefixos $\mathrm{R}^{2}$ podem ser: $i$-, $h$-, $t$ - ou $\emptyset$.

${ }^{210}$ Essas composições, por serem demasiadamente antigas, não são mais percebidas pelos falantes da língua Suruí como elementos distintos ou justapostos, mas sim como unidades.
} 
que ordene, por exemplo, de modo alfabético os itens da entrada e que possa ser mais facilmente localizado pelo usuário. Por isso, em construções do tipo 'guardar na memória', a entrada em Português fica 'memória (guardar na)'; ou em 'tirar a sujeira', fica 'sujeira (tirar a)'. Todavia, no dicionário com a direção Suruí-Português, mantenho o item completo, mesmo que se trate de uma lexia complexa, por isso, a lexia 'akutia nami pe pytukaw' deverá ser encontrada no conjunto de entradas com a letra A.

Um último comentário sobre um conjunto de palavras da classe dos nomes é ainda necessário: trata-se dos adjetivos ou, segundo Rodrigues (2010, p. 24-25), dos nomes descritivos. Assim como ocorre com os nomes de partes de corpo e objetos possuíveis, acima apresentados, os nomes descritivos recebem, em geral, no dicionário, o prefixo $\mathrm{R}^{2}$. Com isso, nomes como pyhyj 'pesado' e rowa 'amargo' constarão no dicionário nas formas ipyhyj 'pesado (ele é)' e irowa 'amargo (ele é)'.

\subsection{Verbos}

Os verbos na língua Suruí, que podem ser transitivos, intransitivos ou bitransitivos (cf. subseção 6.1.3.2), não possuem a forma nominal denominada infinitivo, comum a várias línguas, dentre elas o Português. Assim, para registro dos verbos no dicionário da língua Suruí, opto pelo registro dos verbos acompanhados do prefixo de $3^{\text {a }}$ pessoa do singular u-. Certamente essa decisão implica em colocar todos os verbos em um único grupo, e apresentase como uma alternativa à forma já tradicional de registro de verbos em materiais lexicográficos de línguas da família Tupí-Guaraní, que, com muita frequência, utilizam a raiz do verbo como forma da entrada nesses materiais.

\subsection{Homonímia e polissemia}

Outra questão importante na língua Suruí é que remete a um problema bastante relevante na construção das obras lexicográficas: o tratamento da homonímia e da polissemia. $^{211}$

Na língua Suruí, o nome ikwar pode significar tanto 'buraco de algo ou de alguém' quanto 'vagina de alguém'. Partindo da hipótese de que teria existido um significadobase e, por extensão, teria passado a designar outra coisa, o que poderia justificar

\footnotetext{
${ }^{211}$ Segundo Werner (1982, p. 299), "Homonimia: Igualdad entre los significantes de dos o más palabras que posseen distinto significado. Polisemia: Fenómeno consistente en la reunion de varios significados en una palabra" (Tradução: "Homonímia: igualdade entre os significantes de duas ou mais palavras que possuem significados diferentes. Polissemia: fenômeno consistente na reunião de vários significados em uma palavra", tradução nossa).
} 
perfeitamente uma situação de polissemia nessa língua. No entanto, como só é possível, neste momento, observar a língua Suruí no presente, ${ }^{212}$ não tenho como avaliar se esses casos são, de fato, casos de polissemia.

Dessa maneira, ao me deparar com essas situações, opto por tratá-las como casos de homonímia, porque, assim, eles constituem entradas diferentes. E a principal vantagem nisso é poder apresentar separadamente Descritores e Exemplos para cada forma. Além da proximidade das entradas em um contexto de macroestrutura ordenada alfabeticamente, elas seriam identificadas por meio de números sobrescritos, indo dos significados mais gerais para os mais específicos. Por isso, ikwar 'buraco de algo ou de alguém' precederia ikwar 'vagina de alguém'. Outras duas vantagens em tratar separadamente essas duas palavras é a possibilidade de, no caso de um dicionário multilíngue, oferecer traduções para cada uma delas, haja vista que não é nada comum que um caso de homonímia em uma língua corresponda exatamente a um par homonímico em outra língua; mas também a de poder, no caso de haver ilustrações no material lexicográfico, atribuir imagens diferentes a cada uma dessas realidades.

\subsection{Sinonímia e Antonímia}

Apesar de já possuir na base de dados lexicais do programa Línguas algumas informações relacionadas aos fenômenos da sinonímia e da antonímia na língua Suruí, optei por não inseri-los, ainda, na presente versão do dicionário. O principal motivo é, ainda, a necessidade de aprofundamento do estudo desses dois fenômenos.

Assim, a título de exemplo, poderia citar como ocorrências de sinonímia na língua Suruí: 'ara kwahapara e ipituna kwahapara 'relógio'; itapura'a e aikong 'pomo-de-adão de alguém'; itekwawa e ikehawa 'rede de alguém'. E como ocorrências de antonímia: ipyperewa 'raso' e iwaypy 'fundo'; ma'ey'yma 'vazio' e itymehem 'cheio'; ma'e ahy 'doente' e katuete 'saudável'.

\subsection{Antroponímia}

O estudo da onomástica Suruí, embora seu estudo seja visto em uma perspectiva de que deve ser devidamente explorada, merece ser brevemente comentado aqui, ainda mais

\footnotetext{
${ }^{212}$ Certamente, não excluo a possibilidade de serem feitas reconstruções por meio do método históricocomparativo com outras línguas, chegando a resultados consideráveis sobre a etimologia das palavras dessa língua, mas, como isto ainda não foi feito para a língua Suruí, opto por não seguir esse caminho.
} 
porque os nomes próprios estão muito próximos do que definimos acima como léxico comum para um dicionário geral.

Viveiros de Castro (1986, p. 388) propõe que: "De um modo geral, pode-se dizer que a onomástica Tupi-Guarani típica recorre, como fonte ou critério, ao extrassocial: natureza, inimigos, deuses”. Todavia, a sociedade Suruí-Aikewára, herdeira de uma tradição cujo início é impossível precisar, recorre a fontes ainda mais variadas do que essas, mas, com raras exceções, todas oriundas do léxico comum de sua língua.

Assim, identifico, grosso modo, os seguintes assuntos encontrados no conjunto de nomes Suruí:: 213

1) animais: Kaw Piperati 'marimbondo com chifre', Muru'i 'maruim', Sakyron 'cigarra', Sanu' $i$ 'aranha pequena', Sawapirong 'onça-vermelha'

2) plantas: Emu'em 'cipó de fogo', Kanawa 'yw 'mogno', Pakaru'yw 'pau-santo', Pinuwa 'açaí'

3) minerais: Ita ' $i$ 'pedrinha', Itapem 'pedra chata', Itahenypug 'ouro'

4) partes do corpo: kwarama 'cóccix', Kanawa 'joelho', Kusoeha 'olho de mulher', Sawarapy 'pé de onça'

5) objetos: Arupare 'flecha com ponta cortante' Araw'y 'cocoar com duas penas de arara', Iwyrapari 'arco pequeno', Kujmu'a 'cuia de cabaça'

6) características físicas: Iti'om 'nariz arrebitado', Kusoting 'mulher branca', Murehapu'i 'olho bem fechado'

7) qualidades psicológicas: Murejru 'pessoa teimosa', Warikatu 'muito bonzinho'

8) fenômenos da natureza: Amonete 'chuva genuína', Ku'em 'amanhecer'

9) acidentes geográficos: Ipure 'lago', Iwytyra 'montanha'

10) formas gramaticas: Awari'a 'bem ali', Ko katy 'pra cá'

Assim, cada nome trazia um significado diferente, único, e, até onde pude constatar, havia um esforço para que não houvesse, num mesmo tempo, duas pessoas com o mesmo nome, ocorrendo situações em que o filho ou o neto recebia o nome do pai só se este já fosse falecido. ${ }^{214}$

Segundo informação obtida junto a sábios Suruí, umas das funções do pajé na sociedade Suruí tradicional era a de atribuir o nome à criança recém-nascida, e só ele podia

\footnotetext{
213 A grafia dos nomes com inicial maiúscula já segue uma orientação ortográfica que os próprios professores Suruí já adotaram na escrita de sua língua.

${ }^{214}$ Atualmente, já são atribuídos a filhos e netos os nomes de seus pais ou avós, mesmo que estes ainda estejam vivos, tal é o caso de, por exemplo, Maira (pai) e Maira (filho).
} 
fazer isso. Atualmente, apesar de essa função se de responsabilidade dos próprios pais, há aqueles que preferem recorrer aos mais velhos para obter o nome para a criança.

Ademais, não identifiquei, neste estudo preliminar, nenhuma relação entre os assuntos dos nomes próprios e a participação da pessoa no clã a que ela pertence (Sapakani, Kwati, 'Yw, Inata 'yw, Susiw, Karasa). ${ }^{215}$

Esse conteúdo não deve figurar no dicionário da língua Suruí proposto nesta tese, mas sim deve ser utilizado na construção de um dicionário de nomes próprios ou mesmo um dicionário enciclopédico Aikewára, em que seja possível registrar não somente o significado desses nomes, mas, sobretudo, a história das pessoas (proeminentes ou não na sociedade Suruí) relacionada a cada um deles.

\subsection{Toponímia}

Já com relação à toponímia, a língua Suruí não se revelou tão produtiva quanto na antroponímia. ${ }^{216}$ Por isso, limito-me a apresentar alguns dos topônimos identificados nesta pesquisa, mas sem apresentar as respectivas glosas em Português, uma vez que, até mesmo para os falantes da língua, muitas dessas palavras já não são reconhecidas: Aikewara Ty’wo Ka'a, Amoren Awapaw, Apikujtawera, Arekasuhy, Etom Itahy, Iakokaw, Ikwaw Ipirahyete, Ikwaw Kwatingiwa, Inu'a, Inu'a Iwo, Ipeywhu, Ipirong, Ipirong, Ipureuhu, Ipyrujru, Itakorowohi, Itakorowohi, Itapirong, Itasa'e, Itymupumupu, Iwyenaw, Kosokoso, Kujpiron, Kujronuhu, Kurutuhun, Kwironuhuwawira, Muha, Musena, Mutum, Narosa, Nerona, Pu'epu'e Tawera, Putiputi, Rewyenawa, Sakamin, Sakarekwara, Sapuhuywera, Saratita, Satewpirong, Sepuhepuhetawera, Somirong, Sutywa, Takararayra, Takwapuku, Tapiwajwuku, Taraku'a, Taraku'a, Tasahu, Tasahu Iwyating, Tasahu Ywyating, Tatu, Tawera, Tawoto, Tyete, Umumahemahem, Urumipawera, Wopujron, Ypya O'oj, Yrirongahy. ${ }^{217}$

Todos os topônimos arrolados acima estão localizados ou dentro da T.I. Sororó ou em áreas vizinhas, que pertenciam historicamente aos Suruí e que foram deixadas de fora da

\footnotetext{
215 As primeiras informações sobre a existência de clãs na sociedade foram dadas por Laraia (1967, p.43). A esses grupos ele denomina "grupos de descendência unilinear".

${ }^{216}$ Deve-se considerar, nesse contexto, toda a história do povo Suruí Aikewara, que não levava uma existência nômade, devido às pressões do "progresso", conforme tratei no Capítulo 3 desta tese.

${ }^{217}$ É interessante notar que, há décadas, trabalham na coleta de castanha-do-pará, dentro da reserva da T.I. Sororó, pessoas de fora da comunidade Suruí, mas que, com o convívio, acabaram aprendendo alguma coisa da língua, sobretudo os nomes relacionados à toponímia da área. Tive a oportunidade de conhecer um desses antigos coletores, hoje octogenário, mas que lembrava perfeitamente dos nomes, em Suruí, de todos os lugares por onde ele havia passado. Já com relação à denominação Sororó, ela não é Suruí, e foi atribuída, pelos não índios, à T.I. por causa da proximidade da terra com o rio, este sim, denominado Sororó.
} 
demarcação concluída em 1983 ou que foram indevidamente tomadas deles. A base para essas informações está no mapa do CEDI publicado em Ferraz (1985, p. 117) e que está sendo atualizado por Ikatu e Waiwera.

Do mesmo modo como os antropônimos, esses topônimos não devem constar no dicionário da língua Suruí, mas sim em um outro material lexicográfico, como uma enciclopédia, ou mesmo em um atlas geográfico na língua Suruí.

\subsection{Léxico comum}

Em se tratando do conteúdo lexical principalmente de nomes, verbos e advérbios, é possível identificar no conjunto do corpus da língua Suruí os principais assuntos relacionados a eles. Dessa maneira, ao observar os conteúdos semântico-lexicais presentes na base lexical do programa Línguas, pode-se ter uma ideia da variedade das formas registradas.

Considero neste levantamento um total de 1090 itens lexicais (excluídos os elementos puramente gramaticais) presentes, até o fechamento desta pesquisa, na base de dados da língua Suruí armazenada no programa Línguas.

Baseado nesse conjunto de itens, apresento, a seguir, um gráfico com a estatística relacionada ao conteúdo lexical armazenado nessa base de dados:

\section{GRÁFICO 06 - ESTATÍSTICA DO CONTEÚDO SEMÂNTICO-LEXICAL DA BASE DA LÍNGUA SURUÍ DO TOCANTINS}

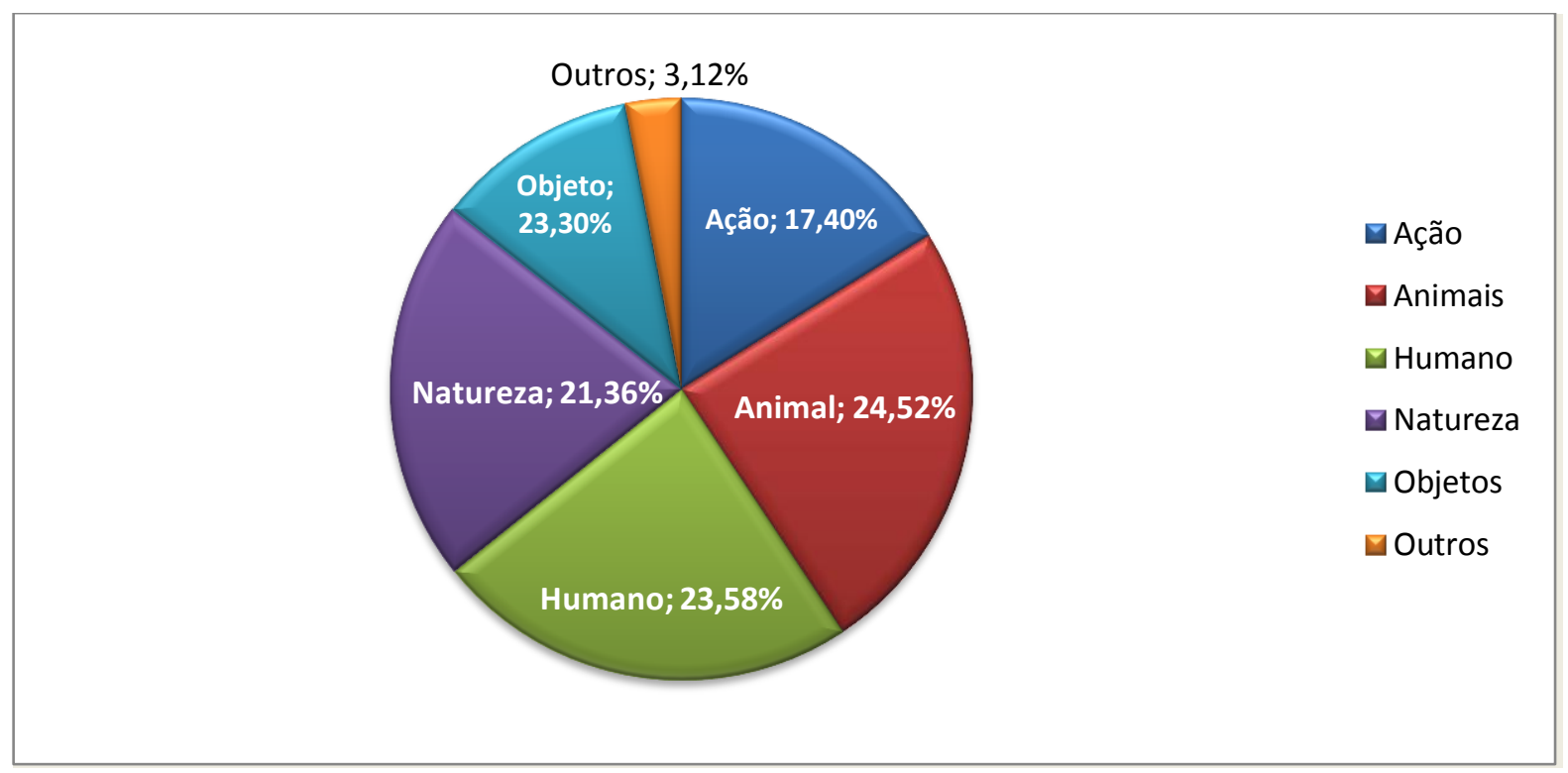

Optei pela utilização da estatística neste trabalho devido ao fato de ela permitir uma apreensão mais aproximativa dos dados, ao invés de apresentar valores absolutos que variam a cada vez que um novo dado é inserido na base, tornando a percepção do conjunto 
menos nítida. ${ }^{218}$ Desta forma, do total de léxico registrado (100\%), depreende-se que a maior parte dele está relacionada a quatro grandes grupos:

- Ação: nesse conjunto estão inseridos alguns nomes e a maioria dos verbos, com mais de $16 \%$;

- Animais: inclui palavras relacionadas às diferentes espécies animais (anfíbio, aracnídeo, ave, crustáceo, diplópode, inseto, mamífero, marsupial, molusco, nematelminto, peixe, quelônio, quilópode, réptil, roedor, verme), mas inclui também palavras relacionadas, por exemplo, a partes do corpo de animais, com mais de $24 \%$; $^{219}$

- Humano: grupo que inclui palavras relacionadas a atividade, construção, corpo humano, denominação, estado civil, gênero, idade, intelecção, interação, meio de transporte, parentesco, profissão e reprodução, com mais de $23 \%$;

- Natureza: considerei neste grupo as palavras relacionadas a fungos, vegetais, clima, relevo, substâncias (água, fogo, terra e ar), espaço e tempo, com mais de $21 \%$.

Se considerar apenas duas categorias, a de animais e vegetais, juntas, elas totalizam um terço do total de itens lexicais armazenados até o momento. Certamente, a pesquisa buscou enfatizar esses dois campos de conhecimento, essenciais para o povo Suruí

Os demais grupos lexicais relativos a objetos, processos e quantidades atingiram, juntos, menos de $4 \%$ do total computado. Isso não significa, naturalmente, que o léxico da língua tenha exatamente esta configuração da amostra que está na base, cujo conteúdo serve para orientar sobre a natureza dos conteúdos e da estruturação do léxico geral da língua Suruí. Além disso, é o conteúdo lexical dessa mesma base que está na estruturação geral dos dicionários produzidos.

Estes dados estatísticos não têm a intenção de demonstrar a frequência de uso dos termos constantes nos corpora da base, informação, sem dúvida, útil para o trabalho lexicográfico e amplamente usado em alguns dos mais recentes dicionários semasiológicos

\footnotetext{
${ }^{218}$ Mesmo com a conclusão da pesquisa relacionada a esta tese, a pesquisa da língua Suruí deve prosseguir a fim de se chegar a um resultado ainda mais completo tanto na descrição dessa língua, quanto na produção de materiais lexicográficos baseados nela.

${ }^{219}$ Se nesta pesquisa utilizei como parâmetro para os marcadores do programa Línguas o conhecimento científico relacionado a animais e plantas, espero, em uma nova pesquisa relacionada à língua Suruí, tentar descobrir a taxonomia baseada no conhecimento dos Aikewara.
} 
(cf., a título de exemplo, o Dicionário de Usos do Português do Brasil, de F. S. Borba (2002) e o Collins English Dictionary, publicado por Harper Collins Publishers, 2011); pois, para conseguir essa informação sobre frequência é necessário dispor, além de um considerável corpus de textos (geralmente escritos) e a utilização de uma metodologia específica, que não está prevista neste trabalho.

Outro fator relevante a ser considerado neste acervo lexical é que ele representa a língua comum falada pelos Suruí hoje, e não um léxico terminológico. Não há dúvida de que a língua Suruí já possui em seu léxico formas especializadas relacionadas a atividades desenvolvidas pelo grupo, tais como a agricultura, a produção de farinha e a coleta da castanha-do-pará, contudo, esse léxico não foi ainda considerado/sistematizado nesta etapa do trabalho, sendo, contudo, um importante tema para uma nova pesquisa. Assim, o conteúdo lexical corresponde, quase integralmente, ao que Rodrigues (1964 [2012], p. 99 [197-198]), denominou vocabulário básico, ou seja, “[...] palavras pouco influenciadas pela mudança cultural e que, por isso mesmo, se conservam em todas as línguas relativamente inalteradas no decorrer do tempo...".

Ao lado desse léxico que pode ser considerado mais antigo e, de certo modo, estável, há ainda outras formas que devem ser consideradas no conjunto do léxico da língua Suruí, são elas:

(1) os neologismos, resultantes, sobretudo, do contato com grupos não indígenas, principalmente os de falantes do Português. Por exemplo, as palavras takwawera (palha de aço) e sumi 'ahu (avião) surgiram em decorrência do contato com realidades de outras culturas.

(2) os empréstimos, resultantes de um processo pelo qual "les utilisateurs d'une langue adoptent intégralement, ou partiellement, une unité ou un trait linguistique (lexical, sémantique, phonologique, syntaxique) d'une autre langue” (LOUBIER, 2011, p. 10), são uma realidade linguística na sociedade Suruí, também resultantes do contato linguístico. Há ainda nessa classe de empréstimos, uma subclasse de empréstimos que podem ser considerados indiretos, pois não são do Português, mas foram introduzidos por meio dele, como é o caso de palavras do Inglês relacionadas à informática.

Dentre os conjuntos citados acima, apenas o primeiro, o dos neologismos deve configurar no interior do dicionário, haja vista sua relevância para a ampliação do léxico da 
língua Suruí. Com relação ao segundo conjunto, ainda não foi estabelecido sistematicamente que formas foram tomadas de empréstimo do Português, assim, acredito que seja mais adequado reservá-los para um momento posterior da produção de materiais lexicográficos.

\subsection{Neologismos}

Ao analisar um conjunto de dados lexicais da língua Suruí do Tocantins, coletados até o momento, busquei estabelecer um subconjunto de dados com características bastante similares: primeiro, esse material lexical teria surgido em um período bem específico: após a situação de contato (cultural, linguístico, econômico, político, etc.) dos Suruí com outros povos, principalmente com os não indígenas falantes da língua portuguesa, a partir da década de 1950, na região próxima aos rios Tocantins e Araguaia; ${ }^{220}$ segundo, esses dados manifestam uma atitude linguística de conservação desse povo frente aos novos elementos advindos de um mundo exterior ao seu.

Essa atitude consiste, antes de tudo, na tentativa de apreender as novas referências que lhes foram sendo apresentadas e isso passa, sem dúvida, pelo ato de nomear cada novo elemento, garantindo-lhes, assim, um lugar no conjunto léxico-semântico de sua língua. No entanto, essa nomeação pode não significar apenas "rotular" um objeto a mais no mundo, porque é possível que haja uma intenção, nessa nomeação, de aproximar o objeto ao próprio conhecimento dos falantes, tornando-o, em alguma medida, familiar a eles. A consequência desse ato coletivo e intencional de nomear pode estar manifestada nas próprias estratégias linguísticas usadas pelos falantes da língua, que precisam interpretar o que não fazia parte de seu universo a partir de suas próprias referências léxico-semântico-culturais e de seus mecanismos linguísticos, como o da metáfora.

Os dados desse subconjunto do corpus relacionam-se a elementos de diferentes domínios, os principais deles são: meios de transporte, instrumentos com haste e metal, utensílios de cozinha, alimentos, vestuário e aparelhos eletrônicos. Como vimos anteriormente, a maioria dos elementos relacionados a esses domínios só passou a ser conhecida pelos Suruí após o contato e motivou, em alguma medida, a introdução (construção) de novos itens lexicais ou de novos usos e sentidos de elementos já existentes no léxico da sua língua. Logo, uma primeira definição necessária para compreender esse conjunto de dados seria a de neologia, que está diretamente ligada à noção de neologismo.

\footnotetext{
${ }^{220}$ Cf. Laraia e Matta (1967, p. 28-30; 1978, p. 63-66); Ferraz (1985, p. 103-104).
} 
Há bem pouco tempo o povo Suruí era ágrafo, ${ }^{221}$ e foi nesse contexto de uso pleno da língua oral que a neologia, enquanto processo por meio do qual novas unidades lexicais passam a fazer parte do repertório da língua, mostrou-se bastante produtiva, podendo ser caracterizada como:

[...] néologie de forme et néologie de sens. Dans le deux cas, il s'agit de dénoter une réalité nouvelle (nouvelle technique, nouveau concept, nouveaux realia de la communauté linguistique concernée). La néologie de forme consiste à fabriquer pour ce faire de nouvelles unités ; la néologie de sens consiste à employer un signifiant existant déjà dans la langue considérée en lui conférant un contenu qu'il n'avait pas jusqu'alors - que ce contenu soit conceptuellement nouveau ou qu'il ait été jusque-là exprimé par un autre signifiant. (DUBOIS, 2002, p. 322) 222 $^{22}$

Esses dois aspectos da neologia podem ser facilmente identificados no interior dos dados utizados neste trabalho. Por exemplo, a neologia de forma pode ser identificada nos seguintes neologismos (com novos significantes) ikomyru 'sutiã dela' e iapyakwara'yma'e 'lanterna dele'; já a neologia de sentido, nos neologismos (com nova relação significantesignificado) so kytykawa 'ralador de castanha' (o tronco da paxiúba) $\rightarrow$ 'liquidificador', e tukurupipina 'grilo' $\rightarrow$ 'moto'.

Já nesses primeiros dados é possível entrever que a neologia não é exatamente um processo fundado somente em aspectos denotativos da linguagem, mas que perpassa por mecanismos de natureza metafórica. Assim, identificou-se, por exemplo, que a língua Suruí, para nomear o veículo 'trator' buscou dois elementos presentes em seu léxico, moj 'cobra' e kyse 'faca', ambos selecionados com base em características que se associam de algum modo ao trator, tais como 'deixar rastro ao passar' (como a cobra) e 'ser capaz de cortar' (como a faca), correspondência essa que é estabelecida em um processo metafórico. ${ }^{223}$

Logo, se há uma relação entre neologia e metáfora, a descrição dos principais processos envolvidos na construção de neologismos pode ser útil para evidenciar essa relação. Para tanto, buscamos identificar os neologismos da língua Suruí com base na tipologia

\footnotetext{
${ }^{221}$ Apesar de os primeiros registros escritos dessa língua datarem de meados da década de 1980 com as iniciativas do Conselho Indigenista Missionário (CIMI), da pesquisadora Ruth Monserrat, do Museu Nacional do Rio de Janeiro, e dos Graham, ligados ao Summer Institute of Linguistics (SIL), o ensino sistemático da escrito não tem nem 5 anos e ainda está bem restrito ao contexto formal de sala de aula.

${ }^{222}$ Tradução: "[...] neologia de forma e neologia de sentido. Nos dois casos, trata-se de denotar uma realidade nova (nova técnica, novo conceito, novas realidades da comunidade linguística considerada). A neologia de forma consiste em fabricar por esse fazer novas unidades; a neologia de sentido consistem em empregar um significante já existente na língua considerada, conferindo-lhe um conteúdo que ela não tinha até então -- que esse conteúdo seja conceptualmente novo ou que ele tenha estado até então expresso por outro significante" (tradução nossa).

${ }^{223}$ Também foi registrada junto aos Suruí outra explicação para a construção moj kyse. Segundo eles, "ao abrir caminhos na reserva Suruí, o trator, além de cortar o mato, cortava também as cobras que nele se encontravam", ou seja, o trator seria um "cortador de cobra".
} 
proposta por Guilbert (1975, p. 17-24), segundo a qual os neologismos podem ser classificados como: fonológicos, sintáticos, semânticos, além do empréstimo. No entanto, observando o conjunto de dados da língua Suruí (e os próprios dados presentados pelo autor), constatamos a necessidade de extrair da categoria da sintaxe outra categoria que denominamos morfológica. Durante essa classificação dos dados, busco evidenciar, sempre que possível, o papel da metáfora enquanto fonte importante de neologismos nessa língua.

\subsection{Classificação dos dados relacionados à neologia}

O neologismo, que está sujeito à lógica de funcionamento da língua em que ele surge, segundo Gilbert (1973, p. 18), deve ser apreendido em sua dupla face (significantesignificado), além disso, sua criação se baseia no relacionamento de elementos mais simples presentes na língua e nesse processo deve ser levado em consideração o aspecto escrito da língua. Esta última afirmação só é válida para línguas que já tenham alguma tradição de escrita, o que não é o caso da maioria das línguas indígenas no Brasil.

Baseado nesses princípios, o mesmo autor estabelece uma tipologia baseada na fonologia, na sintaxe e na semântica, incluindo ainda os empréstimos linguísticos.

- Neologia fonológica

A ocorrência de dados nessa primeira categoria do processo de neologia é, segundo o autor, extremamente rara, porque exige uma substância fonológica inédita associada a uma significação também inédita. Nesse caso, de acordo com Gilbert (1973, p. 19), "Le stock des formations onomatopéiques qui transposent dans une forme linguistique arbitraire les bruits naturels ou les cris des êtres animés est très réduit". ${ }^{224}$ Essa afirmação é válida para a língua Suruí, pois identifiquei, no interior do corpus selecionado, apenas um dado que pode corresponder ao que se prevê para essa categoria, trata-se do seguinte dado.

\section{4 kitikiti}

kiti-kiti- $\varnothing$

riscar (cortando)-RED-ARG

'risca-risca'

'serrote de carpinteiro'

O caráter onomatopaico desta construção neológica, presente já na base, é reforçada com a reduplicação dessa base.

\footnotetext{
224 Tradução: “O conjunto de formações onomatopaicas que passam para uma forma linguística arbitrária os barulhos naturais ou os gritos dos seres animados é bastante reduzido" (tradução nossa).
} 
- Neologia morfológica

Nessa categoria incluo apenas alguns dos neologismos presentes no corpus formados a partir de "combinações de elementos preexistentes na língua" (GUILBERT, 1975, p. 19, tradução nossa). Para esse autor, tal combinação pode se dar tanto com uma construção do tipo base e afixo, quanto com estrutura de natureza frástica.

No entanto, neste trabalho, como faço a distinção entre Neologia Morfológica, para construções do tipo base e afixo, reservamos os dados frásticos para a seção de Neologia Sintática. A seguir, apresentamos os dados separados de acordo com essa tipologia.

- Base + sufixo

Essa combinação de base + sufixo é bastante comum na língua Suruí.

\section{5 sumi'ahu}

sumi?a-hu

flauta (tipo)-INTENS

'flauta (tipo) grande'

'avião'

Sumi'a é uma flauta tradicional da cultura Suruí, fabricada com bambu (takwara), cabaça (kuipi) e cera de sawtipyta (espécie de abelha), com um tamanho aproximado de meio metro. O avião, por emitir um som constante como o dessa flauta, passou a ser designado pelos Suruí com o mesmo nome do instrumento musical com o sufixo intensivo $-h u$, o que corresponde a uma "grande flauta" sumi'a.

\section{6 misakatirona}

misakati(y)-ron-a

veado.fedorento (=burro)-SML-ARG

'que parece um burro'

'boi', 'vaca'

Os Suruí aproveitaram a denominação atribuída ao burro para construir, por grau de semelhança, a forma para boi (e vaca), acrescentando-lhe um sufixo para distinguir as formas.

\section{7 misarona}

misa(r)-ron-a

veado-SML-ARG

'que parece com veado'

'cabra', 'ovelha', 'bode' 
Com um processo similar ao que formou misakatiron, foi constituída a palavra misaron para designar cabra e seus congêneres, bode e ovelha. Assim, por haver grande semelhança na forma desses animais, a maneira de distingui-los foi acrescentar o sufixo -ona.

- Prefixo + base / prefixo + base + sufixo

No conjunto de dados que analisamos não foi encontrada, até o momento, nenhuma ocorrência de combinação do tipo prefixo + base.

- Neologia sintática

- Composição

Estabelecida sob duas perspectivas, a composição poderia ser construída, inicialmente, com base em elementos de línguas-fonte (como o Latim e o Grego com relação ao Português) associados a elementos da língua em uso (com formas livres e/ou presas de um lado e de outro). Isso exigiria do falante um conhecimento razoável não só do funcionamento de cada uma dessas línguas, mas principalmente de como elas se relacionariam com a línguaalvo.

No caso das línguas da família linguística Tupí-Guaraní, nas quais a oralidade (sem uso efetivo do aspecto escrito) é ainda uma realidade predominante dos povos indígenas, logo, não há como recorrer a línguas-fonte, apesar de haver registros de línguas dessa família que datam do século XVI.

Já o segundo modelo de composição se refere a "uma combinação de duas palavras autônomas com relação à função gramatical na frase" (GUILBERT, 1975, p. 19, tradução nossa). Portanto, as combinações possíveis nessa tipologia são: verbo + substantivo; substantivo+ substantivo; substantivo + adjetivo. Mas, neste trabalho, adoto as combinações nome + verbo (ainda sem registros) e nome + nome, porque na língua Suruí nomes podem ser determinados por outros nomes: nome referencial, pronome pessoal ou pronome demonstrativo. Quando um nome é determinado por outro nome, a relação pode ser de natureza determinativa de uma propriedade ou de natureza possessiva.

- NOME + NOME

188 ma'ea potawa

ma?c-a Ø-pot-aw-a

coisa-ARG $\quad \mathrm{R}^{1}$-ferver-NMLZ-ARG 
'o instrumento para cozinhar (ferver)'

'fogão'

Descreve-se com a forma genérica $m a^{\prime} e$ o objeto a partir de sua função.

189 arupo

aru po
sapo (esp.) mão
'mão do sapo (esp.)'
'rastelo', 'garfo'

Aru é uma espécie de perereca que vive na água e é muito comum na região. Ela é verde, possui pernas e dedos alongados, comparados com os longos dentes do rastelo (ancinho) e do garfo.

190 wyrahua tia

wirahu-a ti-a

pássaro (esp.)-ARG bico-ARG

'bico do pássaro (esp.)'

'tesoura'

Segundo informação de Muretama e Tymykong, wyrahu é um pássaro grande (parecido com uma garça) com um bico bastante comprido e grosso, e que vive no rio. $\mathrm{O}$ movimento de abertura e fechamento do bico desse pássaro lembra o movimento de corte de uma tesoura. Variante: tyrykwera munohokawa.

191 'ar-a kwahapara

Par-a Ø-kwaha-par-a

dia-ARG $\mathrm{R}^{1}$-saber-NMLZ-ARG

'o sabedor do dia'

'relógio'

É atribuída uma qualidade ao relógio, ter conhecimento do dia (mas também da noite, tanto que é possível substituir ara por ipituna).

- Derivação sintagmática

Neste tipo de neologia sintática, incluímos todos os dados que são: 
[...] formações caracterizadas por uma transposição direta da sequência sintagmática de frase em unidade lexical sem nenhuma marca exterior da transformação que acontece essencialmente no plano do significado. [...] Nesta categoria podemos incluir os diversos tipos de locuções, verbais, adverbiais, preposicionais.

Trata-se, portanto, do tipo mais descritivo, mas não menos metafórico.

\section{2 akuti nami pe pytukawa}

akuti nami pe pituk-aw-a

cutia ouvido dentro que.fura-NMLZ-ARG

'[o osso] que fura dentro do ouvido da cutia'

'laranja'

O osso que fica dentro do ouvido da cutia tem uma forma que se assemelha à da semente da laranja (mas também das frutas congêneres como limão e tangerina).

- Neologia semântica

Como o processo da neologia semântica se opera no âmbito dos traços ou semas, não há, a princípio, nenhuma alteração no significante do lexema. Além disso, segundo Guilbert (1975, p. 21), essa significação também se estabelece por meio da categoria gramatical no contexto sintático e pelo uso da língua no próprio contexto sociocultural do falante.

193 so kytykawa

so kitik-aw-a
castanha ralar-NMLZ-ARG
'ralador de castanha'
'paxiúba' $\rightarrow$ 'liquidificador'

Descreve-se a principal função do objeto: ralar (esfregar) a castanha-do-pará, fruto de grande importância para a alimentação e para a economia do povo Suruí.

194 ma'ea kytykawa

ma?c-a akitik-aw-a

coisa-ARG ralar-NMLZ-ARG

'ralador de coisa'

'liquidificador' 
A forma mais antiga é so kytykawa, porque os mais velhos usavam o tronco da paxiúba como ralador de castanha-do-pará.

\title{
195 taratirating
}

taratiratin- $\varnothing$

libélula-ARG

'libélula'

'helicóptero'

A associação entre o animal e o objeto está na semelhança da forma e do movimento rápido das asas da libélula com a forma e o movimento das hélices horizontais do helicóptero.

\section{6 tukurupipina}

tukurupipin-a

grilo-ARG

'gafanhoto', 'grilo'

'moto'

A palavra tukurupipina passou a designar também a motocicleta por esta ser percebida pelos Suruí como semelhante a um grilo ou gafanhoto.

\section{- Neologia por empréstimo}

Outro tipo de neologia, bastante comum em situações em que há contato linguístico, é o empréstimo, ou seja, retira-se um signo de seu contexto linguístico original e o transfere, com as devidas adaptações fonéticas, morfológicas (e/ou gráficas se a língua não for ágrafa). No caso da língua Suruí, os empréstimos mais comuns são tomados do Português. ${ }^{225}$

\author{
197 Perẽj \\ perẽ j- $\varnothing$ \\ Belém-ARG \\ 'Belém' \\ '(cidade de) Belém'
}

\footnotetext{
${ }^{225}$ A língua portuguesa foi introduzida na comunidade Suruí logo após o contato há mais de 60 anos. Nesse período, o povo passou de uma situação de monolinguismo na língua Suruí a uma situação de bilinguismo com o Português. Atualmente, as novas gerações (com menos de 20 anos) já são monolíngues em Português, e poucos são os jovens capazes de, ao menos, compreender a língua de seus antepassados.
} 
A palavra Belém, usada em Português, foi adaptada foneticamente para a língua Suruí, ou seja, houve a substituição da consoante oclusiva sonora pela sua homorgânica, ao mesmo tempo em que foi mantida a aproximante final (que é representado pela letra j)

Por fim, é possível constatar diante desses dados a grande importância dos processos de neologia para a língua Suruí, e como eles sinalizam que, mesmo em situação de vulnerabilidade linguística, o povo Aikewára, assim como muitos outros no mundo, pela manutenção de seu conhecimento, de sua história e de seu mundo.

\subsubsection{A macroestrutura do dicionário da língua Suruí}

Se, no caso de um dicionário eletrônico, a questão do ordenamento pode ser, de certo modo, até irrelevante, devido à existência de motores de busca eficientes que recuperam a informação de qualquer ponto do conjunto de dados e o apresentam estruturado para o usuário, o mesmo não acontece no caso dos dicionários impressos, cuja ordenação fixada é um ponto crucial para o sucesso (entenda-se aqui eficiência) da obra lexicográfica.

A macroestrutura de uma obra lexicográfica é, segundo Rey-Debove (1971, p. 21), "l'ensemble des entrées ordonnées, toujours soumise à une lecture verticale partielle lors du repérage de l'objet du message". 226

Nesse sentido, o estabelecimento de uma ordenação deve ser feito em função do público a que se destina o material e também das condições materiais de publicação da obra, sem esquecer, é claro, dos objetivos estabelecidos no próprio PDL que originou es se material.

Mas, não é difícil perceber que a forma mais conhecida de ordenação de um material lexicográfico, sobretudo dicionários, é ainda a que obedece à sequência de letras do alfabeto, tanto que, ao definir o termo dicionário como " [...] a book containing a selection of the words of a language, usually arranged alphabetically, with information about their meanings, pronunciations, etymologies, inflected forms, etc., expressed in either the same or another language" (The Macquarie Dictionary, 1997, p. 598 apud YONG \& PENG, 2007, p. 2 , grifo nosso), ${ }^{227}$ essa forma de ordenamento é destacada como a mais usual.

Apesar de essa forma de ordenamento ser considerada por muitos como canônica, não é, porém, a única possibilidade de apresentação dos lemas, pois um dicionário pode ser

\footnotetext{
226 Tradução: “o conjunto das entradas ordenadas, sempre submetido a uma leitura vertical parcial enquanto local do objeto da mensagem" (tradução nossa).

227 Tradução: "um livro contendo uma seleção das palavras de uma língua, geralmente organizadas em ordem alfabética, com informações sobre seus significados, pronúncias, etimologias, formas flexionadas, etc., expressos na mesma ou em outra língua" (tradução nossa).
} 
organizado com base em critérios semânticos, ou a partir da frequência de uso das palavras (do mais frequente para o menos frequente e vice-versa), das categorias gramaticais, entre outros. Ademais, até mesmo essa ordem alfabética clássica pode variar, sendo dada de duas maneiras:

[...] directa, esto es aplicando la alfabetización desde la primera a la última letra de cada palavra-entrada, o bien inversa, o lo que es lo mismo, realizando la alfabetización en sentido contrario, desde la última letra à la primera, lo que como se recordará, da nombre precisamente a los diccionarios inversos. (PORTO DAPENA, 2002, p. 178). ${ }^{228}$

Outra forma comum de ordenamento da macroestrutura de uma obra lexicográfica, encontrado com relativa facilidade no conjunto de UBL's das línguas indígenas brasileiras, é a que ordena os dados com base em critérios semânticos. Por exemplo, o Pequeno Dicionário por Assuntos: Asuriní do Xingu/Asuriní de Trocará-Português, de Nicholson (1982), o Dicionário temático canela-krahô e português, de Popjes e Popjes (1982) e o Dicionário por Tópicos Urubu-Kaapor-Português, de Kakumasu (1988). Em muitos desses materiais o ordenamento é feito em subconjuntos estabelecidos com base, por exemplo, em campos semânticos, ou seja, são estabelecidos grupos de palavras (em geral, ordenadas alfabeticamente) inseridas em conjunto de temas ordenados, por sua vez, por outros critérios nem sempre explicitados pelo(s) autor(es) do material. ${ }^{229}$

Nesse sentido, é importante destacar a importante contribuição do South American Indian Languages Documentation Project (SAILDP), de Kaufman, Berlin e Rodrigues (1985), por meio do qual foi proposto um extenso questionário ordenado onomasiologicamente totalmente voltado para a sistematização de dados de línguas indígenas. $\mathrm{Na}$ versão original desse questionário, ele continha grupos numerados organizados a partir dos seguintes grandes temas: mineral; relevo; hidrografia; água; clima; tempo (cronologia, estação); ar; fogo; existência; flora; planta, vegetal, hortaliça; árvore frutífera, fruto; erva; plantas rasteiras e trepadeiras; plantas magnoliófitas; plantas angiospermas; parentesco; idade; corpo; animal (geral); mamífero; ave; réptil e anfíbio; animal aquático; animal de pequeno porte; doença; sentido (visão); sentidos (audição, olfato e paladar); sentido (tato); miscelânea; forma (dimensões); qualidade, ação; comunicação (nome/ação); no rosto (nome/ação); poder/posse (nome/ação); religiosidade; diversão; quantidade, tempo; forma geométrica;

\footnotetext{
${ }^{228}$ Tradução: “[...] direta, isto é, aplicando a ordem alfabética da primeira à última letra de cada palavra-entrada, ou ainda inversa, o que é o mesmo, realizando o ordenamento alfabético em sentido contrário, da última letra até a primeira, o que, como se deve lembrar, dá nome exatamente aos dicionários inversos." (tradução nossa).

${ }^{229}$ A título de exemplo, o dicionário de Nicholson (1982) possui os seguintes temas para os grupos, dentro dos quais são ordenados os itens lexicais: "Topografia, solos e terra, céu e corpos celestes, clima e temperatura, água, animais, plantas, tempo, numerais e quantidade, dimensões e forma".
} 
posição do corpo; movimento; meio de transporte; necessidade fisiológica; ingestão (de alimentos); alimento (tipo, preparo); lavrar; guerra; moradia, práticas do cotidiano; vestuário; mão/pé (nome/ação); localização; gramática. ${ }^{230}$

Um documento como esse produzido pelo SAILDP pode ser uma importante referência no momento de se produzir dicionários que tenham macroestrutura ordenada por assuntos, haja vista que a proposta desse questionário lexical é resultado da experiência de seus autores, que realizaram pesquisas durante muitos anos junto a diferentes povos falantes de diversas línguas em várias partes do mundo. Dado o valor dessa proposta, ela foi inserida no programa Línguas a fim de permitir o ordenamento dos dados lexicais também por meio dela.

Feitas essas considerações acerca das possibilidades de ordenamento da macroestrutura dos materiais lexicográficos, passo a tratar especificamente da estruturação do dicionário da língua Suruí.

Para a proposta de dicionário apresentada neste trabalho, opto pelo uso da ordem alfabética como forma de ordenação dos verbetes, inicialmente porque se trata de um critério que, hoje, já é conhecido pela maioria dos Suruí que possuem alguma escolaridade ${ }^{231}$ e que já tiveram contato com materiais lexicográficos em Português na escola da aldeia.

Nada impede, contudo, que sejam projetados outros materiais cuja ordenação seja estabelecida com base em critérios semânticos, sintáticos, pragmáticos ou outros. ${ }^{232}$

Desse modo, ao definir a ordem do dicionário a partir das letras do alfabeto latino como ponto de orientação da macroestrutura do material, inclusive com a mesma lógica de ordenação para todos os níveis (a primeira letra da entrada do verbete é quem rege a sua posição, porém, caso haja mais de uma forma com a mesma letra, passa-se imediatamente à segunda letras, e assim sucessivamente até não haver mais coincidência); não se resolveram ainda todas as questões acerca da ordenação da macroestrutura: na direção Português-Suruí, o ordenamento pelo alfabeto pode ser pleno, isto é, as 26 letras podem definir 26 grupos de verbetes (de A a Z); já na direção Suruí-Português, o ordenamento limita-se a 19 grupos de verbetes (cf. Capítulo 4 sobre a proposta de escrita para a língua Suruí), sendo que há entre

\footnotetext{
${ }^{230}$ Para uma discussão mais detalhada sobre esse documento, cf. Lopes (2011).

231 Estas primeiras versões do dicionário da língua Suruí são experimentais, mas já se entrevê o uso desse material, com os devidos ajustes, é claro, no contexto da escola Suruí, tanto para a leitura quanto para a escrita da língua.

${ }^{232}$ Como já mencionei, os dados armazenados no programa Línguas permite a construção automática de uma série de materiais lexicográficos com diferentes configurações de microestrutura e com diferentes possibilidades de ordenamento (cf. Capítulo 9 sobre a apresentação dessas propostas).
} 
eles uma consoante glotal [?], representada ortograficamente na língua Suruí pela aspa simples direita (' ). Como se trata de uma consoante oclusiva, sigo, neste dicionário, a mesma proposta de Cabral e Rodrigues (2003, p. xxiii) para o ordenamento da glotal no Dicionário da Língua Asuriní do Tocantins: ela está posicionada logo após a também consoante oclusiva $k w$.

Há de se observar, todavia, que o ordenamento automático proposto pelo programa Línguas leva todas as palavras iniciadas por glotal nessa língua (ou seja, iniciadas com um sinal de pontuação) para a posição inicial da ordem, e que o deslocamento de todo esse grupo deverá ser feito manualmente nesta proposta.

\subsubsection{A microestrutura do dicionário da língua Suruí}

A microestrutura de uma obra lexicográfica é, segundo Rey-Debove, “[...] l'ensemble des informations ordonnées de chaque article, réalisant un programme d'information constant pour tous les articles, et qui se lisent horizontalement à la suite de l'entrée" (1971, p. 21). ${ }^{233}$

Nessa definição, fica claro que uma microestrutura de uma obra lexicográfica é organizada com diferentes componentes para fornecer informações sobre a palavra que está na posição de Lema. Deve-se considerar, no entanto, que essa definição apreende a microestrutura em sua virtualidade, ou seja, parte-se de uma estruturação mais abrangente possível dela, e, mesmo que os verbetes reais, no corpo do dicionário, por exemplo, não contenham exatamente todos os componentes descritos, o usuário, conhecendo a estrutura completa, facilmente interpretará formas e funções de todos os componentes que se apresentarem diante dele.

Completando essa informação, cito também outra perspectiva sobre a microestrutura apresentada por Hartmann \& James (2002, p. 94)

The internal design of a reference unit. In contrast to the overall word-list (macrostructure), the microstructure provides detailed information about the headword, with comments on its formal and semantic properties (spelling, pronunciation, grammar, definition, usage, etymology). If the headword has more than one sense, the information is given for each of these (sublemma). Dictionaries vary according to the amount of information they provide, and how they present it in the text of the entry. ${ }^{234}$

\footnotetext{
233 Tradução: “[...] o conjunto das informações ordenadas de cada verbete, realizando um programa de informação constante para todos esses verbetes, e que se lê horizontalmente após a entrada" (tradução nossa). 234 Tradução: "O design interno de uma unidade de referência. Em contraste com a lista de palavras (macroestrutura), a microestrutura fornece informações detalhadas sobre a palavra-entrada, com comentários sobre suas propriedades formais e semânticas (grafia, pronúncia, gramática, definição, uso, etimologia). Se a palavra-entrada tem mais de um sentido, a informação é dada para cada uma delas (sublema). Dicionários variam
} 
Já esses autores evidenciam algumas das informações que podem ser apresentadas em uma microestrutura, como grafia, pronúncia, gramática, definição, usos e etimologia. ${ }^{235}$ Além disso, eles buscam associar a variação dos tipos de dicionários aos diferentes tipos de microestrutura.

A partir da análise de microestruturas das UBL's das línguas indígenas brasileiras (cf. Capítulo 7), foi possível constatar, além dos aspectos acima mencionados, algumas particularidades das configurações de uma microestrutura, tais como: apesar de, em geral, os Operadores se relacionarem ao Lema, alguns deles podem se relacionar ao Descritor e, mais raramente, ao componente Exemplo; mesmo sendo o Lema o componente ordenador de uma microestrutura, ele pode não representar o ponto de referência para todo o conteúdo do verbete, cabendo este papel, por exemplo, ao Descritor. ${ }^{236}$

Feitas essas considerações sobre a natureza da microestrutura de uma obra lexicográfico, passo ao tratamento da microestrutura do dicionário da língua Suruí.

No banco de dados da língua Suruí desenvolvido para o PDL desta tese, as informações armazenadas nele não apresentam ainda a configuração final nem da microestrutura nem da macroestrutura de uma obra lexicográfica específica, pois os campos criados no programa Línguas foram projetados para receber uma grande variedade de informações linguísticas e metalinguísticas acerca dos componentes do léxico, dos enunciados e até dos textos documentados da língua Suruí. Dessa maneira, tornou-se possível construir diferentes tipos de obras lexicográficas a partir de uma mesma base de dados linguísticos. ${ }^{237}$

Assim, uma vez concluídas as etapas de alimentação do banco de dados, análise da fonologia e morfossintaxe da língua Suruí e da sistematização dos modelos lexicográficos para essa língua, passei à fase de modelação e compilação da proposta em si do dicionário dessa língua da família Tupí-Guaraní. ${ }^{238}$

de acordo com a quantidade de informação que fornecem e como a apresentam no texto do verbete." (tradução nossa).

${ }^{235}$ Com exceção da definição, todos os demais componentes citados nessa lista foram denominados, neste trabalho, Operadores. Já a definição foi denominada Descritor. (cf. Capítulo 7).

${ }^{236}$ Essa situação pode ocorrer em situações de o Descritor, os Operadores e o Exemplo estarem todos na língua indígena e somente o Lema na língua não indígena. Nesse caso, seu papel pode ser apenas o de ordenador da macroestrutura.

${ }^{237}$ A inserção dos dados no programa Língua não segue nenhuma ordem predefinida, pois o programa permite o registro dos termos de maneira aleatória (no sentido de não exigir, por exemplo, a obediência a uma ordem alfabética ou por assunto), cabendo, assim, ao próprio sistema ordenar os conjuntos de informações que forem sendo inseridos de acordo com o material a ser produzido a partir dele.

${ }^{238}$ Denomino modelação de uma obra lexicográfica toda a reflexão acerca do projeto de construção do material, ou seja, da seleção de conteúdos ao projeto gráfico a ser usado na versão impressa ou digital da obra. Já compilação se refere à aplicação dessa modelação aos dados reunidos na base lexical a fim de gerar (automaticamente ou não) o material em si. 
Quanto à modelação da proposta, ela foi planejada e executada ao longo do projeto, e está sendo apresentada neste capítulo, já a compilação, ele deve ocorrer de modo automático, baseado no recurso de geração de materiais do programa Línguas. ${ }^{239}$

Assim, por se tratar de um dicionário da língua Suruí que terá duas direções, ou seja, da língua Suruí para o Português e do Português para o Suruí, foi necessário decidir que tipos de modelos seriam mais adequados para cada um deles.

No primeiro caso, em que o Lema é ocupado pela língua Suruí, acredito que as possibilidades de utilização de Operadores seja maior, haja vista ser ela a língua objeto deste estudo. Por isso, dentre os modelos apresentados no Capítulo 9, selecionei os do tipo MODO e MODOE, por serem as estruturas que melhor se adequam aos dados coletados pela pesquisa da língua Suruí e já armazenados no programa de banco de dados. Além disso, há de se destacar que a opção por dois modelos, cuja diferença está apenas no componente Exemplo, se deve em virtude de haver entradas do dicionário que ainda não possuem exemplos registrados. Logo, partindo desse modelo, proponho a seguinte EML para orientar a construção da proposta de microestrutura do dicionário na direção Suruí-Português:

$$
\text { LId: Fn, Gr, Hm, Rm, Vr }\{\mathrm{DPt}(\mathrm{Na}, \mathrm{Vr})(-\mathrm{DLt})[\mathrm{EId} / \mathrm{EPt}]\}^{240}
$$

Dentre os Operadores já observados e descritos no Capítulo 7, selecionei aqueles que considerava mais relevantes para constituir a proposta atual. Assim, relacionados ao LId estão Fn, Gr, Hm, Rm e Vr; ao DPt, apenas o Operador Na; e aos componentes DLt, EId e EPt, nenhum Operador.

Já a proposta para o dicionário com a direção Português-Suruí não requer todos os elementos do modelo usado na primeira proposta, por colocar o Português na posição de Lema, dispensando, por exemplo, o Operador Fn. Assim, proponho o uso dos modelos MOD e MODE, com a seguinte configuração de EML:

$$
\text { LPt: Na, Rm, Vr }\{\text { DId (Hm, Vr) (-DLt) }[\mathrm{EPt} / \mathrm{EId}]\}^{241}
$$

\footnotetext{
${ }^{239}$ Essa programação implica na construção de um novo modelo de dicionário, que pode ser feito a partir de um dos arquivos já existentes configurados para esse fim. Para realizar essa configuração personalizada, na atual versão do programa Língua, é necessário possuir algum conhecimento sobre banco de dados, programação de macros do tipo VBA para Microsoft Office e também uso de mala-direta personalizada.

${ }^{240}$ Apresento, por uma questão de economia, apenas a EML do modelo MODOE, mas deve-se considerar que ela já comporta todos os elementos do modelo MODO.

241 A mesma justificativa apresentada na nota 239 vale para esse novo contexto. Assim, considero que a descrição do modelo MODE já contempla os elementos do modelo MOD.
} 
Nesse modelo, há três Operadores, o Na, o Rm e o Vr, relacionados ao LPt; os Operadores Hm e Vr relacionados a DId, DLt; enquanto os componentes EId e EPt não recebem nenhum Operador.

É importante esclarecer que a decisão por esses modelos lexicográficos também está baseada em um dado observado no capítulo 9 em que analisei as UBL's das línguas indígenas brasileiras: os modelos MODO/MODOE e MOD/MODE são os que contêm as mais altas taxas de ocorrência no conjunto das UBL's do tipo dicionário.

Essas microestruturas tanto da primeira quanto da segunda proposta podem ser geradas e ordenadas automaticamente para cada um dos materiais, a partir dos recursos do programa Línguas. A seguir, passo à descrição de cada uma dessas propostas.

\subsection{A microestrutura do dicionário Suruí baseada no modelo MODOE ${ }^{242}$}

Ao decidir pelo uso de determinado modelo para apresentação da microestrutura de uma obra lexicográfica, deve-se ter em mente que se trata de uma proposta sujeita a variações na forma quando de sua utilização na obra em si. Nesse sentido, um componente como o DLt somente poderá ocorrer em verbetes relacionados a nomes de animais e plantas.

Antes de passar à apresentação dessa proposta, é importante esclarecer ainda que a denominação bilíngue atribuída a esse dicionário pode estar sujeita a discussão, pois, ao envolver um Descritor, o DLt, que ocorre apenas eventualmente, não estaria incorreto afirmar que a obra tem um caráter multilíngue.

Conforme apresentado acima, essa microestrutura para o dicionário da língua Suruí contém um conjunto de elementos inter-relacionados, segundo estabelecido na modelação desse material. A fim de demonstrar ainda com mais clareza as relações dessa estrutura, retomo os componentes da EML e apresento-a sob a forma de um gráfico, destacando, principalmente, a hierarquia existente entre esses componentes (cf. Figura 237).

Uma vez estabelecido o modelo e sua EML, passo a descrever a forma de cada um dos componentes da microestrutura do dicionário da língua Suruí.

As unidades lexicais da língua Suruí serão colocadas na posição de Lema do verbete, também é denominada entrada ou cabeça do verbete, e será apresentada sempre em negrito, com o tipo Times New Roman, tamanho 13, com recuo de 0,25cm a partir da segunda linha.

\footnotetext{
${ }^{242}$ Doravante, menciono apenas o maior modelo usado em cada dicionário, mas considerando as observações feitas nas notas 240 e 241.
} 

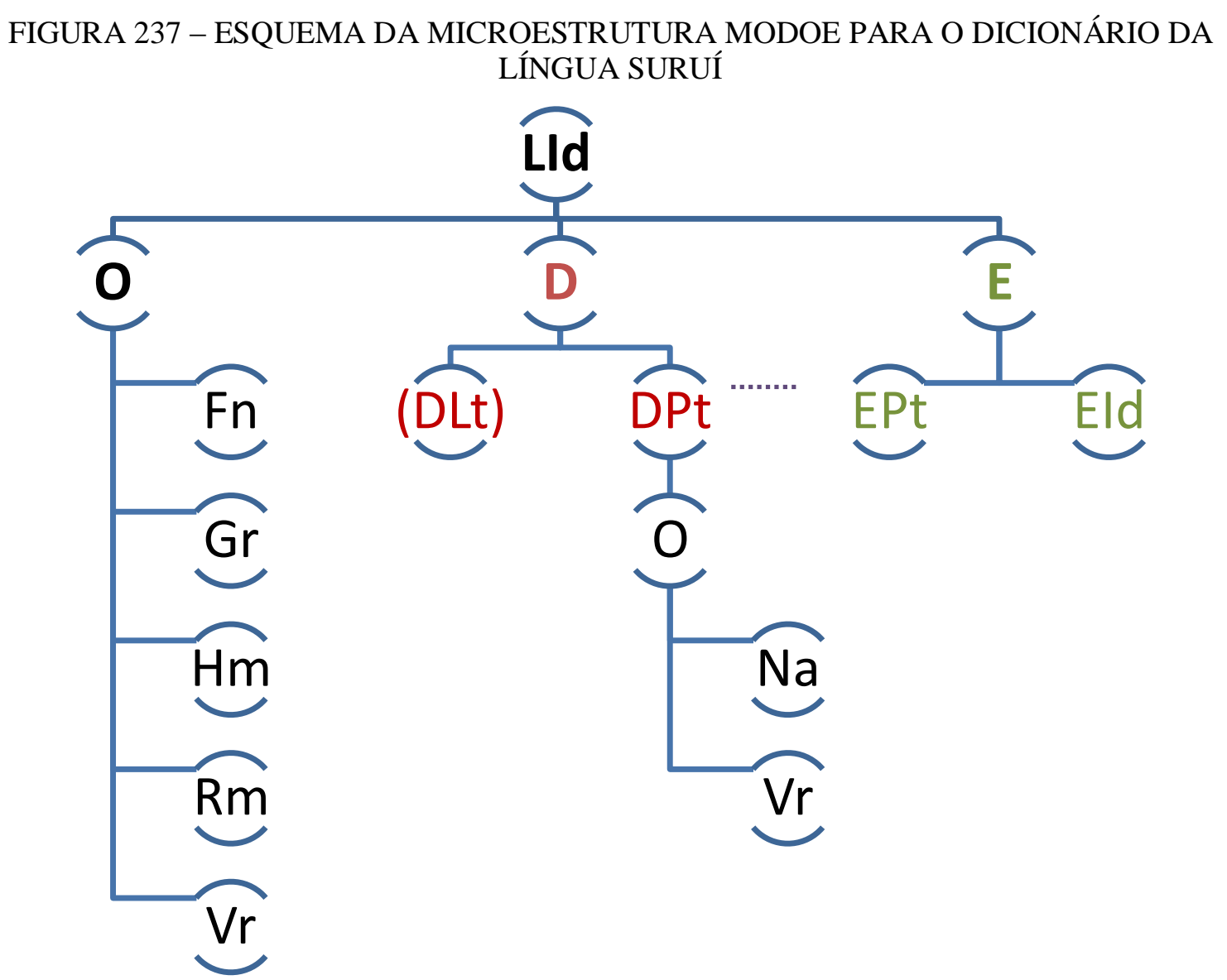

O primeiro Operador a ser usado na microestrutura pode ser o do tipo $\mathrm{Hm}$, inserido junto ao LId na forma sobrescrita. Como sua função é marcar a ocorrência de formas homônimas, seu uso restringe-se a essas situações.

Já as formas variantes (de forma e de sentido) serão apresentadas logo após a entrada, destacada entre parênteses e antecedida pelo sinal diacrítico til ( ). Há de se destacar que, até o ponto alcançado pela pesquisa, poucas formas variantes foram identificadas.

Quanto ao Operador Fn, relacionado a registros de pronúncia no verbete, é representado, nesta proposta, pela forma fonológica da língua. Utilizando o alfabeto fonético internacional, ele é colocado entre barras oblíquas, logo após o LId ou o Operador Vr, se este constar no verbete. A principal função desse Operador, neste dicionário da língua Suruí, é atender a um público especializado de linguistas e antropólogos, mas que pode ser perfeitamente usado pelos próprios falantes da língua Suruí ou os que estiverem aprendendo essa língua, principalmente as pessoas mais jovens da comunidade que estejam ainda na escola.

Outro importante item dessa microestrutura é a indicação da categoria gramatical do LId. Apresentado de forma abreviada e em itálico, é colocado logo depois do Operador Fn. 
Antes da apresentação do dicionário, apresento a lista completa de abreviaturas usadas no interior dos verbetes. ${ }^{243}$

O último Operador relacionado diretamente ao LId é o do tipo Rm. Este Operador é colocado sempre no final do verbete, e apresenta a seguinte configuração: um marcador na forma de uma figura quadrada precede a palavra Suruí eisag 'ver' e, depois dela, há uma seta apontando para a direita. Esse Operador deve ser usado para remeter, por exemplo, a formas hiperônimas ou hipônimas (do verbete katinkwer 'veado-virá' para o verbete misar 'veado'), mas também a formas que se relacionem para constituir um agrupamento (do verbete 'og 'casa' para 'ogete 'casa tradicional' e tapyj 'tapiri'). ${ }^{244}$

Outro importante componente da microestrutura é o Descritor, que, nesse modelo, envolve duas línguas, o Português, que é de uso obrigatório nessa proposta, e o Latim, que só será usado para indicar o nome científico de plantas e animais. O DPt é apresentado sem nenhum efeito gráfico, logo após o Operador Gr. Já o DLt, quando usado, deve vir sempre com efeito itálico, seguindo ou o DPt ou o Operador Na.

O DPt se relaciona com dois Operadores nessa proposta, um do tipo $\mathrm{Na}$ e outro Vr; o primeiro tem a função de completar ou especificar a informação contida nesse Descritor; já o segundo pode conter variantes de forma ou de sentido. Esses Operadores sempre são apresentados entre parênteses logo após o DPt.

Os dois últimos componentes dessa microestrutura são EId e EPt. O primeiro é precedido pela palavra ajnon 'exemplo' seguida de dois pontos. Apenas o EPt é destacado com efeito itálico e ele vem logo após o EId. Como já comentei, a informação presente se refere a enunciados na língua Suruí, colhidos em textos de diferentes gêneros, desde conversas até cantos e mitos. Além disso, há enunciados que foram produzidos especificamente para serem usados no contexto do dicionário.

Concluídas essas explicações, apresento, a seguir, alguns exemplos de microestruturas extraídas do dicionário da língua Suruí.

\footnotetext{
${ }^{243}$ Como a língua Suruí não marca nos nomes a informação de gênero (masculino, feminino ou neutro), a informação a ser acrescida na abreviatura da categoria nome (n.) é a que se refere ao tema da palavra (cf. subseção 6.1 referente à morfologia da língua Suruí).

${ }^{244}$ Mesmo neste caso de agrupamento existe também a possibilidade de se perceber uma relação de hiperonímia.
} 
FIGURA 238 - EXEMPLO 1 DE MICROESTRUTURA USADA NO DICIONÁRIO DA LÍNGUA SURUÍ

katinkwer ( pakwohow) /katijwer/ n.III veado-catingueiro (veado-virá), Mazama gouazoubira. • Eisag $\rightarrow$ misara

FIGURA 239 - EXEMPLO 2 DE MICROESTRUTURA USADA NO DICIONÁRIO DA LÍNGUA SURUÍ

ma'esawar /ma?esa'war/ n.III cachorro. Ajnon: unupo ma'esawara ele bate no cachorro $\cdot$ Eisag $\rightarrow$ sawar

FIGURA 240 - EXEMPLO 3 DE MICROESTRUTURA USADA NO DICIONÁRIO DA LÍNGUA SURUÍ

suka /su'ka/ v.tr. matar. Ajnon: pehe puta pesuka ma'ea pesehow? vocês vão matar aquelas caças?; aha puta ri'a isukaw tasahuamu talvez eu mate um porcão; esuka puhi não mata ele

Apesar de os três exemplos apresentarem EML's diferentes: 1) LId: Fn, Gr, Rm, $\operatorname{Vr}\{\mathrm{DPt}(\mathrm{Vr})\}$; 2) LId: Fn, Gr, Rm \{DPt [EId/EPt] $\}$ e 3) LId: Fn, Gr \{DPt [EId/EPt] $\}$, todas elas têm em comum o fato de terem se baseado na EML principal da proposta para o dicionário da língua Suruí.

\subsection{A microestrutura do dicionário Suruí baseada no modelo MODE}

Ao propor a construção do dicionário na direção Português-Suruí, conforme tratado no início do subcapítulo, decidi pela adoção de um modelo lexicográfico diferente do adotado para a direção Suruí-Português, por considerar que essa mudança de língua usada na posição de Lema tem implicações em toda a microestrutura do material a ser produzido.

Destaco que a mesma base de dados lexicais armazenada no programa Línguas e usada para construir a primeira versão do dicionário também foi a que usei para a construção desta outra proposta de dicionário.

Baseado na EML apresentada para esse dicionário, apresento, a seguir, a sua esquematização, tal como fiz para a proposta anterior: 


\section{FIGURA 241 - ESQUEMA DA MICROESTRUTURA MODE PARA O DICIONÁRIO DA LÍNGUA SURUÍ}

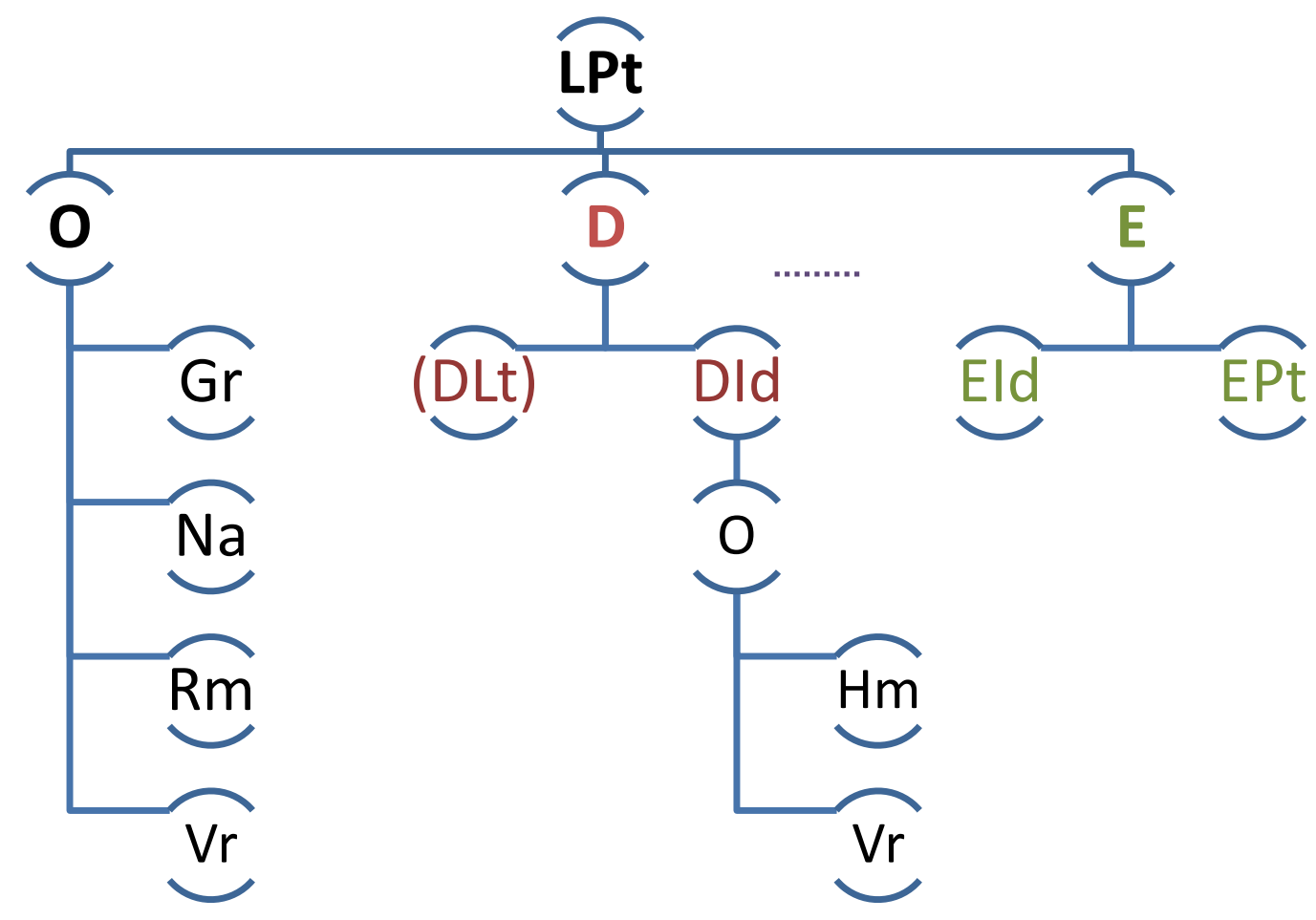

Com uma estrutura composta por menos itens que a primeira, este dicionário leva o Português para a posição de Lema (LPt). Sendo bem mais útil para não falantes da língua Suruí, como é o caso de não indígenas, ele também encontra espaço na comunidade Aikewára, principalmente entre os mais jovens, os quais têm o Português como primeira língua. ${ }^{245}$ A seguir, descrevo cada um dos componentes envolvidos nessa proposta.

O primeiro dos componentes dessa versão do dicionário Suruí é o LPt, destacado com efeito negrito, à semelhança da proposta anterior.

Relacionados ao Lema estão os Operadores $\mathrm{Na}, \mathrm{Rm}$ e Vr; este último apresenta formas variantes (de forma e de conteúdo) da palavra posta na posição de Lema, como, por exemplo, o registro da palavra libélula possui uma variante usada na comunidade Suruí, que é lavadeira, logo o registro de ambas pode ser útil para essa comunidade; já o Operador Na, contém informações que complementam ou detalham a informação dada no Lema. Esses componentes vêm sempre colocados entre parênteses; o Operador Rm, por sua vez, aparece no final do verbete e pode ser identificado pela palavra Ver precedida por um marcador e seguida por uma seta voltada para a direita.

\footnotetext{
${ }^{245}$ Como o foco desse dicionário não é a língua portuguesa, acredito não haver, nesse momento, necessidade de inserir a transcrição fonética ou a forma fonológica das palavras em Português.
} 
Com relação aos Descritores, o principal deles é na língua Suruí (DId), e só ele recebe Operadores (Hm e Vr). Mantive o uso do Operador Hm nesse contexto a fim de auxiliar a pesquisa de uma palavra que estiver como DId no dicionário Suruí-Português, remetendo-a à sua forma de Lema (LId) no dicionário Português-Suruí, estabelecendo, assim, certa interdependência entre eles. Já com relação ao outro Descritor, o DLt, ele só pode constar no caso de nomes de animais e plantas. Apenas este último vem destacado com efeito itálico na microestrutura.

Por este dicionário ter sido gerado com a mesma base de dados do anterior, os exemplos usados neste contexto apenas mudam de posição, ou seja, se antes seguiam a ordem EId-EPt agora o Exemplo em Português passa a ser o primeiro. Do mesmo modo, o que vem destacado nesta nova proposta é a parte na língua Suruí.

Concluída a descrição das duas microestruturas a serem usadas no dicionário da língua Suruí e antes de passar às propostas dos dicionários, algumas observações são necessárias. A primeira delas diz respeito à nomenclatura do tipo das duas UBL's propostas. Ambos os materiais serão denominados, aqui, dicionário, apesar de, no contexto dos materiais lexicográficos das línguas indígenas brasileiras serem comuns as situações em que o material que tem o Lema na língua indígena receber essa denominação, enquanto o seu reverso ser chamado de vocabulário, léxico ou índice. Certamente a variedade do Português usada na construção deste dicionário é a mais próxima da que é efetivamente usada pelos Suruí no seu dia a dia, o que pode causar certo estranhamento a pessoas não habituadas a essa variedade. No entanto, como o material tem como público os falantes dessa comunidade, são as suas demandas que devem ser atendidas em primeiro lugar. Além disso, os Lemas em Português são glosas para compreensão da língua Suruí. Nesse caso, por exemplo, o verbete para iapina tem como glosa 'cabeça dele' e essa mesma forma é levada para a posição de Lema no dicionário com a direção Português-Suruí. Só isso já demonstra o quanto esse dicionário difere, por exemplo, de um dicionário monolíngue tradicional em Português.

Uma última observação diz respeito ao uso dos termos em Latim no DLt. Certamente é necessário investigar mais cada espécie animal e vegetal que é denominada na língua Suruí, a fim de estabelecer com a maior precisão possível essa nomenclatura científica, mas, para isso, vai ser necessário obter assessoria especializada nas respectivas áreas para definir toda essa biotaxonomia. Ademais, mesmo em Português a atribuição de um nome de determinada espécie animal ou vegetal não é tarefa fácil, porque há, por exemplo, ao lado da palavra tahyw 'formiga', várias outras para designar diferentes espécies, como ta'og, 
tahywun, tahywarem, tahywa purupir piw'e, e não consegui encontrar, até o momento, todas as formas em Português para nomeá-las; nestes caso, uso o hiperônimo seguido da observação abreviada 'espécie'. Feitas essas considerações sobre a microestrutura da segunda UBL, ilustro com alguns verbetes extraídos do dicionário Português-Suruí essa proposta:

FIGURA 242 - EXEMPLO 1 DE MICROESTRUTURA USADA NO DICIONÁRIO PORTUGUÊSSURUÍ

bonito (ele é) n.descr. (bem feito) iaruw (aruaru). Ex.: casa bem feita 'oga iaruaru; o que é bonito iaruaruwa'e; ele canta bonito use'engar iaruwa'e; eu cuido do meu filho pra ele ficar bonito ise asemu'an reko wememyra re tawaruwete

FIGURA 243 - EXEMPLO 2 DE MICROESTRUTURA USADA NO DICIONÁRIO PORTUGUÊSSURUÍ

buritizeiro n.m. myriti 'ywa, Mauritia/Mauritiella. Ex.: vocês carregaram a tora do buritizeiro pehe ta peraha pewuhyj myriti 'ywa. - Ver $\rightarrow$ árvore

FIGURA 244 - EXEMPLO 3 DE MICROESTRUTURA USADA NO DICIONÁRIO PORTUGUÊSSURUÍ

cai/caiu ${ }^{1}$ v.intr. u'ar ${ }^{1}$. Ex.: eu quase caí a'ar werew; ele vai cair u'ar puta; ele caiu da árvore u'ar 'ywetewi; nós caímos uru'ar; eu estava correndo e caí wesowesona a'ar; ele caiu lá de cima do galho da árvore 'ywa rokowi i' ar. - Ver $\rightarrow$ cai $/$ caiu $^{2}$

Apesar de os três exemplos apresentarem EML's diferentes: 1) LPt: Gr, Vr (DId (Vr) $[\mathrm{EPt} / \mathrm{EId}]\}$; 2) LPt: Gr, Rm \{DId(-DLt) [EPt/EId] $\}\}$ e 3) LPt: Gr, Hm, Rm \{DId (Hm) [EId/EPt] $\}$, todas elas têm em comum o fato de terem se baseado na EML principal da proposta para o dicionário Português-Suruí.

\subsection{DICIONÁRIO SURUÍ-PORTUGUÊS}

A primeira proposta de dicionário da língua Suruí que apresento neste capítulo é aquela com a direção Suruí-Português (cf. subseção 10.2.3.2.1). Com verbetes distribuídos em 
uma coluna, o dicionário está organizado alfabeticamente, com separadores em cada um dos grupos de letras. ${ }^{246}$

As informações acerca da ortografia e da fonologia da língua Suruí já foram apresentadas, respectivamente, nos capítulos 4 e 5 desta tese. Já as abreviaturas usadas no corpo do dicionário são apresentadas abaixo. ${ }^{247}$

\section{TABELA 84 - ABREVIATURAS USADAS NO DICIONÁRIO SURUÍ-PORTUGUÊS}

\begin{tabular}{c|l}
\hline ABREVIATURA & \multicolumn{1}{c}{ PROPRIEDADE GRAMATICAL } \\
\hline$a d v$. & advérbio \\
\hline$n$. & nome \\
\hline$n . d e s c r$. & nome descritivo \\
\hline$n . I a$ & nome de classe Ia \\
\hline$n . I b$ & nome de classe Ib \\
\hline$n . I I a$ & nome de classe IIa \\
\hline$n . I I b$ & nome de classe IIb \\
\hline$n . I I c$ & nome de classe IIc \\
\hline$n . I I d$ & nome de classe IId \\
\hline$n . I I I$ & nome de classe III \\
\hline$n u m$. & numeral \\
\hline part. & partícula \\
\hline pron. & pronome \\
\hline posp. & posposição \\
\hline pron.dep. & pronome dependente \\
\hline$v$. & verbo \\
\hline v.intr. & verbo intransitivo \\
\hline$v . t r$. & verbo transitivo \\
\hline voc. & vocativo \\
\hline
\end{tabular}

Destaco, enfim, que o dicionário a seguir é, ainda, uma proposta em construção, que deve sofrer modificações até chegar à sua versão definitiva impressa e que deverá ser usada pelo povo Suruí.

\footnotetext{
${ }^{246}$ Esclareço que tanto a separação dos diferentes grupos por letra quanto os próprios separadores entre eles foram adicionados manualmente, pois o programa Línguas, até a atual versão 3.9 ainda não é capaz de realizar esse tipo de configuração personalizada de forma automática.

${ }^{247}$ Apesar de a tese já apresentar na sua parte pré-textual todas as abreviaturas usadas nela, acredito ser útil inserir aqui uma lista apenas com as abreviaturas usadas no corpo do dicionário, porque isso facilita de alguma forma o trabalho do consulente da obra.
} 


\section{DICIONÁRIO DA \\ LÍNGUA SURUÍ DO TOCANTINS \\ (AIKEWÁRA)}

\begin{aligned} & \hline Direção Suruí do Tocantins (LId) - Português (DPt) \\ & \hline Quantidade de entradas $1134^{248} \\ &$\hline Ordenamento das entradas alfabético \\ & \hline Conjuntos de letras a e h i k kw, $\mathrm{m} \mathrm{n} \mathrm{o} \mathrm{p} \mathrm{r} \mathrm{s} \mathrm{t} \mathrm{u} \mathrm{w} \mathrm{y} \\ &$\hline $\begin{array}{r}\text { Expressão da microestrutura } \\ \text { lexicográfica (EML) }\end{array}$ LId: Fn, Gr, Hm, Rm, Vr \{DPt (Na, Vr) (-DLt) [EId/EPt] $\} \\ &$\hline $\begin{array}{r}\text { Programa utilizado no } \\ \text { tratamento dos dados }\end{array} \begin{array}{l}\text { Línguas - Banco de Dados para Documentação Linguística } \\ \text { (versão 3.9) }\end{array} \\ &$\hline\end{aligned}

\footnotetext{
${ }^{248}$ A versão do Dicionário da língua Suruí do Tocantins (Aikewára) apresentada nesta tese possui apenas uma amostra do léxico dessa língua.
} 


\section{A}

a'e /a'?el pron. esse. Ajnon: amonog a'epe 'ywa eu vou cortar essa árvore. - Eisag $\rightarrow$ aiko

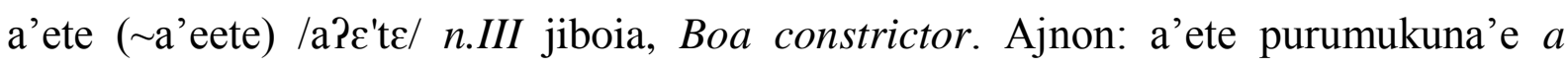
jiboia engole gente; a'ete upurumomomomona'e a jiboia enrola gente. - Eisag $\rightarrow$ mosa

a'eteterona ( ipewara) /a?ztcte'rona/ n.III sucuri, Eunectes murinus. - Eisag $\rightarrow$ mosa

a'wera /a?'wera/ n.III espírito. Ajnon: a'wera usesaukar purupe o espírito aparece pra gente; awapituo wesag sepi a'wera tem gente que vê espírito. - Eisag $\rightarrow$ ywyterera, asomera

a'yra /a'Pira/ n.IIa filho de alguém, (homem falando)

ahekwahawa /ahekwa'hawa/ n.Ia paladar de alguém, sentir gosto

ahuma'e /ahuma'?e/ n.descr. cabelo liso

ahy ( ma'eahy) /a'hi/ n.IIa dor, doente, doído, picante. Ajnon: sene rahy nós (estamos) doentes/doídos; na ahywi ninguém (está) doente; ne memyra ahy pa'e? você está sentindo dor para ter filho?; ti ati'ywa ahy meu ombro está doendo; emahymahy puhi ke não deixe (a comida) picante

aikwesa /as'kwesa/ pron. aquele. Ajnon: aikwesa pa'e ne rejmawa aquele xerimbabo é teu?; aikwesa ipewhua pa'e ne rejmawa ete aquele pato é teu, mesmo; aikwesa use'eng ti rehe oko ele falou (mal) de mim

aiko /ai'ko/ pron. esse. Ajnon: aiko na amonowi ne upe esse eu não dou para você. • Eisag $\rightarrow$ a'e

aiko ku'em kwera re /ai'ko ku'?em 'kwere 're/ adv. ontem (antes de). Ajnon: aiko ku'em kwera re ikyr amona antes de ontem choveu (a chuva); aiko ku'em re rako asowewahem wetoga pupe antes de ontem eu cheguei em casa

aiko ku'ema re ( aiko ra'e wehe) /ai'ko ku'?ema 're/ $a d v$. amanhã (depois de). Ajnon: aiko ku'ema re puta amomomomon bola wehow depois de amanhã eu vou jogar bola; aiko ra'e wehe puta aha ikaw so depois de amanhã eu vou coletar castanha-dopará

aiko re /ai'ko 'rع/ adv. hoje. Ajnon: aiko re rako aesag akuma'e hoje eu vi este homem 
aiko re wehe ( aiko ra'e wehe) /ai'ko ז $\varepsilon$ w'he/ $a d v$. ontem. Ajnon: aiko re wehe rako aesag akuma'e ontem eu vi este homem; aiko re wehe ituri ele chegou ontem; aiko re wehe pa'e pesor? vocês chegaram ontem?; aiko re wehe ikyr choveu ontem; aiko ra'e wehe rako asepurakar wehow ontem eu fui caçar no mato

aimi /ai'mi/ pron. aqueles. Ajnon: aimi wyra'yra remi ti rejmawa aquelas galinhas são meus xerimbabos

aipe /ai'pe/ $a d v$. lá. Ajnon: ise aapyg aipe eu sentando lá

aity /ai'ti/ n.III vespa (esp.)

aj'aw /as'?aw/ adv. aí. Ajnon: aj'aw pa'e? é aí?; ene ereapyg aj'aw tu sentando aí

ajnon /as'non/ $a d v$. assim, isso mesmo

aka'u /aka'Pu/ n.III cacau. Ajnon: aka'ua iputyrame o cacau tá florando; aka'ua putyra uruapo i'u a flor do cacau nós fazemos e bebemos

akara /aka'ra/ n.III acará, Ciclídeos

akara'i /akara'?i/ $n$.III carazinho, Geophagus brasiliensis. • Eisag $\rightarrow$ ipira

akarapew /akara'pew/ n.III acarapeba. • Eisag $\rightarrow$ ipira

akararona /akara'sona/ $n . I I I$ tucunaré, Cichlao cellaris. • Eisag $\rightarrow$ ipira

akaratinga /akara'tina/ $n . I I I$ cará branco. • Eisag $\rightarrow$ ipira

akasuhua /akasu'hua/ n.III cajuaçu (época de)

akasu'u /akasu'?u/ n.III caju

akatikating /akatika'tin/ n.III cedro

akojtimahawa /aksstima'hawa/ n.IIa estojo peniano de alguém

akowoj /ako'wos/ n.III sapo (esp.)

akuma'ea /akuma'Tea/ n.III homem. Ajnon: akuma'e akuraete homem gordo; aiko re wehe rako aesag akuma'e ontem eu vi este homem; moron puta pe akuma'e ihoj osuna? quantos homens vão correr?

akuti /aku'ti/ n.III cutia, Dasyprocta, Dasiproctídeos. Ajnon: ma'esawara usonetewa'e upyhyg akutia o cachorro corredor pegou a cutia

akutia nami pe pytukawahu /aku'tia na'mi 'pe pitukawa'hu/ n.III laranja-da-terra, laranja grande. Ajnon: akutia namy pe pytukawahu haj a laranja-da-terra (é) azeda 
akutia namy pe pytukawa /akutia nami pupe kutu'kawa/ n.III laranja, limão, Citrus aurantium, Citrus limon. Ajnon: apyter akuti nami pe pytukawa eu chupei a laranja akutia namy pe pytukawa 'ywa /akutia nami pe pitu'kawa 'Piwa/ n.III laranjeira, limoeiro

akuw /a'kuw/ n.descr. quente

akuwetuwetun /akuwetuwe'tun/ n.descr. morno

akuwoto /akuwo'to/ n.III calor forte

akwakwaraioko /akwa'kwara io'ko/ n.III feixe de lenha

akwara /a'kwara/ n.IIa rosto de alguém. Ajnon: ti reakwara iakym meu rosto está molhado

akyky ehyra /akiki $\varepsilon$ 'hira/ n.III mel de uruçu

akyky porong /aki'ki po'roy/ n.III uacari-vermelho, Cacajaocalvus rubicundus

akykya /aki'kia/ n.III guariba, Alouatta guariba guariba

ama’ywa /ama'Piwa/ n.Ia esôfago de alguém. Ajnon: ti ama'ywa rupi pelo meu esôfago; ti surua rupi raypy imunehe, amono we ama'ywa rupi pela minha boca primeiro, depois eu mando pelo esôfago

amamaj /ama'mas/ n.III samambaia

ame'a /ame'?a/ n.Ia testículos de alguém. Ajnon: ame'auhu testículos grandes; ame'a ahy doem os meus testículos

amerewa /ame'rcwa/ n.III osga, Hemidactylus mabouia. Ajnon: amerew useupir 'oga re a osga sobe na casa

amoata /amoa'ta/ n.III tamuatá, Callichthys callichthys. • Eisag $\rightarrow$ ipira

amona /a'mona/ n.III chuva. Ajnon: amona yruyrona a chuva é fria; aiko ku'em kwera re ikyr amona antes de ontem choveu (a chuva)

amona tymy /a'mona ti'mi/ n.III temporal

amonamu /a'monamu/ $n . I I I$ chuva (quando for a época de), inverno

amonime /a'moni'me/ n.III tempo de chuva, inverno

amonisu 'ywa /amoni'su '?iwa/ n.III algodoeiro

amonisua /amoni'sua/ n.III algodão 
amuj /a'mus/ n.Ia avô. Ajnon: ti ramusa oko wehe meu avô está vivo amupong /amu'poy/ n.III tambor amutehe /amute'he/ pron. outro, diferente. Ajnon: ko amutehe outra roça amutining /amuti'nin/ n.III maracá estalante amymyjtymy /ami'mis ti'mi/ $n$.III tempo nublado anako /ana'ks/ n.III papagaio (esp.) anisu /ani'su/ n.III calango anuhu /anu'hu/ $n . I I I$ anu. • Eisag $\rightarrow$ wyra anuhupituna /anuhupi'tuna/ n.III anu preto, anum, Cuculídeos, Crotophaga/Guira anusa /anu'sa/ $n . I I I$ rato anyra /ani'ra/ n.III quero-quero, Vanellus chilensis apehawa /ape'hawa/ $n$.III redor (ao redor). Ajnon: 'og uapehaw ao redor da casa apimuku ( arawawa) /apimu'ku/ n.III cobra-d'água, Colubrídeos, Aquelas, Helicops. • Eisag $\rightarrow$ mosa

apiryrua /apiri'su/ $n$.III chapéu de alguém, boné. Ajnon: iapiryrua u'aiko ywete $o$ boné está pendurado no alto

apu'a /apu'?a/ n.descr. redondo. Ajnon: kuipia iapu'a a cuia é redonda; tehahua iapu'a o tucum é redondo; akutia nami pe pytukawa iapu'a a laranja é redonda apyakwara /apia'kwara/ n.Ia ouvido de algo ou de alguém apyj /a'pis/ n.Ia narina de algo ou de alguém. Ajnon: ti apyj myk minha narina (está) entupida

apykawa /api'kawa/ n.III banco

ara /'ara/ n.III claro, dia. Ajnon: aiko ara re wehe rako então outra vez passou o tempo; 'arimu pelo dia

ara hemawa /'ara he'mawa/ n.III leste, onde o sol nasce ara kwahapara /'ara kwaha'para/ n.III relógio. - Eisag $\rightarrow$ ipituna kwahapara ara seaupira amujete /ara scau'pira a'mus $\varepsilon^{\prime}$ te/ n.III manhã (até 10h aprox.) ara sipawa /'ara si'pawa/ $n$.III oeste, onde o sol se põe 
arakuri /araku'ri/ $n . I I I$ saracura

aramewa'e /aramewa'?ع/ n.III recém-nascido

aramuru 'ywa /aramu'ru '?iwa/ n.III favão

arara /a'rara/ n.III arara. Ajnon: kometi aisaj arara agorinha eu vi uma arara; arara uwewe a arara voou; arara use'eng a arara falou; arara userusiw ywyra roko re $a$ arara pousou no galho da árvore

ararakonuhu /ararakonu'hu/ n.III arara cangaçu, arara cabeçuda, Podocnemis dumeriliana

ararasawe /ararasa'we/ n.III pássaro (esp.)

araraw /ara'raw/ n.Ia cocar (de penas de arara)

ararete /ararc't $\varepsilon /$ n.III araracanga, arara-vermelha-pequena, aracanga, arara-macau, Ara macao

araria /ara'ria/ n.III ararinha, arara pequena, Aratinga aurea

araruna /ara'runa/ n.III araraúna

ararunuhu /ararunu'hu/ n.III arara-azul, Anodorhynchus hyacinthinus

arawawa /arawa'wa/ $n$.III cobra-coral, Micrurus. • Eisag $\rightarrow$ mosa

arekasu /areka'su/ n.III preguiça, bicho-preguiça

aretea /arc'tca/ $a d v$. época seca, de junho a setembro

arimu /'arimu/ $a d v$. dia (pelo dia). Ajnon: arimu puta saha nós vamos de dia

aru'akaty /a'ruPaka'ti/ $a d v$. fora, espaço aberto. Ajnon: oho aru'akaty ele foi pra fora; eraha aruakaty leve para fora

arupo /aru'po/ n.III garfo, ancinho, rastelo

asasaj /asa'sas/ n.descr. folgado

asiranawa /asira'nawa/ n.IIa enteada

asomera /aso'mera/ n.III alma. Ajnon: na isaguwi wehe weko asomera eu nunca vi alma (asomera). - Eisag $\rightarrow$ a'wera, ywyterera

asong /a'soy/ n.III tamanduá-mirim, Tamandua tetradactyla. • Eisag $\rightarrow$ tamawa

asumi'apy /asumi?a'pi/ n.III flauta

asuru /asu'ru/ n.III papagaio 
asururonuhu /asururonu'hu/ n.III papagaio (esp.)

asyg /a'sig/ n.III veia de algo ou de alguém

asymuhu /asimu'hu/ n.III maguari. • Eisag $\rightarrow$ wyra

asyra /a'sira/ n.IIa filha (de homem). Ajnon: u'ar pa'e ne rasyra? já nasceu tua filha?

asywen /asi'wen/ n.Ia genro

ati /a'ti/ n.III chifre

atirare /atira're/ n.III cascudo (menor)

atu'a /atu'?a/ n.Ia nuca de alguém. Ajnon: ne atu'a pisun tua nuca está suja; ti atu'a ahy minha nuca dói

atutu /atu'tu/ n.III enfeite de cabeça (para mulher)

atyhu /ati'hu/ n.IIa sogro

awa /a'wa/ n.III quem, alguém. Ajnon: awa pa'e uso'o? quem está chorando?; awa pa'e usekyj? quem morreu?; awa pa'e umuhy pyting 'ya? quem está sujando a água?; pewri'a awa iapukaj lá, alguém está gritando

awa'yahua /awa?ia'hua/ $n$. pessoa jovem, rapaz. Ajnon: emono ywyrapara wa'yahuape dá o arco pro jovem; awa'yahua upurumugeta awaimona ne os jovens e os velhos conversam

awa'imon /awa'?imom/ n.III pessoa velha, ancião. Ajnon: awa'iahua upurumugeta awa'imonane os jovens e os velhos conversam

awai’yma /awai'Pima/ n.descr. estúpido

awai'yma /a'wai'Pima/ n.III motociclista

awa ra’o /awa ra'?っ/ n.III carne de gente

awatia /awa'tia/ n.III milho. Ajnon: eretym ehe pe awatia hoje você planta milho; monamo he pa'e eretym awatia? quando foi que você plantou o milho?; awati pytera rupi puta uruhow eu vou passar pelo meio (da plantação) de milho

awatia ipipisawa /awa'tia ipipi'sawa/ n.III arroz. Ajnon: kuej wehe puta aha ityma awatia ipipisawa weko pupe amanhã eu vou plantar arroz

awyraru $^{1}$ /awira'ru/ n.III cogumelo (esp.)

awyraru $^{2}$ /awira'su/ $n . I I I$ pão 


\section{$\mathrm{E}$}

e'e $/ \varepsilon^{\prime} ? \varepsilon /$ n.descr. doce

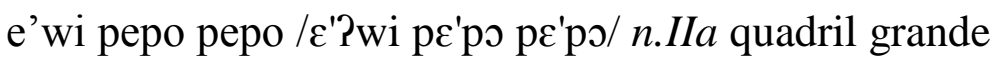

eahy /عa'hì/ $n$.Ia lágrima de alguém

eakwarahy /Eakwara'hi/ n.descr. raiva. Ajnon: ne reakwarahy pa'e? você está com raiva?; ti reakwarahy ri'a eu estou com raiva

eakwen /عa'kwen/ n.descr. cheiroso

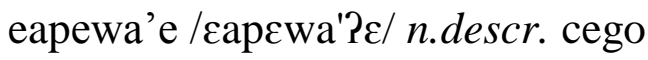

earaj / $\varepsilon$ a'ras/ $n . I I I$ esquecimento

egeypy /عgei'pi/ n.IIa cu de algo ou de alguém, ânus dele

eha / $\varepsilon$ 'ha/ n.IIa olho de algo ou de alguém. Ajnon: useha olho dele próprio; sene reha nosso (incl.) olho

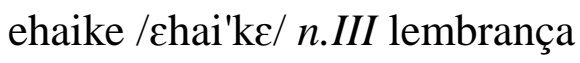

ehakwasu /Ehakwa'su/ n.III sagui-de-mãos-douradas, Saguinus midas

ehapykong /Ehapi'koy/ n.IIa testa

ehasu'ara /Ehasu'Para/ $n . I I a$ óculos de alguém

ehyr /ع'hirs/n.III mel. Ajnon: ehyr he'e ete o mel (é) doce

ehyrete /chirc'tı/ n.III uruçu, Meliponíneos

eimawa /عi'mawa/ n.IIa xerimbabo de alguém, animal de criação. Ajnon: aikwesa pa'e ne reimawa aquele xerimbabo (pato) é teu?; aimi wyra'yra re mi ti reimawa aquelas galinhas são meus animais de criação

eironuhu /cironu'hu/ $n . I I I$ abelhão. • Eisag $\rightarrow$ tuwa

eisu /ci'su/ $n . I I I$ estrela-d'alva, estrela-da-manhã. • Eisag $\rightarrow$ sahytata

eke'i / $\varepsilon k \varepsilon '$ '?i/ $n . I I a$ cunhada

ekewena / $\varepsilon k \varepsilon^{\prime} w \varepsilon n a / ~ n . I I a$ cunhado

ekuj / $/$ 'kus/ $n$.Ia cuia de algo ou de alguém 
ekuwisara /عkuwi'sara/ n.IIa sobrinho

ekwena / $\varepsilon$ 'kwene/ n.Ia cheiro de algo ou de alguém

emaiti /عmai'ti/ n.III besouro (esp.)

eme /ع'me/ n.IIa lábio de alguém

emeiwyra /emei'wica/ n.III beira. Ajnon: porono remeiwyra beira de rio

emekong /عmع'kэy/ n.Ia gengiva de alguém

emekwasuru ( eme’ywa) / emekwasu'ru/ n.IIa vagina (grandes lábios) dela. • Eisag $\rightarrow$ kwar

emi’u /عmi'?u/ n.Ia comida. Ajnon: temi'u episepise a comida (élestá) muito gostosa emi'umi'u /عmi?umi'?u/ n.III amante de alguém

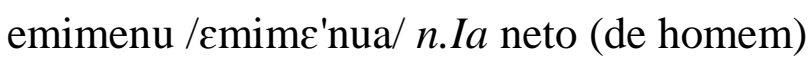

emira /E'mira/ n.IIa irmã (de homem)

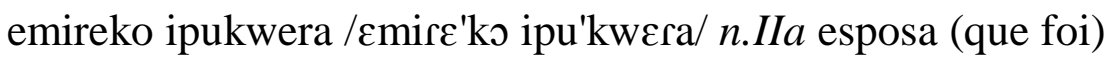

emireko purahua /emircko pura'hua/ n.IIa esposa (segunda)

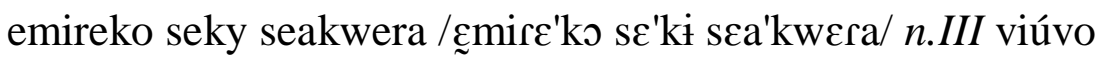

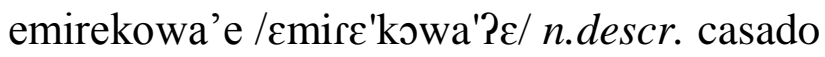

emiriko /عmiri'ks/ n.III mulher (esposa) de alguém. Ajnon: ne remiriko ripo uapukaj ne upe sua esposa está gritando para você

emisariru /عmisari'ru/ n.IIa neto (de mulher)

emiukwera /emiu'kwera/ n.IIa transa, cópula. Ajnon: ti remi'umi'u minha transa [minha coisa comida]

emo /ع'mo/ n.IIa pênis de alguém

emu'em /عmu'em/ n.descr. mentiroso

emun / $r \varepsilon^{\prime} \operatorname{mun} /$ n.Ia coceira

ene $^{1} / \varepsilon^{\prime}$ ne/ part. associativo. Ajnon: Ywykatu Ikatu ene ihoj uke mukumukujta ka'ape Ywykatu e Ikatu entraram dois (dias) no mato; awa'iahu tu'o usemuaraj awa'imonane todos os jovens e todos os velhos brincam 
ene $^{1} / \varepsilon^{\prime}$ ' $\varepsilon /$ pron. tu, teu. Ajnon: ene ti nupo pe você bate em mim; ene pa'e eremono ywyrapara ne ruwa pe você deu o arco para o teu pai; ene ereapyg a'iaw tu sentando aqui

enemy /عnc'mi/ n.III camaleão

enune / $\varepsilon n u ' n \varepsilon / a d v$. adiante. Ajnon: enune uruata na frente, nós andamos; erenune remi iataj na frente, eles andaram

enya /ع'nia/ n.IIa saliva de alguém

enyeny /eniz'ni/ n.descr. brilhante

enywa /عni'wa/ n.IIa queixo de algo ou de alguém

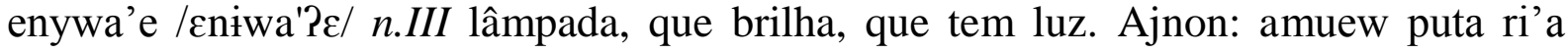
enywa'e eu vou apagar a luz.

enywahawa /eniwa'hawa/ n.IIa barba de alguém

epynunema /عpinu'nema/ n.Ia peido fedorento

erekatara /عscka'tara/ n.IIa marido dela. Ajnon: ti rerekatara puta i'apihawe'ym meu marido vai ficar sem cabelo; na erekatara'uwi que não quer casar (marido)

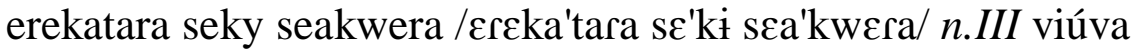

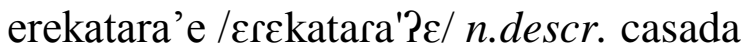

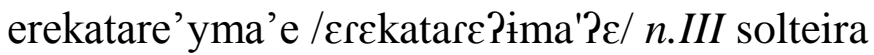

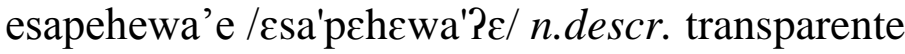

esuj /ع'sus/ n.III broto

etoma / $\varepsilon^{\prime}$ toma/ n.III aldeia

eumaw ( kane’u) /cu'maw/ n.descr. cansado (ele está). Ajnon: ti kane'uete ri'a eu estou muito cansada

ewetypy /عweti'pi/ n.IIb barriga de alguém. Ajnon: ewetypyoto barriga dura

ewia / $\varepsilon^{\prime}$ wia/ n.III minhoca 


\section{$\mathrm{H}$}

haj /'has/ n.descr. azedo. Ajnon: akutia nami pe pytukawa haj a laranja é azeda hajte /haj'te/ n.descr. medroso (bicho)

hejkwehe /hrskwe'he/ adv. passado (há muito tempo). Ajnon: use'eng katuete hejkwehe ele falou a verdade há muito tempo

hianawa /hia'nawa/ n.Ia madrasta

hog rera /'hog 'rera/ n.IIa intestino delgado

hoj tehe 'yma /'hos te'he '?ima/ n.III dentadura

hojme /hos'me/ n.descr. amolado

hosa ( hoj) /'hosa/ n.Ia dente de algo ou de alguém. Ajnon: ti rosahy minha dor de dente

hy /'hì/ n.IIb mãe (de mulher). Ajnon: ko pupe ti hy ihoj pra roça minha mãe foi

hyretoma /hire'toma/ n.III cera (de abelha)

\section{I}

i'asa /i'Tasa/ n.Ia garganta de alguém

i'akorona /i2aks'rona/ n.III abóbora, gerimum. Ajnon: uruasejmonog iakorona nós (exlc.) partimos a abóbora

i'awa /i'Pawa/ n.Ia cabelo de alguém. Ajnon: ti 'aw kujpaw ri'a meu cabelo caiu; i'awitong cabelo loiro; i'atinga'e cabelo branco; i'awrawri cabelo crespo

i'iwaj /i?i'was/ n.III maruim. Ajnon: usepuremuete pa'e i'iwaj? tem muito maruim aqui?

i'omutawa /iPomu'tawa/ n.Ia bigode de alguém

i’wyj / Ri'wì/ $n$.Ia cintura de alguém. Ajnon: ti wysa minha cintura

iahapara /iaha'para/ n.III atravessador

iahu /ia'hu/ $n$.III saúva, Atta. • Eisag $\rightarrow$ tahywa 
iahupisuna /iahupi'suna/ $n$.III saúva preta. • Eisag $\rightarrow$ tahywa

iakasa /iaka'sa/ $n$.Ia útero dela

iakua su'uma /ia'kua su'?uma/ n.III calugi, bebida tradicional à base de mandioca

iakwawa /ia'kwawa/ n.Ia pelos pubianos de alguém. Ajnon: usekwaw wo'o ela tira os próprios pelos pubianos

iakym /ia'kim/ n.descr. molhado (ele está). Ajnon: yryw iakym a roupa está molhada

iamati'o /iamati'?o/ n.Ia clitóris de alguém

iamyw /ia'miw/ n.IIa coriza de alguém

iapekong /iape'kon/ n.Ia escápula de alguém, omoplata. Ajnon: ere 'apekong tua escápula

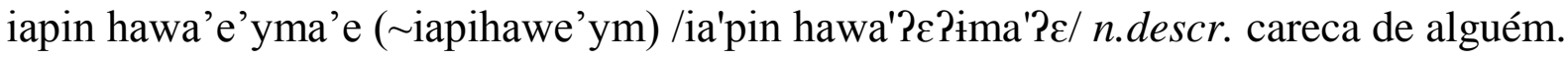
Ajnon: ti rerekatara puta i'apihawe'ym meu marido vai ficar sem cabelo (careca)

iapin kotokoto /ia'pin kotoks'to/ n.descr. loucura de algo ou de alguém

iapina /ia'pina/ n.Ia cabeça de algo ou de alguém. Ajnon: ti apina hy minha cabeça doendo (dor de cabeça); iapina waj 'yma'e pessoa que tem a cabeça vazia (não pensa)

iapinawawa'e /ia'pinawawa'Pع/ n.descr. inteligência de alguém

iapitu'una /iapitu'Puna/ $n$.Ia cérebro de alguém, miolo dele

iapua'oj /iapua'?ss/ n.III raposa, Aqueles, Vulpes

iapyakwara towa'e /iapia'kwara towa'?ع/ n.III gravador

iapyakwara'ym /iapia'kwara'?im/n.descr. surdo

iapyakwara'yma'e /iapia'kwara?ima'?e/ n.III lanterna

iapykutukawa /iapikutu'kawa/ n.III martelo

iapyreta /iapirc'ta/ n.III esteio (de casa). Ajnon: 'oga apyreta esteio da casa; iapyreta upen o esteio (da casa) quebrou

iaruw ( aruaru) /ia'suw/ n.descr. bonito (ele é), bem feito. Ajnon: 'oga iaruaru casa bem feita; iaruaruwa'e o que é bonito; use'engar iaruwa'e ele canta bonito; ise asemu'an reko wememyra re tawaruwete eu cuido do meu filho pra ele ficar bonito

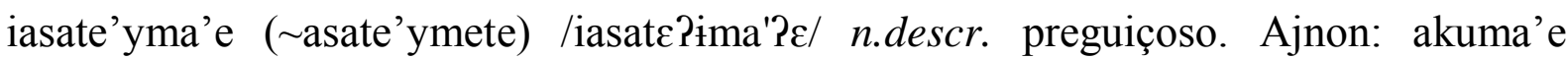
iasate'ym o homem preguiçoso; ise ti asate'ymete eu (sou) preguiçosa 
iati'ywa /iati'?iwa/ n.Ia ombro de alguém. Ajnon: ipyhyj sete ti'ati'ywa está pesado no meu ombro; ti ati'ywa ahy meu ombro está doendo

iatikonga /ia'ti'kona/ $n$.Ia clavícula de alguém

iatuatur /iatua'tur/ n.descr. baixo

iaturu'e /iaturu'?ع/ n.descr. curto. Ajnon: ti rirua iaturu'e minha camisa é curta; ti kong akasa iaturu'e meu calção é curto.

iaturuwewa'e /iaturuwewa'?e/ n.descr. pequeno, curto

iatypy /iati'pi/ n.IIa bochecha de alguém

iawykyahywa /iawikia'hiwa/ n.descr. estragado (ele está). Ajnon: useawykyahyw ele se estragou; ma'e'ywa useawykyahyw a fruta se estragou

ienupara /isnu'para/ $n . I I I$ escutador

ietymakapema /ie'timaka'pema/ n.IIa perna de algo ou alguém

ietymasi'a /ictimasi'?a/ n.Ia canela (parte do corpo) de alguém

igea /i'gea/ n.Ia intestino de algo ou de alguém, tripa dele

igewa'a /igewa'?a/ n.IIa intestino grosso

ihahaw /ha'haw/ n.descr. peludo. - Eisag $\rightarrow$ ihawa

ihawa /i'hawa/ $n$.III pelo (do corpo) de algo ou de alguém. • Eisag $\rightarrow$ ihahaw

ihejtara /ihes'tara/ n.III lavador

ihym /i'him/ n.descr. liso (ele é). Ajnon: 'ywypy ihym o tronco é liso

ikanawa /ikana'wa/ n.Ia joelho de alguém

ikarua katykaty isewag /ika'rua katika'ti isc'wag/ n.descr. destro

ikatua /ika'tua/ n.III macaxeira. Ajnon: aiko ra'e wehe rako ko pupe aha ityma a'y'u roko raj ipyk ikatua muapyga nune ontem eu plantei roça, bebi água e comi macaxeira. - Eisag $\rightarrow$ mandioca

ikawa /i'kawa/ n.Ia gordura de algo ou de alguém

iketawa ( ti kehawa) /ike'tawa/ n.III cama de alguém. Ajnon: ti ketawa iaturuwewa'e minha cama pequena. • Eisag $\rightarrow$ itekwawa

iko ( ikowui) /ikı/ n.III roça de alguém. Ajnon: kuej wehe puta aha weko pupe ityma awatia amanhã eu vou na roça plantar milho; ise awirog koa eu rocei a roça; 
moronime puta pe saha koa pupe? quando vamos para a roça?; use'i wehete puta aapy weko amanhã bem cedo eu vou queimar minha roça; ti ko pupe tiwa'a tem caititu na minha roça; ko pupe puta aha pra roça eu vou

ikom /i'kэm/ n.Ia seio dela. Ajnon: ikomuhu i'apu'a o seio grande é redondo

ikomapyra /ikoma'pira/ n.IIa bico do seio dela

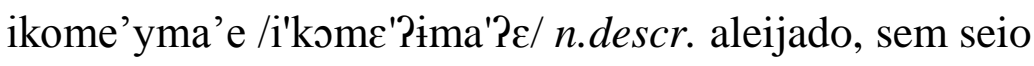

ikomypya /iksmi'pia/ n.Ia peito de alguém (homem)

ikong ${ }^{1} / i^{\prime} k \ni y / n . I I a$ osso de alguém

ikong ${ }^{2} / i^{\prime} k o y / n . I a$ calcinha dela

ikong akasa /i'køy aka'sa/ $n$.Ia calção de alguém

ikong su'ara /i'kon su'Para/ n.III cueca

iku'a /iku'Pa/ n.Ia bunda de alguém. Ajnon: iku'aku'ahu bunda grande

ikua /i'kua/ n.Ia língua de algo ou de alguém

ikupepyter /ikupepi'tes/ n.Ia coluna vertebral de alguém

ikwara /i'kwara/ n.Ia vagina dela. • Eisag $\rightarrow$ emekwasuru, iamati'o, imy'iwa

ikwo /ikwo/ n.Ia dedo médio de alguém

ikysuhu /ikisu'hu/ n.III grilo (esp.)

ima'euej /ima?cu'cs/ n.IIa fome. Ajnon: ti ma'euej minha fome; ne ma'euej pa'e? você está com fome?

imemyra /ime'mica/ n.Ia filho (de mulher). Ajnon: ti memyra uker meu filho dormiu; ne memyra tipiw uapyg teu filho sentou perto de mim

imemytaty /imemita'tì/ n.IIa nora de alguém

imusona /imu'sona/ n.Ia cicatriz de alguém

imuwej /imu'wes/ n.descr. devagar (ele está)

imy'iwa /imi'?iwa/ n.Ia vagina (parte) dela

inamia /ina'mia/ $n . I a$ orelha de algo ou de alguém

inamikohoma /inamiks'homa/ n.Ia brinco dela

inamu'i /inamu'Pi/ n.III inambumirim, Crypturellus tataupa. • Eisag $\rightarrow$ wyra 
inamuhun /inamu'hun/ $n . I I I$ inambu

inamuita /inamui'ta/ n.III inambu (esp.)

inasa /ina'sa/ n.III inajá, najá

inasa 'ywa /ina'sa 'Piwa/ n.III inajá, Maximiliana maripa

inasaron 'ywa /inasa'ron '?iwa/ n.III pupunheira

inasarona /inasa'rona/ n.III pupunha

inasimosa /inasi'møsa/ n.III cobra-cipó. - Eisag $\rightarrow$ mosa

inatahog /inata'hog/ n.III bicho-de-coco, Pachymerus nucleorum

ine /i'nc/ voc. mãe (de homem)

ini'omupira /ini'Pomu'pira/ n.III acari, cari, cascudo. • Eisag $\rightarrow$ ipira

inimo /ini'ms/ n.III linha

inu'a /inu'?a/ n.III pilão

inupinipara /inupini'para/ n.III pintador de algo ou de alguém. • Eisag $\rightarrow$ umuhun

ioko /io'ks/ n.III lenha

ioronuhu /ioronu'hu/ n.III andiroba

ioronuhu 'ywa /ioronu'hu '?iwa/ n.III andirobeira, Carapa guianensis. - Eisag $\rightarrow$ 'ywa iparati'ywa /iparati'?iwa/ n.Ib cotovelo de alguém. Ajnon: anupo weparati'ywa eu bati meu cotovelo

ipe /i'pe/ n.III escama. Ajnon: ipira pe escama de peixe; apin ipira pe estou tirando escama de peixe

ipe'iuhu /ipe?iu'hu/ n.III sumaúma, Ceiba pentandra. • Eisag $\rightarrow$ ’ywa

ipepo /ips'po/ n.III pena de algo

ipepu'awa /ipepu'?awa/ n.III nadadeira

ipepuwyra /ipspu'wira/ n.Ia sovaco de alguém

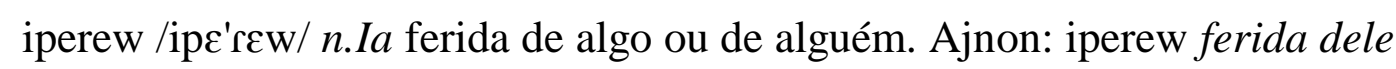

ipeuhua /ipeu'hua/ n.III pato. Ajnon: aikwesa ipewhua pa'e ne rejmawa ete aquele pato é teu, mesmo. - Eisag $\rightarrow$ ave

ipipir /ipi'pir/ n.descr. largo (ele é) 
ipira /ipi'ra/ n.III peixe. Ajnon: ipira pirie'ym peixe seco; ipira ywytingupyra o peixe está salgado. - Eisag $\rightarrow$ akara'i, akarapew, akararona, akaratinga, amoata, ini'omupira, ipira'i, ipirakaw, ipirakwakwahawe'yma, ipirarunuhu, ipiroj, ipisaw, manowe, muru, sesu, tarejri, tarejriuhu, tawarerasapina, tine'a, uruwi, ywyrapopohoma

ipira /i'pira/ n.III pele de algo ou de alguém

ipira ku'omawa /ipira ku?o'mawa/ n.III peixe levantado, baleia. Ajnon: na esagwi wehe ipira ku'omawa eu não vi mais peixe levantado

ipira mu'ahawa /ipi'ra mu?a'hawa/ $n . I I I$ rede de pesca

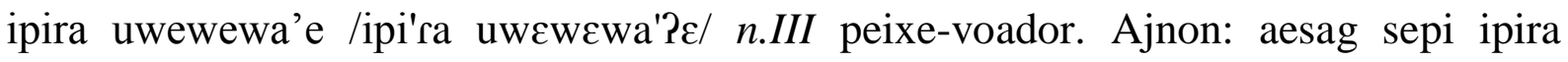
uwewewa'e eu já vi peixe voador

ipira'i /ipira'Pi/ $n$.III peixinho. Ajnon: ipira'i usepuremuete tem muito peixinho. - Eisag $\rightarrow$ ipira

ipirakaw /ipira'kaw/ n.III matrinxã. Ajnon: ipirakaw ipisepise eu gosto de comer matrinxã. • Eisag $\rightarrow$ ipira

ipirakawrona /ipirakaw'sona/ n.III tambaqui. Ajnon: ipirakawrona ikawete o tambaqui é muito gorduroso

ipirakong /ipira'koy/ n.III espinha de peixe

ipirakwakwahawe'yma /ipi'rakwakwahawe'Pima/ n.III matrinxã (esp.). • Eisag $\rightarrow$ ipira ipirapiroto /ipi'rapirs'to/ n.III sardinha. Ajnon: ipirapiroto iputi'uete a sardinha tem muito pitiú

ipirarunuhu /i'pirarunu'hu/ n.III pirarucu, Arapaima gigas. • Eisag $\rightarrow$ ipira

ipirarupi'a ( ipirahua) /ipi'rarupi'?a/ n.III ova de peixe. • Eisag $\rightarrow$ upi’a

ipirera /pi'rcra/ n.III ex-pele, ex-couro

ipiriaj /ipiri'as/ n.III suor de algo ou de alguém

ipiroj /ipi'øs/ n.III piranha, Serrasalmus nattereri. • Eisag $\rightarrow$ ipira

ipirong /ipi'roy/ n.III dinheiro

ipironga /ipi'sona/ n.descr. vermelho (ele é). Ajnon: misara ipirongwa'e o veado é vermelho

ipiruohom /ipirus'hom/ n.IIa placenta de algo ou de alguém 
ipisaw /ipi'saw/ n.III piau, pintado. Ajnon: ipisaw isuruhu'yma'e o piau tem a boca pequena. - Eisag $\rightarrow$ ipira

ipise /ipi'šl n.descr. gostoso (ele é). Ajnon: temi’u episepise a comida (élestá) muito gostosa

ipituna ( pisuna) /ipi'tuna/ $n$.descr. preto. Ajnon: 'ya pituna água preto

ipo /i'po/ n.Ib mão de algo ou de alguém. Ajnon: ita iwewuwewuj ti pope a pedra está leve na minha mão

ipokong /ips'kэy/ n.Ib osso da mão de alguém

ipokupe /ipsku'pe/ n.Ib dorso da mão de alguém

ipokwahaw /ipokwa'haw/ n.Ia anel de alguém

ipopi /ipo'pi/ $n . I b$ dedo anelar de alguém

ipopytera /ipopi'tica/ n.Ia palma da mão de alguém

ipororong /iporo'roy/ n.Ib pulso de alguém. Ajnon: ti poporong ahy meu pulso está doendo; wepororonga rea reko arakuahapara no meu pulso eu coloco relógio

ipu'yr /ipu'?is/ n.Ia colar dela

ipuheakonga /ipu'hea'kэna/ $n . I b$ dedo polegar de alguém. Ajnon: ti puheakong ahy meu polegar está doendo; asepuheakong upo eu bati meu dedo polegar

ipuhopopi /ipu'hっpo'pi/ n.Ib dedo mindinho de alguém, mínimo (dedo) dele

ipuhukupe /ipuhuku'pe/ n.Ia sola (do pé) de alguém

ipuku /ipu'ku/ n.descr. comprido (ele é). Ajnon: akuma'e ipukua o homem é alto

ipupe /ipu'pe/ $a d v$. dentro, em. Ajnon: tekwawa pupe saker na rede nós (incl.) dormimos; asehej ri'a porono pupe eu me lavei no rio; Ikatu oko pupe tiwa'a tem caititu na roça de Ikatu; porono pupe Ikatu ihoj para dentro do rio Ikatu foi; aiko ra'e wehe rako aha ko pupe ityma kumanarona ontem eu fui plantar feijão na roça ipure /ipu'ce/ n.III lagoa

ipuromor ( pinu) /ipurs'mor/ n.III peido de algo ou de alguém ipuru'a /ipuru'Pa/ n.Ia gravidez de algo ou de alguém ipuru'ong ikyitawa /ipuru'on ikii'tawa/ n.III máquina fotográfica de alguém ipurua homa /ipu'ra 'homa/ n.III cordão umbilical 
ipurung /ipu'ruy/ n.descr. grosso (ele é)

ipurupurum /ipurupu'rum/n.descr. secura de algo ou de alguém

iputatara /iputa'tara/ n.III queredor

iputi /ipu'ti/ $n$.Ia cocô de algo ou de alguém, merda, fezes

iputi'a /iputi'Pa/ $n . I b$ tórax de alguém, peito dele

iputikaw /iputi'kaw/ n.III lugar para algo ou alguém cagar

iputing /ipu'tin/ n.III látex

ipuwonaw /ipuwo'naw/ $n . f$. fuso de alguém

ipy /i'pi/ n.Ib pé de algo ou de alguém

ipy'a /ipi'?a/ n.Ia fígado de algo ou de alguém

ipyahowa ( pyyru) /ipia'howa/ n.Ib sapato de alguém

ipyhope /ipiho'pe/ n.Ia dedo indicador de alguém

ipyhopi /ipiho'pi/ n.Ia dedo do pé de alguém

ipyhyakong /ipihia'koy/ n.Ia unha do pé de alguém

ipyhyj /ipi'his/ n.descr. pesado (ele é). Ajnon: ipyhyj sete ti'ati'ywa está pesado no meu ombro

ipyohohong /ipioho'hoy/n.descr. tropeçado (ele está)

ipyperewa /ipipe'rewa/ n.descr. raso. Ajnon: irupema ipyperewa a peneira é rasa. • Eisag $\rightarrow$ waypy

ipypiru'a /ipipiru'?a/ n.Ia calo de alguém

ipyri'o /ipiri'?o/ n.Ia umbigo de alguém

ipyrykyti'i ( pyrykysi'i) /ipirikiti'?i/ n.Ia rim de algo ou de alguém

ipyryryryry /ipiciririti'ri/ n.descr. enrugado (ele é)

ipysu'o /ipisu'Po/ n.Ia tornozelo de alguém

ipyta /ipi'ta/ n.IIa calcanhar de alguém

ipytuna imuehe /ipi'tuna imue'he/ n.III noite (começo da)

ipyw /i'piw/ n.descr. seco (ele é) 
irajty /iras'ti/ $n$.III borra desse. Ajnon: petyma pysahy rajty borra do café irowa /i'rowa/ n.descr. amargo (ele é) iru'ya /iru'Pia/ n.descr. frio de algo ou de alguém, febre de alguém. Ajnon: ne ru'y pa'e? você (está) com febre (frio)?

irua /i'rua/ n.IIb irmão. Ajnon: syryg puta amono ne irua pe eu vou dar o machado para o teu irmão; kunumia irumukusa'e o menino tem um irmão gêmeo

irupema /iru'pema/ n.III peneira. Ajnon: irupema ipyperewa a peneira é rasa

irutehe ( irutehe'yma'e) /irutz'he/ num. três. Ajnon: irutehe'yma'e aityg 'ywa eu já cortei três árvores

iruting /iru'tin/ n.III cofo

isahu /isa'hu/ $n . I I I$ esquerda desse

isahua'e ( isahu) /isa'hua'?ع/ n.descr. canhoto. Ajnon: ysew'a isahu katy ele escreve com a mão esquerda

isamomor /isamo'mor/ n.descr. entristecido (ele está)

isarij /isaris/ n.Ia avó de alguém

isarukonga /isaru'køna/ n.Ia costela de alguém

isasyu'u /isasiu'?u/ n.descr. apertado (ele é)

ise /i'se/ pron. eu. Ajnon: ise hu puta runupo eu bato em vocês dois; ise puta ri'a asoason eu estou correndo; ise purumu'etaramu eu sou professor

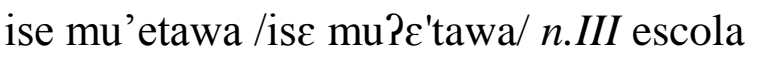

ise sakatu /i'se saka'tu/ n.III tempo bom

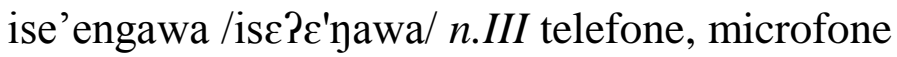

isekwo akwahawa /ise'kwo akwa'hawa/ n.III cinto de alguém

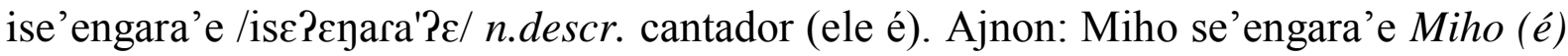
o que canta

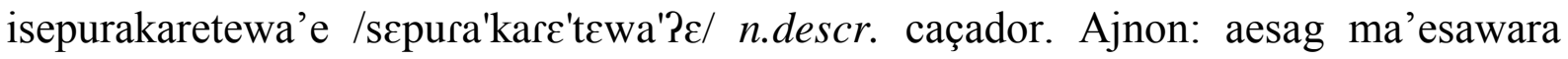
sepurakaretewa'e eu já vi cachorro caçador; ma'esawara usepurakaretewa'e u'u tapi'ira o cachorro que é bom caçador mordeu a anta; usepurakaretewa'e ma'esawara usekuj o cachorro que é bom caçador morreu

iseputahawa /iseputa'hawa/ $n$.III pulso de alguém 
iserutiwa'e /iserutiwa'?ع/ n.descr. tímido (ele é)

isesea /isc'sca/ $n . I a$ tia de alguém

isewakawa /isewa'kawa/ n.III lápis. Ajnon: ise asewag isewakawa ko eu escrevo com o lápis

isi'o /isi'?o/ n.Ia coração de algo ou de alguém

isi'owewuj /isi?owe'wus/ n.Ia pulmão de alguém, bofe

isisiwa'oj /isisiwa'?os/ n.Ia nervo de algo ou de alguém

isukyry /isuki'si/ n.descr. amarelo (ele é). Ajnon: itahynypuk isukyryete o ouro é bem amarelo

isura /i'sura/ n.Ia pescoço de algo ou de alguém

isurua /isu'rua/ $n$.Ia boca de algo ou de alguém. Ajnon: ti surua rupi pela minha boca

isuruwa /isu'cuwa/ n.descr. grande (ele é)

isuwaw /isuw'aw/ n.III colher

isykongira /isiko'yira/ n.IIa reumatismo de alguém

isyryga /isi'riga/ n.Ia machado de alguém

isyw'a /isiw'?a/ n.Ia braço de alguém

isywa inypy’o /i'siwa inipi'?o/ n.Ia antebraço (músculo) de alguém

isywa ypy /i'siwa i'pi/ $n$.Ia antebraço de alguém

ita /i'ta/ n.III pedra. Ajnon: ita iwewuwewuj ti pope a pedra está leve na minha mão; ita muruwisawete pedra enorme; ita tinining pedra branca; ita'i pedrinha; ita ipyrykyti'i pe pedra nos rins

itahynypuk /itahini'puk/ n.III ouro. Ajnon: itahynypuk isukyryete o ouro é bem amarelo

itaky /ita'ki/ n.III pedra de amolar, esmeril. Ajnon: kise hoj me'ete itaky eu amolo a faca na pedra

itamew /ita'mew/ n.descr. mole (ele é). Ajnon: ewetypy itametamew barriga muito mole

itapura'a /itapura'Pa/ n.Ia pomo-de-adão de alguém, gogó dele. • Eisag $\rightarrow$ aikong itasa'e /itasa'?e/ n.III panela de alguém 
itasukonga /itasu'kona/ n.III prego

itekwawa /ite'kwawa/ n.III rede de alguém, lugar de dormir. Ajnon: aapara puta ri'a tekwawa eu vou dobrar a rede; ereapara pa'e ne rekwawa? você está dobrando a sua rede?; tekwawa pupe saker na rede, nós (incl.) dormimos; tekwaw torog o rasgado da rede; aikewara umomon tekwawa aikewara está enrolando (o fio para tecer) rede; ereapara pa'e ne rekwawa rupohoma? você está dobrando a corda da sua rede?

- Eisag $\rightarrow$ kehawa

iti /i'ti/ n.Ia nariz de algo ou de alguém, bico. Ajnon: asetinupen eu quebrei o meu nariz; usetimyk ele se sufocou; nusetimyguwi ele não se sufocou; inemauwi esetimyk está fedendo, tape o seu nariz.

itinga'e /itina'?ع/ n.descr. branco (ele é), claro

itingwoj /itina'wos/ n.III sal

itoku'o /itoku'?o/ n.III concha (de ostra)

itusug /itu'sug/ n.descr. inclinado (ele é)

itusupaw /itusu'paw/ n.descr. podre

ity /i'tí/ $n . I a$ urina de algo ou de alguém

iu'ywa /iu'Pi'wa/ n.III flecha de alguém

iuka'ika'i /iuka?ika'?i/ n.descr. quebrado (ele está)

iukape /iuka'pe/ n.Ia baixo-ventre de alguém

iukyysetewa'e /iukiisctewa'?ع/ n.descr. medroso (ele é)

iupi'a /iupi'?a/ n.III ovo de algo

iusewywyr /iusewi'wìs/ n.descr. inflamado (ele está)

iuso'og /iuso'?og/ n.descr. separado (ele está), divorciado. Ajnon: aso’oga eu (sou) separado (divorciado)

iwapirasuwa /iwapira'suwa/ n.III manga, Mangifera indica. Ajnon: asewerewi uapirasuwa um pedaço de manga

iwira /i'wira/ n.III embira

iwirapitema /iwirapi'tema/ n.III jirau

iworog ehim pewa /iwo'sog $\varepsilon$ 'him 'pewa/ n.III prato. Ajnon: iworog ehim pewa ipyperewa o prato é raso 
iworowa /iwo'rowa/ $n$.III seringueira. Ajnon: iworow rypitinga urumuse puta tata $e u$ acendo fogo com o leite seco da seringueira. - Eisag $\rightarrow$ 'ywa

\section{K}

ka'a /kaPa/ n.III mato. Ajnon: ereho pe ka'a pe ra'e você entra no mato; tapi'ira puta oho ka'a wi uhema a anta vai saindo do mato; Tymykong umukaruwete ka'ape Tymykong andou o dia todo no mato; aiko ra'e wehe re pa'e erehow ka'a pe eataw ontem você foi andar no mato; ka'a pe amukasym eu me perdi no mato

ka'apewara /kaPape'wara/ n.III mato (que é do), bicho do mato

ka'ia /ka'?ia/ n.III macaco-prego, macaco-de-topete, Cebus nigritus. Ajnon: ka'ia usemuaraj yware ywokomumepem o macaco-prego brinca no galho da árvore $e$ quebra os galhos

kahena'ia /kahena'?ia/ n.III sagui, Cebidae

kamara /kama'ra/ n.III pessoa (não indígena) . • Eisag $\rightarrow$ warasu

kanawa 'ywa /kana'wa '?iwa/ n.III mogno. • Eisag $\rightarrow$ 'ywa

kane'u /kanع?u/ n.descr. cansaço

kapiwara /kapi'wara/ n.III capivara, Hydrochaeris hydrochaeris

kara /ka'ra/ n.III cará (tubérculo)

kareru'a /karesu'?a/ n.III rato-do-mato, sauê

karimata /karima'ta/ n.III curimatã, Prochilodus

karuakatu /karuaka'tu/ n.III direita

karuaruhua /karuaru'hua/ n.III paca. Ajnon: ise karuaruhua asuka eu sempre caço paca; karuaruhua ti keywywy re oho usona a paca correu do meu lado

karuayra /karua'íra/ n.III estrela (planeta Júpiter)

karuw /ka'ruw/ n.III tarde

karuw emeete /ka'ruw $\varepsilon^{\prime} m \varepsilon \varepsilon^{\prime} \mathrm{t} \varepsilon /$ n.III tarde (no meio da)

karuwpaw /karuw'paw/ n.III tarde (no fim da) 
katinkwera /kati'Đweca/ n.III veado-virá, catingueiro, Mazana gouazouzira. • Eisag $\rightarrow$ misara, pakwohow

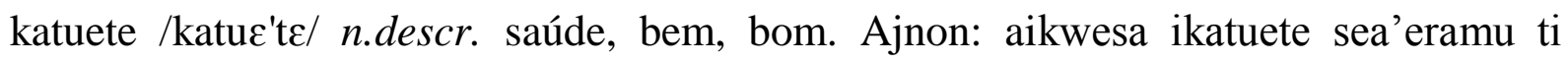
ruryruryw ehe ele é muito bom, por isso eu fico feliz

katy /ka'ti/ $a d v$. direção (na). Ajnon: oho arua katy ele foi pra fora

katykyehyra /katikiz'hira/ $n$.III abelha (esp.). • Eisag $\rightarrow$ tuwa

kawa /'kawa/ n.III caba, marimbondo

kawa retoma /'kawa re'toma/ $n . I I I$ casa de caba, Nycticorax nycticorax

kitikiti /kitiki'ti/ $n . I I I$ serrote

ko katy /'ks ka'tí/ adv. daqui. Ajnon: eho ko katy vá daqui

koko /ko'ko/ n.III pássaro (esp.)

komyru /komi'ru/ n.III sutiã

kono /ko'no/ n.descr. torto

kononoj /kono'nos/ n.descr. manco

kororonuhu /kororonu'hu/ $n$.III inhame

kotawete /kotawe'te/ n.Ia amigo. Ajnon: ise ti kotaweteramu eи sou seu amigo

kotawete'yma /ko'tawetع'?ima/ n.IIa inimigo. Ajnon: ti kotawete'yma'e meu inimigo

kotawypy /kstawi'pi/ n.III história. Ajnon: Miho umume'u kotawypykwera Miho sabe contar histórias antigas

ku'aiwara /ku'Paiw'ara/ n.III saia

$\mathrm{ku}$ 'em $/ \mathrm{ku}$ '?عm/ n.III madrugada

ku'emanune /ku'Emanung/ n.III amanhecendo (quase)

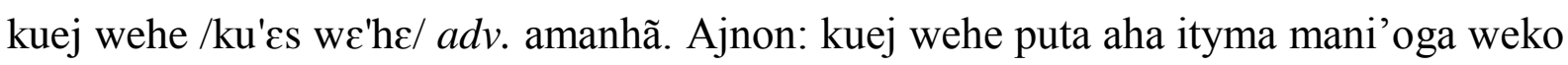
pupe amanhã eu vou plantar mandioca; kuej wehe puta ihoj tasahuaamanhã amanhã ele quer caçar porcão

kuipi /kui'pi/ $n$.III cabaça

kujpia 'ywa /kus'pia '?iwa/ n.III cuieira, Crescentia cujete. • Eisag $\rightarrow$ 'ywa

kujronuhu /kussonu'hu/ n.III cupuaçu 
kumana /kuma'na/ n.III fava

kumanarona /kumana'rona/ n.III feijão. Ajnon: aiko ra'e wehe rako aha ityma ko pupe kumanarona ontem eu fui plantar feijão na roça

kumanu 'ywa /kuma'nu '?iwa/ n.III pau-preto, Diospyros. • Eisag $\rightarrow$ 'ywa

kumara /ku'mara/ n.III comadre

kunumia /kunu'mi/ n.III menino. Ajnon: kunumia irumukusa'e o menino tem um irmão gêmeo

kupara /ku'para/ n.III compadre. Ajnon: kupara ti resag ri'a o compadre está me vendo kupe /ku'pe/ adv. atrás. Ajnon: kupe uruata nós andamos atrás

kupepykawa /kupepi'kawa/ n.III prensa

kupi'i /kupi'?i/ n.III cupim

kupitaw /kupi'taw/ n.III sapo (esp.)

kureta'u /kureta'?u/ n.III tucano (esp.). - Eisag $\rightarrow$ tukan, wyra

kurisu /kuri'su/ n.III sucuri. - Eisag $\rightarrow$ mosa

kurukaw /kuru'kaw/ n.III urinar (lugar de)

kururu /kuru'ru/ n.III sapo

kuso /ku'so/ n.III mulher. Ajnon: kuso sysyng mulher magra; ma'eramu pa'e kuso nuse'engara uwi? por que as mulheres não estão cantando?; ure kuso teseramu uruho ytyma mani'og roko urutym nós fomos com as mulheres plantar mandioca; ure urueraha mani'og kusoa pe nós levamos mandioca para as mulheres

kusomukuwa'e ( kusomukuj) /kusomukuwa'?ع/ n.III moça. Ajnon: kusomukuja ri’a ne saj as moças estão rindo de ti

kutipi /kuti'pi/ n.III cuxiú, Chiropotesutahicki

kuwej wehe /kuweswe'he/ adv. cedo. Ajnon: eretyryg pa'e kuwejwehe você acordou cedo

ky’ysa /ki'?isa/ n.III pimenta

ky’ysa ypya /ki'?isa i'pia/ n.III pimenteira

kykyra’yr /kikira'?ìs/ n.III curica, Pionopsitta caica

kyrywyroj /kiriwi'ros/ n.III escorpião 
kyse ikong apyta /ki's $\varepsilon$ i'k⿰习 api'ta/ $n . I I I$ cabo do facão

kysea /ki'sca/ n.III faca, facão. Ajnon: kyse hoj ne’yw a faca está cega; Muretama upyhyg kysea ti wi Muretama pegou a faca de mim

kysekono /ki'ssko'no/ n.III foice

kyting /ki'tin/ n.descr. limpo

kyto'i /kito'?i/ $n$.I $a$ verruga

kytykawa /kiti'kawa/ n.III ralador. • Eisag $\rightarrow$ ma'e akytykaw, so kytykaw

kywa /'kiwa/ n.III piolho. Ajnon: Jorge apina re ikywa tem piolho na cabeça do Jorge

kywakywara /kiwaki'wara/ n.III bicho-pau, Fasmídeos/Proscopiídeos

kywawa /ki'wawa/ n.III pente

kywyra /ki'wira/ $n$.Ia filho da irmã da mãe, filho do irmão do pai

\section{$\mathrm{Kw}$}

kwanu /kwa'nu/ n.III porco-espinho, Histricídeos

kwara /'kwara/ n.III buraco. Ajnon: ywy kwara ahywykaj eu cavo buraco na terra; eme kwara buraco do lábio

kwarahy /kwara'hi/ n.III sol. Ajnon: usawripo kwarahy fazsol

kwarahya hemawa /kwara'hia he'mawa/ n.III nascer-do-sol

kwarahya katawa /kwarahia ka'tawa/ n.III pôr-do-sol

kwati /kwa'ti/ n.III quati, Nasua nasua

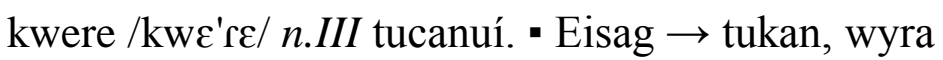

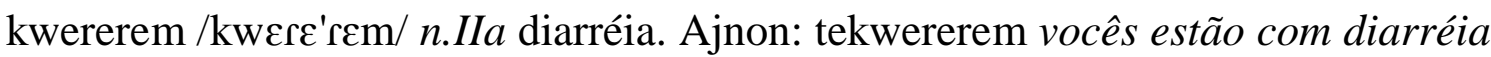


'ar myteripe /'Tar miteri'p $\varepsilon / a d v$. verão (no meio), mês de agosto

'ar putaripe /'Par pu'tari'pe/ n.III meio do dia, meio do claro

'ara rasej /ara ra'ses/ n.III meio-dia

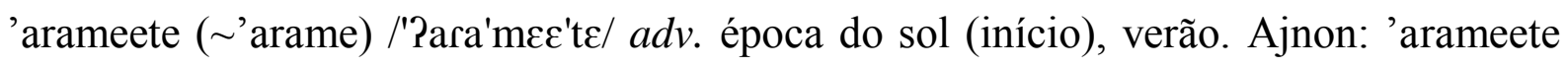
re puta awyrok ti koromamu no início do verão eu vou brocar minha roça (na qualidade do que vai ser minha roça)

'aripe / Rari'pe/ n.III sol (na época de), verão

'aruaru /Parua'ru/ n.descr. reto

'aw /'Paw/ adv. aqui. Ajnon: 'aw pa'e? é aqui?; a'aw pa'e reko? você está morando aqui?; ise aapyg 'aw eu sentando aqui; 'aw wi nahawi sair daqui eu não quero

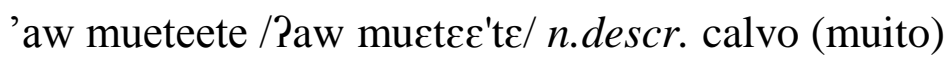

'awaiaia'ia /Rawiaia'Pia/ n.descr. calvície de alguém

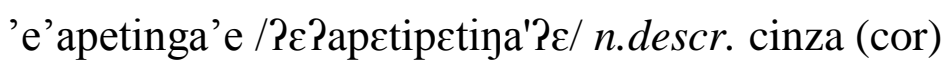

'i'a ( ma?E?iwa) /Ri'Pa/ n.III fruta. Ajnon: ma'e’ywa useawykyahyw a fruta estragou

'ita'uta'uwa'ea /2i'ta?u'ta?uwa'?ea/ n.III laranja (cor)

'oga /'Poga/ n.III casa, residência. Ajnon: asehutese saupir sene rehe 'og (Wajwera umume'u) nós todos juntos construímos nossa casa; ti popytywo e apo 'og (Wajwera umume'u) me ajuda a construir a casa; ti rehe taketehewehe ne wy wekow (Wajwera umume'u) eu posso vir dormir sozinho em casa; ure uruapo 'oga nós fizemos estas casas; ti rogawi ihoj usona ele saiu de casa; apoa'u ri'a wetoga eu quero fazer minha casa. • Eisag $\rightarrow$ 'ogete

'oga muruwisawete /'oga muruisawe'te/ n.III casa grande. • Eisag $\rightarrow$ 'og

'ogete / Pogete/ n.III casa tradicional. Ajnon: uruapo puta 'ogete semu'etawa ukaripe vamos fazer a casa tradicional no terreno onde a gente estuda; uruapo puta 'ogete $\mathrm{t}$ uesag wehe warasu tywo, 'og t unawa vamos fazer a casa tradicional para os não indios poderem ver. $\cdot$ Eisag $\rightarrow$ 'og

'u'emanune /Pu'Psmanu'ne/ n.III madrugada (parte)

'u'u / $u^{\prime}$ 'Pu/ n.III picada 
'ya /'Pia/ n.III água. Ajnon: 'ygygom água fria; 'ypisun água preta; Ikatua weraha 'ya sene upe Ikatu levou água para nós; awa pa'e umuhy pyting 'ya? quem está sujando a água?; mume pa'e 'ya? onde (tem) água?

'ya gahawa /'Pia ga'hawa/ n.III pote de água

'ya mungingongara /'ia munino'nara/ n.III geladeira, freezer. Ajnon: 'ya mungingongara iapetinga'e a geladeira é cinza

'ya pyra /Pia 'pira/ n.III rio acima, a montante. Ajnon: 'ya pyra katy aha eu fui rio acima

'ya tyryrutawa /'Pa tirisu'tawa/ n.III torneira, mangueira, chuveiro

'yapekarahy /2iapekara'hi/ $n$.descr. azul

'yapewy'e ( 'yapewy) / Riapewi'?e/ n.descr. verde. Ajnon: ywyra rowa yapewy a folha da árvore é verde

'ykwawa /2i'kwawa/ n.III igarapé. Ajnon: aha puta 'ype eu vou pra água (igarapé)

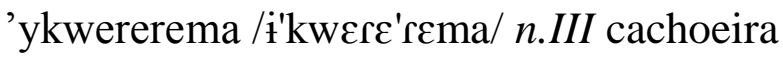

'yrete / Pirc'te/ n.III tempestade

'ywa /'Piwa/ n.III árvore. Ajnon: ma'e 'ywa pa'e que árvore é essa?; amonog a'epe 'ywa eu vou cortar aquela árvore; ma'eramu pa'e imonog 'ywa? por que ele cortou a árvore?; ywyra re aseupir sawara wi eu subi na árvore afastando-me da onça; 'ywa rokowi i'ari ele caiu do galho da árvore; 'ywa re aseupir eu subo na árvore. - Eisag $\rightarrow$ ioronuhu 'ywa, iorowa, ipe'iuhu, kanawa 'ywa, kujpia 'ywa, kumanu 'ywa, myriti 'ywa, petiwaron 'ywa, petiwaron 'ywa, petyma pisara 'ywa, pina'irona 'ywa, pinuwahu 'ywa, sohu, suparaparon ypya, susiw'a 'ywa, suta'ywa, taparaniwa 'ywa, tarajwir 'ywa, tuku 'ywa, turihiwnuhu 'ywa, 'ywyra

'ywa monokawa /'?wa mons'kawa/ n.III motosserra

'ywawa / Pi'wawa/ n.III copo, copo de água

'ywete / Pik'te/ $a d v$. sobre, em cima. Ajnon: iapiryrua u'aiko ywete o boné está pendurado em cima

'ywete /Piwe'te/ n.III tronco

'ywypukwera /Riwipu'kwera/ $n$.III tronco de árvore. • Eisag $\rightarrow$ 'ywa

'ywyra /Riwi'ra/ n.III vara, árvore pequena. Ajnon: ywyra re aseupir sawara wi eu subi na árvore afastando-me da onça. • Eisag $\rightarrow$ 'ywa 


\section{M}

ma'e ahy /ma'? $\varepsilon$ a'hi/ n.III doente

ma'e ahyrona /ma?e ahi'rona/ $n . I I I$ doença grave

ma’e kutitawa /ma'?c kuti'tawa/ n.III faquinha

ma' ea ${ }^{1} / \mathrm{ma}^{\prime}$ '?a/ n.III caça. Ajnon: mo wi pa'e ererur ma'ea ro'o? de onde você trouxe (fez vir) esta carne de caça?; pehe puta pesuka ma'ea pesehow? vocês vão matar aquelas caças?; eresuka pe ma'eamu? você matou algum animal?; urusuka ete ri'a ma'e ma'e nós matamos várias caças

ma' ea ${ }^{2} / \mathrm{ma}^{\prime} \mathrm{ra} / \mathrm{n}$.III coisa, que. Ajnon: ma'e u'ara? o que caiu?; ma'ea ripo ti u'u algo me mordeu; ma'ea pa remonog oma? o que você está cortando?; namukuj ripo ma'ea amukasym eu perdi duas coisas; ma'ea rupi pa'e eremukun ne remi'ua? por onde você engole sua comida?

ma'ea potawa /ma?ca po'tawa/ n.III fogão

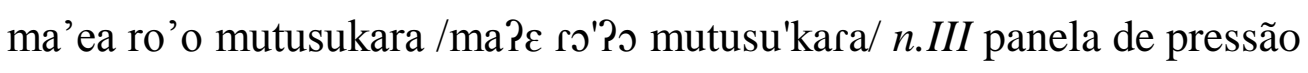

ma'esawara /ma'?esa'wara/ n.III cachorro. Ajnon: unupo ma'esawara ele bate no cachorro; ma'esawara puta usekyj mosa u'uramu o cachorro vai morrer, porque a cobra mordeu ele; esemuhaku'i ke! ma'esawara rapo ne u'u tenha cuidado! o cachorro vai te morder; ma'esawara ti keywywy re oho oko o cachorro andou do meu lado. - Eisag $\rightarrow$ sawara

ma'ey’yma /ma'?ci'?ima/ n.descr. vazio

ma'e kytykawa /ma'?e kiti'kawa/ n.III liquidificador

manganga /mana'ya/ n.III mangangá, abelha, Bombus

mani'oga /mani'?oga/ n.III mandioca. Ajnon: awa pa'e utym mani'og? quem plantou a mandioca?; ure urueraha mani'og kusoa pe nós levamos mandioca para as mulheres.

- Eisag $\rightarrow$ ikatua

manimea /mani'mea/ n.III farinha de mandioca. Ajnon: manimea ko amumaraw wyra'yra rupi'a farofa de ovo (lit. 'farinha misturada com ovo de galinha')

manimea pukujtawa roga ( manimea roga) /mani'mea pukus'tawa roga/ $n$.III casa de farinha. Ajnon: aha puta manime roga pupe wewahema eu vou chegando para dentro da casa de farinha; a-apoa'u re'a manime ne roga pupe 
manowe /mano'we/ $n . I I I$ bagre (esp.). • Eisag $\rightarrow$ ipira masakuwa /masa'kuwa/ n.III coruja, Estrigiformes, Titonídeos, Estrigídeos momomira /momo'mica/ n.III cercado. Ajnon: eremono pa'e imomomyrera pupe tasahumymawa? você já prendeu todos os porcos no cercado?

memiranawa /memiranawa/ n.IIa enteado

memyra /me'mira/ $n$.Ia filha (de mulher), filho, criança. Ajnon: u'ar pa'e ne memyra já nasceu tua filha? (de mulher); emuku'om ti memyra levante a criança (a minha filha); iusawa'ea ne memyra esta criança é tua filha; ne memyra pa'e uapukaj? tua filha gritou?

meru /me'su/ n.III mosca

miahaw /mia'haw/ n.III esteira

mihy ( hy) /mi'hi/ voc. mãe (de mulher)

misakatinga /misaka'tina/ n.III cavalo, burro, jumento, Equídeos

misakatirona /misakatirona/ n.III boi, vaca

misakatirona apitu'um /misakati'sona api'tu'?um/ n.III manteiga

misakatirona arigea po pyrera /misaka'tirona ari'gea po pi'resa/ n.III linguiça de porco

misakatirona kamya /misakati'sona ka'mia/ n.III leite de vaca. Ajnon: misakatirona kamya haj leite azedo; misakatirona kamya po pyrera leite em pó

misara /mi'sara/ n.III veado, Cervídeos. Ajnon: misarar o'o inem a carne de veado está estragada; u'yahawa'e urusuka misara nós matamos o veado que atravessou o rio; misara ipirongwa'e o veado é vermelho. - Eisag $\rightarrow$ katinkwera, misarapirong, pakwohowa

misarapirong /mi'sara pi'roy/ n.III veado-vermelho, Mazama americana. • Eisag $\rightarrow$ misara

misarona /misa'rona/ $n$.III bode, ovelha, cabra, Capra

mitum /mi'tum/ voc. pai (de mulher)

mo /'mo/ $a d v$. onde. Ajnon: mo wi pa'e eresor? de onde vocês vieram?; mo wi pa'e ererur ma'ea ro'o? de onde você trouxe esta carne?; mo wi pa'e ituri? de onde ele chegou? • Eisag $\rightarrow$ mume

mojkyse /moski'ss/ n.III trator 
mojpyruwy /'mospiru'wì/ $n$.III surucucu-de-fogo. • Eisag $\rightarrow$ cobra

mojrona /mos'rona/ n.III jararaca, Bothrops jararaca. • Eisag $\rightarrow$ mosa

monamo /mona'mo/ adv. quando. Ajnon: monamo he pa'e eretym awatia? quando foi que você plantou o milho? • Eisag $\rightarrow$ moronime

moron /mo'ron/ pron. quanto. Ajnon: moron pa'e ne ra'yra? quantos filhos são teus?; moron puta pe akuma'e ihoj osuna? quantos homens vão correr?

moron 'ywa /mo'ron 'Piwa/ n.III árvore (esp.). • Eisag $\rightarrow$ 'ywa

moronime /moroni'me/ $a d v$. quando. Ajnon: moronime puta pe saha koa pupe? quando vamos para a roça? • Eisag $\rightarrow$ monamo

mosa ( moj) /'mosa/ n.III cobra. Ajnon: ma'esawara puta usekyj mosa u'uramu $o$ cachorro vai morrer, porque a cobra mordeu ele; awa pa'e mosa u'u? quem a cobra mordeu?; ise amupig mosa re, ise awisepe mosa nusekysuwi eu atirei na cobra, mas ela ainda vive; ise ri'a asuka we'oma mosa eu estou matando a cobra. - Eisag $\rightarrow$ a'ete, a'eteterona, apimuku, arawawa, inasimosa, mojrona, mosakone'yma, mosokonge'ym, tatyuhu, wajpatana, ywyraka'ymomona

mosakone'yma /'mosakonع'?ima/ n.III cobra-de-duas-cabeças, cobra-cega, Anfisbenídeos. - Eisag $\rightarrow$ mosa

mosarenya /mosare'nia/ n.III veneno da cobra

mosokonge’ym /məsəkəyદ'?im/ n.III cobra-cega. • Eisag $\rightarrow$ mosa

muhomu’oma /muhomu'?oma/ n.III vaga-lume, Lampirídeos/Fengodídeos

mujhatata /mushata'ta/ n.descr. bêbado

mume /mu'me/ adv. onde. Ajnon: mume pa'e rekerehe? onde você dormiu?; mume pa'e 'ya? onde (tem) água? • Eisag $\rightarrow$ mo

murawyky /murawi'ki/ n.III louva-a-deus, põe-mesa, Mantídeos

muru /mu'ru/ n.III cascudo (peixe), Hypostomus plecostomus. • Eisag $\rightarrow$ ipira

muruwisawa /muruwi'sawa/ n.descr. chefe (ele é), liderança (ele é). Ajnon: Maira muruwisawete Mairá (é) liderança

musena /musc'na/ n.III fogo (que cai do céu)

musu'iwyra /musu'Piwi'ra/ n.III andorinha, Passeriformes, Hhirundinídeos. • Eisag $\rightarrow$ wyra

musy’yehyra /musi?ic'hira/ n.III abelha (esp.). • Eisag $\rightarrow$ tuwa 
muti'o /muti'?っ/ n.III camarão

mutuka /mu'tuka/ n.III mutuca, Díptero, Tabanídeos

myiru /mïi'ru/ n.III sandália

myriti /miri'ti/ n.III buriti

myriti 'ywa /miriti 'Piwa/ $n . I I I$ buritizeiro, Mauritia/Mauritiella. Ajnon: pehe ta peraha pewuhyj myriti 'ywa vocês carregaram a tora do buritizeiro. - Eisag $\rightarrow$ 'ywa

mytu /mi'tu/ n.III mutum, Galiformes, Cracídeos. • Eisag $\rightarrow$ wyra

mytuwonguhu /mituwonu'hu/ n.III mutum-castanheiro, mutum-cavalo, Mitu tuberosa

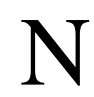

na /'na/ voc. pai (de homem)

namikwara /nami'kwara/ n.IIa buraco da orelha

namukuj ( mukuj) /namu'kus/ num. dois. Ajnon: namukuj ripo ma'ea amukasym eu perdi duas coisas; Ywykatu Ikatu ene ihoj uke mukumukujta ka'ape Ywykatu e Ikatu entraram dois (dias) no mato

nawi /na'wi/ $a d v$. não

ne /'nع/ pron. tu, teu, você, seu. Ajnon: ne ru'y pa'e? você está com febre?; kyse puta ne pokiti a faca vai te cortar; iusawa'ea ne memyra esta criança é teu/tua filho(a); aikwesa pa'e ne rejmawa aquele xerimbabo (pato) é teu?

nonuwewaramu /nonuwewa'ramu/ n.III solteiro

nukewe /nu'kewع/ pron. ninguém. Ajnon: nukewe remi 'oga pupe ninguém entrou na casa

\section{O}

o’o /Ј'?כ/ n.IIa carne. Ajnon: Suara, eremunohonohog pa'e o'o? Suara, você cortou a carne?; mo wi pa'e ererur ma'ea ro'o? de onde você trouxe esta carne?; misakatirona 'o carne bovina; tasahua 'o carne de porcão; tiwa'aro'o carne de caititu 
o'oj /o'Pos/ n.III semente. Ajnon: awatia ro'osa semente de milho; kusa ro'osa semente de cuia

oho /s'ho/ v.intr. vai/foi. Ajnon: aha puta eu vou embora; ka'awi puta ihoj tapi'ira do mato a anta vai sair; ohopapaw pa'e remi? todos já foram?; aha puta ri'a isukaw tasahuamu eu vou talvez matar um porcão; oho puta Perẽj pupe ele vai para Belém. Eisag $\rightarrow$ usor

oko /o'ks/ n.III galho. Ajnon: 'yw oroko galho de árvore; 'ywa rokowi i'ar ele caiu lá de cima do galho da árvore; ure kuso teseramu uruho ytyma mani'og roko urutym nós fomos com as mulheres plantar (galho de) mandioca

opo /s'po/ n.III raiz

oso /o'so/ n.IIa sogra

oto ( otowa'e) /o'to/ n.descr. duro

owa /'owa/ n.IIa folha. Ajnon: ywyra rowa yapewy a folha da árvore é verde

\section{$\mathrm{P}$}

pa'e /pa'Pع/ part. pergunta (marca de). Ajnon: mo wi pa'e eresor? de onde vocês vieram?; eretyryg pa'e kuwejwehe? você acordou cedo?; aikwesa pa'e ne rejmawa aquele xerimbabo (pato) é teu?; ereker pa'e? você dormiu?; Suara, eremunohonohog pa'e o'o? Suara, você cortou (várias vezes) a carne?; awa pa'e uso'o? quem está chorando?

pahakua /paha'kua/ n.III banana. Ajnon: ise apirog pahakua eu descasquei a banana. • Eisag $\rightarrow$ pakohowa

pakohowa /paks'howa/ n.III banana-do-mato, Monstera deliciosa. - Eisag $\rightarrow$ pahakua pakwohowa /pakwo'howa/ n.III veado-branco, Ozotoceros bezoarticus. • Eisag $\rightarrow$ misara

paratuwakonguhu /paratuwakøju'hu/ n.III pica-pau, Piciformes, Picídeos

pe /'pe/ part. para (dativo). Ajnon: syryg puta amono ne irua pe eu vou dar o machado para o teu irmão; ne se'engawera ri'a amume'u iupe eu disse o recado para ele. • Eisag $\rightarrow$ upe 
pea ( ape) /'pea/ n.Ia caminho. Ajnon: uata pea rupi ele está andando no caminho; Ikatu ko rape rupi puta uruhow nós vamos passar pelo caminho da roça de Ikatu

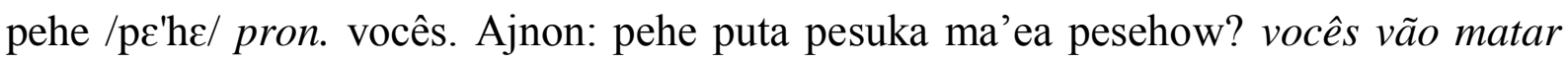
aquelas caças?; urunupopapaw puta pehe eu vou bater em vocês todos; pehe ta peraha pewuhyj myriti 'ywa vocês carregaram a tora de buriti; pehe pa'e purumu'etaramu vocês são professores?; pehe pa'e peapyg pesekwapa vocês sentando aqui

pehitaw /pshi'taw/ n.III vassoura

peke'i /pkke'il/ n.III piquiá, pequiá, pequi, Caryocar brasiliense. Ajnon: uetyg puta remi ohow peke'i 'ywa ehera eles vão cortar o pé de piquiá

penur /pe'nus/ n.descr. ruim

petiwaron /petiwa'son/ n.III goiaba

petiwaron 'ywa /petiwa'son '?iwa/ n.III goiabeira. • Eisag $\rightarrow$ 'ywa

petyma /pe'tima/ n.III fumo, cigarro

petyma pisara /pe'tima pi'sara/ $n . I I I$ tabaco (fumo)

petyma pisara 'ywa /pe'tima pi'sara 'Piwa/ n.III tabaco (árvore). • Eisag $\rightarrow$ 'ywa

petyma pysahy /pe'tima pisa'hì/ n.III café

petymutawa /petimu'tawa/ $n . I I I$ cachimbo

pew /'pew/adv. ali

pewise /pewi'se/ adv. longe. Ajnon: wyra uwewe ete pewise os pássaros voaram muito alto (longe)

piaka /pia'ka/ n.III jaçanã, jacanídeo. • Eisag $\rightarrow$ wyra

pikapikam /pikapi'kam/ n.III roupa seca ao sol

pina'irona /pina?i'sona/ $n . I I I$ graviola, biribá

pina'irona 'ywa /pina?i'rona '?iwa/ n.III gravioleira. • Eisag $\rightarrow$ 'ywa

pinowa /pi'nowa/ n.III palha de babaçu. Ajnon: pinowo olho da palha de babaçu; pinowa wajkiti está riscando palha (cortando para dobrar a palha)

pinuwa /pinu'wa/ n.III açaí. • Eisag $\rightarrow$ susiwa

pinuwahu 'ywa /pinuwa'hu '?iwa/ n.III bacabeira, Oenocarpus. • Eisag $\rightarrow$ 'ywa 
pinuwahua /pinuw ?a'hua/ n.III bacaba

pisu'um ( pisun) /pisu'?um/ n.descr. sujo. Ajnon: usahug ohow upisupisunawi ele banhou porque estava sujo; ne atu'a pisun tua nuca está suja

pitiuhu ( pisiuhu) /pitiu'hu/ n.III tucano (esp.), Ramphastos toco. - Eisag $\rightarrow$ tukan, wyra

poronoa /pors'noa/ n.III rio. Ajnon: aha puta poronoa rupi eu saio do rio; asehej ri'a porono pupe eu me lavei no rio; porono pupe Ikatu ihoj para dentro do rio Ikatu foi; aiko ra'e wehe re pa'e ehow he porono pupe aitapa ontem você foi nadar no rio

puhapuhaw /puhapu'haw/ n.III rola-bosta, escaravelho

puhi /pu'hi/ part. proibitivo. Ajnon: Suta'ar sene 'arimu ihoramu puhi ke pe isaukar puhi quando Suta'ar passar sobre nós, não amostrar (não apontar); eho puhi não vá puhope /pu'ho'pe/ n.III garra (de bicho)

pukongete /pukone'te/ n.descr. forte (muito)

puna /pu'na/ n.III taquara fina (esp.)

purake /pura'ke/ n.III poraquê, peixe-elétrico, puraquê, Electrophorus electricus

purumu'etaramu /puru'mu?c'taramu/ n.III professor/professora. Ajnon: ise purumu'etaramu eu sou professor

purumupisetaramu /puru'mupisc'taramu/ n.III pajé. Ajnon: ise purumupisetaramu eu sou pajé

puta /pu'ta/ part. projetivo. Ajnon: pehe puta pesuka ma'ea pesehow? vocês vão matar aquelas caças?; ise hu puta runupo eu bato em vocês dois; moronime puta pe saha koa pupe? quando vamos para a roça?; aha puta Perẽj pupe eu vou para Belém; aapara puta ri'a tekwawa eu vou dobrar a rede; ti se'eromamu puta ri'a ahywykaj eu vou cavar meu poço

pyasej /pia'ses/ n.III meia-noite

pykahu /pika'hu/ n.III pombo. - Eisag $\rightarrow$ wyra

pykapykawa /pikapi'kawa/ n.III borboleta. - Eisag $\rightarrow$ pykapykawipisuna'e, pykapykawtinga'e, tiwaku

pykapykawipisuna'e /pikapikawipisuna'?e/ n.III borboleta-preta. $\quad$ - Eisag $\rightarrow$ pykapykawa 
pykapykawtinga'e /pikapikawtina'?e/ n.III borboleta (esp.), Morpho. • Eisag $\rightarrow$ pykapykawa

pyky’i /piki'il/ n.III rolinha, Columbídeos, Columbina. - Eisag $\rightarrow$ wyra

pypypypy /pipipi'pi/ $n$.III coruja-branca, Tyto alba. - Eisag $\rightarrow$ masakuwa, wyra

pytera /pi'tera/ n.descr. meio. Ajnon: awati pytera rupi puta uruhow eu vou passar pelo meio (da plantação) de milho

pytowoihu /pitowoi'hu/ n.III bem-te-vi, Pitangus sulphuratus. - Eisag $\rightarrow$ wyra

\section{$\mathrm{R}$}

rako /ra'ko/ $a d v$. atestado pelo falante. Ajnon: uwahemamaw rako todos já chegaram!; urunupo rako pehe nós batemos em vocês; aiko ra'e wehe rako aha ka'a pe weketa ontem eu fui dormir no mato

reko /rع'ko/ part. atestado. Ajnon: ohopapaw reko todos já foram!

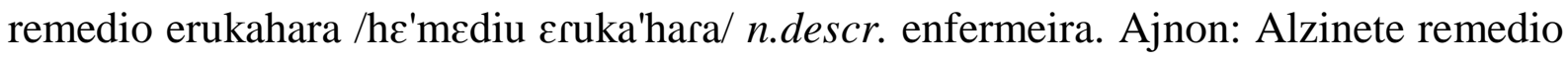
erukahara Alzinete é enfermeira (é a que faz vir o remédio)

remi / $\varsigma$ 'mi// part. coletivizador. Ajnon: aimi wyra'yra remi ti rejmawa aquelas galinhas são meus xerimbabos; uso'o remi eles choraram; uapyg remi ukwapa todos estão sentados; oho puta remi iatika peke'ia 'ywa eles vão cortar a árvore do pequi; kusomuku'i remi usaihejhe as moças estão rindo; ukerpapaw remi todos entraram na casa

ri'a /ri'Pa/ part. declarativo. Ajnon: asemuaraseteete ri'a eu brinquei muito; asonete ri'a wehow asonete ri'a wehow; uker ri'a ele dormiu; a'aw ri'a eu estou deitado; ti 'aw kujpaw ri'a meu cabelo caiu

ripo /ri'po/ posp. dúvida. Ajnon: ma'ea ripo ti u'u algo me mordeu; awa pa'e ripo use'engar? quem está cantando?; awa ripo apukapukaj alguém está gritando muito; aikoj katu ripo isahug para lá (incerteza) ele banhou 


\section{S}

sa'i'um /sa?i'Pum/ n.III barro

sahy /sa'hï/ n.III lua

sahya uwya /sa'hia u'wia/ $n . I I I$ lua ensanguentada, eclipse

sahytata /sa'hita'ta/ n.III estrela. • Eisag $\rightarrow$ eisu, sahy, sahytataw'a

sahytataw'a /sahitataw'?a/ $n$.III estrela cadente (maior). • Eisag $\rightarrow$ sahytata

saimew /sai'mew/ n.III panela de barro

sakami /saka'mi/ n.III jacamim, Gruiformes, Psofídeos, Psophia

sakarana /sakara'na/ n.III jacarandá, Dalbergia, Machaerium

sakare akoj /saka're a'kos/ n.III bule

sakare asywa /saka're a'siwa/ n.III cangalha, cambito de cangalha

sakarea /saka'rca/ $n . I I I$ jacaré

sakarehu /sakare'hu/ n.III jacaré-açu, Tachia guianensis

sakaretinga /sakare'tina/ n.III jacaretinga, Caiman crocodilus

sakua /sa'kua/ n.III jacu, Galiformes, Cracídeos, Penelope. - Eisag $\rightarrow$ wyra

sakuhua /saku'hua/ n.III jacutinga, Pipile jacutinga

sakuna /saku'na/ n.III jacundá, Crenicichla

sanipaw /sani'paw/ n.III jenipapo

sanu /sa'nu/ $n . I I I$ aranha. • Eisag $\rightarrow$ sanu'i, sanupopuku, sanupuhaw, sanupyha

sanu'i /sanu'Pi/ $n . I I I$ aranhiço, aranhinha. • Eisag $\rightarrow$ sanu

sanua rekwawa /sa'nua re'kwawa/ n.III antena parabólica

sanupopuku /sa'nupspu'ku/ n.III aranha-caranguejeira, Subordemortógnatos,

Terafosídeos. • Eisag $\rightarrow$ sanu

sanupuhaw /sanupu'haw/ n.III aranha (esp.). • Eisag $\rightarrow$ sanu

sanupyha /sanupi'ha/ $n$.III teia de aranha. • Eisag $\rightarrow$ sanu 
sapakania /sapaka'nia/ n.III gavião, Falconiformes, Acipitrídeos/Falconídeos. • Eisag $\rightarrow$ sapakanirona, wyra

sapakanirona /sapakani'sona/ n.III águia. • Eisag $\rightarrow$ sapakania, wyra

sapewa /sa'pewa/ tatu (esp.). • Eisag $\rightarrow$ tatu

sapi’i /sapi'Pi/ $n$.III xexéu. • Eisag $\rightarrow$ wyra

sapuhu /sapu'hu/ n.III xexéu (esp.). • Eisag $\rightarrow$ wyra

saratyta /sacati'ta/ n.III caramujo

sarukawa /saru'kawa/ n.III jacu (esp.)

sate'i py'a /satz?i pi'?a/ $n$.III biscoito recheado

satewu'i /satcwu'Pi/ n.III carrapatinho, Amblyomma cajennense. - Eisag $\rightarrow$ satewua

satewua /satc'wua/ n.III carrapato, Ixodídeos/Argasídeos. Ajnon: Ikatu konga re satewuga ituni tem carrapato na perna da Ikatu. - Eisag $\rightarrow$ satewu'i, satewupew, satewupytong

satewupew /satewu'pew/ n.III carrapato-estrela, Amblyomma cajennense. • Eisag $\rightarrow$ satewua

satewupytong/satcwupi'toy/ n.III carrapato-vermelho, Rhipicephalus sanguineus. Eisag $\rightarrow$ satewua

sati'u /sati'Pu/ n.III carapanã, mosquito

satuta'i /satuta'?i/ n.III caracol

sautia /sau'tia/ n.III jabuti. • Eisag $\rightarrow$ sautiakarahawa, sautihu

sautiakarahawa /sau'tiakara'hawa/ n.III tracajá. - Eisag $\rightarrow$ sautia

sautihu /sauti'hu/ n.III jabuti-açu, Chelonoidis denticulata. • Eisag $\rightarrow$ sautia

sautipeuhu /sautipeu'hu/ n.III besouro

sautipewa /sauti'pewa/ n.III barata, Blatídeos

sautipewhurona /sauti'pewhu'rona/ n.III barata-d'água

sawamimawa /sawami'mawa/ n.III gato, Felis catus. • Eisag $\rightarrow$ sawara

sawapinima /sawapi'nima/ $n$.III onça-pintada, Panthera onça. • Eisag $\rightarrow$ sawara

sawapirong /sawapi'soy/ n.III onça-vermelha, suçuarana, Felis concolor. • Eisag $\rightarrow$ sawara 
sawapisuna /sawapi'suna/ $n . I I I$ onça-preta, Panthera onça. • Eisag $\rightarrow$ sawara

sawara /sa'wara/ n.III onça. Ajnon: ywyra re aseupir sawara wi eu subi na árvore afastando-me da onça; sawarahuete a onça grande; sawara usaruetewa'e a onça é braba. - Eisag $\rightarrow$ ma'esawara, sawamimawa, sawapinima, sawapirong, sawapisuna, sawari, sawaruna

sawari /sawa'ri/ $n$.III jaguatirica, Felis pardalis. • Eisag $\rightarrow$ sawara

sawaron /sawa'ron/ n.III lobo

sawaruna ( sawaruna)/sawa'suna/ n.III onça preta. • Eisag $\rightarrow$ sawara

sawatarag /sawata'rag/ n.III lontra, Lutra, Mustelídeos

sawewyra /sawe'wira/ n.III arraia

sawirire /sawiri're/ n.III morcego, Ordem dos Quirópteros

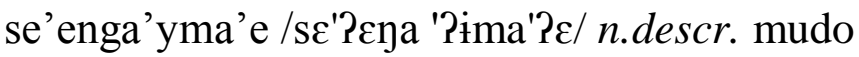

se'engawera /se?cya'wera/ n.III recado. Ajnon: ne se'engawera ri'a amume'u iupe eu disse o recado para ele

sehasakara /schasa'kara/ n.III espelho

sene /se'ne/ pron. nós (incl.). Ajnon: na sene rahywi nós não (estamos) doentes/doídos; Ikatua weraha 'ya sene upe Ikatu levou água para nós

seruti /seru'ti/ n.III anambé-pombo, Gymnoderus foetidus

sesu /se'su/ n.III jeju, jiju, Hoplerythrinus unitaeniatus. • Eisag $\rightarrow$ ipira

setyg /se'tig/ n.III batata-doce. • Eisag $\rightarrow$ setyrona

setyrona /scti'sona/ $n$.III batata. Ajnon: aiko ra'e wehe rako aha ityma ko pupe setyrona ontem eu fui plantar batata na roça. • Eisag $\rightarrow$ setyg

so /'so/ n.III castanha-do-pará, Bertholletia excelsa. Ajnon: so putyra flor de castanhado-pará; aiko ra'e wehe puta aha ikaw so depois de amanhã eu vou coletar castanhado-pará

so kytykawa /'so kiti'kawa/ n.III ralador de castanha. • Eisag $\rightarrow$ kytykaw

sohu /so'hu/ n.III sapucaia, Lecythis grandiflora. • Eisag $\rightarrow$ 'ywa

soko /so'ko/ n.III socó, Nycticorax nycticorax. • Eisag $\rightarrow$ wyra

sope /so'pe/ n.III ouriço de castanha 
$\mathrm{su} /$ 'su/ n.III espinho. - Eisag $\rightarrow$ tatina'ywa

su'i /su'Pi/ n.III jia

su'un /su'Pun/ n.III sinal, mancha

suewiewir /suewiew'ir/ $a d v$. repetidamente. Ajnon: uapukaj suewiewira ele grita repetidamente

suewir /sucw'ir/ adv. novamente. Ajnon: aker suewir eu dormo de novo; aku'om suewir eu me levanto novamente; uapukaj suewiewira ele grita repetidamente

sumi'a /sumi'?a/ n.III flauta (tipo)

sumi'ahu /sumi?a'hu/ n.III avião

suparapara /supara'para/ n.III abacaxi-do-mato

suparaparon ypya /suparapa'ron i'pia/ n.III abacaxizeiro. • Eisag $\rightarrow$ 'ywa

suparaparona /suparapa'rona/ n.III abacaxi. - Eisag $\rightarrow$ suparapar

supati /supa'ti/ n.III rato (esp.)

susiw'a 'ywa /susiw'?a '?iwa/ n.III açaizeiro, Euterpe oleracea. • Eisag $\rightarrow$ 'ywa

susiw’arya /susiw?a'ria/ n.III suco do açaí

susiwa /susi'wa/ n.III açaí (grande). Ajnon: susiwa haj açaí (está) azedo. • Eisag $\rightarrow$ pinuwa, pinuwahua

susiwa 'awa /susiwa'?awa/ n.III cacho do açaí. • Eisag $\rightarrow$ susiwa

suta 'ywa /suta '?iwa/ n.III jatobá, Hymenaea. • Eisag $\rightarrow$ 'ywa

suw'e /suw'?ع/ n.III perereca, Anfíbios anuros arborícolas

suwe /su'we/ n.III sapo (esp.)

swaratia /swaratia/ n.III espinho (ponta de). • Eisag $\rightarrow$ su

sykong /sy'koy/ n.III chocalho (tipo)

sypew /si'pew/ n.III enxada

syru'otawa /siru?ว'tawa/ n.III máquina de costura

syryg /si'rig/ n.III machado. Ajnon: syryg puta amono ne irua pe eu vou dar o machado para o teu irmão 


\section{$\mathrm{T}$}

ta'oga /ta'?oga/ n.III formiga (esp.). - Eisag $\rightarrow$ tahywa

tahakwari /tahakwa'ri/ n.III taquara (esp.)

tahywa /ta'hiwa/ n.III formiga, Formicídeos. - Eisag $\rightarrow$ ta'oga, tahywuna, tahywarema, tahywa purupir piwe

tahywa purupir piwe /ta'hiwa puru'pir pi'we/ n.III formiga-de-fogo. • Eisag $\rightarrow$ tahywa tahywarema /tahiwa'rema/ $n . I I I$ formiga-correição. • Eisag $\rightarrow$ tahywa tahywuna /tahi'wuna/ n.III formiga (esp.)

takwara syw'a /ta'kwara siw'?a/ n.III telha

takwawera /takwa'wera/ $n . I I I$ palha de aço

tamawa /tama'wa/ n.III tamanduá-bandeira. • Eisag $\rightarrow$ asong

tameaimun /tameai'mun/ n.III peixe (esp.). • Eisag $\rightarrow$ ipira

tami'iwehe /tami'iwe'he/ n.III pescada (peixe). - Eisag $\rightarrow$ ipira

tangara /tana'ra/ n.III tangará. • Eisag $\rightarrow$ wyra

taparaniwa 'ywa /tapara'niwa '?iwa/ n.III árvore (esp.). • Eisag $\rightarrow$ 'ywa

tapi'ipisuna /tapi'Pipi'suna/ n.III anta-preta, Tapirus Kabomani. • Eisag $\rightarrow$ tapi'ira

tapi'ira /tapi'?ira/ n.III anta, Tapirus terrestris. Ajnon: ti re mi suka tapi'ira minha coisa matada a anta; tapi'ira puta oho ka'a wi uhema a anta vai saindo do mato. Eisag $\rightarrow$ tapi'ipisuna, tapi'itinga

tapi'ise /tapi?i'se/ n.III coelho, Oryctolagus cuniculus

tapi'itinga /tapi?i'tina/ n.III anta-branca, Tapirus terrestris. Ajnon: ma'esawara usepurakaretewa'e u'u tapi'itinga o cachorro que é bom caçador mordeu a antabranca

tapisara ( tapisapisara) /tapi'sara/ num. muitos

tapoworona /tapowo'rona/ n.III paneiro (de cipó-titica). Ajnon: Miho uapokwahaw tapoworona Miho sabe fazer paneiro 
tarajwir 'ywa /taraswi's Piwa/ n.IIa sumaúma (esp.). • Eisag $\rightarrow$ 'ywa

tararawre /tararaw're/ n.III japiim, Cacicus cela

taratiratinga ${ }^{1} /$ taratica'tina/ n.III libélula, jacinta

taratiratinga ${ }^{2} /$ taratira'tina/ n.III helicóptero

tareiri /tarci'ri/ n.III traíra, Hopliasmalabaricus. • Eisag $\rightarrow$ ipira

tarejriuhu /tares'riu'hu/ n.III trairão. • Eisag $\rightarrow$ ipira

tasahua /tasa'hua/ n.III porcão, queixada, Tayassu pecari. Ajnon: aha puta ri'a isukaw tasahuamu talvez eu mate um porcão; asuka ete puta tasahuamu com certeza eu vou matar um porcão; kuej wehe puta ihoj tasahua amanhã ele quer caçar porcão. • Eisag $\rightarrow$ tasahumymaw

tasahua mymawa arigea po pyrera /tasa'hua mi'mawa ari'gea po pi'rera/ $n$.III linguiça de porco

tasahua sywa pekongwera /tasa'hua siwa peko'Đwera/ n.III pá

tasahumymaw /tasa'humi'maw/ n.III porco, Suídeos. Ajnon: eremono pa'e imomomyrera pupe tasahumymawa? você já prendeu todos os porcos? - Eisag $\rightarrow$ tasahu

tasahuron komopikara /tasahu'son komopi'kara/ n.III gafanhoto (esp.)

tasarona /tasa'rona/ n.III taioba, Xanthosoma violaceum

tata /ta'ta/ n.III fogo (em geral), fogueira. - Eisag $\rightarrow$ tatahu, tatatinga

tatahu /tata'hu/ n.III cinzas. - Eisag $\rightarrow$ tata

tatahuwa /tata'huwa/ n.III poeira

tatapekwawa /tatape'kwawa/ n.III abanador

tatatinga /tata'tina/ n.III fumaça. • Eisag $\rightarrow$ tata

tatatirong /tatati'roy/ n.III neblina

tatin /ta'tin/ n.III lombriga, verme. Ajnon: rigepe ikoj ti tatina no meu intestino está meu verme

tatina'ywa /tatina'?iwa/ n.III agulha. • Eisag $\rightarrow$ su

tatu /ta'tu/ n.III tatu. Ajnon: mowy pa'e iture tatu? de onde o tatu saiu? - Eisag $\rightarrow$ sapewa, tatuete, tatuhu, tatupew 
tatuete /tatuc'te/ $n . I I I$ tatu-galinha. - Eisag $\rightarrow$ tatu

tatuhu /tatu'hu/ n.III tatu-canastra. - Eisag $\rightarrow$ tatu

tatupew /tatu'pew/ n.III tatupeba, Euphractus sexcinctus. • Eisag $\rightarrow$ tatu

tatyuhu /tatiu'hu/ n.III surucucu, Bothrops jararacussu. • Eisag $\rightarrow$ mosa

tawareraj /taware'ras/ n.III mucura, Didelphis

tawarerasapina /ta'ware'rasa'pina/ n.III peixe-cachorro, peixe-cabeça-de-cachorro, pirapucu, timbucu, Raphiodon vulpinus. - Eisag $\rightarrow$ ipira

tawoto /tawo'tı/ n.III gavião vermelho. • Eisag $\rightarrow$ wyra

tayiwa /tai'iw?a/ n.III época de mamuĩ

tehahua /tcha'hua/ n.III tucumã, Astrocaryum/Bactris. Ajnon: tehahua iapu'a o tucum é redondo

tehe /tع'he/ posp. mesmo. Ajnon: upoku ikaru tehe ele come com a própria mão

temi'u pyuhawa /temi'?u piu'hawa/ n.III concha (de cozinha)

ti /'ti/ pron. eu, meu. Ajnon: ti ko pupe tiwa'a tem caititu na minha roça; ko pupe ti hy ihoj pra roça minha mãe foi; tipiw ihoj karuarahua usona a paca correu perto de mim; ise ti asate'ymete eu sou preguiçosa; ti kane'uete ri'a eu estou muito cansada

ti'iwa /ti'Piwa/ n.III arco-íris

tikwa /ti'kwa/ n.III papagaio (esp.). • Eisag $\rightarrow$ wyra

timo /ti'ms/ n.III timbó. Ajnon: atimukamuka puta wehow 'ar pyteripe eu vou botar timbó [na água para matar peixe] no meio do verão

tine’a /tinc'?a/ n.III mandi, Pimelodella gracilis. - Eisag $\rightarrow$ ipira

tiniarona /tinia'rona/ $n . I I I$ peixe (esp.). • Eisag $\rightarrow$ ipira

tipiw /ti'piw/ $a d v$. perto. Ajnon: tipiw ihoj karuarahua usona a paca correu perto de mim; ne memyra tipiw uapyg teu filho sentou perto de mim

tirikwera pypetawa /tirikwera pipetawa/ n.III varal

tiwa'a /tiwa'?a/ n.III caititu, porco-do-mato, Tayassu tajacu. Ajnon: aihyra'u ri'a tiwa'a eu quero assar o caititu; Ikatu oko pupe tiwa'a tem caititu na roça de Ikatu tiwaku /tiwa'ku/ n.III borboleta-coruja. - Eisag $\rightarrow$ pykapykawa 
tukan /tu'kan/ n.III tucano, Piciformes, Ramphastos, Ranfastídeos. - Eisag $\rightarrow$ kwere, kwreta'u, pisiuhu

tukanaw /tuka'naw/ n.IIa cocar (de penas de tucano)

tukangyra /tuka'yira/ n.III tucandeira, tocandira, Poneríneos

tukanuhu /tukanu'hu/ n.III tucanuçu

tuku 'ywa /tu'ku '?iwa/ n.III tucunzeiro, Astrocaryum/Bactris. • Eisag $\rightarrow$ 'ywa

tukurupipina ${ }^{1} /$ tukurupi'pina/ n.III gafanhoto

tukurupipina $^{2} /$ tukurupi'pina/ n.III moto

tuny /tu'ni/ n.III pulga

tupasa /tu'pasa/ n.III tipoia

turihiwnuhu /turihiwnu'hu/ n.III mamão

turihiwnuhu 'ywa/turihiwnu'hu '?iwa/ n.III mamoeiro, Carica papaya. - Eisag $\rightarrow$ 'ywa

tururi /turu'ri/ n.III bico-roxo, tururu, Nomonyx dominicus

tutyr /tu'tis/ n.IIa tio (de mulher)

tuwa $^{1} /$ 'tuwa/ n.III abelha. - Eisag $\rightarrow$ katykyehyra, musy'yehyra

tuwa $^{2}$ /'tuwa/ n.IIb pai de alguém. Ajnon: usuwa pai dele próprio; ti ruwa, eresuka pa'e ma'ea? meu pai, você matou algo?; ene pa'e eremono ywyrapara ne ruwa pe você deu o arco para o teu pai. - Eisag $\rightarrow$ na

ty $^{1} /$ 'ti $/ n . I I I$ seiva

$\operatorname{ty}^{2} /$ 'tia/ n.III bagaço. Ajnon: tymo rajty bagaço de timbó; so rajty bagaço de castanha; inata rajty bagaço de coco

ty’ymon /tiłi'mon/ n.III olho-d'água

tykyrayra /tikira'ica/ n.III periquito-verde, Psitacídeos. • Eisag $\rightarrow$ wyra

tymemyra pyhykarera ( ti hy angaw) /time'mura pihika'rera/ n.III parteira, mãezinha

typaw /ti'paw/ n.descr. seco

typyhyhawa /tipihi'hawa/ n.III remo

tyrua /ti'sua/ n.III companheiro 
tyrykwera /tiri'kwera/ n.III roupa

tyrykwera apotawa /tiri'kwera apo'tawa/ n.III tecido (para fazer roupa)

tyrykwera pimumykawa /tiri'kwera pimumi'kawa/ n.III ferro de passar

tyryrypya /tiriri'pia/ n.III bagre (esp.). - Eisag $\rightarrow$ ipira

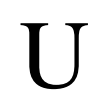

u'ar ${ }^{1} / u^{\prime}$ 'Tar/ v.intr. cai/caiu. Ajnon: a'ar werew eu quase caí; u'ar puta ele vai cair; u'ar 'ywetewi ele caiu da árvore; uru'ar nós caímos; wesowesona a' ar eu estava correndo e caí; 'ywa rokowi i'ar ele caiu lá de cima do galho da árvore. • Eisag $\rightarrow$ kuj, kukuj u'ar ${ }^{2}$ /u'Par/ v.intr. nasce/nasceu. Ajnon: a'ar eu nasci; u'ar puta ele vai nascer; u'ar pa'e ne rasira? já nasceu tua filha?; ne ra'yra pe u'ara? teu filho já nasceu? (pergunta para o homem)

u'asuka /u?asu'ka/ v.tr. aterra/aterrou. Ajnon: a'asuka oga aterrar (o piso da) casa u'aw /u'?aw/ v.intr. deita/deitou na rede. Ajnon: a'aw ri'a eu (estou) deitado na rede; a'aw puta ri'a wehow estou indo me deitar na rede

u'e ( u'i) /u'?ع/ v.intr. diz/disse, conta/contou. Ajnon: i’i hejkwehe ele contou faz muito tempo; uru'e nós (excl.) dissemos; uruse'eng ehe aikwesa ikatuete uru'e sepi ehe nós falamos sobre a bondade dele

$\mathrm{u}^{\prime} \mathrm{u}^{1} / \mathrm{u}^{\prime} \mathrm{Pu} /$ v.tr. come/comeu. Ajnon: ma'ea rupi pa'e eremukun ne remi'ua? por onde você engole sua comida?; u'u puta ri'a ele vai comer; ise apirog pahakurona i'u eu descasquei e comi a banana. - Eisag $\rightarrow$ karu

$\mathrm{u}^{\prime} \mathrm{u}^{2} / \mathrm{u}^{\prime} \mathrm{Tu} /$ v.tr. morde/mordeu, pica/picou. Ajnon: ma'esawara puta usekyj mosa u'uramu o cachorro vai morrer, porque a cobra mordeu ele; awa pa'e mosa u'u? quem a cobra mordeu?; ma'e pa'e ne u'u? o que te mordeu?; ma'ea ripo ti u'u algo me mordeu

u'umu'om /u?umu'?om/ v.tr. enfia/enfiou. Ajnon: ywyra u'umu'om ele enfia estaca u'y’u /u'i'?u/ bebe/bebeu água. Ajnon: aiko ra'e wehe rako ko pupe aha ityma a'y'u roko raj ipyk ikatua muapyga nune ontem eu plantei roça, bebi água e comi macaxeira; u'y'u puta ri'a ele vai beber 
u'yahaw /uPia'haw/ v.intr. atravessa/atravessou o rio. Ajnon: uru'yahaw nós atravessamos o rio; u'yahawa'e urusuka misara nós matamos o veado que atravessou o rio; 'yahaw katy aha eu fui rio abaixo; 'ya rupi i'yahawi ele atravessou o rio

ua /'ua/ voc. irmã (mulher falando)

ua'ar werew /ua?ar we'rew/ v.intr. desequilibra-se/desiquilibrou-se. Ajnon: aa'ar werew eu me desiquilibrei; ua'ar werew puta ele vai se desiquilibrar

uagahaw ahemawa /uaga'haw ahe'mawa/ n.III sul

uahaw /ua'haw/ v.tr. atravessa/atravessou. Ajnon: upeahaw (ele) atravessar o caminho

uahem /ua'hem/ v.intr. chega/chegou. Ajnon: uahemamaw pa'e? todos já chegaram?; uwahemamaw rako todos já chegaram!; monamu puta pa'e ituri wahemamapa? quando todos vão chegar?; uruwahemame ri'a kowi nós (excl.) chegamos da roça; aiko ra'e wehe rako awahem akaru akerako ontem eu cheguei, comi e dormi

uahyryrym /uahiri'sim/ v.intr. escorrega/escorregou. Ajnon: aahyryrym eu escorreguei; uahyryrym puta ele vai escorregar

uaiko /uai'ko/ v.tr. pendurado (está/esteve). Ajnon: uaiko ele está pendurado; iapiryrua uaiko ywete o boné está pendurado no alto

uajkiti ( wajkisi) /uaski'ti/ v.tr. risca/riscou, corta/cortou. Ajnon: wajkiti pinowa está riscando palha (cortando para dobrar a palha)

uakawa'i opo pyrera /uakawa'?i o'po pi'rera/ n.III papel, caderno

uamuwew /uamuw'ew/ v.tr. apaga/apagou. Ajnon: amuew puta ri'a tata eu vou apagar o fogo; amuewpapaw ri'a tata eu acabei de apagar o fogo inteiro, completamente; oko umuew roko ikwehew ele sempre apagava o fogo

uanawa /ua'nawa/ n.f. padrasto

uapar /ua'par/ v.tr. dobra/dobrou. Ajnon: aapar puta ri'a tekwawa eu vou dobrar a rede; uapar puta ri'a uekwawa Suelia Sueli, você vai dobrar a sua rede; ereapar pa'e ne rekwawa rupohoma? você está dobrando a corda da sua rede?

uapekar /uape'kar/ v.tr. abre/abriu Ajnon: aapekar eu abri; uapekar puta ri'a ele vai abrir

uapo ${ }^{1}$ /ua'po/ v.tr. faz/fez. Ajnon: aapoa'u ri'a wetoga eu quero fazer minha casa; ure uruapo 'og nós fizemos estas casas; aapoa'u ri'a manime ne roga pupe eu preciso fazer farinha na tua casa (de farinha)

uapo $^{2}$ /ua'po/ v.tr. desenha/desenhou, pinta/pintou. Ajnon: aapo puta ma'e arawa eu vou desenhar/pintar qualquer coisa 
uapukaj /uapu'kas/ v.intr. grita/gritou. Ajnon: aapukaj eu gritei; awa pa'e uapukasatuete? alguém está gritando muito?; ne memyra pa'e uapukaj tua filha gritou; pew ri'a awa iapukaj lá, alguém está gritando; ne remiriko ripo uapukaj ne upe sua esposa está gritando para você; Ikatua ripo uapukapukaj Ikatu está gritando muito

uapukapukaj /uapupuka'kas/ v.intr. ecoa/ecoou, grita/gritou muito. Ajnon: awa ripo apukapukaj alguém está gritando muito; aapukapukaj eu gritei

uapy /ua'pi/ v.tr. queima/queimou. Ajnon: use'i wehete puta aapy weko amanhã bem cedo eu vou queimar minha roça

uapyg /ua'pig/ v.tr. senta-se/sentou-se. Ajnon: aapyg wetuna eu estou sentado; ure uruapyg iri'a urukupa nós todos estamos sentandos; uruapyg puta ri'a nós (excl.) vamos nos sentar; ne memyra tipiw uapyg teu filho sentou perto de mim

uapyhara /uapi'hara/ v.tr. trança/trançou, teço/teceu. Ajnon: aapyhara eu trancei; uapyhara puta ele vai trançar

uarikure /uariku're/ $n . I I I$ tripé para cozinhar

uasun /ua'sun/ v.intr. espirra/espirrou. Ajnon: aasun eu espirrei; uasun puta ri'a eu vou espirrar

uasupaw /uasu'paw/ v.intr. agrisalha/agrisalhou. Ajnon: iasupawame'ete ele está começando a ficar com os cabelos bem grisalhos

uata /ua'ta/ v.intr. anda/andou. Ajnon: aata eu ando; uata puta ele vai andar; enune uruata na frente, nós andamos; aiko ra'e wehe re pa'e erehow ka'a pe eataw ontem você foi andar no mato; aiko ra'e wehe rako ata akaru ase'engar ontem eu andei, comi e cantei

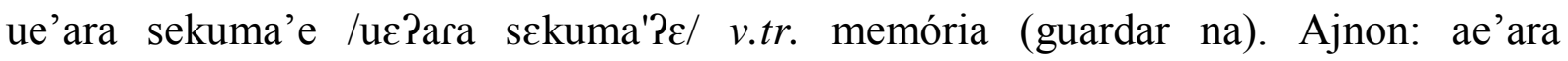
sekuma'e eu lembrei (guardei na memória)

ueraha /usra'ha/ v.tr. leva/levou. Ajnon: Muretama weraha kyse ipyhyka ti wi Muretama levou a faca que pegou de mim

uerur /uع'rur/ v.tr. traz/trouxe. Ajnon: mo wi pa'e ererur ma'ea ro'o? de onde você trouxe (fez vir) esta carne de caça?

uesag /uع'sag/ v.tr. vê/viu. Ajnon: kupara ti resag ri'a o compadre está me vendo; aiko re wehe rako aesag akuma'e ontem eu vi este homem; awa pa'e he Wajwera uesag? quem foi a pessoa que Wajwera viu?; wapitu'o wesag sepi a'wera tem gente que vê espírito; awa pa'e rejsag? quem você viu?; na esagwi wehe ipira ku'omawa eu nunca vi peixe levantado 


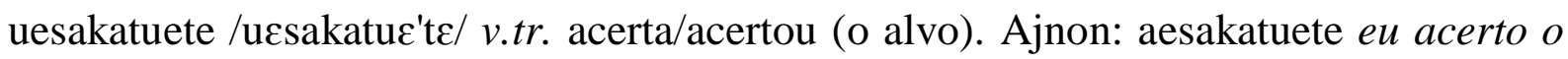
alvo; uesakatuete puta ele vai acertar o alvo

uesyj /uc'sis/ v.tr. arrasta/arrastei

uetun /uc'tun/ v.tr. cheira/cheirou

uhaku'og /uhaku'?og/ v.tr. ponte (fazer). Ajnon: ahaku'og eu fiz ponte

uhej /u'hes/ v.tr. lava/lavou. Ajnon: asyruhej eu lavo roupa; asehej ri'a porono pupe eu me lavei no rio

uhem /u'hem/ v.intr. sai/saiu. Ajnon: ahem eu saí; uhem puta ri'a eu vou sair; uruhem nós (excl.) saímos

uhen /u'hen/ v.tr. esvazia/esvaziou. Ajnon: ahen eu esvaziei; uhen puta ele vai esvaziar

uhir /u'hir/ v.tr. risca/riscou

uhojme'e /uhosme'?ع/ v.tr. amola/amolou

uhumyru ( mymyrur) /uhumi'su/ v.tr. procura/procurou. Ajnon: ahumyru eu procurei; uhumyru puta ele vai procurar; uruhumyru nós (excl.) vamos procurar; amymyrur ri'a kysea wekow eu estou procurando a faca; eho imymyrur vá e procure algo

uhuw /u'huw/ v.tr. encontra/encontrei

uhuwapyg /uhuwa'pig/ v.tr. fecha/fechou

uhuwepemopog /uhuwepemo'pog/ v.tr. destampa/destampou

uhyw /u'hiw/ v.tr. seca/secou. Ajnon: uhyw puta ri'a ele vai secar

uhywykaj /uhiwi'kas/ v.tr. cava/cavou. Ajnon: ywykwara ahywykaj eu cavo buraco na terra; ti se'eromamu puta ri'a ahywykaj vou cavar meu poço

uihyr /ui'his/ v.tr. assa/assou. Ajnon: aihyra'u ri'a tiwa'a eu quero assar o caititu; uruihyr tasahua nós (excl.) assamos porcão

uikyj /ui'kis/ v.tr. arranca/arrancou. Ajnon: ise pa aikysa'u mani'oga ne ko pupe? eu posso arrancar mandioca na tua roça?

uime /ui'me/ v.intr. ri/riu. Ajnon: aime eu ri

uinu /ui'nu/ v.tr/intr. ouve/ouviu. Ajnon: ainu eu ouço; majere tainune fique calado, eu quero ouvir; imonuarera purunutakwera ainu antigamente eu ouvia histórias; useupir sawara reinupa ele subiu na árvore porque ele ouviu o barulho da onça 
uityg /ui'tig/ v.tr. derruba/derrubou. Ajnon: irutehe'yma'e aityg 'ywa eu já cortei três árvores; uetyg puta remi ohow peke'i 'ywa ehera eles vão cortar o pé de pequi; aiko ku'ema ere puta uruho iejtyka ka'a depois de amanhã nós vamos derrubar mato

uka /u'ka/ v.tr. junta/juntou, coleta/coletou. Ajnon: aiko ra'e wehe puta aha ikaw so depois de amanhã eu vou coletar castanha-do-pará

uka'e /uka'?e/ v.intr. sara/sarou, seca/secou. Ajnon: ise aka'eete eu sarei bem; aikwesa uka'eete ele sarou bem

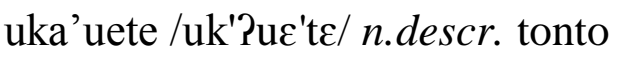

ukaj /u'kas/ v.tr. queima-se/queimou-se. Ajnon: akaj еи me queimei

ukamyg /uka'mig/ v.tr. amassa/amassou

ukamykamyg /ukamika'mig/ v.tr. esmaga/esmagou. Ajnon: akamykamyg eu esmaguei; ukamykamyg puta ri'a ele vai esmagar

ukara /u'kara/ n.III terreiro

ukaru /uka'ru/ v.intr. come/comeu. Ajnon: aiko ra'e wehe rako aata akaru ase'engar ontem eu andei, comi e cantei; ukaru puta ri'a ele vai comer; kopesor sakaru vem aqui, vamos comer; emono ma'esawara tukaru dar comida pro cachorro; te 'ine ukaru deixa ele comer

ukaruw /uka'ruw/ v.intr. entardece/entardeceu. Ajnon: Tymykong umukaruwete ka'ape Tymykong andou o dia todo no mato

ukasym /uka'sim/ v.intr. perde/perdeu. Ajnon: amukasym weywyrapara eu perdi minha espingarda; ma'ea ripo amukasym eu perdi alguma coisa; ukasym ele está perdido (desaparecido); namukuj ripo ma'ea amukasym eu perdi duas coisas

uke /u'ke/ v.intr. entra/entrou. Ajnon: ake eu entro; uke puta ele vai entrar; uruke nós (excl.) entramos; ukerpapaw remi todos entraram na casa

uker /u'ker/ v.intr. dorme/dormiu. Ajnon: ti memyra uker meu filho dormiu; ereker pa'e? você dormiu?; mume pa'e rekerehe? onde você dormiu?; uker ri'a upa ele está dormindo; aker puta ri'a wehow use'iwehe ete wehe ne tatyryg ne eu vou dormir $e$ acordar cedo; tekwawa pupe saker na rede, nós (incl.) dormimos

ukiti /uki'ti/ v.tr. corta/cortou. Ajnon: kyse puta ne pokiti a faca vai te cortar; akiti eu corto; ukiti puta ri'a ele vai cortar. - Eisag $\rightarrow$ umonog, umonohog

ukojte /ukos'te/ v.tr. gosta/gostou. Ajnon: akojte ne rehe eu gosto de você

uku'om /uku'Pom/ v.tr. levanta-se/levantou-se. Ajnon: aku'om suewir eu me levanto de novo; uku'om puta ele vai se levantar 
ukuj /u'kus/ v.intr. cai/caiu. Ajnon: ukukuj ele caiu várias vezes; akuj eu caí; ukuj puta ri'a ele vai começar a cair; ti 'aw kujpaw ri'a meu cabelo caiu; ti rerekatara 'awa ukujpawameete meu marido já está com o cabelo caindo. • Eisag $\rightarrow$ 'ar

ukupe /uku'pe/ n.III parede

ukupir /uku'pir/ v.tr. capina/capinou. Ajnon: ise akupir koa eu capinei a roça

ukurug /uku'rug/ v.intr. mija/mijou. Ajnon: akurug puta ri'a eu vou mijar; urukurug nós mijamos

ukurupesu /ukurupe'su/ v.tr/intr. sopra/soprou. Ajnon: akurupesu eu soprei; ukurupesu puta ele vai soprar

ukutuk /uku'tuk/ v.tr. fura/furou. Ajnon: akutuk eu furo. • Eisag $\rightarrow$ mumuk

ukwahaw /ukwa'haw/ v.intr. sabe/sabia. Ajnon: akwahaw eu sei; Miho uapokwahaw tapoworona Miho sabe fazer paneiro

ukweraw /ukwe'raw/ v.intr. escapa/escapou. Ajnon: akweraw eu escapei; ukweraw puta ele vai escapar; urukweraw nós (excl.) escapamos

ukyr /u'kif/ v.intr. chove/choveu. Ajnon: aiko ku'em kwera re ikyr amona antes de ontem choveu

ukysingog /ukisi'nog/ v.tr. sujeira (tira/tirou a). Ajnon: akysingog eu tirei a sujeira

ukytyg /uki'tig/ v.tr/intr. rola/rolou, esfrega/esfregou. Ajnon: akytyg eu rolei; ukytyg ele vai rolar

ukyyse /ukï'se/ v.intr. medo (tem/teve). Ajnon: akyyse eu tenho medo

umanu /uma'nu/ v.tr. engasga/engasgou

umim /u'mim/ v.tr. esconde/escondeu. Ajnon: amim eu escondo; umim puta ele vai esconder; urumim nós (excl.) escondemos

umomon /umo'mon/ v.tr. enrola/enrolou, rola/rolou. Ajnon: aikewara umomon tekwawa aikewara está enrolando (o fio para tecer) rede; amomon tekwawa eu enrolo rede; aiko ku'ema re puta amomomomon bola wehow depois de amanhã eu vou jogar bola

umomor /umo'mor/ v.tr. joga/jogou

umono /umo'ns/ v.tr. dá/deu. Ajnon: aiko na amonowi ne upe esse eu não dou para você; ko, amono ne upe eu vou te dar; syryg puta amono ne irua pe eu vou dar o machado para o teu irmão; emono ma'esawara tukaru dá comida pro cachorro 
umonog /umo'nog/ v.tr. corta/cortou. Ajnon: ypo amonok eu corto o cipó; amonog a'epe 'ywa eu vou cortar essa árvore; ma'eramu pa'e imonog 'ywa? por que ele cortou a árvore?; uruasejmonog i'akorona nós (excl.) cortamos a abóbora; ma'ea pa remonog eoma? o que você está cortando? - Eisag $\rightarrow$ ukiti, umonohog

umonohog /umonっ'həg/ v.tr. corta/cortou em pedaços. Ajnon: amunohog ete 'ywa eu já cortei muitas árvores; ma'e pa'e eremunohonohog? o que você está cortando?; Suara, eremunohonohog pa'e o'o? Suara, você cortou (várias vezes) a carne?; umonohonohog oko ele corta em pedaços lenha (galho). - Eisag $\rightarrow$ ukiti, umonog

umuapyg /umua'pig/ v.tr. cozinha/cozinhou. Ajnon: amuapyg eu cozinhei; umuapyg puta ri'a ele vai cozinhar

umuason /umua'son/ v.tr. empurra/empurrou. Ajnon: awa poripo muason quem está empurrando?

umuhun /umu'hun/ v.tr. pinta/pintou. Ajnon: amuhun eu pintei; umuhun puta ele vai pintar. $\cdot$ Eisag $\rightarrow$ inupinipara

umuhypyting /umuhipi'tin/ v.tr. suja/sujou. Ajnon: awa pa'e umuhypyting 'ya? quem está sujando a água?; amuhypyting 'ya eu sujei a água

umukasim /umuka'sim/ v.tr. perde-se/perdeu-se. Ajnon: ka'a pe amukasim eu me perdi (desapareci) no mato; umukasim puta ele vai se perder

umuku'om /umuku'?om/ v.tr. levanta/levantou. Ajnon: emuku'om ti memyra levante a criança; emuku' on puhi não o levante; amuku'om eu levanto

umukun /umu'kun/ v.tr. engole/engoliu. Ajnon: ma'ea rupi pa'e eremukun ne remi'ua? por onde você engole sua comida?; ma'ea sene imukunawa por onde a gente engole o alimento

umume'u /umume'?u/ v.tr. conta/contou. Ajnon: umume'u hejkwehe ele contou faz tempo; ne se'engawera ri'a amume'u iupe contei o recado para ele; Miho umume'u kotawypykwera Miho sabe contar histórias antigas

umumuk /umu'muk/ v.tr. fura/furou. Ajnon: usenamimumuk ele furou sua própria orelha; useememumuk ele furou seu próprio lábio. • Eisag $\rightarrow$ kutuk

umunge /umu'yc/ v.tr. põe/pôs. Ajnon: eremungepapaw pa'e ne rejmawa? você já prendeu todos os animais?

umupig /umu'pig/ v.tr. atira/atirou. Ajnon: ise amupig mosa re, ise awisepe mosa nusekysuwi eu atirei na cobra, mas ela ainda vive

umupoiru /umupoi'ru/ v.tr. ajuda/ajudou. Ajnon: amupoiru eu ajudo; umupoiru puta ele vai ajudar; urumupoiru nós (excl.) ajudamos 
umupurungyta /umupuruji'ta/ v.tr. conversa/conversou. Ajnon: urumupurungyta puta ri'a eu vou conversar com você; awa pa'e ne mupurungyta? quem conversou contigo?

umur /u'mur/ v.tr. entrega/entregou

umuse'engar /umuse?E'yar/ v.tr. música (tocar). Ajnon: amuse'engar eu toco música; umuse'engar puta ri'a ele vai tocar música

umusekog /umuse'kog/ v.tr. encosta/encostei. Ajnon: amusekog eu encostei

umusi /mu'si/ v.tr. teme/temeu

umutururu /umuturu'ru/ v.tr. escorre/escorreu

umuw'iw /umuw'?iw/ v.tr. acaricia/acariciou. Ajnon: amuw'iw eu acaricio; umuw'iw puta ele vai acariciar

unemun /unc'mun/ v.intr. cospe/cuspiu. Ajnon: anemun eu cuspi; unemun puta ri'a ela vai cuspir

unung /u'nuy/ v.tr. tece/teceu. Ajnon: anung ri'a wetekwawa eu estou tecendo a minha rede

unupo /unu'po/ v.tr. bate/bateu. Ajnon: urunupo puta eu vou (posso) bater em você; ene puta ti nupo pe você vai bater em mim; iusawa'ea re mi usunupo aqueles crianças estão se batendo; ise puta runupopapaw eu vou bater em vocês todos

upapar /upa'par/ v.tr. lê/leu, conta/contou. Ajnon: apapar eu leio ou eu conto (números); upapar puta ri'a ele vai ler

upari /upa'ri/ $n$.III cercadinho (para animal)

upe /u'pe/ part. para (dativo). Ajnon: aiko na amonowi ne upe esse eu não dou para você; ne remiriko ripo uapukaj ne upe sua esposa está gritando para você. • Eisag $\rightarrow$ pe

upe'uma /upe'?uma/ n.III resina

upehaw /upe'haw/ n.IIb sobrancelha de alguém

upehyj /upc'his/ v.intr. sono (está/esteve com). Ajnon: Ikatu upehysete Ikatu está com muito sono

upen ( nupen) /u'pen/ v.tr. quebra/quebrou. Ajnon: asetinupen eu quebrei o meu nariz; iapyreta upen o esteio (da casa) quebrou

upepikyohaw /upepikis'haw/ n.IIa cílio de alguém 
upesu /upe'su/ v.tr. abana/abanou. Ajnon: apesu eu abano; upesu puta ele vai abanar; urupesu nós (excl.) abanamos

upetymu /upeti'mu/ v.intr. fuma/fumou. Ajnon: apetymu eu fumei; upetymu puta ele vai fumar; urupetymu nós (excl.) fumamos

upi $^{1}$ /u'pi/ v.tr. pica/picou. Ajnon: usupi tehe mosa musuhuwi uma cobra não pica a outra; upi puta ri'a ela vai picar

upi $^{2}$ /ru'pi/ posp. através. Ajnon: awati pytera rupi puta uruhow eu vou passar pelo meio (da plantação) de milho

upiawog /upia'wog/ v.tr. abre/abriu. Ajnon: apiawog eu abri; upiawog puta ele vai abrir

upin /u'pin/ v.tr. raspa/raspou. Ajnon: apin eu raspei; upin puta ri'a ele vai raspar upir /u'pir/ v.tr. ergue/ergueu. Ajnon: aupir ti rekwawa eu ergui minha rede

upirog /upi'rog/ v.tr. descasca/descascou. Ajnon: ise apirog pahakurona i'u eu descasquei e comi a banana

upisong /upi'son/ v.tr. belisca/beliscou

upiti'u /upiti'?u/ n.descr. pitiú. Ajnon: ipira piti'u peixe pitiú; sakare'u pa'e ne piti'u? a carne de jacaré (é) pitiú?; mosa ipiti'uete a cobra (é) muito pitiú

upo'o /upo'Po/ v.tr. colhe/colheu. Ajnon: apo'o eu colhi; upo'o puta ela vai colher

upo'upor/upo?u'por/ v.intr. quica/quicou. Ajnon: upo'upor puta ri'a ele vai quicar

upohoma /upo'homa/ n.III corda. Ajnon: tupohoma kurukwara amarrado com corda

upongahyahy /u'ponahia'hi/ v.intr. troveja/trovejou. Ajnon: aiko ku'em kwera re ipongahyahyj antes de ontem trovejou

upor /u'por/ v.intr. pula/pulou. Ajnon: apor eu pulei; upor puta rì'a ele vai pular

upu'an /upu'?an/ v.intr. afia/afiou. Ajnon: apu' an kyse eu afiei a faca; upu'an puta ri'a kyse ele vai afiar a faca

upu'om /upu'?om/v.tr. atola/atolou. Ajnon: apu'om eu atolei

upug /u'pug/ n.III porta

upuhir /upu'hir/ v.tr. solta/soltou. Ajnon: apuhir eu soltei

upuhope /upuho'pe/ n.IIa unha de alguém

upupur /upu'pur/ v.tr. ferve/ferveu. Ajnon: upupur puta ela vai ferver 
upurahaj /upura'has/ v.intr. dança/dançou. Ajnon: apurahaj eu dancei; upurahaj puta ele vai dançar; upurahaj ta ri mi nupumaruwi ohow eles não estão indo caçar, vão dançar (porque é a festa do Sapurahaj); aiko ra'e wehe rako erewahem erese'engar eresemume ontem você chegou, cantou e dançou

upuramor /upura'mor/ v.intr. peida/peidou. Ajnon: apuramor eu peidei; upuramor puta ri'a ele vai peidar

upurawyky /upurawi'ki/ v.intr. trabalha/trabalhou. Ajnon: upurawyky pa'e ra'e? eles trabalharam?; apurawykyeteete ri'a eu trabalhei muito

upuse /upu'sc/ v.intr. engatinha/engatinhou. Ajnon: apuse eu engatinhei; upuse puta ele vai engatinhar

uputi /upu'ti/ v.intr. caga/cagou. Ajnon: aputi eu caguei; uputi puta ele vai cagar; uruputi nós (excl.) cagamos

upuwon /upu'won/ v.intr. fia/fiou. Ajnon: apuwon eu fiei; upuwon puta eu vou fiar; urupuwon nós (excl.) fiamos

upwaraw /upwa'raw/ v.tr. desamarra/desamarrou. Ajnon: apwaraw upohoma eu desamarrei a corda

upyhyg /upi'hig/ v.tr. pega/pegou. Ajnon: Muretama weraha kyse ipyhyka ti wi Muretama levou a faca que pegou de mim; apyhyg puta ri'a eu vou pegar; ma'esawara usonetewa'e upyhyg akutia o cachorro corredor pegou a cutia

upypirong /upipi'roy/ v.tr. enche/encheu. Ajnon: apypirong eu encho; upypirong puta ele vai encher

upyrongehe /upironc'he/ v.intr. pisca/piscou. Ajnon: apyrongehe eu pisquei; upyrongehe puta ri'a ele vai piscar

upysi'o /upisi'?ə/ n.IIc tornozelo de alguém

upyta /upi'ta/ v.intr. parado (fica/ficou). Ajnon: apyta eu fico parado; upyta puta ele vai ficar parado; urupyta nós (excl.) ficamos parados

upyter /upi'tes/v.tr. chupa/chupou. Ajnon: apyter akuti nami pe pytukawa eu chupei a laranja

ur /'ur/ v.intr. vem/veio. Ajnon: Muretama umur ti upe kysea Muretama me deu (fez vir) a faca; mo wi pa'e ererur ma' ea ro'o? de onde você trouxe (fez vir) esta carne?; mo wi pa'e ituri? de onde ele chegou (veio)?

ure /u'rel pron. nós (excl.). Ajnon: ure uruapo 'oga nós fizemos estas casas; ise a'asuron, ure uru asurona eu abracei ele, nós abraçamos ele; ure kuso teseramu 
uruho ytyma mani'og roko urutym nós fomos com as mulheres plantar mandioca; ure urueraha mani'og kusoa pe nós levamos mandioca para as mulheres; ure purumu'etaramu nós somos professores

uru'ag /uru'Pag/ v.tr. vira/virou

uru'aru'ag /uru?aru'Pag/ v.tr. gira/girou. Ajnon: aru'aru'ag eu girei; uru'aru'ag puta ele vai girar

urutaw /uru'taw/ n.III urutau, mãe-da-lua. • Eisag $\rightarrow$ wyra

urutyryryg /urutici'rig/v.tr. puxa/puxou

uruwi /uru'wi/ $n . I I I$ surubim, Sorubim. • Eisag $\rightarrow$ ipira

uruwu /uru'wu/ n.III urubu. Ajnon: arara uruwu ne'iwewej a arara e o urubu voaram.

- Eisag $\rightarrow$ wyra

uruwuete /uru'wue'te/ n.III urubu, Catartídeos. - Eisag $\rightarrow$ wyra

uruwupeuhu /uru'wupcu'hu/ n.III urubu-preto, urubu-de-cabeça-preta, Coragyps atratus. • Eisag $\rightarrow$ uruwu

uruwutinuhu /uru'wutinu'hu/ n.III urubu-rei, urubutinga, Sarcorhamphus papa. • Eisag $\rightarrow$ uruwu

usahug /usa'hug/ v.tr. lava-se/lavou-se. Ajnon: aikoj katuripoj sahug para lá ele se lava; usahug ohow upisupisunawi ele se lavou porque estava sujo; esahug eho vai tomar banho; asahug eu me lavo

usawa'ea /usawa'?عa/ $n$.III criança. Ajnon: iusawa'ea ne memyra esta criança é teu/tua filho(a); iusawa'ea remi ti memyra estas crianças são meus/minhas filhos(as); iusawa'ea remi usunupo aqueles crianças estão se batendo

usawa'ea akuma'ea / usawa'?ea akuma'?ea / n.III menino (homem). Ajnon: namukuj iusawa'e são dois meninos

use'eng /usc'?cy/ v.intr. fala/falou. Ajnon: ase'eng eu falei; use'eng puta ele vai falar; uruse'eng nós (excl.) vamos falar; use'eng hejkwehe ele falou faz tempo

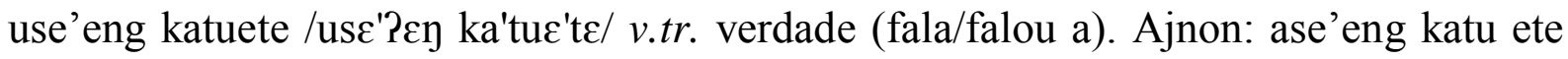
eu falei a verdade

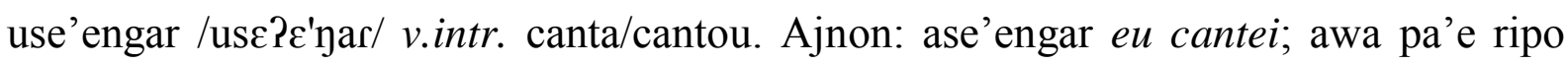
use'engar? quem está cantando?; ma'eramu pa'e kuso nu se'engar uwi? por que as mulheres não estão cantando?; uruse'engar nós (excl.) cantamos; aiko ra'e wehe rako erewahem erese'engar eresemume ontem você chegou, cantou e dançou 


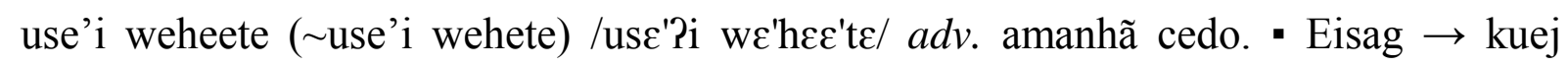
wehe

usekogywe /uscko'giwe/ v.tr. encosta-se/encostou-se. Ajnon: asekogywe eu me encostei; usekogywe puta ele vai se encostar

usekyj /usc'kis/ v.intr. morre/morreu. Ajnon: ma'esawara puta usekyj mosa u'uramu $o$ cachorro vai morrer, porque a cobra mordeu ele; ise amupig mosa re, ise awisepe mosa nusekysuwi eu atirei na cobra, mas ela ainda não morreu; usepurakaretewa'e ma'esawara usekuj o cachorro que é bom caçador morreu; awa pa'e usekyj? quem morreu?

usemim /usc'mim/ v.tr. esconde-se/escondeu-se. Ajnon: asemim ma'ea sukatawpe eu me escondi onde mata o bicho (caça); usemim puta ele vai se esconder; urusemim nós nos escondemos

usemu'an /uscmu'Pan/ v.tr. cuida/cuidou. Ajnon: ise asemu'an reko wememyra re tawaruete eu cuido do meu filho pra ele ficar bonito

usemuaraj /uscmua'ras/ v.tr. brinca/brincou. Ajnon: asemuaraseteete ri'a eu brinquei muito; usemuaraj puta ele vai brincar; urusemuaraj nós (excl.) brincamos; awa'iahu tu'o usemuaraj awa'imonane todos os jovens e todos os velhos brincam

usemypukura /usemipu'kura/ v.tr. acocora-se/acocorou-se. Ajnon: asemypukura eu me acocoro; usemypukura puta ri'a ela vai se acocorar

usenong /usc'non/ v.tr. estende-se/estendeu-se. Ajnon: asenong eu me estendi; usenong puta ele vai se estender

useopo /uses'po/ v.intr. pinta-se/pintou-se. Ajnon: aseopo eu me pintei

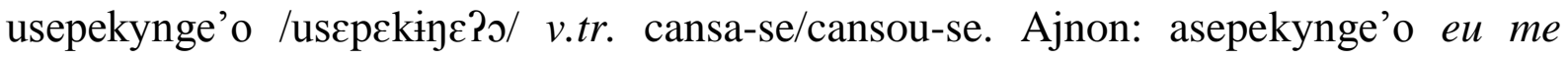
cansei; usepekynge'o puta ele vai se cansar

usepese /uscpe'se/ num. um, uma. Ajnon: usepese ripo ma'ea amukasym eu perdi uma coisa

usepurakar /usepura'kar/ v.tr/intr. caça/caçou. Ajnon: awa nusepurakaruwi ohow ninguém está caçando; aiko ra'e wehe rako asepurakar wehow ontem eu fui caçar no mato

usepyg /usc'pig/ v.tr. enrola-se/enrolou-se. Ajnon: asepyg eu me enrolei; usepyg puta ele vai se enrolar

usepymy /usepi'mi/ v.tr. afunda-se/afundou-se 
useru'ag /uscru'?ag/ v.tr. vira-se/virou-se. Ajnon: aseru'ag eu me virei; useru'ag puta ele se virou

userusi /uscru'si/ v.intr. pousa/pousou. Ajnon: arara userusiw ywyra roko re a arara pousou no galho da árvore

usesywyg /usesi'wig/ v.tr. enforca-se/enforcou-se. Ajnon: usesywyg puta ri'a ele vai se enforcar

useupir /uscu'pir/ v.intr. sobe/subiu. Ajnon: aseupir 'ywa re eu subo na árvore; ywyra re eseupir sawara wi ohow ele subiu na árvore afastando-se da onça indo

usewag /use'wag/ v.intr. escreve/escreveu. Ajnon: asewag eu escrevo

usewerekohyw /use'wereks'hiw/ v.tr. briga/brigou. Ajnon: asewerekohyw eu brigo; usewerekohyw puta ele vai brigar; urusewerekohyw nós (excl.) brigamos

usewon /use'won/ v.tr. embrulha-se/embrulhou-se

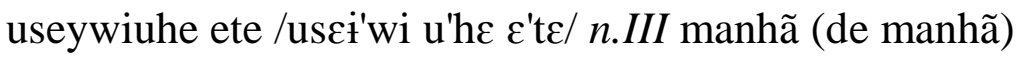

uso'o /uso'?っ/ v.intr. chora/chorou. Ajnon: awa pa'e uso'o? quem está chorando?; uso'o remi eles choraram; aso'o eu chorei

usogupir /usogu'pir/ v.tr. casa (levanta/levantou). Ajnon: asogupir eu levantei casa; usogupir puta ele vai levantar casa

uson /u'son/ v.intr. corre/correu. Ajnon: asonete ri'a wehow eu corri muito; ise puta ri'a asoason eu vou correr muito; wesowesona a'ar eu estava correndo e caí; karuaruhua ti keywywy re oho usona a paca correu do meu lado

usor /u'sor/ v.intr. vai/foi. Ajnon: asor iko eu estou indo; mo wi pa'e eresor? de onde vocês vieram?; moronime puta pe saha koa pupe? quando vamos para a roça?; awa nusepurakaruwi ohow ninguém está caçando. • Eisag $\rightarrow$ ur

usosog /uso'sog/ v.intr. arrota/arrotou. Ajnon: asosog eu arrotei; usosog puta ele vai arrotar; urusosog nós (excl.) arrotamos

usowewahem /uso'wewa'hem/ v.intr. chegando (vem/veio). Ajnon: aiko ku'em kwera re rako asowewahem wetoga pupe antes de ontem eu cheguei em casa

usuka /usu'ka/ v.tr. mata/matou. Ajnon: pehe puta pesuka ma'ea pesehow? vocês vão matar aquelas caças?; aha puta ri'a isukaw tasahuamu talvez eu mate um porcão; esuka puhi não mata ele; ti ruwa, eresuka pa'e ma'ea? meu pai, você matou algo?; asemim ma'ea sukatawpe eu me escondi onde mata o bicho (caça); ise ri'a nasukawi mosa eu não estou matando a cobra 
usuron /usu'ron/ v.tr. abraça/abraçou. Ajnon: ise ti asuron ele me abraçou; ure uruasurona nós nos abraçamos

usuruhywo /usuruhi'wo/ v.tr. costura/costurou

usy'oj /usi'?os/ v.tr. coça/coçou. Ajnon: asy'oj eu cocei; usy'oj puta ele vai coçar

usyw /u'siw/ v.intr. desce/desceu. Ajnon: asyw eu desço; usyw puta ele vai descer; uruasyw nós (excl.) descemos

usywyg /usi'wig/ v.tr. enforca/enforcou

utimyk /uti'mik/ v.tr. tapa/tapou. Ajnon: usetimyk ele se sufocou; nusetimyguwi ele não se sufocou; inemauwi esetimyk está fedendo, tape o seu nariz

utorog ( munorog) /uto'rog/ v.tr/intr. rasga/rasgou. Ajnon: tekwawa utorog a rede rasgou

utumuse'em /utumuse'?cm/ v.intr. assobia/assobiou. Ajnon: atumuse'em eu assobio; urutumuse'em nós (excl.) assobiamos

utururu /uturu'ru/ v.tr/intr. pinga/pingou. Ajnon: utururu puta ri'a ela vai pingar

utym /u'tim/ v.tr. enterra/enterrou. Ajnon: ise puta atym 'ywa eu vou plantar aquela árvore; ure kuso teseramu uruho ytyma mani'og roko urutym nós fomos com as mulheres plantar mandioca; monamo he pa'e eretym awatia? quando foi que você plantou o milho?; awa pa'e utym mani'og? quem plantou a mandioca?; aiko ra'e wehe rako aha ityma ko pupe kumanarona ontem eu fui plantar feijão na roça; kuej wehe puta aha ityma awatia weko pupe amanhã eu vou plantar milho

utyryg /uti'rig/ v.intr. acorda/acordou. Ajnon: atyryg eu acordei; awa pe utyryg? alguém acordou?; aker puta ri'a wehow use'iwehe ete wehe ne tatyryg ne eu vou dormir e acordar cedo; eretyryg pa'e kuwejwehe você acordou cedo

uwa $^{1} / \mathrm{uw}^{\prime} \mathrm{Ta} /$ n.III caranguejo

$\mathrm{uwa}^{2}$ /u'wa/ n.III rabo. Ajnon: ma'esawara ruwa rabo de cachorro

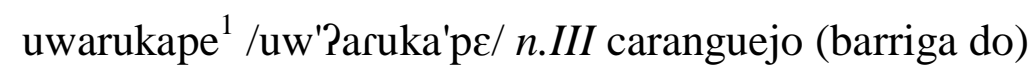

uwarukape ${ }^{2}$ /uw'Paruka'pe/ n.III revólver

uwakasa /uwaka'sa/ n.IIc coxa de alguém

uwawag /uwa'wag/ adv. depressa

uwe'en /uwe'?cn/ v.intr. vomita/vomitou. Ajnon: awe'en eu vomitei; uwe'en puta ele vai vomitar; uruwe'en nós (excl.) vomitamos 
uwewe /uwe'we/ v.intr. voa/voou. Ajnon: uwewe puta ri'a ele vai voar; arara uwewe $a$ arara voou; arara uruwu ne'iwewej a arara e o urubu voaram; wyra uwewe ete pewise os pássaros voaram muito alto

uwewuj /uwe'wus/ v.intr. boia/boiou. Ajnon: awewuj eu boio; uwewuj puta ele vai boiar; uruwewuj nós (excl.) boiamos

uwirog /uwi'rog/ v.tr. roça/roçou. Ajnon: ise awirog koa eu rocei a roça

uwisaw sapakania /uwi'saw sapaka'nia/ n.III gavião-real, Harpia harpyja. • Eisag $\rightarrow$ wyra

uwoj /u'wos/ v.tr. corrói/corroeu

uwon /u'won/ v.tr. embrulha/embrulhei. Ajnon: awon eu embrulho; uwon puta ele vai embrulhar

uwuhyj /uwu'his/ v.tr. carrega/carregou. Ajnon: pehe ta peraha pewuhyj myriti 'ywa vocês carregaram a tora do buritizeiro

uwuwur /uwu'wur/ v.intr. incha/inchou. Ajnon: awuwur eu inchei; uwuwur puta ele vai inchar

uwya /u'wia/ n.IIc sangue de algo ou de alguém

uwyosa /uwi'ssa/ n.III cartucho de bala

uwyryg /uwi'rig/ v.intr. encolhe/encolheu

uytaw /ui'taw/ v.intr. nada/nadou. Ajnon: aiko ra'e wehe re pa'e ehow he porono pupe aitapa ontem você foi nadar no rio; uytaw puta ele vai nadar; uruytaw nós (excl.) nadamos

\section{W}

waj'irararon 'ywa/was'?irararon '?iwa/ n.III murucizeiro

waj'irararona /was'?irara'rona/ n.III muruci, murici, Byrsonima

wajnom /was'nom/ n.III beija-flor, Apodiformes, Troquilídeos. • Eisag $\rightarrow$ wyra

wajpatana /waspa'tana/ n.III cobra-preta, Clelia cloelia. $\cdot$ Eisag $\rightarrow$ mosa

wapitu'o /wapitu'?o/ n.III pessoa(s). Ajnon: wapitu'o wesag sepi a'wera tem pessoas que veem espírito 
wararu /wara'ru/ n.III caranguejo (esp.)

warasu /wara'su/ n.III pessoa não indígena. • Eisag $\rightarrow$ kamara

warasua onga resawkahawa /wara'sua 'ona resawka'hawa/ $n . I I I$ televisão

warunare py'a /waruna're pi'?a/ n.III biscoito salgado

wawere /wawe're/ n.III quatipuru, esquilo

waypy /wai'pi/ n.descr. fundo. Ajnon: waypyete pa'e? é fundo?; 'ya ruaypy fundo da água; waypy te pa'e porono re apyra? é verdade que esse rio é fundo? - Eisag $\rightarrow$ ipyperew

wehe /we'he/ $a d v$. novamente. Ajnon: aiko ara re wehe rako então outra vez passou o tempo; aiko re wehe rako aesag akuma'e ontem eu vi de novo este homem; na esagwi wehe ipira ku'omawa eu não vi mais peixe levantado

weraw ( weraweraw) /we'raw/ n.III relâmpago

wetehuna'e /wetchuna'?e/ n.descr. marron

wetypype iwsawa'e ituni /wetipi'pe iwsawa'? $\varepsilon$ i'tuni/ $n . I I I$ feto

wyra /wi'ra/ n.III ave. Ajnon: wyra uwewe ete pewise os pássaros voaram muito alto. • Eisag $\rightarrow$ anuhu, inamu'i, ipewhua, kwere, kwreta'u, musu'i, mytu, masakuwa, piaka, pykahu, pyky'i, pypypypy, pytowoihu, sakua, sapakanirona, sapakania, sapakanirona, sapi'i, sapuhu, tukan, uruwu, uruwuete, uruwupeuhu, uruwutinuhu, uwisaw sapakania, wajnom, wyra'yra, wyra'yra akuma'e

wyra'i /wira'?i/ n.III passarinho. • Eisag $\rightarrow$ wyra

wyra'yra /wira'Pira/ n.III galinha. Ajnon: wyra ipisuna'e galinha preta; aimi wyra'yra remi ti rejmawa aquelas galinhas são meus xerimbabos. • Eisag $\rightarrow$ wyra

wyra’yra akuma'e /wira'Pira akuma'?c/ n.III galo, Gallus. • Eisag $\rightarrow$ wyra

wyra'yra ymemura /wira'?ira ime'mura/ n.III pinto. • Eisag $\rightarrow$ wyra’yra, wyra'yra akuma'e, wyra

wyrahuatia /wirahua'tia/ n.III tesoura

wyratimehu /wiratime'hu/ n.III pato (esp.). • Eisag $\rightarrow$ wyra

wyratinga /wira'tina/ n.III garça, Ciconiiformes, Ardeídeos. • Eisag $\rightarrow$ wyra 
y’a /i'?a/ n.III macaco-aranha, coatá, cuatá, Ateles belzebuth

yan ’ywa /ian 'iwa/ n.III árvore (esp.). • Eisag $\rightarrow$ ’ywa

ygara /i'gara/ n.III canoa

ykyruyron /ikirui'ron/ n.III camapu, Physalis

ykyruyrona 'ywa /ikifui'sona '?iwa/ n.III camapuzeiro

ymemyra /ime'mira/ n.III filhote (de bicho). Ajnon: tasahua ymemura filhote de porcão; misara ymemura filhote de veado; tapi'iraymemura filhote de anta

ymyra /imi'ra/ n.III mão-de-pilão

ynata /ina'ta/ n.III coco. Ajnon: inataoto coco duro

ypewara /ipe'wara/ n.III bicho da água

ypo /i'po/ n.III cipó. Ajnon: ypo amonok eu corto o cipó

yputyra /ipu'tica/ n.III flor

ypytuna /ipi'tuna/ n.III noite

ypytuname ete /ipituna'm $\varepsilon \varepsilon^{\prime} t \varepsilon / n . I I I$ anoitecer

yrutehehy /irutche'hì/ num. quatro

yse'e ( $\sim$ se'e) /isc'? 2 / n.III poço. Ajnon: u'ar pa'e yse'ea pupe ele caiu no poço; ti se'eromamu puta ri'a ahywykaj eu vou cavar meu poço; amuaypy ti se'eroma eu cavo fundo meu poço

ysewara /iscwa'ra/ n.III poço (o que é do)

ytypesawa /itipe'sawa/ n.III vassoura

ytywyra /iti'wira/ n.III roupa seca

ywaga /i'waga/ n.III céu

ywagahaw ( tapi'ira rape) / iwaga'haw/ n.III via-láctea, caminho-de-são-tiago

ywatinga /iwa'tina/ n.III nuvem

ywete /iwe't $/$ / adv. cima (em cima) 
ywoto ywa /iwsto 'Piwa/ n.III pau-brasil. • Eisag $\rightarrow$ 'ywa

ywy /i'wi/ n.III terra, chão. Ajnon: ywypisun terra preta; ywykatu terra boa; ywypiron terra vermelha

ywyra pira /iwi'ra 'pira/ n.III casca (do pau). • Eisag $\rightarrow$ 'ywa

ywyraka'ymomona /iwira'ka?imo'mona/ n.III cobra-papagaio, Corallus caninus. Eisag $\rightarrow$ mosa

ywyrapara $^{1}$ /iwira'para/ n.Ia arco. Ajnon: emono ywyrapara wa'yahuape dá o arco pro jovem; ene pa'e eremono ywyrapara ne ruwa pe você deu o arco para o teu pai

ywyrapara $^{2}$ /iwira'para/ n.Ia espingarda. Ajnon: amukasym weywyrapara eu perdi minha espingarda

ywyrapopohoma /i'wirapopo'homa/ n.III traíra (esp.). • Eisag $\rightarrow$ ipira

ywyraukaj /iwi'rau'kas/ n.III graveto, pauzinho

ywyrow ehym iapo pyrera /iwi'sow ع'him ia'po pircra/ $n . I I I$ moeda

ywysukyra /iwisu'kira/ n.III açúcar

ywyterera /iwite'resa/ n.III espírito (tipo). Ajnon: ywyterera usesa ukara ywyterera aparece no caminho (terreiro). - Eisag $\rightarrow$ a'wera, asomera

ywytinga /iwi'tina/ n.III areia

ywytuhu /iwitu'hu/ n.III vento. Ajnon: ywytuhuete o vento (está) forte

ywytuhurona /iwituhu'rona/ n.III vento forte

ywyty /iw'i'tì/ n.III serra (relevo)

ywytyra /iwi'tica/ n.III morro. • Eisag $\rightarrow$ ywy 


\subsection{DICIONÁRIO PORTUGUÊS-SURUÍ}

A segunda proposta de dicionário da língua Suruí que apresento neste capítulo é aquela com a direção Português-Suruí (cf. subseção 10.2.3.2.2). Com verbetes distribuídos também em uma coluna, o dicionário está organizado alfabeticamente, com separadores em cada um dos grupos de letras.

Com relação às abreviaturas deste dicionário, retomo a mesma justificativa da subseção anterior e acrescento que, mesmo sendo essas abreviaturas baseadas na nomenclatura gramatical brasileiras, nem sempre elas coincidem. Desta forma, apresento, a seguir, as abreviaturas usadas no Dicionário Português-Suruí:

TABELA 85 - ABREVIATURAS USADAS NO DICIONÁRIO PORTUGUÊS-SURUÍ

\begin{tabular}{c|l}
\hline ABREVIATURA & \multicolumn{1}{|c}{ PROPRIEDADE GRAMATICAL } \\
\hline adv. & advérbio \\
\hline n. & nome \\
\hline n.descr. & nome descritivo \\
\hline n.f. & nome feminino \\
\hline n.f.m. & nome feminino e masculino \\
\hline n.m. & nome masculino \\
\hline num. & numeral \\
\hline part.int. & partícula interrogativa \\
\hline prep. & preposição \\
\hline pron. & pronome \\
\hline pron.dep. & pronome dependente \\
\hline v. & verbo \\
\hline v.int. & verbo intransitivo \\
\hline v.tr. & verbo transitivo \\
\hline voc. & vocativo \\
\hline
\end{tabular}

Reafirmo, aqui, a natureza experimental destas obras lexicográficas, que, sendo fruto de um trabalho conjunto com os professores e demais falantes da língua Suruí, deverão passar, com a ajuda deles, por ajustes significativos antes de chegarem à sua versão final para uso na comunidade Aikewara. 


\section{DICIONÁRIO DA}

\section{LÍNGUA SURUÍ DO TOCANTINS}

(AIKEWÁRA)

\begin{aligned} & \hline Direção Português (DPt) - Suruí do Tocantins (LId) \\ & \hline Quantidade de entradas $11255^{249} \\ &$\hline Ordenamento das entradas alfabético \\ & \hline Conjuntos de letras a b c d e f g h i j l m n o p q r s t u v x \\ & \hline $\begin{array}{r}\text { Mxpressão da microestrutura } \\ \text { lexicográfica (EML) }\end{array}$ LPt: Gr, Na, Rm, Vr \{DId (Na, Vr) (-DLt) [EPt/EId] $\} \\ &$\hline $\begin{array}{r}\text { Programa utilizado no } \\ \text { tratamento dos dados }\end{array} \begin{array}{l}\text { Línguas - Banco de Dados para Documentação Linguística } \\ \text { (versão 3.9) }\end{array} \\ &$\hline\end{aligned}

${ }^{249}$ Conforme mencionado na nota 248, esta versão do Dicionário da língua Suruí do Tocantins (Aikewára) possui apenas uma amostra do léxico dessa língua. 


\begin{abstract}
A
abacaxi n.m. suparaparona. - Ver $\rightarrow$ abacaxi-do-mato

abacaxi-do-mato n.m. suparapara. - Ver $\rightarrow$ abacaxi

abacaxizeiro n.m. suparaparon ypya. - Ver $\rightarrow$ árvore

abana/abanou v.tr. upesu. Ex.: eu abano apesu; ele vai abanar upesu puta; nós (excl.) abanamos urupesu

abanador n.m. tatapekwawa

abelha $n . f$. tuwa. • Ver $\rightarrow$ abelha (esp.), abelhão

abelha (esp.) n.f. katykyehyra, musy’yehyra. - Ver $\rightarrow$ abelha

abelhão $n . f$. eironuhu. • Ver $\rightarrow$ abelha

abóbora n.f. (gerimum) i’akorona. Ex.: nós (exlc.) partimos a abóbora uruasejmonog iakorona
\end{abstract}

abraça/abraçou v.tr. usuron. Ex.: ele me abraçou ise ti asuron; nós nos abraçamos ure uruasurona

abre/abriu v.tr. upiawog. Ex.: eu abri apiawog; ele vai abrir upiawog puta

açaí n.m. pinuwa. - Ver $\rightarrow$ açaí (grande)

açaí (grande) n.m. susiwa. Ex.: açaí (está) azedo susiwa haj. • Ver $\rightarrow$ açaí, bacaba

açaizeiro n.m. susiw'a 'ywa, Euterpe oleracea. - Ver $\rightarrow$ árvore

acará n.m. akara, Ciclídeos

acarapeba $n . m$. akarapew. - Ver $\rightarrow$ peixe

acari n.m. (cari, cascudo) ini'omupira. - Ver $\rightarrow$ peixe

acaricia/acariciou v.tr. umuw'iw. Ex.: eu acaricio amuw'iw; ele vai acariciar $u m u w^{\prime} i w$ puta

acerta/acertou (o alvo) v.tr. uesakatuete. Ex.: eu acerto o alvo aesakatuete; ele vai acertar o alvo uesakatuete puta

acocora-se/acocorou-se v.tr. usemypukura. Ex.: eu me acocoro asemypukura; ela vai se acocorar usemypukura puta ri'a 
acorda/acordou v.intr. utyryg. Ex.: eu acordei atyryg; alguém acordou? awa pe utyryg?; eu vou dormir e acordar cedo aker puta ri'a wehow use'iwehe ete wehe ne tatyryg ne; você acordou cedo eretyryg pa'e kuwejwehe

açúcar n.m. ywysukyra

adiante $a d v$. enune. Ex.: na frente, nós andamos enune uruata; na frente, eles andaram erenune remi iataj

afasta/afastou v.tr. uapekar. Ajnon: eu afastei aapekar; ele vai afastar uapekar puta ri'a

afia/afiou v.intr. upu'an. Ex.: eu afiei a faca apu'an kyse; ele vai afiar a faca upu'an puta ri'a kyse

afunda-se/afundou-se v.tr. usepymy

agrisalha/agrisalhou v.intr. uasupaw. Ex.: ele está começando a ficar com os cabelos bem grisalhos iasupawame'ete

água n.f. 'ya. Ex.: água fria 'ygygom; água preta 'ypisun; Ikatu levou água para nós Ikatua weraha 'ya sene upe; quem está sujando a água? awa pa'e umuhy pyting 'ya?; onde (tem) água? mume pa'e 'ya?

águia $n . f$. sapakanirona. - Ver $\rightarrow$ ave, gavião

agulha $n . f$. tatina'ywa. - Ver $\rightarrow$ espinho

aí $a d v$. aj'aw. Ex.: é aí? aj'aw pa'e?; tu sentando aí ene ereapyg aj'aw

ajuda/ajudou v.tr. umupoiru. Ex.: eu ajudo amupoiru; ele vai ajudar umupoiru puta; nós (excl.) ajudamos urumupoiru

aldeia $n . f$. etoma

aleijado n.descr. (sem seio) ikome'yma'e

algodão n.m. amonisua

algodoeiro n.m. amonisu 'ywa

ali $a d v$. pew

alma $^{1} n . f$. (vulto de pessoa) ywyterera. - Ver $\rightarrow$ espírito, alma $^{2}$

alma $^{2}$ n.f. asomera. Ex.: eu nunca vi alma (asomera) na isaguwi wehe weko asomera. Ver $\rightarrow$ espírito, alma ${ }^{1}$ 
amanhã $a d v$. kuej wehe. Ex.: amanhã eu vou plantar mandioca kuej wehe puta aha ityma mani'oga weko pupe; amanhã ele quer caçar porcão kuej wehe puta ihoj tasahuaamanhã

amanhã (depois de) $a d v$. aiko ku'ema re (aiko ra'e wehe). Ex.: depois de amanhã eu vou jogar bola aiko ku'ema re puta amomomomon bola wehow; depois de amanhã eu vou coletar castanha-do-pará aiko ra'e wehe puta aha ikaw so

amanhã cedo $a d v$. use'i weheete (use'i wehete). - Ver $\rightarrow$ hoje

amanhecendo (quase) n.f. ku'emanune

amante de alguém n.m. emi'umi'u

amarelo (ele é) n.descr. isukyry. Ex.: o ouro é bem amarelo itahynypuk isukyryete

amargo (ele é) n.descr. irowa

amassa/amassou v.tr. ukamyg

amigo n.m. kotawete. Ex.: eu sou seu amigo ise ti kotaweteramu

amola/amolou v.tr. uhojme'e

amolado $n$. hojme

anambé-pombo n.m. seruti, Gymnoderus foetidus

anda/andou v.intr. uata. Ex.: eu ando aata; ele vai andar uata puta; na frente, nós andamos enune uruata; ontem você foi andar no mato aiko ra'e wehe re pa'e erehow ka'a pe eataw; ontem eu andei, comi e cantei aiko ra'e wehe rako aata akaru ase'engar

andiroba $n . f$. ioronuhu

andirobeira $n . f$. ioronuhu 'ywa, Carapa guianensis. - Ver $\rightarrow$ árvore

andorinha $n . f$. musu'iwyra, Passeriformes, Hhirundinídeos. • Ver $\rightarrow$ ave

anel de alguém n.m. ipokwahaw

anoitecer n.m. ypytuname ete

anta n.f. tapi'ira, Tapirus terrestris. Ex.: minha coisa matada a anta ti re mi suka tapi'ira; a anta vai saindo do mato tapi'ira puta oho ka'a wi uhema. - Ver $\rightarrow$ antabranca, anta-preta

anta-branca n.f. tapi'itinga, Tapirus terrestris. Ex.: o cachorro que é bom caçador mordeu a anta-branca ma'esawara usepurakaretewa'e u'u tapi 'itinga 
anta-preta $n . f$. tapi'ipisuna, Tapirus Kabomani. - Ver $\rightarrow$ anta

antebraço (músculo) de alguém n.m. isywa inypy’o

antebraço de alguém n.m. isywa ypy

antena parabólica $n . f$. sanua rekwawa

anu $n . m$. anuhu. $\cdot$ Ver $\rightarrow$ ave

anu preto n.m. (anum) anuhupituna, Cuculídeos, Crotophaga/Guira

apaga/apagou v.tr. uamuwew. Ex.: eu vou apagar o fogo amuew puta ri'a tata; eu acabei de apagar o fogo inteiro, completamente amuewpapaw ri'a tata; ele sempre apagava o fogo oko umuew roko ikwehew

apertado (ele é) n.descr. isasyu'u

aquele pron. aikwesa. Ex.: aquele xerimbabo é teu? aikwesa pa'e ne rejmawa; aquele pato é teu, mesmo aikwesa ipewhua pa'e ne rejmawa ete; ele falou (mal) de mim aikwesa use'eng ti rehe oko

aqueles pron. aimi. Ex.: aquelas galinhas são meus xerimbabos aimi wyra'yra remi ti rejmawa

aqui $a d v$. 'aw. Ex.: é aqui? 'aw pa'e?; você está morando aqui? a'aw pa'e reko?; eu sentando aqui ise aapyg 'aw; sair daqui eu não quero 'aw wi nahawi

aranha $n . f$. sanu. - Ver $\rightarrow$ aranha-caranguejeira, aranhiço, teia de aranha

aranha (esp.) n.f. sanupuhaw. - Ver $\rightarrow$ aranha

aranha-caranguejeira n.f. sanupopuku, Subordemortógnatos, Terafosídeos. - Ver $\rightarrow$ aranha

aranhiço n.f. (aranhinha) sanu'i. - Ver $\rightarrow$ aranha

arara n.f. arara. Ex.: agorinha eu vi uma arara kometi aisaj arara; a arara voou arara uwewe; a arara falou arara use'eng; a arara pousou no galho da árvore arara userusiw ywyra roko re

arara cangaçu n.f. (arara cabeçuda) ararakonuhu, Podocnemis dumeriliana

arara-azul n.f. ararunuhu, Anodorhynchus hyacinthinus

araracanga $n . f$. (arara-vermelha-pequena, aracanga, arara-macau) ararete, Ara macao

araraúna $n . f$. araruna

ararinha $n . f$. (arara pequena) araria, Aratinga aurea 
arco n.m. ywyrapara ${ }^{1}$. Ex.: dá o arco pro jovem emono ywyrapara wa'yahuape; você deu o arco para o teu pai ene pa'e eremono ywyrapara ne ruwa pe

arco-íris n.m. ti'iwa

areia $n . f$. ywytinga

arraia $n . f$. sawewyra

arranca/arrancou v.tr. uikyj. Ex.: eu posso arrancar mandioca na tua roça? ise pa aikysa'u mani 'oga ne ko pupe?

arrasta/arrastei v.tr. uesyj

arrota/arrotou v.intr. usosog. Ex.: eu arrotei asosog; ele vai arrotar usosog puta; nós (excl.) arrotamos urusosog

arroz n.m. awatia ipipisawa. Ex.: amanhã eu vou plantar arroz kuej wehe puta aha ityma awatia ipipisawa weko pupe

árvore n.f. 'ywa. Ex.: que árvore é essa? ma'e 'ywa pa'e; eu vou cortar aquela árvore amonog a'epe 'ywa; por que ele cortou a árvore? ma'eramu pa'e imonog 'ywa?; eu subi na árvore afastando-me da onça ywyra re aseupir sawara wi; ele caiu do galho da árvore 'ywa rokowi i'ari; eu subo na árvore 'ywa re aseupir. - Ver $\rightarrow$ abacaxizeiro, açaizeiro, andirobeira, bacabeira, buritizeiro, cuieira, goiabeira, gravioleira, jatobá, mamoeiro, mogno, pau-preto, sapucaia, seringueira, sumaúma, sumaúma (esp.), tabaco, tucunzeiro

árvore (esp.) n.f. yan 'ywa. - Ver $\rightarrow$ árvore

árvore (esp.) n.f. taparaniwa 'ywa. • Ver $\rightarrow$ árvore

árvore (esp.) n.f. moron 'ywa. - Ver $\rightarrow$ árvore

assa/assou v.tr. uihyr. Ex.: eu quero assar o caititu aihyra'u ri'a tiwa'a; nós (excl.) assamos porcão uruihyr tasahua

assim $a d v$. (isso mesmo) ajnon

assobia/assobiou v.intr. utumuse'em. Ex.: eu assobio atumuse'em; nós (excl.) assobiamos urutumuse'em

associativo part. ene ${ }^{1}$. Ex.: Ywykatu e Ikatu entraram dois (dias) no mato Ywykatu Ikatu ene ihoj uke mukumukujta ka'ape; todos os jovens e todos os velhos brincam awa'iahu tu'o usemuaraj awa'imonane

aterra/aterrou v.tr. u'asuka. Ex.: aterrar (o piso da) casa a'asuka oga 
atestado n. reko. Ex.: todos já foram! ohopapaw reko

atestado pelo falante $a d v$. rako. Ex.: todos já chegaram! uwahemamaw rako; nós batemos em vocês urunupo rako pehe; ontem eu fui dormir no mato aiko ra'e wehe rako aha ka'a pe weketa

atira/atirou v.tr. umupig. Ex.: eu atirei na cobra, mas ela ainda vive ise amupig mosa re, ise awisepe mosa nusekysuwi

atola/atolou v.tr. upu'om. Ex.: eu atolei apu'om

atrás adv. kupe. Ex.: nós andamos atrás kupe uruata

através $a d v$. upi ${ }^{2}$. Ex.: eu vou passar pelo meio (da plantação) de milho awati pytera rupi puta uruhow

atravessa/atravessou v.tr. uahaw. Ex.: (ele) atravessar o caminho upeahaw

atravessa/atravessou o rio v.intr. u'yahaw. Ex.: nós atravessamos o rio uru'yahaw; nós matamos o veado que atravessou o rio u'yahawa'e urusuka misara; eu fui rio abaixo 'yahaw katy aha; ele atravessou o rio 'ya rupi i'yahawi

atravessador n.m. iahapara

ave n.m. wyra. Ex.: os pássaros voaram muito alto wyra uwewe ete pewise. - Ver $\rightarrow$ águia, andorinha, anu, beija-flor, bem-te-vi, coruja, coruja-branca, galinha, galo, gavião, gavião-real, inambumirim, jaçanã, jacu, mutum, pato, pombo, rolinha, tucano, tucano, tucanuí, urubu, urubu-rei, xexéu

avião n.m. sumi'ahu

avô n.m. amuj. Ex.: meu avô está vivo ti ramusa oko wehe

avó de alguém $n . f$. isarij

azedo n.descr. haj. Ex.: a laranja é azeda akutia nami pe pytukawa haj

azul n.descr. 'yapekarahy

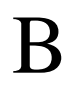

bacaba $n . f$. pinuwahua

bacabeira $n . f$. pinuwahu 'ywa, Oenocarpus. - Ver $\rightarrow$ árvore

bagaço num. ty ${ }^{2}$. Ex.: bagaço de timbó tymo rajty; bagaço de castanha so rajty; bagaço de coco inata rajty 
bagre (esp.) n.m. manowe. - Ver $\rightarrow$ peixe

bagre (esp.) n.m. tyryrypya. - Ver $\rightarrow$ peixe

baixo n.descr. iatuatur

baixo-ventre de alguém n.m. iukape

banana $n . f$. pahakua. Ex.: eu descasquei a banana ise apirog pahakua. - Ver $\rightarrow$ bananado-mato

banana-do-mato n.f. pakohowa, Monstera deliciosa. - Ver $\rightarrow$ banana

banco n.Ia apykawa

barata $n . f$. sautipewa, Blatídeos

barata-d'água $n . f$. sautipewhurona

barba de alguém $n . f$. enywahawa

barriga de alguém $n . f$. ewetypy. Ex.: barriga dura ewetypyoto

barro n.m. sa'i'um

batata $n . f$. setyrona. Ex.: ontem eu fui plantar batata na roça aiko ra'e wehe rako aha ityma ko pupe setyrona. - Ver $\rightarrow$ batata-doce

batata-doce $n . f$. setyg. - Ver $\rightarrow$ batata

bate/bateu v.tr. unupo. Ex.: eu vou (posso) bater em você urunupo puta; você vai bater em mim ene puta ti nupo pe; aqueles crianças estão se batendo iusawa'ea re mi usunupo; eu vou bater em vocês todos ise puta runupopapaw

bêbado $n$.descr. mujhatata

bebe/bebeu água u'y'u. Ex.: ontem eu plantei roça, bebi água e comi macaxeira aiko ra'e wehe rako ko pupe aha ityma a'y'u roko raj ipyk ikatua muapyga nune; ele vai beber u'y'u puta ri'a

beija-flor n.m. wajnom, Apodiformes, Troquilídeos. - Ver $\rightarrow$ ave

beira $n . f$. emeiwyra. Ex.: beira de rio porono remeiwyra

belisca/beliscou v.tr. upisong

bem-te-vi n.m. pytowoihu, Pitangus sulphuratus. - Ver $\rightarrow$ ave

besouro n.m. sautipeuhu

besouro (esp.) n.m. emaiti 
bicho da água n.m. ypewara

bicho-de-coco n.m. inatahog, Pachymerus nucleorum

bicho-pau n.m. kywakywara, Fasmídeos/Proscopiídeos

bico do seio dela n.m. ikomapyra

bico-roxo n.m. (tururu) tururi, Nomonyx dominicus

bigode de alguém n.m. i'omutawa

biscoito recheado n.m. sate'i py'a

biscoito salgado n.m. warunare py’a

boca de algo ou de alguém $n . f$. isurua. Ex.: pela minha boca ti surua rupi

bochecha de alguém $n . f$. iatypy

bode n.m. (ovelha, cabra) misarona, Capra

boi n.m. (vaca) misakatirona

boia/boiou v.intr. uwewuj. Ex.: eu boio awewuj; ele vai boiar uwewuj puta; nós (excl.) boiamos uruwewuj

bonito (ele é) n.descr. (bem feito) iaruw (aruaru). Ex.: casa bem feita 'oga iaruaru; o que é bonito iaruaruwa'e; ele canta bonito use'engar iaruwa'e; eu cuido do meu filho pra ele ficar bonito ise asemu'an reko wememyra re tawaruwete

borboleta $n . f$. pykapykawa. - Ver $\rightarrow$ borboleta-coruja, borboleta-preta

borboleta (esp.) n.f. pykapykawtinga'e, Morpho. - Ver $\rightarrow$ borboleta

borboleta-coruja $n . f$. tiwaku. - Ver $\rightarrow$ borboleta

borboleta-preta $n . f$. pykapykawipisuna'e. - Ver $\rightarrow$ borboleta

borra desse n.f. irajty. Ex.: borra do café petyma pysahy rajty

braço de alguém n.m. isyw'a

branco (ele é) n.descr. (claro) itinga'e

briga/brigou v.tr. usewerekohyw. Ex.: eu brigo asewerekohyw; ele vai brigar usewerekohyw puta; nós (excl.) brigamos urusewerekohyw

brilhante n.descr. enyeny 
brinca/brincou v.tr. usemuaraj. Ex.: eu brinquei muito asemuaraseteete ri'a; ele vai brincar usemuaraj puta; nós (excl.) brincamos urusemuaraj; todos os jovens e todos os velhos brincam awa'iahu tu'o usemuaraj awa 'imonane

brinco dela n.m. inamikohoma

broto n.m. esuj

bule n.m. sakare akoj

bunda de alguém $n . f$. iku'a. Ex.: bunda grande $i k u^{\prime} a k u$ 'ahu

buraco n.m. kwara. Ex.: eu cavo buraco na terra ywy kwara ahywykaj; buraco do lábio eme kwara

buraco da orelha n.m. namikwara

buriti n.m. myriti

buritizeiro n.m. myriti 'ywa, Mauritia/Mauritiella. Ex.: vocês carregaram a tora do buritizeiro pehe ta peraha pewuhyj myriti ’ywa. - Ver $\rightarrow$ árvore

\section{$\mathrm{C}$}

caba $n . f$. (marimbondo) kawa

cabaça $n . f$. kuipi

cabeça de algo ou de alguém $n . f$ iapina. Ex.: minha cabeça doendo (dor de cabeça) $t i$ apina hy; pessoa que tem a cabeça vazia (não pensa) iapina waj 'yma'e

cabelo de alguém n.m. i'awa. Ex.: meu cabelo caiu ti 'aw kujpaw ri'a; cabelo loiro $i$ 'awitong; cabelo branco i'atinga'e; cabelo crespo i'awrawri

cabelo liso n.descr. ahuma'e

cabo do facão n.m. kyse ikong apyta

caça $n . f$. ma'ea ${ }^{1}$. Ex.: de onde você trouxe (fez vir) esta carne de caça? mo wi pa'e ererur ma'ea ro'o?; vocês vão matar aquelas caças? pehe puta pesuka ma'ea pesehow?; você matou algum animal? eresuka pe ma'eamu?; nós matamos várias caças urusuka ete ri'a ma'e ma'e

caça/caçou v.tr/intr. usepurakar. Ex.: ninguém está caçando awa nusepurakaruwi ohow; ontem eu fui caçar no mato aiko ra'e wehe rako asepurakar wehow 
caçador n.descr. isepurakaretewa'e. Ex.: eu já vi cachorro caçador aesag ma'esawara sepurakaretewa'e; o cachorro que é bom caçador mordeu a anta ma'esawara usepurakaretewa'e u'u tapi'ira; o cachorro que é bom caçador morreu usepurakaretewa'e ma'esawara usekuj

cacau n.m. aka'u. Ex.: o cacau tá florando aka'ua iputyrame; a flor do cacau nós fazemos e bebemos aka'ua putyra uruapo i'u

cachimbo n.m. petymutawa

cacho do açaí n.m. susiwa 'awa. - Ver $\rightarrow$ açaí, açaí (grande)

cachoeira $n . f$. 'ykwererema

cachorro n.m. ma'esawara. Ex.: ele bate no cachorro unupo ma'esawara; o cachorro vai morrer, porque a cobra mordeu ele ma'esawara puta usekyj mosa u'uramu; tenha cuidado! o cachorro vai te morder esemuhaku'i ke! ma'esawara rapo ne u'u; o cachorro andou do meu lado ma'esawara ti keywywy re oho oko. • Ver $\rightarrow$ onça

café $n . m$. petyma pysahy

caga/cagou v.intr. uputi. Ex.: eu caguei aputi; ele vai cagar uputi puta; nós (excl.) cagamos uruputi

cai/caiu ${ }^{1} v$.intr. u'ar $^{1}$. Ex.: eu quase caí a'ar werew; ele vai cair $u^{\prime}$ ar puta; ele caiu da árvore $u$ 'ar 'ywetewi; nós caímos uru'ar; eu estava correndo e caí wesowesona a'ar; ele caiu lá de cima do galho da árvore 'ywa rokowi i'ar. - Ver $\rightarrow$ cai/caiu ${ }^{2}$

cai/caiu ${ }^{2}$ v.intr. ukuj. Ex.: ele caiu várias vezes $u k u k u j$; eu caí akuj; ele vai começar a cair ukuj puta ri'a; meu cabelo caiu ti 'aw kujpaw ri'a; meu marido já está com o cabelo caindo ti rerekatara 'awa ukujpawameete. - Ver $\rightarrow$ cai/caiu ${ }^{1}$

caititu n.m. (porco-do-mato) tiwa'a, Tayassu tajacu. Ex.: eu quero assar o caititu aihyra'u ri'a tiwa'a; tem caititu na roça de Ikatu Ikatu oko pupe tiwa'a

caju n.m. akasu'u

cajuaçu (época de) $a d v$. akasuhua

calango n.m. anisu

calcanhar de alguém n.m. ipyta

calção de alguém n.m. ikong akasa

calcinha dela $n . f$. ikong $^{2}$

calo de alguém n.m. ipypiru'a 
calor forte n.m. akuwoto

calugi n.m. (bebida tradicional à base de mandioca) iakua su'uma

calvície de alguém $n$.descr. 'awaiaia'ia

calvo (muito) n.descr. 'aw mueteete

cama de alguém n.f. iketawa (ti kehawa). Ex.: minha cama pequena ti ketawa iaturuwewa'e. $\cdot$ Ver $\rightarrow$ rede de alguém

camaleão n.m. enemy

camapu n.m. ykyruyron, Physalis

camapuzeiro n.m. ykyruyrona 'ywa

camarão n.m. muti’o

caminho n.m. pea (ape). Ex.: ele está andando no caminho uata pea rupi; nós vamos passar pelo caminho da roça de Ikatu Ikatu ko rape rupi puta uruhow

canela (parte do corpo) de alguém $n . f$. ietymasi'a

cangalha $n . f$. (cambito de cangalha) sakare asywa

canhoto n.descr. isahua'e (isahu). Ex.: ele escreve com a mão esquerda ysew'a isahu katy

canoa $n . f$. ygara

cansaço $n$. kane'u

cansado (ele está) n.descr. eumaw (kane'u). Ex.: eu estou muito cansada ti kane 'uete ri'a

cansa-se/cansou-se v.tr. usepekynge'o. Ex.: eu me cansei asepekynge'o; ele vai se cansar usepekynge'o puta

canta/cantou v.intr. use'engar. Ex.: eu cantei ase'engar; quem está cantando? awa pa'e ripo use'engar?; por que as mulheres não estão cantando? ma'eramu pa'e kuso nu se'engar uwi?; nós (excl.) cantamos uruse'engar; ontem você chegou, cantou e dançou aiko ra'e wehe rako erewahem erese'engar eresemume

cantador (ele é) n.descr. ise'engara'e. Ex.: Miho (é) o que canta Miho se'engara'e capina/capinou v.tr. ukupir. Ex.: eu capinei a roça ise akupir koa

capivara $n . f$. kapiwara, Hydrochaeris hydrochaeris 
cará (tubérculo) n.m. kara

cará branco n.m. akaratinga. - Ver $\rightarrow$ peixe

caracol n.m. satuta'i

caramujo n.m. saratyta

caranguejo n.m. uwa ${ }^{1}$

caranguejo (barriga do) n.f. uwarukape ${ }^{1}$

caranguejo (esp.) n.m. wararu

carapanã n.m. (mosquito) sati'u

carazinho n.m. akara'i, Geophagus brasiliensis. - Ver $\rightarrow$ peixe

careca de alguém n.descr. iapin hawa'e'yma'e (iapihawe'ym). Ex.: meu marido vai ficar sem cabelo (careca) ti rerekatara puta i'apihawe 'ym

carne n.f. o'o. Ex.: Suara, você cortou a carne? Suara, eremunohonohog pa'e o'o?; de onde você trouxe esta carne? mo wi pa'e ererur ma'ea ro'o?; carne bovina misakatirona 'o; carne de porcão tasahua 'o; carne de caititu tiwa'aro'o

carne de gente $n . f$. awa ra'o

carrapatinho n.m. satewu'i, Amblyomma cajennense. - Ver $\rightarrow$ carrapato

carrapato n.m. satewua, Ixodídeos/Argasídeos. Ex.: tem carrapato na perna da Ikatu Ikatu konga re satewuga ituni. - Ver $\rightarrow$ carrapatinho, carrapato-estrela, carrapatovermelho

carrapato-estrela n.m. satewupew, Amblyomma cajennense. • Ver $\rightarrow$ carrapato

carrapato-vermelho n.m. satewupytong, Rhipicephalus sanguineus. - Ver $\rightarrow$ carrapato

carrega/carregou v.tr. uwuhyj. Ex.: vocês carregaram a tora do buritizeiro pehe ta peraha pewuhyj myriti 'ywa

cartucho de bala n.m. uwyosa

casa n.f. (residência) 'oga. Ex.: nós todos juntos construímos nossa casa asehutese saupir sene rehe 'og (Wajwera umume'u); me ajuda a construir a casa ti popytywo e apo 'og (Wajwera umume'u); eu posso vir dormir sozinho em casa ti rehe taketehewehe ne wy wekow (Wajwera umume'u); nós fizemos estas casas ure uruapo 'oga; ele saiu de casa ti rogawi ihoj usona; eu quero fazer minha casa apoa'u ri'a wetoga. - Ver $\rightarrow$ casa tradicional 
casa (levanta/levantou) v.tr. usogupir. Ex.: eu levantei casa asogupir; ele vai levantar casa usogupir puta

casa de caba $n . f$. kawa retoma, Nycticorax nycticorax

casa de farinha $n . f$. manimea pukujtawa roga (manimea roga). Ex.: eu vou chegando para dentro da casa de farinha aha puta manime roga pupe wewahema a-apoa'u re'a manime ne roga pupe

casa grande $n . f$. 'oga muruwisawete. - Ver $\rightarrow$ casa

casa tradicional n.f. 'ogete. Ex.: vamos fazer a casa tradicional no terreno onde a gente estuda uruapo puta 'ogete semu'etawa ukaripe; vamos fazer a casa tradicional para os não índios poderem ver uruapo puta 'ogete $t$ uesag wehe warasu tywo, 'og $t$ unawa. - Ver $\rightarrow$ casa

casada n.descr. erekatara'e

casado n.descr. emirekowa'e

casca (do pau) n.f. ywyra pira. - Ver $\rightarrow$ árvore

cascudo (menor) n.m. atirare

cascudo (peixe) n.m. muru, Hypostomus plecostomus. - Ver $\rightarrow$ peixe

castanha-do-pará $n . f$. so, Bertholletia excelsa. Ex.: flor de castanha-do-pará so putyra; depois de amanhã eu vou coletar castanha-do-pará aiko ra'e wehe puta aha ikaw so

cava/cavou v.tr. uhywykaj. Ex.: eu cavo buraco na terra ywykwara ahywykaj; vou cavar meu poço ti se'eromamu puta ri'a ahywykaj

cavalo n.m. (burro, jumento) misakatinga, Equídeos

cedo $a d v$. kuwejwehe. Ex.: você acordou cedo eretyryg pa'e kuwejwehe

cedro n.m. akatikating

cego n.m. eapewa'e

cera (de abelha) n.f. hyretoma

cercadinho (para animal) n.m. upari

cercado n.m. momomica. Ex.: você já prendeu todos os porcos no cercado? eremono pa'e imomomyrera pupe tasahumymawa?

cérebro de alguém n.m. (miolo dele) iapitu'una

céu n.m. ywaga 
chapéu de alguém n.m. (boné) apiryrua. Ex.: o boné está pendurado no alto iapiryrua u'aiko ywete

chefe (ele é) n.descr. (liderança (ele é)) muruwisawa. Ex.: Mairá (é) liderança Maira muruwisawete

chega/chegou v.intr. uahem. Ex.: todos já chegaram? uahemamaw pa'e?; todos já chegaram! uwahemamaw rako; quando todos vão chegar? monamu puta pa'e ituri wahemamapa?; nós (excl.) chegamos da roça uruwahemame ri'a kowi; ontem eu cheguei, comi e dormi aiko ra'e wehe rako awahem akaru akerako

chegando (vem/veio) v.intr. usowewahem. Ex.: antes de ontem eu cheguei em casa aiko ku'em kwera re rako asowewahem wetoga pupe

cheira/cheirou v.tr. uetun

cheiro de algo ou de alguém n.m. ekwena

cheiroso n.descr. eakwen

chifre n.m. ati

chocalho (tipo) n.m. sykong

chora/chorou v.intr. uso'o. Ex.: quem está chorando? awa pa'e uso'o?; eles choraram uso'o remi; eu chorei aso'o

chove/choveu v.intr. ukyr. Ex.: antes de ontem choveu aiko ku'em kwera re ikyr amona

chupa/chupou v.tr. upyter. Ex.: eu chupei a laranja apyter akuti nami pe pytukawa

chuva n.f. amona. Ex.: a chuva é fria amona yruyrona; antes de ontem choveu (a chuva) aiko ku'em kwera re ikyr amona

chuva (quando for a época de) $a d v$. (inverno) amonamu

cicatriz de alguém $n . f$. imusona

cílio de alguém n.m. upepikyohaw

cima (em cima) $a d v$. ywete

cinto de alguém n.m. isekwo akwahawa

cintura de alguém $n . f$. i'wyj. Ex.: minha cintura $t i$ wysa

cinza (cor) n.descr. 'e'apetinga'e

cinzas $n . f$. tatahu. $\cdot$ Ver $\rightarrow$ fogo 
cipó n.m. ypo. Ex.: eu corto o cipó ypo amonok

claro n.m. (dia) ara. Ex.: então outra vez passou o tempo aiko ara re wehe rako; pelo dia 'arimu

clavícula de alguém $n . f$. iatikonga

clitóris de alguém $n . f$. iamati’o. - Ver $\rightarrow$ vagina

cobra n.f. mosa (moj). Ex.: o cachorro vai morrer, porque a cobra mordeu ele ma'esawara puta usekyj mosa u'uramu; quem a cobra mordeu? awa pa'e mosa u'u?; eu atirei na cobra, mas ela ainda vive ise amupig mosa re, ise awisepe mosa nusekysuwi; eu estou matando a cobra ise ri'a asuka we'oma mosa. - Ver $\rightarrow$ cobracega, cobra-cipó, cobra-coral, cobra-d’água, cobra-de-duas-cabeças, cobra-papagaio, cobra-preta, jararaca, jiboia, sucuri, surucucu

cobra-cega $n . f$. mosokonge'ym. - Ver $\rightarrow$ cobra

cobra-cipó n.f. inasimosa. - Ver $\rightarrow$ cobra

cobra-coral n.f. arawawa, Micrurus. $\cdot$ Ver $\rightarrow$ cobra

cobra-d'água n.f. apimuku (arawawa), Colubrídeos, Aquelas, Helicops. - Ver $\rightarrow$ cobra cobra-de-duas-cabeças n.f. (cobra-cega) mosakone'yma, Anfisbenídeos. - Ver $\rightarrow$ cobra cobra-papagaio n.f. ywyraka'ymomona, Corallus caninus. - Ver $\rightarrow$ cobra

cobra-preta $n . f$. wajpatana, Clelia cloelia. - Ver $\rightarrow$ cobra

coça/coçou v.tr. usy'oj. Ex.: eu cocei asy'oj; ele vai coçar usy'oj puta

cocar (de penas de arara) n.m. araraw

cocar (de penas de tucano) n.m. tukanaw

coceira $n . f$. remun

coco n.m. ynata. Ex.: coco duro inataoto

cocô de algo ou de alguém n.m. (merda, fezes) iputi

coelho n.m. tapi'ise, Oryctolagus cuniculus

cofo n.m. iruting

cogumelo (esp.) n.m. awyraru ${ }^{1}$

coisa $n . f$. (que) ma'ea ${ }^{2}$. Ex.: o que caiu? ma'e u'ara?; algo me mordeu ma'ea ripo ti u'u; o que você está cortando? ma'ea pa remonog oma?; eu perdi duas coisas 
namukuj ripo ma'ea amukasym; por onde você engole sua comida? ma'ea rupi pa'e eremukun ne remi'ua?

colar dela n.m. ipu'yr

coletivizador part. remi. Ex.: aquelas galinhas são meus xerimbabos aimi wyra'yra remi ti rejmawa; eles choraram uso'o remi; todos estão sentados uapyg remi ukwapa; eles vão cortar a árvore do pequi oho puta remi iatika peke'ia 'ywa; as moças estão rindo kusomuku'i remi usaihejhe; todos entraram na casa ukerpapaw remi

colhe/colheu v.tr. upo'o. Ex.: eu colhi apo'o; ela vai colher upo'o puta

colher $n . f$. isuwaw

coluna vertebral de alguém $n . f$. ikupepyter

comadre n.f. kumara

come/comeu ${ }^{1}$ v.tr. u'u ${ }^{1}$. Ex.: por onde você engole sua comida? ma'ea rupi pa'e eremukun ne remi'ua?; ele vai comer u'u puta ri'a; eu descasquei e comi a banana ise apirog pahakurona i'u. - Ver $\rightarrow$ come/comeu ${ }^{2}$

come/comeu ${ }^{2}$ v.intr. ukaru. Ex.: ontem eu andei, comi e cantei aiko ra'e wehe rako aata akaru ase'engar; ele vai comer ukaru puta ri'a; vem aqui, vamos comer kopesor sakaru; dar comida pro cachorro emono ma'esawara tukaru; deixa ele comer te 'ine ukaru. - Ver $\rightarrow$ come/comeu ${ }^{1}$

comida $n . f$. emi'u. Ex.: a comida (é/está) muito gostosa temi’u episepise

compadre n.m. kupara. Ex.: o compadre está me vendo kupara ti resag ri’a

companheiro n.m. tyrua

comprido (ele é) n.descr. ipuku. Ex.: o homem é alto akuma'e ipukua

concha (de cozinha) n.f. temi'u pyuhawa

concha (de ostra) n.f. itoku'o

conta/contou v.tr. umume'u. Ex.: ele contou faz tempo umume'u hejkwehe; contei o recado para ele ne se'engawera ri'a amume'u iupe; Miho sabe contar histórias antigas Miho umume'u kotawypykwera

conversa/conversou v.tr. umupurungyta. Ex.: eu vou conversar com você urumupurungyta puta ri'a; quem conversou contigo? awa pa'e ne mupurungyta?

copo n.m. (copo de água) 'ywawa

coração de algo ou de alguém n.m. isi'o 
corda $n . f$. upohoma. Ex.: amarrado com corda tupohoma kurukwara

cordão umbilical n.m. ipurua homa

coriza de alguém $n . f$. iamyw

corre/correu v.intr. uson. Ex.: eu corri muito asonete ri'a wehow; eu vou correr muito ise puta ri'a asoason; eu estava correndo e caí wesowesona a'ar; a paca correu do meu lado karuaruhua ti keywywy re oho usona

corrói/corroeu v.tr. uwoj

corta/cortou ${ }^{1} v . t r$. umonog. Ex.: eu corto o cipó ypo amonok; eu vou cortar essa árvore amonog a'epe 'ywa; por que ele cortou a árvore? ma'eramu pa'e imonog 'ywa?; nós (excl.) cortamos a abóbora uruasejmonog i'akorona; o que você está cortando? ma'ea pa remonog eoma?. - Ver $\rightarrow$ corta/cortou ${ }^{2}$, corta/cortou em pedaços

corta/cortou ${ }^{2}$ v.tr. ukiti. Ex.: a faca vai te cortar kyse puta ne pokiti; eu corto akiti; ele vai cortar ukiti puta ri'a. - Ver $\rightarrow$ corta/cortou ${ }^{1}$, corta/cortou em pedaços

corta/cortou em pedaços v.tr. umonohog. Ex.: eu já cortei muitas árvores amunohog ete 'ywa; o que você está cortando? ma'e pa'e eremunohonohog?; Suara, você cortou (várias vezes) a carne? Suara, eremunohonohog pa'e o'o?; ele corta em pedaços lenha (galho) umonohonohog oko. - Ver $\rightarrow$ corta/cortou ${ }^{1}$, corta/cortou $^{2}$

coruja n.f. masakuwa, Estrigiformes, Titonídeos, Estrigídeos

coruja-branca $n . f$. pypypypy, Tyto alba. - Ver $\rightarrow$ ave, coruja

cospe/cuspiu v.intr. unemun. Ex.: eu cuspi anemun; ela vai cuspir unemun puta ri'a

costela de alguém $n . f$. isarukonga

costura/costurou v.tr. usuruhywo

cotovelo de alguém n.m. iparati'ywa. Ex.: eu bati meu cotovelo anupo weparati'ywa

coxa de alguém $n . f$. uwakasa

cozinha/cozinhou v.tr. umuapyg. Ex.: eu cozinhei amuapyg; ele vai cozinhar umuapyg puta ri'a

criança n.f. usawa'ea. Ex.: esta criança é teu/tua filho(a) iusawa'ea ne memyra; estas crianças são meus/minhas filhos(as) iusawa'ea remi ti memyra; aqueles crianças estão se batendo iusawa'ea remi usunupo

cu de algo ou de alguém n.m. (ânus dele) egeypy

cueca $n . f$. ikong su'ara 
cuia de algo ou de alguém $n . f$. ekuj

cuida/cuidou v.tr. usemu'an. Ex.: eu cuido do meu filho pra ele ficar bonito ise asemu'an reko wememyra re tawaruete

cuieira $n . f$. kujpia ’ywa, Crescentia cujete. • Ver $\rightarrow$ árvore

cunhada $n . f$. eke'i

cunhado n.m. ekewena

cupim n.m. kupi'i

cupuaçu n.m. kujronuhu

curica $n . f$. kykyra'yr, Pionopsitta caica

curimatã n.m. karimata, Prochilodus

curto n.descr. iaturu'e. Ex.: minha camisa é curta ti rirua iaturu'e; meu calção é curto ti kong akasa iaturu'e.

cutia $n . f$. akuti, Dasyprocta, Dasiproctídeos. Ex.: o cachorro corredor pegou a cutia ma'esawara usonetewa'e upyhyg akutia

cuxiú n.m. kutipi, Chiropotesutahicki

\section{D}

dá/deu v.tr. umono. Ex.: esse eu não dou para você aiko na amonowi ne upe; eu vou te dar ko, amono ne upe; eu vou dar o machado para o teu irmão syryg puta amono ne irua pe; dá comida pro cachorro emono ma'esawara tukaru

dança/dançou v.intr. upurahaj. Ex.: eu dancei apurahaj; ele vai dançar upurahaj puta; eles não estão indo caçar, vão dançar (porque é a festa do Sapurahaj) (dança) upurahaj ta ri mi nupumaruwi ohow; ontem você chegou, cantou e dançou aiko ra'e wehe rako erewahem erese'engar eresemume

daqui $a d v$. ko katy. Ex.: vá daqui eho ko katy

declarativo part. ri'a. Ex.: eu brinquei muito asemuaraseteete ri'a; asonete ri'a wehow asonete ri'a wehow; ele dormiu uker ri'a; eu estou deitado a'aw ri'a; meu cabelo caiu $t i$ 'aw kujpaw ri'a

dedo anelar de alguém n.m. ipopi 
dedo do pé de alguém n.m. ipyhopi

dedo indicador de alguém n.m. ipyhope

dedo médio de alguém n.m. ikwo

dedo mindinho de alguém n.m. (mínimo (dedo) dele) ipuhopopi

dedo polegar de alguém n.m. ipuheakonga. Ex.: meu polegar está doendo ti puheakong ahy; eu bati meu dedo polegar asepuheakong upo

deita/deitou na rede $v$.intr. u'aw. Ex.: eu (estou) deitado na rede $a$ 'aw ri'a; estou indo me deitar na rede a'aw puta ri'a wehow

dentadura $n . f$. hoj tehe 'yma

dente de algo ou de alguém n.m. hosa (hoj). Ex.: minha dor de dente ti rosahy

dentro $a d v$. (em) ipupe. Ex.: na rede nós (incl.) dormimos tekwawa pupe saker; eu me lavei no rio asehej ri'a porono pupe; tem caititu na roça de Ikatu Ikatu oko pupe tiwa'a; para dentro do rio Ikatu foi porono pupe Ikatu ihoj; ontem eu fui plantar feijão na roça aiko ra'e wehe rako aha ko pupe ityma kumanarona

depressa $a d v$. uwawag

derruba/derrubou v.tr. uityg. Ex.: eu já cortei três árvores irutehe'yma'e aityg 'ywa; eles vão cortar o pé de pequi uetyg puta remi ohow peke'i 'ywa ehera; depois de amanhã nós vamos derrubar mato aiko ku'ema ere puta uruho iejtyka ka'a

desamarra/desamarrou v.tr. upwaraw. Ex.: eu desamarrei a corda apwaraw upohoma

descasca/descascou v.tr. upirog. Ex.: eu descasquei e comi a banana ise apirog pahakurona i'u

desce/desceu v.intr. usyw. Ex.: eu desço asyw; ele vai descer usyw puta; nós (excl.) descemos uruasyw

desenha/desenhou v.tr. (pinta/pintou) uapo ${ }^{2}$. Ex.: eu vou desenhar/pintar qualquer coisa aapo puta ma'e arawa

desequilibra-se/desiquilibrou-se v.intr. ua'ar werew. Ex.: eu me desiquilibrei $a a^{\prime} a r$ werew; ele vai se desiquilibrar ua'ar werew puta

destampa/destampou v.tr. uhuwepemopog

destro n.descr. ikarua katykaty isewag

devagar (ele está) n.descr. imuwej 
dia (pelo dia) $a d v$. arimu. Ex.: nós vamos de dia arimu puta saha

diarréia $n . f$. kwererem. Ex.: vocês estão com diarréia tekwererem

dinheiro n.m. ipirong

direção (na) $a d v$. katy. Ex.: ele foi pra fora oho arua katy

direita $n . f$. karuakatu

diz/disse v.intr. (conta/contou) u'e (u'i). Ex.: ele contou faz muito tempo i’i hejkwehe; nós (excl.) dissemos uru'e; nós falamos sobre a bondade dele uruse'eng ehe aikwesa ikatuete uru'e sepi ehe

dobra/dobrou v.tr. uapar. Ex.: eu vou dobrar a rede aapar puta ri'a tekwawa; Sueli, você vai dobrar a sua rede uapar puta ri'a uekwawa Suelia; você está dobrando a corda da sua rede? ereapar pa'e ne rekwawa rupohoma?

doce n.descr. e'e

doença grave $n . f$. ma'e ahyrona

doente n.m. ma'e ahy

dois num. namukuj (mukuj). Ex.: eu perdi duas coisas namukuj ripo ma'ea amukasym; Ywykatu e Ikatu entraram dois (dias) no mato Ywykatu Ikatu ene ihoj uke mukumukujta ka'ape

dor $n . f$. (doente, doído, picante) ahy (ma’eahy). Ex.: nós (estamos) doentes/doídos sene rahy; ninguém (está) doente na ahywi; você está sentindo dor para ter filho? ne memyra ahy pa'e?; meu ombro está doendo ti ati'ywa ahy; não deixe (a comida) picante emahymahy puhi ke

dorme/dormiu v.intr. uker. Ex.: meu filho dormiu ti memyra uker; você dormiu? ereker pa'e?; onde você dormiu? mume pa'e rekerehe?; ele está dormindo uker ri'a upa; eu vou dormir e acordar cedo aker puta ri'a wehow use'iwehe ete wehe ne tatyryg ne; na rede, nós (incl.) dormimos tekwawa pupe saker

dorso da mão de alguém n.m. ipokupe

duro n.descr. oto (otowa'e)

dúvida $n$.f. ripo. Ex.: algo me mordeu ma'ea ripo ti u'u; quem está cantando? awa pa'e ripo use'engar?; alguém está gritando muito awa ripo apukapukaj; para lá (incerteza) ele banhou aikoj katu ripo isahug 


\section{$\mathrm{E}$}

ecoa/ecoou v.intr. (grita/gritou muito) uapukapukaj. Ex.: alguém está gritando muito awa ripo apukapukaj; eu gritei aapukapukaj

embira $n . f$. iwira

embrulha/embrulhei v.tr. uwon. Ex.: eu embrulho awon; ele vai embrulhar uwon puta embrulha-se/embrulhou-se v.tr. usewon

empurra/empurrou v.tr. umuason. Ex.: quem está empurrando? awa poripo muason enche/encheu v.tr. upypirong. Ex.: eu encho apypirong; ele vai encher upypirong puta encolhe/encolheu v.intr. uwyryg

encontra/encontrei $v . t r$. uhuw

encosta/encostei v.tr. umusekog. Ex.: eu encostei amusekog

encosta-se/encostou-se v.tr. usekogywe. Ex.: eu me encostei asekogywe; ele vai se encostar usekogywe puta

enfeite de cabeça (para mulher) n.m. atutu

enfermeira n.f. remedio erukahara. Ex.: Alzinete é enfermeira (é a que faz vir o remédio) Alzinete remedio erukahara

enfia/enfiou v.tr. u'umu'om. Ex.: ele enfia estaca ywyra u'umu'om

enforca/enforcou v.tr. usywyg

enforca-se/enforcou-se v.tr. usesywyg. Ex.: ele vai se enforcar usesywyg puta ri'a engasga/engasgou v.tr. umanu

engatinha/engatinhou v.intr. upuse. Ex.: eu engatinhei apuse; ele vai engatinhar upuse puta

engole/engoliu v.tr. umukun. Ex.: por onde você engole sua comida? ma'ea rupi pa'e eremukun ne remi'ua?; por onde a gente engole o alimento ma'ea sene imukunawa

enrola/enrolou v.tr. (rola/rolou) umomon. Ex.: aikewara está enrolando (o fio para tecer) rede aikewara umomon tekwawa; eu enrolo rede amomon tekwawa; depois de amanhã eu vou jogar bola aiko ku'ema re puta amomomomon bola wehow 
enrola-se/enrolou-se v.tr. usepyg. Ex.: eu me enrolei asepyg; ele vai se enrolar usepyg puta

enrugado (ele é) n.descr. ipyryryryry

entardece/entardeceu v.intr. ukaruw. Ex.: Tymykong andou o dia todo no mato Tymykong umukaruwete ka'ape

enteada $n . f$. asiranawa

enteado n.m. memiranawa

enterra/enterrou v.tr. utym. Ex.: eu vou plantar aquela árvore ise puta atym 'ywa; nós fomos com as mulheres plantar mandioca ure kuso teseramu uruho ytyma mani'og roko urutym; quando foi que você plantou o milho? monamo he pa'e eretym awatia?; quem plantou a mandioca? awa pa'e utym mani'og?; ontem eu fui plantar feijão na roça aiko ra'e wehe rako aha ityma ko pupe kumanarona; amanhã eu vou plantar milho kuej wehe puta aha ityma awatia weko pupe

entra/entrou v.intr. uke. Ex.: eu entro ake; ele vai entrar uke puta; nós (excl.) entramos uruke; todos entraram na casa ukerpapaw remi

entrega/entregou v.tr. umur

entristecido (ele está) n.descr. isamomor

enxada $n . f$. sypew

época de mamuĩ $a d v$. tayiwa

época do sol (início) $a d v$. (verão) 'arameete ('arame). Ex.: no início do verão eu vou brocar minha roça (na qualidade do que vai ser minha roça) 'arameete re puta awyrok ti koromamu

época seca $a d v$. (de junho a setembro) aretea

ergue/ergueu v.tr. upir. Ex.: eu ergui minha rede aupir ti rekwawa

escama n.f. ipe. Ex.: escama de peixe ipira pe; estou tirando escama de peixe apin ipira pe

escapa/escapou v.intr. ukweraw. Ex.: eu escapei akweraw; ele vai escapar ukweraw puta; nós (excl.) escapamos urukweraw

escápula de alguém n.f. (omoplata) iapekong. Ex.: tua escápula ere 'apekong escola $n . f$. ise mu'etawa 
esconde/escondeu v.tr. umim. Ex.: eu escondo amim; ele vai esconder umim puta; nós (excl.) escondemos urumim

esconde-se/escondeu-se v.tr. usemim. Ex.: eu me escondi onde mata o bicho (caça) asemim ma'ea sukatawpe; ele vai se esconder usemim puta; nós nos escondemos urusemim

escorpião n.m. kyrywyroj

escorre/escorreu v.tr. umutururu

escorrega/escorregou v.intr. uahyryrym. Ex.: eu escorreguei aahyryrym; ele vai escorregar uahyryrym puta

escreve/escreveu v.intr. usewag. Ex.: eu escrevo asewag

escutador n.m. ienupara

esmaga/esmagou v.tr. ukamykamyg. Ex.: eu esmaguei akamykamyg; ele vai esmagar ukamykamyg puta ri'a

esôfago de alguém n.m. ama'ywa. Ex.: pelo meu esôfago ti ama'ywa rupi; pela minha boca primeiro, depois eu mando pelo esôfago ti surua rupi raypy imunehe, amono we ama'ywa rupi

espelho n.m. sehasakara

espingarda $n . m$. ywyrapara ${ }^{2}$. Ex.: eu perdi minha espingarda amukasym weywyrapara

espinha de peixe $n . f$. ipirakong

espinho n.m. su. - Ver $\rightarrow$ agulha

espinho (ponta de) n.f. swaratia. - Ver $\rightarrow$ espinho

espírito n.m. a'wera. Ex.: o espírito aparece pra gente a'wera usesaukar purupe; tem gente que vê espírito wapitu'o wesag sepi a'wera. • Ver $\rightarrow$ alma

espírito (tipo) n.m. ywyterera. Ex.: ywyterera aparece no caminho (terreiro) ywyterera usesa ukara. - Ver $\rightarrow$ alma

espirra/espirrou v.intr. uasun. Ex.: eu espirrei aasun; eu vou espirrar uasun puta ri'a esposa (que foi) n.f. emireko ipukwera

esposa (segunda) n.f. emireko purahua

esquecimento n.m. earaj

esquerda desse $n . f$. isahu 
esse $^{1}$ pron. a'e. Ex.: eu vou cortar essa árvore amonog a'epe 'ywa. - Ver $\rightarrow$ esse $^{2}$

esse $^{2}$ pron. aiko. Ex.: esse eu não dou para você aiko na amonowi ne upe. - Ver $\rightarrow$ esse $^{1}$

esteio (de casa) n.m. iapyreta. Ex.: esteio da casa 'oga apyreta; o esteio (da casa) quebrou iapyreta upen

esteira $n . f$. miahaw

estende-se/estendeu-se v.tr. usenong. Ex.: eu me estendi asenong; ele vai se estender usenong puta

estojo peniano de alguém n.m. akojtimahawa

estragado (ele está) n.descr. iawykyahywa. Ex.: ele se estragou useawykyahyw; a fruta se estragou ma'e'ywa useawykyahyw

estrela $n . f$. sahytata. - Ver $\rightarrow$ estrela cadente, estrela-d'alva, lua

estrela (planeta Júpiter) n.f. karuayra

estrela cadente (maior) n.f. sahytataw'a. - Ver $\rightarrow$ estrela

estrela-d'alva $n . f$. (estrela-da-manhã) eisu. • Ver $\rightarrow$ estrela

estúpido n.descr. awaj’yma

esvazia/esvaziou v.tr. uhen. Ex.: eu esvaziei ahen; ele vai esvaziar uhen puta

eu pron. (meu) ti. Ex.: tem caititu na minha roça ti ko pupe tiwa'a; pra roça minha mãe foi ko pupe ti hy ihoj; a paca correu perto de mim tipiw ihoj karuarahua usona; eu sou preguiçosa ise ti asate'ymete; eu estou muito cansada ti kane'uete ri'a

eu pron. ise. Ex.: eu bato em vocês dois ise hu puta runupo; eu estou correndo ise puta ri'a asoason; eu sou professor ise purumu'etaramu

ex-pele n.m. (ex-couro) ipirera

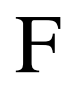

faca $n . f$. (facão) kysea. Ex.: a faca está cega kyse hoj ne ’yw; Muretama pegou a faca de mim Muretama upyhyg kysea ti wi 
fala/falou v.intr. use'eng. Ex.: eu falei ase'eng; ele vai falar use'eng puta; nós (excl.) vamos falar uruse'eng; ele falou faz tempo use'eng hejkwehe

faquinha $n . f$. ma'e kutitawa

farinha de mandioca $n . f$. manimea. Ex.: farofa de ovo (lit. 'farinha misturada com ovo de galinha') manimea ko amumaraw wyra'yra rupi'a

fava $n . f$. kumana

favão n.m. aramuru 'ywa

faz/fez v.tr. uapo ${ }^{1}$. Ex.: eu quero fazer minha casa aapoa'u ri'a wetoga; nós fizemos estas casas ure uruapo 'og; eu preciso fazer farinha na tua casa (de farinha) aapoa' $u$ ri'a manime ne roga pupe

febre de alguém n.f. (frio de alguém) iru'ya. Ex.: você está com febre? ne ru'y pa 'e?

fecha/fechou v.tr. uhuwapyg

feijão n.m. kumanarona. Ex.: ontem eu fui plantar feijão na roça aiko ra'e wehe rako aha ityma ko pupe kumanarona

feixe de lenha n.m. akwakwaraioko

ferida de algo ou de alguém $n . f$. iperew. Ex.: ferida dele iperew

ferro de passar n.m. tyrykwera pimumykawa

ferve/ferveu v.tr. upupur. Ex.: ela vai ferver upupur puta

feto $n . m$. wetypype iwsawa'e ituni

fia/fiou v.intr. upuwon. Ex.: eu fiei apuwon; eu vou fiar upuwon puta; nós (excl.) fiamos urupuwon

fígado de algo ou de alguém n.m. ipy’a

filha (de homem) n.f. asyra. Ex.: já nasceu tua filha? u'ar pa'e ne rasyra?

filha (de mulher) n.f. (filho, criança) memyra. Ex.: já nasceu tua filha? (de mulher) u'ar pa'e ne memyra; levante a criança (a minha filha) emuku'om ti memyra; esta criança é tua filha iusawa'ea ne memyra; tua filha gritou? ne memyra pa'e uapukaj?

filho (de mulher) n.m. imemyra. Ex.: meu filho dormiu ti memyra uker; ne memyra tipiw uapyg teu filho sentou perto de mim

filho da irmã da mãe n.m. (filho do irmão do pai) kywyra

filho de alguém n.m. ((homem falando)) a’yra 
filhote (de bicho) n.m. ymemyra. Ex.: filhote de porcão tasahua ymemura; filhote de veado misara ymemura; filhote de anta tapi'iraymemura

flauta $n . f$. asumi'apy

flauta (tipo) n.f. sumi'a

flecha de alguém $n . f$. iu'ywa

flor $n . f$. yputyra

fogão n.m. ma'ea potawa

fogo (em geral) n.m. (fogueira) tata. - Ver $\rightarrow$ cinzas, fumaça

fogo (que cai do céu) n.m. musena

foice $n . f$. kysekono

folgado n.descr. asasaj

folha $n . f$. owa. Ex.: a folha da árvore é verde ywyra rowa yapewy

fome n.f. ima'euej. Ex.: minha fome ti ma'euej; você está com fome? ne ma'euej pa'e?

fora $a d v$. (espaço aberto) aru'akaty. Ex.: ele foi pra fora oho aru'akaty; leve para fora eraha aruakaty

formiga $n . f$. tahywa, Formicídeos. - Ver $\rightarrow$ formiga-correição, formiga-de-fogo

formiga (esp.) n.f. tahywuna, ta'oga

formiga-correição n.f. tahywarema. - Ver $\rightarrow$ formiga

formiga-de-fogo n.f. tahywa purupir piwe. - Ver $\rightarrow$ formiga

forte (muito) n.descr. pukongete

frio de algo ou de alguém n.descr. iru'ya. Ex.: você (está) com febre (frio)? ne ru'y pa'e?

fruta $n . f$. 'i'a (ma?c?iwa). Ex.: a fruta estragou ma'e 'ywa useawykyahyw

fuma/fumou v.intr. upetymu. Ex.: eu fumei apetymu; ele vai fumar upetymu puta; nós (excl.) fumamos urupetymu

fumaça $n . f$. tatatinga. - Ver $\rightarrow$ fogo

fumo n.m. (cigarro) petyma 
fundo n.descr. waypy. Ex.: é fundo? waypyete pa'e?; fundo da água 'ya ruaypy; é verdade que esse rio é fundo? waypy te pa'e porono re apyra?. - Ver $\rightarrow$ raso

fura/furou ${ }^{1}$ v.tr. ukutuk. Ex.: eu furo akutuk. - Ver $\rightarrow$ fura/furou ${ }^{2}$

fura/furou ${ }^{2}$ v.tr. umumuk. Ex.: ele furou sua própria orelha usenamimumuk; ele furou seu próprio lábio useememumuk. • Ver $\rightarrow$ fura/furou $^{1}$

fuso de alguém n.m. ipuwonaw

\section{G}

gafanhoto n.m. tukurupipina ${ }^{1}$

gafanhoto (esp.) n.m. tasahuron komopikara

galho n.m. oko. Ex.: galho de árvore 'yw oroko; ele caiu lá de cima do galho da árvore 'ywa rokowi i'ar; nós fomos com as mulheres plantar (galho de) mandioca ure kuso teseramu uruho ytyma mani'og roko urutym

galinha n.f. wyra'yra. Ex.: galinha preta wyra ipisuna'e; aquelas galinhas são meus xerimbabos aimi wyra'yra remi ti rejmawa. - Ver $\rightarrow$ ave

galo n.m. wyra'yra akuma'e, Gallus. - Ver $\rightarrow$ ave

garça $n . f$. wyratinga, Ciconiiformes, Ardeídeos. - Ver $\rightarrow$ ave

garfo n.m. (ancinho, rastelo) arupo

garganta de alguém $n$.f. i'asa

garra (de bicho) n.f. puhope

gato n.m. sawamimawa, Felis catus. - Ver $\rightarrow$ onça

gavião n.m. sapakania, Falconiformes, Acipitrídeos/Falconídeos. • Ver $\rightarrow$ águia, ave gavião vermelho n.m. tawoto. - Ver $\rightarrow$ ave

gavião-real n.m. uwisaw sapakania, Harpia harpyja. • Ver $\rightarrow$ ave

geladeira n.f. (freezer) 'ya mungingongara. Ex.: a geladeira é cinza 'ya mungingongara iapetinga'e

gengiva de alguém $n . f$. emekong

genro n.m. asywen 
gira/girou v.tr. uru'aru'ag. Ex.: eu girei aru'aru'ag; ele vai girar uru'aru'ag puta goiaba $n . f$. petiwaron

goiabeira $n . f$. petiwaron 'ywa. - Ver $\rightarrow$ árvore

gordura de algo ou de alguém $n . f$. ikawa

gosta/gostou v.tr. ukojte. Ex.: eu gosto de você akojte ne rehe

gostoso (ele é) n.descr. ipise. Ex.: a comida (é/está) muito gostosa temi'u episepise

grande (ele é) n.descr. isuruwa

gravador $n . m$. iapyakwara towa'e

graveto n.m. (pauzinho) ywyraukaj

gravidez de algo ou de alguém $n . f$. ipuru'a

graviola $n . f$. (biribá) pina'irona

gravioleira $n . f$. pina'irona 'ywa. - Ver $\rightarrow$ árvore

grilo (esp.) n.m. ikysuhu

grita/gritou v.intr. uapukaj. Ex.: eu gritei aapukaj; alguém está gritando muito? awa pa'e uapukasatuete?; tua filha gritou ne memyra pa'e uapukaj; lá, alguém está gritando pew ri'a awa iapukaj; sua esposa está gritando para você ne remiriko ripo uapukaj ne upe; Ikatu está gritando muito Ikatua ripo uapukapukaj

grosso (ele é) n.descr. ipurung

guariba n.f.m. akykya, Alouatta guariba guariba

\section{$\mathrm{H}$}

helicóptero $n . m$. taratiratinga ${ }^{2}$

história n.f. kotawypy. Ex.: Miho sabe contar histórias antigas Miho umume'u kotawypykwera

hoje adv. aiko re. Ex.: hoje eu vi este homem aiko re rako aesag akuma'e

homem n.m. akuma'ea. Ex.: homem gordo akuma'e akuraete; ontem eu vi este homem aiko re wehe rako aesag akuma'e; quantos homens vão correr? moron puta pe akuma'e ihoj osuna? 


\section{I}

igarapé $n . f$. 'ykwawa. Ex.: eu vou pra água (igarapé) aha puta 'ype

inajá n.f.m. (najá) inasa

inajá n.m. inasa 'ywa, Maximiliana maripa

inambu $n . m$. inamuhun

inambu (esp.) n.m. inamuita

inambumirim n.m. inamu'i, Crypturellus tataupa. - Ver $\rightarrow$ ave

incha/inchou v.intr. uwuwur. Ex.: eu inchei awuwur; ele vai inchar uwuwur puta

inclinado (ele é) n.descr. itusug

inflamado (ele está) n.descr. iusewywyr

inhame n.m. kororonuhu

inimigo n.m. kotawete'yma. Ex.: meu inimigo ti kotawete'yma'e

inteligência de alguém n.descr. iapinawawa'e

intestino de algo ou de alguém n.m. (tripa dele) igea

intestino delgado n.m. hog rera

intestino grosso n.m. igewa'a

irmã (de homem) n.f. emira

irmã (mulher falando) voc. ua

irmão n.m. irua. Ex.: eu vou dar o machado para o teu irmão syryg puta amono ne irua $p e$; o menino tem um irmão gêmeo kunumia irumukusa'e

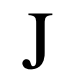

jabuti n.m. sautia. • Ver $\rightarrow$ jabuti-açu, tracajá

jabuti-açu n.m. sautihu, Chelonoidis denticulata. $\cdot$ Ver $\rightarrow$ jabuti

jacamim n.m. sakami, Gruiformes, Psofiídeos, Psophia 
jaçanã n.m. piaka, jacanídeo. • Ver $\rightarrow$ ave

jacarandá n.m. sakarana, Dalbergia, Machaerium

jacaré n.m. sakarea

jacaré-açu n.m. sakarehu, Tachia guianensis

jacaretinga n.m. sakaretinga, Caiman crocodilus

jacu n.m. sakua, Galiformes, Cracídeos, Penelope. - Ver $\rightarrow$ ave

jacu (esp.) n.m. sarukawa

jacundá n.m. sakuna, Crenicichla

jacutinga $n . f$. sakuhua, Pipile jacutinga

jaguatirica $n$.f. sawari, Felis pardalis. - Ver $\rightarrow$ onça

japiim n.m. tararawre, Cacicus cela

jararaca $n . f$. mojrona, Bothrops jararaca. • Ver $\rightarrow$ cobra

jatobá n.m. suta 'ywa, Hymenaea. • Ver $\rightarrow$ árvore

jeju n.m. (jiju) sesu, Hoplerythrinus unitaeniatus. - Ver $\rightarrow$ peixe

jenipapo n.m. sanipaw

jia $n . f$. su'i

jiboia n.f. a'ete (a'eete), Boa constrictor. Ex.: a jiboia engole gente a'ete purumukuna'e; a jiboia enrola gente a'ete upurumomomomona'e. - Ver $\rightarrow$ cobra

jirau n.m. iwirapitema

joelho de alguém n.m. ikanawa

joga/jogou v.tr. umomor

junta/juntou v.tr. (coleta/coletou) uka. Ex.: depois de amanhã eu vou coletar castanhado-pará aiko ra'e wehe puta aha ikaw so

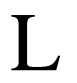

lá $a d v$. aipe. Ex.: eu sentando lá ise aapyg aipe 
lábio de alguém n.m. eme

lagoa $n . f$ ipure

lágrima de alguém $n . f$. eahy

lâmpada n.f. (que brilha, que tem luz) enywa'e. Ex.: eu vou apagar a luz amuew puta ri'a enywa'e

lanterna $n . f$. iapyakwara'yma'e

lápis n.m. isewakawa. Ex.: eu escrevo com o lápis ise asewag isewakawa ko

laranja $n . f$. (limão) akutia namy pe pytukawa, Citrus aurantium, Citrus limon. Ex.: eu chupei a laranja apyter akuti nami pe pytukawa

laranja (cor) n.m. 'ita'uta'uwa'ea

laranja-da-terra $n . f$. (laranja grande) akutia nami pe pytukawahu. Ex.: a laranja-da-terra

(é) azeda akutia namy pe pytukawahu haj

laranjeira $n . f$. (limoeiro) akutia namy pe pytukawa 'ywa

largo (ele é) n.descr. ipipir

látex n.m. iputing

lava/lavou v.tr. uhej. Ex.: eu lavo roupa asyruhej; eu me lavei no rio asehej ri'a porono pupe

lavador n.m. ihejtara

lava-se/lavou-se v.tr. usahug. Ex.: para lá ele se lava aikoj katuripoj sahug; ele se lavou porque estava sujo usahug ohow upisupisunawi; vai tomar banho esahug eho; eu me lavo asahug

lê/leu v.tr. (conta/contou) upapar. Ex.: eu leio ou eu conto (números) apapar; ele vai ler upapar puta ri'a

leite de vaca n.m. misakatirona kamya. Ex.: leite azedo misakatirona kamya haj; leite em pó misakatirona kamya po pyrera

lembrança $n . f$. ehaike

lenha $n . f$. ioko

leste n.m. (onde o sol nasce) ara hemawa

leva/levou v.tr. ueraha. Ex.: Muretama levou a faca que pegou de mim Muretama weraha kyse ipyhyka ti wi 
levanta/levantou v.tr. umuku'om. Ex.: levante a criança emuku'om ti memyra; não o levante emuku'on puhi; eu levanto amuku'om

levanta-se/levantou-se v.tr. uku'om. Ex.: eu me levanto de novo aku'om suewir; ele vai se levantar uku'om puta

libélula $n . f$. (jacinta) taratiratinga ${ }^{1}$

limpo n.descr. kyting

língua de algo ou de alguém $n . f$. ikua

linguiça de porco $n . f$. tasahua mymawa arigea po pyrera

linguiça de porco n.f. misakatirona arigea po pyrera

linha $n . f$. inimo

liquidificador n.m. ma'e kytykawa

liso (ele é) n.descr. ihym. Ex.: o tronco é liso ’ywypy ihym

lobo n.m. sawaron

lombriga $n . f$. (verme) tatin. Ex.: no meu intestino está meu verme rigepe ikoj ti tatina

longe $a d v$. pewise. Ex.: os pássaros voaram muito alto (longe) wyra uwewe ete pewise

lontra $n . f$. sawatarag, Lutra, Mustelídeos

loucura de algo ou de alguém n.descr. iapin kotokoto

louva-a-deus n.m. (põe-mesa) murawyky, Mantídeos

lua $n . f$. sahy

lua ensanguentada n.m. (eclipse) sahya uwya

lugar para algo ou alguém cagar n.m. iputikaw

\section{M}

macaco-aranha n.m. (coatá, cuatá) y’a, Ateles belzebuth

macaco-prego n.m. (macaco-de-topete) ka'ia, Cebus nigritus. Ex.: o macaco-prego brinca no galho da árvore e quebra os galhos ka'ia usemuaraj yware ywokomumepem 
macaxeira n.f. ikatua. Ex.: ontem eu plantei roça, bebi água e comi macaxeira aiko ra'e wehe rako ko pupe aha ityma a'y'u roko raj ipyk ikatua muapyga nune. - Ver $\rightarrow$ mandioca

machado n.m. syryg. Ex.: eu vou dar o machado para o teu irmão syryg puta amono ne irua pe

machado de alguém n.m. isyryga

madrasta $n . f$. hianawa

madrugada $n . f$. ku'em

madrugada (parte) n.f. 'u'emanune

mãe (de homem) voc. ine

mãe (de mulher) voc. mihy (hy)

mãe (de mulher) n.f. hy. Ex.: pra roça minha mãe foi ko pupe ti hy ihoj

maguari n.m. asymuhu. - Ver $\rightarrow$ ave

mamão n.m. turihiwnuhu

mamoeiro n.m. turihiwnuhu 'ywa, Carica papaya. - Ver $\rightarrow$ árvore

manco n.descr. kononoj

mandi n.m. tine'a, Pimelodella gracilis. - Ver $\rightarrow$ peixe

mandioca $n$.f. mani'oga. Ex.: quem plantou a mandioca? awa pa'e utym mani'og?; nós levamos mandioca para as mulheres ure urueraha mani'og kusoa pe. - Ver $\rightarrow$ macaxeira

manga n.f. iwapirasuwa, Mangifera indica. Ex.: um pedaço de manga asewerewi uapirasuwa

mangangá n.m. (abelha) manganga, Bombus

manhã (até 10h aprox.) n.f. ara seaupira amujete

manhã (de manhã) n.f. useywiuhe ete

manteiga $n . f$. misakatirona apitu'um

mão de algo ou de alguém n.f. ipo. Ex.: a pedra está leve na minha mão ita iwewuwewuj ti pope

mão-de-pilão $n . f \cdot$ ymyra 
máquina de costura $n . f$. syru'otawa

máquina fotográfica de alguém $n . f$. ipuru'ong ikyitawa

maracá estalante n.m. amutining

marido dela n.m. erekatara. Ex.: meu marido vai ficar sem cabelo ti rerekatara puta i'apihawe'ym; que não quer casar (marido) na erekatara'uwi

marron n.descr. wetehuna'e

martelo n.m. iapykutukawa

maruim n.m. i'iwaj. Ex.: tem muito maruim aqui? usepuremuete pa'e i'iwaj?

mata/matou v.tr. usuka. Ex.: vocês vão matar aquelas caças? pehe puta pesuka ma'ea pesehow?; talvez eu mate um porcão aha puta ri'a isukaw tasahuamu; não mata ele esuka puhi; meu pai, você matou algo? ti ruwa, eresuka pa'e ma'ea?; eu me escondi onde mata o bicho (caça) asemim ma'ea sukatawpe; eu não estou matando a cobra ise ri'a nasukawi mosa

mato n.m. ka'a. Ex.: você entra no mato ereho pe ka'a pe ra'e; a anta vai saindo do mato tapi'ira puta oho ka'a wi uhema; Tymykong andou o dia todo no mato Tymykong umukaruwete ka'ape; ontem você foi andar no mato aiko ra'e wehe re pa'e erehow ka'a pe eataw; eu me perdi no mato ka'a pe amukasym

mato (que é do) n.m. (bicho do mato) ka’apewara

matrinxã n.m. ipirakaw. Ex.: eu gosto de comer matrinxã ipirakaw ipisepise. • Ver $\rightarrow$ peixe

matrinxã (esp.) n.m. ipirakwakwahawe'yma. - Ver $\rightarrow$ peixe

medo (tem/teve) v.intr. ukyyse. Ex.: eu tenho medo akyyse

medroso (bicho) n.descr. hajte

medroso (ele é) n.descr. iukyysetewa'e

meia-noite $n . f$. pyasej

meio n.descr. pytera. Ex.: eu vou passar pelo meio (da plantação) de milho awati pytera rupi puta uruhow

meio do dia $a d v$. (meio do claro) 'ar puta ripe

meio-dia n.m. 'ara rasej

mel n.m. ehyr. Ex.: o mel (é) doce ehyr he'e ete 
mel de uruçu n.m. akyky ehyra

memória (guardar na) v.tr. ue’ara sekuma'e. Ex.: eu lembrei (guardei na memória) ae'ara sekuma'e

menino n.m. kunumia. Ex.: o menino tem um irmão gêmeo kunumia irumukusa'e menino (homem) n.m. usawa'ea akuma'ea. Ex.: são dois meninos namukuj iusawa'e mentiroso n.descr. emu'em

mesmo n.descr. tehe. Ex.: ele come com a própria mão upoku ikaru tehe mija/mijou v.intr. ukurug. Ex.: eu vou mijar akurug puta ri'a; nós mijamos urukurug milho n.m. awatia. Ex.: hoje você planta milho eretym ehe pe awatia; quando foi que você plantou o milho? monamo he pa'e eretym awatia?; eu vou passar pelo meio (da plantação) de milho awati pytera rupi puta uruhow

minhoca $n . f$. ewia

moça $n . f$. kusomukuwa'e (kusomukuj). Ex.: as moças estão rindo de ti kusomukuja ri'a ne saj

moeda $n . f$. ywyrow ehym iapo pyrera

mogno n.m. kanawa ’ywa. - Ver $\rightarrow$ árvore

mole (ele é) n.descr. itamew. Ex.: barriga muito mole ewetypy itametamew

molhado (ele está) n.descr. iakym. Ex.: a roupa está molhada yryw iakym

morcego n.m. sawirire, Ordem dos Quirópteros

morde/mordeu v.tr. (pica/picou) u'u². Ex.: o cachorro vai morrer, porque a cobra mordeu ele ma'esawara puta usekyj mosa u'uramu; quem a cobra mordeu? awa pa'e mosa u'u?; o que te mordeu? ma'e pa'e ne u'u?; algo me mordeu ma'ea ripo ti u'u

morno n.descr. akuwetuwetun

morre/morreu v.intr. usekyj. Ex.: o cachorro vai morrer, porque a cobra mordeu ele ma'esawara puta usekyj mosa u'uramu; eu atirei na cobra, mas ela ainda não morreu ise amupig mosa re, ise awisepe mosa nusekysuwi; o cachorro que é bom caçador morreu usepurakaretewa'e ma 'esawara usekuj; quem morreu? awa pa'e usekyj?

morro n.m. ywytyra. $\cdot$ Ver $\rightarrow$ terra

mosca $n . f$. meru

moto $n$.f. tukurupipina ${ }^{2}$ 
motociclista n.m. awaj'yma

motosserra $n . f$. 'ywa monokawa

mucura n.f. tawareraj, Didelphis

mudo n.descr. se'enga'yma'e

muitos num. tapisara (tapisapisara)

mulher n.f. kuso. Ex.: mulher magra kuso sysyng; por que as mulheres não estão cantando? ma'eramu pa'e kuso nuse'engara uwi?; nós fomos com as mulheres plantar mandioca ure kuso teseramu uruho ytyma mani'og roko urutym; nós levamos mandioca para as mulheres ure urueraha mani'og kusoa pe

mulher (esposa) de alguém $n . f$. emiriko. Ex.: sua esposa está gritando para você ne remiriko ripo uapukaj ne upe

muruci n.m. (murici) waj'irararona, Byrsonima

murucizeiro n.m. waj'irararon 'ywa

música (tocar) v.tr. umuse'engar. Ex.: eu toco música amuse'engar; ele vai tocar música umuse'engar puta ri'a

mutuca n.f. mutuka, Díptero, Tabanídeos

mutum n.m. mytu, Galiformes, Cracídeos. - Ver $\rightarrow$ ave

mutum-castanheiro n.m. (mutum-cavalo) mytuwonguhu, Mitu tuberosa

\section{$\mathrm{N}$}

nada/nadou v.intr. uytaw. Ex.: ontem você foi nadar no rio aiko ra'e wehe re pa'e ehow he porono pupe aitapa; ele vai nadar uytaw puta; nós (excl.) nadamos uruytaw

nadadeira $n . f$. ipepu'awa

não $a d v$. nawi

narina de algo ou de alguém n.f. apyj. Ex.: minha narina (está) entupida ti apyj myk

nariz de algo ou de alguém n.m. (bico) iti. Ex.: eu quebrei o meu nariz asetinupen; ele se sufocou usetimyk; ele não se sufocou nusetimyguwi; está fedendo, tape o seu nariz inemauwi esetimyk 
nasce/nasceu v.intr. u'ar' ${ }^{2}$. Ex.: eu nasci $a$ 'ar; ele vai nascer $u$ 'ar puta; já nasceu tua filha? u'ar pa'e ne rasira?; teu filho já nasceu? (pergunta para o homem) ne ra'yra pe u'ara?

nascer-do-sol n.m. kwarahya hemawa

neblina $n . f$. tatatirong

nervo de algo ou de alguém n.m. isisiwa'oj

neto (de homem) n.m. emimenu

neto (de mulher) n.m. emisariru

ninguém pron. nukewe. Ex.: ninguém entrou na casa nukewe remi 'oga pupe

noite $n . f$. ypytuna

noite (começo da) n.f. ipytuna imuehe

nora de alguém $n . f$. imemytaty

nós (excl.) pron. ure. Ex.: nós fizemos estas casas ure uruapo 'oga; eu abracei ele, nós abraçamos ele ise a'asuron, ure uru asurona; nós fomos com as mulheres plantar mandioca ure kuso teseramu uruho ytyma mani'og roko urutym; nós levamos mandioca para as mulheres ure urueraha mani'og kusoa pe; nós somos professores ure purumu'etaramu

nós (incl.) pron. sene. Ex.: nós não (estamos) doentes/doídos na sene rahywi; Ikatu levou água para nós Ikatua weraha 'ya sene upe

novamente $a d v$. suewir. Ex.: eu dormo de novo aker suewir; eu me levanto novamente aku'om suewir; ele grita repetidamente uapukaj suewiewira

novamente $a d v$. wehe. Ex.: então outra vez passou o tempo aiko ara re wehe rako; ontem eu vi de novo este homem aiko re wehe rako aesag akuma'e; eu não vi mais peixe levantado na esagwi wehe ipira ku'omawa

nuca de alguém n.f. atu'a. Ex.: tua nuca está suja ne atu'a pisun; minha nuca dói $t i$ atu'a ahy

nuvem $n . I I I$ ywatinga 


\section{$\mathrm{O}$}

óculos de alguém n.m. ehasu'ara

oeste n.m. (onde o sol se põe) ara sipawa

olho de algo ou de alguém n.m. eha. Ex.: olho dele próprio useha; nosso (incl.) olho sene reha

olho-d'água n.m. ty'ymon

ombro de alguém n.m. iati'ywa. Ex.: está pesado no meu ombro ipyhyj sete ti'ati'ywa; meu ombro está doendo ti ati'ywa ahy

onça $n . f$. sawara. Ex.: eu subi na árvore afastando-me da onça ywyra re aseupir sawara wi; a onça grande sawarahuete; a onça é braba sawara usaruetewa'e. - Ver $\rightarrow$ cachorro, gato, , jaguatirica, onça-pintada, onça-vermelhar, onça-preta

onça preta $n . f$. sawaruna. - Ver $\rightarrow$ onça

onça-pintada $n . f$. sawapinima, Panthera onça. - Ver $\rightarrow$ onça

onça-preta $n . f$. sawapisuna (sawaruna), Panthera onça. - Ver $\rightarrow$ onça

onça-vermelha $n . f$. (suçuarana) sawapirong, Felis concolor. • Ver $\rightarrow$ onça

onde $^{1} a d v$. mume. Ex.: onde você dormiu? mume pa'e rekerehe?; onde (tem) água? mume pa'e 'ya?. - Ver $\rightarrow$ onde $^{2}$

onde $^{2} a d v$. mo. Ex.: de onde vocês vieram? mo wi pa'e eresor?; de onde você trouxe esta carne? mo wi pa'e ererur ma'ea ro'o?; de onde ele chegou? mo wi pa'e ituri?. Ver $\rightarrow$ onde $^{1}$

ontem $a d v$. aiko re wehe (aiko ra'e wehe). Ex.: ontem eu vi este homem aiko re wehe rako aesag akuma'e; ele chegou ontem aiko re wehe ituri; vocês chegaram ontem? aiko re wehe pa'e pesor?; choveu ontem aiko re wehe ikyr; ontem eu fui caçar no mato aiko ra'e wehe rako asepurakar wehow

ontem (antes de) $a d v$. aiko ku'em kwera re. Ex.: antes de ontem choveu (a chuva) aiko ku'em kwera re ikyr amona; antes de ontem eu cheguei em casa aiko ku'em kwera re rako asowewahem wetoga pupe

orelha de algo ou de alguém $n . f$. inamia

osga n.f. amerewa, Hemidactylus mabouia. Ex.: a osga sobe na casa amerew useupir 'oga re 
osso da mão de alguém n.m. ipokong

osso de alguém n.m. ikong ${ }^{1}$

ouriço de castanha n.m. sope

ouro n.m. itahynypuk. Ex.: o ouro é bem amarelo itahynypuk isukyryete

outro pron. (diferente) amutehe. Ex.: outra roça ko amutehe

ouve/ouviu v.tr/intr. uinu. Ex.: eu ouço ainu; fique calado, eu quero ouvir majere tainune; antigamente eu ouvia histórias imonuarera purunutakwera ainu; ele subiu na árvore porque ele ouviu o barulho da onça useupir sawara reinupa

ouvido de algo ou de alguém n.m. apyakwara

ova de peixe $n . f$. ipirarupi'a (ipirahua). - Ver $\rightarrow$ ovo

ovo de algo n.m. iupi'a

\section{P}

pá n.f. tasahua sywa pekongwera

paca n.f. karuaruhua. Ex.: eu sempre caço paca ise karuaruhua asuka; a paca correu do meu lado karuaruhua ti keywywy re oho usona

padrasto n.m. uanawa

pai (de homem) voc. na

pai (de mulher) voc. mitum

pai de alguém n.m. tuwa. Ex.: pai dele próprio usuwa; meu pai, você matou algo? $t i$ ruwa, eresuka pa'e ma'ea?; você deu o arco para o teu pai ene pa'e eremono ywyrapara ne ruwa pe. - Ver $\rightarrow$ pai (voc.)

pajé n.m. purumupisetaramu. Ex.: eu sou pajé ise purumupisetaramu

paladar de alguém n.m. (sentir gosto) ahekwahawa

palha de aço $n . f$. takwawera

palha de babaçu n.f. pinowa. Ex.: olho da palha de babaçu pinowo; está riscando palha (cortando para dobrar a palha) pinowa wajkiti

palma da mão de alguém $n . f$. ipopytera 
paneiro (de cipó-titica) n.m. tapoworona. Ex.: Miho sabe fazer paneiro Miho uapokwahaw tapoworona

panela de alguém $n . f$. itasa'e

panela de barro n.f. saimew

panela de pressão $n . f$. ma'ea ro’o mutusukara

pão $n . m$. awyraru ${ }^{2}$

papagaio n.m. asuru

papagaio (esp.) n.m. anako, asururonuhu, tikwa. - Ver $\rightarrow$ ave

papel n.m. (caderno) uakawa'i opo pyrera

para (dativo) ${ }^{1}$ prep. upe. Ex.: esse eu não dou para você aiko na amonowi ne upe; sua esposa está gritando para você ne remiriko ripo uapukaj ne upe. - Ver $\rightarrow$ para $^{2}$

para (dativo) $)^{2}$ prep. pe. Ex.: eu vou dar o machado para o teu irmão syryg puta amono ne irua pe; eu disse o recado para ele ne se'engawera ri'a amume'u iupe. - Ver $\rightarrow$ para $^{1}$

parado (fica/ficou) v.intr. upyta. Ex.: eu fico parado apyta; ele vai ficar parado upyta puta; nós (excl.) ficamos parados urupyta

parede $n . f$. ukupe

parteira $n . f$. (mãezinha) tymemyra pyhykarera (ti hy angaw)

passado (há muito tempo) $a d v$. hejkwehe. Ex.: ele falou a verdade há muito tempo use'eng katuete hejkwehe

passarinho n.m. wyra'i. - Ver $\rightarrow$ ave

pássaro (esp.) n.m. ararasawe, koko

pato n.m. ipeuhua. Ex.: aquele pato é teu, mesmo aikwesa ipewhua pa'e ne rejmawa ete. - Ver $\rightarrow$ ave

pato (esp.) n.m. wyratimehu. - Ver $\rightarrow$ ave

pau-brasil n.m. ywotoywa. - Ver $\rightarrow$ árvore

pau-preto n.m. kumanu 'ywa, Diospyros. - Ver $\rightarrow$ árvore

pé de algo ou de alguém n.m. ipy 
pedra $n . f$. ita. Ex.: a pedra está leve na minha mão ita iwewuwewuj ti pope; pedra enorme ita muruwisawete; pedra branca ita tinining; pedrinha ita' $i$; pedra nos rins ita ipyrykyti'i pe

pedra de amolar $n . f$. (esmeril) itaky. Ex.: eu amolo a faca na pedra kise hoj me'ete itaky pega/pegou v.tr. upyhyg. Ex.: Muretama levou a faca que pegou de mim Muretama weraha kyse ipyhyka ti wi; eu vou pegar apyhyg puta ri'a; o cachorro corredor pegou a cutia ma'esawara usonetewa'e upyhyg akutia

peida/peidou v.intr. upuramor. Ex.: eu peidei apuramor; ele vai peidar upuramor puta ri'a

peido de algo ou de alguém n.m. ipuromor (pinu)

peido fedorento n.m. epynunema

peito de alguém (homem) n.m. ikomypya

peixe n.m. ipira. Ex.: peixe seco ipira pirie'ym; o peixe está salgado ipira ywytingupyra. - Ver $\rightarrow$ acarapeba, acari, bagre (esp.), cará branco, carazinho, cascudo, jeju, mandi, matrinxã, matrinxã (esp.), peixe-cachorro, peixinho, piau, piranha, pirarucu, surubim, tamuatá, traíra, traíra (esp.), trairão, tucunaré,

peixe (esp.) n.m. tameaimun, tiniarona. - Ver $\rightarrow$ peixe

peixe levantado n.m. (baleia) ipira ku'omawa. Ex.: eu não vi mais peixe levantado na esagwi wehe ipira ku'omawa. - Ver $\rightarrow$ peixe

peixe-cachorro n.m. (peixe-cabeça-de-cachorro, pirapucu, timbucu) tawarerasapina, Raphiodon vulpinus. - Ver $\rightarrow$ peixe

peixe-voador n.m. ipira uwewewa'e. Ex.: eu já vi peixe voador aesag sepi ipira uwewewa'e. - Ver $\rightarrow$ peixe

peixinho n.m. ipira'i. Ex.: tem muito peixinho ipira'i usepuremuete. - Ver $\rightarrow$ peixe pele de algo ou de alguém $n . f$. ipira

pelo (do corpo) de algo ou de alguém n.m. ihawa. - Ver $\rightarrow$ peludo

pelos pubianos de alguém n.m. iakwawa. Ex.: ela tira os próprios pelos pubianos usekwaw wo'o

peludo $n$. hahaw. - Ver $\rightarrow$ pelo

pena de algo n.f. ipepo 
pendurado (está/esteve) v.tr. uaiko. Ex.: ele está pendurado uaiko; o boné está pendurado no alto iapiryrua uaiko ywete

peneira $n . f$. irupema. Ex.: a peneira é rasa irupema ipyperewa

pênis de alguém n.m. emo

pente n.m. kywawa

pequeno n.descr. (curto) iaturuwewa'e

perde/perdeu v.intr. ukasym. Ex.: eu perdi minha espingarda amukasym weywyrapara; eu perdi alguma coisa ma'ea ripo amukasym; ele está perdido (desaparecido) ukasym; eu perdi duas coisas namukuj ripo ma'ea amukasym

perde-se/perdeu-se v.tr. umukasim. Ex.: eu me perdi (desapareci) no mato ka'a pe amukasim; ele vai se perder umukasim puta

perereca $n . f$. suw'e, Anfíbios anuros arborícolas

pergunta (marca de) part. pa'e. Ex.: de onde vocês vieram? mo wi pa'e eresor?; você acordou cedo? eretyryg pa'e kuwejwehe?; aquele xerimbabo (pato) é teu? aikwesa pa'e ne rejmawa; você dormiu? ereker pa'e?; Suara, você cortou (várias vezes) a carne? Suara, eremunohonohog pa'e o'o?; quem está chorando? awa pa'e uso'o?

periquito-verde n.m. tykyrayra, Psitacídeos. - Ver $\rightarrow$ ave

perna de algo ou alguém $n . f$. ietymakapema

perto adv. tipiw. Ex.: a paca correu perto de mim tipiw ihoj karuarahua usona; teu filho sentou perto de mim ne memyra tipiw uapyg

pesado (ele é) $n$. ipyhyj. Ex.: está pesado no meu ombro ipyhyj sete ti'ati'ywa

pescada (peixe) n.f. tami'iwehe. - Ver $\rightarrow$ peixe

pescoço de algo ou de alguém n.m. isura

pessoa jovem n.f. (rapaz) awa'yahua. Ex.: dá o arco pro jovem emono ywyrapara wa'yahuape; os jovens e os velhos conversam awa'yahua upurumugeta awa'imona ne

pessoa não indígena $n . f$. kamara, warasu

pessoa velha $n . f$. (ancião) awaimon. Ex.: os jovens e os velhos conversam awa'iahua upurumugeta awaimona ne

pessoa(s) n.f. wapitu'o. Ex.: tem pessoas que veem espírito wapitu'o wesag sepi a'wera 
piau n.m. (pintado) ipisaw. Ex.: o piau tem a boca pequena ipisaw isuruhu'yma'e. • Ver $\rightarrow$ peixe

pica/picou v.tr. upi ${ }^{1}$. Ex.: uma cobra não pica a outra usupi tehe mosa musuhuwi; ela vai picar upi puta ri'a

picada $n . f$. 'u'u

pica-pau n.m. paratuwakonguhu, Piciformes, Picídeos

pilão n.m. inu'a

pimenta $n . f$. ky'ysa

pimenteira $n . f$. ky’ysa ypya

pinga/pingou v.tr/intr. utururu. Ex.: ela vai pingar utururu puta ri'a

pinta/pintou v.tr. umuhun. Ex.: eu pintei amuhun; ele vai pintar umuhun puta. - Ver $\rightarrow$ pintador de algo ou de alguém

pintador de algo ou de alguém n.m. inupinipara. - Ver $\rightarrow$ pinta/pintou

pinta-se/pintou-se v.intr. useopo. Ex.: eu me pintei aseopo

pinto n.m. wyra'yra ymemura. - Ver $\rightarrow$ galinha, galo

piolho n.m. kywa. Ex.: tem piolho na cabeça do Jorge Jorge apina re ikywa

piquiá n.m. (pequiá, pequi) peke'i, Caryocar brasiliense. Ex.: eles vão cortar o pé de piquiá uetyg puta remi ohow peke' $i$ 'ywa ehera

piranha $n . f$. ipiroj, Serrasalmus nattereri. - Ver $\rightarrow$ peixe

pirarucu n.m. ipirarunuhu, Arapaima gigas. - Ver $\rightarrow$ peixe

pisca/piscou v.intr. upyrongehe. Ex.: eu pisquei apyrongehe; ele vai piscar upyrongehe puta ri'a

pitiú n.descr. upiti'u. Ex.: peixe pitiú ipira piti'u; a carne de jacaré (é) pitiú? sakare'u pa'e ne piti'u?; a cobra (é) muito pitiú mosa ipiti'uete

placenta de algo ou de alguém $n . f$. ipiruohom

poço n.m. yse'e (se'e). Ex.: ele caiu no poço u'ar pa'e yse'ea pupe; eu vou cavar meu poço $t i$ se'eromamu puta ri'a ahywykaj; eu cavo fundo meu poço amuaypy ti se'eroma

poço (o que é do) $n$. ysewara 
podre n.descr. itusupaw

põe/pôs v.tr. umunge. Ex.: você já prendeu todos os animais? eremungepapaw pa'e ne rejmawa?

poeira $n . f$. tatahuwa

pombo n.m. pykahu. - Ver $\rightarrow$ ave

pomo-de-adão de alguém n.m. (gogó dele) itapura’a (aikong)

ponte (fazer) v.tr. uhaku'og. Ex.: eu fiz ponte ahaku'og

poraquê n.m. (peixe-elétrico, puraquê) purake, Electrophorus electricus

porcão n.m. (queixada) tasahua, Tayassu pecari. Ex.: talvez eu mate um porcão aha puta ri'a isukaw tasahuamu; com certeza eu vou matar um porcão asuka ete puta tasahuamu; amanhã ele quer caçar porcão kuej wehe puta ihoj tasahua. - Ver $\rightarrow$ porco

porco n.m. tasahumymaw, Suídeos. Ex.: você já prendeu todos os porcos? eremono pa'e imomomyrera pupe tasahumymawa?. - Ver $\rightarrow$ porcão

porco-espinho n.m. kwanu, Histricídeos

pôr-do-sol n.m. kwarahya katawa

porta $n . f$. upug

pote de água n.m. 'ya gahawa

pousa/pousou v.intr. userusi. Ex.: a arara pousou no galho da árvore arara userusiw ywyra roko re

prato n.m. iworog ehim pewa. Ex.: o prato é raso iworog ehim pewa ipyperewa

prego n.m. itasukonga

preguiça $n . f$. (bicho-preguiça) arekasu

preguiçoso n.descr. iasate'yma'e (asate'ymete). Ex.: o homem preguiçoso akuma'e iasate'ym; eu (sou) preguiçosa ise ti asate'ymete

prensa $n . f$. kupepykawa

preto $n$.descr. ipituna (pisuna). Ex.: água preto 'ya pituna

procura/procurou v.tr. uhumyru (mymyrur). Ex.: eu procurei ahumyru; ele vai procurar uhumyru puta; nós (excl.) vamos procurar uruhumyru; eu estou procurando a faca amymyrur ri'a kysea wekow; vá e procure algo eho imymyrur 
professor/professora $n$. purumu'etaramu. Ex.: eu sou professor ise purumu'etaramu proibitivo part. puhi. Ex.: quando Suta'ar passar sobre nós, não amostrar (não apontar) Suta'ar sene 'arimu ihoramu puhi ke pe isaukar puhi; não vá eho puhi

projetivo part. puta. Ex.: vocês vão matar aquelas caças? pehe puta pesuka ma'ea pesehow?; eu bato em vocês dois ise hu puta runupo; quando vamos para a roça? moronime puta pe saha koa pupe?; eu vou para Belém aha puta Perẽj pupe; eu vou dobrar a rede aapara puta ri'a tekwawa; eu vou cavar meu poço ti se'eromamu puta ri'a ahywykaj

pula/pulou v.intr. upor. Ex.: eu pulei apor; ele vai pular upor puta rì'a

pulga $n . f$. tuny

pulmão de alguém n.m. (bofe) isi'owewuj

pulso de alguém n.m. iseputahawa

pulso de alguém n.m. ipororong. Ex.: meu pulso está doendo ti poporong ahy; no meu pulso eu coloco relógio wepororonga rea reko arakuahapara

pupunha $n . f$. inasarona

pupunheira $n . f$. inasaron 'ywa

puxa/puxou v.tr. urutyryryg

\section{Q}

quadril grande n.m. e'wi pepo pepo

quando ${ }^{1} a d v$. monamo. Ex.: quando foi que você plantou o milho? monamo he pa'e eretym awatia?. - Ver $\rightarrow$ quando $^{2}$

quando $^{2} a d v$. moronime. Ex.: quando vamos para a roça? moronime puta pe saha koa pupe?. - Ver $\rightarrow$ quando $^{1}$

quanto pron. moron. Ex.: quantos filhos são teus? moron pa'e ne ra'yra?; quantos homens vão correr? moron puta pe akuma'e ihoj osuna?

quati n.m. kwati, Nasua nasua

quatipuru n.m. (esquilo) wawere

quatro num. yrutehehy 
quebra/quebrou v.tr. upen (nupen). Ex.: eu quebrei o meu nariz asetinupen; o esteio (da casa) quebrou iapyreta upen

quebrado (ele está) n.descr. iuka'ika'i

queima/queimou v.tr. uapy. Ex.: amanhã bem cedo eu vou queimar minha roça use' $i$ wehete puta aapy weko

queima-se/queimou-se v.tr. ukaj. Ex.: eu me queimei $a k a j$

queixo de algo ou de alguém n.m. enywa

quem n.f. (alguém) awa. Ex.: quem está chorando? awa pa'e uso'o?; quem morreu? awa pa'e usekyj?; quem está sujando a água? awa pa'e umuhy pyting 'ya?; lá, alguém está gritando pewri'a awa iapukaj

quente $n$. akuw

queredor n.m. iputatara

quero-quero n.m. anyra, Vanellus chilensis

quica/quicou v.intr. upo'upor. Ex.: ele vai quicar upo'upor puta ri'a

\section{$\mathrm{R}$}

rabo n.m. uwa ${ }^{2}$. Ex.: rabo de cachorro ma'esawara ruwa

raiva $n . f$. eakwarahy. Ex.: você está com raiva? ne reakwarahy pa'e?; eu estou com raiva ti reakwarahy ri'a

raiz n.f. opo

ralador n.m. kytykawa. - Ver $\rightarrow$ liquidificador, ralador de castanha

ralador de castanha n.m. so kytykawa. - Ver $\rightarrow$ ralador

raposa n.f. iapua'oj, Aqueles, Vulpes

rasga/rasgou v.tr/intr. utorog (munorog). Ex.: a rede rasgou tekwawa utorog

raso $n . d e s c r$. ipyperewa. Ex.: a peneira é rasa irupema ipyperewa. - Ver $\rightarrow$ fundo

raspa/raspou v.tr. upin. Ex.: eu raspei apin; ele vai raspar upin puta ri'a

rato $n . m$. anusa 
rato (esp.) n.m. supati

rato-do-mato n.m. (sauê) kareru'a

recado n.m. se'engawera. Ex.: eu disse o recado para ele ne se'engawera ri'a amume'u iupe

recém-nascido n.m. aramewa'e

rede de alguém n.m. (lugar de dormir) itekwawa. Ex.: eu vou dobrar a rede aapara puta ri'a tekwawa; você está dobrando a sua rede? ereapara pa'e ne rekwawa?; na rede, nós (incl.) dormimos tekwawa pupe saker; o rasgado da rede tekwaw torog; aikewara está enrolando (o fio para tecer) rede aikewara umomon tekwawa; você está dobrando a corda da sua rede? ereapara pa'e ne rekwawa rupohoma?. - Ver $\rightarrow$ cama de alguém

rede de pesca $n . f$. ipira mu'ahawa

redondo n.descr. apu'a. Ex.: a cuia é redonda kuipia iapu'a; o tucum é redondo tehahua iapu'a; a laranja é redonda akutia nami pe pytukawa iapu'a

redor (ao redor) $a d v$. apehawa. Ex.: ao redor da casa 'og uapehaw

relâmpago n.m. weraw (weraweraw)

relógio n.m. ara kwahapara (ipituna kwahapara)

remo n.m. typyhyhawa

repetidamente $a d v$. suewiewir. Ex.: ele grita repetidamente uapukaj suewiewira

resina $n . f$. upe'uma

reto n.descr. 'aruaru

reumatismo de alguém n.m. isykongira

revólver n.m. uwarukape ${ }^{2}$

ri/riu v.intr. uime. Ex.: eu ri aime

rim de algo ou de alguém n.m. ipyrykyti'i (pyrykysi'i)

rio n.m. poronoa. Ex.: eu saio do rio aha puta poronoa rupi; eu me lavei no rio asehej ri'a porono pupe; para dentro do rio Ikatu foi porono pupe Ikatu ihoj; ontem você foi nadar no rio aiko ra'e wehe re pa'e ehow he porono pupe aitapa

rio acima n.m. (a montante) 'ya pyra. Ex.: eu fui rio acima 'ya pyra katy aha 
risca/riscou v.tr. (corta/cortou) uajkiti (wajkisi). Ex.: está riscando palha (cortando para dobrar a palha) wajkiti pinowa

risca/riscou v.tr. uhir

roça de alguém n.f. iko (ikowui). Ex.: amanhã eu vou na roça plantar milho kuej wehe puta aha weko pupe ityma awatia; eu rocei a roça ise awirog koa; quando vamos para a roça? moronime puta pe saha koa pupe?; amanhã bem cedo eu vou queimar minha roça use'i wehete puta aapy weko; tem caititu na minha roça ti ko pupe tiwa'a; pra roça eu vou ko pupe puta aha

roça/roçou v.tr. uwirog. Ex.: eu rocei a roça ise awirog koa

rola/rolou v.tr/intr. (esfrega/esfregou) ukytyg. Ex.: eu rolei akytyg; ele vai rolar ukytyg

rola-bosta n.m. (escaravelho) puhapuhaw

rolinha n.f. pyky’i, Columbídeos, Columbina. - Ver $\rightarrow$ ave

rosto de alguém n.m. akwara. Ex.: meu rosto está molhado ti reakwara iakym

roupa $n . f$. tyrykwera

roupa seca $n . f$. ytywyra

roupa seca ao sol $n . f$. pikapikam

ruim n.descr. penur

\section{S}

sabe/sabia v.intr. ukwahaw. Ex.: eu sei akwahaw; Miho sabe fazer paneiro Miho uapokwahaw tapoworona

sagui n.m. kahena'ia, Cebidae

sagui-de-mãos-douradas n.m. ehakwasu, Saguinus midas

sai/saiu v.intr. uhem. Ex.: eu saí ahem; eu vou sair uhem puta ri'a; nós (excl.) saímos uruhem

saia $n . f$. ku'aiwara

sal n.m. itingwoj

saliva de alguém $n . f$. enya 
samambaia $n . f$. amamaj

sandália $n . f$. myiru

sangue de algo ou de alguém n.m. uwya

sapato de alguém n.m. ipyahowa (pyyru)

sapo n.m. kururu

sapo (esp.) n.m. akowoj, kupitaw, suwe

sapucaia $n . f$. sohu, Lecythis grandiflora. - Ver $\rightarrow$ árvore

sara/sarou v.intr. (seca/secou) uka'e. Ex.: eu sarei bem ise aka'eete; ele sarou bem aikwesa uka'eete

saracura n.f. arakuri

sardinha n.f. ipirapiroto. Ex.: a sardinha tem muito pitiú ipirapiroto iputi'uete

saúde n.f. (bem, bom) katuete. Ex.: ele é muito bom, por isso eu fico feliz aikwesa ikatuete sea'eramu ti ruryruryw ehe

saúva $n . f$. iahu, Atta. - Ver $\rightarrow$ formiga

saúva preta $n . f$. iahupisuna. - Ver $\rightarrow$ formiga

seca/secou v.tr. uhyw. Ex.: ele vai secar uhyw puta ri'a

seco n.m. typaw

seco (ele é) $n . d e s c r$. ipyw

secura de algo ou de alguém n.descr. ipurupurum

seio dela n.m. ikom. Ex.: o seio grande é redondo ikomuhu i'apu'a

seiva $n . f$. ty $^{1}$

semente n.f. o'oj. Ex.: semente de milho awatia ro'osa; semente de cuia kusa ro 'osa

senta-se/sentou-se v.tr. uapyg. Ex.: eu estou sentado aapyg wetuna; nós todos estamos sentandos ure uruapyg iri'a urukupa; nós (excl.) vamos nos sentar uruapyg puta ri'a; teu filho sentou perto de mim ne memyra tipiw uapyg

separado (ele está) n.descr. (divorciado) iuso'og. Ex.: eu (sou) separado (divorciado) aso oga

seringueira $n . f$. iworowa. Ex.: eu acendo fogo com o leite seco da seringueira iworow rypitinga urumuse puta tata. - Ver $\rightarrow$ árvore 
serra (relevo) n.f. ywyty

serrote n.m. kitikiti

sinal n.m. (mancha) su'un

sobe/subiu v.intr. useupir. Ex.: eu subo na árvore aseupir 'ywa re; ele subiu na árvore afastando-se da onça indo ywyra re eseupir sawara wi ohow

sobrancelha de alguém $n . f$. upehaw

sobre $a d v$. (em cima) 'ywete. Ex.: o boné está pendurado em cima iapiryrua u'aiko ywete

sobrinho n.m. ekuwisara

socó n.m. soko, Nycticorax nycticorax. - Ver $\rightarrow$ ave

sogra n.f. oso

sogro n.m. atyhu

sol n.m. kwarahy. Ex.: fazsol usawripo kwarahy

sol (na época de) n.m. (verão) 'aripe

sola (do pé) de alguém $n . f$. ipuhukupe

solta/soltou v.tr. upuhir. Ex.: eu soltei apuhir

solteira $n . f$. erekatare'yma'e

solteiro $n . m$. nonuwewaramu

sono (está/esteve com) v.intr. upehyj. Ex.: Ikatu está com muito sono Ikatu upehysete

sopra/soprou v.tr/intr. ukurupesu. Ex.: eu soprei akurupesu; ele vai soprar ukurupesu puta

sovaco de alguém n.m. ipepuwyra

suco do açaí n.m. susiw’arya

sucuri $n . f$. kurisu. - Ver $\rightarrow$ cobra

sucuri $n . f$. a'eteterona (ipewara), Eunectes murinus. - Ver $\rightarrow$ cobra

suja/sujou v.tr. umuhypyting. Ex.: quem está sujando a água? awa pa'e umuhypyting ’ya?; eu sujei a água amuhypyting 'ya

sujeira (tira/tirou a) v.tr. ukysingog. Ex.: eu tirei a sujeira akysingog 
sujo n.descr. pisu'um (pisun). Ex.: ele banhou porque estava sujo usahug ohow upisupisunawi; tua nuca está suja ne atu'a pisun

sul n.m. uagahaw ahemawa

sumaúma n.f. ipe'iuhu, Ceiba pentandra. • Ver $\rightarrow$ árvore

sumaúma (esp.) n.f. tarajwir 'ywa. • Ver $\rightarrow$ árvore

suor de algo ou de alguém n.m. ipiriaj

surdo n.descr. iapyakwara'ym

surubim n.m. uruwi, Sorubim. - Ver $\rightarrow$ peixe

surucucu n.f. tatyuhu, Bothrops jararacussu. • Ver $\rightarrow$ cobra

surucucu-de-fogo n.f. mojpyruwy. - Ver $\rightarrow$ cobra

sutiã $n . m$. komyru

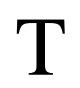

tabaco (árvore) n.m. petyma pisara 'ywa. • Ver $\rightarrow$ árvore

tabaco (fumo) n.m. petyma pisara

taioba $n . f$. tasarona, Xanthosoma violaceum

tamanduá-bandeira n.m. tamawa. • Ver $\rightarrow$ tamanduá-mirim

tamanduá-mirim n.m. asong, Tamandua tetradactyla. • Ver $\rightarrow$ tamanduá-bandeira

tambaqui n.m. ipirakawrona. Ex.: o tambaqui é muito gorduroso ipirakawrona ikawete

tambor n.m. amupong

tamuatá n.m. amoata, Callichthys callichthys. - Ver $\rightarrow$ peixe

tangará n.m. tangara. - Ver $\rightarrow$ ave

tapa/tapou v.tr. utimyk. Ex.: ele se sufocou usetimyk; ele não se sufocou nusetimyguwi; está fedendo, tape o seu nariz inemauwi esetimyk

taquara (esp.) n.f. tahakwari

taquara fina (esp.) n.f. puna 
tarde $n . f$. karuw

tarde (no fim da) n.f. karuwpaw

tarde (no meio da) n.f. karuw emeete

tatu n.m. tatu. Ex.: de onde o tatu saiu? mowy pa'e iture tatu?. - Ver $\rightarrow$ tatu-canastra, tatu-galinha, tatupeba

tatu (esp.) n.m. sapewa. - Ver $\rightarrow$ tatu

tatu-canastra n.m. tatuhu. - Ver $\rightarrow$ tatu

tatu-galinha n.m. tatuete. - Ver $\rightarrow$ tatu

tatupeba n.m. tatupew, Euphractus sexcinctus. - Ver $\rightarrow$ tatu

tece/teceu v.tr. unung. Ex.: eu estou tecendo a minha rede anung ri'a wetekwawa

tecido (para fazer roupa) n.m. tyrykwera apotawa

teia de aranha $n . f$. sanupyha. $\cdot$ Ver $\rightarrow$ aranha

telefone n.m. (microfone) ise'engawa

televisão $n . f$. warasua onga resawkahawa

telha $n . f$. takwara syw'a

teme/temeu v.tr. umusi

tempestade $n . f$. 'yrete

tempo bom n.m. ise sakatu

tempo de chuva n.m. (inverno) amonime

tempo nublado n.m. amymyjtymy

temporal n.m. amona tymy

terra n.f. (chão) ywy. Ex.: terra preta ywypisun; terra boa ywykatu; terra vermelha ywypiron

terreiro n.m. ukara

tesoura $n . f$. wyrahuatia

testa $n . f$. ehapykong

testículos de alguém n.m. ame'a. Ex.: testículos grandes ame'auhu; doem os meus testículos ame'a ahy 
tia de alguém $n . f$. isesea

timbó n.m. timo. Ex.: eu vou botar timbó [na água para matar peixe] no meio do verão atimukamuka puta wehow 'ar pyteripe

tímido (ele é) n.descr. iserutiwa'e

tio (de mulher) n.m. tutyr

tipoia n.m. tupasa

tonto $n$. descr. uka'uete

tórax de alguém n.m. (peito dele) iputi’a

torneira $n . f$. (mangueira, chuveiro) 'ya tyryrutawa

tornozelo de alguém n.m. upysi'o

tornozelo de alguém n.m. ipysu’o

torto n.descr. kono

trabalha/trabalhou v.intr. upurawyky. Ex.: eles trabalharam? upurawyky pa'e ra'e?; eu trabalhei muito apurawykyeteete ri'a

tracajá n.m. sautiakarahawa. - Ver $\rightarrow$ jabuti

traíra n.f. tareiri, Hopliasmalabaricus. - Ver $\rightarrow$ peixe

traíra (esp.) n.f. ywyrapopohoma. - Ver $\rightarrow$ peixe

trairão n.m. tarejriuhu. - Ver $\rightarrow$ peixe

trança/trançou v.tr. (teço/teceu) uapyhara. Ex.: eu trancei aapyhara; ele vai trançar uapyhara puta

transa $n . f$. (cópula) emiukwera. Ex.: minha transa [minha coisa comida] ti remi 'umi'u transparente $n$.descr. esapehewa'e

trator n.m. mojkyse

traz/trouxe v.tr. uerur. Ex.: de onde você trouxe (fez vir) esta carne de caça? mo wi pa'e ererur ma'ea ro'o?

três num. irutehe (irutehe'yma'e). Ex.: eu já cortei três árvores irutehe'yma'e aityg 'ywa

tripé para cozinhar n.m. uarikure 
tronco n.m. 'ywete

tronco de árvore n.m. ’ywypukwera. - Ver $\rightarrow$ árvore

tropeçado (ele está) n.descr. ipyohohong

troveja/trovejou v.intr. upongahyahy. Ex.: antes de ontem trovejou aiko ku'em kwera re ipongahyahyj

tu, teu pron. (você, seu) ne. Ex.: você está com febre? ne ru'y pa'e?; a faca vai te cortar kyse puta ne pokiti; esta criança é teu/tua filho(a) iusawa'ea ne memyra; aquele xerimbabo (pato) é teu? aikwesa pa'e ne rejmawa

tu, teu pron. ene ${ }^{1}$. Ex.: você bate em mim ene ti nupo pe; você deu o arco para o teu pai ene pa'e eremono ywyrapara ne ruwa pe; tu sentando aqui ene ereapyg a'iaw

tucandeira n.f. (tocandira) tukangyra, Poneríneos

tucano n.m. tukan, Piciformes, Ramphastos, Ranfastídeos. - Ver $\rightarrow$ ave, tucanuçu, tucanuí

tucano (esp.) n.m. kureta'u, pitiuhu (pisiuhu). - Ver $\rightarrow$ ave, tucano

tucanuçu n.m. tukanuhu. - Ver $\rightarrow$ ave, tucano

tucanuí n.m. kwere. - Ver $\rightarrow$ ave, tucano

tucumã n.m. tehahua, Astrocaryum/Bactris. Ex.: o tucum é redondo tehahua iapu'a

tucunaré n.m. akararona, Cichlao cellaris. $\cdot$ Ver $\rightarrow$ peixe

tucunzeiro n.m. tuku 'ywa, Astrocaryum/Bactris. - Ver $\rightarrow$ árvore

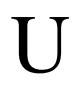

uacari-vermelho n.m. akyky porong, Cacajaocalvus rubicundus

um, uma num. usepese. Ex.: eu perdi uma coisa usepese ripo ma'ea amukasym

umbigo de alguém n.m. ipyri’o

unha de alguém $n . f$. upuhope

unha do pé de alguém $n . f$. ipyhyakong 
urina de algo ou de alguém $n . f$. ity

urinar (lugar de) n.m. kurukaw

urubu n.m. uruwuete, Catartídeos. - Ver $\rightarrow$ ave

urubu n.m. uruwu. Ex.: a arara e o urubu voaram arara uruwu ne'iwewej. - Ver $\rightarrow$ ave urubu-preto n.m. (urubu-de-cabeça-preta) uruwupeuhu, Coragyps atratus. - Ver $\rightarrow$ ave, urubu

urubu-rei n.m. (urubutinga) uruwutinuhu, Sarcorhamphus papa. - Ver $\rightarrow$ ave, urubu uruçu $n . f$. ehyrete, Meliponíneos

urutau n.m. (mãe-da-lua) urutaw. - Ver $\rightarrow$ wyra

útero dela n.m. iakasa

\section{V}

vaga-lume n.m. muhomu'oma, Lampirídeos/Fengodídeos

vagina (grandes lábios) dela $n . f$. emekwasuru (eme’ywa). • Ver $\rightarrow$ vagina dela

vagina dela (parte) n.f. imy’iwa. - Ver $\rightarrow$ vagina

vagina dela $n . f$. ikwara. - Ver $\rightarrow$ clitóris, vagina (grandes lábios)

vai/foi ${ }^{1}$ v.intr. usor. Ex.: eu estou indo asor iko; de onde vocês vieram? mo wi pa'e eresor?; quando vamos para a roça? moronime puta pe saha koa pupe?; ninguém está caçando awa nusepurakaruwi ohow. - Ver $\rightarrow$ vai $/$ foi $^{2}$

vai/foi ${ }^{2}$ v.intr. oho. Ex.: eu vou embora aha puta; do mato a anta vai sair ka'awi puta ihoj tapi 'ira; todos já foram? ohopapaw pa'e remi?; eu vou talvez matar um porcão aha puta ri'a isukaw tasahuamu; ele vai para Belém oho puta Perẽj pupe. - Ver $\rightarrow$ vai/foi ${ }^{1}$

vara $n . f$. (árvore pequena) 'ywyra. Ex.: eu subi na árvore afastando-me da onça ywyra re aseupir sawara wi. - Ver $\rightarrow$ árvore

varal n.m. tirikwera pypetawa

vassoura $n . f$. ytypesawa

vassoura $n . f$. pehitaw 
vazio n.descr. ma'ey’yma

vê/viu v.tr. uesag. Ex.: o compadre está me vendo kupara ti resag ri'a; ontem eu vi este homem aiko re wehe rako aesag akuma'e; quem foi a pessoa que Wajwera viu? awa pa'e he Wajwera uesag?; tem gente que vê espírito wapitu'o wesag sepi a'wera; quem você viu? awa pa'e rejsag?; eu nunca vi peixe levantado na esagwi wehe ipira ku’omawa

veado n.m. misara, Cervídeos. Ex.: a carne de veado está estragada misarar o’o inem; nós matamos o veado que atravessou o rio u'yahawa'e urusuka misara; o veado é vermelho misara ipirongwa'e. • Ver $\rightarrow$ veado-branco, veado-vermelho, veado-virá

veado-branco n.m. pakwohowa, Ozotoceros bezoarticus. • Ver $\rightarrow$ veado

veado-vermelho n.m. misarapirong, Mazama americana. - Ver $\rightarrow$ veado

veado-virá n.m. (catingueiro) katinkwera, Mazana gouazouzira. • Ver $\rightarrow$ veado

veia de algo ou de alguém $n . f$. asyg

vem/veio v.intr. ur. Ex.: Muretama me deu (fez vir) a faca Muretama umur ti upe kysea; de onde você trouxe (fez vir) esta carne? mo wi pa'e ererur ma'ea ro'o?; de onde ele chegou (veio)? mo wi pa'e ituri?

veneno da cobra n.m. mosarenya

vento n.m. ywytuhu. Ex.: o vento (está) forte ywytuhuete

vento forte n.m. ywytuhurona

verão (no meio) $a d v$. (mês de agosto) 'ar myteripe

verdade (fala/falou a) v.tr. use'eng katuete. Ex.: eu falei a verdade ase'eng katu ete

verde $n$. 'yapewy'e ('yapewy). Ex.: a folha da árvore é verde ywyra rowa yapewy

vermelho (ele é) n.descr. ipironga. Ex.: o veado é vermelho misara ipirongwa'e

verruga $n . f$. kyto'i

vespa (esp.) n.f. aity

via-láctea $n . f$. (caminho-de-são-tiago) ywagahaw (tapi’ira rape)

vira/virou v.tr. uru'ag

vira-se/virou-se v.tr. useru'ag. Ex.: eu me virei aseru'ag; ele se virou useru'ag puta viúva $n . f$. erekatara seky seakwera 
viúvo n.m. emireko seky seakwera

voa/voou v.intr. uwewe. Ex.: ele vai voar uwewe puta ri'a; a arara voou arara uwewe; a arara e o urubu voaram arara uruwu ne'iwewej; os pássaros voaram muito alto wyra uwewe ete pewise

vocês pron. pehe. Ex.: vocês vão matar aquelas caças? pehe puta pesuka ma'ea pesehow?; eu vou bater em vocês todos urunupopapaw puta pehe; vocês carregaram a tora de buriti pehe ta peraha pewuhyj myriti 'ywa; vocês são professores? pehe pa'e purumu'etaramu; vocês sentando aqui pehe pa'e peapyg pesekwapa

vomita/vomitou v.intr. uwe'en. Ex.: eu vomitei awe'en; ele vai vomitar uwe'en puta; nós (excl.) vomitamos uruwe'en

\section{$\mathrm{X}$}

xerimbabo de alguém n.m. (animal de criação) eimawa. Ex.: aquele xerimbabo (pato) é teu? aikwesa pa'e ne reimawa; aquelas galinhas são meus animais de criação aimi wyra'yra re mi ti reimawa

xexéu $n . m$. sapi'i. - Ver $\rightarrow$ ave

xexéu (esp.) n.m. sapuhu. - Ver $\rightarrow$ ave 


\section{CONCLUSÃO}

Ao concluir esta tese de doutorado acredito ter atingido os principais objetivos estabelecidos há quatro anos quando me propus a contribuir com os estudos lexicográficos de uma língua indígena brasileira, o Suruí do Tocantins.

Partindo de uma pesquisa bibliográfica dos trabalhos linguísticos, e também de alguns trabalhos antropológicos, já produzidos sobre a língua Suruí do Tocantins, fiz a revisão da literatura científica, o que contribuiu para a construção do capítulo sobre o povo e as propostas de escrita para essa língua da família Tupí-Guaraní.

Além disso, pesquisei uma bibliografia relacionada tanto a aspectos gramaticais e lexicais quanto a questões ligadas à lexicografia, a fim de obter orientações teóricas que me permitissem refletir e descrever de maneira adequada essa língua indígena, ao mesmo tempo em que fosse guiada uma reflexão sobre as possibilidades do fazer lexicográfico, especialmente no contexto indígena brasileiro; acrescida a essas finalidades, empreendi também uma pesquisa sobre os materiais lexicográficos, produzidos no Brasil ou no exterior e relacionados às línguas indígenas brasileiras nos últimos cinco séculos, fechando, assim, a pesquisa bibliográfica e abrindo meu acesso a uma grande quantidade de materiais, fundamentais para a apresentação dos dados consistentes no âmbito dessa produção. Ainda com base nos dados obtidos com esses materiais, pude fazer um levantamento de grande número de formas lexicográficas, nas quais identifiquei diferentes padrões de macro e microestruturas já efetivamente empregadas no contexto dessas línguas e que pude sistematizar em quatorze diferentes padrões, a partir dos quais me baseei para construir quatorze grupos de modelos lexicográficos apresentados no interior desta tese.

Paralelamente a essa etapa, realizei a pesquisa de campo junto ao povo Suruí, tanto nas minhas idas à T.I. Sororó, quanto nas vindas de alguns deles até Brasília, ${ }^{250}$ sempre contando com a participação de professores Suruí, principalmente de Tymykong e Ikatu, que colaboraram com minha pesquisa, desde o primeiro momento, como copesquisadores de sua própria língua. O resultado desta pesquisa foram os dados linguístico-culturais da língua Suruí, gravados, transcritos e devidamente armazenados em um programa de computador,

\footnotetext{
250 Sobre as viagens dos Suruí a Brasília, sempre houve o apoio do Laboratório de Línguas e Literaturas Indígenas da Universidade de Brasília (LALLI/UnB), quer sob a coordenação do prof. Aryon Rodrigues, quer sob a coordenação da profa. Ana Suelly Cabral, que nunca pouparam esforços para que os indígenas pudessem se deslocar até aqui, a fim de não só colaborar com a documentação de suas línguas, mas, principalmente, para produzir materiais para uso em sua comunidade e também estudar sua própria língua em um ambiente acadêmico-científico.
} 
denominado Línguas - Banco de Dados para Documentação Linguística, cuja descrição foi feita em detalhes (configuração e uso) no capítulo sobre documentação linguística.

Esse software, por sua vez, foi desenvolvido especificamente para permitir não somente o armazenamento organizado de toda a documentação do material linguístico obtido nas diferentes etapas da pesquisa, mas também, a sua utilização para a construção, da maneira mais prática possível, de, por exemplo, materiais lexicográficos com diferentes configurações por mim, mas também pelos próprios professores-pesquisadores Suruí. Ademais, foi necessário pensar em elementos relacionados a uma proposta ortográfica para a língua Suruí, pois, sem isso, não seria possível chegar a uma forma escrita para essa língua, que pudesse ser usada no programa de documentação e, principalmente, nos materiais que resultariam desse processo.

A última parte desse trabalho, e que foi a que demandou um esforço e tempo muito grandes, e que requereu várias idas a campo, foi a proposição do primeiro dicionário da língua Suruí. Esse dicionário, apresentado nas direções Suruí-Português e Português-Suruí, ${ }^{251}$ mais do que uma finalidade acadêmica, pretende atender a uma demanda real de um povo que começa a se apropriar de sua língua sob uma nova forma: a escrita. ${ }^{252}$ Tal proposta, no entanto, iniciada no contexto desta tese, deve continuar com o trabalho dos próprios professores Suruí dentro de sua própria comunidade, ampliando e melhorando essa proposta inicial através da manipulação do programa desenvolvido para esse fim. E, assim, como eles poderão continuar esse trabalho, cujos resultados interessam diretamente e principalmente a eles próprios, espero que o programa desenvolvido possa ajudar outros povos a concretizarem seus diferentes projetos de documentação linguística e produção de seus diferentes materiais lexicográficos.

Certamente muito ainda há a se fazer em termos de pesquisa linguística da língua Suruí, como, por exemplo, aprofundar o estudo gramatical, a fim de se chegar a uma proposta de gramática que atenda às necessidades de professores e estudantes dessa língua no contexto

\footnotetext{
${ }^{251}$ Essas duas formas do dicionário Suruí não são as únicas possíveis de serem geradas a partir dos dados coletados e armazenados no programa Línguas, que pode gerar, até a sua versão 3.9, 48 diferentes tipos de materiais lexicográficos, mas sim que elas se referem aos materiais que foram descritos e que ficarão armazenados nas versões impressa e eletrônica desta tese.

252 Ao empreender a pesquisa para esta tese durante estes últimos quatro anos, pude, na qualidade de pesquisador, presenciar um fato que já ocorreu centenas de vezes na história da humanidade, mas que é sempre fascinante de ser constatado: o momento em que um povo se apropria de uma nova forma de expressão de sua língua. E é isso que está acontecendo com o povo Aikewara, que, em sua luta pela sobrevivência de sua língua, busca novas formas de expressão, agora por meio da escrita, a fim de valorizá-la, ensiná-la e fortalecê-la entre os falantes remanescentes e os mais jovens de sua comunidade. Eis uma das razões pelas quais esta pesquisa valeu muito a pena.
} 
escolar, mas também que possa atender a qualquer pessoa da comunidade Aikewara interessada em conhecer e aprofundar seu conhecimento sobre o funcionamento de sua língua nativa.

Outro trabalho necessário e urgente é a produção de materiais didáticos para ensino dessa língua, materiais estes que devem se basear em conhecimento seguro sobre a gramática e o léxico Suruí. Mas também devem ser pensados materiais lexicográficos outros, como dicionários temáticos, dicionários ilustrados, enciclopédias, vocabulário ortográfico, dicionários eletrônicos (principalmente porque, hoje, a informática já é de uso mais ou menos comum entre os mais jovens), entre outros.

Ao lado desses materiais, a fixação de uma ortografia e a sua difusão, primeiro no contexto escolar e, depois, em diferentes meios sociais, deve servir para estimular o aumento da atividade escrita, o que pode levar, por exemplo, à produção de obras literárias, manuais, textos midiáticos, registros documentais da história do povo, dos seus mitos, de suas músicas, e tudo isso na língua Suruí. ${ }^{253}$

Acredito, portanto, que esta tese, que foi elaborada em um importante e decisivo momento da história da língua do povo Aikewara, representa apenas um ponto que marca o início de uma nova etapa do trabalho aqui empreendido, porque, como bem disse o prof. Aryon Rodrigues há quase meio século, o estudo das línguas indígenas constitui "a maior tarefa da linguística no Brasil”, e, por isso, nosso trabalho está apenas começando. ${ }^{254}$

\footnotetext{
${ }^{253} \mathrm{E}$, nesse contexto, é imprescindível que se tenha à disposição materiais de referência, como os dicionários, auxiliando a produção e compreensão da língua escrita.

${ }^{254}$ Busquei considerar no texto final desta tese todas as observações e sugestões feitas pelos membros da banca que avaliou este trabalho, a quem sou profundamente agradecido. Nos raros casos de opiniões com perspectivas conflitantes entre os membros da banca, tive que decidir por incorporar na tese as sugestões que mais se aproximavam de decisões tomadas em comum acordo com a orientadora e com a comunidade indígena, principal interessada nesta tese.
} 


\section{REFERÊNCIAS}

AIKHENVALD, alexandra Y. Languages of the Amazon. New York: Oxford University Press, 2011.

ALBISETTI, Cesar; VENTURELLI, Angelo Jayme. Enciclopedia Bororo: Volume 1 Vocabulário e Etnografia. Campo Grande: Instituto de Pesquisas Etnográficas, 1962.

AL-KASIMI, Ali M. Linguistics and Bilingual Dictionaries. Leiden, Holanda: E. J. Brill, 1983.

AMARANTE, Elizabeth A. Rondon; MONSERRAT, Ruth Maria Fonini; Alunos da Escola Mỹky. Dicionário Cultural Mỹky. S.1.: Povo Mỹky, 1998. 34p. (Fascículo 1: Ãkakje'y Alimentação)

ARNAUD, Expedito. Mudanças entre grupos indígenas tupí da região do Tocantins-Xingu (Bacia Amazônica). Boletim do Museu Paraense Emílio Goeldi, Nova série Antropologia, n. 84, p. 1-50, 1983.

ASSIS, Cecy Fernandes (Org.). Ñe'ë ryru Avañe'ë-Dicionário Guarani-Português. São Paulo: Ed. do Autor, 2000. 194p. (Projeto Karumbe)

ATKINS, B. T. Sue; RUNDELL, Michael. The Oxford Guide to Practical Lexicography. Nova York: Oxford University Press, 2008.

BABINI, Maurizio. Do conceito à palavra: os dicionários onomasiológicos. Ciência e Cultura, v. 58, n. 2, p. 38-41 jun. 2006. São Paulo. Disponível em: <http://cienciaecultura.bvs.br/scielo.php? script=sci_arttext\&pid=S0009-67252006000200015\&lng=en\&nrm=iso $>$. Acesso em: 15 out. 2014.

BALBI, Giovanni. Catholicon ou Summa quae vocatur Catholicon. 1485 [manuscrito do séc. XIII]

BALDINGER, Kurt. Semasiologia e onomasiologia. Tradução de Ataliba T. de Castilho. Alfa: Revista de Linguística, v. 9, p. 7-36, 1966.

BALDUS, Herbert. Bibliografia Crítica da Etnologia Brasileira. São Paulo: Nicolau Indústria Gráfica, 1970. 859p.

BARBOSA, José Natal. Contribuição à análise fonológica do Suruí do Tocantins. 1993. 58f. Dissertação (Mestrado em Linguística), sob a orientação de Aryon Dall'Igna Rodrigues Departamento de Linguística, Instituto de Letras, Universidade de Brasília, 1993.

BARBOSA, Maria Aparecida. Estrutura, funções e processos de produção de dicionários terminológicos multilíngües. Revista do GELNE, n. 2, p. 41-44, 1999.

BARNES, Eduardo Vieira. Resumo do relatório circunstanciado de identificação e delimitação da Terra Indígena Tuwa Apekuokawera. In: PARÁ. Diário Oficial, ano CXXI, n. 32.103, caderno 5, p. 11-13, 24 fev. 2012.

BELTRÃO, J. F. Laudo Antropológico: Área Indígena Sororó a propósito da BR-153. 1998.

BIDERMAN, Maria Tereza Camargo. A ciência da lexicografia. Alfa, n. 28 (supl.), p. 1-26, 1984. Teoria lingüística. São Paulo: Martins Fontes, 2001.

BOAS, Franz. Handbook of American Indian Languages. Washington, D.C.: Government Printing Office, 1911. 
BOUDIN, Max Henri. Dicionário de Tupi Moderno (Dialeto tembé-ténêtéhar do alto rio Gurupi). São Paulo: Governo do Estado, 1966.

BRANDON, Edgar Ewing. Robert Estienne et le Dictionnaire Français au XVIe siècle. Baltimore, EUA: J. H. Furst Company, 1904. 133p.

BRASIL, Presidência da República. Decreto $n^{o}$ 63.367, de 8 outubro de 1968, que declara interdita a área indígena que discrimina e dá outras providências. Disponível em: <http://www2.camara.leg.br/legin/fed/decret/1960-1969/decreto-63367-8-outubro-1968-404772publicacaooriginal-1-pe.html>. Acesso em: 30 abr. 2013.

. Decreto $n^{\circ} 88.648$, de 30 de Agosto de 1983, que homologa a demarcação topográfica da área indígena que menciona, no Estado do Pará. Disponível em: <http://www2.camara.leg.br/legin/fed/decret/1980-1987/decreto-88648-30-agosto-1983-438841publicacaooriginal-1-pe.html>. Acesso em: 30 abr. 2013.

. Constituição da República Federativa do Brasil. Brasília, DF: Senado Federal, Secretaria Especial de Informática, 1988. Disponível em: <http://www.senado.gov.br/legislacao/const/ con1988/CON1988_06.06.2013/CON1988.pdf>. Acesso em: 30 mar. 2013.

BRASIL, MEC. Lei de diretrizes e bases da educação nacional, Lei $\mathrm{n}^{\circ}$ 9.394, de 20 de dezembro de 1996. Brasília: Senado Federal, 1996. Disponível em: <http://legis.senado.gov.br/legislacao/ ListaTextoIntegral.action?id=75723>. Acesso em: 30 mar. 2013.

Um milhão de salas de aula vão receber dicionários em 2012. Site do Ministério da Educação. 2011. Disponível em: <http://portal.mec.gov.br/index.php?option=com_content\& view=article \&id=16212:um-milhao-de-salas-de-aula-vao-receber-dicionarios-em-2012\&catid= 211\&Itemid=164>. Acesso em: 30ago.2014.

BRASIL, Instituto Nacional de Estudos e Pesquisas Educacionais Anísio Teixeira. Estatísticas sobre educação escolar indígena no Brasil. Brasília, DF: INEP/MEC, 2007.

BRASIL. IBGE. O Brasil indígena: os indígenas no Censo Demográfico 2010. Brasília, DF: Ministério da Justiça, FUNAI, IBGE, 2010.

BRASIL, Fundação Nacional do Índio. Despacho do presidente, em 24 jan. 2012, n. 3, no qual aprova os estudos de identificação da Terra Indígena Tuwa Apekuokawera de ocupação do grupo indigena Surui/Aikewar, localizada nos municípios de Marabá e São Geraldo do Araguaia, Estado do Pará. Com resumo do Relatório Circunstanciado de Identificação e Delimitação de autoria do antropólogo Eduardo Vieira Barnes. Diário Oficial da União, Seção 1, n. 18, p. 34-36, 25 jan. 2012. Disponível em: <http://www.in.gov.br/visualiza/index.jsp?data=25/01/2012\&jornal=1\& pagina $=34 \&$ totalArquivos=120>. Acesso em: 30 abr. 2013.

BUENO, Francisco da Silveira. Vocabulário Tupi-Guarani-Português. São Paulo: Nagy, 1982. 581p. [2.ed. São Paulo: Nagy, 1983; 3.ed. São Paulo: Brasilivros, 1984; 4.ed. São Paulo: Brasilivros, 1986. 629p.; 5.ed. São Paulo: Brasilivros, 1987. 629p.; 6.ed. São Paulo: Efeta, 1998. 688p.; 7.ed. São Paulo: Efeta, 2008. 688p. ISBN 978858663203-7]

BUSSMANN, Hadumod. Routledge Dictionary of Language and Linguistics. Tradução e edição de Gregory Trauth e Kerstin Kazzazi. Londres, Inglaterra, e Nova York, EUA: Routledge, 1996.

CABRAL, Ana Suelly Arruda Câmara. Prefixos relacionais em Asuriní do Tocantins. Moara, Belém, v. 8, p. 7-24, jul./dez. 1997.

Suruí do Tocantins: gravação de lista de palavras [1997]. Entrevistador: Ana Suelly Arruda Câmara Cabral. Marabá, PA, 1997. Cassetes sonoros. 
Flexão relacional na família Tupí-Guaraní. Boletim da Abralin, Fortaleza, n. 25, p. 233262, dez. 2000.

O desenvolvimento da marca de objeto de segunda pessoa plural em Tupí-Guaraní. In: CABRAL, Ana Suelly Arruda Câmara; RODRIGUES, Aryon Dall'Igna. Estudos sobre línguas indígenas I. Belém: UFPA, 2001. p. 117-145.

O Observatório da Educação Escolar Indígena e a experiência piloto de formação de mestres e doutores indígenas em linguística teórica, descritiva e histórica no Brasil. Teoria e Prática da Educação, v. 16, n. 2, p. 157-168, 2013.

CABRAL, Ana Suelly Arruda Câmara; LOPES, Jorge Domingues. Suruí do Tocantins: gravação de lista de palavras [abr. 2012]. Entrevistadores: Ana Suelly Arruda Câmara Cabral e Jorge Domingues Lopes. Brasília, DF, 2012a. Cartão de memória.

CABRAL, Ana Suelly A. C.; LOPES, Jorge D. ; SILVA, Ariel P. C.; SOUSA, Suseile A. Esboço gramatical do Asuniní do Trocará. In: CABRAL, Ana Suelly et al. (Orgs.). Contribuições para o Inventário da Língua Asuriní do Tocantins: Projeto Piloto para a Metodologia Geral do Inventário Nacional da Diversidade Linguística. Brasília, DF: Laboratório de Línguas Indígenas/UnB, 2012.

CABRAL, Ana Suelly Arruda Câmara; LOPES, Jorge Domingues; SOLANO, Eliete de Jesus Bararuá. Suruí do Tocantins: vocabulário e enunciados [set. 2013]. Entrevistadores: A.S.A.C. Cabral, J.D. Lopes e E.J.B. Solano. São Domingos do Araguaia/São Geraldo do Araguaia, PA, 2013. 3 cartões de memória SD.

CABRAL, Ana Suelly A. C.; MASTOP, Luíza. Suruí do Tocantins: enunciados [fev. 2002]. Entrevistadoras: Ana Suelly Cabral e Luíza Mastop. São Geraldo do Araguaia, PA, 2002. 1 cassete sonoro.

CABRAL, Ana Suelly Arruda Câmara; RODRIGUES, Aryon Dall'igna. Dicionário da Língua Asuriní do Tocantins. Belém: UFPA/IFNOPAP; Brasília: UnB/IL/LALI, 2003. 267p.

. The interface of stress and nasality in tupí-guaraní languages in a historical perspective. Revista Lingüística, Revista do Programa de Pós-Graduação em Linguística da Universidade Federal do Rio de Janeiro, v. 7, n. 1, jun. 2011. Rio de Janeiro, Pós-Graduação em Linguística da UFRJ. Disponível em: <http://www.letras.ufrj.br/poslinguistica/revistalinguistica>. Acesso em: out. 2014.

CABRAL, Ana Suelly Arruda Câmara; RODRIGUES, Aryon Dall'igna; FRANCESCHINI, Dulce do Carmo. Reconstrução interna dosprefixos relacionais da língua Mawé. Revista Brasileira de Linguística Antropológica, v. 5, n. 2, p. 401-419, dez. 2013.

CABRAL, Ana Suelly Arruda Câmara; SILVA, Ariel Ariel Pheula do Couto; SOUSA, Suseile Andrade. Expressão do caso argumentativo em três línguas Tupí-Guaraní: Asuriní do Tocantins, Avá-Canoeiro e Zo'é. Anais do SILEL, v. 3, n. 1, 2013. Uberlândia: EDUFU, 2013.

CALEPINO, Ambrogio. Dictionum latinarum e greco pariter dirivantium, earundemque interpretationum ... Viena: Adam Petri, 1512.

. Lexicon. Paris: Pierre Gaudoul, 1526.

. Dictionarium. Veneza: Paolo Manuzio, 1573.

CAMPBELL, Lyle; GRONDONA, Verónica (Eds.). The indigenous languages of South America: a comprehensive guide. Berlin/Boston: De Gruyter Mouton, 2012. 750p. (The world of linguistics; 2) 
CASTELNAU, Francis de. Expédition dans les parties central de l'Amérique du Sud, de Rio de Janeiro a Lima, et de Lima au Para; pendant les années 1843-1847. Paris: P. Bertrand, 1851. V.5. 480p.

CEDI, Centro Ecumênico de Documentação e Informação. Aconteceu: Povos Indígenas no Brasil / 1982, Especial 12, abr. 1983.

Aconteceu: Povos Indígenas no Brasil / 1983, Especial 12. São Paulo: Instituto Socioambiental, abr. 1984.

Aconteceu: Povos Indígenas no Brasil / 1991-1995, Especial 14. São Paulo: Instituto Socioambiental, abr. 1996.

2000.

. Aconteceu: Povos Indígenas no Brasil / 1996-2000. São Paulo: Instituto Socioambiental, 2011 .

. Aconteceu: Povos Indígenas no Brasil / 2006-2010. São Paulo: Instituto Socioambiental,

CHACON, Thiago (Coord.). Dicionário Enciclopédico Kubeo-Multilingue ( $1^{\circ}$ rascunho). São Gabriel da Cachoeira, AM, 2012. mimeo.

CIMI. Vocabulário Aikewar (Suruí do Pará). Assessoria linguística de Ruth Monserrat. Belém: CIMI Norte II, 1986. 57p.

CLEROT, L.F.R. Glossário etimológico dos termos geográficos, geológicos, botânicos, zoológicos, históricos e folclóricos de origem tupi/guarani, incorporados ao idioma nacional. Brasília, DF: Senado Federal, 2010. (Coleção Edições do Senado Federal; 143)

COMRIE, Bernard. Aspect. Nova York, EUA: Press Syndicate of the University of Cambridge, 1976.

Tense. Nova York, EUA: Press Syndicate of the University of Cambridge, 1985.

Chicago, 1989.

Language universals and linguistic typology. 2.ed. Chicago, EUA: University of

CORRÊA-DA-SILVA, B. C. Mawé/Awetí/Tupí-Guaraní: Relações Linguísticas e Implicações Históricas. 2010. 424p. Tese (Doutorado em Linguística), sob a orientação de Aryon D. Rodrigues, Instituto de Letras, Universidade de Brasília, 2010.

CORREIA, Margarita. Os dicionários portugueses. Lisboa, Portugal: Caminho, 2009.

COSTA, Lucivaldo Silva da. Suruí do Tocantins: depoimento [abr. 2002]. Entrevistador: Lucivaldo S. da Costa. São Geraldo do Araguaia, PA, 2002. 2 cassetes sonoros.

COUDREAU, Henri A. Voyage a Itaboca et a l'Itacayuna: $1^{\text {er }}$ juillet 1897 - 11 octobre 1897. Paris: A. Lahure, 1898.

DALBY, D.; HAIRE, P. E. H. Le langaige du Bresil: A Tupi Vocabulary of the 1540s. Transactions of the Philological Society, v.65, n. 1, p. 42-66, 1966.

D'ANGELIS, Wilmar da Rocha. Como nasce e por onde se desenvolve uma tradição escrita em sociedades de tradição oral? Campinas, SP: Curt Nimuendajú, 2007.

DIARIO DO MARANHÃO: Jornal do Commercio, Lavoura e Industria, n. 09381, p. 3, de 15 nov. 1904. 
DIETRICH, Wolf. Lingüística Amerindia Sudamericana: Las lenguas indígenas de América. 2002. [Última atualização em 7 out. 2014]. Disponível em: http://www.uni-muenster.de/ Romanistik/Organisation/Lehrende/Dietrich/LingAmerSud/index.htmlAcesso em: 02 fev. 2014.

DOOLEY, Robert A. Léxico Guarani, dialeto Mbyá com informações úteis para o ensino médio, a aprendizagem e a pesquisa lingüística. Cuiabá: Sociedade Internacional de Lingüística, 2006.

DOSTAL, W. The situation of the indian in South America. Genebra: Word Council of Churches, 1972.

DUBOIS, Jean et al. Dictionnaire de linguistique. Paris, França: Larousse-Bordas, 2002.

DUBOIS, Jean; DUBOIS, Claude. Introduction à la lexicographie: le dictionnaire. Paris: Larousse, 1971. (Coleção Langue et Langage)

EHRENREICH, Paul. Divisão e distribuição das tribus do Brasil segundo o estado actual dos nossos conhecimentos. Tradução de João Capistrano de Abreu. Revista da Sociedade de Geographia do Rio de Janeiro, t. VIII, p. 3-55, 1892. Rio de Janeiro: Typ. de G. Leuzinger \& Filhos.

ESTIENNE, Robert. Dictionarivm Latinogallicum, iam indè post multas editiones plurimum adauctum... Paris: Carolum Stephanum, 1561.

FABRE, Alain. Diccionario etnolingüístico y guía bibliográfica de los pueblos indígenas sudamericanos. 2005. Disponível em: 〈http://www.ling.fi/DICCIONARIO.htm〉. Acesso em: 23 out. 2012.

FAULSTICH, Enilde. Avaliação de dicionários: uma proposta metodológica. Organon, Revista do Instituto de Letras da Universidade Federal do Rio Grande do Sul, v. 25, n. 50, p. 181-220, $2011 \mathrm{a}$.

FAULSTICH, Enilde. Glossário de termos empregados nos estudos da Terminologia, da Lexicolografia e da Lexicologia. Brasília: Centro Lexterm, 2011b. Ms.

FAULSTICH, Enilde; OLIVEIRA, Michelle Machado de. Para que serve um dicionário analógico? Um estudo de lexicografia comparativa. Revista Intercâmbio dos Congressos de Humanidades, v. X, p. 1-16, 2007. Disponível em: <Para que serve um dicionário analógico?>. Acesso em: 23 abr. 2012.

FERRAZ, Iara. Relatório: Duplo impacto: o Projeto Carajás e os "projetos de apoio" às comunidades indígenas Gavião e Suruí do Pará. São Paulo: Centro de Trabalho Indigenista, 1984. 10p.

Suruí. In: RICARDO, Carlos Alberto (Coord.). Povos indígenas no Brasil: Sudeste do Pará (Tocantins). São Paulo: CEDI, 1985. p. 100-121. V. 8.

FERREIRA, Helder Perri (Org.). Dicionário de verbos português-Yanomama - Napẽpẽni thẽ thaa thaatarapẽhe nahã thãaxo, yanomama thããxo, thẽkipẽã wẽanowei siki. São Paulo: ISA, 2011.

FIGUEIREDO, Glaucy Ramos. O Ramo IV e o seu desmembramento em línguas independentes: contribuição aos estudos histórico-comparativo da família Tupí-Guaraní. 2004. 114f. Dissertação (Mestrado em Linguística), sob a orientação de Ana Suely Arruda Câmara Cabral - Programa de Pós-Graduação em Letras, Centro de Letras e Artes, Universidade Federal do Pará, Belém, 2004. 
FINATTO, Maria José Borcony. Imagens do léxico: a visão dos dicionários de língua. In: LIMA, Marília dos Santos; GUEDES, Paulo Coimbra (Orgs.). Estudos de linguagem. Porto Alegre: Sagra-D.C. Luzzatto, 1996. p. 96-106.

FUNASA. Demografia Aldeia Sororó. 2012. mimeo.

GRAHAM, Albert; GRAHAM, Suzana. Frases na língua Aikewar-Surui. São Geraldo do Araguaia, PA: Instituto Linguístico de Verão, 1988. 142p. Ms.

GRAHAM, Albert; GRAHAM, Suzana [?]. Epurumita tiupe - Conversa comigo na língua Suruí do Pará e a língua portuguesa: cópia experimental. Belém: Instituto Linguístico de Verão, 1991.

GREENBERG, Joseph. Universals of language. Cambridge: M.I.T. Press, 1963.

GUILBERT, Louis. La créativité lexical. Paris, França: Larousse, 1975. (Coleção Langue et Langage)

GIVÓN, T. Syntax: An introduction. Amsterdam/Philadelphia: John Benjamins Publishing Company, 2001.

A compreensão da gramática. Tradução de Maria Angélica da Cunha, Mário Eduardo Martelotta e Filipe Albani. São Paulo: Cortez, 2012.

HAENSCH, G.; WOLF, L.; ETTINGER, S.; WERNER, R. La lexicografía: de la lingüística teórica a la lexicografía práctiva. Madri: Gredos, 1982.

HARRISON, Carl H. Verb prominence, verb initialness, ergativity and typological disharmony in Guajajara. In: DERBYSHIRE, D. C.; PULLUM, G. (Eds.). Handbook of Amazonian languages. Berlim: Mouton de Gruyter, 1986. p. 407-439.

HARRISON, Carl; HARRISON, Carole. Guajajara-Português - Tradução com análise e notas gramaticais. In: Dicionário Guajajára-Português. Anápolis, GO: SIL, 2013. 474p. p. 10244.

HARTMANN, R. R. K. (ed.). The History of Lexicography. Amsterdam, Inglaterra: John Benjamins Publishing Company, 1986.

HARTMANN, R.R.K.; JAMES, G. Dictionary of Lexicography. Londres, Inglaterra, e Nova York, EUA: Routledge, 2002.

HAVILAND, John B.; FARFÁN, José Antonio (Ed.). Bases de la documentación linguística. México: Instituto Nacional de Lenguas Indígenas, 2007. 468p. Acervo do LALI/UnB.

HOUAISS ELETRÔNICO. Versão 3.0. Rio de Janeiro: Objetiva, 2009. (CD-ROM)

IDESP. Instituto do Desenvolvimento Econômico e Social do Estado do Pará. Boletim Estatístico do IDESP. Belém, 1996.

IKATU; TYMYKONG. Aikewara se'engete. Brasília: LALI/UnB e Observatório da Educação Escolar Indígena, 2012. 55p.

IPA - International Phonetic Association. The International Phonetic Alphabet (Revised to 2005). 2012. Disponível em: <http://www.langsci.ucl.ac.uk/ipa/images/IPA2005_3000px.png>. Acesso em: 15 dez. 2012. 
JENSEN, C. J. S. O desenvolvimento histórico da língua Wayampi. 2004. 183f. Dissertação (Mestrado em Linguística), sob a orientação de Aryon Dall'Igna Rodrigues, Instituto de Estudos da Linguagem, Universidade Estadual de Campinas, Campinas, SP, 1984.

JOGOS TRADICIONAIS INDÍGENAS DO PARÁ. 2014. Disponível em: <http://seel.pa.gov. br/jogosindigenas/etnias-participantes>. Acesso em: 06 jun. 2014.

KAKUMASU James Y.; KAKUMASU, Kiyoko. I. Dicionário por Tópicos Urubu-KaaporPortuguês. Brasília, DF: Fundação Nacional do Índio - FUNAI / Summer Institute of Linguistics - SIL, 1988.

KAUFMAN, Terrence; BERLIN, Brent; RODRIGUES, Aryon; Questionnaire. In:

Projeto de Documentação das Línguas Indígenas da América do Sul. [South American Indian Languages Documentation Project (SAILDP)]. Pittsburgh \& Berkeley: University of Pittsburgh \& University of California, 1985. Mimeo.

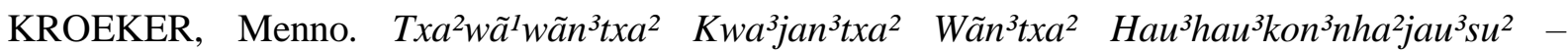
Dicionário Escolar Bilíngue Nambikuara-Português, Português-Nambikuara. Porto Velho: Sociedade Internacional de Linguística, 1996.

LALI, Laboratório de Línguas Indígenas. Observatório da Educação Escolar Indígena. Disponível em: <http://www.laliunb.com.br/cariboost_files/info_projeto_institucional_observ_ educ.pdf>. Acesso em: 16 mai. 2013.

LARA, Luis Fernando. Teoría del Diccionario Monolingüe. México, DF: El Colegio de México, 1997. (Série Estudios de Lingüística y Literatura; 33)

LARAIA, Roque de Barros. Arranjos poliândricos na sociedade Suruí. Revista do Museu Paulista, v. XIV, 1963.

Tupi: índios do Brasil atual. São Paulo: FFLCH/USP, 1986. 303p. (Série Antropologia;

LARAIA, Roque de Barros; MATTA, Roberto da. Índios e castanheiros: a emprêsa extrativista e os índios no médio Tocantins. São Paulo: Difusão Européia do Livro, 1967. 146p. (Coleção Corpo e Alma do Brasil; XXI)

LARAIA, Roque de Barros; MATTA, Roberto da. Índios e castanheiros: a empresa extrativista e os índios no médio Tocantins. 2.ed. Prefácios das duas edições. Rio de Janeiro: Paz e Terra, 1978. 208p. (Coleção Estudos Brasileiros; 35)

LIZOT, Jacques. Diccionario enciclopédico de la lengua yãnomãmi: con la colaboración de Hepëwë, Nõhõkuwë y Tiyetirawë. Traducción del manuscrito francés: Marie Gamondés Tulián, Ana Flora Reig, Francesca Lo Truglio. Caracas: Epsilon Libros, 2004.

LOPES, Jorge Domingues. Análise do questionário lexical do Projeto de Documentação das Línguas Indígenas da América do Sul. Brasília, DF: 2011. mimeo.

Suruí do Tocantins: gravação de palavras, frases e textos [nov. 2012]. Entrevistador: Jorge Domingues Lopes. São Geraldo do Araguaia, PA, 2012. Cartão de memória.

Catálogo lexicográfico das línguas indígenas brasileiras. Brasília, DF: 2014. mimeo.

LOPES, Jorge Domingues; CABRAL, Ana Suelly Arruda Câmara. Diversificação linguística na família Tupí-Guaraní: Asuriní do Tocantins, Suruí do Tocantins e Parakanã. In: Congresso Internacional de Dialetologia e Sociolinguística, 2, 2012, Belém, PA. Anais... São Luís: 
EDUFMA, 2012. p. 1614-1624. Disponível em: <http://www.youblisher.com/p/540229-ANAISII-CIDS-2012>. Acesso em: 15 jan. 2013.

LOUBIER, Christiane. De l'usage de l'emprunt linguistique. Montréal: Office Québécois de la Langue Française, 2011.

LOUKOTKA, Čestmír. Classification of South American Indian Languages. Los Angeles: University of California/Centro Latinoamericano de Venezuela, 1968. (Reference Series; 7)

MARTIUS, Carl Friedrich Philipp von. Glossaria Linguarum Brasiliensium: Wörtersammlung brasilianischer Sprachen. Beiträge zur Ethnographie und Sprachenkunde Amerika's zumal Brasiliens. Leipzig: Friedrich Fleischer, 1867. V.2 (Zur Sprachenkunde) 548p.

MASON, J. A. The languages of South American Indians. In: Handbook of South American Indian. Washington, EUA, 1950. V. 6.

MELATTI, Julio Cezar. Capítulo 29 Tocantins-Xingu. In: Áreas Etnográficas da América Indígena. Brasília, DF, 2011. Disponível em: <http://www.juliomelatti.pro.br/areas/ 29tocxin.pdf>. Acesso em: 01 mai. 2013.

MELIÁ, Bartomeu. Educação indígena e alfabetização. São Paulo: Loyola, 1979.

Desafios e tendências na alfabetização em língua indígena. In: EMIRI, L.; MONSERRAT, R. (Orgs.). A conquista da escrita - encontros de educação indígena OPAN. São Paulo: Iluminuras, 1989. p. 9-16.

MELlO, Antônio Augusto Souza. Estudo Histórico da Família Lingüística Tupi-Guarani: Aspectos Fonológicos e Lexicais. 2000. 286f. Tese (Doutorado em Linguística), sob a orientação de Paulino Vandressen e Aryon Dall'Igna Rodrigues - Departamento de Língüística e Língua Vernácula do Instituto de Comunicação e Expressão da Universidade Federal de Santa Catarina, Florianópolis, 2000.

MELLO, Octaviano. Dicionário de rimas Tupi (Nheengatu). In: (Nheengatu) Português e vice-versa. São Paulo: Folco Masucci, 1967. p. 103-123.

Dicionário Tupi

MITHUN, Marianne. How to Avoid Subordination. Papers Selected from the Parassession on Subordination, Berkeley Linguistics Society, n. 10, p. 493-524, 1984. Berkeley: University of California.

MONSERRAT, Ruth Maria Fonini. Suruí do Tocantins: gravação de palavras e frases [dez. 1985]. Entrevistadora: Ruth Maria Fonini Monserrat. São Geraldo do Araguaia, PA, 1985a. Cassetes sonoros.

Surui: fonética e fonologia. Notas de campo. 1985b. mimeo.

. Ortografia Surui. Proposta 1. 1986a. mimeo.

. Surui. Formulário padrão. 1986b. mimeo.

. Línguas indígenas no Brasil contemporâneo. In: GRUPIONI, Luís Donisete Benzi (Org.). Índios no Brasil. 4.ed. São Paulo: Global; Brasília: MEC, 2000. p. 93-104. Disponível em: < http://www.academia.edu/400205/indios_No_Brasil>. Acesso em: 30 abr. 2013.

MONSERRAT, Ruth Maria Fonini; SOARES, Marília Facó, Hierarquia referencial em línguas tupí. In: SIMÕES, A. M. \& REIS, C. A. (Orgs.). Ensaios de Lingüística. Cadernos de Lingüística 
e Teoria da Literatura, v. 9. p. 164-187, dez. 1983. Belo Horizonte: Faculdade de Letras da Universidade Federal de Minas Gerais.

NAVARRO, Eduardo de A. Dicionário de tupí antigo: a língua indígena clássica do Brasil. São Paulo: Global, 2013. 620p.

NEVES, Débora David das. A língua Suruí do Tocantins: uma introdução à morfossintaxe. 1999. 50f. Dissertação (Mestrado em Linguística), sob a orientação de Carmen Lúcia Reis Rodrigues Programa de Pós-Graduação em Letras, Centro de Letras e Artes, Universidade Federal do Pará, Belém, 2000.

NEVEU, F. Dicionário de ciências da linguagem. Tradução de Albertina Cunha e José Antônio Nunes. Petrópolis, RJ: Vozes, 2008.

NICHOLSON, Velda. Pequeno Dicionário por Assuntos: Asuriní do Xingu/Asuriní de Trocará Português. In: . Breve estudo da língua Asurini do Xingu. Brasília, DF: Summer Institute of Linguistics, 1982.

OLIVEIRA, João Pacheco de; FREIRE, Carlos Augusto da Rocha. A Presença Indígena na Formação do Brasil. Brasília: Ministério da Educação, Secretaria de Educação Continuada, Alfabetização e Diversidade; LACED/Museu Nacional, 2006.

OLIVEIRA, O. Este dicionário quer ajudar a quem está aprendendo... In: SILVA, B. et al. Paradakary Urudnaa - Dicionário Wapichana/Português, Português/Wapichana. Boa Vista: Editora UFRR, 2013.

PARÁ. Imprensa Oficial do Estado do Pará. Diário Oficial, n. 32103, 24 fev. 2012.

PAULA, Ruth Wallace de Garcia. Catálogo do material linguístico da Comissão Rondon. Boletim do Museu do Índio, Documentação, $\mathrm{n}^{\circ}$ 2, 40p., 1982. Rio de Janeiro.

PAYNE, T.E. Describing Morphosyntax. Cambridge: Cambridge University Press, 1997. Press, 2006

Exploring language structure: A student's guide. Cambridge: Cambridge University

PIKE, Kenneth L. Phonemics: a tecnique for reducing languages to writing. Ann Arbor/ The University of Michigan Press, 1947.

POPJES, Jack; POPJES, Josephine. Dicionário temático canela-krahô e português. Ed. experimental incompleta. Brasília, DF: Summer Institute of Linguistics, 1982.

PORTO DAPENA, J. Alvaro. Manual de técnica lexicográfica. Madrid: Arco/Libros, 2002.

POTTIER, Bernard. Représentations mentales et catégorisations linguistiques. Paris: Éditions Peeters, 2001.

QUEIROZ, Renato da Silva. O depoimento de Tibakou: As experiências de vida de um índio Suruí. Revista do Instituto de Estudos Brasileiros, n. 18, p. 119-128, 1976.

. Por falar em Suruí... Revista de Antropologia, n. 23, p. 91-97, 1980.

RANGEL, Egon de Oliveira. Dicionários em sala de aula. Brasília, DF: Ministério da Educação, Secretaria de Educação Básica, 2006.

RAPOSO, Celino Alexandre. Dicionário da língua Makuxi. Boa Vista: Editora da UFRR, 2008. 
REVISTA Pará+, n. 27, 2004.

REY, Alain. Lexique: Images et modeles du dictionnaire a la lexicologie. Paris: A Colin, 1977.

REY-DEBOVE, Josette. Étude linguistique et sémiotique des dictionnaires français contemporains, Paris: The Hague, Mouton, 1971.

Étude linguistique et sémiotique des dictionnaires français contemporains. Países Baixos: Mouton, 1971.

RIBEIRO, Darcy. Indigenous Cultures and languages of Brazil. In: HOPPER, Janice H. Indians of Brazil in the twentieth century. Washington: Institute for Cross-Cultural Research, 1967.

RICARDO, Carlos Alberto (Coord.). Povos indígenas no Brasil: Sudeste do Pará (Tocantins). São Paulo: CEDI, 1985.

RIVET, P. Langues de l'Amérique du Sud et des Antilles. In: MEILLET, A.; COHEN, M. (Org.) Les langues du Monde. Paris, 1924. p. 639-712.

RODRIGUES, Aryon Dall'Igna. A nomenclatura na família Tupí-Guaraní. Boletín de Filología, Montevideo, n. 43/45, p. 98-104, 1950.

Die Klassifikation des Tupi-Sprachstammes. Proceedings of the 32nd. International Congres s of Americanists (orgs. por J. Yde), p. 679-684, 1958. Copenhague.

A classificação do tronco linguístico Tupí. Revista de Antropologia, v. 12, n. 1/2, p. 99104, jun./dez. 1964. (Republicado na Revista Brasileira de Linguística Antropológica, v. 3, n. 2 , p. 197-203, jul. 2012)

. Tarefas da linguística no Brasil. Estudos Lingüísticos - Revista Brasileira de Linguística Teórica e Aplicada, v. 1, n. 1, p. 4-15, 1966.

. Línguas ameríndias. In: GRANDE ENCICLOPÉDIA DELTA-LAROUSSE. Rio de Janeiro: Editora Delta, 1970a. p. 4034-4036.

. Classificação genética consensual das línguas indígenas do Brasil [versão adaptada por Melatti]. In: MELATTI, Julio Cezar. Índios do Brasil. Brasília, DF: Coordenada, 1970b. p. 44-50.

Relações internas na família lingüística Tupí-Guaraní. Revista de Antropologia, v. 27/28, p. 33-53, 1984/1985.

The Present State of the Study of Brazilian Indian Languages. In: KLEIN, Harriet M.; STARK, Luisa R. (Orgs.). South American Indian Languages: Retrospect And Prospect. Austin: University of Texas Press, 1985. p. 405-439. 1986.

Linguas brasileiras: para o conhecimento das línguas indígenas. São Paulo: Loyola,

Línguas indígenas: 500 anos de descobertas e perdas. DELTA. Revista de Documentação em Lingüística Teórica e Aplicada, v. 9, n. 1, p. 83-103, 1993. São Paulo: Associação Brasileira de Lingüística.

Glottalized stops in Proto-Tupi. In: ENCONTRO DE VERÃO DA SSILA. Albuquerque, EUA: Universidade do Novo México, 1995.

Argumento e predicado em Tupinambá. Boletim da ABRALIN, n. 19, p. 57-66, 1996. 
. A originalidade das línguas indígenas brasileiras [conferência realizada na inauguração do Laboratório de Línguas Indígenas da Universidade de Brasília em 08 de julho de 1999]. Brasília, DF: Laboratório de Línguas Indígenas, 1999. 17p. Disponível em: <http://www.laliunb.com.br>. Acesso em: 03 dez. 2012.

Breve história da língua dos índios vistos por Cabral. Universa, v. 8, n.3, p. 541-552, 2000. Brasília, DF, UCB. $2002.135 \mathrm{p}$.

. Línguas brasileiras: para o conhecimento das línguas indígenas. 4.ed. São Paulo: Loyola,

. As vogais do Proto-Tupí. In: RODRIGUES, A. D.; CABRAL, A. S. A. C. (Orgs.). Novos estudos sobre línguas indígenas. Brasília, DF: Editora da UnB, 2005a. p. 35-46.

A Reconstruction of Proto-Tupi Phonology. In: WORKSHOP EM LINGÜÍSTICA HISTÓRICA E LÍNGUAS EM CONTATO, Brasília, DF: LALI/UnB, 2005 b.

Sobre as línguas indígenas e sua pesquisa no Brasil. Ciência e Cultura, v. 57, n. 2, jun. 2005c. São Paulo.

. As línguas indígenas no Brasil. In: RICARDO, B.; RICARDO, F. (Ed.). Povos indígenas no Brasil 2001/2005. São Paulo: Instituto Socioambiental, 2006. p. 59-63.

A estrutura do Tupinambá. A estrutura do Tupinambá [1981]. In: CABRAL, Ana Suelly Arruda Câmara; RODRIGUES, Aryon Dall'Igna (Org.). Línguas e Culturas Tupí 2. Campinas, SP: Curt Nimuendajú; Brasília, DF: LALI/UnB, 2010. p. 167-203.

. Para o estudo histórico-comparativo das línguas Jê. Revista Brasileira de Linguística Antropológica, v. 4, n. 2, p. 279-288, dez. 2012.

Línguas indígenas brasileiras. Brasília, DF: Laboratório de Línguas Indígenas da UnB, 2013. 29p. Disponível em: 〈http://www.laliunb.com.br〉. Acesso em: 15 mai 2013.

RODRIGUES, Aryon Dall'Igna; CABRAL, Ana Suelly Arruda Câmara. Revendo a classificação interna da família Tupí-Guaraní. In: CABRAL, A. S. A. C., RODRIGUES, A. D. (Orgs.). Línguas indígenas brasileiras: fonologia, gramática e história. Tomo I. Belém: UFPA, 2002. p. 327-337.

Tupían. In: CAMPBELL, Lyle; GRONDONA, Verónica (Eds.). The indigenous languages of South America: a comprehensive guide. Berlin/Boston: De Gruyter Mouton, 2012. p. 495-574. (The world of linguistics; 2)

Tupian languages. Oxford: Oxford University Press, 2014. V. 1. Recurso disponível em: <http://dx.doi.org/10.1093/OBO/9780199772810-0166>. Acesso em: 12 out. 2014.

SANTOS, Ilda Mendes dos (Org.). La découverte du brésil: Les premiers témoignages (15001530). Tradução, seleção de textos e introdução de Ilda Mendes dos Santos. Dijon-Quetigny, França: Chandeigne, 2000. p. 175-180.

SCHMIDT, W. Die Sprachfamilien und Sprachenkreise der Erde. Heidelberg: C. Winter, 1926.

SHOPEN, T. Language Typology and Syntactic Description. Volume I: Clause Structure. 2.ed. NovaYork, EUA: Cambridge University Press, 2007.

SILVA, Denise. Apêndice I: Proposta de Dicionário Terena-Português. In: Estudo lexicográfico da língua terena: proposta de um dicionário bilíngüe terena-português. 2013. 292f. Tese (Doutorado em Linguística), sob a orientação de Cristina Martins Fargetti, Universidade 
Estadual Paulista "Júlio de Mesquita Filho", Faculdade de Ciências e Letras (Campus de Araraquara), 2013.

SILVA, José de Oliveira dos S. da (Nek'i Satere Mawe); FRANCESCHINI, Dulce do Carmo; CARNEIRO, Denize de Souza. Revitalização linguística e cultural Sateré-Mawé. In: ANAIS DO SILEL. Uberlândia, MG: EDUFU, 2009. V.1.

SAMPAIO SILVA, Orlando. Os Suruí. In: Índios do Tocantins: notas do caderno de Campo. Manaus: Valer, 2009. p. 45-84. (Série Memórias da Amazônia)

SEKI, Lucy. Gramática do Kamaiurá - língua tupi-guarani do Alto Xingu. Campinas, SP: Editora Unicamp, 2000. 519p.

SILVEIRA BUENO, F. da. Vocabulário Tupi-Guarani-Português. 5.ed. rev. ampl. São Paulo: Brasilivros, 1987.

SNELL-HORNBY, Mary. The bilingual dictionary - victim of its own tradition? In: HARTMANN, R. R. K. (ed.). The History of Lexicography. Amsterdam, Inglaterra: John Benjamins Publishing Company, 1986. p. 207-218.

SOLANO, Eliete de J. B. Descrição gramatical da língua Araweté. 2009. 519f. Tese (Doutorado em Linguística), sob a orientação de Ana Suelly Cabral, Universidade de Brasília, 2009.

SOUSA, J. Martínez de. Diccionario de lexicografía práctica. Barcelona, Espanha: Biblograf, 1995.

STADEN, Hans. Warhaftige Historia vnd beschreibung eyner Landtschafft der Wilden, Nacketen, Grimmigen Menschfresser Leuthen, in der Newenwelt America... Gedruckt zu Marpurg, $\mathrm{Zu}$ Marpurg im Kleeblatt, bei Andress Kolben, 1557.

STEINEN, Karl von den. Duch Central-Brasilien: Expedition zur erforschung des schingú im jahre 1884. Leipzig: F. A. Brockhaus, 1886. 372p.

STEINEN, Karl von d. Unter den Naturvölkern Zentral-Brasiliens: Reiseschilderung und Ergebnisse der Zweiten Schingú-Expedition 1887-1888. Berlin: Geographische Verlagsbuchhandlung von Dietrich Reimer, 1894. 570p.

STRADELLI, Ermano. Vocabulário português-nheengatu e nheengatu-português. 2.ed. Cotia, SP: Ateliê Editorial, 2014. 536p. ISBN 978857480638-9.

THE LINGUASPHERE REGISTER. 1999. Disponível em: <http://www.linguasphere.info>. Acesso em: 04 abr. 2014.

THE UNICODE CONSORTIUM. The Unicode Standard, Version 6.2.0, (Mountain View, CA: The Unicode Consortium, 2012. ISBN 978-1-936213-07-8. Disponível em: <http://www.unicode.org/versions/Unicode6.2.0/>. Acesso em: 12 jan. 2013.

TIBIRIÇÁ, Luíz Caldas. Dicionário Guaraní-Português. São Paulo: Traço, 1989. 174p.

TIBIRIÇÁ, Luíz Caldas. Dicionário Tupi-Português: com esboço de gramática de Tupi Antigo. São Paulo: Traço, 1984. 200p.

TOVAR, Antonio. Catálogo de las lenguas de América del Sur. Buenos. Aires, Sudamericana, 1961. 406p.

UNESCO. Interactive Atlas of the World's Languages in danger, 2010. Disponível em: <http://www.unesco.org/culture/languages-atlas/index.php>. Acesso em: 13 mai. 2013. 
$19 \mathrm{p}$.

Projet UNESCO: Atlas des langues en danger dans le monde. Paris: UNESCO, 2011.

VAN VALIN JR., ROBERT D. An Introduction to Syntax. Nova York, EUA: Cambridge University Press, 2004.

VIEIRA FILHO, João Paulo Botelho. Aspectos de assistência a saúde dos índios Paracanã Apuiterewa, Xikrin do Cateté, Paracanã do Paranati, Parakanã do Marydjewara, frete de atração de Marabá, Gaviões de Mãe Maria e Suruí. Relatório à Companhia Vale do Rio Doce, jul. 1988.

VIVEIROS DE CASTRO, Eduardo. Araweté: Os Deuses Canibais. Rio de Janeiro: Jorge Zahar, 1986.

VOORT, Hendrikus Gerardus Antonius van der. Part III: Dictionary: 2 Kwaza-English vocabulary. In: . A grammar of Kwaza. Amsterdam: Mouton de Gruyter, 2004. 1026 p. p. 618-729.

WELKER, Herbert A. Dicionários: uma pequena introdução à lexicografia. 2.ed. rev. e ampl. Brasília, DF: Thesaurus, 2004.

WERNER, Reinhold. La definición lexicográfica. In: HAENSCH, G. et al. La lexicografía: de la lingüística teórica a la lexicografía práctica. Madri, Espanha: Gredos, 1982. (Coleção Biblioteca Románica Hispánica. III. Manuales; 56).

WOLF, Lothar. Signo lingüístico y estructuras semánticas. In: HAENSCH, G.; WOLF, L.; ETTINGER, S.; WERNER, R. La lexicografía: de la lingüística teórica a la lexicografía práctiva. Madri, Espanha: Gredos, 1982. p. 329-347.

YONG, Heming; PENG, Jing. Bilingual Lexicography from a communicative perspective (Terminology and Lexicography Research and Practice). Amsterdam/Philadelphia: John Benjamins Publishing Company, 2007. 


\section{BIBLIOGRAFIA CONSULTADA}

ALVAREZ, G. O. Os Surui, parentesco e cosmologia Tupi. A trajetória antropológica de Roque de Barros Laraia. Brasília, DF: Associação Brasileira de Antropologia, 2008. Vídeo (DVD).

ANCHIETA, José P. de. Arte da grammatica da lingoa mais vsada na costa do Brasil. Coimbra, Portugal: Antonio de Mariz, 1595.

BRASIL, MEC. Referencial curricular nacional para as escolas indígenas. Brasília, DF: MEC/SEF, 1998.

CABRAL, Ana Suelly Arruda Câmara. Fundamentando a Reconstrução de Prefixos Relacionais para o Proto-Tupí. In: Congresso Internacional da Associação Brasileira de Lingüística, 5, 2007, Belo Horizonte. Caderno de Resumos. Belo Horizonte: Associação Brasileira de Lingüística, 2007. p. 438-439.

CABRAL, Ana Suelly A. C. Pronomes e prefixos pessoais em línguas do tronco Tupí. 2001. (Comunicação)

CALDAS, Raimunda Benedita Cristina. Dicionário Bilíngue Ka'apór-Português. In:

Uma proposta de dicionário para a língua Ka'apor. 334f. 2009. Tese (Doutorado em Linguística), sob a orientação de Ana Suelly Arruda Câmara Cabral, Instituto de Letras, Universidade de Brasília, Brasília, DF,, 2009. p. 191-314.

IDIOMAS em risco - Um projeto de Aliança pela diversidade linguística. Suruí (Suruí do Tocantins) [também conhecido como Suruí do Pará, Akewere, Akewara]. 2012. Disponível em: <http://www.endangeredlanguages.com/lang/mdz>. Acesso em: 30 abr. 2013.

MATTOSO CÂMARA JR., J. Classificação das línguas indígenas do Brasil. Letras, v. 10, p. 5666, 1959.

SILVA, Tabita Fernandes da; CALDAS, Raimunda Benedita Cristina. Prefixos relacionais do Ka1apór. In: Jornada de Estudos Lingüísticos do Nordeste, 18, 2000, Fortaleza. Programa e Resumos JELNE- Livro de Resumos. Fortaleza: 2000. p. 89.

O modo Indicativo II em Tenetehára: considerações históricas. Revista Brasileira de Linguística Antropológica, v. 5, n. 2, p. 421-434, dez. 2013.

SOLANO, Eliete de J. B. Prefixos relacionais em Araweté. In: CABRAL, Ana Suelly Arruda Câmara; RODRIGUES, Aryon Dall'Igna; DUARTE, Fábio Bonfim (Orgs.). Linguas e Culturas Tupí II. Campinas, SP: Curt Nimuendajú, 2010. V. 2, p. 85-94.

SWADESH, Morris. Amerindian non-cultural vocabularies (mimeographed sheet). Lexicostatistic dating of prehistoric ethnic contacts. Proceedings of the American Philosophical Society, v. 96, p. 452-463, 1952. 


\section{ANEXOS}

\section{ANEXO A — MAPA DA ÁREA INDÍGENA SORORÓ (SURUÍ) EM 1983}

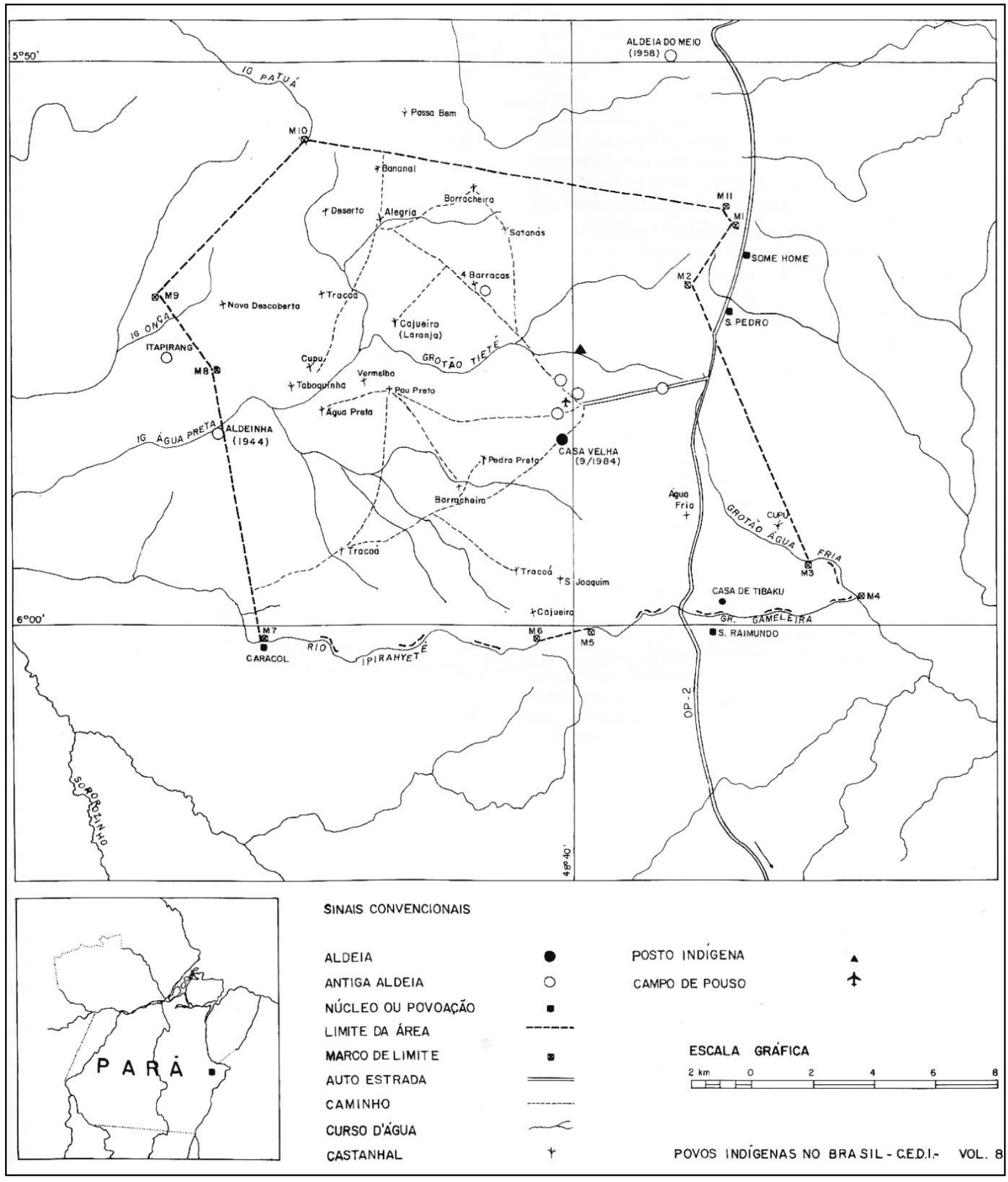

Fonte: Povos Indígenas do Brasil (CEDI, 1985, p. 117) 


\section{ANEXO B - MAPA DA TERRA INDÍGENA TUWA APEKUOKAWERA}

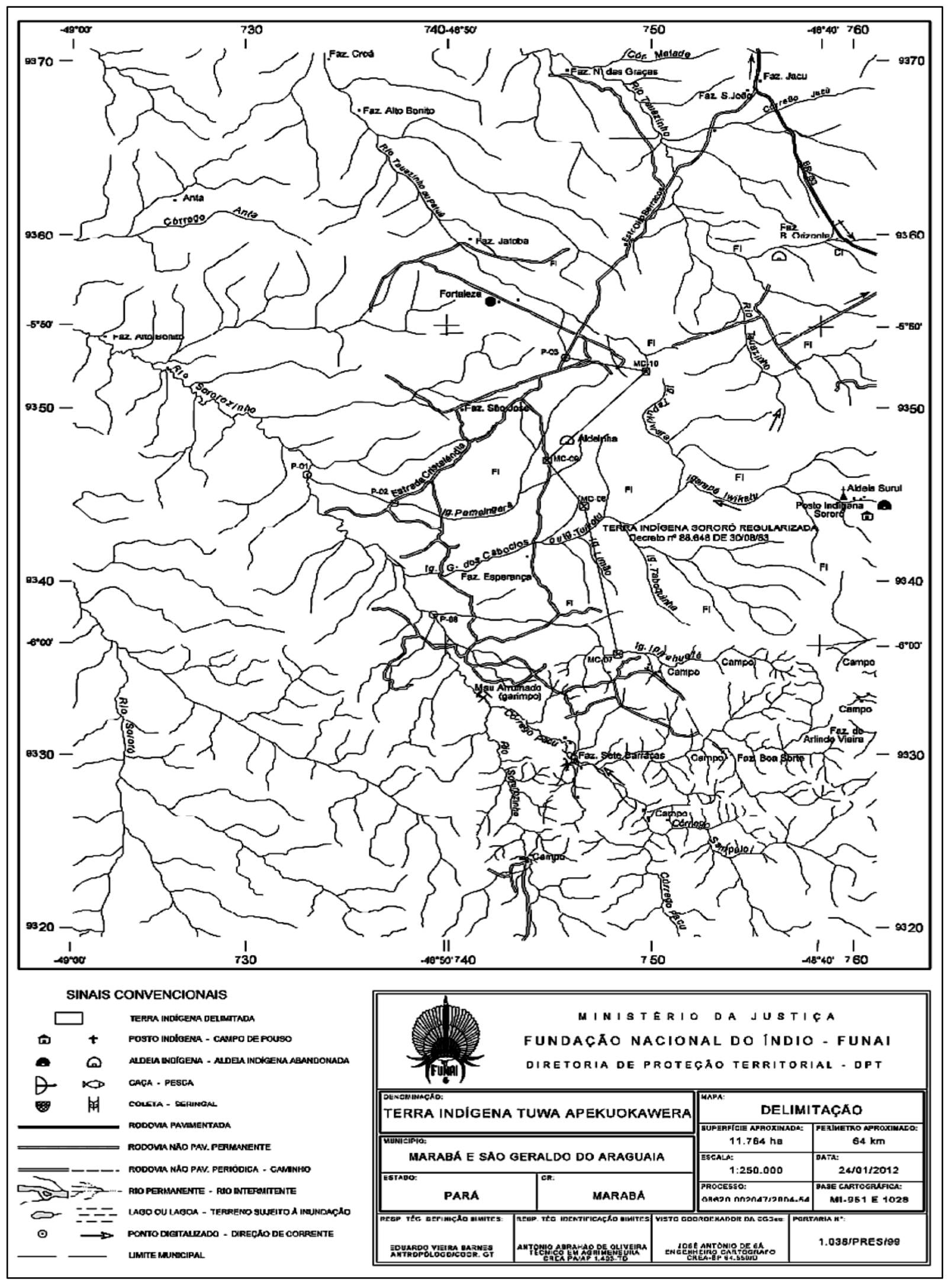

Fonte: Barnes (2012, p. 13). 
ANEXO C - MAPA DA TERRA INDÍGENA TUWA APEKUOKAWERA, ANEXADA À TERRA INDÍGENA SORORÓ, EM 2012

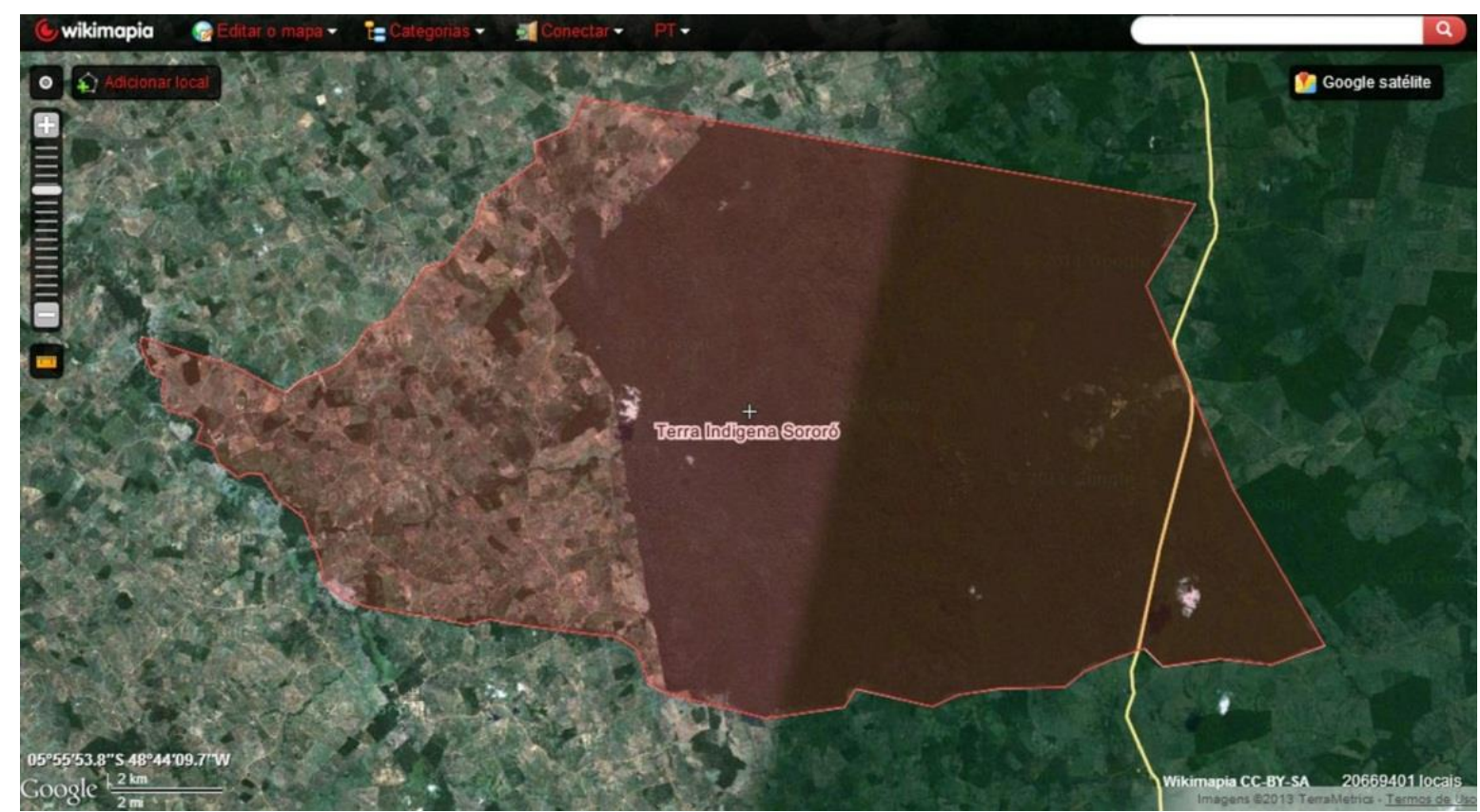

Fonte: Site http://wikimapia.org/

ANEXO D - TRECHO DE MAPA RODOVIÁRIO DA REGIÃO ONDE ESTÁ SITUADA A TERRA INDÍGENA SORORÓ, COM DESTAQUE PARA OS CURSOS DE ÁGUA

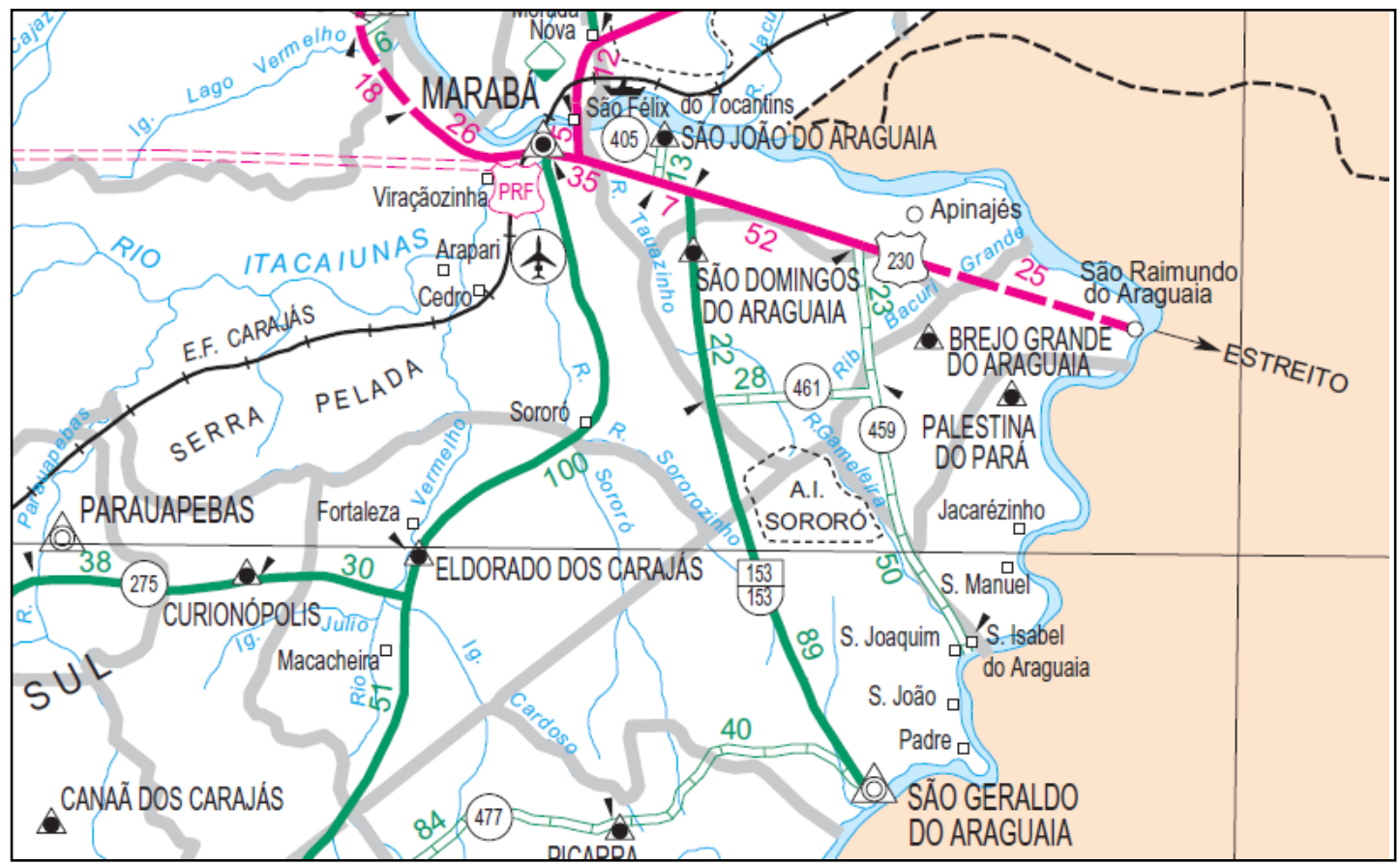

Fonte: DNIT (2002). 


\title{
ANEXO E - TRECHO DO RESUMO DO RELATÓRIO CIRCUNSTANCIADO DE IDENTIFICAÇÃO E DELIMITAÇÃO DA TERRA INDÍGENA TUWA APEKUOKAWERA
}

\author{
FUNDAÇÃO NACIONAL DO ÍNDIO \\ DESPACHO DO PRESIDENTE \\ Em 24 de janeiro de 2012
}

№ 3 - O PRESIDENTE DA FUNDAÇÃO NACIONAL DO ÍNDIOFUNAI, no uso das atribuições conferidas pela Portaria $\mathrm{n}^{\circ}$ $2.302 / \mathrm{SE} / \mathrm{MJ} / 2011$ e em conformidade com o $\$ 7^{\circ}$ do art. $2^{\circ}$ do Decreto $1775 / 96$, tendo em vista o Processo FUNAI/BSB $n^{\circ}$ 08620.002047/2004-54 e considerando o Resumo do Relatório Circunstanciado de Identifícação e Delimitação de autoria do antropólogo Eduardo Vieira Barnes, que acolhe, face às razões e justificativas apresentadas, decide:

Aprovar as conclusões objeto do citado resumo para afinal. reconhecer os estudos de identificação da Terra Indígena TUWA APEKUOKAWERA de ocupação do grupo indigena Surui/Aikewar, localizada nos municípios de Marabá e São Geraldo do Araguaia, Estado do Pará.

\section{MÁRCIO AUGUSTO FREITAS DE MEIRA}

ANEXO

RESUMO DO RELATÓRIO CIRCUNSTANCIADO DE IDENTIFICAÇÃO E DELIMITAÇÃO DA TERRA INDÍGENA TUWA APEKUOKAWERA

Referência: Processo FUNAI/BSB/2047/2004. Denominação: Terra Indígena Tuwa Apekuokawera (anteriormente denominada Terra Indígena Sororó - Gleba Tuapekuakau). Localização: Municípios de Marabá e São Geraldo do Araguaia, Estado do Pará. Superfície aproximada: 11.764 ha. Perímetro aproximado: $64 \mathrm{Km}$. Povo indígena: Suruí/Aikewar. Tronco Linguístico: Tupi, família linguística: Tupi-Guarani. População: 404 pessoas (2011). Grupo Técnico constituído pela Portaria n. ${ }^{\circ}$ 1.038/PRES/FUNAI, de 4 de novembro de 1999, coordenado pelo antropólogo Eduardo Vieira Barnes.

I - DADOS GERAIS: A Terra Indígena Tuwa Apekuokawera, contígua à Terra Indígena Sororó, está localizada nos municípios paraenses de São Geraldo do Araguaia e Marabá, junto às cabeceiras do rio Sororozinho, afluente do rio Sororó, que desemboca no rio Itacaiúnas, próximo à cidade de Marabá. Da aldeia denominada Taquapuku (taboca grande, na língua Suruí/Aikewar), onde mora a maioria das famílias Suruí, chega-se à cidade de Marabá utilizando-se a rodovia BR-153 (antiga OP-02) e a Transamazônica, após percorrer uma distância de aproximadamente $100 \mathrm{~km}$. A Serra das Andorinhas, ao sul da área, no município de São Geraldo do Araguaia, constitui importante referência geográfica da ocupação histórica dos índios Suruí/Aikewar. A área caracteriza-se pela formação rochosa responsável pela existência das corredeiras de Santa Isabel, que impedem a

navegaação de grande porte. Neste local surgiu o povoảdo hómônimo onde, em 1923, o Frei Dominicano Antônio Salas fez o primeiro registro escrito sobre os Suruí/Aikewar, chamando-os, na época, de Sororós. Na primeira metade do século XX, os Suruí/Aikewar foram paulatinamente alijados de seu grande território histórico devido à ação de frentes econômicas, configurando-se um processo de esbulho renitente. Os Suruí/Aikewar, que hoje somam pouco mais de 400 pessoas, constituem-se num grupo indígena que habita a região sudeste do Estado do Pará, situados na região contornada pelo baixo rio Araguaia, próximo à sua foz, no rio Tocantins, e o rio Vermelho (afluente do rio Itacaiúnas, tributário do Tocantins), conformando a região conhecida como "Bico do Papagaio", célebre pelos conflitos fundiários. São também conhecidos como Suruí do Pará, Suruí do

Fonte: Diário Oficial da União, Seção 1, n. ํ 18, p. 34, de 25 de janeiro de 2012. 


\section{ANEXO F — PÁGINAS DO VOCABULÁRIO AIKEWAR (CIMI, 1986)}
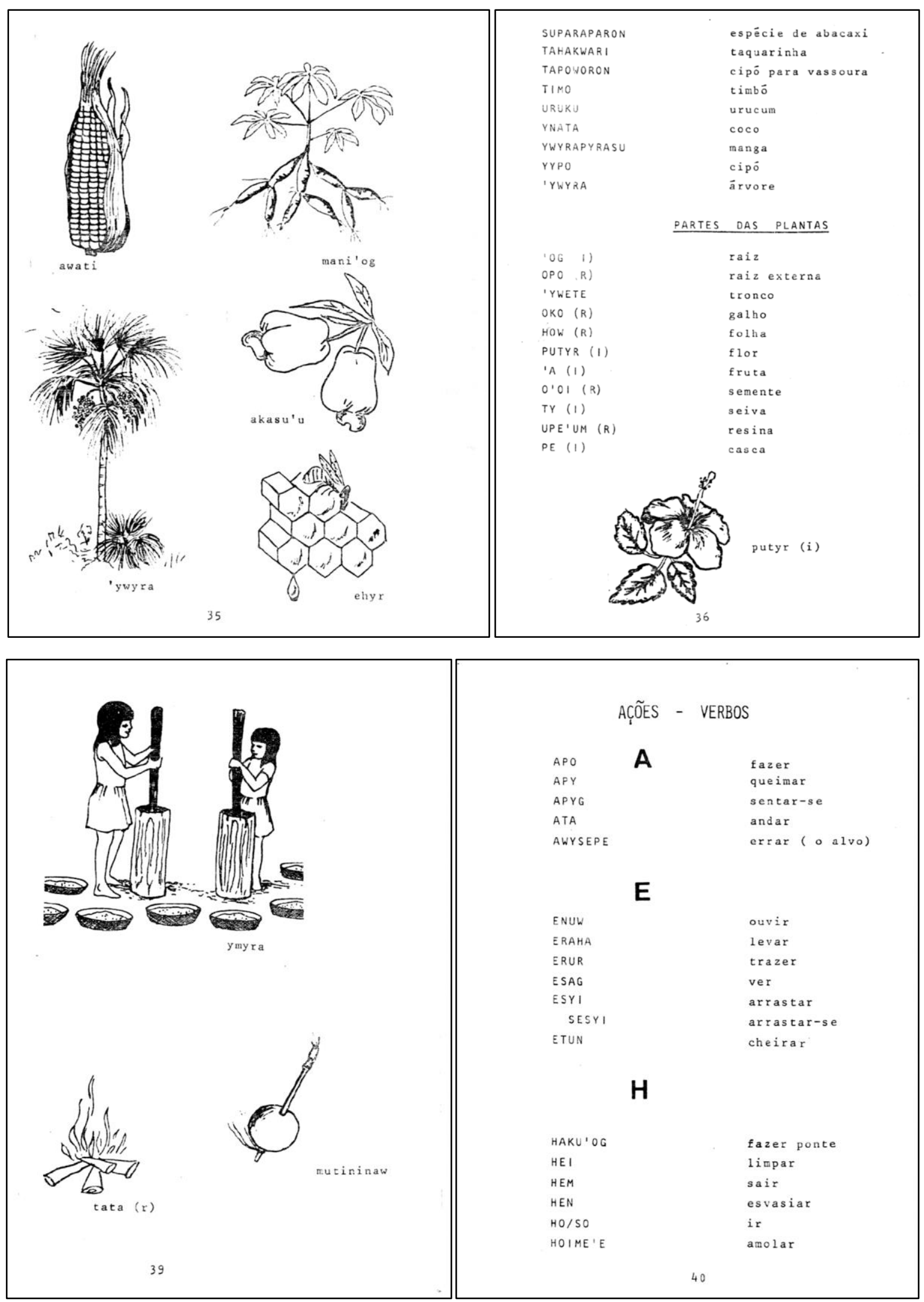

Fonte: Cimi (1986, p. 35-36; 39-40) 
ANEXO G - MÚSICAS CANTADAS EM SURUÍ POR MIHO, GRAVADAS POR IKATU E TRANSCRITAS E DIGITADAS NO COMPUTADOR POR TYMYKONG, EM ABRIL DE 2014 PARA SEREM USADOS NA FESTA SAPURAHAJ (INSERIDOS AQUI TAL COMO FORAM PRODUZIDOS ORIGINALMENTE)

SAUTIA SE'ENGARA

WYRARAWRE WYRARAWRE

WYRARAWRE WYRARAWRE AKWAW

USEMU'AMO'AMORE WYRARAWRE

WYRARAWRE WYRARAWRE AKWAW

TUHETU TUHETU

TUHETUHE TUHETUHE

IWEWYWEWYNE WYRAWE E E E

IWEWYWEWYNE WYRAWE E E E

ARWAPOJGARA ARIMU WYRAWE E E E ARWAPOJGARA ARIMU WYRAWE E E E TUHETU TUHETU

TUHETUHE TUHETUHE

ARIKASU SE'ENGARA

$\left(1^{\circ}\right)$ MORUPIPO MORUPIPO

O O EI EI EI EI

E E E E

MORUPIPO MORUPIPO O O EI EI EI EI

MORONGATYWISE PEPO SAWARA ANGEKO

MORONGATYWISE PEPO SAWARA ANGEKO

USUPEPYPEPYKATU

$\left(2^{\circ}\right)$ WAWUSE WAWUSE EEEEE WAWUSE WAWUSE EEEEE WAWUSE WAWUSE EEEEE 
ERETISO ERETISO ERETISO

SERA'YRA PEISAGANE TIRE PEISAGANE

ERETISO ERETISO ERETISO

TAPI'IRA SE'ENGARA

PAHAKUTYNUNUNUNG

PAHAKUTYNUNUNUNG

EKUTYG EKUTYKUTYG KOG

EKUTYG EKUTYKUTYG KOG

TASAHU SE'ENGARA

AWAHEM WEHOW'WE

AWAHEM WEHOW'WE

AWAHEM WEHOW'WE

AWAHEM WEHOW'WE

HUM HUM HUM

AWAHEM WEHOW'WE

AWAHEM WEHOW'WE

AWAHEM WEHOW'WE

AWAHEM WEHOW'WE

AHA WAHEMAKOWE

AHA WAHEMAKOWEHOW'WE

PINOKUTYWIHUPE

AWAHEM WEHOW'WE

AWAHEM WEHOW'WE

HUM HUM HUM

TASAHU SE'ENGARA

IWYRATUKA IWYRATUKA TUKARE

TERERERERE TERERERERE OJ OJ

IWYRATUKA IWYRATUKA TUKARE 
TERERERERE TERERERERE OJ OJ

IWYRATUKA IWYRATUKA TUKARE

TERERERERE TERERERERE OJ OJ

AWAPUKAJ TUWA A'YRA

IWYRATUKA IWYRATUKA TUKARE

TERERERERE TERERERERE OJ OJ

IWYRATUKA IWYRATUKA TUKARE

TERERERERE TERERERERE OJ OJ

IWYRATUKA IWYRATUKA TUKARE

TERERERERE TERERERERE OJ OJ

AWAPUKAJ AWAPUKAJ TUWA A'YRA

TERERERERE TERERERERE OJ OJ

IWYRATUKA IWYRATUKA TUKARE

TERERERERE TERERERERE OJ OJ 


\section{APÊNDICE}

Orientações para uso de atalhos de teclado para inserção de símbolos do Alfabeto Fonético Internacional no editor de texto Word para Windows

$\mathrm{U}$ tilizado, sobretudo, por linguistas, fonoaudiólogos e tradutores, no mundo todo, mas também, por professores e estudantes dos cursos de graduação e pós-graduação em Letras (nas disciplinas de iniciação à linguística ou de fonologia das línguas, por exemplo), o alfabeto fonético internacional (AFI, em Português, e IPA, em Inglês international phonetic alphabet) é "um sistema de notação fonética baseado no alfabeto latino, criado pela Associação Fonética Internacional” (AFI 2011), com o intuito de padronizar os símbolos utilizados na transcrição fonética dos sons de qualquer língua do mundo.

Para inserção dos símbolos do AFI em um editor de texto, tal como o Word para Windows, recorre-se com frequência a fontes (tipos) especiais, dentre as quais as mais conhecidas são IPAKIEL (fonte TrueType, de P. B. Payne), IPAPHON (fonte TrueType, de Henry Rogers), SIL Doulos, SIL IPA93 e SIL IPA (fontes TrueType, do SIL); todas elas, porém, devem ser adquiridas e instaladas no computador do usuário (para inserção e leitura dos símbolos).

Contudo, há, pelo menos, dois problemas na utilização dessas fontes especiais: o primeiro refere-se à necessidade, tanto para o criador do documento quanto para aquele que vai receber o material produzido, de terem o mesmo arquivo de fonte especial, instalado em seus computadores, pois, caso não o tenham, não será possível interpretar corretamente os caracteres do arquivo. Outra dificuldade no uso de fontes especiais em um arquivo produzido em editor de texto é a sua reutilização em outros sistemas digitais, como na internet, pois, as linguagens de programação (tais como a html) não conseguem interpretar essas fontes especiais.

Uma alternativa ao uso dessas fontes é a utilização das próprias fontes comuns já instaladas na maioria dos computadores, tais como Arial, Times New Roman ou Tahoma, a partir do padrão Unicode, desenvolvido e promovido pelo The Unicode Consortium (2012), que "permite aos computadores representar e manipular, de forma consistente, texto de qualquer sistema de escrita existente" (Unicode 2001). Por se tratar de um padrão internacional independente de plataforma, ela é interpretada por qualquer editor de texto atual (eliminando qualquer problema de compatibilidade de softwares ou com a internet), o que permite a utilização de todos os símbolos para transcrição fonética, sem necessidade de acrescentar outras fontes.

No caso do editor de texto Word para Windows, a inserção de símbolos do AFI no padrão Unicode pode ser feito a partir de dois processos:

1. A partir da janela INSERIR/Símbolo, na aba Símbolos, selecionar Fonte: Times New Roman (Arial, Tahoma, Verdana ou outra fonte comum) e Subconjunto: extensões IPA. No quadro principal aparecerão todos os caracteres disponíveis do alfabeto fonético internacional; basta, então, escolher e clicar sobre um dos caracteres que ele será inserido no corpo do texto em edição.

2. A partir de teclas de atalho do teclado, conforme orientação dada no próprio site da Microsoft: "Se souber o código do caractere, poderá digitar o código no seu documento e pressionar ALT $+\mathrm{X}$ para convertê-lo em um caractere. Por exemplo, pressione 002A e, em seguida, pressione ALT+X para produzir o símbolo *.” (Microsoft Office 2011)

Obs.: No caso do Word (do Windows), atentar para o uso adequado do padrão Unicode (hex), pois há, na mesma caixa de inserção de símbolos, os padrões ASCII (decimal) e ASCII (hex). 
Desse modo, podemos utilizar, para inserir mais rapidamente os símbolos do AFI em um documento do Word (versão 2003 e subsequentes) para Windows, os atalhos de teclado (layout Brasil/ABNT), bastando, para isso, seguir a orientação acima descrita (uso da combinação $\mathrm{ALT}+\mathrm{X})$ e com o apoio da lista que apresentamos a seguir.

Nessa lista, constam os símbolos das extensões do AFI produzidos a partir do padrão Unicode, cujo código numérico de atalho se encontra ao lado de cada um deles. Assim, para produzir algum dos elementos constantes na tabela abaixo, basta digitar a sequência numérica do atalho e combiná-la com ALT $+X$. Por exemplo, para fazer a consoante palatal $\int$, basta digitar os números $0283 \mathrm{em}$ combinação com as teclas ALT+X. Imediatamente aquele conjunto de números passará ao símbolo correspondente.

Observação importante: apesar de o padrão Unicode utilizar por padrão quatro dígitos para identificar um símbolo, o editor de texto Word é capaz de construir esse mesmo símbolo apenas com três dígitos, dispensando a digitação do número 0 inicial. Assim, combinando o número 283 com ALT+X, obtemos $\int$.

Para facilitar a visualização dos códigos, distribuímos, na medida do possível, os caracteres de acordo com a sequência numérica do padrão Unicode e também com suas características mais ou menos comuns; o que resultou em uma divisão da tabela em 05 partes:

1: símbolos fonéticos que podem ser inseridos ao lado de outros caracteres normais do texto.

2: caracteres com formatação especial (sobrescritos ou subscritos), diacríticos (não combináveis com caracteres) e símbolos matemáticos, que também podem ser colocados ao lado de caracteres normais do texto.

3: caracteres do alfabeto grego.

4: diacríticos que podem ser combinados com caracteres. Neste caso, para inserir diacríticos sob ou sobre as vogais, recomenda-se digitar o número correspondente ao símbolo, selecioná-lo e, então, utilizar a tecla de combinação ALT+X.

5: outros caracteres.

Portanto, recomendamos a utilização do padrão Unicode (com fontes comuns, como Times New Roman, Arial, p.ex.) quando houver necessidade de inserir símbolos do AFI em transcrições fonéticas ou trabalhos afins, pois, desta forma, assegura-se a compatibilidade do documento, no que se refere às fontes adotadas, quando de sua transferência para quaisquer outros computadores e/ou softwares de edição de texto, no caso, por exemplo, de uma publicação dos dados.

Jorge Domingues Lopes

Professor da Universidade Federal do Pará

Doutorando do Programa de Pós-Graduação em Linguística,

Laboratório de Línguas Indígenas da Universidade de Brasília

\section{Referências}

Contribuidores da Wikipédia, "Unicode," Wikipédia, a enciclopédia livre, http://pt.wikipedia.org/w/index.php?title=Unicode\&oldid=26004786 (accessed julho 14, 2011).

Contribuidores da Wikipédia, "Alfabeto fonético internacional," Wikipédia, a enciclopédia livre, http://pt.wikipedia.org/w/index.php?title=Alfabeto_fon\%C3\%A9tico_internacional\&oldid=260243 97 (accessed julho 14, 2011).

Microsoft Office, "Inserir um símbolo ou caractere especial," http://office.microsoft.com/pt-br/wordhelp/inserir-um-simbolo-ou-caractere-especial-HA001230737.aspx (acessed julho 20, 2011). 

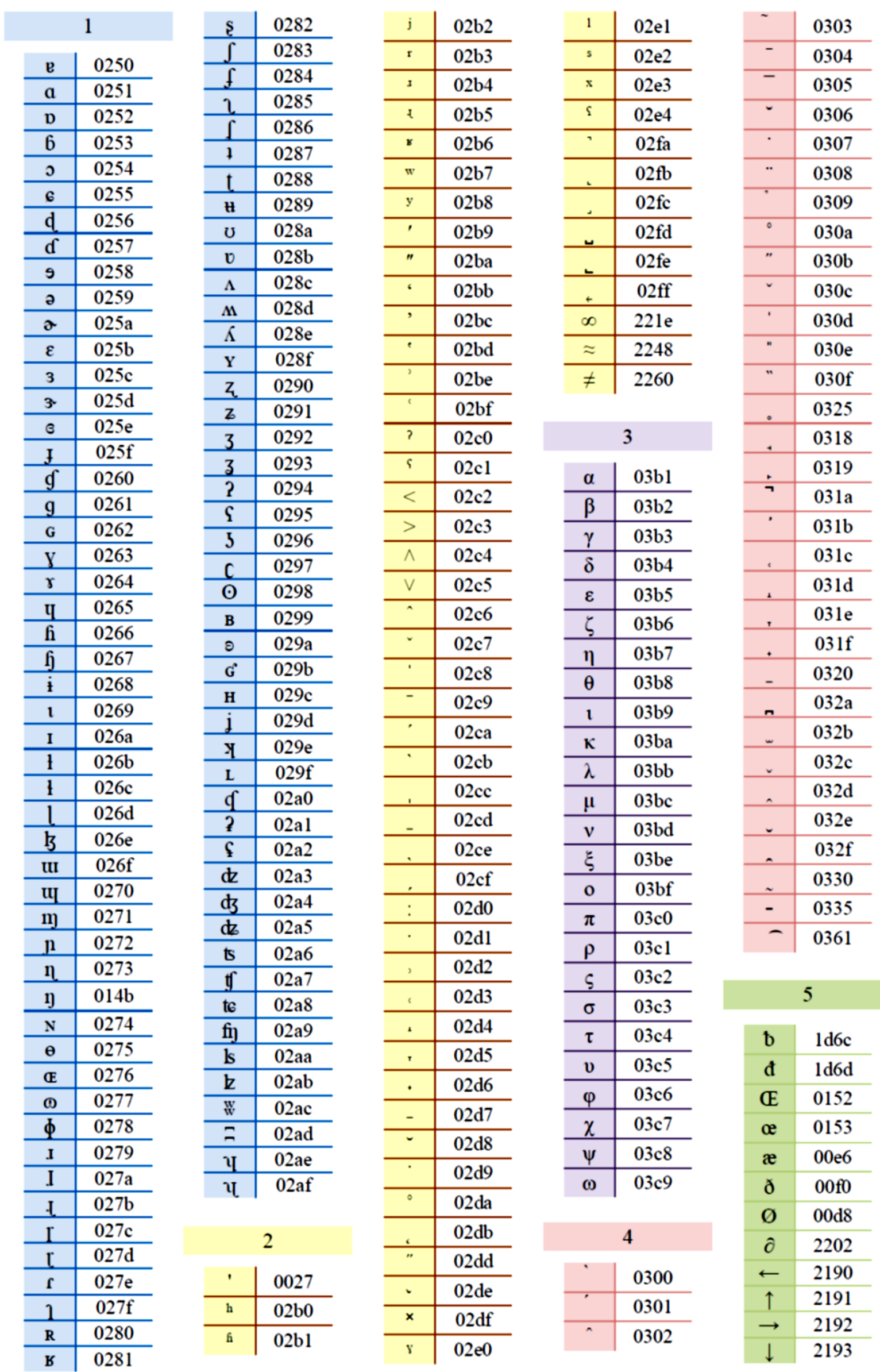

5

\begin{tabular}{|c|c|}
\hline $\mathrm{b}$ & $1 \mathrm{~d} 6 \mathrm{c}$ \\
\hline $\mathrm{d}$ & $1 \mathrm{~d} 6 \mathrm{~d}$ \\
\hline $\mathbb{E}$ & 0152 \\
\hline$\propto$ & 0153 \\
\hline$æ$ & $00 \mathrm{e} 6$ \\
\hline$\delta$ & $00 \mathrm{f0}$ \\
\hline$\varnothing$ & $00 \mathrm{~d} 8$ \\
\hline$\partial$ & 2202 \\
\hline$\leftarrow$ & 2190 \\
\hline$\uparrow$ & 2191 \\
\hline$\rightarrow$ & 2192 \\
\hline$\downarrow$ & 2193 \\
\hline
\end{tabular}

